
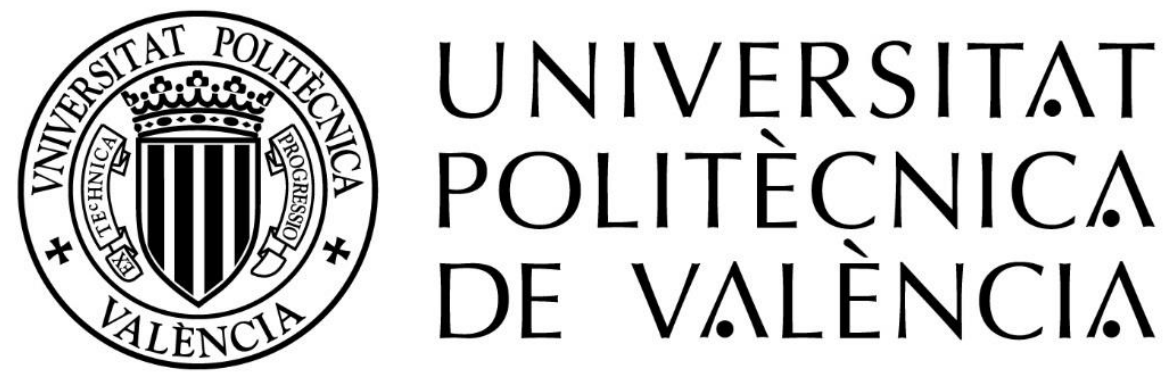

TESIS DOCTORAL

EL ESPACIO CELEBRATIVO COMO CONFIGURADOR DEL PROYECTO ARQUITECTONICO DE LA SAGRADA FAMILIA DE ANTONIO GAUDÍ

DIRECTORES:

IGNACIO VICENS HUALDE

JOSEP V. GOMEZ SERRANO

AUTOR:

JUAN ANGEL REIG MARTINEZ

ARQUITECTO (UPV) 
ESCUELA TECNICA SUPERIOR DE ARQUITECTURA DE VALENCIA (ETSAV) UNIVERSIDAD POLITECNICA DE VALENCIA (UPV)

\section{EL ESPACIO CELEBRATIVO COMO CONFIGURADOR DEL PROYECTO ARQUITECTONICO DE LA SAGRADA FAMILIA DE ANTONIO GAUDÍ}

JUAN ANGEL REIG MARTINEZ ARQUITECTO (UPV)

DIRECTORES: IGNACIO VICENS HUALDE Y JOSEP GÓMEZ SERRANO 
PARA SOLE

JUAN PABLO

MIGUEL

MARIA

Y ANA 


\section{AGRADECIMIENTOS}

A mi querida esposa, Sole, con profundo agradecimiento por su cariño, paciencia, confianza y ánimo demostrados en todo un itinerario personal y profesional compartido de muchos años, y en el periodo de redacción de esta tesis en particular.

A mis hijos, Juan Pablo, Miguel, Maria y Ana, por el cariño, paciencia e ilusión con que han vivido este tiempo.

A Carmen Criado (+), por su ilusión y oración por esta investigación.

Al Dr. Ignacio Vicens Hualde, por sus enseñanzas en la elaboración de esta Tesis, el tiempo y la confianza depositada en el autor.

Al Dr. Josep Gómez Serrano, por su confianza y ayuda, explicación y comentarios en todo lo relacionado con el proyecto de Antonio Gaudí para la Sagrada Familia.

Al Dr. Jordi Bonet Armengol, por sus valiosos consejos, recuerdos y comentarios relacionados con la figura de Gaudí y su padre Lluis Bonet Garí.

Al Dr. Jordi Faulí, por las facilidades otorgadas con los planos de la Sagrada Familia.

Al Rector de la Sagrada Familia, Lluis Bonet Armengol, por los valiosos libros y comentarios recibidos.

Al Dr. Jorge Torres, por su valiosa ayuda en el mundo administrativo universitario tan desconocido para mí.

A Laia Vinaixa, responsable del Archivo de documentación de la Sagrada Familia, por su valiosa ayuda en la búsqueda de documentación.

A Pere Tena (+), obispo auxiliar de Barcelona y gran liturgista, por sus valiosos comentarios sobre Liturgia.

A los Dres. Armand Puig Tarrech y Jaume Aymar Rigolta, por sus comentarios y ánimo para la elaboración de esta Tesis.

A los Dres. Jaime Sancho Andreu y Juan Andrés Talens Hernandis, por su ayuda facilitandome libros y acceso a bibliotecas

Juan Angel Reig Martínez

Valencia, Enero de 2016 


\section{RESUMEN}

La presente Tesis quiere aportar una visión novedosa del proyecto arquitectónico de Antonio Gaudí para la Sagrada Familia dentro del diálogo histórico entre Arquitectura y Liturgia. Los objetivos que se persiguen están relacionados con la visión sacra del edificioiglesia, entendiendo éste no como espacio aislado de lo profano sino como lugar litúrgico insertado en el medio físico y humano donde la comunidad orante celebra la Fe cristiana. Desde la coherencia entre la formación recibida, sus escritos -Manuscrito de Reus-, y la madura expresión de la experiencia profesional adquirida, Gaudí realiza un planteamiento sumamente atractivo y revolucionario para la época desde los planos arquitectónico y litúrgico.

Los proyectos de Santa Coloma y de Mallorca dialogan interactivamente con la ejecución de la Sagrada Familia en un tiempo en que la arquitectura eclesiástica no va más allá de lo que significaban los votos nacionales. Gaudí muestra cómo la concepción integral, unitaria y armónica del espacio celebrativo puede configurar completamente el proyecto arquitectónico. Frente a la pregunta ¿qué quiere ser el edificio-iglesia?, estructura, espacios y elementos constructivos son ordenados moderna e imaginativamente según su idea de belleza, ligada al concepto de carácter religioso de un edificio, a su significación teológica y funcionalidad litúrgica. Destaca también la permeabilidad física y dialogo artístico con el hábitat urbano.

El proyecto se asienta en sólidos fundamentos: la exaltación del dogma católico, la búsqueda de un sistema estructural estable y sabia utilización de la luz como elemento de definición arquitectónica. El resultado es que Gaudí consigue una arquitectura expresionista y protorracionalista, viva, que se genera en permanente dialogo con las exigencias de la liturgia renovada del momento. En el debate forma-función respetando las preexistencias se libera progresivamente de condicionamientos estilísticos para seguir su propio discurso. Investigando la problemática del edificio-iglesia desde sus orígenes lo reelabora continuamente en términos de una visión desmaterializada y netamente espiritual.

La geometría estructural, entretejida de superficies regladas en bóvedas y columnas, y la comunicación de la iluminación -sea natural o artificial- sigue un plan fundamentado en la ordenación litúrgica del espacio. La precedencia de actuaciones y la disposición de elementos arquitectónicos están al servicio de una visión mística del espacio arquitectónico como espacio celebrativo del culto. El simbolismo religioso de los elementos constructivos, la iluminación y la acústica se constituyen en vehículos sensibles de la teología litúrgica. El espacio arquitectónico interior es percibido a través de una serie de itinerarios conceptuales, materiales e inmateriales, ligados al sentido trascendente del culto. Al hallazgo de una más eficiente solución estructural, lumínica y sonora, se unen el simbolismo religioso, expresionismo constructivo y mobiliario litúrgico con el fin de alcanzar el máximo "confort litúrgico". De esta manera, el equilibrio armónico de la composición arquitectónica y las soluciones constructivas alcanzadas muestran una arquitectura eclesiástica plenamente habitable y, por tanto, humana. 


\section{THESIS INTRO}

The aim of this thesis is to offer a new vision of Antonio Gaudi's architectural project for the Sagrada Familia, within the context of the historical dialogue between architecture and liturgy. The thesis considers the sacred vision of the 'church-building' concept, understanding this not as an isolated sanctuary from the outside secular world, but as a place where liturgy is in constant dialogue with the physical and human environment in which the Christian faith is celebrated by the religious community. Gaudí proposes something extremely attractive and revolutionary at both the architectural and liturgical levels, maintaining the coherence between the instruction he had received, his writings (mainly the Reus Manuscript), and the mature expression of his professional experience.

The Santa Coloma and Mallorca projects engage directly with his idea of what the Church should be when the construction of Sagrada Familia begins, in times when ecclesiastical architecture was no more substantial than that embodied by the national vows. Gaudi demonstrates how a comprehensive, unified and harmonic approach to the congregational area could give form to the architectural project in its entirety. In answer to the question, 'What should the 'church-building' represent?', the structure, space, and construction elements are ordered and regulated in an imaginative manner, being both modern and concise in line with Gaudi's idea of beauty, linked to the idea of the 'character' of church architecture, it's theological meaning and its functionality in liturgical terms. It is also worth pointing out the physical permeability and artistic dialogue with the urban surroundings. The project is based on solid foundations: The elevation of the Catholic dogma, the search for a stable structural system and wise use of light as a means of architectural definition. As a result, Gaudi achieves a type of architecture, which is both expressionist and living protorationalist, self-generating and in permanently engagement with the demands of the most up to date liturgical praxis at that time: The Liturgical Movement. This movement emerges from the Benedictine abbeys of Central Europe in the early twentieth century, and is officially promoted by Pius $X$ and continues right up to the Second Vatican Council.

Gaudi's answer to the 'form versus function' debate is to progressively remove the previous style constraints from the space. His architectonic language overcomes the conditioning factors, and reworks everything with a non-material and purely spiritual vision. The structural geometry based on the interweaving of ruled surfaces into domes and columns, follows a plan which is based on the liturgical ordering of the space. The significance of events and religious elements arises from the act of worship and is explained by the theological liturgy. The space, which has been dematerialised by the use of light and colour, offers itself in service to the transcendental nature of worship, aided by a painstakingly calculated constructive symbolism and liturgical furniture. In this way, the iconographic and acoustic balance pursued is fully efficient in returning the place of Christian worship to its original essence, thereby obtaining a notable liturgical harmony, which is perceived both internally and externally. 


\section{RESUM}

La Tesi vol presentar una visió novedosa del projecte arquitectònic d'Antoni Gaudí per a la Sagrada Familia dins del diáleg históric entre Arquitectura i Liturgia. Els objectius cercats están relacionats amb una concepció sacra de l'edifici-església, entés aquest no com un espai aillat del mon profá sinó com un indret litúrgic que conversa amb el medi físic i humá on cel.lebra la seua Fe la comunitat cristiana. Des de la coherència amb l' educació i formació rebudes, els seus escrits -especialment el Manuscrit de Reus-, i la madura expressió de l'experiencia professional adquirida, Gaudí realitza un plantejament molt atractiu i revolucionari des dels punts de vista arquitectònic i litúrgic.

Els projectes de Santa Coloma i de Mallorca es presenten com assaigs dins d'un itinerari que tria dur a terme la seua idea d'el que vol esser una Església. Ambdós son orientats cap a la execució de la Sagrada Familia perque aquest es un projecte molt singular en un temps en que l'arquitectura eclesiástica europea no va més enllá d'el que signifiquen els vots nacionals. Gaudí mostra cóm la concepció integral, unitaria i armónica del espai cel.lebratiu pot configurar completament el projecte arquitectònic. Davant de la questió ¿qué vol esser l'edifici-església?, l' estructura, espais, i elements constructius son imaginativament ordenats $d^{\prime}$ una manera moderna i sintética segons la seua idea de la bellesa, lligada al carácter d'aquesta arquitectura i a la seua significació teológica i funcionalitat litúrgica. Hi ha que destacar també la permeabilitat física i l'interacció artística amb l'hábitat urbá. El projecte posa els seus fonaments sobre la lloança del dogma católic que es coverteix en motor de la recerca d'un sistema estructural estable i d'una cuidada utilització de la llum com a element clau de la definició espacial. A la fí de la seua tasca Gaudí arriba a un expressionisme protorracionalista vibrant, en continua autogeneració a partir de la praxis litúrgica més actual d'aquell temps: el Moviment Litúrgic. Aquest, eixint dels monéstirs benedictins centroeuropeus al començament del segle XX, es dessentrotlla amb l'empenta oficial del Papa Pius X fins al Concili Vaticá II.

En el debat forma-funció, Gaudí allibera progresivament l'espai dels condicionaments estilístics mitjançant un llenguatge que reelabora el problema en termes d'una visió estructural, funcional i artistica. La geometría, entreteixida amb un bon grapat de superficies reglades emprades en voltes i columnes, segueix un plà fonamentat en la jerarquizació dels espais. La precedència en les actuacions i els elements constructius es posen al servei del culte, prenent com a base la teología litúrgica. L'espai, desmaterialitzat per la llum i el color, i significat per una imaginativa iconografía, tria la trascèndencia, bé que reforçat pel imaginatiu simbolisme constructiu i el mobiliari litúrgic. D’aquesta manera, l'equilibri iconográfic i acústic cercats ens mostren útils per al retrovament del espai de culte cristià amb el seu sentit original, obtenint-se un gran confort litúrgic, com clarament es percebéix externa e internament. 


\section{INDICE}

CAPITULO 1 PRESENTACIÓN.

CAPITULO 2 ANTECEDENTES: ESTRUCTURA Y FUNDAMENTOS.

2.2 Revisión de la Bibliografía utilizada

P. 23

2.3 Sobre la función del Arte sacro en la Liturgia de la Iglesia. .P. 49

- Fundamentos del dialogo Arte-Liturgia.

- La tradición histórica.

2.4 Arquitectura religiosa versus Arquitectura sacra. Cuestiones a resolver en la dimensión celebrativa.

- La interpretación de lo religioso y lo sagrado en la Arquitectura Moderna.

- La dimensión celebrativa.

- Elementos arquitectónicos para la comprensión del espacio sacro.

- Cuestiones arquitectónicas a resolver en la dimensión celebrativa.

2.5 Historiografía de la obra gaudiniana

P. 81

CAPITULO 3 ARQUITECTURA Y LITURGIA: UNA RELACIÓN PERMANENTE. P. 99

3.1 La Liturgia como vida de la Iglesia, una aproximación. P. 99

3.2 El renacer litúrgico de la Iglesia desde la segunda mitad del siglo XIX hasta el pontificado de Pio $X$ P. 103

- Fundamentos y protagonistas del Movimiento Liturgico.

- El impulso de Pio X y la participación de los fieles en el culto.

3.3 La renovación litúrgica en España. 


\section{CAPITULO 4 ANTONIO GAUDÍ Y SU CONCEPTO DE LA ARQUITECTURA}

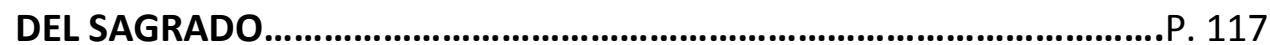

4.1 La idea de arquitectura religiosa en Gaudí a través de sus escritos

- El Manuscrito de Reus

- $\quad$ La construcción del Templo.

4.2 El Entorno de Gaudí y la formación de su concepto de arquitectura sacra P. 149

- Formación y aprendizaje.

- Clientes y amigos.

- Colaboradores y asistentes.

- Relación con el obispo diocesano.

4.3 La liturgia vivida por el arquitecto

4.4 Gaudí y el congreso litúrgico de Montserrat.

4.6 El Pensamiento de Gaudí en su madurez.

- Conversaciones, reflexiones y recuerdos con sus colaboradores y asistentes.

\section{CAPITULO 5 APROXIMACION A LA ARQUITECTURA RELIGIOSA}

DE ANTONIO GAUDÍ.

5.1 Panorama de la Arquitectura religiosa en tiempos de Gaudí.

- El Historicismo en la arquitectura religiosa del momento.

- Algunos ejemplos de arquitectura eclesiástica española en el contexto del siglo XIX

- Las iglesias votivas en Europa: Montmartre, Viena, Bruselas, Roma, El Tibidabo.

5.2 Interacción de la iglesia de la Colonia Güell y la Seo de Mallorca con el proyecto de la Sagrada Familia.

- La iglesia de la Colonia Güell en el itinerario de la Sagrada Familia: una lectura litúrgica de su arquitectura.

- Intervención en la Seo de Mallorca: El concepto de restauración litúrgica. Intervención en el Patrimonio y Liturgia. Simbolismo, elementos y mobiliario del espacio para la liturgia. 
6.1 Datos de partida del Proyecto........................................................................... 299

a) El concepto de Templo Expiatorio en la Asociación de devotos de

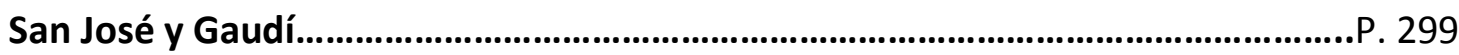

b) La idea de Bocabella: el primer proyecto.................................................................. 307

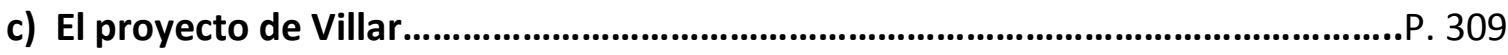

d) Antonio Gaudí y el proyecto de la Sagrada Familia.................................................P. 315

d.1- Primeras actuaciones.

d.2- El Programa de Gaudí.

d.3- Proyectos gaudinianos de la Sagrada Familia.

6.2 El enfoque cultual del proyecto de Gaudí a través de la

Identificación de los espacios litúrgicos en la Sagrada Familia......................P. 373

a) Identificación del proyecto arquitectónico con la dimensión celebrativa............P. 373

b) Criterios de composición arquitectónica en clave litúrgica..................................P. 387

c) La Cripta como declaración de intenciones del arquitecto....................................P. 399

d) Los espacios litúrgicos en la Sagrada Familia........................................................ P. 415

d.1- Planteamiento del aula celebrativa:

- Los focos de la celebración: altar, ambón, sede.

- El lugar de la asamblea y el coro.

d.2- La envolvente: fachadas y campanarios.

d.3- Capillas del Bautismo y de la Penitencia.

d.4- El Claustro y la Capilla de la Asunción.

d.5- Espacios sirvientes : Sacristía, Accesos, Talleres, Escuelas, etc.

6.3 Elementos arquitectónicos que estructuran el espacio litúrgico

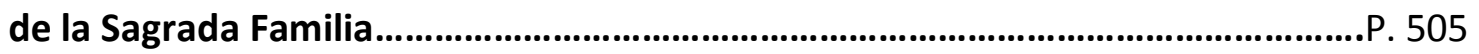

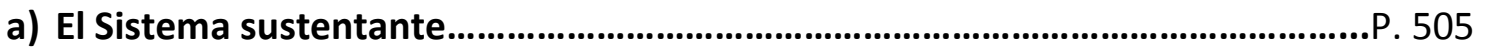

- Estabilidad y Sistema estructural.

- Módulo estructural y cubrición del aula celebrativa.

- Visualización del espacio litúrgico.

b) Acondicionamiento del aula litúrgica.

- Dimensión teológica y simbólica del aula litúrgica.

- Iluminación del aula litúrgica.

- Acústica.

- Mobiliario litúrgico.

c) Dimensión urbana. P. 581 


\title{
EL ESPACIO CELEBRATIVO COMO CONFIGURADOR DEL PROYECTO ARQUITECTONICO DE LA SAGRADA FAMILIA DE ANTONIO GAUDÍ
}

\author{
CAPITULO 1 PRESENTACIÓN. FUNDAMENTOS. VITALIDAD Y ACTUALIDAD DEL \\ PROYECTO DE LA SAGRADA FAMILIA. LAS CLAVES ARTíSTICA, CONSTRUCTIVA, \\ LITÚRGICA.
}

Casi todas las grandes figuras de la Arquitectura del siglo XX han tenido que enfrentarse dentro de su trayectoria profesional al reto que supone el dfiseño de un espacio arquitectónico para el culto. La catedral de $N \underline{\underline{a}} S \underline{\underline{a}}$ de los Angeles, de Rafael Moneo, o la de Santa Maria de Tokio, de Kenzo Tange, la Chiesa di Giubileo en Roma, de Richard Meier, la de Saint Pierre en Firminy o Notre Dame du Haut en Rochamp, de Le Corbusier, Nossa Senhora de la Aparecida en Brasilia, de Oscar Niemeyer, etc. no son sino algunos ejemplos relativamente recientes de los muchos que se han dado históricamente y ponen de manifiesto la singularidad e importancia de la arquitectura eclesiástica en el panorama artístico mundial.

En los inicios del siglo pasado surge el proyecto de la Sagrada Familia de Antonio Gaudí como uno de los ejemplos de arquitectura eclesiástica más logrados cuyo legado todavía hoy dia nos descubre aspectos de interés que analizar. Entre los proyectos de Gaudí destaca la Sagrada familia, no sólo por su dimensión y completa concepción artística sino porque durante su dilatado periodo de ejecución -todavía en vida del arquitecto- se produce una evolución tan completa del mismo, que traducida en una innovadora concepción estructural y espacial, y en una abundantísima simbología e iconografía, hace de este edificio-iglesia un auténtico hito constructivo, cultural y litúrgico.

En contraposición a la admiración que en los últimos años está suscitando esta obra en todo el mundo, no hay que olvidar los años de crítica negativa, silencio y postergación en medios artísticos y arquitectónicos especializados -con posterioridad a la muerte de Gaudí- probablemente generados por planteamientos socioculturales y forma de entender la expresión arquitectónica diferentes del momento histórico en que se iniciaron las obras. Posteriormente, el debate y fuerte oposición de la mayoría de la crítica arquitectónica a la continuidad en su construcción, iniciado en la década de los años sesenta, propugnando como homenaje a la genialidad de Gaudí y como mejor opción la consolidación y conservación de lo ejecutado hasta ese momento, no aportó mayor profundidad a su estudio y análisis arquitectónico, permaneciendo el edificio dentro de los parámetros artísticos y cuasi arqueológicos demostrativos de un tiempo y un artista concretos. 
Puestas así las cosas, ha sido la labor divulgadora realizada por George Collins en la Universidad de Columbia a partir de los años setenta, la notoriedad dada a la obra por las opiniones vertidas por Dalí y otros artistas, y la difusión de las investigaciones realizadas por la Cátedra Gaudí en España y Roberto Pane en Italia, la que ha devuelto a las páginas de numerosos estudios, publicaciones y exposiciones este proyecto póstumo gaudiniano. Además hay que reseñar la notable contribución que para la popularidad de este edificio ha tenido el desarrollo experimentado en la ejecución de sus obras en los últimos veinte años, con la participación de numerosos especialistas y universidades de todo el mundo. Así pues, en la actualidad y desde hace varios años, hay una correspondencia entre la profusión de estudios especializados de este proyecto -dentro de toda la obra arquitectónica gaudiniana o incidiendo directamente en él- y la amplia notoriedad que está teniendo entre el gran público en los últimos años y que hacen de él unos de los edificios más visitados.

Sin embargo, en el contexto de la arquitectura eclesiástica y del arte sagrado su contenido aún no está suficientemente estudiado. Tanto es así que son muy recientes las obras que se ocupan de ella tratando fundamentalmente su dimensión simbólica pero sin entrar en las posibles aportaciones al discurso entre forma y función en el ámbito litúrgico o al tratamiento de los elementos y recursos arquitectónicos en los espacios de culto.

Es objeto de la presente Tesis fundamentar el diálogo entre Liturgia católica y Arquitectura sacra investigando la configuración del proyecto arquitectónico a partir del espacio celebrativo, y todo ello tomando como ejemplo la intervención de Antonio Gaudí rehaciendo el Templo expiatorio de la Sagrada Familia. 


\section{CAPITULO 2 ESTRUCTURA Y FUNDAMENTOS.}

\subsection{Objetivos y Metodología de la Investigación.}

OBJETIVOS.

Existen una serie de parámetros a resolver en la dimensión celebrativa del espacio arquitectónico eclesiástico que han sido objeto de singulares propuestas en el ámbito de la arquitectura contemporánea, utilizando diversos lenguajes, manifiestos y trazas, y cuya resolución todavía es materia de investigación para los arquitectos comprometidos con la forma y el diseño del edificio-iglesia.

Plantearse los objetivos de esta Tesis es tratar algunas de las siguientes cuestiones con la base teórica actual aplicada a la evocación de una idea plasmada en el espacio celebrativo gaudiniano:

Relación forma-función en la arquitectura cristiana del sagrado.

Desde que la Iglesia abandona la domus-ecclesiae y la sustituye por la basílica como espacio celebrativo ha habido una larga tradición de iglesias con planta canónica, de cruz latina o de cruz griega, y también centralizadas; pero, también ha permanecido el concepto de hauskirche en las plantas de salón del gótico y neogótico germánico, de la iglesia en rotonda y los martyrium, las iglesias ovales de escenografia barroca, los monumentos nacionales y templos votivos en el siglo XIX, y hasta las más variadas propuestas de planta actuales; buscando en algunos casos la mejor solución para la celebración litúrgica, tal y como era entendida según la ritualidad y concepción del fenómeno religioso de la época, y en otros, una amplia gama de objetivos implicados aunque no directamente emanados de dicho fenómeno. Sigue siendo, pues, necesario preguntarse cuál es la naturaleza de la relación entre forma y función en los espacios de culto y qué entendemos por tipología del edificioiglesia para seguir afrontando los retos que demanda la arquitectura eclesiastica a todas las partes implicadas en su programación, diseño, ejecución, uso y disfrute.

- $\quad$ Recuperación de una visión sacra de la arquitectura del edificio iglesia.

Para ello es preciso recuperar una visión sacra del edificio, abandonando la noción de contenedor uni o polifuncional, por lo que significan las personas y las actuaciones humanas que allí se desarrollan, con una nueva sensibilidad hacia el misterio cristiano, que podría denominarse casi ritual según la terminología kahniana. Si la basílica, de herencia romana, supuso la adaptación de una jerarquización de los espacios representativos de la autoridad Imperial al culto cristiano con unos recorridos libres y liberados de la clandestinidad en un espacio reinventado, también abrió la puerta a la identificación -durante siglos- de la autoridad espiritual con el poder temporal, hasta tal punto que el edificio-iglesia 
absorbió en sus trazas, espacialidad, simbología y lenguaje una visión monumental de la que todavía en el siglo XX le cuesta desprenderse.

En ese contexto, ¿̇es realmente posible una visión de la arquitectura eclesial desde la dimensión celebrativa de lo que en ella acontece? Si esto es así, necesariamente habrá de reflejarse en las trazas y planta del edificio, en su estructura y composición, en la construcción y su lenguaje, en el propio espacio que se conforma y su tectónica, en la simbología e iconología, pues todo él se verá afectado por la actitud, las acciones, la expresión y las vivencias de los "concelebrantes", de acuerdo con la jerarquía, orden y misión de cada uno de ellos.

\section{Aproximación al concepto de templo expiatorio.}

En todas las culturas y religiones ha existido la noción del templo como lugar sagrado de la comunicación de la divinidad con el hombre. En el Cristianismo el templo sagrado más que un lugar o un edificio es cada hombre, en cuanto a su dimensión completa de persona humana-cuerpo, alma o psique, y espíritu- en el cual habita Dios. Siendo esto así, ¿cuál es la razón de ser de un templo expiatorio y qué es lo que le distingue de otra iglesia?

\section{Identificación de claves para una lectura arquitectónica del espacio celebrativo.}

La iglesia o convocación supone una comunidad de personas que se reúnen para celebrar conjuntamente su fe en Cristo, principalmente el misterio eucarístico de la presencia de Dios que convoca, se manifiesta y une a quienes participan en la celebración. No se trata de un lugar, de un topos sagrado, constituido en hito geográfico como un espacio aislado y contrapuesto al mundo profano circundante, sino que lo que lo hace sagrado es la convocación y celebración cultual que allí acontece. En términos teológicos esta sacralidad cultual cristiana es independiente del espacio en el que tiene lugar, pudiendo éste estar plenamente insertado en el ámbito profano y en permanente dialogo con él, puesto el carácter sacro deriva de la comunicación que se establece entre la comunidad celebrante y el Dios cristiano, Uno y Trino, que actúa en ella en ese momento y lugar. Esta comunicación se ve favorecida, en términos arquitectónicos, por una configuración espacial propia y unos elementos arquitectónicos determinados y diferentes en función de una serie de factores. Si la celebración es, pues, el corazón y razón de ser del edificio donde se reúne la comunidad, en este sentido, responde a un culto, unos ritos y una dinámica que impregnan el espacio, su división, perímetro y significación arquitectónica completa y total. 
- $\quad$ Identificación de los espacios celebrativos en la Sagrada Familia.

Surge la cuestión, a veces olvidada, de significar los espacios celebrativos retornando al sentido teológico y la función liturgica de los mismos. Cuando se trata de un edificio de las dimensiones, complejidad y simbología de la Sagrada Familia de Antonio Gaudí cobra mayor importancia establecer una ordenación compositiva acorde con este planteamiento. Se trata de unas obras que se han prolongado en el tiempo notablemente, con una documentación que nos ha llegado de forma fragmentada. Ha sido necesario estudiar, recomponer y analizar ésta para captar la idea del arquitecto, las leyes de generación interna. La investigación constructiva respecto de la manera más adecuada de llevarlas a cabo utilizando las más variadas herramientas informaticas y de cálculo ha supuesto una vitalista evolución del proyecto, al igual que en vida de Gaudi, implicando también la colaboración de profesionales y estamentos de diversas nacionalidades.

A la vista de estos y otros considerandos se hace verdaderamente atrayente acercarse a la configuración de los espacios destinados a la celebración del culto, para estudiar qué cualidades y características los definen y hacen singulares; si hay alguna concepción unitaria que los informe y cuál es; analizar el resultado de una agregación de cuestiones y elementos que se ha sucedido en el tiempo e intentar sumergirse en el objetivo perseguido como configurador del diseño.

Querríamos averiguar si realmente son los espacios celebrativos los que pueden dar la clave del diseño y desarrollo del edificio -que quiere ser él mismo, en su función y en su filosofía, dentro la praxis constructiva y de los lenguajes arquitectónicos de su tiempo- o estamos ante un caso más, eso sí ilustrado, de arquitectura religiosa en su faceta monumental.

Encontrar, pues, unas leyes internas que conformen lo que Gaudí llamaba el carácter del edificio y que permitan la lectura total del mismo, en su dimensión arquitectónica, artística y litúrgica, estructural y constructiva, puede convertirse en un ángulo nuevo y fascinante para la visión de este edificio.

- $\quad$ Elementos arquitectónicos del proyecto gaudiniano al servicio de la Liturgia. Todo edificio responde a un programa de necesidades dado o se conforma a la vez que él, ya sea por acción o incluso por omisión (pues hasta la ausencia de un programa adecuado constituye un programa, bastante negativo, pero programa al fin y al cabo $)^{1}$. En el caso de la iglesia el programa de necesidades, aun conteniendo quizá otros elementos ajenos a ella, siempre ha de incluir la Liturgia.

\footnotetext{
${ }^{1}$ En referencia a la ausencia de programa especifico, adecuado al cumplimiento de unos objetivos ligados al uso del edifiico, se podría estar hablando del término deconstructivo "transprograming".
} 
En la medida en que ésta se entienda en un sentido pleno, y no como mero ritual externo, cobrará mayor dimensión y protagonismo, suscitará preguntas y planteará cuestiones que la Arquitectura debe resolver.

Qué elementos arquitectónicos pueden ofrecer respuestas adecuadas y cómo hacerlo es una cuestión fundamental para los arquitectos de todos los tiempos si se quiere realizar un edificio fiel a su vocación y funcionalidad. Sin duda será interesante comprender los elementos arquitectónicos de la Sagrada Familia tal y como los concibió Antonio Gaudí y tratar de descifrar su implicación en la liturgia cristiana, en el marco de la ritualidad de su época y en el sentido más auténtico del espíritu de la liturgia, para disponer de una vía útil para desarrollar el proyecto arquitectónico al servicio de la Liturgia a través de los distintos lenguajes y técnicas que se pueden dar en pleno siglo XXI.

Viabilidad de la Liturgia como configuradora del proyecto arquitectónico de la Sagrada Familia de Antonio Gaudí.

Al finalizar esta investigación se buscará concluir, entre otras cuestiones, la viabilidad del diálogo Liturgia-Arquitectura como fuente de inspiración para el proyecto arquitectónico de la Sagrada Familia de Gaudí y, en consecuencia, la validez de profundizar en el mismo para facilitar cualquier arquitectura eclesiástica que nos propongamos realizar en nuestros días.

\section{METODOLOGIA}

La Metodología de trabajo que se ha establecido para la presente Tesis se basa en los siguientes pasos e instrumentos que nos ayudarán a percibir las diversas componentes compositivas, estructurales, constructivas, artísticas, simbólicas y urbanísticas desde el factor aglutinante que supone el uso del edificio:

1. En primer lugar, la descripción de las Fuentes de la documentación utilizada, especialmente en lo que se refiere al proyecto, su imagen gráfica y textos originales de Antonio Gaudí o de sus inmediatos colaboradores.

2. La confirmación y comentario de la bibliografía inicialmente propuesta y después utilizada, distinguiendo su temática, interés y datación cronológica (siguiendo las normas APA 6a edición) que nos permitirá, no sólo establecer una distinción entre las fuentes originales o más próximas a las ideas del autor y aquellas que posteriormente han estudiado y analizado la obra y su génesis, sino que además dará con las principales pautas de la historiografía reciente respecto del proyecto de la Sagrada Familia de Antonio Gaudí. 
3. Repaso de algunas controversias básicas para el tema de la Tesis que permitan establecer las bases o puntos de partida: arquitectura religiosa-arquitectura sagrada, arte-estética de lo sagrado, funcionalidad-monumentalidad en el edificio-iglesia, etc. y en general todas aquellas cuestiones de índole arquitectónica y constructiva que tienen que ver con la significación de la Liturgia de la Iglesia Católica en el edificio y su espacio celebrativo. Mediante las herramientas de análisis y el moderno tratamiento que se da a la relación entre arquitectura y liturgia en el arte actual se quiere llegar a visualizar esa relación en el contexto de la segunda mitad del siglo XIX y principios del XX.

4. El conocimiento del Movimiento Litúrgico y la renovación litúrgica católica en el siglo XIX, sus fundamentos y líneas básicas; el impulso del pontificado de Pio $X$ a la participación de los fieles en la liturgia; su repercusión en España, el congreso litúrgico de Montserrat, sus protagonistas y acciones derivadas, con incidencia directa en la actividad profesional de Gaudí, será instrumento de conocimiento imprescindible para situarnos en el contexto de la aportación de Gaudí.

5. Rastrear el pensamiento de Gaudí en lo concerniente a su idea de la arquitectura religiosa, presente desde desde sus años de estudiante y que se manifiesta primera vez en sus escritos de juventud, agrupados bajo la denominación de Manuscritos de Reus, será paradigmático para desentrañar su interés por el edificio-iglesia. Otros escritos posteriores como las Notas aclaratorias al proyecto de cripta -para promover los enterramientos en la Sagrada Familia- y sus reflexiones de madurez en materia de espacios de culto y la arquitectura en general -recogidas por sus colaboradores y asistentesnos permitirán observar cómo la inquietud teórica se plasma en disposiciones arquitectónicas concretas, garantizando un interesantísimo hilo conductor. Esta producción literaria cobra especial relevancia si se tiene en cuenta que Gaudí escribe relativamente poco y sólo en la juventud, conformándose posteriormente su personalidad como la de un hombre de acción.

6. También será preceptivo hacer una breve referencia a su vida, carácter y psicología, cuyos rasgos y evolución aportan datos de notable interés para el investigador; a sus maestros en la profesión, clientes y amigos, que influyen en su recorrido humano y profesional: Joan Martorell, Eusebio Güell, Cristobal Grau, Torras i Bages, Campins, Joan Maragall, Mossen Vardaguer, etc.; así como tener presentes los testimonios trasmitidos por sus colaboradores y biógrafos más inmediatos: Ràfols, Folguera, Puig Boada, Bergós y Martinell. 
7. El Panorama de la arquitectura eclesiástica europea en la segunda mitad del siglo XIX a través de la casuística de algunos templos previos o coetáneos con la Sagrada Familia constituye así mismo un marco de interés para comprender el contexto cultural y arquitectónico en el que surge el edificio a la vez que las posibles novedades que aporta. El fenómeno del templo votivo en la Europa del siglo XIX a través de algunos casos significativos y los historicismos, las ubicaciones de los templos "nacionales", los programas, los símbolos, etc.

8. La producción arquitectónica religiosa de Antonio Gaudí anterior a la Sagrada Familia constituye también un muestrario de sus intereses iniciales. Colaboraciones, obras menores y primerizas, proyectos no realizados o que no se concluyen, etc. le permiten adquirir una sensibilidad y un conocimiento de la materia que resultan de indudable interés para comprender el proyecto de la Sagrada Familia, especialmente en lo que se refiere a las interacciones con la restauración litúrgica de la Seo de Mallorca y el proyecto de la iglesia de Santa Coloma en la colonia Güell.

9. Los sucesivos proyectos y planimetría de la Sagrada Familia han de ser analizados y comparados para comprender el desarrollo arquitectónico que persigue el edificio. Los distintos dibujos de planta, alzados y maquetas del proyecto, el discurso a los Josefinos, la diversas soluciones estructurales, la misma secuencia seguida en la definición progresiva del proyecto,... dan idea de la propia evolución del proyecto y de su génesis con relación a la concepción del aula litúrgica.

10. Comprender el espacio configurado por la estructura y planta del aula litúrgica de la Sagrada Familia e identificar los diferentes espacios celebrativos y de servicio del proyecto - Cripta, Nave o aula litúrgica, Sacristias, Capillas, Nártex, Claustro, Campanarios, etc- puede ayudarnos a entender lo que es una iglesia y a verificar sus conexiones con las necesidades marcadas según un programa litúrgico dado.

11. La Arquitectura diseña, organiza y ejecuta numerosos elementos que pueden tener y tienen una importante componente litúrgica. La iluminación que en todo edificio juega un papel tan importante aquí es clave para la participación en lo que se celebra; el color y la pintura pueden potenciar una atmosfera determinada, una mejor aprehensión del carácter del edificio o al contrario, servir de evasión; la sonoridad y su acústica, pieza clave para el confort celebrativo; la música y el canto son factores inherentes al culto litúrgico y por tanto propios según el momento histórico; el mobiliario, a la vez que tiene un sentido funcional, denota la sensibilidad artística y liturgica de la comunidad 
celebrante; la iconografia es reflejo de la ritualidad y de la teología en el contexto cultural y social del momento; la visualización de una simbología determinada tiene mucho que ver con la teología y espiritualidad que se quieren comunicar, y con el lenguaje que se utiliza para esa comunicación. Intentaremos acercarnos a estos elementos con la mirada del arquitecto que, a su vez, quiere dialogar con especialistas en materias y disciplinas muy diversas que intervienen en estas arquitecturas cultuales.

12. Los templos siempre han ocupado un lugar preeminente en todas las culturas, y las iglesias cristianas históricamente han significado un hito en las ciudades y pueblos. La Sagrada Familia también se constituye como hito urbano, con una escala y una vocación, una proyección al exterior dotada de una fuerte carga simbólica y trascendente, una señalización muy marcada de la frontera entre el mundo profano y el mundo religioso. 


\subsection{Revisión de la Bibliografía utilizada.}

En el apartado de FUENTES Y BIBLIOGRAFIA al final de esta Tesis figura la relación completa de la Bibliografía utilizada para esta investigación así como las fuentes utilizadas para su incorporación, remarcando, a su vez, la importancia del mismo edificio como fuente valiosa de información. En el presente apartado nos limitaremos a referenciar la bibliografía y autores que he considerado más consistentes para la metodología y objetivos de la investigación.

Respecto de la Bibliografía utilizada se ha considerado prioritario abordar la investigación desde una doble vertiente. Por un lado, la aproximación desde la Teología Litúrgica a la trascendencia y belleza del culto cristiano, especialmente eucarístico, y a las dimensiones comunitaria y celebrativa del misterio que en él acontece, que arranca desde sus orígenes cuando la Iglesia apostólica reproduce todo lo enseñado y vivido con Jesucristo. Esta visión de la Liturgia cristiana penetra en su sentido más profundo introduciéndonos en la categoría de vida de la Iglesia, aunque sin olvidar toda su ritualidad más genuina.

- Borobio, D. (2008) La dimensión estética de la liturgia. Barcelona. Cuadernos Phase 180.

Su interés radica en ligar la belleza que se muestra a través de la liturgia con el arte, en la línea de lo que han puesto de manifiesto los últimos pontífices. Contribuye a explicitar el sentido trascendente de la belleza del misterio de Cristo y la santidad a la que están llamados todos los cristianos -camino de belleza- y para la que tiene un valor catequético la vida litúrgica. En consecuencia, el edificio-iglesia, como casa del pueblo de Dios donde celebra su fe, sustenta la estética del espacio desde la dimensión celebrativa de la eucaristía, del bautismo, y del resto de sacramentos y actos litúrgicos.

- Evdokimov, Paul. (1991). El arte del icono. Teologia de la belleza. Madrid. Ed. Claretianas.

Este estudio sobre la belleza y el arte, partiendo de la teología cristiana, la espiritualidad oriental y la visión bíblica y patrística de la belleza, constituye una de las publicaciones básicas para explicar el arte cristiano, sus fuentes y principios. El autor hace suya la fe de Dostoyevsky en la capacidad del arte para transformar el alma del espectador si la belleza responde a la verdad y al bien, y no a un mero goce sensual. Visión del templo cristiano como un espacio sagrado "ordenado", estructurado, por la Liturgia y la Cultura.

- Maldonado, L. (2002) Liturgia, arte, belleza. Madrid. San Pablo.

Ensayo teológico, el autor reflexiona sobre la relación entre teología y estética, fe y arte, señalando la importancia que tiene la unión entre experiencia litúrgica y experiencia artística tiene la evangelización en nuestro tiempo. Avanza comentarios interesantes sobre la incidencia de la poesía y algunas artes en la liturgia, especialmente la música y la pintura, también el teatro, pero aún citándolas no desarrolla la ligazón de las artes del espacio, arquitectura y escultura, con la celebración litúrgica. 
- Wadell, Paul J, C.P. (2002) La Primacia del Amor, una introducción a la ética de Tomás de Aquino. Madrid. Ed. Palabra.

Este ensayo sobre la ética del Aquinate aporta una nueva visión para la comprensión de la evolución de la dimensión personal de Gaudí que quizá no se haya tenido demasiado en cuenta a la hora de valorar su producción religiosa y especialmente el trabajo en la Sagrada Familia, en el que llega a centrarse exclusivamente.

En este sentido hay que mencionar también algunas publicaciones que se han considerado relevantes en este acercamiento a la Liturgia desde la Teología y que ayudan a comprender su significación como expresión pública y oficial de la vida de la Iglesia a lo largo de la Historia, atendiendo tanto a la ritualidad, ceremonial y rubricismos como a su implicación en la constitución y espiritualidad de la asamblea celebrante, y a su plasmación en los espacios destinados al efecto, en sus signos y en sus símbolos.

- Righeti, Mario. (1956). Historia de la Liturgia. Madrid. BAC.

Constituye una de las publicaciones clásicas sobre los orígenes, desarrollo, orden partes, ceremonial, etc. de la Liturgia, con especial atención a la Eucaristia. Abunda en el origen de la misa, la misa primitiva según los escritos de San Justino, la misma romana más antigua con sus prenotandos, cantos, etc. y la $\mathrm{H}^{\mathrm{a}}$ del canon romano. También habla de la Eucaristia como sacramento y la misa ambrosiana. Finalmente dedica unos capítulos al resto de sacramentos y a los sacramentales, en la Liturgia. El autor fue abad mitrado de la colegiata de № Sa del Remedio (Génova) y consultor de la SC de los Ritos. Traduccion y ed. en español preparada por Cornelio Urtasu Irisarri, profesor de Do Canónico en el Seminario Mayor de Valencia.

- Lopez Martin, J. (2000) La liturgia de la Iglesia. Teología, historia, espiritualidad y pastoral. (3a Ed., rev.) Madrid. BAC.

Obra básica para entender la definición de Liturgia antes y después del Vaticano II, así como la incidencia de la publicación del cardenal Gomá después del congreso de Montserrat. Realiza un repaso de La liturgia en la Historia, desde la Roma clásica, el predominio franco-germánico, el bajo Medievo, la uniformidad en torno a Trento, el Movimiento Litúrgico y la reforma litúrgica del Vaticano II. Incide en el valor de la comunicación, lenguaje litúrgico, signos, simbolismo y arte para la vivencia liturgica.

- Basurko, Xabier. (2006) Historia de la Liturgia. Barcelona: Centre de Pastoral Litúrgica.

Imprescindible para el análisis de los espacios de culto cristiano. Incide en las diversas tipolgias de basílicas, martyria, baptisterios, etc. a la luz de los ritos los diferentes ritos cuyo devenir histórico explica. Aporta una clasificación de la Liturgia cristiana en cuatro grandes etapas hasta el Vaticano II: los ritos latinos hasta la unificación de Gregorio VII, la etapa desde éste al concilio de Trento, la liturgia protestante y la liturgia barroca hasta los preliminares del Movimiento Litúrgico, y el desarrollo posterior del mismo con Pio X, Lambert Beauduin, Odo Casel y Romano Guardini hasta el Vaticano II. 
- Guardini, Romano. (1952). "El espíritu de la liturgia." Barcelona.

El título es definitorio y la aportación de este autor fundamental para entender lo que es y significa la Liturgia para la Iglesia. Desde el año 1918 en que se publicó en alemán hasta el momento actual esta obra ha tenido una gran influencia en términos de arquitectura en las iglesias alemanas en el periodo entreguerras y posteriores, aunque en España se tradujo muy tarde (1943). La primera traducción al francés, anterior a la muerte de Gaudí, pudo ser conocida en el entorno litúrgico del arquitecto.

- Ratzinger, Joseph. (2010). La fiesta de la Fe. (4ạ Ed.) Bilbao: Desclée De Brouwer. Ensayo centrado en resaltar la dignidad del hombre. Aborda algunas cuestiones fundamentales y estructura de la celebración litúrgica.

- Ratzinger, Joseph. (2005) La belleza, la chiesa. Roma: Ed. Vaticana e Itaca.

Ensayo sobre la belleza y la necesidad de encontrarla que experimenta el hombre a través de la historia. Da una base conceptual respecto del acercamiento a la belleza desde la experiencia en contraposición al sólo conocimiento racional. Constituye un nexo interpretativo de la Etica de Tomás de Aquino en la biografia personal de Gaudí con el libro de Wadell "La Primacia del Amor, una introducción a la ética de Tomás de Aquino" y el de Reig "Antoni Gaudí y la belleza, la Sagrada Familia un proyecto vivo". Su tesis sustenta cómo la belleza auténtica -manifestada en el rostro de Cristo- es capaz o contiene la verdad completa, superando la estética griega clásica y por consiguiente dando respuesta a las atrocidades de la historia.

- Tena, P. y AAVV. La Iglesia celebrante y su teología. Barcelona: Cuadernos Phase no54. Barcelona. CPL.

Su aportación se centra en describir el sentido y origen divino de la convocación de la asamblea litúrgica que dá una categoría totalmente trascendente al encuentro en el lugar litúrgico. En términos de lenguaje litúrgico actual explica el objetivo primordial de la celebración en ser llenos del Espíritu Santo, formando con Cristo un solo cuerpo y un solo espíritu. La contribución de Tena a remarcar el sentido comunitario y la importancia de la asamblea liturgica es importante al insistir en cómo ésta debe estar abierta a la vida de la comunidad como pueblo cristiano y a la universalidad.

Es fundamental situarse en el contexto de la Renovación Litúrgica Católica que se promueve desde los monasterios benedictinos de Centroeuropa y que tiene su soporte e impulso fundamental para la Iglesia en el pontificado de Pio X para comprender cómo se desarrollaba el culto eclesial desde la norma tridentina y qué puede llegar a suponer para la arquitectura eclesiástica un renovado dialogo entre la liturgia el arte. En este contexto del Movimiento Litúrgico, sus protagonistas y características fundamentales, su introducción en España y las personas que llevan a cabo esta renovación en tiempos de Gaudí, constituyen un marco adecuado, junto con algunas lecturas del arquitecto, para 
entender el alcance de lo que está fraguando al calor de la arquelogia litúrgica y el denodado empeño de facilitar una más viva participación de los fieles en la eucaristía.

- AAVV Asociación Española de Profesores de Liturgia. (2009) El Movimiento Litúrgico y la reforma litúrgica. Barcelona. Centre de Pastoral Litúrgica, Culmen et Fons.

Preliminares y focos del Movimiento Litúrgico en España, Silos y Montserrat. Referencia a la importancia de la música sacra y del canto gregoriano (el padre Suñol y su escuela), publicaciones y revistas, etc. El congreso litúrgico de Montserrat, sus conclusiones y trascendencia a posteriori.

- Botte, B. (2013) El Movimiento Liturgico, Testimonios y recuerdos, en Cuadernos Phase 211. Barcelona. CPL.

Para percibir lo que significó el Movimiento Litúrgico se describe la situación existente con el cambio de siglo, cuando la misa era cosa de clérigos y el pueblo asistía mudo y pasivo a las funciones litúrgicas. Recoge su experiencia de trato con los principales iniciadores de este movimiento, en especial con Dom Beauduin y Dom Marmion, así como las actividades desarrolladas en la abadia de Mont-César y en la de Maria-Laach.

- Lercaro, G. y Rousseau, O. (2001) Pio X y la Reforma Litúrgica. Barcelona: Cuadernos Phase 112. CPL

Escrito por personalidades que tuvieron participación activa en el desarrollo de la reformad litúrgica emanada del Vaticano II, ahonda principalmente en la participación activa como principio fundamental de la reforma emprendida con el Motu Proprio de Pio $\mathrm{X}$, buscada a través del conocimiento y amor a la liturgia por parte del pueblo cristiano como activo para fomentar su participación en un culto colectivo en contraposición al individualismo del Protestantismo que había suprimido la liturgia, de facilitar el acceso a la comunión de todos los fieles, los enfermos y los niños, y del reencuentro con el canto y la música en la liturgia (canto gregoriano) y la reforma del Breviario con el restablecimiento de la importancia del domingo, lo que llevó consigo la incorporación de los laicos a sus rezos y la necesidad de su traducción. Destaca el carácter magisterial de la reforma litúrgica de Pio $\mathrm{X}$ saliendo de los monasterios $\mathrm{Y}$ entrando por la puerta grande de la Iglesia universal. Se incluyen la carta pastoral de restauración del canto gregoriano, el Motu Proprio y otros decretos sobre la comunión de Pio $X$.

- Franquesa, Adalbert. (1966) I/ Congrés Liturgic de Montserrat, Vol. 1. (2a Ed.) Montserrat. Publicaciones de la Abadía.

Franquesa trata de la significación histórica del Primer Congreso, 1915, su preparación remota y próxima (destacando la figura del obispo Campins, la labor de la Lliga espiritual de la Mare de Deu de Montserrat y los congresos de Arte Cristiano en Cataluña), referenciando la participación de Gaudí en la Mesa del Congreso. Respecto de la celebración del congreso resalta la exposición del obispo Joan Benlloch sobre la participación del pueblo en la liturgia y la de clausura, a cargo del nuncio Mons. 
Ragonessi sobre el valor educativo de la liturgia católica, que fue quien sugirió al Dr. Gomá la redacción del libro del mismo título. Incluye los puntos fundamentales del congreso y las consecuencias o frutos del mismo.

- Franquesa, Adalbert. (1965) El Congreso litúrgico de Montserrat de 1915. Qüestions de vida cristiana, no25, separata. (2a Ed.) Montserrat: Publicaciones de la Abadía.

Referencia del congreso liturgico de Montserrat de 1915 centrada en el papel de la Abadia y la situación de la liturgia en Cataluña, los principales promotores (Carreras y Sunyol), conclusiones del congreso y algunos eventos litúrgicos posteriores en Cataluña.

- Gomá y Tomás, Isidro. (1918) El valor educativo de la Liturgia Católica. Barcelona. Librería y Tipografia Católica Pontificia.

Escrito en 1918 tras el congreso de Montserrat, es importante para describir el espíritu que animaba la celebración del congreso: mostrar el papel fundamental que desempeña la Liturgia en la vida de la Iglesia y en consecuencia revitalizarla. Presenta numerosas citas de publicaciones de monjes benedictinos iniciadores del Movimiento Liturgico. Al tratar del Arte como un elemento objetivo de educación al servicio de la Liturgia y del simbolismo en el templo cristiano, iglesia material, se ocupa de cuestiones presentes en el Circulo de San Lucas, los amigos del Arte Cristiano y otros ámbitos próximos al interés de Gaudí. Describe las partes del templo, el mobiliario litúrgico, y utensilios sagrados.

- Solans, Joaquin. (1901) Manual Litúrgico. Octava edición del original de 1880. Barcelona. Imprenta de Subirana Hermanos.

Manual Liturgico, breve exposicion de las sagradas ceremonias que han de observarse en la Misa, así privada como solemne, en la Exposición del SS. Sacramento, en las funciones más principales de ente año, en la Administración de los SS. Sacramentos, Bendiciones, etc. del Ritual Romano y en la visita Pastoral. Establece la conexión entre las preces y rúbricas litúrgicas tal y como habian sido aprobadas en tiempos del concilio de Trento, de la cual se preocupa el autor en señalar la obligatoriedad de observar el Ritual Romano publicado por Paulo V, y siglo XIX. Por la época y el lugar de publicación, pudiera haber formado parte de la biblioteca particular de Antonio Gaudí antes de su participación en el Congreso Litúrgico de Monteserrat.

- Antoñana, Gregorio Martínez de. (1923) "Manual de Liturgia Sagrada". Segunda edición del original de 1921. Madrid. Editorial del Corazón de Maria.

Manual litúrgico según la reforma del Código de Derecho Canónico y del Misal Romano (Ed. típica de 1920) que cierran las reformas litúrgicas emprendidas por el Papa Pio X. Interesante para dar una idea de la situación de la Liturgia en los últimos años de trabajo de Gaudí en la Sagrada Familia. Entre la bibliografía que menciona haber manejado hay libros que pudo haber conocido o leído Gaudí, puesto que abarcan un periodo de tiempo que va de 1875 a 1919. En concreto menciona L'Année Liturgique, 
que si leia y releia Gaudí, asi como una versión del Ceremonial de los obispos de 1902 y el Manual Liturgico de Solans, edicion de 1913.

- Carreras i Mas, Lluis y Tarré, Josep (1915) "Eucologi: publicació oficial del Congrés Liturgic de Montserrat" Barcelona. Ramos Editor.

Uno de los libros de lectura continuada de Gaudí, viniendo a sustituir al Manual de Solans. Promovido por el Congreso Litúrgico de Montserrat, del cual era publicación oficial, comprende las oraciones privadas de los fieles y los textos de los actos oficiales y públicos de la Iglesia, de acuerdo a la jornada diaria y al calendario litúrgico, con una pequeña introducción dogmática, los ritos, el Propio del tiempo con sus lecturas, oraciones, etc., el Orden de la Misa, e incluso, para favorecer la participación de los fieles, las notas del canto gregoriano correspondientes a las principales fiestas.

- Gueránguer, Dom Prósper. (1954). El Año litúrgico. Primera edición española del original L'Année Liturgique de 1875, traducida por los monjes de Silos. Tomo I. Burgos: Ed. Aldecoa.

De todos conocido como uno de los libros de cabecera de Gaudí, es un manual biblíco litúrgico que repasa todo el ciclo anual con explicación histórica, mística y liturgica de los tiempos liturgicos y de sus solemnidades, fiestas y memorias, expuestas a la luz de los Santos Padres y la Teologia. Fue obra capital en la biblioteca de Antonio Gaudí, quien, al decir de sus colaboradores, tenia completamente gastadas las páginas de este libro que releia continuamente. Probablemente Gaudí leyó el original en francés, idioma que dominaba, ya que la primera traducción al español es ésta de 1954.

- Schuster, Cardenal A.I. (1956) Liber Sacramentorum. Estudio histórico-litúrgico sobre el Misal Romano. Versión española de la edición original italiana de Turín, 1919. (Tomo 1) Barcelona. Herder.

Obra destinada a sus alumnos de la Escuela Superior de Música Sagrada, estudia histórica y arqueológicamente el Misal Romano, a la vez que sus aspectos místicos y teológicos, a partir de unas nociones generales de la Liturgia, su división y fuentes. Repasa la reforma gregoriana del siglo VI, el desarrollo de la "schola musical lateranense", la situacion de la penitencia en la antigua disciplina eclesiastica, la dedicación de las basilicas,...e incluso las artes sagradas. Se corresponde con Gomá y Carreras en la difusión e impulso que se quiere dar a la renovación litúrgica, aunque desde el ámbito de la música sagrada que también desarrolló el P. Suñol en Barcelona.

El Arte cristiano, cuando es cultual, se nutre de la misma Liturgia para colaborar en su epifania estética; se vuelve vehículo de su significado trscendente y de su misión pastoral, no como añadido ornamental sino como explosión de la creatividad artística, que se traduce en diversos estilos, elementos y formas. Para una aproximación a la relación existente entre Liturgia y Arte, que entiende éste no solo como instrumento al servicio de aquella sino como parte inherente de la misma, es necesario hacer memoria del bagaje litúrgico adquirido hasta el momento; pero también hay que adentrarse en la dimensión estética de la liturgia y en reflexiones que ponen el acento en cuestiones candentes 
respecto del Arte Sacro, su concepción, experiencia y gestión, y puntos de contacto o de fricción con otras disciplinas.

Así será posible disponer de un sólido soporte para comprender el significado más profundo del edificio-iglesia por cuanto se parte de suficientes significados para establecer las distintas categorías de relación entre el sentido del culto y su expresión artística; surgirán herramientas válidas para analizar históricamente el fenómeno del espacio cultual cristiano y para aportar aspectos clave a tener en cuenta en cualquier análisis de dicho espacio arquitectónico, que ha ido variando y conformándose en función de la teología y liturgia de cada tiempo.

- AA.VV. (P. Tena, D. Iguacen, L. Maldonado, I. Oñatibia, J. Bellavista) El arte en la Liturgia. Barcelona. Cuadernos Phase no47. CPL

Conjunto de artículos de primeras figuras con relación a la necesidad del permanente dialogo del arte y la liturgia en el plano teologico. Impecable argumentación de Tena sobre la belleza y el derecho de los fieles a ella como un asunto urgente para la Iglesia de hoy. Maldonado hace una observación fenomenológica de la belleza, citando testimonios de pensadores religiosos del siglo XX, mártires en la Segunda Guerra Mundial, y entra en la reflexión de la estética al servicio de la belleza de la celebración en la asamblea cristiana. Oñatibia insiste en la oportunidad e importancia del diálogo de la iglesia con los artistas, y en el papel formador y custodio del arte sacro que tienen los Institutos de Arte Sacro y las Comisiones episcopales de Arte Sacro y Liturgia, cuyo establecimiento y funcionamiento considera fundamental.

- AAVV "Arte Sacro, un proyecto actual" Actas del I Curso de Arte Sacro. Madrid. 1999. Fundacion Felix Granda.

Actas del curso celebrado en Madrid en octubre de 1999. Recoge las ponencias, comunicaciones y mesas redondas realizadas, de diversos enfoques y materias relativos a Liturgia, Literatura y Pensamiento, Arquitectura, Artes Plásticas y Música. Así, por ejemplo, Juan Plazaola diserta sobre la nueva sensibilidad y el arte sacro, y Alfonso Lopez Quintás sobre el poder formativo del arte sacro. Mario Botta presenta cinco iglesias realizadas, y Luis Aymá Gonzalez nos introduce en la Arquitectura sacra contemporánea: la elocuencia del espacio.

- AAVV "Artes Plásticas: experiencia y gestión de lo sagrado" en Actas II Curso de Arte Sacro. Madrid. (2000) Fundación Felix Granda.

Actas del curso celebrado en Madrid en octubre de 2000. Fred Licht habla de la dimensión religiosa del arte en su ponencia sobre Arte religioso contemporáneo. Michel Pochet nos introduce en la autenticidad del arte contemporáneo como autenticidad humana, y por tanto testimonio de una experiencia. Ma Antonietta Crippa, en su ponencia Arte y mensaje cristianos, hoy: la emersión de lo sacro, llama la atención sobre los arquitectos y la arquitectura en la génesis del bien común y presenta algunos ejemplos como el de Antonio Gaudí. 
- Ferrer Grenesche, Juan Miguel y AAVV. ((2013) "La liturgia, inspiradora de las artes". Barcelona. Centre de Pastoral Liturgica.

Plantea diversas cuestiones de actualidad respecto de la relación entre Arte y Liturgia apoyándose en la línea argumental de Benedicto XVI que sitúa la cuestión del camino de la belleza en el centro de la misión evangelizadora. JM Ferrer dejan claro que el arte sacro cristiano deviene-arte litúrgico- cuando nace de y para la acción litúrgica, cuestión básica en la presente investigación y en el pensamiento y producción de Gaudí, asegurando que éste no es un mero aderezo oranamental sino que forma parte de la acción litúrgica. De ahí que el lugar de la celebración busca reflejar esta realidad. JM del Rio Carrasco se adentra en la función eclesial de las artes después del Vaticano II y Francisca Soto plantea la cuestión de la liturgia a la hora de tratar la restauración de una obra.

- Plazaola, J. (1965).Arte sacro actual. Madrid. BAC

En este libro se incide en lo sacro, lo religioso y lo artístico desde la Grecia clásica, las exigencias y condiciones técnicas del arte, los imperativos de la liturgia, el artista y el templo cristiano. Con mayor detalle se trata de los espacios celebrativos y elementos al servicio de la asamblea cristiana reunida, de las imágenes, iconografía y utensilios litúrgicos. Como Apéndices aporta una completa trascripción de documentos eclesiásticos, sumos pontífices desde Gregorio Magno a Pablo VI, definiciones de concilios, prescripciones de Derecho canónico, Decretos, documentos episcopales de alcance nacional y otros.

- Plazaola, J. (2006) Arte sacro actual. Madrid. BAC.

Esta versión actualizada de la obra del mismo autor, constituye en realidad un libro distinto por cuanto el planteamiento varia ligeramente y la revisión de sus contenidos y realizaciones artísticas es menos teórica y está mucho más circunscrita al culto cristiano, en las exigencias de la renovación litúrgica iniciada con el Movimiento Litúrgico y ampliada con el Concilio Vaticano II y en la visión actual del arte sacro. Presta más atención al desarrollo de la arquitectura ligada a la Liturgia y a las condiciones del artista que desarrolla su actividad en el campo de lo sacro.

La incidencia de la Liturgia en la Arquitectura de las iglesias cristianas ha sido abordada en algunos estudios y publicaciones. Me parece importante señalar que algunos de ellos son coetáneos con la vida de Gaudí, otros han seguido el camino que discurre desde el Movimiento Litúrgico hasta su culminación en el Concilio Vaticano II, los más han pretendido aplicar las directrices eclesiales postconciliares a la arquitectura eclesiástica, pero todos inciden en la singular dimensión de la arquitectura sagrada y la dificultad de la adecuación del espacio litúrgico. 
- Tarré, Josep. (1925) "Estructura litúrgica en la construcció dels temples" en Anuari dels amics de l'art liturgic. Barcelona. Cercle Artistic de Sant Lluc.

Da una notas históricas para la comprensión de la evolución de los edificios iglesia desde las primeras basílicas, a la luz de la celebración litúrgica de la eucaristía y según lo que marca el Ceremonial de los obispos y la Congregación de los Ritos, poniendo de relieve la actuación realizada por Gaudí en la seo de Mallorca. Plantea cuestiones como la tipología de la planta, la centralidad del edificio, la estructura y cubrición del espacio, analizando diversos ejemplos históricos. Así mismo da diversas normas prácticas litúrgicas, y analiza según ellas algunos templos del siglo XIX coetáneos con la Sagrada Familia. Fundamental para apreciar el esfuerzo gaudiniano en su arquitectura ecelsiastica dentro de un entorno artístico y litúrgico sensible a la renovación liturgica y el concurso de las artes en ella.

- AAVV (2003) Templo cristiano y espacio litúrgico. Madrid. Fundación Felix Granda.

José Luis Gutierrez-Martin prologa dos ponencias del simposio "La Arquitectura Sacra en el siglo XXI: Diálogo Creación-Finalidad" en el III Curso de Arte Sacro celebrado en la sede del Colegio de Arquitectos de Madrid, desde la necesidad que tiene la liturgia del arte para ser mediación más fiel y auténtica del misterio que en ella acontece. Así, Pedro Rodríguez responde a la cuestión de qué es propiamente un Templo Católico con una explicación teológica que desde los orígenes del Cristianismo y de la mano de los textos bíblicos muestran el edificio de la iglesia como el lugar donde se reúne la comunidad para la celebración que fundamenta la fe cristiana, la Parusía eucarística, presencia de Jesucristo sobre el altar, y que continua después presente para la oración, adoración, etc. en el Sagrario.

- Fernandez del Amo Moreno, J.L. (2006) Arquitectura de la Liturgia, en Ars Sacra n으․

Reedición del articulo original del mismo título publicado originalmente en 1948, en el que el autor reivindica la Liturgia como directriz para el diseño de los edificios-iglesia, haciendo especial reseña de la obra de Guardini sobre el Espiritu de la Liturgia y su influencia en la Arquitectura eclesial de la Alemania inmediatamente posterior a la Primera Guerra Mundial y del cardenal Gomá en España después del Congreso Litúrgico de Monteserrat.

- Lercaro, G. (1971) Art Sacrée et achitecture moderne. Paris. CERF.

Lercaro defiende la idea de que el contenido es capaz de dar lugar a valores arquitectónicos propios y aboga por encontrar el lugar adecuado de la acción litúrgica en el momento actual, dejando que otras generaciones puedan hacer las adaptaciones que correspondan. Capellades incide en la situación en Francia respecto del hecho religioso en la década de los sesenta. E. A. Sövik diserta acerca de las cualidades que configuran la arquitectura religiosa. J. G. Davies nos introduce en el debate sobre la forma y la función en arquitectura, de la mano de las opiniones de algunos maestros de la arquitectura moderna. 
- Godoy Fernandez, Cristina. (1989). Arquitectura cristiana y liturgia. Reflexiones en torno a la interpretacion funcional de los espacios. Barcelona. UNED.

Aporta una serie de datos arqueológicos respecto de determinadas liturgias de Occidente y su incidencia en la construcción de las iglesias.

- Humphrey, Caroline y otros. (1997) Arquitectura sagrada. Madrid-Barcelona. Circulo de lectores.

Trata de la expresión del fenómeno religioso en la Arquitectura a lo largo de la Historia de la Humanidad y de las diferentes culturas y religiones. Presenta un registro gráfico de algunos edificios de arquitectura sagrada y una sintética referencia a técnicas de construcción. Así mismo secuencia diversos elementos arquitectónicos del espacio sagrado en términos culturales.

- Bérgamo, Maurizio y Matia del Prette. "Espacios celebrativos. Estudio para una arquitectura de las iglesias a partir del Concilio Vaticano II". Bilbao (1998) Colección Teshuvá.

Investigación realizada en el departamento de Proyectos arquitectónicos de la Facultad de Arquitectura de Venecia durante los años 1991-1993. Estudio sobre el planteamiento arquitectónico de las iglesias después del Concilio Vaticano II partiendo de la problemática que presenta la figuración arquitectónica y el simbolismo litúrgico. Resulta de interés el análisis de la asamblea liturgica postconciliar y sus diferentes propuestas organizativas, a la vez que la pretensión de ligar ésta con los espacios celebrativos de los primeros tiempos del Cristianismo profundizando en el misterio de la celebración pascual. En cambio resulta excesivamente sucinta la critica de diversas iglesias históricas y la presentación de tres experiencias proyectuales en Europa.

- Crippa, Maria Antonietta. (2002) "Espacio Sagrado y Arquitectura", en Diccionario de Iconografia y Arte Cristiano. Madrid. Paulinas.

Diccionario temático italiano. Entrada sobre las diferenciaciones espaciales del espacio sagrado y su relación con la liturgia, mencionando el hito que supuso para la arquitectura del edificio-iglesia los proyectos de Rudolf Schwarz en la Alemania posterior a la Primera Guerra Mundial.

- Farnés, P. (1989) Construir y adaptar las iglesias. Orientaciones doctrinales y sugerencias prácticas sobre el espacio celebrativo, según el espíritu del Concilio Vaticano II. Barcelona. Ed. Regina.

Breve tratado sobre los espacios celebrativos con una buena base histórico liturgica y según el espíritu de la concilio Vaticano II. Da orientaciones doctrinales sólidas y sugerencias prácticas para que la asamblea celebrante capte lo que se celebra, ayudándole a ello la adecuación del espacio liturgico. Recoge el tratamiento del altar, ambón, lugar para la Penitencia, de la reserva eucarística, etc. en la historia y más concretamente en el Movimiento litúrgico, como antecedentes del Vaticano II. Constituye un buen punto de partida para la reflexión y el diseño de nuevas iglesias. Presenta una interesante introducción de J.L. del Palacio sobre bautismo y baptisterios. 
Antes de adentrarnos en la obra de Gaudí merece la pena detenerse en algunos estudios y tratados que analizan la Arquitectura Religiosa desde el Ochocientos, al objeto de disponer de una visión sintética de la producción arquitectónica respecto de la tipología de los edificios iglesia en el contexto histórico de la investigación, así como para mostrar algún ejemplo significativo de las iglesias y templos votivos dentro del fenómeno tan característico que se produce con posterioridad a la desaparición de los Estados Pontificios y la guerra Franco-Prusiana en 1870.

- Benévolo, Leonardo. (1999) " $H \underline{a}$ de la Arquitectura Moderna". 8o Edición. Barcelona. Gustavo Gili. UPV

Dentro de esta clásica obra generalista es interesante mencionar el enfoque de la arquitectura de Viollet-le-Duc, excluido de toda referencia romántica o sentimental, como una pretensión de propiciar un código arquitectónico más realista que el de las Academias clásicas basado en el uso apropiado de los materiales y la obediencia a las necesidades funcionales. Presenta fotografías de algunos ejemplos de arquitectura religiosa de principios de siglo XX de interés.

- Flores, Carlos (1989). Arquitectura española contemporánea, 1880-1950. Vol. 1. Madrid. Ed. Aguilar.

Enmarca a Gaudí en el apartado del Modernismo catalán dentro de la corriente general que ve su figura desde una visión escultórica y plástica más de artista que de arquitecto (tal y como se concebia mayoritariamente a éste en el siglo XX). Aporta algunos datos e imágenes de iglesias medievalistas españolas que permiten constatar la diferencia de planteamientos de la Sagrada Familia de Gaudí aunque no profundiza.

- Hichtcock, Henry-Russell. (2008).Arquitectura de los siglos XIX y XX. Madrid: Ed. Cátedra.

Presenta un interesante repertorio de arquitectura eclesiástica europea en el siglo XIX. Respecto de la presente investigación su interés radica en la referencia que hace al panorama de las iglesias neomedievalistas europeas y americanas, y su influencia en el diseño de iglesias votivas neogóticas como la Votivkirche de Viena o las de inspiración románica, bizantina y gótica en Francia: Sacrée Coeur de Paris, Marsella, Saint Dennis, etc.

- Navascués, Pedro (1996). Arquitectura Española 1808-1914, en "Summa Artis, Historia General del Arte", Tomo XXXV. Madrid. Espasa Calpe.

Dentro del neomedievalismo señala la importancia de la arquitectura religiosa después del Concilio Vaticano I, asumido aquel como estilo netamente católico en academias y congresos de arquitectura. Hace un recorrido cronológico y monumental de algunas obras del periodo como la catedral de la Almudena, citando otras iglesias, seminarios, capillas, etc. hasta llegar a detenerse en la obra de Antonio Gaudí y dentro de ella en su proyecto para la Sagrada Familia como experiencia funcional y estructural que difiere notoriamente de otros ejemplos del mismo periodo. 
- Fernández Cobián, Esteban. (2005) El espacio sagrado en la arquitectura española contemporánea". La Coruña. ETSA

A partir de fundamentos básicos en el campo de la Arquitectura y la Liturgia Cristiana se adentra en experiencias de arquitectura eclesiástica europea ligadas a la renovación de ésta que se produce desde la segunda mitad del siglo XIX. No obstante el análisis del Quickborn y las arquitecturas de los Schwarz, Bartning, Bóhm, Steffan, etc. a partir de los años 20, no se aprecia una conexión clara entre los postulados de los liturgistas pioneros del Movimiento Liturgico, excepción hecha de Guardini, y dichas realizaciones, faltando datos sobre arquitectos un poco anteriores pero de fuertes resonancias en el Movimiento Lirturgico como Martin Webber. En la segunda parte se centra en la experiencia española hasta 1950. Es Ilamativo el escaso espacio que dedica a Gaudí, coetáneo de Webber en muchas obras, mencionando únicamente su expresionismo arquitectónico y su interés por la Liturgia.

- Gil Gimenez, Paloma. (1999) La idea del Templo en la Arquitectura del siglo XX. Barcelona. Ed. del Serbal.

Tesis Doctoral de 1996 en la ETSA de Valladolid. Repaso de la obra arquitectónica y fundamentos de los proyectos de edificios-iglesia de algunos arquitectos europeos de comienzos del siglo XX: Josef Plecnik, Otto Burnning, Hans Poelzig, Domenikus Bhom, Rudolf Schwarz.

Aunque hay adentrarse en los proyectos de arquitectura de Antonio Gaudí (sus claves, periodos y obras más significativas) para aproximarnos a la visión de su producción artístico-litúrgica, que se desarrolla a la apr que aquella a lo largo de toda su actividad profesional, resulta todavía más imprescindible acercarse a su pensamiento, tanto a nivel oral como escrito, que no es estático ni puramente estético sino evolutivo, interdisciplinar y sintético en grado sumo.

- Bassegoda Nonell, Joan. Aproximación a Gaudí. Barcelona. 1992. Cátedra Gaudí. Dentro de la línea recopilatoria de Bassegoda presenta el interés de mencionar algunas realizaciones de sus colaboradores influenciadas por la arquitectura gaudiniana y pero sobre todo sus colaboradores en oficios determinados, algunas de cuyas técnicas y soluciones constructivas describe.

- Bassegoda Nonell, Joan, y Garcia Gabarró, Gustavo. "La cátedra de Gaudí. Estudio analítico de su obra." Barcelona 1999- Ediciones de la UPC.

Recopilación y síntesis de algunos estudios realizados en la cátedra Gaudí, especialmente en relación con las distintas etapas de la obra arquitectónica del arquitecto así como consideraciones respecto de la denominada superación del gótico por Gaudí y la influencia de la arquitectura neogótica en el siglo XIX. Muestra también una síntesis de la Tesis doctoral de Gustavo Garcia Gabarró respecto de la inspiración en la naturaleza y las formas arquitectónicas naturales de la arquitectura gaudiniana. 
- Bohigas, Oriol. (1968). Arquitectura Modernista. Barcelona. Lumen.

El enfoque de Gaudí como un arquitecto modernista que evoluciona hasta llegar a encerrarse cultural y arquitectónicamente en la Sagrada Familia después de un periodo de madurez y plenitud profesional -edificios de viviendas del Paseo de Gracia, el Parque Güell y la iglesia de la Colonia Güel- hoy dia está superado. Bohigas no conoce la producción eclesiástica de Gaudí ni sus fundamentos, y tampoco se hace eco de sus hallazgos estructurales.

- Casanelles, E. (1965). Nueva visión de Gaudí. Barcelona: Polígrafa.

Enfoque pionero de la dimensión artística de Gaudí desde la crítica del arte del siglo XX y algunas claves de la psicología y vida del arquitecto.

- Casanelles, E., Collins, G. y AAVV (1991). Antoni Gaudí. Barcelona: Eds. del Serbal.

Estudio crítico de la arquitectura gaudiniana con una cuidada selección de textos básicos para su conocimiento a cargo de Salvador Tarragó. Rubió trata de la sistematización de la componente estructural y su respuesta al dilema estructuraforma. Folguera analiza el estilo y la técnica en la producción gaudiniana. Cirlot interpreta las principales etapas de la producción gaudiniana y la Sagrada Familia según la psicología del arquitecto. Casanelles analiza la vertiente artística de la Sagrada Familia dentro su obra y en relacón con las corrientes del momento. Collins es el que de una manera más consistente se aproxima al debate estructura-forma, partiendo de las técnicas constructivas tradicionales que emplea, de los testimonios de colaboradores que recoge y de las novedades que trae el Templo Expiatorio. Tarragó presenta el debate estructura-forma desde las distintas etapas de su producción y la influencia que ve de diversos edificios históricos, haciendo hincapié en la relación entre estructuralismo y plasticidad para acabar valorando la Sagrada Familia como una obra excepcional aunque casi arqueológica al no entrar en su dimensión teológico-litúrgica.

- Cirlot, Juan-Eduardo. (1952) El arte de Gaudí. Barcelona.

Cirlot realiza una clasificación artística de la obra de Gaudí atendiendo a la etapa de formación, diversos periodos creativos y producción de los últimos años. A destacar una primera interpretación mística de la Sagrada Familia y la inserción de Gaudí dentro de la corriente expresionista europea.

- Cirlot, Juan-Eduardo. (1966) Gaudí. Barcelona. Ed. R.M.

Visión artística y global de la obra gaudiniana que considera revolucionaria en el campo de la arquitectura eclesiástica con una concepción sensiblemente unitaria, global y sagrada de cada proyecto, que constituye un campo de experimentación en constante y compleja evolución hacia una síntesis de forma, técnica, construcción, uso y simbolismo. Resulta de interés también la mención de las principales influencias recibidas durante los años de formación, los puntos de contacto con el inicio de las actividades de Gropius y los manifiestos de la Bauhuas, y algunas aportaciones que presenta su proyecto de la Sagrada Familia respecto al proyecto anterior. 
- Collins, George R. (1977). The Drawings of Antonio Gaudí. New York: The Drawing Center. (Ed. castellana. Dibujos de Gaudí, catalogación. Estudios Pro Arte nำ10. Barcelona. Abril-junio 1977.

Incluye un razonado analisis del conjunto de la arquitectura de Gaudí haciendo un repaso desde el contexto histórico-político de la época y la fuerte influencia mudéjar en la decoración así como la utilización de tradiciones constructivas catalanas, etc. hasta el desarrollo de las distintas fases de la producción gaudiniana. Apunta una lúcida visión más estructuralista del lenguaje modernista de Gaudí que el de Domenech i Montaner, influyendo la fachada de la Pasión como un anticipo de la última fase del Proyecto, y entroncando la vertiente geometrizante y ordenada de su última arquitectura con las corrientes preracionalistas europeas de los años veinte. Imprescindible recopilación de dibujos originales de Gaudí, aportados por el profesor Collins con la inestimable ayuda de Bassegoda y de un gran número de colaboradores y estudiosos de la obra gaudiniana.

- De Fusco, Renato. (1981) Historia de la Arquitectura Contemporánea, vol. I, edicion en castellano del original Storia dell'Architettura Contemporánea , 1975, Roma. Barcelona. Blume.

Si bien encuadra la obra de Gaudí como una de las variaciones de L'Art Nouveau, al destacar su sentido evolucionista desde la continuidad entre la tradición española, el eclecticismo y el modernismo, y las soluciones que anticipa más allá de su momento cultural apunta a una vision protorracionalista con un sentido moderno expresado del valor imaginario que comunica en lo artístico.

Giralt Miracle, Daniel. (2002) Gaudí, la búsqueda de la forma. Barcelona. Lunwerg.

Breve Publicación con motivo del 150 aniversario de su nacimiento, a partir de la exposición realizada. Prólogo de Giralt-Miracle analizando su concepto de forma y función a partir de la geometría estructuralista y el método de trabajo de Gaudí. Alsina y Gomez-Serrano abordan el tema de la geometria gaudiniana desde la creatividad tridimensional que utilizó Gaudí.

- Gonzalez Moreno-Navarro, José Luis y Casals Balagué, Albert. (2002). Gaudí y la razón constructiva. Madrid. Akal.

Visión incompleta de la obra de Gaudí desde el punto de vista constructivo por cuanto que no se valoran datos existentes de utilización y ensayos de los nuevos materiales.

- Lahuerta, Juan José y AA.VV. (1990). Gaudí i el seu temps. Barcelona: Barcanova. Documentado estudio sociológico de la arquitectura gaudiniana con referencias a la escuela de Arquitectura y los profesores que tuvo en diversas asignaturas consideradas como troncales, el carácter ecléctico de la arquitectura española en el siglo XIX, los puntos de contacto entre el lenguaje modernista y la producción gaudiniana, y su encuadre dentro del mundo intelectual, religioso y artístico catalán del cambio de siglo. 
- Martinell Brunet, César. (1967). Gaudí: su vida, su teoría, su obra. (1ạ ed.) Barcelona. COACB

De entre las obras clásicas, escritas por los primeros colaboradores de Gaudí, está considerada como una de las fundamentales. Aborda su vida personal, pensamiento arquitectónico y obra ampliamente apoyados sobre datos, testimonios, conversaciones y recuerdos con el autor, fotografías, dibujos y planos, que también contrasta, de tal manera que la información aportada resulta muy razonada y verídica. Aunque carece de critica la sistematización en las tres vertientes propuestas resulta altamente atractiva para la comprensión de la personalidad y obra de Gaudí. Como apéndice figuran los escritos sobre Ornamentación. Obra editada por el Colegio de Arquitectos.

- Mercader, Laura. (2002). Antoni Gaudí: escritos y documentos. Barcelona: El Acantilado.

Libo documentalista. Recopilación completa y ordenada de los distintos manuscritos, cartas y textos de Gaudí según criterios relativos a la exposición del pensamiento e ideas, documentos de proyectos, informes, cartas y epistolario, etc.

- Pane, Giulio y AAVV. (2008) Attualità di Gaudí/ a cura di Giulio Pane. Napoli. CLEAN

Recensión de diversos foros y congresos realizados en la Universidad de Nápoles, en 1993, 2004 y 2005. Se incide críticamente en diversas actuaciones de rehabilitación realizadas en obras de Gaudí, mostrando las alteraciones y deficiencias ejecutadas en algunas así como un interesante debate sobre la continuidad de las obras de la Sagrada Familia. En el congreso de 2005 se hace una novedosa e interesante aproximación critica a la obra de Gaudí desde diversos autores catalanes e italianos incidiendo en la modernidad de su contribución a la Arquitectura desde su trabajo a la vez artesanal y experimental, la concepción estructural puesta de manifiesto en distintas obras y periodos, así como los diferentes tipos de intervención realizados en obras sagradas inconclusas.

- Pane, Giulio y AAVV. (1993) Antoni Gaudí: una proposta di libertá. Simposio sobre Antonio Gaudí. Milano. Politécnico de Milano.

Profesores de Nápoles y Milán, Bassegoda y Jordi Bonet abordan la novedad y libertad del diseño de Gaudí que es capaz de renovarse continuamente y analizan la oportunidad o no de la prosecución de las obras de la Sagrada Familia, etc.

- Puig Boada, Isidre (1981) El Pensament de Gaudí: compilació de textos $i$ comentaris. Barcelona: La Gaya Ciencia.

Fundamental. Recopilación ordenada de textos manuscritos de Gaudí realizada por uno de sus más próximos colaboradores y estudiosos de su obra. Incorpora reflexiones y comentarios realizados por Gaudí en plena madurez, agrupados por su temática e indicando quien era su interlocutor en cada caso. Libro referencial para conocer el pensamiento que sustenta la arquitectura gaudiniana. Recomendado por el Colegio de Arquitectos. 
- Solá-Morales, Ignasi. (1983) Gaudí. Barcelona: Ediciones Polígrafa.

Estudio de la arquitectura gaudiniana a partir de su trascendencia para la ciudad de Barcelona, incluyendo fotografías muy constructivas y una ficha introductoria de sus principales obras. Apunta una seria reflexión sobre cada una de las etapas de la producción gaudiniana partiendo de su formación universitaria e incidiendo en aquellos aspectos primordiales de cada proyecto que permiten una lectura de su evolución.

La arquitectura religiosa de Gaudí ha sido estudiada fundamentalmente por Joan Bassegoda Nonell del cual se pueden citar porque aportan gran cantidad de datos: Los proyectos de Gaudí para las religiosas de Jesús-Maria, 1877-1882 (1969), Gaudí, la arquitectura del espíritu (2001), Gaudí, Espais Sagrats (2002), Gaudí: todas sus obras (2007), El gran Gaudí (1989) y gaudí: o espacio, luz y equilibrio (2002).

Joan Bergós, uno de los arquitectos colaboradores y más profundamente conocedores de su obra, tiene un libro fundamental, en el que aborda su concepción del arte, la arquitectura y la liturgia, Gaudí, el hombre y su obra, en el que establece además las diversas etapas de su obra e incide en su arquitectura eclesiástica más emblemática: iglesia de la Colonia Güell, catedral de Mallorca y la Sagrada Familia.

Isidre Puig Boada nos deja un completo estudio del proyecto de la Esglesia de la colonia Güell (1976), adentrándose en la concepción arquitectónica del edificio iglesia que tenia el arquitecto y que en este caso puede plantearse con libertad desde el principio, resultando del mayor interés su interpretación volumétrica del edificio.

Existen también otras publicaciones de ineludible conocimiento, como las de Emilio Sagristá, Rotger Capllonch, Kerrigan, Llabrés, Aina Pascual, y la tesis doctoral de Ma Soledad Liaño, respecto de la catedral de Mallorca; las que se adentran en la liturgia aprendida por Gaudí durante su estancia en Astorga con el obispo Grau, Conrad Kent (1989), profundizan en los fundamentos ideológicos de la arquitectura del Gaudí de madurez, Jaume Genis i Terre (2009).

La Fundacion Joan Maragall ha dedicado diversos estudios a analizar la dimensión trascendente de Gaudí y su arquitectura, Anna Blasco y AAVV. (2004), y el Centro de Estudios Gaudinistas ha organizado amplias jornadas a sus obras sacras más emblemáticas y a la forma de trabajar de Gaudí, congregando a especialistas de la talla de Crippa, Flores, Bassegoda, Bonet, Llabrés, Tomlow, etc.

- Bassegoda Nonell, J. (1969). Los proyectos de Gaudí para las religiosas de Jesús Maria (1877-1882) Barcelona: Ediciones Literarias y Científicas.

Los datos históricos y descripción arquitectónica de los proyectos realizados en el Colegio de Tarragona y en el de San Andrés del Palomar (altar y tabernáculo de las capillas) permiten conocer los primeros trabajos de Gaudí en arquitectura eclesiástica. Lanza la hipótesis de la posible colaboración de Gaudí en la ejecución de toda la capilla de Tarragona y describe el comienzo de la relación con el obispo Grau. 
- Bassegoda Nonell, Joan. (2001) Gaudí, la arquitectura del espíritu. Barcelona: Salvat Editores.

Ilustrativo repaso y descripción de las obras de naturaleza religiosa de Antonio Gaudí, desde las primeras obras menores de altares y capillas, pasando por las colaboraciones en los proyectos de Martorell y Villar, y otras aportaciones a cofradías y hermandades, hasta llegar a la restauración litúrgica de la catedral de Mallorca, la iglesia de la colonia del Parque Güell y la Sagrada Familia. Recoge el discurso a los josefinos de 1891 a partir de manuscritos más antiguos, cuyo contenido constituye una sólida muestra de las ideas de Gaudí respecto del encargo recibido.

- Bassegoda Nonell, J., Crippa, Mạ A. y AAVV. (2002) Gaudí. Espais Sagrats. Barcelona: Lundwerg.

La obra gaudiniana desde la óptica de la arquitectura sagrada, con la aportación de ensayistas nacionales y extranjeros. Crippa trata del concepto de sagrado y la racionalidad constructiva de Gaudí. Bassegoda incide en el mismo tema pero desde el análisis de la Iglesia de la Colonia Güell y otros proyectos de Gaudí. Jordi Bonet hace un repaso de las visicitudes de la obra de la Sagrada Familia desde la muerte de Gaudí hasta ahora. Olives-Puig se acerca al simbolismo de la Sagrada Familia. Ramón Pannikar trata de la concepción del espacio sagrado para Gaudí desde la óptica de su filosofía. Finalmente Hou The-Chien y Masayuki Irie dan una visión oriental de la producción gaudiniana. La obra se acompaña de un buen numero de fotografías de gran calidad.

- Bassegoda Nonell, Joan. (2007) Gaudí todas las obras. Menorca. Triangle Puntals.

Reflexiones sobre el concepto de racionalidad y de funcionalidad en Gaudí. La conclusión de que encontró la belleza al buscar un edificio racionalmente litúrgico se corresponde con el pensamiento que expone Gaudí en sus escritos pero no aporta novedades.

- Bassegoda Nonell, Joan. (1989) El gran Gaudí. Sabadell. AVSA.

Tiene el interés de analizar las principales obras de Gaudí con una recopilación de datos y fechas. En la Sagrada Familia realiza una descripción del proceso de plasmación material de la idea de construir el Templo y de las personas que ayudaron a ello. Explica con detalle el inicio de las obras, los hechos relacionados con el cambio de arquitecto y las fechas de los principales hitos constructivos y de diseño del proyecto, destacando que en 1906 se publicó por primera vez un croquis del conjunto total de la obra. Indicaciones del simbolismo de la obra, de los materiales y dimensiones. Trata también la restauración litúrgica de la catedral de Mallorca. Menciona que en la exposicion de Paris de 1910 en homenaje a Gaudi fueron hasta 4 o 5 las soluciones de Villar. Indica que la primera solucion o proyecto (grabados de El Propagador) era una iglesia gótico-románica, la 2a solucion torre gótica y atrevido cimborio, contrato en apendice X del libro de Martinell 1967. 19-03-1882/25-08-1883 Pliego de condiciones solo excavacion y desmonte de la cripta. 
- Bassegoda Nonell, J. (2002) Gaudí: o espacio, luz y equilibrio. Madrid. Criterio Libros.

Aporta datos respecto de la relación profesional entre Bocabella y el primer arquitecto, Villar, la renuncia de éste a las obras y lo que quedó reflejado en actas notariales. Cuestiona que el cambio de perfil de los arcos de la Cripta, que pasan de semicirculares a ojivales, fuese cosa de Gaudí como mencionan Ràfols, Collins y Martinell, apoyándose en una segunda versión del proyecto de Villar, más goticista, que ellos omiten, quizá por desconocimiento. El autor afirma también que Gaudí respetó bastante los últimos dibujos del proyecto de Villar (2 dibujos acuarelados de secciones de la Cripta) y que llegaron a visitar conjuntamente las obras. Aunque no aporta muchos datos al respecto, esta dinámica entra en la lógica del comienzo de la actuación de Gaudí en el proyecto que conocemos por documentos conservados y las afirmaciones de colaboradores.

- Bergós Massó, Joan. (2000) Gaudí, el hombre y su obra. (2a Ed.) Barcelona. UPC, Cátedra Gaudí, Ed. Aymá.

Edición actual de uno de los estudios clásicos de la obra de Gaudí, escrito por uno de sus más íntimos colaboradores. Bergós analiza su obra arquitectónica desde el conocimiento de la persona, hombre y arquitecto, que dá el haber mantenido tantas conversaciones con él. Entra en su concepción del arte, la arquitectura y la liturgia, con conocimiento de la materia. Establece diversas etapas en la producción gaudiniana. Trata los detalles de los proyectos sacros de Gaudí, especialmente de la iglesia de la colonia Güell, la seo de Mallorca y la Sagrada Familia. Obra fundamental.

- Blasco Bardas, Anna Mạ y AAVV. (2004) Gaudí i la dimensió trascendent. Barcelona. Fundació Joan Maragall y Ed. Cruïlla.

Iniciativa de la Fundación Joan Maragall para profundizar en el estudio de Gaudí con ocasión del 150 aniversario de su nacimiento. Antoni Pladevall trata de la religiosidad de Gaudí en el contexto de la de su época. Anna Ma Blasco realiza un interesante análisis de las relaciones personales de Gaudí con Maragall y Pijoan. Joan Galtés nos introduce en las relaciones del arquitecto con el mundo eclesiástico del momento en Cataluña y especialmente con Torras i Bages, Verdaguer y Casanovas. Crippa trata la concepción del sagrado en su arquitectura y Judith Rodhrer apunta su visión del catolicismo y el catalanismo entorno al proyecto de la Sagrada Familia.

\section{- Centro de Estudios Gaudinistas (2002). IX Jornades Internacionals d'Estudis} Gaudinistes. Gaudí a Mallorca. Palma de Mallorca.

Recoge interesantes artículos para el conocimiento de la obra de la catedral de Mallorca, entre ellos un interesante y documentado artículo de Pere Joan Llabrés sobre el obispo Campins, Gaudí y el carácter litúrgico de la restauración de la Seo de Mallorca. Otros artículos de interés inciden en la historiografía clásica de la arquitectura gaudiniana, la decoración cerámica realizada por Gaudí y Jujol en la catedral, su mobiliario litúrgico y breves aportaciones de Carlos Flores y Tokuthosi Torii a la interpretación de la arquitectura gaudiniana. 
- Genís i Terre, Jaume. (2006). Els fonaments ideològics de l'arquitectura religiosa del Gaudí de maduresa. Tesis Doctoral. Universidad Pompeu Fabra. Barcelona. Publicada en 2009, Gaudí entre l'arquitectura cristiana i l'art contemporani. Publicacions Abadia de Montserrat.

Trabajo interdisciplinario de filosofía, historia del arte y literatura. Aborda la figura de Gaudí a partir de antecedentes literarios y arquitectónicos (hermanos Schlegel, Victor Hugo, Hegel, Piferrer, Rogent, Peguin y Ruskin) y de algunas incursiones en el simbolismo de la arquitectura de la Sagrada Familia y la iglesia de la Colonia Güell.

- Kent, Conrad. "El obispo Grau y la arqueología sagrada", en Simposio sobre Gaudí y su obra. Astorga. 1889-1989.

Ponencia relativa a las inquietudes litúrgicas del obispo Grau, las corrientes en el episcopado español de la época y la relación de Grau con Gaudí.

- Kerrigan, Anthony. (1960) Gaudí en la catedral de Mallorca. Palma de Mallorca: Impremta Mossen Alcover.

Corta pero sintética y razonada publicación en la que se fundamenta el hecho sorprendente del encargo de este proyecto a un arquitecto tan imaginativo, autodidacta y poco respetuoso con el neogótico oficialista imperante como Gaudí, en la conjunción de intereses comunes dentro del marco de la renovación liturgica del momento que ambos comparten, de ahí que pueda describir sintéticamente los objetivos que perseguían promotor y arquitecto en esta singular intervención.

- Llabrés i Martorell, Pere Joan. (2002). Gaudí a la Seu de Mallorca. Palma de Mallorca: Govern de les Illes Balears.

Síntesis de la intervención gaudiniana en la catedral de Mallorca, casi como inventario o fichas de los elementos diseñados y resituados por Gaudí, con fotografías, y una muy interesante relación del mobiliario litúrgico diseñado por el arquitecto.

- Pascual, Aina; Durliat, Marcel; Murray, Donald G. (1995) "la catedral de Mallorca". Palma de Mallorca. Jose J. de Olañete Ed.

Descripción de celebraciones, autos sacramentales y procesiones en su interior, etc. Muestra la ambientación y funcionalidad del edificio con anterioridad a la intervención de Gaudí que permiten comprender el interés de Campins por su restauración liturgica y las claves del proyecto. Aporta datos y dibujos de anteriores proyectos de intervención.

- Puig Boada, Isidre. ((1976). L'Esglesia de la Colonia Güell. Barcelona. Lumen.

El estudio más completo del proyecto de la Iglesia de la Colonia Güell realizado por un colaborador inmediato de Gaudí. Partiendo del análisis de documentos y materiales así como del conocimiento del autor, propone una fundada base litúrgica, estructural y constructiva para explicar el proyecto. Plantea planos y secciones del edificio en función de las maquetas funiculares y croquis originales. Permite acercarse a lo que 
Gaudí entendía por volver a los orígenes en la concepción de la arquitectura y la volumetría de una iglesia desde unas sólidas bases conceptuales.

Para la descripción detallada de la construcción de la Sagrada Familia en tiempos de Antonio Gaudí, comparación con otras iglesias, visicitudes acaecidas, etc., es imprescindible acudir a diversos números y artículos del boletín de la Asociación de devotos de San José desde el año 1895 a 1949, muchos de ellos escritos por José Mạ Dalmases Bocabella (nieto del fundador Jose Ma Bocabella), especialmente los cinco álbumes especiales que recogen planos, dibujos y fotografías de los diferentes proyectos elaborados por el arquitecto.

Mención especial hay que hacer de los libros y artículos publicados por Puig Boada EI Templo de la Sagrada Familia, El ideal del templo cristiano y la Sagrada Familia, Los problemas de la luz, Cesar Martinell, Gaudí i la Sagrada Familia, comentada per ell mateix, y Francesc de P. Quintana, Les formes guerxes del Temple de la Sagrada Familia, que son como testamentos técnicos de la experiencia de estos arquitectos como inmediatos colaboradores de Gaudí. No hay que olvidar la primera biografia de Gaudí a cargo de J. F. Ràfols publicada por primera vez en 1929 y la conferencia de Doménec Sugrañes, Disposició estática del Temple de la Sagrada Familia, pronunciada en 1923 y recogida en el Anuario de la Asociacion de Arquitectos de Cataluña.

Joan Bassegoda y AAVV reúnen una selección de artículos publicados en la revista Temple entre 1971 y 1994, incluyendo texto de la conferencia de George R. Collins con motivo de su doctorado honoris causa, en la UPC; también publica las Conversaciones de Gaudí con Joan Bergós; y Lluis Bonet i Armengol compila (2010) diversos artículos publicados en EI Propagador de la devoción a San José y en otros diarios y revistas de la época, con ocasión de la muerte de Gaudí, entre 1926 a 1929, que constituyen una privilegiada fuente para el conocimiento y repercusión de la obra gaudiniana en el contexto de la sociedad catalana dutante los años de su vida e inmediatamente posteriores a su defunción.

Jordi Bonet i Armengol, director de las obras de construcción durante largos años aporta diversas publicaciones que describen con detalle el proceso de definición del proyecto desde las maquetas originales y dibujos concervados, así como el desarrollo informatico y constructivo de su estructura en los últimos años, tarea en la que han seguido Jordi Fauli, director actual de las obras, y Josep Gomez-Serrano. Para comprender la inspiración que encuentra Gaudí en la naturaleza para la génesis de su proyecto estructural es preciso con contar con la tesis doctoral de Gustavo Garcia Gabarró (1994), dirigida por Bassegoda. Debemos reseñar igualmente el libro de Tokutthosi Torii, El mundo enigmático de Gaudí (1983), y el de Etsuro Sotoo, La libertad vertical: conversaciones sobre la Sagrada Familia (2010), que aportan interesantes opiniones respecto de las formas y de la plástica del proyecto. 
- AAVV. Asociación Espiritual de Devotos de San José (1915) Album del Templo Expiatorio de la Sagrada Familia. Barcelona: Herederos Vda. Pla.

Primera descripción del proyecto de Gaudí y de las partes principales de su arquitectura. Fotografias de la evolución de las obras y del mobiliario litúrgico diseñado. Datos numéricos de dimensiones, alturas, superficie y capacidad. Señala como fecha de comienzo de la direccion de obra por Gaudí, el 3-11-1883, aunque en el libro de Martorell de 1967, pag. 50 indica que s/documento del nieto de Elias Rogent por el cual el contratista solicita arbitraje de Rogent para resolver diferencias con el nuevo director de las obras, este comenzó su labor el 3-03-1884.

- AAVV. Asociación Espiritual de Devotos de San José (1917) Album del Templo Expiatorio de la Sagrada Familia. Barcelona: Herederos Vda. Pla.

Sigue el mismo texto del primer álbum pero incorporando la traducción a otros idiomas europeos. Presenta fotografías de la construccion con algunas actualizaciones. Plantea una breve exposición del sistema de transmisión de cargas con algunos dibujos explicativos.

- AAVV. Asociación Espiritual de Devotos de San José (1922-25) Album del Templo Expiatorio de la Sagrada Familia. Barcelona: Herederos Vda. Pla.

Sigue el mismo esquema de descripción que en los álbumes anteriores.

- AAVV. Asociación Espiritual de Devotos de San José (1929) Album del Templo Expiatorio de la Sagrada Familia. Barcelona: Herederos Vda. Pla.

Actualiza el texto explicativo de la obra con mayor abundancia de cuestiones e incorpora dibujos de planta y secciones que permiten comprender la evolución del proyecto. Aporta muchos dibujos de comparación con otras iglesias y catedrales.

- Asociación de Devotos de San José, Asociación. El Propagador de la Devoción a San José. Barcelona.

№ 1-01-1895. Informe de las obras: el claustro.

№ 1-10-1901. Informe de las obras: foto del claustro desde el exterior.

№s 15-10-1912 Y 15-11-1913 Informe de las obras: maqueta de conjunto.

№ 15-05-1915. Ensayo de Campanas en el Templo Expiatorio de la Sagrada Familia.

№s 1-03-1917 Y 1-05-1917 Informe de las obras: explicación del grabado de la planta del Templo.

№s 15-06-1917 Y 1-04-1918: Sección transversal de las cinco naves. Informe de las obras: D. Sugrañes explica la sección. Segundo Album del Templo.

№s 15-09-1922 Y 15-03-1923. Informe de las obras: Martí Matlleu, J.: reseña histórica del templo y sus jardines. Reseña histórica de las escuelas.

№ 1-03-1925. Mientras se acaba un campanario.

№ 1-09-1925. El Templo expiatorio de la Sagrada Familia, comparado con las basílicas de San Pedro del Vaticano y San Marcos de Venecia. 
№ 1-02-1926. Gráficos comparativos de la altura de la Sagrada Familia con la de las mayores construcciones.

№ 15-08-1926 y 20 № extraordinario de la misma fecha a la memoria de Antonio Gaudí. Aparece por primera vez el proyecto esquemático del Templo realizado por Gaudí en 1893. Habla de los sucesivos proyectos desde la fundación en 1866 de la Asociación de Devotos de San José: Primer Plan, 1875, reproduce exactamente la basílica de Loreto. Se coloca la primera piedra en 1882. 20 Proyecto, Francisco del Villar -arqto. diocesano y catedrático de la Escuela de Arquitecturaiglesia gótica, 1882-1883. Primer croquis de Gaudí, dibujo desde el ábside.

№ 1-10-1926. La Divina Providencia formando a Gaudí para nuestro Templo.

№s 1 y 15-11-1926. Gaudí el amigo de la Liturgia Sacra.

№ 1-06-1927. Art. de Puig Boada "El ideal del templo cristiano y la Sagrada Familia"

№ 5-12-1927. Estado actual de las obras del Templo Expiatorio de la Sagrada Familia.

№ 1-03-1932. Walter Gropius visita Barcelona.

№ 1-06-1932. El GATEPAC y Gaudí.

№ 1-02-1948. Los modelos y la maqueta del Templo.

№ 1-04-1948. Un ventanal del crucero.

Revista Templo (El Propagador de la Devoción a San José). Barcelona.

Marzo de 1949. El Templo de la Sagrada Familia y el Ayuntamiento de Barcelona.

Mayo de 1949. Aspectos marianos del templo.

Octubre de 1950 Articulo de Puig Boada "Los problemas de la luz".

- Bassegoda Nonell, J. y AAVV. (1996) L'Estudi de Gaudí: selección d'articles publicats a la revista Temple entre 1971 i 1994. Barcelona. Publicaciones de la UPC, Cátedra Gaudí.

Referencia la concesión del doctorado honoris causa a George Collins en la UPC, con la conferencia pronunciada por éste sobre la significación e influencia de la obra de Gaudí, de la cual se pueden sintetizar las siguientes conclusiones: sus edificios no sólo son dinámicos en sí mismos sino que evidencian la continua evolución del arquitecto; en el manifiesto de la Bauhaus en Weimar parece reflejarse alguna influencia de la obra gaudiniana tal y como se trabajaba en el Taller del Templo; La influencia gaudiniana en las formas laminares tridimensionales de hormigón es un campo todavía por resaltar. Se reseña el inicio de la cátedra Gaudí y las lecciones o temas estudiados a lo largo de los primeros años de su andadura. Entre los artículos recopilados también que destacar uno sobre el modelo de Gaudí para la iglesia de la Colonia Güell y otros sobre los inicios de su actuación en la Sagrada Familia. 
- Bonet i Armengol, Lluis. (2010) La mort de Gaudí i el seu ressò a la revista El Propagador de la devoción a San José. Barcelona: Ed. Claret y Real Cátedra Gaudí.

Recopilación de artículos publicados en la revista El Propagador, de la Asociación de Devotos de San José, promotora de la Sagrada Familia, con ocasión de la muerte de Gaudí, desde el año 1926 a 1929. Merece destacarse los articulos respecto del plan general y el claustro, el interés de Gaudí por la Liturgia, etc., así como la trascripción de interesantes conferencias, especialmente la de Bonet Garí sobre las diferentes etapas de la obra gaudiniana y la de Puig y Boada al respecto del ideal del Templo cristiano y la Sagrada Familia de Barcelona.

- Bonet i Armengol, Jordi. (2001). El modulat geometric del Temple de la Sagrada Familia. (2a Ed.) Barcelona: Pórtic.

Recoge el proceso de estudio estructural y desarrollo geométrico por ordenador de la última solución del proyecto de la Sagrada Familia, con abundancia de dibujos.

- Bonet i Armengol, Jordi y AAVV (2012) La Sagrada Familia de Gaudí: el Templo Expiatorio desde sus comienzos hasta hoy. Barcelona: Lunwerg. Versión en castellano de "Sagrada Familia: de temple expiatori a basílica". Barcelona 2010. Lunwerg.

Fotografias muy buenas de Pepe Navarro y Pep Daudé. Articulo de Crippa.

- Bonet i Armengol, J. y Puig, Armand. (2013) Arquitectura y símbolo de la Sagrada Familia. Barcelona. Pórtic.

Desde dos puntos de vista diferentes, los autores -teólogo biblista uno y arquitecto director de las obras otro- nos acercan a la comprensión del proyecto desde la simbología cristiana y la investigación arquitectónica que ha hecho posible la continuidad en su ejecución. Es una actualización del libro anterior de Bonet y del de Puig de 2011 con nuevas fotografías y más datos que se quiere completar para la difusión del proyecto.

- Faulí i Oller, Jordi. (2006) "El Temple de la Sagrada Familia". Madrid: Aldeasa. Basado en la Tesis Doctoral del autor, actual Director de las obras, y partiendo de un recorrido cronológico de las distintas plantas y secciones del proyecto, desde Villar y Gaudí hasta hoy dia, realiza un estudio profundo y detallado del diseño y formas geométricas de los principales elementos constructivos del proyecto.

- Garcia Gabarró, Gustavo. (1994) Leyes de la naturaleza y composición arquitectónica: el ejemplo de Antonio Gaudí. Tesis Doctoral dirigida por Joan Bassegoda, ETSAB. Barcelona.

Tesis Doctoral que se acerca a una visión naturalista del proyecto intentando desgranar el diseño y funcionamiento de las estructuras a partir de un análisis que se inspira en la observación de la Naturaleza 
- Gómez Serrano, Josep y AAVV. (2008). Sagrada Familia XXI/ Gaudí ara. Barcelona: Edicions UPC.

Con prólogos de Jordi Bonet, Daniel Giralt-Miracle, y Toyo Ito, hace un sintético repaso de la cronología de los hechos de la vida y de las obras de Gaudí, acompañando fotografías y fechas. Principalmente se centra en una explicación sucinta y concreta de los estudios y dibujos por ordenador de los elementos principales de las obra desde el año 1991, aportando planos, fotografías y dibujos que permiten hacerse una idea del proceso de construcción seguido -en 2D y 3D- para desarrollar el proyecto de Gaudí.

- Martinell Brunet, César. (1950). Gaudí i la Sagrada Familia, comentada per ell mateix. Barcelona: Aymá SL Edicions.

Por el conocimiento y trato directo con Gaudí en los últimos años de su trabajo en la Sagrada Familia resulta de gran utilidad su visión del proyecto y la manera con que aborda su análisis. Arroja pistas y establece criterios razonados de interés para una visión arquitectónica del proyecto desde su funcionalidad liturgica.

- Puig Boada, Isidre (1974). El Templo de la Sagrada Familia. Barcelona: Universidad Politécnica de Cataluña.

En la versión original, 1953, se menciona la estrecha relación de Bergós con Gaudí. Esencial para conocer el proceso artístico, constructivo y litúrgico del templo de la Sagrada Familia. Así, por ejemplo, hace referencia a los estudios y experimentos con tornavoces y campanas con el fin de obtener un sonido claro.

- Puig, Armand. (2011). La Sagrada Familia según Gaudí. Barcelona. El Aleph.

Estudio de la simbología del proyecto por uno de los mejores especialistas: la inspiración divina, el símbolo, la proporción y la belleza, las medidas fundamentales. Interpretación de la basílica como la nueva Jerusalén y la síntesis arquitectónica del misterio cristiano. Aporta dibujos y croquis explicativos de gran interés dando una visión muy completa y fundamentada del proyecto desde la teología liturgica.

- Quintana, Francesc de P. (1927) "Les formes guerxes del Temple de la Sagrada Familia, en La Ciutat i la Casa.n-6. 1927 Barcelona.

Autorizada explicación y opinión de uno de los colaboradores inmediatos de Gaudí que posteriormente dirigió la obra- respecto del compartamiento estructural de las formas alabeadas que empleó Gaudí.

- Ràfols, Josep Francesc. (2006). Gaudí. Barcelona: Claret y Cátedra Gaudí.

Edición facsímil de la primera biografia o estudio de la obra de Gaudí, aumentada con una Introducción de la edición de 1952, (1 a Ed. Aedos. 1929) Imprescindible para conocer en profundidad las ideas y forma de trabajar de Gaudí en sus proyectos y en concreto en el de la Sagrada Familia y otros de índole religiosa o sacra. Incorpora los textos de Sugrañes sobre la disposición estática del Templo y de Quintana sobre las formas curvadas del mismo a que hace mención el anterior articulo de revista. También una cronología de Gaudí y sus obras. 
- Sugrañes, Doménec. (1923) Disposició estática del Temple de la S.F. Barcelona: Anuario de la Asociación de Arquitectos de Cataluña. (ARXIU SF)

Artículo en el Anuario de 1923 del COAC que recoge su conferencia donde explica el funcionamiento estructural de las naves y bóvedas del Templo en comparación con la sección de las basílicas romanas y templos románicos y góticos. Acompaña un estado de cargas de la sección de la cubierta y la descripción de la situación de los esfuerzos cor respondientes a dichas cargas.

- Tokutthosi, Torii (1983). El mundo enigmático de Gaudí. Madrid: Instituto de España.

Investigación referente a las similitudes de forma de la Sagrada Familia con el proyecto para las Misiones franciscanas de Tanger, reflexionando sobre el posible origen de la forma paraboloide de los campanarios y sus semejanzas con determinadas arquitecturas tradicionales del norte de Africa. Dispone de dos tomos, uno de ellos dedicado exclusivamente a fotografías y dibujos de esta obra y de otras, de gran interés. Aporta interesantes anejos información económica de la obra en tiempos de Gaudí. 


\subsection{Sobre la función del Arte sacro en la Liturgia de la Iglesia.}

\section{- Fundamentos del diálogo Arte-Litúrgia.}

El diálogo entre liturgistas y arquitectos es relativamente reciente pero ya cuenta con un notable ejercicio de encuentros, reflexiones, vías de comunicación y publicaciones que jalonan este itinerario prometiendo abundantes y sustanciosos frutos para la arquitectura eclesiástica. Este diálogo ha vuelto a poner sobre la mesa la necesidad que tiene la Iglesia del arte sacro en estos momentos, y la función que está llamado a ejercer en el seno de la comunidad cristiana. Tras unos años de invasión tecnológica que parece penetrarlo todo, se abre nuevamente camino, aunque sea lentamente, a la dimensión sagrada del arte y la constatación de que la arquitectura religiosa merece ser funcional pero no funcionalista. Como ha señalado Ferrer Grenesche (Colegio Oficial de Aparejadores de Madrid, 2012): "Arte se identifica como <la actividad humana, individual o colectiva, de la que nacenproductos culturales- o comportamientos que son objeto de juicio de valor o relaciones de gusto; así como el resultado de la misma>." Ahora bien, no toda producción cultural puede considerarse como arte o recibir el calificativo de artística, pues "lo artístico requiere un nivel de maestría y de creación" ${ }^{2}$, aunque no sólo, como veremos.

Siguiendo la argumentación anterior, cuando faltan estas dos características podemos hablar de un objeto o producto agradable, útil, funcional y revestido de una cierta dignidad, que variará en función de su sinceridad constructiva, pudiendo ser artesanal, fabril, industrializado, etc. pero difícilmente le aplicaremos la condición de artístico. Para hablar de arte o de lo artístico debemos implicar en alguna fase de la concreción del producto el espíritu creativo que infunde "vida", y por tanto la comunica, a la materia o comportamiento que ha sido confeccionado con habilidad o maestría.

Este espíritu creativo del hombre ha sabido percibir, ya en las antiguas culturas históricas, la distinción entre lo sacro y lo profano, como una frontera nítida y real entre la actividad consagrada y dedicada a lo divino, realizada en un lugar santo sometido a ciertas condiciones de acceso y por ello dotada de una cierta supremacía, fuerza o moralidad, respecto de aquellas otras comunes y exentas de cualquier misterio que constituían la cotidianeidad de las relaciones humanas. Así el hombre, intrínsecamente religioso, como se manifiesta incluso en la misma Prehistoria, ha sentido necesidad de sumergirse en el cosmos, en el mundo vinculado a los dioses añorando en su vida todo atisbo de sacralidad. ${ }^{3}$

\footnotetext{
2 Cf. Ferrer Grenesche, Juan Miguel. (2013). "El arte sacro y su relación con el culto cristiano. Una aportación para el año de la Fe", en La liturgia inspiradora de las artes. Barcelona. CPL.

${ }^{3}$ Cf. Plazaola, Juan. (1965). El Arte sacro actual. Madrid. BAC. P. 9: "El hombre religioso siente la añoranza del mundo <como era en el principio>, cuando salió de las manos del Creador; por eso busca ritos que $<$ renueven el tiempo: la fiesta es la repetición periódica del tiempo originario."
} 
El Cristianismo transformó la idea de trascendencia acentuando la creencia en un Dios que es a la vez Padre, y un padre tan próximo y personal que por ello mismo transforma el temor ante lo sacro en amor, de tal manera que ahora el hombre no tiene que ganarse la benevolencia divina en un lugar concreto sino que celebra ese amor personal allá donde esté y sobre todo lo celebra comunitariamente, no sólo como una emoción religiosa sino como una presencia trascendente ante la cual vibra todo su ser.

Esta convocación para la celebración del amor divino, para ser mediación de su presencia, es la que le confiere a lo sagrado cristiano un carácter social completamente novedoso en el cual, como dice Plazaola, la imagen sacra no es separativa del mundo sino que se constituye en una imagen cultual comunitaria totalmente novedosa ${ }^{4}$; pues aunque es cierto que "Dios no habita en templos fabricados por mano de los hombres" (Act. 7,46), no es menos cierto que Jesucristo había dicho "donde estén dos o más reunidos en mi nombre allí estoy yo en medio de ellos" (Mt. 18,2). Por consiguiente, los primeros cristianos siguen asistiendo a las reuniones que se llevan a cabo en las sinagogas pero inauguran unas reuniones revolucionarias en el contexto de todos los tiempos y culturas: la reunión para la fracción del pan, como memorial y celebración real de la resurrección de Cristo, en las casas de los creyentes y en torno a la mesa familiar. Esta realidad de la eucaristía en el día del Señor como memorial de su Pascua se sitúa en el origen de la configuración de un espacio adecuado para la celebración de esta Fe y en la creación de todo objeto o suceso artístico cristiano que simboliza y ayuda a la experiencia de la gracia en un contexto de familia, no sólo de carne y sangre sino de psique y espíritu, significando con ello que abarca a la totalidad de la persona y de las personas que forman parte de esa familia humana.

El paso siguiente, de la domus ecclesiae al edificio de la Iglesia, algo más tarde y por necesidades prácticas, con la progresiva adaptación de la basílica romana y la posterior configuración tipológica del espacio sacro según las diversas zonas de influencia de una liturgia ya fijada y también diversificada, no hace perder la noción de comunidad a los llamados a la santidad, sino que precisamente por mantener viva esa llamada promueve en paralelo un desarrollo artístico que se manifiesta en la arquitectura y también en la pintura y otras artes al servicio del culto y de la piedad popular. Por tanto se configura el Arte sagrado cristiano como una epifanía del Misterio de la presencia de Dios con los hombres por medio de Jesucristo mediante la acción del Espíritu, y como una teología de la imagen y del gesto que acompañan a la Palabra. Sin embargo, ésto no siempre se ha comprendido y aceptado aún dentro de la tradición cristiana, ya que hay que reseñar periodos iconoclastas que con mayor o menor profundidad y difusión han sido recurrentes en estos dos mil años de historia del arte cristiano, de la misma manera que en otros momentos ha proliferado abundantemente la iconofilía.

\footnotetext{
${ }^{4}$ Cf. Ibid. P. 21.
} 
Hay que reconocer echando una mirada al discurrir histórico de estos dos mil años de tensiones y cambios entre partidarios y detractores de la iconografía cristiana, y por tanto de la exaltación de los valores sensibles, que esa misma tensión no ha acabado con el Cristianismo sino que esta dialéctica, penetrada del amor de un Dios que no duda en entrar visiblemente en la historia humana, lo ha mantenido con un vigor extraordinario. En el Cristianismo se elabora una auténtica teología de la imagen, en concordancia con la visibilidad de la liturgia y con la exposición iconográfica de los hechos de la historia de la salvación.

Paul Edmokimov analiza profundamente la relación entre la Palabra de Dios y la imagen en el Cristianismo y nos explica la profundidad del sentido de la iconografía bizantina, afirmando de estas imágenes que no se trata de una mera representación de Cristo, María y los santos, sino que estamos ante una impronta de su presencia y que por tanto lo que mueve es a la contemplación y a la oración. Aunque en Occidente la imagen adopta un discurso más racional, catequético y pedagógico (necesario por otra parte si pensamos en la barrera litúrgica que supuso el latín frente a la ignorancia de este idioma por el pueblo y aún el mismo analfabetismo en la lengua vulgar), podemos también encontrar una notable tradición de acompañamiento artístico a las celebraciones litúrgicas. Tanto en Oriente como en Occidente, como dice Gutiérrez Martín: "Liturgia y Arte trascienden los límites del fenómeno, transfigurando la realidad dispersa y cambiante en momento de perfecta unidad y permanencia" ${ }^{5}$

El Arte cristiano aspira, pues, a la trascendencia y por eso busca manifestar la belleza, pero no como una experiencia estética pura, nihilista, únicamente racional y encerrada en sí misma y en un mero goce, sino como una belleza asentada en la verdad y el bien trinitarios y volcada a la experiencia de comunión comunitaria. Esto sólo se verá cuestionado por la Reforma Protestante del siglo XVI, la cual parece refugiarse en la música y el canto como casi únicas manifestaciones artísticas permitidas, aunque en el siglo XX ha evolucionado también en la arquitectura admitiendo planteamientos novedosos a partir de la arquitectura eclesial desarrollada en Alemania en los albores del siglo pasado.

Respecto del concepto de arte religioso y de arte sacro existe una cierta confusión en la utilización de estas expresiones ${ }^{6}$, que conviene aclarar. Humphrey y Vitebsky señalan

\footnotetext{
${ }^{5}$ Cf. Gutierrez Martín, J.L. (2000) "La liturgia en el Magisterio Conciliar", en AAVV: Arte Sacro un proyecto actual, actas del curso celebrado en 1999. Madrid. Fundación Felix Granda. P.29.

${ }^{6}$ Cf. Echeverria, J. y Mennekes, F. (2011) Intrusos en la Casa. Arte Moderno, espacio sagrado. Alzuza. Fundacion Museo Jorge Oteiza. Jon Echeverria no se encuentra muy a gusto con el término arte sacro "porque dicho término tiene unas connotaciones demasiado definidas" y prefiere utilizar el término arte religioso, al cual le asigna la función de" definir el espacio sagrado de las iglesias". Este autor al tratar de la decadencia del arte religioso habla de un cambio que se habría producido en el estatuto de la imagen,
} 
cómo en las diferentes culturas humanas el arte sagrado se implica directamente en la relación de los seres humanos con la divinidad. ${ }^{7}$ De tal manera que en la construcción de los edificios cultuales se da el arte en su máxima expresión constituyendo espacios sagrados, llamados así porque hacen referencia a todo lo que comporta el culto a los dioses y su previsible protección, diferentes y claramente segregados de los espacios comunes o profanos, ajenos a ellos.

Ferrer Grenesche explica cómo en la tradición bíblica judeocristiana la amplitud del término sacro parece dilatarse de la mano del Creador y su obra ${ }^{8}$, llevando asociado la pertenencia o no al orden establecido por el Creador, bien en su plan original o a través de la obra redentora de Cristo.

En esta dimensión redentora y pascual de Jesucristo, dice: "Entre los cristianos lo sacro adquiere un valor sacramental. Declara y hace realmente presente el ya sí del Reino, a la par que ayuda a su consumación". Se entra así en una dimensión en la que lo sagrado no tiene que ver sólo con lo ritual sino que presenta un valor moral, trascendente y celebrante en el seno de la asamblea del pueblo cristiano, lo que supone una auténtica revolución cultual, pasar de la fenomenología religiosa cultural e histórica a la liturgia, que como explica es "actualidad de la presencia y obrar de Dios, por medio de los ritos y del entramado de símbolos y signos litúrgicos, que permiten a la Iglesia asociarse al obrar divino y fundar así una vida de agrado, a su gloria" 9

Así pues, para este liturgista, el arte religioso sería el que expresa la apertura a la trascendencia, es decir que muestra positivamente a los hombres la religión. En cambio, el arte sacro "brota directamente de la experiencia religiosa", y por tanto, tiene que ver directamente con la comprensión, contemplación y manifestación de la relación de Dios con los hombres. En palabras de Ferrer Grenesche "será la expresión artística de un credo y un estilo de vida, de los contenidos de una fe. Cuando el arte sacro es cristiano, tal arte, es el <resplandor de la verdad cristiana $>$ y de la <santidad de Dios>, es la expresión de la Presencia y el obrar de Dios, es un arte sacramental (como se ha estudiado abundantemente en Oriente al hacer la <teologia del icono>). Arte litúrgico es el arte

motivado por el rechazo de Lutero al uso devocional y cultual de las imágenes, que "Hans Belting califica como el transito desde la era de la imagen a la era del arte". Echeverria explica que de esta manera se modifica el tipo de experiencia de aquel que se situa ante estas nuevas imágenes artísticas: de la experiencia religiosa del creyente se pasa a la experiencia estética del observador 'desinteresado".

7 Cf. Humphrey, C. y Viterbsky, P. (1996). "Arquitectura Sagrada. La expresión simbólica de lo divino en estructuras, formas y adornos". Culturas de la sabiduría. Madrid/Barcelona. Ed. Debate: "Con la arqta. Sagrada los seres humanos intentan acercarse a lo divino creando un espacio especial en el que mantener ese contacto tan poderoso y preciado." p. 7.

${ }^{8}$ Cf. Ferrer Grenesche. (2013) "El arte sacro y su aportación al culto cristiano. Una aportación al año de la Fe", en La liturgia inspiradora de las artes. AAVV. Barcelona. CPL. p. 20.

${ }^{9}$ Cf. cita anterior, p. 21. 
sacro cristiano que nace de y para la acción litúrgica. En ella tiene su inspiración y su habitat."

Por tanto, el arte sacro cristiano vemos que está tan radicalmente presente en la acción litúrgica, no como un aditivo estético, sino como parte integrante de esa acción que es presencia de Dios y de su obrar entre los hombres y participación de éstos en la pascua de Jesucristo, de tal modo que se pueden citar aquí las palabras de Benedicto XVI en su exhortación apostólica Sacramentum caritatis cuando habla de la dimensión artística de la liturgia cristiana: "La verdadera belleza es el amor de Dios que se ha revelado definitivamente en el Misterio Pascual. La belleza de la liturgia es parte de este misterio; es expresión eminente de la gloria de Dios y, en cierto sentido, un asomarse del Cielo sobre la tierra. ....La belleza, por tanto, no es un elemento decorativo de la acción litúrgica; es más bien un elemento constitutivo, ya que es un atributo de Dios mismo y de su revelación." 10

De esta manera se entiende que la liturgia sea como el generador y sustentante del arte sacro cristiano pues todo en ella tiene que ver con Jesucristo y por medio de El con la Trinidad, la asamblea de los santos en el Cielo, los hermanos en la fe cristiana de la tierra y la realidad entera de la Creación. Igualmente quedan así sensiblemente unidas la acción litúrgica con el arte sacro que por ella y en ella germina, puesto que éste está fundado en la belleza divina. La acción celebrativa cristiana implica pues a la totalidad de la persona humana y de sus sentidos, como la comprendían los filósofos griegos en cuanto que realidad corporal, alma racional y espíritu. Si los sentidos del ser humano son capaces de disfrutar de la arquitectura, la pintura, escultura, música y canto, literatura, y otras artes, todas ellas pueden entrar a formar parte, por tanto, en la celebración litúrgica. La liturgia cristiana, pues, al mostrar en la celebración parte de la belleza divina, deviene Ars celebrandi cuando se realiza en la obediencia fiel a las normas litúrgicas en su plenitud, provocando una espectacular epifanía artística de la que forman parte el espacio mismo y todo lo que en él acontece ordenado a la celebración: su ornamentación, enseres, ritos y gestos, materia de los sacramentos, la expresión de la Palabra y los libros que la contienen, música y cantos, etc.

Se puede así comprender que el espacio celebrativo une mediante la acción litúrgica la creación divina original con la recreación que establece Jesucristo y la consumación final de que habla el Apocalipsis, adoptando así un sentido plenamente simbólico la cúpula en el crucero, un elemento tan repetido en la historia de la arquitectura eclesiástica.

Si el artista no es creyente, su capacidad creadora inspirada por su creatividad, aún alcanzando notables cotas artísticas que puede poner al servicio de la Liturgia, permanecerá desprovista de la impronta de su espíritu y será difícil que actúe como sello

${ }^{10}$ Cf. Benedicto XVI. (2007) Ex. Sacramentum Caritatis 35. 
en su vida. Para que la creación artística cultual tenga un reflejo vital en la vida del artista, éste ha de unir la creatividad a su condición de creyente; y si disfruta de un conocimiento vivo de la liturgia se hace capaz de hacer de su trabajo y de su vida una auténtica liturgia pues es llamado al amor por Dios mismo, como toda la naturaleza creada, pero une a su condición de criatura una llamada personal e irrevocable a la santidad que se manifiesta en un recorrido personalísimo jalonado de hitos recorridos por la acción del Don de Dios en su persona. La Iglesia intenta ser fiel a esta propuesta divina a través de diversas acciones formativas pero fundamentalmente mediante la preparación de la celebración, la invitación a celebrar adecuadamente la liturgia, y finalmente, mediante la invitación a gustar de lo ya celebrado. ${ }^{11}$

La Constitución Conciliar Sacrosanctum Concilium sobre la Liturgia se pronuncia sobre la fidelidad de las bellas artes (especialmente del arte religioso y del arte sacro) a su objeto de intentar responder y expresar la infinita belleza divina afirmando que, en cuanto se afanan en su principal propósito de colaborar con la obra de Dios y llevar a los hombres hacia ella, son fieles a su dedicación a Dios y a su alabanza. ${ }^{12}$

En idénticos términos pero todavía más concretos habla Benedicto XVI al tratar el arte al servicio de la celebración en Sacramentum caritatis cuando dice: "...el objetivo de la arquitectura sacra es ofrecer a la Iglesia (...) el espacio más apto para el desarrollo adecuado de su acción litúrgica. En efecto, la naturaleza del templo cristiano se define por la acción litúrgica misma..."13 y manifiesta la necesidad de que en todo lo que concierne a la Eucaristía haya una búsqueda de la belleza.

Recogiendo esta idea, sigue afirmando Ferrer Grenesche que el artista en Oriente se preparaba para realizar los iconos mediante ayunos, oraciones, estudios y participación en la liturgia misma.

Es decir, afirma que al elegir hacer arte sacro, el artista pone su arte al servicio de la liturgia y ésta se convierte en inspiradora de su acción. De ahí que el artista considere fundamental disponer de un buen programa teológico-litúrgico que será el auténtico programa de necesidades de la obra artística y permitirá insertar cada una de las partes en el conjunto, redundando así en la veracidad y estructura interna del proyecto, favoreciendo la comprensión y goce estético del mismo, a la vez que estimulando las cualidades espirituales y racionales del autor de cada obra artística sagrada. Es un proceso que actúa en ambas direcciones, por un lado el artista ha de realizar esta

\footnotetext{
${ }^{11}$ Cf. Ferrer Grenesche. (2013) “El arte sacro y su aportación al culto cristiano. Una aportación al año de la $\mathrm{Fe}^{\prime \prime}$, en La liturgia inspiradora de las artes. AAVV. Barcelona. CPL. p. 26.

${ }^{12}$ Cf. Constitución Sacrosanctum Concilium, Concilio Vaticano II, num. 122.

${ }^{13}$ Cf. Benedicto XVI (2007). Ex. Ap. Sacramentum caritatis, 18.
} 
inmersión litúrgica para realizar su obra de arte y por otra parte, al crear ésta, se siente continuamente impulsado a seguir sumergiéndose en el misterio celebrado que le amplia el campo visual del intelecto y del alma provocando nuevas energías creativas.

Como indica José Manuel del Rio Carrasco, citando al Concilio Vaticano II, "los artistas, por consiguiente, cumplen en la Iglesia una función ministerial, en cuanto que la ayudan a traducir su mensaje divino en el lenguaje de las formas y las figuras, a hacer sensible el mundo invisible." De ahí la necesidad de comprender la arquitectura sacra cristiana, no sólo en términos puramente técnicos o incluso estéticos, desprovista de toda interpretación cultual sino más bien con la visión funcional, que en este caso es singular, trascendente y comunitaria. O como dirá el mismo autor, pasar de "un arte de los cristianos a un arte cristiano"14. Borobio pone de manifiesto (2008) cómo según el Concilio Vaticano II la naturaleza y función del arte sagrado viene integrada en el conjunto dinámico de los signos, agentes y acciones de la liturgia en el momento de la celebración ${ }^{15}$. Por tanto, si hay una relación entre contenido teológico y expresión celebrativa, representada por signos y símbolos, y entre sentido teológico y acción sagrada, también la hay entre espacio sagrado y función litúrgica a desempeñar, y todo ello contando con la asamblea celebrante, de tal manera que el espacio es ordenado por la celebración y para la celebración de cada sacramento, y requiere un orden.

En consecuencia cabe analizar las profundas relaciones existentes entre la celebración litúrgica que se da en las iglesias, especialmente la eucaristía, y el arte cristiano en términos pedagógicos de catequesis visual que acompaña a la Palabra pero también como adecuación de un espacio a la oración, la contemplación y la celebración.

La renovación litúrgica impulsada por el Movimiento Litúrgico a finales del siglo XIX y principios del XX propició el interés por la participación activa de los fieles volviendo la mirada, unas veces arqueológica y otras magisterial, a los orígenes de los ritos litúrgicos cristianos y por ello devolviendo al empobrecido dialogo arquitectura-liturgia de aquel entonces unos aires nuevos.

Posteriormente desarrollada como reforma litúrgica por el Concilio Vaticano II y sus documentos posteriores ha surgido un notable interés por la formación litúrgica de los artistas y expertos en arte por la necesidad de adaptar el espacio a las condiciones de la asamblea que ha de acoger. ${ }^{16}$

14 Cf. Del Rio Carrasco, J.M. (2013). "La función eclesial de las artes y su aportación a la cultura contemporánea", en La liturgia, inspiradora de las artes. AAVV. Barcelona. CPL. p. 39

${ }^{15}$ Borobio, D. (2008). Dimensión estética de la liturgia. Cuadernos Phase 180. Barcelona. CPL

${ }^{16}$ Cf. Lopez, J. (2000). "La liturgia en el Magisterio Conciliar", en AAVV: Arte Sacro un proyecto actual, actas del curso celebrado en 1999. Madrid. Fundación Felix Granda. P 34. 
En este contexto se sitúa la presente investigación respecto a la consideración del espacio celebrativo en el proyecto arquitectónico de Antonio Gaudí para la Sagrada Familia, como una muestra de la íntima conexión y honesto dialogo entre la liturgia, entendida en su más lato sentido de experiencia personal y comunitaria, y la arquitectura eclesiástica moderna, cuya constante búsqueda de la solución a los retos que aquella plantea todavía no se ha valorado lo suficiente. De esta manera, sin quedarnos en el mero contenido formal, quisiéramos llegar a postulados básicos de la concepción gaudiniana de la arquitectura cristiana del espacio de culto.

\section{- La tradición histórica.}

Normalmente, filósofos, historiadores del arte y liturgistas suelen coincidir en que la Historia del Arte Cristiano en Occidente hasta el siglo XVIII se identifica siempre con la Historia del Arte en general. El historiador austriaco Alois Riegl indica que hacer auténtica historia del arte es penetrar en la "voluntad artística" (kunswollen) de los artistas de cada época. Para Plazaola hay una cuestión filosófica previa para acercarse al verdadero sentido del arte cristiano y es la dimensión cuasi religiosa del arte. Al hablar del arte sacro cristiano cita a Ruskin -"todo gran arte es oración"-, a Clive Bell cuando habla de que el arte y la religión son los dos caminos que llevan al hombre al éxtasis, etc. para terminar hablando de la "escatología del arte". ${ }^{17}$ En análogos términos se expresa Fred Licht cuando dice que todo arte pertenece al reino del espíritu, pero también destaca que el arte religioso es "un arte relacionado con una serie de dogmas, rituales y creencias reconocidas y a las que obedece una determinada e identificable comunidad" ${ }^{18}$

Para este profesor e investigador de Princeton sólo la Iglesia Católica ha creado un corpus de arte religioso que va desde aproximadamente el siglo II hasta finales del siglo XVIII. Sin embargo algunos pensadores señalan al siglo XIV como el tiempo en el que "la mayor parte de los valores defendidos con anterioridad se encuentran en dificultad al situarse en un contexto histórico muy diferente ${ }^{19}$, dado que hay un lento pero continuo recorrido que lleva a exaltar la experimentación y la comprobación empirica a la categoría de absoluto para el conocimiento, relegando el razonamiento y la moral a un sentimiento, y la estética a un gusto. Si tenemos en cuenta en el Cristianismo occidental la progresiva

\footnotetext{
${ }^{17}$ Cf. Plazaola Artola, J. (1965). Arte sacro actual. Madrid. BAC.

${ }^{18}$ Cf. Licht, F. (2001). "Momentos de desorientación. aspiraciones, éxitos y fracasos del arte religioso contemporáneo", en AAVV. Actas del II Curso de Arte Sacro celebrado en Madrid el año 2000. Madrid. Fundación Félix Granda.

${ }^{19}$ Cf. Dominguez Balaguer, R. (2007). Requiem por Europa. Ascenso y ocaso de la cultura ética occidental. Baracaldo. Grafite Ediciones. Incide en cómo los ilustrados cambian la búsqueda de las esencias por las del funcionamiento, lo cual parece dejar a la materia como motor de la historia en detrimento de la razón.
} 
individualización de la vida cultual motivada por la barrera idiomática que supone la utilización del latín como lengua del culto y la consiguiente clericalizacion de la vida litúrgica, la proliferación del devocionismo particular y con ello la utilización del arte religioso como instrumento pedagógico en sustitución de una auténtica preparación a los sacramentos, reduciendo la vivencia comunitaria cristiana a la categoría de los grandes festejos y funciones, procesiones y manifestaciones de la fe popular, es posible entender reacciones iconoclastas como la Reforma Protestante del s. XVII o intentos de normativizacion artística como los decretos y preceptos de S. Carlos Borromeo intentando aplicar los criterios del Concilio de Trento a la liturgia y el arte en su diócesis. Algunos eclesiásticos de notable inquietud intelectual y artística realizarán también una labor encomiable de mecenazgo cultural y artístico, formación intelectual y catequesis, como S. Juan de Ribera, pero el dialogo entre las instituciones eclesiásticas y el arte religioso cada vez se va a volver más plagado de dificultades que prácticamente se tornarán insalvables una vez que se rebasen los ámbitos temporales y conceptuales del academicismo decimonónico.

Ya en el tránsito del siglo XVIII al XIX algunos pintores como Goya, con notables incursiones en el arte religioso como sus cuadros de Jesus en el huerto o La última comunión de S. José de Calasanz, al salirse de los patrones establecidos, tenían serios problemas para que sus obras fuesen aceptadas por las autoridades eclesiásticas. Sin embargo, en pleno siglo XIX se va a dar un nuevo paso en el distanciamiento iniciado en el siglo anterior entre creación artística e institución eclesiástica, que según señala Jon Echeverria se debería tanto a la proliferación de objetos litúrgicos y religiosos realizados en serie, cuyo carácter sentimentaloide, banal y mercantil, deviene en arte popular en detrimento del propio criterio estético de la Iglesia ${ }^{20}$,

como también a la escasa formación artística de la jerarquía eclesiástica (lo cual precipita la tendencia decadente del arte religioso), pues no hay que olvidar que el Concilio de Trento ponía en manos del Ordinario del lugar la sanción respecto a la idoneidad o no del arte destinado a las iglesias ${ }^{21}$. Plazaola menciona como a finales del XIX aparecen las primeras manifestaciones del simbolismo, un arte de raíz metafísica y espiritualista que se apoya en el signo, no en la imagen, pero del cual la Iglesia sigue al margen; y el P.

\footnotetext{
${ }^{20}$ Cf. Echeverria, J. y Mennekes, F. (2011) Intrusos en la Casa. Arte Moderno, espacio sagrado. Alzuza. Fundacion Museo Jorge Oteiza. P.24: "Estos objetos acaban copando la decoración de las iglesias a partir de 1860.....Esta proximidad a los estereotipos publicitarios da pie a una curiosa paradoja: al adoptar como modelo el <arte popular popular $>$, lo que constituye un acto de autosecularizacion en una época donde la Iglesia se resiste enconadamente a los procesos de secularización".

${ }^{21}$ Cf. Plazaola, J. (2006). El Arte sacro actual.Madrid. 2006. P. 416: Decreto sobre las imágenes sagradas de Urbano VIII (1623-1644).
} 
Régamey calificaría el arte religioso de finales del siglo como sentimental, interesado por lo anecdótico y elemental, ajeno al sentido del misterio que se quiere evocar. Así se entiende, como ha señalado Ma Antonietta Crippa, que cuando en el siglo XIX muchos artistas se apuntaban al movimiento socialista y muchos se hacían utópicos buscaban no una idea política sino una dimensión comunitaria en la que pudieran percibir experimentalmente la autenticidad.

En este estado de cosas, hacia 1888 , un movimiento de pintores y artistas franceses entre los cuales figura Maurice Denis se autoasigna la tarea de renovar el arte mediante un nuevo lenguaje plástico que sea moderno y religioso. En el periodo de 1910 a 1922 Denis publica diversos ensayos y libros sobre sus teorías estéticas, entre ellos Nouvelles Théories sur l'Art Moderne et sur l'Art Sacré 1914-1921, en los que considera como la principal cualidad del arte sagrado, no la fe del artista en términos dogmáticos sino la fidelidad de la obra a la verdad, para lo cual el artista ha de llegar a lo más íntimo de sí mismo y hacer surgir de dentro de sí su experiencia religiosa; y en 1919 funda unos talleres de Arte sagrado con George Desvallières en los que trata de llevar a la práctica la armonía entre la vida cristiana del artista y su inspiracion artística, a la manera de las scholas de la Iglesia antigua y preconizando la formación filosófica, litúrgica y teológica y litúrgica, unida al trabajo colectivo.

Romano Guardini ya había señalado (1918) que "toda intimidad se proyecta al exterior de una manera plástica" y al referirse a la obra artística hablaba de un sentido sublime que es el de ser reflejo de las cosas según la Verdad, la Veritatis Splendor. Y en este sentido dice: "El artista sufre y lucha por conquistar, en reñido trance, la expresión de su intimidad más viva..." 22 Tambien Maritain desde la filosofía cristiana había incidido en esta cuestión resaltando la implicación de las creencias religiosas del artista en su creación y poniendo el punto de mira en la calidad del arte religioso.

Sin embargo, el camino emprendido por el Arte Sacro en la Modernidad no iba a ser fácil ni mucho menos rápido, pues la vuelta al dialogo sincero entre los artistas y la Jerarquia de la Iglesia, si bien se nutria de grandes singularidades en el campo de la teología, la liturgia, la filosofía y el arte que buscaban con notable sinceridad la renovación de la vida artística y religiosa de la Iglesia en los comienzos del siglo $\mathrm{XX}^{23}$ también comporta

22 Cf. Guardini, R. (1918). Vom Geist der Liturgie. Traducción al castellano de la 12e edición alemana por Herder y Cạ, 1946. Barcelona. Araluce.

${ }^{23}$ Que Denis y Rodin buscaran en el simbolismo la materialización de una experiencia trascendente superior a la simple apariencia material, que Desvallières, Bloy, Roualt, etc. irradiaran ternura o violencia pero sincera libertad expresionista frente al conformismo, que Régamey y Couturier realizaran un esfuerzo pedagógico tan grande y que éste último recurriera a notables artistas para sus proyectos religiosos, o que incluso el mismo Dalí tocara en el principio de su producción artística temas religiosos desde su particular surrealismo, etc. no evitaría que las direcciones que tomaban los artistas y los principios para la aceptacion 
periodos e incidentes que implicaban serios obstáculos, cuando no retrocesos en el devenir del arte sacro más reciente. ${ }^{24}$

Cuando en 1937 Couturier y Régamey se hacen cargo de la dirección de la revista l'Art Sacrée denuncian el aislamiento del arte cristiano de los siglos XIX y XX respecto del arte contemporáneo y propugnan como arte verdadero el que "lleva en sí la capacidad de ser espiritual y trascender las realidades puramente perceptibles" siguiendo la estela de Guardini; cuando Couturier entra en contacto con destacados artistas e intelectuales exiliados en Estados Unidos como Maritain, Chagall, Léger, Strawinsky, ...apunta a un debate sobre la validez y significado del arte no-figurativo al centrar la discursión sobre la posible deformación de la figura humana, y cuando denuncia la decadencia del arte cristiano como consecuencia del rebajamiento y regresión de la vida cristiana en Occidente, incide además en la escasa formación artistica de los responsables eclesiásticos; pero cuando convoca a artistas no necesariamente cristianos como Le Corbusier, Matisse, Chagall, Bonnard,... a realizar obras de carácter religioso bajo la premisa de que su gran intuición y de que su genio artístico puede suplir la falta de fe aunque sin prescindir del conocimiento y sintonía con el Cristianismo, en contraposición a la renovación propuesta por Maritain y Denis -que habían incidido más en la experiencia cristiana vivida por el artista- ${ }^{25}$ comienza una evolución en su pensamiento que le llevará a posiciones más radicales y diferentes a las de Maritain, Denis y el mismo Régamey, que

del arte religioso moderno por la Iglesia divergiesen cada vez más durante la primera mitad del siglo XX $\mathrm{Y}$ que esta divergencia se manifestara principalmente en temas como la radicalidad de posturas respecto de la capacidad del arte no figurativo para mostrar el misterio cristiano o la contrapuesta apreciación de la armonización entre teología y creatividad, entre culto y temática, lo que sitúa en el centro del desencuentro aspectos tan sensibles a unos y otros como la espiritualidad cristiana o la inmaterialidad espiritual sin más, la epifania de la revelación cristiana o la búsqueda de una moderna ascesis cultural, la celebración del misterio pascual o el simple progreso espiritual de la sociedad.

${ }^{24}$ Cf. Plazaola, J. (2006). El Arte sacro actual.Madrid. 2006. P. 366: "El problema se centraba generalmente en la capacidad del arte anicónico para expresar realidades espirituales. Pero -se preguntaban algunos¿alcanza una dimensión espiritual y cristiana un arte simplemente por omitir las apariencias sensibles? ¿No es confundir la espiritualidad cristiana con la simple inmaterialidad? Lo que ciertamente puede afirmarse es que al arte abstracto impone una especie de ascetismo en la percepción del mundo sensible, que puede facilitar la ascensión religiosa del alma hacia las realidades del espíritu. Pero para que esa ascesis se oriente de hecho hacia la contemplación religiosa y cristiana será necesario que vaya dirigida por el amor de Dios y sólo por él. El esfuerzo del llamado arte abstracto es, pues, análogo de la ascesis mística. Nada menos, pero nada más."

25 Cf. Echeverria, J. y Mennekes, F. (2011) Intrusos en la Casa. Arte Moderno, espacio sagrado. Alzuza. Fundacion Museo Jorge Oteiza. P.37. Echevarria citando directamente a Couturier (Art et Catholicisme. Montreal. Editions de l'Arbre. 1941. Pp. 61-63) : "La exigencia de cierta unidad vital en la que han de participar todas las formas del arte de una época y la inexistencia de un medio favorable al arte en el mundo católico contemporáneo nos lleva a la necesidad de apelar a la vitalidad del arte profano si queremos reanimar el arte cristiano." 
se pueden sintentizar en "el valor religioso esencial de una obra es más íntimo que su tema".

Así, en opinión de Echeverria esta "sustancia religiosa" que abre nuevas perspectivas al arte religioso, supone también una nocion ampliada de lo religioso en su relación con el arte que hace que términos como "arte religioso", "arte sacro" o "arte para iglesias" pierdan su razón de ser. ${ }^{26}$ Couturier, al reelaborar así su pensamiento tras las realizaciones en Assy, Audincourt y Vence, en el sentido de que la propia sinceridad creativa del artista es la que le otorga plena libertad, la cual parece depender únicamente de su imaginación y sensibilidad (rechazando la tradición en función de la individualidad artística), contribuye a la actualidad cultural de este debate pero quizá deja el camino preparado a una interpretación nueva de lo religioso y de lo sagrado en la Arquitectura Moderna que pierde el lazo de conexión con la liturgia que preconizaba Guardini.

El debate que es largo, complejo, con sus avances, paradas y retrocesos, pero vivo y capital para la vida de la Iglesia, pues actualiza la relación entre el dogma y la creatividad artística y por consiguiente la búsqueda del lenguaje artístico conveniente o posible en el discurrir de este siglo. La Iglesia se ratifica en la condena tridentina de las imágenes insólitas y el Código de Derecho Canónico de 1917 decreta el decoro y ampara la tradición sin poder llegar a definirla, conviviendo así numerosas iniciativas que conforman un estado dialéctico de la cuestión juntamente con diversas condenas del Santo Oficio en la década de los años veinte y hasta casi el pontificado de Juan XXIII.

Pio X se centrará en todos sus documentos en subordinar las cuestiones artísticas al culto, y Pio XI, en la inauguración de la Nueva Pinacoteca Vaticana, hará valer la concepción de la belleza que planteó el Aquinate para ratificar la competencia de los obispos en sus diócesis de acuerdo con el CIC vigente. Pio XII inaugura los discursos a los artistas y artesanos, además de intentar abrir las puertas al canto, la música y el arte modernos siempres que estén al servicio del culto. ${ }^{27}$ Como dice Plazaola, "Hoy, 50 años después de

${ }^{26}$ Cf. Echeverria, J. y Mennekes, F. (2011) Intrusos en la Casa. Arte Moderno, espacio sagrado. Alzuza. Fundacion Museo Jorge Oteiza. P.40: "Couturier se une de este modo a aquellos artistas que atribuyen a sus imágenes <profanas> una naturaleza religiosa o espiritual. Ya no es la institución religiosa la que dicta, a partir de la correspondencia entre dogma e imagen, la naturaleza espiritual o sagrada del arte, sino que la <dimensión religiosa > del arte surge de la <visión interior> del artista y de su búsqueda de un significado profundo de la realidad."

${ }^{27}$ Cf. Pio XII (1947) “Encíclica Mediator Dei”, en Cf. Plazaola, J. (2006). El Arte sacro actual.Madrid. 2006. P. 426-428: "No obstante, no se puede afirmar que la música y el canto modernos deban ser excluidos por completo del culto católico. Antes bien, si no tienen nada de profano o de inconveniente para la santidad del lugar y de la acción sagrada es necesario ciertamente abrirles las puertas de nuestras iglesias...Lo que hemos dicho de la música, dicho queda de a propósito de las otras artes, y especialmente de la arquitectura, de la escultura y de la pintura. No se deben despreciar y repudiar genéricamente y como criterio fijo las 
aquellos debates, no vale la pena volver a ellos. Casi todo el mundo admite hoy que asi como la Iglesia nunca podrá renunciar al uso de las imágenes, como afirma el Concilio Vaticano II, en muchos lugares y tiempos podrá echar mano del arte abstracto tanto con fines expresivos como decorativos." 28

En 1952 el Santo Oficio publica la Instrucción De Arte Sacra enfatizando la vinculación entre la liturgia y el arte sacro, y pide a los artistas no utilizar "imágenes no usuales" o que "no estuvieran en consonancia con el uso aprobado por la Iglesia", y al finalizar el Concilio Vaticano II, Pablo VI se dirige a los artistas manifestándoles la necesidad que tiene la Iglesia de ellos e invitándoles a descubrir la auténtica belleza: "Este mundo en el que vivimos tiene necesidad de belleza para no caer en la desesperación. La belleza, como la verdad, es la que infunde alegría en el corazón de los hombres, es como un fruto precioso que resiste el paso del tiempo, que une a las generaciones y las hace compartir la admiración". ${ }^{29}$

Posteriormente Juan Pablo II, al dirigirse también a los artistas en 1999, insistirá en esta dimensión de servicio al bien común que tiene el artista y en la necesidad que tiene la Iglesia de su creatividad para comunicar la belleza de la antropología cristiana. Por eso, para Karl Rahner "el artista religioso es como un ministro del Misterio", o como dice Angel Sancho (2000) "el arte sagrado es un servicio a la fe", pero ni uno ni otro agotan la belleza y la fuerza actuante de ese Misterio, que exige en el arte sagrado la sinceridad de la verdad, aun cuando el lenguaje deba expresarse limitadamente en un contexto y en un momento dados.

Pero también en tiempos recientes se incide no solamente sobre el artista sino sobre su producción sacra, contextualizada y destinada a un fin concreto, y así Heinrich Pfeiffer, S.J. enseña (1986) que los objetos artísticos creados con una finalidad cultual deben ser situados en el contexto histórico-eclesial en el que nacen, y Timothy Verdon -delegado diocesano de arte sacro y bienes patrimoniales de la diócesis de Florencia- sostiene (2009), que "el objeto de arte y de culto cristiano es correctamente interpretado cuando viene puesto en su lugar y función litúrgica, ante todo en la celebración de la Misa católica." 30 Vernon desarrolla un método historiográfico y estético-teológico con el que interpreta el conocimiento de las obras de arte cristianas dentro de lo que llama "sistema litúrgico" donde han nacido.

formas e imágenes recientes más adaptadas a los nuevos materiales con que hoy se confeccionan aquellas...."

${ }^{28}$ Cf. Plazaola, J. (2006). El Arte sacro actual.Madrid. 2006. P. 366.

${ }^{29}$ Cf. Pablo VI (1965). Mensaje a los artistas, 8-12-1965. Ciudad del Vaticano.

${ }^{30}$ Gascón Aranda, A. (2013). "Per <<Viam Pulchritudinis> Arte y Liturgia", en Arte y Liturgia. AAVV. Barcelona. CPL. P.19 
La constitución Sacrosanctum Concilium 122 enseña que las cosas destinadas al culto son signos y símbolos de las realidades celestiales, por lo que Vernon dice (2011) que "también el arte de la Iglesia habla mediante signos"31, y al hablar de un nuevo movimiento de seglares, matrimonios y sacerdotes de la Iglesia Episcopaliana de Estados Unidos que, inspirados en el espíritu benedictino, han creado una comunidad monástica denominada Comunidad de Jesús y explicar el conjunto iconográfico del templo en Orleans (Massachussets), manifiesta que "la forma material del edificio destinado al culto tiene que ver con la identidad espiritual llamada a vivir allí en el amor la comunión creada por el mismo Cristo". ${ }^{32}$

Antonio Gascón Aranda, S.M., en su reflexión acerca de la historiografía del arte y la reflexión estética contemporánea (2011), haciendo un repaso de cómo la historia del arte nace como tal disciplina erudita en el siglo XIX atendiendo a la clasificación y contexto histórico de los objetos, y cómo pronto surgen diversas corrientes que enfocan su visión desde el mercado y la economía, la cultura, la tradición y las religiones, refiere en el ámbito occidental lo que supuso el movimiento cultural de mayo del 68 en el que los artistas se sirven de sucesos, manifestaciones, etc. para reivindicar su expresividad, y llega, por tanto, a la consideración de que también los objetos de culto artísticos deben ser comprendidos en su contexto y en su función, por tanto, en el tiempo y espacio de la liturgia.

Así pues, abundando en la pregunta de Juan Pablo II cuando se dirigía a los artistas -¿el hombre contemporáneo necesita del arte sacro?- podríamos contestar como hace Pere Tena, aludiendo al sentido profético del P. Capellades respecto del derecho del hombre a la belleza ${ }^{33}$, que rotundamente sí, el hombre contemporáneo necesita y tiene derecho a la belleza, debiendo ser más sensibles a ello los responsables de las iglesias. Esta es la línea que anticipó Pablo VI en su mensaje a los artistas -la preocupación por el hombre moderno-, que posteriormente continuaría Juan Pablo II y que se plasmaría en el

\footnotetext{
${ }^{31}$ Vernon, T. (2009). L'arte nella vit della Chiesa. Ciudad del Vaticano. Libreria Editrice Vaticana. P. 89.

${ }^{32}$ Vernon, T. (2011). Belleza e vita. La espiritualità nell'arte contemporanea. Milano. Ed. San Paolo, Cinisello Balsamo. P.10.

${ }^{33}$ Cf. Tena, P. (1993). "El derecho a la Belleza", en El Arte en la Liturgia, AAVV. Cuadernos Phase 47. Barcelona. CPL. p.5: "El P. Capellades aludía al informe de un gran semanario que, haciendo el pronóstico para el 'hombre 1985', introducía así las grandes conquistas de los entonces próximos veinte años: Después del derecho al trabajo, a la seguridad, a la salud, vendrá el derecho de los hombres a la belleza. y el P. Capellades decía entonces: 'Este derecho ¿nos atrevemos acaso a negarlo a nuestros feligreses de mañana que son, ahora, los niños de nuestras catequesis? ¿Estamos acaso enfrentados con una elección draconiana: belleza o pobreza? En realidad este es un dilema falso. Lo bello no es necesariamente más costoso que lo feo."
} 
pontificado de Benedicto XVI en el tema de la Asamblea plenaria de 2006 del Consejo Pontificio de la Cultura como la Via Pulchritudinis o Via de la Belleza.

La Via Pulchritudinis se inscribe en la misión de ayudar a la Iglesia a transmitir la fe en Cristo por medio de una pastoral que responda a los retos de la cultura contemporánea. De tal manera que esta Via de la Belleza se propone, partiendo de la experiencia sencilla del encuentro con la belleza, suscitar la admiración, abrir el camino de la búsqueda de Dios y capacitar, por tanto, al espíritu del hombre para el encuentro con Cristo. Por tanto, la Via de la Belleza exige una educación porque parte del principio de que la belleza no es autentica sino en relación con la verdad, al objeto de no ser reducida a un esteticismo reductivo y por tanto efímero, teniendo como fundamento la llamada a los filósofos a profundizar en las dimensiones de lo verdadero, lo bueno y lo bello según el dialogo de fe y razón que establece Juan Pablo II en la encíclica del mismo nombre. Así, se adentra en lo que Tomás de Aquino llama la integridad o perfección, la justa proporción o armonía y la claridad, y representa una vía pastoral una de cuyas tres líneas de pensamiento es la belleza de las artes: "el arte sagrado debe tender a ofrecernos una síntesis visual de todas las dimensiones de nuestra fe".

Fernandez Cobián se plantea (2005) si le es posible a un artista cristiano, y por tanto al arquitecto que hace un edificio-iglesia, conjugar este discurso con el de la modernidad, con el ejercicio actual de su profesionalidad en el marco de la avanzada sociedad tecnológica que parece arrebatarnos.

O bien, ¿debemos considerar sin más que cualquier iglesia moderna tiene intrínsecamente menos valor que una antigua y que su arquitectura ha de ser totalmente neutra y autónoma de la categoría sagrada, que así queda relegada al universo de la especulación existencial? ${ }^{34}$. Pero también, inmersos en la realidad cultural y sociológica de nuestro tiempo ¿cómo dar respuesta al programa de necesidades de una iglesia en términos de la excelencia, tal y como plantea Ignacio Vicens? Estas y otras muchas cuestiones -con hondas incidencias en términos de inmediatez pastoral y de viabilidad económica- han de plantearse y contestarse dentro del ejercicio profesional de quien afronta la arquitectura ecelsiástica, sí, pero también por parte de quien la encarga, planifica y gestiona.

\footnotetext{
${ }^{34}$ Cf. Fernandez Cobián, E. (2005). El espacio sagrado en la arquitectura española contemporánea. Santiago de Compostela. COAG. Fernández Cobián en esta Tesis Doctoral publicada por el Colegio de Arquitectos de Galicia en la que hace un repaso del debate sobre la arquitectura religiosa moderna española en el periodo 1950-1965 a partir del desarrollo de la liturgia y de las realizaciones pioneras surgidas, especialmente en Alemania, después de los inicios del Movimiento Litúrgico, hace abrigar esperanzas muy fundadas de una respuesta positiva.
} 
Creer que únicamente el tratamiento de problemas técnicos resuelve el edificio-iglesia es una ingeniuidad en la que todavía se insiste en muchas ocasiones. ¿Cómo afrontar entonces el problema desde la arquitectura? ¿Es posible para el arquitecto entrar de lleno en el contexto próximo e inmediato de su obra, en la liturgia vivida, como parecen sugerir Pfeiffer y Verdon, y que ésta pueda ser fuente de inspiración para su proyecto? En la presente investigación se desea ahondar en esta dirección planteándonos el espacio litúrgico como configurador del proyecto arquitectónico de una iglesia, y analizándolo en el caso singular de la Sagrada Familia de Antonio Gaudí cuyo autor vive un itinerario personal de inmersión litúrgica sin renunciar a la excelencia. 


\subsection{Arquitectura religiosa versus Arquitectura sacra. Cuestiones a resolver en la dimensión celebrativa.}

\section{- $\quad$ La interpretación de lo religioso y de lo sagrado en la Arquitectura Moderna.}

La amplia interpretación de lo religioso suscitada principalmente en los últimos cincuenta años ha generado espacios muy diversos en el panorama de la arquitectura religiosa internacional. En primer lugar, hay que recordar que la falta de acuerdo en la terminologia de los conceptos induce a cierta confusión a la hora de establecer una distinción clara de las diversas categorías que tienen que ver con el edificio religioso. Términos como sacro o profano, religioso, cultual o eclesiástico se encuentran en el centro de un debate no cerrado, que afecta directamente al objeto del edificio y, en consecuencia, al desarrollo del programa de necesidades del proyecto. Es necesario, pues, tomar partido, proponer unas bases terminológicas que serán evidentemente conceptuales y necesarias para poder acercarse a la interpretación de lo religioso y lo sagrado en la Arquitectura Moderna.

Es generalmente aceptada la utilización del término sacro en materia artística para referirse a aquellas muestras de arte que tienen que ver con el mundo de lo sagrado, de la trascendencia del hombre, en oposición al mundo de la cotidianeidad, de lo profano. Por eso mismo las culturas históricas siempre han buscado lugares físicos prominentes, aislados y separados, donde erigir edificaciones singulares (claramente diferenciadas del común de los espacios dedicados a las actividades profanas y cotidianas). Estas edificaciones sagradas devienen en espacios "habitados" por la divinidad, únicos lugares donde era posible el culto público o privado. Los templos griegos y romanos, y de las civilizaciones orientales, responden a este lugar único de encuentro entre el hombre y los dioses. Incluso el Templo de Jerusalén reúne la doble condición de lugar oficial de culto y presencia de la gloria de Yahvé.

El Cristianismo revoluciona la religión, convirtiendo en biunívoca la comunicación divino humana y extrapolándola de los lugares sagrados para interiorizarla en cada persona, en todo momento y en cualquier situación. De ahí que la vida de cada individuo pueda pasar a tener la condición de sagrada, como imagen y semejanza de la divinidad, lo cual puede acontecer aún estando plenamente insertada en la sociedad profana. Ahora el templo no es el lugar único de la presencia divina y de la realización de un culto significado en los ritos externos, sino la interioridad más íntima de cada persona perteneciente a la comunidad cristiana. En este sentido el edificio religioso en el Cristianismo es en su origen cultual, donde la comunidad de los creyentes se reúne para celebrar un públicamente la eucaristía a la vez que prepara a los que pueden tomar parte activa en ella. La Iglesia es la asamblea o comunidad que se reúne bajo una advocación determinada para celebrar el culto eucarístico, dando nombre con minúscula al edificio-iglesia que también alberga la función de enseñar los misterios de la fe a los catécumenos y neófitos. 
Aunque hoy dia el término arquitectura eclesial o eclesiástica pudiera entenderse como circunscrito a las edificaciones oficiales de la Iglesia como Institución, los edificios de la Curia, .... es más coherente denominar arquitectura eclesiástica - de la Iglesia, Ecclesia- al conjunto de edificaciones que surgen para albergar las funciones correspondientes al ejercicio de los carismas que detalla San Pablo en su epsitola a los Corintios, con lo que se amplia el conjunto de tipologías arquitectónicas a todos los servicios y funciones que realiza la Iglesia y sus miembros en cuanto a su condición, esto es: edificios cultuales, administrativos de gobierno de la Curia en todos sus niveles, de carácter docente, asistencial, hospitalario, tribunales, etc. El edificio cultual cristiano alberga primordialmente una función, que es fundamentalmente comunitaria, como un acontecimiento que se realiza cada vez que se reune la asamblea. Este edificio, que toma su nombre-iglesia- de la asamblea que allí se reúne ha de ser adecuado para la acogida y la celebración liturgica, la preparación a los sacramentos, la educación permanente en la fe, la oración y contemplación, etc.

La definición de un programa de necesidades en la arquitectura cristiana, especialmente si se refiere a un edificio de culto, ha de contar previamente con un preciso conocimiento de la función y carisma que en el ha de ejercitarse. Una falta de concreción en este sentido derivará en un enfoque impreciso y por tanto, en la ambigüedad del programa de necesidades. Así mismo, la descontextualización litúrgica respecto a las directrices vigentes en cada momento histórico o la ausencia de su consideración puede llevar aparejados ejercicios de mimésis arquitectónica de ejemplos históricos de fortuna que son reproducidos "industrialmente" pero que resultan muy precarios para la funcionalidad del culto cristiano. En otros casos la pérdida de este carácter litúrgico del edificio conlleva graves riesgos de desnaturalización dentro de un itinerario que termina en un contenedor cultural -catedral laica de la modernidad- cuyo valor arquitectónico puede ser notable pero cuya valoracion cultual ha mermado grandemente. Arquitecturas fundadas en el intercambio de ideas, en la comunicación de información, en la contemplación de un paisaje e incluso en la meditación y reflexión personales, pueden tener que ver más con un foro ciudadano, con un lugar de encuentro de razas, culturas y religiones diferentes, e incluso con un espacio para la meditación u oración personal que con un edificio de culto de nunguna de ellas.

Hay que referirse también al amplísimo volumen de información disponible en las sociedades tecnológicas de hoy que, sin embargo, se han mostrado incapaces de generar un nivel de conocimiento, comprensión y disfrute del Arte similar en el ciudadano del siglo XXI. Al obviar la educación en beneficio de la información el Arte ha sido vapuleado de tal modo por el consumismo y oportunismo comerciales que ha de luchar cotidianamente por no banalizarse y desvirtuarse. 
Una tendencia que pusiera el énfasis únicamente en la inmediatez de la percepción de los hechos arquitectónicos en detrimento de su significado, podría de abonar el escenario de la inmadurez cultual y arquitectónica.

De ahí el riesgo de las arquitecturas que se mueven en un discurso marcado por el despojamiento a ultranza que puede llegar a un minimalismo e iconoclastia radicales, y de aquellas otras que reproducen sin más unas formas y una plástica descontextualizadas bajo la óptica del historicisimo. Ambos casos corren el riesgo de ser contrapuestos, por distintos motivos, como excluyentes a ejemplos válidos del pasado sin entrar en el fondo de la cuestión, pues la arquitectura cristiana sagrada ha de vincular artísticamente la celebración litúrgica de la Iglesia en cada época y cada lugar. ${ }^{35}$

La mayoría de la población consume el arte de los "mass media" de turno sin pararse un momento a dialogar con él. Por eso no es extraño encontrarse con opiniones aprioristicamente irreconciliables. Por un lado las de aquellos que deploran cualquier manifestación de arte moderno en la Iglesia, presos de un conocimiento artístico limitado y ligado a un momento histórico pasado o a una piedad mal entendida. Por otro, quienes confunden la libertad y expresividad arquitectónica consecuente que conceden los materiales y tecnologías actuales, y los ideales culturales de universalidad, con el atemperamiento y adecuación de un espacio para la celebración del culto. En este aspecto hay que abundar en lo manifestado por Ignacio Vicens (Contra la Voluptuosidad) que es una llamada apremiante a la educación artística, a la legitima autonomía del arte respecto de un pietismo mal entendido, y al dialogo fructífero de la racionalidad con la fe para sentar los fundamentos de un camino de excelencia para una relación de excelencia, la de la comunidad cristiana con su Dios.

Recorrer como actuales postales o cromos del pasado no tiene sentido, siempre es mejor ver el prototipo. Acercarnos a algunas arquitecturas actuales ligadas al uso religioso puede resultar muy esclarecedor por la diversidad de soluciones propuestas, según sea el promotor y atendiendo al enfoque del arquitecto, dando idea del vigor que han tomado en los últimos años estas arquitecturas. ${ }^{36}$ En la mayor parte de los casos no estamos hablando de edificios cultuales sino que las fronteras entre lo religioso y lo cultural o mediatico parece que se difuminan hasta llegar a confundirse centrando el mayor interés en promover la capacidad de comunicación que pueda surgir entre diferentes credos religiosos que en mostrar el itinerario trascendente propio de cada creencia y facilitar la celebración de su fe.

\footnotetext{
${ }^{35} \mathrm{Cf}$. Frias, Ma A. y De Isla, Ana B. (2000). "Significado y contemplación en la Arquitectura Sacra", en Arte sacro, un proyecto actual. Madrid. Fundación Felix Granda. P.217-18, Nota: "....la eficacia en cuanto al carácter sacro conseguido no reside tanto en una respuesta literal a la ordenación litúrgica y simbólica cuanto a su nivel arquitectónico considerado como arte", "La arquitectura sacra es fe hecha cultura, y lo cultural pertenece a cada época, a cada lugar."

${ }^{36}$ Cf. Paredes Benitez, Cristina. (2009) Arquitectura de los templos sagrados. Barcelona.
} 
¿Cómo consideraremos el Palacio de la Paz y la Reconciliación de Foster en Astana (Kazhastán) proyectado para el Congreso de líderes del mundo y religiones tradicionales? La capilla ecuménica de St. Henrys en Turku, Finlandia, de Sanaksenaho Architects, nos plantea un interrogante análogo, pues su condición de foro abierto al ecumenismo cristiano tampoco permite considerarla estrictamente como un espacio adscrito a una comunidad determinada que se reúne para celebrar lo que para ella significa la comunión con un Dios que lo trasciende y lo inunda todo. Otra capilla de singular diseño, la capilla Leaf, en Yumanashi, Japón, de Klein Dythma Architecture, recreando un paisaje de armonía y sosiego, está dedicada únicamente a la celebración de bodas. La Casa de Meditación de Pascal Arquitectos en Ciudad de México parece responder más a un concepto filosófico oriental que a una diversificación de funciones y cultos en el Hebraismo, hasta ahora no conocidos.

Es un fenómeno generalizado la proliferación de nuevas propuestas edilicias en el ámbito de un concepto extendido de lo religioso vinculadas a escenarios conceptuales no siempre cultuales, estrictamente funcionalistas o de carácter efímero, anteriormente poco conocidas o valoradas pero estimuladas ahora por los cambios sociales acaecidos en los últimos cincuenta años. No obstante, cabe preguntarse si la satisfacción de las nuevas exigencias funcionales solicitadas por el auge del tratamiento aséptico y funcionalista de la práctica religiosa que pretenden imponer los "massmedia" no irá en detrimento del autentico carácter cultual y comunitario de los edificios religiosos en el ámbito de cualquier credo.

Ciñéndonos al mensaje cristiano, la evolución litúrgica, la variedad de ritos y de contextos históricos socioculturales han generado históricamente una diferente manera de entender el diseño de una iglesia cuyo reflejo ha sido una gran diversidad de soluciones arquitectónicas. Es posible constatar un alto procentaje de acuerdo en la preocupación por la estabilidad, la magnificiencia y ornamento de la iglesia, el simbolismo e imagineria, la imagen edilicia y la implantación urbana,...casi siempre presentes en la inquietud de quienes han hecho posibles estas iglesias. No siempre ocurre lo mismo cuando se trata de la funcionalidad o adecuación de una iglesia a su uso, por cuanto entran en discusión concepciones ligadas a la experiencia personal de la liturgia y de la fe, mucho más difíciles de casar entre los posibles interlocutores. Muchas veces el espacio arquitectónico es vivido por los usuarios como inhóspito para el culto y la oración, y sin embargo es su práctica la que está deficitaria de renovación; en otras ocasiones planteamientos eclesiales muy deterministas en cuanto a la ubicación, el sentido social o la función religiosa se encuentran sorprendentemente desprovistos de una clara identificación con la comunidad concreta que ha de celebrar su fe en el edificio. 
En cualquier caso, es innegable, como indica Antón Capitel, que la arquitectura eclesiástica moderna ha tenido un indudable protagonismo en el siglo XX, y "ha sido al menos tan afortunada, fecunda, y desde luego, variada como en las épocas que suponía el más absoluto protagonismo arquitectónico." ${ }^{13}$ Esta realidad tan diversa y polémica está también en el trasfondo del debate. Incluso en países como Italia, con un amplio programa de construcción de nuevas iglesias de la Conferencia Episcopal, se plantea la necesidad de un dialogo permanente y franco entre los liturgistas y teólogos, y los arquitectos, a los que a veces se une de diverso modo el usuario de las edificaciones, la comunidad cristiana, tanto a nivel de jerarquía como de los fieles laicos. Se constata, pues, la vigente necesidad de seguir preguntándonos qué es el edificio iglesia y qué quiere ser en cada caso, y con ello disponer la sensibilidad necesaria para percibir el programa de necesidades más adecuado en cada caso.

En un intento de contestar a la pregunta en términos de su arquitectura, Fernández Cobián se aproxima a la tipología de los edificios litúrgicos apuntando a la clasificación del CIC de 1917 y el de 1983, si bien señala que adolece de un "fin eminentemente jurídico y no responde a una concepción arquitectónica del espacio." ${ }^{38}$; cita la clasificación de Manuel Garrido Bonaño en la Gran Enciclopedia Rialp (1975) como más centrada en la realidad constructiva, al hablar de basílicas -mayores y menores- catedrales, colegiatas, santuarios y ermitas; y menciona también la de Eduard Junyent (1940) en su libro La Iglesia. Construcción. Decoración. Restauración, que habla de catedrales, parroquias, iglesias conventuales y capillas, utilizando criterios espaciales que tienen que ver con la liturgia, como la posición relativa del coro y del altar, el baptisterio, etc.

Anteriormente el Manual Litúrgico de Solans del año 1901, sin pretender realizar una clasificación tipológica en el sentido arquitectónico, distingue por razones de la celebración de la Misa entre las iglesias publicas (que deben estar dedicadas o al menos bendecidas), y los oratorios (públicos, semipúblicos y privados atendiendo al tipo de licencia necesaria para la celebración de la Misa y el resto de funciones religiosas que se pueden realizar), mostrando la importancia de la función litúrgica para la comprensión de los distintos espacios de culto cristianos.

\footnotetext{
${ }^{37}$ Capitel, A. (1999). "Prólogo", en La idea del Templo en la Arquitectura del siglo XX. Gil Giménez, Paloma. Madrid. Ed. del Serbal

${ }^{38}$ Cf. Fernandez Cobián, E. (2005). El espacio sagrado en la arquitectura española contemporánea. Santiago de Compostela. COAG: "El Código de Derecho Canónico de 1917 reflejaba dos clases de templos: las iglesias y los oratorios. Dentro de las primeras distinguía las catedrales, las colegiatas, las iglesias conventuales y las iglesias parroquiales, y dentro de los oratorios separaba los públicos, los semipúblicos y los privados. Por su parte, el código de 1983 sólo cita expresamente las iglesias catedrales y las iglesias parroquiales, aunque agrega una distinción entre oratorios y capillas privadas, incorporando aparte la noción de <santuario> como lugar de peregrinación." P. 21
} 
El Manual de Antoñana (1921) mantiene lógicamente la misma norma que el de Solans pero precisando con mayor detalle que "Ia iglesia es el edificio sagrado dedicado al culto con el principal intento de que esté a disposición de todos los fieles", para así distinguirla de los oratorios o capillas, que con la misma clasificación que Solans, están o no abiertos a todos los fieles según sean públicos o semipúblicos y privados.

Queda claro que desde el punto de vista litúrgico se valora el significado de lo sagrado en las iglesias, capillas, o en espacios integrados en otros edificios más amplios, como el espacio en el que se celebra el culto eucarístico, principalmente, y el resto de celebraciones liturgicas; además, se ha de tener presente la importancia del para quién es, para aclarar la idea de arquitectura eclesiástica, pues ésta surge en y para una asamblea determinada en el tiempo y en el espacio. El Comité francés para el Arte sagrado lo tiene muy claro cuando dice que la primera función del edificio iglesia es posibilitar la reunión de los cristianos para celebrar su fe $\mathrm{f}^{39}$, y su finalidad primera celebrar su liturgia; y así como el Misal y los ritos han sufrido históricamente cambios y actualizaciones para una mejor expresión del contenido esencial en orden a la participación activa de los fieles, también el espacio litúrgico ha de atender las diferentes necesidades que se plantean con el curso de los tiempos para una mejor ayuda a la celebración comunitaria de la fe. ${ }^{40}$

Por ello, dado que la acción litúrgica no agota el ser de la liturgia, como dice Gutierrez Martín, se trata de que en la arquitectura eclesiástica (salvando el riesgo de lo que denomina experiencia estética desfenomenalizada cuando no se da el encuentro adecuado entre Arte y Liturgia) éste se configure no como simple ornamento de la Liturgia -a veces incluso totalmente secularizado- sino como vehículo de la manifestación más fiel y auténtica del misterio que en ella acontece. ${ }^{41}$

\footnotetext{
${ }^{39}$ Cf. AAVV. Comité National d'Art Sacré. (1971) L'église maison du peuple de Dieu. Paris. Ed. du Cerf. P.12: "La première fonction de l'église est de permettre à des chrétiens, dispersés dans le monde, de se ressembler au nom de leur foi ».

${ }^{40}$ Admitiendo lo que conlleva el espíritu de la liturgia en una comunidad renovada por una fe viva que se acrecienta dia a dia, hay que considerar los diferentes espacios dedicados a la oración, la meditación, la acogida, la catequesis, etc. como notables arquitecturas del silencio o de la comunicación, según el caso, constatando que en ellas el factor de escala y su relación con la nave celebrativa resultan de gran importancia a la hora de responder al programa planteado y precisamente por ello éste ha resultado ser un buen aliado en la batalla por el espacio litúrgico en pleno siglo XXI.

${ }^{41}$ Cf. Gutierrez Martin, J.L. (2000). "La liturgia en el Magisterio Conciliar", en en Arte sacro, un proyecto actual, Actas del I Curso de Arte Sacro celebrado en Madrid en 1999. Madrid. Fundación Felix Granda. P.28: " $Y$ en este sentido, todo verdadero arte, en cuanto ámbito de trascendencia y anhelo del absoluto, goza de un cierto carácter sacro. Mas aún, en gran medida, el arte mismo es la forma de lo sagrado."
} 
En realidad, ya lo había dicho certeramente J.L. Fernández del Amo a finales de los años 40: "Desde los cimientos hasta la cruz señera de sus torres, el templo ha de ser concebido de un modo integral y orgánico." 42 Volviendo pues a lo qué quiere ser el edificio iglesia no vendría mal la contestación que da desde la teología Pedro Rodriguez indicando como razón última de su existencia "el lugar donde celebrar los misterios de la fe, especialmente la eucaristía, donde Cristo se hace presente y hace a los presentes miembros de su cuerpo y templos de su Espíritu anticipando la Jerusalén celestial", mostrando también que este espacio tiene "el calor permanente de la presencia real de Cristo en el sagrario" 43. De ahí que convenga remarcar el carácter de permanente apertura a los fieles que tiene este edificio como ha recordado el Concilio Vaticano II cuando éste casi parecia olvidado. Puestas así las bases conceptuales también merece la pena recordar cómo Louis Khan atribuye un carácter casi ritual al arte de componer sabiamente las partes de un conjunto, realizando un proyecto completo y total en sí mismo en los términos de la concinnitas albertiana $^{44}$. Lo que no es sino la expresión en términos de un adecuado laicismo de lo que Carrasco o Rhaner denominan función ministerial del artista cristiano. Veremos que estas categorias artística-renacentista y ministerial-teológica pueden encontrarse también en lo confesado por el mismo Gaudí a sus colaboradores al hablar de su propia experiencia de trabajo en la Sagrada Familia: "Es una obra que está en las manos de Dios y en la voluntad del pueblo. El arquitecto viviendo con el pueblo y dirigiéndose a Dios, va haciendo su faena." 45

\section{- La dimensión celebrativa.}

La dimensión celebrativa es lo específicamente inherente a la arquitectura eclesiástica, por ello todo lo que afecte a esta dimensión tiene una repercusión amplificada en el espacio que la acoge. Maurizio Bergamo y M. del Prette (Espacios celebrativos, 1997) lo han puesto de manifiesto: "Así mismo, toda la arquitectura de las iglesias de época paleocristiana, que no es sino un soporte físico y formal de las acciones litúrgicas y de los ritos que constituyen su contenido esencial, y está ordenada de modo que los expresen

\footnotetext{
42 Cf. Fernández del Amo, J.L. (2006). “Arquitectura de la Liturgia”, en revista Ars Sacra no37, Madrid, publicado originalmente en revista Alferez no16, 1948, pp 4-5.

43 Cf- Rodriguez, P. (2000). “¿Qué es propiamente un Templo Católico?”, en Templo Cristiano y Espacio Litúrgico, AAVV. Madrid. Fundación Felix Granda.

${ }^{44}$ Cf. Porthogesi, Paolo. (1981)."Después de la arquitectura moderna”. Barcelona. Gustavo Gili.

${ }^{45}$ Cf. Puig Boada, I. (1981) El Pensament de Gaudí. Barcelona. COAC. La Gaya Ciencia. P. 180: "Es una obra que està en las mans de Déu i en la voluntat del poble. L'arquitecte vivint amb el poble, i dirigint-se a Déu, va fent la seva feina."
} 
con un lenguaje figurativo sacramental de signos espaciales e iconográficos de una fuerza impresionante: por esa razón su representación figurativa sigue siendo elocuente todavía hoy. Con la desaparición de la importancia dada al signo en el sacramento y la preponderancia de un planteamiento racionalista y verbal, se llega a perder también la fuerza de significado del espacio de las iglesias, y prevalece tan sólo el problema de expresar con la arquitectura conceptos racionales y no sacramentales, tales como

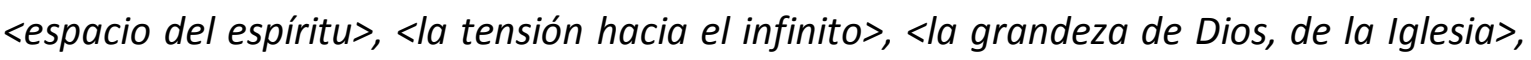
$<$ la opción por los pobres $\rangle$, <el centro del barrio>, etc." ${ }^{\prime 46}$

Bergamo y Del Prette, siguiendo lo argumentado por Guardini respecto del espíritu de la liturgia, una liturgia viva y vivida en el seno de la asamblea cristiana, han señalado cómo la participación activa del pueblo cristiano en la liturgia responde a una experiencia real del sacerdocio común de los fieles implicado con el sacerdocio ministerial en la celebración del misterio eucarístico y que de esta manera transforma la vida de cada persona de la comunidad que se reúne para celebrarlo; y, por tanto, cómo el planteamiento de los espacios que lo sustenta ha de nacer de este espíritu. De tal manera que las iniciativas de los arquitectos pueden verse entorpecidas por la falta de implicación de éstos con la experiencia litúrgica de los usuarios pero también por la falta de una renovación en la fe de la comunidad cristiana, cargada con la rémora de la inercia pasiva y el costumbrismo sociocultural que reducen cada vez más la inquietud por lo que allí acontece a una dinámica pasiva y ciertamente fugaz, cuestión que es fácilmente observable en el elevado número de fieles que llegan tarde al comienzo de la celebración y en la rapidez con que se alejan de la iglesia, a veces incluso, antes de que se haya producido la bendición final.

Urge pues continuar con el ejercicio de intentar conjugar el lenguaje formal arquitectónico del edificio con la dimensión litúrgica de la asamblea celebrante para no caer en apriorismos que solo conducen a callejones sin salida. Propiciar el dialogo de la técnica con el espíritu litúrgico que se requiere y del lenguaje formal con el figurativo, sumará posibilidades al éxito de la construcción cultual. Afortunadamente hay signos esperanzadores de este dialogo, que de una manera u otra casi siempre se ha dado a lo largo de la Historia y del cual se quiere presentar como ejemplo el proyecto de la Sagrada Familia de Antonio Gaudí.

El planteamiento no es sencillo y puede ser objeto de una amplia discusión en términos de arquitectura, pues siendo muy conocida la expresión de Louis Sullivan, la forma sigue a la función, es igualmente válida arquitectónicamente, la idea de Mies van der Rohe,

\footnotetext{
${ }^{46}$ Cf. Bergamo, M. y Del Prette, M. (1997). "Espacios celebrativos". Traducción española del original italiano. Bilbao. Ediciones EGA. P. 15
} 
que ratificarían muchos arquitectos modernos, cuando se declara partidario de buscar una forma práctica y satisfactoria y, entonces, adaptar la función a la forma. Siguiendo el análisis que hace para la arquitectura religiosa J. G. Davies ${ }^{47}$, la razonable idea de Sullivan llevada al extremo podría desembocar en el utilitarismo pero no seria garantía de éxito en cuanto a lo que quiere ser un edificio iglesia. Un artilugio mecánico, o una construcción funcional sin más pueden resolver una cuestión práctica, una actividad a realizar, pero no expresan nada, no tienen el carácter ni la expresividad arquitectónica que se le demanda a un espacio vinculado a los sentimientos y manifestaciones culturales o trascendentes del hombre. Para se produzca arquitectura hay que acercarse a lo que manifiesta Wright, y que nos recuerda Davies: "la utilidad deviene en belleza por el verdadero triunfo de la visión imaginativa"48. Es la imaginación creadora del arquitecto la que trasciende el conjunto de las funciones y formas de sus partes y de su conjunto para conformar el sentido unitario del edificio. Según Davies, Wright va en el proceso creador del interior al exterior. Gaudí afirmaba que las formas exteriores han de ser trasunto de las interiores. Si añadimos lo que manifiesta Le Corbusier respecto de que el objetivo del edificio es conseguir una construcción en la que se pueda vivir con arreglo a una serie de funciones y necesidades especificas en cada caso, podríamos coincidir con el autor australiano cuando se declara partidario de una actitud de servicio en la arquitectura religiosa, que dé respuesta a las necesidades del hombre en términos de la totalidad de su existencia física y espiritual.

Es decir, un edificio, susceptible de infinitas variantes, cuyo proyecto responda a lo sagrado y a lo profano, pero que como dice Davies "no excluya la liturgia del mundo ni el mundo de la liturgia"49. ¿Es posible para el arquitecto, hoy dia, crear una iglesia tal que cautivase de tal manera al visitante que le llevara a desear participar en la celebración litúrgica? Evidentemente la respuesta parece ser negativa, aunque no hay que olvidar el efecto causado por Santa Sofia de Constantinopla en el pasado quizá no se haya vuelto a intentar en demasía en el presente. A este respecto no debe echarse en saco roto la impresión que reciben los visitantes de la Sagrada Familia de Barcelona aunque no todos sean participes de la acción liturgica o incluso bautizados. De hecho algunos, como Sotoo, vienen para quedarse.

${ }^{47}$ Cf. Davies, J.G. (1971) "La tendence de I'Architecture Moderne et I'appréciation des édifices religieux» en AAVV. Art Sacrée et achitecture moderne". Paris. CERF. P. 90 : "Sous sa forme absolue l'idée qu'une bonne architecture est produit automatiquement par une stricte attention à l'utilité, à l'économie et à autres considérations pratiques, en vient à réduire la construction d'un édifice à celle d'une machine. "

${ }^{48}$ Cf. Davies, J.G. (1971) "La tendence de l'Architecture Moderne et l'appréciation des édifices religieux» en AAVV. Art Sacrée et achitecture moderne". Paris. CERF. P. 91 : "l'utilité devient beauté par véritable triomphe de la vision imaginative. "

${ }^{49}$ Cf. Davies, J.G. (1971) “La tendence de l'Architecture Moderne et l'appréciation des édifices religieux» en AAVV. Art Sacrée et achitecture moderne". Paris. CERF. P. 93. 
En todo caso, ¿es posible valorar la positiva impresión que produce en una persona de cualquier edad, dotada cuando menos de sensibilidad, con o sin una formación adecuada, la experiencia de la belleza artística y por tanto arquitectónica? Creemos que sí y así lo admite la misma Iglesia Católica (Via Pulchritudinis) y gran parte del mundo artístico, pues la belleza atrae y enamora. Un edificio así, que irradia su belleza, de su contenido y de su contingente, desde el interior al exterior; una arquitectura sirviente de la belleza del rito, del gesto, ... de la celebración comunitaria de la fe, en función no de la riqueza de sus materiales sino de la aportación de su tecnologia y diseño a la función que constituye el sentido del edificio, puede ser un buen punto de partida para que la creatividad artística del hombre moderno renueve los espacios liturgicos. $Y$ ya se sabe que no ha de esperarse de la creación artística que sea previsible, sino rabiosamente sincera, imaginativa y sorprendente.

Se trata pues de componer sabiamente, como decía Louis Khan, los distintos espacios y partes del conjunto, comprendiendo la función de cada uno de ellos, sus secuencias y conexiones (determinados en este caso por la liturgia que los dota de vida), y plantear los elementos arquitectónicos de tal manera que el lenguaje iconográfico y el lenguaje formal sean lo más perfectamente uno. Así cada espacio dispondrá unos requerimientos y todos y cada uno de los espacios conformarán un único organismo constructivo fiel reflejo del comportamiento de las personas. Porque el comportamiento de las personas que componen la comunidad celebrante aprehende el espacio arquitectónico previamente construido haciéndolo suyo y reconfigurandolo como un concreto espacio celebrativo, que puede ser acorde o discorde con áquel. Este debiera ser hijo de su tiempo, de la cultura concreta en que surge, de quien lo crea, pero sobre todo de la comunidad que lo promueve y que se reúne para celebrar un misterio de comunicación comunitaria, íntima y misteriosa con la Trascendencia. De ahí la responsabilidad del arquitecto, lograr que la comunidad celebrante lo haga suyo, la asuma como propio.

La asamblea cristiana termina por adueñarse de él de una manera o de otra, haciéndolo bellamente suyo si lo ha comprendido y dialogado con su creador, o por el contrario rechazándolo, si no lo ama ni se ama a sí misma. Por ello, cuando Bergamo y del Prette indican que una de las cuestiones que más fuertemente se plantean hoy en día es resolver la conexión entre los ritos propios del culto (lenguaje figurativo de los símbolos y los sacramentos), los comportamientos, gestos y lenguaje de esos ritos (lenguaje figurativo del cuerpo individual y colectivo), y las arquitecturas (lenguaje figurativo de los espacios, formas e iconografia) para constituir un espacio litúrgico adecuado, están sintetizando un proceso que ha durado siglos y debe darse a su debida escala en cada diseño de una iglesia.

Desde algunas opiniones especializadas se tiene la percepción de que las iglesias modernas viven hoy inmersas en una casi total ausencia del lenguaje de los símbolos, 
desprovistas casi por completo de imágenes y ornamentación hasta llegar a las fronteras del minimalismo arquitectónico, y más preocupadas por la técnica constructiva y el diseño tecnológico que por dar una respuesta adecuada a las necesidades de la comunidad celebrante. Pero para ser ecuánimes también habría que preguntarse cómo es la comunidad celebrante que así opina y hasta dónde llega su programa de necesidades...

Se trata de profundizar en la cuestión de preguntarnos, como hace José Luis del Palacio (Arquitectura y Liturgia, 2000) si la estética de nuestras iglesias responde al espíritu del Concilio Vaticano Il y qué piensa el hombre de hoy cuando entra en ellas, porque respecto de la segunda cuestión que se plantea habría que señalar que la respuesta es tan variable y cualitativa como diferente es la espiritualidad y formación de quien se la plantee a si mismo. ¿Quién se pregunta si es la idea de centralidad del altar o la participación de los fieles lo que se persigue en esta o aquella iglesia que se construye, o únicamente interesa plasmar el lugar de la jerarquía eclesiástica en un espacio especialmente configurado al efecto? Fuera de un liturgista y algunos arquitectos, ¿quién tiene una concepción clara de los focos litúrgicos? Se desconoce o se ignora el espíritu de la Sacrosantum Concilium y de toda la renovación litúrgica surgida tras el Concilio Vaticano II porque a menudo se impone la funcionalidad ligada a la inercia adquirida de muchos años, la idea de monumentalidad arquitectónica, y las querencias individuales, tanto en el arquitecto, en la comunidad cristiana a la que se pretende servir, o en el seno de los organismos eclesiásticos especializados. Nadie parece estar libre de estos "pecados" contra el espacio litúrgico.

El resultado satisfactorio requiere su tiempo y buenas dotes de paciencia por el arquitecto, y debe conseguirse mediante la aportación de muchas opiniones que el ministro artístico ha de saber conjugar, traducir y mostrar, con un auténtico espíritu de servicio a la causa. Hay que instruir y formar iy con urgencia! Al objeto de que el resultado final pueda ser aprehendido por los usuarios como casa suya, la casa de la asamblea cristiana más que la casa de Dios. Porque Dios no reside en ninguna Casa. La arquitectura ha de servir como nexo de unión entre los especialistas diocesanos en teología y liturgia, y la comunidad cristiana que allí se reúne encabezada por su pastor, armonizando los condicionantes urbanísticos y técnicos con los requerimientos funcionales del edificio, y todo ello presidido por una sensibilidad creativa y artística puesta al servicio del hombre en su totalidad, con sus necesidades materiales, culturales y espirituales. Quizá persiguiendo estos objetivos nos sorprendamos a nosotros mismos con la apreciación del sentido de lo bello en nuestra sociedad aunque sea en detrimento de lo que Del Palacio llama la tiranía de lo útil y la esclavitud de la rutina..$^{50}$

\footnotetext{
${ }^{50}$ Cf. Del Palacio, J.L. (2000) "Prólogo" a Bouyer, L. Arquitectura y Liturgia. Bilbao. Grafite Ed. P. 13: "El sentido de lo estético es lo que más hace superar la tirania de lo útil y lo funcional, dándonos capacidad de apreciar lo gratuito y lo festivo, infundiendo en nosotros paz y serenidad, reconciliándonos con nosotros mismos y con el mundo que nos rodea."
} 


\section{- Elementos arquitectónicos para la comprensión del espacio sacro.}

Si pudiéramos partir de una convención previa, considerar como espacio sacro cristiano al ámbito arquitectónico donde acontece algo sagrado, la celebración de la presencia misteriosa pero real de Jesucristo y su comunicación con un pueblo congregado en su nombre que es llevado a la trascendencia, en la eucaristía principalmente pero también en otros sacramentos, transformando los sentimientos, la voluntad y la vida de cada individuo en virtud de esta activa participación en el culto y la oración, qué duda cabe que nos estaríamos refiriendo al espacio cultual propiamente dicho o aula litúrgica de una iglesia. La noción de separación del espacio sacro respecto del espacio mundano en su concepción histórica se ve totalmente superada por la noción de asamblea cristiana que viene del mundo y está, no segregada de él, sino en contacto con el mundo y también con la asamblea celeste de los santificados; y la comunión interpersonal creada entre los individuos que la constituyen -que es la que da sentido a la creación de un espacio ordenado al bien de las personas en todas sus dimensiones, corpórea, psíquica y espiritual- se desarrolla no al margen sino en la cotidianeidad del mundo profano.

La asamblea cristiana necesitaba de un espacio más amplio que las primitivas domus ecclesiae, ordenado según las necesidades de un culto cada vez más complejo a medida que se desarrollaba la liturgia, insertado en un contexto territorial y cultural determinado que marca su orientación constructiva y dimensión decorativa, y pronto a manifestarse como hito arquitectónico de primer orden. En este espacio, y más concretamente en el aula celebrativa, Bergamo y del Prette plantean la necesidad de restablecer el nexo entre lenguaje verbal y lenguaje figurativo, de tal manera que el trabajo a realizar en el espacio litúrgico no sea únicamente verbal o gestual sino que se traduzca en términos arquitectónicos. ${ }^{51}$ Cobra, pues, importancia la investigación arquitectónica de un proceso de diseño que -como el de la Sagrada Familia de Gaudí- aune la comunicación o representación en el espacio litúrgico de los ritos formalizados (símbolos y sacramentos), de los comportamientos (lenguaje del cuerpo y de las interacciones de grupo) y de las arquitecturas (lenguaje de los espacios y su conformación, de los signos y de la iconografía).

Aldazabal remarca la importancia la importancia del lenguaje simbólico, no sólo de los signos sacramentales sino del espacio mismo de la celebración, puesto que como el mismo señala la misma disposición del espacio ayuda a la asamblea celebrante a captar lo que allí se celebra ${ }^{52}$.

\footnotetext{
${ }^{51}$ Cf. Bergamo, M. y Del Prette, M. (1997). Espacios celebrativos. Traducción española del original italiano. Bilbao. Ediciones EGA. P. 17

${ }^{52}$ Cf. Aldazabal, José. (1988). "Presentación”, en Farnés, P. Construir y adaptar las iglesias. Barcelona. Regina.
} 
Pero arquitectónicamente la cuestión es todavía más amplia, abarca todo el edificio y requiere una visión global y sistemática. El programa de necesidades del edificio iglesia ha ido variando de acuerdo con el momento histórico y el territorio al que pertenece pero es posible y necesario señalar una serie de elementos arquitectónicos que lo caracterizan. De hecho, como señala Bouyer, la iglesia bizantina tradicional, y dentro de esta tipología Santa Sofía de Constantinopla, surgió como una creación específica de los arquitectos al servicio del culto cristiano y se convirtió por mucho tiempo en el modelo más logrado de adecuación al uso litúrgico cristiano. ${ }^{53}$

Por tanto, en el proceso de composición arquitectónica del edificio iglesia es posible sintetizar algunos elementos que facilitan su comprensión como espacio cultual:

- El propio espacio interior del aula celebrativa que presenta una concepción sensiblemente unitaria del volumen edificado y es luz que lo ilumina -delimitado por las trazas de una determinada y precisa configuración en planta, por las bóvedas y cubiertas que lo resaltan y por la envolvente muraria que lo limita- es clave primera del lugar liturgico. Si responde a un criterio ordenado que emana de la celebración comunitaria y es adecuadamente tratado para su percepción y confort se convierte en núcleo generador de todo el proyecto.

- La estructura y la tectónica que comporta este espacio, que como el esqueleto del cuerpo le dan estabilidad y permiten su movimiento, su metabolismo interno, facilitan el dinamismo litúrgico o promueven su fosilización. Pueden permitir su percepción unitaria o favorecer su fragmentación por lo que se convierten en soporte fundamental del espacio celebrativo. Dentro de ella la bóveda, o mejor la cúpula, siempre ha hecho referencia a la comunión entre la Iglesia peregrina y la Iglesia triunfante, estableciendo una relación temporal, sagrada y simbólica con un orden y un sistema propios.

- La dimensión urbana del edificio, como hito arquitectónico y simbólico referenciado a un determinado entorno, cuenta con la envolvente muraria exterior como vehículo de la comunicación del edificio iglesia con el hábitat que le rodea; dialoga con la sociedad y cultura de su tiempo de igual manera que la fisonomía y piel del cuerpo que puede mostrar acogida y afecto -o rechazo a los hombrespermaneciendo en el subconsciente de la población aún cuando se haya perdido $u$ olvidado la asistencia al culto y la participación en los diversos actos litúrgicos.

${ }^{53}$ Cf. Bouyer, Louis. (2000) Arquitectura y Liturgia. Bilbao. Grafite Ediciones. P. 67 
- El carácter simbólico de la celebración, que ha de ser expresivo del misterio cristiano según señala la liturgia católica desde el Concilio Vaticano $\|^{54}$, se manifiesta a través de la dimensión artística del edificio, de sus formas, colores y texturas, de la escultura, pintura y otras artes, y constituye un lenguaje de la mayor importancia par el carácter y uso del edificio. Necesita por tanto un adecuado tratamiento. La bondad de su inserción arquitectónica dependerá de la fluida comunicación entre los especialistas teóricos (teólogos y liturgistas), los artistas (arquitectos, pintores y escultores) y los usuarios (el pueblo cristiano representado tanto por la jerarquía como por los fieles en general). En este sentido, se necesita de una acción formativa previa para la asunción del edificio iglesia por la comunidad cristiana.

Para Bouyer el culto cristiano se caracteriza por su dinamismo y éste ha de quedar claramente visible en la disposición del edificio. Nos encontramos pues con un foco de organización y generación proyectual que radica en la liturgia y que aspira a poner en juego todas las posibilidades de ejercicio del artista.

\section{- Cuestiones arquitectónicas a resolver en la dimensión celebrativa.}

En el elenco de propuestas que puede proponer el arquitecto emerge la inquietud por reflexionar y plantear soluciones a algunas cuestiones concretas que han sido afrontadas con desigual fortuna a lo largo de la historia arquitectónica o que han pasado totalmente inadvertidas dentro del quehacer profesional habitual, y permanecen a la espera de que arquitectos y resto de actores del edificio dialoguen y se atrevan a presentar más audaces soluciones. En primer lugar quiero referirme a la tensión litúrgica de la nave desde la frontera entre el interior y el exterior -con la necesidad de un tratamiento adecuado para el umbral del edificio como espacio de acogida- y al recorrido hasta el fondo de la misma en una secuencia que tiene que ver con el mismo dinamismo de la celebración litúrgica.

Así mismo cobra primordial importancia la percepción global y unitaria del espacio celebrativo propiamente dicho, que manteniendo y resaltando los distintos focos de la celebración de acuerdo con su jerarquía, orden y conexión, procure una adecuada relación visual y litúrgica de toda la asamblea, sabiendo garantizar al mismo tiempo el concepto de centralidad del altar y disponiendo correctamente los espacios sirvientes. En este sentido se debe señalar cómo sigue ocupando gran parte de las energías del proceso proyectual y de los debates subsiguientes la relación y diseño de los distintos elementos del presbiterio, su relación con la asamblea de los fieles y las circulaciones que se producen en las celebraciones litúrgicas.

${ }^{54}$ Cf. Farnés Scherrer, Pere. (1988). Construir y adaptar las iglesias. Barcelona. Regina. P. 10 
La disposición acústica del aula celebrativa también continúa siendo muchas veces una asignatura pendiente en el plano arquitectónico cuya resolución se deja al ámbito electroacústico cuando es primordial la adecuada audibilidad de la Palabra durante el culto y la envolvente sintonía coral y musical de la asamblea. Y aunque la cuestión de las campanas parece que hoy día haya decaído en el contexto de la gran urbe moderna, sigue teniendo un carácter simbólico y relacional que no habría que olvidar.

La situación del baptisterio, cuestión todavía bastante difusa en la reglamentación litúrgica actual y sometida por ello -la mayor parte de las veces- a la práctica habitual del en las iglesias pequeñas, es cuestión ampliamente debatida entre los que quieren mantener la dimensión simbólica del itinerario cristiano desde el primer sacramento de iniciación cristiana hasta la participación eucarística, los que quieren primar la visualización y con ello la participación de toda la asamblea congregada para la eucaristía, y aquellos que priorizan la cercanía al ámbito de los movimientos del ministro ordenado y con ello los motivos prácticos de su ubicación en el mismo presbiterio.

La ubicación del tabernáculo para el Sacramento tampoco es una cuestión totalmente solucionada puesto que diversas cuestiones, unas veces la reducida superficie del edificio y otras la disparidad de enfoques con relación a su dignidad, accesibilidad y relación con la nave celebrativa, dificultan la adopción de soluciones universalmente reconocidas como acertadas. La libertad que ofrece la normativa litúrgica no debería hacer perder de vista el sentido de la reserva para los enfermos ausentes de la misa y la conveniencia de tratar diferenciadamente la adoración eucarística -en un espacio separado, aunque adecuado, digno y accesible desde el aula eucarística- de la celebración eucarística.

La disposición de espacios adecuados para el sacramento de la Penitencia ha ido complicándose progresivamente desde el abandono de las trazas jesuíticas de las iglesias y la recuperación del sentido completo de este sacramento que había caído casi en el olvido a favor de la sóla confesión individual de los pecados. Resulta esperanzador que progresivamente haya vuelto a valorarse el sentido de acogida al penitente, la proclamación de la Palabra y la exhortación a la conversión subsiguiente. También ha de valorarse cómo el canto y la oración comunitaria pueden ayudar a vivir este sacramento como una celebración donde se dá la reconciliación comunitaria en virtud de la misericordia divina.

La actualidad y oportunidad del diseño de espacios adecuados para el enterramiento de los fieles ligados a una comunidad es una cuestión arquitectónica que por distintos motivos irá a más en el diseño de las nuevas iglesias. Bien al modo de las tradicionales criptas o camposantos, bien como columbario, resurge el testimonio y signo de pertenencia a la Iglesia en una sociedad que banaliza el cuerpo humano $y$, sin embargo, no sabe cómo enfrentarse a la muerte. 
Evidentemente no se puede pretender la respuesta a todas y cada una de estas cuestiones mediante el análisis de un proyecto concreto, en ocasiones anterior en el tiempo a la visualización de alguna de estas necesidades programáticas, pero si resulta interesante analizar conceptualmente el proyecto arquitectónico de Gaudí para la Sagrada Familia y su manera de afrontar el lugar liturgico. Si éste proyecto respondiese a un enfoque así, claramente perceptible, y si fuese posible entresacar las claves del mismo -visualizándolas arquitectónicamente- podríamos encontrarnos con alguna sorpresa de la mano de la imaginación desbordante de su principal autor, de su fundamentación histórica y litúrgica, y del empeño en realizar una composición arquitectónica de los espacios siguiendo los postulados anteriores. Porque necesariamente hay una evolución histórica del edificio cristiano de culto que responde, con mayor o menor fortuna según el momento histórico y las circunstancias sociológicas, a las necesidades de unas acciones y ritos cambiantes aun cuando su esencia haya permanecido inalterada.

En la transición del siglo XIX al XX asistimos a profundos cambios en el enfoque de la Misa cuyo carácter comunitario se reivindica, traduciéndose en una serie de recomendaciones arquitectónicas, para la mejor participación del pueblo, que Gaudí plasma en sus proyectos. En consecuencia podriamos hablar de innovación gaudiniana en una arquitectura eclesiástica que se anticipa a las actuaciones del Quickborn alemán. Gaudí actuaria veinte años antes que Schwarz y Guardini en la Sagrada Familia planteando un espacio celebrativo notoriamente distinto de la tradición histórica tridentina mostrando una sensibilidad plástica muy próxima al espíritu que anima, desde un lenguaje mucho más racionalista, las salas celebrativas e iglesias arquitecto y teólogo alemanes (tal y como lo concibe Guardini en su famosa obra) y también, por qué no decirlo, podría afrontarse la visión del espacio gaudiniano a la luz de la filosofia de la arquitectura que describe Louis Khan.

Así pues, liturgia y arquitectura, filosofía y diseño, arte y evangelización, se nos presentan como facetas a integrar y reivindicar en el proyecto arquitectónico. Si queremos tomarnos la molestia de afrontarlo desde una clave celebrativa -cuestión que hoy día parece estar en laborioso diálogo con la actividad restauradora del patrimonio arquitectónico eclesiástico ${ }^{55}$ - podemos encontrar una via adecuada para conjugar la herencia recibida del patrimonio histórico-cultural y su disfrute como bien público con la propiedad eclesiástica de dicho bien y el reconocimiento del carácter primordial de su función cultual. ${ }^{56}$

\footnotetext{
${ }^{55}$ Cf. Soto Morales, Fa. (2013). "Influencia del uso litúrgico en la restauración de las obras", Ponencia en el Congreso La Arquitectura al servicio de la Liturgia celebrado en el Colegio de Aparejadores de Madrid en mayo de 2012, recogida en Ferrer, J.M. y Folgado, J.R. (edts.). La liturgia inspiradora de las artes. Barcelona. CPL.

${ }^{56}$ Cf. Aldanondo Salaverria, I. (2012) "Regimen jurídico del Patrimonio Cultural de la Iglesia Católica en España", en AAVV. Arquitectura y Liturgia. Barcelona. CPL. Que recoge las ponencias y comunicaciones de las XXXVI Jornadas de la Asociación Española de Profesores de Liturgia celebradas en el Monasterio de El Escorial del 30 de agosto al 1 de septiembre de 2011.
} 


\subsection{La historiografía de la obra gaudiniana. Las corrientes de análisis de la arquitectura de Gaudí. Síntesis de los diferentes enfoques planteados.}

La apreciación historiogáfica de Gaudí es diversa, desde quien le ha visto como un fenómeno religioso, político, como un individuo aislado y raro, hasta su percepción como un genial artista y o como un arquitecto muy imaginativo pero encerrado en sí mismo. En lo que respecta a enjuiciar su obra la cuestión es todavía más amplia y tremendamente compleja en sus líneas de reflexión, remontándose en sus inicios a los últimos años de la vida del arquitecto.

Por ello y con el fin de afrontar de una manera más sintética (cualidad que destacaba mucho Gaudí) y conceptual los diferentes enfoques, que según la ruta de aproximación seguida han proporcionado las preferencias ideológico-culturales y las connotaciones artistico-técnicas según los cuales ha sido observada, investigada y analizada la arquitectura y pensamiento de Antonio Gaudí, resulta legítimo establecer un método de aproximación historiográfica a su obra que nos permita visualizar desde contextos ideológicos, culturales y temporales diferentes no sólo la amplia variedad de posturas críticas acerca de ella sino también los diversos ángulos de visión para su conocimiento, la globalidad y detalles que conlleva, y las propuestas a futuro que pudiera generar.

La clasificación que se propone no responde a un criterio meramente cronológico, tampoco quiere ser una visión desde la perspectiva sociológica ni atender exclusivamente al valor artístico o al estilo arquitectónico que le pueda otorgar la crítica especializada, sino que busca conjugar elementos de proximidad al arquitecto; componentes ideológicos, que conlleven o no su presencia en estudios de Historia de la Arquitectura; opiniones vertidas en congresos y seminarios con referencia a los aspectos más importantes o polémicos de su proyecto y construcción; los hallazgos realizados en el seno de instituciones, que han tenido relevancia para el conocimiento y divulgacion de la obra gaudiniana; y, finalmente, las aportaciones de la crítica actual, que han suponiendo una valoración positiva o negativa de aspectos muy concretos de su arquitectura han mantenido viva la reflexión sobre su incidencia en el campo de la arquitectura sacra.

De esta manera se propone como más interesante para la presente investigación los siguientes enfoques de aproximación al conocimiento de su obra:

1) En primer lugar, resulta imprescindible conocer la visión de los colaboradores inmediatos del arquitecto, esto es J. F. Ràfols, Francesc Folguera, isidre Puig Boada, Joan Bergós y César Martinell.

2) Aunque no constituye una visión especializada sobre su obra, hay que reseñar la mención a la obra gaudiniana en las publicaciones referentes a la Historia de la Arquitectura, fundamentalmente a través de las obras de Giedion, Hictcock, Benévolo, Zevi, Tafuri, Navascués y Flores. 
3) Las investigaciones realizadas en la cátedra Gaudí de Barcelona, en el departamento de $\mathrm{H}^{\mathrm{a}}$ del Arte de la Universidad de Columbia, Nueva York, y en Harvard, principalmente en la década de los años sesenta, constituyen a mi juicio el punto de inflexión que marca el comienzo de un nuevo y más riguroso periodo de análisis de la producción del arquitecto.

4) La concepción de la dimensión artística total de la arquitectura gaudiniana que se abre a los foros de diálogo y la polémica respecto de la continuidad de la Sagrada Familia constituyen una muestra de la actualidad del debate sobre su obra.

5) El diálogo respecto de la modernidad de Gaudí, visto desde los congresos y seminarios realizados principalmente en Italia, abre la oportunidad a esta Tesis.

6) Finalmente, el interés renovado desde finales del siglo XX por el estudio de la arquitectura eclesiástica confirma en gran medida la metodología de la Tesis.

\section{Visión que de Antonio Gaudí nos dan sus colaboradores inmediatos.}

Joan Francesc Ràfols, colaborador delineante en el despacho de Gaudí en la Sagrada Familia desde 1913 a 1916, asistente del arquitecto hasta su muerte en 1926 y primer biógrafo suyo, es el que, palabras de Joan Bassegoda, con humilde perseverancia recogió desde los primeros momentos todos los datos, fichas, documentos, anotaciones, etc. disponibles a su alcance para realizar su biografía del arquitecto. Además utilizó información gráfica procedente del Archivo de la Sagrada Familia, archivo Mas, archivo de la Escuela de Arquitectura y del Centro Excursionista de Cataluña, pudiendo publicar la cronología de la obra gaudiniana y diversos artículos en el Propagador de la Devoción a San José, entre los años 1926 y 1927. En 1929 la editorial Canosa publica su biografía de Gaudí, con dos ediciones, en catalán y en castellano, una extensa bibliografía y un articulo de Francesc Folguera sobre la posición innovadora de Gaudí y su ensayo de una nueva arquitectura. En 1952 y 1960 se reeditó el libro (sin el articulo de Folguera) pero con un comentario de Ràfols respecto de lo que la critica especializada hablaba de Gaudi posteriormente al año 1929.

El estilo de Ràfols, aunque vehemente y directo, aporta aspectos biográficos -personales y de relaciones de amistad- que constituyen una valiosa información para el conocimiento de los fundamentos del pensamiento gaudiniano y por tanto de su trabajo profesional, especialmente en lo que hace referencia al desarrollo del proyecto de la Sagrada Familia. Ràfols ve los trabajos en colaboración con Joan Martorell y otras obras realizadas en diversos colegios religiosos como una preparación para sus posteriores proyectos de arquitectura religiosa, e incluso aborda algunas obras civiles de madurez, desde la perspectiva de lo sagrado y lo profano. Trascribe expresiones textuales de Bocabella y del propio Gaudí con relación a la ejecución de las obras del Templo Expiatorio, y aporta información de carácter confidencial que permite constatar su proximidad y veracidad 
respecto de los protagonistas de la ejecución de las obras. Sin duda que sus opiniones y explicaciones del Templo Expiatorio, de sus muebles y de los objetos de uso litúrgico, que a veces complementa con las de Bergós y Domènec Sugranyes, dan pie a sustentar un enfoque del proyecto arquitectónico desde la vivencia litúrgica de su principal autor.

Isidre Puig Boada, considerado entre los cuatro primeros biógrafos, estudiosos y divulgadores de la obra gaudiniana que fueron también colaboradores directos (Ràfols, Bergós, Martinell y el propio Puig Boada) como aquel que manifiesta una más clara devoción profesional por su maestro resultante del gran conocimiento que tenia de su espíritu artístico y de su profunda admiración personal y profesional ${ }^{57}$, recoge, clasifica y ordena por temas el pensamiento arquitectónico que aparece en los manuscritos gaudinianos y la procedencia gran cantidad de conversaciones y dichos del arquitecto. Aunque no es fácil encontrar en Puig Boada -ni tampoco en el resto de sus cuatro biógrafos clásicos- un planteamiento crítico de la obra gaudiniana, tienen el meritorio valor de la proximidad a las fuentes y de la fidelidad a la información que divulgan, por lo que hay que considerlos como una fuente privilegiada para su conocimiento.

Su libro "El Pensament de Gaudi" reproduce de una manera singularmente estructurada las ideas y escritos originales del joven Gaudí, trascribe los comentarios e ideas que expresa el arquitecto maduro a sus colaboradores y conocidos sobre una amplia variedad de temas, citando además la persona en dialogo con la cual se producen, y finalmente adjunta interesantes ilustraciones de muchas de sus obras, de tal manera que su contribución presenta aspectos documentalistas a la vez que constituye una aproximación ordenada y referenciada de su pensamiento artístico y arquitectónico.

La aportación fundamental de Puig Boada consiste en su interés por rastrear el Templo Expiatorio a la luz de sus escritos, es decir, de las ideas que manifiesta Gaudí en referencia a lo sagrado y a la arquitectura eclesiástica ${ }^{58}$, de ahí que resulte un apoyo imprescindible para la realización de esta investigación que la toma como uno de sus puntos de partida. Si la totalidad de la obra gaudiniana es compleja y evolutiva en el tiempo, y así ha sido objeto de diversas estructuraciones para su mejor comprensión según las tendencias y desarrollo de sus aspectos estilísticos, constructivos y artísticos, la obra de la Sagrada Familia refleja perfectamente este carácter evolutivo en el tiempo y en el espacio que da un singular interés a su estudio y comprensión. Queda pues justificado que no es absoluto

\footnotetext{
${ }^{57}$ Cf. Puig Boada, I. (1981) El pensament de Gaudí. Barcelona. Publicaciones del COACB. Prólogo del Decano del COACB.

${ }^{58}$ Cf. Puig Boada, I. (1981). El Pensament de Gaudí. Barcelona. COAC. La Gaya Ciencia. P. 12: "Seria bona cosa resseguir ara el Temple a la llum inéditta d'aquests escrits, dels quals Gaudí no ens parlà mai i el coneixment dels quals es deu a l'intelligent recerca del peoner J.F. Ràfols, efectuada arran de la mort del mestre."
} 
ajena a esta singladura técnica del proyecto una visión trascendente del mismo, que se sustenta en el conocimiento de la liturgia vivida, a cuyo sentido y ritualidad pretende dar satisfacción el edificio en su totalidad. El propio Puig Boada, devoto gaudinista, seria el precursor de esta línea de aproximación cuando señala entusiásticamente que en la obra mencionada: "La Providencia preparaba a su sirviente para la tarea que le reservaba para cinco años después, cuando le viene el nombramiento para el que seria el mejor templo cristiano del mundo, y en el cual la eclosión de su arte y de su fe crecientes es paralela $e$ incontenible." ${ }^{\prime 59}$

Joan Bergós Massó, biógrafo, colaborador directo y amigo personal de Antonio Gaudí, al que acompaña en sus largos paseos dominicales escucha de su boca reflexiones y comentarios que posteriormente transcribía al final de cada jornada. Por eso es capaz de adentrarse en la psicología más personal e íntima del arquitecto, aquella que parece constituir una de las claves de su personalidad y su quehacer profesional.

Gracias a él sabemos del exhaustivo estudio al que somete los textos y láminas que caían en sus manos, llenando de anotaciones y dibujos los unos y asimilando profundamente las imágenes de obras arquitectónicas que las otras le mostraban. Así acontecía con el Diccionario de Arquitectura y el Diccionario de mobiliario francés de Viollet-le-Duc por ejemplo, o con los grabados de edificios del viajero francés Laborde en su recorrido por toda España.

Bergós nos da la visión de un joven apasionado, impetuoso e irascible al que sus vivencias de fe cristiana trasforman en un hombre sereno y equilibrado con ocasionales arranques de genio, que reflexiona profundamente sobre los problemas del arte y la vida. ${ }^{60}$ Su visión es la de un artista integral dotado de una profunda imaginación cuya arquitectura siempre quiere anticiparnos algo: nuevos usos para las cubiertas de los edificios, adopción del hormigón armado como material para la ejecución de jácenas estructurales; preocupación por la iluminación y ventilación de espacios anteriormente privados de ello (instaura puertas caladas); investigación del sonido y la música, llegando a la fabricación de diversos modelos de campanas tubulares; interés acerca del color y la iluminación en el espacio celebrativo, que conlleva numerosos estudios y ensayos hasta dar con toda un repertorio formal de vanos y lucernarios, vitrales, etc. ; Siguiendo a Bergós podemos apreciar las investigaciones y trabajo profesional con los que Gaudí resuelve los más complejos problemas arquitectónicos. Cómo desarrolla un original sistema estructural de trasmisión de cargas que abre su discurso a la modelización y experimentación de gran numero de cuestiones que inciden en la concepción arquitectónica global del edificio.

\footnotetext{
${ }^{59}$ Cf. Puig Boada, I. (1981). El Pensament de Gaudí. Barcelona. COAC. La Gaya Ciencia. P. 12.

${ }^{60}$ Cf. Bergós Massó, J. (1953). Antonio Gaudí, el hombre y la obra. 2a Edición de 1974. Barcelona. Publicaciones de la UPC. P. 29
} 
Bergós es, pues, el arquitecto desgrana el proceso proyectual, los problemas que se plantea y cómo los afronta, integrando en la solución cuantos detalles y singularidades constructivas, o disciplinas artísticas resulten de interés. Su aportación es constructivamente consistente y se ve reforzada por la inclusión del factor litúrgico como pieza clave para entender su arquitectura eclesiástica. Nos descubre, así, sólidas razones para afrontar, no sólo un completísimo programa simbólico, sino la concepción de la planta y la estructura en función del uso litúrgico. Es el primero en plantearse una clasificación en etapas, que además resulta bastante convincente: el denominado periodo Preliminar, en el que trabaja como colaborador de otros arquitectos y en el cual ya están presentes obras de fuerte significado litúrgico; el periodo Mudejar-Morisco; el asimilado a un Gótico evolucionado que produce obras tan significativas como el colegio teresiano y la torre de Bellesguard; el Naturalismo expresionista de las casas para la alta burguesía barcelonesa, de la cripta de la Colonia Guëll y del Parque del mismo nombre, así como de la restauración litúrgica de la catedral de Mallorca; y finalmente, el que llama de Síntesis orgánica representado por las Escuelas y Templo de la Sagrada Familia.

Por último, hay que mencionar dentro de estas cuatro fuentes básicas para el conocimiento de la obra gaudiniana la aportación de las diversas publicaciones de Cesar Martinell, cuya principal virtud es aunar la cercanía personal de Ràfols, la aproximación profesional de Bergós y el conocimiento del pensamiento gaudiniano que nos brinda Puig Boada. De esta manera el enfoque de Martinell deviene en tremendamente práctico y sintético, con escaso margen de error o improvisación.

Martinell es paisano de Gaudí, del Camp de Tarragona, fue fundador y primer director en 1958 del Centro de Estudios Gaudinistas y entiende el carácter mediterráneo y luminoso del quehacer profesional del maestro. En su libro Conversaciones con Gaudí, escrito entre 1915 y 1926 con ocasión de las sucesivas visitas de su autor al taller de Gaudí en la Sagrada Familia, describe la génesis de distintos elementos de la obra junto con otras explicaciones y reflexiones que recibe del propio Gaudí. En Gaudi: su vida, su teoría, su obra, aborda desde la triple visión humana, de su pensamiento y su producción arquitectónica, su contribución a la arquitectura. En La Sagrada Familia Martinell aporta un enfoque muy completo del edificio desde el punto de vista litúrgico y líneas para su análisis que denotan por la cercanía al autor, los fundamentos sobre los que Gaudí concibe y desarrolla su proyecto.

En este primer enfoque clásico o primigenio de aproximación a la arquitectura de Gaudí podemos incluir también a Francesc Folguera. Su análisis nos presenta a un arquitecto que investiga constantemente y en profundidad todos los estilos históricos, alguien que quiere resolver cada obra, cada problema arquitectónico, experimentando nuevas soluciones partiendo de un problema formal concreto que afronta con una increíble dosis de imaginación. 
Su aportación se sitúa en la línea de un estudio crítico de la producción del arquitecto que aparece en colaboración con Ràfols en la publicación de 1928. Foguera nos presenta a Gaudí interesado no en teorizar o descubrir una norma general de actuación sino en buscar una solución concreta a un problema determinado, contando con el cúmulo de su conocimiento sobre los estilos históricos, con la ayuda de la técnica de su tiempo y finalmente con su inquietud personal respecto del carácter, uso y función del proyecto arquitectónico en el que trabaja. Nos habla de un Gaudí que se sumerge en la esencia que descubre de cada estilo histórico hasta llegar a las raíces plásticas del clasicismo griego, a la integridad espiritual del gótico, al ingenio estructural del bizantino, a la armonía del renacimiento y la libertad imaginativa y utilización de las diversas artes del barroco, para utilizar todo este análisis en beneficio de su visión corpórea y estructuralista del edificio. Para él la geometría, la construcción, la mecánica no costituyen el centro de su arquitectura sino técnicas al servicio de un fin. Apunta cómo en sus últimos años, trabajando en la Sagrada Familia, se muestran las últimas consecuencias del estilo evolutivo de Gaudí: cómo utiliza los macizos y los vanos, el espesor de los cerramientos, ...para una creación lumínica precisa, la que se requiere para el uso litúrgico del espacio.

2. Antonio Gaudí en las principales publicaciones de la Historia de la Arquitectura Internacional y Española .

Llama la atención que no se menciona a Gaudí en la obra Espacio, Tiempo y Arquitectura (1940) de Sigfrid Giedion, ni la recoge en su Historia crítica de la Arquitectura Moderna (1980) Kenneth Frampton, ni tampoco Norberg-Schultz lo cita en Arquitectura Occidental (2001), por recoger tres ejemplos de estudios críticos del desarrollo de la arquitectura a nivel internacional, en momentos diferentes.

Sin embargo, al hilo de un artículo de Nikolaus Pevsner en 1952 sobre la arquitectura de Gaudí que fue premiado por poner en evidencia la fuerza y originalidad de su arquitectura ${ }^{61}$, Henry Russell Hitchcock publica en 1958 Architecture 19th and 20th Centuries, editado por el mismo Pevsner, en el que menciona a Gaudí como una figura aislada pero dentro de lo que ve como corriente modernista, que hunde sus raíces por un lado en Ruskin y el lenguaje neogótico y por otro en la tradición mudéjar española. Hitchcock cree que Gaudí experimenta un gran cambio en su obra arquitectónica a partir de los años 90 en los que ya tiene en mente el proyecto global de la Sagrada Familia y considera ésta como el monumento religioso más importante de los últimos cien años. ${ }^{62}$

\footnotetext{
${ }^{61}$ Cf. Lima, Antonieta Iolanda. (2008). "Gaudi nella storiografia del secondo Novecento", en AAVV. Attualità di Gaudí/ a cura di Guilio Pane. Napoli. CLEAN.

${ }^{62}$ Cf. Hichtcock, Henry Russell. (2008). Arquitectura de los siglos XIX y XX. Ed. En castellano. Madrid. Ed. Cátedra, Anaya. P. 437.
} 
Señala que al igual que pasa con el global de su producción, de la cual realiza una primera clasificación, la Sagrada Familia es un proyecto evolutivo en el tiempo que plantea en sus últimos años una brillante solución para la nave.

No obstante, para llegar a una adecuada mención y encuadre de Antonio Gaudí en el panorama de la Arquitectura de los dos últimos siglos hay que reseñar como fundamental la lectura europea de la Arquitectura de los siglos XIX y XX y más concretamente la visión del Modernismo y de la naciente Arquitectura Moderna que hacen los grandes analistas italianos como Zevi, Benévolo, De Fusco, Tafuri y Dal Co.

Es a raíz del interés de Bruno Zevi por Gaudí cuando éste comienza a adquirir notoriedad en la critica arquitectónica internacional. Zevi realiza una aproximación a los movimientos arquitectónicos de finales del siglo XIX en su Storia dell' Architettura Moderna (1950), situando en sus orígenes el interés por el neogótico que propugnan Ruskin y Morris en Inglaterra, que libera a la Arquitectura del Neoclasicismo y el corsé académico precedentes.

En esta ruptura antiacadémica destaca la aportación de las grandes figuras de L'Art Nouveau, entre las cuales situa al genio de Gaudí, viéndolo como un arquitecto neogótico dotado de una imaginación y orientación personalísimas, pero al que asigna en palabras de Antonietta I. Lima un papel ajeno a las corrientes arquitectónicas europeas comparándolo como figura solitaria y precursora con el americano Wright.

En 1957 Hitchcock habia promovido una exposición en el MOMA de Nueva York que genera interés por su obra y la abre a un más amplio diálogo, pero cuando en 1960 Leonardo Benévolo publica su primera edición de la Storia dell'Architettura Moderna, a diferencia de Hichtcock, da una visión más próxima del Art Nouveau a la realidad del territorio donde surge y que se expresa, no como un estilo único internacional, sino como "un vocabulario coincidente en las distintas obras aparecidas en lugares distantes", tal y como señala Vilardell en su estudio sobre Gaudí y la historiografia clásica de la arquitectura moderna ${ }^{63}$.

Benévolo reconoce a Gaudí su carácter de pionero dentro del panorama de la arquitectura de finales del siglo XIX pues cronológicamente su casa Vicens es significativamente anterior a la casa Tastel de Victor Horta, pero también lo singulariza en sus valores y producción arquitectónica a partir del momento en que se despega de su etapa modernista para seguir su propia y particularísima evolución.

\footnotetext{
${ }^{63}$ Cf. Vilardell, Joan E.(2002). "Gaudí y la historiografía clásica de la arquitectura moderna", en Gaudí a
} Mallorca. Palma de Mallorca. IX Jornades Internacionals d’Estudis Gaudinistes. Centre d’Estudis Gaudinistes. 
Renato de Fusco en su Storia dell'Architettura Contemporanea (1975) encuadra la obra de Gaudí dentro de una de las variaciones de L'Art Nouveau, rechazando su carácter de genio aislado y apreciando su sentido evolucionista en un proceso marcado por la continuidad desde la tradición española (mudéjar, románico, gótico, plateresco, manierismo, barroco) al eclecticismo y el modernismo, anticipando soluciones arquitectónicas y figurativas que corresponden al cubismo, al expresionismo y al surrealismo, y viéndolo como un artista moderno, cuyas obras necesitan para ser generadas, además de los dibujos, el concurso de los modelos de tres dimensiones.

En 1976 aparece la Architettura Contemporánea de Tafuri y Dal Co, que supone una nueva manera de ver el lenguaje artístico dentro de un contexto de historia total en el que el Modernismo ya no se ve conceptualmente como un movimiento artístico que busca la sinceridad arquitectónica sino como una tentativa de la alta burguesía de construir su propio espacio físico cultural. Desde esta perspectiva, Tafuri ve a Gaudí dentro de un movimiento que intenta maridar los ideales medievales con la naciente industrialización, lo cual hace que se comprenda su inserción en el contexto de la cultura burguesa catalana de finales del siglo XIX. Concibe la madurez del arquitecto como el intento supremo de desarrollar hasta sus últimas consecuencias un nuevo concepto de arquitectura que éste creía haber descubierto.

Resulta también interesante señalar en este apartado la visión española de Gaudí en el devenir general de la Historia de la Arquitectura, que aunque circunscrita a la realidad hispana y a encuadres de producción eclesiástica o modernista mucho más concretos presentan particularidades ciertamente interesantes para su datación. Así, la visión de Pedro Navascués sobre Gaudí es la de su inserción en un capítulo de la arquitectura española que se desarrolla entre los años 1808 y $1914^{64}$, dentro del panorama de la arquitectura eclesiástica que se produce en esos años, al destacar el historicismo medieval, si bien llama la atención sobre la improcedencia de una lectura rápida y superficial de la Sagrada Familia, de la que destaca especialmente su interés estructural y su dinamismo litúrgico.

Carlos Flores, primeramente cuando habla del Modernismo catalán (1993), señala la escasa o marginal influencia de Antonio Gaudí en el desarrollo de la arquitectura contemporánea y lo ve más que como arquitecto genial como plástico genial ${ }^{65}$, no está de

\footnotetext{
${ }^{64}$ Cf. Navascués P. (1996). "Arquitectura Española, 1808-1914", dentro de Summa Artis, Ha General del Arte, Tomo XXXV**. Madrid. Espasa Calpe.

${ }^{65}$ Cf. Flores, C. (1989).Arquitectura española contemporánea. Madrid. Aguilar. P.87:"todo su dominio de la construcción y de la mecánica sirve de base y fundamento a su mundo formal sorprendente e inimitable. Gaudí es escultor y plástico por encima del arquitecto aunque tenga obras en que estos aspectos preponderantes de su personalidad quedan en segundo plano y estemos próximos a dar con su ven arquitectónica pura".
} 
acuerdo con Meier Greefe en su libro "Spanische Reise" de establecer un paralelo entre Horta y Gaudí, ni plástica, ni constructiva ni espacialmente. Piensa que su valor más alto está en anticipar en su obra la plástica del medio siglo venidero y en su expresión artística. Posteriormente, y entrando en el análisis concreto de la Sagrada Familia (2002) visualiza este proyecto desde el punto de vista simbólico y formal, apoyándose en unas manifestaciones de Bergós que lo consideraba como <un compendio de toda la doctrina de la Iglesia> , y llega a decir que "Gaudí, desde un principio, se esforzará por convertir el Templo de la Sagrada Familia en resumen y símbolo tanto de la historia de la Iglesia Católica como de sus principales dogmas y enseñanzas." 66 Para Flores el largo tiempo que dedica a las soluciones arquitectónicas de esta obra tiene como finalidad constituirla en una "summa teológica en piedra".

3. La aportación de las instituciones académicas a la reflexión y análisis de la arquitectura gaudiniana, principalmente a partir de los años sesenta.

En el contexto de los años 60 cobra especial protagonismo la acción investigadora y divulgadora que realiza la Cátedra Gaudí, en Barcelona, desde su creación en 1956, con la dirección primeramente de Joan F. Ràfols y Josep $M$ a Sostres, posteriormente del recientemente fallecido profesor Joan Bassegoda (2012) y en la actualidad de Jaume Sanmartí, recopilando y analizando documentación original, promoviendo conferencias y exposiciones, dictando cursos y dirigiendo tesis doctorales, y constituyéndose de esta manera en fuente impulsora de muchas otras acciones posteriores en orden a la valoración de la obra del arquitecto reusense.

Por los mismos años, la actuación desarrollada por Josep LI. Sert, sucesor de Gropius al frente de la Escuela de Diseño de Harvard y por George R. Collins, catedrático de $\mathrm{H}^{\mathrm{a}}$ del Arte de la Universidad de Columbia, Nueva York, como director de su Programa de Arte y del Archivo de arquitectura catalana, y miembro del Spanish Institute, se constituye en un motor del interés por Gaudí mediante la difusión internacional de su obra. al que todavía no se le había puesto en el circuito de la crítica internacional, quizá por provenir de un país que todavía permanecía bajo un régimen político autoritario. En 1960 se realiza una muestra itinerante por diversas capitales europeas y americanas, y se publica la primera obra de Collins sobre Gaudí llegando a ser uno de los más importantes estudiosos a nivel internacional de la arquitectura española de los siglos XIX y XX, el Modernismo catalán y especialmente la obra de Gaudí. Muy probablemente influenciada por esta muestra surge en ese mismo año el libro de Leonardo Benévolo ya mencionado anteriormente y se realiza también en 1961 una exposición en Génova, que serán fuente de inspiración para la posterior tarea investigadora de Roberto Pane en Italia.

${ }^{66}$ Cf. Flores, C. (2002). La lección de Gaudí. Madrid. Aguilar. P. 253. 
Collins señala que "El interés contemporáneo mundial por la arquitectura de Gaudí nació, en parte, al advertirse que las estructuras y formas inusitadas que empleó tienen algo en común con las de tipo cascarón actuales". 67 Como reconocido experto en la obra de Gaudí, a la que ha dedicado notables años de investigación ${ }^{68}$ y del que publicó en 1977 The drawings of Antonio Gaudí, los dibujos originales de Gaudí, presenta una visión de su arquitectura cargada con una profunda componente espiritual y por eso mismo plenamente impregnada de la personalidad e imaginación de su autor, a la vez que insertada en el conocimiento y uso de las técnicas constructivas de la arquitectura popular hispánica.

En segundo lugar, Collins, destaca el interés que manifestó Walter Gropius por su concepción artística global, de tal manera que menciona sus semblanzas con el manifiesto de la Bauhaus de Weimar sobre la catedral del futuro, y cómo la continuidad en la percepción de la obra gaudiniana en el extranjero se debe principalmente a su componente plástica componente plástica y al interés que despertó en artistas como Dalí llegando a remarcar el fuerte efecto que produce la experiencia real de las obras de Gaudí. ${ }^{69}$ En su primer libro sobre Gaudí ya hacia mención a la iconografía de la Sagrada Familia como una "Summa Teológica" de la Iglesia moderna como culminación de muchos años de investigación. Así pues, podemos considerar la aportación de Collins como una objetiva apertura del campo de la crítica a las diversas categorías desde las que se puede analizar el pensamiento y la obra gaudinianos, y todo ello con la difusión que permite el ámbito anglosajón.

Joan Bassegoda i Nonell, Director de la Cátedra Gaudí desde 1968 hasta su jubilación en el año 2000 , ejerció una prolífica acción recopiladora e investigadora de la obra gaudiniana, consiguiendo la declaración de monumento nacional de las obras de Gaudí, restaurando los pabellones Güell en los cuales se ubicó la cátedra durante muchos años, y dirigiendo la realización de exposiciones y tesis doctorales sobre la arquitectura de Gaudí. De 1969 es una pequeña publicación sobre las primeras obras de arquitectura religiosa de Gaudí, trabajando para las religiosas de Jesús-Maria en Tarragona, y en años sucesivos recopila numerosas frases y textos de Gaudí para una mejor comprensión de su pensamiento y obra, como por ejemplo Conversaciones de Gaudí con Joan Bergós, en 1974, en la revista Hogar y Arquitectura, y participa en restauraciones, encuentros y publicaciones sobre Gaudí convirtiéndose en uno de los mayores especialistas de su obra.

${ }^{67}$ Cf. Collins, G.R. (1970). "Antonio Gaudí: Estructura y Forma", en Jornadas de Estudios Gaudinistas. Barcelona. Blume.

${ }^{68}$ Cf. Collins, G. R. (1973) Antonio Gaudí and Catalan Movement, 1870-1930. Charlottesville. University Press of Virginia. William B. O'Neal Ed.

${ }^{69}$ Cf. Collins, G. R. (1993). "Discurso de investidura como Doctor Honoris" Causa por la UPC, en L'estudi de Gaudí, Bassegoda y AAVV (1996). Barcelona. Publicaciones de la UPC, Cátedra Gaudí, 
Dentro de esta labor enciclopédica desarrollada por el profesor Bassegoda merece la pena destacar la incorporación de varios edificios de Gaudí al patrimonio de la UNESCO, la restauración así mismo de algunas de sus obras, y la publicación de muchos libros, de los que destacaremos Aproximación a Gaudí (1992), en el que analiza algunas técnicas y soluciones constructivas empleadas por el arquitecto; L'estudi de Gaudí (1996), selección de artículos publicados en la revista Temple entre los años 1971 y 1994, en el que apunta la significación e influencia de la obra de Gaudí en el manifiesto de la Bauhaus de Weimar y en el posterior interés por las láminas tridimensionales de hormigón; El gran Gaudí (1989), probablemente la mayor enciclopedia de la arquitectura de Gaudí con información, en mayor o menor medida según el caso, sobre todas sus obras.

En 1999 publica conjuntamente con Gustavo Garcia Gabarró La cátedra de Gaudí, en la que además de recogerse sintéticamente la tesis doctoral de este último respecto de las formas naturales y su implicación en la arquitectura gaudiniana, realiza una clasificación de su arquitectura no estricta y secuencialmente cronológica, sino atendiendo a su forma y presentándola como una agregación sucesiva de lenguajes y vías de experimentación arquitectónica, desde sus obras primerizas colaborando con otros arquitectos, el llamado periodo de influencia oriental, el neogoticismo, el naturalismo (que sitúa desde 1895 a 1916) en el que menciona el Parque Güell, los principales edificios de viviendas y algunas actuaciones en la seo de Mallorca y Monstserrat, el periodo de geometria reglada, que se superpone al anterior situándolo entre 1908 y 1917, y que desarrolla básicamente en la Sagrada Familia partiendo de experiencias anteriores, y el que denomina estilo definitivo, trabajos en esta misma obra desde 1917 a 1926, año en que muere.

4. El enfoque de la obra gaudiniana desde la polémica respecto de la continuidad de la Sagrada Familia, la investigación y desarrollo del proyecto, y la nueva visión total de la arquitectura gaudiniana.

La fundación en 1952, por Josep Ma Sostres y Enric Casanelles, de la sociedad de Los amigos de Gaudí que tan activa parte ha tenido en el relanzamiento internacional de su obra, especialmente en Estados Unidos y Japón, y posteriormente, en 1967, la del Centro de Estudios Gaudinistas, presidido por Cesar Martinell, amigo y colaborador de Gaudí, marca un periodo de la historiografía crítica de Gaudí básicamente conformada por la búsqueda y exposición documental de su obra, su técnica y su dimensión artística, así como por la proliferación de los foros de debate de los especialistas, que amplian considerablemente el enfoque de su obra propiciando así un conocimiento más profundo de la misma.

En este sentido es de destacar el papel jugado por las Jornadas Internacionales de Estudios Gaudinistas que periódicamente se ha venido celebrando con creciente interés. 
Si bien las primeras, muy centradas en la polémica sobre la continuidad de las obras de la Sagrada Familia, se realizaron en 1967, y hasta 1994, fecha de las segundas Jornadas, trascurrieron 27 años sin aparente actividad oficial, ésta seguía viva mediante la concurrencia de las más variadas opiniones. Así, cabe mencionar la aportación de Oriol Bohigas, resituando el Modernismo catalán en la esfera europea ${ }^{70}$, en contraposición al anteriormente pretendido aislamiento de la cultura modernista catalana y de la obra de Gaudí, sin perder su carácter propio y autóctono. Bohigas, uno de los intelectuales firmantes del Manifiesto en contra de la continuidad de las obras de la Sagrada Familia, publicado en la Vanguardia el 9 de enero de 1965, ve a Gaudí con una cierta despreocupación por las nuevas posibilidades tecnológicas que ofrecía el hierro, pero en una línea claramente expresionista, siguiendo la estructuración de la arquitectura moderna propuesta por Pevsner ${ }^{71}$, precursora del movimiento expresionista alemán.

Durante más de veinte años esta polémica va a capitalizar gran parte de la crítica de los especialistas, situándose en el lado opuesto la Junta Constructiva de la Sagrada Familia (con una respuesta oficial publicada el 15 de febrero del mismo año en el Noticiero Universal), a cuyo frente destaca el ingente trabajo técnico de investigación y reconstrucción de maquetas y dibujos, modelización estructural y desarrollo de proyecto, así como una cuidadosa ejecución de las obras, que lleva a cabo un buen número de arquitectos, desde Quintana y Bonet Garí (colaboradores de Gaudí y continuadores de su trabajo) hasta Jordi Bonet i Armengol, Josep Faulí, Josep Gómez Serrano, etc. en estos últimos años, contando con la colaboración de las investigaciones realizadas por Frei Otto, Jos Tomlow, Mark Burry, etc. y el concurso de un notable número de artistas escultores, pintores, etc. que han querido sumarse a esta singular obra.

También hay que señalar algunas voces que se alzan en mitad de este debate para reivindicar una lectura más amplia de la arquitectura y del pensamiento de Gaudí más allá del debate sobre la continuidad de las obras del Templo expiatorio, entre los cuales cabe destacar a Juan Eduardo Cirlot, quien se plantea el naturalismo y expresionismo del arte gaudiniano como consustanciales con su obra pero no excluyentes el uno del otro sino afirmando de él que es un "arquitecto dramático" 72; Alexandre Cirici, que nos plantea una visión unitaria y plástica de la creación artística y arquitectónica de Gaudí, especialmente en la Sagrada Familia.

\footnotetext{
${ }^{70}$ Cf. Bohigas, Oriol (1968). Arquitectura modernista. Barcelona. Ed. Lumen

${ }^{71}$ Cf. Bohigas, Oriol (1973) Reseña y catálogo de la Arquitectura Modernista. Barcelona. Ed. Lumen. P. 144: "Esta despreocupación, le convierte dentro del campo tecnológico, no precisamente en un genio anticipador, sino más bien en el último arquitecto de una era, en el brillante clausurador de la arquitectura pétrea, si es que esta clasificación tecnológica nos importara demasiado."

${ }^{72}$ Cf. Cirlot, J.E. (2002) “Gaudi”. Barcelona. Ajuntament de Barcelona. Triangle Postals.
} 
En una línea similar pero con una dosis trascendencia se mueve Enric Casanelles, quien ve en la condición de creyente Gaudí un factor de permanencia de su producción artística ${ }^{73}$. Analogamente Salvador Tarragó, secretario de Los Amigos de Gaudí y estudioso de su obra, aunque no se mostró partidario de proseguir con las obras de la Sagrada Familia destacaba la necesidad de que la polémica suscitada por ello no impidiera la visión del innegable valor arquitectónico del proyecto gaudiniano y sigue la apreciación de Collins calificando como su "destino" unir forma y estructura para que se aproximen a la naturaleza. ${ }^{74}$

A su vez Ignasi Solá-Morales capta certeramente la evolución arquitectónica de Gaudí y explica el periodo final de su actividad como un intento por "llevar más lejos las posibilidades de sus hallazgos", de tal manera que su trabajo en la iglesia de la Colonia Güell y en la Sagrada Familia constituirían casi el resumen de su biografía arquitectónica. ${ }^{75} \mathrm{No}$ obstante señala el carácter fundamentalmente personal de su singladura arquitectónica, pese a contar con un buen número de colaboradores de distintas especialidades, y concluye rechazando su modernidad, aunque no lo impresionante y singular de su obra, al hacerlo hijo de una sociedad decimonónica inmersa en la monumentalidad.

5. La Crítica Italiana y el debate sobre el legado arquitectónico gaudiniano a través de los congresos y seminarios especializados.

El inicio del análisis de la arquitectura de Gaudí por la crítica italiana especializada puede situarse coetáneamente con las investigaciones realizadas en América por Collins, siendo Roberto Pane, profesor de la Universidad de Nápoles y reconocido colaborador de la Unesco, uno de los primeros en estudiar ampliamente su obra (Gaudí, 1964). Su estudio es profundo y completo, explicitando las conexiones culturales y linguisticas de Gaudí, motivando su origen y evolución en función de su propio recorrido imaginativo y madurez personal interior, y estableciendo los fundamentos para relacionar la experimentación entre la razón constructiva y la forma en la arquitectura de Gaudí.

73 Cf. Casanelles, E. (1965) Nueva visión de Gaudí. Barcelona. Polígrafa. P. 111: “El artista moderno ha dudado de todo contenido, de toda fe, de toda creencia. Su arte ha podido ser una revolución, una revolución de la forma, que se canta, que se glosa a sí misma, y también se destruye....Este arte sólo podía fugacidades geniales. Gaudí hizo lo mismo con la forma; sólo que fue creyente, y aquí es, en Gaudí, donde vemos por primera vez un arte que se hace absoluto, donde la estructura es lo mismo que el contenido. Algo muy parecido a lo que haría más tarde Teilhard de Chardin con la actitud de su pensamiento."

${ }^{74}$ Cf. Tarragó, S. (1991). "Entre la Estructura y la forma”, en AAVV. Antoni Gaudí. Barcelona. Ed. del Serbal.

${ }^{75}$ Cf. Solá-Morales, I. (1983). Gaudí. Barcelona. Polígrafa. P. 29: "Ciertamente, Gaudí pensó que este Templo debia resumir el conjunto de sus investigaciones y hallazgos a lo largo de su carrera como arquitecto." 
La vía de la crítica italiana estaba abierta y, sin olvidar el debate de la continuidad de la Sagrada Familia, analiza una gran variedad de cuestiones que hacen volver la mirada a su figura al aparecer en nuevas Historias de la Arquitectura ${ }^{76} y$ confrontar la amplitud de facetas de su obra en diversos congresos, encuentros y seminarios internacionales, como los organizados en el Politécnico de Milán y el Ayuntamiento de Nápoles en 1993, o el Forum y congreso internacional celebrados en esta última ciudad en los años 2004 y 2005 respectivamente. A ellos son invitados arquitectos españoles relacionados con la ejecución de las obras de la Sagrada Familia o que han investigado su obra, como Bonet y Bassegoda, y más recientemente Gonzalez y otros. Emerge con vigor la amplitud del debate reciente: su revisión historiográfica a la luz de nuevos análisis de su obra y de la valoración de su libertad de imaginación y de diseño, la continua actualidad de su arquitectura que suscita su tenaz búsqueda de la forma conjugada con la sabia utilización de materiales y técnicas, el carácter sacro de los espacios que ejecuta y el simbolismo que en ellos surge y que su autor domina por completo, etc.

Casi como hilo conductor en el area italiana durante este periodo destaca la figura de Giulio Pane que reivindica la modernidad de Gaudí ${ }^{77}$, reflexiona sobre su fantasia e imaginación, y su proceso racionalista del diseño, dentro de su visión de la búsqueda voluntarista de la verdad de la forma que se impone a los materiales. Pane alerta del riesgo de reducir la explicacion de la arquitectura de Gaudí desde una inspiración etereoideológica sin profundizar en el conocimiento y crítica de su obra.

Marcello Grisotti llama la atención respecto de la actitud de Gaudí ante las obras, que le hace ser considerado como un "constructor" en el sentido moderno del término. Así mismo Carlo Mezzetti apunta lo que su faceta de hombre de obra significa en cuanto a la creación arquitectónica y Francesco Brunno nos habla del dialogo constante que se produce en sus obras entre el exterior y el interior dando una especial continuidad a su diseño.

Haciendo una relectura historiográfica de Gaudí, para Pasquale Belfiore está fuera de duda su modernidad, y cree que su experimentación en la geometría y en la estática de la estructura concibiendo arquitecturas "sin forma de edificio" le hace estar en relación con otras figuras más recientes como Gehry, Isozaky y Foster.

\footnotetext{
${ }^{76}$ Cf. De Fusco, R. (1974) Storia dell' architettura contemporanea. Bari. Laterza

77 Cf. Pane, Giulio (1993) "Prefacio", en AAVV, Antoni gaudí: una proposta dei libertà, Actas del Congreso celebrado en el Politecnico de Milano. Milano. Dipartimento di Ingegneria di Sistemi Edilizi e Territoriali. Facoltà di Ingegneria. P. 5: Gaudi fa talvolta storce il naso ai "moderni", senza che essi avvertano l'implicito snobismo e la contraddizione del loro atteggiamento, poiché anch'egli fu"moderno", a suo tempo e a suo modo. Ma Gaudi è anche uno dei pochi artisti la cui opera riesca ancora oggi -e magari proprio nel senso di prestarsi ad uno scomodo confronto- destabilizante e rivoluzionaria, nonostante le superficiali affinità con il gusto modernista, cui tanto spesso quanto a torto é stata apparentata."
} 
Mạ Antonietta Crippa pone de relieve su contribucion al dialogo artesanía-arquitectura y destaca la unidad de construcción y decoración en el proyecto gaudiniano como anclaje metódico de la concepción de la idea en la posibilidad técnica y expresiva ofrecida por la artesanía y su puntual desarrollo en la producción industrial, y que ésto ya lo avanzaba en sus escritos del Manuscrito de Reus. Respecto de la experimentación estructural, Mario Migliore lo inserta en un proceso de mejora del sistema boveda-arco.

Algunos arquitectos españoles han participado en estos debates de la crítica italiana aportando más opiniones sobre cuestiones que siguen estando muy abiertas. José Luis Gonzalez Moreno-Navarro opina que no siempre llegó Gaudí a sistemas en sí mismo racionales sino que muchas veces su propuesta estructural hay que verla como una solución para crear un nuevo espacio arquitectónico. Para Jordi Bonet, hasta hace poco director de las obras de la Sagrada Familia, la continuación en su ejecución ha permitido una investigación mucho más potente y profunda sobre esta obra y el pensamiento de Gaudí consiguiendo un redescubrimiento actual de su legado arquitectónico que de otro modo se hubiese quedado en un plano mucho más teorico.

Verónica L. Bucconi aporta una interesante visión sobre el carácter incompleto de las tres principales obras sacras de Gaudí y la diferente lectura que se ha dado de ellas, señalando que se dan tres situaciones diferentes: la restauración y consolidación a modo de conclusión de la Cripta de la iglesia de la Colonia Güell; la continuación de la Sagrada Familia como proyecto que se rehace a sí mismo continuamente, ya desde el primer momento en vida de Gaudí, y que hay que observar dentro de un proceso más amplio; y finalmente la intervención en la catedral de Mallorca como un creativo proceso de descomposición y recomposición de elementos en clave litúrgica.

\section{La visión de Gaudí a partir del interés por el desarrollo de sus estructuras y su concepto} arquitectónico de lo sagrado.

Durante los últimos años la figura de Gaudí y el conocimiento de su arquitectura ha experimentado un nuevo impulso constatándose tanto la permanencia de su actualidad como la aparición de nuevos aspectos a investigar en su quehacer profesional. Diversos factores han contribuido a ello: por un lado la investigación y desarrollo realizados durante los últimos veinticinco o treinta años en la Sagrada Familia mediante la introducción de modernos programas de cálculo estructural, de desarrollo 3D y el concurso de diversas universidades en el ámbito internacional ${ }^{78}$

\footnotetext{
${ }^{78}$ Jordi Bonet Armengol, arquitecto director de las obras de la Sagrada Familia desde 1985 hasta 2012, ha introducido los modernos programas informáticos de calculo y desarrollo espacial en el proceso de definición y ejecución de las obras, abriendo la arquitectura de Gaudí al mundo universitario mediante la aportación de nuevas técnicas y materiales, y la intervención de arquitectos de la UPC como Buxadé, Margarit y Gomez-Serrano, en España, Mark Burry y su equipo de la universidad de Melbourne en Australia, etc.
} 
Por otro lado, en el año 2002, con motivo del Año Internacional Gaudí, en el 150 aniversario de su nacimiento, se realiza una exposición y numerosos actos. Uno de ellos es el libro Gaudí, la busqueda de la forma, en cuya introducción Daniel Giralt-Miracle señala muy acertadamente que "el de Gaudí era un mundo de pruebas, de tanteos, de errores, de correcciones que le permitían aproximarse al máximo a la solución de los problemas", indicando con ello que pasó de la maqueta al calculo, posteriormente dibujando y finalmente construyendo, por lo cual su via es la del ensayo y de las soluciones encontradas sobre la marcha, razón por la cual afirmaria que "mis ideas estructurales y estéticas son de una lógica indisputable." ${ }^{\prime 79}$ Giralt Miracle capta muy bien el ideario estético de Gaudí que concibe como global de todas las artes, en el cual "tienen tanta importancia los elementos ornamentales como los sistemas constructivos" ${ }^{80}$.

Juan José Lahuerta estudia la figura de Gaudí desde su inserción en el contexto cultural y político de la burguesia sustentadora del catalanismo conservador, teniendo en cuenta el círculo de amistades y de relaciones en el que se mueve y los artículos y publicaciones que aparecen entorno a su figura, tanto en vida como con ocasión de su fallecimiento. La visión de Lahuerta aporta una gran carga política pero también corrobora la idea no ver a Gaudí como un genio aislado e incomprendido, tal y como lo habían presentado muchos críticos sino como alguien bien relacionado ideológicamente y activo en el conjunto de relaciones entretejido a lo largo de su vida. Entiende su cultura arquitectónica como fotográfica e impresionista, esto es aprehendida de la observación detallada y el análisis exhaustivo de dibujos, grabados y fotografías de arquitecturas sacadas de la tradición histórica existente. Lahuerta nos introduce en el mundo del pensamiento de Gaudí comparando las ideas que cree percibir en éste por la influencia de otros artistas con lo expresado y realizado por el arquitecto, de tal manera que nos propone un tejido mental, el de los hilos ideológicos del discurrir y el obrar arquitectónico del genio, que tiene un denso entramado animado por las relaciones profesionales con el grupo de jóvenes arquitectos que siguen la estela de Joan Martorell. ${ }^{81}$

Ma Antonietta Crippa también ha dedicado mucho tiempo a la reflexión sobre la figura de Antonio Gaudí. La suya es una aproximación sucesiva pero continua respecto de lo que considera los fundamentos de su arquitectura y sus sustratos más significativos. En el congreso mencionado del Politécnico de Milán, definía a Gaudí como nudo entre la modernidad y la tradición en la cultura occidental, de tal manera que su comprensión de la tradición arquitectónica a través de una serie de referentes puntuales y su profundo dialogo con la naturaleza son plenamente cognoscitivos y racionales, no miméticos,

\footnotetext{
${ }^{79}$ Cf. Giralt-Miracle, D. y AAVV. (2002) Gaudí: la busqueda de la forma. Barcelona. Lunwerg. P. 21.

${ }^{80}$ Cf. Giralt-Miracle, D. (2010). La Sagrada Familia: de Temple Expaitori a Basílica. Barcelona. Lunwerg. P.59

${ }^{81}$ Cf. Lahuerta, J.J. (1993). Antoni Gaudí, 1852-1926. Arquitectura, Ideologia y Política. Madrid. Electa.
} 
aunque después continuen siendo objeto de reelaboración con una imaginación y libertad prodigiosas $^{82}$. Primeramente destaca de Gaudí su prolífica invención de formas, pero después, al recorrer, de la mano de Bergós su obra y su pensamiento, define la Sagrada Familia como un acto $\mathrm{fe}^{83}$, en el cual se funde su genialidad con aquello que llamaba el carácter del edificio y su uso para dar con esa belleza a la que nos remite Von Balthasar. Entramos así en otro enfoque, ciertamente novedoso hasta el momento: Gaudí y su concepto de lo sacro.

Crippa incide en el sentido de lo sagrado que hay en su arquitectura, invadida toda ella por una simbología que hunde sus raíces en la utilización de símbolos cristianos y precristianos, y defiende su búsqueda de una dimensión social de lo sagrado. Ve a Gaudí como un innovador que transforma radicalmente los contextos físicos y arquitectónicos en los que se insertan sus espacios, en dialogo con la "utopia del yo" de Lévinas - "un espacio para la utopía en el cual el yo se recoge morando en la casa"84- y con la naturaleza. Esta sacralidad se manifiesta poderosamente en su arquitectura cultual, de tal manera que en los últimos años ha llamado poderosamente la atención -tanto entre arquitectos como entre liturgistas y expertos en arte sacro- generando diversos estudios que tratan de ahondar en los criterios litúrgicos y convicciones personales que pudieran rastrearse en sus proyectos para iglesias, en su pensamiento y en una lectura simbólica de sus principales obras. ${ }^{85}$ La Fundación Maragall y la SCEL han propiciado algunas investigaciones acercándonos a su religiosidad, amistades eclesiásticas y concepción del hecho arquitectonico.

Especialmente Jordi Bonet, con su gran conocimiento como director de las obras de la Sagrada Familia y Armand Puig desde el punto de vista de su universo simbólico, han incidido en esta pretensión de aunar en la lectura de su proyecto arquitectónico la mirada teológica y la experiencia arquitectónica.

${ }^{82}$ Cf. Crippa, Mạ Antonietta. (1993) "Una tradizione vivente solidamente ragionata”, en AAVV, Gaudí. Una proposta di libertà, Actas del Congreso celebrado en el Politécnico de Milano. Milano. Dipartimento di Ingegneria di Sistemi Edilizi e Territoriali. Facoltà di Ingegneria.

${ }^{83}$ Cf. Crippa, Maria Antonietta. "Gaudí entre la historiografía contemporània i la recerca efectiva de la bellesa", en Bergós, J. y AAVV.(2000) Gaudí, I'home i l'obra. Barcelona. Lundwerg.

${ }^{84}$ Cf. Crippa, Ma Antonietta y AA.VV (2001) Gaudí: hábitat, naturaleza y cosmos. Barcelona/ Madrid: Lundwerg. P. 28

85 Cf. Blasco, Ana Mạ , Pla i Arxé, Ramon y AAVV. (2004) Gaudí i la dimensió trascendent. Barcelona. Fundació Maragall i Ed. Cruilla; el articulo publicado por R. Bofill en la sociedad catalana de estudios litúrgicos: La premonició gaudiniana respecte dels criteris liturgics del Concili Vaticà II; el libro de Crippa, Bassegoda y AAVV, (2002) Gaudí:Espais Sagrats. Barcelona. Lunwerg. Genis i Terre, J. (2009). Gaudí, ente l'arquitectura cristiana i l'art contemporani. Barcelona. Publicacions de l'Abadia de Montserrat; y también el recientemente publicado por Puig, A. y Bonet, J. (2013) Arquitectura y símbolo de la Sagrada Familia. Barcelona. Pórtic. 


\section{CAPITULO 3 ARQUITECTURA Y LITURGIA: UNA RELACION PERMANENTE.}

\subsection{La Liturgia como vida de la Iglesia, una aproximación.}

Felix Garcia afirma, en la introducción a la versión española del célebre libro de Guardini El espíritu de la Liturgia, que ésta "brota del hecho de la comunidad viviente religiosa, que es producto de la aportación regulada de las energias individuales" ${ }^{86}$, porque el Movimiento Litúrgico iniciado en la segunda mitad del siglo XIX tuvo la virtud de remover las conciencias individuales y los estamentos de la Iglesia Católica para volver la mirada al ser más auténtico de la vida cristiana, la participación de todos los fieles, laicos y eclesiásticos, en la celebración de los misterios del culto.

La categoría que mejor define a la acción litúrgica es la de celebración. Celebrar es una acción de naturaleza social relacionada con el concepto comunitario de fiesta mediante un rito. Pero, sin abandonar la relación existente entre culto y cultura, entre arte y liturgia, hay que remarcar que la liturgia no es sólo el conjunto de rúbricas, el ceremonial, la ubicación del altar, la presidencia, y otros elementos del aula celebrativa, sino que mediante su dimensión expresiva y simbólica ha de procurar la participación de las personas en la celebración cristiana para que ésta, lejos de quedarse en un mero concepto teológico conmemorativo de un hecho importante pero únicamente histórico, actúe a favor de los hombres en función de su fe. Es fundamental, como ha señalado J. Corbon (Liturgia Fundamental, 2001), el encuentro humano-divino, propio del misterio de Cristo, para que tenga soporte y fundamento la celebración litúrgica y las acciones que en ella se dan, las cuales no agotan la liturgia. Es decir, que la experiencia cultural y estética es consecuencia de la experiencia religiosa, y ésta pasa, según afirma Gutierrez Martín, por "la encarnación viva del misterio para ser participado en la vida de los fieles" 87.

De ahí que el carácter sacro de la celebración litúrgica "deriva de ser mediación presencializadora (anámnesis) de lo santo en orden a la comunión". Prescindir de esta mediación seria despojar a la liturgia de la trascendencia y reducirla al ámbito de una manifestación cultural, de un sentimiento religioso, de un recurso meramente humano. Por el contrario, si la liturgia permanece en el ámbito de la trascendencia, del encuentro íntimo divino-humano, hace partícipes a los fieles de la percepción de lo bello, y por tanto, de la participación imaginativa en su expresión y creación.

\footnotetext{
${ }^{86}$ Cf. Garcia, F. (1946). "Introducción" en la traducción española de la 12a edición alemana de "Guardini, $R$ Vom Geist der Liturgie”, El Espiritu de la Liturgia. Barcelona. Araluce. P. 19

${ }^{87}$ Cf. Gutierrez Martín, J.L. (2000) "La liturgia en el magisterio conciliar, hacia un fundamento teológico de la sacralidad", en AA, VV. Arte sacro: un proyecto actual, Actas del I curso de Arte Sacro. Madrid. Fundación Felix Granda. P. 21
} 
De ahí que la creación artística pueda estar orientada y ordenada a la trascendencia si está impregnada de la búsqueda de la verdad y del bien. El arte, pues, puede tener una dimensión sagrada cuando se convierte en vehículo de la mediación de la trascendencia, que supera los límites de una estética encerrada en sí misma y coopera con la invitación a la plenitud del hombre ${ }^{88}$, pero esta mediación no se reduce a lo que Bouyer dice que ha pasado con el arte religioso occidental desde el siglo XIII, menos orientado a la aprehensión de lo trascendente y más centrado en una funcionalidad subjetiva cuya misión seria la de expresar el sentimiento religioso por el hecho de mostrar su desconexión con la liturgia ${ }^{89}$.

El Arte, en opinión de Evdokimov, se "emancipa" y separa de todo canon, toda regla, a partir del siglo XVIII, iniciando un camino de desintegración de las cosas reflejo del desasosiego del alma del artista moderno que "no conoce ni el advenimiento ni el crecimiento del ser, ni la sucesión progresiva de acontecimientos, sino que esconde una coexistencia de quiebras, de trozos que se recubren unos a otros sin ligazón ni continuación ordenada". ${ }^{90}$

Así pues, frente al atasco del arte religioso que se manifiesta también en el alma del artista, y que había corrido parejo con la individualización de la experiencia religiosa, reducida, en gran parte de los fieles laicos y sobre todo en los siglos XVII y XVIII, a la esfera del devocionismo privado, aparece la necesidad de renovar el sentido de pertenencia a la comunidad cristiana, de recuperar la Liturgia como vida de la Iglesia. Hacía falta cambiar la peligrosa asociación establecida entre Liturgia y ritualismo, ceremonialismo, pompa cultual, que había convertido la religión en religiosidad y el culto en espectáculo de vida emocional, en palabras del Dr. Gomà (El valor educativo de la Liturgia Católica, 1918).

Por eso como escribía el Dr. Mayer, profesor de Teologia de la Universidad de Freising, "el renacimiento litúrgico ha revelado a los laicos la esencia misma de la Iglesia, que no radica ciertamente en el carácter jurídico, ni en el estado eclesiástico, ni en la predicación

88 Cf. Evdokimov, Paul (1991) El arte del icono. Teología de la belleza. Madrid. 2000. Publicaciones Claretianas. P.44: al referirse a lo que mueve a los pueblos dice que es el: “...inextinguible deseo de alcanzar la plenitud: el Espíritu de vida, como dice la Escritura, es el principio estético o el principio moral, como lo Ilaman los filósofos; yo diría simplemente que es la búsqueda de Dios. Ahora bien, desde el momento en que el Espíritu Santo habla por la belleza, como ha hablado por los profetas, la salvación por la belleza ya no es el principio autónomo del arte sino una fórmula religiosa: <<El Espiritu Santo es una comprensión inmediata de la belleza, la conciencia profética de la armonía>>".

${ }^{89}$ Cf. Bouyer, L. Los católicos occidentales y la liturgia bizantina, en <<Dios Vivo>>, nำ21

90 Cf. Cf. Evdokimov, Paul (1991) El arte del icono. Teología de la belleza. Madrid. 2000. Publicaciones Claretianas. P.84: "El arte no figurativo, informal, abstracto, suprime todo soporte ontológico negando todo objeto concreto. No es una manzana roja sino el color rojo en sí, una mancha coloreada en la que el artista proyecta un significado comprensible sólo por él mismo. 
de la moral, ni en el sencillo anuncio del Evangelio o la enseñanza del Dogma, sino en la vida sacramental litúrgica, en la celebración de los misterios del culto"91

El cardenal Gomá afirma que el rito es lenguaje religioso de los pueblos ${ }^{92}$ y en esas mismas fechas, en 1918, sale a la luz una de las obras capitales de Guardini, El espíritu de la Liturgia, que ayuda a comprender la renovación del fenómeno litúrgico que se había iniciado con el Movimiento Liturgico. Al prologar su primera edición en alemán, el P. Herwegen, abad del monasterio benedictino de Maria-Laach, señala: "toda la creación se convierte, por la Liturgia, en grandioso coro de alabanza a su Creador".

Esta es la idea que quiere transmitir Guardini de la acción litúrgica de la comunidad: un símbolo, proyección de lo interno al exterior que se verifica con carácter de necesidad esencial, obedeciendo a una exigencia de la naturaleza. ${ }^{93}$ Por tanto Guardini escribe que la Liturgia, como la obra artística, desconoce una finalidad práctica y utilitarista, siendo que su sentido está en saber situarse ante Dios para desahogarse libremente en su presencia y "vivir dentro de ese dichoso mundo de verdades, de fenómenos, de realidades, de misterios y símbolos divinos, pensando que el vivir la vida de Dios, es vivir real y profundamente la suya propia." Estas palabras del teólogo alemán forzosamente han de llevar, para quien tenga un cierto grado de conocimiento de la arquitectura religiosa de Gaudí, a una concordancia de actitudes basada en la experiencia litúrgica vivida, puesto que según declaraciones propias había leído al respecto mucho menos de lo que se le presuponía atestiguando que lo suyo era la práctica, la participación en los misterios sagrados.

Veamos alguna otra cuestión de interés, antes de repasar cómo surgió la renovación del espíritu litúrgico en Europa y cómo pasa a España y dialoga con el entorno de Gaudí. Para Guardini ese movimiento libre impulsado por el Espiritu divino, impregnado de profundo sentido, encaminado a la plenitud de vida, generador también de imaginación artística admirablemente conciliada con la realidad, constituye una imagen viva de la Liturgia, que no es un trabajo sino un jugar ante Dios, ser uno mismo la obra de Arte. Así pues, sigue

${ }_{91}$ Cf. Felix Garcia (1933). “Introducción”, en Guardini, R. (1918). Vom Geist der Liturgie, El Espiritu de la Liturgia, 2aㅡ. ed. en español de 1943. Barcelona. Araluce.

${ }^{92}$ Cf. Gomá y Tomás, Isidro (1918). El valor educativo de la Liturgia Católica. Barcelona, Rafael Casulleras Editor. P.32

${ }^{93}$ Cf. Guardini, R. (1918). El espiritu de la Liturgia. Traducción al español de 1946. Barcelona. Araluce. P.130: "El verdadero símbolo nace como expresión natural de un estado especial del espíritu. Claro está que está sujeto a las leyes generales de toda obra de arte y, por lo tanto, debe elevarse sobre lo puramente concreto pues es a la vez reflejo real y expresivo de un estado del alma, tiene que expresar la realidad de un contenido universal, en relación con el alma o la vida humana, y no solo en un aspecto o relación en el espacio o temporal." 
diciendo: "La liturgia es Arte que se transforma en vida" y también "Podemos afirmar que una cosa real o una obra de arte son bellas, cuando su esencia y su íntima significación están plenamente expresadas por su ser", de donde concluye que "...para que la Belleza pueda expresarse, requiérese previamente la existencia de algo capaz de manifestación plástica, de ser exteriorizado, ya sea una verdad esencial, ya una emoción vivida." 94

Por último es importante referenciar la cita que el propio Guardini hace del P. Herwegen: "...la Liturgia se ha convertido, sin pretenderlo conscientemente la Iglesia, se ha transformado y convertido en una verdadera obra de arte, la Liturgia contenía en sí tantos elementos esenciales de belleza que, de suyo, podía ser considerada como creación artística. Pero el principio interno que desde dentro le prestaba su forma y figura era la esencia del Cristianismo." 95

${ }^{94}$ Cf. Guardini, R. (1918). El espíritu de la Liturgia. Traduccion al español de 1946. Barcelona. Araluce. P. 156: "Vivir litúrgicamente, movido por la Gracia y orientado por la Iglesia, es convertirse en una obra viva de arte, que se realiza delante de Dios Creador, sin otro fin que el de ser y vivir en su presencia: es cumplir las palabras del Divino Maestro que ordenan que nos hagamos como niños; es renunciar a la artificiosa y falsa prudencia de la edad madura que en todo pretende hallar un resultado práctico, y jugar como David lo hacia delante del Arca de la Alianza."

${ }^{95}$ Cf. Herwegen, I. (1916). El arte como principio de la Liturgia. Paderborn. P. 18 


\subsection{El Renacer Litúrgico de la Iglesia desde la segunda mitad del siglo XIX hasta el pontificado de Pio X.}

\section{- Fundamentos y protagonistas del Movimiento Litúrgico}

Comúnmente se suele señalar como el origen de esta corriente renovadora o restauradora de la Liturgia la actuación del P. Dom Prósper Gueranguer al frente de la abadia benedictina de Solesmes (Francia) coincidiendo con el restablecimiento de la vida monástica en la misma y la publicación de su célebre obra "L'Année Liturgique", si bien este hay que verlo más desde el punto de vista conceptual o catequético que de establecimiento real de una praxis renovada. Para entender lo que significó el Movimiento Litúrgico hay que reseñar, siquiera brevemente cómo era la vida litúrgica y cómo se celebraba la eucaristia en el siglo XIX. Ésta había mantenido prácticamente el mismo cuerpo ritual desde Trento con la inestimable ayuda de un latín al que nadie parecía hacer demasiado caso y que, desde luego, nadie entendía fuera del ámbito eclesiástico, dando lugar a la inmersión en las devociones individuales y a toda clase de situaciones en la actitud callada y pasiva de los fieles. La comunión no tenía por qué distribuirse en el momento litúrgicamente establecido durante la celebración eucarística, considerándose ésta más como una acción de gracias individual o un ceremonial eclesiástico al que se asistía con algún esporádico canto, en latín naturalmente, y terminada la cual se recitaban algunas oraciones prescritas por León XIII, fomentándose las devociones populares como la mejor manera de práctica religiosa de los laicos.

En palabras de Bernard Botte, "La liturgia era, pues, la parte ceremonial del culto vaciado de su contenido real"96 (de ahí que en muchos casos se aludiera a ella desde la visión del laico con la denominación de "función litúrgica"), puesto que ni siquiera los sacerdotes habían recibido formación sobre los textos litúrgicos, su sentido y riqueza, dando la impresión de ocuparse únicamente de la gestualidad de los ritos y las palabras de los textos, sin contar tampoco con una predicación en lengua vulgar que ayudase a los laicos que acudían al obligatorio precepto dominical.

En este ambiente la influencia de Dom Geranguer a través de su obra "L'Année Liturgique", de hondo contenido catequético y destinada a los fieles, cuyo primer tomo se publicó en 1841, fue extraordinaria, primeramente dentro de la orden benedictina y después en toda la Iglesia. El año anterior ya había publicado "Las instituciones litúrgicas", destinado al clero; ambas obras continuarían con más tomos en los años sucesivos, hasta 1851, siendo el propósito de las mismas promover la oración y especialmente la oración oficial de la Iglesia desde una cuidada explicación y sentido sobre la misma y los misterios del Cristianismo, los tiempos litúrgicos y las fiestas y festividades del año, intentando recuperar la catequesis que recibían los catecúmenos de la Iglesia en los primeros siglos,

\footnotetext{
${ }^{96}$ Botte, B.(2013). "El Movimiento Litúrgico, testimonios y recuerdos”. Barcelona. Cuadernos Phase 211.
} 


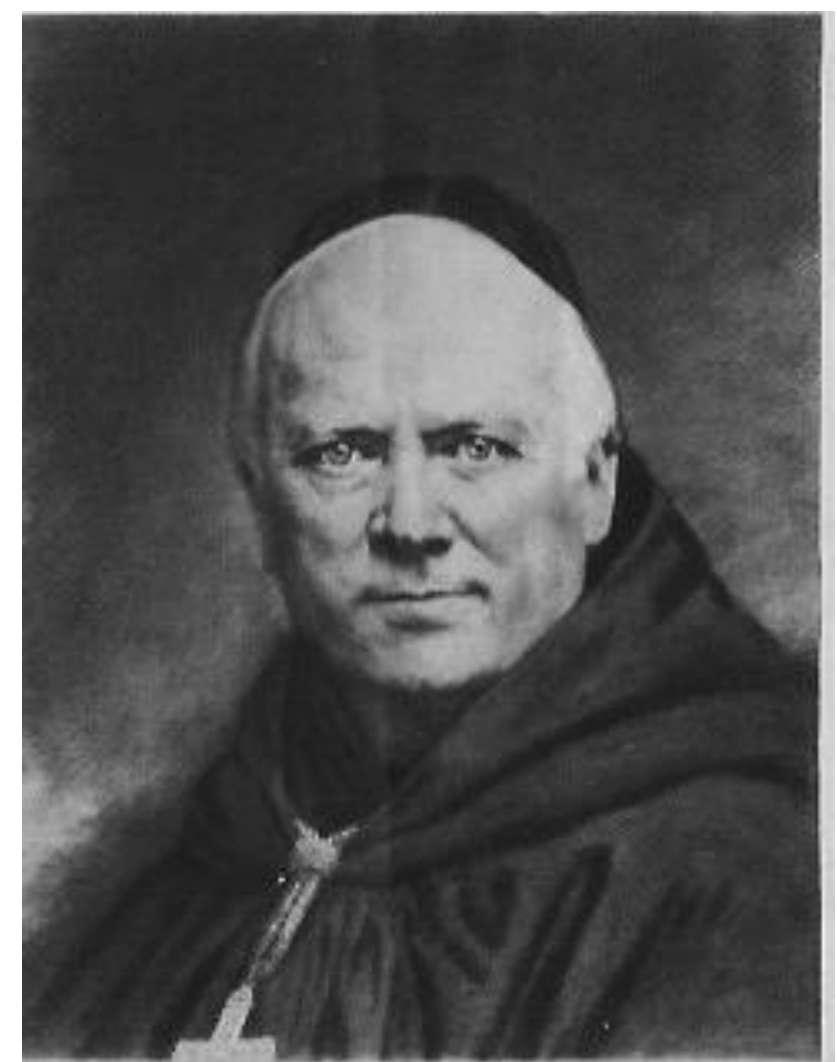

Dom Prosper Gueranguer, abad de Solesmes. Fuente:

Garrido Bonaño. (2008) Grandes maestros y promotores del Movimiento Liturgico. Madrid. Bac. 
durante la primera parte de la misa. Gueránguer, si bien no llegó a conocer la liturgia en lengua vulgar, lamenta el uso y abuso de los devocionarios privados buscando promover el amor y participación en la oración litúrgica, colectiva y oficial de la Iglesia, que ve fuente de toda perfección cristiana, mediante su comprensión a través de sus escritos catequéticos. En la habituación de los fieles al año litúrgico volvió a insertarles en las principales solemnidades cristianas: Pascua, Ascensión, Pentecostés, Encarnación y Navidad.

Los monasterios benedictinos, Solesmes, Maridsous, Beuron, y sobre todo Maria-Laach, se constituyen en avanzadilla de la idea de renovación litúrgica en Europa, tratando de reencontrarse "arqueológicamente" con el sentido comunitario de la liturgia cristiana y promoviendo activamente un gran número de jornadas, estudios y publicaciones que hicieron de la orden benedictina la correa trasmisora de la inquietud católica europea por buscar en la liturgia la mejor vivencia religiosa. De ahí que la renovación de los fundamentos teológico-liturgicos que bulle en los círculos eclesiásticos más dinámicos del momento anhele su plasmación en la arquitectura de los espacios celebrativos.

Pero fue con el pontificado de Pio X, que comienza en 1903, cuando el Movimiento litúrgico, insertado ya en la vida de los monasterios benedictinos de Francia, Bélgica y Alemania, entra en una nueva fase de mayor oficialidad, universalidad y apoyo magisterial por cuento persigue con su desarrollo una mayor participación de los fieles en la celebración litúrgica. La eucaristía, significada comunitariamente con la potenciación de la música y el canto gregoriano para la participación activa de los fieles, la comunión dentro de la misa, y la reforma del breviario para su uso público cotidiano abierto al pueblo, van a ser los instrumentos de una pastoral que busca renovar la vida de la Iglesia. Ya en con anterioridad en 1895, siendo Patriarca de Venecia, había publicado unas disposiciones pastorales promoviendo el canto y la música en las iglesias, pero fue durante su pontificado cuando dedicó todas sus energías a buscar esta participación activa en la eucaristía, sirviéndose para ello de diversos documentos de su magisterio y de su labor en pro del estudio y difusión de la música y el canto gregoriano en la liturgia.

Al mismo tiempo, y animado por la actuación del Pontífice, Dom Lambert Beauduin proclama en el congreso de Malinas (23-27 de septiembre de 1909) lo que se vendría en llamar el llamamiento a la concienciación por la formación y la vida litúrgica, iniciando ese mismo año con gran éxito de suscriptores las publicaciones semanales La Vie liturgique y de Het Kerkelijk Leven en los que incluía las lecturas de las misas de los domingos y breves textos litúrgicos; al año siguiente en el monasterio de Mont César en Lovaina y con la presencia del cardenal Mercier se inauguran las primeras Jornadas Litúrgicas. Beauduin parte del ejercicio sacerdotal de Jesucristo en la vida de la Iglesia y de cómo hay una estrecha relación entre la liturgia de la tierra y la liturgia del cielo. 
Tiene presente cómo la celebración litúrgica no es sólo del sacerdote sino de todo el pueblo fiel que participa en ella y así se describe en el formulario litúrgico.

\section{- El impulso de Pio X y la participación de los fieles en el culto.}

Elevado a la cátedra de San Pedro en 1903, afrontó desde el principio la restauración del culto divino como su primer y más urgente deber, como un programa para conseguir la participación activa de los fieles en los misterios sagrados y en la oración pública de la Iglesia. En contraposición al individualismo religioso propugnado desde el Renacimiento, aflorado en el Protestantismo y que también se había instalado en la Iglesia Católica mediante el devocionismo personal, el Movimiento Litúrgico, al investigar en la naturaleza de la liturgia quería volver a acercar a las comunidades católicas a la celebración eucarística y a la oración oficial de la Iglesia.

La obra de Pio X de restauración de la vida y del espíritu cristiano se concreta en tres direcciones: la propiciación de la comunión en la misa, la participación activa de los fieles en ella a través de la potenciación de la música y del canto litúrgicos, y la reforma del breviario. Especial mención merece el Motu Proprio Tra le Solicitudini sobre la música sagrada, de 22 de noviembre de 1903, promulgado a los tres meses escasos del comienzo de su pontificado, en el que el Papa da una significación especial al canto y la música como partes integrales de la liturgia y piezas fundamentales para promover la participación de los fieles en la celebración eucarística: "Como parte integrante de la liturgia solemne, la música sagrada tiende a su mismo fin, el cual consiste en la gloria de Dios y la santificación y edificación de los fieles". 97

Ya en el comienzo o introducción se señala que "nada debe ocurrir en el templo que turbe, ni siquiera disminuya, la piedad y la devoción de los fieles; nada que dé fundado motivo de disgusto o escándalo, nada, sobre todo, que directamente ofenda el decoro y la santidad de los sagrados ritos y, por este motivo, sea indigno de oración y la majestad divina", percibiéndose nítidamente la función principalísima del edificio de la iglesia, los sagrados ritos, de los que no hay que distraer la atención y al mismo tiempo la denominación de casa de oración colectiva a la majestad divina. Quiere esto decir que todo debe estar orientado a la piedad y devoción de los fieles que participan colectivamente en los sagrados ritos, los cuales están ordenados juntamente con la belleza y suntuosidad del edificio ("lo primero es proveer a la santidad y dignidad del templo") para la alabanza a Dios y la santidad de los participantes en la "pública y solemne oración de la Iglesia".

${ }^{97}$ Cf. Pio X. (1910). Motu Proprio Tra le Solicitudine. Principios generales. 
Establece pues las normas que han de inspirar la Música Sagrada para gloria de Dios y educación y santificación de los fieles, los cuales todavía no podian participar de la misa en lengua vulgar pero sí responder con la música y los cantos a las plegarias liturgicas del celebrante "añadiendo más eficacia al texto mismo". De esta manera se establecen la

"santidad y bondad de las formas" de la música sagrada, que a la par de mostrarla como parte constitutiva de la liturgia la constituyen en "arte verdadero", aspectos sumamente relevantes para el diseño de una iglesia que quiere responder a la más actual y verdadera liturgia de la Iglesia en esos momentos. De la difusión y trascendencia de la confirmación del canto gregoriano como canto propio de la Iglesia romana "el único que la Iglesia heredó de los antiguos Padres", da testimonio la creación de una comsion encargada de la edición vaticana auténtica de las melodías gregorianas (en la que participaron dos monjes benedictinos de Solesmes, Dom Mocquerau y Dom Pothier), publicándose el Graduale en 1907 y el el Antiphonarium en 1912. Pero el gran impulso se lo dio la creación de la Escuela Superior de Música Sacra que abre sus puertas en 1911 y la Academia Pontificia de Música, la proliferación de centros destinados a la enseñanza y difusión del canto gregoriano y la misma formación que de este canto recibieron ilustres personalidades de la época, entre ellas el mismo Antonio Gaudí.

El Motu Proprio señala como el canto gregoriano que fue celosamente custodiado durante el curso de los siglos en sus códices litúrgicos, "estudios recientísimos han restablecido felizmente en su pureza e integridad". Dicta que "deberá restablecerse ampliamente en las solemnidades del culto" y que se procure que el pueblo vuelva a usar del canto gregoriano para que "los fieles tomen de nuevo parte más activa en el oficio litúrgico, como solían antiguamente." Para que no quede duda alguna de este auténtico programa de necesidades a aplicar en edificios nuevos y existentes donde existen los medios para hacerlo según los términos modernos de una auténtica normativa proyectual, vuelve a manifestar que "también esta música deberá restablecerse copiosamente en las solemnidades religiosas, especialmente en las basilicas más insignes, en la iglesias catedrales y en las de los seminarios e institutos eclesiásticos, donde no suelen faltar los medios necesarios".

Sobre el tipo de música sacra, además de propugnar la actualización de la polifonía clásica conjuntamente con el canto gregoriano, rechaza cualquier género moderno que tenga un cariz teatral, señalando que lo que se admita esté perfectamente acomodado a las exigencias litúrgicas y que el canto se realice en lengua latina, oficial de la Iglesia. Hay que tener en cuenta la profusión de autos sacramentales, procesiones y representaciones que se hacían en el interior de las grandes iglesias y catedrales, y que si bien tenían una argumentación religiosa y promovían la piedad popular no formaban parte de las celebraciones litúrgicas propiamente dichas podían ser un obstáculo a su participación en los sagrados ritos, tal y como señalaba Pio X. 
Sin rechazar de plano este tipo de representaciones, Pio X pone el acento en favorecer la dignidad de las celebraciones litúrgicas en detrimento de otras manifestaciones religiosas no litúrgicas. ${ }^{98}$ Se establece así una preeminencia de la celebración liturgica sobre actos públicos y manifestaciones de la religiosidad popular que habían mantenido durante mucho tiempo la vida cristiana de los fieles desde tiempos medievales pero ahora se mostraban insuficientes para sostener en su fe a unas sociedades industrializadas, convulsas también en lo que al orden social se refiere.

Dado el numero de partes de la misa que conservan musicalmente el concepto y forma, a la vez que la existencia de composiciones musicales, para el Kyrie, Gloria, Credo, etc. y teniendo en cuenta las disposiciones que el Caeremoniale episcoporum prescribe para el canto gregoriano en la salmodia y música de los oficios del breviario, se comprende fácilmente la importancia dada al canto y la música en la liturgia eucarística de Pio X y por tanto su repercusión a la hora de proyectar una iglesia de acuerdo con estas normas. Se establecen disposiciones para los cantores de la iglesia, sean seglares o cuando siendo celebrantes y ministros, hacen el oficio de coro eclesiástico. Si bien no se permite en ese tiempo que las mujeres formen parte del coro, por estarles impedido a éstas cualquier oficio litúrgico, se promueve la separación por sectores de la capilla musical: eclesiásticos, niños y hombres, disponiendo que sólo se admitan a ésta hombres de conocida piedad y probidad de vida. Para reforzar esta prescripción se recomienda el uso del hábito talar y sobrepelliz así como una cierta salvaguarda de la vista del público.

En cuanto al uso de instrumentos tan sólo se permite de manera habitual el acompañamiento del órgano, permitiéndose previa licencia del Ordinario otros instrumentos, en algún caso particular y según el Caeremoniale episcoporum. (Llama la atención como luego veremos que este texto fue uno de los pocos que Gaudí gustaba de leer y repasar en su vida diría cuando trabajaba en las obras del Templo de la Sagrada Familia). Según esto, "como el canto debe dominar siempre, el .órgano y los demás instrumentos deben sostenerlo sencillamente, y no oprimirlo".

\footnotetext{
98 Desde la Edad Media se sigue representando en la basílica de Sta. Maria de Elche el Misteri d'Elx, declarada Patrimonio de la humanidad, que escenifica el misterio cristiano de la Asunción de Maria a los cielos. Es famosa y también se sigue representando desde la época medieval La Processó del Corpus de Valencia que saliendo de la Catedral recorría las calles del centro histórico para, siendo muchos los reyes que asisian a su recorrido. Gabriel Llompart ha estudiado el teatro sagrado en la catedral de Palma y señala también la gran cantidad de interpretaciones drámaticas que se realizaban en su interior, como el Davallament, obra cantada que ya en el siglo XVi provoca conflictos entre el Obispo y el cabildo, conviertiéndose recortada y traducida al latín en una especie oratorio sacro intentando reducir su componente teatral para reconducirla en un acto de devoción en la línea que marcaba TrentoCf. Llombart, Gabriel. (2000) "El teatro en la catedral de Palma de Mallorca", en Pascual, Aina y AAVV. La catedral de Mallorca. Palma de Mallorca. José J. de Olañete Ed.
} 
Este cuidado en las disposiciones que atañen a la celebración de la eucaristia hacen retomar la distinción entre el espacio celebrativo por antonomasia y la función litúrgica que allí se desarrolla respecto de otros espacios o celebraciones, prescribiéndose disposiciones precisas para cada caso: "en las procesiones que salgan de la lglesia, el Ordinario podrá permitir que asistan bandas de música, con tal que no ejecuten composiciones profanas, acompañando himnos religiosos en latín o lengua vulgar, por cantores y piadosas cofradías". También la extensión de la música dentro de la liturgia a celebrar es objeto de ordenada regulación, de tal manera que se supedite perfectamente a la dinámica y secuencia de ésta, y a los ritos que ejercita el celebrante, así el Sanctus debe terminarse de cantar antes de la elevación de la consagración.

En consecuencia con la variedad de ritos, el orden liturgico y la distincion respecto del gran numero de manifestaciones religiosas, se dispone el nombramiento en cada diócesis de personas verdaderamente competentes en liturgia y en música sagrada que constituyan comisiones especiales para cuanto se refiere a ésta en las iglesias. También se insta a promover la formación de los seminaristas en el canto gregoriano y la constitución por el clero de una Schola cantorum, para la ejecución de la polifonia sagrada y de la buena música litúrgica. Esta cuestión también será de gran trascendencia arquitectónica para las iglesias que quieran adaptarse a este renacer litúrgico por cuanto se habla de:

"27. Póngase cuidado en restablecer, por lo menos en las iglesias principales, las antiguas Scholae cantorum", como se ha hecho ya con excelente fruto en buen número de localidades. No será difícil al clero verdaderamente celoso establecer tales Scholae hasta en las iglesias de menor importancia y de aldea; antes bien, eso le proporcionará el medio de reunir en torno suyo a niños y adultos, con ventaja para sí y edificación del pueblo."

Pues, efectivamente, si las Scholae cantorum deben constituirse por clero, niños y hombres integrando con su canto la liturgia eucarística, las condiciones de proximidad, visualización y acústica de quienes ejercen esta misión y el lugar que ocupan en la celebración respecto del celebrante conllevan estudios pormenorizados y ciertamente rigurosos para su adecuada implantación en el espacio sacro que han de traducirse en soluciones arquitectónicas concretas en la iglesia.

Que las disposiciones apuntaban a la permanencia da idea la siguiente disposición:

"28. Procúrese sostener y promover del mejor modo donde ya existan las escuelas superiores de música sagrada, y concúrrase a fundarlas donde aún no existan, porque es muy importante que la Iglesia misma provea a la instrucción de sus maestros, organistas y cantores, conforme a los verdaderos principios del arte sagrado." 
Que se confirma en la última disposición (29) recomendando "a los maestros de capilla, cantores, eclesiásticos, superiores de seminarios, de institutos eclesiásticos y de comunidades religiosas, a los párrocos y rectores de iglesias, a los canónigos de colegiatas y catedrales, y sobre todo a los Ordinarios diocesanos, que favorezcan con todo celo estas prudentes reformas, desde hace mucho tiempo deseadas y por todos unánimemente pedidas..."

De la importancia que quiso dar el pontífice a este Motu Proprio y a la renovación litúrgica que promueve da idea el hecho de presentarlo en el décimo tercer centenario de San Gregorio Magno, en la misa pontifical celebrada en la basílica de San Pedro, cuando la masa de jóvenes de todos los colegios e institutos romanos cantó en gregoriano el ordinario de la misa, como señala Giacomo Lercaro al referirse a la obra de Pio X. ${ }^{99}$

El decreto Sacra Tridentina Synodus, de 20 de diciembre de 1905, significa el acercamiento real de los fieles a la comunión diaria, que si bien el Concilio de Trento había recomendado, se encontraba en la práctica con una muy difícil materialización por el rigorismo de la herejía jansenista respecto de las disposiciones necesarias para recibir la comunión, de tal manera que clases sociales enteras como los comerciantes o las personas casadas quedaban excluidas de la comunión al considerar los jansenistas el trato comercial y el carnal (aún dentro del matrimonio) como opuestos a la recepción del sacramento de la Eucaristía. Así el decreto, apoyándose en el espíritu tridentino y citando otras disposiciones de papas anteriores, recomienda e invita a la comunión frecuente y diaria, señalando además que ayuda para dejar los pecados veniales. Al mismo tiempo recomienda acercarse a ella debidamente preparado y recuerda para ello la práctica de la confesión de los pecados y el consejo del confesor. Tanto es así que incluso el mes de mayo siguiente promulgó un decreto de concesión de indulgencias a los cristianos que rezaran piadosamente por la extensión de la comunión diaria.

En la misma línea está el decreto Post Editum, de 7 de diciembre de 1906, sobre la dispensa del ayuno a los enfermos para favorecer que reciban la comunión, y el posterior decreto Quam singulari de 8 de agosto de 1910, que establece la edad de la razón o discreción para que los niños reciban la primera comunión, y que fija alrededor de los siete años. Pero además, este decreto fija las normas de preparación para la primera comunión, la responsabilidad de los adultos en su preparación, la comunión anual obligatoria y la confesión sacramental previa. Puede observarse, pues, las consecuencias que este decreto conlleva en cuanto a la catequesis y preparación previas, la administración del sacramento de la Penitencia y la recomendación frecuente de ambos sacramentos estableciendo con carácter de mínimo su recepción una vez al año.

\footnotetext{
${ }^{99}$ Cf. Lercaro, G. (2001 ). La participación activa. Principio fundamental de la reforma pastoral y liturgica de Pio X, en "Pio X y la reforma liturgica". Barcelona. CPL. Cuadernos Phase 112.
} 
En 1911 el decreto Divinu Afflatu vino a completar este programa apostólico de participación activa en la vida de la Iglesia de Pio $X$, estableciendo una reforma del Breviario o salterio que además de obligar al clero a su recitación como Oficio diario, restablecía la primacía del domingo sobre el santoral dentro del año litúrgico y posibilitaba a los fieles el acceso a la catequesis de los salmos al restituir al año litúrgico sus caracteres esenciales. De esta manera, al unirse los fieles laicos al clero en el rezo de las Víspera de los días festivos, el Breviario tuvo que ser traducido a la lengua vulgar de los fieles lo que redundó en un mayor conocimiento de éstos respecto de los misterios cristianos. Si como dice Lercaro el Papa había dicho que "la participación activa en los sagrados misterios y la alabanza divina era la fuente indispensable del espíritu cristiano; y estando seguro que, si se saciaba en esta fuente, el pueblo volvería a encontrar su verdadero espíritu, invitó a los sacerdotes y a los fieles a renovar su vida."

De todo lo anteriormente expuesto se deduce la esperanza y el interés que en los medios eclesiásticos despertó el Movimiento Litúrgico como un renacer de la vida cristiana que se tradujo en una actividad marcada por congresos, publicaciones, enseñanza y difusión del canto gregoriano, regulación de la música sacra e interés por hacer llegar a los fieles laicos las disposiciones que buscaban facilitarles su plena incorporación a la vida de la Iglesia. 


\subsection{La renovación litúrgica en España.}

Con anterioridad a 1903 podemos contemplar la situación de la liturgia en España a través de las actas de los congresos católicos que se celebran en diversas diócesis y en las cartas de los Nuncios a los seminarios, en los que comienza a potenciarse el estudio del canto gregoriano siguiendo la estela marcada por Solesmes.

Los manuales litúrgicos de la época también nos dan una información de primera mano de la liturgia en España a finales del siglo XIX. Uno de ellos, quizá el de mayor renombre y difusión, es el de Joaquin Solans, cuya primera edición es de 1880. En la octava edición, publicada en 1901, dos años antes que el Motu Proprio Tra le Solicitudini distingue entre misa privada y misa solemne y cantada, entendida esta última todavía como una celebración especial y excepcional. Señala la obligación de observar en España el Ritual Romano y el Ceremonial de los Obispos (cuestión que nos hace pensar en una situación de un cierto desorden litúrgico postridentino o falta de rigor en la aplicación, aún considerando el largo tiempo transcurrido), y después de recordar lo que son ritos, ceremoniales y rúbricas, da recomendaciones respecto del silencio que debe observarse y objetos que pueden tenerse en la sacristía, de que el altar debe ser de piedra y que, estando adosado al retablo, y debe disponer la cruz mirando al celebrante y al pueblo, ya sea encima del sagrario o directamente sobre el altar, en cuyo caso se dispondrán los candeleros con velas a ambos lados de la misma. No entra en mayores cambios respecto de la liturgia tridentina aunque detalla todos los signos y ritos de la Misa, la cual se celebra totalmente en latín, y recomienda la comunión durante la misma. Da disposiciones para la distribución de la comunión mencionando que el celebrante baja del altar y va a la verja de entrada al presbiterio para distribuirla entre los fieles, refiriéndose a las disposiciones de San Carlos Borromeo e Inocencio XI (1679), lo que permite hacerse una idea de la separación todavía existente en las iglesias entre presbiterio y resto del aula litúrgica. El mismo detalle con el que trata las misas privadas y votivas confirma esta situación inmediatamente anterior a las disposiciones de Pio X.

En la parte segunda, al desarrollar la misa solemne, se hace mención de todos los objetos a colocar sobre el altar mayor e incluso presenta un esquema del presbiterio con la disposición de los celebrantes, ministros, acólitos, etc. y todo el conjunto de ceremonias a realizar. Llama la atención al hablar del Sagrario (que menciona cubierto por el velo o cortina en forma de pabellón y rematado con una cruz pequeña), la referencia a su colocación en el altar mayor siguiendo la recomendación tridentina de San Carlos Borromeo. Al hablar de la Exposición del Santísimo Sacramento menciona también las gradas que pueden existir en el altar y la forma de acceder por detrás, lo que da idea de la situación de sagrario y altar situados junto a un fondo mural o de retablo, en altura y al fondo del conjunto. 

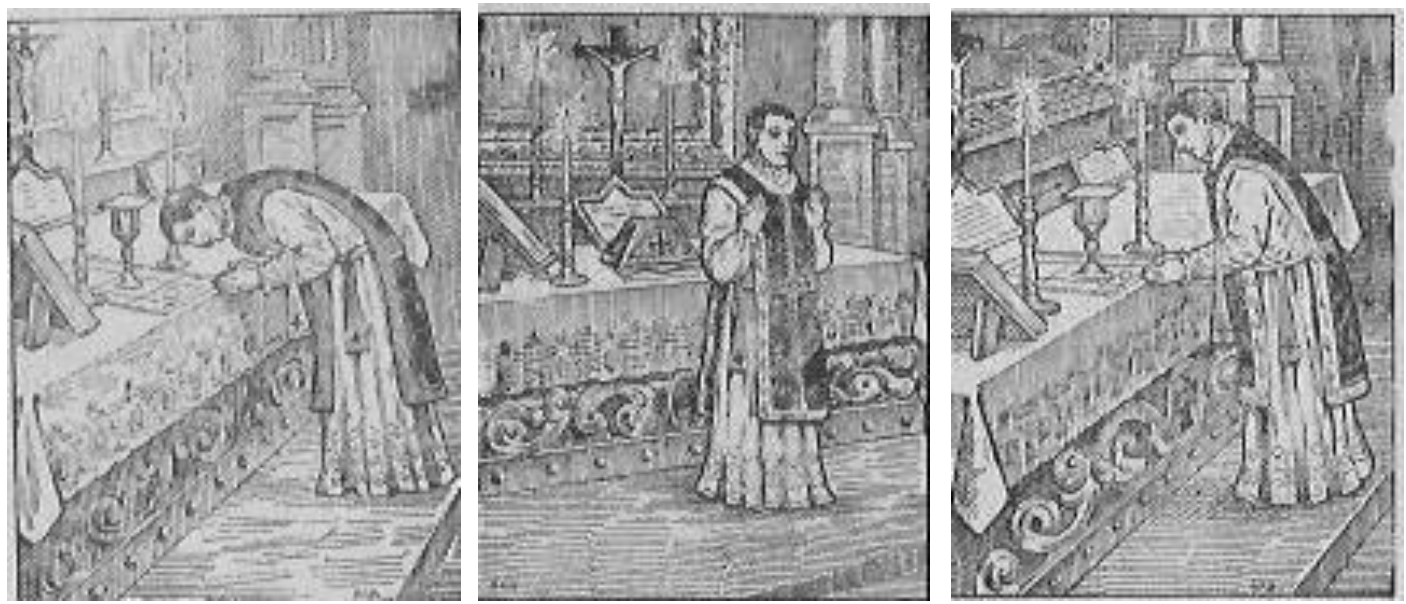

Grabados del Manual de Solans, 1901. Fuente: Solans, Joaquin. (1901) Manual Litúrgico. Octava edición del original de 1880. Barcelona: Imprenta de Subirana Hermanos. 
Fácilmente se ve que estas disposiciones tenían un carácter regulador de las disposiciones heredadas de Trento, anteriores al impulso innovador de Pio X. De ahi que la situación más generalizada, aunque no única como veremos más adelante, nos ofrece un altar mayor adosado a un retablo en el que puede estar el tabernáculo del Sacramento, con una separación física mediante una reja o cancel entre el presbiterio o santuario y la nave de la iglesia. Habrían de pasar algunos años para que las nuevas disposiciones se reflejaran en los manuales liturgicos y libros oficiales de la Iglesia, en la acción pastoral y, sobre todo, en la construcción y reforma de las iglesias.

En la parte tercera trata de las funciones ordinarias que deben observarse durante el año como bendición y distribución de candelas, la ceniza cuaresmal, las palmas, procesiones, etc.; de lo que denomina función de cada uno de los días del Triduo de la Semana Santa, incluyendo la misa de gloria que celebraba la Resurrección el sábado al mediodía. Llama la atención la profusión de cantos litúrgicos y oraciones cantadas del coro, que denotan un gran número de ministros y acólitos, además del coro, la limitación de lecturas a epístola y evangelio con ausencia de homilía al pueblo, respondiendo acertadamente a la denominación de función. En la cuarta se ocupa de lo que establece el Ritual Romano para el Bautismo y el resto de Sacramentos, Exequias, Bendiciones, Procesiones y Dedicación de una Iglesia. Contempla la posibilidad de que haya algún altar en el que el sacerdote esté ya de cara al pueblo. Se señala con claridad la diferencia entre misas solemnes y cantadas, misas votivas, conventuales, etc. y menciona la lectura de la epístola y el evangelio. ${ }^{100}$

Como señala Olivier Rosseau la magnitud de la obra litúrgica de Pio $\mathrm{X}$ es enorme y significativa pues el edificio litúrgico apenas se había movido desde Trento, estaba asentado en la pasividad de los fieles, el devocionismo privado y la enorme distancia celebrativa entre clero y laicos. Lo mismo se puede decir del edificio-iglesia, petrificado en el inmovilismo litúrgico aun cuando cuajado, en muchos casos, de espléndidas obras de arte.

Hay que resaltar, así mismo, que este pontífice no había pasado por la docencia ni por las cancillerías, su experiencia se limitaba a la vida pastoral, y precisamente su gusto por la música y el canto sagrado "no eran, en modo alguno, un fin en sí mismo en su actividad pastoral". Su célebre frase "no se debe cantar y orar durante la Misa, se debe cantar y orar la Misa" constituye un icono de su deseo de renovación litúrgica con un carácter no ya arqueológico sino magisterial. ${ }^{101}$

\footnotetext{
100 Cf. Solans, J. (1901) “Manual litúrgico”. Barcelona. Subirana Hermanos.

${ }^{101}$ Cf. Rousseau, O. y AAVV. (2001). La obra litúrgica de Pio X, en "Pio X y la reforma litúrgica". Barcelona. Cuadernos Phase 112. CPL.
} 
De esta manera los iniciadores benedictinos del Movimiento Litúrgico, los obispos y cuantos eclesiásticos y laicos estaban interesados por la renovación litúrgica pudieron proseguir con el soporte y directriz de Roma los estudios, publicaciones, reuniones y congresos que pretendían recuperar el espíritu de las celebraciones y por tanto de la vida de la Iglesia, y lo que es más importante desde el discurso de esta Tesis, soñar con nuevas disposiciones para las iglesias, promoviendolas en unos casos o alabando sus valores en otros, como veremos que acontece en el entorno del Circulo Artistico de San Lucas y otros escenarios en los que se mueve Gaudí.

Es necesario señalar la importante labor ejercida en España por las abadías de Silos y Montserrat. El mismo año de la publicación del Motu Proprio de Pio X comienzan en Silos los cursos de salmodia y canto gregoriano según las directrices de Solesmes y sus monjes son llamados para formar en el canto gregoriano a los coros de algunas catedrales. Algunos obispos (Madrid-Alcalá, Barcelona y Palencia) confían la formación musical en sus seminarios diocesanos a los monjes benedictinos, los cuales también llevan el movimiento litúrgico a otros países de habla hispana. En ambas abadías se realizan publicaciones donde se exponen las ideas nacidas de este renacer litúrgico-musical, y se realizan los congresos de música sagrada de Valladolid (1907), Sevilla (1908) y Barcelona (1912), así como el congreso litúrgico de Montserrat en julio de 1915.

Este congreso venía siendo preparado desde el Adviento de 1914 por Lluís Carreras principalmente, a través de la revista Vida Cristiana que en esas fechas inicia su andadura. Según señala José Manuel Gonzalez ${ }^{102}$ el congreso promovió:

- La llamada a la participación integral de los fieles en los sagrados misterios.

- La catequesis litúrgica.

- La preparación en lengua vulgar de los textos litúrgicos.

- La comunión frecuente dentro de la Misa.

- El canto en lengua vulgar en las Misas rezadas.

- El estudio de la Sagrada Liturgia, mediante la investigación y publicación de las Fuentes litúrgicas y la introducción de la asignatura de liturgia en los estudios de segunda enseñanza como modo de formar al Pueblo de Dios.

A este congreso se tiene noticia de que asistió Gaudí, y aunque todo apunta a que su participación fue más bien honorífica en una junta de artistas e intelectuales interesados por la materia que acudían a escuchar que no como ponente u organizador de las jornadas, es de señalar la referencia en él del nuncio Ragonesi a la Sagrada Familia. En cualquier, de su asistencia nos ocuparemos más adelante por las repercusiones que en su quehacer pudieron surgir de ello.

${ }^{102}$ Gonzalez, J.M. y AAVV. (2009). "El Movimiento litúrgico y la reforma litúrgica". Barcelona. Culmen et fons. CPL. 


\section{ANTONIO GAUDÍ Y SU CONCEPTO DE LA ARQUITECTURA DEL SAGRADO.}

\subsection{La idea de arquitectura religiosa en Gaudí a través de sus escritos.}

Desde la primera catalogación de los escritos de Gaudí, realizada por Josep Francesc Ràfols y utilizada en su biografía que se publicó en 1929, se han sucedido diversas recopilaciones y estudios, destacando como más completos los correspondientes a Isidre Puig Boada ${ }^{103}$ y Laura Mercader; el primero, por su acertado criterio arquitectónico a la hora de ordenar el pensamiento gaudiniano clasificando sus escritos e incluyendo, además, las conversaciones y reflexiones del Gaudí de madurez, a las cuales asiste personalmente en diversas ocasiones y recoge en otras -con una exactitud elogiablecitando su procedencia o interlocutor; y la segunda, por su rigurosa faceta documentalista y ordenada catalogación, con referencias y explicaciones varias.

Mercader clasifica los manuscritos de Gaudí como Escritos, Documentos y Epistolario. Dentro del primer grupo, Escritos, establece a su vez una distinción entre los Estudios de Arquitectura, Construcción y Ornamentación, las Memorias Descriptivas y los Artículos Periodísticos. En el segundo grupo -los Documentos- integra Documentación de proyectos de obra, Informes Técnicos, Notas y Apuntes, y en el tercer grupo. diversa Documentación Académica y Bibliográfica. Finalmente el Epistolario recoge las diversas cartas remitidas por el arquitecto a una serie de personas, amigos y conocidos, entre las cuales merece destacar las enviadas al poeta Joan Maragall y el obispo Torras i Bages. ${ }^{104}$

Clarifica Mercader desde el punto de vista metodológico la diferencia entre los Escritos, que siempre reflejan el contenido conceptual del autor y los Documentos, los cuales puede llegar a realizar o firmar en señal de conformidad y no siempre se deben a su redacción personal -ya que pueden tratar de una más grande variedad de cuestiones sin aportar luz sobre la carga de pensamiento de quien lo suscribe-. En la recopilación de Mercader se nos presenta el conjunto de estudios sobre Arquitectura, Construcción y Ornamentación denominados: Cuaderno de notas (1873-1879), La casa solariega (18781883) y La construcción del templo (1878-1883), la Memoria Descriptiva Notas aclaratorias del proyecto de cripta para enterramientos en el Templo expiatorio de la Sagrada Familia (Barcelona, 1916), el artículo periodístico del 1 y 2 de febrero de 1881 publicado en el diario La Renaixensa, la correspondencia con el obispo de Astorga para el proyecto de reconstrucción del palacio episcopal (1892-1893), el dictamen sobre el proyecto de fachada de la colegiata de Sta. Maria de la Aurora en Manresa (1915), así como el epistolario con el poeta Joan Maragall, siendo -todos ellos- los que a priori

\footnotetext{
${ }^{103}$ Puig Boada, Isidre. (1981). "El Pensament de Gaudí: compilació de textos i comentaris". Barcelona. COAC. La Gaya Ciencia.

${ }^{104}$ Mercader, Laura (2002). “Antonio Gaudí: escritos y documentos.” Barcelona. El Acantilado. P.19
} 
aportan mayor información para conocer el pensamiento de Gaudí al respecto de la arquitectura del sagrado.

Sin embargo Gaudí no es un teórico ni un escritor sino un hombre de acción. Puig Boada se refiere a esto cuando comenta la etapa de gran desarrollo de su producción profesional como un periodo de tiempo en el que el arquitecto parece que permanece como callado volviendo años más tarde sobre su discurso al recoger sus colaboradores algunas reflexiones, conversaciones y asertos respecto de sus ideas ahora plasmadas en numerosos proyectos y obras. Puig Boada -en su doble condición de arquitecto y asistente inmediato- realiza una preparación cuidadosa de la información que maneja agrupando conceptualmente los temas de escritos, recuerdos y frases salidos de la pluma o de las conversaciones mantenidas por Gaudí en el taller de la Sagrada Familia, en sus prolongados paseos por las calles de Barcelona, o en otras situaciones acaecidas en las postrimerías de su vida. Clasifica los escritos en cuatro grandes apartados -Manuscritos de Reus, Pequeño Resumen de Arte y Construcción, Apuntes sobre la casa familiar y La Renaixença- y agrupa temáticamente las reflexiones y asertos dentro de un apartado genéricamente titulado Gaudí ens parla, en el que éste vierte sus maduradas opiniones respecto del Mediterráneo, las Artes, la Arquitectura, la Escultura, el Color, la Geometria, la Estabilidad, la Construcción, las cualidades del hombre, la salud del cuerpo, el Templo de la Sagrada Familia, la Religión, la Liturgia y la Ascesis.

Así pues, en el Cuaderno de Notas y La construcción del Templo -recogidos en lo que Puig Boada denomina Manuscritos de Reus- es donde encontramos el primer corpus conceptual de lo que Gaudí entiende que debe esperarse de la arquitectura y de la construcción de una iglesia, aunque sin olvidar una segunda fase igualmente importante bautizada por el mismo Puig Boada como Gaudí ens parla- constituida por referencias y comentarios recogidos principalmente por el mismo, Ràfols, Martinell y Bergós. Los manuscritos, correspondientes a los años de estudiante y primeros de inicio de la profesión, presentan un discurso -en gran parte centrado en la arquitectura eclesiástica y gran número de materias entorno a ella- cuya coherencia se mantiene en la última etapa de su vida a través de los resultados obtenidos en gran numero de obras realizadas o iniciadas.

Llama la atención este interés específico por la arquitectura cristiana, desde su juventud, que se inserta muy notoriamente dentro de un abanico de cuestiones que tienen que ver con la arquitectura, la cultura, la historia y el ejercicio profesional que serian lógicas en un profesional recién titulado. Es bien conocido que Gaudí durante su etapa de estudiante analiza gran cantidad de edificios históricos quedando especialmente impactado por la arquitectura hispanoárabe, aunque también manifiesta su admiración por la Grecia clásica la arquitectura bizantina. En el escrito sobre Ornamentación que comienza a escribir un 10 de agosto de 1878 con las siguientes palabras "Propóngome hacer estudios serios de ornamentación. 
Mi objeto es hacerla interesante e inteligible", expresa cómo durante los años de estudio en la Escuela Provincial de Arquitectura habia tenido tiempo de observar y estudiar pormenorizadamente la colección de láminas, que había comprado la Escuela en 1871, de los monumentos y piezas de arte españoles que el fotógrafo francés Jean Laurent había fotografiado en sus desplazamientos para el levantamiento de la red geodésica nacional. A esto respceto conviene señalar cómo Mercader da la relación detallada de las láminas que cita Gaudí, en las que se encuentran todo tipo de edificios (civiles, militares y religiosos), elementos constructivos y mobiliario agrupados por zonas geográficas. ${ }^{105}$

Con independencia de la motivación por la cual comienza a escribir sus obligaciones cotidianas y sus pensamientos arquitectónicos -Hensbergen cita como causa más probable de ello la muerte de su madre ${ }^{106}$ apoyándose en que lo hace dos meses después de su defunción, y Mercader especula con que el joven arquitecto juzga idóneo escribir para expresar y organizar sus ideas al finalizar o terminar sus estudios universitarios- lo cierto es que sigue la línea de tratadistas decimonónicos como Viollet-le-Duc (al que cita y había leído profusamente) y del que su profesor Rogent era decidido partidario, lo cual da idea de su aproximación analítica a una figura de rabiosa actualidad a la que llega por causa directa o indirecta del profesor y director de la Escuela, algo muy lógico de entender. Genís i Terre ha estudiado los fundamentos ideológicos de la arquitectura religiosa de Gaudí, que atribuye a la influencia de Ruskin y a la aportación teórica del romanticismo arquitectónico de los hermanos Schlegel,también a través de las enseñanzas de Elias Rogent. Rogent, decidido partidario de la arquitectura medieval, seguidor del fundamento técnico de la bóveda de arista que preconiza Viollet-le-Duc pero romántico buscador de una arquitectura cristiana a la manera de la concepción alemana del gótico como estilo nacional. Lahuerta ha puesto de manifiesto también el conocimiento que tenia Gaudí en su juventud de la obra de Ruskin y especialmente de sus ideas respecto del contenido religioso de la arquitectura. ${ }^{107}$

\footnotetext{
105 Ibid. Pp. 112-122

${ }^{106}$ Hensbergen, Gijs van. (2001), Gaudí. Barcelona. Plaza y Janés.

107 Genís i Terre, Jaume (2006). Els fonaments ideológics de l'arqquitectura religiosa del Gaudí de maduresa. Barcelona. Uv. Pompeu Fabra. Tesis doctoral de Humanidades dirigida por Antoni Marí Muñoz, catedrático de Teoria del Arte. P.168: "Ruskin establia tres Ileis sobre la bondat d'un edifici. En primer Iloc, que realitzi correctament les seves funcions constructives. En segon lloc, que expressi allò per al que va ser construit amb el millor llenguatge. I, finalment, que complagui amb la seva presencia independentment de la seva funciò social i simbólica. Tanmateix, l'arquitectura, com a art, és una activitat eminentment espiritual: els edificis han d'expressar-se i això exigeix una interpretaciò que aquell qui no conegui el llenguatge no podrá llegir."
} 
Así pues, motivado quizá por la influencia de su prestigioso profesor el joven arquitecto se lanza con la precisión analítica que le caracteriza a crítica de raíz del pensamiento y de la obra del arquitecto francés encontrando ésta última como muy vulnerable y falta de un fundamento apropiado.

En diciembre de 1876 (año en el que mueren su madre y su hermano mayor), comienza a escribir notas y apuntes de diversas obras en las que colabora -conjuntamente con otros estudiantes- al servicio de arquitectos y maestros de obra como Villar y Fontseré. Estos Escritos que Mercader denomina Dietarios y que Joan Bergós encuadra en el denominado Periodo Preliminar de su obra se corresponden con la actividad que Gaudí desarrolla alrededor de 1878 (año en que obtiene el título de arquitecto en 1878) en la cual se encuadran sus trabajos en diversas obras civiles en Barcelona -Fuente monumental del Parque de la Ciudadela (1877-1882), Farolas de la Plaza Real y de la Barceloneta (1878), vitrina de la Guanteria Comella (1878)- también se corresponde con el encargo de la Coorperativa Mataronenese (1878) y diversos proyectos religiosos de limitada importancia pero de hondo calado litúrgico -Camarín de la Virgen en la Iglesia del Monasterio de Montserrat (1875-1877), Reforma de la capilla y altar del Colegio JesúsMaría de Tarragona (1878-1879), Altar, tabernáculo y diversos elementos litúrgicos de la capilla del Colegio Jesús-María de San Andrés del Palomar (1879)- con lo cual no se puede decir que su trabajo estuviese centrado exclusivamente en trabajos de arquitectura cristiana, sino que obras de todo tipo y contenido son las que lleva a cabo cuando comienza a escribir.

Sin embargo, en estos años tan incipientes de su actividad profesional muestra un notable conocimiento de las Escrituras y una gran sensibilidad para las cuestiones de raiz litúrgica que se observan en el cuidado diseño de gran número de elementos arquitectónicos al servicio del culto ${ }^{108}$. En mi opinión, esto no es sólo consecuencia de la atenta observación visual de multitud de imágenes gráficas de arquitecturas registradas por viajeros, tratadistas y otros arquitectos ${ }^{109}$ que refiere a la historia de la cultura occidental durante sus años de estudiante, sino también a su formación juvenil en Reus y al convencimiento personal de la importancia que ha tenido la arquitectura religiosa a lo largo de la historia. Con relación a ésta su pensamiento arquitectónico discurre a través de tres líneas argumentales: la inquietud por la belleza y la estética -en lo que podríamos

\footnotetext{
${ }^{108}$ Nota del autor: El denominado Manuscrito de Reus o Cuaderno de Notas es un conjunto de anotaciones o dietarios y de escritos sobre ornamentación, cuestiones de historia, naturaleza, geometría, método para realizar un buen proyecto, grande iglesia, etc. y por tanto, de variada temática muchas veces entrelazada, que escribe en el periodo de 1873 a 1879.

109 Puig Boada, I. (1981) El Pensament de Gaudí. Barcelona. La Gaya Ciencia. P. 28: “Examinant fotografies de l'Alhambra, he observat que les columnas, com que tenen poc diametre, s'escurcen si s'allarga el capitell per mitjà de motllures en el fust; crec en l'aplicació de colors, especialment en la base a fi de que quedi un tros curts de fust. Idem en les distintes sales per a sostenir voltes, columnas petites que...."
} 
considerar una reflexión común al mundo artístico en el que se desenvuelve, especialmente a partir del abandono del arte academicista-, el interés por conceptualizar la tipología de un edificio-iglesia y la propuesta arquitectónica que plantea como solución a los retos que encuentra en diferentes elementos constituyentes de su programa de necesidades.

\section{Belleza y Ornamentación.}

Las ideas de Gaudí sobre la belleza responden a un planteamiento clásico y ontológico, no entendiendo ésta como una mera referencia estética formal a modo de decoración que se suporpone estilísticamente a un edificio sino como la armoniosa conjugación de sus principales elementos o cualidades de entre los cuales destaca su adecuación al uso al que está destinado el edificio como el verdadero itinerario que conduce a ella: "Para que un objeto sea altamente bello es preciso que su forma nada tenga de superfluo, sino las condiciones materiales que lo hacen útil; se ha de tener en cuenta el material de que se dispone y los usos que ha de prestar, y de aquí nacerá la forma general." Aún encontrando similitudes con Viollet-le-Duc en su Entretiens sur l'architecture (1863), el concepto gaudiniano de belleza en la Arquitectura, ligado tan rotundamente al uso del edificio, está en la línea de lo que Sullivan define como función, y quizá, aún más, en dialogo con el planteamiento imaginativo, plástico y orgánico de Whrigt; de tal manera que compartiendo con el arquitecto americano la admiración por la naturaleza, su atenta observación desde la niñez le predispone a buscar la simbiosis entre función e imaginación como axis programático de su obra.

De esta manera es posible entender una evolución entre sus primeras obras modernistas -que como ha señalado Bohigas (1968) son anteriores a las realizaciones de Horta y Van de Velde, y denotan un singular entusiasmo ornamental- y su arquitectura de madurez, en la que los recursos están más trabajados, más estructurados con la consecución de conjuntos o masas arquitectónicos e incluso, con la estabilidad y generación de todo el proyecto. Este proceso paulatino de interiorización y asimilación de la naturaleza en el diseño del proyecto arquitectónico es tan radicalmente integral que escapa a una mirada superficial. De ahí que haya quien diga que nunca utilizará este discurso de la naturaleza en su arquitectura eclesiástica.

Para Gaudí la ornamentación en una iglesia no responde al mimetismo naturalista de las formas sino que es el resultado de una interacción plástica de las artes, en especial de arquitectura, escultura y pintura. Prefiere la escultura en el exterior y la pintura la concibe como un medio de representación de escenas en el interior. Podría decirse que su referencia a la escultura y la pintura hay que verla en clave catequética en el externo y contemplativa en el interno. 
Concibe la escultura completamente condicionada por la luz y la vista; siendo que una luz no apropiada deforma los objetos interiores y, la posición y tamaño de la escultura se encuentran tan conexionados, ambos deben tenerse muy en cuenta y cerciorarse con el tacto de la verdadera forma. Se muestra más partidario de la escultura exterior adherida al edificio, en sitio preferente pero sin conformar la silueta del edificio porque supone devaluar el objeto edilicio - "la verdadera silueta nace de la propia estructura del monumento"-, prefiriendo el relieve, que admite gran desarrollo y libertad compositiva en la reproducción de escenas, a los nichos, hornacinas, y todo aquella escultura muraría que debilite el soporte y limite su percepción. Para Gaudí el relieve revalora la construcción y aunque no descarta la estatuaria aislada, que exige de gran importancia y que encarne "ideas muy principales que hayan motivado la creación del monumento", prefiere la extensión del conjunto de un relieve a la manera de los frontones griegos, la imaginería de las catedrales medievales y las inscripciones murarías, valorando como objeto de estudio especial el gran desarrollo que le confirió la cultura árabe con sus inscripciones, composición y estilo que ha tenido tiempo de admirar en las fotografías de la Alhambra y entre otros edificios del sur español.

En el interior, ve la pintura en clave de espiritualidad, como formación catequética y contemplación mística, mencionan do la exposición madrileña del Entierro de San Esteban o las cúpulas pintadas de la arquitectura bizantina (de las que resalta su fuerte contenido simbólico en las celebraciones del culto cristiano), de tal manera que se pongan de manifiesto no sólo las cualidades morales (como en la sociedad medieval cristiana) sino aquellas imágenes que contribuyen a mostrar los misterios de la santa religión.

\section{El carácter religioso de un edificio.}

Una segunda idea que llama poderosamente la atención es la alta consideración que otorga a la arquitectura eclesiástica y la introducción de un concepto al que dará una singular importancia, el carácter religioso ${ }^{110}$ del edificio iglesia, considerándolo inherente al misterio que en él acontece.

\footnotetext{
${ }^{110} \mathrm{Cf}$. Puig Boada, Isidre. (1981). El pensament de Gaudí. Barcelona. La Gaya Ciencia. P. 35: “El carácter religiós és el que tendeix sempre al més grandiós des del moment que son objectiu és un misteri, qualitat que s'assoleix per una infinitat de mitjans, que ens obliga a considerar actualmente la religió en relació a la societat. ...El carácter religiós camina indecís, els objectes religiosos son esclaus d'una idea profana: l'art."

"El carácter, puede decirse, es el criterio de la ornamentación. Actualmente el carácter depende de la nacionalidad y de los usos y esplendor del que lo usa. Un objeto público ha de tener un carácter severo, que está reñido con un objeto usual de la familia o individuo. Un objeto publico ha de responder con el carácter a su destino; la gravedad, la grandeza de forma y sencillez que, para enriquecerlo, deberán no templarlo por medio de ideas más suaves y naturalmente descifrables, sino por ideas geométricas, las primeras son preferibles para asuntos particulares. La geometría tiene grandes condiciones para los edificios públicos y religiosos."
} 
Esta consideración parte de sus creencias religiosas y del ambiente en el que se ha desarrollado su infancia y juventud, llevándole a focalizar en la pérdida de las características arquitectónicas que tienen que ver estrictamente con el culto cristiano en el espacio celebrativo en favor de que lo llama imperativos del arte dominante -el estilo y la estética-como la cuestión clave que abordar en el proyecto arquitectónico: "En fer un temple no s'exigeix d'ell que tingui les qualitats pròpies de un Déu terrible que es sacrifica per la criatura....sinó que se cerca la imitació de formes d'altres edats, que serien magnifiques per a aquella época, pel fet que encara percebem quelcom d'aquell sagrat encens. Però aquell llenguatge no ès el nostre...". Piensa que en las iglesias que se construyen en su época se tiene más presente el estilo artístico, en ese momento fundamentalmente neogótico, que la religión -entendida ésta en su funcionalidad liturgica-, las ideas románticas que las religiosas, por lo que ve estas arquitecturas como realizaciones desprovistas de capacidad para reflejar los misterios de la religión. ${ }^{111}$ Estas convicciones muestran con claridad la primordial valoracion del misterio de la Eucaristia que hace Gaudí, y conllevan un interés por priorizar las funciones y ritos religiosos respecto de las formas y lenguajes arquitectónicos.

Gaudí se plantea la ornamentación, entendida como conjugación plástica de las artes, como una ayuda para llegar a descubrir el carácter del edificio -"la ornamentación es una parte, si bien esencial, para darle carácter; sin embargo, no es más que el metro y el ritmo en la poesía"- , pero teniendo claro que no se trata de reunir o cumplir un repertorio de funcionalidades que se van recopilando "para darnos un resultado heterogéneo" sino de un concepto marcado por una "solución de unidad que atienda a las condiciones materiales del objeto, a su uso, al carácter; y sintetizadas y sabidas las buenas soluciones, tomar la resolución más adecuada al objeto; de lo que se desprende que hay que atender al uso, al carácter y a las condiciones físicas". Lo que le interesa es descubrir el "alma" del edificio ${ }^{112}$, aquello que lo define por la necesidad o intención que lo ha motivado y por el sello o impronta que conlleva, siendo que su concepción unitaria del edificio busca reflejar en todo él su adecuación al uso, mostrando de esta manera su belleza: "La primera cualidad que ha de tener un objeto para ser bello es cumplir con el objeto a que está destinado", y esto desde la unidad del uso y del edificio.

\footnotetext{
111 Ibid. P. 35: “...s'obtenen més idees romántiques que religioses -produint una tutela de la religió, de l'art d'altres temps- i no un art que s'identifiqui amb la religió per expresar-la com caldria, sinó d'un art que s'imposa com a estil. De aquí que les concepcions modernes són les que podriem anomenar purament arquitecturals.

112 Es interesante mencionar aquí la actualidad del concepto de carácter en un edificio-iglesia. Fernández Cobián al hablar de los nuevos templos que se realizan en España en la década de los 50 dice que se les achacó falta de carácter específico; "se echaba de menos la dignidad que se suponía debería tener la casa de Dios"...."A principios de los años cincuenta también se decía que a las iglesias eclécticas les faltaba sentimiento e inspiración." (Fernandez Cobian, E. (2005). El Espacio Sagrado en la Arquitectura Española Contemporánea. Santiago de C. COAG P. 204)
} 
"El uso puede decirse que es el móvil de la creación del objeto. El carácter es la definición de las circunstancias estético morales, y las condiciones físicas son las que tienden a los materiales de durabilidad, conservación, etc. "113

Puede encontrarse una correspondencia entre este carácter del edificio que lo define todo él, unitaria y globalmente, desde el móvil de su creación, conformando su adecuación al uso, sus circunstancias estético morales y las condiciones físicas de durabilidad, con los postulados más recientes de Khan, la voluntad de ser de la arquitectura edilicia. Gaudí examina y clasifica al carácter de un edificio partiendo de una diferenciación de origen medievalista que establecia los tres estamentos de la cosa pública: religioso, civil y militar; liga el carácter particular de una edificicación a la satisfacción de las necesidades que comporta el habitat de la célula familiar -"cuyo objetivo es la familia, sus necesidades y conveniencias, y representación de ella y sus individuos"- y análogamente entiende que existe un carácter del edificio religioso que no es ajeno a ciertas cualidades a desgranar pero sí a la simple imitación de un lenguaje arquitectónico anterior superpuesto a un espacio vacio de contenidos adecuados a su función.

"El carácter religioso es el que tiende siempre a lo más grandioso, desde el momento que su objetivo es un misterio, cualidad que se alcanza por infinidad de medios. Eso nos obliga a considerar actualmente la religión con relación a la sociedad, puesto que ha pasado aquel tiempo en que la fe y el entusiasmo religioso levantaron el infinito número de catedrales; pudiendo indicar que el carácter religioso anda indeciso, los objetos religiosos son esclavos de una idea profana: el arte. Al hacer un templo no se exige de él que tenga aquellas cualidades propias de un Dios terrible que se sacrifica por la criatura, la mansión de la omnipotencia de millares de millones de sistemas solares, ni tampoco hacer el objetivo de vencer de una manera elevadísima, cual es el Sacrificio incruento, sino que se busca la imitación de formas de otras edades, que magnificas serian para aquella época, puesto que aún percibimos algo de aquel sagrado incienso. Pero aquel lenguaje no es el nuestro, y lo que vemos en la reproducción de aquellas formas es más el recuerdo de las formas plásticas, reminiscencias de aquellos hombres, que la idea que se cierne sobre ellas, revelándonos de una manera vaga la Divinidad. Es decir, que en la continuación de los estilos góticos adoramos mas la Edad Media, con cualidades y defectos; sus formas plásticas nos traen a la memoria los hechos, los personajes, las tradiciones de aquellas gentes, pudiendo decir que más se tienen con esto ideas románticas que religiosas, produciendo una tutela la religión del arte de otros tiempos; no un arte

\footnotetext{
${ }^{113}$ Cf. Ibid. P. 34 : «L'us pot dir-se que és el móbil de la creació de l'objecte. »
} 
que se identifique con la religión para expresarla, cual debiera ser, sino un arte que se impone como estilo." 114

Este párrafo es suficientemente expresivo para dar idea de cómo Gaudí rechaza la imitación de un arte en cuanto a lo que tiene de reproducción de formas externas, desprovistas de un verdadero estudio del uso del edificio, que se imponen con el prestigio cultural o ideológico sobre la satisfacción más idónea de la función a desarrollar. Así las cosas, el verdadero arte no habria de imponerse como un estilo determinado sino a través de la satisfacción, ordenada e imaginativa de un programa de necesidades, que da lugar a una concepción unitaria del proyecto. De aquí podría seguirse el afán gaudiniano por la síntesis arquitectónica y el alto grado de libertad de imaginación que comporta la totalidad de su producción. Se puede decir que Gaudí fue un adelantado a su tiempo en esta concepción de la arquitectura eclesiástica volcada a la adecuación a su uso, y prueba de ello es lo que señala Fernández Cobián respecto a los patrones que se toman de referencia en la arquitectura de las iglesias españolas durante la segunda mitad del siglo $X X .^{115}$

La concepcion unitaria del edificio.

La concepción unitaria del edificio -según se desprende de los Manuscritos de Reus- viene determinada por un ejercicio de síntesis proyectual que teniendo como guía el uso de culto se sirve de todos los recursos que pone a su disposición el arte arquitectónico: estructura y estabilidad, utilización de la luz y el color, de lo elementos constructivos más adecuados, de los simbolismos que le son propios, de la plasticidad de las formas, etc. en la medida que ayude a la consecución del objetivo perseguido. Éste no pasa por alcanzar un alto grado de barroquismo ni por concebir un espacio minimalista, en lo que seria destacar alguna de estas concepciones de la ornamentación o del espacio como valores prioritarios a poner de manifiesto. Por ello Gaudí sigue escribiendo y critica tanto la pobreza de recursos artísticos puestos a disposición de la construcción religiosa como la proliferación indiscriminada y descontextualizada de formas y elementos estilísticos históricos:

114 Cf. Mercader, Laura (2002). "Antonio Gaudí: escritos y documentos.” Barcelona. El Acantilado. P.50. Según Mercader Gaudí utiliza el concepto de estilo con relación a la forma exterior.

115 Cf. Fernandez Cobián, E. (2005) El Espacio Sagrado en la Arquitectura Española Contemporánea. Santiago de Compostela. COAG. P.206: "La complejidad de la iglesia no estribaba en resolver un conjunto de problemas técnicos, sino de crear un ámbito en el cual los fieles pudiesen asistir en comunidad a la celebración de los Misterios. De ahí que se recomendara encarecidamente que los arquitectos que tuvieran que acometer el proyecto de un templo estuvieran dotados de una sólida información liturgia. En este sentido, mas que que recurrir a los ejemplos alemanes_Böhm, Schwarz, etc.- se ponía como ejemplo el caso de Gaudí y su continua petición de consejo a los especialistas en liturgia." 
"De aquí que las concepciones modernas son lo que pudiéramos llamar puramente arquitecturales; ni a la pintura, ni a la escultura se les da plaza para poner en evidencia los misterios de la santa religión, ni ocupan, cual debieran, la representación de los mártires, como en el Renacimiento, en sus brillantes y sublimes pinturas; ni tampoco el símbolo, que anteriormente tanto privó, tiene la importancia debida, sino que toda se concede, parece ridículo, a la hoja de col, al acanto, a los calados, a las molduras, pero esto con formas puramente plásticas, ¿por ventura infunden religiosidad tales accesorios como detalles que, como detalles, no están conformes con nuestro modo de ser? ¿Dónde están aquellos expresivos relieves que nos recuerdan, ya el martirio, ya el misterio, la caridad o la contemplación? Ahora sólo se ponen algunos santos, y aún éstos para que den motivo a colocar alguna peana o un doselete afiligranado; es decir, buscar un pretexto para traer a colación una forma puramente plástica."116

Gaudí no persigue una forma o un estilo determinado, aunque no se substrae al influjo del neomedievalismo, mudejarismo y bizantinismo, imperantes en la época, sino la exaltación del misterio cristiano. Ambas realidades conviven en su teoría y en su obra. No es extraño, pues, que fije la mirada en la producción arquitectónica francesa -cuya cercana influencia cultural y desarrollo económico se dejan sentir en esos años- tanto a nivel de tratadistas como de edificios cosntruidos. Le es más fácil concentrar su atención y también su crítica a la iglesia del Sacrée Coeur de Paris (tachándola de proyecto fallido, incompleto, falto de detalles, imitación de formas históricas vacias) que en una iglesia de raíz germana o anglosajona, pero también se aproxima más el concepto de iglesia votiva de la cual la de Montmartre es un ejemplo señero- a su ideal de arquitectura eclesiástica moderna que cualquier otra obra coetánea.

“...y necesariamente producimos edificios incompletos que nada dicen, porque los elementos de que disponemos son completamente distintos, ¿pueden, a pesar de todos los sacrificios, compararse nuestros edificios modernos con los de aquellos tiempos?, ¿resistirá la comparación el edificio del Sagrada Corazón de París con la catedral de la misma ciudad, y no quedará muy y mucho atrás solamente con nombrar las de Reims, Colonia, Estrasburgo, Chartres?, ¿dónde están las cuidadas portadas, las siete torres, las inmensas bóvedas? $Y$ atiéndase que los últimos edificios son debidos a la iniciativa o de una población o a la de un príncipe, y el Sagrado Corazón es o será debido al esfuerzo de toda la Cristiandad; y todo esto para tener un enorme monumento que no nos expresará lo que deseamos y no podrá ponerse al nivel de los que quiere imitar." 117

\footnotetext{
${ }^{116}$ Cf. Mercader, Laura (2002). “Antonio Gaudí: escritos y documentos.” Barcelona. El Acantilado. P.50-51

${ }^{117}$ Cf. Mercader, Laura (2002). “Antonio Gaudí: escritos y documentos.” Barcelona. El Acantilado. P.52-53
} 
La crítica del proyecto de Abadie no es banal, sino que se fundamenta en la función de los elementos arquitectónicos constitutivos del edificio y en la simbología. Cuando habla de una portada catedralicia en Reims o Colonia que echa en falta en el Sacré Coeur, su juicio es arquitectónico y se basa en argumentos ya utilizados en el curso de sus escritos: la concepción unitaria del edificio religioso, la utilización del arte al servicio de los misterios de la religión, la importancia de la simbología, la función de una portada y el valor de la estatuaria para la mejor adecuación al uso del edificio religioso. Su valoración de las torres de una iglesia se apoya en el tradicional uso civil y religioso de las torres y campanarios. Las bóvedas son objeto de su atención como un elemento estructural y compositivo del que valora en gran medida su idoneidad para la conformación del espacio litúrgico.

Esta concepción unitaria es la que le hace ser crítico con los estilos históricos, sintetizando lo que entiende por cualidades y por defectos, pues valora el proyecto desde todos los ángulos pero a través de una concepción liturgica del edificio-iglesia. A este respecto es ilustrativo que achaque a la arquitectura árabe -no ser arquitectura, sólo decoración- y de la arquitectura gótica se queje de su -precariedad estructural y falta de unidad-, según recoge en sus testimonios el mismo Puig Boada.

También utiliza argumentos en los que se muestra tremendamente crítico con la forma desprovista de todo contenido simbólico, semiótico o funcional. Su rechazo a una solución formal de portada asimilada a un lenguaje que se imita pero que aparece desprovisto de ese sentido moderno de lo que quiere expresar es una lanza en pro de la autenticidad arquitectónica bajo todos los considerandos. Gaudí no rechaza los originales, porque los percibe contextualizados, expresivos, verídicos en lo que comunican, sino las copias. Otra cosa es que parta de soluciones históricas, que rediseña con libertad creativa y en beneficio de la idea que persigue, para comunicar aquello que considera a destacar en el carácter religioso de su arquitectura. En este sentido prefiere la pintura a la escultura para mostrar la espiritualidad cristiana, al considerar que con mayor facilidad se avienen los detallados trazos en las dos dimensiones de la tela a mostrar la expresividad moral, la espiritualidad cristiana, proponiendo además la creación de escuelas o talleres de pintores que siguiendo las enseñanzas del maestro llegasen a aprender los secretos del arte, dentro de un intemporal sentido evangelizador del mismo.

Eso no significa que desdeñe o rechace la forma escultórica sino que cada disciplina es conjugada armoniosamente para configurar el espacio construido teniendo como guía la idea arquitectónica del lugar de culto. Éste conlleva un orden y una amplia diferenciación de funciones en el ámbito comunitario e individual: un lugar donde se ora, donde se celebra los actos religiosos, en el que también hay "una cátedra donde se va a instruirse y fortalecerse moralmente por medio de las conferencias", etc. De tal manera esto es así que denota un alto grado de conocimiento de las funciones históricamente se han dado en el edificio iglesia: 
"Antes el principal objeto eran los oficios; ahora va agregado otro, las pláticas, hasta indicar que bajo este punto de vista se requiere una satisfacción de esta necesidad." 118

El discurso es denso, arranca de la consideración casi teológica de lo que acontece en el edificio, cómo y cuándo se produce -señala que cada vez son más frecuentes las funciones nocturnas debido a las ocupaciones diurnas de la gente- $y$ se ordena de dentro a fuera:

"Las formas exteriores han de ser trasunto de las interiores; encima de grandes pilares pueden levantarse arcos y bóvedas de formas equilibradas, nervios de ladrillo y enjutas de mampostería o tabicadas; la cúpula puede jugar un gran papel para dar luces altas y propias para iluminar las pinturas de las paredes y las mismas bóvedas..."119

Salvador Tarragó comentando este acusado sentido de la forma generada por la estructura que está presente en los escritos de Gaudí manifiesta la actualidad del mismo en la arquitectura moderna cuando señala:

"El establecimiento de esta intima unidad (entre estructura y forma), que Nervi definiría admirablemente como "la inherente expresividad estética de toda buena solución estructural' o sea la integración entre la función estructural como la forma abstracta, constituye uno de los principios definidores de la arquitectura moderna." 120

\section{Planta, Estructura, Espacio.}

Gaudí plantea la triple relación entre la planta de la iglesia, su estructura y el espacio interior que se genera, como la base que configura el edificio arquitectónicamente, el fundamento de lo que éste quiere ser. Valora la bóveda de crucería y su modulación -tan claramente preconizada unos años antes por Viollet-le-Duc principalmente en sus

"Entretiens sur l'architecture" (1863-1872)- pero encuentra en la forma esférica inscrita en un cuadrado sostenido por cuatro pilares en las esquinas un módulo más útil para ordenar el espacio, sobre todo teniendo en cuenta su admiración por la arquitectura cristiana bizantina y las iglesias de planta central de las cuales parece tomar como ejemplo la basílica de San Marcos.

\footnotetext{
${ }^{118}$ Cf. Mercader, Laura (2002). "Antonio Gaudí: escritos y documentos." Barcelona. Acantilado. P.54

${ }^{119}$ Cf. Mercader, Laura (2002). “Antonio Gaudí: escritos y documentos.” Barcelona. Acantilado. P.56

${ }^{120}$ Tarragó, S. "Entre la estructura y la forma”, en AA.VV. (1991) Antoni Gaudí. Barcelona. Ed. del Serbal. P.158
} 
"Ciñéndonos más a la forma de la planta y los medios de cubrirla, indicaremos que la forma esférica inscrita en un cuadrado, dando como resultado cuatro pechinas, y éstas sostenidas por cuatro pilares, es una forma sumamente aérea. Tomándola como elemento de construcción en cada uno de los cuadrados, se puede adoptar un cuarto de naranja, que al paso que recibe los empujes superiores, pueden también éstos quedar sostenidos por otras dos pechinas para llegar al cuadrado, formando con la cúpula central una cruz en cuyos cuatro senos cabrían cuatro capillas independientes, y que darían al conjunto gran efecto. Tomando la cúpula como manera de cubrir espacios cuadrados, naturalmente que de este elemento se puede hacer un sinnúmero de aplicaciones según la grandiosidad del proyecto, pudiendo emplearlo desde la iglesia más sencilla, con una sola cúpula a la forma más grandiosa por combinación de cúpulas. "121

El módulo estructural de cubrición elegido tiene la ventaja de ser regular sin diferenciación de orientación o sentido, y por tanto puede conferir unidad a las trazas de la planta, siendo que esta unidad la vé como fundamental: "La nave principal de una iglesia tiene algo que ver con la unidad de la Divinidad, e igualmente la cúpula central indicaría siempre esta misma unidad."122

La planta cuadrada puede ser engendrada por agregación del modulo básico hasta la dimensión que se quiera, se puede pensar también en una derivación rectangular primando una orientación o varias, en una cruz, latina o griega, etc. pero todo ello quedaría reducido a una mera cuestión de composición si no tuviésemos en cuenta lo que añade a continuación: un elemento vertebrador de claro componente simbólico, el cimborio, la cúpula interior y exterior que marca la primacía de la comunicación vertical, divino humana, que eleva la dimensión de lo que allí se hace a la trascendencia: "Una iglesia sin cimborio, interior y exteriormente, no tiene la gran importancia de la cruz y su cruce. ${ }^{\prime 123}$ E insiste en el sentido simbólico del cimborio cuando dice:

\footnotetext{
${ }^{121}$ Cf. Mercader, Laura (2002). “Antonio Gaudí: escritos y documentos.” Barcelona. Acantilado. P.56-57

${ }^{122}$ Ibid. P.56

${ }^{123}$ Ibid. P. 57
} 


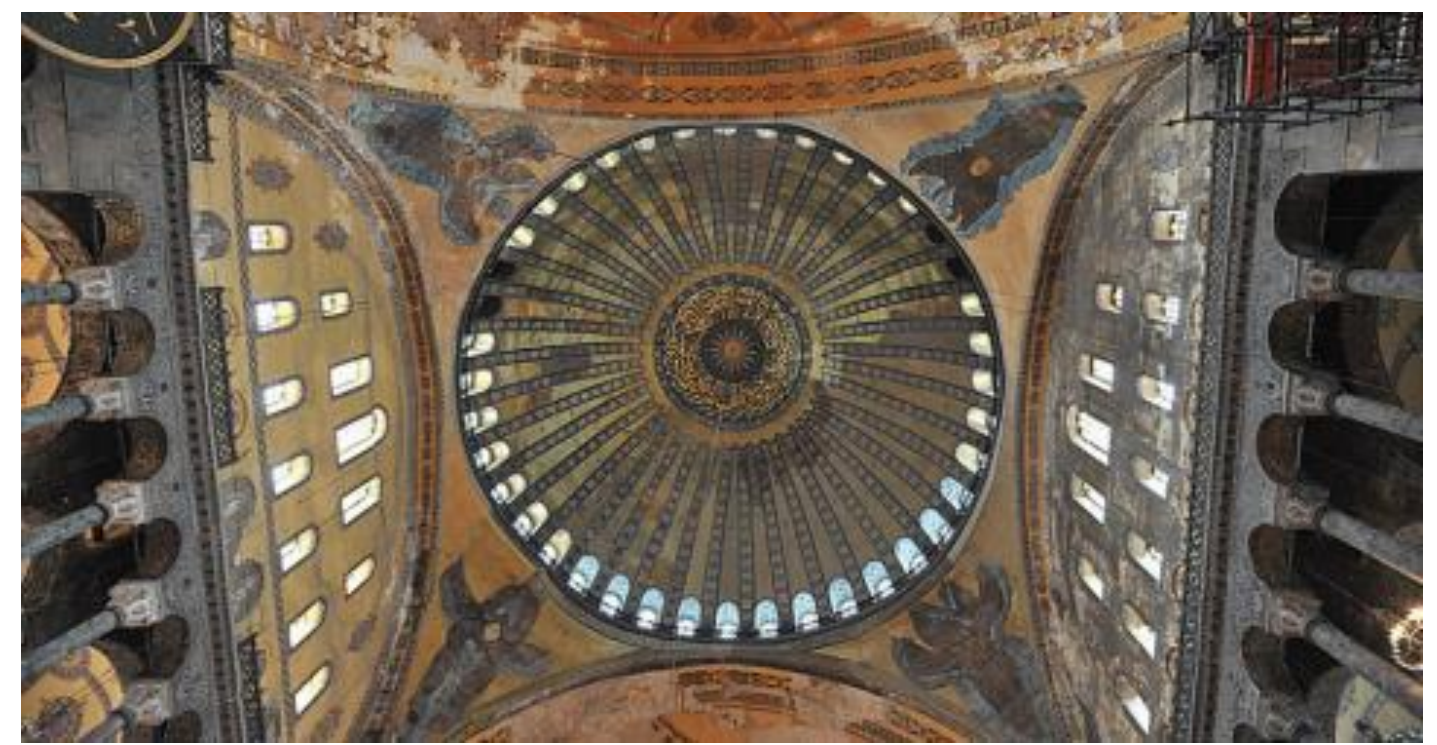

Cúpula de Santa Sofia de Constantinopla. La luz, el color, la forma, las imágenes, la iconografía,..al servicio de una arquitectura cultual y simbólica únicas. Fuente: Myrabella.

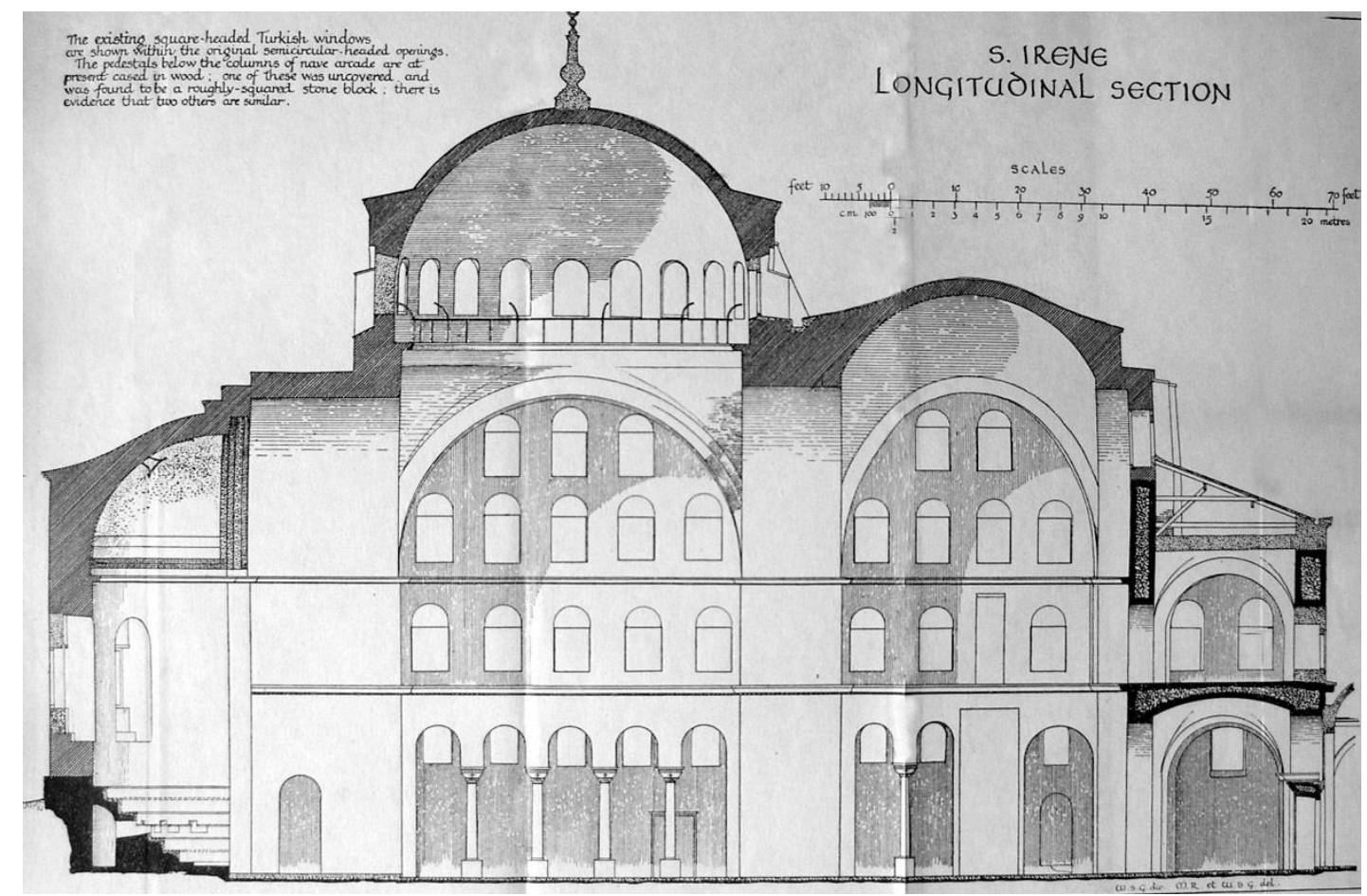

Santa irene. Sección longitudinal. Fuente: Van Millingen. Alexander (2010). Byzantine Churches in Constantinople, 1a ed. 1912. London. Paperback. 
"La cúpula de media naranja con lucernario coge una grandiosidad y un espíritu notables; hace desaparecer la pesadez y materialidad de la forma. Una bóveda de arista necesita, estéticamente, la clave en el cruce para señalar un punto importante, y la sucesión de puntos dan la grandiosa perspectiva."124

Lo que Gaudí plantea no es meramente un sistema estructural teórico sino que piensa en la composición de la planta de una iglesia, en su ordenación con un elemento estructural repetitivo como la cúpula inserta en un cuadrado, que comporta además una importante carga simbólica por sí misma y como elemento neurálgico cuando constituye un cimborio. El cimborio simboliza la cruz y trasmite dos cualidades esenciales para el uso litúrgico: una en el plano material, la luz cenital, y otra, en el inmaterial, la desaparición de la pesadez de la forma. Es la inmaterialidad de la forma lo que persigue el arquitecto señalando además la impotencia de la bóveda de arista para alcanzarla. A estas ventajas añade la imagen de trascendencia que siempre se la ha dado a la dirección vertical:

"La cúpula, que es el sitio que proporciona la luz, eleva las ideas y pensamientos. Su construcción sobre cuatro pilares da una división natural, horizontal, que hace crecer todavía la altura. ${ }^{125}$

Comunicación de la realidad humana, terrestre, con la Divinidad, apertura a la luz como símbolo de la trascendencia, verticalidad, altura; elementos todos ellos comunes a la sacralidad de lo que allí acontece. No todo es simbolismo en la cúpula esférica, hay una estructura material, a la que concede un gran protagonismo en la estabilidad del edificio:

"Pero la gran ventaja que posee la cúpula esférica es destruir los empujes por medio de un arco de hierro hasta que los materiales hayan adquirido la necesaria consistencia. Entonces, aunque se destruya dicho aro, obra como una sola pieza toda la cúpula; esto siempre que se pueda construir con materiales preparados a máquina y que se pueda disponer de moldes y de caja para la construcción. "126

\footnotetext{
${ }^{124}$ Cf. Puig Boada, I. (1981). El Pensament de Gaudí. Barcelona. La Gaya Ciencia. P. 39: "La cúpula de mitja taronja amb lluernes pren una grandiositat $i$ un esperit notables, car fa desaparèixer la pesantor $i$ la materialitat de la forma. Una volta per aresta necessita estèticament la clau a l'encreuament, per tal d'assenyalar un punt important i la successió de punts de la grandiosa perspectiva."

125 Cf. Puig Boada, I. (1981). El Pensament de Gaudí. Barcelona. La Gaya Ciencia. P. 40: “La cúpula, que es el lloc que proporciona la llum, eleva a grans idees i pensaments, la seva construcción damunt de quatre pilars dóna una divisió natural, horizontal, que fa créixer encara la seva altura."

${ }^{126}$ Ibid. P. 40: "Per'la gran avantatge que posseeix la cúpula esférica és pot destruir les empentes per mitjà d'un cèrcol de ferro, fins que els materials hagin adquirit la consistencia necessària. Aleshores, encara que es destruixi el cèrcol, tota la cúpula obra igual que si hagués estat feta s'una sola peça. Això sempre que es pugui construir amb materials preparats a màquina i que es pugui disposar de motlles i de caixa per a la construccio."
} 


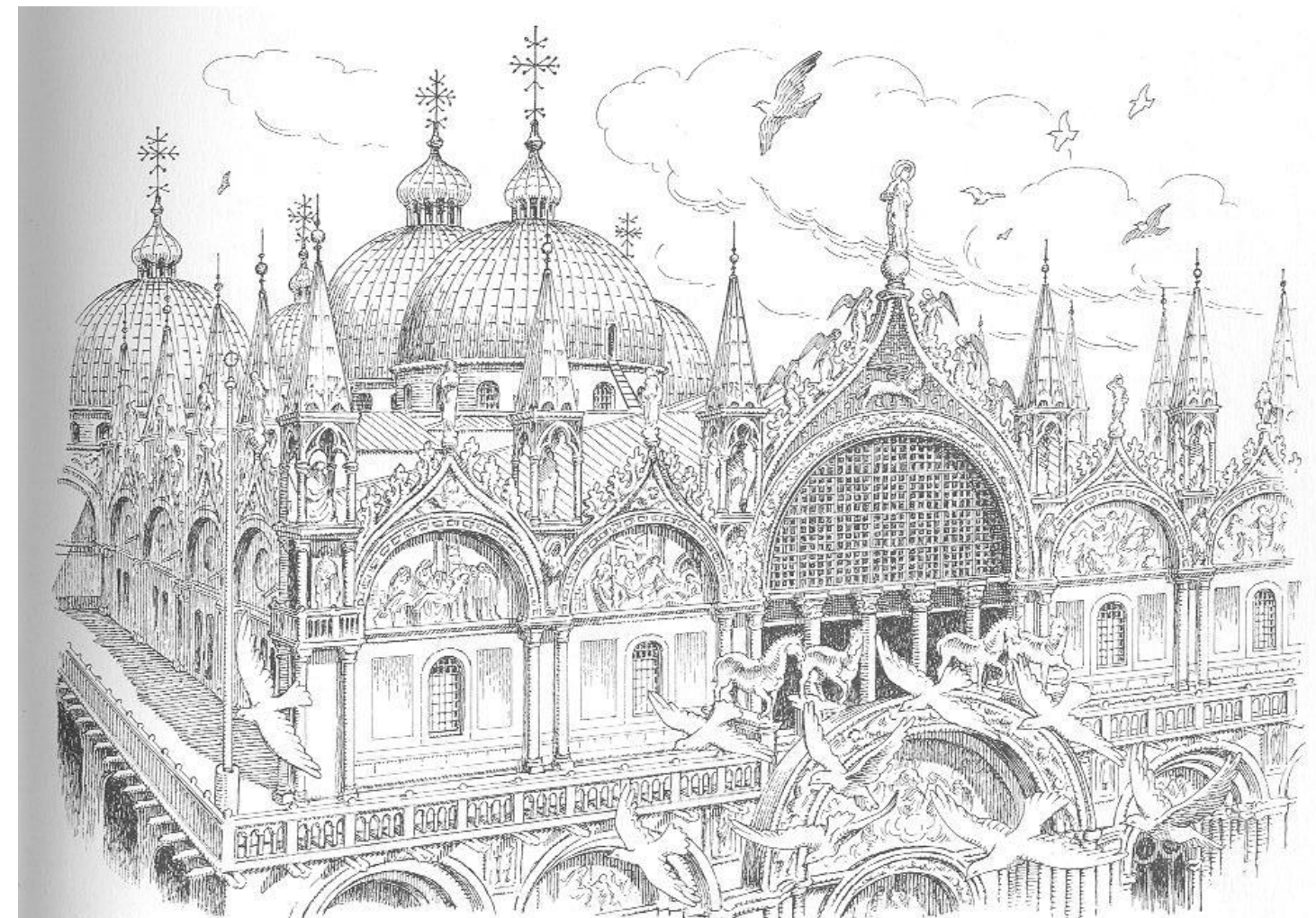

San Marcos de Venecia. Grabado. Fuente: Bassegoda Nonell, J. (1976) Historia de la Arquitectura. Barcelona. Editores Técnicos Asociados.
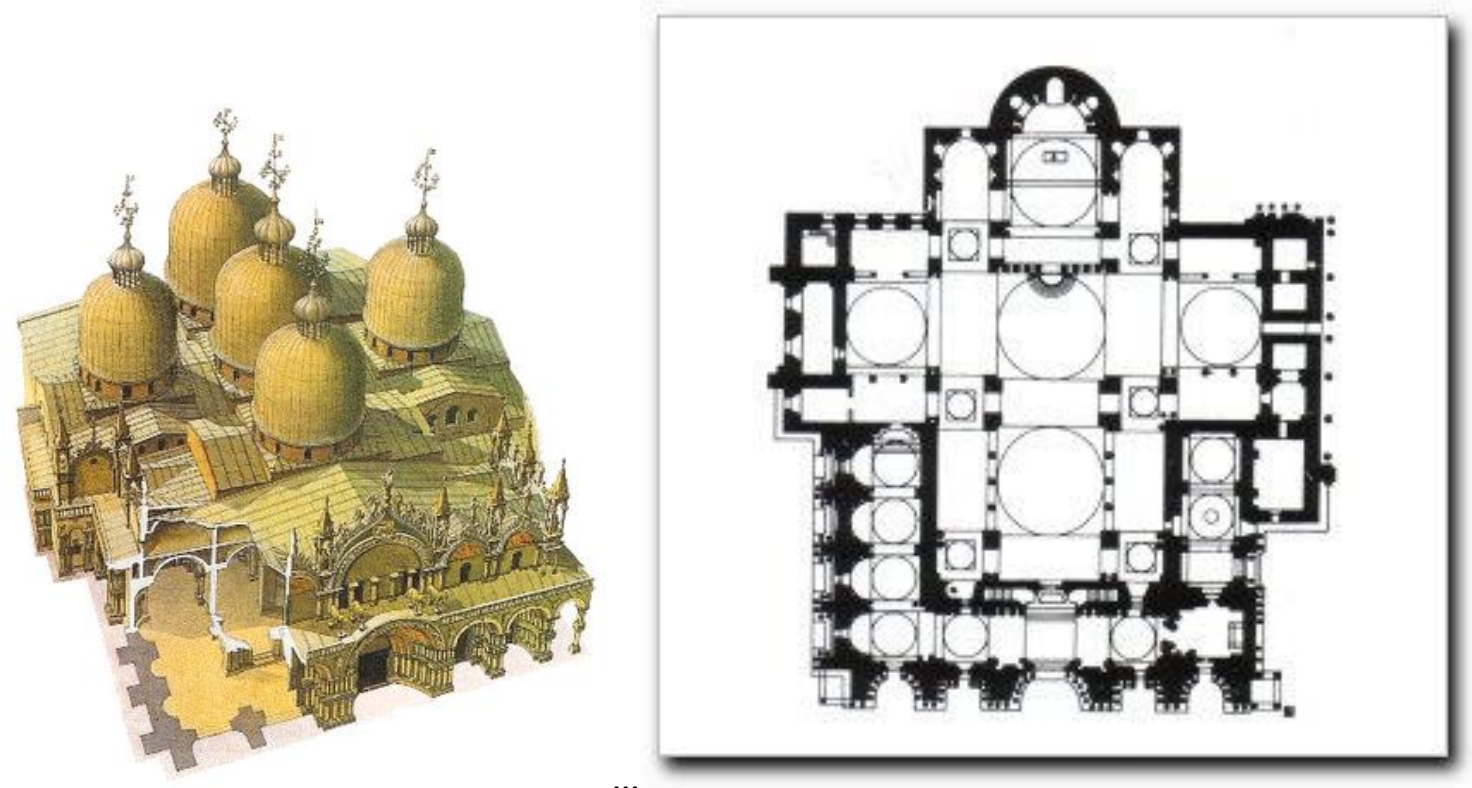

San Marcos de Venecia. Axonometria y Planta. Fuente: Isabel W. 
Gaudí valora la estática gráfica como un medio valioso para construir según los avances de la época, lamentado que hubiese caído en desuso en los siglos precedentes construyendose de una manera excesivamente intuitiva y práctica. El estudio de las curvas de presión y contenciones de fuerzas, muy en boga en aquellos años en los estudios de la Escuela de Arquitectura, confiere, a su juicio, un aire de modernidad a los proyectos.

Gaudí es un estructuralista, gustando de las formas sencillas que resuelven los espacios arquitectónicos sin necesidad de recurrir a un decorativismo añadido y postizo, sino que la misma forma estructural es la que tiene encomendada la ornamentación del espacio, siguiendo una línea protoracionalista; en este sentido asevera que que la multiplicación de molduras complica las cosas y roba protagonismo a las partes constitutivas de un objeto, haciendo aparecer confusa la estructura: "Las formas derivadas de la geometría dan gran distinción y claridad. Cuando las formas son más perfectas exigen menos ornamentación..."127

Es interesante constatar que esta afirmación la hace cuando está escribiendo sobre el carácter de los edificios religiosos y pretende concluir sus ideas al respecto. Concibe, pues, la estructura y sus formas como la autentica ornamentación inherente a la arquitectura eclesiástica, en contraposición a un decorativismo estilístico que considera vacio y trasnochado. "La imitación de estilos necesariamente ha de llevar ornamentación superflua, los estilos sencillos son los de buena estructura. La estructura estética es la que explica la construcción con sus variados recursos y fecundos problemas resueltos, haciendo agradables los objetos por sí mismos." 128

Gaudí conocía las armaduras de hierro y las vigas mixtas de hierro y madera que había patentado William Howe en Estados Unidos (1840) así como la teoría de resistencia de vigas de hierro del británico Eaton Hodgkinson (1846) que se había traducido al francés y se podía encontrar en la biblioteca de la Escuela de Arquitectura; estaba al tanto de los adelantos de la fabricación del hormigón con cemento portland, puesto que colaboró en la construcción de determinados pabellones de la fábrica de cemento Asland de Eusebio Güell en Castellar de Nuch según idea de Rafael Guastavino.

También hay que señalar su intuición (quizá surgida del estudio de la naturaleza) como método de aproximación a la proporción de las partes, de los soportes. Hace mención de los soportes aislados de hierro, el nuevo material que comenzaba a utilizarse en aquellos años, e intuye que está llamado a jugar un papel importante en la construcción, citando a

\footnotetext{
${ }^{127}$ Cf. Mercader, Laura (2002). Antoni Gaudí: escritos y documentos. Barcelona. El Acantilado. P.70.

128 Ibid. P.71.
} 


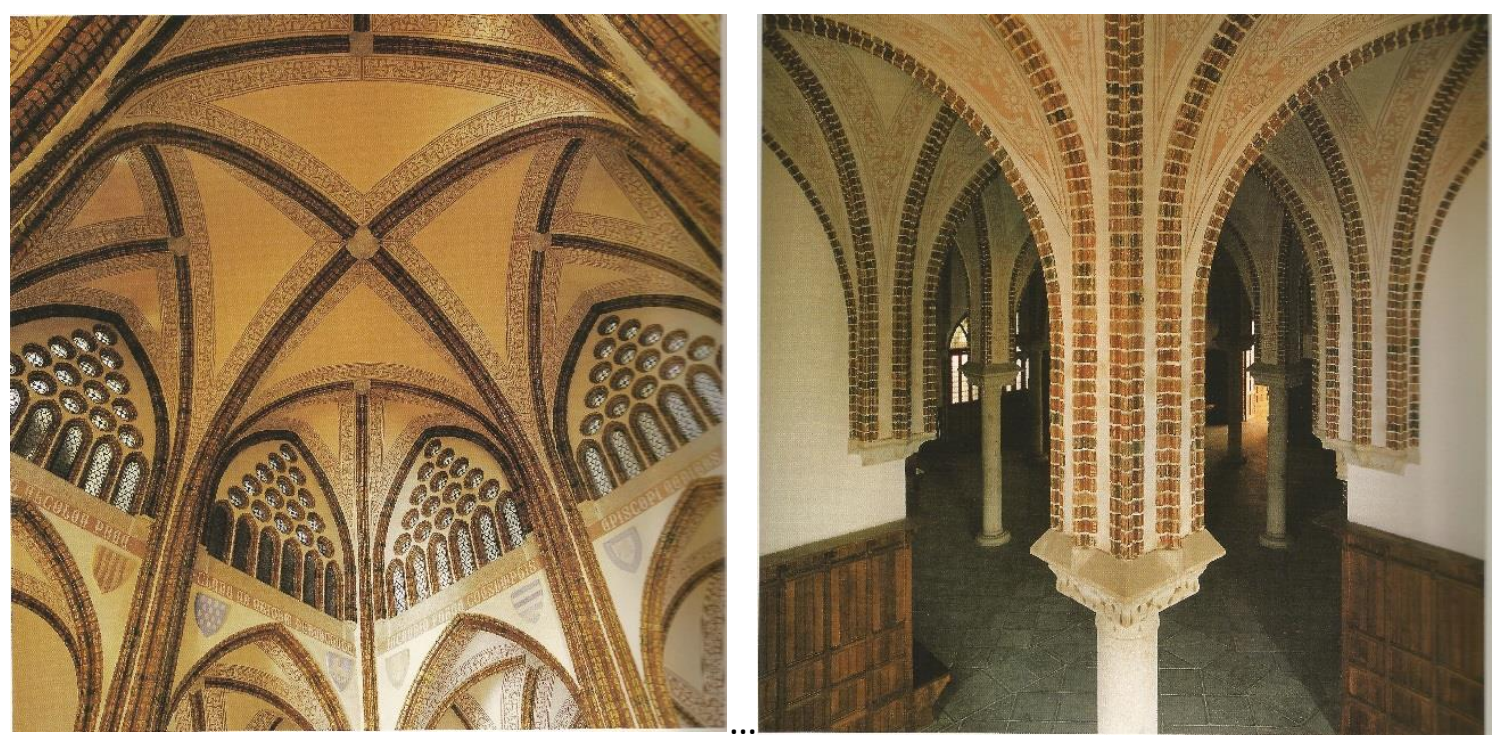

Palacio episcopal de Astorga. Bóveda y Pilar. Fuente: Cirlot, J.E., fotografías de Pere Vivas y Ricard Pla. (2002). Gaudí: una introducción a su arquitectura. Barcelona. Triangle Postals

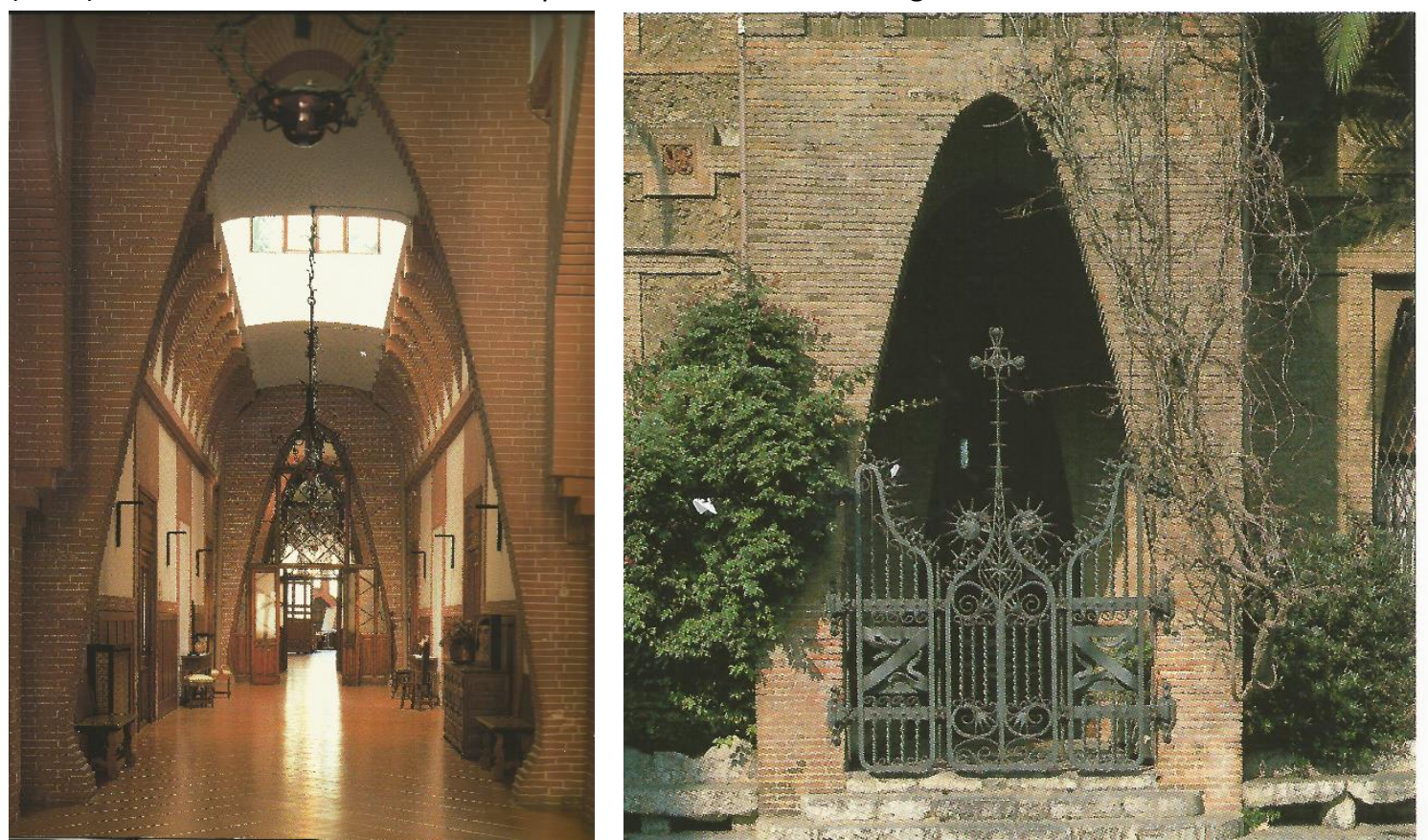

Arco, bóveda, estructura, espacio. Colegio Teresiano. Fuente: Giralt Miracle, D. (2002) Gaudí, la búsqueda de la forma. Barcelona. Lunwerg. 
William Howe y Eaton Hodgkinson -Love y Okinson en el escrito de Gaudí- ${ }^{129}$, y añadiendo algunos comentarios respecto de los dinteles de hierro.

Igualmente se deja sentir en su preocupación por los muros que contrarrestan empujes, por la relación entre el sustentante y el sostenido respecto a la altura. Si nos preguntamos qué le hizo no proseguir por este camino estructural que marcaban los nuevos materiales: perfiles metálicos y hormigón armado, quiza podriamos contestar que su pensamiento estaba centrado en el tremendo esfuerzo de encontrar una estructura autoestable a partir de innumerables ensayos en los que pretende sintetizar el comportamiento de las estructuras fisicas que se dan en la naturaleza integrando al mismo tiempo con una fecundisma imaginación la conjugacion de materiales y soluciones tradicionales (y por tanto de sobra conocidos en su comportamiento y durabilidad) con un amplio programa simbolico al que otorga un importante papel a la hora de definir el carácter de un edificio religioso.

\section{Unidad e Imagen urbana.}

Si la triple conjunción Geometría de planta-Modulo estructural-Volumen generado, constituye un sistema válido para la concepción y construcción de un espacio ordenado y convenientemente jerarquizado para la asamblea eucarística, también contribuye a conformar el carácter religioso del edificio-iglesia gaudiniano basado precisamente en la visión mistica del espacio real, como podremos ver más adelante en sus proyectos. Por el momento nos limitaremos a tomar nota de ello y constatar así mismo otro rasgo fundamental del pensamiento gaudiniano que aparece en sus escritos: la imagen urbana de esta tipología de edificios.

Ya hemos dicho que para Gaudí el exterior de un edificio ha de estar en consonancia con el interior, o mejor, ha de ser consecuencia del interior: "las formas exteriores han de ser trasunto de las interiores" (Mercader, Antoni Gaudí: escritos y documentos, p.56). Pero Puig Boada trascribe también la preocupación de Gaudí por preservar el carácter religioso del edificio cuidando su acabado exterior, el cual deberá ser digno, aunque no sobrecargado de ornamentación.

\footnotetext{
129 Ibid. P.76: "Imprescindiblemente los soportes aislados de hierro están llamados a jugar un gran papel y tenemos medios para determinar la relación susodicha: las fórmulas de Love y Okinson." La autora menciona en una nota que debe referirse a las armaduras de hierro que inventó el estadounidense William Hove (1803-1852) y a la teoría de la resistencia de las vigas de hierro del mecánico británico Eaton Hodgkinson (1789-1861), y que los estudios de mecánica aplicada en el University College de Londres de éste último, traducidos al francés y editados en Paris en 1857 por Victor Dalmont, se encontraban en la biblioteca de la Escuela de Arquitectura de Barcelona, perteneciendo al arquitecto Josep Oriol Mestres Esplugas (1815-1895).
} 

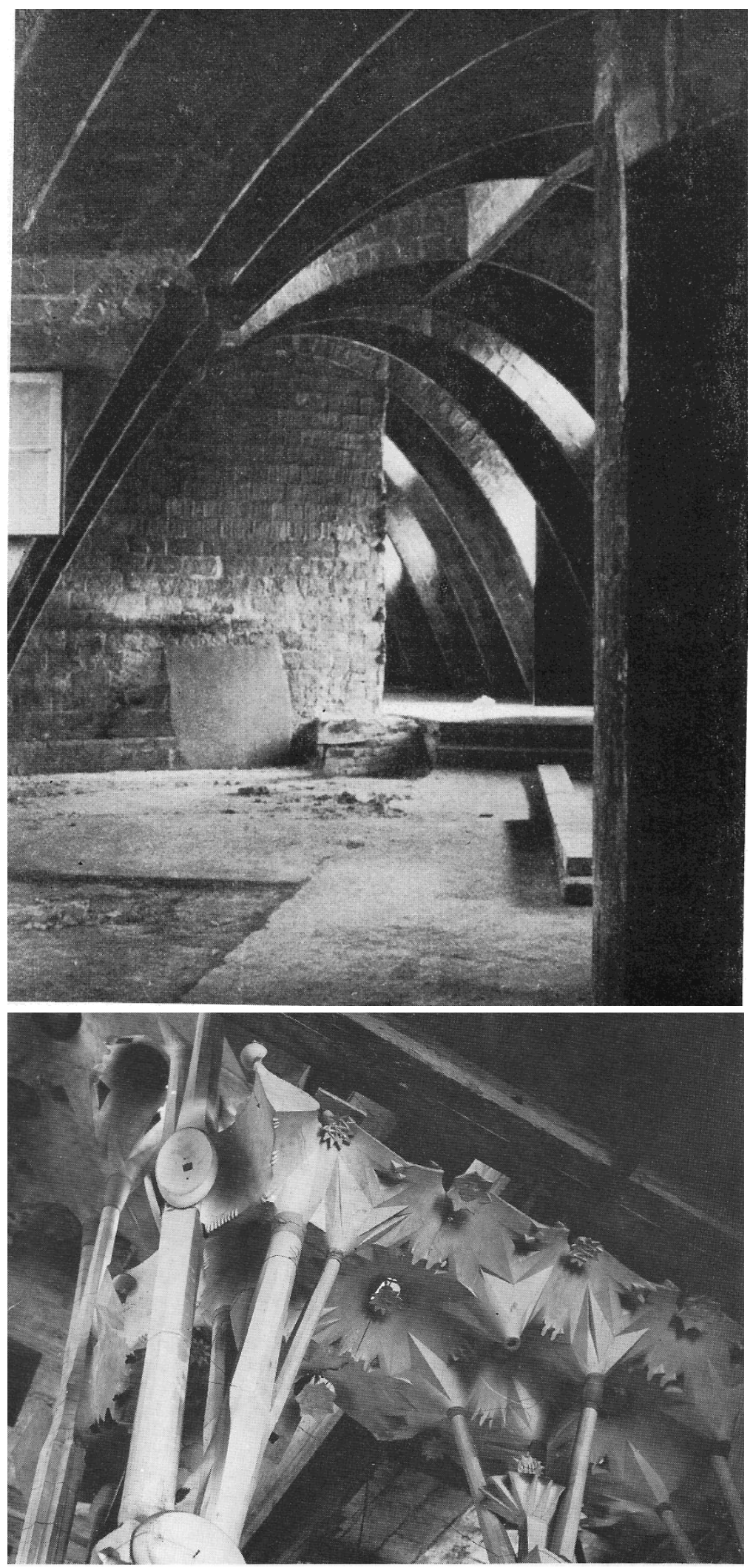

Arcos de ladrillo en la Mansarda de la Casa Milá. Maqueta de la bóveda y columnas arborescentes del 3er proyecto estructural de la sagrada Familia. Fuente: Bergós, J. (2000) Gaudí: el hombre y su obra. Barcelona. UPC. Cátedra Gaudí. 
El interés por esta imagen urbana del edificio-iglesia lo vincula a la concepción unitaria del proyecto y a la alta consideración en que ha situado a la arquitectura eclesiástica. ${ }^{130}$ Llama la atención sobre las agregaciones, que considera desuniformizadoras desde la perspectiva de un proyecto completo en sí mismo, y sobre cómo dialoga éste con el resto de edificios, con los lugares públicos ciudadanos, con el entorno inmediato, ...etc. señalando que la construcción debe tener más riqueza, que en otras edades, para mantener su rango, disponer de un aspecto acabado y digno sin que esto quiera referirse al lujo o a la ostentación material "por más que no esté sobrecargado de ornamentación".

Sus ideas responden a un concepto de dignidad edilicia, al cuidadoso tratamiento del edificio como una unidad en la cual ha de estudiarse y ejecutarse hasta el más mínimo detalle. La crítica al proyecto de Abadie para Montmartre resalta precisamente esta falta de cuidado en los detalles, al igual que sucede en la Opera de Garnier. De este edificio, destinado al recreo de las clases pudientes, nos dice que se descuidan las fachadas laterales y los detalles de cubiertas y cornisas (que cambian abruptamente de material), que se emplean esculturas de yeso que imitan todo y no satisfacen nada, que no se tratan todas las partes del edificio unitariamente pues se descuidan unas de para favorecer a otras, y, finalmente, que todo ello va en detrimento de la unidad del edificio y su conjunto, de la trasposición del cuidado interior al exterior.

Para conseguirlo afirma que no es partidario de la multiplicación de la ornamentación pues señala, como ya hemos mencionado anteriormente, que "la multiplicación de molduras induce necesariamente a la complicación de los motivos ornamentales" y que "Ias formas expresadas con sencillez tiene mayor grandeza". Se muestra favorable a la utilización de las formas derivadas de la geometría, por su sencilla claridad, que une a una clara concepción estructural -que así exigen menos ornamentación- persiguiendo la armonia de la estructura con la plasticidad de las formas: "La imitación de estilos necesariamente ha de llevar ornamentación superflua, los estilos sencillos son los de buena estructura. La estructura estética es la que explica la construcción con sus variados recursos y fecundos problemas resueltos, haciendo agradables los objetos por si mismos." 131

\footnotetext{
130 Puig Boada, Isidre (1981). El Pensament de Gaudí: compilació de textos i comentaris. Barcelona. La Gaya Ciencia. P. 40: "I si, realment, alguna de les nostres catedrals presenten un aspecto no molt agradable $o$ descurat, és degut als afegitons posteriors que s'hi han fet."

${ }^{131}$ Cf. Mercader, Laura (2002). Antoni Gaudí: escritos y documentos. Barcelona. El Acantilado. P.71.
} 


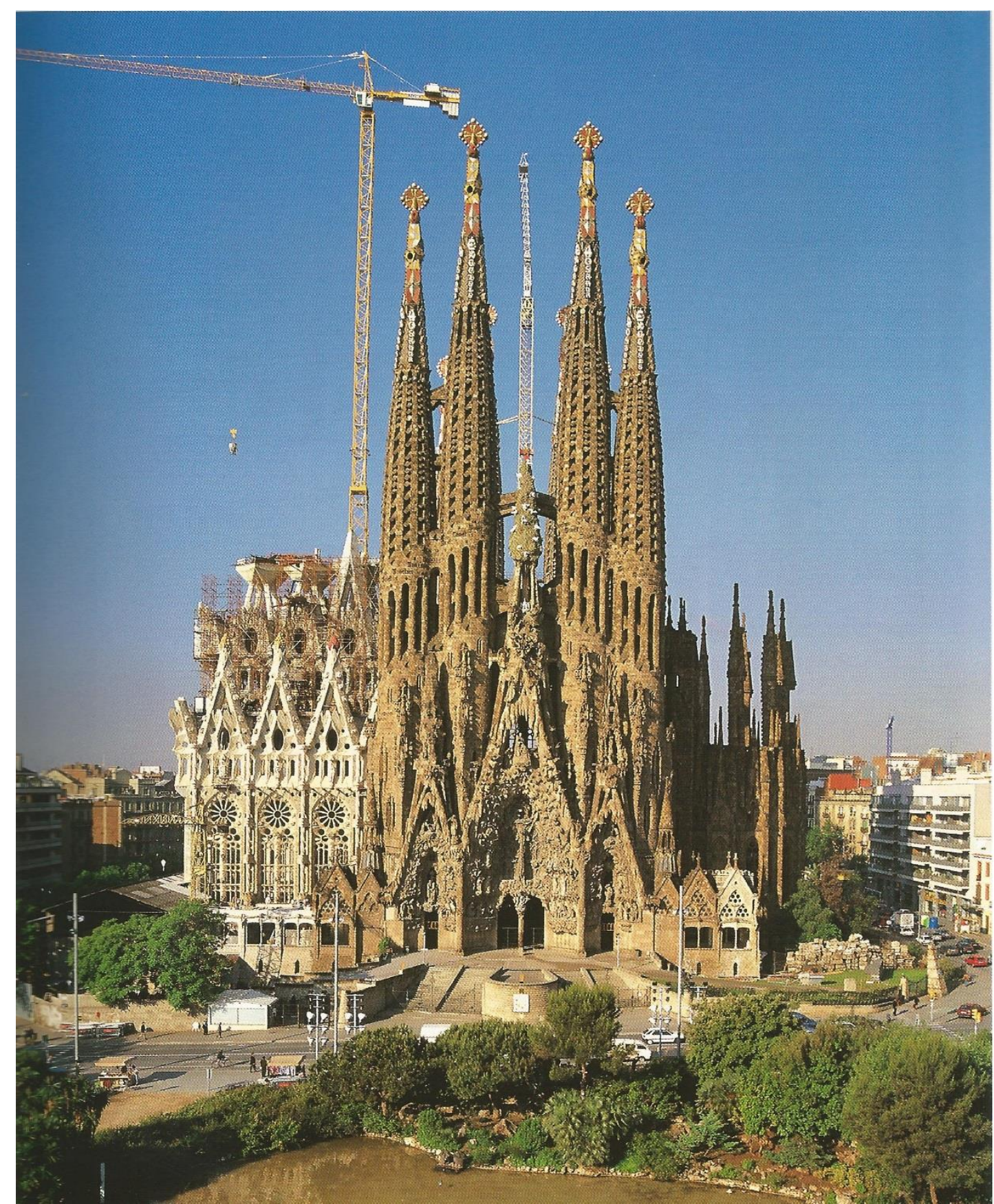

Plaza de la Sagrada Familia: Fachada Este y Portada del Nacimiento. Fuente: Cirlot, J.E. (2002). Gaudí. Fotografias de Pere Vivas y Ricard Pla. Ayto. de Barcelona. Triangle Postals. 
De esta manera la unidad entre el interno y el externo del edificio vendrá dada por la sustitución de la improvisación o copia de estilos por el estudio global de las necesidades materiales y aspiraciones morales que se tienen respecto del proyecto. En lo referente a los materiales de construcción Gaudí se muestra menos explicito en el Manuscrito de Reus que en el discurso a posteriori que recoge Puig Boada. En estos primeros años parte de una valoración de aquellos materiales que conoce y que tradicionalmente ha sido contrastados, defendiendo su idoneidad por la franqueza y fina ejecución. ${ }^{132}$

No obstante, dentro de su concepción pétrea y cerámica de las construcciones se decanta por el hormigón en macizos al objeto de reducir costes respecto de lo que seria un elemento macizo de piedra, aunque revistiéndolos exteriormente con sillería. En este aspecto, todavía se haya lejos de considerar el hormigón armado como un material capaz de mostrar una imagen decorativa digna. Con el hierro tendrá menos escrúpulos decorativos pues es notoria su mención y utilización en diversos proyectos que arrancan desde los primeros años de ejercicio profesional.

Interiormente preconica el uso de estucos para recibir pinturas pues concibe un gran desarrollo de imágenes pictóricas en paramentos verticales siguiendo la tradición medieval del occidente cristiano y la herencia de las iglesias bizantinas; para la cubrición propone el empleo de las bóvedas tabicadas de ladrillo, de diversos gruesos y gran tradición en el área mediterránea; de formas equilibradas y fácil construcción, al objeto de disponer varias capas en la cubierta que confieran al edificio mayor resistencia al fuego y mejores condiciones térmicas, estas bóvedas fueron puestas en valor por aquellos años por Rafael Guastavino en gran numero de edificios públicos de Estados Unidos.

\section{Visión arquitectónica del espacio de culto cristiano.}

Al considerar la arquitectura religiosa como la cumbre de la práctica profesional, ésta ocupa la mayor extensión de sus escritos de juventud (1878) lo que supone un indicio de por dónde irán sus inquietudes al finalizar la carrera y comenzar de su quehacer profesional.

\footnotetext{
132 Ibd. En la P.56 se refiere a los materiales a utilizar en la construcción de una iglesia: "Los materiales a propósito empleados son: la sillería sin pulimentar la estatuaria en algunos casos, el ladrillo y el barro cocido para relieves y ornamentación; en ciertas partes el hierro, el bronce, el plomo, la madera escasamente"; y en la P. 58 añade: "los materiales de la construccion, la sillería sencilla en su color natural, las cubiertas con barro cocido barnizado, la escultura igualmente en piedra y monograma del mismo material, todo lo más la escultura en plomo para ciertas partes altas doradas o sin dorar". También en Puig Boada, Isidre (1981). El Pensament de Gaudí: compilació de textos i comentaris. Barcelona. La Gaya Ciencia; Encontramos (P. 38): Anem ja als materials apropiats per donar carácter a les construccions religioses, començant pel carácter exterior dels Temples...Els materials a propòsit que cal emprar són: la pedra picad sense pulir; la estatuària , en determinats casos; el maó i la terracuita, per a relleus i ornamentació; en alguns llocs portes de bronze; el ferro; el plom; la fusta, escassament...."
} 
Por tanto se ocupa ya con gran detalle de todas aquellas cuestiones a aplicar a los edificios destinados al culto. Algunas cuestiones que aborda son de índole compositiva y constructiva como la "severidad en la composición" y "la franqueza, pero no la rudeza, en la cubrición de formas sobrado pesadas e inconvenientes"133, en la línea de la simplicidad y de la funcionalidad expuestas anteriormente; también en relación con el carácter especial que da a la iglesia para significarla mediante un podio o graderío respecto de su entorno; pero las más de ellas responden al sentido cultual del edificio y por consiguiente a las funciones que en él se dan.

Mercader y Puig Boada al referir lo mencionado por Gaudí en sus manuscritos nos hacen ver cómo éste considera la conveniencia de disponer un claustro exterior y cirundante al santuario al que de esta forma quiere realzar, pero otorgando también a aquel un uso procesional especifico. ${ }^{134}$

Al comentar más tarde esta disposición del claustro Martinell encuentra también una razón en la mejora del aislamiento sonoro en la nave celebrativa respecto del ruido de las calles, sin dejar de señalar la idoneidad para las procesiones litúrgicas que no tengan que salir a la via pública. ${ }^{135}$

Siguiendo con la descripción que el arquitecto hace de cómo deben ser las diferentes partes y recintos de la iglesia, menciona cómo debe ser el acceso, y aquí sí que encontramos una clara intencionalidad de acogida cristiana, de apertura al mundo, de estar en contacto con el mundo, pues aboga por un "portal de gran tamaño, no para el hombre individuo, sino para la Humanidad entera que cabe toda en el seno de su Creador".

\footnotetext{
${ }^{133}$ Cf. Puig Boada, Isidre (1981). El Pensament de Gaaudí: compilació de textos i comentaris. Barcelona. La Gaya Ciencia. P. 41: “...;.la severitat en la construcción; la franquesa però no la duresa de no cobrir les formes massa pesades $i$ inconvenients; ..."

${ }^{134}$ Cf. Mercader, Laura (2002). Antoni Gaudí: escritos y documentos. Barcelona. El Acantilado. P.59; también Puig Boada, Isidre (1981). El Pensament de Gaudí: compilació de textos i comentaris. Barcelona. La Gaya Ciencia. P.61: "Un claustro procesional que esté especialmente alrededor del ábside da gran aislamiento al santuario, veneración y es conveniente a los usos del culto." También en Puig Boada, Isidre (1981). El Pensament de Gaudí: compilació de textos i comentaris. Barcelona. La Gaya Ciencia. P. 44: "Un claustre procesional ha d'estar, especialmente, al voltant de l'absis, perquè dóna un gran aïllament al santuari, $i$ vneració i conveniencia als usos del culte."

135 Cf. Martinell Brunet, Cesar (1967). Gaudi, su vida, su teoría, su obra. Barcelona. COACB. P.310:"... aquí Gaudí lo dispuso alrededor, con pequeños espacios destinados a jardín, para alejar los ruidos de la calle....En su conjunto es de inspiración gótica y ya está construido en sus tramos próximos a la fachada del Nacimiento, por él, una vez en función el templo, podrán discurrir actos litúrgicos o procesiones que no requieran la salida a la calle,"
} 
No olvida la simbología e iconologia de los misterios cuando menciona el "recuerdo oportuno de ciertos misterios y santos", ni su proyección exterior al querer situar las campanas a cierta altura para "alcanzar a los más alejados." En este sentido plantea también la verticalidad no sólo como signo de espiritualidad, común a todas las religiones, sino también para mejorar la iluminación natural el edificio, pues las elevadas casas de la época que circundan a una iglesia pueden impedir la luz intensa y diáfana del firmamento en las vidrieras ${ }^{136}$.

Gaudí se declara conocedor del edificio de la iglesia y de la función específica que tienen los distintos espacios y elementos arquitectónicos dentro del culto:

- Respecto de las capillas (se entiende las secundarias, no la capilla mayor), invita a hacerlas aisladas o casi independientes, y capaces. Entiende esta capilla para la administración de sacramentos como distinta de la nave principal o espacio celebrativo por antonomasia por lo que no es una cuestión de distribución, y distinguiendo, por tanto, así entre distintas funciones litúrgicas. ${ }^{137}$

- Realza el altar como elemento primordial de la celebración ecuaristica y asevera: "es de sencilla forma para las exigencias litúrgicas, pero es cierto que muchas veces una idea de lujo, mejor que verdadera religiosidad, han convertido nuestros altares en verdaderos almacenes de formas e imágenes, perjudicando al templo, haciéndolo mezquino, con tal abundancia de objetos que no cabrían de manera desahogada en él, debiéndose replegar por las sinuosidades de las bóvedas"138. En el contexto de la segunda mitad del siglo XIX denota conocer la realidad que acontecía en la mayoría de las iglesias con anterioridad a la difusión de las normas que propugnaban los impulsores del Movimiento Litúrgico, pues el altar se había convertido en ese estrado o almacén de objetos, ciertamente litúrgicos sí, pero que impedían centrarse en el misterio de la eucaristía. Queda claro que Gaudí estaba al tanto de la renovación litúrgica que se iniciaba en la Iglesia Católica y que se sumaba a ella, buscando la restauración del sentido litúrgico de la Misa.

\footnotetext{
${ }^{136}$ Cf. Puig Boada, Isidre (1981). El Pensament de Gaaudí: compilació de textos i comentaris. Barcelona. La Gaya Ciencia. P. 42: "Naturalment que, si busquem llums altíssimes, en general ens aillarem del món exterior, ens elevarem cap a Déu. Les pintures de les parets tenen molts avantatges, perquè són més adequades les llums altes i, per tant, distants, la cual cosa és molt convenient, en això de la distancia, perquè quedin esmorteïts els vidres de colors."

137 Cf. Mercader, Laura (2002). Antoni Gaudí: escritos y documentos. Barcelona. El Acantilado. P. 61: "La capilla para la administración de los sacramentos es conveniente y necesaria en las iglesias particulares, pero no es cuestión de distribución, que nada tiene que ver con el carácter que las construcciones religiosas deben presentar actualmente."

138 Ibid. P. 62.
} 
Afirma que "El altar en primer lugar sirve para el santo sacrificio de la misa y de los divinos oficios, así pues, se actuará dando gran realce al ara y lo que la rodea, ya elevándola por medio de gradas, aislándola y dotándola de todos los elementos que infunden respeto." ${ }^{139} \mathrm{Y}$ también indica que debe hacerse de "las materias más ricas y durables", que remarcan su importancia simbólica -el altar es Cristo- y fija su mirada en los templetes o ciborios como el de San Pedro en Roma así contribuyen a darle realce, respeto y veneración.

- En relación al coro da bastantes pormenores, que debe situarse por las circunstancias actuales alrededor del santuario, que debe ser espacioso y grande, contribuyendo a dar realce al altar, y que en el ocupe su lugar el clero. Son los años en que la orden benedictina promueve la recuperación de la Liturgia de las Horas en las grandes iglesias, que han de disponer de un lugar apropiado para el coro. En concordancia con esto Pio X fundamentará la participación de la fieles en la Misa impulsando la reforma y potenciación del canto gregoriano.

- La sacristía, la concibe próxima al altar y comunicada con el presbiterio, pero separada y a diferente nivel del protagonismo que confiere al coro, marcando así, diferencias respecto de la tradición tridentina.

- La percepción que tiene del claustro es sumamente coincidente con estas ideas reformadoras que pretendían diferenciar el culto litúrgico de otras manifestaciones de religiosidad popular. Así mismo, lejos de plantearse un claustro arqueológico o residual, pura imitación del antiguo espacio de los catecúmenos que eran admitidos al seno de los misterios eucarísticos en la vigilia de la Pascual, lo concibe dinámico y perimetral al santuario o presbiterio donde se realiza el misterio eucaristico, al servicio de los recorridos procesionales y populares que en otro tiempo se realizaban en el interior de la nave principal, después a lo largo de calles y plazas públicas y en el momento histórico que le toca vivir ciertamente alterados por una situación social convulsa más propensa a las manifestaciones y reivindicaciones en momentos de cambio económico y político que a las muestras de religiosidad. De esta manera $y$, al mismo tiempo que con una función de aislamiento y protección del espacio litúrgico frente al ruido, la climatología y todo lo que comporta el clima social de la vías públicas que rodean al Templo, escribe que ubicándolo perimetralmente al ábside también le permite ser utilizado para los usos del culto, dando un "gran aislamiento al santuario,

139 Ibid. P. 62. 
veneración, y es conveniente a los usos del culto." 140

El conocimiento del ceremonial de los obispos, de las procesiones y resto de funciones litúrgicas, unido al atractivo que siente por la Liturgia y el recuerdo de las funciones a las que asistió en su niñez le dan pie para mostrar sus ideas. De la exposición del sacramento afirma que, "es una de las ceremonias más magnificas y grandiosas" 141 rememorando su asistencia en los años de juventud pasados en Reus y Tarragona, y enjuicia los modernos sagrarios probablemente mucho más sencillos que los que conoció en su niñez, su sistema de apertura, etc. como poco reverentes. Conoce perfectamente las ceremonias que se realizaban en la catedral de Tarragona al ser su abuela materna de esa ciudad, y las pone como ejemplo de su grandísimo atractivo.

- Propone un templete para realzar la colocación de la custodia, la cual "podría hacerse con un pedestal con gradas que pasen por delante y que forme dicho pedestal como un altar más elevado"142. Para Gaudí es fundamental que la mirada de los fieles pueda contemplar las celebraciones y no ser entorpecida por coronas de iluminación suspendidas de las bóvedas, rechazando este sistema para la iluminación de las elevadas cúpulas, y prefiriendo elementos mucho más sencillos que soportados por las columnas no impidan la visión.

Es un decidido partidario del color en la arquitectura, a imitación de la naturaleza, y afirma que "La ornamentación ha sido, es y será colorada. La naturaleza no nos presenta ningún objeto monótonamente del todo uniforme ni en la vegetación, ni en la geología, ni topografía, ni en el reino animal. Siempre el contraste de color es más o menos vivo, y de aquí que obligadamente debamos colorar, en parte o en todo, un miembro arquitectónico; coloración que tal vez desaparecerá pero que la mano del tiempo se encarga de darle una propia y preciosa coloración fruto de la antigüedad"143. A Gaudí le interesa el dialogo de la arquitectura con la escultura y la pintura, fruto de su formación y de su percepción unitaria de los edificios. Prefiere la escultura en el exterior y la pintura como un medio de representar escenas en el interior. La primera la ve condicionada por la luz y la vista, la posición y el tamaño; es partidario de no insertarla en nichos o huecos que debiliten la fábrica resistente sino de mostrar su volumen y su colaboración a la silueta del edificio,

\footnotetext{
${ }^{140}$ Cf. Puig Boada, Isidre (1981). El Pensament de Gaaudí: compilació de textos i comentaris. Barcelona. La Gaya Ciencia. P. 40: “Un claustre procesional ha d'estar, especialmente, al voltant de l'absis, perquè dóna un gran aillament al santuari, i veneració i conveniencia als usos del culte."

${ }^{141}$ Cf. Mercader, Laura (2002). Antoni Gaudí: escritos y documentos. Barcelona. El Acantilado. P. 62.

142 Ibid. P. 62.

${ }^{143}$ Ibid.. P. 46.
} 
concibiendo el relieve como un valor añadido de la construcción. Considera la pintura y la escultura en cuanto a su capacidad para clarificar planos, límites y contrastes: "La pintura arquitectónica en ciertos puntos tiene la inmensa ventaja que hace más enérgicos los contornos y los planos esculturales, dando una idea más clara del objeto. La ornamentación escultural tiene siempre por objeto el aumentar la importancia de las superficies sin darles pesadez"144 Gaudí se decanta por la tradición de las pinturas murarías en las iglesias, la imagineria de las catedrales y el desarrollo de las inscripciones que valora en la arquitectura arabe.

Los escritos de Gaudí inciden también en elementos arquitectónicos que configuran desde siempre el proyecto de la iglesia a los cuales quiere renovar su sentido dentro del espacio celebrativo:

- Las entradas a la Iglesia las concibe más que como un elemento material de separación, cierre o apertura, como un espacio de transición entre el interno y el externo cuya función primordial es la acogida : "en cada una de las puertas, un pórtico que la antecede seria sumamente conveniente para presentar la comparación de una pieza pequeña y baja y luego presentársela inconmensurable de grandísima altura." ${ }^{145}$

- Afirma que las campanas "deben estar puestas encima del cimborio y a toda la mayor altura posible" ${ }^{146}$, rememorando la función civil de refugio, torre y vigía de épocas pretéritas pero también resaltando su condición sonora ligada a la celebración liturgica de la comunidad cristiana. Al hablar de ellas y su situación en los cimborios, hace mención expresa de las cúpulas de San Marcos de Venecia alabando su secuencia de bóvedas internas respecto del extradós de las cúpulas que permiten visualizar éstas airosamente.

Todas estas ideas entremezcladas de tradición vivida, conocimiento litúrgico e inquietud por llegar a la clave de los problemas arquitectónicos de una iglesia se los plantea Gaudí al enjuiciar el gran número de iglesias que se han hecho en los siglos XVIII y XIX. Afirma que se han construido atendiendo más a la novedad o al estilo que no a su sentido cultual, que entiende como prioritario, no sujeto a modas. El edificio iglesia presenta una aspiración innata a perpetuarse, reflejo de los misterios que se celebran -"han de ser perdurables como la religión que cobijan; un objeto baladí, de moda, es puramente

\footnotetext{
${ }^{144}$ Cf. Puig Boada, Isidre (1981). El Pensament de Gaaudí: compilació de textos i comentaris. Barcelona. La Gaya Ciencia. P. 33

${ }^{145}$ Cf. Mercader, Laura (2002). Antoni Gaudí: escritos y documentos. Barcelona. El Acantilado. P. 64

${ }^{146}$ Ibid. P. 64
} 
mundanal, sin duración ni resistencia"147_ aunque eso no le hace perder de vista la tradición histórica heredada de elementos constructivos que el neomedievalismo del siglo XIX había vuelto a sacar a la palestra. Precisamente es la idea del edificio iglesia imbuida de un completo conocimiento litúrgico, junto con la asombrosa síntesis de elementos y tipologías provenientes de la historia arquitectónica pasados por la criba del conocimiento de los materiales y las soluciones constructivas contrastadas, lo que le hace estar en permanente evolución. Así se explica que analice los triforios y tribunas de las iglesias, propios de un lenguaje medieval, pero desde la perspectiva de la asistencia a los oficios divinos pues "empequeñece al objeto sacrosanto del culto; esto de ver el altar más bajo que los asistentes es de mal efecto, por esto alrededor de la capilla mayor se guardan de dejarlo invadir por el público". ${ }^{148}$

Mercader trascribe un curioso apartado del Cuaderno de Notas, denominado Método para la buena realización de un proyecto, que también recoge Puig Boada, en el que Gaudí resume sus ideas en cinco etapas o partes de proyecto más una sexta de ejecución o realización:

"10 Estudio necesidades morales y materiales extra construcción, indicación ligera de material.

2o Fijación de los materiales y sistema constructivo.

3o Detalles separados, motivos ornamentales y estudio de la construcción propiamente dicha.

4o Estudio de conjunto y unificación, que es el que sirve para la presentación a los profanos, corrección de lo anterior y corte y medios de realización.

5 o Detalles al natural para fijar decididamente y sin vacilaciones la ejecución.

6o Realización."

Y que el mismo Gaudí pretende aclarar añadiendo en su manuscrito:

1. Conocimiento perfecto de las necesidades y casos análogos, cualidades y defectos, examen de la idea definitiva que se presente, ajustándola a las ideas admitidas indiscutibles o resueltas.

2. Materiales y sistemas constructivos.

3. Medios de realización en grandes detalles.

4. Unificación y simplificación.

5. Detalles en todas y cada una de las partes, uniones, ensamblajes, dimensiones y bultos y cortes.

6. Solución de las dificultades del último número.

\footnotetext{
${ }^{147}$ Ibid. P. 65

148 Ibid. P. 66
} 
A continuación da algunas consideraciones relativas a la necesidad de conocer el punto donde se va a proyectar purgándolo de lo superfluo y precisando bien las dificultades o inconvenientes, para proceder a ensayar la aplicación de la forma a la idea, tendiendo siempre a una forma simplificada. Llega a incidir en los medios materiales -dibujo al lápiz o al carbón, tinta, etc.- para sacar buenos resultados y remarca el sombreado como técnica necesaria.

Finalmente destaca la importancia de la planta del edificio, por la cual se ha de empezar el proyecto, a la que seguidamente añade la sección y después las fachadas. ${ }^{149}$ De esta manera parece que comience a sintetizar su concepto de una grande iglesia cuando incide en las cúpulas pintadas - "para la iluminación alrededor de la cúpula o cúpulas, una corona de grandes ventanales tapados con láminas de alabastro grabadas al hueco con asuntos decorativos y representativos $y$, en los bordes prismas de cristal que descomponiendo la luz viniesen a reflejarla con mil cambiantes. Esto necesita madurarse y no está más que en embrión."_150

Respecto de los motivos de ornamentación escribe su interés por encontrar una forma de expresión que dé idea de la naturaleza descartando lo superfluo y dejando como una forma simplificada y sintética con la cual quiere captar la esencia, el espíritu de aquella. Por eso busca destacar las cualidades que le interesa resaltar por la forma, el color, etc. y al analizar cómo los griegos se preocuparon de la fuerza y la actividad pero cuyos rostros eran frecuentemente inexpresivos, y la sociedad cristiana de la Edad Media se interesó por las cualidades morales, la expresión, pasa a describir la expresión que le interesa captar del rostro de Cristo crucificado, manifestando que el rostro es el espejo del alma.

De esta manera incide en que la belleza de la forma es "la poesía de ciertas ideas que se reflejan exactamente en la forma que contemplamos" y que por tanto "para que haya recuerdo poético es preciso haber conocido antes el objeto y, por lo tanto, conocer lo que se quiere representar para que la representación produzca su efecto."

Al final de este manuscrito dice que estudiados los motivos de ornamentación lamenta la tendencia hacia el naturalismo por convencionalista y se manifiesta partidario de encontrar un sistema que pudiese descarnar a la idea de la naturaleza de todo lo superfluo, es decir, que le dé su forma, o mejor, expresión sintética que no fotográfica.

\footnotetext{
${ }^{149}$ Ibid. P. 90: "Si el proyecto es de importancia de planta, se empezará por ella, y cuando se hallen vencidas todas las dificultades, se procederá al corte y después a la fachada."

${ }^{150}$ Ibid. P. 90
} 
Así, indica que los griegos buscaron representar las cualidades que denotan fuerza y actividad, en la Edad Media la sociedad cristiana se interesaba por las cualidades morales buscándolas en la expresión del rostro ${ }^{151}$

En La construcción del Templo (1878-1883), al mismo tiempo que en otro sobre la casa solariega, Gaudí sintetiza algunas de las ideas anteriormente expuestas sobre las iglesias en el Cuaderno de notas -según Mercader, fruto de su colaboración profesional en esos años con Villar y Martorell- centrándose en algunos comentarios sobre la ejecución de una obra aunque no aporta novedades sobre su percepción de la arquitectura eclesiástica. El trabajo con Francisco de Paula del Villar (arquitecto diocesano y autor entre otras obras de importantes realizaciones en el Monasterio de Montserrat en las que había dibujado Gaudí y de los primeros proyectos para la Sagrada Familia) y Joan Martorell (con el que había colaborado en la iglesia de las Salesas, las Adoratrices y el dibujo de la nueva fachada de la catedral de Barcelona para el concurso convocado al efecto), los dos principales arquitectos que hacían obras religiosas en la Cataluña de finales del siglo XIX, debió inducirle a plasmar nuevas reflexiones sobre estos asuntos, aunque como ya hemos dicho más centrados en lo que supone la organización de la ejecución de una obra que en los conceptos que anteriormente había expresado.

Se ratifica así mismo mencionando que los asuntos religiosos son los más elevados y por consiguiente aquellos que "necesitan el empleo de todos los medios en su más alto grado". Del templo afirma que es el primer edificio de la población moderna y que debe "inspirar el sentimiento de la Divinidad" y "reunir la grandeza a la severidad"152, si bien estas últimas cualidades las entiende no en el sentido material de tamaño o apariencia sino más bien como una cualidad interna o moral de la edificación que la hace ser el edificio primero o principal de una población.

Es consciente de la tendencia a reproducir formas renacentistas y medievales según el discurrir de los tiempos y aunque valora sus aportaciones, al considerar las tradiciones de ellos recibidas, como por ejemplo el elemento constructivo de la cúpula y la decoración pictórica del Renacimiento, no por ello deja de señalar defectos y características de aquellos trabajos que no encuentra de aplicación a la construcción del tiempo en el que vive: la ingente cantidad de mano de obra que cede protagonismo a la maquinaria y los procedimientos constructivos que facilitan el trabajo, a los esfuerzos intelectuales que organizan la construcción, etc.

\footnotetext{
151 Ibid. P. 93: "El Cristo Crucificado con sus carnes escuálidas expresa lo que debió padecer en su muerte y pasión, pero qué expresión y verdad en el rostro, el miembro más importante para la expresión, no en balde se le ha llamado el espejo del alma."

${ }^{152}$ Ibid. P. 93:
} 


\subsection{El Entorno de Gaudí en la formación de su concepto de Arquitectura Sacra.}

\section{Formación y aprendizaje.}

En la formación arquitectónica de Antonio Gaudí podemos distinguir claramente dos vías de aprendizaje de conocimientos, la que se corresponde con los estudios oficiales cursados en la Escuela de Arquitectura y la que desarrolla como estudiante autodidacta de materias no incluidas en el programa docente de la Escuela y colaborador con otros arquitectos y constructores como Joan Martorell, Francisco de Paula del Villar, Fontseré, principalmente.

Es bien conocido el irregular expediente académico de Gaudí ${ }^{153}$, que se interesa por asignaturas técnicas como Proyectos y Materiales, que se daban en la Escuela de Arquitectura, y otras más humanísticas como Filosofia y Estética -que recibe de Llorens i Barba y Milà i Fontanals respectivamente- pero que muestra escasa disposición a emplear su tiempo en el estudio de materias -relacionadas en el programa de los estudios de Arquitectura como Mecánica Racional, Química General, Geografia, Algebra, etc.- pero cuyas clases se daban en la Facultad de Ciencias de Barcelona, lo cual muestra la fuerte convicción respecto de los temas que bien pronto le interesaron desde el comienzo de su formación universitaria.

Pere Hereu ha estudiado las asignaturas que se impartían en aquellos años en la Escuela de Arquitectura, que seguía el modelo francés de l'École Polytechnique, y en concreto la Teoría del Arte Arquitectónico que impartía Elias Rogent, primer director de la Escuela, y arquitecto de reconocida influencia en la vida cultural del momento. ${ }^{154}$ Según señala Hereu la teoría de la Arquitectura que enseña Rogent en la Escuela recibe la doble influencia cultural del grupo que se organiza entorno a los hermanos Milà y Fontanals y a la obra de Viollet-le-Duc, de notable difusión en esos años por toda Europa. Afirma que la influencia en Rogent de la concepción artística y cultural del grupo de los Milà, que preconizaban una integración artística de hondo contenido espiritual, se ve reforzada por el impacto del conocimiento directo de la nueva arquitectura neogótica alemana en el trascurso de algunos viajes que realiza a este país en los años de la exaltación prusiana de la nueva nación alemana unificada.

${ }^{153}$ Cf. Martinell, C. (1967). Gaudí: su vida, su teoría, su obra. Barcelona. COACB. Apendice III.

154 Cf. Hereu, P.(1990) "La idea d'Arquitectura a l'Escola que Gaudí conegué", en Gaudí i el seu temps. Barcelona. Barcanova; Vease también sobre las asignaturas, temario de enseñanza y profesores en esos años las siguientes publicaciones que cita Hereu: Cátedra de Composición II (1977). Exposició commemrativa del Centenari de l'Escola d'Arquitectura de Barcelona, 1875-76/1975-76. Exercicis. Projectes. Un assaig d'interpretació. Barcelona, ETSAB. I. Solà-Morales Rubiò. "Origens de l'escola d'Arquitectura de Barcelona", en Cassasas Ymbert, J. (1988). Elies Rogent i la Universitat de Barcelona. Barcelona. Generalitat de Catalunya i Universitat de Barcelona. 
Por otro lado la concepción que tiene Viollet-le-Duc de las estructuras góticas como un sistema de estructural cuasiperfecto de arcos que trasmiten linealmente los empujes y cargas de las bóvedas a unos muros cuya única función parece ser la de cerramiento, junto con la influencia de otros tratadistas franceses como Blanc, Batissier y Daly, determina su Teoria General del Arte Arquitectónico como obra de referencia para sus clases en la Escuela de Barcelona, enfocando la atención de Gaudí hacia el análisis crítico de los estilos históricos y de sus obras más representativas. ${ }^{155}$

Dicho esto conviene recordar que Gaudí no fue precisamente un teórico de la arquitectura. Naturalmente que se puede constatar y rastrear, y así lo hacen Hereu, Mercader, Lahuerta, Isac, Rodherer, etc., la influencia en sus escritos y pensamiento de los postulados e ideas que en relación con la Teoría de la Arquitectura, los estilos y la concepción de la arquitectura religiosa recibe en la Escuela de la mano de sus profesores, pero no queda ahí la cosa, ni mucho menos. Su producción literaria es escasa y se basa principalmente en inquietudes, reflexiones y aseveraciones personales que rara vez fundamenta en líneas argumentales coherentemente soportadas por estudios anteriores. Además, ésta se ciñe a los primeros años de ejercicio profesional, abandonando bien pronto cualquier pretensión de investigación o enseñanza teóricas, las cuales acaba manifiestamente rechazando para centrarse en la práctica profesional.

E incluso hay que recordar cómo en sus años de formación universitaria la enseñanza teórica reglada no es la única fuente de aprendizaje sino que el joven estudiante pasa largas horas analizando sintéticamente fotografías y grabados de edificios correspondientes a los más diversos estilos históricos españoles y europeos. De ahí que su perfil investigador y docente se inscriba en el contexto de la continuidad de esta práctica personal en su ejercicio profesional -a la manera de los artistas clásicos en cuyo taller o escuela se reunia a la vez práctica, dialogo y enseñanza con sus discípulos- que a un afán reglamentario docente o divulgador. Este es el sentido en el que cabe interpretar el Taller que organiza en el emplazamiento de la Sagrada Familia, reuniendo en torno a sus proyectos un grupo significativo de colaboradores y asistentes.

Conviene también señalar ahora la otra forma que tiene Gaudí de entrar en contacto con la Arquitectura -que en su caso adquiere un protagonismo inusitado y a mi juicio fundamental- llegando a constituir un importantísimo camino de formación paralelo a la enseñanza teórica recibida en la Escuela: a saber, el ejercicio de colaboración profesional con arquitectos titulados unos años antes, como Villar y Martorell, y la relación como grupo profesional que establece con éste último y otros colegas coetáneos suyos como

155 Cf. Hereu, P.(1990) "La idea d'Arquitectura a l'Escola que Gaudí conegué", en Gaudí i el seu temps. Barcelona. Barcanova. P. 26: “...trobem que Rogent ha realitzat dues feines: d'una banda ha donat un seguit d'indicacions, fins i tot de normes, encaminades a satisfer, sobretot pel que fà al problema del carácter, les necessitats de la pràctica projectual; d'una altra banda, ha fixat les bases per a l'analisi de l'arquitectura i, fonamentalment, per a la determinació dels trets que caracterizen els estils històrics." 
Cascante, Oliveras, etc. situados en un discurso de vanguardia premodernista y con los cuales llega a una cierta sinergia de recursos, funciones e ideas en diversas obras, tal y como ha explicitado el profesor Bassegoda. ${ }^{156}$

Bassegoda muestra cómo este grupo comparte industriales, intercambia ideas, experiencias y funciones dentro de una cierta organización común de diversos proyectos y obras, en la que a veces es posible deslindar la mayor implicación de cada uno de los miembros del equipo en diversos proyectos como: la Iglesia de los jesuitas de la C/ Caspe y la de las Salesas, ambas en Barcelona; los dibujos para el concurso de la fachada de la catedral de Barcelona y para el proyecto de la Iglesia de Villaricos en Almeria; así como el conjunto de proyectos realizados para la familia del Marqués de Comillas en dicha localidad. Defiende incluso una labor de consejo profesional por parte de Martorell a Gaudí en el proyecto de la Sagrada Familia basándose en el testimonio que da Martinell en su libro Gaudí: su vida, su teoría, su obra. (1967). Martorell, arquitecto diocesano, mayor que Gaudí, había termnado antes la carrera de Arquitectura (1871) y había sido el introductor del joven arquitecto en un selecto circulo de clientes para los cuales trabajaba. Además, Martorell era arquitecto diocesano y su participación en el concurso de la fachada de la catedral -probablemente a instancias del Obispo- da idea del grado de experiencia y relaciones que había adquirido en el ámbito de la arquitectura eclesiástica. De ahí que, considerando también la brillantez de su propuesta, la mayoría de las publicaciones y gran número de arquitectos se mostraron a su favor y que tanto el periódico la Renaixensa como el Cercle Artístic de Sant Lluc la defendieran con entusiasmo varias veces. ${ }^{157}$

Esta situación de prestigio profesional de Martorell, cuya actividad está ligada al catalanismo conservador y la intensidad de la colaboración profesional que se establece entre él y Gaudí en ese mismo año, 1882, que es también el de los proyectos de la iglesia de los jesuitas de la calle Caspe, las Salesas y Villaricos -en orden creciente de intervención de Gaudí- permiten encuadrar el inicio de la andadura profesional de éste dentro de un campo tan específico como es el de la arquitectura eclesiástica de la mano de uno de los mejores especialistas del momento.

\footnotetext{
${ }^{156}$ Cf. Bassegoda Nonell, J. (1989). El gran Gaudí. Sabadell. AVSA. P.188: "No hay duda de que la relación Martorell-Oliveras-Cascante-Gaudí se materializa en un conjunto de edificios que tienen en común entre sí el premodernismo de Martorell, compuesto de mudejarismo y neogosticismo violletiano."

157 Ibid. P.193: "En 1887, concretamente el 4 de abril, se puso la primera piedra de las obras de la nueva fachada según el proyecto Mestres-Font, y por esta razón La Renaixensa decidió salir de nuevo en defensa del rechazado proyecto de Martorell publicando un grabado. Volvió a publicarse ne 1904 por el Cercel de Sant Lluc cuando se iniciaron las obras del cimborio."
} 
En consecuencia y muy poco antes de que le sea encargada la dirección de obra de la Sagrada Familia vemos ya a Gaudí aportando soluciones novedosas para el altar en el crucero de la iglesia de Villaricos. ${ }^{158}$

Martorell disponía en su biblioteca de libros de Puguin (Exemples of Gothic Architecture, Londres, 1838), Viollet-le-Duc (Entretiens sur I'architecture, Paris, 1863) y Herman Ruckwardt (Cölner neubauten. Eine somml der schönsten façaden... zweite série. Beulen, Ch. Claesen et cie, s/a.) como afirma Aymar Ragolta ${ }^{159}$, lo que unido a los trabajos en colaboración reseñados, y a la presentación de Gaudí a los Güell y los Lopez como clientes y al obispo Torras i Bages como consejero espiritual, ayuda a comprender la dimensión de la influencia de Martorell en los primeros años de actividad profesional de Gaudí, siendo esta vía educativa mucho más vitalista y completa que las enseñanzas de la Escuela ya que combina una notable carga de fundamentacion teórica y pràctica.

Bassegoda asevera que fue Martorell quien inició a Gaudí en el estudio y utilización de la estática gráfica para la estructura de los proyectos, aunque menciona que ya con anterioridad debió leer en la biblioteca de algún arquitecto o en la de la Escuela una obra muy conocida en dicho tiempo: Elementos de Arquitectura de John Millington, escrito en inglés y publicado en Filadelfia en 1839, que fue traducido al castellano por Mariano Carrillo de Albornoz y publicado por la Imprenta Nacional de Madrid en $1848 .{ }^{160} \mathrm{El}$ profesor Bassegoda también ha puesto de relieve cómo otros arquitectos del entorno de Gaudí también utilizaron los llamados arcos equilibrados, como por ejemplo: José Goday Casals en el Teatro de la Casa de Caridad en 1912; Jerónimo Martorell Tarrats, en la Escuela Industrial de Artes y Oficios de Sabadell en 1916-19; Bernardino Martorell Puig en el convento de Valldonzella en los mismos años; Ignacio Brugera Llobet en el proyecto de Office Building para Nueva York, en 1919; y su amigo y colaborador Cesar Martinell, en los años 20, en diversas cooperativas agrícolas en el Campo de Tarragona, etc. lo que nos dá idea de la actualidad en aquellos años del sistema de fuerzas funiculares y de la interrelación profesional de Gaudí. ${ }^{161}$

\footnotetext{
158 Ibid. P.183: "Una de las características del proyecto de Gaudí para Villaricos era la colocación del altar en el crucero."

${ }^{159}$ Cf. Aymar i Ragolta, J. (1993). Joan Martorell, mestre de Gaudí. Tesis Doctoral. Uv. De Barcelona.

160 Cf. Bassegoda Nonell, J. (1992) Aproximacion a Gaudí. Barcelona. Cátedra Gaudí. P. 50: “...se sabe que Juan Martorell le inició en la estática gráfica que es una ciencia experimental derivada del estudio de las catenarias y las polifunículas de equilibrio."

161 Ibid. P. 52: "Este catálogo permite descubrir que un buen número de obras se hicieron en Cataluña entre 1883 y 1930 con arcos equilibrados de ladrillo y que para su cálculo se utilizó el sistema de cadenas metálicas de las que se suspendían pesos proporcionalmente equivalentes a las fuerzas que debían insistir sobre los arcos, cuya forma era la conjugada de la cadena suspendida."
} 
En este aspecto resulta valioso el testimonio de Ràfols, que se hace eco de la utilización de la estática gráfica en España adjudicando el honor de su introducción e impulso a Juan Martorell i Montells ${ }^{162}$, por lo que se ve una vez más la decisiva influencia que este arquitecto debió tener sobre Gaudí, ya que en esos años, como afirma Bassegoda, no entraba esta materia en el Plan de Estudios de la Escuela Provincial de Arquitectura de Barcelona.

De esta manera la labor de Martorell para facilitar el acceso de Gaudí al proyecto de la Sagrada Familia -reflejada por numerosos biógrafos- no sería sino el colofón de una intensa relación de sintonía y colaboración profesional. Martorell debió sentirse tranquilo cuando despúes de una controversia profesional con Villar por el desarrollo de las obras de la Sagrada Familia, logra colocar a un arquitecto de su plena confianza para desarrollar un proyecto que comenzaba a discurrir por cauces preocupantes para su visión. Algunas veces tuvo que emplearse también, como afirma Martinell, aportando prudentes consejos a su ex pupilo, pero de lo que no cabe duda es de que desde el primer momento se produce una gran sintonía entre la Asociación de los josefinos y Gaudí. Bassegoda llega a afirmar que el cambio que toma el proyecto en 1885 es debido en gran parte a la fluida e intensa colaboracion existente desde unos años antes entre ambos arquitectos ${ }^{163}$ iniciada en los tiempos de estudiante con el estudio de la estática gráfica y la arquitectura neogética ${ }^{164}$ - de aquí que concluyamos como fundamental para el arranque del proyecto gaudiniano de la Sagrada Familia la intensa y fluida relación entre ambos arquitectos.

\section{Clientes y amigos.}

Personaje clave en las relaciones humanas y profesionales de Gaudí, paisano suyo de Reus, Juan Bautista Grau es discípulo y ayudante de Manuel Milà i Fontanals en sus años

162 Cf. Ràfols, J.F. (1921) "L'arquitecte Joan Martorell", en revista Vell i Nou, Epoca II, vol. II, núm. 16, Barcelona, juliol de 1921, pp. 124-13

163 Cf. Bassegoda Nonell, J. (1992). Aproximación a Gaudí. Barcelona. Cátedra Gaudí. P.27: "Quizás el antecedente más inmediato fuera su colaboración con Juan Martorell, acreditado neogótico, en el proyecto de la iglesia para el convento de benedictinos celestinos de Cuevas de Vera (Almeria), nunca realizado, o en la iglesia de las Salesas del paseo de San Juan, terminada precisamente en 1885. Así parece demostrarlo la alta torre de planta cuadrada frente a la puerta principal de las Salesas, del mismo tipo que figura en el diseño de Gaudí para la Sagrada Familia."

164 Bassegoda Nonell, J. (1999). La cátedra de Gaudí. Barcelona. Edicions de la UPC. P.30: "Precisamente Juan Martorell fue una gran ayuda para Gaudí pues consta que le inició en el estudio de la estática gráfica, que no se explicaba entonces en la Escuela de Arquitectura, y fue el quien propuso a Gaudí para arquitecto de la Sagrada Familia, además de presentarle a las familias de Comillas y Güell. Gaudí decía de Martorell que era un sabio y un santo. Es muy interesante comentar que Gaudí adquirió de Martorell dos enseñanzas decisivas en su vida, el conocimiento de la arquitectura neogótica y la estática gráfica. Lo primero le sirvió para entender este estilo medieval eminentemente ligado a la estructura y lo segundo para superar las soluciones góticas y penetrar en el mundo de las formas equilibradas." 
escolares, durante el curso 1858-59, pudiendo muy bien haber asimilado sus teorías estéticas basadas en Sto. Tomás de Aquino. Ordenado sacerdote, sigue estudiando diversas carreras y desde 1864 a 1886, años en que es nombrado obispo de Astorga, ocupa diversos cargos clave en la Archidiócesis de Tarragona entre ellos el de Vicario General. Grau es un decidido partidario de la renovación litúrgica que ya en sus tiempos de Tarragona había dejado traslucir en la publicación de un boletín, El criterio tridentino, mediante el cual pretendía influir en la fiel observancia de los criterios emanados en el concilio de Trento para la pureza litúrgica. Trento es Reforma Católica y por tanto Clasicismo y Barroco de una Iglesia centrada en defender los sacramentos y la presencia real de Jesucristo en la Eucaristía. Grau parte de esta fidelidad a los dogmas que defiende la Iglesia Católica, pero no se detiene ahí, su conocimiento y nivel cultural, filosófico y arqueológico le incitan a estar al tanto de la renovación litúrgica que con carácter de nuevos aires prende en el siglo XIX en la Iglesia a través de los monasterios de la orden benedictina.

Conrad Kent ha puesto de manifiesto la amistad y paralelismo de vida de Grau con Enrique de Ossó, llamando la atención de cómo en la década de los ochenta Gaudí se encuentra trabajando para los dos amigos, realizando el palacio episcopal de Astorga para Grau y ejecutando en Barcelona el colegio de las Teresianas para la Compañía de Santa Teresa de Jesús que había fundado Ossó en Tarragona en 1873. Kent ve a Grau plenamente identificado con la misión social de la Iglesia surgida del Concilio Vaticano I en el pontificado de Pio IX y en esa misión se inscribe el plan que propugna en su última carta pastoral, en 1893, a la que denomina Acción Católica. También participa de la preocupación del nuevo Papa Leon XIII por la Liturgia y se manifiesta proclive a la recuperación de la liturgia tridentina en los oficios litúrgicos y especialmente en la misa, que había caído en desuso favoreciendo toda clase de devociones particulares y un excesivo protagonismo del santoral. Por eso acoge con prontitud el nuevo movimiento litúrgico que con carácter arqueológico comenzaba a surgir en los monasterios benedictinos de Centroeuropa. ${ }^{165}$

Lo que es innegable es la gran influencia e inquietud que Grau trasmite a Gaudí en materia litúrgica, que partiendo de un interés común por el conocimiento y revalorización de lo establecido por el Magisterio de la Iglesia en general y preceptuado por el Rito Romano respecto de la celebración de la Misa, le lleva a plantearse cuestiones de tipo artístico y arquitectónico relacionadas con el culto.

165 Cf. Kent, Conrad. (1989). "El obispo Grau y la arqueología sagrada", en Simposio sobre Gaudí y su obra. Centenario de la primera piedra. 24 junio. 1889-1989. Astorga. P. 131, Nota 3: "En los cuatro tomos de la revista El criterio Tridentino, publicados entre 1890 y 1893, se hace referencia a la obra litúrgica de Dom Gueránguer y al Año Cristiano de Croisset, dos influencias en la formación de Antonio Gaudí. Sin embargo, en la 'Sección científico-litúrgica' de la revista, se insiste sobre todo en delinear la forma ortodoxa de celebrar la misa." 
Siendo ambos paisanos y estando el primero ocupando altos cargos en la sede tarraconense, había facilitado a Gaudí la entrada de su sobrina, Rosita Egea, en un colegio de monjas de Tarragona. Precisamente es en esta ciudad donde el joven arquitecto realiza algunos de sus primeros encargos profesionales, a instancias de Grau, entonces Vicario General, que además tienen que ver con el culto: el altar y presunta colaboración en la capilla del colegio de Tarragona de la Congregación de Jesús-María y la decoración del coro de la Iglesia de San Andrés del Palomar de la misma congregación.

A partir de 1887, año en que Gaudí recibe el título de arquitecto y el encargo del proyecto de palacio episcopal en Astorga, su relación se hace más intensa, como atestiguan el correo epistolar sobre el proyecto y los viajes que realiza alli ${ }^{166}$. Bergós dice que durante estas visitas el obispo Grau le despertó el interés por la liturgia, estudiando el Ceremonial de los obispos y el Misal Romano, y habituándole a la lectura diaria de l'Année Liturgique de Dom Gueranguer, de tal manera que la influencia de Grau puede considerarse como determinante en su interés por la Liturgia. ${ }^{167}$ Kent también lo corrobora afirmado que el obispo queria establecer un Museo Arqueológico Cristiano en el Seminario Conciliar de Astorga hacia 1889 y añadiendo que su interés por la arqueología le motivó a adquirir unos terrenos en Bellesguard, identificados con el último rey de la dinastía de Barcelona, y donde más tarde Gaudí realizaría su célebre proyecto. Especial atención merece el singular trato existente en Torras i Bages y Gaudí, pues aunque no pueda encuadrarse estrictamente su relación dentro del marco profesional ni tampoco estén de acuerdo diversos estudiosos en calificarla de amistad, si que se sitúa en contexto común a ambos ámbitos de su actividad. Hay bastante coincidencia en señalar la constitución del Cercle Artístic de Sant Lluc (1893) y su actividad artística cristiana como el inicio del trato entre ambos, aunque el arquitecto no ingresó en el circulo artístico hasta 1899.

Los colaboradores más próximos de Gaudí nos refieren la oportuna intervención de Torras i Bages, en la cuaresma de 1894, para disuadir al arquitecto de continuar un riguroso ayuno penitencial que tenia preocupados a sus ayudantes en la obra de la Sagrada Familia, lo cual da idea del ascendiente moral del eclesiástico en la vida del arquitecto.

166 Cf. Galtés i Pujol, Joan. (2004). "Els vincles de Gaudí amb el món eclesiàstic", en AA.VV. Gaudí i la dimensió trascendent. Barcelona. Ed. Cruilla. P.54: "Les obres s'iniciaren al juny de 1889 i duraren sis anys. Durant aquest temps Gaudi féu diversos viatges a Astorga per visitar les obres (dues visites el 1890, tres el 1892 i quatre el 1893), sempre hostejat al seminari dioceà on hi havia el bisbe mateix."

${ }^{167}$ Cf. Bergós i Massó, Joan (2000). Gaudí, I'home i l'obra. Barcelona. U.P.C., Cátedra Gaudí y Ed. Aymá. P. 42: "Plegats feien estudis del Ceremonial de Bisbes, del Missal Romà, i I'habituà a la lectura quotidina de l'Année Liturgique de Dom Gueranger, que ja no deixà més." 


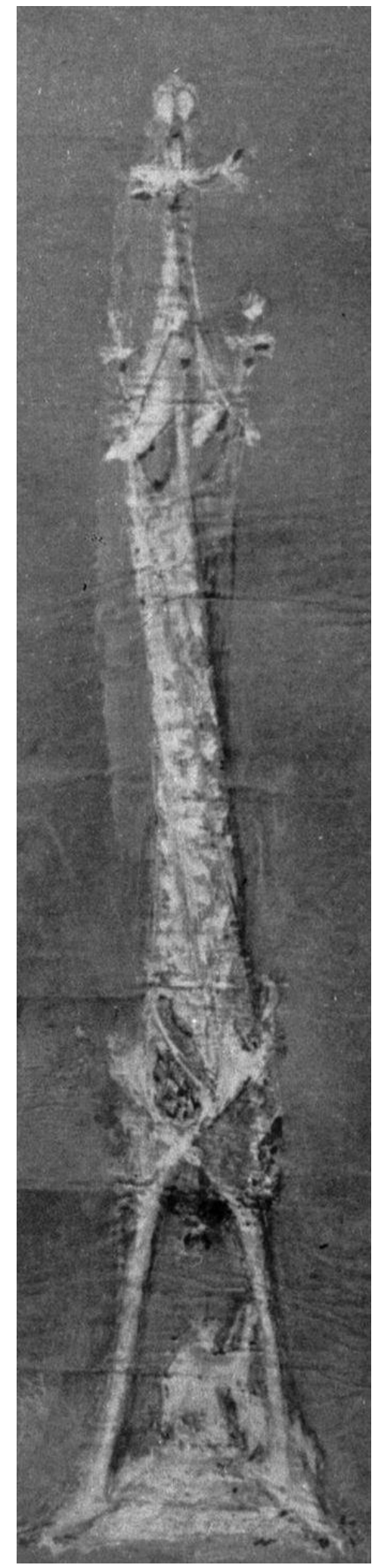

Dibujo del Monumento proyectado por Gaudí para el exterior de la Sagrada Familia, en memoria del obispo Torras $\mathrm{i}$ Bages. Fuente: Martinell, C. (1967). Gaudí: su vida, su teoría, su obra. Barcelona. CAOCB. 
Joan Galtés menciona en ese mismo año un escrito de Torras y Bages loando la obra de la Sagrada Familia (Els vincles de Gaudí amb el món eclesiàstic, 2004) y señala cómo Gaudí tuvo la ocasión de escuchar diversas conferencias suyas sobre temas artísticos en el curso de los años siguientes en el Circulo de San Lucas, prueba de la coincidencia de criterios artísticos y moralesque se daba entre ambos. En los años siguientes se produce un intercambiando visitas mutuas, del arquitecto a Vic así como del obispo a la Colonia y al Parque Güell en 1910. Como muestra de la mutua confianza también se puede mencionar cómo el prelado escoge a Antonio Gaudí en unión con Josep Font y Josep Pericas para emitir un dictamen en 1915 acerca del proyecto de restauración y embellicimiento exterior de la iglesia de Santa Maria de Manresa concebido por el también arquitecto Alejandro Soler.

Así pues, la relación de Torras i Bages puede considerarse desde la amistad (como así le gustaba referirla a Gaudí) y según ella concebiria un diseño estatuario en su honor después de morir en 1916, aunque mejor podria entenderse desde la influencia del pensamiento religioso y cultural del obispo, como una simbiosis del ideal cristiano y catalán que Gaudí acepta plenamente, ya que como dice Jordi Castellanos, Torras i Bages había asumido un papel de orientador de los artistas que se le habían acercado o confiado en los años de consiliario del Círculo. ${ }^{168}$ Lo que si está claro es que Gaudí responde positivamente a los consejos de Torras i Bages y abraza con entusiasmo la misión de formación y difusión del Círculo asistiendo a conferencias artisticas, participando en exposiciones de arte litúrgico e ingresando en la Lliga espiritual de la Mare de Deu de Montserrat, lo cual indica su sintonía con otros arquitectos e intelectuales como Joan Rubió, Puig i Cadafalch, Prat de la Riba, Joan Maragall, etc. ${ }^{169}$

Digamos, pues, que Gaudí se inserta plenamente en el círculo de artistas e intelectuales que se sitúa en el entorno de Torras i Bages razón por la cual éste solicitaría su participacion en sendos dictámenes artísticos, uno sobre el proyecto del pintor Sert para la catedral de Vic y otro respecto del proyecto de reforma de la catedral de Manresa ya mencionado.

De ahí que Lahuerta vea la arquitectura religiosa de Gaudí inserta en la visión política de la restauración de la influencia de la Iglesia en la sociedad catalana a través del catalanismo conservador, en la que prelados como Torras i Bages, Morgades y Casañas tendrían un papel preeminente.

${ }^{168}$ Cf. Castellanos, Jordi. (1990) "Torras i Bages, i Gaudí, en Gaudí i el seu temps. Barcelona. Barcanova. P. 152. Según Castellanos, Torras y Gaudí coinciden en su concepción de la armonía del cosmos que se refleja en la naturaleza, si bien Torras i Bages llega a ella de la mano de la escolástica y Gaudí entra más en la síntesis de todas las artes, en una misión didáctica, moralizadora, sugestiva, del arte.

${ }^{169}$ La Lliga propugnaba pedir a Dios por la reconstitución espiritual y temporal del pueblo catalán mediante la intercesión de la Virgen de Montserrat. 


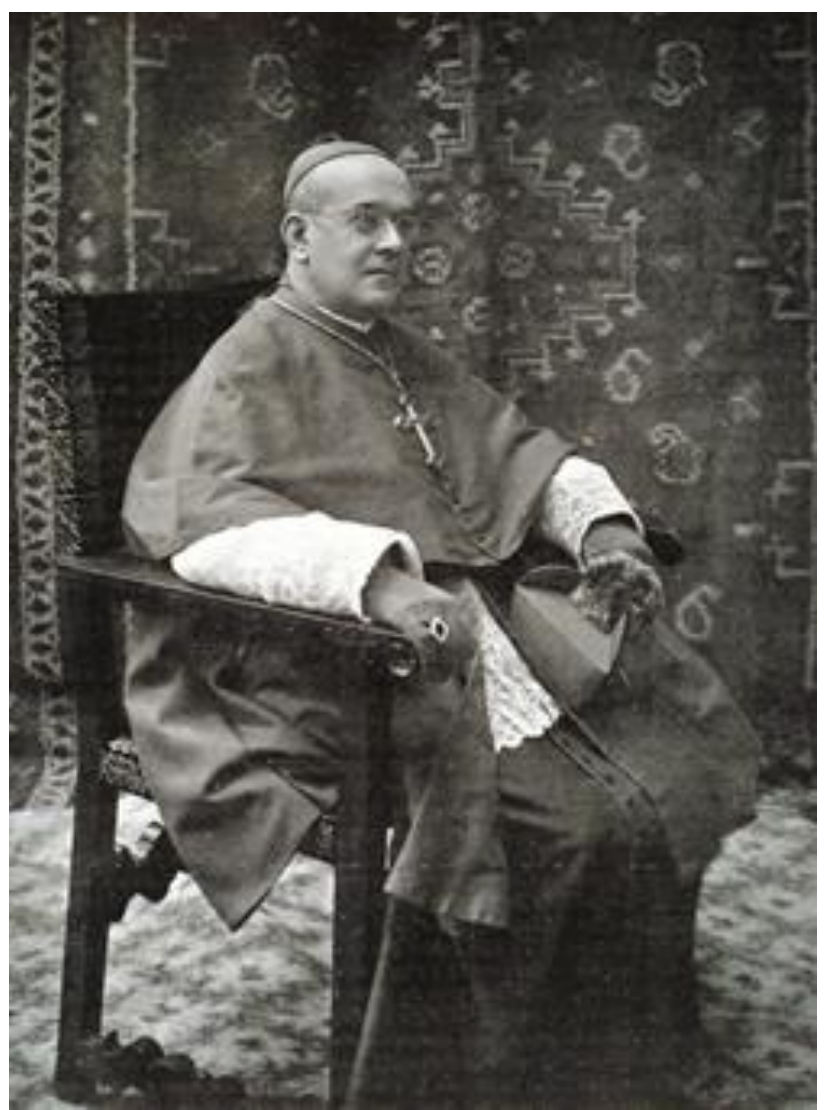

El obispo de Mallorca Pere Joan Campins (1898-1915). Fuente: Fototeca de la Enciclopedia Catalana.

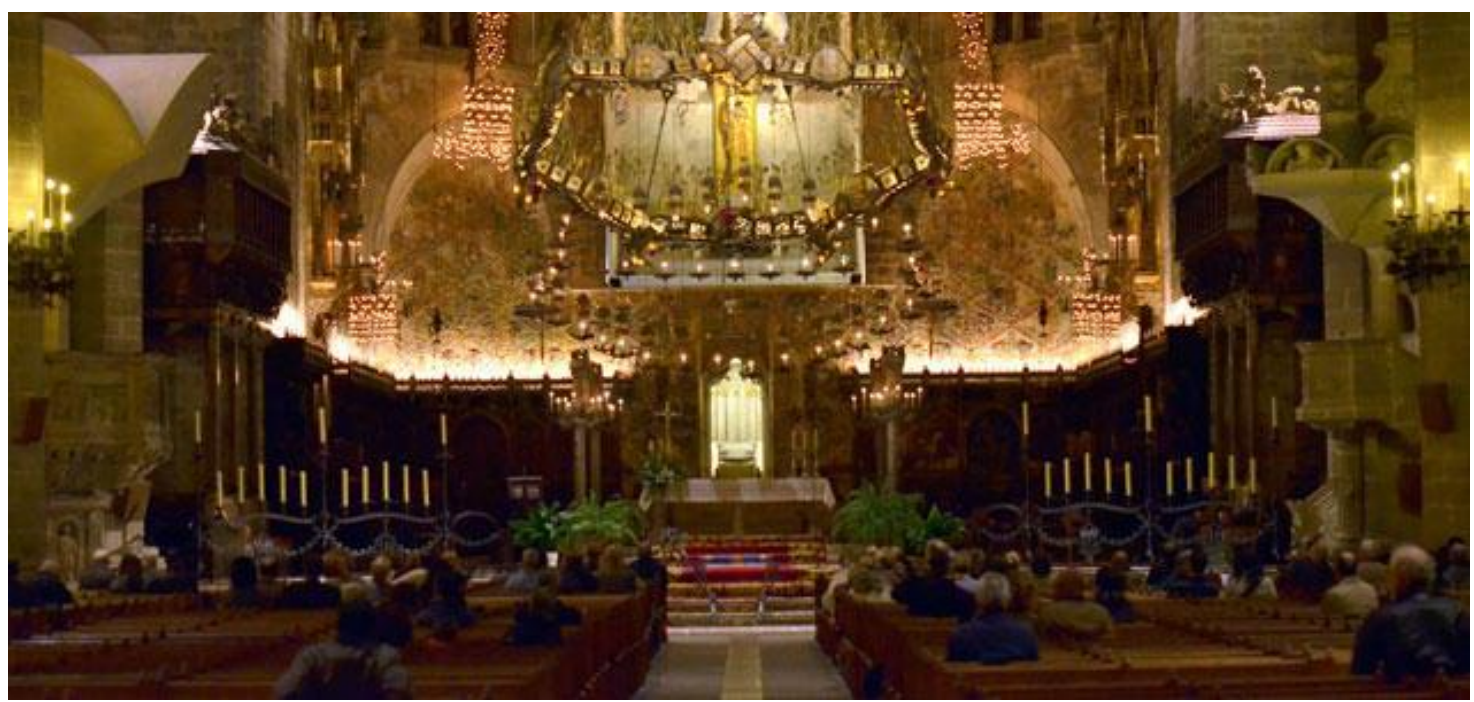

El coro de la catedral de Mallorca restaurado. Fuente: Diario de Mallorca 6-11-2012. 
En ese sentido la visita de Torras i Bages al Parque Güell y a la Sagrada Familia se podrían interpretar como demostrativos de su interés por conocer de primera mano la nueva catedral en construcción -la catedral de los pobres- y el urbanismo que impulsaba Güell (símbolo del nuevo patricio urbano e industrial plenamente acorde con las ideas de renovación religiosa que se exponían en los círculos y congresos intelectuales católicos) y llevaba a cabo uno de los más significados artistas del Círculo de San Lucas. No obstante, Gaudí parace concentrarse en un planteamiento estrictamente litúrgico de la Sagrada Familia, sobre todo a partir de la muerte del obispo Torras, de Güell, Berenguer, etc., sin aceptar las invitaciones a participar en la política activa y volviendo a las inquietudes que había despertado en él Grau. En 1913 entra a formar parte de la organización del Primer Congreso de Arte Cristiano de Cataluña cuyo secretario es Lluis Carreras que más tarde impulsará el congreso litúrgico de Montserrat. Con ello entra en una fase más madura y más amplia de su pensamiento artístico no tan directamente influenciada por la personalidad político-religiosa del prelado de Vic.

En este marco más concretamente litúrgico arquitectónico puede situarse su relación con Pere Joan Campins, obispo de Mallorca, que además es una relación profesional más madura para ambas partes. Campins es un decidido partidario del Movimiento Litúrgico y de la participación del pueblo en la liturgia que pretende desarrollar e implantar lo que Pio $X$ en Roma ha promulgado, y el arquitecto se encuentra en plena madurez de su trayectoria profesional, pues había realizado ya el colegio de las Teresianas, diseñado el proyecto de Tanger y se encontraba en plena ejecución de la Sagrada Familia cuando recibe el encargo formal de intervenir en la catedral de Mallorca. Kerrigan se pregunta el por qué de la elección de Gaudí cuando éste había dado ya suficientes muestras de no seguir al dictado las normas de Viollet-le-Duc, sino muy al contrario, de estar enfrascado en una obra tan evolutiva como la Sagrada Familia, en un proyecto tan novedoso como la Cripta de la colonia Güell, y contando además con el referente de no haber terminado el colegio teresiano, iprecisamente por discrepancias respecto de la capilla! La respuesta que da es que Campins estaba convencido de la necesidad de la renovación litúrgica y "deseaba ante todo la purificación litúrgica de la Seo, la cátedra, el cuerpo de la iglesia, ante la presencia de su clero y de sus fieles" 170 y por tanto, pocos arquitectos tan devotos de la Liturgia Católica se podían encontrar en aquellos momentos.

Prueba de ello es la carta pastoral que Campins publica el 10 de agosto de 1904 con motivo de las obras de la catedral en la que justifica las mismas en las necesidades que impone la renovación litúrgica. ${ }^{171}$

\footnotetext{
170 Kerrigan, Anthony. (1960) Gaudi en la catedral de Mallorca. Palma de Mallorca. Impremta Mossen Alcover. P. 4

${ }^{171}$ Cf. Campins, P. J. (1904) Carta pastoral sobre la restauración de la santa iglesia catedral de Mallorca. Boletin Oficial del Obispado de Mallorca. №15. 16-VIII-1904. P. 262: "La severidad litúrgica es el único ornamento propio del templo santo".
} 


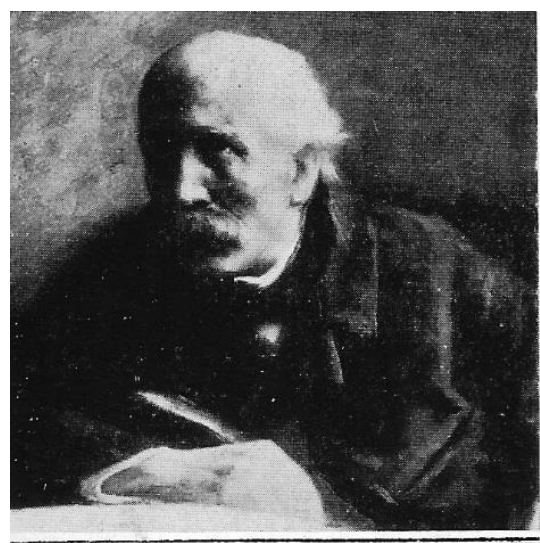

Jose $\mathrm{M}^{\mathrm{a}}$ Bocabella promotor de la Asociacion de devotos de San José y del proyecto de Templo Expiatorio de la Sagrada Familia. Fuente: Martinell, C. (1967) Gaudí: su vida, su teoría, su obra. COACB. P 50.

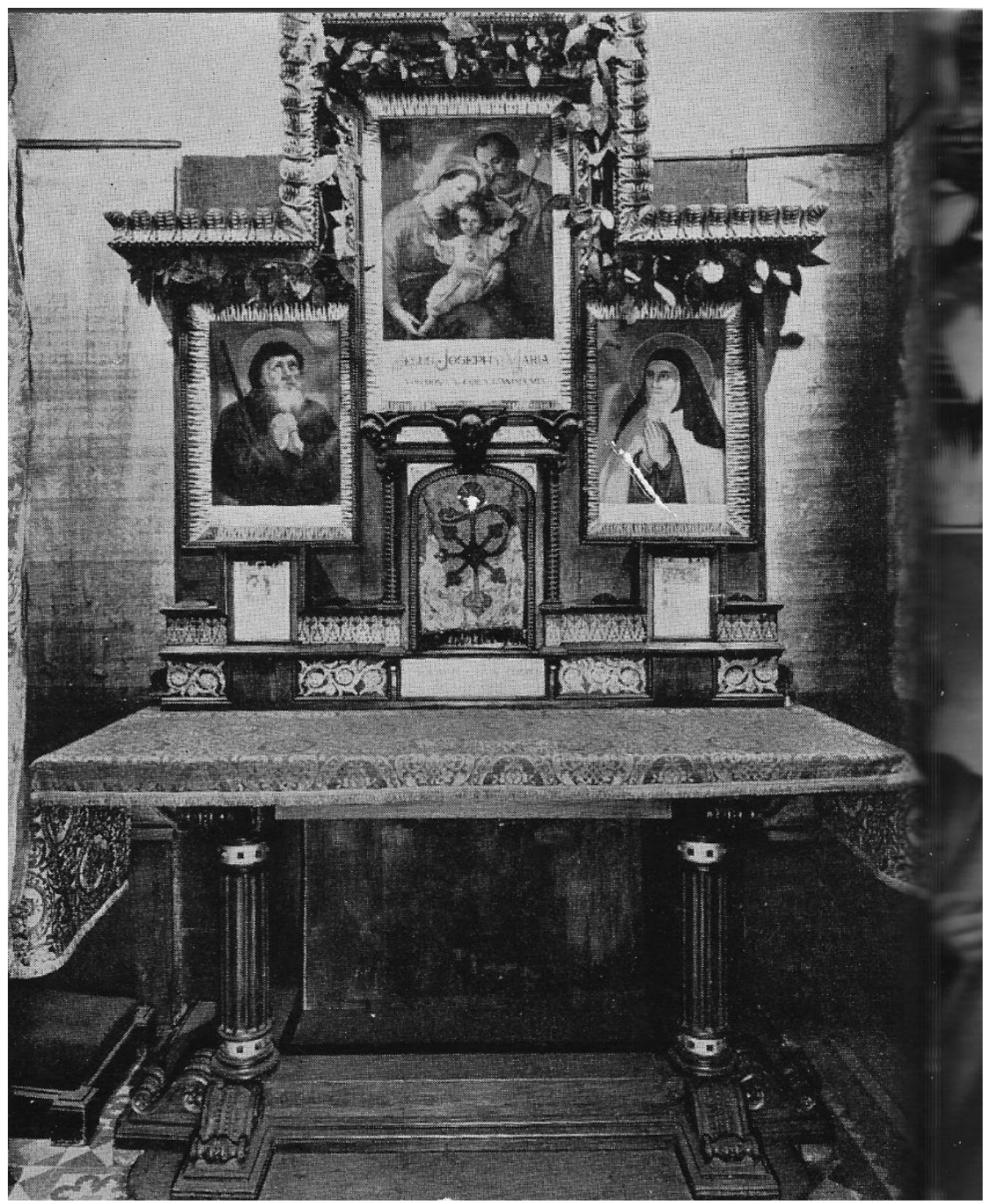

Altar de la Capilla de los Bocabella, realizado en su domicilio por Antonio Gaudí. Bocabella había obtenido autorización de la Santa Sede para poder celebrar Misa en su casa. Fuente: Martinell, C. (1967) Gaudí: su vida, su teoría, su obra. COACB. P 50. 
Campins bucea, pues, en la pureza y renovación litúrgicas propugnadas por Dom Prosper Gueranguer, que en 1841 habia publicado L'Année Liturgique como fuente de la belleza interior, y se adhiere rápidamente al Motu proprio sobre la música sagrada que había promulgado Pio X el año anterior. Lahuerta también se muestra partidario de considerar la carta pastoral del obispo como el auténtico programa de necesidades de la intervención, que ha de ser enjuiciada desde la óptica de la rehabilitación litúrgica, pues la pureza del culto y los ritos inherentes a él es la que marcará las prioridades de la actuación sobre cualquier otra cuestión, considerando la catedral como una edificación eregida por y para un solo objeto, el de ser casa de la Iglesia. Por eso cuándo Lahuerta interpreta la contundencia de las palabras de la epístola de Campins como algo que supedita las intervenciones históricas realizadas en la catedral a su uso o función no hace sino captar la visión trascendente, litúrgica, que éste tiene del edificio.

Debido a ello es fácil comprender la armonía de criterios que se produce en su relación con Gaudí, el cual ve este proyecto como grandioso: se trata de la oportunidad de intervenir en una de las más acertadas catedrales cristianas del estilo histórico más ponderado para ellas, el gótico, con el ánimo de volver al origen de la finalidad para la que fue construida, devolviéndole la sencillez y pureza de la decoración liturgica que el trascurso de la historia había enmascarado.

Lahuerta ha estudiado el alcance de la propuesta de renovación liturgica del obispo Campins situándolo dentro del movimiento de restauración de la Iglesia en Cataluña y Mallorca con el cambio de siglo ${ }^{172}$, cuyas pretensiones pasaban por un mayor acercamiento a los fieles en todos los aspectos concernientes a la Liturgia y la Pastoral incluyendo la utilización de la lengua propia. El profesor Bassegoda también insiste en esta sintonía de ideas y objetivos entre el prelado y el arquitecto: "El doctor Campins consultó a Gaudí sobre las obras a realizar en la catedral y quedó sorprendido de la claridad de ideas del arquitecto." ${ }^{173}$ De la conjunción de ideas entre cliente y arquitecto en un proyecto tan grandioso por sus objetivos surge la adecuada sincronización en lo profesional y en lo humano. El encargo y toda la confianza depositada en él serán para Gaudí y éste responderá con su entusiasta entrega profesional, intentando abarcar todos los aspectos que redundan una concepción completa del espacio litúrgico: revisión estructural, investigación cromatista de las vidrieras, adecuación del espacio de la asamblea liturgica, diseño del mobiliario litúrgico, estudio de la iluminación, cuidado de la simbología pictórica, etc.

172 Cf. Lahuerta, J.J. (2012) La reforma de la catedral de Palma i la restauració política de l'Església a Catalunya i Mallorca, Recerques: Història, economía i cultura. ISSN 0210-380X, №25, 1992. (Ejemplar dedicado a: Cultura i societat a la Restauració).

${ }^{173}$ Cf. Bassegoda Nonell, J. (1989). El gran Gaudí. Sabadell. AUSA, Catedra Gaudí. P. 453 

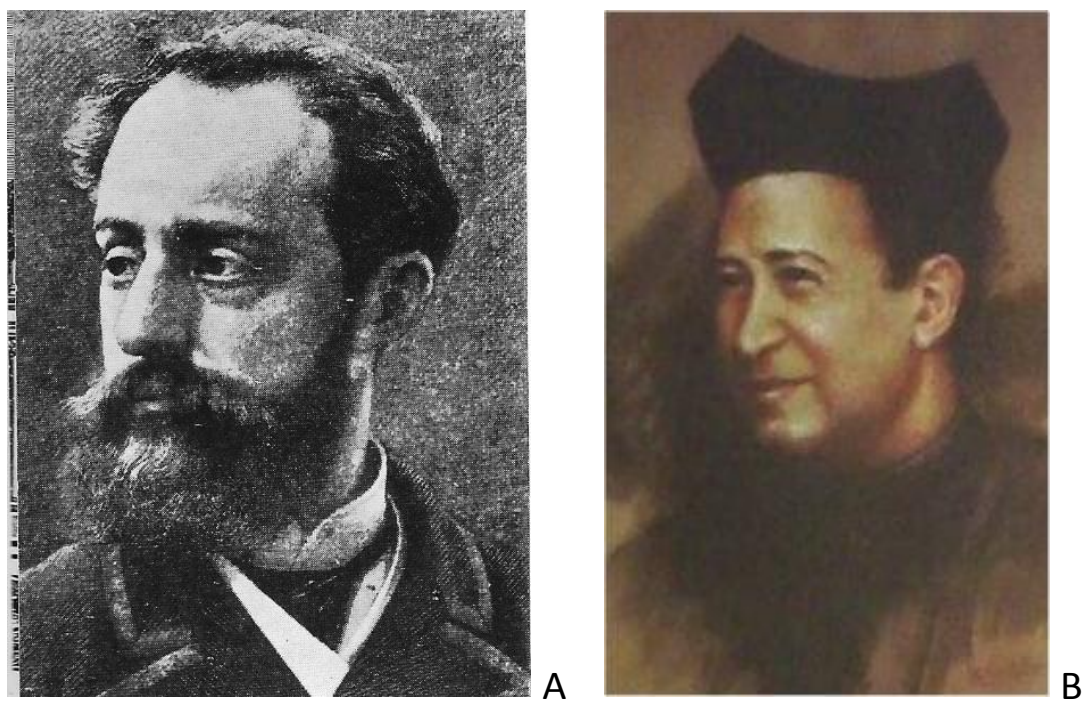

A. Eusebio Güell i Bacigalupi, principal mecenas de Gaudí. Fuente: Martinell, C. (1967) Gaudí: su vida, su teoría, su obra. COACB. P 50.

B San Enrique de Ossó, fundador de las Escuelas Teresianas. Fuente: Fundacion Escuela Teresiana.

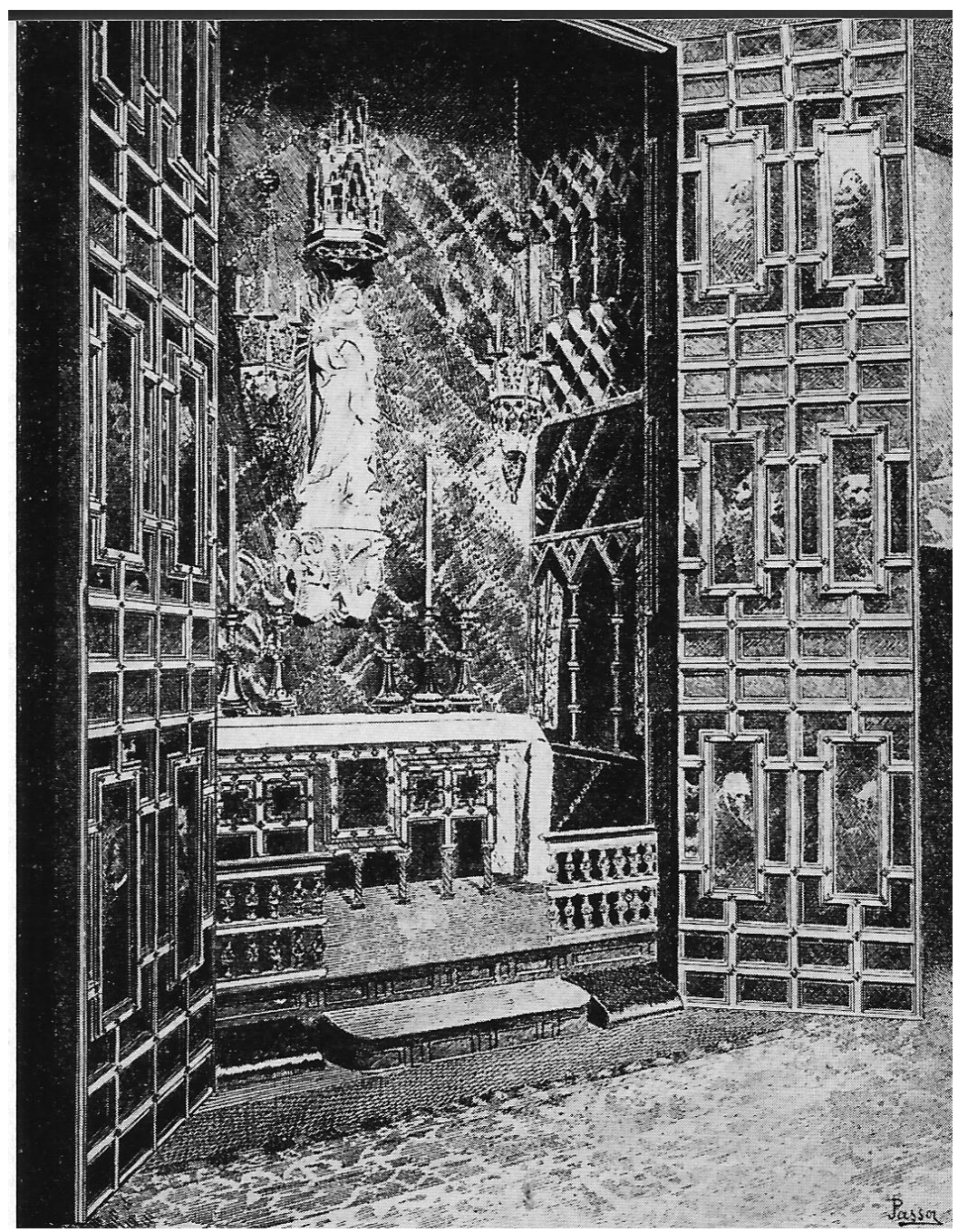

Altar del Oratorio del Palacio Güell que se abria al salón al abrir las puertas. Fuente: Martinell, C. (1967) Gaudí: su vida, su teoría, su obra. COACB. P 50 
En la relación que se da entre Antonio Gaudí y José Ma Bocabella encontramos un referente clásico de la confianza profesional que se da entre el arquitecto y su cliente, aunque en este caso va más allá por el hecho de la naturaleza del encargo y la personalidad de ambos. Josep $\mathrm{M}$ a Bocabella es un librero viudo y muy devoto de San José, que lidera activamente una asociación religiosa hasta el punto de convertirla en promotora e impulsora de la construcción de una iglesia dedicada a la Sagrada Familia. Su influencia sobre Gaudí muy probablemente se debiera a su particular enfoque del proyecto y a su estilo de vida personal que causan honda mella en el ánimo del joven y nuevo director de las obras. Puestos en contacto por Joan Martorell, lo cual no es poco, al haberse autoasignado el librero la tarea de facilitar a Gaudí su familiarización con el misterio de la Sagrada Familia podrá desarrollar una serie de acciones que exceden con mucho la mera relación profesional.

Bocabella encarga a Gaudí un altar en el oratorio que tenia en su domicilio familiar, regala al arquitecto la revista que editaba su Asociación de devotos de San José y sobre todo, le da testimonio de un ánimo admirable frente a las dificultades económicas por las que pasa la ejecución de las obras de la Sagrada Familia. De aquí nacerá una auténtica relación de amistad entre cliente y arquitecto que impregna la vida de éste imperceptiblemente al principio pero que después proseguirá en tiempos de Manuel de Dalmases i Riba, yerno de Bocabella, como un claro signo de reconocimiento a éste. ${ }^{174}$ Llama la atención la sencillez de líneas de este altar para la capilla privada de los Bocabella y lo contenido en la decoración, que también se observa en la capilla oratorio de los Güell. Parece que Gaudí sintetiza en estas obras lo que cree fundamental, esto es la dimensión de recogimiento y oración personal, que en el caso de los Bocabella compatibiliza con la Misa privada, cuya autorización de la Santa Sede había obtenido el activo librero.

Lahuerta (Antonio Gaudí: arquitectura, ideología y política, 1993) menciona que Bocabella había publicado un libro del Padre Josep Manyanet titulado El Espiritu de la Sagrada Familia que ya en 1869 propugnaba la construcción de un templo de esa advocación. Más que la idea del proyecto, en la cual parece que también tienen que ver las coincidencias de librero y arquitecto en Montserrat y la peregrinación de los josefinos a Roma y Loreto, nos interesa apuntar la fundamental contribución del solícito "apostolado" de Bocabella al desarrollo de la imaginación gaudiniana en el proyecto simbólico de la Sagrada Familia, tan radicalmente fundamentado en la tradición teológica cristiana.

${ }^{174}$ Cf. Reig Martinez, J. (2013).Antonio Gaudí y la belleza: la Sagrada Familia un proyecto vivo. Valencia. Edicep. P. 65: "Las profundas huellas que se dejaron mutuamente Bocabella y Gaudi fueron recordadas por el yerno del librero, Manuel de Dalmases i Riba, y de las cuales quedan a modo de piedras vivas la cercanía de su sepultura, el altar que realiza para la vivienda de los Bocabella, etc. Este altar formaba parte del oratorio del domicilio familiar de Bocabella y estaba dedicado a la Sagrada Familia (los Bocabella disponían de la preceptiva licencia otorgada en 1890 por el Papa Leon XIII para la celebración de la eucaristía." 


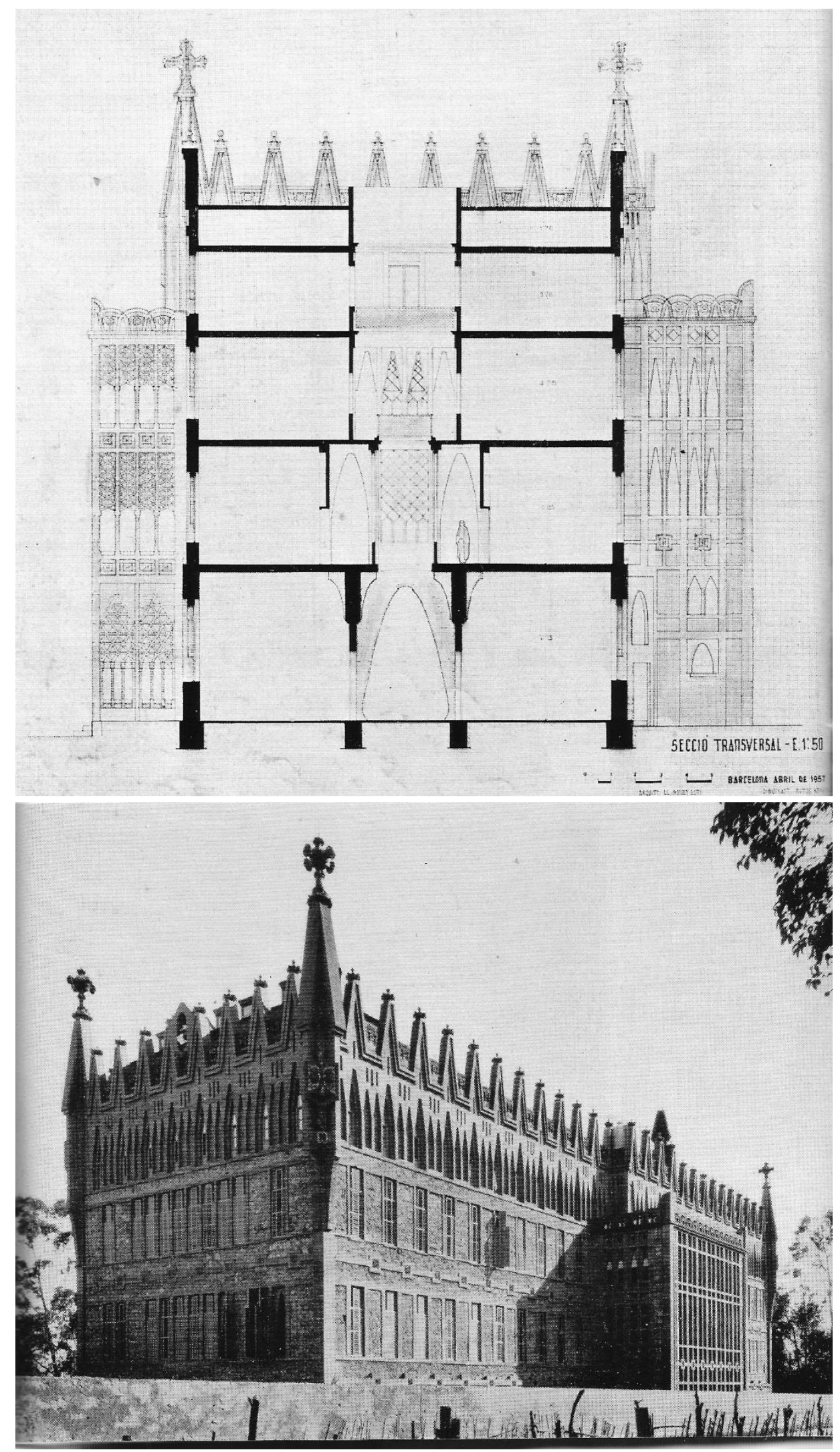

Plano del Proyecto y Fotografia del Colegio convento de Sta. Teresa en la C/ Ganduxer. Fuente: Martinell, C. (1967) Gaudí: su vida, su pensamiento, su obra. Barcelona. COACB 
Por otra parte la dimensión del proyecto concebido por Bocabella y los josefinos se aprecia desde un primer momento en las medidas y ubicación del solar adquirido, en las referencias primigenias al santuario loretano y reconocimiento de la labor de la asociación por la Santa Sede, y en la complaciente acogida a las ideas arquitectónicas de Gaudí, pudiendo concluirse que la amplitud del planteamiento del promotor es la que permite que el enorme esfuerzo técnico y artístico del arquitecto pueda cobrar realidad. Bocabella es el promotor ideal para la arquitectura eclesiástica de Gaudí: un laico entregado sin reservas a la causa de la buena arquitectura que no cede ante las dificultades economicas, con amplias relaciones con el mundo eclesiástico, una fe y convicción inquebrantable en la bondad de la causa y la viabilidad del proyecto encomendado a la Providencia, y a los que aporta la eficiente organización de la Asociación Josefina.

Aunque no directamente relacionada con el proyecto de la Sagrada Familia, la relación profesional entre Eusebio Güell y Antonio Gaudí está transida de mutuas coincidencias en el plano de la arquitectura eclesiástica y de la concepción de ésta desde el ámbito de la doctrina social de la Iglesia Católica. Si nos atenemos a lo que indica Martinell (Gaudí: su vida, su teoría, su obra, 1967) su relación bien pronto adquiere un marchamo de mutua admiración y confianza que desenvocan en una prolongada amistad. La progresiva complacencia del empresario por los diseños y obras del arquitecto, que comenzando por la vitrina de la guantería Comella llegan aun punto de madurez con los resultados en casa propia del proyecto para su palacio de la C/ Conde de Asalto, sin duda que redundó en una generosa confianza del magnate que benefició a posteriores proyectos como el Parque Güell y la Colonia e iglesia Santa Coloma.

También fue clave en el encargo del proyecto de las Misiones Franciscanas de Tanger, aunque éste no se llevara a cabo por razones de viabilidad económica. En todos estos proyectos que giran en la órbita del mecenazgo de los Güell y los López se percibe con nitidez el sello de la doctrina social católica que ambas familias asumen con plena convicción impregnando al arquitecto de un marcado interés por la sensibilidad social en la organización del trabajo.

Esta sensibilización social, promovida en el proyecto original de la Sagrada Familia por Bocabella y en los proyectos anteriores por los patricios mencionados, también se muestra en las obras del Templo Expiatorio dando lugar a la creación de espacios específicos para escuelas para niños y talleres de artesanos, a una organización más humana del trabajo y un trato más familiar y cercano del director de las obras con las familias de los trabajadores. Es bien conocida, además, la ayuda que Gaudí prestó a otros artistas en situación de penuria económica, etc. Desde el punto de vista de la relación entre ambos personajes, y de su mutua influencia humana y profesional, no hay olvidar cómo Gaudí percibe en este cordial y confiado mecenazgo una sensibilidad hacia su arquitectura y una estimulante confianza sumamente importantes para su trayectoria. 
Es lo que llamaríamos en términos de la Etica del Bien de Tomás de Aquino una amistad que funciona en ambas direcciones. ${ }^{175}$ En esta via de la admiración profesional y humana hay que mencionar también el trato con Enrique de Ossó con ocasión de la construcción de la casa madre de la Compañía de Santa Teresa de Jesús en la c/ Ganduxer de Barc elona. La relación del padre Ossó con Gaudí se puede calificar de principio a fin como altamente profesional dentro del respeto mutuo. Bassegoda (Gaudí: todas sus obras, 2007) refiere anécdotas muy ilustrativas con relación a la ejecución de las obras del Colegio de la C/ Ganduxer ${ }^{176}$, explicitando cómo su reducido presupuesto económico no hizo disminuir el interés del arquitecto por el proyecto que constituye un ejemplo de imaginación y creatividad. Es significativa la incorporación de un notable programa simbolico inspirado en la espiritualidad de Sta. Teresa de Avila y de su orden.

Gaaudí recibe el encargo en 1888, apenas cuatro años después del de la Sagrada Familia, y trabaja en él hasta 1890, poco antes de la terminación de la Cripta y discurso a los josefinos. Durante estos escasos años la obra de la C/ Ganduxer es, además de un alarde de detalles en materia arquitectura docente, un campo de pruebas en materia de simbología religiosa para su incorporación a la Cripta y Abside de la Sagrada Familia. Llama la atención que la preocupación de Ossó por el coste de las obras, dada la penuria en que se desarrollaban, y sus conversaciones en este sentido con Gaudí no quiebran la relación de mutuo respeto y estima que presidia sus diferencias de criterio. Ciertamente que en este proyecto es conocido y no ha de pasar inadvertido el firme criterio liturgico de Gaudí, ya mencionado con anterioridad, que da origen a su renuncia a la ejecución de un espacio litúrgico privativo de la Orden y que considera, por tanto, restringido en el panorama de su vocación católica.

\section{- Colaboradores y asistentes.}

El amplio número de asistentes y colaboradores que trabajan en el Taller de la Sagrada Familia da una imagen adecuada del detalle y organización del trabajo con que Gaudí aborda el proyecto. El método que Gaudí emplea para la realizacion de un proyecto anteriormente mencionado al hablar de la idea de arquitectura religiosa a través de sus

175 Cf. Cf. Reig Martinez, J. (2013).Antonio Gaudí y la belleza: la Sagrada Familia un proyecto vivo. Valencia. Edicep. P. 53

${ }^{176}$ Cf. Bassegoda Nonell, J. (2007). Gaudí: todas sus obras. Menorca. Triangle Puntals. P.5: "Se cuenta que el padre Enric d'Ossó, hoy san Enrique de Ossó, le pidió a Gaudí en 1888 que le explicara cómo seria el edificio del Colegio Teresiano, que entonces se estaba edificando. Gaudí contestó con una frase verdaderamente lapidaria: 'En esta casa se estará bien'. Expresión que encierra el saber más profundo de la arquitectura. Las casas se construyen para sentirse bien en ellas, no para que al arquitecto le otorguen premios internacionales o para que el edificio sea catalogado como monumental o histórico artístico. Tales aditamentos son también posibles en un edificio donde se está bien, pero no son ni necesarios, ni suficientes." 
escritos, el Manuscrito de Reus principalmente- supone un ejercicio de constante experimentación basado en el estudio de detalles constructivos de esus proyectos, muchas veces realizados al natural y a escala $1: 1$, construccion de mdelos y maquetas, comentario y elección de soluciones, presentación al cliente y seguimiento de la ejecución. La amplitud de materias y cuestiones que aborda -sistema estructural y de estabilidad, soluciones y procedimientos constructivos, estudio de la iluminación natural, iconografía e imágenes, simbología de los elementos constructivos, mobiliario, etc.requirieron desde muy pronto, además de su incansable dedicación personal, la colaboración de un grupo de arquitectos jóvenes que, impresionados por los hallazgos y discurso arquitectónicos de aquel a quien consideraban su maestro, no dudaron en seguirle en el plano de la asistencia y colaboración, bien fuese a tiempo completo o entrando y saliendo del taller instalado en la Sagrdada Familia. En este grupo de colaboradores lo que predomina es la admiración profesional hacia el director de las obras que conllevaría posteriormente una encomiable labor de divulgación y reconocimiento públicos. De ahí que en la mayor parte de los casos es difícil encontrar en ellos aportaciones a la formación del concepto gaudiniano de arquitectura sacra fuera de lo que seria la estrecha colaboración en la puesta en marcha de los criterios y decisiones del maestro. Este seria el caso de Berenguer, auténtica mano derecha de Gaudí en la realizacion de dibujos y proyectos concretos, seguimiento de la construccion, etc. cuya estrecha colaboración sólo truncaría su prematura muerte.

Sin embargo, entre los arquitectos colaboradores de Gaudí en la Sagrada Familia Berenguer, Rubió, Jujol, Sugrañes, Puig Boada, Martinell, Bergós, etc.- parece que hay consenso suficiente para destacar la actuación de Rubió como altamente apreciada por Gaudí en el plano de la imagineria y simbolismo religioso. Es significativo su apoyo a la actuación en los trabajos del Coro de la catedral de Mallorca (fuertemente contestada por el cabildo) pero también su aprecio por Casa Milá. Existe el testimonio de Martinell referente a la colaboración que le prestaba Rubió ya en 1893, en la etapa de construcción de la parte alta del ábside de la Sagrada Familia, a quien dice confiaba cuestiones técnicas relacionadas con la estructura general. Posteriormente, a finales de la década de 1910, se incoporan a los trabajos Berenguer, Jujol, Sugrañes y finalmente Quintana en $1919^{177}$, pero como señala Pabón de Rocafort (1990) ${ }^{178}$, hay una cierta confusión en los términos colaborador, asistente, auxiliar, etc., y por otro lado muchos de ellos entraban y salian del taller gaudiniano en función de sus respectivos trabajos e intereses personales,

\footnotetext{
177 Martinell, C. (1952). La Sagrada Familia. Barcelona. Aymá. P.: 13.

178 Cf. Pabón de Rocafort, Arlén. (1990) "Els col.laboradors arquitectònics d’Antoni Gaudí, en AA. VV. Gaudí i el seu temps. Barcelona. Barcanova. Menciona, basándose en pruebas documentales, la colaboración de Berenguer, Rubió, Jujosl y Sugrañes en algunas fases del proyecto, además de la amistad y ayuda circunstancial de Puig Boada, Martinell y Bergós, aunque resulta difícil precisar la intervención concreta de cada uno de estos últimos.
} 
permaneciendo sólo unos pocos como totalmente entregados a este proyecto en una dedicación completa.

Conforme avanza el proyecto, este se va haciendo más complejo y más insertado en el movimiento de renovación litúrgica parece cada vez más difícil concretar la participación de sus colaboradores aunque Pabón se muestra partidario de considerar muy significativo el hecho de que Gaudí, en vida, quiso que fuera Sugrañes el continuador de la dirección de obra, indicando con ello no solamente la confianza en el conocimiento del proyecto que tenia Sugrañes por su completa y prolongada dedicación a las obras sino premiando a su vez ésta con el honor de su designación como arquitecto director de las obras.

\section{- La relación con el Obispo diocesano.}

José Ma Urquinaona y Bidot (1814-1883) fue nombrado obispo de Barcelona en 1877, erigiendo el nuevo seminario dos años después. Consiguió de Leon XIII el patronazgo de la Virgen de Montserrat para Cataluña y su coronación. Asistió al Concilio Vaticano I y fue elegido senador en las Cortes Españolas.

Jaume Catalá i Albosa (1835-1899). Fue obispo de Barcelona desde 1883 a 1899. Gozó de gran popularidad por la defensa de los derechos de los obreros. Su experiencia en la Nunciatura Apostólica, el Tribunal de la Rota y la Administración Apostólica de Ceuta le sirvió para ser el primer obispo recibido por el Sultán de Marruecos.

Josep Morgades i Gili (1826-1901). Nombrado obispo de Vic en 1882, fue seguidor de la línea social que preconizaba la encíclica Rerum Novarum de Leon XIII, promulgando una extensa pastoral diocesana sobre el tema y favoreciendo la implantación en Manresa del noviciado de la Congregacion de Madres de Desamparados que proovia la beata Madre Petra, dedicada a la acogida y protección de madres solteras y familias en dificultad. En 1889 fundó el Museo episcopal de Vic, pionero en su época en el ámbito de la arqueología y arte cristiano. Nombrado obispo de Barcelona en 1899 fue decidido partidario de la utilización catequética del catalán como lengua pastoral de la Iglesia en Cataluña, promoviendo la constitución y edificación del Seminar Conciliar

Salavador Casañas i Pagés (1834-1908). Nombrado obispo de Barcelona en 1901 a petición del Ayuntamiento de la ciudad, autorizó al año siguiente la creación de la Asociación de Madres de Desamparados de San José de la Montaña, promovida por la beata Madre Petra y participó en 1903 en el conclavé que eligió Papa a Pio X, siendo objeto de un atentado anarquista del que salió ileso en 1905. Al año siguiente impulsó la participación del catalanismo católico en la coalición Solidaridad Catalana que resultó vencedora de las elecciones de ese año. 
Juan José Laguarda i Fenollera (1866-1913). Fue nombrado obispo de Barcelona en 1909 tomando posesión poco tiempo después de la Semana Trágica de Barcelona en la se incendiaron gran parte de los edificios religiosos de la ciudad dentro de un clima social completamente convulso y agitado. El nuevo obispo, hondamente preocupado por la cuestión social hace suyo el planteamiento educativo y social de las Escuelas provisionales de la Sagrada Familia, en medio de un barrio obrero de la ciudad, inaugurándolas solemnemente en noviembre de ese mismo año. ${ }^{179}$ Respecto de las supuestas dificultades posteriores entre el arquitecto y el prelado - con referencia a la idea de transformar el Templo expiatorio en Parroquia al objeto de satisfacer las necesidades del populoso barrio en que se encontraba- el mismo Tarragona señala la práctica ausencia de datos que lo confirmen. En cualquier caso la pososibilidad de que Gaudí abandonase las obras si el proyecto llegara a reducirse, transformando o no la fachada del Nacimiento en la principal como sugiere Tarragona que se podía haber planteado y reduciendo a la nada el ambicioso programa expuesto por el arquitecto, debe contemplarse como totalmente verosímil a tenor de otros casos anteriores. Además, en 1912 Gaudí ya había dibujado la fachada de la Pasión y trabajaba activamente tanto en los grupos escultóricos como en el sistema estructural de las naves.

Enrique Reig i Casanova (1858-1927). Fue obispo de Barcelona desde 1914 a 1920, impulsando la coronación pontificia de la imagen de San José de la Montaña. Durante su mandato tiene lugar el Congreso litúrgico de Montserrat de tanta significación para el dialogo entre Arte y Liturgia en el ambiente cultural especializado de la época. Para Gaudí este periodo es el del máximo reconocimiento de su labor al frente del proyecto pues no en balde diversos eclesiásticos influeyentes en el medio artisitico y cultural de la ciudad como son Trens y Tarré ponen la Sagrada Familia como ejemplo de la arquitectura que sintoniza con la renovación liturgica que el Congreso de Montserrat pretende llevar a la vida pastoral de las diócesis. El mismo Gaudí asiste al congreso, se apunta a y recibe un nuevo espaldarazo oficial del mundo eclesiástico cuando atiende la visita del nuncio Ragonesi y el obispo Reig

Ramón Guillamet i Coma (1856-1926). Obispo de Barcelona desde 1920 a abril de 1926, aunque desde 1925 y debido a su grave enfermedad se hizo cargo de la gestión del obispado el obispo coadjutor Josep Miralles i Sbert.

179 Cf. Tarragona i Clarassó, J.M. (2002) “Gaudí va voler deixar les obres de la Sagrada Familia. Un episodi poc conegut de la seva biografia, relacionat amb el bisbe Laguarda.", en Actas de IX Jornadas Internacionales de Estudios Gaudinistas. Palma de Mallorca. Centro de Estudios Gaudinistas. Tarragona, apoyándose en una nota del diario La Veu de Catalunya, refiere un supuesto episodio en el que Gaudí está a punto de dejar la dirección de las obras ante la posibilidad de que el Templo tuviese que terminarse con rapidez para su dedicación como Parroquia. 
Josep Miralles i Sbert (1860-1947). Fue obispo titular desde 1926 a 1930, siendo desplazado de la diócesis de Barcelona en tiempos de la Dictadura de Primo de Rivera por su defensa del uso de la lengua catalana en la actividad eclesial. 


\subsection{La liturgia vivida por el arquitecto.}

Para Antonio Gaudí la liturgia era una antigua conocida, pues ya menciona Ràfols su asistencia al Oficio Parvo de la Virgen durante su periodo de escolarización en los Escolapios de Reus ${ }^{180}$, y ratifica Bergós al señalar que en sus años de estudiante de Arquitectura debatía con sus compañeros cuestiones de arquitectura y liturgia ${ }^{181}$. Martinell se hace eco del grado de conocimiento que muestra del libro del Apocalipsis al insertar una completa escenografía de imágenes y escenas del mismo en los paramentos del proyecto de entrada a un cementerio, trabajo que se la había puesto en la Escuela de Arquitectura al finalizar el primer año (1874). ${ }^{182}$

En los años siguientes Gaudí alterna sus estudios con la colaboración que presta a Villar en su proyecto para el dibujo del camarín de la Virgen del Monasterio de Montserrat (1875-77) y en 1878, nada más recibir el título de arquitecto, ya está trabajando en sendos proyectos ligados al culto cristiano que recibe de la mano de Cristobal Grau: el altar de la capilla del colegio Jesus-Maria de Tarragona y el altar, tabernáculo, custodia, iluminación y pavimento de la capilla del colegio de la misma orden en San Andrés del Palomar (1879). ${ }^{183}$ También de estos años es el diseño de mobiliario para la capilla panteón de los Marqueses de Comillas a instancias de Joan Martorell, que por aquellos años ejercía una labor de padrinazgo profesional como se aprecia también al considerar la colaboración de Gaudí en el proyecto de la iglesia de las Salesas, el dibujo de la fachada de la catedral y el proyecto de la iglesia de Villaricos. Todos estos trabajos giran alrededor del año 1882 y muestran la incipiente trayectoria de un arquitecto habituado a trabajar en proyectos y elementos arquitectónicos que tienen que ver con el culto.

180 Cf. Ràfols, J. F. (2006). Gaudí 1852-1926. Ed. facsímil, aumentada con una introducción, de la edición de 1952 que reproducía las ediciones anteriores de 1928 y 1929. Barcelona. Real catedra Gaudí y Ed. Claret. P. 14.

${ }^{181}$ Cf. Bergós, J. (2000) Gaudí, el hombre y su obra. (2a Ed.) Barcelona. UPC, cátedra Gaudí y Ed. Aymá. P. 46: “...se interesó por cuestiones funcionales y por las artes del templo, mucho antes com arquitecto que como fiel cristiano. Como hemos dicho, ya de estudiante, discutía con sus compañeros sobre la necesidad de trasladar el coro de la catedral de Barcelona y dejar la nave libre para los fieles."

182 Cf. Martinell, C. (1967) Gaudí: su vida, su teoría, su obra. Barcelona. COACB.

${ }^{183}$ Bassegoda apunta la hipótesis de que Gaudí interviniese como autor o colaborador del proyecto de la capilla misma de Tarragona basándose en la utilización de columnas de fundición para este proyecto, en unos años en los que el arquitecto proyectaba también este mismo tipo de columnas para la Fuente Monumental del Parque de la Ciudadela colaborabando con Fontseré, para las farolas de la Plaza Real y para la Cooperativa Mataronense. Cf. Bassegoda Nonell, J. (1969) Los proyectos de Gaudí para las religiosas de Jesús-Maria (1877-1882).Barceloma. Ediciones Literarias y Cientificas. 
Se trata de colaboraciones e intervenciones que, no obstante su reducida dimensión, se enfrentan con aspectos concretos del espacio y mobiliario litúrgicos. Son cuestiones que tiene la ocasión de debatir y profundizar durante sus viajes a Astorga para la ejecución del proyecto del nuevo palacio episcopal del obispo Grau, durante los años 1887-1893, en que muere el obispo. Es un tiempo decisivo a la hora de vincular la atención arquitectónica de Gaudí a las necesidades litúrgicas, en el que hay que situar la lectura, estudio y reflexión cotidianos de L'Année Liturgique primero, y del Ceremonial de Obispos, Misal Romano y otros libros a los que le habitua Grau después, que le permiten configurar una trabajada biblioteca personal en la que no olvida la Biblia y el Breviario -la Liturgia de las Horas. Como ha señalado Ràfols Gaudí estaba muy ocupado con el Palacio Güell y la Sagrada Familia y no quería salir de Barcelona hasta que no tuviese terminada la obra de la Casa de Güell (de hecho no se desplazó a atender personalmente a las obras del Capricho en Comillas, siendo que éste era para la familia de los Lopez emparentada con Güell), y sin embargo si encuentra la ocasión para ir hasta seis veces a Astorga a hablar con Grau y trabajar en el palacio episcopal. ${ }^{184}$

Ràfols menciona a Dalmases cuando éste afirma que en Astorga encontró más amplios horizontes para su alma. El caso es que Gaudí debió de tomarse muy en serio sus estudios y conversaciones con Grau cuando, como afirma Martinell, llega a realizar propuestas al Vaticano sobre la conveniencia de eliminar el conopeo del tabernáculo para una mejor visualización del mismo. De ahí que se sientiera fuertemente impresionado por la enfermedad y muerte del obispo.

Afirma Bergós que fue Grau quien introdujo a Gaudí en el rezo cotidiano de la liturgia de las Horas y la asistencia a la Misa diaria ${ }^{185}$ lo cual supone la entrada del arquitecto en la lliturgia vivida, y en este aspecto Conrad Kent resalta que la preocupación litúrgica de Grau, y en un comienzo también la de Gaudí, fue la búsqueda de lo ortodoxo y lo romano en la celebración de la misa, orientación que enlazaba con el carácter de recuperación arqueológica y fidedigna del culto cristiano que preconizaba Gueranguer, y que atestigua la voluntad del obispo de establecer un Museo Arqueológico Cristiano en el Seminario

\footnotetext{
184 Cf. Ràfols, J. F. (2006) Gaudi 1852-1926. Ed. facsímil aumentada de la edición 1925, Ed. Aedos, que reproducía las originales de 1928 y 1929 de Ed. Canosa. Barcelona. Catedra Gaudí y Ed. Claret. P.56: "L'arquitecte, en fer-li l'encàrrec, resta molt agraït al señor Bisbe i compatrici qui es es va recordar d'ell, li manifesta per carta la seva gratitud, li proposa un qüestionari per conèixer postalment dades indispensables pel desentrotllament del projecte, puix Ilavors-enfeinadissim com estaba al Palau Güell i al Temple Expiatorino li és posible perdre el temps en viatges poc utils y assenyala fins haver deixat finides les obres de l'estatge del seu noble admirador..."

${ }^{185}$ Cf. Bergós, J. (2000) Gaudí, el hombre y su obra. (2ª Ed.) Barcelona. UPC, cátedra Gaudí y Ed. Aymá. P. 45: "...el obispo le contagió el entusiasmo por la liturgia; juntos hacían estudios del Ceremonial de los Obispos y del Misal Romano, y lo habituó a la lectura cotidiana de L'Année Liturgique de Dom Gueranguer, el cual ya no dejó nunca de meditar."
} 
Conciliar de Astorga hacia 1889. ${ }^{186}$ No parece coincidencia, pues, que en esos años de relación tan intensa con la Liturgia crtistiana de la mano de Grau, en 1891 (dos años antes de que Gaudí interrumpiera sus trabajos en Astorga por la muerte del obispo y desavenencias con los canónigos y la Junta diocesana), exponga ante la Asociación de los josefinos un completo programa de la Sagrada Familia con fuerte sabor litúrgico y connotaciones simbólicas de todo orden que debió impresionar a un auditorio ciertamente pio pero menos versado en dichas cuestiones. Además de su contenido, este discurso es altamente significativo por lo temprano que se produce dentro del largo periodo de años que ocupan su trabajo en el proyecto.

La sensibilidad de Gaudí para con las exigencias arquitectónicas del culto cristiano, en constante crecimiento desde sus primeras colaboraciones con Martorell y Villar y que ha bebido en fuentes romanistas y renovadoras durante su estancia con Grau en Astorga, incorpora también la serena armonía de la simbologia mística teresiana en los elementos arquitectónicos de forja, ladrillo y cerámica del colegio y convento de la C/ Gaanduxer en Barcelona (1888-1890). Gaudí se inspira en los símbolos y anagramas teresianos para estudiar los más pequeños detalles del proyecto, un proyecto tremendamente imaginativo y brillante pese a la austeridad de medios que le impone Enrique de Ossó y que denota ya su fuerte concepción litúrgica de la arquitectura religiosa, puesta de manifiesto en el episodio de la capilla.

La renuncia a la obra por el carácter privado o accesible a todos los fieles de la capilla (al concebir ésta como un autentico espacio celebrativo del colegio abierto a cualquier fiel que quiera participar en el culto esucaristico en contraposición con la concepción restringida de su acceso, en la última planta del edificio) aporta un dato significativo respecto de las cuestiones que preocupaban al arquitecto, fuertemente imbuido de la concepción universal de la liturgia cristiana y su espacio arquitectónico, que consideraba como básicas.

1891 es el año de cubrición de la cripta de la Sagrada Familia y del discurso a los josefinos, adelantándose en un año a la publicación de La Tradición Catalana de Torras i Bages y en dos, 1893, a la inauguración del Círculo Artistico de Sant Lluc con la presencia de Martorell, lo cual ratifica nuevamente la importancia de los viajes realizados a Astorga. La posterior asistencia de Gaudí a las conferencias del eclesiástico en el Cercle Artistic de Sant Lluc lo mismo que en la Lliga Espiritual de la Mare de Deu de Montserrat atestiguan un medio artístico favorable a su quehacer profesional que comparte con otros profesionales bajo el paraguas de una parte de la jerarquía eclesiástica muy interesada en

\footnotetext{
${ }^{186}$ Cf. Kent, Conrad. (1989). "El obispo Grau y la arqueología sagrada”, en Simposio sobre Antonio Gaudí y su
} obra, con ocasión del centenario de la primera piedra del palacio episcopal de Astorga. 
la conjunción del arte y la liturgia con vistas a la formación de un grupo de artistas cristianos que influyesen en la producción artística del momento.

Son años de inmersión en las necesidades que le plantea el mundo eclesiástico y en los que Gaudí sigue desarrollando una gran capacidad de síntesis entre las necesidades de la educación y del culto en proyectos como el que le trasmite el P. Lerchundi para las Misiones Franciscanas de Tanger (1892), ampliamente estudiado por T. Torii (EI mundo enigmático de Gaudí, 1983), aunque no algunos no lleguen a realizarse. Gaudí trabaja en la portada del Nacimiento, en el claustro y en multitud de temas relacionados con la Sagrada Familia pero no pierde ocasión de realizar obras de detalle como el diseño de un altar para la residencia particular de Bocabella y experimentar con elementos simbólicos y religiosos, ya sea en el interior de un edificio residencial (Palacio Güell), en las torres de otros edificios (Parque Güell, Bellesguard,...), intentando su extensión a modo de dedicación de un edificio o fachada (Casa Milà), etc. De aquí el dialogo entre Gaudí y Campins para intervenir litúrgicamente en la catedral de Palma le pilla muy rodado, pudiéndose catalogar de especializado entre dos grandes conocedores de la Liturgia.

Como ha señalado Franquesa ${ }^{187}$, lo que plantea la carta pastoral del obispo de 10 de agosto de 1904 es de gran calado, partiendo del espíritu arqueologista de Solesmes pero adelantándose al desarrollo pastoral del Motu Proprio de Pio X -Tra le sollicitudini- (22-111903), al llevar en ella misma la instrucción liturgica a sus fieles diocesanos y promover una obra arquitectónica de tal ambición cultual.

Su idea de la severidad litúrgica como el único ornamento del templo santo prende en el ánimo del arquitecto que menciona en una carta, conservada en el Archivo Episcopal de Mallorca, su admiración y agradecimiento a Campins diciendo que su maestro de liturgia era el obispo mallorquin. ${ }^{188}$ También Campins habla de Gaudí en esa misma carta pastoral como de un "hombre de capacidad superior, profundo conocedor del arte de construir y de toda su historia que ejerce con maestría desde hace tiempo" pues éste se hallaba en plena madurez de su quehacer profesional y su fama aumentaba gracias, entre otras obras, al desarrollo de la Sagrada Familia de la cual se había terminado la cripta; cuestión que también es reconocida por el canónigo Mateu Rotger al hablar de la restauración de la catedral en su libro del mismo nombre de 1907.

187 Cf. Franquesa, Adalbert. (1966). "El Congrés de 1915 i la seva significació histórica”, conferencia pronunciada en el I/ Congrés Liturgic de Montserrat. Barcelona. Publicaciones de la Abadia de Montserrat. P. 16

${ }^{188}$ Cf. LLabrés i Martorell, P.J. (2002). “La Liturgia a la restauració de la Catedral de Palma, el bisbe Campins i Gaudi", en IX Jornadas Internacionales de Estudios Gaudinistas. Barcelona. Centre d'Estudis Gaudinistes. P. 15: "Ara bé, com escriu també el dit biògraf, el bisbe Campins es decidí a dur endavant la restauració de la Seu per cumplir l'esperit i les normes de la sagrada liturgia i seguir la tradició dels temples cristians." 
Como dice Llabrés, Campins emprende una obra de restauración litúrgica cuando nadie en España pensaba en ello, y lo hace con completo conocimiento de lo que está ocurriendo en Centroeuropa y en Roma en el seno de la Iglesia Católica, y cita para ello las actas del capitulo catedralicio en las que se describen las obras a emprender como "indispensables para la total observancia del Ceremonial Romano".

Se entiende así que Bergós presente la experiencia de la liturgia de Gaudí y su aplicación a la arquitectura como algo vivido en primera persona por el arquitecto, tras su entrada en ese mundo hasta entonces casi privativo de unos pocos monjes y eclesiásticos ${ }^{189}$; Bergós refiere cómo Gaudí era capaz de apreciar una buena pronunciación en latín en el curso de un pontifical celebrado por el nuncio de Su Santidad y asevera que en la intervención en la Seo mallorquina no tiene necesidad de consultar tratados sino que su bagaje previo es de tal calibre que le basta seguir su propio método experimental: observación y análisis de deficiencias respecto del programa. ${ }^{190}$

El trabajo de Mallorca y su coetáneo del proyecto de iglesia de Santa Coloma, es el penúltimo paso en la liturgia vivida por el arquitecto, que compatibiliza el desarrollo de su arquitectura eclesiástica con la asistencia cotidiana al culto y otras manifestaciones religiosas. No olvidemos que en 1909 tiene lugar la decisiva participación de Dom Lambert Beauduin en el congreso litúrgico de Malinas (Bélgica) para recuperar el culto de la Iglesia como base de la vida cristiana y promover la participación de los fieles en la Misa. ${ }^{191}$ En este ambiente de renovación que se dá en Centroeuropa se organiza el 1er Congreso de Arte Cristiano de Cataluña en 1913, inaugurado por Torras i Bages, al que acude Gaudí con una participación valorada como de las más notables. En él participan amigos y conocidos suyos como el P. Casanovas, el doctor Josep Tarré, el músico y

189 Cf. Bergós, J. (2000). Gaudí, el hombre y su obra. 2ª Edicion. Barcelona. Aymá. P.47: “El había aprendido la liturgia viva siguiendo el ciclo anual de la Iglesia con los quince densos volúmenes de Dom Gueranguer, del cual había sustituido la edición de bolsillo, de letra muy pequella, por la de biblioteca en rustica, a fin de que fuera legible con la poca luz de la catedral y se pudiera abrir y hasta doblarse completamente; estos volúmenes acabaron con las tapas negruzcas y con los lomos reforzados con papeles d goma y tiras de tela de dibujar."

190 Cf. Bergós, J. (2000). Gaudí, el hombre y su obra. 2a Edicion. Barcelona. Aymá. P.47: “...no buscó en los tratados de liturgia que entonces ya se empezaban a publicar con normas para su trabajo; sino que siguiendo su método experimental pasó un año observando y anotando todas las deficiencias que la equivocada disposición del mobiliario litúrgico originaba en el ceremonial de las funciones episcopales, restándoles sentido y esplendor."

191 Cita Fernandez Cobián, E. (2005) El espacio sagrado en la Arquitectrura Española Contemporanea. La Coruña. COAG, los esfuerzos de Beauduin, en ese congreso,en la publicación de la revista Questions liturgiques (1910) y la celebración de las semanas litúrgicas de Lovaina. Que en 1911 edita un misal dominical y en 1914 el libro La pieté de l'Eglise, que en el campo arquitectónico se hizo eco de sus enseñanzas el arquitecto alemán Martin Weber (1840-1941). 
gregorianista P. Suñol, etc. Galtés considera que su participación en la junta organizadora confirma su erudita forma de tratar artisticamente todo lo religioso y cuando el P. Ignasi Casanovas, muy interesado en el arte religioso, y a quien Gaudí admiraba, le cita en su conferencia L'art al temple en este mismo congreso como un arquitecto evidentemente interesado por la Liturgia católica no haria otra cosa sino referirse a algo que es público y notorio ${ }^{192}$. Lahuerta (1993) situa las ideas del P. Casanovas ${ }^{193}$ insertadas plenamente en los ambientes artísticos barceloneses católicos sustentadores del Cercle de Sant Lluc y la Lliga de $N$ a $S \underline{a}$ de Montserrat, y destaca también la participación de Josep Tarré (autor, entre otros, de un libro sobre el cardenal Mercier que había presidido el congreso de 1909 en Malinas) con una conferencia altamente significativa sobre Arte y Liturgia ${ }^{194}$.

192 Cf. Cf. Pla i Arxé, R. (2004). "Relacions amb Torras I Bages, Casanovas I alters intellectuals", en AA. VV. Gaudí I la dimensió transcendent. Barcelona. Ed. Cruïlla; Castellanos, Jordi (1990) "Torras i Bages i Gaudí", en Lahuerta, J.J. Gaudi i el seu temps. Barcelona. Barcanova; Galtés i Pujol, Joan. (2004) “Els vincles de Gaudí amb el món eclesiástic" en AA. VV. Gaudí I la dimensió transcendent. Barcelona. Ed. Cruïlla

193 Lahuerta, J.J. (1993) Antonio Gaudí: arquitectura, ideología y política. Madrid. Alianza Editorial. P. 217: "El artista sentirá siempre la tentación de deternerse en los fáciles elementos estéticos que tiene la religión, sin alcanzar mas ftigosamente loas fuentes enesenciales de la vida religiosa, tales como el contenido dogmatico y doctirnal de la literatura sagrada, la eficacia sobrenatural de la gracia, vivida en la práctica cotidiana, la formación individual en las olidas y perfectas virtudes. La religión cristiana es una vida y como tal, o se vive íntegramente, o es una pura fantasmagoría."

194 Lahuerta, J.J. (1993) Antonio Gaudí: arquitectura, ideología y política. Madrid. Alianza Editorial. P. 217: "La primera ley constitutiva de la Liturgia, es la sacralización de todo lo que se utiliza, sustryendolo del uso profano, consagrándolo a Dios, transformándolo y espiritualizándolo a través de su eficacia sobrenatural." 


\subsection{Gaudí y el Congreso Liturgico de Montserrat.}

El Congreso Litúrgico de Montserrat de 1915, preparado desde un año antes por un grupo de ilustres eclesiásticos liderados por Lluis Carreras que presentó y ofreció la idea al abad Marcet, supone un nuevo paso en la actividad de Gaudí en el campo de la arquitectura eclesiástica, tanto por su asistencia a un foro plenamente eclesiástico y a las posteriores lecciones de canto gregoriano como por las consecuencias prácticas que tiene para el proyecto de la Sagrada Familia. Adalbert Franquesa (El Congrés de 1915 i la seva significació histórica, 1966) menciona a Gaudí y a Llimona (a la sazón presidente del Cercle artístic de Sant Lluc) entre otros intelectuales de la vida cultural catalana, presidentes de asociaciones religiosas, provinciales de órdenes religiosas y prelados que participan en la Mesa del Congreso. Aunque no participa en la Junta organizadora ni en la Presidencia de Honor -mientras que si aparecen en la primera, el P. Gregorio Suñol, el arquitecto Puig i Cadafalch, además del auténtico promotor del congreso, el Dr. Lluis Carreras- es incuestionable que la presencia de Gaudí está totalmente relacionada con su inserción en congregaciones y asociaciones católicas como la Lliga espiritual de la Mare de Deu de Montserrat y el Cercle Artistic de Sant Lluc, y su fama como arquitecto de prestigio en el ámbito eclesiastico.

Franquesa afirma que Lluis Carreras había frecuentado con otros eclesiásticos los centros y reuniones donde había surgido el Movimiento Litúrgico, lo cual explicaría la rápida transmisión a nuestro país de las ideas que propugnaba Dom Lambert Beauduin, Dom Ildefons Herwegen y otros liturgistas ligados a los monasterios benedictinos. ${ }^{195}$ Según refiere los obispos nombraron comisiones en cada diócesis y se publicó toda la información del congreso en los boletines oficiales. Pero, ¿cuál es entonces la participación de Gaudí en el congreso? A juzgar por lo que señala Franquesa, no aparece ninguna ponencia o intervención del arquitecto pero si que queda constancia de la influencia del congreso y de sus frutos en sus actividades con posterioridad a la finalización de las sesiones del mismo.

El Congreso dio comienzo con un día completo de celebraciones litúrgicas dentro de la octava de la festividad de San Pedro y San Pablo, desde la vísperas del dia anterior hasta la hora nona del martes, para que se viera el coro sacerdotal de la Iglesia alabando a Dios en las horas diversas del día alrededor de la misa solemne de pontifical celebrada por el

\footnotetext{
${ }^{195}$ Franquesa Adalbert. (1966). "El Congrés de 1915 i la seva significació histórica", conferencia pronunciada en el I/ Congrés Liturgic de Montserrat. Barcelona. Publicaciones de la Abadia de Montserrat. P. 25: "Si volguéssim caracteritzar el congrés de l'any 15, l'hauriem de fer en la línea de reforma de sant Pius $X$, interpretada i enriquida paralelament pel moviment liturgic belga creat i dirigit per Dom Lambert Beauduin. No debades els protagonistas del nostre Congrés, i el Dr. Carreras en primer terme, havien freqüentatels centres i les reunions ben aviat. Personalmentsóc testimoni del bon recod i l'estima que el gran iniciador belga conservà de mon bon ami el Dr. Carreras fins a la seva mort."
} 


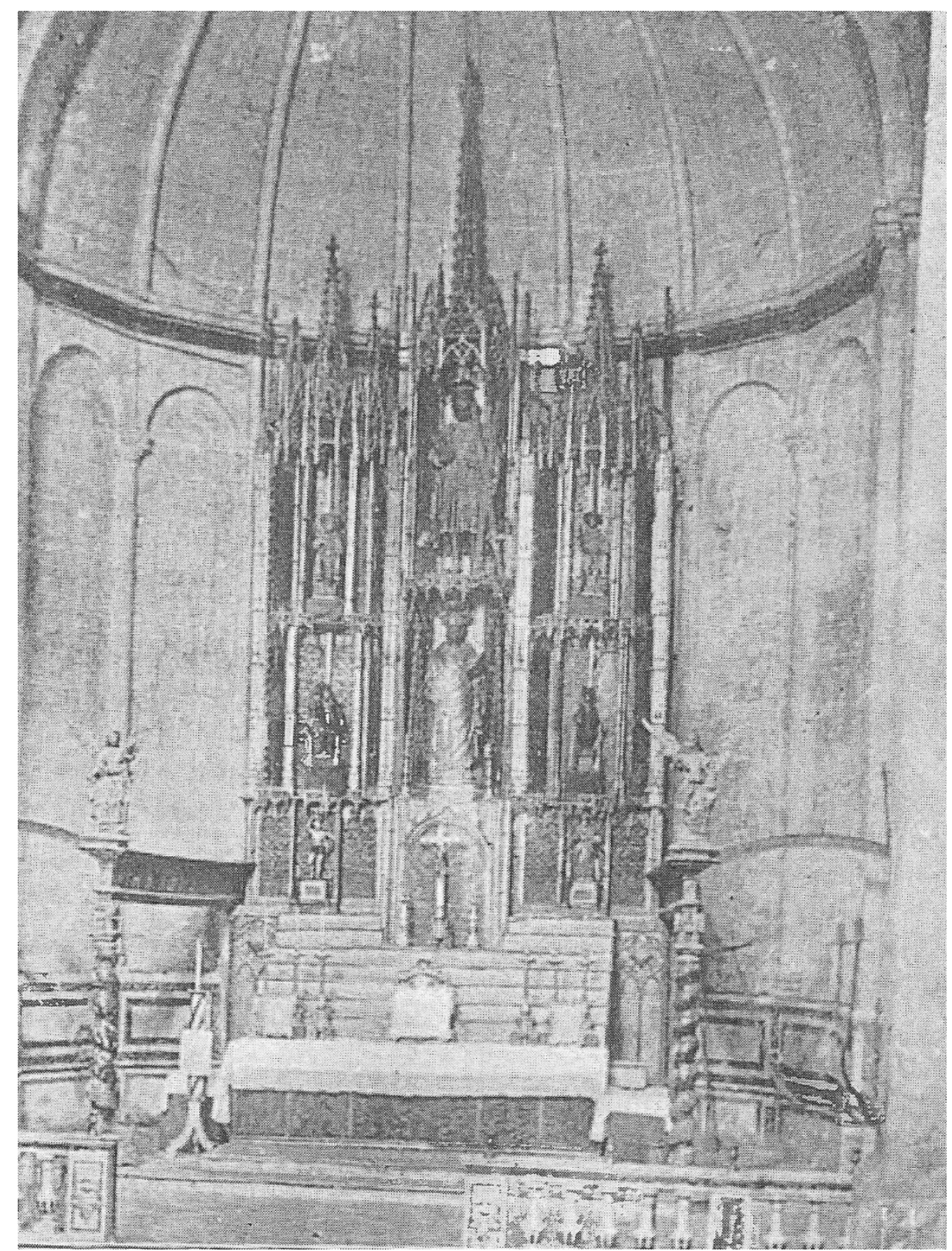

Altar mayor de la iglesia del Monasterio de San Cugat del Vallés en 1925, apreciándose el altar estratificado como basamento del retablo y el concepto de Santuario delimitado por la balaustrada a modo de cancel, situaciones anteriores a la renovación pretendida por el Movimiento Liturgico. Fuente: Trens, M. (1925) "La Mensa", en Anuari dels Amics de l'Art Litúrgic. Barcelona. Cercle Artístic de Sant Lluc. 
Arzobispo de Tarragona (oficios a los que ya asistia diariamente el arquitecto pero que ahora tiene la ocasión de vivirlos con un coro sacerdotal). ${ }^{196}$

En las homilías de las misas, en latín (idioma que dominaba perfectamente Gaudí, a lo cual ya nos hemos referido anteriormente), los obispos exponen sus ponencias en relación con las instituciones fundamentales de donde deriva la vida litúrgica. Entre ellos figura Torras i Bages y el obispo de Urgel, Dr. Joan Benlloch, que habla de la participación del pueblo en la liturgia. El nuncio, Mons. Ragonesi realiza la ordenación de cincuenta seminaristas y en diversas sesiones intervinieron como conferenciantes Puig y Cadafalch y el P. Suñol, distinguiéndose las sesiones en tres secciones: estudios históricos, ministerios sacerdotales y, gregorianismo y popularización de la liturgia. Se aprecia, por tanto, que el desarrollo del programa del congreso pudo responder plenamente a las expectativas de Gaudí pues conjuga la amplitud y magnificencia de las celebraciones litúrgicas con una fundamentación histórica y unas recomendaciones prácticas en cuanto a la pretendida participación de los fieles a través del canto gregoriano. La sesión de clausura corre a cargo del nuncio Mons. Ragonesi que habla del valor educativo de la liturgia católica solicitando al futuro cardenal de Toledo, Dr. Isidro Gomà, la redacción de una obra sobre este mismo tema, que apareció dos años más tarde y es considerada por Franquesa como uno de los frutos directos del congreso.

Por lo demás, el congreso sigue las orientaciones de Beauduin en Malinas: partir de la vida litúrgica de la Iglesia y de la intención pastoral de llevar a los fieles a ella para revitalizar la Iglesia, unos objetivos plenamente prácticos y pastorales en consonancia con el carácter síntetico y práctico de Gaudí, que es profesional de la arquitectura y no teólogo. Se trataba, pues, de llevar la renovación litúrgica vivida en el monasterio a la parroquia, y por tanto, al pueblo. Entre las conclusiones que destaca Franquesa y que aparecen publicadas en los boletines diocesanos se pueden citar:

- La participación activa de los fieles en los misterios sagrados y en la oración pública y solemne de la Iglesia como el deber primero e indispensable del verdadero espíritu cristiano, en total sintonía con lo que Pio X había sancionado en su Motu Proprio.

- La invitación a la participación integral del pueblo en los actos litúrgicos siguiendo los textos, tomando parte en el canto y participando en las ceremonias sagradas.

\footnotetext{
${ }^{196}$ Cf. Franquesa, A. (1966). "Il Congrés Liturgic de Montserrat". Vol. 1 (2a Ed.) Montserrat. Publicacions de l'Abadía. P. No se trata de dictar ninguna reforma liturgica para proponerla a la Santa Sede y solicitar su intervencion...sino de examinar cuidadosamente lo que ya está prescrito y los modos de llevarlo a la practica. "
} 


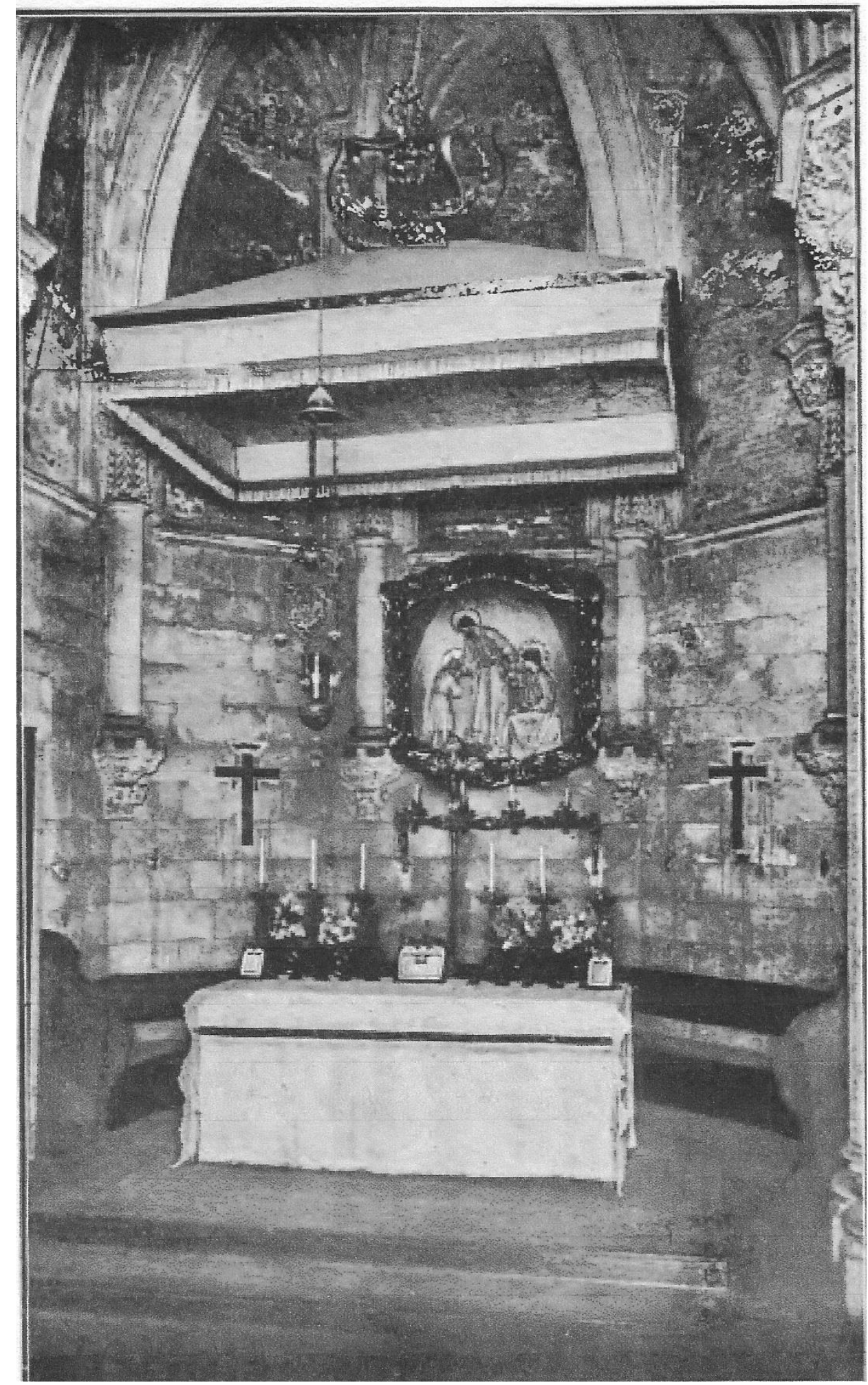

Baldaquino textil y Altar mayor de la Cripta de la Sagrada Familia. En este caso, a diferencia del presbiterio de la iglesia del Monasterio de San Cugat del Vallés, el altar es una mesa aislada del fondo mural, entorno al cual se dispone el banco para los ministros. Fuente: Trens, M. (1925) "La Mensa", en Anuari dels Amics de l'Art Litúrgic. Barcelona. Cercle Artístic de Sant Lluc. 
- la invitación a los fieles a sentirse concelebrantes de la Misa, en cierta forma, con el sacerdote, a comulgar dentro de ella y no ocuparse de otra cosa durante su celebración.

- la potenciación de la Parroquia como celula primera de las instituciones jerarquicas y la declaración de la Misa como el acto oficial y más solemne de cuantos se realizan en la Parroquia, no olvidando la vinculación existente entre la vitalidad de la Parroquia y la bien practicada liturgia de la Misa.

- la instrucción de la catequesis litúrgica para preparar a los fieles en su participación activa en las funciones de culto.

- la propagación del conocimiento y uso de los libros oficiales de la Iglesia, recomendándose la difusión del Eucologio, publicación del Congreso.

- la difusión entre los fieles del conocimiento de la liturgia, su gusto por las formulas, ritos y cantos, en sintonía con la orientación que ha tomado el Papa Pio $X$.

Sabemos que el Eucologio del Dr. Carreras fue lectura asidua de Gaudí y que el abad Marcet promovió la construcción de un coro en el presbiterio de la iglesia del Monasterio al objeto de aplicar en casa propia las conclusiones del congreso. Qué satisfacción encontraría Gaudí al constatar que él ya había plasmado este tipo de actuación con anterioridad en sus proyectos de la Sagrada Familia y de la Seo de Mallorca. En 1918, casi coetáneamente con el congreso, hay que situar la labor del abad Herwegen al frente del monasterio benedictino alemán de Sta. Maria Laach, en el que que tienen lugar retiros litúrgicos y conferencias, talleres de arte sacro, estudios patrísticos, etc. con la aprticipacion de teologois como Odo Cassel, Pius Parsch y Romano Guardini, quien publicaría su celebre obra El espíritu de la liturgia (1918). Siendo que en ese mismo año aparece en España la obra de Isidro Gomá El valor educativo de la Liturgia católica, y viendo la relación entre ambas publicaciones, Walter Zahner ha llamado la atención sobre la conveniencia de estudiar la repercusión que pudo haber tenido en España dicha obra de la misma manera que tuvo la de Guardini en la construccion de iglesias en Alemania. ${ }^{197}$

197 Zahner, W. (2007). La construcción de iglesias en Alemania durante los siglos XX y XXI, en Actas del I Congreso Internacional de Arquitectur Religiosa Contemporanea. La Coruña. COAG 


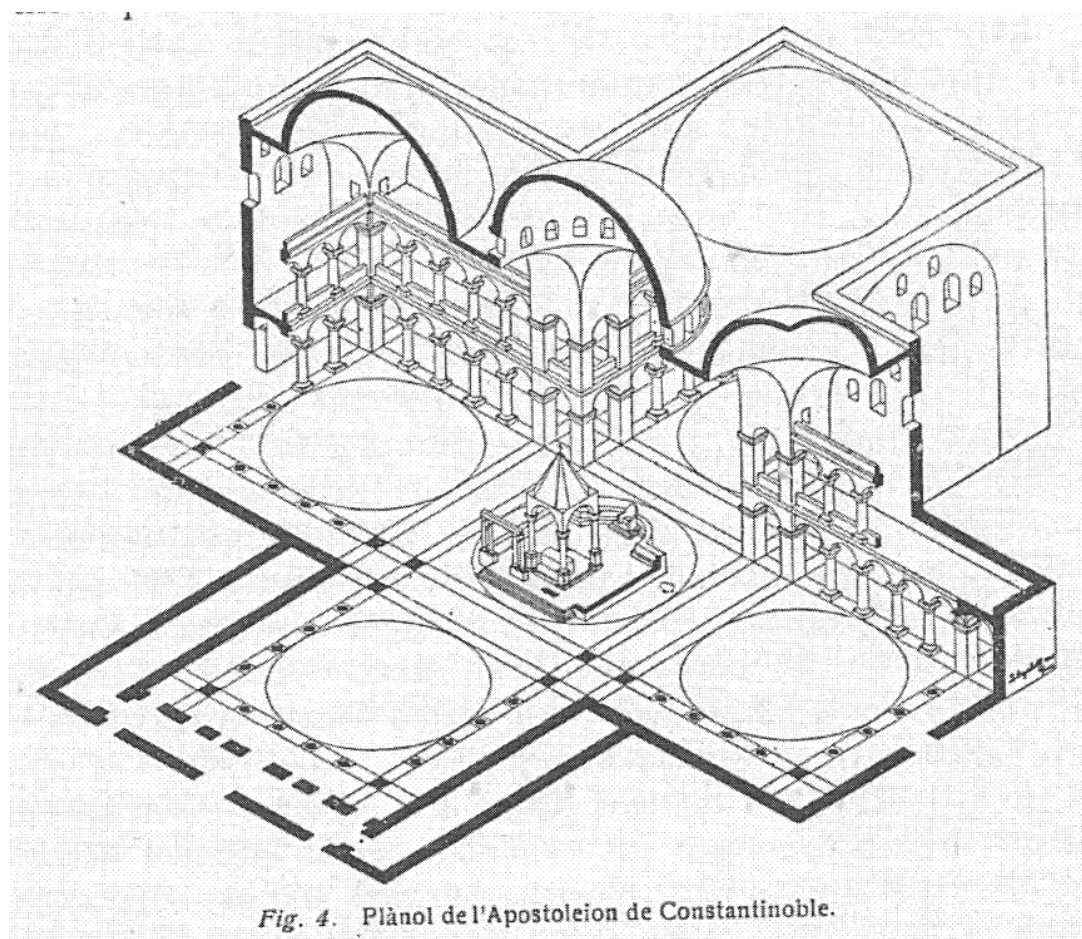

Dibujo perspectivo de la basilica de los Santos Apostoles de Constantinopla, 2a edificación de tiempos de Justiniano (s. VI), que es mencionada por Josep Tarré como el mejor ejemplo de basilica de planta central, y en el que puede apreciarse la modulación cupular de su estructura. Fuente: Tarré, J. (1925) "L'estructura litúrgica en la construcción dels temples", en Anuari dels amics de l'Art litúrgic. Barcelona. Cercle Artístic de Sant Lluc.

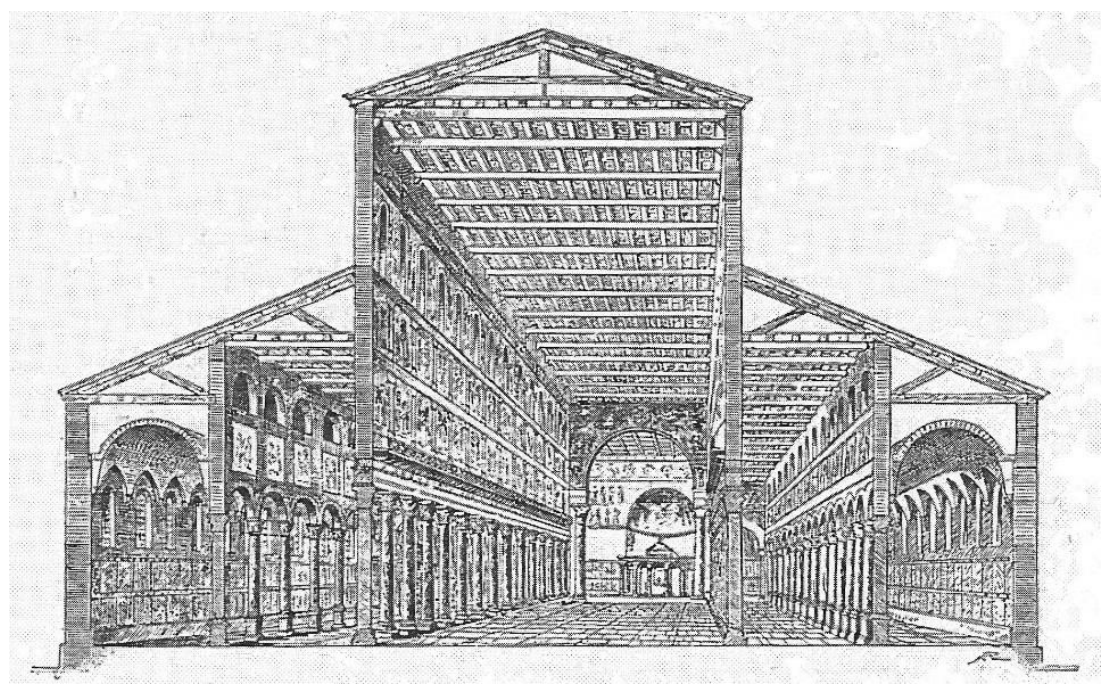

Perspectiva interior de la primitiva basilica de San Pedro del Vaticano que aparece en el articulo de Josep Tarré junto con la planta de la basilica de San Pablo y un esquema de planta de basilica latina que trascribe del libro Sacramentario dei fideli de Dom Battisti, testimonio del indudable interés que había entre los Amigos del Arte Litúrgico por la evolución hsitórica de la planta de las iglesias. Fuente: Tarré, J. (1925) “L'estructura litúrgica en la construcción dels temples", en Anuari dels amics de l'Art litúrgic. Barcelona. Cercle Artístic de Sant Lluc. 
Precisamente uno de los aspectos clave de esta investigación es establecer las relaciones causa efecto entre lo que Gaudí escucha y participa en el congreso -base del libro de Gomá- y el proyecto arquitectónico de la Sagrada Familia, que en en dicho año contaba ya con su tercera y definitica solución estructural "arborescente". Una consecuencia de la influencia del Congreso en la vida eclesiástica, cultural y artística catalanas es la constitución, dentro del Círculo Artistico de San Lucas, del grupo de Amigos del Arte Litiurgico promovido por el entonces consiliario D. Manuel Trens ${ }^{198}$, que organiza en 1925 la primera exposición de arte litúrgico en Barcelona, así como también la publicación en ese mismo año del "Anuario de los Amigos del Arte Litúrgico". Precisamente en éste se cita la Sagrada Familia de Gaudí como una intersante búsqueda de nuevos caminos para la estructura liturgica de los templos. Y también en el mismo Anuario se pone de ejemplo la solución diseñada por Gaudí para el Sagrario de la Cripta y parael baldaquino textil del altar mayor de la Cripta. ${ }^{199}$

En esta exposición de Arte Litúrgico se muestran realizaciones de numerosos artistas como los arquitectos Martorell, Gaudí, Folguera, Jujol, Puig Boada, Berós y Bonet, y los pintores hermanos Llimona, etc. La exposición quiere reunir y mostrar lo mejor del arte sagrado que se realiza en esos momentos, evocando la figura de Joan Martorell y Antoni Gallissá, destacados arquitectos y fundadores del Circulo Artístico que habían fallecido recientemente, en 1903 y 1906 respectivamente, y a quienes se atribuye la renovación del arte sagrado en los albores del movimiento litúrgico. 200

\footnotetext{
198 El Cercle Artistic de Sant Lluc nació en 1893 por escisión del Círculo Artistico. Manuel Trens i Ribas, primer director del Museo Arqueológico Diocesano de Barcelona, fundado en 1916, era consiliario del Cercle desde 1921, promoviendo el grupo de Amigos del Arte Litúrgico y la edición del Anuario, que se publicó desde 1925 a 1930.

199 Cf. Tarré (1925). "L'estructura litúrgica de la construcción dels temples", en Anuari dels Amics de l'Art Litúrgic. Barcelona. Cercle Artistic de San Lluc. P. 26. También el art. M. Trens en el mismo anuario "La Creu de l'Altar" que muestra el baldaquino del Altar mayor de la Cripta y el Sagrario en su altar correspondiente, similar a la solución del Monasterio de Mont Cesar en Lovaina, Bélgica. (P. 77 y P.101)

200 La Exposicion se realiza en la Sala Parés de Barcelona, del 29 de noviembre al 11 de diciembre de 1925. En el catálogo aparecen diversas obras debidas a Gaudí:

-Llàntia de l'altar del Sagrat Cor.

-Taula de combregar.

-Dos candelers de Missa (de ferro forjat).

-Candeler de pontifical.

-Das fanals del Viàtic.

-Faristol de ferro forjat.

-Canelobre del Ciri Pasqual (columna de marbre i metall).

-Tenebrari.

-Faldistori amb domàs de seda verd per a cobrir-lo. dos coixins.
} 
En el primer número del Anuario de los Amigos del Arte Liturgico, publicado en adviento de 1925, se describe éste como un boletín que sirva de "guía de todos los que con su trabajo, su orientación y su mecenazgo intervienen en la construcción y embellecimiento del templo cristiano, con el fin de que ni el artista, ni el sacerdote ni el benefactor consciente $o$ inconscientemente conculquen con sus preocupaciones $u$ ocurrencias personales las severas prescripciones de la liturgia."201 El Anuario se estudian desde el punto de vista histórico y litúrgico todas las cuestiones referentes a la arquitectura de las iglesias, a sus pintura, orfebrería, iconografía y escultura, tratando también cuestiones de la máxima actualidad como la posibilidad del traslado del Coro de la catedral de Barcelona que los canónigos acordarían el uno de enero de 1927, a imitación de lo realizado unos años antes en la Seo de Mallorca.

Josep Tarré, como gran conocedor del Movimiento Liturgico belga al que hace referencia al ponderar la bondad liturgica de las iglesias de los monasterios benedictinos, participa también en el Anuario con un evidente protagonismo y unas ideas precisas y claras en sintonía con la visión de la arquitectura eclesiástica y el arte sacro que tiene Antonio Gaudí. Teniendo en cuenta la especialización de Tarré en ciencias litúrgicas y arte sacro, unido a su doctorado en teología, su coincidencia con Gaudí es sintomática de la sólida reputación de experto en Liturgia de que gozaria éste. La aportación de Tarré al Anuario ofrece el interés del momento en que se publica, el fundamentado repaso de las tipologías de planta de las iglesias desde los primeros tiempos del Cristianismo y su comentario sobre las disposiciones y normas prácticas a tener en cuenta en las iglesias para el culto católico. Además resulta significativa la coincidencia en la crítica de algunos proyectos, a los que considera copia de ejemplos anteriores, como el Sacrée Coeur de Montmartre, el Sacro Cuore de Roma, la iglesia del Seminario Conciliar de Barcelona o la Basílica de la Transfiguracion del monte Tabor en Israel.

En cambio Tarré elogia la remodelación del presbiterio de la seo mallorquina de Gaudí que sigue las orientaciones del Caeremoniale Episcoporum respecto del tratamiento de la cátedra del obispo -propugnado su situación al fondo del ábside rodeado de los asientos de los presbíteros como en las antiguas basílicas romanas- y realiza numerosas observaciones sobre la ubicación de las sacristías, baptisterio, coro, etc. que son coincidentes con el proyecto de la Sagrada Familia. Haciendo un recorrido por diversas configuraciones de la planta de las iglesias concluye que la forma basilical latina es "la más generalizada y la que más ha perdurado en la evolución del culto litúrgico y de los estilos arquitectónicos.", lo cual no le impide valorar las iglesias de planta central como el Apostoleion de Constantinopla, y aquellas que en Oriente y Occidente han seguido sus trazas, para resaltar la ordenación del altar y el presbiterio como centro litúrgico del espacio y la utilización de la cúpula como elemento de cubrición de las naves.

${ }^{201}$ AA. VV.(1925) “Anuari dels Amics de l’Art Litúrgic ». 1 $1^{\mathrm{er}}$ no. Barcelona. Cercle Artistic de Sant Lluc. 
En este sentido podera la belleza de la cúpula adoptada por Brunelleschi en la capilla del claustro de la Santa Croce de Roma y por Bramante en su proyecto para San Pedro, pues aunque esta disposición era contradictoria con la tradición romana de la estructura de las iglesias realza la ubicación del altar y su ciborio. Lo interesante es que en su recorrido histórico de las iglesias, además de su dimensión artística, podera su funcionalidad liturgica. ${ }^{202}$

El panorama que Tarré describe de la arquitectura religiosa del siglo XIX, de la que dice no ha sabido hacer nada que no sea copiar formas y estilos pasados, bien podría haber sido suscrito por Gaudí pues es coincidente con las ideas que éste enfatiza en el Manuscrito de Reus (1873-1879), por lo que teniendo en cuenta que Tarré es más joven -apenas contaba un año de vida cuando Gaudí da comienzo a sus escritos, y es ordenado sacerdote en 1899- no es de extrañar que a su conocimiento litúrgico e histórico de la arquitectura eclesiástica se le pueda sumar un plus de admiración personal por el quehacer profesional de Gaudí. Su valoración del pensamiento y obra arquitectónica eclesiástica gaudinianos se refleja en comentarios respecto de la reforma del presbiterio y nave mayor en Mallorca, el proyecto de la iglesia para la colonia Güell y por supuesto, la estructura y composición del Templo Expiatorio. Resulta curioso, por el grado ce coincidencia con la opinión de Gaudí, la descripción que hace de la Iglesia del Sacrée Coeur de Montmartre, París: "Edificios de la importancia del Sagrado Corazón de Montmartre, que en otras épocas habrían constituido un hito en la historia del arte y un fecundo modelo de nueva forma, no son otra cosa que copias más o menos acertadas de ejemplares conocidos. En el templo votivo de Montmartre, Abadie hizo, podemos decir, una hibrida mezcla del románico de Aquitania con el románico de Auvernia, predominando el aspecto exterior de Saint Front de Périgueux." 203

\footnotetext{
${ }^{202}$ Cf. Tarré, Josep. (1925). L'estructura litúrgica en la construcción dels Temples, en "Anuari dels Amics de I'Art Lirturgic". Barcelona. Cercle Artistic de Sant Lluc. P.22: "I el presbiteri està desplaçat, perquè la importancia suprema de la cúpula en tota construcción, deixa en segon lloc l'absis, amb l'altar major que hauria d'esser en el creuer."

${ }^{203}$ AA. VV.(1925) “Anuari dels Amics de l'Art Litúrgic ». 1 ${ }^{\text {er }}$ no. Barcelona. Cercle Artistic de Sant Lluc.
} 


\subsection{Gaudí y el canto gregoriano. La escuela del padre Sunyol.}

Afirma Adalbert Franquesa que el Movimiento Liturgico entró en España debido a la difusión del canto gregoriano que el movimiento benedictino, iniciado en Solesmes, realiza a través de los monasterios de Silos y Montserrat ${ }^{204}$. En este sentido el gregorianismo de Suñol seria clave para la incorporación de Montserrat a la corriente renovadora Iturgista que se desarrollaba en Centroeuropa. De hecho tras la realización del Congreso Liturgico el abad Marcet introdujo una reforma del presbiterio de la iglesia para dar cabida precisamente al coro y por consiguiente al canto en una mayor sintonía y aproximación con la celebración de la eucaristía.

Vemos en efecto que ambos van de la mano en la concienciación por la importancia de la renovación liturgica que está aconteciendo y en su difusión pastoral. En Adviento de 1901 se había instaurado ya en la Abadia el canto gregoriano en substitución del canto plano, y en el primer número de la Revista Montserratina, en 1907, habia aparecido un artículo del P. Suñol respecto del Canto Gregoriano en el que avanzaba sus ideas programáticas al respecto del binomio liturgia-canto siguiendo las directrices de Pio X. En 1904 es el cardenal Casañas, arzobispo entonces de Barcelona, quien siguiendo la línea marcada por el Papa crea la Schola Cantorum del Seminario de Barcelona y la Comisión diocesana de Música Sacra. En 1912, en los albores de la preparación del congreso litúrgico, se convoca el Congreso de Música Sacra de Barcelona. Así mismo, en 1914, un año antes de la celebración del Congreso litúrgico se lanza, conjuntamente entre sus organizadores y el Monasterio de Montserrat, la revista Vida Cristiana para la difusión o apostolado liturgico de cuanto se iba a tratar en el congreso.

En el desarrollo del congreso vemos que Canto gregoriano y Popularización de la liturgia habían constituido una de las tres secciones en que se había organizado las sesiones de estudio del mismo. Del mismo modo, de entre las trece comunicaciones que en ella se presentaron destaca una sobre "El cant del poble en les festes de l'Esglesia", del maestro Millet que habla bien a las claras del carácter que quería conferírsele al canto litúrgico entre los fieles. Citaremos también otra conferencia de gran trascendencia para las sesiones y la posterior difusión de lo allí tratado, la del Nuncio Ragonesi sobre el valor educativo de la liturgia católica que promoverá el libro del mismo título escrito por el futuro cardenal Isidro Gomà, verdadera síntesis de lo estudiado en el congreso.

En 1916, finalizado el congreso, se funda en Barcelona, con la presidencia del Obispo entonces D. Enrique Reig i Casanova- y en el palacio episcopal, la Asociación Gregorianista bajo la dirección del padre Suñol. Éste organiza un curso superior de canto gregoriano en

204 Cf. Franquesa, A. (1965). El Congrés Litúrgic de Montserrat de 1915, en "Questions de vida cristiana", no25, separata (2a Ed.) Montserrat. Publicacions de l'Abadía. Ed. Estela. 
el Palau de la Música Catalana al que acuden, entre otros Antonio Gaudí y uno de sus colaboradores, Jujol, el maestro Millet, Barberá, Pujol, etc. y muchos alumnos de la Escuela Municipal de Música y del Conservatorio del Liceo.

La Asociación Gregorianista participó también en una Semana Gregoriana en Besalú y promovió las Scholae Cantorum que se fundan en muchas parroquias. De hecho el padre Suñol había publicado en 1905 un Método completo de canto gregoriano, que se publicó en castellano, francés, alemán e italiano, y se tradujo al portugués y serbio, introduciendo también en ese mismo año el canto gregoriano en sustitución del canto plano en la fiesta de la Virgen de Montserrat en la catedral de Barcelona, y participando muy activamente en congresos de Música sagrada en Valladolid (1907), Sevilla (1908) y Barcelona (1912). Así pues, Suñol, una de las figuras más importantes en la organización y difusión del congreso de Montserrat y por tanto de su acercamiento al pueblo, forma parte del elenco de personajes relacionados con la renovación liturgica y su repersusion en el arte cristiano con los que se relaciona Gaudí en un periodo clave de su producción arquitectónica ligada al culto cristiano ligado al trabajo en Santa Coloma y Mallorca, y a la evolución del proyecto estructural de la Sagrada Familia. 


\subsection{El pensamiento de Gaudí en su madurez.}

Para conocer el concepto de Arquitectura de Gaudí en su madurez y sus ideas respecto de lo que significa el proyecto de una iglesia hay que apoyarse en lo que refieren y trasmiten Ràfols, Puig Boada, Bergós y Martinell cual fieles discípulos que recogen y refieren sus reflexiones y comentarios. Aunque se ha denunciado que su labor crítica es prácticamente nula, todos ellos gozan de la ventaja de la fidelidad y frescura de la primera transcripción de su pensamiento, en unos años en los que el maestro ya no escribe. Puig Boada (El Pensament de Gaudí: compilació de textos i comentaris, 1981) constituye la fuente básica para analizar el discurso conceptual de Gaudí en su madurez no sólo por ser el primero que recoge sus opiniones sino porque las sistematiza conceptualmente. Si para Bassegoda el escaso conocimiento de la vida personal de Gaudí se debe a su timidez y al hecho de moverse en un ambiente exclusivo muy diferente de las corrientes estilísticas de su tiempo, y Martinell habla de la espontaneidad y radicalidad de sus diálogos como fuente de más de una controversia verbal, éstas no dejan de ser cuestiones accesorias a la hora de comprender la evolución experimentada en la forma de comunicar su pensamiento. Habria que unir una interioridad -en la que se inscribe una mentalidad fuertemente analítica respecto de la estructura interna del mundo material, de la naturaleza pero también de disciplinas arquitectónicas- a la que dedica una notable dosis de energía personal junto con un esfuerzo gigantesco en el campo de la actividad profesional para justificar la ausencia de estímulo para proseguir sus escritos de juventud.

Revisando las biografias y crítica especializada podemos también concluir que su personalidad no discurre por sendas "fuera del sistema", ni nos encontramos frente a una persona recluida y aislada del contacto social -como por otra parte atestigua su pertenencia a sociedades excursionistas, círculos artísticos, asociaciones religiosas marianas, amistades y contactos con personajes eclesiásticos y civiles de reconocida trayectoria en la sociedad catalana y compañeros de profesión- sino que aquella se configura como la de un artista que se va introduciendo cada vez más en un selecto y especifico mundo intelectual y profesional que discurre más o menos autónomamente de otros itinerarios culturales. Es por ello que conforme pasan los años y su círculo de amistades se va reduciendo (por ley de la naturaleza), sus jóvenes colaboradores y asistentes más allegados se convierten en interlocutores y testigos de un quehacer que por su método y complejidad es expresión privilegiada de su pensamiento. Estos, cual fieles escribas, recogen y anotan con auténtica devoción las reflexiones de su maestro.

César Martinell, paisano y amigo, además de dar una idea general de su vida, pensamiento y obra, ordena los recuerdos cronológicamente. Son años de continuas visitas y acompañamiento en el taller del Templo expiatorio que estructura a modo de itinerario narrativo de la totalidad de sus facetas y vida. Marciá Codinachs también presenta manuscritos gaudinianos comentados por él mismo, y los ilustra con dibujos del 
autor. Joan Bergós, confidente de largos paseos y conversaciones dominicales, nos muestra un conocimiento muy cercano entremezclando elementos biográficos con descripciones de edificios y comentarios críticos. Pero desde el punto de vista estrictamente conceptual y sintético, cualidad que valoraba mucho Gaudí, resulta del mayor interés la recopilación que hace Puig Boada de sus escritos y comentarios de madurez, sustentados en el largo tiempo que este profesional dedicó a trabajar en la Junta Constructiva de las Obras del Templo. Primeramente colabora con Antoni Gaudí, después con los arquitectos que le sucedieron en los trabajos (Domenech Sugranyes y Francisco de Paula Quintana, a partir de 1.926), finalmente dirige las obras en 1950 . Todo ello le convierte en uno de los mejores especialistas en Gaudí en el apartado profesional, cuestión refrendada por el reconocimiento que de sus estudios hace tanto el Colegio de Arquitectos de Cataluña como Bassegoda desde la cátedra Gaudí. ${ }^{205}$

Así pues, después de los escritos de juventud hay un largo periodo de tiempo en que Gaudí parece como callado, en silencio, hasta que en su vejez comunica las reflexiones de toda una vida manteniendo largas conversaciones con estudiantes de arquitectura y profesionales que visitan las obras de la Sagrada Familia. Este último periodo puede concretarse entre 1914 y 1926, fecha de su muerte, correspondiendo con la fase más madura y elaborada de su trayectoria profesional.

Puig Boada clasifica los comentarios y aseveraciones de Gaudí en función de su temática, distinguiendo también a quién se lo decía, y los agrupa dentro de un capítulo que denomina significativamente Gaudí ens parla (Gaudí nos habla). En el Manuscrito de Reus, principalmente $y$ en otros escritos de juventud, Gaudí explicita unas inquietudes encaminadas a un discurso sobre la belleza y la arquitectura, que liga con el planteamiento de la filosofía clásica respecto de la armonía y la proporción, razonando que ambas están implicadas en la adecuación de un edificio al uso, objeto y funcionalidad que lo han originado. Después de una larga trayectoria profesional este enfoque no ha variado sino que parece haberse trascendido en aras de una se complacencia más ontológica en la que encuentra cimenta la relación entre verdad y arte como vasos comunicantes y columnas en los que apoyar su concepto de belleza.

\footnotetext{
205 Puig Boada, Isidre. (1981) El Pensament de Gaudí. Barcelona: Publicaciones del COACB, Barcelona. Prólogo del Decano del COACB: "aquest home (Isidre Puig Boada) es un devot de Gaudí i un gran coneixedor del seu esperit artístic". En Nota: Palabras que refiere de Puig Boadas. Así mismo el Decano indica en el prólogo a este libro que a sus 90 años, Puig Boada, fiel al maestro, ofrece una materia que domina y estima por encima de todo y a la cual ha dedicado gran parte de su vida. Al tratarse de una recopilación de conversaciones y dichos de Gaudí, Puig Boada los recoge en el idioma catalán que él empleaba al hablar (ya que sin embargo, en los pocos escritos que ha dejado Gaudí empleó el castellano). Con el fin de facilitar una mejor compresión para quien no domine ese idioma, transcribiré traducciones personales de dichas frases. Se mantienen, no obstante, los originales en catalán en las notas a pie de página.
} 
Entiende que buscando en el arte la verdad -que en el siglo XX se llamaría sinceridadaquél se vuelve atractivo, pero esta verdad-sinceridad no la sustenta como una suerte de goce estético o formal en sí mismo sino que la persigue desentrañando su estructura más interna y sus claves más cualificadas. Trata de aplicar sus descubrimientos al proyecto de la Sagrada Familia como un minucioso ejercicio de composición arquitectónica en el que estabilidad y estructura, estudio de la iluminación y diseño de vanos, iconografía, texturas y color de materiales, etc. se alcanzan mediante un ingenioso y tenaz esfuerzo de continuos ensayos precedidos de una mentalidad analítica y sintética tan bien desarrollada ${ }^{206}$. Su arquitectura busca perpetuarse no como estilo o lenguaje, que aunque difícilmente clasificable es propuesto con vehemencia, sino como metodología e instrumento en pro de un homenaje al misterio y función a los que sirve. De ahí que la concepción arquitectónica unitaria que persigue se plantee en términos, no de copia, sino de libertad frente a los estilos históricos.

Cuando Gaudí menciona su célebre frase -la originalidad consiste en acercarse, en volver a los orígenes- no está preconizando el que haya que buscar la originalidad de una solución arquitectónica en términos de novedad o descubrimiento formal sino que, como se deduce de sus aseveraciones, su concepto de originalidad se apoya en el itinerario histórico de experiencias planteadas con referencia a un problema para acercarse de nuevo a él desde el principio, desde su origen, buscando la mejor y más lógica solución conceptual posible. Es un ejercicio de constancia y de paciencia, de síntesis y de investigación. Su disertación juvenil sobre la Ornamentación, que entiende no añadida o superpuesta sino integrada en el edificio, deviene ahora en una tentativa integradora de tal calibre que implica a la estabilidad y características resistentes de los materiales, a su construcción, a la iconografia que pueden traslucir formas, el color, los textos e imágenes.

Gaudí, observador concienzudo y detallista de la realidad y poderosísima mente imaginativa, ha tenido largo tiempo para estudiar la naturaleza y aprender de ella durante una infancia a menudo convaleciente por lo cual está en condiciones de apreciar sus logros como lo hubiese hecho un buen naturalista decimonónico:

"El gran libro, siempre abierto y que es preciso esforzarse en leer, es el de la Naturaleza; los otros libros están sacados de éste y en ellos hay equivocaciones $e$ interpretaciones de los hombres. Hay dos revelaciones: una doctrinaria de la Moral y

${ }^{206}$ Cf. Garcia Gabarró, Gustavo (1994). Leyes de la naturaleza y composición arquitectónica: el ejemplo de Antonio Gaudí. Tesis Doctoral dirigida por Joan Bassegoda. Barcelona. ETSAB. Garcia Gabarró ha estudiado con detalle el proceso de estudio y asimilación de las leyes de la naturaleza que Gaudí que extrae mediante su detallada observación, cómo se inspira en ellas para dar rienda suelta a su imaginación en la fantasía y expresionismo de su diseño así como para utilizar el color como algo consustancial con la arquitectura; pero además nos introduce en un posible origen del proceso creativo de las estructuras que utiliza a partir de las funículas de fuerzas y las superficies regladas. 
de la Religión, y la otra guiadora por los hechos, que es el gran libro de la Naturaleza." 207

La evocación de la naturaleza como inspiradora de la técnica nace, pues, de la prolongada visualización analítica, operación que impulsa la experimentación para no crear nada superfluo o gratuito, para no dejar a la imitación.

La arquitectura debe ser la visión global de todas las circunstancias del proyecto, reflexionando e indagando sobre cuantas disciplinas y parámetros conduzcan al apetecido resultado unitario en el que estabilidad, armonía, luz, color, simbolismo e iconografía conforman un espacio que logrando ser funcional revierte en estético. De ahí el rechazo a lo que denomina muletas estructurales, arbotantes y contrafuertes que ve como apuntalamientos de un sistema imperfecto que no ha logrado depurar su funcionamiento. En este sentido su iniciativa estructuralista podría verse como el comienzo de un itinerario hacia la sinceridad que propugnaría el racionalismo del Movimiento Moderno. A Gaudí le interesa el conjunto armonioso que es conformado por la luz -visual, funcional y simbólicamente-, porque toda arquitectura, y quizá aún más la eclesiástica, se revela por el tratamiento de la luz: "La arquitectura es la primera arte plástica, la escultura y la pintura necesitan de la primera. Toda su excelencia viene de la luz. La arquitectura es la ordenación de la luz, la escultura es el juego de la luz, la pintura, la reproducción de la luz por el color, que es la descomposición de la luz."208

Por ello la respuesta adecuada a la liturgia no es la reproducción mimética o la copia más o menos afortunada de un modelo histórico, sino la investigación lumínica del espacio cultual: llegar a comprender su sentido en la celebración liturgica y su problemática, cómo se crea el espacio de la asamblea y cómo debe ser iluminado, cómo se aprecia el simbolismo de la materialidad de las formas y cómo incide la luz en el espacio simbólico y la experiencia espiritual. Lo original no seria lo novedoso sino la raíz, el germen, que sustenta el acontecimiento que da lugar al hecho constructivo: "La originalidad consiste en acercarse, en volver al origen". ${ }^{209}$

\footnotetext{
207 Puig Boada, Isidre. (1981). El Pensament de Gaudí. Barcelona: COAC. P.92: “El gran llibre, sempre obert $i$ que cal esforçarse a llegir, és el de la Naturalesa; els altres llibres són trets d'aquest i hi ha les equivocacions i interpretacions dels homes. Hi ha dues revelacions: I'una doctinària de la Moral i d ela Religió, i l'altra guiadora pels fets, que és la del gran llibre de la Naturalesa."

208 Puig Boada, Isidre. (1981). El Pensament de Gaudí. Barcelona: COAC. Pag.98: “L’arquitectura és el primer art plàstic; l'escultura i la pintura necessiten de la primera. Tota la seva excellència ve de la llum. L'arquitectura es l'ordenació de la llum; l'escultura és el joc de la llum; la pintura, la reproducció de la llum pel color, que és la descomposició de la llum."

209 Puig Boada, Isidre. (1981). El Pensament de Gaudí. Barcelona: COAC. Pag.98: "L'originalitat consisteix a apropar-se, a retornar a l'origen."
} 
El espacio tiene valor en sí mismo y lo tiene para cada hombre. Y cada hombre dialoga con él de una manera, unas vecer rechazándolo, otras habitándolo un tanto distraídamente y otras percibiéndolo como fuente de bienestar. El espacio arquitectónico es para el hombre y por tanto en la Arquitectura "La construcción es como la justicia que resuelve siempre un caso concreto" 210 . La arquitectura no es solamente estabilidad, dirá, ésta es una parte de ella,...pero para que una obra arquitectónica sea bella es preciso que todos sus elementos tengan lo justo en cuanto a situación, dimensión, forma y color, de tal manera que el hábitat conseguido para el hombre devenga en confort ontológico para él, y el arquitecto es el hombre sintético, plástico y constructivo, que dirige los trabajos y realiza como la "Constitución de la Obra".

Con una percepción global y bastante completa de lo que durante muchos años ha sido su ejercicio profesional, Gaudí se manifiesta como "gobernante de la obra", que supera el proyecto inicial y da lugar a la necesidad de nuevos planos, estudios y maquetas que debieran rehacerse hasta lograr la armoniosa finalización que persigue reflejar ese carácter del edificio del que habla en el Manuscrito de Reus. Este no viene de una visión romántica formal o de la utilización y repetición de clichés históricos sino de la lógica interna y razonada del proyecto. Por ello cuando afirma que el carácter religioso es el más elevado, lo hace en función de la valoración qu reconoce al misterio que acontece, que presenta el culto cristiano.

La alta consideración que otorga en sus escritos a los edificios destinados al culto cristiano le da un criterio fundamentado en la severidad y sinceridad constructivas, en la aguda percepción de la diferenciación y transición entre el espacio profano y el sacro, y en la comprensión de los diferentes recintos que constituyen un lugar litúrgico. Su conocimiento y amplia visión histórica de las diferentes piezas que históricamente lo han conformado: baptisterio y aula de los catecúmenos, claustro, itinerario de reinserción penitencial, disposición del aula liturgica y del coro dentro de ella, sacristía y demás espacios auxiliares, cripta, ...le otorgan una muy buena posición de salida para recorrer el camino que marca la renovación liturgica emprendida en los albores del siglo XX, herramienta definitiva para la composición arquitectónica del conjunto eclesial.

Pero, cabria preguntarse ¿Por qué tanto interés en la arquitectura de las iglesias? Sus inicios se pueden rastrear documentalmente en el Manuscrito de Reus y La construcción del Templo (1878-1883), cuando escribe que en la iglesia se han de emplear los medios en su más alto grado para inspirar el sentimiento de la Divinidad. Esta disposición racional, fruto del sentimiento y de la voluntad, se afirma en su ánimo durante los años de estudio y reflexión litúrgica junto al obispo Grau, pero son los prolongados años de

\footnotetext{
210 Puig Boada, Isidre. (1981). El Pensament de Gaudí. Barcelona: COAC. Pag.102: "43. Arquitectura. La construcció, com la justicia, resol sempre un cas concret."
} 
trabajo en la Sagrada Familia con muy cualificadas intervenciones previas en la catedral de Mallorca y en la Iglesia de la Colonia Güell, etc. los que le capacitan para utilizar la Liturgia como auténtico programa de necesidades del edificio-iglesia y como una herramienta para su ordenación a todos los niveles: teológico, simbólico, iconográfico, material y constructivo.

De ahí que el proceso que Gaudí pone en marcha para la realizacion de su proyecto sea tradicional y moderno a un tiempo. Tradicional porque se apoya en el más remoto y continuado proceso histórico, hundiendo sus raíces teológicas y simbólicas en los tiempos apostólicos y el esplendor de la arquitectura medieval. Moderno porque desentraña el carácter, la voluntad de ser del edificio-iglesia, y desnudándolo de decorativismos y convencionalismos lo centra en un decidido proceso de investigación y experimentación estructural, constructivo, lumínico, cromático y acústico que no puede ser más original para los inicios del siglo XX, más preocupados por el carácter artístico del edificio y la elección del estilo más adecuado. En este sentido, subordinar el proyecto a las necesidades, simbología, iconografia y ceremonial que emanan de la experiencia litúrgica significa también ordenar el espacio y su estructuración. $Y$ en esta via emprendida, que conlleva una visión unitaria del espacio celebrativo, cobra fuerza la fusión de construcción con ornamentación, jerarquizando el diseño lumínico y acústico desde el rito y su significación litúrgica.

En todas las religiones naturales el templo -signo de la dimensión trascendente del hombre- había representado el lugar por excelencia de la comunicación del hombre con su Creador. Conocedor de esta religiosidad natural, Gaudí sabe que en las distintas civilizaciones el hombre ha sentido la necesidad de llevarse cerca de sí, a su hogar, una parte de esa relación con la trascendencia, mediante la creencia en unas divinidades más próximas, más familiares, con quienes pudiese de alguna manera continuar esa comunicación así :

“...El templo es la construcción por excelencia y después de él sólo está la casa, que ya antiguamente era considerada respetuosamente por los campesinos, porque guardaba los lares, deidades de la casa y de la familia, como lo prueba el hallazgo en Pompeya de miles de estatuitas de los dioses familiares." 211

Si históricamente el templo se había constituido en la edificación más importante que pudiera construirse en las sociedades organizadas, el carácter que atribuye al edificioiglesia fundamenta su grandeza en el hecho de ser el lugar donde el pueblo cristiano

\footnotetext{
${ }^{211}$ Puig Boada, Isidre. (1981). El Pensament de Gaudí. Barcelona. La gaya Ciencia P.110: "...El temple és la construcció per excellència i després d'ell sols ho és la casa, que ja antigament era considerada respectuosament pels pagesos, perquè guardava els lares, els déus llars de la casa i de la familia, como ho prova la troballa a Pompeia de milers d'estatuetes dels deus familiars.
} 
celebra el memorial de un Dios que se sacrifica por su criatura lo cual le cautiva y empeña en un esfuerzo profesional titánico. Por ello, si critica el estilo gótico y su manera de trasmitir los empujes y bóvedas no es por una visión teórica de la Arquitectura sino porque está pensando en ese carácter y significado del edificio-iglesia:

"Todas las formas y todos los elementos resistentes del Templo se basan en las funiculas de las fuerzas actuantes, por lo cual se puede prescindir de los contrafuertes. El arte gótico no se separó nunca de las bóvedas y de los arcos de generación circular, y aquellas que, para seguir aproximadamente las funiculas, no lo podían hacer más que de una manera fragmentaria, como los arbotantes, eran sacadas fuera del templo, con lo cual estos elementos más necesarios quedaban a la intemperie, más vulnerables y expuestos a deteriorarse." $\left.{ }^{212}\right)$

Además lo conceptúa de postizo -al entender que la mecánica estructural va por un lado y la ornamentación geometrizada es un añadido "que se podría afeitar con una navaja sin que se resintiese la estructura"213-, y considera que la radicalidad que suponía la utilización de las superficies regladas mejoraría notablemente el funcionalismo estructural y en consecuencia la dignidad del edificio. Sin embargo prevé que su percepción estructural no va a ser entendida en la Exposición Universal de Paris por la crítica francesa, muy influida por el neomedievalismo de Viollet-le-Duc, razón por la cual no le afecta una cuestión de nombres para definir su búsqueda denominándoal perfeccionamiento del gótico.

Gaudí ataca el concepto, diciéndole a Bergós que el Dictionaire raisonné de l'Architecture violletiano no es ni diccionario ni razonado, o que las restauraciones neogóticas de San Sernin o en N $\mathrm{a}$ S $\mathbf{a}$ del Taur, en Touluse, reflejan un monumentalismo carente de carácter religioso y desprovisto de rigor ${ }^{214}$, opiniones que hoy dia serian ampliamente suscritas por la gran mayoría de los estudiosos de la Arquitectura.

212 Cf. Puig Boada, I. (1981) El Pensament de Gaudí: compilació de textos i comentaris. Barcelona. La Gaya Ciencia. P.106. L'estil gótic II: Totes les formes $i$ tots els elements resistents del Temple es basen en les funícules de les forces actuants, per la qual cosa hom pot prescindir dels contraforts. L'art gótic no se separà mai de les voltes i dels arcs de generació circular, i aquelles que, per tal de seguir aproximadament les funícules, no hop odien ésser més que d'una manera frgmentària, com els arbotants, eren tretes fora del temple, amb la qual cosa aquests elements més necessaris queden a la intemperie, més vulnerables $i$ exposats a deteriorar-se."

${ }^{213}$ Puig Boada, Isidre. (1981). El Pensament de Gaudí. Barcelona. La Gaya Ciencia P.107. Estil gótic IV: "L'art gótic consta de dues coses ben separades: l'una és una estructura mecánica sola, i al damunt, afegida, una ornamentació geometrizada; amb una navalla podriem afaitar l'ornamentació, sense que se'n resentís gens l'estructura."

214 Puig Boada, Isidre. (1981). El Pensament de Gaudí. Barcelona. La Gaya Ciencia P.112. Viollet-le-Duc: “EI diccionari de Viollet-le-Duc no és tal diccionari; sinó un conjunt de monografies incompletes, reduïdes en forma enciclopédica per conveniencia editorial. 
El no defiende un tradicionalismo arqueológico, romántico o monumental sino lo que denomina tradicionalismo vivo fundado en la liturgia -que podria explicarse en el caso de la arquitectura de culto como una experiencia liturgica del espacio arquitectónico que deviene tras un largo proceso de histórico en tradición viva- poniendo de ejemplo la Seo de Mallorca, o-que se fundamenta en un proceso intelectual libremente imaginativo del hábitat residencial- como el proyecto de Bellesguard. En este sentido él mismo recuerda, reconoce y así se lo manifiesta a Puig Boada (Gaudí ens parla), haber utilizado estilos históricos en su trayectoria profesional, pero asegurano que se ha situado frente a ellos como dentro de lo más inherente de su concepción arquitectónica, con una actitud respetuosa hacia sus características pero al mismo tiempo libre en la imaginación de las formas, ausente de mimetismos. Gaudí reconoce su admiración por el estilo bizantino cuando asegura que él ha venido a coger la arquitectura donde la dejó el estilo bizantino, entendiendo esta aseveración como referida a la arquitectura eclesiástica bizantina, a su capacidad para la creación de espacios cultuales ordenados y centralizados en su principal foco -el altar- y al empleo de la cúpula como elemento compositivo y constructivo predominante.

No hay más que recordar el comentario que hace a Bergós (y recoge Puig Boada) respecto de la cúpula renacentista de las iglesias, que le agrada por lo que significa de centralidad en el crucero del edificio pero a la que achaca defectos acústicos de importancia para el culto ya que presenta resonancias incompatibles con la voz del oficiante y la audición de los que asisten; y para mejorar la acústica de estas cúpulas propone diversas soluciones según se hayan construido de una manera u otra. ${ }^{215}$ Respecto del cimborio, resalta su función de iluminar el centro del crucero, pero también su incidencia como hito o referencia exterior del edificio, siendo la iluminación de las iglesias un tema al que dedica también numerosas reflexiones criticando que se trate banalmente sin considerar su relevancia para el culto -pues su exceso o defecto impiden la adecuada visualización de los oficios y ceremonias- ${ }^{216}$. Considera que ésta ha de ser la necesaria y por tanto ser estudiada en función de cada lugar concreto del templo: no es igual en un espacio de recogimiento que sobre el altar, iluminando la nave o enfatizando algún elemento arquitectónico o función liturgica.

\footnotetext{
${ }^{215}$ Puig Boada, Isidre. (1981). El Pensament de Gaudí. Barcelona. La Gaya Ciencia P.117. Arranjament acústic de les cúpules: "S'aconsegueix posant pilastretes que rompin la continuïtat del cilindre o tambor; si la cúpula és una volta bufada o una mitja taronja sobre petxines, la solución és fer les petxines convexes (el mateix trinagle curvilini esfèric omplert amb un casquet esfèric convex, ja que l'esfera convexa és dispersant, així com la cóncava és concentrant). El fet d'haver-hi superficie convexa i cóncava és, a més, motiu d'harmonia, perquè aquesta, per la seva existencia, necesita la presencia de tots els elements positius i negtius."

${ }^{216}$ Puig Boada, Isidre. (1981). El Pensament de Gaudí. Barcelona. La Gaya Ciencia P.118. Il.luminació dels temples: "En els temples tot ha d'esser ponderat i regulat per les sàvies lleis de la litúrgia, sense adulteracions. De la mateixa manera que han estat corregits els abusos en la música teatral que s'havia introduit al culte, també s'hauria de fer una depuració en les arts plàstiques dins dels temples."
} 
Son años en su idea de que la Liturgia ordene el espacio y el tiempo ha pasado del terreno de las intuiciones y discursos teóricos a asentarse en el de las convicciones sustentadas por las experimentaciones proyectuales y constructivas. La palabra tiene una función capital en el tiempo y como vehículo de la oración, resaltando que por ello no puede faltar su adecuado estudio en la Sagrada Familia, haciendo mención de la importancia del coro (a la manera clásica distribuido en hombres, mujeres y niños) y de su tratamiento como prevalencia litúrgica del texto sobre la música. No es que se olvide de ésta sino que la sitúa en su lugar litúrgico posponiendo su valor musical o temática religiosa a la función de acompañamiento del culto, en su orden y en sus tiempos, facilitando la participación de los fieles. ${ }^{217}$ No sería posible este planteamiento prevalente de la palabra sobre la música, la consideración de ésta como música sacra al servicio de la liturgia, y la cuidada disposición de un coro envolvente y ordenado si no hubiese estado al tanto de lo que propugnaban Pio $X$ y el Movimiento Litúrgico. Como se significa explícitamente en el Motu Proprio Tra le sollicitudini (1903), el canto y la música son partes integrantes de la Liturgia no por que tengan temática religiosa sino porque se constituyen en respuesta del pueblo, que no podía participar en un dialogo en lengua vernácula a las plegarias y textos del Ritual de la Misa. Y esto lo tiene muy en cuenta Gaudí ${ }^{218}$ que leía el Manual Liturgico de Solans (8a edición, 1901) el cual preconizaba de obligado cumplimiento el Ritual Romano y el Ceremonial de los Obispos, constantemente releídos por nuestro arquitecto. Es más, da idea de la fidelidad de Gaudí a estos libros y documentos de la Iglesia el hecho de que se apuntara al curso de canto gregoriano del Padre Suñol, que era uno de los muchos que se realizaron en toda la Cristiandad a instancias de la recién creada Academia Pontifica de la Música que se constituyó en Roma tal y como demandaba el Motu Proprio del Papa. En el se instaba al restablecimiento del canto gregoriano y a la creación de las Scholae Cantorum en las principales iglesias, basílicas y catedrales, y eso es lo que sigue al pie de la letra Gaudí.

La neta distinción de los diferentes espacios -liturgicos o sirvientes- del edificio, con el conocimiento de su uso según se trate de un aula celebrativa o de la enseñanza de la doctrina o catequesis -que sitúa fuera de aquella en locales de una entrecubierta a la que se pueda acceder mediante ascensores (por lo cual se plantea que las cubiertas no sean de madera, fungibles, sino pétreas, incluso disponiéndolas en dos capas con espacios utilizables entre ellas)- y el tratamiento de los recursos espaciales, acústicos, lumínicos, etc. que afectan a la palabra, el canto y la música constituyen aspectos clave de la madurez profesional de Gaudí en el campo de la arquitectura cultual.

\footnotetext{
217 Puig Boada, Isidre. (1981). El Pensament de Gaudí. Barcelona. La Gaya Ciencia P.143. L'espai i el temps junts: "els oficis divins, la litúrgia, és l'acoblament d'ambdues: l'acció, resum de l'art plàstica de l'espai, i del temps, la veu, la música, el cant, les campanes.

218 Puig Boada, Isidre. (1981). El Pensament de Gaudí. Barcelona. La Gaya Ciencia P.160: “Abans, dins de les esglésies, es feien representacions dramàtiques, els actes sacramentals, els quals, encara que tinguessim un fons religiós, no eren actes pròpiament religiosos".
} 
Son muchas las aseveraciones que hace a Martinell, Bergós, Puig Boada respecto de la geometría, las curvas, superficies regladas, las catenarias y funículas, el hormigón armado, la flexión y el sentido constructivo -cuestiones desarrolladas en los proyectos de la Iglesia de Sta. Coloma y en la Sagrada Familia que han sido profusamente estudiadas por Jordi Bonet (El modulat geometric del Temple de la Sagrada Familia), Jordi Fauli (EI Temple de la Sagrada Familia) y Josep Gomez-Serrano (Sagrada Familia XXI/ Gaudí ara) entre otros ${ }^{219}$, pero todas ellas veremos que están orientadas a un fin concreto, el de la visión unitaria y completa del edificio-iglesia y su espacio de culto.

Intentaremos ver cómo su implicación con el carácter expiatorio del proyecto de la Sagrada Familia, acomodándose a estudiar sin prisas y de acuerdo con la disponibilidad cambiante de fondos económicos las soluciones y detalles que quiere llevar adelante llega a constituir un medio adecuado para llevarlo a cabo proporcionando los tiempos y los proyectos colaterales con los que ensayar su pensamiento arquitectónico. Gaudí refiere que en la Sagrada Familia todo es providencial, ¿por qué no incluir en esa convicción los tiempos, los ensayos, las pruebas, los hallazgos,....si están dirigidos a materializar la idea de lo que quiere ser el edificio-iglesia? Después de todo si las catedrales medievales necesitaron centurias y las iglesias modernas tan sólo algunos años, ¿no es posible entender que en el siglo XX se hayan necesitado décadas para establecer un puente entre el decaimiento litúrgico del siglo XIX y el Vaticano II?, o ¿entre los historicismos y el racionalismo? ¿Cómo expresar en unas pocas décadas una concepción tan unitaria $y$ completa del espacio celebrtativo? En este sentido quizá no se haya analizado todavía lo que supone este proyecto globalmente en el ámbito de la arquitectura eclesiástica. Su simbología, su proceso constructivo, su significación artística, ... son aproximaciones válidas pero que no agotan la comprensión de lo que significa la Sagrada Familia para el diseño de un espacio de culto. Queremos ver en los siguientes apartados cómo este proyecto revoluciona el fenómeno de las iglesias votivas del siglo XIX y también el diseño del espacio celebrativo, anticipándose a la influencia del Quickborn en el diseño de las iglesias alemanas, aun cuando el ejemplo gaudiniano quedara parcialmente oculto por el desconocimiento, el rechazo o las visiones utilitaristas, que han impedido hasta la fecha analizar y extraer sus aportaciones más valiosas.

\footnotetext{
219 Cf. Bonet i Armengol, J. (2001) El modulat geométric del Temple de la Sagrada Familia. Barcelona. Lunwerg. Recoge el proceso estructural y desarrollo geométrico por ordenador de la última solución del proyecto de la Sagrada Familia, con abundancia de dibujos y representaciones; Faulí Oller, J. (2006). El Temple de la Sagrada Familia. Madrid. Aldeasa. Presenta una interesante cronología de plantas y secciones del proyecto de Gaudí, además de establecer una correspondencia entre su estrategia arquitectónica de desarrollo del proyecto y la concienzuda disposición estructural del mismo; Gomez-Serrano, J. y AA.VV.(2008). Sagrada Familia XXI/ Gaudí ara. Barcelona. Ed. UPC. Se centra en una explicación detallada de los estudios, procesos y dibujos 2D y 3D por ordenador de los principales elementos de la estructura última de la Sagrada Familia, cómo se ha llegado a desarrollar el proyecto gaudiniano para su construcción.
} 


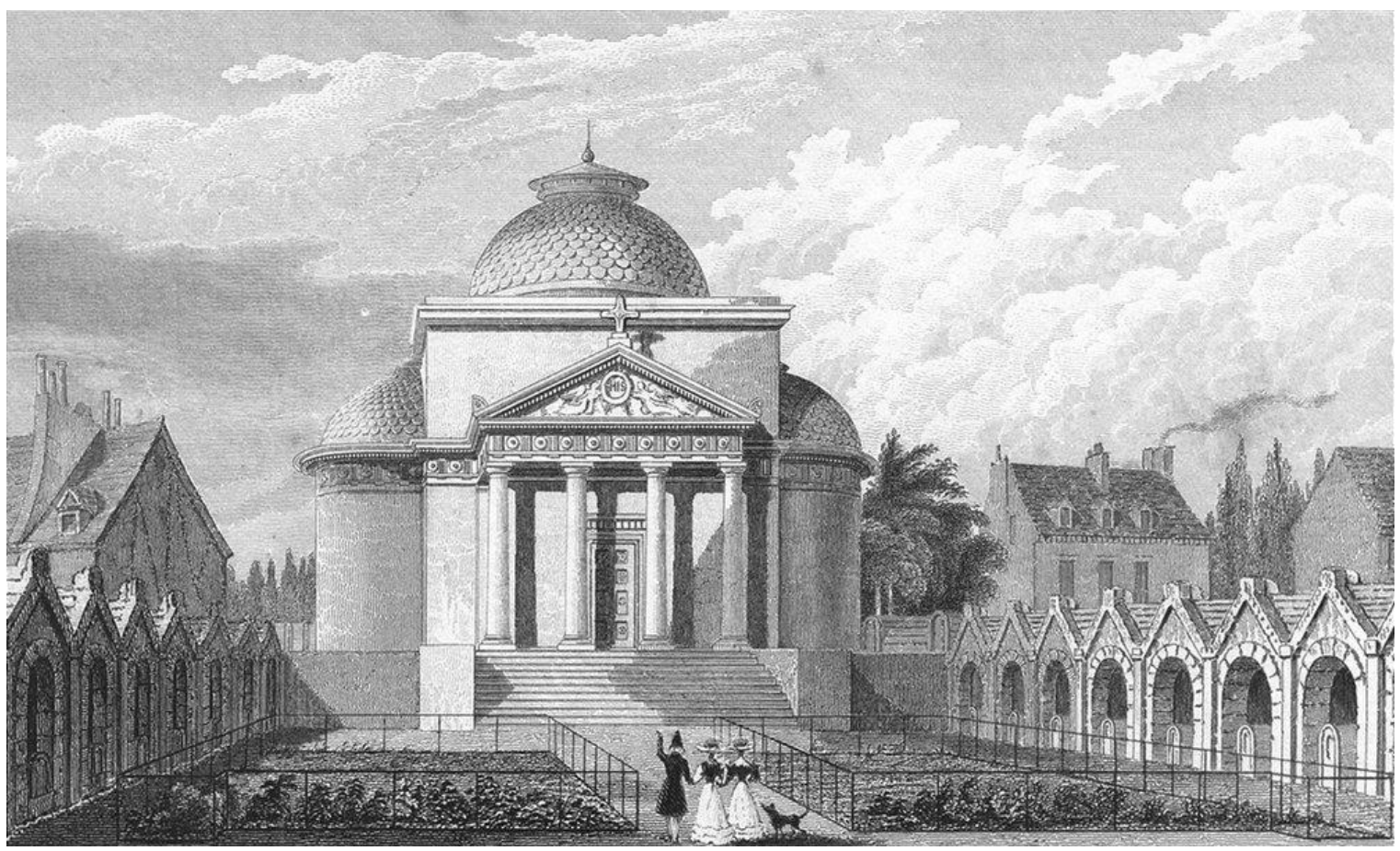

Chapelle Expiatoire, Paris, promovida por Luis XVIII en 1816-1824, en memoria de Luis XVI y Ma Antonieta, según grabado de 1871 . Fuente: antiquaprint gallery. 


\section{CAPITULO 5 APROXIMACIÓN A LA ARQUITECTURA RELIGIOSA DE GAUDÍ.}

\subsection{Panorama de la Arquitectura religiosa europea en tiempos de Gaudí: del historicismo a la búsqueda de un lenguaje nuevo.}

Durante siglos la arquitectura eclesiástica ha sido la que mayor atención ha suscitado en las diferentes culturas, permitiendo ensayar las más variadas soluciones a todo tipo de problemas arquitectónicos, tanto en el plano constructivo como estilístico. La realización de iglesias, monasterios y catedrales en Europa fue el motor de la economía mediante el desarrollo de los oficios artesanos, configurando núcleos activos de población en su entorno inmediato y creando las bases de gran número de las profesiones que hoy conocemos. No es menos cierto que en el ochocientos la arquitectura eclesiástica se mantenía como uno de los sectores de la construcción más prolíficos, incorporando en muchos casos los nuevos materiales y métodos de organización surgidos de la revolución industrial pero, sobre todo, siendo campo de experimentación de las diferentes corrientes de pensamiento respecto del estilo a seguir, el objetivo a buscar con su realización, e incluso la forma de promoverla desde las distintas iniciativas públicas o privadas.

Edificios de uso cultual, cenobítico, docente, asistencial, etc. emergen durante el siglo XIX en Europa al amparo de la iniciativa de instituciones y órdenes religiosas o vinculadas a asociaciones y promotores civiles impregandos de un fuerte ideario cristiano que se lanzan a una considerable actividad edificatoria. Algunos de ellos son promovidos como hitos monumentales con el propósito de cumplir algún voto público o privado, o en expiación de alguna gran causa de índole moral; otras veces, las más, se corresponden con el auge que experimenta el sentimiento religioso a raíz de las convulsiones socioeconómicas y politicas posteriores a la Revolucion Francesa con motivo de la restauración de régimenes más conservadores, dando satisfacción sin embargo a un amplio abanico de necesidades sociales todavía no atendidas por la sociedad civil. Este es el caso de los colegios e instituciones docentes, los orfanatos y asilos, los hospitales y casas de caridad, etc.

También las ideas de renovación urbana y los criterios higienistas en la trasformación de las ciudades, las edificaciones y actuaciones urbanisticas surgidos de los intentos de aplicación del socialismo utópico de Fourier y muchos otros, y la propia visión de la Iglesia acerca de la cuestión social, explicitada en la encíclica social Rerum Novarum de Leon XIII (1891), serán acicates para una nueva forma de plantearse la arquitectura de índole eclesiástica. 


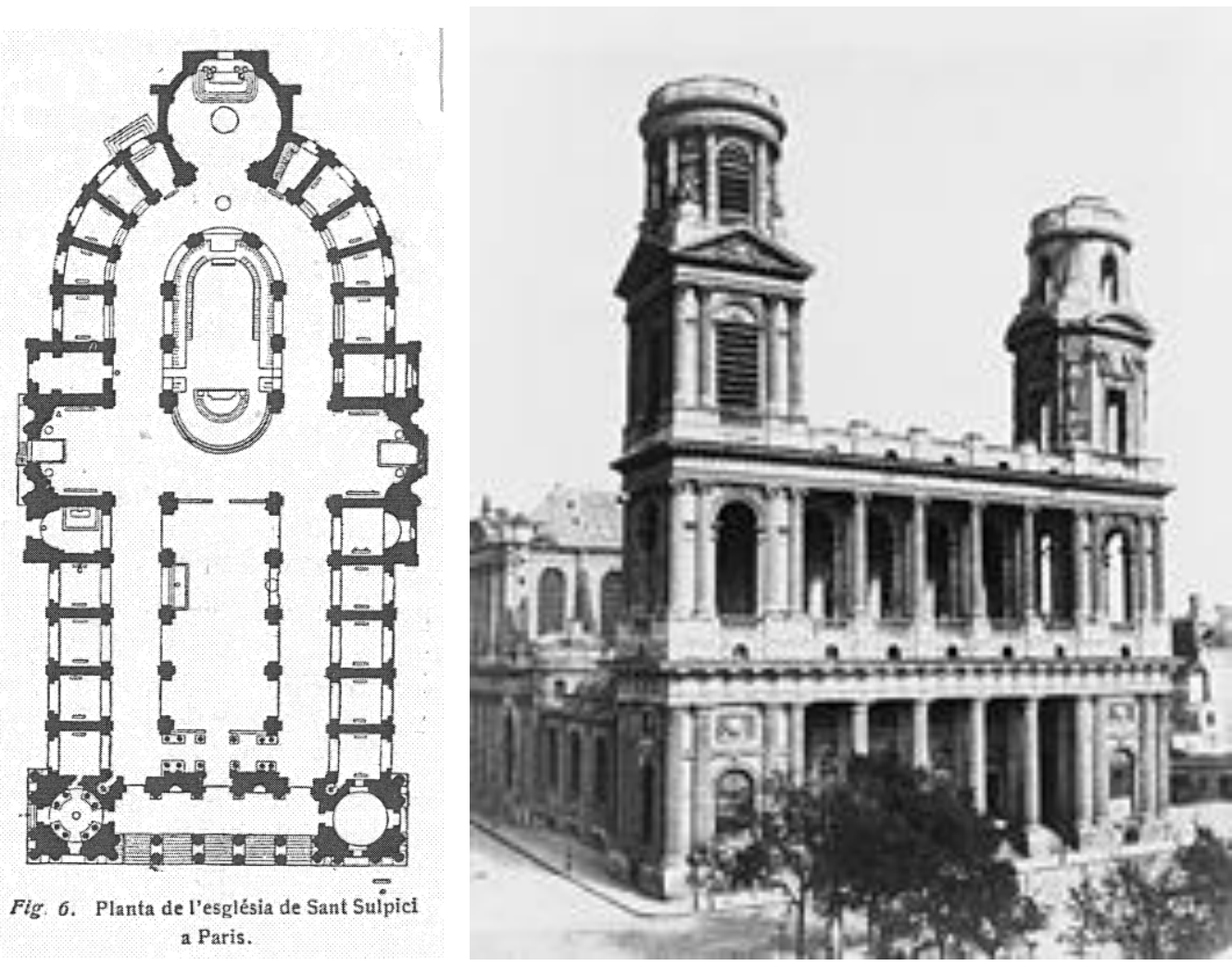

San Sulpicio, Paris, J.I. Hittorf (1824-44). Planta. Fuente: Anuario de los Amigos del Arte Liturgico, Barcelona. 1925. Fotografia de 1851-1870 realizada por Edouard Baldus.
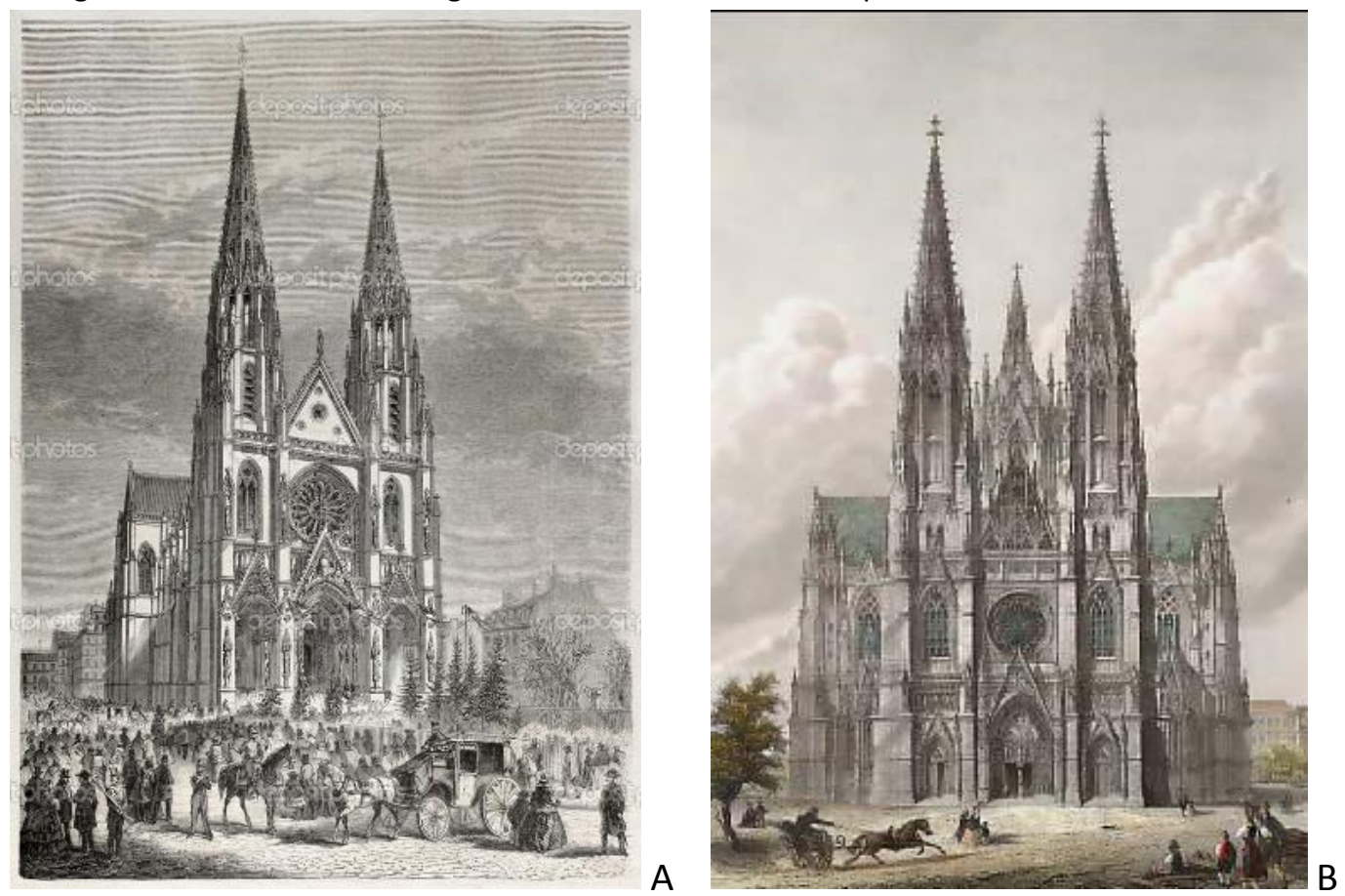

Iglesia de St. Clotilde de Paris (A) que sirvió de modelo para la Iglesia votiva de Viena (B), según un grabado publicado en L'Illustration, journal unversel, Paris, creado por Fichot y Gaildreau. Fuente: Foto de marzolino_deposit potos. Foto de Antique-prints.de 
En el ambiente de deseos de reparación con el que comienza el siglo XIX en Francia Luis XVIII promueve la Chapelle Expiatoire (1816-1824) en memoria de los reyes borbónicos Luis XVI y Ma Antonieta ajusticiados por la Revolución Francesa, y se demanda un clero nuevo que devuelva a los fieles franceses su sentido de pertenencia a la Iglesia universal, olvidándose de pasados imperios particulares. Ejemplo de esta situación es el Seminario e iglesia de Saint Sulpice, construcción clascista iniciada en el siglo XVII, que presenta una marcada disposición longitudinal y simétrica con una capilla dedicada a la Virgen al final del ábside y un amplio coro en el presbiterio rodeando la presidencia; también la iglesia de Saint Vincent-de-Paul, de J.I. Hittorf (1824-44), ejemplo de profusa policromía interior, presenta un amplio presbiterio con un calvario como motivo iconográfico encima del altar mayor.

Rechazado el normativismo y el academicismo imperantes desde la llustración, el Neomedievalismo, y más concretamente el Neogótico, hace furor como estilo "oficial" de la abundante y variada producción arquitectónica de este siglo. El auge político de la Europa de las nacionalidades se traduce en una búsqueda romántica de un estilo artístico propio que se asume y proclama como nacional, como en el caso del gótico en la Alemania del II Imperio. En el ámbito eclesiástico no sólo la Iglesia Católica sino todas las confesiones cristianas, llegan a identificarse de tal manera con el neogoticismo que lo consagran con el verdadero estilo cristiano por excelencia, aquel que explicita la verdad del mensaje cristiano en contraposición a otros estilos que se consideran más paganos.

Los edificios cristianos de culto experimentarán el auge de un lenguaje historicista como única expresión artística apta para la neseñanaza y vivencia de la religión. La recreación y combinación de estilos del pasado, especialmente el gótico se convierte así en el lenguaje romántico de la terminación de importantes catedrales medievales, de nuevas fachadas, e incluso de las realizaciones "ex novo" que se acometen en esos años. Como ha señalado Hitchcock ${ }^{220}$ las iglesias inglesas, alemanas y americanas eran mayormente neogóticas en este periodo de mitad del siglo XIX, con sus variantes nacionales en la planta, la ornamentación y los materiales, y respondían a un patrón común de planta rectangular o de cruz latina con una torre campanario super estilizada dispuesta según el eje central longitudinal a modo de nártex de entrada. Francia y en general la mitad sur de Europa se decantan más por una planta tradicional de cruz latina de mayor envergadura y una mayor fidelidad al gótico francés de L'ille de France, dejándose sentir su influencia por los países de tradición católica. Así Sainte Clotilde (1846-57), de Gau y Ballu, inspirará la iglesia votiva de Viena (Votivkirche).

${ }^{220}$ Cf. Hitchcock, H.R. (2008). "Arquitectura de los siglos XIX y XX". 8 Edición en castellano. Madrid. Ediciones Cátedra. 

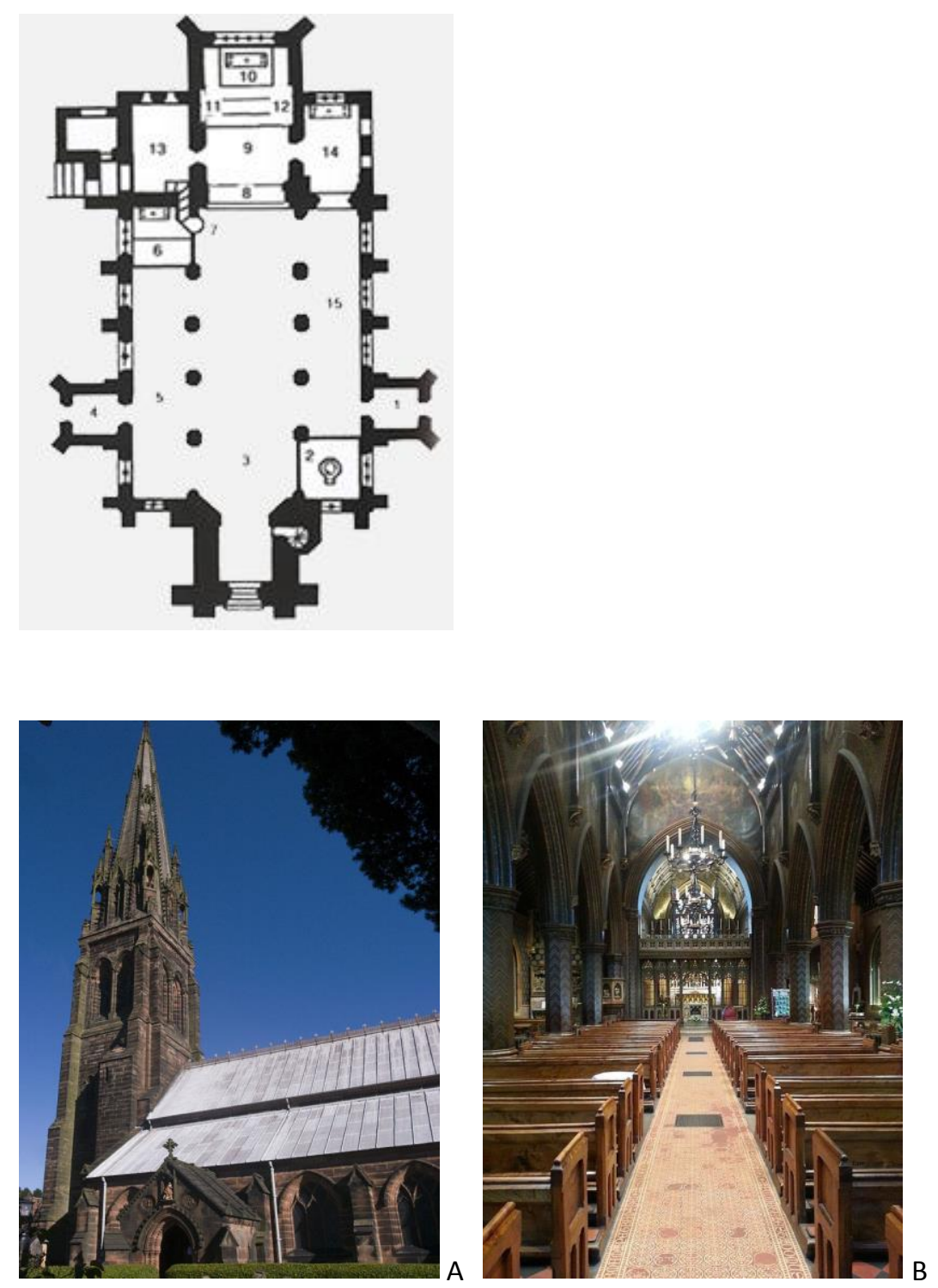

Planta, exterior e Interior de St. Giles, en que se ve el presbiterio delimitado por un cancel, según proyecto de Augustus Weby Puguin (1840-46). Fuente: The St Giles Catholic Church Website
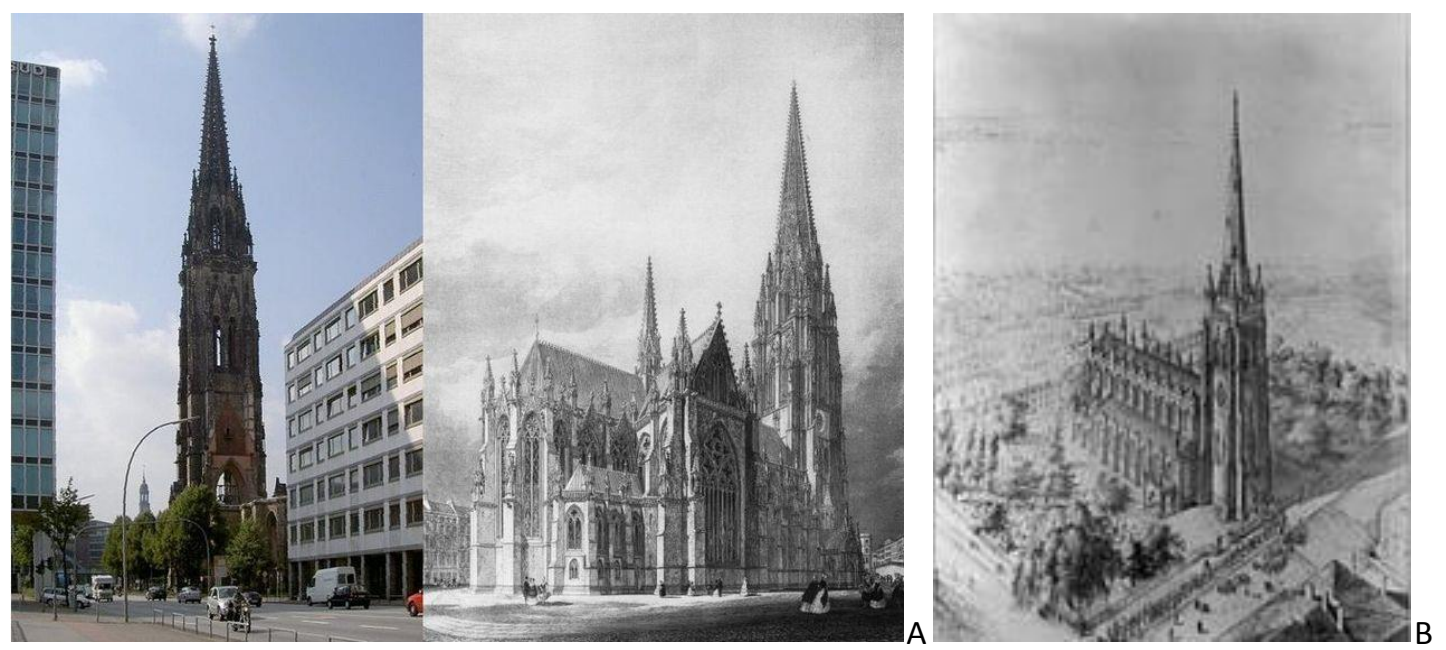

A: St. Nikolai Kirche, Hamburg (1844-1874) George Gilbert Scott. B: Trinity Church, New York (18431846) Richard Upjohn 
Ejemplos sobresalientes de esta asunción de lo gótico en las arquitecturas civil y religiosa del siglo XIX se pueden encontrar en las ideas y proyectos de A. Welby Puguin (18121852). Su extensa produccion, que va desde obras parciales en presbiterios de Iglesias hasta el diseño completo de éstas, de conventos y hospitales, presenta tres casos señalados a modo de hitos en la profundización de su obra: la intervención decorativa en el proyecto de Charles Berry para el Parlamento (1834), que dispone de un detallado tratamiento de las fachadas a modo de portadas medievales que se articulan escenográficamente siguiendo pautas totalmente barrocas, y que supondrá la notoriedad para Puguin; la catedral de St. Chad de Birmingam (1937) inspirada en las Hallenkirche alemanas con un amplia nave interior de considerable altura (más de dos veces y media de la anchura), en la cual destaca el amplio programa decorativo y la amplitud de la cripta para enterramientos; y la iglesia de St. Giles (1841), en la cual el programa de iglesia salón se precisa con un cuidado estudio de los diversos recintos liturgicos y una completa policromia interior. Baptisterio, presbiterio, sacristia, capilla del Sacramento, capilla de la Virgen, disponen de su lugar preciso dentro del aula celebrativa.

Según pone de relieve Genís i Terre, Puguin identifica el gótico con el único estilo capaz de alojar con dignidad los espacios de culto cristianos coincidiendo con Hegel en que lo que identifica el infinito en la arquitectura gótica es la inmaterialidad del espacio. ${ }^{221} \mathrm{Y}$ Pere Hereu, al estudiar las teorías arquitectónicas que se daban en la Escuela de Barcelona en tiempos de Gaudí ha señalado la identificación de las lecciones de Rogent con las tesis hegelianas respecto de la identificación de la organización estructural gótica con la arquitectura cristiana -confirmada según el director de la Escuela por las explicaciones de Viollet-le-Duc- pero en clara contradicción con las realizaciones del momento, desprovistas de ideales y contenidos, meras copias del pasado. Rogent influiría en Gaudí y Domenech i Montaner, de tal modo que aquel reflejaría sus inquietudes en el Manuscrito de Reus y éste publicaría su famoso artículo "En busca de una arquitectura nacional". ${ }^{222}$

En 1864-67 Viollet-le-Duc había hecho una iglesia parroquial en un suburbio de Paris, Saint-Denys-de-l'Entrée, que a diferencia de otras iglesias neogóticas del momento es totalmente abovedada y muy bien iluminada (gracias a la anchura de las crujías que disponen grupos de ventanas sobre una especie de triforio).

\footnotetext{
${ }^{221}$ Cf. Genís i Terre, J. (2006). Els fonaments ideològics de l'Arquitectura religiosa del Gaudí de maduresa. Barcelona. Tesis Doctoral Universidad Pompeu Fabra.

${ }^{222}$ Cf. Hereu, P. (1990). “La Idea d'Arquitectura a l'Escola que Gaudí conegué”, en AAVV. Gaudí i el seu temps. Barcelona. Barcanova.
} 


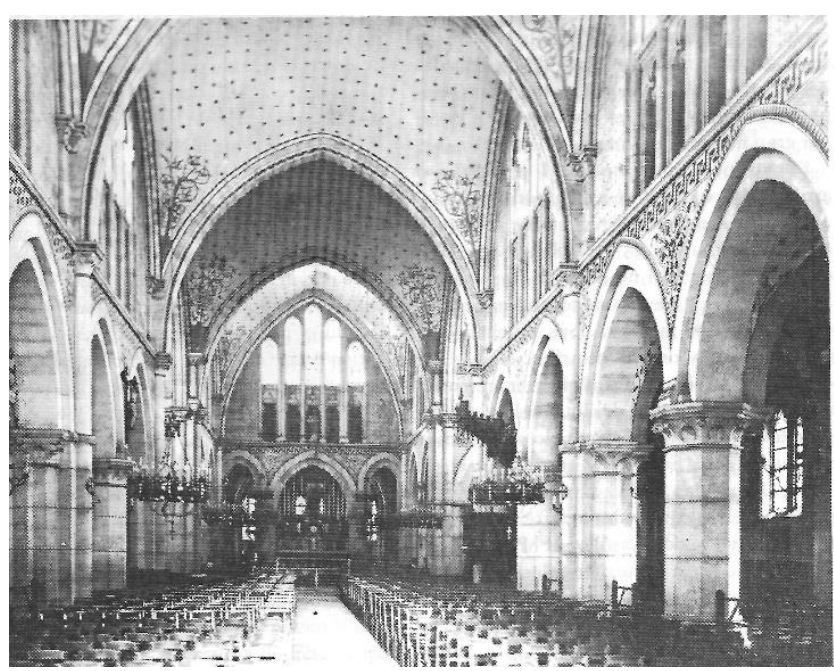

Iglesia de Saint Denis de l'Entrée, Paris (1864-1867). Viollet-le-Duc. El módulo que conforma la secuencia de bóvedas de crucería de la nave central decorado con motivos florales se corresponde con los correspondientes a los triforios realzando la pretendida linealidad de la trasmisión de fuerzas de los arcos.
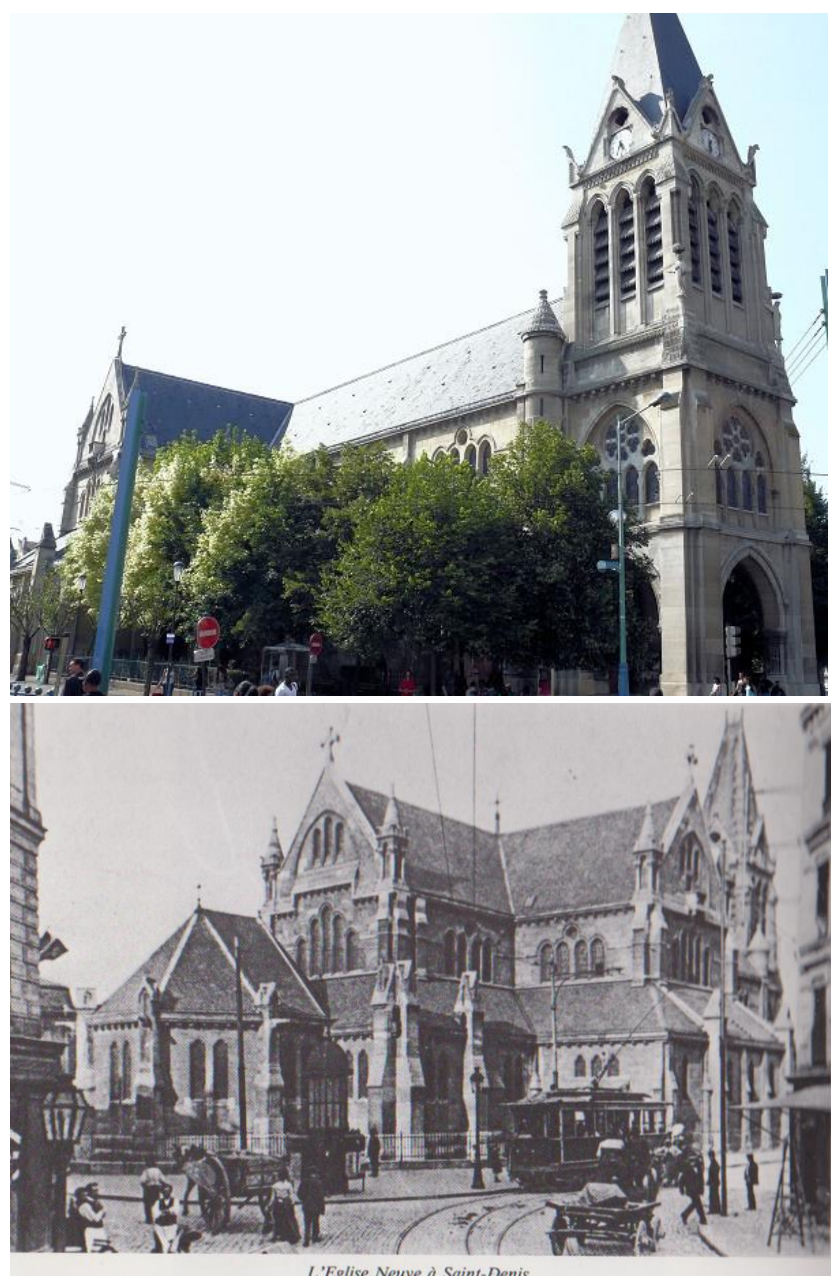

Fachada principal y Vista del transepto y ábside, de Saint Denis de l'Entrée. Las fachadas se organizan sobre la base de paramentos planos segmentados Mediante pilastras o contrafuertes prolongados como pináculos decorativos. 
Bien puede considerarse esta iglesia violletiana como la plasmación de las ideas que exponía en sus Entretians su l'architecture que publicó en dos volúmenes en 1863 y 1872 que tanta influencia tuvo en la arquitectura del siglo XIX y que fue leído por Gaudí (probablemente en francés) durante sus años de estudio en la Escuela de Arquitectura. Benévolo afirma que Viollet-le-Duc sigue una línea neogótica racional por la claridad del sistema constructivo y la economía de soluciones así como por lo que entiende como exacta correspondencia a los programas distributivos, y en esto estaría en una posición opuesta a la visión romántica o sentimental de la misma forma medievalista; a las pretendidas leyes generales de la arquitectura mantenidas por las Academias opondría otras menos ambiciosas pero más adecuadas a la realidad, el uso apropiado de los materiales y la obediencia a las necesidades funcionales. ${ }^{223}$ Sin embargo, es bien conocida la decepción que causa en Gaudí la visita a San Sernin de Touluse criticando las realizaciones violletianas por su falta de rigore interpretación romantica del gótico por incorporación de elementos nuevos no existentes.

Casi por los mismos años, entre 1868-1875, se construye en Viena la iglesia parroquial de № Sa de la Victoria (Maria vom Siege), de Firedrich von Schmidt, respondiendo a un tipo de planta de salón cubierta con bóveda de ladrillo, con naves laterales de la misma altura que la nave central, muy al estilo medieval germánico. En este caso, Schimdt plantea un octógono sobre el que se dispone una cúpula de nervios con capillas hexagonales agrupadas alrededor de un ábside poligonal. El interior, complejo en las trazas de la planta, presenta una gran diafanidad y considerable volumetría, debido a su enorme cúpula central, con una abundante policromía. El exterior presenta una imagen ciertamente unitaria y verticalizada por la cercanía entre cúpula y campanarios, pero también por la profusión de capillas, torres y edículos alrededor del volumen central de la cúpula.

En el entorno más inmediato de influencia en Gaudí está la obra arquitectónica de Joan Martorell, arquitecto ecléctico de dilatada experiencia en el ámbito de la arquitectura religiosa. Martorell era conocedor de la arquitectura europea del momento y ejercía de arquitecto diocesano en Barcelona. En la iglesia y convento de las Adoratrices en Barcelona (1874-1875) se percibe una gran libertad en la composición de la fachada, con una utilización de todo tipo de elementos decorativos pero sobre todo utilizando libremente una torre campanario central muy estilizada que no respondía a ninguna tradición gótica española o mediterránea sino más bien está en la línea de las realizaciones historicistas del area anglogermana.

\footnotetext{
${ }^{223}$ Cf. Benevolo, L. (1999). “Historia de la Arquitectura Moderna”. 8a edición en lengua castellana. Barcelona. Gustavo Gili.
} 

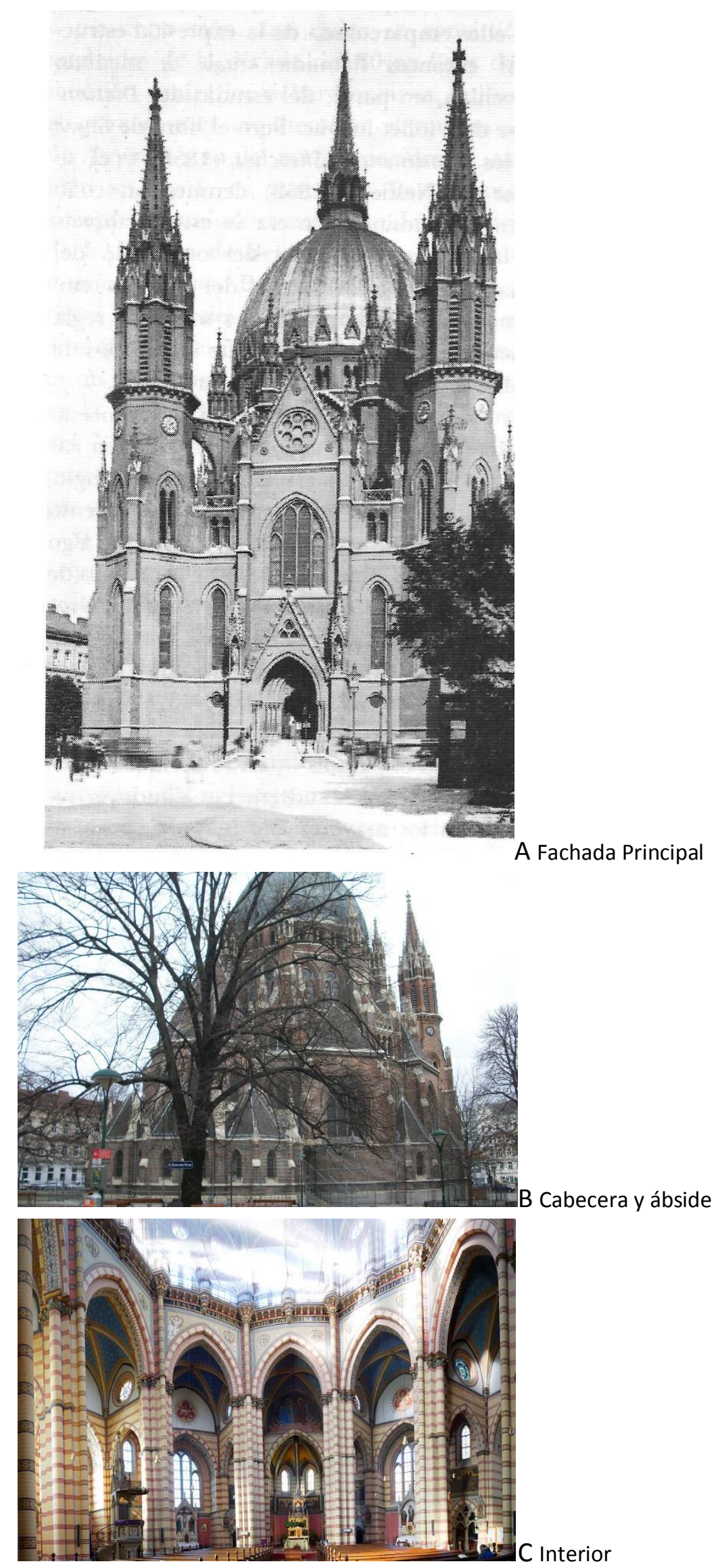

Na Sa de la Victoria (Maria vom Siege), 1868-1875, de Firedrich von Schmidt. 
A diferencia de éstas iglesias historicistas centroeuropeas y de la violletiana St. Denis de l'Entrée, en las iglesias de Martorell se aprecia una gran imaginación compositiva integrando la torre central en el plano y ritmo de la portada, sin renunciar a plantear otras secundarias como enmarcando sus extremos. En la iglesia de las Salesas (1882-85) además destaca el movimiento de la portada descomponiendo su plano en diversos cuerpos, niveles y grupos escultóricos le asemejan también a otras realizaciones más eclécticas como la de Maria vom Siege de F. von Schmidt, terminada apenas siete años antes. Este tratamiento plástico de la fachada, la composición con sendas torres laterales que acompañan a aquella en un plano retrasado y la disposición de una galería de arcos como remate de fachada del volumen de la nave central, no entran en los esquemas repetitivos del historicismo goticista sino que avanzan una libertad de lenguaje que busca realzar el edificio mucho más allá de lo que cualquier medievalista hubiese podido prever.

El campanario central, utilizado por Viollet-le-Duc en Saint Denis-de-l'Entrée no es un cuerpo estático adosado a la nave de la iglesia sino la manifestación externa de la nave con un dinámico planteamiento de vanos, volúmenes y decoración. La afición que muestra por las esquinas y ángulos le ayudan a obtener un mayor desarrollo escenográfico; las numerosas agrupaciones de ventanas y sus diferentes tipos (rosetones en los testeros, ventana ojival en la torre campanario, grupos laterales entre contrafuertes, cimborio, etc.) amplian la versatilidad de la diferente iluminación que se consigue; la recreación y libre utilización de elementos tomados del románico catalán en fachadas y crucero le conceden un punto de cercanía con la cultura en la que se inserta; la libre disposición escénica del fondo del presbiterio supone también una mayor libertad a la hora de interpretar el aula liturgica, etc., todo ello con gran cuidado del diseño y ejecución, indican una decidida voluntad de ruptura con los clichés y la inquietud por conseguir un resultado diferente dentro de un estilo personal.

También durante el siglo XIX proliferan las actuaciones en catedrales que habían quedado inconclusas, habían sucumbido parcialmente a los efectos destructivos de las guerras más recientes o simplemente eran objeto de modificación para adaptarlas al gusto romántico de la sociedad y a la emblemática proyección que se supone debía tener el templo más representativo de una urbe cosmopolita del ochocientos. Se pueden citar como ejemplo de la visión romántica del Medievo las intervenciones violletianas en las catedrales de Amiens y Paris, pero en mi opinión el caso más significativo para identificar la arquitectura gótica con un auténtico estilo nacional seria el de la catedral de Colonia (1840-1880). Su terminación en el más puro estilo ojival católico bajo el auspicio y protección del gobierno prusiano, mayormente luterano, y su extraordinario halo de influencia mediática dentro y fuera de Alemania hará que sea proclamado como estilo nacional oficial alemán para la arquitectura eclesiástica del momento. 


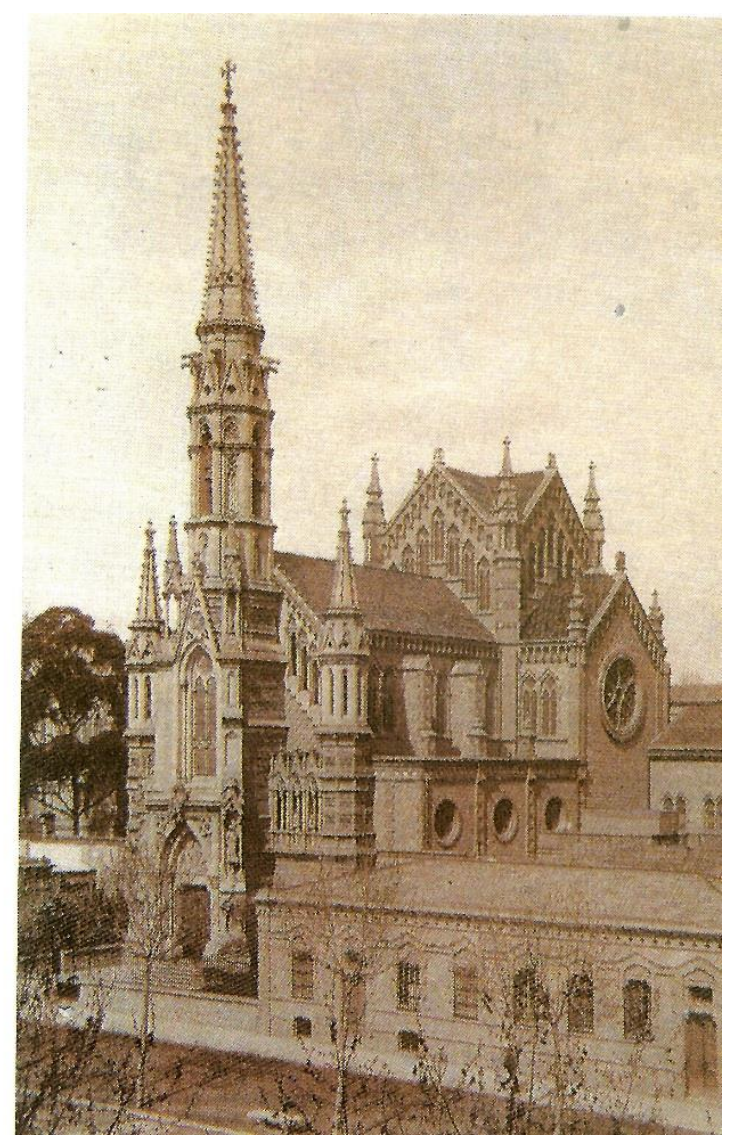

Iglesia de las Salesas en Barcelona (1882-1885) de Joan Martorell, contemporánea con el encargo de la Sagrada Familia a Antonio Gaudí. Fuente: Navascués, P. (1996) “Arquitectura Española 1808-1914”, en.Suma Artis, $H^{\underline{a}}$ General del Arte. Tomo XXXV. Madrid. Espasa Calpe.

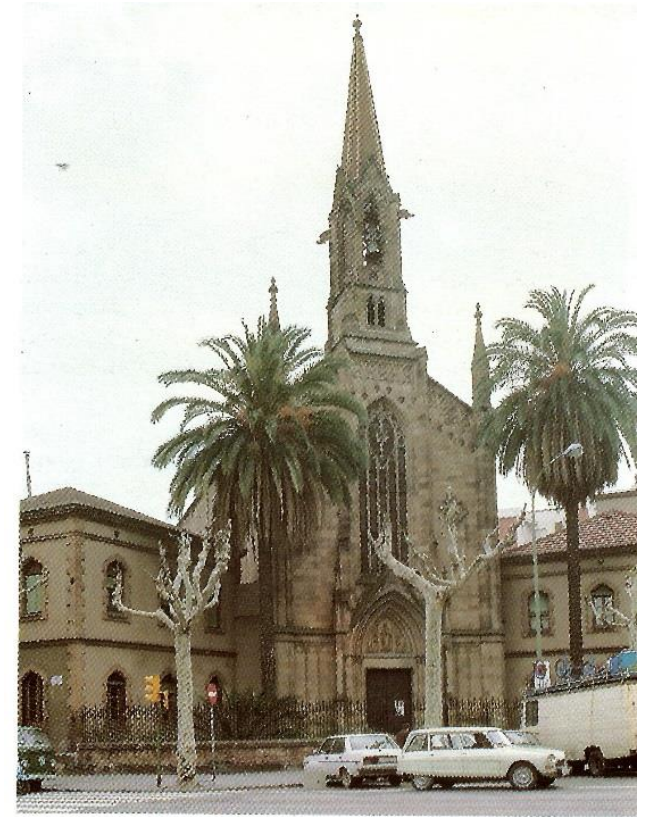

Fachada de la Iglesia y Convento de las Adoratrices, de Joan Martorell. A diferencia de las iglesias historicistas del area anglogermana y también de St. Denis de l'Entrée, los proyectos de Martorell integran la torre campanario en la portada sin renunciar a disponer otras secundarias en el mismo plano. Fuente: Navascués, P. (1996). “Arquitectura española 1808-1914” en Summa Artis, Historia General del Arte, Tomo XXXV. Madrid. Espasa Calpe. 
También la fachada del Duomo de Milán hay que verla como una actuación de prestigio, si bien en este caso unida a la reforma litúrgica del Presbiterio para su plena adaptación a las normas promovidas en su dia por San Carlos Borromeo después del Concilio de Trento. Esta tardia conclusión de la adaptación a unas normas surgidas 3 siglos antes da idea de la inercia y languidez en que había caído la liturgia católica en los siglos XVIII y XIX así como del entusiasmo que despertó en círculos eclesiásticos especializados la renovación surgida en los cenobios benedictinos centroeuropeos.

Siguiendo su estela, otras urbes europeas como Florencia (1878) o Barcelona (1887-90) se plantean la ejecución de fachadas para sus catedrales, que anteriormente no habían tenido o bien resultaban ahora de una pobreza exasperante en este ambiente de prestigio que presidia el comienzo de la industrialización. Es el triunfo de las ideas violletianas: la técnica al servicio de una idea romántica que muestre el prestigio de un poder temporal o espiritual. Significativo es el caso de Barcelona por la viva polémica que surge al debatirse en la prensa la conveniencia, para el proyecto de la fachada principal de la catedral, de una reproducción neogótica o de una reinterpretación del mismo estilo dentro de la imaginación modernista.

El cabildo catedralicio había convocado en 1882 un concurso de ideas para realizar la fachada principal, y la discusión se centraba entre las propuestas de Oriol Mestres, a quien apoyaba el mecenas de la actuación, y de Joan Martorell, arquitecto diocesano, a quien se había pedido su participación. El cabildo podia haber realizado la obra sin necesidad de recurrir a un concurso puesto que ésta iba a ser sufragada por un mecenas y se disponía de suficientes y preparados arquitectos diocesanos para realizar el proyecto pero, quizá por el deseo de adaptarse a una sociedad bulliciosa de ideas en la que proliferaban distintas corrientes y opiniones respecto de la arquitectura eclesiástica más adecuada o por una cuestión de imagen, el hecho es que se convocó un concurso restringido en el que Martorell tuvo una participación destacada. No es de extrañar que el cabildo, presidido por un obispo tan activo como Urquinaona, quisiera dar notoriedad a la actuación que pretendía para la fachada de la iglesia más emblemática de la diócesis mediante un concurso.

Tampoco lo es el hecho de que en este concurso los arquitectos que actuaban bajo la estela de Martorell quisieran ayudar a su maestro en un proyecto más imaginativo y libre de los cánones goticistas al uso. Tengase en cuenta que apenas cinco años antes (1877) Domenech i Montaner había publicado en la revista La Reinaixença su articulo a favor de una arquitectura moderna y nacional catalana que contemple la pluralidad y el respeto a lo particular como aspectos básicos. 

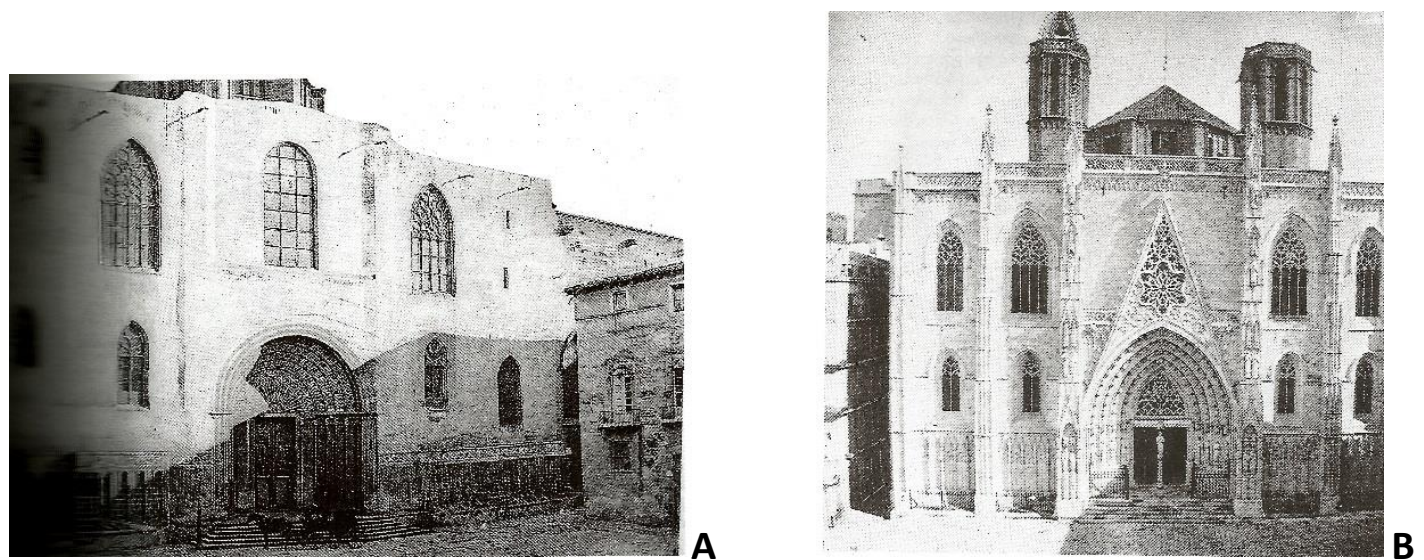

A: Fachada de la catedral de Barcelona antes de la intervención realizada en el siglo XIX. B: Propuesta de Oriol Mestres Fuente: Navascués, P. (1996) “Arquitectura Española 1808-1914", en.Suma Artis, $H^{\underline{a}}$ General del Arte. Tomo XXXV. Madrid. Espasa Calpe
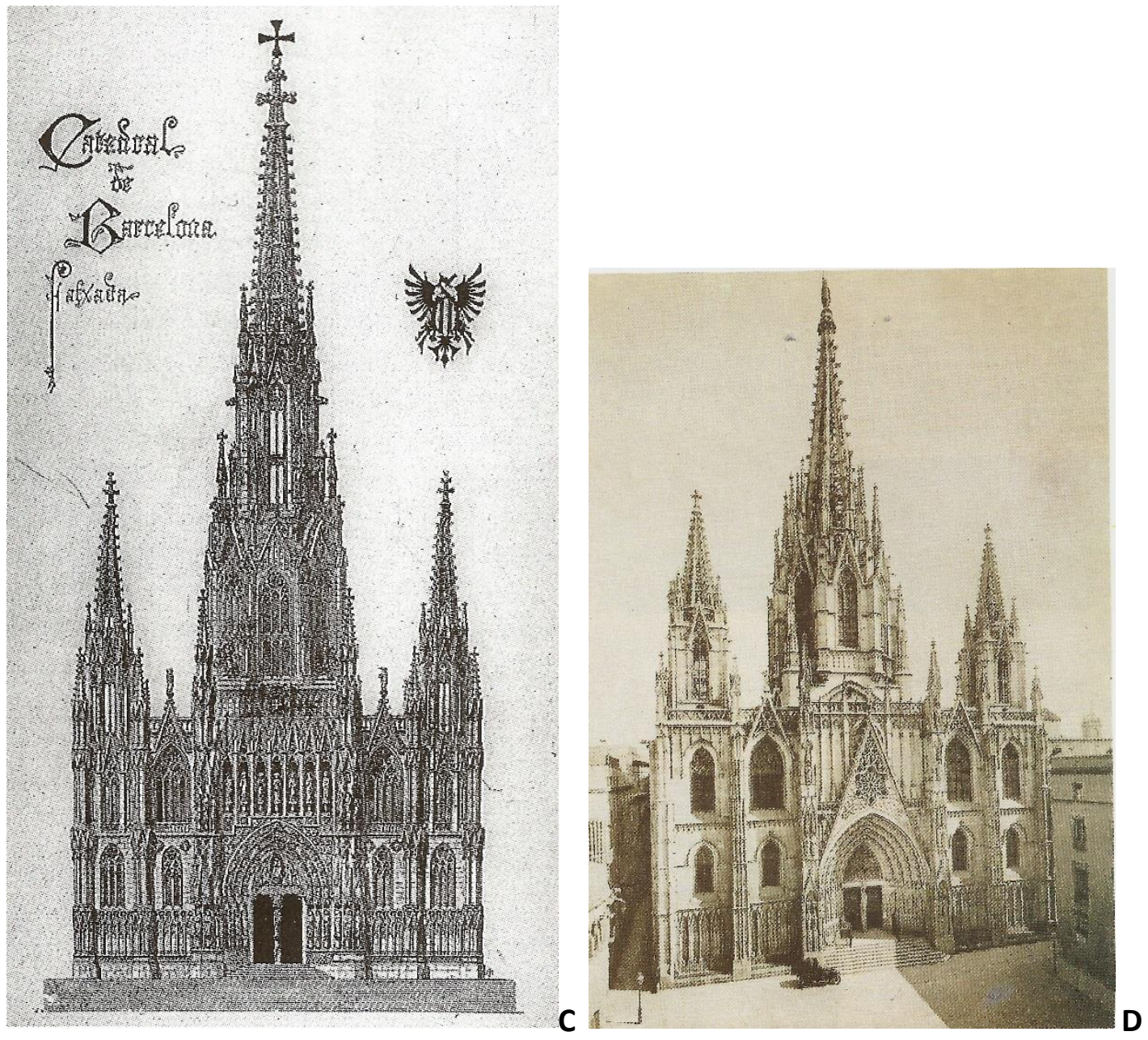

C: Propuesta de Juan Martorell para la fachada de la catedral de Barcelona, con delineación de Gaudí y rotulación de Domenech i Montaner. D: Fachada realizada de la catedral de Barcelona, según proyecto de Oriol Mestres e incorporaciones de Augusto Font. Fuente: Navascués, P. (1996) “Arquitectura Española 1808-1914", en.Suma Artis, $H^{\underline{a}}$ General del Arte. Tomo XXXV. Madrid. Espasa Calpe. 
En este sentido habría que ver la colaboración de Antonio Gaudí redibujando la imaginativa fachada propuesta por Martorell y la de Domenech i Montaner rotulándola como una expresión de apoyo a un discurso más novedoso. Su propuesta se aleja de la realidad catedralicia existente, sin duda influido por las ideas de Viollet-le-Duc y la visión de algunos ejemplos de la arquitectura religiosa neomedievalista centroeuropea de este periodo -haciéndolo especialmente atractivo por este dialogo con la arquitectura contienental más reciente- pero no se puede calificar de copia de otro modelo previo sino que se inserta en un itinerario ecléctico personal presente también en otros proyectos como las iglesias de Port Bou, las Adoratrices y sobre todo las Salesas. En el proyecto la verticalidad de las torres se funde con un desarrollo escénico de la fachada ciertamente espectacular hasta dar con una solución barroca y realmente original que presenta algunas similitudes con la iglesia de Maria vom Siege, de F. von Schmidt.

El proyecto de Martorell es rechazado en beneficio del menos costoso y más tibio o sosegado de Oriol Mestres, pero la posterior incorporación de elementos existentes en su propuesta, como el nuevo cimborio estilizado y aguja, las torres laterales en los extremos de la fachada y la molduración de la portada principal, hacen asemejarse la fachada construida a la propuesta de Martorell y dan idea de la fuerza que expresaban los diseños de los jóvenes arquitectos que se agrupan en torno a él. También hay que hacer notar en el dibujo de la fachada de Martorell las cruces en lo alto de las agujas que en ocasiones están repetidas con diferentes materiales, y la profusión de imágenes escultóricas sobrepasa con mucho el ámbito de la arquivolta alcanzando incluso a las pilastras y a las molduras superiores con un protagonismo hasta ese momento poco o nada utilizado en la ciudad condal.

Mientras esto ocurre en Barcelona, en el resto de España también se preparan actuaciones eclesiásticas de la misma o mayor envergadura, como el proyecto de la catedral de la Almudena de Madrid (1883). Aunque en el origen de la realización de esta iglesia -dedicada a la Virgen de la Almudena- se encuentra en el deseo de construir un templo dedicado a la patrona de Madrid no cabe duda que fue fundamental para llevarla a cabo la protección que dio a esta idea la reina Maria de las Mercedes de Orleans primera mujer de Alfonso XII (en el que había dejado una honda huella tras su prematura muerte). En efecto, su proximidad, o mejor inclusión, en el conjunto del Palacio Real de Oriente contribuyó desde el principio a otorgar una singularidad especial a este proyecto, tanto en lo que hace referencia a sus dimensiones y estilo como a su fuerte carga simbólica como iglesia oficial del Palacio. 

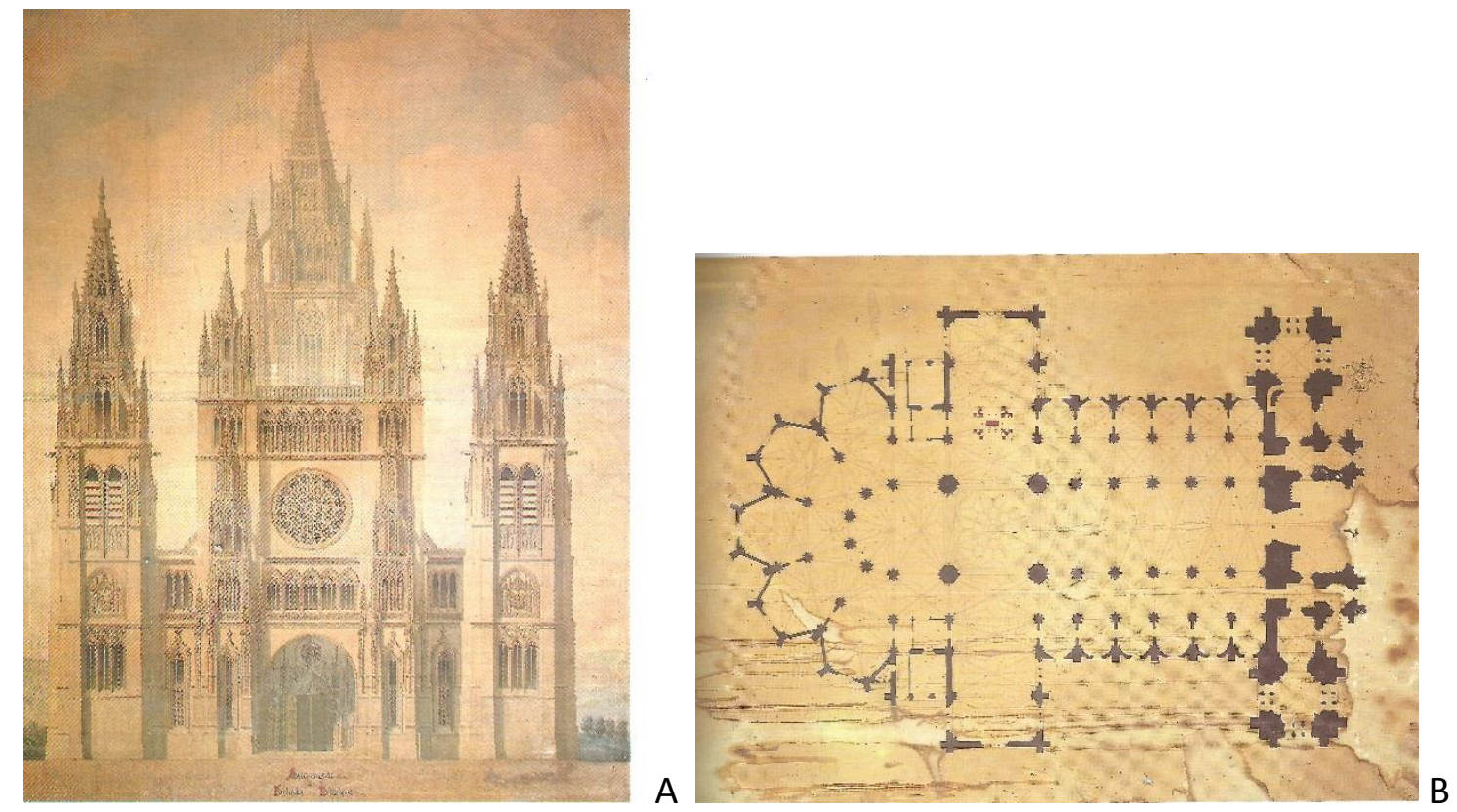

A: Fachada Principal del 1er proyecto para La Almudena de Madrid (1880) Francisco de Cubas. B: Planta de ese mismo proyecto. Fuente: Navascués, P. (1996) “Arquitectura Española 1808-1914”, en Suma Artis, $H^{\underline{a}}$ General del Arte. Tomo XXXV. Madrid. Espasa Calpe
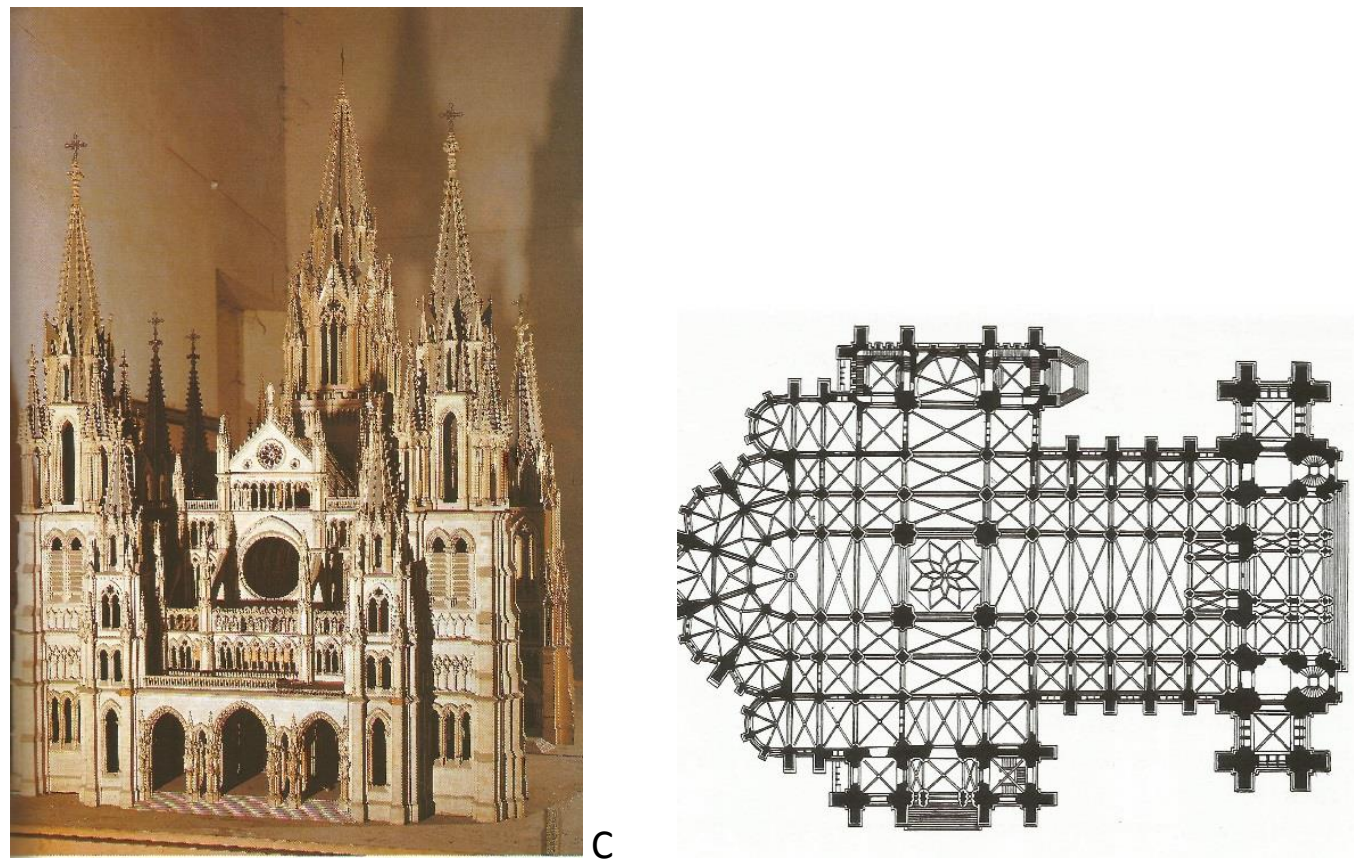

C: Maqueta de la fachada principal del del proyecto definitivo del Marqués de Cubas para la catedral de la Almudena de Madrid (1883) D: Planta del mismo proyecto. Fuente: Navascués, P. (1996) "Arquitectura Española 1808-1914", en Suma Artis, $H^{\underline{a}}$ General del Arte. Tomo XXXV. Madrid. Espasa Calpe 
Francisco de Cubas realiza un diseño plenamente inspirado en el gótico francés, aunque a lo largo de las sucesivas versiones de las fachadas se puede observar una reelaboración más personal, quizá por el conocimiento e influencia de otros ejemplos más libres e imaginativos, que se manifiesta sobre todo en la proliferación y tratamiento de torres y sus agujas, y el cimborio. Las obras comienzan en 1883, pasando a ser catedral de la nueva diócesis de Madrid, erigida como tal en 1884 por Leon XIII. De los sucesivos diseños neogóticos del Marqués de Cubas, con planta de cruz latina de tres naves, capillas laterales, girola y cripta, se llega a una integración final con el Palacio de Oriente utilizando su mismo lenguaje barroco en un proceso de identificación progresivo que, en mi opinión, responde al verdadero espíritu fundacional de la reina Maria de las Mercedes. En el proyecto van trabajando sucesivamente -por fallecimiento del Marques de Cubas en 1899- los arquitectos Miguel Olabarria, Enrique Repullés y Vargas, Juan Moya y, finalmente, Fernando Chueca Goitia y Carlos Sidro. Estos últimos, ganadores de un concurso convocado para terminar la catedral (1944), modifican sustancialmente el proyecto con la intención de integrarlo con el Palacio Real, recibiendo el Premio Nacional de Arquitectura de ese mismo año por el proyecto.

El proyecto neogótico del Marques de Cubas debe en su primera versión no poco al alzado principal de la catedral de León y a las intervenciones violletianas en el patrimonio francés, presentando un estilizado cimborio y torres simétricas de fina aguja calada a los pies de las iglesia, capillas entre los contrafuertes de la girola, arbotantes y contrafuertes en un intento de reproducción para Madrid del más genuino gótico de la Isla de Francia. Para la cripta, como era usual en la época, se preferió un estilo neorrománico con detalles bizantinos, más sobrio. La modificación primordial de Chueca y Sidro fue la de rebajar la altura del nuevo edificio con el fin de que resultara más armonioso en relación con el Palacio Real, pasando la nave central de medir 32 metros a 25,8. La catedral queda así plenamente insertada en el conjunto palaciego respondiendo más a la idea de magna capilla palatina que a la de cátedra episcopal y esta cualidad es la que parece ha sido más valorada de su actuación.

En este largo y cambiante periodo de ejecución de las obras, oscilando entre el sentido palatino del edificio y su dimensión catedralicia, en 1984, el cardenal Suquia promueve la constitución de un Patronato, con la participación del Ayuntamiento, Comunidad Autónoma, Caja de ahorros, Cámara de Comercio, Asociación de la Prensa, etc. para reanudar las obras, que se consiguen terminar en 1993 para su dedicación por el Papa Juan Pablo II. Durante esta fase final de las obras fue construida una cúpula sobre el crucero en lugar del cimborio neogótico inicialmente previsto, se organiza la sillería del coro a ambos lados del altar y la sede a su derecha, y se ubican esculturas realizadas por diversos artistas. La capilla del Santísimo, es decorada por el P. Ivan Marko Rupnik, responsable del taller de arte del Centro Aletti, enmarcado en una producción artística de marcado acento litúrgico. Ya en 1999 se pintan techos, se colocan vidrieras y se adecuan los exteriores. 


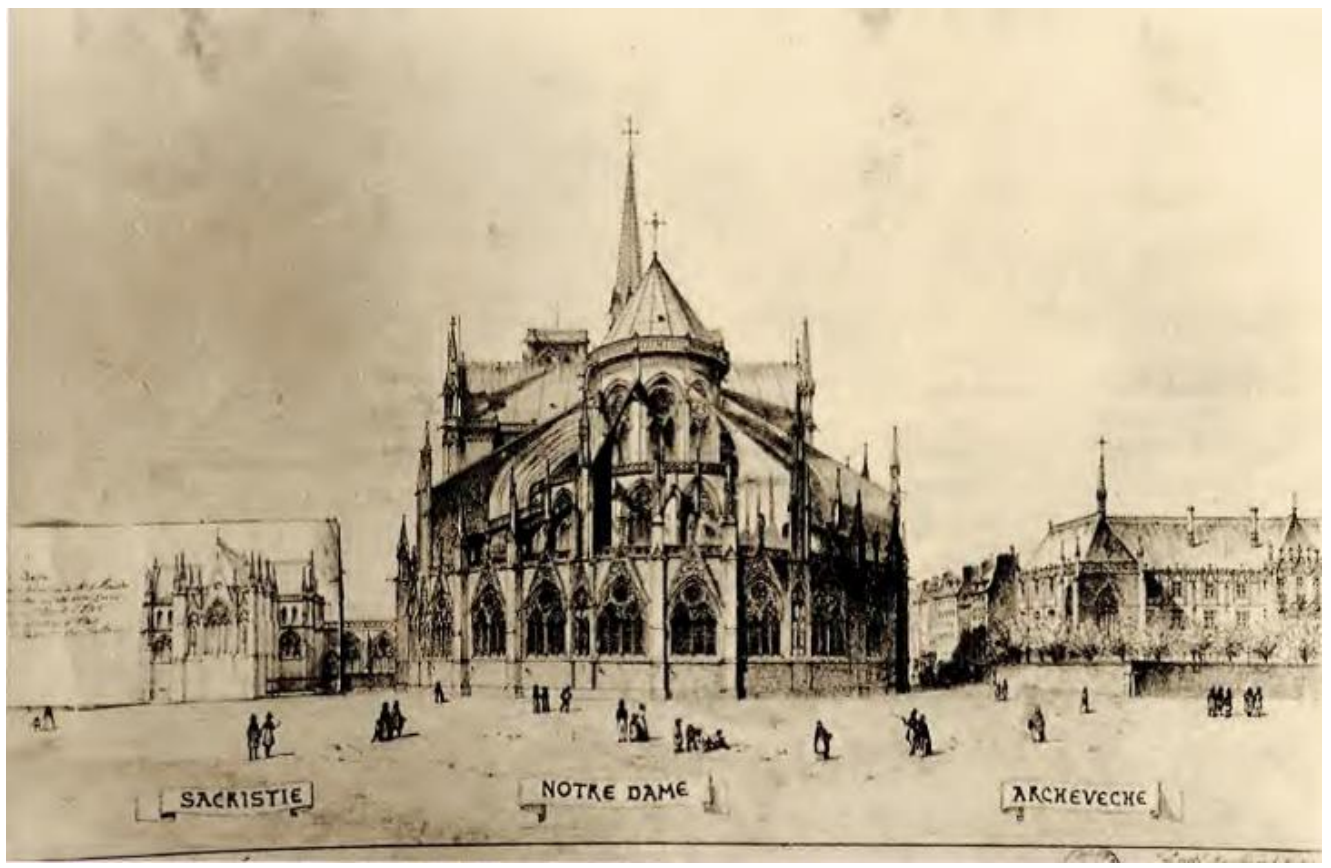

Proyecto de restauración de la catedral Notre Dame de Paris, Viollet-le-Duc, 1850. Fuente:

Archivo de la Comisión de Monumentos de Paris.
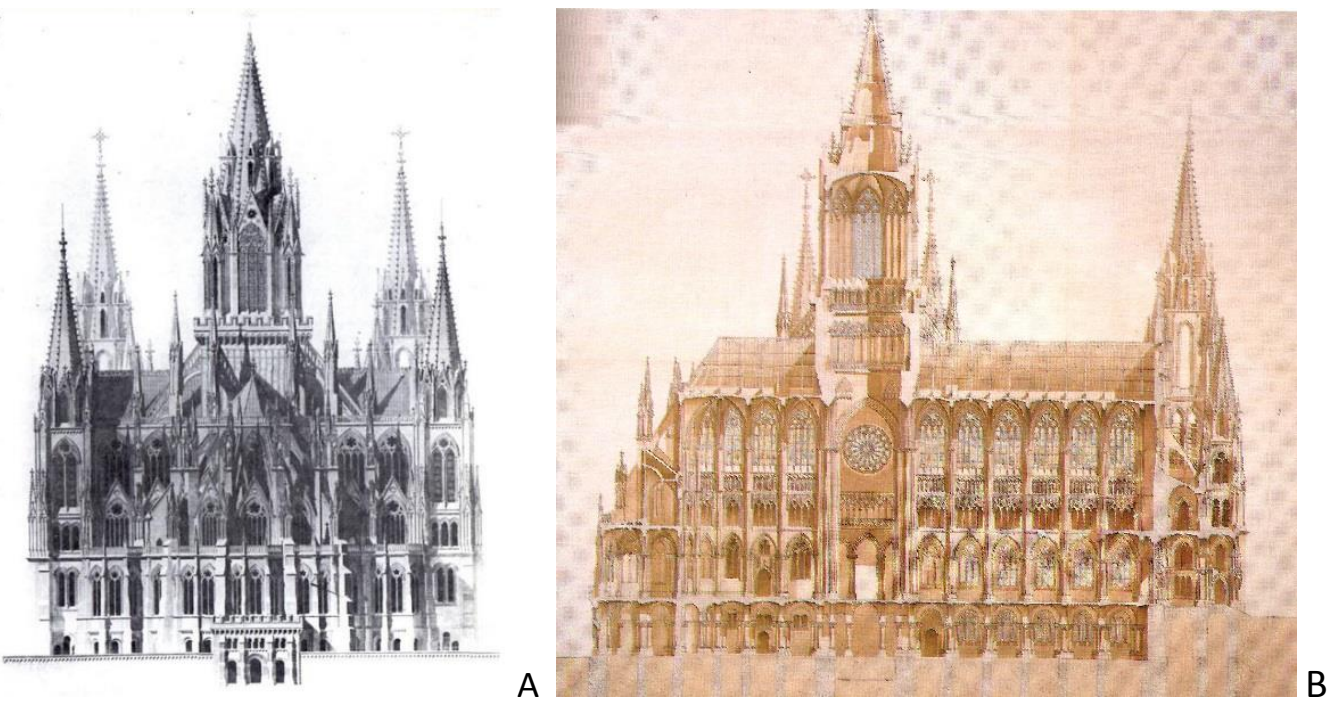

A: Cabecera del proyecto definitivo para la catedral de la Almudena de Madrid (1883) Francisco de Cubas. B: Sección longitudinal del mismo proyecto. Fuente: Navascués, P. (1996) “Arquitectura Española 1808-1914”, en Suma Artis, $H^{a}$ General del Arte. Tomo XXXV. Madrid. Espasa Calpe

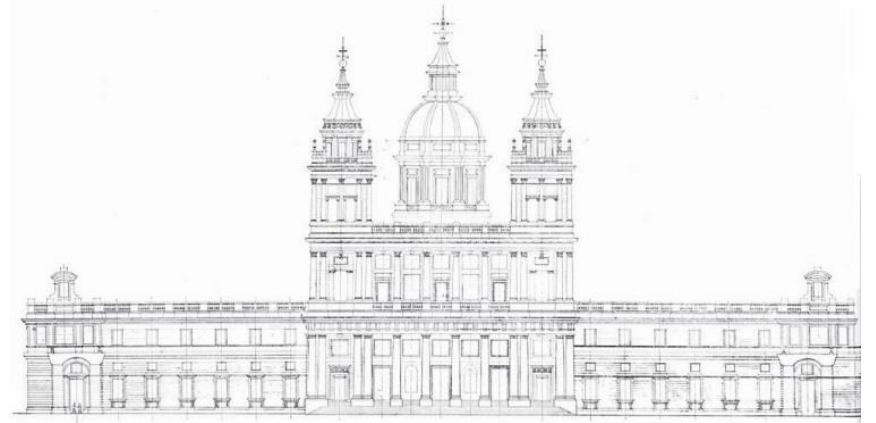

Fachada principal realizada de la catedral de la Almudena. Madrid. (1944) Fernando Chueca Goitia y Carlos Sidro. Fuente: Alfredo Aviñó Garcia. 
Otro ejemplo de arquitectura neogoticista de influencia centroeuropea es la catedral del Buen Pastor en San Sebastián (1888-1897), obra del arquitecto Manuel Echave. Su disposición de la torre campanario en el eje del edificio y sobre el pórtico de la entrada principal podria haber sido firmada por Puguin o Gilbert Scott, y sus elementos decorativos y la aguja calada en el campanario recuerdan a otras realizaciones de la misma época como la catedral de Colonia, Barcelona, etc. Probablemente fueron todas estas similitudes y su porte medievalista lo que motivó que fuese elegida para catedral de la nueva diñocesis que se crea en el año 1953, realizándose posteriormente diversas modificaciones en su interior -reforma del presbiterio, sede, altar y coro- para su dedicación como sede episcopal.

Si en el marco de la erección de nuevas diócesis se dan diversos ejemplos de adaptación de iglesias que se construyen en el siglo XIX con un lenguaje historicista neogótico -como también se ha mencionado los casos más relevantes de terminación de fachadas, en ese mismo estilo considerado como el ideal para el culto cristiano, en las catedrales históricas-, en este último caso hay que mencionar también las intervenciones que se realizan en su interior para la adaptación a las nuevas directrices litúrgicas.

De 1902 es la reforma que promueve el arzobispo Ramón Martinez Vigil en la catedral de Oviedo, con el fin de desmontar el coro histórico situado en el centro de la nave principal y situarlo en el presbiterio para mejorar la visulizacion de las funciones litúrgicas por los fieles y favorecer la conjunción del canto sacro en las misas. En este caso, al no poder utilizar la sillería existente en el presbiterio porque debido a su altura hubiese tapado el retablo mayor de 1511, hubo que realizar una nueva para esta ubicación.

De esos mismos años es la intervención de Gaudí en la catedral de Palma, a la que nos referiremos más adelante, con mayor fortuna en cuanto a la reutilización de los elementos del coro original, el alcance y detalle de la intervención.

Merece la pena detenerse en el caso de las iglesias votivas, ya mencionado, por cuanto las características de su financiación, su notable envergadura y la rapidez con que florecen estas iniciativas dotan a este sector de un protagonismo que quizá todavía no ha sido suficientemente estudiado. Los votos nacionales, surgidos con una intencionalidad religiosa, son rápidamente asumidos por las altas instancias de la sociedad civil y del poder politico como forma de aglutinar el sentimiento y orgullo nacionales después de algún revés o apuro sufrido por la nación, siendo su ejemplo más paradigmático la iglesia de Montmartre en Paris.

En un clima de inestabilidad política consecuencia de las últimas revoluciones y guerras europeas, las convulsiones ocasionadas por el cambio en la organización social y económica, debido a la aparicion del liberalismo y socialismo, se ven muchas veces como ocasionados por el fuerte decaimiento moral de la sociedad en cuya reparación ha de jugar un papel importante la construcción de iglesias de carácter expiatorio que faciliten una renovación del sentimiento religioso. 


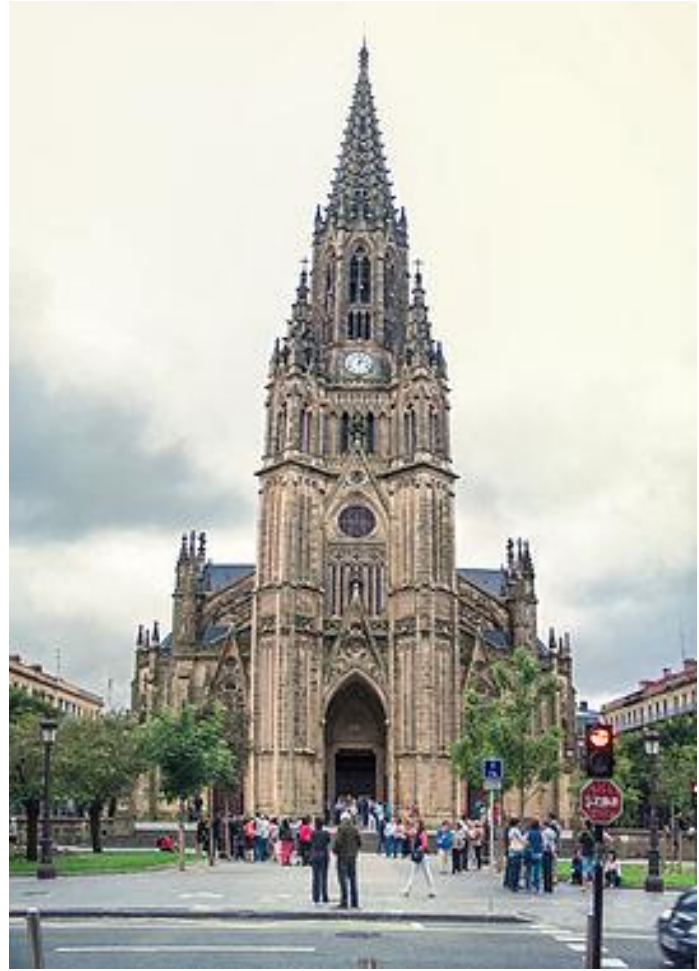

Catedral del Buen Pastor. San Sebastian (1888-1897) Manuel Echave. Fuente:
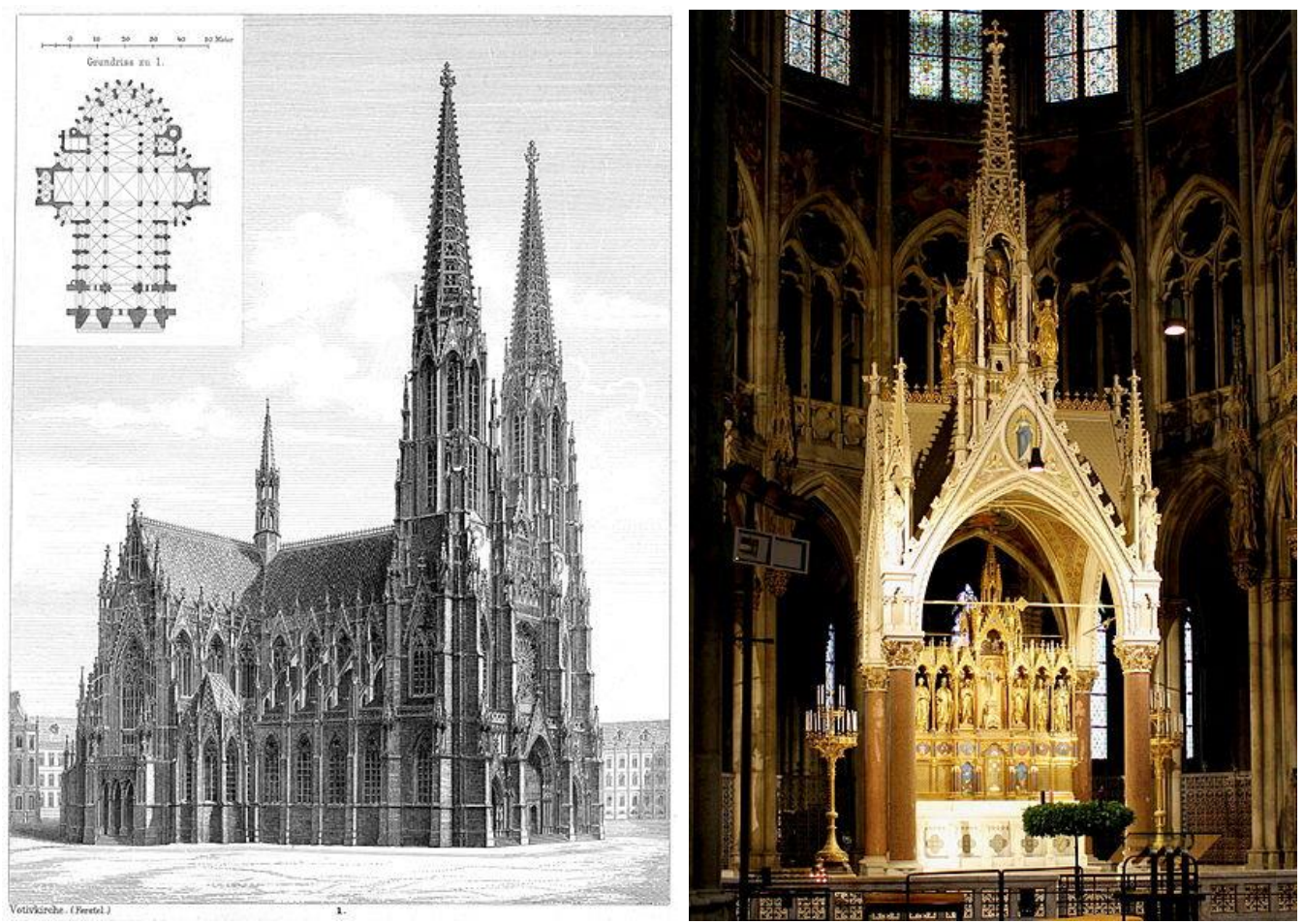

Dibujo de Iglesia votiva de Viena y fotografía del baldaquino y retablo del altar mayor. (1856). Heinrich von Ferstel. Fuente 
El mismo Papa Pio IX, que había visto perder los estados pontificios y se sentía recluido en el Vaticano, a instancias de los obispos franceses había extendido la devoción al Sagrado Corazón en la Iglesia Universal y desde 1850 muchas naciones se habían consagrado a él. También en 1875, después de la derrota francesa en la guerra francoprusiana, León XIII, mediante una fórmula prescrita por él, consagró la humanidad entera al Sagrado Corazón promoviendo desde 1899 la devoción al Sagrado Corazón.

Dentro de esta corriente de promoción de iglesias votivas hay que situar la de Viena, proyectada en 1853 por Heinrich von Ferstel, ganador de un concurso para realizarlacon el objetivo de dar gracias a Dios por salvar la vida del emperador Francisco José tras ser víctima de un atentado político. Presenta en un lenguaje neogótico inspirado en Santa Clotilde de Paris, una disposición tradicional con planta de cruz latina de tres naves, con girola, capillas entre contrafuertes y dos esbeltas torres acabadas sendas agujas caladas. Por su carácter nacional se realizó una campaña de recaudación de fondos para su construcción. En el interior es de destacar la disposición del órgano y coro sobreelevados a los pies de la nave, tal y como acontecía en las iglesias posteriores a Trento, así como la situación del púlpito en el crucero, recuerdo de la época mendicante. En el presbiterio, separado de la nave principal mediante balaustrada y cancela, el altar está adosado a un retablo de nueva factura y ambos enmarcados bajo un baldaquino de imitación oijval y considerables dimensiones coronado por estatuaria y cruces de diversos materiales.

Más significación tendrá en el apartado de las iglesias votivas la basilica del Sacrée Coeur de Paris, en Montmartre, concebida en un contexto político e económico difícil, después de la toma de Roma por las fuerzas piamontesas que promovían la unificación de Italia y, sobre todo, de la derrota militar francesa en la guerra franco-prusiana de 1870 , en la que habían caído muchos franceses.

Aunque los fondos son aportados por recaudación de particulares, diócesis, ordenes religososas, congregaciones y sodiedades, lo cierto es que la iniciativa privada (dos jóvenes padres de familia, M. Legentil y $M$. Rohault de Fleury, miembros de las conferencias de San Vicente de Paul) recibió desde el inicio el impulso eclesiástico nacional a partir de que el cardenal Guibert, arzobispo de Paris, a principios de 1872 aprueba el voto nacional por el que los franceses se comprometen a construir esta iglesia en Paris, en signo de fe, de esperanza y de regeneración moral y religiosa. Y también desde el punto de vista económico fue fundamental que al año siguiente la Asamblea Nacional promulgara una ley que proclamaba de utilidad pública la construcción de una iglesia consagrada al Sagrado Corazón en la colina de Montmartre. Para ejecutar esta construccion se elige realizar un concurso de proyectos en 1874 , siendo elegido el del arquitecto Paul Abadie, en estilo románico-bizantino y comenzando la construcción en junio de 1875. Se consagra la basilica en 1919, bajo el pontificado de Benedicto XV habiéndose realizado la obra en apenas 44 años, tiempo record para una iglesia votiva. 

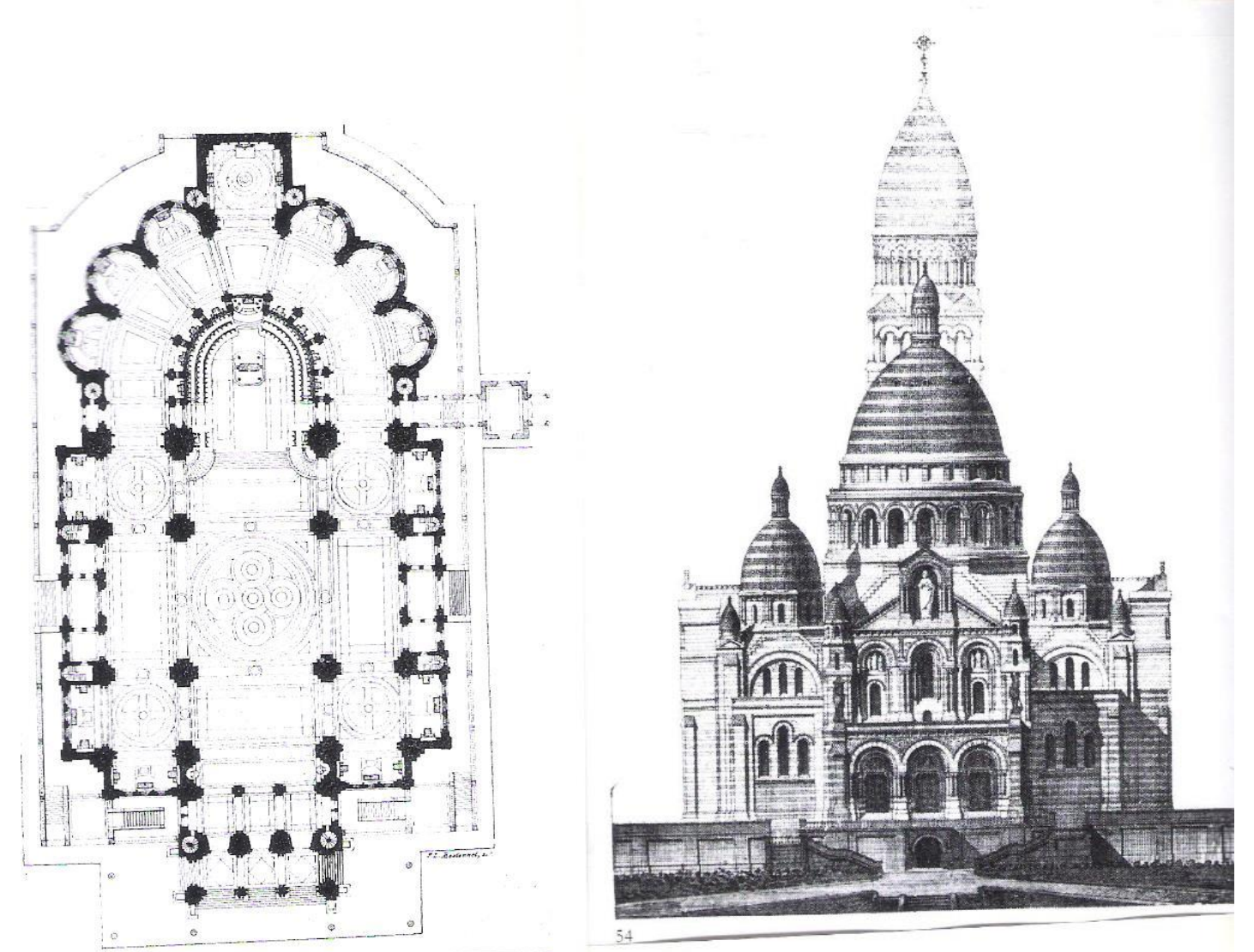

Planta y Alzado de la Iglesia del Sacrée Coeur, Montmartre, Paris, según proyecto de Paul Abadie. Fuente: Torii, T. (1993) El mundo enigmático de Gaudí. Madrid. Instituto de España.
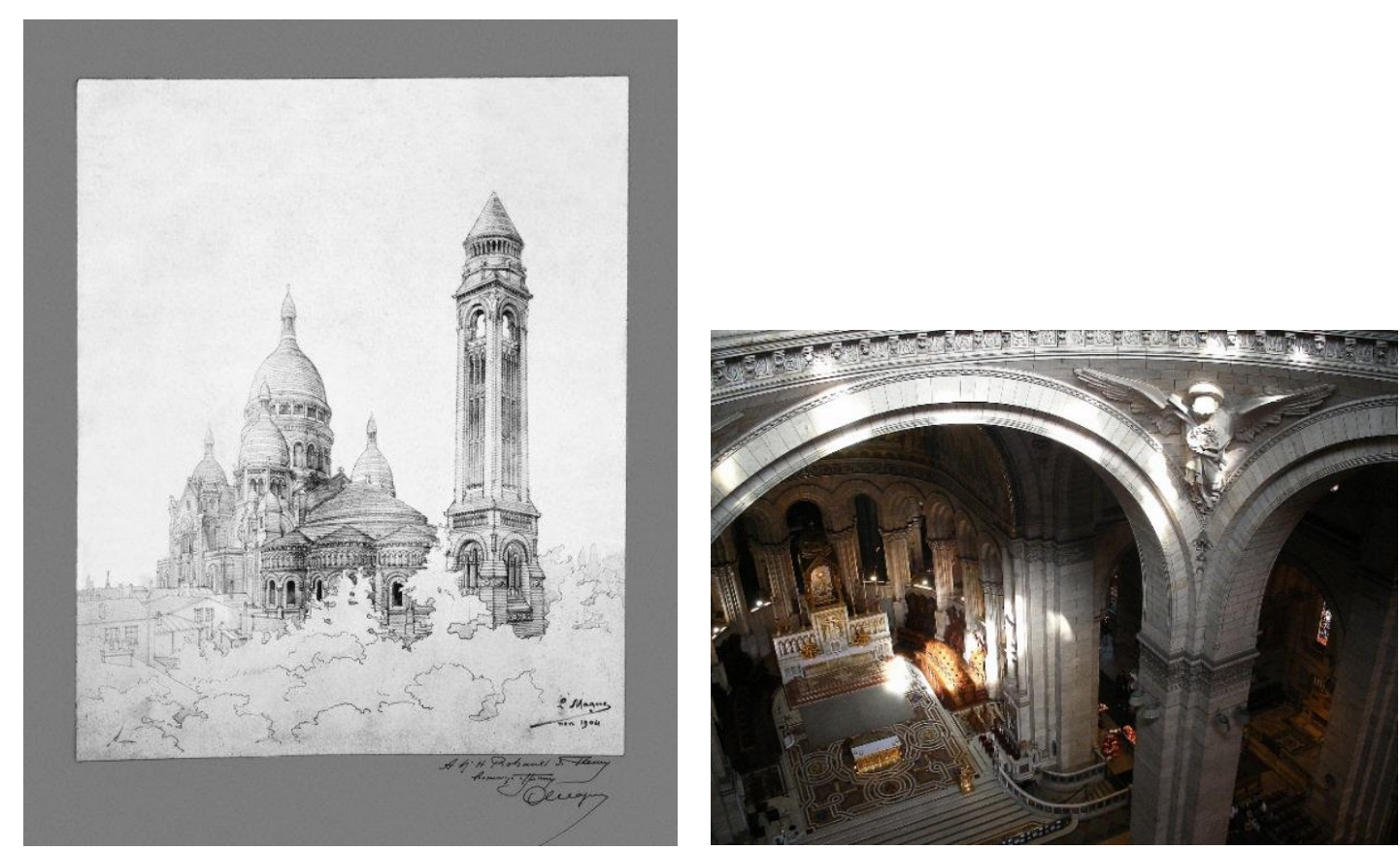

Grabado de 1904 representando la vista posterior de la basilica del Sacrée Coeur. Se aprecian las diversas bóvedas y pináculos, en especial la torre, situada tras el abside, que no llegó a construirse. Fotografia del Interior de la Iglesia del Sacrée Coeur, Montmartre, Paris, según proyecto de Paul Abadie. Se aprecia la amplitud del coro eclesiástico en el presbiterio a ambos lados del altar originalmente adosado a un mural de piedra, a la manera medieval. 
Gaudí fue muy crítico con esta iglesia a la que calificaba de simple imitación del pasado que se quedaba muy lejos de lo que pretendía, y análogamente Hitchcok le aplica el calificativo de "penosamente arqueológica". Su planta es híbrida, combinando un ábside medievalista con girola y capillas con una nave cuadrada que erige su centralidad en torno a un domo que no ocupa el teorico transepto de la iglesia sino el punto central de su nave. Las capillas de la nave ocupan los huecos de los elementos estructurales murarios y un nártex se adosa a la fachada principal para enfatizar su portada principal. Llama la atención la preeminencia de la capilla absidal dedicada a la Virgen situada en el eje longitudinal de la iglesia a imitación de Saint Sulpice o Saint Dennys-de-l'Entrée. Esta ubicación será también adoptada en la Sagrada Familia, lo cual indica que a pesar de la fuerte carga crítica de Gaudí hacia este proyecto, la arquitectura francesa era de obligada visualización y referencia en el contexto de finales del siglo XIX. El estilo, entre bizantino y románico con acabado sensiblemente blanco, no llama la atención por ninguna parte, pero si que lo hace la profusión de bóvedas y pináculos, incluso una torre campanile externo al edificio que no llegó a construirse. En el interior dispone el órgano sobreelevado a la entrada según la tradición tridentina y un amplio presbiterio con coro para eclesiásticos dispuesto a la usanza y forma del Medievo que enmarca el altar mayor adosado a un mural escultórico en piedra blanca, que parece responder a ser la base de la presentación del Sacramento.

Otro ejemplo europeo de iglesia votiva de carácter nacional lo encontramos en la Basílica del Sagrado Corazón de Koekelberk, en Bruselas, que surge por iniciativa del rey Leopoldo II para festejar el 75 aniversario de la independencia de Belgica, pretendiendo fundir arte y sentimiento religioso, a la vez que conseguir promover un hito arquitectónico para la ciudad a imitación del Sacrée Coeur de Paris en la colina de Montmartre.

Para ello se escoge también un lugar prominente en el que Pierre Langerock realiza un primer diseño (1903) sobre la base de un enorme edificio neogótico inspirado en las ideas de la "catedral ideal" de Viollet-le-Duc. El proyecto presenta una disposición clásica ojival de planta de cruz latina con cinco naves con arbotantes y contrafuertes, además de girola, y tres portadas flanquedas por sendas torres y otra cuadrada en el crucero a modo de cimborio, todas ellas con gran verticalidad con agudisima flecha calada. No obstante, el diseño medievalista de Langerock presenta como particularidad a destacar respecto de otras construcciones neogóticas del momento el gran numero de torres campanarios que dispone -hasta seis distribuidas por parejas en las portadas- de similar altura e importancia, que parecen enmarcar el cimborio del crucero reforzando la verticalidad de un conjunto que por sus dimensiones hubiese resultado muy horizontal. Se pretendía reforzar la imagen de esta basilica nacional mediante una urbanizacion de los terrenos que significara su ubicación elevada a modo de un clásico santuario sagrado. 

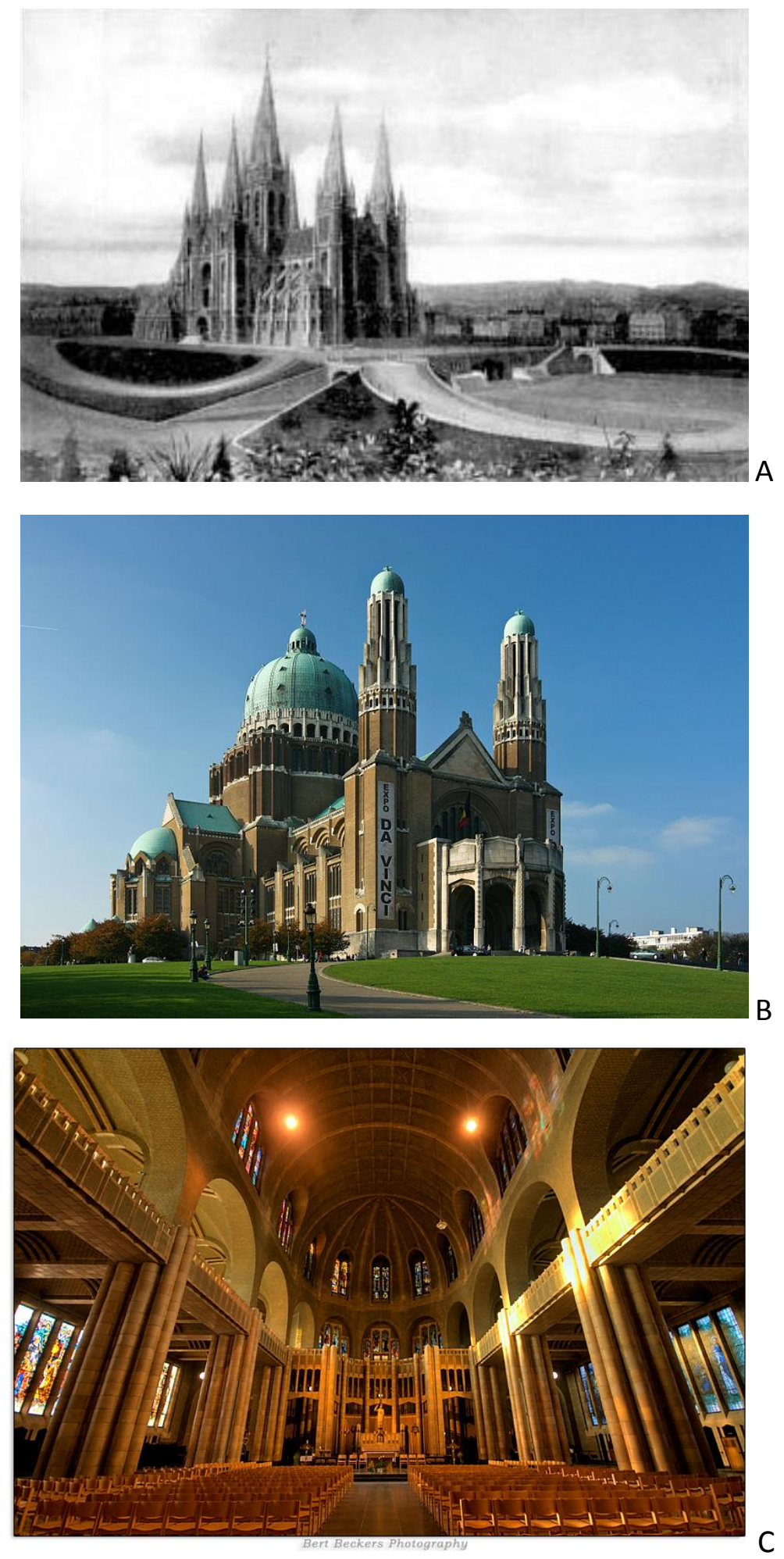

A: Imagen del proyecto de Langerock para la basilica nacional de Koekelberk, Bruselas (1903)

B: Basilica nacional de Koekelberk, Bruselas, realizada según proyecto de Albert Van Hoffel

C: Interior del aula celebrativa de la Basilica nacional de Koekelberk, Bruselas. 
Puesta la primera piedra el 12 de octubre de 1905, al comienzo de la Primera Guerra Mundial sólo se habían construido los cimientos dando suficientes argumentos de tipo económico para que se abandone hacia 1919 el colosal proyecto de Langerock encargándosese a Albert Van Huffel otro mucho más comedido y desprovisto de gran parte de las connotaciones nacionales que lo habían motivado. En los años veinte el proyecto se reorienta según unas directrices más eclesiásticas a tono con su uso, pues no en balde Van Huffel había sido propuesto por Dom Sebastien Braun, abad de Maredsous y por el cardenal Mercier, puntas de lanza de la renovación liturgica en Belgica. La iglesia se abre al culto en 1935, terminándose en 1970.

El proyecto realizado, según las trazas que comenzó a diseñar Van Huffel en 1921, mantiene la disposición de planta de cruz latina, si bien es una construcción de diemensiones más modestas. Su programa incluia además del aula liturgica diversas salas de reuniones, celebraciones, y exposiciones, cripta, museo, cafetería, etc. Con un planteamiento Art-Decó de ladrillo y hormigón armado, busca más poner de manifiesto el espacio litúrgico, sus diferentes recintos y necesidades que adscribirse a un estilo concreto. En el destaca un enorme cimborio cuadrilobulado en sus vértices sobre el que se dispone un tambor y la cúpula. Su interior adopta la disposición de una gran sala rectangular, flanqueda por una galería elevada en todo su perímetro, que orienta toda la visual hacia un amplio presbiterior en medio del cual se situa el altar mayor. A los lados, las dos naves laterales bajo la galería son espacios de comunicación ampliamente iluminados donde se dispone el mobiliario de los confesionarios.

Otro templo votivo del area francófona es la Basílica de Notre Dame de Fourvières, en Lyon, dedicada a la Virgen, a quien se le atribuía que salvó a la ciudad de una epidemia de cólera en 1823. Posteriormente, también se le atribuyó el hecho de que el ejercito prusiano no llegara a apoderarse de la ciudad en la guerra franco-prusiana. Otros hablan de que fue construida como hito que marcase el triunfo de los valores cristianos sobre los socialistas de la comuna de Lyon de 1870.

Fue construida con fondos privados entre 1872 y 1896 sobre una colina que domina la ciudad. Su arquitecto, Pierre Bossan, realizó los primeros diseños en 1846 en el curso de un viaje a Palermo. apreciándose la impresión que debió producirle la catedral siciliana en la volumetria general del edificio y la portada principal porticada, pero su construcción encontró una gran oposición hasta 1870; el edificio toma elementos de la arquitectura románica y bizantina, disponiendo tres naves en sentido longitudinal y una cripta dedicada a San José. 

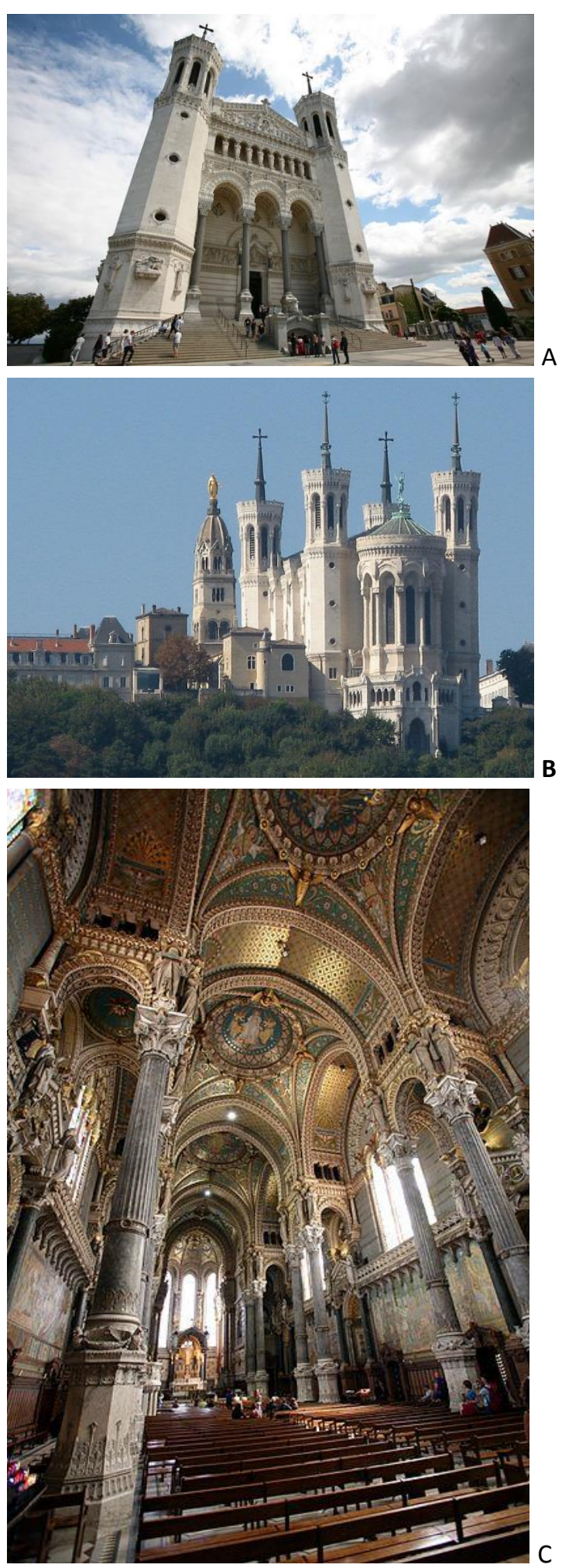

Basilica de Notre Dame de Fourvières, Lyon(1872-1896). Se aprecia la influencia de la catedral de Palermo en la portada principal.

A: Fachada principal y accesos

B: Silueta de torres y flechas sobre la ciudad.

C: Interior de la Basilica de Notre Dame de Fourvières, Lyon. La nave única presenta una secuencia de arcos formeros dobles que la estructuran longitudinalmente en sucesivas bóvedas esféricas. Se aprecia igualmente la abundante policromía en una iconología de corte bizantino. 
En el interior, sensiblemente diáfano, se aprecia una estructura bastante diáfana modulada según intercolumnios que disponen cúpulas en los espacios resultantes de la separación entre cada pareja de arcos dobles. Una abundante decoración de mosaicos y policromía decora paredes y techos. En el exterior cuatro torres dispuestas en las correspondientes esquinas de la nave parecen querer darle una cierto deseo de centralidad y verticalidad que lo alargado de la nave se encarga de negar.

En el mismo año de 1870 Pio IX promueve en Roma la iglesia del Sacro Cuore di Gesù como un templo votivo internacional en las cercanías de la nueva estación Termini de ferrocarriles. Debido a la anexión de Roma al Reino de Italia de los Saboya se paralizó su construcción hasta que en 1879 se encomienda el proyecto a San Juan Bosco y la orden salesiana que lo reanuda con proyecto de Francesco Vespignani, terminándose en 1887. Es una iglesia de estilo neorrenacentista con tres naves divididas por columnas de granito, con crucero y cúpula.

En el conjunto de iglesias votivas que se erigen bajo la advocación al Sagrado Corazón de Jesús, habitual en aquel momento por el impulso que le había dado el Papa Pio IX, hay que destacar también como una de las más conocidas la que se realiza en Barcelona, en la montaña del Tibidabo. La idea surge a finales del siglo XIX debido a los rumores sobre la construcción de un templo protestante y un hotel-casino en ese mismo emplazamiento, ante lo cual una "Junta de caballeros católicos" adquiere la propiedad del terreno, cediéndolo en 1886 a San Juan Bosco, de visita entonces en Barcelona para consolidar las Escuelas Profesionales de Sarriá.

En 1889 se declara la cumbre de la montaña como de utilidad pública - un año con motivo de la Exposicion Universal de Barcelona se había urbanizado la carretera de Vallvidrera-, pero el proyecto sufre un retraso al realizarse el observatorio astronómico Fabra en las inmediaciones, de tal manera que hasta el 28 de diciembre de 1902 no se coloca la primera piedra por el entonces obispo de Barcelona Salvador Casañas. A partir de 1909 recibe un gran impulso de donativos particulares merced a la acción de una señora madre de familia -Amelia Vivé Negra- que consigue una amplia difusión y penetración popular.

En el programa del edificio Don Bosco hizo prevalecer los espacios destinados a los sacramentos de la Reconciliación y de la Eucaristia por lo se dispuso además de la cripta y de la nave liturgica una capilla de adoración permanente. Tras sufrir diversas visicitudes y destrucciones en el periodo 1936-39, se terminan las obras en 1961, durante el pontificado de Juan XXIII, colocando una estatua de bronce del Sagrado Corazón en lo alto del templo, de 7,5 m de altura, obra del escultor Josep Miret para sustituir a otra destruida de Fredéric Marés. 


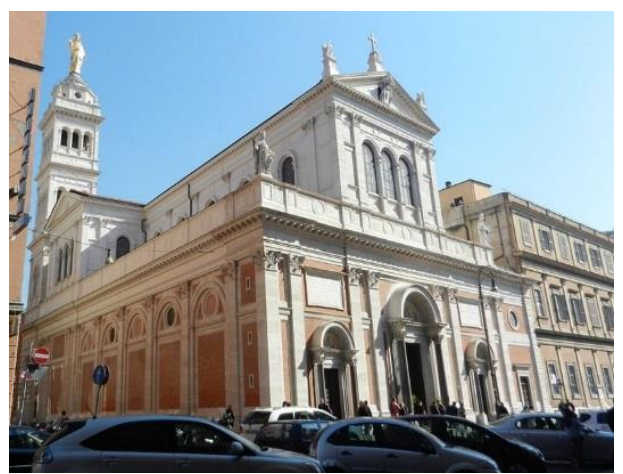

Exterior y fachada principal de la Iglesia del Sacro Cuore di Gesù en Roma, según proyecto de Francesco Vespignani (1880-1887)

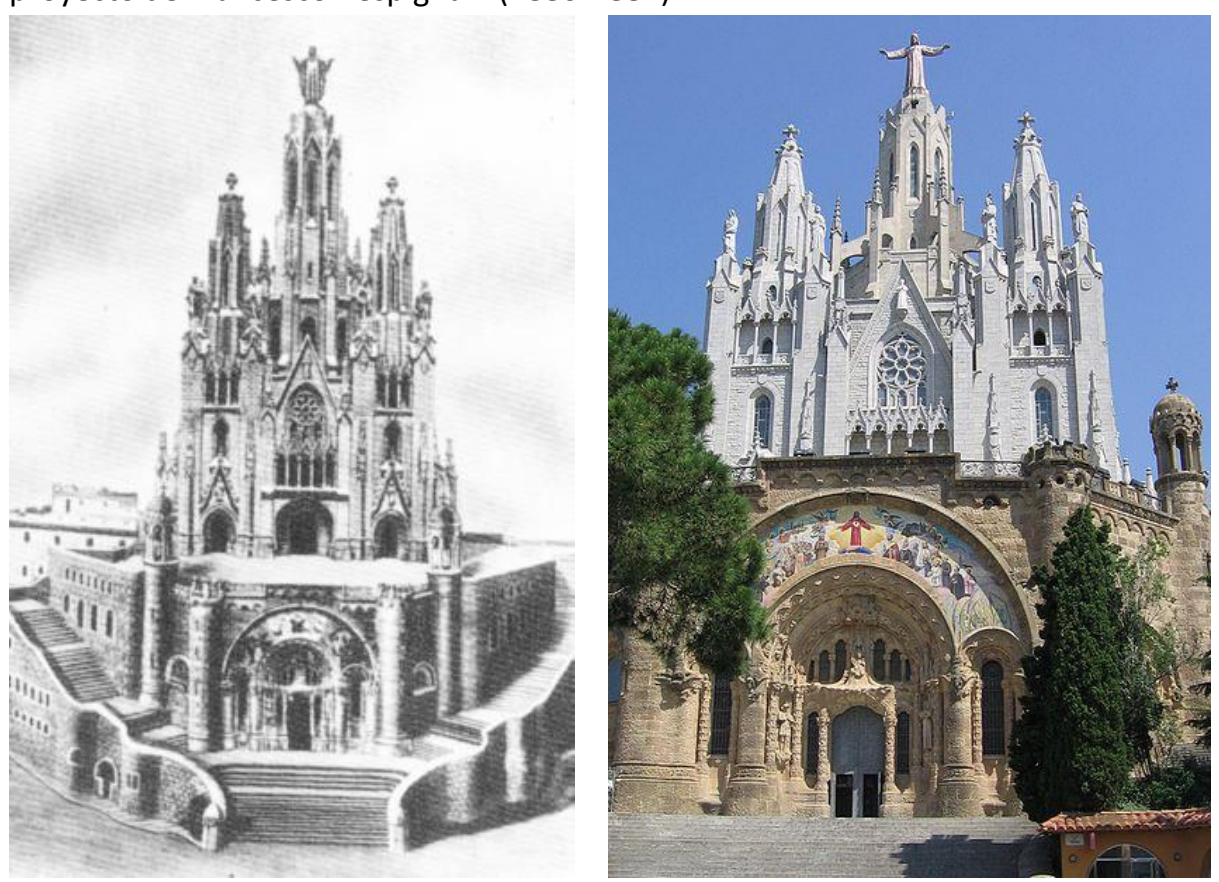

Dibujo y fotografía del Templo nacional expiatorio del Sagrado Corazón, en el Tibidabo, Barcelona. (1902-1961)

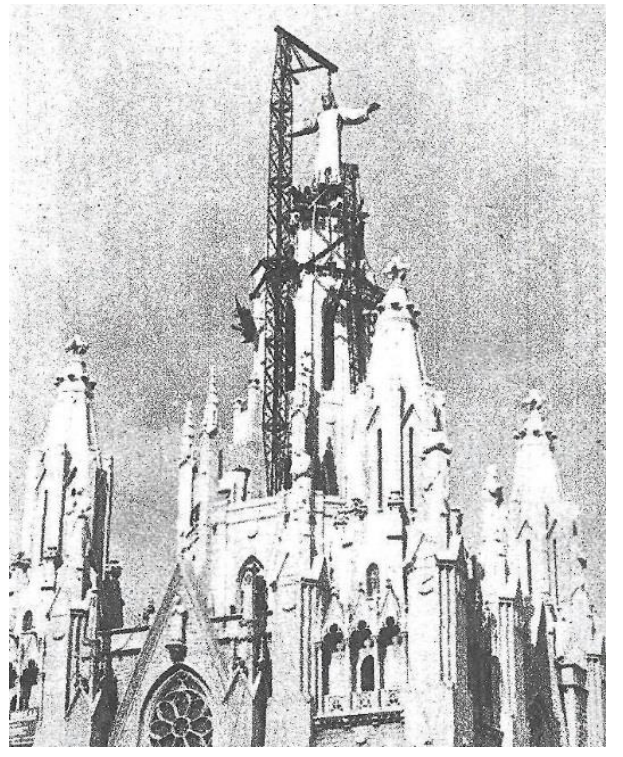

Fotografia de la colocación de la estatua del Sagrado Corazón en lo alto del cimborio.

Fuente: La Vanguardia 11-10-1961 
El proyecto, obra de Enrique Sagnier, aunque terminado por su hijo José Maria, realizado con piedra de Montjuic y presidido por una doble escalinata monumental, dispone los dos espacios tradicionales en la arquitecrura eclesiástica del ochocientos, nivel inferior con la cripta y la capilla del Sacramento, y nivel superior con una iglesia de tres naves con capillas semicirculares y cúpula. La cripta se construye entre 1903 y 1911 en estilo bizantino con elementos neogóticos y clasicistas, y decoración modernista. En cuanto a la iglesia superior, siguiendo una línea románica de fuerte verticalidad gótica, construida entre 1915 y 1951, dispone una planta cuadrada con tres ábsides, cúpula central y cuatro torres más bajas en las esquinas. 


\subsection{Interacción de la Iglesia de la colonia Güell y la Seo de Mallorca con la Sagrada Familia.}

la Iglesia de la Colonia Güell en el itinerario de la Sagrada Familia: una lectura liturgica de su arquitectura.

Según el índice de la producción artística de Gaudí publicado en el Calendario Josefino para 1927 éste trabaja en el proyecto entre 1898 y $1914^{224}$, y Martinell refiere que mientras permaneció al frente de la dirección de las obras, desde 1908 a $1914^{225}$, tuvo como ayudantes a Francisco Berenguer, Joan Rubió, el ingeniero alsaciano Eduardo Goetz y al oficial escultor Juan Bertrán.

Unos años antes, Gaudí habia dibujado los proyectos para la Iglesia del Monasterio benedictino de Villaricos, Almeria (1882) y el edificio para las misiones franciscanas en Tanger, Marruecos (1892-1893), habiendo terminado recientemente su intervencion en el colegio de Santa Teresa de Jesús de la C/ Ganduxer de Barcelona (1889 a 1894). Hay que destacar también que desde 1884 dirigia las obras de la Sagrada Familia, y con anterioridad había realizado diversas intervenciones en el ámbito de la arquitectura cristiana de culto como los altares y otros elementos para la capilla de los Colegios de Jesús-Maria de San Andres del Palomar (1879-1881) y Tarragona (1880-82), el altar de San José en la Cripta de la Sagrada Familia (1885) y el del oratorio de José Ma Bocabella en su residencia particular (1885).

${ }^{224}$ Cf. AA. VV. (2010) "Cronologia de las obras de D. Antonio Gaudí" en la Recopilación La mort de Gaudí i el seu ressò a la revista 'El Propagador de la devoción a San José' a cargo de Lluis Bonet i Armengol. Barcelona. Real Catedra Gaudí y Ed. Claret. P. 205. Se indica que el índice de la obra gaudiniana fue elaborado a partir del inventario de papeles encontrados en su casa, intercalado con datos de su vida anotados por el arquitecto. J. F. Ráfols.

${ }^{225}$ Puig Boada, L'Esglesia de la Colonia Güell, concreta el periodo de tiempo en que el arquitecto estuvo trabajando directamente en el proyecto: "Gaudí dejo la obra el 3 de octubre de 1914. Continuaron sin su intervención desde el 24 de octubre hasta el 8 de marzo de 1916, con pequeños trabajos de acabado y de adecuación al culto." Bassegoda, en su libro El gran Gaudí (1989), dice que las obras de la cripta se llevaron a cabo entre 1903 y 1916, que E. Casanelles consultó las carpetas del archivo parroquial de Santa Coloma que contiene datos de la construcción y señala que las obras duraron hasta 1916, pero indica también que la maqueta funicular quedó abandonada al interrumpirse las obras en 1914, lo cual coincidiría con el abandono de la dirección de las obras por parte de Gaudí que señala Puig Boada. Carlos Flores se plantea por qué deja Gaudí las obras en 1914 si Güell no muere hasta 1918, dejando primeramente la obra a Berenguer en enero de 1914, y al morir éste a Canaleta, si podían haberse prolongado hasta noviembre de 1915 o incluso hasta 1916. Flores llega a plantear dos hipótesis: que el ensayo o experimento de la maqueta funicular había dado de si todo lo que podía ser interesante y era el momento de abandonar, o que el resultado no le satisfacía y por tanto era erróneo para aplicar a la Sagrada Familia. Bassegoda, en Gaudí, o espacio, luz y equilibrio (2002) apunta que las obras discurrían a un ritmo muy lento hasta 1916 en que se pararon a causa de las dificultades surgidas con motivo de la Gran Guerra, y que tras el fallecimiento de Eusebio Güell sus herederos, en especial D. Santiago Güell, no se sentían muy inclinados a terminar el edificio. 

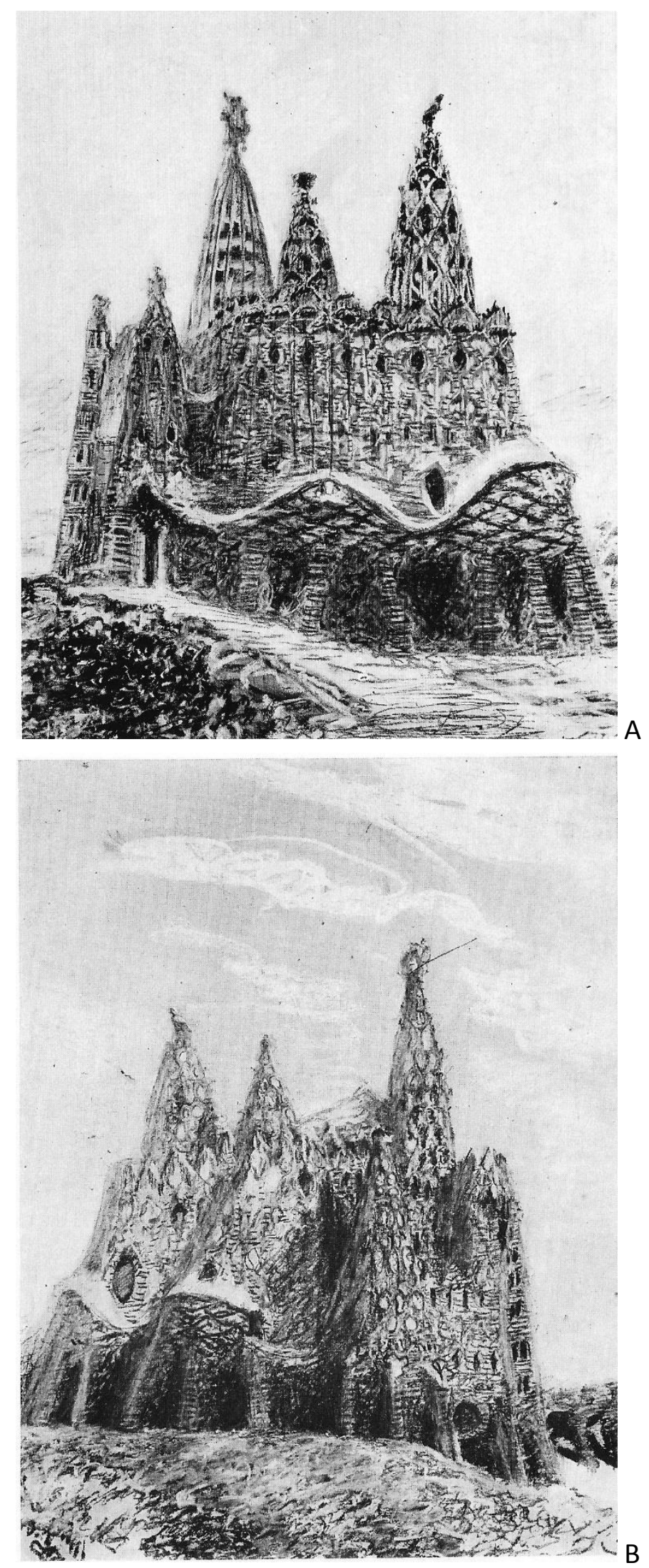

Dibujos de alzado de la Iglesia de la Colonia Güell.

A: Croquis lateral derecho. B: Croquis lateral izquierdo.

Fuente: Puig Boada, I. (1976). L'Esglesia de la Colonia Güell.

Barcelona. Lumen 
Así mismo había expuesto públicamente a los miembros de la Asociación de devotos de San José, en su célebre discurso del 19 de marzo de 1891, su Programa para la Sagrada Familia, como declaración de intenciones del proyecto. Precisamente, por esos años se había terminado el ábside (1893) y ya desde 1891 se encontraba trabajando en la Fachada del Nacimiento. Todos estos trabajos y proyectos muestran un arquitecto de dilatada experiencia en arquitectura eclesiástica, especialmente en todo lo que se refiere al culto cristiano, de tal manera que cuando se enfrenta a la complejidad de una obra como la iglesia de la Colonia Güell, se encuentra en plena madurez de su quehacer profesional, con un dilatado curriculum en espacios dedicados al culto, pues ha estudiado con detalle sus recintos, necesidades y mobiliario litúrgicos en diversos proyectos. Este hecho y su inquietud por perfeccionar la estabilidad de la estructura de una iglesia le lleva a analizar en profundidad los numerosos ejemplos de esta tipologia arquitectónica realizados en los más variados estilos que conocía. En el Manuscrito de Reus manifesta ya una sincera admiración por las iglesias de planta central herederas de la tradición bizantina a la par que una actitud bastante critica hacia los sistemas estructurales neomedievales a los que consideraba imperfectos y plagados de elementos postizos. Las intervenciones realizadas por Viollet-le-Duc no le satisfacen por infidelidad al estilo ojival y sus realizaciones históricas, y tampoco encuentra satisfacción en otras realizaciones de la época -iglesias votivas, en su mayor parte como Montmartre- a las que encuentra faltas de fundamento litúrgico, desprovistas de carácter y configuradas como un collage de clichés históricos más o menos afortunados. Estas opiniones, contrastadas con la visita a diversas iglesias del sur de Francia y con la experiencia profesional acumulada son ratificadas y ampliadas en conversación con sus más afines allegados, como se ha indicado en el apartado 4.6 El pensamiento de Gaudí en su madurez.

La iglesia debía satisfacer las necesidades religiosas de las 150 viviendas proyectadas junto a la fábrica -que daba empleo a mil trabajadores, de los cuales 500 habitaban en la colonia, los cuales también disponían de servicios médicos, culturales y deportivos-. La lentitud de las obras junto unidos a los continuos ensayos y experimentaciones estructurales mediante la maqueta funicular, con el consiguiente incremento del coste, y los cambios sociales y económicos tras la Primera Guerra Mundila que podían dar al traste con el planteamiento general de la Colonia, terminan convenciendo a Eusebio Güell de la oportunidad de parar la ejecución en 1914, prolongándose durante cerca de dos años los trabajos de acabado y de apertura al culto de la Cripta, aunque ya sin la presencia de Gaudí. ${ }^{226}$

\footnotetext{
${ }^{226}$ Cf. Puig Boada (1976). L'Esglesia de la Colonia Güell. Barcelona. Lumen. Puig Boada realiza un completo estudio de este proyecto inconcluso a partir de los materiales y documentos de que dispone, planteando una serie de gráficos que dan una idea muy precisa de la interpretación de la funiculas. Los materiales que cita son las distintas piedras utilizadas y datadas. Los documentos son croquis, planos de planta, fotografías, dibujos, y escritos, que también enumera. El resultado es un reconstrucción teórica de la planta superior y una interpretación estructural coherentes y probablemente muy próximas a la realidad del proeceso de diseño de Gaudí.
} 


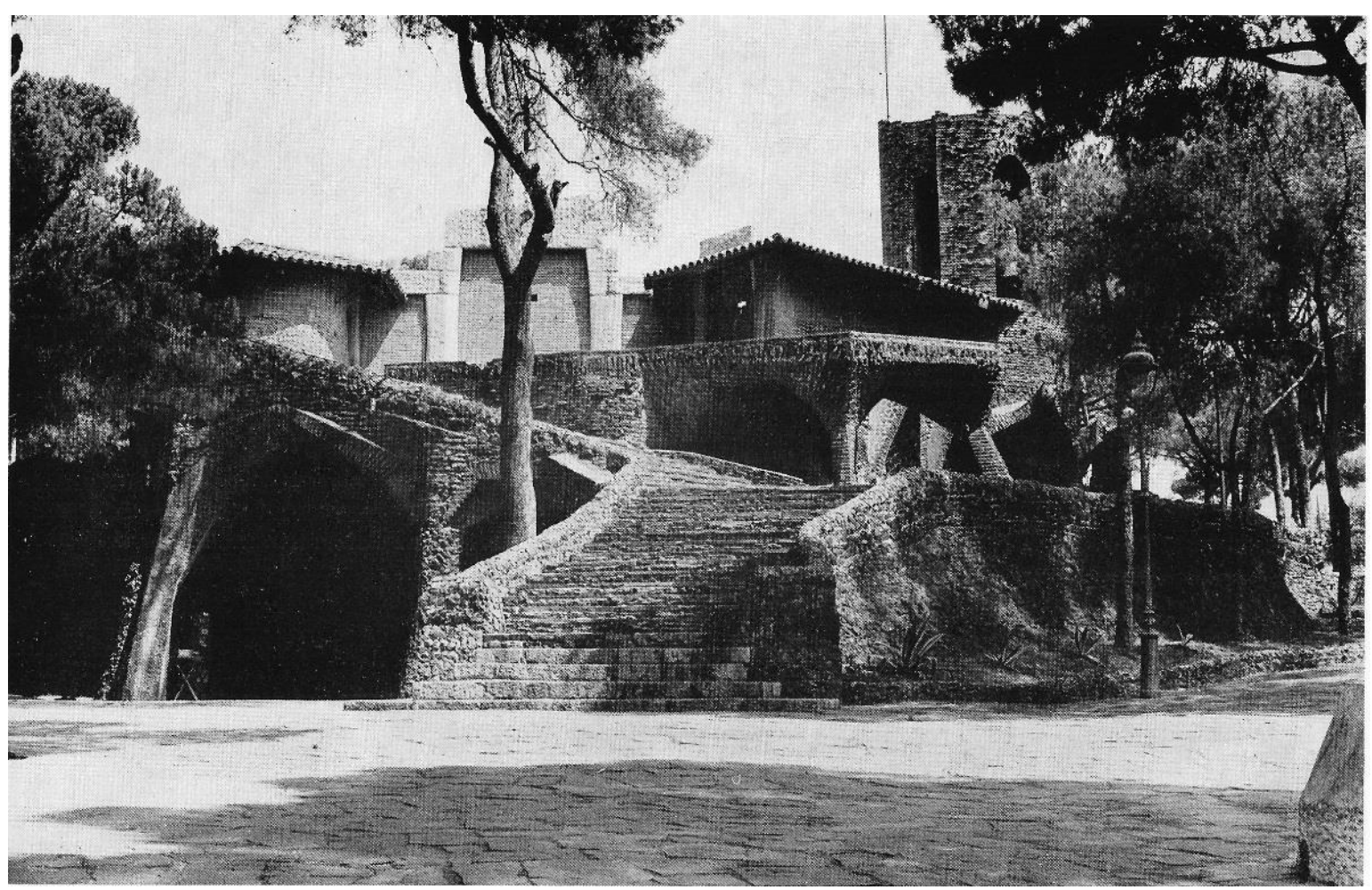

Visión frontal de la iglesia (Cripta) de Santa Coloma. Fuente: Puig Boada (1976) L'Esglesia de la Colonia Güell. Barcelona. Ed. Lumen.

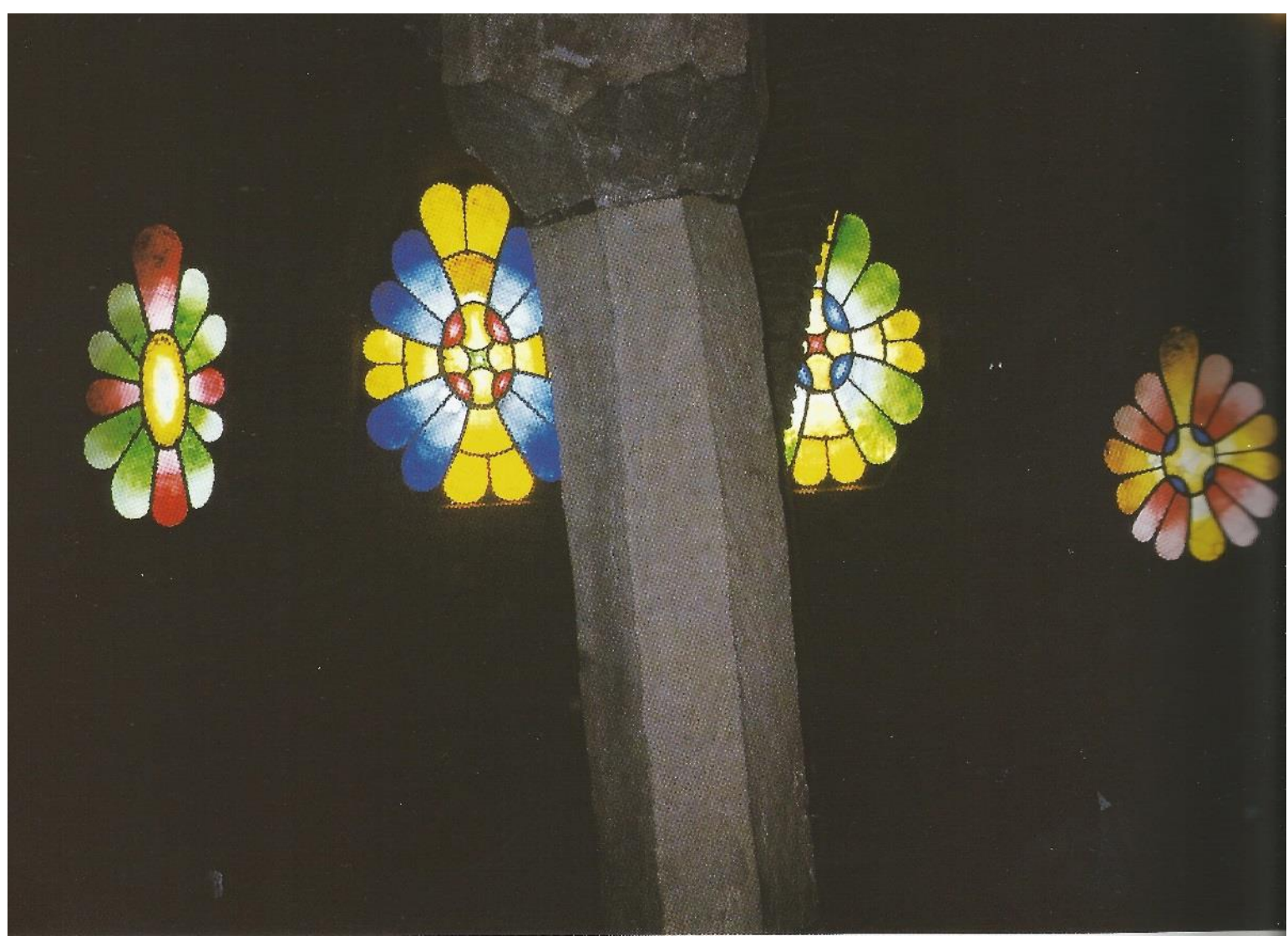

Interior. Vidrieras, simbolos y colores. Columna de basalto inclinada, fuste y capitel sin trabajar.

Fuente: Flores, C. (2002) La lección de Gaudí. Madrid. Espasa Calpe. 
Posteriormente a la muerte de Güell en 1918 sus hijos se desentendieron de la idea primigenia y quedó inconclusa la iglesia. ${ }^{227}$

Según Bassegoda esta obra "se convirtió en el más querido de los proyectos de Gaudí, y fue una especie de laboratorio de ensayos técnicos de lo que más tarde se hizo en la Sagrada Familia."228 Para Puig Boada (1976), este proyecto ocupa un lugar central en la producción gaudiniana al afrontar de una manera nueva la estructura y estabilidad del edificio-iglesia, ya que hasta ese momento había intentado superar las carencias que veía en los estilos históricos utilizando elementos usuales de estos estilos, como arcos, columnas y molduras, reinterpretándolos en función de su imaginación y su inquietud por la autosustentación, y con el afán de mejorar su comportamiento estructural o constructivo. Ahora se plantea el problema de la estabilidad desde el principio, sin distinguir entre pilares y arcos, elementos horizontales o verticales, sin contar con las soluciones históricas, centrando sus esfuerzos en encontrar los sistemas y las formas más idóneos para la construcción de los volúmenes que concibe.

Las obras se inician en 1908, recién terminada la casa Batlló y en plena construcción de la casa Milà. Quiere esto decir que se encuadran en el periodo que Bergós denomina de Naturalismo expresionista y que para muchos críticos es considerado de plena madurez del arquitecto. Gaudí escoge en el terreno de la colonia una situación preminente, en una pequeña colina poblada de pinos, para realizar su proyecto de iglesia, lo que unido a su particular estructura, inserción en el entorno y tratamiento de los materiales y elementos constructivos, da idea del cuidado con el que diseñó este proyecto.

Bassegoda añade que el camino de acceso desde la carretera, muy estudiado por Gaudí, fue concebido por éste como un itienerario de paulatina visualización del edificio, que quiso encajar los colores del edificio con los de la naturaleza circundante -eligiendo personalmente para ello las piedras de basalto y ladrillos quemados en exceso que facilitasen la integración con el terreno rocoso y la tierra oscura sobre la que se asienta la iglesia-, situando en las partes más altas una ladrilleria más acorde con los troncos de los pinos circundantes. Si se hubiese construido la iglesia superior, afirma Bassegoda, habría utilizado otros colores más próximos a los de la vegetación de los arboles, al cielo, al amarillo de la luz solar, etc. porque lo significativo es la interpretación simbólico-religiosa que da a esta gradación cromática refiriendola al itinerario espiritual de perfeccionamiento del alma humana.

\footnotetext{
227 La Cripta fue bendecida por el arzobispo de Barcelona D. Enrique Reig el 3 de noviembre de 1915 y durante el periodo 1936-39 fue almacen de material. En 1955 los herederos de Güell vendieron toda la colonia a la firma comercial Bertrand Serra y posteriormente se hizo cargo de ella un consorcio de administraciones públicas que ha ejecutado alguna obra de conservación.

${ }^{228}$ Cf. Bassegoda Nonell, J. (2002) Gaudí o espacio, luz y equilibrio. Madrid. Criterio Libros.
} 


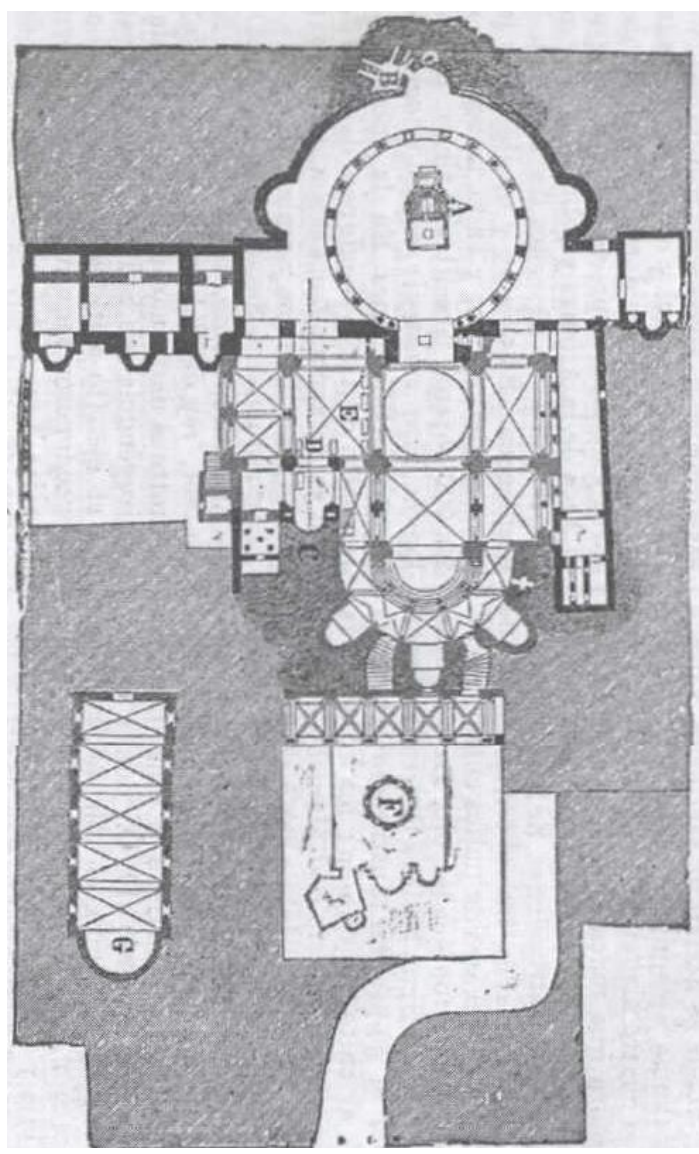

Planta del conjunto de la Iglesia del Santo Sepulcro de Jerusalén en la que se inspiró Gaudí para diseñar la iglesia de la Colonia Güell.

Fuente: Bassegoda, J.(2002). "Gaudí i el Sagrat", en Bassegoda, Crippa y AAVV. Espais Sagrats. Barcelona. Lunwerg.

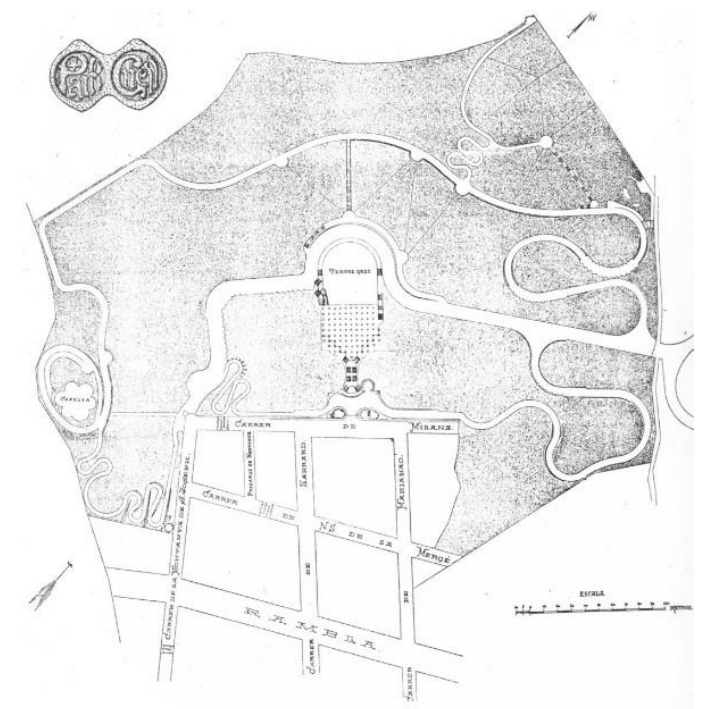

Plano del Parque Güell publicado en el Anuario de Arquitectos de Cataluña en 1903. Fuente: Torii, T. (1983) El mundo enigmático de Gaudí. Madrid. Instituto de España. 
Entramos, pues, en una asociación de aspectos que van a confluir en la idea unitaria que quiere conferir al proyecto. Agradecido sin duda de recibir el encargo de proyectar una iglesia nueva, Gaudí se plantea lo que puede significar este edificio y lo hace abordando desde sus raíces todas las cuestiones que le inquietan. Puig Boada explica la conocida frase gaudiniana de volver al origen como un replanteo total de la problemática arquitectónica que le afecta. ${ }^{229}$

El proyecto es concebido como una investigación respecto de lo qué quiere ser una iglesia, desde diversas vías de aproximación: la estructural, buscando resolver su estabilidad y sistema estructurante sin sujeción a soluciones impuestas por los estilos históricos, que considera imperfectas; la simbólica, en cuyo proyecto quiere significar la trascendencia del edificio mediante una cuidada selección de materiales y sus texturas, de las formas y elementos constructivos, los colores, ...; la iconográfica, con un amplio programa figurativo que pretende mostrar las claves del misterio cristiano en el contexto de la acción liturgica; la integración con el entorno, la configuración de la asamblea celebrativa según la renovación que propugnaba la Iglesia Católica por aquellos años, etc., debiendo haber supuesto -si se hubiese ejecutado todo él- un auténtico hito paradigmático en el contexto de la arquitectura eclesial.

El convencimiento personal de la importancia del objetivo que persigue le lleva a no despreciar la sencillez de los materiales empleados puesto que consideraba que lo externo habia de ser consecuencia de lo interior. $Y$, ¿Qué hay más interior en la arquitectura que la idea o voluntad de lo que quiere ser el mismo hecho arquitectónico -a la manera que diría Louis Khan- que hunde sus raíces en la configuración de la estabilidad y tectónica del edificio, y en la uso para el que se construye, en este caso marcado por la intemporalidad de la acción litúrgica.

Bassegoda (Espais Sagrats, 2002) muestra la relación existente entre el proyecto frustrado de la capilla -Capelya- del Parque Güell, que se puede ver en el plano de Julià Bardié de 1901, y el de la Iglesia de la Colonia como dos intentos sucesivos de reinterpretar el conjunto de la Iglesia del Santo Sepulcro en los que Gaudí intenta llevar adelante este espacio simbólico cristiano -hito edificado de una trascendencia en la que verdaderamente cree- y menciona la identificación que Jan Molema hace de la fotografía que figura en el libro de Ràfols de 1929 como correspondiente al primero de estos proyectos.

229 Cf. Puig Boada, I. L'Església de la colonia Güell. Barcelona. Lumen. P.43: "Lo que significa un templo cristiano y el honor de edificarlo. El planteamiento general de los servicios que comprende. El establecimiento de la estructura correspondiente. La estabilidad del conjunto. El estilo o expresión arquitectónica que tendrá. Las soluciones constructivas que asegurarán su durabilidad." 

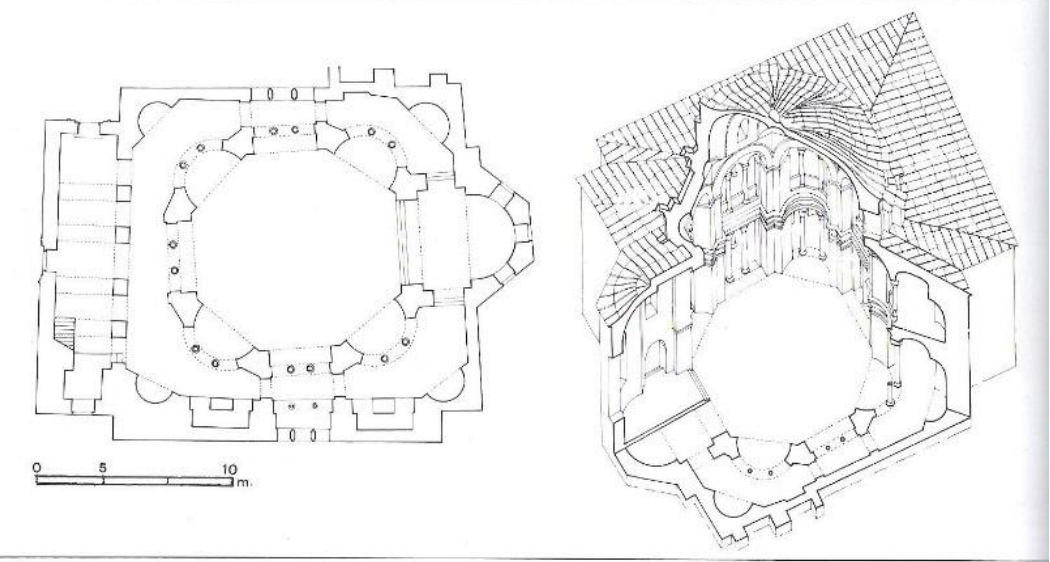

Planta y sección de la iglesia de los santos Sergio y Baco (s. VI). Fuente: Universidad de la Coruña.

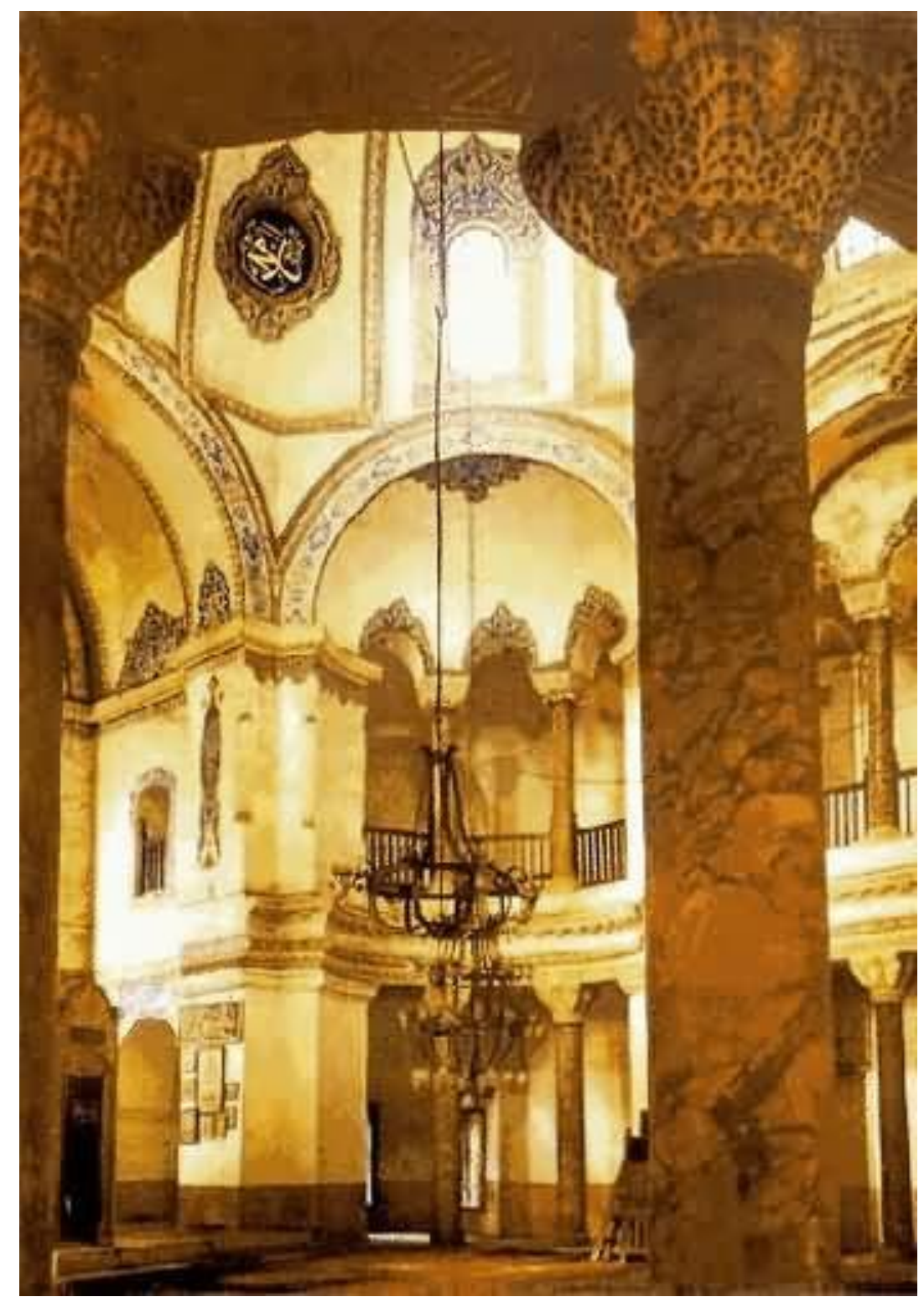

Interior de la iglesia de los santos Sergio y Baco (s. VI).

Fuente: Universidad de La Coruña. 
La idea del Santo Sepulcro de Jerusalén que aparece en el proyecto de Santa Coloma de Cervelló es recurrente en la arquitectura eclesiástica, desde las formas de los primitivos martirya y las disposiciones de planta central de las primitivas iglesias bizantinas a las plantas circulares u octogonales de los baptisterios, alcanzando su más alta significación en la tipología de iglesias de planta central, cuadrada, de cruz griega, octogonal o circular, que rápidamente se extiende por el oriente mediterráneo convirtiéndose en modelo de éxito para el culto cristiano y del cual son ejemplos afortunados las iglesias de los Santos Sergio y Baco, de los Santos Apostoles, y especialmente, Santa Sofia de Constantinopla y San Marcos de Venecia. Así pues, nada tiene de extraño que Gaudí, profundo conocedor de la $\mathrm{H}$ a de la Arquitectura, de los Textos sagrados y de la Liturgia, así como convencido creyente, quisiera dedicar el proyecto de iglesia que le encarga Güell para el servicio religioso de los habitantes de la Colonia al misterio de la muerte y resurrección de Jesucristo.

Respecto de este objetivo fuertemente simbólico que Gaudí pretende plasmar en su proyecto, frustrado primeramente en la construcción de la Capelya del Parque Güell, pero que reanuda en la montaña pelada del mismo parque con la construcción de tres cruces símbolo del Calvario y, sobre todo en la Colonia con un proyecto más ambicioso, los estudios del profesor Bassegoda aportan interesantes datos que van desde la reutilización de materiales para la maqueta de uno a otro proyecto hasta el análisis de los dibujos de la iglesia superior no construida, permitiendo percibir un nítido diseño litúrgico para el espacio interior. ${ }^{230}$

En los dibujos que se conservan del interior del proyecto para la iglesia superior de Sta. Coloma se aprecia nítidamente la escena del Calvario como fondo del presbiterio y del altar mayor. En un nivel superior, identificable con la bóveda del ábside, se visualizan también diversas escenas de la escatología celeste y entre ellas lo que parece ser el Juicio Final. Las imágenes presentan en su movimiento algunas similitudes con la celebre pintura de Miguel Angel para la Capilla Sixtina, más fácilmente reconocibles en el primer croquis que en el segundo. En ambos dibujos la iconografía cristiana sigue desplegándose por los paramentos verticales -columnas y bóvedas- llegando incluso al interior de las cúpulas.

En la Cripta, debajo de donde hubiera estado el altar mayor de la iglesia superior y ligeramente sobreelevado, existe un espacio vacio cuya apariencia semeja una galería o cueva, y donde se suele disponer el coro cuando tiene lugar alguna celebración importante en la Cripta.

${ }^{230}$ Cf. Bassegoda Nonell, J. (2002) "Gaudí i el Sagrat", en Bassegoda, J. y AA. VV. Gaudí: Espais Sagrats. Barcelona. Lunwerg. Afirma que del plano del Parque Güell de 1901 es posible conocer la forma de la planta de la iglesia que quería construir allí, aunque no se puede deducir si pensaba realizar una cripta. El zocalo del actual Calvario pudo ser el volumen de dicha Cripta, cuya planta alzada por el Dr. Arquitecto Hiroya Tanaka corresponde al plano de Juliá Bardié de 1901. 


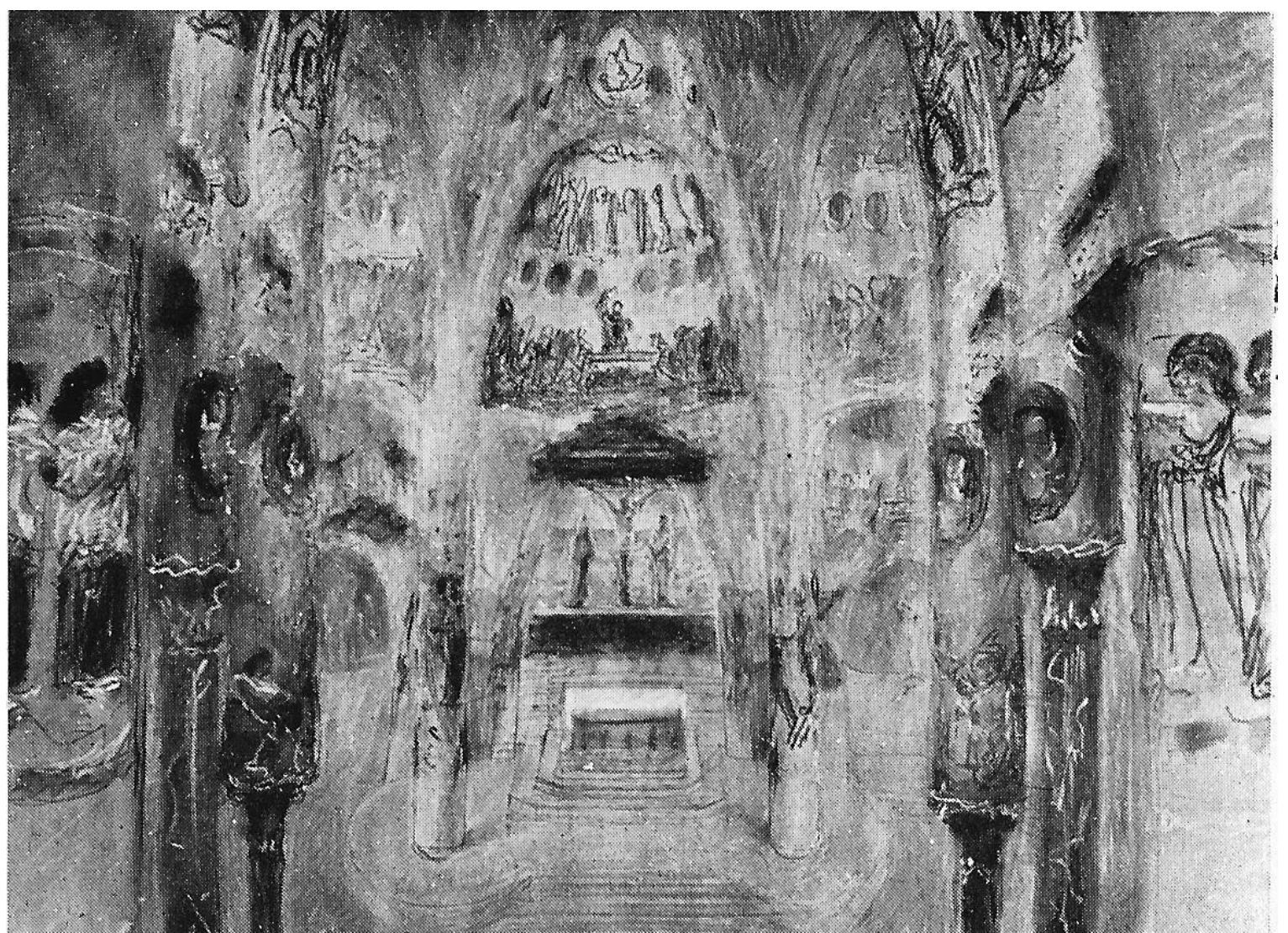

Primer croquis del interior de la Iglesia de la Colonia Güell.

Fuente: Puig Boada (1976) L'Esglesia de la Colonia Güell. Barcelona. Lumen. 
Siguiendo con la intención simbólica del proyecto, dedicado al misterio que aconte en otra montaña -Gólgota-, este espacio vacio podria reforzar también la alusión a la tumba vacía en el escenario de la pascua cristiana. En este sentido Puig Boada, que también considera al Santo Sepulcro como inspirador de este proyecto, tiene claro además los objetivos de servicio y realce del culto que Gaudí persigue. ${ }^{231}$ En la Cripta, concebida por el arquietecto como la representación de la tumba de Cristo, da una lectura simbólica a su ubicacion en el centro de la planta mediante las claves de la bóveda de ladrillo; su triunfo se plasmaría en el altar del presbiterio contando con el coro como fondo de escena.

En el altar de la iglesia superior se volveria a incidir sobre la misma idea de la iglesia de Jerusalén disponindo otro espacio celebrativo más elevado que haga alusión a la Resurrección y Ascension en lo alto.

A partir de esta idea fuertemente simbólica del proyecto, para aproximarnos a lo que quiere significar este edificio en el itinerario compositivo de la Sagrada Familia, es necesario llegar a visualizar todo el en su conjunto, a partir de la iglesia superior y de los estudios e investigaciones que se han realizado sobre ella. En 1898 -fecha en la que Ràfols menciona que empieza a trabajar Gaudí en el proyecto de la iglesia de Sta. Coloma- ya había tenido trato con Grau y en 1899 conoce a Campins y las ideas que éste pretendia para la restauración litúrgica de la Seo de Mallorca (anticipándose por poco tiempo a lo que preconizaba Pio X para la Iglesia Universal en 1903). Por tanto, la actuación del arquitecto en Santa Coloma se situa en unos años clave para la renovación del culto liturgico de la Iglesia. El Pontífice no trata abiertamente un modelo arquitectónico de iglesia pero sí muestra una decidida voluntad de procurar mediante la renovación de la asamblea litúrgica -fundamentalmente a través de la asunción de la música y del canto gregoriano- la participación activa de los fieles en la celebración eucarística.

Para lograrlo había que renovar y reforzar, con todos los medios disponibles al alcance de la jerarquía eclesiástica que encargaba las iglesias y de los arquitectos que las diseñaban, la focalidad y visualización primordial del altar, la diafaneidad del espacio celebrativo, la disposición más adecuada para el canto del coro y la respuesta de la asamblea, el consecuente tratamiento de la acústica, la ordenación de los espacios sirvientes y servidos para el culto, la accesibilidad para la recepción de la comunión frecuente, etc.

${ }^{231}$ Cf. Puig Boada, I. (1976). L’Església de la colonia Güell. Barcelona. Lumen. P. 47: “Un visitante situado al pie del cancel de entrada y de cara al presbiterio, puede ver casi de una ojeada todo el interior del Templo de Santa Coloma. Gozará plenamente de la visibilidad del ábside con el presbiterio y el altar, y poder seguir así atentamente los oficios divinos, con su mirada puesta en la Mesa, gracias a una estructura arquitectónica constantemente referida a este punto, con una visibilidad interior que las columnas no estorban por su esbeltez, $n$ i en extensión ni en altura...El observador veria las cupulas de la nave central, las semicupulas de las laterales, las bóvedas bajas que las apuntaban y los muros perimetrales...." 


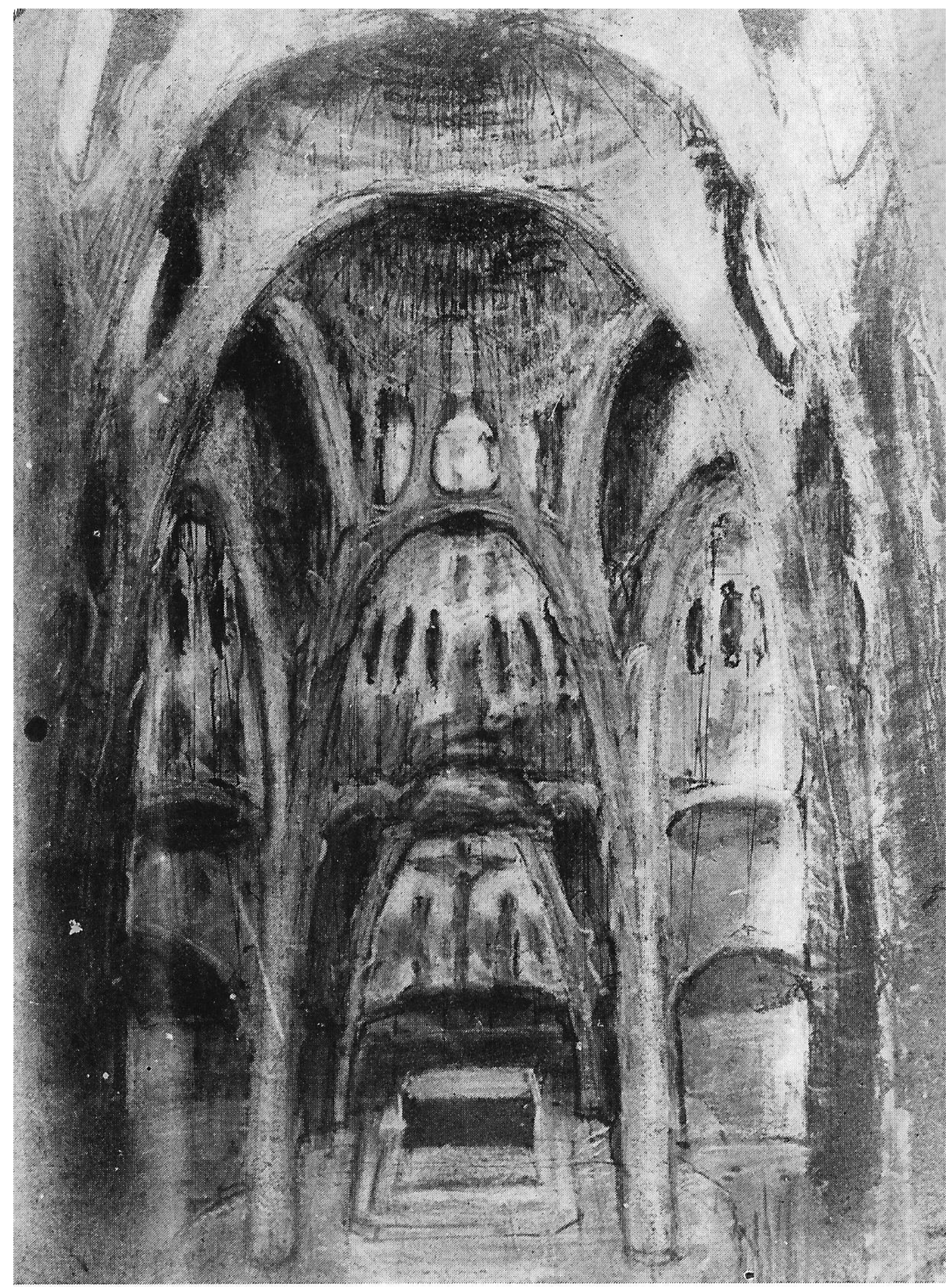

Segundo croquis del interior de la Iglesia de la Colonia Güell.

Fuente: Puig Boada (1976) L'Esglesia de la Colonia Güell. Barcelona. Lumen. 
En definitiva se trataría ahora de componer arquitectónicamente con cuidado especial fundamentado en la renovación liturgica- el espacio adscrito al culto público, comunitario, aunque ello fuese en detrimento de la relevancia artística con que anteriormente se habían ejecutado las iglesias. A las capillas y espacios destinados a devociones particulares que habian tenido tan gran desarrollo en siglos anteriores sucedería ahora un renovado interés por el aula liturgica en si misma.

Gaudí, que por aquellos años habia sido un tenaz defensor del uso publico y accesible de la capilla del colegio de la C/ Ganduxer en abierta oposición a la Madre Priora del convento teresiano (aunque ello le costara la renuncia a seguir con la dirección de los trabajos cuando ésta hizo prevalecer su idea de capilla de uso interno), parece tener claro el significado comunitario de la asamblea cristiana y la importancia de una mayor cercanía entre el altar como centro de toda la celebración y los fieles, tanto visual como físicamente. El proyecto de la catedral Mallorca solapándose con éste en el tiempo, le aportaría además un conocimiento más concreto del ceremonial de los obispos, del mobiliario litúrgico necesario para el culto y de la adecuada disposición de los distintos elementos de soporte arquitectónico a la asamblea aún en el caso de un edificio histórico existente.

En el proyecto de la Iglesia de la Colonia Güell todo parecer encaminarse a dar una visión unitaria y completa de lo Gaudí entendía por un templo cristiano, un edificio históricamente implicado en el nacimiento y desarrollo de la Arquitectura de todos los tiempos y dedicado a un uso cultual primordial, el de la celebración eucarística, completado como lugar privilegiado de oración, dotado de una concepción estructural grandiosa como manifiesta que corresponde a la tipologia del edificio, y con un programa litúrgico fuertemente personalizado en lo compositivo e iconológico, en el que todo debía concurrir a su magnificencia.

La altura del recinto vuelve a jugar una importante baza en cuanto a la dimensión simbólica y cultual, ayudada por la imagineria en el tratamiento pictórico del recinto. La disposición del coro, presumiblemente envolvente en la iglesia superior -si nos atenemos a la ordenación de las columnas y a los croquis del interior-, y claramente audible en la Cripta -elevado detrás del presbiterio- irían en la línea de favorcer la participación de los fieles en la celebración, realzada por la verticalidad constructiva de bóvedas y cúpulas que parecen distanciarse de la tierra para desafiar a la gravedad.

Para ello utiliza las herramientas técnicas y artísticas que precisa. Unas veces se trata de las posibilidades mecánicas de los materiales, de su textura o color, otras veces incorpora la geometría de las formas alabeadas, los ensayos respecto de la transmisión de las cargas, o la decoración mural y de columnas, como hemos visto. Pero hay que reconocer la existencia de un objetivo preciso que se persigue y ayuda a explicar ciertos márgenes de incoherencia en la utilización de estas herramientas. 


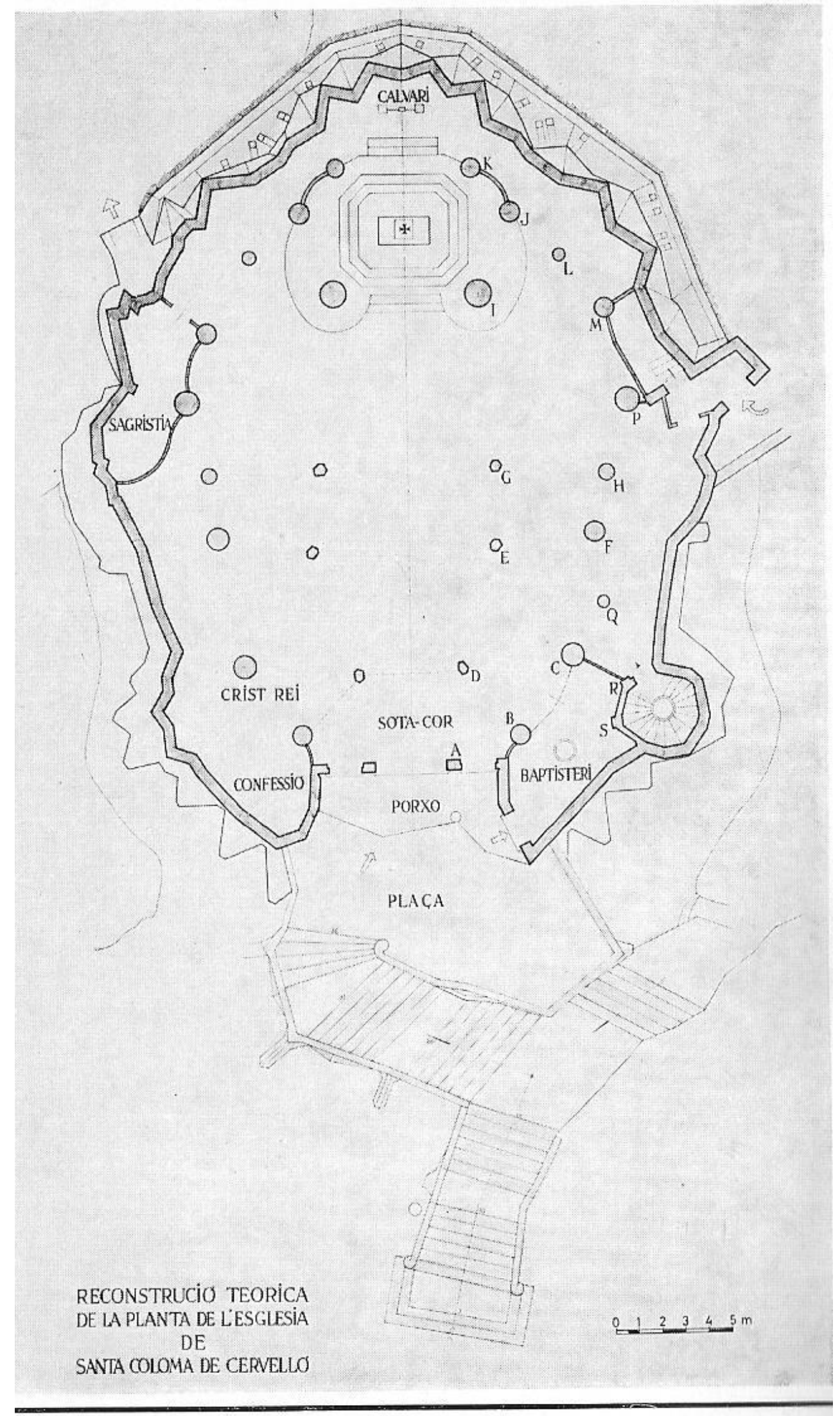

Planta de la Iglesia Superior, Colonia Güell, según Puig Boada. Fuente: Puig Boada, I. (1976) L'Esglesia de la Colonia Güell. Barcelona. Lumen. 
Las afirmaciones en plena madurez profesional (Bergós, Puig Boada) al respecto de la maqueta funicular, considerada como herramienta útil pero no sacralizada, son bastante elecuentes. Gaudí explicita su rechazo a convertirse en un funiculario y supeditarlo todo a las geometrías, diagramas de esfuerzos y reticulas -puesto que la técnica no ha de imponer las formas- ${ }^{232}$ estableciendo los límites a la técnica en pro de su idea del proyecto. Este tampoco se basa en la dimensión artística del edificio, ya ampliamente comentada en el Manuscrito de Reus, aunque la incluya con una visión muy expresionista de la construcción, sino que hay que buscarla en otras categorías más relacionadas con su lectura de la belleza del espacio arquitectónico. Por tanto, más alla del debate respecto de la inclinación de los pilares centrales de la Cripta $^{233}$ resulta de interés para nuestro tema destacar que de la investigación realizada por Tomlow y su equipo del Instituto de Estructuras Ligeras de la Universidad de Sttutgart salen propuestas de reconstrucción de planta, secciones y volúmenes que presentan una compleja organización compositiva para este proyecto. Tomlow completa las propuestas de Puig Boada con una serie de volúmenes y secciones que presentan dos niveles de galerías intermedias, coros altos, y una cuidada disposición de vanos para la iluminación natural del recinto, llegando a elaborar unas sugerentes plantas en sus distintos niveles. Destaca la significación del espacio del altar como foco principal que es adelantado desde el presbiterio hacia la nave aislándolo del fondo mural. El tratamiento lateral de las comunicaciones con el coro alto y con la cripta para no interferir con el aula celebrativa y la ausencia de espacios sirvientes (que parece ubicar en el nivel inferior) nos llevan a considerar la nave de la iglesia superior como un espacio dedicado íntegramente a la celebración eucarística, que es estructurado mediante un acoplamiento de cúpulas (Puig Boada).

232 Cf. Puig Boada, I. (1981) El Pensament de Gaudí: compilació de textos i comentaris. Barcelona. La Gaya Ciencia. P. 156: "Els funicles son mitjans cientifics de comprovació que s'utilitzen quan es necessari. Emperò és en va pretendre que una cosa científica (analítica) ens doni formes artistiques (sintetiques). Es com els qui volen que el barómetre digui el temps que farà, o que el termómetre indiqui el calor (que és un complex de temperatura, humitat, vent, etc.)"

233 Jos Tomlow realizó un estudio de la segunda maqueta funicular en la Universidad de Sttutgart elaborando un modelo de reconstrucción de planta y secciones (1989). Respecto de la inclinación de las columnas centrales de la Cripta, Tomlow (2002) sigue mostrándose partidario de explicarlo por la diferente luz, proporción de los arcos y sobre todo absorción de las fuerzas horizontales entre la parte central y la zona del altar. Jose Luis Gonzalez, partiendo del primer estudio de Tomlow y de cálculos más recientes por ordenador realizados por Casals (1993), llega a la conclusión de que la inclinación de los pilares no es consecuencia automática de la diferencia de luces de los arcos sino que es una decisión personal de Gaudí que elige un material con suficiente margen de seguridad para absorber las cargas verticales del pilar con un reducido diámetro, basalto, inclinándolo para favorecer la visibilidad del altar. Pere Roca (2002) apunta a la resolución de todos los estados de carga, desde la construcción de los pilares hasta el último que hubiera supuesto la finalización de la iglesia superior, para apuntar que Gaudí sobredimensionó estos pilares para que conjuntamente con el muro perimetral proporcionasen al conjunto de arcos y nervios un mayor confinamiento y la capacidad de adaptarse a la variedad de estados de equilibrio; así como para afrontar con seguridad todos los estados intermedios de carga y que por motivos compositivos dio menos inclinación al plano de los arcos perimetrales que al nucleo central. 


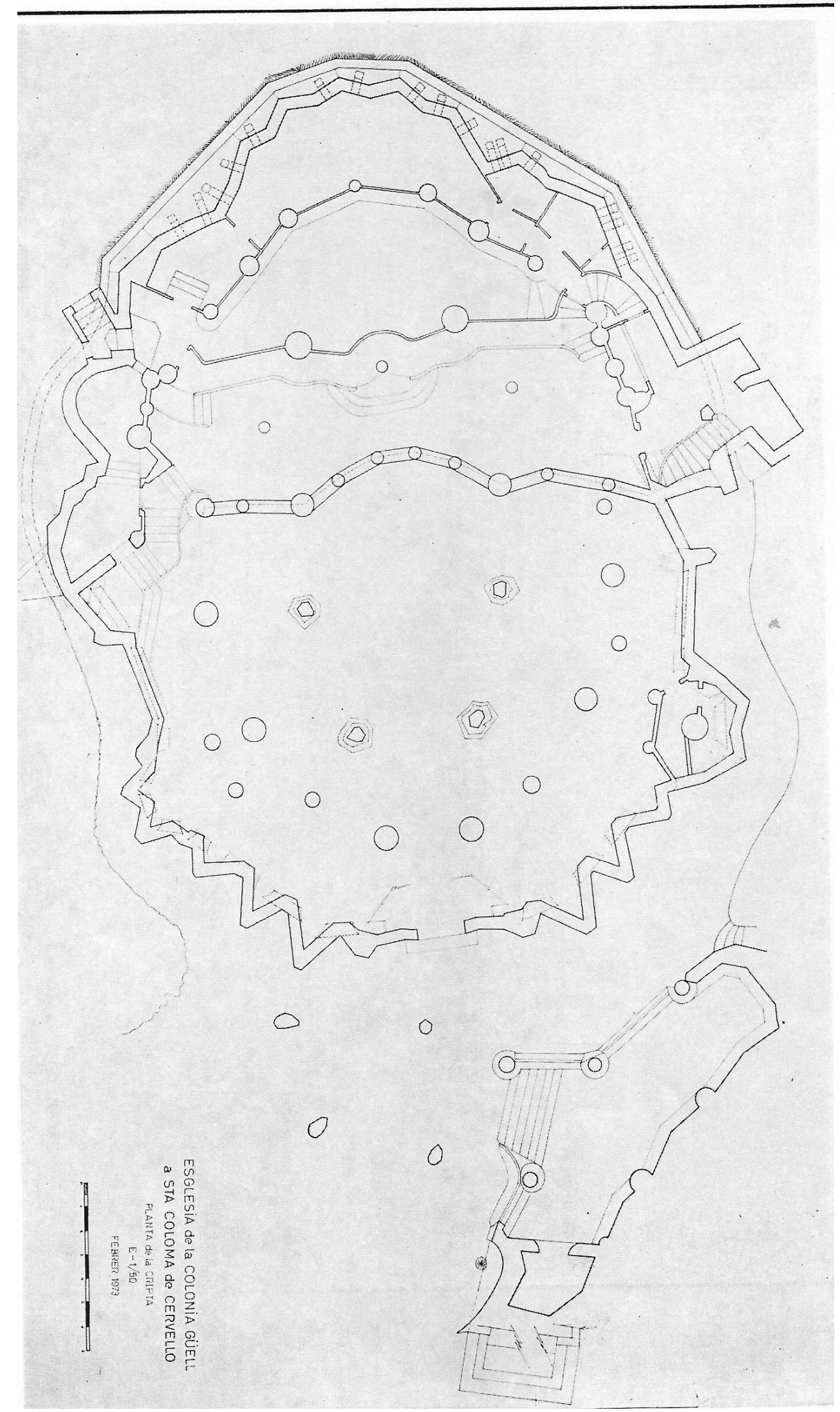

Planta de la Cripta de la Iglesia de la Colonia Güell. Fuente: Puig Boada, I. (1976). L’Esglesia de la Colonia Güell. Barcelona. Lumen. 
Esta composición no se reduciria a la cúpula central y a la del abside, sino que formaría un conjunto dispuesto según un determinado orden en su verticalidad (signo de elevación espiritual). En este orden tendría que ver la situación del presbiterio con el altar como ámbito más restringido de carácter ministerial, el teórico crucero haciendo referencia a la bóveda celeste, las torres que señalizan el nártex o entrada, e incluso otros recintos específicos -que figuran en la planta reconstruida por Puig Boada-como los recintos para la Confessio y para el Baptisterio.

Respecto de la inclinación y el mínimo trabajo de labra que presentan las columnas inclinadas de basalto -afirma Puig Boada, con martillo de madera y no de hierro, siguiendo lo que Dios dice a Moisés en el libro del Exodo- sean acertadas o no las opininones de Tomlow, Casals y Pere Roca, que unos interpretan como diferentes mientras otros concilian, el hecho es que su inclinación contribuye notablemente a acentuar la lectura simbólica de la Cripta que menciona Puig Boada, en mi opinión acertada tal y como me he referido. De la misma manera, la textura rugosa de los materiales y el tratamiento de la luz vidriada irían en la misma dirección: tratar de regular y disminuir fuertemente la cantidad de luz que ha de penetrar en un espacio que se quiere ambientar con un cierto recogimiento mediante la dimensión, forma y ubicación de los ventanales. En cambio otros elementos -como las palomas blancas en lo alto de las torres de la iglesia superior- símbolo de las almas liberadas (Puig Boada) rematarían el verticalizado itinerario simbólico del proyecto al cual ya se ha hecho referencia al tratar del color de los materiales y su adecuación al entorno.

En cuanto a la configuración de la planta, algunos estudios hablan de una idea de centralidad que se manifiesta en los proyectos de madurez, y concretamente en esta iglesia, a partir de una tradición clásica europea unida a una cierta jerarquización propia de esta tipología. ${ }^{234}$ No hemos hallado alusión ninguna a las trazas centralizadas renacentistas en sus escritos, pero sí son continuas las referencias -en el Manuscrito de Reus y en su pensamiento maduro- a una arquitectura eclesiástica ${ }^{235}$ basada en el conocimiento histórico, la alta consideración de la arquitectura bizantina ${ }^{236}$, su capacidad de análisis y síntesis, y la adhesión a los postulados del Movimiento Litúrgico. De ahí que coherentemente emprenda la via de la experimentación profesional hacia disposiciones constructivas fundamentadas, primero en el módulo básico de la cúpula -iglesia de Sta. Coloma-, y después, como veremos, en un proyecto protorracionalista más evolucionado -Sagrada Familia-.

${ }^{234}$ Cf. Solá-Morales, I. (1983). Gaudí. Barcelona. Polígrafa. P. 26-27.

235 Cf. Mercader, L. (2000) Antonio Gaudí, escritos y documentos. Barcelona. El Acantilado. P. 50-71; Puig Boada, I. (1981); El Pensament de Gaudí. Barcelona. COAC. La Gaya Ciencia. P. 196. P. 217-220.

${ }^{236}$ Cf. Puig Boada, I. (1981). El Pensament de Gaudí. Barcelona. COAC. La Gaya Ciencia. P. 62-63., P.104, P.109: "Jo he vingut a agafar l'arquitectura allà on la deixà lèstil bizanti". 

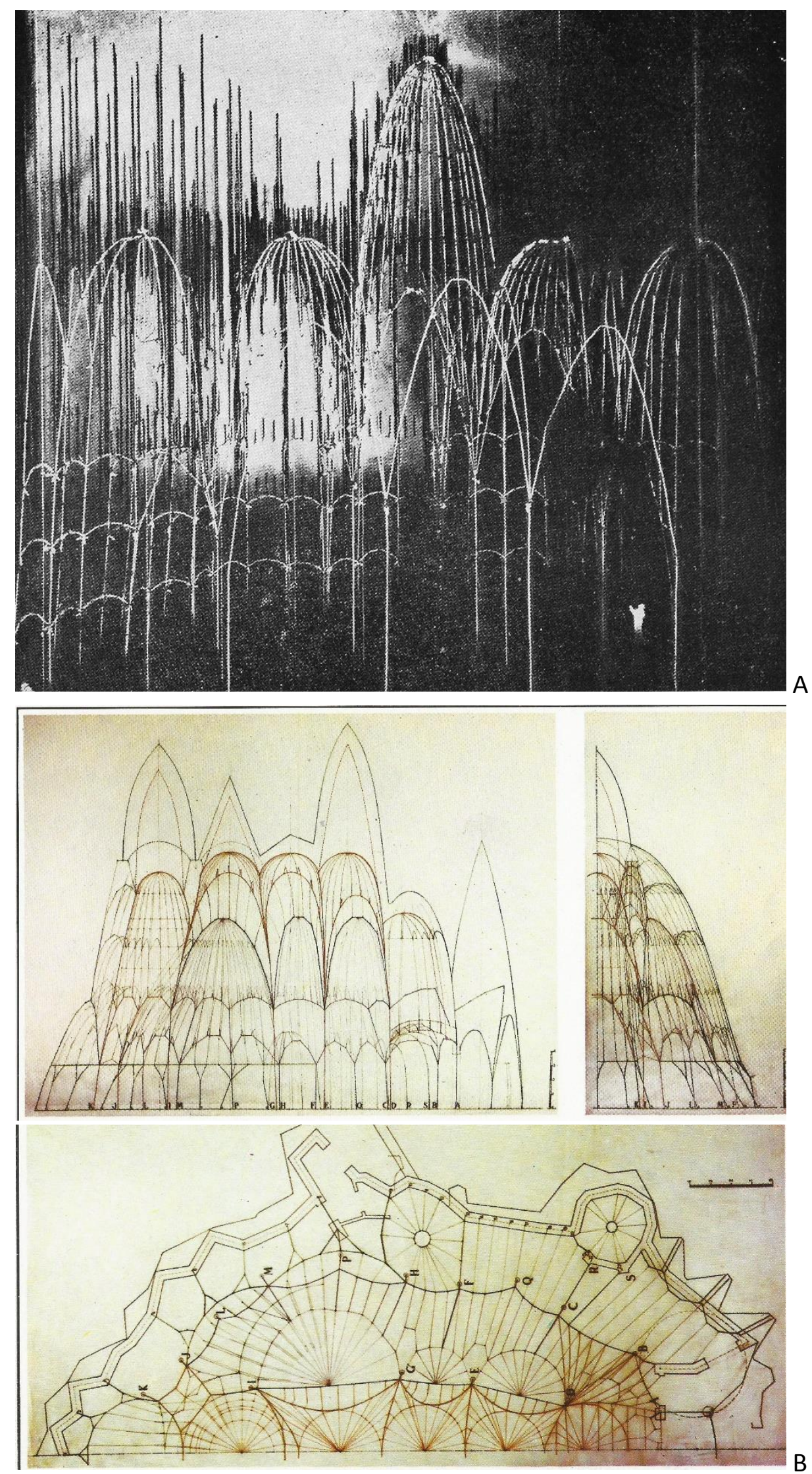

A: Maqueta funicular de ensayo de la Iglesia de la Colonia Güell guardada en el obrador de la Sagrada Familia. B: Interpretación de Puig Boada de las funículas para la planta, sección longutidinal y aspecto parcial de la transversal. Fuente: Puig Boada (1976) L'Esglesia de la Colonia Güell. Barcelona. Lumen. 
Hay quien ve en la planta de esta iglesia una prefiguracion de una asamblea liturgica más moderna -ligada al periodo posterior al Concilio Vaticano II- ${ }^{237}$, pero en mi opinión no hay más concordancia que la que se deriva de considerar la renovación que prentendia el Movimiento Liturgico como lo que realmente es, un prólogo o paso previo a la Constitucion Sacrosanctum Concilium, a lo cual ya nos hemos referido en los apartados 3.b - El Renacer litúrgico de la Iglesia desde la segunda mitad del siglo XIX hasta el pontificado de Pio X, 3.c -La Renovación Litúrgica en España- y 4. -Antonio Gaudí y su concepto de Arquitectura de lo Sagrado-. Volveremos a esta cuestión más adelante en el apartado 6. -El proyecto de la Sagrada Familia de Antonio Gaudí en clave celebrativa.

Ciertamente que Puig Boada interpreta la planta de este proyecto en clave celebrativa y asevera que es aquí donde Gaudí puede actuar libremente sin más condicionamientos que los de su imaginación ${ }^{238}$, pero en mi opinión no se puede ir más allá de lo que Gaudí y su circulo más inmediato de eclesiásticos habían interpretado de la renovación liturgica surgida en Centroeuropa. Por otro lado, la interpretación cupular y funicular del espacio que imagina y pretende construir Gaudí le aporta un medio increíblemente eficaz para lograr la mejor diafaneidad interior y la prevalencia del altar respecto de la horizontalidad de la planta que justifican por si solas el esfuerzo realizado. A esto vendría a unirse la idónea elevación vertical cuyo simbolismo en el espacio cultual cristiano es enorme, permitiéndolo abordar un completo programa iconográfico claramente figurativo.

Comparando las plantas de la Iglesia superior y de la Cripta del libro de Puig Boada, una de las primeras cosas que llama la atención es que, pese a la continuidad en la configuración de planta del edificio y la disposición de los pilares, la comunicación entre ambos recintos es externa al espacio celebrativo, bien desde el exterior o a través de escaleras situadas en espacios secundarios de circulación. Puesto que el proyecto se concibió como único esto lleva a pensar sobre el motivo por el cual la Cripta se pensó como un espacio de culto totalmente independiente de la Iglesia superior.

Históricamente la cripta o confessio, contenía la sepultura o reliquias de los santos y mártires cuya ubicación bajo el altar mayor contribuía a recordar su testimonio en defensa de la fe que se celebraba.

\footnotetext{
237 Cf. Bofill, R.M. (1990) La premonició gaudiniana respecte dels criteris liturgics del Concili Vaticà II. Barcelona. IEC. P. 16-20.

${ }^{238}$ Puig Boada, I. (1976) L'església de la colonia Güell. Barcelona. Lumen. Pg. 46: “Toda la disposición interior aparece preparada para centrar la atención principalmente hacia el presbiterio y darle también la máxima dignidad..."
} 

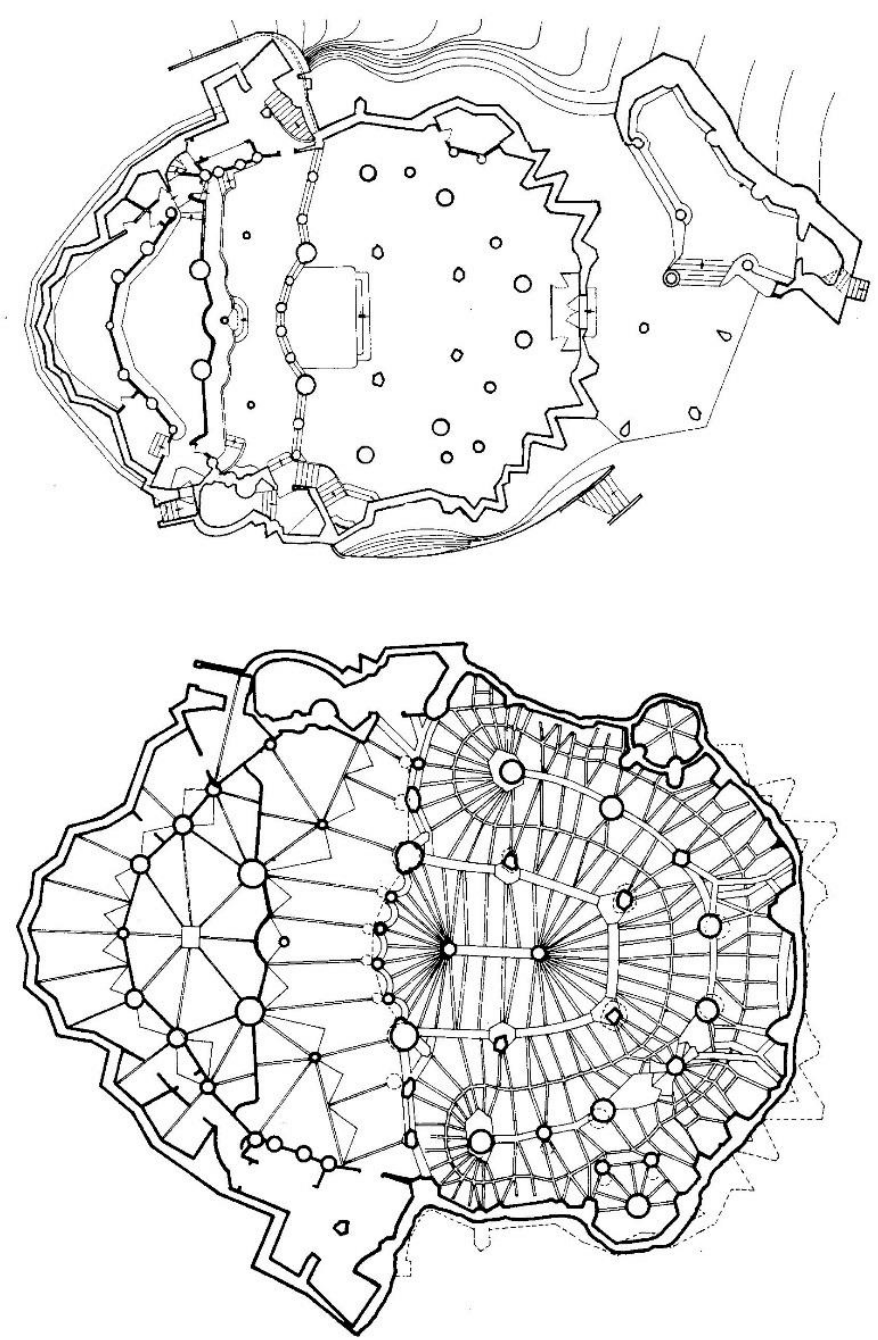

Colonia Guell (1908-1917)

Plantas de suelo y bóveda de la Cripta de la Iglesia de la Colonia Güell. Fuente: Bassegoda, J. y Garcia Gabarró, G. (1999). La catedra de Gaudí: Estudio analítico de su obra. Barcelona. Eds. de la UPC.

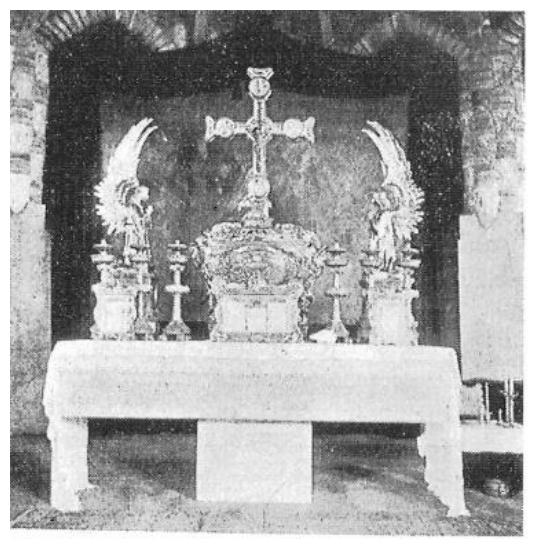

Altar de la Cripta en 1920, fotografía conservada en el Archivo Cuyàs. Fuente: Lahuerta J.J. (1993) Antonio Gaudí: arquitectura, ideología y politíca. Madrid. Alianza Editorial. 
Esta motivación y veneración, extendida rápidamente por toda la Iglesia durante el pontificado de San Gregorio, cayó en desuso durante la Edad Media hasta convertirse con el trascurrir de los siglos en lugar de sepultura o panteón de hombres ilustres. En el siglo XIX, y probablemente por motivos higiénicos, las iglesias que se contruyen independizan la cripta del aula liturgica como espacios totalmente independientes, comunicándose por el exterior o alguna escalera lateralizada en recinto propio. En el caso de Sta. Coloma no parece que se planteara desde sus inicios ningún tipo de panteón para la Cripta sino que más bien su disposición es la de un espacio abierto a los fieles cuyo uso admite diversas funciones litúrgicas.

Si la pretensión original era construir una iglesia superior no tenia demasiado sentido realizar otra aula liturgica en el nivel de la cripta a menos que se quisiera utilizar provisionalmente -como en el caso de la Cripta de la Sagrada Familia- o se adoptase esa solución una vez que no se tenia clara la continuidad en la ejecución de las obras. Si, como afirma Bassegoda, cuando Gaudí se fue a vivir en 1906 a la casa del Parque Guell antes del inicio de las obras de Sta. Coloma (1908)- mandó construir en ella un pequeño mirador para ver el pequeño Calvario construido en el camino de la Capelya en función de que ésta ya no se iba a realizar allí, habría tenido tiempo de reconsiderar sus ideas respecto de esta iglesia -en la que supuestamente llevaba trabajando desde 1898 según Ràfols- introduciendo desde el principio las coordenadas fundamentales del proyecto. $\mathrm{Si}$ como afirma Bocabella estuviéramos ante el segundo intento afrontar el tema del Calvario seria muy lógico pensar en un tratamiento similar y diferenciado de los recintos, esto es, un espacio celebrativo en la parte alta fundado en el triunfo de la resurrección de Cristo y otro espacio inferior, contemplativo, destinado a la oración y a honrar la memoria de la tumba de Cristo. Esto explicaría la casi total ausencia de comunicación interna entre ambos recintos a semejanza del conjunto original en Jerusalen.

El hecho de que en 1914 se desestimara continuar con la construccion de la iglesia superior debió propiciar la redefinición de la Cripta como aula liturgica, cuyo esquema de planta -generado a partir de la Anástasis del Santo Sepulcro- lo permitia sin mayores problemas, siendo consagrada en 1915. Por lo demás, las texturas, desnudez y color de los materiales, así como su disposición, nos hablan más de un sepulcro santo, o confessio, que de una iglesia según el desbordante programa iconográfico gaudiniano. En función de ello, concuerda la propuesta de planta de la Iglesia Superior propuesta por Puig Boada con la planta inferior, auténtico Oratorio público con una disposición de los espacios sirvientes realmente incómoda para atender el culto. El planteamiento de tres altares en un recinto tan reducido (diseñados dos de ellos por Jujol y otro por Puig Boada en 191415) y el testimonio grafico de 1920, muestran una realización litúrgicamente más tradicional que la debida personalmente a Gaudí en la Cripta de la Sagrada Familia, cronológicamente anterior. 


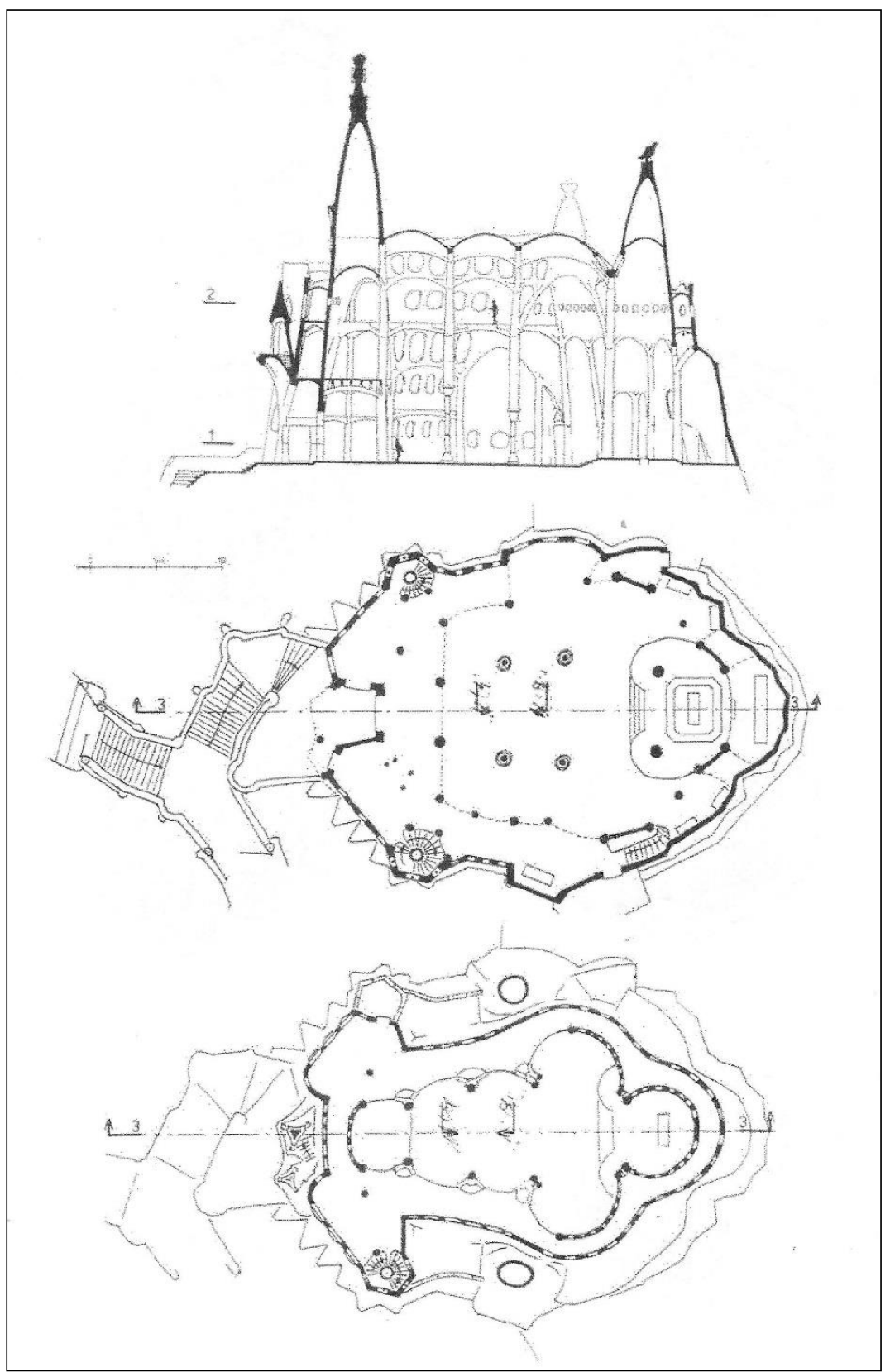

Interpretacion de Jos Tomlow de la sección y plantas superiores para coros. Fuente: Tomlow, J. (2002) “La evolución de la innovación estructural de Gaudí, en Gaudí, estrcutura y naturaleza. Madrid. OP Ingeneria y Territorio, nำ59. 
Casanelles afirma que viendo la disposición de la planta de la Cripta y su estructura central es muy posible que Gaudí pensara en situar en esa posición el altar ${ }^{239}$, pero Puig Boada al estudiar conjuntamente los dibujos de fachadas y del interior remarca que la cripta es sólo una pequeña parte del proyecto y no encuentra correspondencia directa entre una hipotética ubicación del altar en el centro físico de la cripta y las torres proyectadas para la iglesia superior. ${ }^{240}$ En mi opinión, el razonamiento anterior resolvería estas cuestiones al considerar inicialmente el espacio central como el lugar más sagrado a imitación del centro de la Anástasis de Jerusalen y posteriormente realizarse los tres altares en sus ubicaciones actuales, razón por la cual las torres de la iglesia superior responderían a otro planteamiento como sugiere Puig Boada.

En dialogo con la fundamentación histórica, el simbolismo religioso que denotan los dibujos, la interpretación de la estructura y plantas de este proyecto, y la situación litúrgica de la Iglesia en esos años resulta lógico pensar en una Cripta dedicada a la oración y la adoración (en el que ocasionalmente podria celebrarse igualmente la eucaristía), reservando la configuración del aula liturgica como verdadero espacio celebrativo a la Iglesia superior.

En la iglesia superior el altar se situa exento pero claramente al fondo del ábside. Pretender atribuir al proyecto una centralidad geometrica del altar más allá de la centralidad focal establecida por su visualización, la iconografía circundante y la posible ubicación de los coros en alto parece querer anticipar gratuitamente ubicaciones que no se corresponden con el momento litúrgico que vivió el arquitecto. En la iglesia superior las cúpulas definidas por la maqueta funicular proporcionan un orden jerarquizdo del espacio de culto a la par que garantizan la estabilidad e iluminación natural del conjunto. La interpretación de Puig Boada y también los estudios de Tomlow serian concordantes con la utilización de las bóvedas semiesféricas de muchas iglesias bizantinas en las naves y de sus correspondientes en los ábsides -dispuestas de tal manera que constituyen el módulo repetitivo que configura los espacios principales y secundarios de su planta de cruz griega, ayudándose además en la absorción de los esfuerzos horizontales-

En los croquis del interior de la iglesia de la colonia Güell y en los dibujos de Puig Boada y Tomlow se aprecia una configuración estructural con evidentes analogías con las iglesias de San Juan de Efeso y SanMarcos de Venecia.

\footnotetext{
239 Cf. Casanelles, E. (1965). Nueva visión de Gaudí. Barcelona. Ed. del Serbal. P. 110: "Viendo la estructura central, que tiene forma de tabernáculo, acude la idea de que Gaudí pensó posiblemente situar en ella el altar: los fieles habrían rodeado completamente el lugar más sagrado de la Cripta. Nos movemos ahora dentro de los espacios internos del alma del arquitecto, perfectamente conocedor de la profundidad comunitaria de la liturgia cristiana."

${ }^{240}$ Cf. Puig Boada, I. (1976). L'Església de la colonia Güell. Barcelona. Lumen. Compárense la maqueta, plantas y secciones del funicular que presenta con las mismas plantas de la cripta.
} 

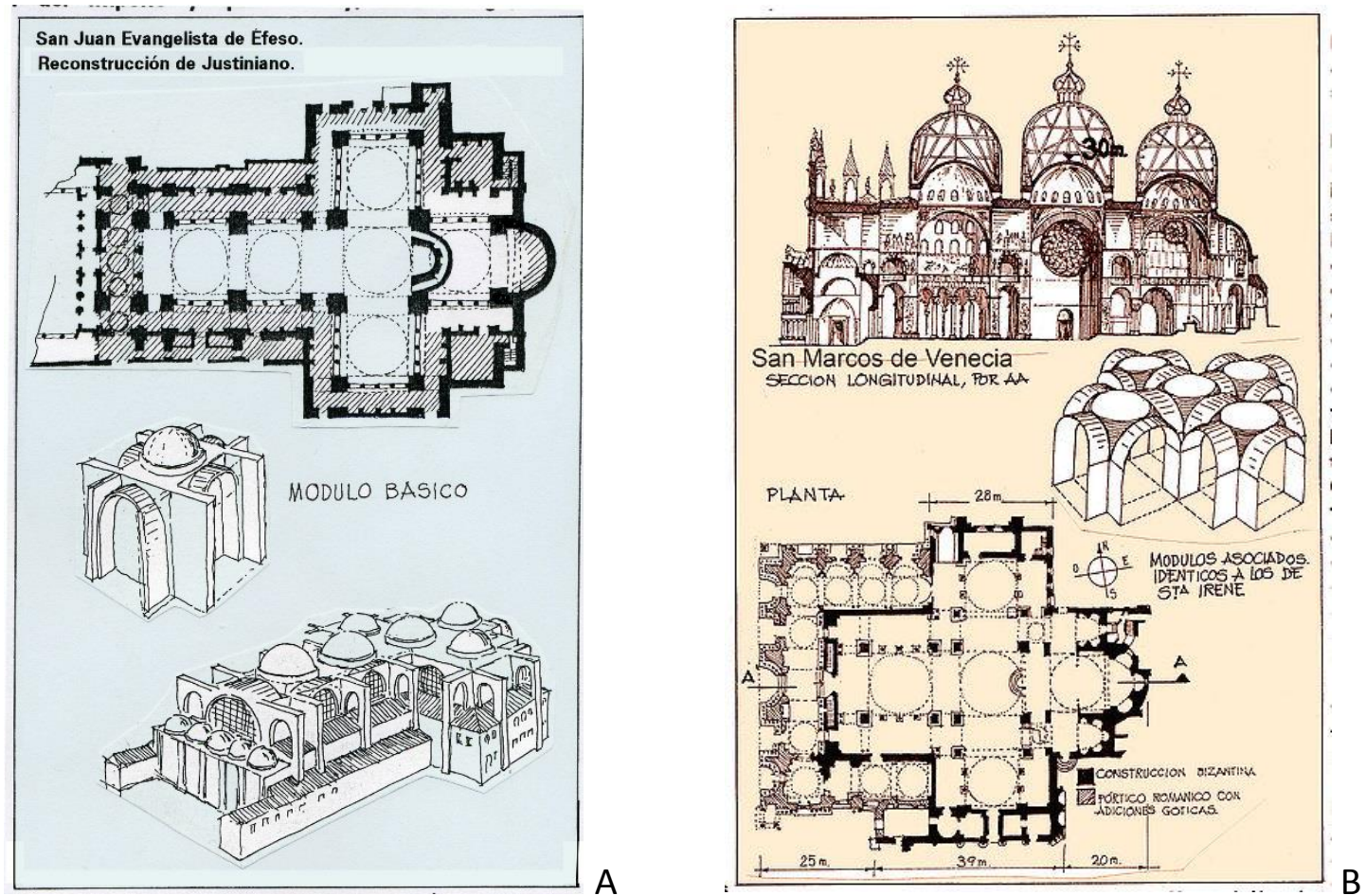

A: Iglesia de San Juan de Efeso. Dibujo de planta y axonometría con el módulo básico estructural.

B: San Marcos de Venecia. Planta, Seccion y módulos estructurales.

Fuente: Departamento de Construccion de la ETSA de la Universidad de las Palmas de Gran Canaria.
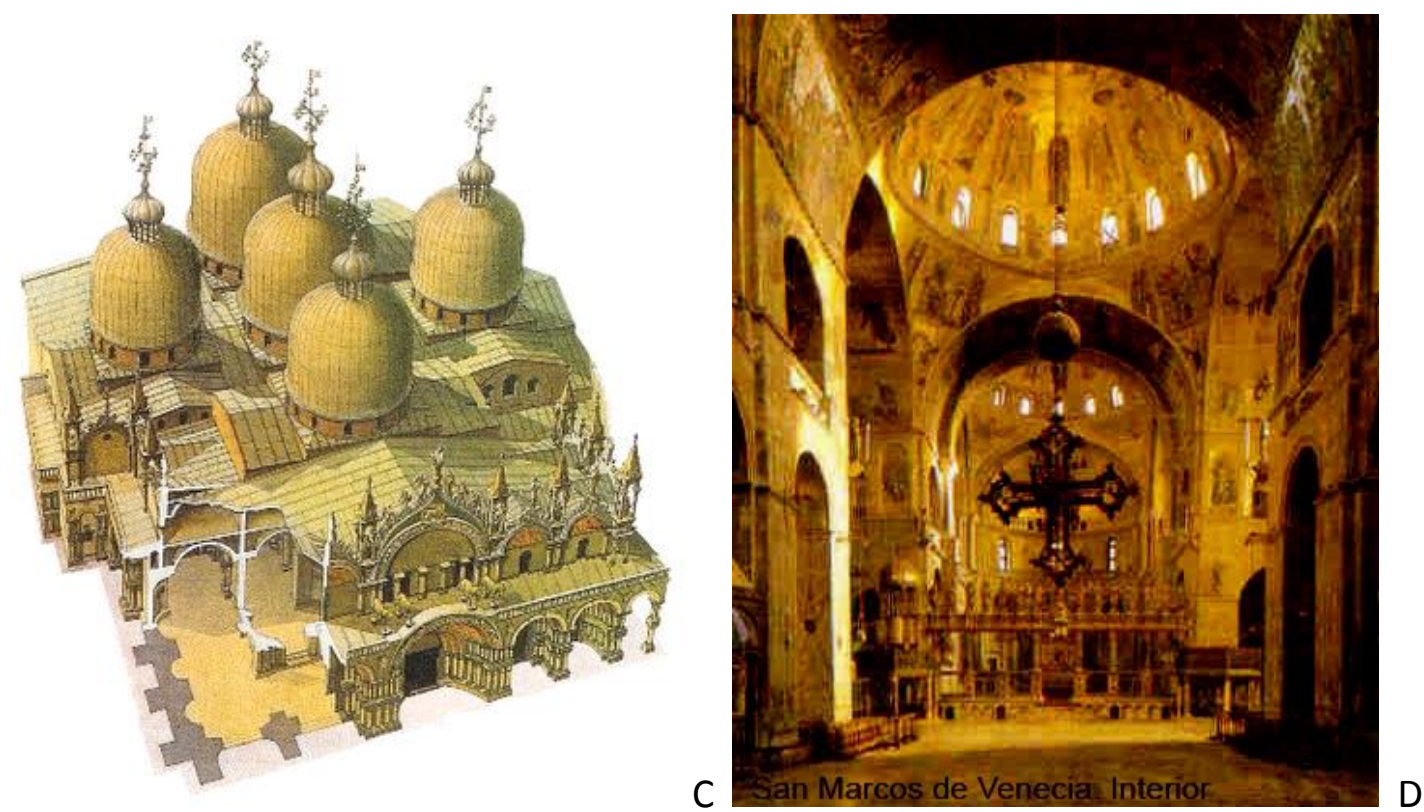

C: Axonometria de San Marcos de Venecia. Fuente: Benevolo, L. (1982) Diseño de la ciudad 3. Barcelona. Gustavo Gili.

D: Interior de la misma iglesia, se aprecia la amplia iconografía de pinturas murales y el cancel delimitador entre crucero y presbiterio. Fuente: Depto. de Construccion de la ETSA de la Uv. de Las Palmas de G.C. 
En los dibujos y en las maquetas funiculares, especialmente en las primeras que se realizan como ensayo, se distingue con nitidez el uso repetitivo de la cúpula que proyecta Gaudí para solucionar la estructura del espacio celebrativo, cuyas columnas de apoyo, además, dan continuidad al amplio programa iconográfico que pone a disposición de la catequesis litúrgica. ${ }^{241}$ También Navascués afirma que la planta de esta iglesia resulta de la aplicación de este sistema de bóvedas. El arquitecto aprecia el programa estructural e iconográfico de San Marcos como el más idóneo para desarrollar el espacio que imagina para rememorar el conjunto del Santo Sepulcro en la montaña barcelonesa ${ }^{242}$.

Siendo que Gaudí en el Manuscrito de Reus alaba las características de la cúpula de media naranja, a la vez que preconiza que la forma exterior debe ser consecuencia de lo que demanda el interior, su planteamiento estructural autosustentante a base de cúpulas repetitivas es de una coherencia meridiana. Pero la intuición de Gaudí respecto de la utilización de la cúpula y de su estabilidad irá más allá de este caso concreto -como diría Fernandez Casado- buscando su aplicación como sistema estructural de cubrición en superficies de distinta geometría y uso, pues por las mismas fechas '(1908-1913) lo utiliza en el pórtico del Parque Güell, y también tendrá su aplicación en la Sagrada Familia. ${ }^{243}$

Fernandez Casado considera que Gaudí se plantea la resolución de los problemas de estabilidad arquitectónica a través del ladrillo y la piedra fuera de tiempo, pues el hormigón, que conocía y empleaba en algunas ocasiones, estaba comenzando a ser utilizado en estructuras cada vez mayores ${ }^{244}$ y también el hierro había desarrollado notables estructuras edilicias e ingenieriles. Pero Gaudí es un utópico de las prestaciones de los materiales y soluciones constructivas tradicionales y tampoco debe considerarse que permanece al margen de las posibilidades que prestan los nuevos materiales pues como han señalado Josep Gomez Serrano y Jordi Coll está demostrada la utilización del hormigón y del hierro en varias de sus obras.

${ }^{241}$ Cf. Puig Boada, I. (1976). L'Església de la colonia Güell. Barcelona. Lumen P. 53: “Este volumen interior, al estar dispuesto en un plano central y en otros envolventes de superficies continuas le facilita a la decoración mural requerida para seguir en ella la enseñanza litúrgica"

242 Cf. Navascués, P. (1996). "Arquitectura Española 1808-1914”, en Summa Artis, Historia General del Arte, Tomo XXXV. Madrid. Espasa Calpe. P. 637: “...la planta es el resultado de un procedimiento que parte del sistema bóvedas, de tal forma que el muro perimetral así como la localización de los puntos de apoyo, de gran impacto en su representación gráfica, no responden a un esquema preconcebldo sino que es consecuencia formal de un nuevo y revolucionario sistema de bóvedas y control de empujes."

${ }^{243}$ Cf. Fernandez Casada, C. (2002). "Gaudí visto desde la arquitectura del ingeniero", en Gaudí, estructura y naturaleza, №59 Revista OP Ingenieria y Territorio. Madrid.

${ }^{244}$ Cf. Fernandez Casado, C. (2002). “Gaudí visto desde la arquitectura del ingeniero”, en Gaudí. Estructura y naturaleza. Revista Ingenieria y Terrotorio no 59. Barcelona. Colegio de Ingenieros de Caminos, canales y puertos. 

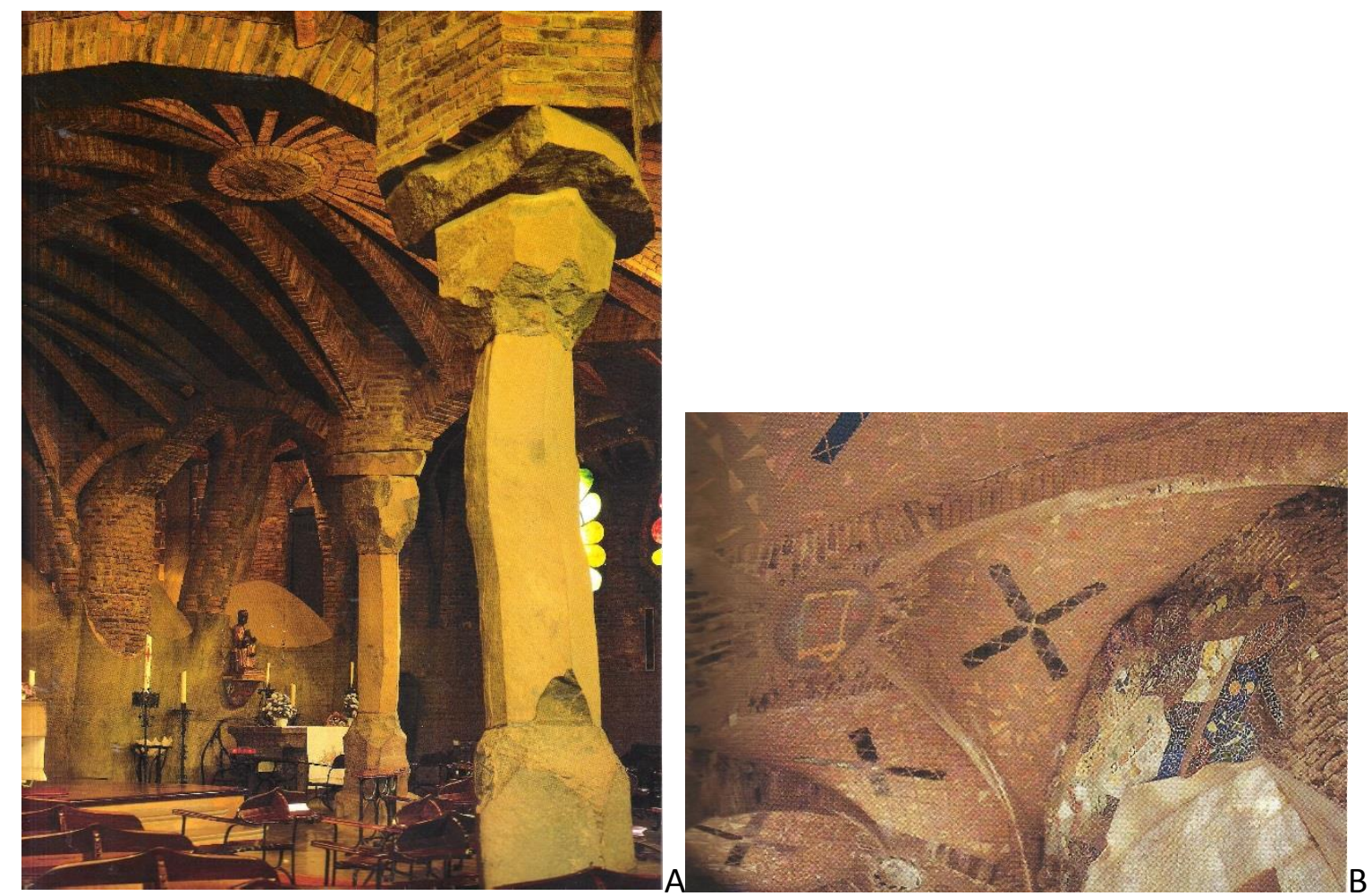

A: Interior de la Cripta de la Iglesia de la Colonia Güell (1898-1914). Fuente: Daniel Giralt-Miracle. (2002) La búsqueda de la forma. Barcelona. Lunwerg.

B: Simbologia en el pórtico de acceso. Fuente: Lahuerta, J.J. (1993) Antonio Gaudí: arquitectura, ideologia y política. Madrid. Alianza Editorial.

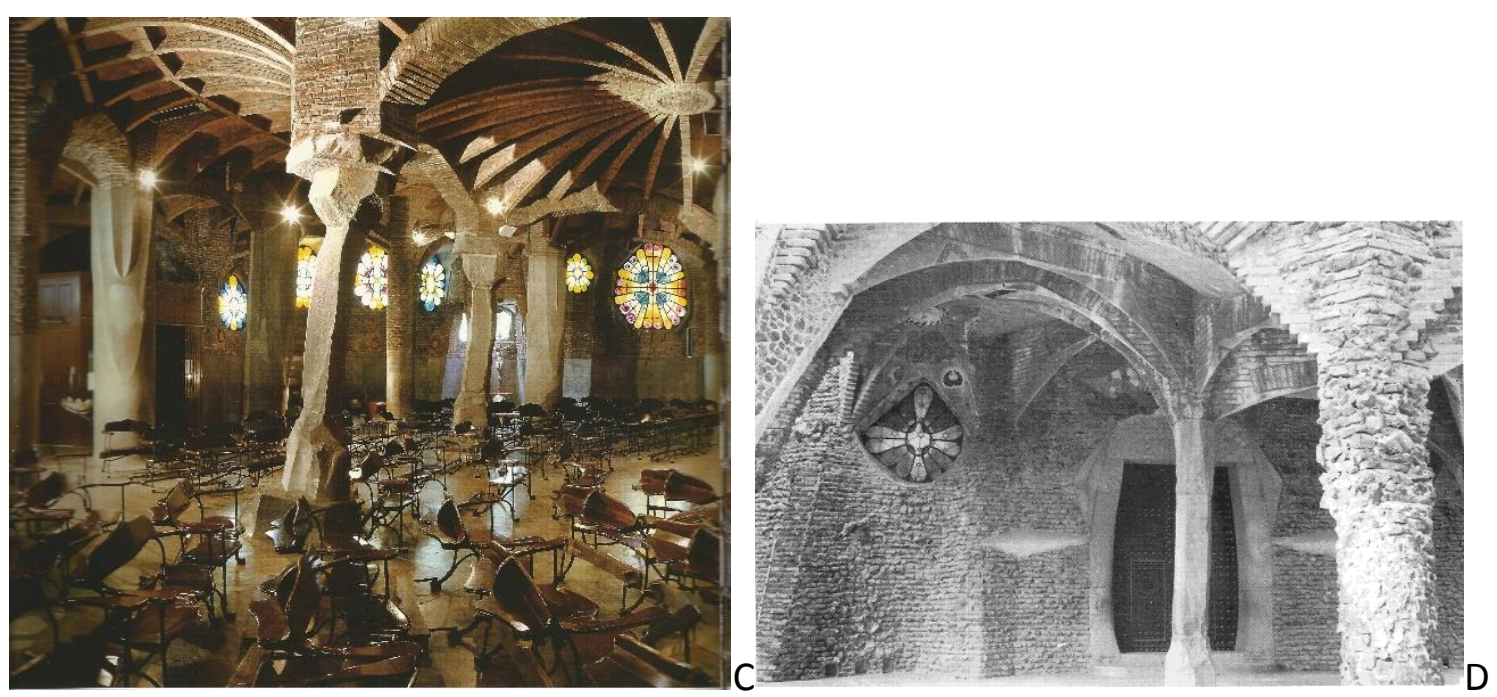

C: Interior de la Cripta de la Iglesia de la Colonia Güell (1898-1914). Fuente: Martinell, C. (1967) Gaudí: su vida, su teoría, su obra. Barcelona. COACB.

D: Porche de Acceso a la Cripta. Fuente: Bergós, J, (2000) Gaudí, e hombre y su obra. Barcelona. UPC 
Más bien habría que pensar que su portentosa imaginación aplicada a la investigación de la estabilidad estructural y la funcionalidad del edificio -con todo lo que suponen en el ámbito de la arquitectura eclesiástica en cuanto a simbología, iconografia y proceso constructivo- le absorbe su tiempo y su capacidad de síntesis hasta el punto limitar los ensayos con los nuevos materiales. Así pues, aún cuando la estructura y sistema cupular puedan ser en este caso de piedra y ladrillo, se constituyen en protagonistas del volumen arquitectónico configurando un singular itinerario visual que se plasma en la seriación de las tres cúpulas dispuestas a lo largo de un recorrido o eje central desde el Nartex hasta el presbiterio, pasando por una cúpula central con referencia al tradicional crucero. La resolución de la estabilidad estructural de esta idea -encomendada a las funículas de fuerzas y sus maquetas- constituye de por sí un notable hallazgo como sistema autoportante valorable en cuanto a su posterior desarrollo y perfeccionamiento, como veremos en apartados siguientes. Por tanto la afirmación de Navascués encuentra su razón original en la inquietud de Gaudí por resolver la diafanidad y estabilidad del espacio celebrativo, que aunque es redefinido varias veces en funcion de diversos criterios no deja de ser coherente en todo su proceso ${ }^{245}$.

El mismo afirma que "las funiculas son líneas y no pueden determinar las envolventes, que son superficies, es la estética y no la estática la que determina las envolventes"246, llegando a decir muy claramente que las funiculas son medios científicos de comprobación pero que no nos pueden dar formas artísticas: "Seria bueno ver cómo los funicularios buscarían las curvas de presión en los monumentos al estilo de Santa Sofia, por ejemplo." Puig Boada señala que en aquellos años Gaudí tenia estudiado todo el programa simbólico de la Sagrada Familia ${ }^{247}$ con lo que nos encontraríamos con una curiosa situación: por un lado la iglesia de la colonia Güell avanza un proyecto estructural libre de ataduras compositivas previas que va a ser después reelaborado e implantado en la Sagrada Familia con un notable ejercicio de sistematización y perfeccionamiento, pero en el apartado simbólico es la iglesia de la colonia Güell la que se beneficia del trabajo desarrollado para el Templo Expiatorio .

\footnotetext{
${ }^{245} \mathrm{Cf}$. Salavador Tarragó (2002) “La relación estructura y forma en Gaudi”, en Gaudí. Estructura y naturaleza. Barcelona. Revista OP del Colegio de Ingenieros de Caminos, canales y puertos. El autor se apoya en la explicación teórica de Joan Rubió sobre la arquitectrura gaudiniana y el sistema estructural que desarrolla para reafirmar la libertad compositiva de Gaudí respecto de las exigencias inherentes a los modelos estructurales que desarrolla, pero que redefine continuamente en función de concepciones ideologicas respecto a su concepto de iglesia, y de las distintas valoraciones espirituales y culturales que asume, para concluir que el arquitecto es esencialmente ecléctico, inconformista y sintético en la relación estructuraforma. El autor también apunta la aplicación gaudiniana de las bóvedas tabicadas como precedente de las bóvedas laminares de hormigón armado que desarrollarían Torroja y Candela posteriormente.

${ }^{246}$ Cf. Puig Boada, I. (1981). “Gaudi ens parla”, en El pensament de Gaudí: compilació de textos i comentaris. Barcelona. La Gaya Ciencia.

${ }^{247}$ Sin duda se refiere al discurso realizado en 1891 a los josefinos, que refieren Bassegoda y Matamala, y al que nos referiremos en el apartado siguiente de esta investigación.
} 
Si se observan con detalle los dibujos del interior de la iglesia superior se aprecia con claridad que el altar está separado del fondo del ábside propiciando la celebración cara al pueblo y que se pretende desarrollar todo un programa decorativo e iconológico en columnas, cúpulas y paramentos verticales, realzando los principales axiomas y misterios del Cristinanismo que conoce perfectamente. No obstante, propiciar, no es lo mismo que celebrar. El que la situación del ara -altar- se situe exenta no tiene por qué responder directa e inmediatamente a un uso versus populum sino que puede ser explicada en términos de lo que propugna en esos años el Movimiento Litúrgico como una significación como foco litúrgico primordial de la asamblea.

Si partimos de que en 1891 estuviese listo o al menos esbozado el programa simbólico para desarrollar en la Sagrada Familia (cuestión que trataremos posteriormente en el apartado 6.1 El proyecto de la Sagrada Familia en clave celebrativa) y es posible datar en 1898 el primer proyecto espacial y estructural para sus naves y transepto, según Bassegoda ${ }^{248}$, ambas dos líneas de trabajo del proyecto de la Sagrada Familia serían anteriores al proyecto y ejecución de los trabajos de la iglesia de Santa Coloma, constituyéndose éste último en claro ensayo cronológico además de conceptual del segundo proyecto estructural del Templo Expiatorio, desarrollado según diversas opiniones a partir de 1914-1915. Es decir, que inmediatamente después de la dedicación de la Cripta de la iglesia de la Colonia Güell y bajo el doble convencimiento de las posibilidades técnicas de los ensayos realizados en la colonia y la frustración por no haber podido proseguir allí la ejecución de las obras, se desarrolla un vuelco total en el sistema estructural de la Sagrada Familia. En los apartados 6.2 El enfoque cultual del proyecto de Gaudí a través de la identificación de los espacios litúrgicos en la Sagrada Familia, y 6.3 Elementos arquitectónicos que estructuran el espacio litúrgico, nos proponemos ahondar en esta cuestión, introduciendo además el factor tiempo de la mano del Congreso Liturgico de Montserrat y la disponibilidad financiera para las obras.

Consecuentemente la interaccion con la Sagrada Familia hay que entenderla como el perfeccionamiento del sistema estructural planteado para Sta. Coloma y el desarrollo del programa iconográfico que en esta iglesia no se pudo llevar a la práctica. Cabe entender ahora la afirmación de Puig Boada de que el arquitecto no aceptó hacer ninguna otra obra a partir de 1914, a excepción de la Sagrada Familia, "para poder llevar a término lo que había descubierto y experimentado en Sta. Coloma, al pararse definitivamente esta obra"249.

\footnotetext{
${ }^{248}$ Cf. Bassegoda Nonell, J. (1989). El gran Gaudí. Sabadell. AUSADL.

249 Cf. Puig Boada, I. (1976) L’Esglesia de la Colonia Güell. Barcelona. Lumen.
} 
Martinell también se hace ceo del interés de Gaudí por continuar en la Sagrada Familia la experimentación arquitectónica que había quedado interrumpida en Sta. Coloma ${ }^{250}$ y su testimonio -recogido por Puig Boada- le hace decir que probablemente esos años de arduo trabajo estructural en Santa Coloma le hicieron posible realizar con relativa facilidad el último proyecto estructural de la Sagrada Familia. Ahora bien, no se trata de una traslación directa y sencilla, sino que la composición y tratamiento arquitectónico de los espacios celebrativos alcanza una complejidad y desarrollo mucho mayor en la Sagrada Familia. Tampoco debe olvidarse que el programa iconográfico de Santa Coloma, que recuerda el interior de San Marcos o de Santa Sofia, alcanza un desarrollo plástico y simbólico mucho mayor en la Sagrada Familia. Estas cuestiones permiten acercarse paulatinamente al Templo Expiatorio valorándolo en toda su complejidad desde los diferentes prismas que inciden en él. Es difícil precisar que hubiese aportado el proyecto de Santa Coloma de haberse realizado en todo su alcance pero si seguimos el hilo argumental precedente, fácilmente podemos intuir un espacio celebrativo centralizado focalmente en un altar exento, con diversos niveles en su perímetro (quizá previstos para ser ocupados por una amplia masa coral), con un programa iconográfico soportado por un amplio desarrollo de la pintura muraria en el que la textura de los materiales comienza a tener un protagonismo simbólico importante. Si analizamos el edificio en su entorno también visualizaríamos su cuidada integración en la topografía circundante y el estimulante dialogo con el entorno físico que lo hace tan atractivo. Pero el programa y medios puestos al servicio del edificio de la calle Mallorca es mucho más complejo y completo.

Quintana afirma que Gaudí actúa libre de todo prejuicio en Sta. Coloma y que su forma de trabajar allí responde a su poderosa imaginación y a la concepción integralmente plástica del edificio cuyo modelado extrae de las curvas de presiones de la maqueta funicular ${ }^{251}$, pero creemos poder afirmar que el uso cultual del edificio y su programa le impulsan a buscar la constante mejora de la iluminación y visibilidad interna haciendo posible la evolución del proyecto estructural. Su imaginación y su sensibilidad para mostrar artísticamente los contenidos fundamentales del Cristianismo harian el resto, puesto que en este edificio no se parte de ninguna preexistencia o programa dado.

${ }^{250}$ Cf. Martinell, C. (1950). Gaudí i la Sagrada Familia, comentada per ell mateix. Barcelona. Aymá Ediciones.

${ }^{251}$ Cf. Quintana, F. de Paula (1927) "Les fomes guerxes del Temple de la Sagrada Familia", original en La Ciutat i la Casa, en Ràfols, J. F. (2006) Gaudi, 1852-1926. Barcelona. Real Cátedra Gaudí y Ed. Claret. P. 162: "Amb el seu formidable sentit mecánic i amb la seva meravellosa percepció de les formes guerxes aconseguí uns resultats tan sorprenents en aplicar-les desembarassadament a les columnas $i$ a les voltes de la dita cripta, que no pogué resistir'se d'aplicar la seva ductilitat i la seva riqueza lluminosa a les formes del gran Temple, l'obra mestra de la seva fantasia poderosa. L'església de la Colonia Güell fou, doncs, com una mena d'assaig del Temple de la Sagrada Familia." 
Como manifiesta Martinell, tenia la libertad necesaria para dejar las texturas y detalles constructivos de los materiales según su libre elección, ya sea mostrando rugosidades y asperezas, ya disponiendo cuidados revocos y enlucidos. ${ }^{252}$ Bergós también alude al ambicioso programa que se autoimpone, incoporando los símbolos religiosos más adecuados en cada caso, indicando cómo Gaudí le mostró en su libreta un cuadro sinóptico (sintético) conteniendo lo que considera fundamental de la doctrina cristiana ${ }^{253}$.

\section{La Seo de Mallorca y la restauracion liturgica de una catedral.}

La intervención de Antonio Gaudí en la catedral de Mallorca -tan alabada por unos y denostada por otros- constituye a mi parecer un eslabón más en la cadena de actuaciones arquitectónicas que, en dialogo con la Liturgia católica, fundamentan el diseño gaudiniano del espacio celebrativo como configurador de su arquitectura eclesiástica. Gaudí concibe el edificio-iglesia desde dentro de sí mismo y desde el interior de lo que quiere ser, con lo cual entronca su pensamiento arquitectónico con su mentalidad de usuario cualificado. Ciertamente que en el caso de la Seo mallorquina la iniciativa es episcopal pero la identificación de criterios se da en tal grado que podemos considerar este proyecto como si hubiese sido programado conjuntamente por el arquitecto mismo en el sentido moderno del término, lo cual además presenta la estimulante dimensión de tratarse, no de una obra nueva, sino de una intervención en un edificio histórico.

Si el obispo Campins publica su carta pastoral sobre la restauración de la catedral de Mallorca el 15 de agosto de 1904, con posterioridad al inicio de las obras, ello obedece a la prudencia que le guía para salvaguardar la viabilidad del proyecto. Citando las Constituciones Apostólicas y la Didascalia, se apoya en una concepción de la Casa de Dios como Casa de la Iglesia -muy moderna para su época e incluso todavía hoy, en determinados ambientes- para proponer una profunda restauración litúrgica de la Seo. Campins toma posesión de la diócesis en julio de 1898, y a los pocos meses, el 20 de noviembre de 1899, se entrevista con Gaudí en los talleres de la Sagrada Familia acompañado de los canónigos Emili Sagristá y Martí Llovera, quedando los tres "sorprendidos y fascinados del conocimiento arquitectónico y litúrgico de Gaudí, de su desbordante fantasía y de su fácil palabra", según relata el propio Sagristà254.

\footnotetext{
${ }^{252}$ Cf. Martinell, C. (1967). Gaudí: su vida, su teoría, su obra. Barcelona. COACB. P.353-355.

${ }^{253}$ Cf, Bergós, J. (1954). Gaudí, el hombre y su obra. Barcelona. Aymá.

254 Cf. Sagristà, E. (1962) "Gaudí en la catedral de Mallorca. Anécdotas y recuerdos." Castellón de la Plana. Sociedad Castellonense de Cultura.
} 

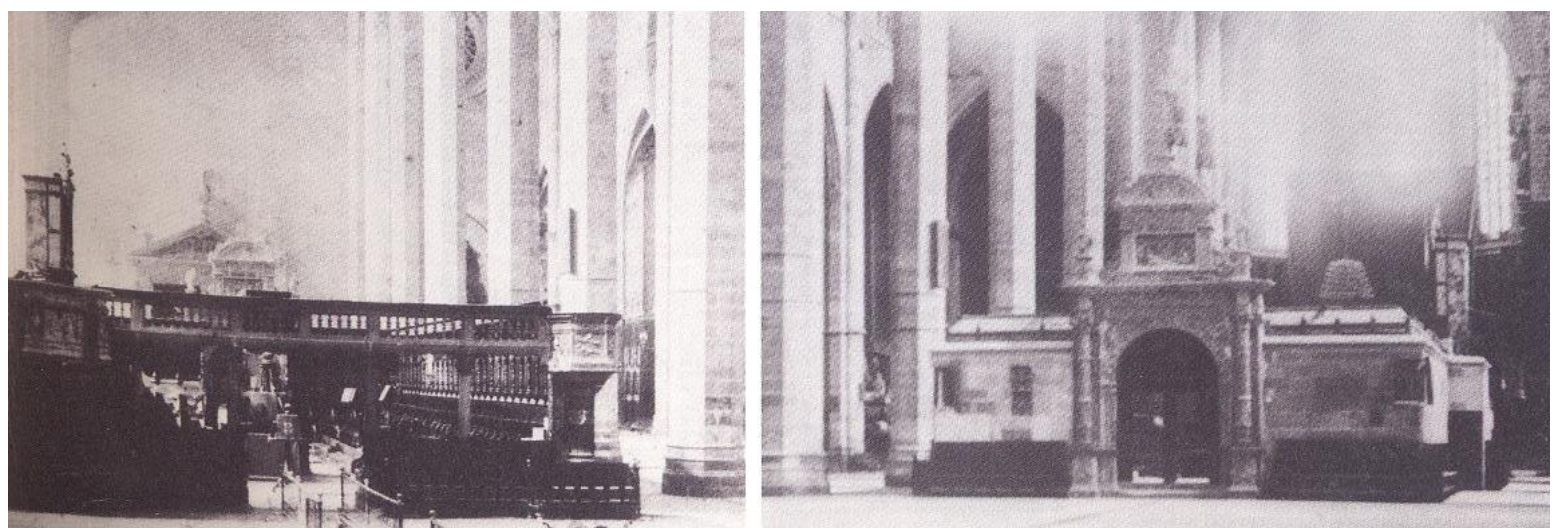

Situacion del Coro en medio de la nave de la catedral de Palma de Mallorca. Fuente: Llabrés, P.J. (2002) Gaudí a la Seu de Mallorca. Palma de Mallorca. Govern de les Illes Balears.

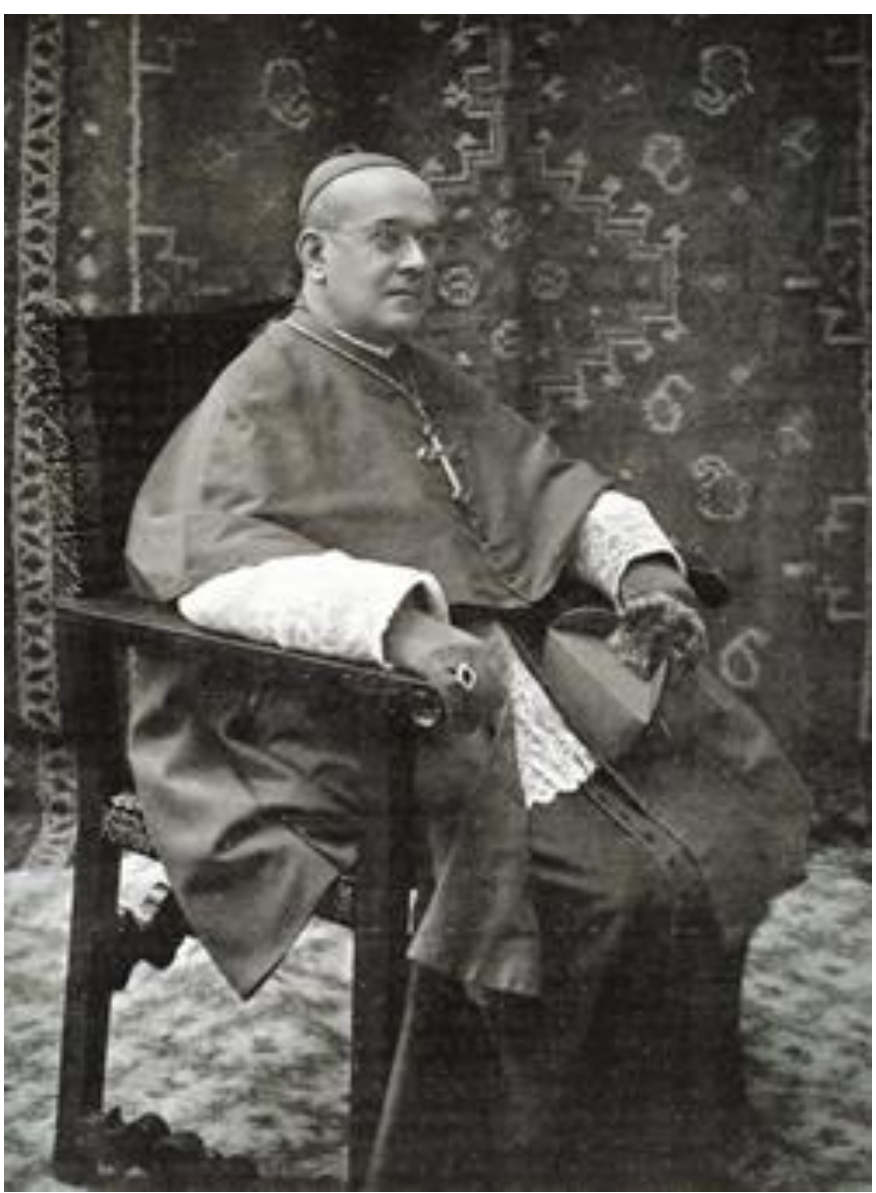

El Obispo Campins. Fuente: Fototeca Enciclopedia Catalana. 
La primera comunicación de Campins al cabildo sobre sus intenciones es de junio de 1901 anunciando en ella la programación de su visita a las catedrales Montpellier, Orvieto, Florencia, Bolonia... ${ }^{255}$, en compañía del canónigo Mateu Rotger -historiador reconocidocon ocasión de la preceptiva visita "ad limina" tras la proclamación de Pio X como pontífice. La cronología de fechas muestra dos cosas, la primera que la idea de Campins es ciertamente personal y arranca desde los primeros meses de su elevación a la sede mallorquina, puesto que al cabo de unos meses ya se entrevista con el arquitecto de la Sagrada Familia acompañado de dos canónigos. La segunda es que expone sus intenciones al cabildo después de hablar con Gaudí y desea fundamentar su intervención restauradora en el contraste con la autoridad del Papa y la visita a otras catedrales históricas en areas culturales próximas. Por consiguiente es posible constatar que la intención de Campins es anterior a la proclamación de Pio $\mathrm{X}$ como pontífice y a la publicación de su Motu Proprio, enmarcándose de lleno en el ambiente de renovación liturgica que propugnan los monasterios benedictinos de Centroeuropa, yendo encaminada a buscar un arquitecto que sea capaz de interpretar el espíritu e indicaciones del Movimiento Liturgico. Es precisamente al volver de ese viaje cuando se entrevista de nuevo con Gaudí en Barcelona el 19 de agosto de ese mismo año, 1901, encargándole el proyecto según Llabrés, quien afirma que en esa reunión le expone al arquitecto sus planes de restauración de la catedral de Mallorca y de su decoración "que havia de donar esplendor $i$ dignitat al santuari. L'arquitecte $i$ el bisbe intercanviaren opinions sobre diverses catedrals i les seves reformes, que ambdós coneixien."256

Pero volviendo a la carta pastoral del obispo -autentico programa de necesidades de la intervención- no conviene olvidar que su publicación se produce nueve meses después del Motu Proprio papal Tra le Solicitudini, lo cual indicaria una vez más la prudencia del obispo, que ve conveniente fundamentar litúrgica y eclesiásticamente la intervención en el documento papal ${ }^{257}$, así como difundirla al poco de comenzadas las obras pero una vez que el cabildo ya había dado su aprobación.

255 Cf. Llabrés, P. J. (2002). "La liturgia a la restauració de la Catedral de Palma, el bisbe Campins i Gaudí", en AA.VV. Gaudí a Mallorca. IX Jornadas Internacionales de Estudios Gaudinistas. Palma de Mallorca. C.E.G. En la Catedral de Mallorca se habían realizado sucesivas ampliaciones e intervenciones desde la misma Edad Media como por ejemplo la realización de un nuevo coro en medio de la nave, al estilo del resto de las catedrales españolas. Como indica Pere Llabrés, se construye un nuevo coro hacia el año 1339 en medio de la nave y enfrente del original que situaba a ambos lados de la catédra episcopal y se denominaba "cor del bisbe".

256 Cf. Llabrés Martorell, Pere Joan y AAVV (2002). La liturgia a la restauració de la catedral de Palma, el bisbe Campins i Gaudí, en "Gaudí a Mallorca. XI Jornades Internacionals d'Estudis Gaudinistes". Barcelona. Centre d'Estudis Gaudinistes.p.17.

257 Cf. Campins i Barceló, J. (1904) Carta pastoral sobre la restauración de la Santa Iglesia Catedral de Mallorca. Palma de Mallorca. Boletin Oficial del Obispado de Mallorca, №15, 16-08-1904. P.262: “La severidad litúrgica es el único ornamento propio del templo santo". 

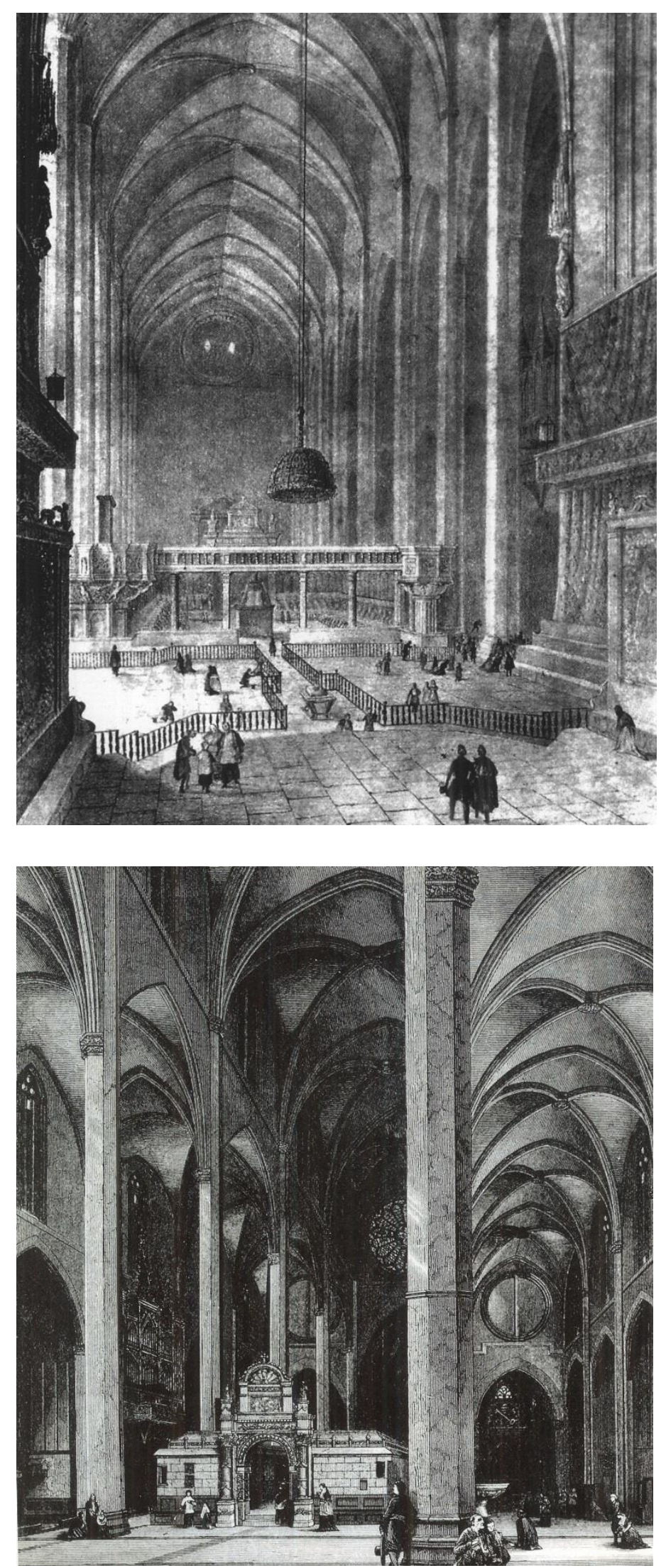

Dos aspectos del interior de la Catedral de Mallorca antes de la Intervención de Gaudí. Fuente: P. J. Llabrés (2005) Gaudí a la Catedral de Mallorca. Barcelona. Triangle Postals. 
De las obras que comprende el proyecto de Gaudí, sin duda que la demolicion del coro y su traslado dede el centro de la nave al presbiterio es la operación más notoria. Según señala Mateu Rotger esta cuestión había sido tratada anteriormente por el obispo y el Capítulo de la Seo, pues ya el concilio de Trento propugnaba acercar más el pueblo a las celebraciones litúrgicas y enaltecía la figura y derechos del obispo por encima de los capítulos catedralicios. Así se comprende la reorganización que el Papa Gregorio XIII hace de las cabeceras de las iglesias en Roma en las cuales sitúa el coro y la schola cantorum, y las instrucciones de San Carlos Borromeo, en 1577, para construir iglesias con el coro alrededor del altar mayor.

Sin embargo estas disposiciones no se habían llevado a la práctica en un gran número de casos. En España la tradicional situación del coro en medio de la nave, que había aportado notables ejecuciones artísticas desde finales del Medievo y comienzos del Renacimiento, hacía que los cabildos catedralicios fueran reacios a cualquier cambio en ese sentido.

Menciona también el canónigo Rotger que la idea de trasladar el coro en la Seo de Mallorca ya se tenia en el siglo XVIII cuando peligró la clave de la bóveda de la nave central -pensando que la capilla Real era su lugar original- y reseñando además que esta era también la opinión de Jaime Villanueva, cuando visita la catedral en 1814. Hacia poco que este traslado se había realizado en Santa Maria del Mar de Barcelona, y cita cómo la idea del traslado había estado incluida en el proyecto de restauración de Juan Bta. Peyronnet de $1854^{258}$, que constaba de dos fases: la primera destinada a reparar los elementos ruinosos y realizar una nueva fachada, y la segunda, que incluia la ornamentación interior, traslado del coro y reforma del presbiterio. Precisamente esta segunda es la que no se llegó a realizar en ese momento al superar el coste de la obra los recursos disponibles. En opinión de Llabrés -citando a Mossén Alcover, biógrafo de Campins- el cabildo y la opinión pública de la ciudad eran favorables a una actuación que liberara la nave del coro que se situaba en medio de ella ${ }^{259}$, y no tiene la menor duda en señalar que al obispo le guiaba su interés en cumplir con el espíritu y normas litúrgicas de la época llevando el edificio a una situación próxima con el gótico original. Para ello había que trasladar el coro y recuperar la sede episcopal gótica, lo que suponía desmontar también los retablos barroco y gótico.

\footnotetext{
${ }^{258}$ Cf. Rotger Capllonch; M. (1907) Restauracion de la catedral de Mallorca. Palma de Mallorca. Armengol i Montaner. A titulo título de ejemplo de las ideas que animaban la intervención arquitectónica de Gaudí es interesante citar unas palabras de un articulo publicado en laVveu de Catalunya por su colaborador Joan Rubió, que fue también publicado por su interés en el Diario de Mallorca el 18 de enro de 1906 y que recoge Rotger en su libro. P. 89: "Una catedral ha de ser, en substancia, una cátedra, un presbiteri, un altar y una nau per al poble".

${ }^{259}$ Cf. Llabrés, P,J. (2002). "La liturgia a la restauració de la Catedral de Palma. El bisbe Campins i Gaudi", en IX Jornadas Internacionales de Estudios Gaudinistas. Barcelona. Centro de Estudios Gaudinistas. P. 11-32.
} 


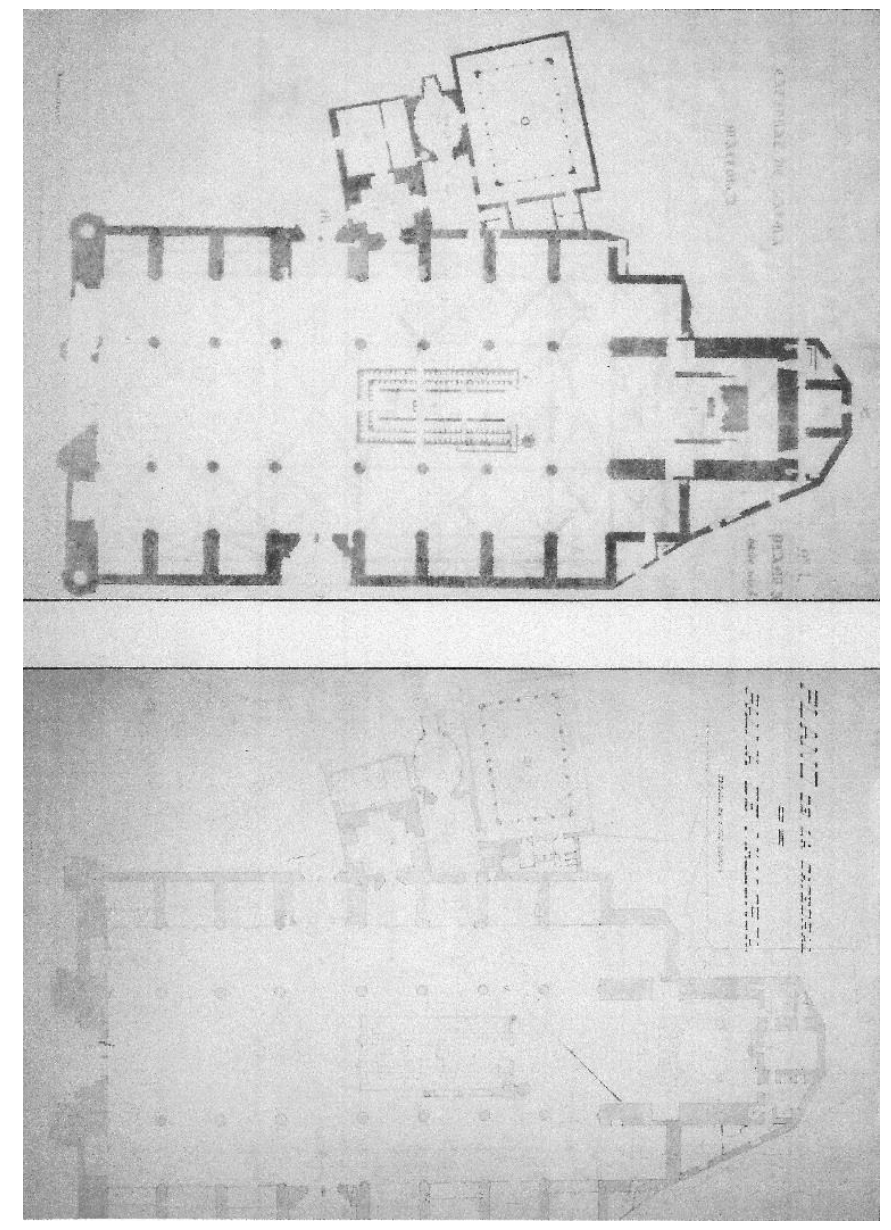

Plano histórico de la Catedral de Mallorca. Fuente: Pascual, Aina y AA.VV. (1995). La Catedral de Mallorca. Palma de Mallorca. J.J. de Olañate Ed.

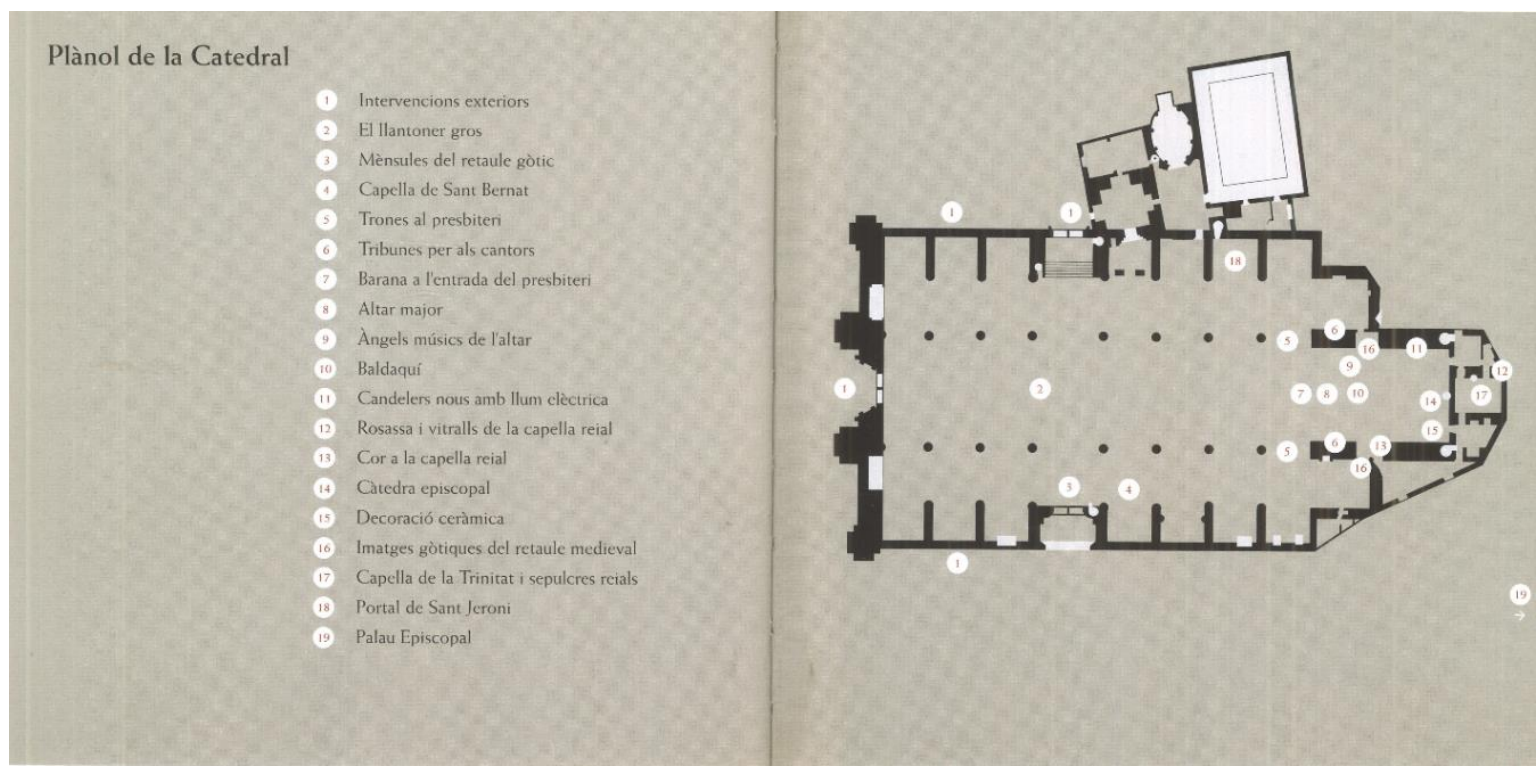

Plano sintético de la Intervención de Gaudí en la catedral de Mallorca. Fuente: Llabres, P.J. (2005) Gaudía la catedral de Mallorca. Barcelona. Triangle Postals. 
El cabildo catedralicio se entera, pues, del encargo a Gaudí en sesión convocada por el obispo Campins del 7 de marzo de 1902, y el arquitecto llega a Palma el 26 del mismo mes para conocer in situ la catedral, que visita durante tres días hasta que el 29 del mismo mes, exponiendo al obispo, deán, algunos miembros del capítulo y a otros personajes de importancia de la ciudad, sus ideas programáticas. ${ }^{260}$

Aunque la actuación en el coro es la más conocida, debido a la tradición histórica del coro central en las catedrales españolas -y quizá por ello haya sido juzgada negativamente por una parte de la crítica- no es la única del proyecto puesto que éste también contemplaba la repristinación de bóvedas, el mobiliario litúrgico, la reubicación de elementos tan sobrasalientes como el antiguo retablo, las cantorías, etc. Por Rotger sabemos también que el 11 de abril de ese mismo año -1902- Gaudí manifiesta su voluntad de proceder a la apertura de los ventanales góticos cegados y a la realización de sus vidrieras; que el 13 de agosto tenia ya una maqueta en madera de su proyecto y que en octubre avanza el plan completo de lo que quiere ser una restauración del conjunto, siendo acogido con esperanza y satisfacción.

Así pues tenemos que en apenas siete meses Gaudí realiza las labores de inspección y análisis del edificio, redacción del plan y maqueta del proyecto, y presentación al cabildo. Siguiendo a Rotger sabemos que la reacción del cabildo es positiva, pues el 14 de marzo de 1903 el cabildo catedralicio agradece al obispo la propuesta de reforma y pide a Gaudí que comiencen las obras. Este llega a Palma el 5 de abril y expone a la Comision Capitular su proyecto de apertura de ventanales con vitrales adaptados a la luz mediterránea y el 14 de noviembre de aquel mismo año el Capítulo aprueba el proyecto, siendo ratificado por la Junta de obras el 14 de marzo de 1904 y comenzando los trabajos el 20 de junio siguiente. Teniendo en cuenta lo dicho anteriormente debemos concluir que el proyecto estaba bien documentado litúrgicamente y resultaba atrayente al cabildo en cuanto a las soluciones arquitectónicas y su manera de abordarlas.

Además se había contado con que la difusión y explicación de sus líneas maestras al pueblo, de tal manera que las indulgencias concedidas por Pio $\mathrm{X}$ a los donativos que se recibieran -según mencionaba la carta pastoral de Campins ${ }^{261}$, , podían ayudar a garantizar su viabilidad económica.

${ }^{260} \mathrm{Cf}$. Rotger, M. (1907)“Restauración de la catedral de Mallorca.” Palma de Mallorca. Armengol i Montaner.

261 Cf. Llabrés, P. J. (2002). Gaudí a la Seu de Mallorca. Palma de Mallorca. Govern de les Illes Balears. Llabrés señala como Campins al concluir la carta pastoral reafirma su intención restauradora y con ella sus intenciones: 1. Restituir al pueblo el espacio dentro del templo que le corresponde. 2. Establecer el Ceremonial de los obispos como en el resto del mundo católico, lo cual implicaba el traslado del coro desde la nave al ábside mayor. 3. Restaurar la Capilla de la Trinidad colocando allí los sepulcros de los reyes de Mallorca, y realizando allí la exposición y adoración del Santisimo. 4. Recuperar y hacer patente la Sede pontifical. 

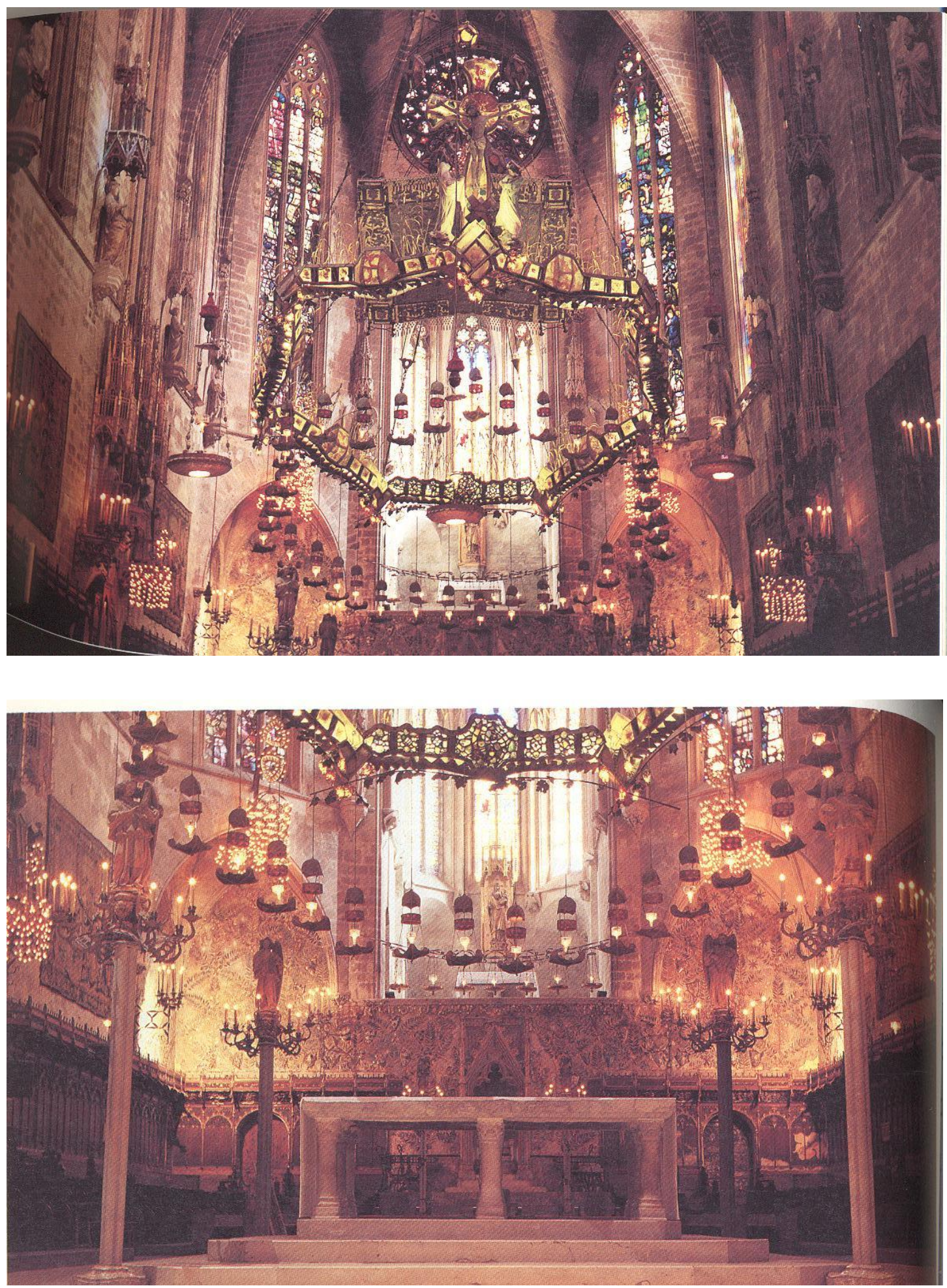

Seo de Mallorca: Vistas superior e inferior del Presbiterio después de la Intervencion de Gaudí. Fuente: Llabres, P.J. (2002) Gaudí a la Seu de Mallorca. Palma de Mallorca. Govern de les Illes Balears 
La situación de la catedral antes de la intervención de Gaudí se puede sintetizar en un inmenso espacio de gran altura en penumbra completa, al estar cegados numerosos ventanales y no disponer de iluminación eléctrica, con un coro central que impedía la visión y participación de los fieles en la liturgia eucarística, una cátedra oculta por dos retablos sobrepuestos, y una utilización litúrgica restringida al cabildo con esporádicas procesiones y autos sacramentales a los que asistían pasivamente los fieles. ${ }^{262}$

Según data el Calendario Josefino las obras se realizan en el periodo de 1904-1914. Desde el verano de 1904 hasta el 8 de diciembre de ese mismo año se ejecuta la fase de las obras más rápida, más visible y más fiel al programa del obispo, inaugurándose con las solemnes vísperas del 7 de diciembre. La rapidez de ejecución y el calificativo que le otorga a la obra realizada el canónigo Rotger -"razonable e inapelable"-, ejecutada por el "sabio y piadoso" arquitecto, hacen suponer que Gaudí conocía perfectamente el programa del Obispo con anterioridad a la redacción del proyecto, que el proyecto se ceñia a él con bastante fidelidad y que gozaba de la aprobación general.

Anteriormente al obispo Campins se habían alzado voces autorizadas, como la del P. Villanueva y el informe que se realiza previamente al proyecto de Peyronnet, en los se dice que la planta del edificio adolecía de defectos capitales -muy comunes en las catedrales- como era la mala situación del Coro, la poca extensión del altar y lo reducido del presbiterio. ${ }^{263}$ En este informe -al hablar del estado de ruina de la fachda principal- se propone para el interior de la catedral trasladar el Coro a la Capilla Real y ampliar la extensión del presbiterio en todo el ámbito del espacio que cubre la primera bóveda, buscándose además que se visualicen bien los divinos oficios desde todos los puntos de la iglesia, pero las obras sólo alcanzaron el exterior por motivos presupuestarios y el fallecimiento del obispo Cervera.

El proyecto de Gaudí es todavía más ambicioso puesto que además del traslado del Coro y la adecuada reutilización y reubicación de elementos existentes, centra la intervención según tres ejes primordiales: la ampliación y completa adecuación funcional del presbiterio incluyendo todo lo que hace referencia al altar, sede, cantorías y pulpitos;

\footnotetext{
262 Cf. Pascual, Aina y AAVV. (1995). La catedral de Mallorca. Palma de Mallorca. José de Olañete Editor. Además de dibujos y grabados de la fachada de la catedral anterior al proyecto de Peyronnet, hay interesantes textos sobre el teatro medieval que se llevaba a cabo en el interior y la liturgia tridentina y barroca que se desarrollaba.

${ }^{263}$ Cf. Rotger Capllonch, M. (1907) Restauracion de la catedral de Mallorca. Palma de Mallorca. Armengol i Montaner.A título de ejemplo de las ideas que animaban la intervención arquitectónica de Gaudí es interesante citar unas palabras de un articulo publicado en la Veu de Catalunya por su colaborador Joan Rubió, que fue también publicado por su interés en el Diario de Mallorca el 18 de enro de 1906 y que recoge Rotger en su libro. P. 89: "Una catedral ha de ser, en substancia, una cátedra, un presbiteri, un altar y una naur pera'l poble".
} 


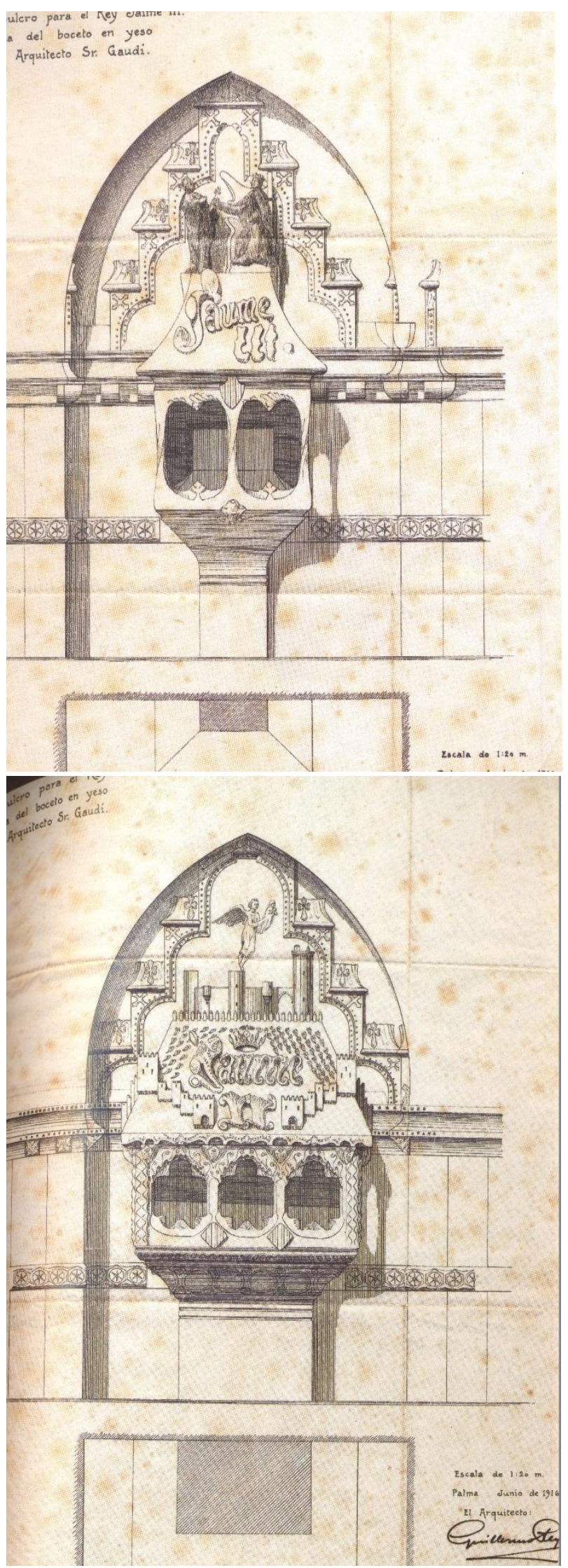

Dibujos de Gaudí para las tumbas de los Reyes de Mallorca en la Capilla de la Trinidad. Fuente: Llabrés, P.J. (2002) Gaudí a la Seu de Mallorca. Palma de Mallorca. Govern de les Illes Balears. 
La disposición de un nivel de iluminación adecuado para las celebraciones en el aula liturgica, reformada y ampliada, mediante la recuperación de la iluminación natural prevista desde la construcción original -reabriendo las ventanas y actuando en los vitrales que estaban cegados- y la incorporación de una iluminación eléctrica acorde con el edificio; y finalmente, el cuidadoso diseño y ejecución de un mobiliario litúrgico completamente adecuado al culto que se pretendía renovar y acercar al pueblo. Además de esto el proyecto aporta un pormenorizado estudio estructural -de la mano de Joan Rubió- que comprueba la esbeltez estructural de los pilares, y un cuidadoso estudio de aprovechamiento y reubicación de aquellos elementos decorativos que por la praxis litúrgica del momento no se consideraba mantuviesen una función concreta en el aula celebrativa.

En este sentido, y teniendo en cuenta una vez más los criterios del Movimiento Liturgico respecto de la centralidad del altar, llama la atención la recolocación del retablo medieval según un criterio decorativo muy novedoso para la época. Además, siguiendo postulados muy del gusto del nacionalismo romántico, el proyecto incluia la reforma de la Capilla de la Trinidad para realzar los enterramientos de los reyes medievales convirtiéndola en un verdadero panteón dinástico nacional.

De la sintonía entre promotor y arquitecto habla bien a las claras el hecho de que, en algunos casos, el obispo es el que planifica la iconografía de los vitrales a realizar en los vanos cegados ${ }^{264}$. Hay que señalar también que esta fase de obras es anterior al comienzo de los trabajos de construcción de la iglesia de la Colonia Güell pudiendo haber repercutido este hecho junto con la índole más decorativa que van tomando los trabajos en la isla en la progresiva delegación de la dirección de las obras de Gaudí. A partir de 1905 el ritmo de la obra disminuye. Sabemos que Gaudí realiza pruebas con los vitrales para obtener el color deseado y que por el procedimiento empleado estas requieren un proceso lento y detallado. ${ }^{265}$

\footnotetext{
${ }^{264}$ Cf. Llabrés, P,J. (2002). "La liturgia a la restauració de la Catedral de Palma. El bisbe Campins i Gaudi", en IX Jornadas Internacionales de Estudios Gaudinistas. Barcelona. Centro de Estudios Gaudinistas. P. 22: "Campins mateix planificà la iconografía dels vitralls de la capella reial. Respon a les invocacions darreres de la lletania lauretana, per tal com la Seu és dedicada a Sta. Maria."

265 Cf. Bassegoda, J.. (2002) Gaudí: la arquitectura del espíritu. Barcelona. Salvat. P. 140-141: “Estas vidrieras se hicieron emplomadas y también usando el sistema de bandajes, o sea, piezas de cobre en forma de $U$ que sujetan los cristales. La razón se debía a que Gaudí usó tres cristales superpuestos del tipo 'plaqué', que aún siendo más delgados que los comunes de vidriera, en conjunto tomaban un grueso mayor del que puede abrazar con sufieciente garantía el plomo. Gaudí ponía tres cristales por una simple razón. El de en medio era cristal transparente donde se pintaba la grisalla o dibujo con las figuras de cada tema, y los otros dos en la parte de fuera y de dentro se llenaban con cristales con colores primarios de tal forma que al atravesarlos la luz daban el color complementario deseado. De esta manera para conseguir el verde, se ponía cristal azul y otro amarillo. Así era la luz la que producía los colores y no la pintura."
} 


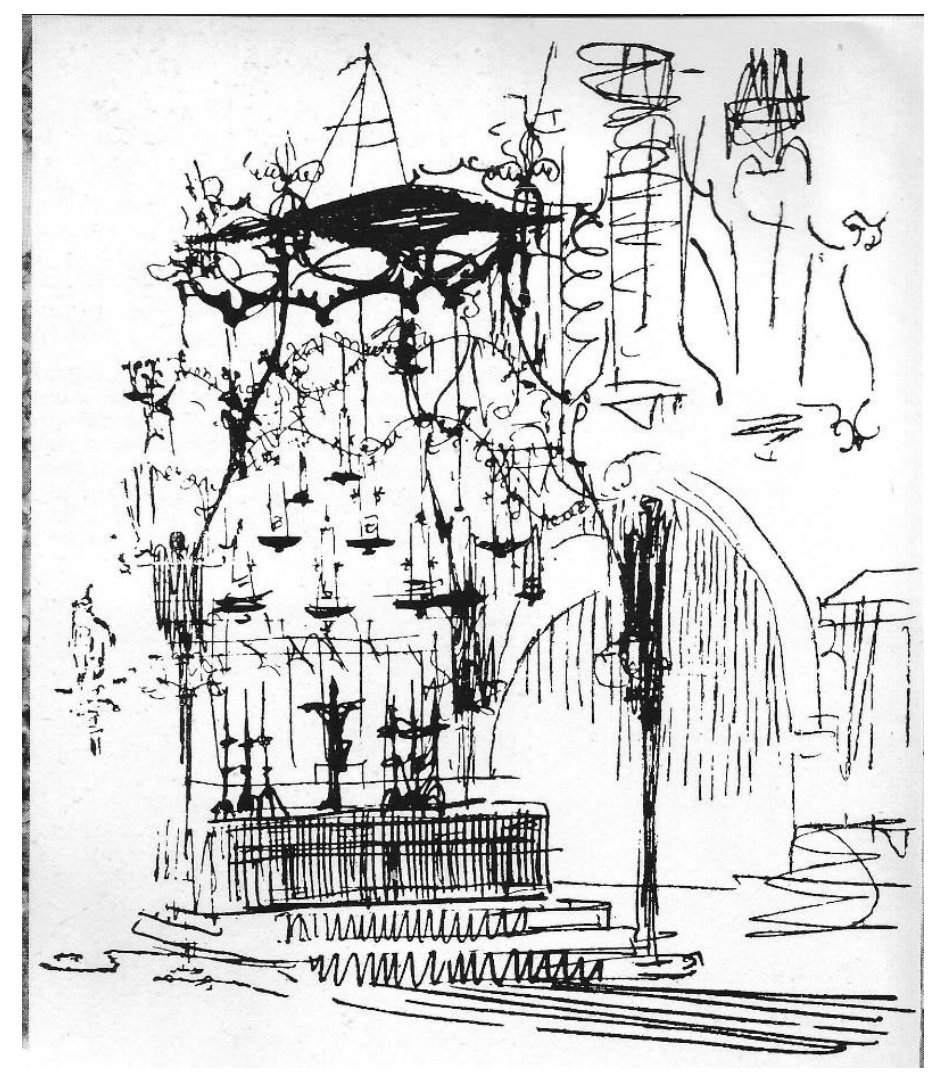

Croquis para el baldaquino de la Seo de Mallorca. Fuente: Martinell, C. (1967) Gaudí: su via, su teoría, su obra. Barcelona. COAC.

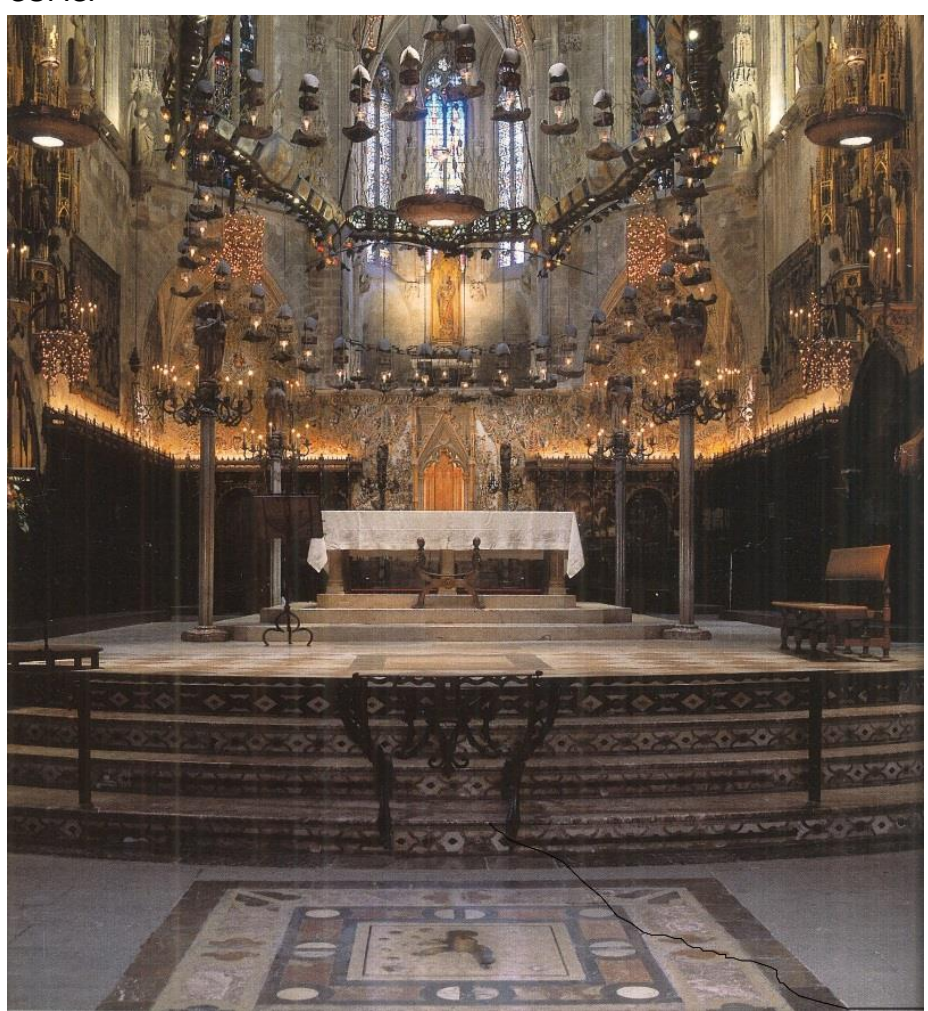

Vision frontal del Presbiterio con el altar, baldaquino y lámparas,Sede, coro y barandilla artística en su acceso. Fuente: Llabres, P.J. (2005) Gaudí a la catedral de Mallorca. Barcelona. Triangle Postals. 
Al ser muy ambicioso el proyecto, se extiende a otros trabajos de carácter minucioso como son los púlpitos y el baldaquino, el mobiliario litúrgico, la iconografía de los textos de la sillería del Coro y la prueba de repristinacion cerámica de las bóvedas. Pero además del ritmo, también decae paulatinamente el interés de Gaudí por el proyecto, lo cual es fácil de comprender. En los años siguientes Gaudí está totalmente volcado en el arranque de las obras de Santa Coloma y la vertiente menos conocida -como afirma Llabrés- del encargo que Campins había realizado a Gaudí, la decoración de la Seo restaurada, debía absorver también un considerable tiempo. Por ello creemos que Gaudí ha de elegir en su fuero interno entre el proyecto estructural de Santa Coloma y el desarrollo del programa decorativo de Mallorca. Así pues, confía a Jujol -que había entrado a trabajar en el taller de Gaudí entre 1905 y 1907 pero gozaba de la confianza del maestro por su trabajo en la Casa Milà y probablemente también en la Casa Batlló ${ }^{266}$ - el desarrollo y ejecución del proyecto decorativo, para dedicarse con mayor intensidad a las obras de la iglesia de Sta. Coloma -que se realizaban con pocos operarios de una manera artesanal- y a los estudios del funicular de fuerzas. En principio, Gaudí debía sentirse motivado por cuanto el programa decorativo lo veria en la misma línea de su discurso en la Sagrada Familia a los josefinos y las pinturas que se aprecian en los croquis de la Iglesia de Sant Coloma. ${ }^{267}$ Ahora las obras cobran una perspectiva más detallista, se imponen la cerámica, la pintura y el mobiliario litúrgico en el proyecto, y Gaudí no puede ocuparse directamente de todos los detalles. La cerámica del fondo de la capilla real, el proyecto de restauración para la capilla de la Trinidad, la decoración y tornavoces de los púlpitos renacentistas que ya habían sido trasladados a la entrada del presbiterio, además del estudio para el tratamiento del altar y el diverso mobiliario litúrgico, se constituyen en autenticos protagonistas de este periodo y banco de pruebas para la Sagrada Familia. En 1912 se comienza a instalar un baldaquino sobre el altar que ha sido muy celebrado por Kerrigan, Gomez de la Serna, Saiz de Oiza, etc. por su simbolismo, elegancia y perfeccion formal. Sin embargo la pintura de la sillería del coro y los exagonos de cerámica de las bóvedas llevados directamente por Jujol con el visto bueno de Gaudí, en el fondo del presbiterio (lugar que ocupaba el cabildo catedralicio en las celebraciones litúrgicas), propician una oposición creciente a éste y a la continuación de estos trabajos que determinan el abandono de Gaudí en 1914 permaneciendo Rubió para terminar lo terminable hasta la muerte del obispo Campins en 1915. ${ }^{268}$

266 Cf. Pabón de Rocafort, A. (1990) "Els col.laboradors arquitectònics d'Antoni Gaudí", en Lahuerta, J.J. y AA.VV. Gaudí i el seu temps. Barcelona. Barcanova. P. 232-233.

267 Cuando Josep Ma Jujol llega a Palma en 1909 cuenta con 29 años de edad y aporta un gran sentido colorista y artístico.

${ }^{268}$ Cf. Martinell, C. (1967). Gaud: su vida, su teoría, su obra. Barcelona. COACB. 1a edición. P. 431: “Otro motivo de discrepancia fueron las pinturas de la sillería y la inscripción que desplació a los canónigos, defendida por el arquitecto, que produjo otra escisión importante. El revestimiento de parte del presbiterio con exágonos de reflejos metálicos, también pareció a los eruditos que era impropio de un templo medieval..." 


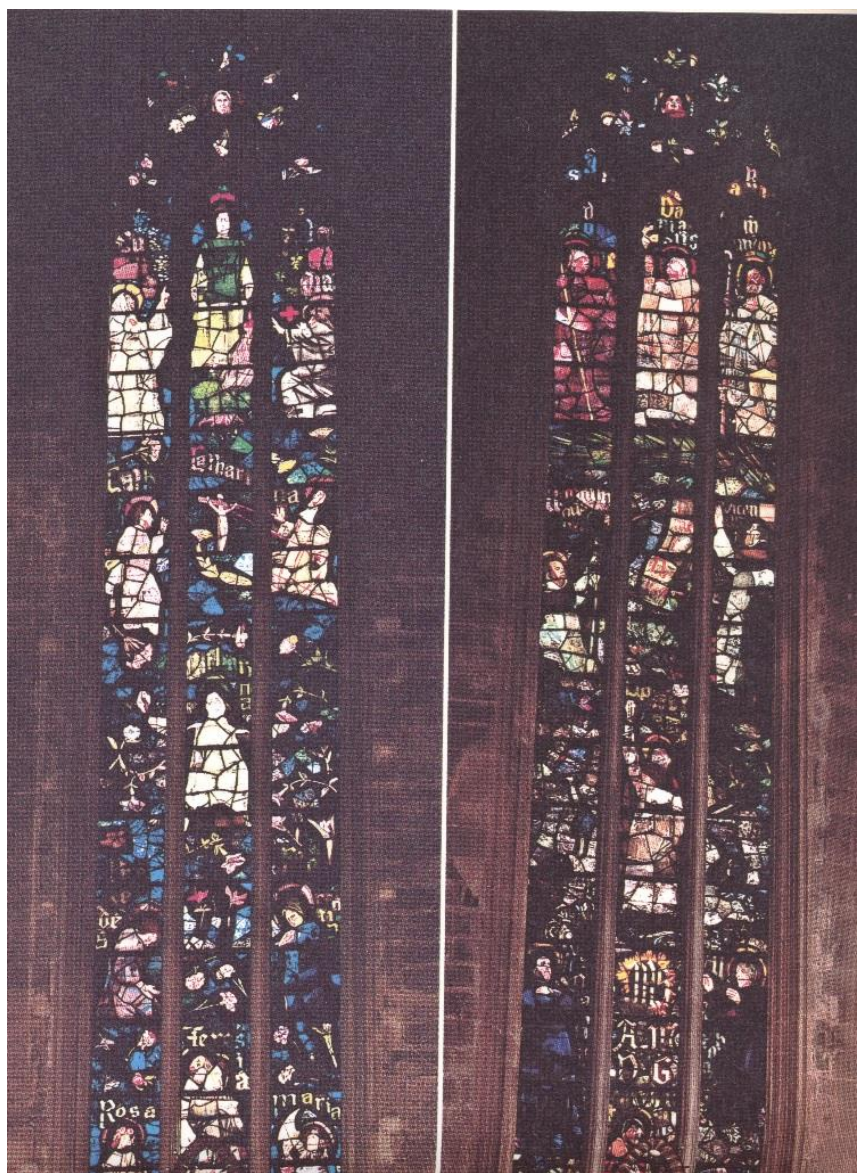

Seo de Mallorca. Vidrieras realizadas por Gaudí con la técnica de la Tricomia. Fuente: Llabres, P.J. (2002) Gaudía la Seu de Mallorca. Palma de Mallorca.

Govern de les Illes Balears

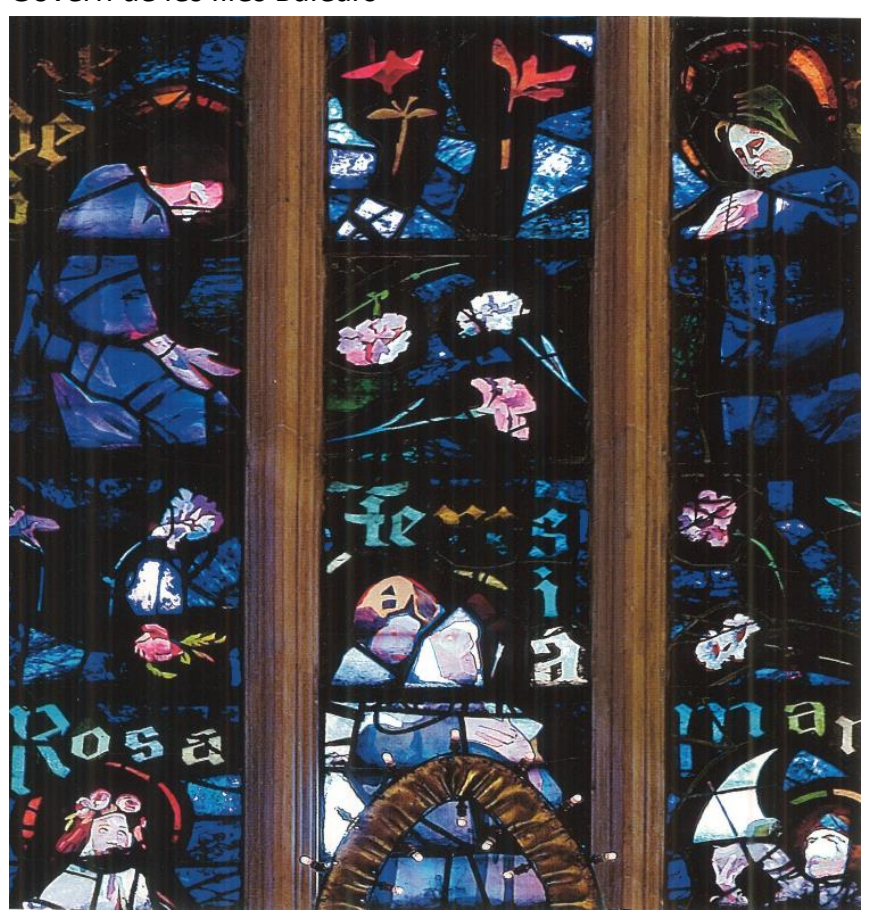

Seo de Mallorca. Detalle de las vidrieras diseñadas para la Capilla Real. Fuente: Llabres, P.J. (2005) Gaudí a la catedral de Mallorca. Barcelona. Triangle Postals. 
El altar es el centro y foco principal de la reforma de Gaudí, aislado y separado de los antiguos retablos, con una notable visibilidad y amplitud suficiente como para ser rodeado en la plegaria eucarística -incluso para celebrar cara al pueblo-, realzado con la elevación de tres escalones que marcaba la liturgia en aquel tiempo y un baldaquino que hubiese firmado cualquier diseñador actual.

El adelanto del altar hacia la nave y su tratamiento en los términos ya descritos se producen, pues, en el contexto de una adecuación completa de la asamblea a los criterios del Movimiento Liturgico, que parte de la cercanía y adecuación del presbiterio a la nave liturgica -contando para ello con la recuperación de la cátedra episcopal como sede, la reubicación del coro ministerial a ambos lados de aquella (ésta última ya promovida por el concilio de Trento) y la incorporación de la schola cantorum en las proximidades del altar (para potenciar al máximo el canto en la liturgia)- pero también de la mejora de las condiciones de percepción acústica y visual de la celebración desde la nave. Cabe también entender en este sentido la reubicación de los pulpitos con sus tornavoces -situándolos en lugar relevante y frente a la asamblea de los fieles para la proclamación de la Palabra de Dios- la decoración el presbiterio, y el sútil diseño de una barandilla en su entrada eliminando el antiguo y pesado cancel que separaba antiguamente presbiterio y aula litúrgica. Finalmente, la iluminación eléctrica proyectada en el lampadario, columnas rematadas por figuras angélicas a los lados del altar y, resto del presbiterio y nave, es un magnifico ensayo de tratamiento diferenciado de aquella según las necesidades de la celebración litúrgica y del culto dialogo que lleva a cabo con la arquitectura y el mobiliario diseñados.

Otro de los ejes primordiales de la actuación tiene que ver con la iluminacion del interior de la catedral. Por un lado la realización de nuevos vitrales para los ventanales que se volvían a abrir, recuperando su visión y su funcion, mediante el ingenioso procedimiento de la adición de tres vidrios de colores simples y un cuarto posterior de tamizado, ensayando con la disposición e intensidad de estos colores primordiales para obtener el resultado por agregación que quería. Por otro lado la iluminación eléctrica del presbiterio, que permanece aun hoy como una muestra más de ingenio, respeto por la obra de fábrica y adecuación a la función litúrgica. En el resto de la nave apenas si le dio tiempo a incorporar alguna iluminación colgante y la que se dispuso en los anillos metálicos de los pilares. 

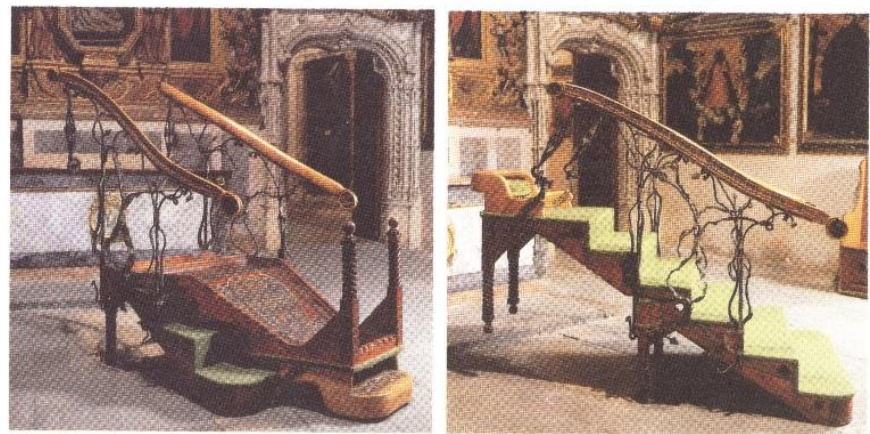

escala per a l'exposició del Santissim escalera para la exposicioin del Santisime
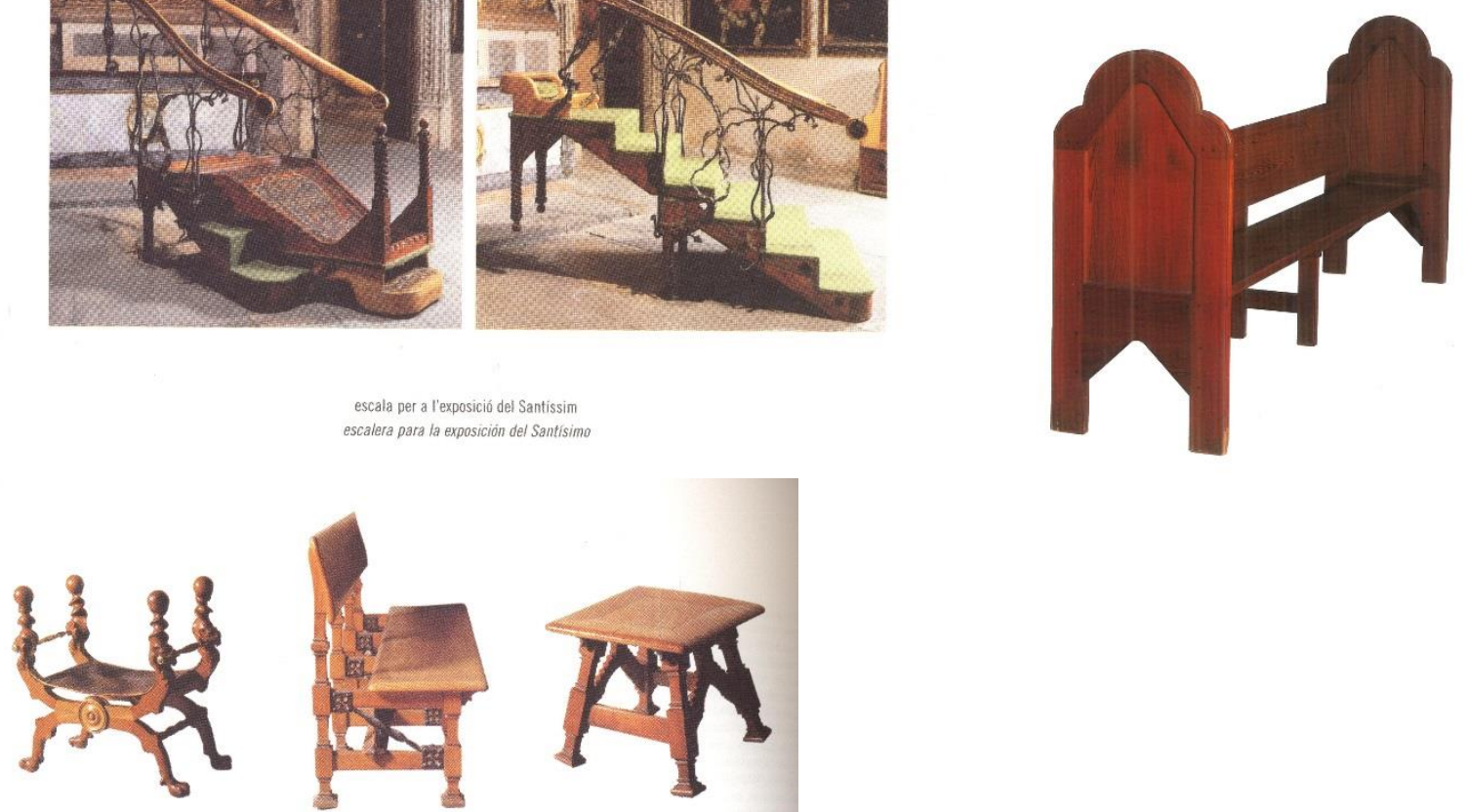

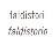

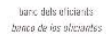
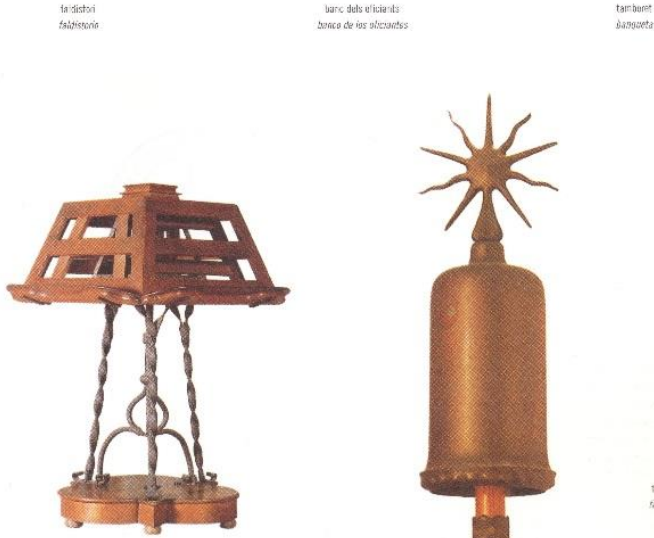

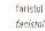

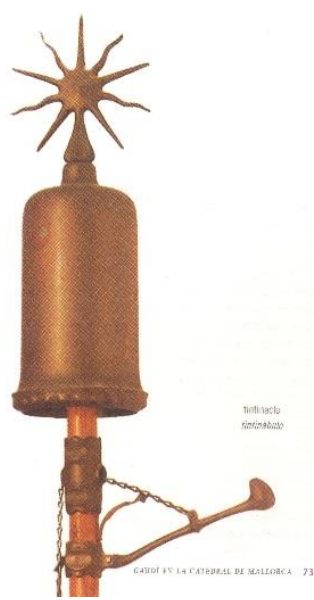

Seo de Mallorca. Mobiliario Liturgico diseñado por Antonio Gaudí: Escaleras para la exposición del Santísimo. Banco para fieles. Faldistorio, Banco de los oficiantes y Banqueta. Facistol y Tintinábulo. Fuente: Llabres, P.J. (2005) Gaudí a la Seu de Mallorca. Palma de Mallorca. Triangle Postals. 
También el mobiliario diseñado por Gaudí para la catedral de Mallorca es una muestra de su sensibilidad artística basada en un completo conocimiento del ceremonial litúrgico, y ha quedado como una muestra de incalculable valor histórico artístico. Confesionario, Bancos para asiento de los fieles, Faldistorio para el obispo en las celebraciones en que éste debía sentarse delante del altar, Bancos para el sacerdote oficiante y los ministros que le acompañan, Bancos para los sochantres de la cantoria, Sillas para el presbiterio asistente y los ministros del culto que le ayudaban, Escalera para facilitar la presentación del Sacramento en el altar mayor, Facistoles para los libros de canto del coro, Conopeo y Tintinabulo para las procesiones litúrgicas, consituyen un conjunto único diseñado por un solo artista y plenamente integrado en el espacio arquitectónico en que se ubica. El resultado resulta impensable sin el conocimiento y sensibilidad litugicos del autor, demostrando una vez más la coherencia de su ideal de belleza aplicado al edificio iglesia.

Se podrá estar de acuerdo o en desacuerdo con el proyecto de Gaudí y sus realizaciones en la catedral pero lo cierto es que su intervención estaba sólidamente asentada en la Liturgia y que los criterios compositivos aplicados revelan una sensibilidad muy actual. En términos de arquitectura eclesiástica su descomposición y recomposición de piezas resulta difícil de igualar, en un proyecto que administra todos los elementos y recursos a su alcance para dotarlo de unidad.

Cuando Gaudí se hace eco de la importancia del canto litúrgico y de la necesidad de dotar al presbiterio de una auténtica Schola Cantorum próxima al altar actúa en términos de arquitectura moderna reutilizando elementos del antiguo Corredor dels Ciris barroco, que se dispone sabiamente a ambos lados del mismo entre el Coro Catedralicio, ubicado detrás del altar y presidido por la Sede episcopal, y la Nave, donde el pueblo ha de seguir el canto liturgico. Esta disposición coral ordenada según los ministros y participantes de la schola entorno al altar es primordial en el proyecto de Gaudí para la Seo, pero veremos que todavía se manifiestará con mayor rotundidad en la Sagrada Familia al no tener las limitaciones que establecen las trazas de una catedral gótica existente.

Recuerda Torii que en 1906, dos años después de la inauguracion de la primera fase de las obras de la restauración litúrgica de la catedral de Mallorca, se publican dos dibujos de la totalidad del Templo de la Sagrada Familia que pueden considerarse como "más o menos definitivos en lo que a la composición general se refiere" 269 , y que a partir de 1914 dibuja la planta subterránea de la Sagrada Familia (precisamente cuando ya había abandonado las obras de Mallorca y de la iglesia de Santa Coloma), que se publica en 1916.

269 Cf. Torii, T. (2002) "Mallorca en las obras de Gaudí, en AA.VV. Gaudí a Mallorca. XI Jornades Internacionals d'Estudis Gaudinistes. Barcelona. Centre d'Estudis Gaudinistes. P. 106 


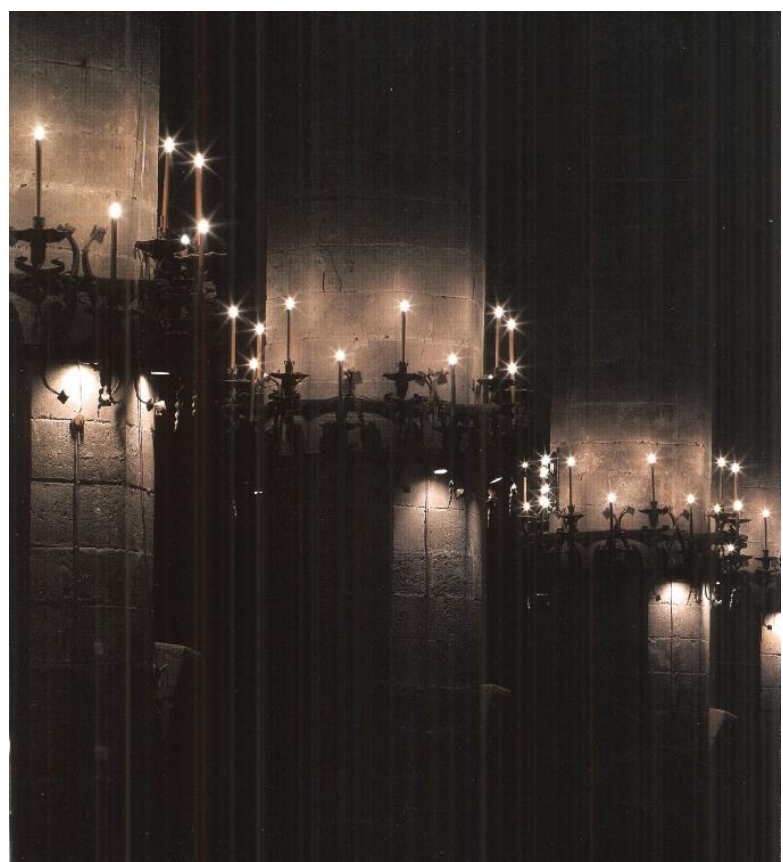

Iluminacion en las columnas de la nave. Fuente: Llabrés, P.J. (2005) Gaudí a la Seu de Mallorca. Barcelona. Triangle Postals.

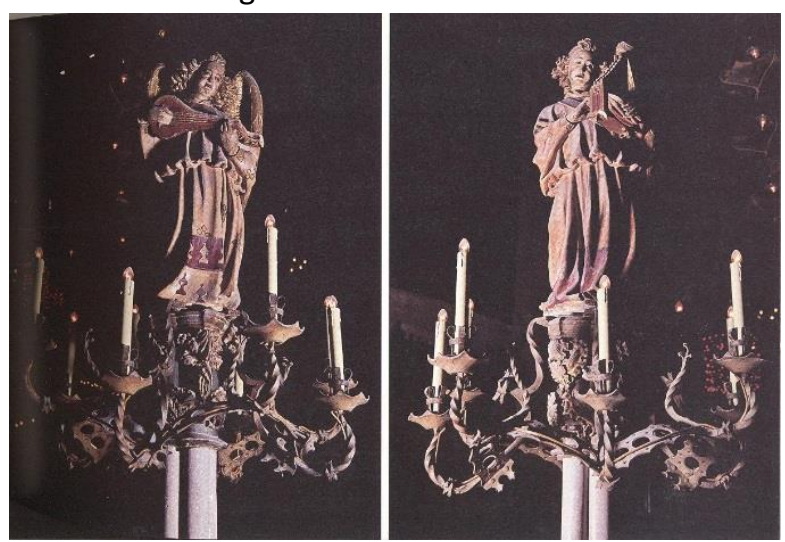

Reubicacion de los angeles músicos en la iluminación lateral del altar. Fuente: Llabres, P.J. (2002) Gaudí a la Seu de Mallorca. Palma de Mallorca. Govern Illes Balears.

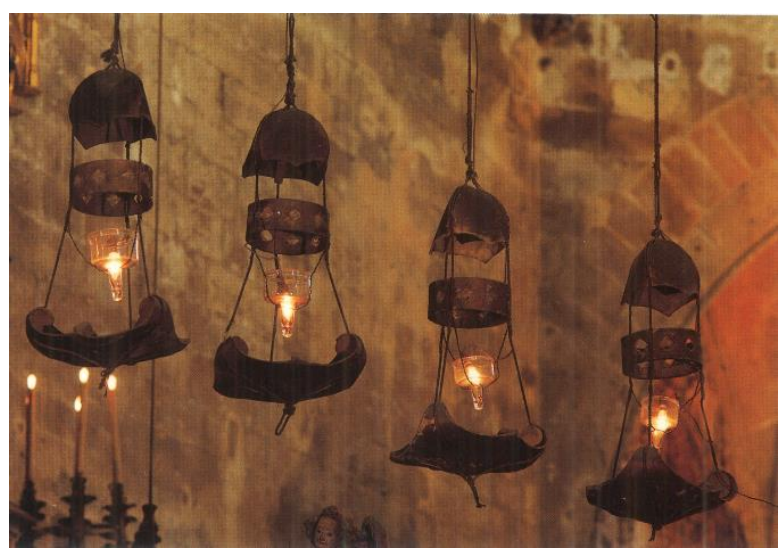

Iluminación y simbología en el baldaquino sobre el altar (Hch 20,8) Fuente: Llabrés, P.J. (2005) Gaudí a la Seu de Mallorca. Barcelona. Triangle Postals. 
Torii avanza la hipótesis, basada en tres citas ya enunciadas en su libro El mundo enigmático de Gaudí, de que fue a raíz de su trabajo en Mallorca cuando decide cambiar la tipología de planta de cruz griega por cruz latina entre 1901 y 1903 . En mi opinión nunca ha estado probado que Gaudí pensara en una planta de cruz griega para la Sagrada Familia, aunque sí pudo percibir las posibilidades de adaptación de una planta de cruz latina como aula liturgica renovada.

Lo que si que resulta convincente es la ligazón temporal y liturgica entre estas obras, resultando fundado considerar la intervención en la catedral de Palma como un importante eslabón en el proceso constructivo de la Sagrada Familia, sin olvidar su aportación al siempre interesante dialogo sobre el carácter de las intervenciones en edificios históricos de culto. La actualidad de este debate restaurador del patrimonio eclesiástico en España, en el que entran en juego la normativa y el concepto de restauración que conlleva junto con la permanente necesidad de adecuación a su uso primordial, hace especialmente relevante este ejercicio de sensibilidad profesional en el siempre necesario dialogo abierto entre Liturgia y Proteccion del Patrimonio Arquitectónico. ${ }^{270}$

La intervención pública restauradora, acorde con los criterios que establece la legislación específica en la materia, en muchas ocasiones se encuentra con que éstos no son lo suficientemente precisos como para constituirse en vademecun de toda la casuística posible. Puede llegar a plantearse, pues, una disparidad de opiniones encontradas respecto de una actuación concreta a realizar en un edificio de culto, puesto que no todo lo artístico resulta adecuado al culto en todas las épocas y circuntancias. En ocasiones resulta verdaderamente difícil compaginar el testimonio secuencial de todas las intervenciones históricas realizadas con la actividad cultual actual. Partiendo de la consideración del edificio como un organismo vivo en cuanto a su itinerario histórico de utilización y las sucesivas actuaciones en él realizadas, puede resultar controvertida su adecuación funcional en un momento dado, siendo esta circunstancia de especial relieve en los edificios ligados al culto. Tal es el caso de la intervención de Antonio Gaudí en la Seo de Mallorca, muy rechazada por algunos en función de la alteración de la preexistencia histórica y de la nueva contextualización de elementos ya existentes como el coro, los retablos, etc.

En cuanto al alcance y límites de una intervención arquitectónica en un edificio de culto histórico cabe plantearse si hay que plantear el proyecto como testimonio notarial de sus visicitudes históricas o más bien enfocarlo a garantizar su persistencia en función del uso.

\footnotetext{
${ }^{270}$ Como se puso de manifiesto en el Congreso Internacional de la Arquitectura al servicio de la Liturgia, celebrado en Madrid, Universidad San Pablo CEU, en octubre de 2013.
} 

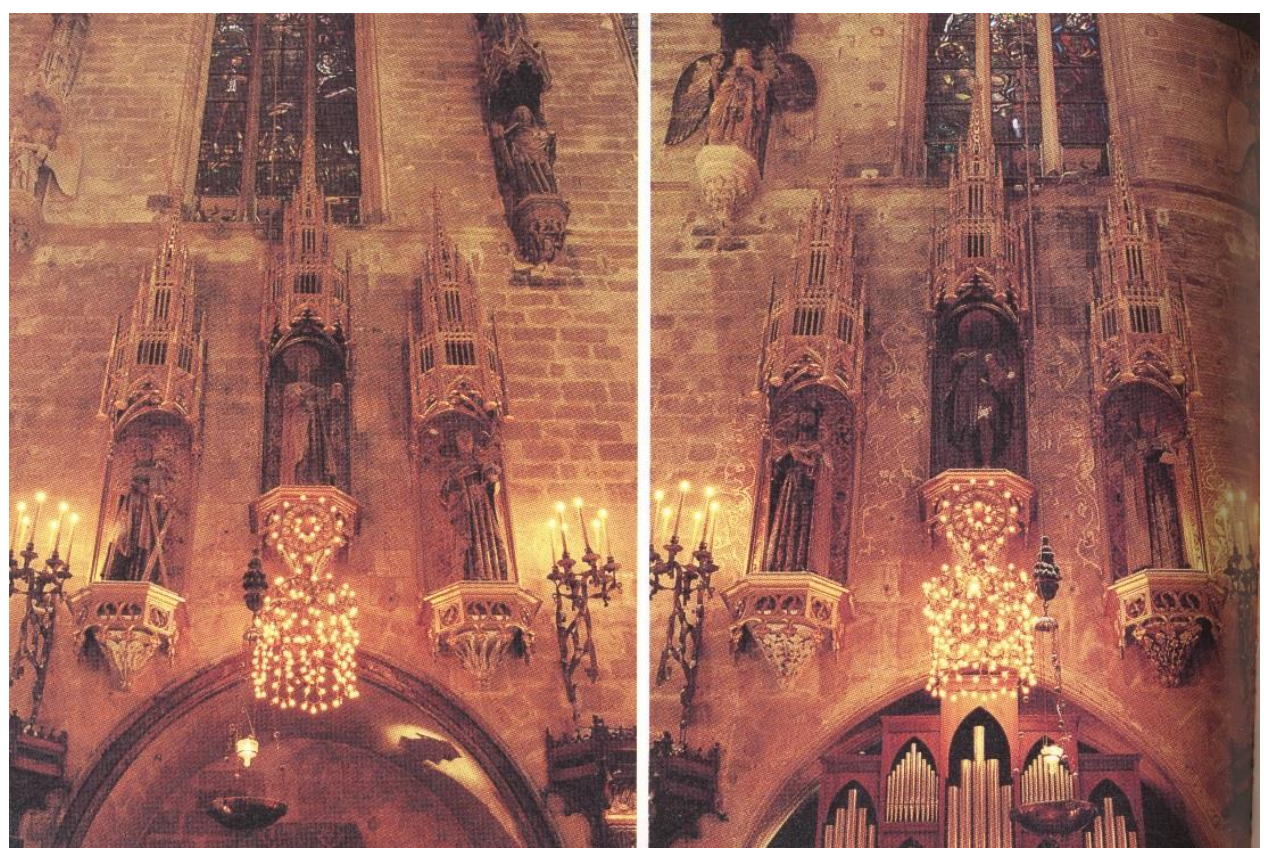

Reubicacion de esculturas del retablo gótico en los muros del aula liturgica. Fuente: Llabres, P.J. (2002) Gaudí a la Seu de Mallorca. Palma de Mallorca. Govern Illes Balears.

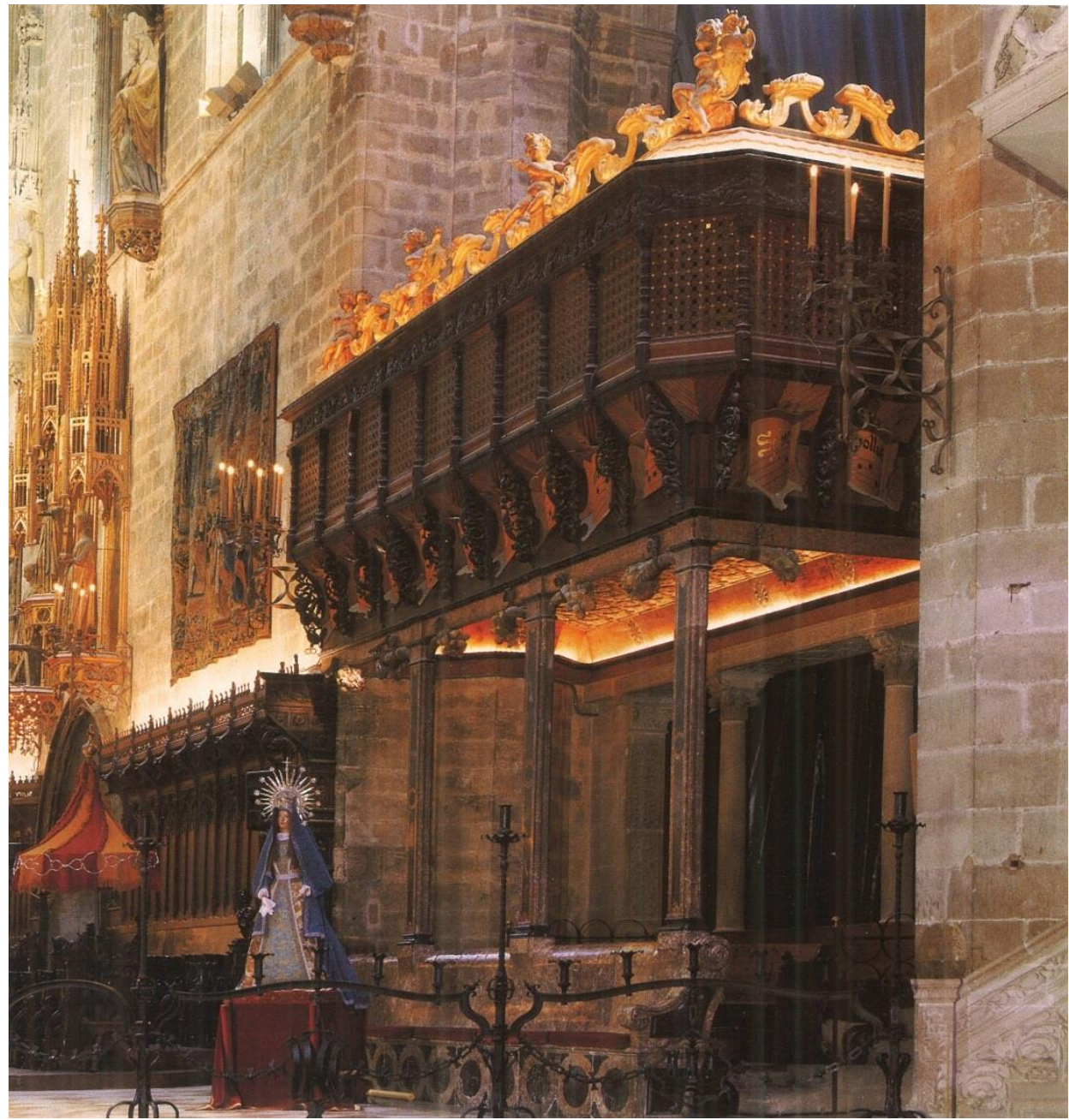

Reutilizacion de elementos del coro central para la Schola Cantorum del Presbiterio. Fuente: Llabres, P.J. (2005) Gaudí a la Seu de Mallorca. Barcelona. Triangle Postals. 
En términos de la legislación urbanística actual el uso y disfrute del edificio de culto siempre es compatible per sé con su conservación en las condiciones de habitabilidad, seguridad y ornato, en consecuencia no debiera temerse una intervención en la que prevalezca su funcionalidad litúrgica siempre que se respete las características más sobresalientes que configuran el edificio. Dejando claro que la legislación en materia de patrimonio pretende su cumplimiento con el fin de salvaguardar éste de su degradación y consiguiente desaparición, poniéndolo en valor nuevamente- y que la financiación pública ha de responder a criterios nítidamente coherentes con la protección arquitectónica que aquella establece, merece también ponerse de manifiesto el hecho de que la naturaleza del bien a proteger demanda su adecuado uso según el ars celebrandi que tiene su origen en el mismo nacimiento de la Iglesia hace 21 siglos y su permanente actualización, según lo que marcan las disposiciones litúrgicas vigentes y el Código de Derecho Canónico.

Quizá haya que buscar las soluciones a este debate en el marco de la consideración del edificio como expresión artística generada por su carácter o especial funcionalidad, el culto cristiano, que da origen al mismo, y que es incapaz de aislarse de su sentido de ser, de existir, como arquitectura, como diría también Louis Khan. Estariamos, pues, considerando lo inmaterial como generador de lo material, en términos gaudinianos volviendo la mirada hacia la que constituiría el carácter religioso del edificio. El sentido de este carácter, si es cultual, como lo entendía Gaudí en tantos casos, capilla del colegio de las Teresianas, iglesia de Sta. Coloma, catedral de Mallorca, Templo expiatorio de la Sagrada Familia, etc. es abierto y comunitario en su especificidad. Este carácter no es excluyente de los presupuestos de una normativa sectorial pero si tiene voluntad de afirmarse en términos de jerarquía programática, como por otra parte, siempre sucede en toda actividad humana, en la que ha de establecerse un orden conceptual que permita una secuencia de actuaciones. El tema es jurídica y arquitectónicamente complejo demandando un estudio y dialogo particularizado a cada caso sin apriorismos estilísticos o normativos.

En el caso de la Seo mallorquina el proyecto está plagado de soluciones que desarrollan hasta el más mínimo detalle el programa de intenciones de Campins ${ }^{271}$, en moderno y armonioso diálogo con la obra de fábrica existente, aunque desde la visión primordial de su adecuación al objeto para el que ha sido construida. En el debate de la restauración como conservación del patrimonio existente, de la preocupación por la consolidación de las estructuras y formas precarias, creemos que Gaudí aporta un proceso de descomposición y recomposición sumamente interesante, combinando el reconocimiento histórico artístico del edificio con un moderno sentido de dialogo con su arquitectura, y ambos con la fundamentación metodológica que le confiere el considerar como objetivo primordial de la intervención a realizar la consecución de su plena funcionalidad litúrgica (según la declaración programática explicitada por la autoridad eclesiástica).

${ }^{271}$ Cf. Llabrés i Martorell, P. J. (2002). Gaudí a la Seu de Mallorca. Palma de Mallorca. Govern de les Illes Balears. 

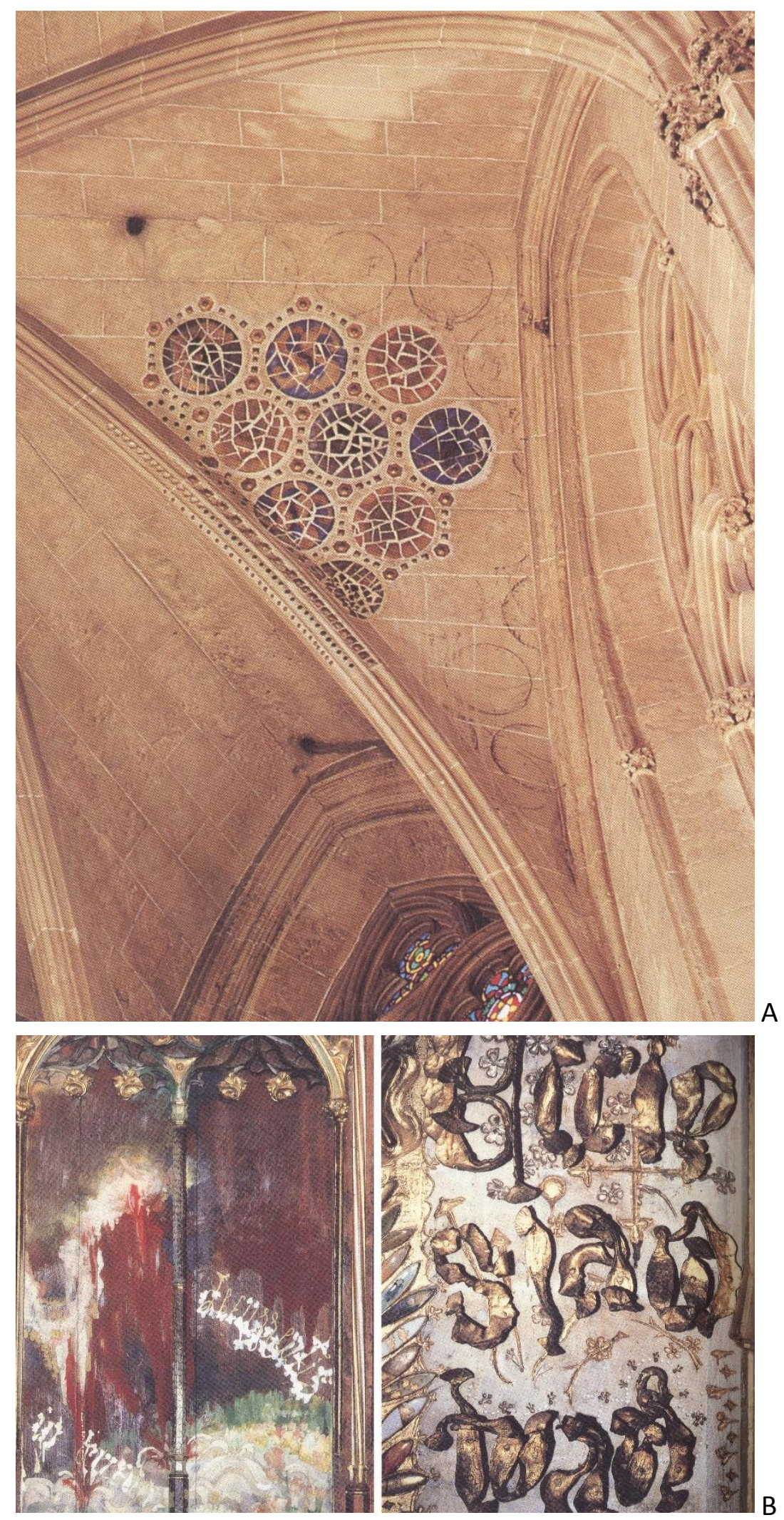

Detalles de la intervención decorativa de Gaudí en la catedral de Mallorca. A: Decoracion cerámica en bóveda. B: Decoración pictórica en Coro del Presbiterio y cerámica en muro de fondo.

Fuente: Llabres, P.J. (2002) Gaudí a la Seu de Mallorca. Palma de Mallorca. Govern Illes Balears. 
Ello no impide el respeto del edificio histórico y sus elementos artísticos aunque algunos de ellos sufran una modificación o alteración pues de lo que se trata es de su valoración como elementos inherentes o no a la condición liturgica del edificio. Las categorías en las que nos movemos parece que están más claras en otros ámbitos, en los que la actuación del arquitecto resulta más libre, frecuentemente vinculada a una cierta funcionalidad que antecede a su memoria histórica sin anularla. En el caso de la arquitectura cultual histórica quizá haya que visualizar la recolocación de elementos según la actualización de su código ordenancista desde una actitud de sinceridad conceptual que lejos de ejecutar una deconstrucción sin más lo que hace es ponerlos en valor según la cultura y la fe de cada tiempo.

No olvidemos que la mejor manera de conservar un bien cultural inmueble es habitarlo adecuadamente según el uso que le es propio, potenciando de acuerdo con ello sus posibilidades de apertura y contemplación.

Gaudí no pretende una restauración estilística ojival puesto que rechaza la interpretación violletiana del gótico. Su actitud es la del artista que, educado en el renacimiento, domina las claves de lo histórico y clasicista, lo interpreta libremente y desarrolla con la expresividad y fuerza de que hace gala el gusto barroco un sentido escénico cuya finalidad no es meramente estilística o estética sino litúrgica. De ahí que con las limitaciones propias de toda intervención, subjetiva y criticable per se, lo que marca ésta es la voluntad de conseguir la plenitud de su uso litúrgico según las directrices renovadoras del momento histórico en que vive.

Este uso -culto y cultual- es capaz de mantener e incluso mejorar la armonía interna del edificio, tal y como reflejan los testimonios y grabados del momento $y$, también, los mismos estudios previos de Gaudí al llegar a la isla, sin descuidar el dialogo artístico entre el conjunto y sus elementos ni su condición de hito ciudadano. La liturgia reivindica, pues, su condición de generadora de la imaginación y expresividad artística del edificio, siendo como el hilo conductor que lo mantiene vivo y armonioso en el trascurso de la historia. La obsolescencia liturgica conduce en cambio, aún cuando la arquitectura manifieste exuberantes formas artísticas, a un paulatino deterioro funcional y constructivo del edificio-iglesia considerado como tal cuyo final inexorable es la hibernación museística o el cambio de uso -en un intento de revitalizar el contenedor- por pérdida de su capital humano. Quizá sea esto lo que algunos persigan considerando más valiosas las piedras que las personas que las habitan pero en esto nuestra simpatía está con la Liturgia Católica y con Gaudí valorando la arquitectura cultual como un servicio a cada ser humano, como asamblea comunitaria y como persona individual única e irrepetible. 


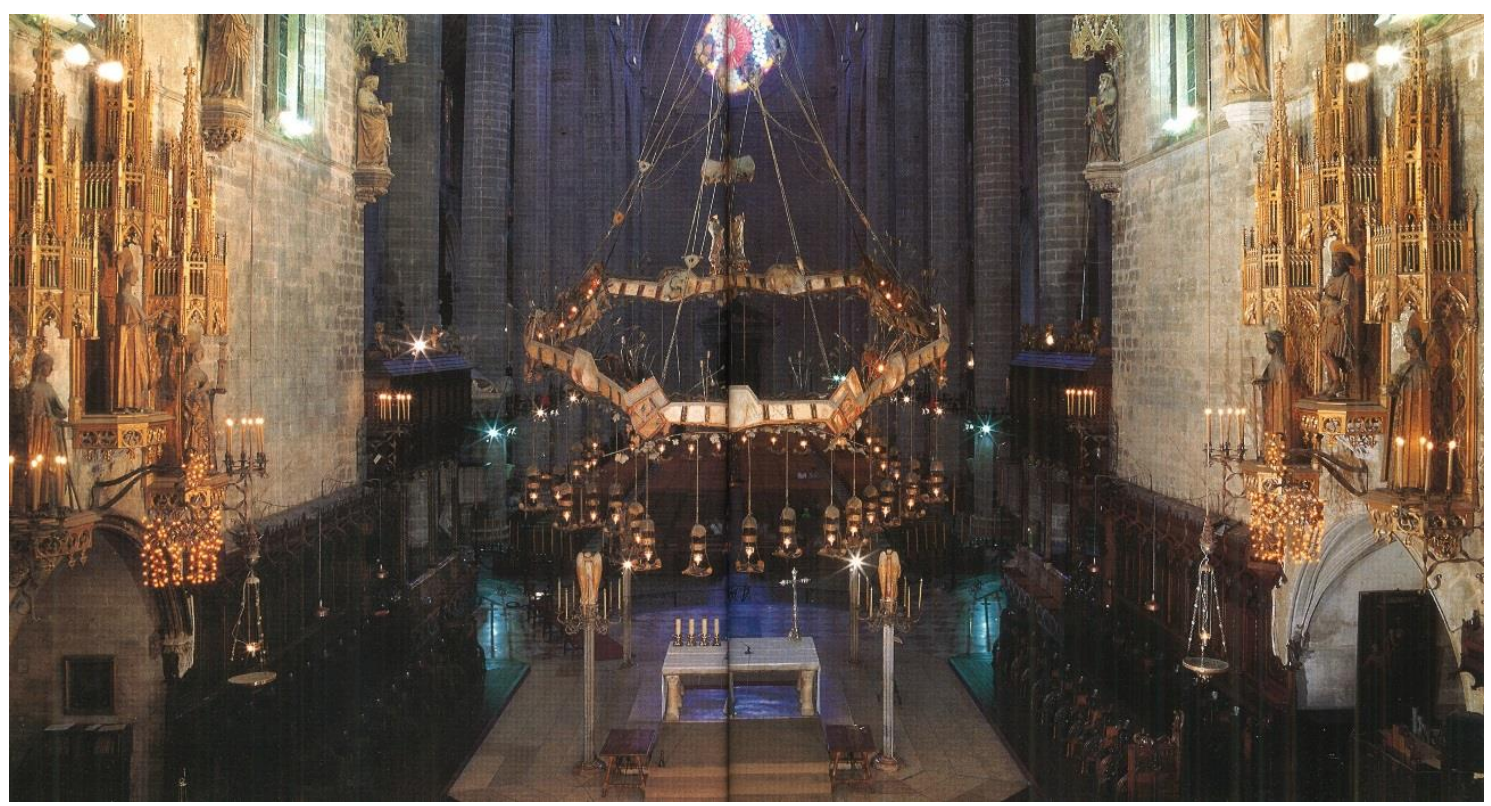

A

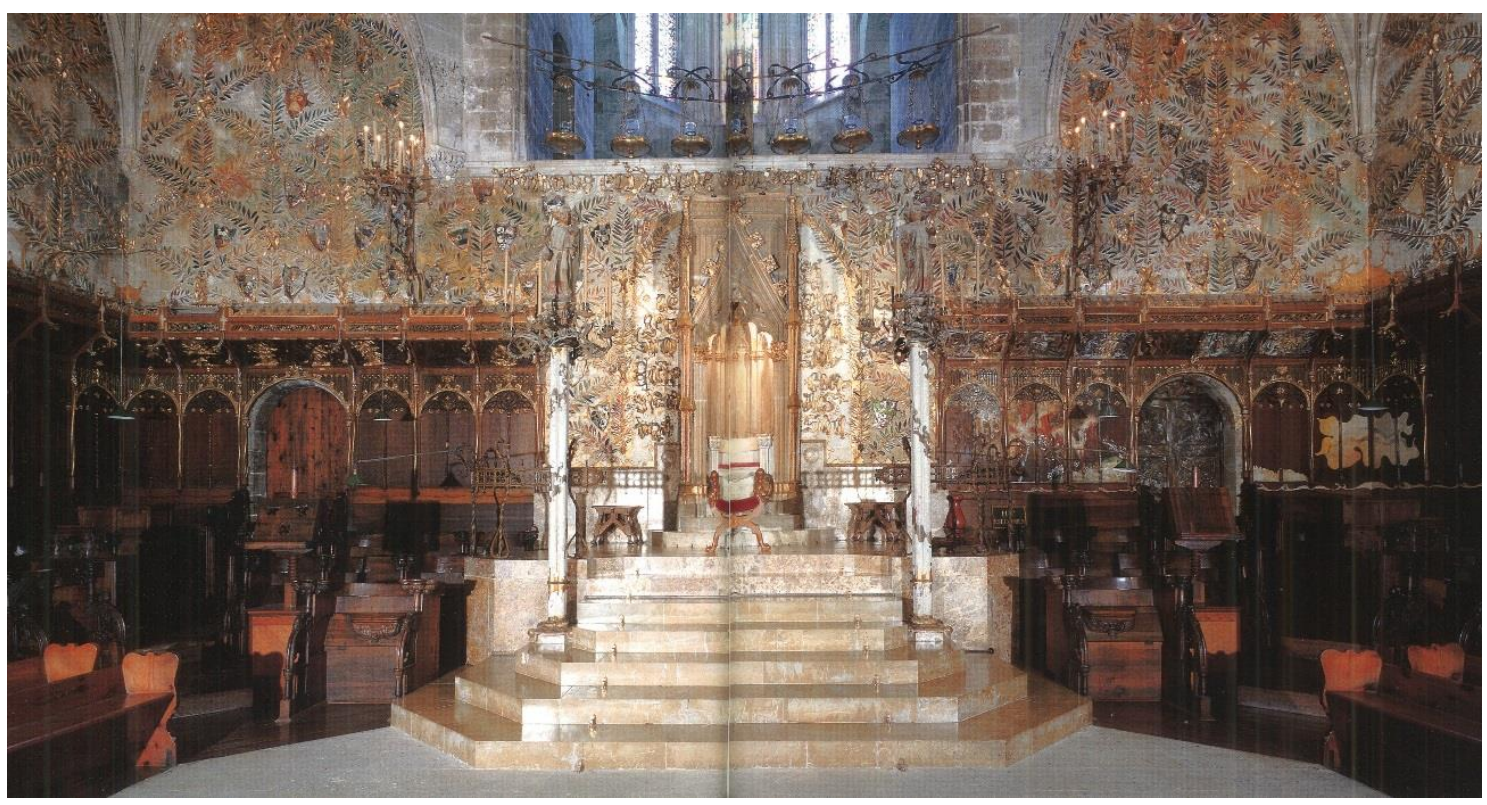

B

A: Vista general del aula liturgica desde la Capilla Real. Fuente:

B: Vista de la Sede espiscopal y el coro con la decoración del muro de fondo del Presbiterio. 
Desde esta perspectiva la intervención de Gaudí puede considerarse paradigmática, lo cual no la excluye del legítimo debate y discrepancia respecto de los criterios puestos en juego y los resultados obtenidos. Su permanente y armonioso dialogo con el edificio en su devenir histórico, que no excluye un programa decorativo e iconográfico en continuidad con el planteamiento de Campins, muestra la vigencia de su planteamiento en el debate cultural de la restauración del patriomonio artístico eclesiástico. Como señala Verónica Boccuni (2008) la herencia artística que representa esta obra, se refleja sobre algunos importantísimos significados que una intervención sobre una sólida preexistencia puede asumir: conservar una implantación arquitectónica de notable valor histórico-artistico, pero renovándola a través del propio lenguaje original; adecuar a nuevas funciones dentro del mismo uso, pero experimentando la utilizacion de soluciones nuevas que tienen la capacidad de dialogar con lo antiguo, sin deformarlo o querer a toda costa determinarlo. ${ }^{272}$

272 Cf. Boccuni, Verónica L. (2008)."'L'incompiuto di Gaudí: esiti ed interpretazioni attraverso tre opere sacre", en Pane, Giulio y AAVV. Attualità di Antonio Gaudí. Nápoles. CLEAN Edizioni. Boccuni estudia el caracter inacabado de algunas obras emblemáticas de la arquitectura sacra de Gaudí, llegando a la conclusión de que las diversas caracteristicas que reunen de cada una de ellas dan posibilidades de diferentes actitudes ante ellas. En el caso de Mallorca sostiene que detenida la obra, la indeterminacion de lo no terminado expresa todavia hoy su plena autenticidad. 


\section{CAPITULO 6 ANÁlISIS DEL PROYECTO DE LA SAGRADA FAMILIA EN CLAVE CELEBRATIVA.}

\subsection{Datos de partida del Proyecto Gaudiniano de la Sagrada Familia.}

\section{a) El concepto de Templo Expiatorio en la Asociación de devotos de San José y Gaudí.}

El sentimiento comunitario de expiación como repulsa del ambiente general materialista y descreído del siglo XIX, muy marcado en el ámbito católico europeo por la Revolución Francesa y el dominio bonapartista primeramente, y después por la pérdida de la soberanía temporal de los Estados Pontificios y el resultado de la guerra Franco-Prusiana, junto con la fuerte controversia que se produce en toda Europa entre Liberalismo, Marxismo y Anarquismo, que provoca grandes tensiones sociales, hace florecer un gran número de congregaciones religiosas centradas en la educación cristiana y promueve un florecimiento de la arquitectura religiosa, en cantidad y calidad, dentro de una considerable variedad de funciones y tipologías.

En este contexto surge con fuerza en el panorama de la arquitectura eclesiástica europea la figura de la iglesia votiva. Frecuentemente asociada al surgimiento de un fuerte sentimiento político de renovación del patriotismo nacional, su arquitectura se apoya en los estilos neomedievalistas como marca artística de cada estado ${ }^{273}$. La conciencia mayoritaria en la sociedad de cada país, y en muchas comunidades particulares, se encauza a través de la acción de gracias o la penitencia por algún hecho de significativa relevancia pública con el convencimiento de que una vuelta a los valores religiosos tradicionales fomentará el fortalecimiento de los ideales y convicciones que se consideran acordes con el deseado resurgimiento de la nación en el contexto internacional. Esta dinámica ideológica de las burguesías nacionales que utiliza los edificios votivos para el reagrupamiento social frente a las grandes compulsiones sociales, en torno a un hito edificatorio, motiva que la construcción de éstos contemple en la mayor parte de los casos el apoyo o participación directa de las finanzas públicas. Este tipo de financiación público-privada, que persigue también la aportación de los donativos aristocráticos y populares, contribuirá grandemente al rápido inicio y realización de muchas de estas obras. El Sacré Coeur de Montmartre será el caso más relevante, pero también Koekelberck en Bruselas y Viena con sus respectivas singularidades.

\footnotetext{
${ }^{273}$ Nota del autor: veáse lo mencionado en el apartado 5a Panorama de la Arquitectura religiosa en tiempos de Gaudí de esta investigación, en el que se describen sucintamente los ejemplos que se promueven en Francia, Austria, Bélgica con la edificación del Sacrée Coeur de Paris, Lyon, la iglesia votiva de San Esteban en Viena, la basilica de Koekelberk en Bruselas, etc.
} 

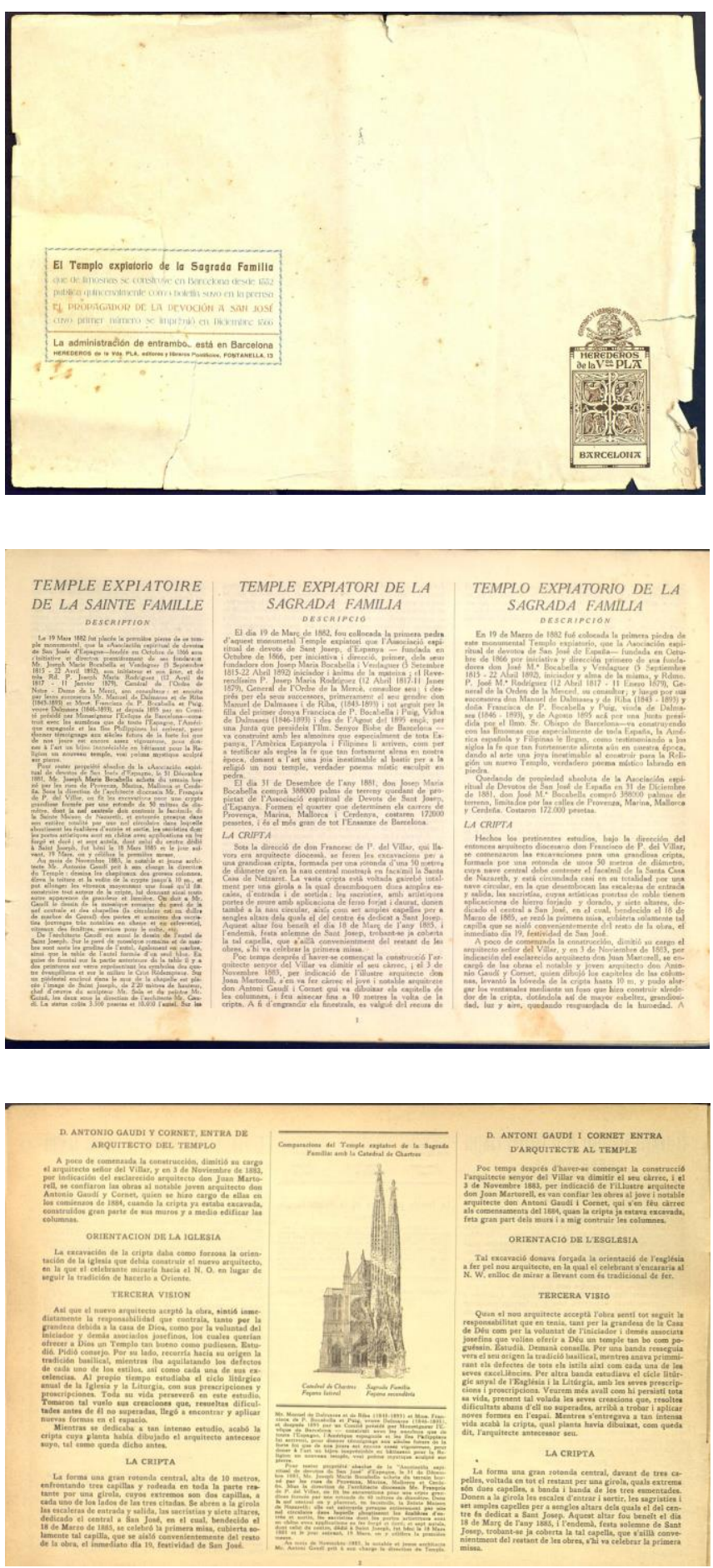

La Asociación de Devotos de San José, promovida por el librero viudo José Ma Bocabella publicará además de su revista el Propagador de la devoción de San José, de periodicidad mensual, diversos Albumes para dar a conocer el progreso de las obras de la Sagrada Familia. Fuente: Arxiu de la Sagrada Familia. 
El edificio que promueve en el llano de Barcelona la Asociación Espiritual de los devotos de San José, sin embargo, se identifica más plenamente con lo que sería un templo expiatorio pretendidamente independiente del oficialismo político del momento, debido a su radical iniciativa privada, y con vocación universalista.

En medio de las tensiones eclesiásticas y sociales del momento los josefinos, con Bocabella a la cabeza, acertarán a centrar su proyecto recabando los apoyos y estímulos oficiales que están a su alcance pero sin ceder lo más mínimo en cuanto a la financiación privada de las obras, el programa a desarrollar y el ritmo de ejecución que corresponda. ${ }^{274}$

Partiendo de una clara intención expiatoria -por los "extravíos que en la piedad del "pueblo habían producido los movimientos revolucionarios"_-275 que ya venía preparando Bocabella desde hacia tiempo con la revista El Propagador, su singular sistema de financiación -ajeno a todo lo que no sean aportaciones privadas voluntarias- determinará un larguísimo periodo de ejecución de las obras que acabará redundando en una mayor y más rica apertura conceptual del proyecto. ${ }^{276}$ Este más amplio horizonte de objetivos no hay que verlo encuadrado únicamente en la mayor sensibilidad social, acción mediadora por la paz y participación de los católicos en la vida pública que caracterizó el pontificado de Benedicto XV.

\footnotetext{
${ }^{274}$ Algunos autores refieren las tensiones con el Obispo Joan Laguarda i Fenollera para acabar lo antes posible el templo, aunque fuese de menores dimensiones a las proyectadas, y convertirlo en parroquia. Cf. Tarragona i Clarassó, J.M. "Gaudí va voler deixar les obres de la Sagrada Familia. Un episodi poc conegut de la seva biografia, relacionat amb el bisbe Laguarda", en AAVV (2002) Gaudí a Mallorca, IX Jornades internacionals d'Estudis Gaudinistes. Barcelona. Centre d'Estudis Gaudinistes.

275 Cf. Ràfols, J. F. (2006) Gaudí: 1852-1926. Ed. Facsímil de al edición de 1952. Barcelona. Catedra Gaudí y Ed, Claret. P. 39

${ }^{276}$ Cf. Rohrer, Judith. (1990). "Una visió apropiada: el Temple de la Sagrada Familia de Gaudí i la política arquitectónica de la Lliga Regionalista", en AAVV. Gaudí i el seu temps. Barcelona. Barcanova. Rohrer relaciona la iniciativa de Bocabella y los josefinos con los avatares ideológicos del catalanismo concervador; La misma autora en "Catolicisme, catalanisme i polémica: Gaudí i la Sagrada Familia", en AA. VV. (2004) Gaudí i la dimensió trascendent. Barcelona. Fundación Joan Maragall y Ed. Cruilla, señala la intención expiatoria original de los Josefinos respecto de una época liberal a nivel mundial y de un republicanismo anticlerical español, enmarcada en la etapa del aislamiento vaticano de Pio IX, pero que después se abre a más amplios horizontes coincidiendo con el papado de Leon XIII y la cuestión social. Apunta también a $E I$ Propagador de la devoción a San José, mayo-junio de 1876, como la publicación donde se pueden encontrar algunas de las primeras declaraciones sobre la necesidad de la expiación, pero también cómo la Sagrada Familia continuaría el curso de su ejecución durante el siglo XX moviéndose con notable destreza y equilibrio entre los diversos sectores ideológicos de la prensa civil y religiosa.. También otros autores como Lahuerta, J.J. (1993) Antonio Gaudí: arquitectura, ideología i política. Madrid. Alianza Editorial; Genís i Terre, J. (2006). Els fonaments ideológics de l'arquitectura religiosa del Gaudí de maduresa. Tesis Doctoral en la U. Pompeu Fabra. Barcelona; han tocado este asunto, si bien este último desde una perspectiva más centrada en la arquitectura, la filosofía y el arte.
} 
Desde el punto de vista arquitectónico, la persistente voluntad de sus iniciadores de adecuar el proyecto al uso litúrgico y su expresiva forma de mostrarlo en el proceso constructivo mediante el desarrollo de un imaginativo expresionismo enfocado a los misterios que pretende mostrar y a la simbología cristiana, se beneficiarán para su maduración del dilatado periodo de ejecución de las obras. En este sentido parece que el tiempo ha venido a dar la razón a su arquitecto cuando decía que "en la Sagrada Familia todo es providencial y que el Propietario no tiene prisa". 277

Antoni Pladevall, que ha estudiado la dimensión trascendente del proyecto que impulsa Bocabella ${ }^{278}$, se plantea si la armonía que llega a conseguir Gaudí entre el programa de la obra, su ejecución y su vida, es consecuencia del ambiente vivido por el arquitecto y su círculo más próximo o de una progresiva "conversión" de Gaudí, llegando a una conclusión no conclusiva respecto de esta cuestión: el arquitecto era un hombre de fe, creyente y practicante de los actos de culto, aunque sin inquietud por hacerse grandes planteamientos doctrinales. En mi opinión, en la misma cuestión que plantea está la respuesta, pues ambas líneas evolucionan parejas. Su bagaje espiritual y cultural cuenta con aportaciones como las de Torras i Bages, Verdaguer, Ossó, Martorell, etc., pero también bebe de la renovación litúrgica que defienden Grau, Campins, Carreras, Trens, Tarré y Sunyol en comunicación con los focos centroeuropeos de renovación litúrgica y con la sede petrina. No obstante, la concepción tan avanzada en lo litúrgico que preconiza para sus proyectos de arquitectura cultual y la profesionalidad que pone a su servicio, no creo que puedan explicarse únicamente por el influjo del círculo de sus conocidos.

Ciertamente el ambiente eclesiástico en el que se mueve el arquitecto le aporta conocimientos y le sumerge en una atmósfera propicia al desarrollo de la sensibilidad litúrgica, pero ésta no es uniforme y no explica por sí sola la voluntaria tenacidad de la investigación gaudiniana de los proyectos eclesiásticos. Sin duda otros arquitectos como el Marqués de Cubas en Madrid o Enrique Sagnier en Barcelona se movían en ambientes aristocráticos y eclesiásticos, y producían obras de arquitectura ligadas al culto cristiano, pero no encontramos en ellos y sus proyectos la misma concepción simbólica y artística que estructuran el proyecto ni el grado de implicación con la teología litúrgica que lo sustenta.

277 Cf. Puig Boada, I. (1981) El Pensament de Gaudí. Barcelona. La Gaya Ciencia, COAC, p. 193: “A la Sagrada Familia tot es providencial, àdhuc la meva entrada com arquitecte..."

278 Cf. Pladevall, A. (2004). "La religiositat de Gaudí i de la seva época", en AA. VV. Gaudí i la dimensió trascendent. Barcelona. Fundación Joan Maragall y Ed. Cruilla. P.31: "No creiem que es plantegés mai si era integrista o progresista: ell era, simplement, creient, obert a tota millora i manifestació de religiositat i amb aquesta omplia la buidor que li va deixar la manca progressiva de familia i d'amor o caliu humà que la vida li va imposar." Para Pladevall el objetivo primordial de Bocabella y los josefinos era favorecer la promoción e intensificación del sentimiento religioso de los cristianos y más concretamente de la sociedad catalana del momento, en sintonía con la proclamación de San José como patrón de la Iglesia Universal y bajo la protección de la Sagrada Familia, buscando la regeneración de la vida familiar cristiana. 


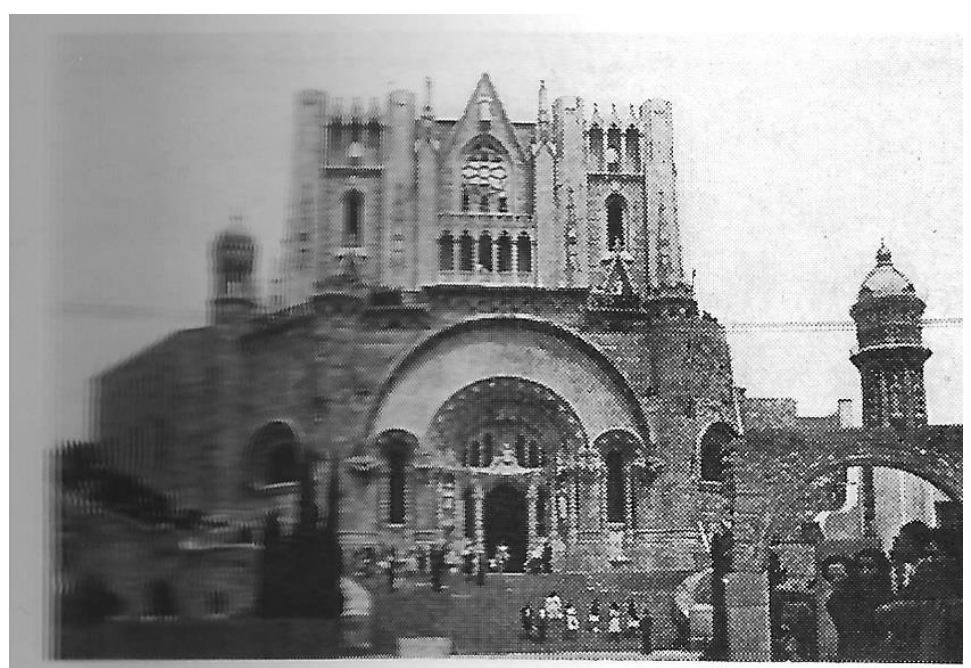

Ejecución de las obras del Templo del Tibidabo en Barcelona. Fuente: Lahuerta, J.J. (1993) Antonio Gaudí: arquitectura, ideología y política. Madrid. Alianza Editorial. 
Es preciso entrar en la dinámica personal del arquitecto para comprender su unicidad. ${ }^{279}$ El programa expuesto por Gaudí a los Josefinos en 1891, germen del programa teológicosimbólico y constructivo del proyecto, y la propia dinámica de su intervención profesional son factores clave en la plasmación de los renovados objetivos y significados del Templo expiatorio ${ }^{280}$. Aunque es conocida la influencia de Torras i Bages en la vida de Gaudí, dentro y fuera del Cercle Artistic de Sant LLUC, esta estuvo siempre orientada según una cierta dirección espiritual del obispo. En cambio, la afinidad, reconocimiento, admiración y amistad, centradas en la Liturgia, preside sus relaciones con Grau, y también con Campins. La mutua consideración artística y cultural que otorgan al proyecto de la Sagrada Familia está en el centro del intercambio epistolar y comunicación con Maragall, pero podemos encontrar una mayor compenetración profesional, artística y humana con Martorell, Casanovas y Ossó, según el caso, que dejarán honda huella en su ánimo si nos atenemos a la ética de la amistad de Tomás de Aquino. ${ }^{281}$

${ }^{279}$ Cf. Giralt-Miracle, D. (2010) “L'Art a la Sagrada Familia”, en AA. VV. Sagrada Familia, de temple expiatori a basilica. Barcelona. Lunwerg: "La Sagrada Familia....es lóbra que explica millor la seva evolució i es l'obra que concentra tots el ideals (espirituals, patriótics, artístics i técnics) que informen la seva existencia."; Crippa, Ma Antonietta (2010) "El carácter religiós de la catedral de Gaudi", en AA.VV. Sagrada Familia, de temple expiatori a basilica. Barcelona. Lunwerg: "Cal prendre nota ...de l'enorme diferencia que separa les obres de gaudí d'aquells dels arquitectes del seu temps $i$ del nostre, en general $i$ en relació amb la construcción dels llocs de culte"; Reig Martinez, J. (2013). Antoni Gaudí y la Belleza: la Sagrada Familia, un proyecto vivo. Valencia. Edicep. P. 124: "Al objeto de comprender cómo vive el arquitecto éste encargo profesional hay que recordar antes que nada su envergadura y relevancia social, cuestiones que no se le escapan a Gaudí, el cual ya mencionaba este tipo de proyectos en su Cuaderno de Notas como los más importantes a que podía aspirar un arquitecto."

280 Cf. Martinell, C. (1952) La Sagrada Familia. Edición en castellano de Gaudí i la Sagrada Familia comentada per ell mateix. Barcelona. Aymá. P. 17: “...además de todo esto, es seguro que la Sagrada Familia tuvo gran parte en su formación religiosa. Gaudi concibió el templo, pero el templo formó a Gaudí."; Reig Martineez, J. (2011) Antoni Gaudí i la belleza. La Sagrada Familia, un proyecto vivo. Valencia. Edicep. P. 160: "...su mente agilisima y su espíritu pronto concebían un montón de planes para ayudar a en los momentos de mayor dificultad financiera a que no se detuviera la edificación y en esta concienciación en las obras de la Fe, para la contribución económica de la construcción del Templo expiatorio, implicará de muy diversa manera a sus amigos..."

${ }^{281}$ Cf. Galtés, J. "Els vincles de Gaudí amb el mon eclesiástic", y Plá i Arxé, "Relacions amb Torres i Bages, Casanovas i altres intelectuals", en AA. VV. (2004) Gaudí i la dimensió trascendent. Barcelona. Fundación Joan Maragall y Ed. Cruilla; Castellanos, J. "Torras i Bages, i Gaudi”, en Lahuerta, J.J. y AA.VV. (1990) Gaudí i el seu temps.Barcelona. Barcanova; Blasco, A., "Gaudí, Maragall i Pijoan", en AA.VV. (2004) Gaudí i la dimensió trascendent. Barcelona. Fundación Joan Maragall y Ed. Cruilla, repasa los artículos publicados por Maragall y las cartas cruzadas entre Pijoan y éste, para destacar el aprecio del poeta por el edificio y lo que representa, como símbolo de piedad y anhelo de trascendencia, su admiración por el artista, pero su escasa sintonía o amistad en la manera de vivir la fe. De Pijoan destaca el aprecio por la obra arquitectónica de Gaudí pero también el inicio de una cierta apropiación de esta obra por la política de la Lliga Regionalista; Reig Martinez, J (2013) Antoni Gaudí y la Belleza: la Sagrada Familia, un proyecto vivo. Valencia. Edicep. 
Dentro de este ambiente de amistades, confluencia de aspiraciones artísticas y religiosas, de influencias mutuas, no hay que olvidar la praxis investigadora y ensayista del arquitecto que dispone de un prolongado periodo de tiempo para perfeccionar su proyecto más querido. Su evolución, seguida a través de los dibujos, maquetas y proyectos de estructuras que han perdurado, da cumplida muestra de la completa e incansable dedicación del arquitecto. La gran armonía que se dá entre las convicciones de su vida personal y el ejercicio profesional, que se despliega aquí en una especialísima vinculación del espacio arquitectónico con el culto religioso y en una prodigiosa imaginación puesta al servicio de un compacto programa simbólico, es el motor de los sucesivos proyectos estructurales en un perseverante deseo de adecuación del edificio a su uso. Crippa (Sagrat i profà en l'arquitectura de Gaudí) afirma que no es casual la atención privilegiada que demuestra por el edificio-iglesia y su adhesión al mito de la catedral gótica que recorre el siglo XIX pero que, en su caso, renueva completamente de una manera imaginativa.

\section{b) La idea de Bocabella y el primer proyecto.}

Bocabella funda en 1866 la Asociación Espiritual de Devotos de San José, y ya a partir de 1867 cuenta con una revista semanal titulada muy consecuentemente con los objetivos de la asociación, "El Propagador de la devoción a San José", que aparecerá sin interrupción hasta 1936 cesando después su publicación y volviendo a reanudarse en 1948 con el nombre de Templo (Temple desde 1981). Según Bassegoda es comúnmente reconocido el hecho de que Bocabella tuvo esta idea al contemplar un cuadro de la Sagrada Familia en Montserrat ${ }^{282}$. En 1869 la Asociación es agregada a la Obra del dinero de San Pedro por el Papa Pio IX, pasando a gozar de toda clase de bendiciones del pontífice. El 8 de diciembre de 1870 San José había sido declarado por decreto pontificio patrono de la Iglesia Universal y dos años después, en 1872, Bocabella y los Josefinos peregrinan a Roma y Loreto ofreciendo al Papa una imagen de la Sagrada Familia obra del escultor Fracisco Pagés Serratosa. Martinell (1967) afirma que es en el curso de esta visita cuando el librero viudo concibe toma la determinación de construir una iglesia que albergue una reproducción de la Santa Casa de Loreto.

Dos nuevos impulsos recibe Bocabella para llevar a cabo esta idea. En 1874 un emprendedor fraile mercedario amigo suyo, José Maria Rodriguez, que ya le había

282 Cf. Bassegoda, J. (1989) El gran Gaudí. Sabadell. AVSA. P. 209: “...empezó a publicar el semanario denominado <El Propagador de la Devoción a San José> a imitación de otra publicación similar que dirigía en Sainte Foi de Dijon el marista francés Joseph Huguet." 


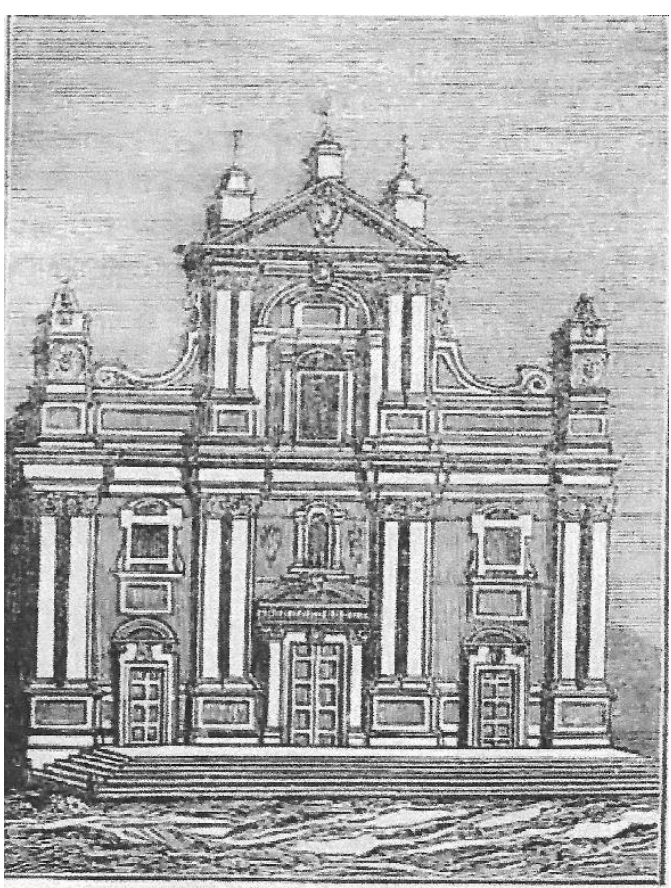

Ll templo de la sagrada Familia.

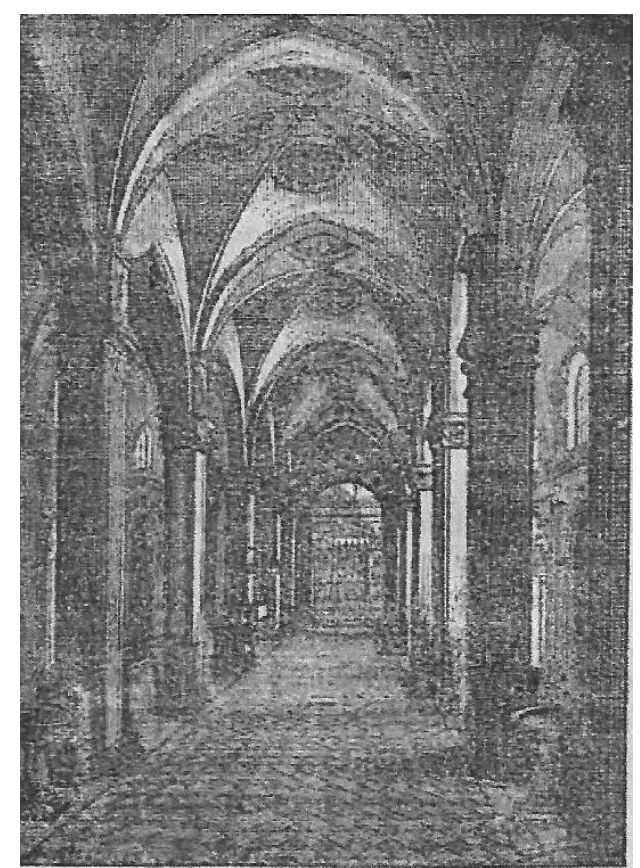

El templo de la sagrada Fanilia.

Grabados de la fachada e interior del santuario de Loreto publicados en el Porpagador, no de noviembre de 1875, p. 310 y 374, como fachada y templo de la Sagrada Familia. Fuente: Arxiu de la Sagrada Familia

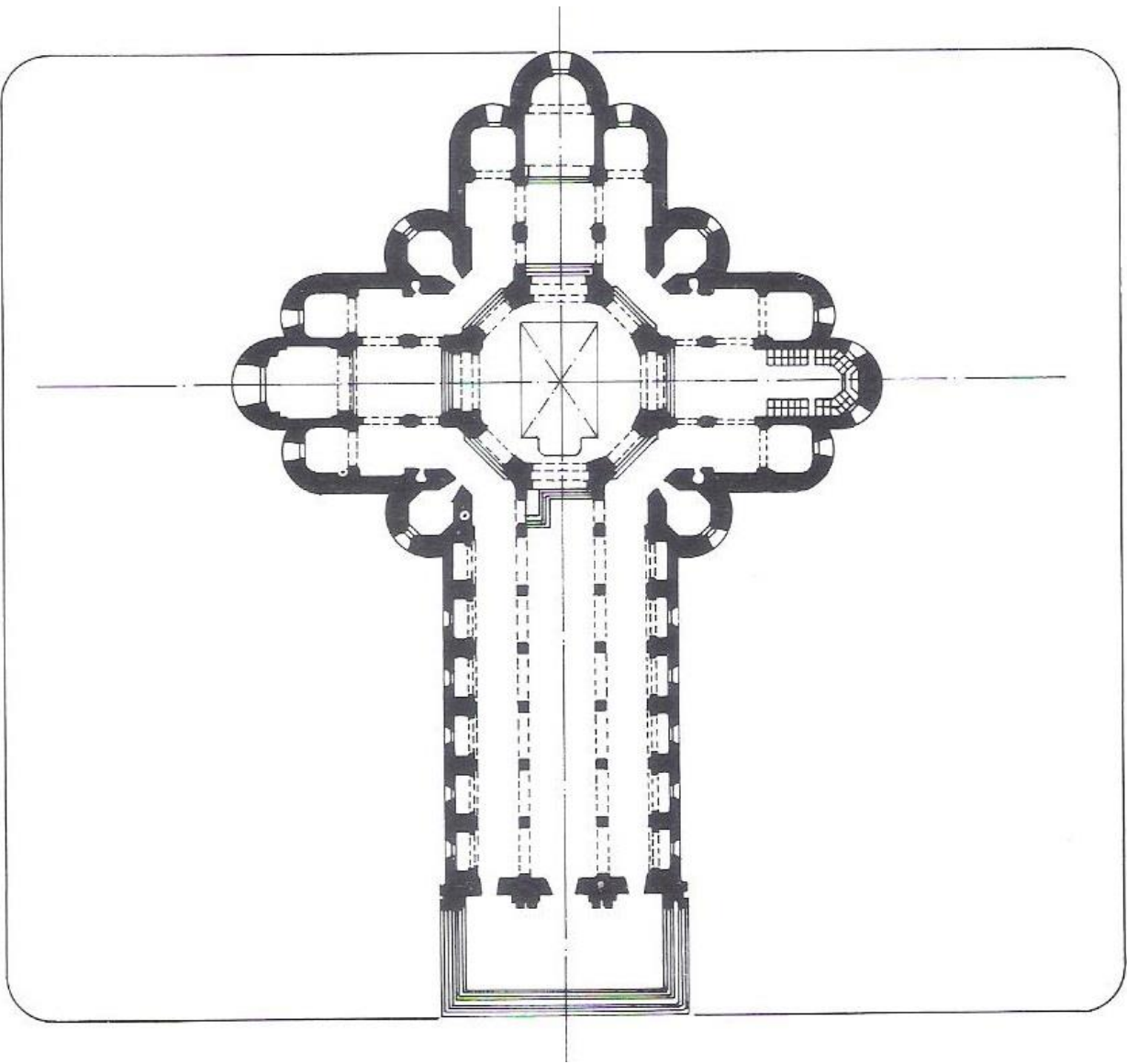

Planta de la iglesia de Na $\$$ a de Loreto (1468-1554) según un dibujo del s.XVII, encajada por Torii en una cuadricula del ensanche barcelonés. Fuente: Torii, T. (1983) El mundo enigmático de Gaudí. Madrid. Instituto de España. 
animado a lanzar una edición de más de quince mil ejemplares de Los siete domingos de san José, le sugerirá llevar a cabo la construcción de un templo dedicado a la Sagrada Familia, y aún antes el p. José Manyanet, a quien Bocabella había publicado algunos libros, le había propuesto con ocasión del Concilio Vaticano I la construcción de un gran templo dedicado a la figura de San José (1869-71). Consciente de lo idóneo de sus planes intenta una emisión de acciones para financiar las obras de construcción de un templo (1875) que debía imitar la iglesia de Na Sa a de Loreto y reproducir en su interior la Santa Casa de la Familia de Nazaret cuyos restos se veneraban en aquella.

Al año siguiente comienza a buscar un solar y en 1877 el arquitecto diocesano Francisco de Paula del Villar se ofrece al librero para realizar gratuitamente los planos. Después de diversas visicitudes se adquiere una manzana del ensanche de unos $12.800 \mathrm{~m} 2$ en el entonces municipio de San Martí de Provençals, escriturándose la compra el 31 de diciembre de 1881.

Poco se sabe de este primer proyecto, salvo la intención mencionada. Torii (El mundo enigmático de Gaudí, 1983) ha hecho el ejercicio de insertar la planta de Loreto en una cuadricula del ensanche barcelonés para indicar la verosimilitud de esta primera idea de Bocabella y su asociación, pero no hay nada que nos sugiera una intencionalidad estilística determinada en esta primera idea programática de los Josefinos. Cabe mencionar que la fachada e interior de la basílica de Loreto son publicadas en el Propagador $^{283}$ lo cual hace suponer que la intencionalidad primera sólo alcanzaba a la mera reproducción del edificio loretano y a la búsqueda de unos terrenos adecuados para llevar a cabo la construcción. No obstante, en estos primeros años de arranque del proyecto sí que se manifiesta claramente la voluntad de Bocabella y su asociación de financiarlo mediante donativos particulares e ingresos debidos a las suscripciones del Propagador.

\section{c) El proyecto de Villar.}

El ofrecimiento gratuito de Francisco del Villar para hacer el proyecto, que mencionan Martinell (1967) y Bassegoda (1989) entre otros, es rápidamente aceptado por los Josefinos, plenamente conscientes de la dificultad de ejecutar un proyecto que debía nutrirse de las aportaciones voluntarias de los fieles. Es interesante detenerse en el detalle y transparencia documental con que Bocabella aborda su relación contractual con

\footnotetext{
283 Torii, T. (1983). El mundo enigmático de Gaudí. Madrid. Instituto de España. Tomo II. Láminas. P.123: Fachada publicada en El Propagador (IX-1875) e Interior publicado en el Propagador (XI 1875).
} 


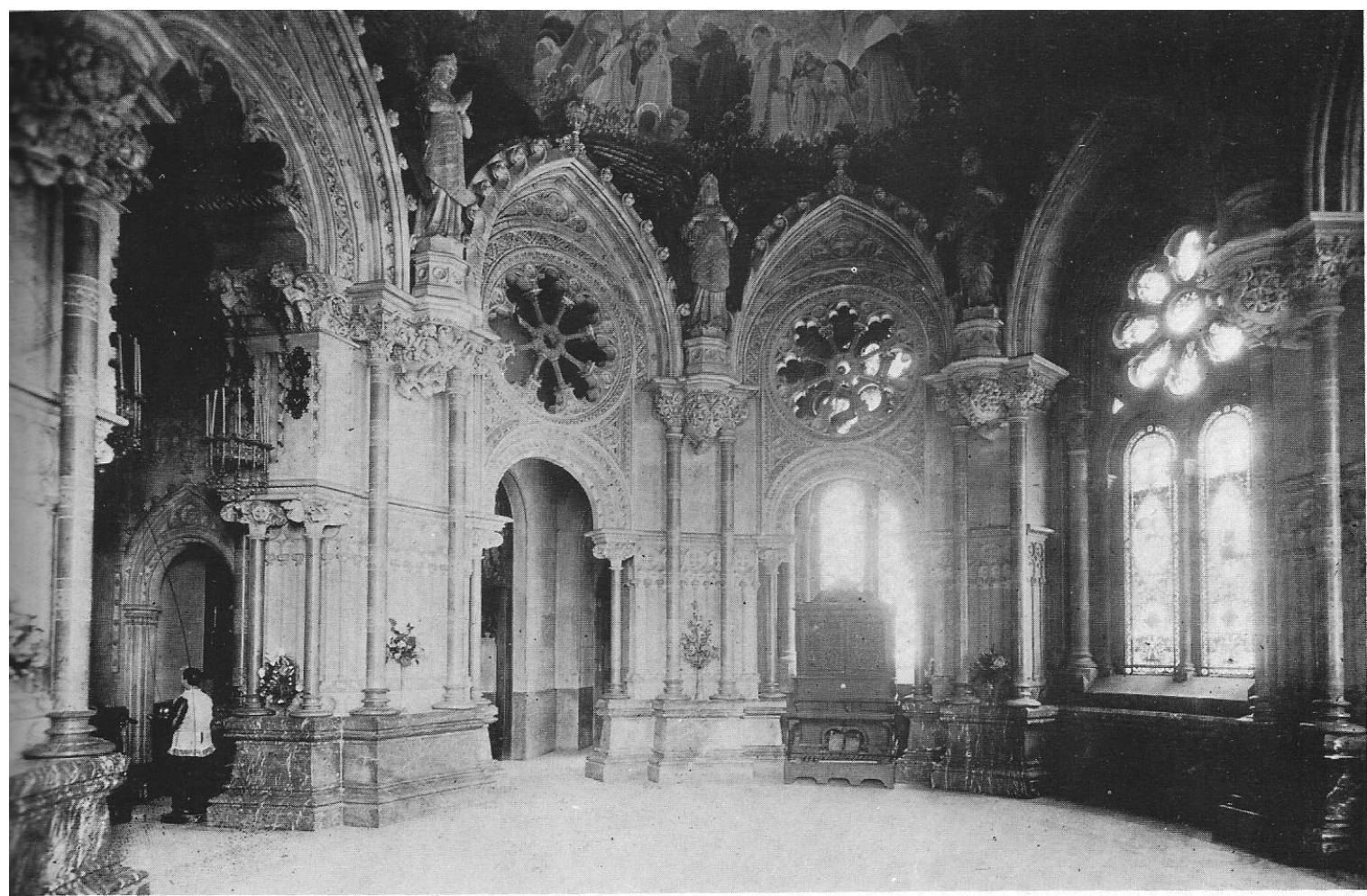

Camarín de Montserrat realizado por el arquitecto Francisco del Villar, 1884-1887. Fuente: Torii, T. (1983). El mundo enigmático de Gaudí. Madrid. Instituto de España.
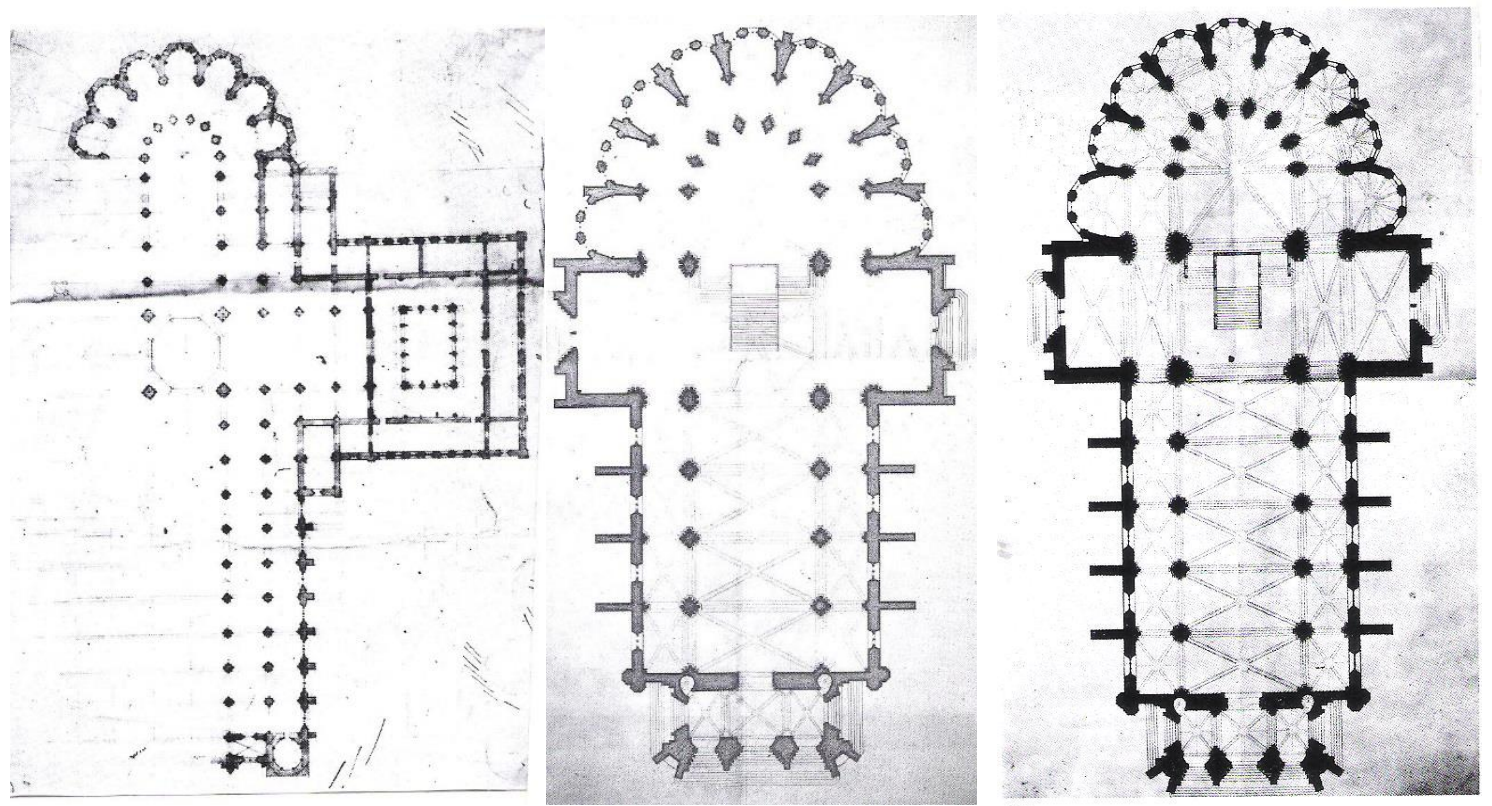

Izquierda: Planta del primer Proyecto de Villar según T.Torii (1983) El mundo enigmático de Gaudí.Podria corresponderse con las dimensiones que se mencionan en el Propagador: $97 \mathrm{~m}$ de fondo y $44 \mathrm{~m}$ de fachada.Centro y derecha: Plantas de lo que podrían ser la segunda y tercera versión del proyecto de Villar, correspondientes al periodo 1882-1883 según Torii (1983) en El mundo Enigmático de Gaudí. Se aprecia el proceso de fijacion de las tres naves de cuatro a cinco tramos y una cripta, bajo el presbiterio, de acceso centralizado similar a la de la catedral de Barcelona. En esta solución no se aprecia claustro. 
Villar, aún siendo éste un profesional de reconocido prestigio como arquitecto diocesano y profesor de la Escuela de Arquitectura ${ }^{284}$, llevando ante notario el contrato profesional con el arquitecto.

El contrato describe con precisión el cometido profesional de Villar, sus atribuciones como proyectista y director de las obras así como las condiciones económicas en el ejercicio de su labor profesional sin olvidar la gratuidad del proyecto, pero esto no impide que Bocabella busque y establezca un asesoramiento técnico para la Asociación, una consultoría en términos actuales, en la persona de Joan Martorell, también arquitecto diocesano y profesional de reconocido prestigio en materia de arquitectura eclesiástica. Martorell es el verdadero hombre de confianza de Bocabella, reúne en sí mismo el prestigio de un ejercicio profesional ligado a las vanguardias de la arquitectura protomodernista del momento, dispone de amplia experiencia en el campo de la arquitectura eclesiástica y es hombre de profundas convicciones religiosas, aconsejando soluciones constructivas más económicas para llevar a cabo la obra y proponiendo la contratación del nuevo arquitecto director, una vez que Villar cesa en sus trabajos, en una línea profesional mucho más cercana a sus planteamientos. Estas cuestiones hacen pensar en un encargo a Villar en función de su actividad diocesana y por motivos de economía de medios en el inicio de las obras pues no en balde había renunciado a percibir ninguna cantidad por el proyecto.

La ceremonia oficial de colocación de la primera piedra tiene lugar el 19-03-1882 en la zona central del solar ${ }^{285} \mathrm{y}$ el comienzo de las obras el 25-08-1883._Bassegoda (El gran Gaudí, 1989) habla de un mínimo de tres proyectos de Villar, que probablemente pudieron llegar a ser cinco si consideramos las variantes de plantas y alzados que presenta Torii (El mundo enigmático de Gaudí, 1983). Este autor menciona varios proyectos de Villar para la Sagrada Familia, que van desde un planteamiento inicial muy medievalista que sitúa alrededor de 1881 hasta las últimas versiones (1882-1883) mucho más estilizadas.

\footnotetext{
${ }^{284}$ Cf.Martinell, C. (1967). Antonio Gaudí. Su vida, su pensamiento, su obra. Barcelona. COACB; también Bassegoda Nonell, J. (1989) El gran Gaudí. Barcelona. AUSA. Ambos aportan el Pliego de Condiciones para los trabajos del contratista Macario Planella. Bassegoda incide en las clausulas que establecían las condiciones de ejecución en el caso de que pilares, arcos y bóvedas fueran íntegramente de sillería, no solamente revestidos, y en el articulado que posibilitaba tanto al arquitecto como a la Junta Constructiva a realizar cambios en el proyecto. Al suscitarse la discusión sobre integridad o revestimiento, el asesor técnico, Joan Martorell, advierte a la Junta de la viabilidad de dichos elementos revestidos y del encarecimiento económico que supondría su realización integra en sillería de piedra. Sin embargo en el Pliego añadido el 28 de marzo de 1884, se dice que el constructor, Macario Planella se ajustará a los planos y detalles del nuevo arquitecto director, Antonio Gaudí.

285 Cf. Pujol, Nuria. (2010). "Ceremonia inaugural de la primera piedra de la Sagrada Familia”, en Revista Diplomacia i Protocol, no7, diciembre de 2010.
} 

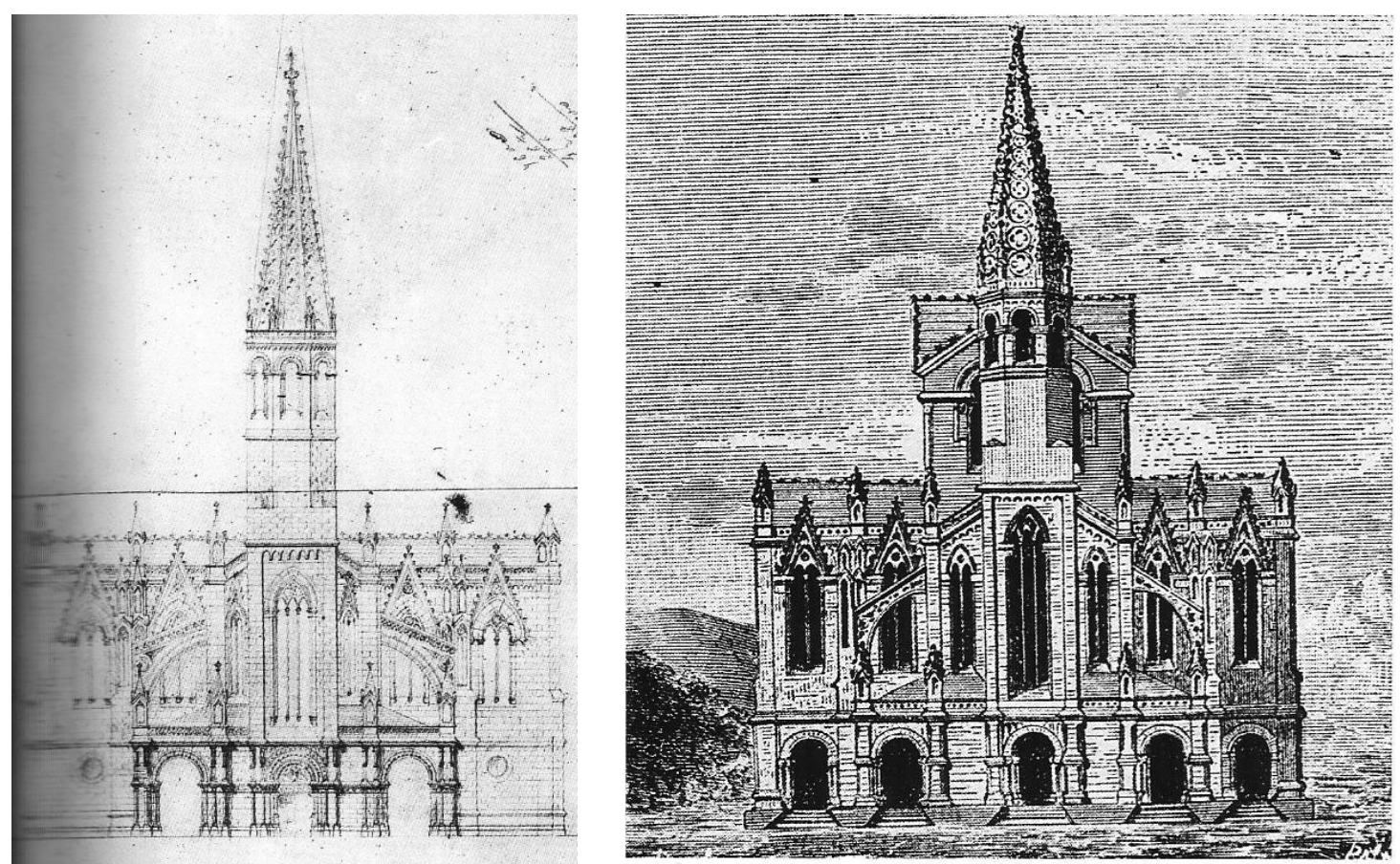

Dos versiones de la fachada principal del proyecto de Villar, en el periodo 1882-83. En el dibujo de la izquierda se aprecia una primera solución de campanario con cubierta plana al que se le ha añadido un chapitel que Torii presenta como base de la segunda solución. Fuente: Torii, T. (1983) El mundo enigmático de Gaudí. Madrid. Instituto de España.

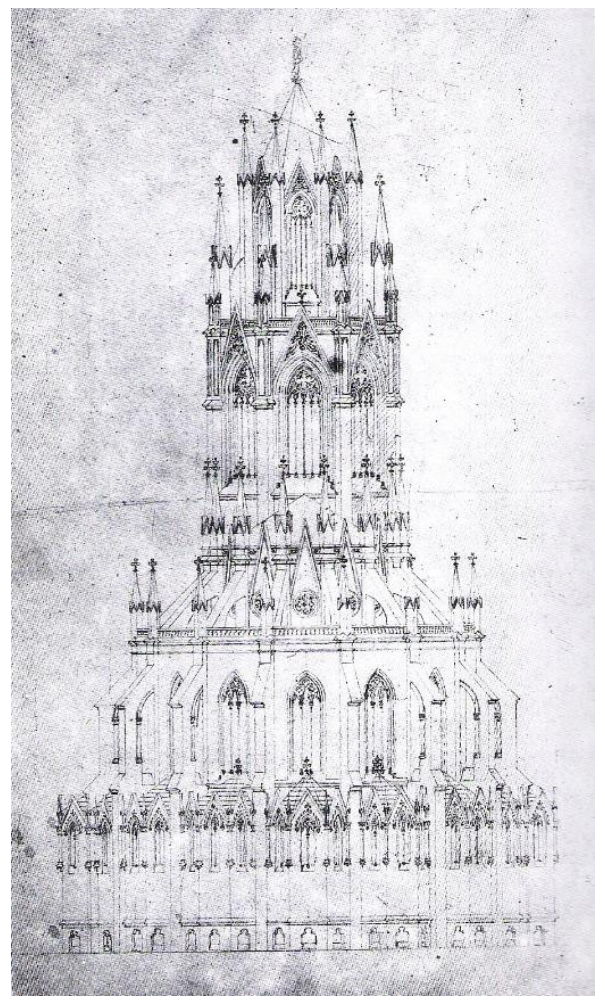

Fachada Posterior del Proyecto de Villar en 1883. Fuente: Torii, T. (1983) El mundo enigmático de Gaudí. Madrid. Instituto de España. 
Desde el punto de vista estilístico se aprecia en las últimas versiones un tratamiento mucho más cuidado y ecléctico de las fachadas con algunas posibles influencias de la arquitectura de su colega Joan Martorell que ese mismo año, 1882, estaba realizando la iglesia de las Salesas y el dibujo para el concurso de la nueva fachada de la catedral de Barcelona. Es de notar cómo el proyecto de Villar incorpora una notable estilización y verticalidad del edificio. Además de incrementarse el protagonismo del cimborio, inicialmente de planta cuadrada y muy austero, que pasa a adquirir un fuerte protagonismo con una planta octogonal y factura claramente goticista (sin duda en consonancia con el homónimo del dibujo de Martorell para la catedral barcelonesa al que la prensa, gran número de intelectuales y asociaciones cívicas de la ciudad se mostraban favorables), la torre campanario parece tomar nota de los ejemplos que ofrecen la iglesia de las Adoratrices y todavía más de las Salesas que está en construcción por aquellos años.

Coetáneo con estos proyectos hay que situar el plan de Bocabella para el edificio, que quiere incorporar jardines a su alrededor, acompañados de escuelas y talleres católicos, con un afán educativo y moralizador respecto de los niños callejeros. ${ }^{286}$ Por eso resulta muy significativo el hecho de que Villar intentaría ofrecer a los Josefinos un proyecto algo mayor en dimensiones que lo proyectado en $1881 \mathrm{y}$, sobre todo, más acorde con la libertad compositiva que aportaban otros arquitectos, entre ellos los que trabajaban en el entorno de Martorell, sinceramente interesados por un lenguaje modernista que tenía referencias europeas y comenzaba a calar en el ánimo de la burguesía barcelonesa. Quizá Villar comenzaba a percibir lo ambicioso del plan que se proponían ejecutar los josefinos. En cualquier caso el ritmo de la construcción era lento como demuestra el hecho de que el Pliego de Condiciones de las obras que lleve fecha de 25 de agosto de $1883^{287}$.

Aunque la extensión de la excavación para la Cripta fuese notable, los trabajos progresarían con lentitud debido a la escasa financiación disponible. Prueba de ello es que cuando se suscita la polémica que dará origen a la renuncia de Villar los pilares se encontraban ejecutados a tan sólo a un metro de altura, siendo la causa de la discusión la necesidad de optimizar al máximo el coste de las obras validando técnicamente la solución de rellenar aquellos con mampostería en lugar de hacerlos macizos de cantería.

\footnotetext{
286 Torii, T. (1983). El mundo enigmático de Gaudí. Tomo 1. Madrid. Instituto de España. P. 125. “El templo estará rodeado de jardines de esparcimiento y solaz de los niños y acompañado de escuelas y talleres católicos, con el objeto de moralizar a esos enjambres de muchachos callejeros, que divagan perdidos, facilitándoles con ello su desarrollo físico y moral." Texto que cita de El Propagador, Año 16, no5, abril de 1882, p. 146.

${ }^{287}$ Martinell, C. (1967) Gaudí: su vida, su teoría, su obra. Barcelona. COACB.
} 


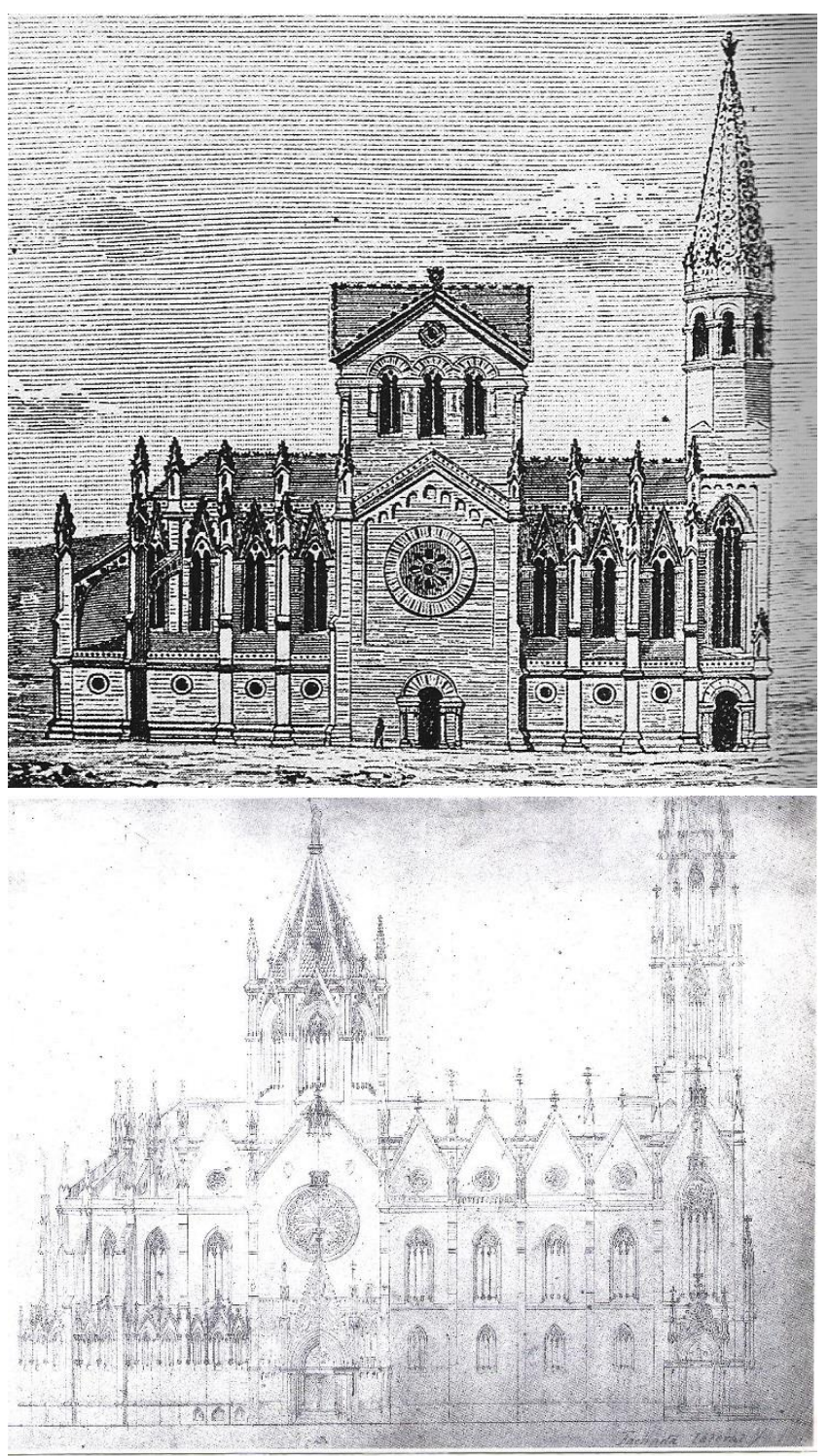

Fachada lateral y posterior de las diversas versiones del proyecto de Villar. En el dibujo de la izquierda, que Torii menciona publicado en el Propagador con ocasión de la colocación de la primera piedra el crucero presenta un cimborrio de planta sensiblemente cuadrada. En los otros dos dibujos Torii dice que la altura del cimborrio del crucero pasa de 80 a $86 \mathrm{~m}$ exigiendo una mayor altura en los miembros que componen los muros del ábside. Obsérvese también la progresiva verticalización del proyecto, que también se puede constatar con la evolución de la torre campanario. Fuente: Torii, T. (1983) en El mundo Enigmático de Gaudí. Madrid. Instituto de España. 


\section{d) Antonio Gaudí y el proyecto de la Sagrada Familia.}

\section{d.1- Primeras actuaciones.}

Se puede afirmar que Gaudí, que aparece documentalmente por vez primera como director de las obras el 28-03-1884 288 , aunque ya había sido propuesto para ello en 3-11$1883^{289}$, no oculta su satisfacción por este importante encargo cuando todavía no era un arquitecto conocido ni acumulaba la experiencia que posteriormente conseguiría con otros de proyectos en los que trabajará en los próximos años. ${ }^{290}$ Cronológicamente su actuación comienza en la Cripta, ocupándose ya desde ese primer momento de mejorar su iluminación natural y ventilación al incrementar la altura libre interior, pero también abarca a todo lo que hace referencia a los altares, imágenes, mobiliario litúrgico y detalles decorativos. Por eso no ha de extrañar que la planta de conjunto del proyecto de 1885 , realizado en tan corto espacio de tiempo y para la obtención del permiso municipal de obras, siga una línea similar a las últimas versiones de Villar aunque con algunas diferencias bien significativas.

La primera de ellas hace referencia al acceso a la Cripta desde la nave, que ya no es central bajo el crucero como en el proyecto de Villar, en una solución probablemente tomada de la ejecutada poco antes en la catedral de Barcelona sino que presenta una solución doblemente lateralizada utilizando el espacio de las primeras capillas absidales y ajena totalmente al espacio de la nave celebrativa, de la cual se independiza. Además se ejecuta un foso alrededor del ábside que da más luz al recinto de la Cripta y evita la humedad propia de un espacio enterrado al facilitar grandemente su ventilación natural. Por otro lado, la iglesia sigue disponiendo de tres accesos o portadas según el esquema tradicional de una planta de cruz latina pero la complejidad de su diseño ha aumentado considerablemente al configurarse el espacio de acceso a la iglesia en cada una de ellas

288 Cf. Flores, C. (La lección de Gaudí. 2002. Madrid. Espasa Calpe, P. 71-72) y Bassegoda, J. (El gran Gaudí.1989. Sabadell. AVSA, P.210) hacen mención al primer escrito en el que consta oficialmente Gaudí como director de las obras. Se trata de un documento firmado el 28-03-1884, que será un Añadido al Pliego de Condiciones de Bocabella de 25-08-1883, en el que se hace mención expresa a Gaudí como director de las obras. Otro documento es el dibujo de la capilla de S. José en la Cripta que el arquitecto firma en diciembre de 1884 y se publica en el Propagador el 1-03-1885 (Torii, T., El mundo enigmático de Gaudí. Madrid. 1983. Instituto de España. P. 83).

${ }^{289}$ Martinell (Gaudí: su vida, su teoría, su obra. 1967. Barcelona. COACB. Apendice) publica un contrato por fases para la ejecución de las obras de la Sagrada Familia con el constructor Macario Planella; Torii (EI mundo enigmático de Gaudí. 1983. Madrid. Instituto de España. Pag. 83) hace mención que a la dimisión de Villar el 3-11-1883 como arquitecto director de la Sagrada Familia, y Bassegoda (El gran Gaudí, 1989. Sabadell. AVSA. Pag. 210) también se hace eco del nombramiento de Gaudí como director de las obras a partir de esa fecha aludiendo a lo publicado en el Propagador, numero de 1 de septiembre de 1915.

290 En 1885 Gaudí recibió el encargo de la Casa Vicens en la C/ Carolinas, y en ese mismo año, de D. Eusebio Güell, el de realizar su casa palacio en la C/ Conde del Asalto. Posteriormente, recibiría los encargos del Palacio episcopal de Astorga (1887) y del Colegio de Santa Teresa de Jesus de la C/ Ganduxer (1889). 

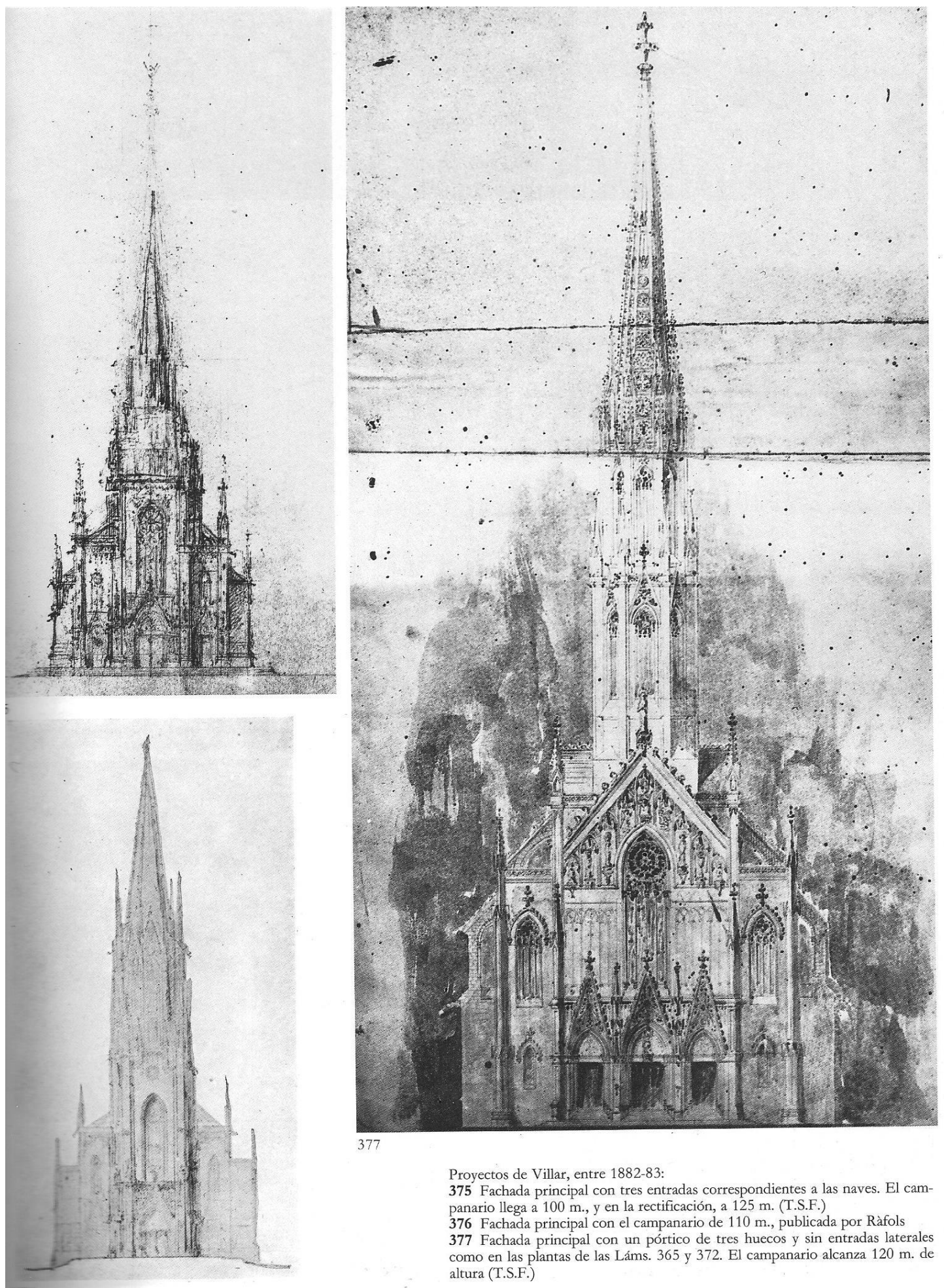

Proyectos de Villar, entre 1882-83:

375 Fachada principal con tres entradas correspondientes a las naves. El campanario llega a $100 \mathrm{~m}$., y en la rectificación, a $125 \mathrm{~m}$. (T.S.F.)

376 Fachada principal con el campanario de $110 \mathrm{~m}$., publicada por Ràfols 377 Fachada principal con un pórtico de tres huecos y sin entradas laterale como en las plantas de las Láms. 365 y 372. El campanario alcanza 120 m. de altura (T.S.F.)

Evolución de la altura y composición de la torre campanario y fachada principal del proyecto de Villar según recoge T. Torii en El mundo enigmático de Gaudí. La altura pasa de 100 a $110 \mathrm{~m}$ primero y luego a 120 en el dibujo de la derecha. La fachada principal recoge la solución del nártex como base del campanario centralizado, con y sin entradas para las naves laterales, en los dos primeros dibujos, pasando a una solución mucho más compleja en el dibujo de la derecha, con una portada con tres entradas más amplia que el ámbito ocupado por la torre campanario, profusamente ornamentada y flanqueda por sendos pináculos o edículos que conforman los distintos planos de la fachada. 
O como un auténtico nártex de la nave celebrativa a través de una sucesión de espacios claramente delimitados desde el exterior al interior.

Otro aspecto que se revela fundamental es la incorporación del claustro al proyecto en estas fechas tan iniciales y, sobre todo, la disposición perimetral de éste, que no hace sino alejar las trazas de la iglesia cada vez más de la composición de su antecesor. En este dibujo puede percibirse claramente la intención de vincular estos accesos entre sí mediante el claustro que circunda todo el perímetro de la iglesia. Se distingue así un exonártex completamente integrado en el discurrir del claustro por el que se accede a la portada propiamente dicha de la Iglesia, que a su vez introduce, en las naves del espacio celebrativo. Una disposición de doble nártex se encuentra en iglesias bizantinas como San Salvador de Chora y Santa Sofia de Constantinopla. Con independencia de la originalísima disposición del claustro gaudiniano lo cierto es que parece haber una similar intencionalidad en recrearse y ponderar el tránsito del externo al interno de la iglesia. También en San Marcos de Venecia se aprecia un cierto carácter envolvente del nártex respecto de las naves interiores.

Gaudí también otorga una gran amplitud al espacio inmediato de aproximación a cada portada de la iglesia, especialmente a la principal. No sólo consigue magnificar su visualización y mejorar su accesibilidad dentro de los límites que imponen las dimensiones de la manzana de edificación del ensanche y la pendiente de las calles Cerdeña y de la Marina sino que incide en su dimensión como hito urbano queriendo significar lo que en sus respectivas urbes representan Le Sacré Coeur de Montmartre, Koekelberg, Viena, etc. Como prueba de la importancia que otorga el nuevo arquitecto director a este tema hay que señalar que para conseguir esta ampliación de los espacios de acceso no duda en disponer un tramo menos que su antecesor en las naves del edificio, pasando de 5 a 4 .

Martinell (1967) da un completo repaso a estas primeras actuaciones, centradas en la ejecución de la cripta, que con las modificaciones introducidas en altura, iluminación y ventilación, la independización de su acceso y el detallado estudio de la ornamentación escultórica y los altares, de los muebles y elementos litúrgicos, harían de ésta un espacio mucho más habitable que cualquier otra cripta hasta entonces conocida. Al hacerse cargo del proyecto de la Sagrada Familia Gaudí manifiesta ya un gran interés teológico y litúrgico por el encargo profesional recibido intentando una reorientación del edificio en dirección a Oriente. Esto también hubiese supuesto una mayor libertad compositiva al ofrecer una mayor longitud el eje diagonal de la manzana y poder diseñar la planta de la iglesia sin los condicionantes de una obra ya iniciada, pero también una dificultad práctica sin duda importante para la débil economía de los Josefinos pues hubiese supuesto deshacer lo ya construido en la cimentación y pilares de la Cripta para comenzar de nuevo. 

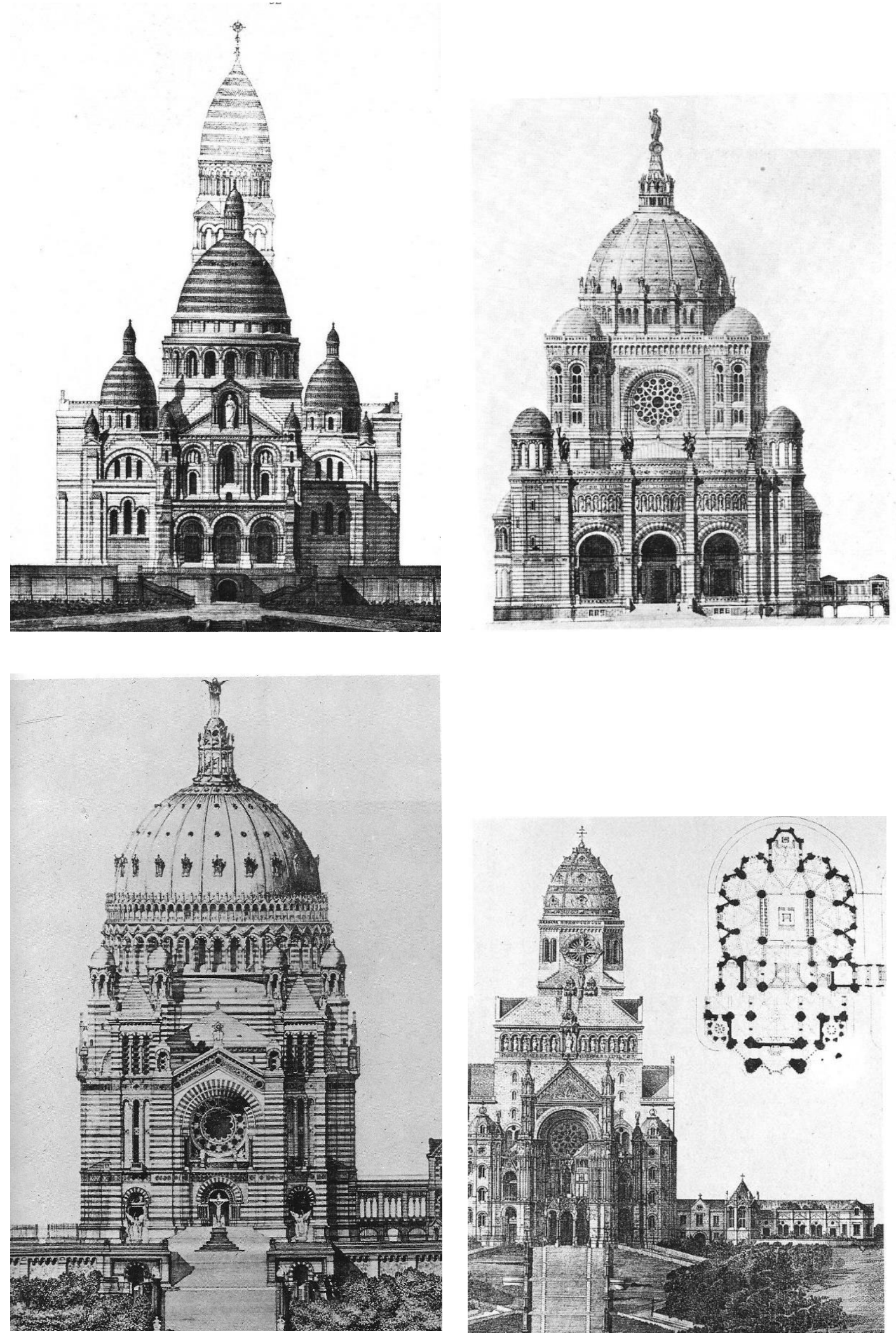

Fachada principal del Sacrée Coeur de Montmartre según los proyectos de Paul Abadie, Davioud y Lamaire, Bernard y Tournade, y Moyaux (de izda. a dccha. y de arriba a abajo). Fuente: : Torii, T. (1983) en El mundo Enigmático de Gaudí. Madrid. Instituto de España. 
Superados estos escollos iniciales en la relación contractual con la Asociación, gracias a los buenos oficios de Martorell que templa los ánimos del joven arquitecto, y que son debidos a la rigurosidad conceptual con que quiere desarrollar sus trabajos, entramos en un periodo de gran sintonía con las ideas de Bocabella que se centran en disponer cuanto antes para el uso la Cripta.

Disponer de ésta para el culto cuanto antes, tres años después de realizada la ceremonia de colocación de la primera piedra, es de la mayor importancia para un proyecto tan ambicioso que ha de nutrirse de las aportaciones voluntarias de los fieles y en este sentido el nuevo arquitecto había dado muestras de ocuparse de todos los detalles. Altar, imágenes, mobiliario, vidrieras, lámparas, etc. requieren fuertemente su atención al mismo tiempo que la concepción global del edificio, que también ha de regularizar su situación administrativa al solicitar en el mismo año el preceptivo permiso municipal de obras.

\section{d.2 El Programa de Gaudí.}

César Martinell, haciéndose eco del testimonio de Joan Rubió, refiere que Bocabella había regalado a Gaudí un ejemplar de "El Año Cristiano" que éste leía asiduamente y en el cual dice que se inspiró para el simbolismo del templo; e igualmente considera la convivencia con Grau y Campins como fundamental para llegar a comprender el interés de Gaudí por la liturgia y la arquitectura religiosa, testimonio valioso por la cercanía a Gaudí de quien lo refiere. El largo periodo de ejecución de las obras debió hacer el resto ${ }^{291}$ pues, la particular condición de los promotores de Santa Coloma y de Mallorca, Güell y Campins, rayando en el mecenazgo, da la oportunidad de poner en práctica ideas concebidas para la Sagrada Familia que adoptan en estas otras obras un método de trabajo sumamente experimental y artesanal que en otras condiciones difícilmente hubiera sido posible llevar a cabo.

Martinell también se muestra partidario de considerar que Gaudí bien pronto tuvo claro el programa del edificio y que gracias a su gran imaginación y al conocimiento que tenia de la religión y de su culto pudo ir detallándolo con gran espontaneidad. En contraposición, lo dilatado del periodo de construcción facilitaría la constante evolución del proyecto constructivo, que es rehecho continuamente como demuestran la planimetría, los estudios y maquetas, propiciando una elaborada y armónica integración

291 Cf. Martinell, C. (1952) La Sagrada Familia. Edición en castellano de Gaudi i la Sagrada Familia comentada per ell mateix. (1951). Barcelona. Aymá. P.18.: “Gaudí concibió el templo, pero el templo formó a Gaudi". 


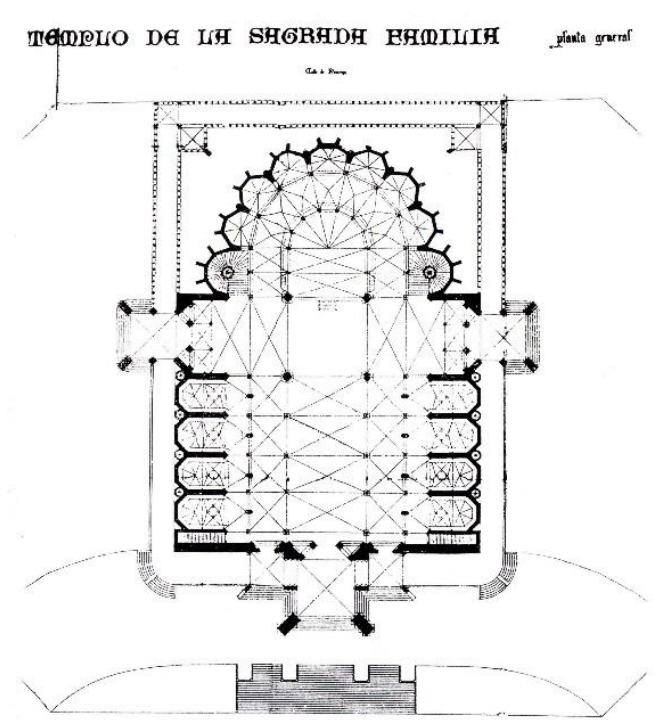

A

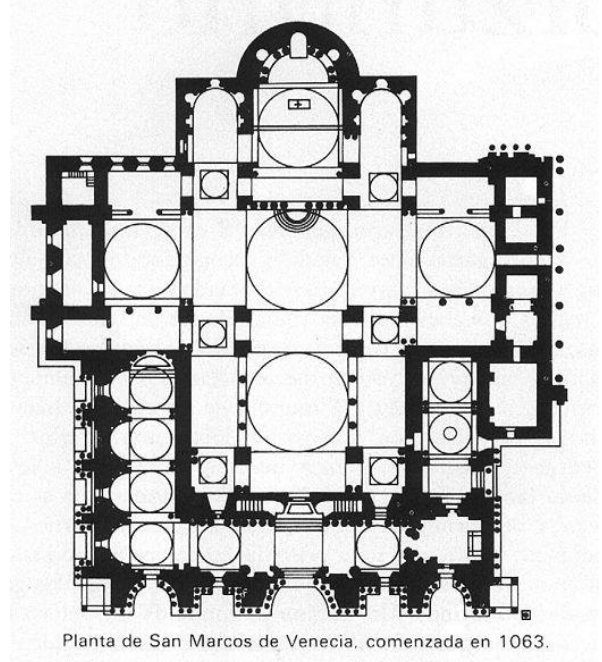

B

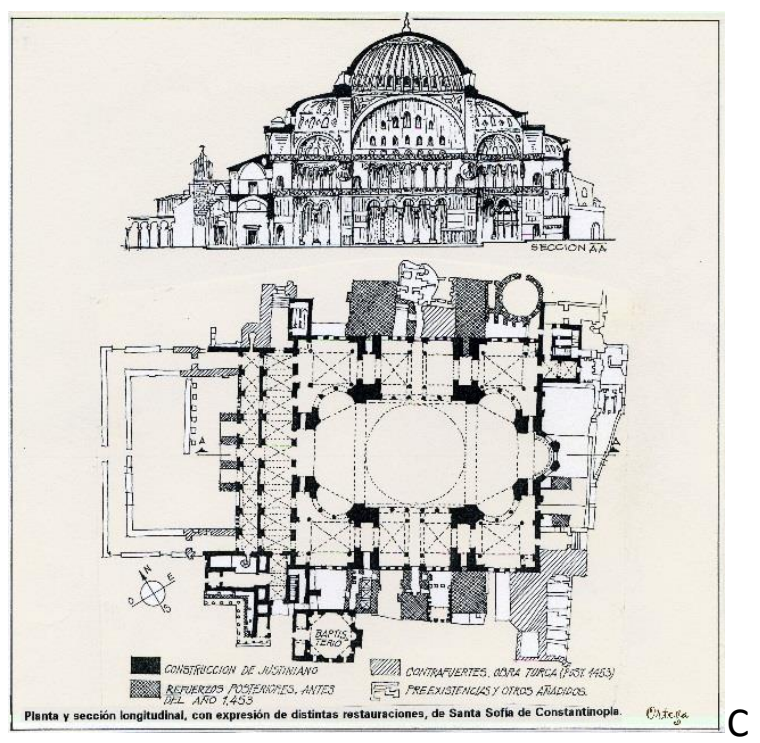

A: Planta del proyecto de Gaudí presentado en 1885 al Ayuntamiento de Sant Martí de Provençals para la obtención del Permiso de Obras: el claustro circunscribe la nave litugica. Fuente: Archivo de la Sagrada Familia.

B: Planta de San Marcos de Venecia. El claustro abraza la nave. C: Planta y Sección de Santa Sofia de Constantinopla. El claustro antecede a la nave. Fuente: editorial .dca. ulpgc.es 
de los diferentes aspectos que concurren en la arquitectura cultual lo que redunda en una de las características más significativas del proyecto. ${ }^{292}$

Puede tomarse el discurso a los Josefinos en 1891 como la expresión más adecuada de la idea programática de Gaudí para su proyecto. Llorenç Matamala, colaborador tan cercano en la Sagrada Familia, recoge esta alocución con su estilo abrupto y descarnado de escultor, y la trasfiere a su hijo, siendo valorada por Bassegoda con la importancia que merece este gesto ${ }^{293}$. El hecho es que habiéndose terminado la excavación de la Cripta en 1882 y utilizándose para los oficios religiosos desde 1885, el retraso en su cubrición (que se hubiera querido tener dispuesta dos años después y que por la falta de financiación económica no se tuvo hasta 1890) ${ }^{294}$, convirtió este hito de la construcción en un evento de primera magnitud para la Asociación de los devotos de San José, que sin duda, debió ser utilizado por Bocabella para animar a sus correligionarios y relanzar el proyecto un año antes de su fallecimiento._Cobran singular importancia estas palabras porque en ellas expone Gaudí su visión global del proyecto, porque nos hacen ver la sintonía de su relación con Bocabella y la completa visión simbólico-religiosa que tenía ya en los primeros siete años de su trabajo como director oficial de las obras. Afirma Bassegoda que esta alocución se produce en una mañana de domingo (previamente a la festividad de San José o ese mismo dia) y después del oficio celebrado en la cripta, y que tiene lugar en el espacio situado encima de la recién cerrada cripta, esto es en el espacio a ocupar por el futuro altar mayor de la iglesia.

292 Cf. Martinell, C. (1952) La Sagrada Familia. Edición en castellano de Gaudi i la Sagrada Familia comentada per ell mateix. (1951). Barcelona. Aymá. P.15:"El gran poema que era el simbolismo religioso del templo lo tenía concebido en conjunto; variaba a veces cuestiones de detalle, afinaba aspectos que quedaron esbozados hasta mejor preveer, pero la visión general subsistia con su polifónica grandiosidad impresionante y los detalles artísticos aparecían con una naturalidad de floración espontánea, como notas de una armonía prefijada. En cambio, el problema constructivo, si bien estaba previsto en su conjunto, al emprender cada detalle, planteaba continuamente nuevos pequeños problemas, que otras manos conformistas no lo hubieran sido porque se hubieran forjado en la cómoda fragua de la rutina, pero en Gaudí, avido de creciente perfección, eran sometidos una y cien veces al estudio y al ensayo que los librara de toda escoria defectuosa."

293 Cf-Matamala, J. (1999). "Antonio Gaudí, mi itinerario con el arquitecto". Barcelona. Claret; Bassegoda Nonell; J. (2001) Gaudí: la arquitectura del espíritu. Barcelona. Salvat Editores. Como Anexo al final de la Tesis se reproduce íntegra la versión que trascribe Bassegoda en su libro, que según Josep Gómez Serrano es una versión arreglada del manuscrito original de Matamala que obraba en la cátedra Gaudí.

${ }^{294}$ Precisamente la imposibilidad de alcanzar con las limosnas la cantidad condicional de 30.000 ptas. es el hecho que señala Torii para que no pudiera terminarse la cubrición en 1887 como querían Bocabella y los josefinos (Torii, T. El mundo enigmático de Gaudí. 1983. Madrid. Instituto de España), el cual aporta datos del déficit que acumulaba la construcción de la Cripta durante esos años señalándolo como la causa de que se interrumpieran casi por completo las obras del Templo en 1888, pero también cómo crecieron las limosnas en ese mismo años y el siguiente, 1889, permitiendo entonces que se reanudaran las obras sin déficit y poder comenzar el ábside en 1890. 


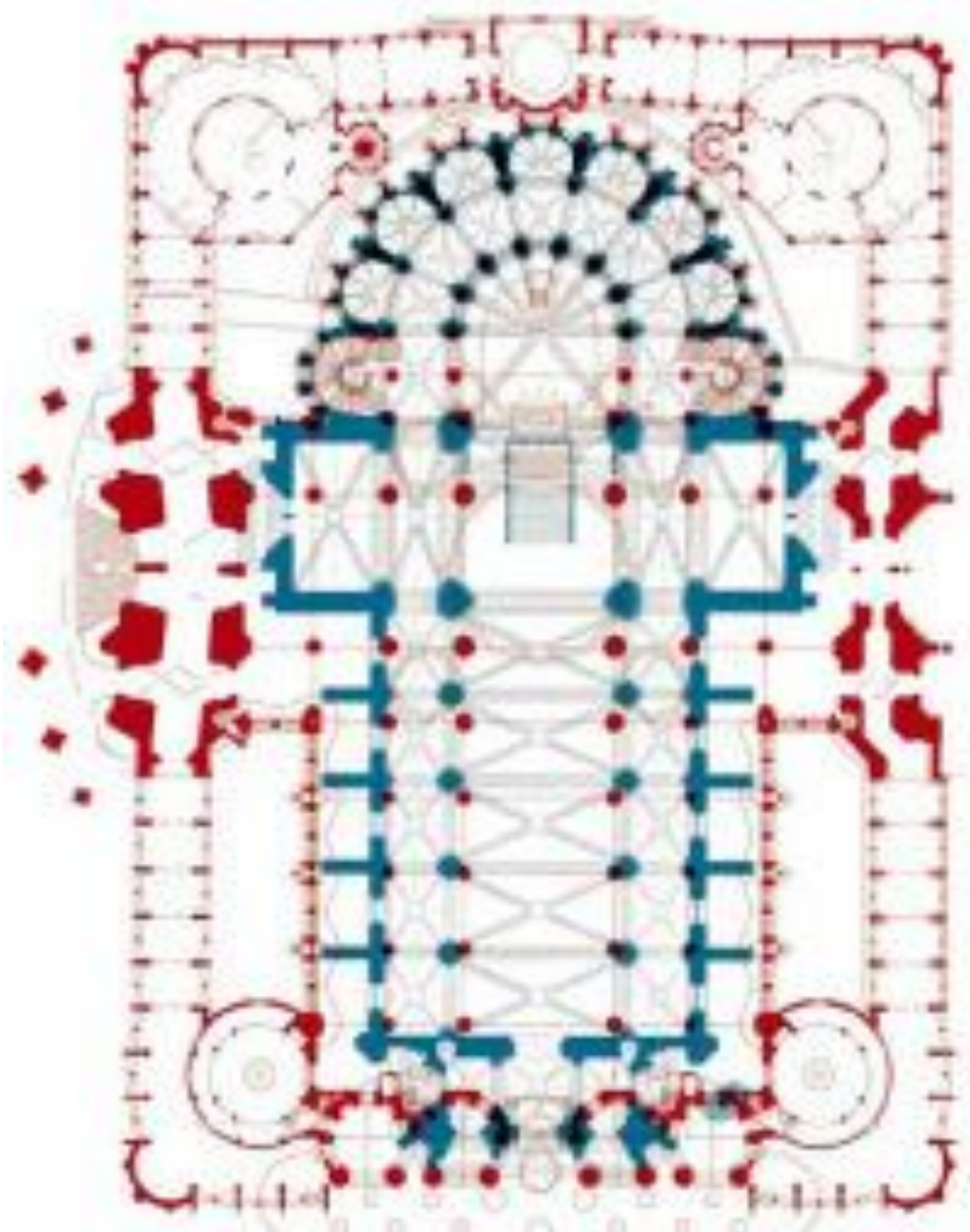

\section{2 projecte de Francesc de Paula del Villar 1883-1926 projecte d'Antoni Gaudi}

Superposición planta de Villar con planta actual del proyecto de Gaudí. Fuente: Mã Dolores Guerrero Perales 
Las palabras del arquitecto constituyen una declaración de intenciones de lo que para él ha de ser el proyecto. Terminada la cripta, comienza rememorando éste espacio como casa de Dios y casa de oración con el mismo espíritu cristiano que se tenía en los primeros tiempos del Cristianismo y en las catacumbas de Roma, y haciéndose eco del deseo de los josefinos de venerar una reproducción de la casa de Loreto, para pasar inmediatamente al fondo de la cuestión:

"Sobre la cripta estará el altar mayor. La planta será de disposición basilical, con cruz latina y cinco naves, que en el transepto serán tres. Tendrá tres fachadas, la principal sobre la calle Mallorca, accesible por cinco puertas correlativas a las naves, y las laterales con tres puertas para las tres naves. Cerrará el perímetro, por el lado norte, el ábside, cuyos muros serán continuación de los de la cripta. El templo será accesible en cada fachada por amplias escalinatas, pues estas, a modo de basamento, imprimen carácter a los edificios, así como grandeza y monumentalidad. Armonizaremos la traza gótica que condicionaba el plan de mi antecesor, arquitecto Del Villar, con soluciones originadas en el estilo bizantino que se ajustan a la liturgia católica actual."295

Fijémonos cómo en 1891 y de sus propias palabras ya se tiene la certeza de que se va a construir una iglesia de planta de cruz latina con cinco naves y tres en el transepto, en la que se quiere resaltar el $\mathrm{n}$ - de puertas para cada portada o fachada, y se deja bien claro que sin dejar de armonizar el proyecto con las trazas góticas heredadas de Villar se está pensando en soluciones inspiradas en la tradición bizantina que considera más ajustadas a lo que demanda la liturgia católica actual. Considera pues las necesidades de la liturgia "actual" como el programa que ha de inspirar las actuaciones tendentes a convertir el edificio en un "verdadero símbolo, una obra de arte" de la época en que vive, de tal manera que trasluce el empeño y esfuerzo que invertirá en él hasta el punto de manifestar su intención de compararlo con las catedrales medievales.

"Quisiéramos que el conjunto del templo fuera un verdadero símbolo, una obra de arte, a tono con la época que vivimos. El desarrollo del estudio sobre el primitivo plan nos permitirá una riqueza de elementos asimilable a lo que lograron los constructores medievales con las catedrales."

Juzga primordial dotar al proyecto de una dimensión teológico simbólica que se despliega en un lenguaje de formas e imágenes, utilizando no sólo el figurativismo sino todos los recursos arquitectónicos a su alcance para dotar al espacio de la dimensión sobrenatural que desea reflejar.

${ }^{295}$ Cf. Bassegoda Nonell, J. (2001). Gaudí: la arquitectura del espíritu. Barcelona. Salvat Editores. Pags. 192205. 
"Ostentará en el exterior las imágenes apologéticas y catequizantes para introducir a los fieles en la contemplación del mundo sobrenatural que se proyectará en el interior."

Gaudí se muestra capaz de prometer hasta 12 campanarios, cuatro por fachada, cuestión que llama la atención por lo preciso y concreto del esquema que tiene ya en su mente.

"Si en el proyecto de nuestro antecesor era un solo campanario el que se destacaba de la masa del templo, además del cimborio, en nuestro proyecto emergerán de cada fachada cuatro campanarios, que con el conjunto de las tres fachadas representarán a los doce Apóstoles. Encima de los cruceros emergerán cuatro torres, representativas de los evangelistas, alrededor del cimborrio principal. En el ábside se levantará otra, dedicada a la Virgen, de altura intermedia. El cimborrio principal, dedicado a Jesucristo, culminará con la cruz de cuatro brazos. "

Da la visión completa de las trazas del proyecto que se corresponden con el plano dibujado en 1885 lo que da idea de la firmeza de su idea primigenia:

"Detrás de las alas del transepto, junto al ábside, habrá dos grandes sacristías que comunican con el presbiterio y con los claustros. Éstos correrán alrededor del templo sin interrupción a lo largo de las fachadas, siguiendo por detrás del ábside, donde se levantará la capilla dedicada a la Asunción de la Virgen. Su extenso circuito permitirá realizar procesiones solemnes en tiempo lluvioso o frio. Tendrán también función aislante del ruido, separando las naves de la calle. El subsuelo de las naves laterales y parte del de los claustros estará destinado a escuelas de artes y oficios; así junto a la iglesia, el pueblo hallará formación y cultura."

Describe completamente las escenas religiosas a desarrollar en la escultura y arquitectura de las distintas fachadas, en las explanadas de acceso, y el túnel por donde ha de discurrir la calle Mallorca, insertándola en un amplio y concienzudo discurso teológico que tiene su orientación en el libro del Apocalipsis, mostrando así el alcance y profundidad de sus conocimientos bíblicos y el protagonismo que quiere dar al simbolismo cristiano en la arquitectura de la basílica. Asombra cómo tiene pensada ya una soprendente iluminación cenital del pórtico de la fachada de la Gloria: “....la bóveda del pórtico será iluminada por catorce lámparas..." y sobre todo, concibe el espacio interior como un espacio litúrgico ordenado por la singular concepción y ubicación del altar.

"En cuanto al interior, pensamos dotarlo de ambiente propicio para la devoción y fiel a las normas litúrgicas. Como hemos dicho, el altar mayor estará situado encima de la bóveda de la cripta, bajo el arco triunfal, entre los dos cimborrios principales, y se subirá al mismo por una amplia escalinata. En el altar se adorará al Divino Crucificado, de cuyo madero saldrá una parra simbolizando las palabras de Cristo: 
"Yo soy la vid, vosotros los sarmientos. Si estáis unidos a mi produciréis frutos; si os separáis os secaréis y seréis lanzados al fuego. " La parra formará un dosel que será lampadario al mismo tiempo. Cincuenta lámparas penderán de él, recordando la frase del Salvador: "Yo soy la luz del mundo", al igual que en el primitivo altar de San Juan de Letrán.

Encima del lampadario, según es de ritual, habrá un gran baldaquino. En la bóveda interna del cimborrio de la Virgen se representará el Padre Eterno, según la visión profética que dice: "La veste del Padre llena la bóveda del cielo". De su manto, extendido por toda la cúpula, saldrán figuras de querubines y debajo estará el lampadario representando al Espíritu Santo, que, situado entre el Padre, en la bóveda, y el Hijo, en el altar, completarán el símbolo trinitario evocado en el Credo. En cambio, otro lampadario, situado en el cimborrio principal, dedicado a Jesucristo, representará la Jerusalén celeste."

Gaudí no se conforma con formas, lenguajes o escenas, sino que lo quiere es conseguir un espacio adecuado a la funcionalidad cultual dotado de unas características formales, constructivas, lumínicas e iconológicas que hagan de él un espacio completamente desmaterializado, un espacio espiritual abierto a los signos, a la experiencia sensorial, a la imaginación y a la trascendencia.

"En mística visión, en las naves laterales las columnas se verán rodeadas de ángeles que descienden de la Gloria portadores de palmas y coronas, y otras con las almas santificadas ascendiendo hasta las bóvedas. Los santos fundadores de órdenes religiosas tendrán sus imágenes en hornacinas a diversas alturas. Los ventanales con vidrieras de colores formarán un todo armónico con la arquitectura. También habrá profusión de leyendas con textos del Evangelio o de las Epístolas que conforman las enseñanzas de la Iglesia."

Aunque no hay ninguna alusión directa a este discurso en los libros de Ràfols, Bergós, Puig Boada o Martinell, pues tratan de describir su arquitectura como sus más entusiastas y cercanos colaboradores y de plasmar por escrito sus conversaciones con la fidelidad del discípulo a su maestro, todos ellos coinciden y parten del enfoque teológico del proyecto como idea primigenia para su desarrollo. Martinell asevera sin reservas la primacía en el tiempo del proyecto simbólico religioso dentro del planteamiento global de Gaudí, como hemos apuntado en el punto anterior. Afirma que éste había prometido a Bocabella la inauguración de la Cripta para marzo de 1887 si se daban las pertinentes condiciones económicas de financiación de las obras de las que hace mención Torii, y que no se dieron ${ }^{296}$.

${ }^{296}$ Cf. Torii, T. (1983) El mundo enigmático de Gaudí. Madrid. Instituto de España. Pps. $34-35$ y Apendice I. 
Por ello resulta del todo razonable pensar que en el inicio del año 1891, una vez saldadas las deudas económicas y terminada la cubrición de la Cripta, habiendo alcanzado el ábside una buena altura, y con ocasión de una festividad tan señalada para los promotores como la del 19 de marzo, fuera el momento más oportuno para una explicación del proyecto. El objetivo de Bocabella es claro, nada mejor que una conferencia del arquitecto para reforzar el ánimo de aquellos que han de contribuir en primera instancia a la promoción de la obra y su difusión, y así estar en mejores condiciones para afrontar el futuro con la confianza puesta en la Providencia, una vez que se había superado la primera grave crisis económica para su financiación. Además probablemente el librero viudo vería próximo el fin de sus días, como así ocurrió al año siguiente, y querria dejar las cosas bien encauzadas para que tomase el relevo su yerno Manuel de Dalmases.

Si se toma como dato de partida este discurso en 1891, después de haberse presentado un proyecto al Ayuntamiento de Sant Martí de Provençals para la concesión de licencia de obras, estaríamos ante un hecho verdaderamente importante como es la primera manifestación pública de la idea concreta que Gaudí tiene para el proyecto, idea que como veremos está firmemente asentada en los conceptos que ya había dejado por escrito unos años antes en el Manuscrito de Reus y que ahora tiene la oportunidad de llevar a la práctica en un encargo que vé desde todos los puntos de vista como providencial. Así pues, Gaudí manifiesta, antes de trabajar en el proyecto de las Misiones Franciscanas en Tanger (1892-1893), su intención de que la disposición en planta de la iglesia fuera de cruz latina, con cinco naves en el eje principal y tres en el transepto, con independencia de las formas concretas que tomara posteriormente la construcción. Introduce también dos novedades importantes en el proyecto: la estructuración de las portadas con cuatro campanarios cada una, lo que da un total de doce, en alusión a los doce apóstoles de Jesucristo; y por otra parte, la idea de realizar dos cimborios, uno en el crucero y otro en el ábside de la iglesia.

El discurso avanza las líneas básicas de la concepción simbólica de la construcción con suficiente detalle, debiendo complacer a los piadosos josefinos a la par que demostraba ante ellos su profundo conocimiento de las Escrituras. Tal cantidad de premisas de índole teológica en la obra arquitectónica llamaría excesivamente la atención si no fuera por las fuertes convicciones del arquitecto que las sustenta -a las que ya nos hemos referido al hablar del Manuscrito de Reus y sus investigaciones con Grau- y por la naturaleza del auditorio. Si comienza esta exposición rememorando el espíritu cristiano de los primeros siglos y haciendo referencia a las catacumbas de Roma es porque ya en el Manuscrito de Reus se plantea el carácter y razón de ser del edificio-iglesia en función de su máxima adecuación al uso al que está destinado. 
En el origen de los espacios de culto cristiano está el lugar convenientemente dispuesto para la reunión o convocación de los fieles que se reúnen para la celebración de la eucaristía primeramente ${ }^{297}$. Asociadas a ellas se desarrollan, con mayor o menor impulso en el trascurso del tiempo, actividades de instrucción, catequéticas, de oración, acogida y acompañamiento. Gaudí considera además que el objetivo primordial de sus trabajos ha de ser la preparación de un lugar digno para celebrar el misterio pascual-Dios terrible que se sacrifica por la criatura- ${ }^{298}$, es un romanista, cuestión que ha aprendido de Gueránguer $^{299}$ y de acuerdo con lo que promueve el Movimiento Litúrgico concentra su atención en la participación de la asamblea cristiana en la función litúrgica con un sentido comunitario vivo en los tiempos apostólicos que ahora se quiere recuperar. Por ello, sin perder de vista la tradición de disponer la cripta bajo el altar no realiza una confessio sino que distingue entre lo que es un lugar de oración, en el que también se pueden celebrar funciones litúrgicas, del aula celebrativa propiamente dicha.

No descarta aportaciones históricas que considera de interés ni rechaza partir de preexistencias, como las que le impone el proyecto de Villar, pero sabe encaminarlas según su concepto de iglesia, fundada en la cátedra del obispo, que es quien preside y dirige la convocación de la comunidad cristiana. Sobre este basamento debe asentarse el edificio como lugar de culto de la comunidad y de ahí surge la importancia de la accesibilidad, las aportaciones de diferentes estilos, la imaginería apologética y catequizante, etc., orientadas a la exaltación de la celebración por antonomasia de la liturgia católica -la celebración de la eucaristía-.

La amplia imaginería y simbología que describen sus palabras para su ejecución en las fachadas y exteriores quiere contribuir a configurar el carácter religioso del edificio de que hablaba en El Cuaderno de Notas, buscando recuperar y explicitar plásticamente los principales temas de la doctrina cristiana. Si en su juventud escribía que -el carácter religioso anda indeciso, los objetos religiosos son esclavos de una idea profana: el arte-300 ahora tiene la oportunidad de desarrollar artísticamente toda una simbología de formas animales, vegetales y materiales, tomadas de las Sagradas Escrituras que desde las

\footnotetext{
${ }^{297}$ Sobre el fundamento de la preparación del espacio litúrgico vease. Mc 14, 15-16 y también Lc 22, 7-13

${ }^{298} \mathrm{Cf}$. El apartado de la Idea de arquitectura religiosa en Gaudía través de sus escritos dentro del punto 4 de esta Tesis, Antonio Gaudí y su concepto de la arquitectura de lo sagrado, donde se comenta el Manuscrito de Reus.

299 Dom Prosper Gueranguer impulsó la utilización de la liturgia de rito romano en Francia en detrimento de otros ritos galicanos en aras de la uniformidad de la renovación litúrgica con el objetivo de la facilitar la participación de los fieles en las celebraciones antes del Concilio Vaticano II. Gaudí, siguiendo las directrices eclesiásticas de los obispos de tradición tarraconense se siente fiel seguidor del rito romano.

${ }^{300}$ Ibid. El apartado de la Idea de arquitectura religiosa en Gaudí a través de sus escritos dentro del punto 4 de esta Tesis,
} 
cresterías de los pináculos del ábside hasta las puntas de los campanarios pasando por toda la envolvente del edificio le permiten mostrar, a quienes se acercan al edificio, signos y símbolos utilizados en la Revelación cristiana o en la pastoral litúrgica de la L Iglesia: "Queremos que el conjunto del templo fuera un verdadero símbolo, una obra de arte, a tono con la época que vivimos". ${ }^{301}$

También es posible seguir en este discurso la concepción unitaria del edificio, que con tanto interés presentaba en el Manuscrito de Reus: frutos, báculos y escudos episcopales, escenas bíblicas, leyendas y textos de las enseñanzas de la Iglesia, formas y colores, imágenes e itinerarios simbólicos, etc. hábilmente dispuestos y entrelazados contribuyen a la conjunción de los programas exterior e interior, orientada a la función litúrgica a realizar en el aula celebrativa. Pero esta característica del proyecto también se apoya en elementos arquitectónicos como los campanarios y cimborios, puesto que no se trata de un elemento único como en el caso del proyecto anterior -que se destacaba de la masa del templo- ${ }^{302}$ sino que precisamente por su número, situación y composición conforman un volumen formalmente complejo pero conceptualmente sencillo. De esta manera el arquitecto permanece fiel a su idea de desarrollar el dialogo entre planta, estructura y espacio interior, concibiendo unitariamente el volumen arquitectónico y éste completamente ornamentado e iluminado según el criterio y necesidades de las celebraciones litúrgicas.

La evolución del proyecto estructural será consecuencia de continuar investigando la forma de cubrir una planta mediante un sistema de módulos basados en una cúpula o bóveda esférica con pechinas apoyada en cuatro puntos, tal y como describía en el Manuscrito de Reus como elemento capaz de un sinfín de aplicaciones -pudiendo emplearlo desde la iglesia más sencilla, con una sola cúpula a la forma más grandiosa por combinación de cúpulas-. ${ }^{303}$

Gaudí sigue describiendo la implantación del edificio sobre un basamento al que se accede en cada fachada por amplias escalinatas, que imprimen carácter a los edificios, así como grandeza y monumentalidad. Afirma, no gratuitamente sino como fruto de un riguroso análisis integrador de la arquitectura eclesial, que la incorporación de soluciones originadas en el estilo bizantino se ajusta a la liturgia católica actual, y plantea el conjunto como un verdadero símbolo, una obra de arte, en la misma línea de la concepción global del edificio religioso de sus escritos de juventud.

\footnotetext{
301 Cf. El discurso a los josefinos reproducido íntegramente en este apartado.

302 Cf. El discurso a los josefinos reproducido íntegramente en este apartado.

${ }^{303}$ Cf. El apartado de la Idea de arquitectura religiosa en Gaudí a través de sus escritos dentro del punto 4 de esta Tesis, Antonio Gaudí y su concepto de la arquitectura de lo sagrado, donde se comenta el Manuscrito de Reus.
} 
Así pues el programa que anuncia en 1891 es suficientemente potente por su envergadura y por los detalles que avanza como para considerarlo el punto de partida de la metódica aplicación práctica en la Sagrada Familia de las ideas esbozadas en sus escritos. A partir de este momento va a tener la oportunidad de dibujar y construir en el Templo Expiatorio lo que había ensayado tímidamente en los arcos parabólicos de la entrada, en las formas apuntadas del cupulín o en la decoración interior del Palacio Güell (1886-89); lo que dibuja y le hubiese gustado construir en los campanarios de la Misiones Franciscanas de Tánger (1892-1893); lo que magnifica a partir de una primera reinterpretación material y simbólica de remates cerámicos cruciformes en el colegio de las teresianas (1889-1894) y en la torre de la Casa Batlló (1904-1906), que bien pudieron servirle de ensayo para el remate final con cerámica veneciana de los campanarios de la fachada del Nacimiento (torre de San Matias, 1926) aludiendo a los símbolos episcopales de los sucesores de los apóstoles; también el espacio y la imaginería que aparecen en los dibujos para el interior del proyecto de la iglesia de Santa Coloma (1898-1914) pueden considerarse como una primera tentativa de aplicación práctica del programa expuesto a los josefinos, y la misma trasmisión de esfuerzos que pacientemente estudia en la maqueta funicular de esta iglesia es universalmente reconocida como un ensayo de la estructura de la Sagrada Familia (1916-26); análogamente los detalles simbólicos y la policromía de las vidrieras de su cripta, así como los ensayos con los vidrios de colores en Mallorca, anticipan las vidrieras de la nave del Templo (1920-26) aunque en este proyecto el tema de la luz es mucho más complejo; hasta la disposición y tratamiento del altar de la catedral de Mallorca, su lampadario y presbiterio, juntamente con el variadísimo mobiliario litúrgico que allí desarrolla (1900-1914), son el precedente más inmediato de lo que desea realizar en la Sagrada Familia.

Como veremos, la singular aplicación de los diversos elementos arquitectónicos que inciden en la construcción de la Sagrada Familia, aunque dibujada, ensayada y probada a lo largo de años en diversos proyectos, requiere un exigente esfuerzo de síntesis aunando la herencia arquitectónica y la tradición litúrgica que considera compatibles con su proyecto mediante una metódica reelaboración de los resultados obtenidos a partir de su capacidad de imaginación, que trataremos de desentrañar. En este discurso emerge con claridad la naturaleza de su interés y la dimensión del trabajo que se propone realizar: integrar en la construcción de su catedral cuantos recursos le sirvan para plasmar de la manera más plástica posible la adecuación del lugar de culto como espacio arquitectónico según las condiciones que cree que demanda el misterio que se celebra. Para tal fin se sirve de todas las artes $\mathrm{y}$ de todos los estilos reinterpretando las soluciones que encuentra en función de una personal escala de prioridades. 


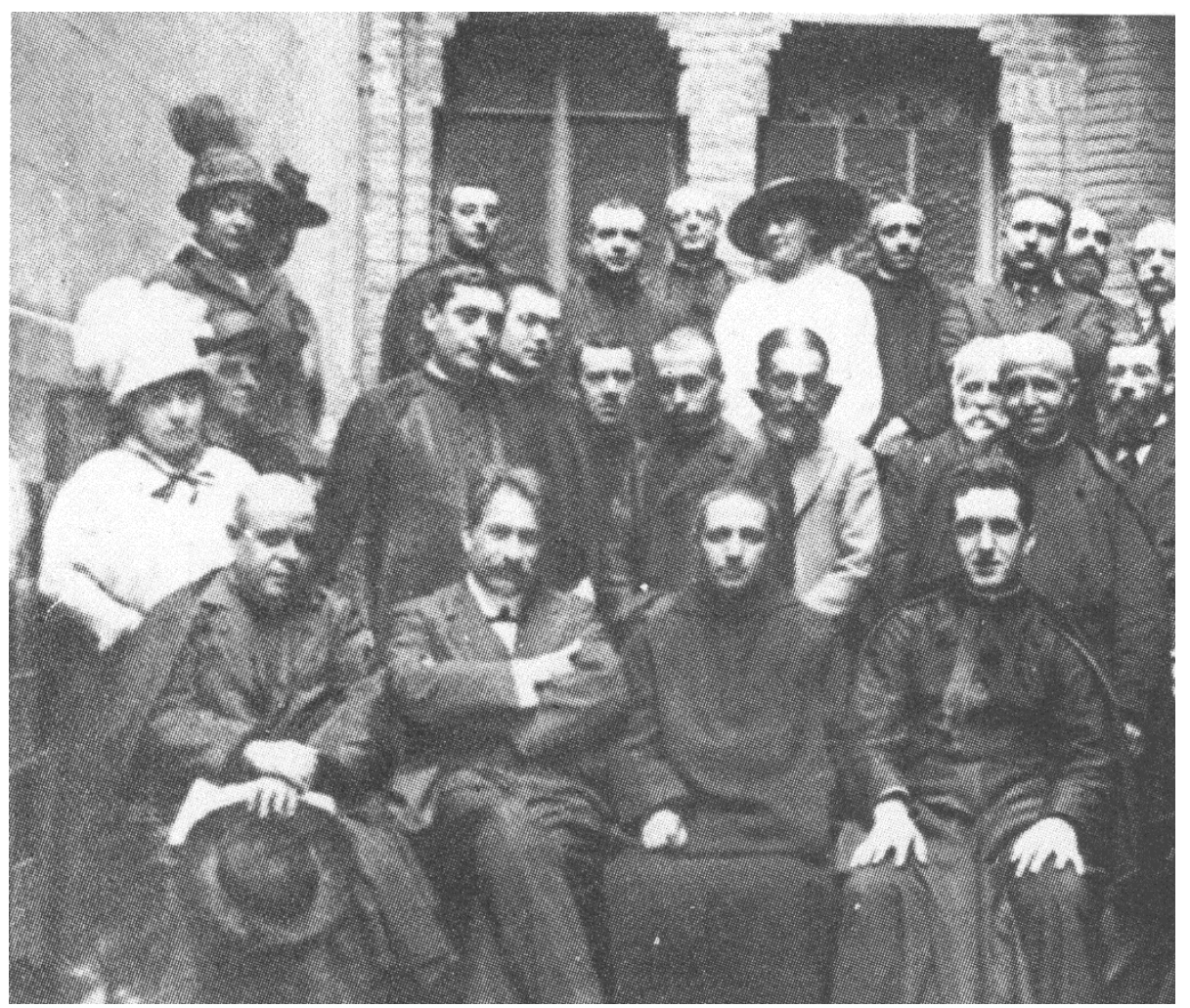

Antonio Gaudí en un curso de canto gregoriano. Fuente: Giralt-Miracle, D. (2002). Gaudí, la búsqueda de la forma. Barcelona. Lunwerg. 
Su proyecto es como en una lección descomunal de arquitectura porque -la historia de la arquitectura es la historia del templo- ${ }^{304}$ que se diseña desde dentro hacia fuera -las formas exteriores han de ser trasunto de lo interior- ${ }^{305}$, precisando que el conjunto del edificio será un verdadero símbolo, una obra de arte, a tono con la época que vivimos ${ }^{306}$ al servicio de su uso y de la funcionalidad que quiere otorgarle.

Con esta clara determinación respecto del espacio litúrgico, dotarlo del confort celebrativo más adecuado a la renovación que se proponía llevar a cabo la Iglesia Católica, precisa los focos de la asamblea con condiciones totalmente novedosas para su época. Respecto del altar mayor su condición sobreelevada y aislada respecto de la nave celebrativa, encima de la bóveda de la cripta en una posición muy adelantada respecto del presbiterio (bajo lo que se denominaba el arco triunfal), le prefiguran con una centralidad muy originaria que se realza con todo un sofisticado repertorio de características y elementos que ayudan a fijar la atención sobre él: lampadario y cruz colgantes, exento encima de una escalinata, etc. respondiendo a lo que se planteaban los impulsores centroeuropeos del Movimiento Litúrgico.

La pormenorización del discurso es verdaderamente sorprendente aunque se considere la naturaleza piadosa de la audiencia, pues todo parece estar pensado para la solemnidad religiosa: "ostentará en el exterior las imágenes apologéticas y catequizantes para introducir a los fieles en contemplación del mundo sobrenatural que se proyectará en el interior".

Parece como si al describir la abundante imaginería escultórica de cada una de las fachadas y su simbiosis con los elementos arquitectónicos que las conforman, así como el plan que concibe para su cara interna, columnas, bóvedas, etc. quisiera dar idea de la amplitud de su conocimiento de la Liturgia Católica y de lo meditado de su plan ante un auditorio suficientemente preparado para valorarlo. Se trata de un completo programa figurativo de los principales misterios del Cristianismo con una clara distinción entre el externo y el interno del edificio. Cada una de las fachadas, de los frisos, galerías altas, bóvedas del pórtico, etc. exponen un programa concienzudamente pensado que se expone con el objetivo de cautivar a una audiencia plenamente identificada con la regeneración de la sociedad a partir de la contemplación de los misterios de la Fe.

\footnotetext{
${ }^{304}$ Cf. Bergós, J. (1974).Gaudí, el hombre y la obra. Barcelona. UPC. Cátedra Gaudí. P.46.

${ }^{305}$ Cf. Mercader, L. (2000). Antonio Gaudí: escritos y documentos. Barcelona. El Acantilado. P. 56. Esta frase textual de Gaudí que aparece en el Manuscrito de Reus, y portanto es recogida en la recopilación de Mercader, también es citada por Puig Boada en su libro El Pensament de Gaudí.

306 Cf. "Discurso a los Josefinos", en Bassegoda, J. (2001) Gaudí: la arquitectura del espíritu. Barcelona. Salvat Ed.; y en Matamala, J. (1999). Mi itinerario con el arquitecto. Barcelona. Ed. Claret
} 
Además de ello Gaudí da la impresión de tener pensado el uso de cada recinto que describe y su fundamentación teológica, la implicación que debe esperarse de la luz y el color en su arquitectura, la correspondencia de las leyendas y textos escritos con los elementos constructivos y el ceremonial de las celebraciones, la armonía de la policromía y enseñanzas de la iconografía con la magnificencia de la liturgia romana, la idoneidad de la acústica de los campanas y el simbolismo de los materiales que constituyen columnas y cerramientos de la nave con la función que conllevan los elementos sustentados. En este programa también se ocupa de la distribución de los espacios en orden a una celebración litúrgica que se quiere participativa:

"la distribución de los espacios se regulará de tal modo que queden los destinados a los fieles y los coros en las cantorías. Encima del deambulatorio habrá lugar para un coro de setecientos niños, detrás del presbiterio. A lo largo de la nave lateral y en el triforio habrá lugar para mil cantores, que ocuparán la $U$ formada por la fachada principal y las dos naves laterales." 307

De esta manera, aún sin mencionar expresamente este texto, Martinell expone la concepción gaudiniana del edificio (La Sagrada Familia, 1952) con arreglo al mismo orden que se desprende del texto del discurso: requerimientos litúrgicos, programa iconográfico y simbólico, sentido artístico y estructura arquitectónica, casando ambos de una manera muy convincente. Para Martinell están claros los objetivos que persigue Gaudí e identifica sus disposiciones litúrgicas con la concreción de los espacios y elementos que describe. ${ }^{308}$

\footnotetext{
${ }^{307}$ Cf. Bassegoda Nonell, J, (2002) Gaudí: la arquitectura del espíritu. Salvat. P.205. Llama la atención de esta descripción que pone en boca del propio Gaudí "puesto que el plan de la obra fue seguido fielmente por él y por los que le sucedieron". Matamala dice que "fue la primera exposición sobre su grandiosa visión del templo", cf. Matamala Flotats, J. (1999). Mi itinerario con el arquitecto. Claret- Real cátedra Gaudí. P. 80.

308 Para Martinell la idea de Gaudí está clara desde el principio y se basa en la Liturgia de la Iglesia Católica. Cf. Martinell, C.(1952) La Sagrada Familia. Barcelona. Aymà. P. 24: "La idea primordial de Gaudí fue que este templo se adaptase con la mayor perfección posible a la práctica de los cultos divinos. Para ello partió del templo basilical gótico en planta de cruz latina, con cinco naves longitudinales y tres transversales,...."
} 


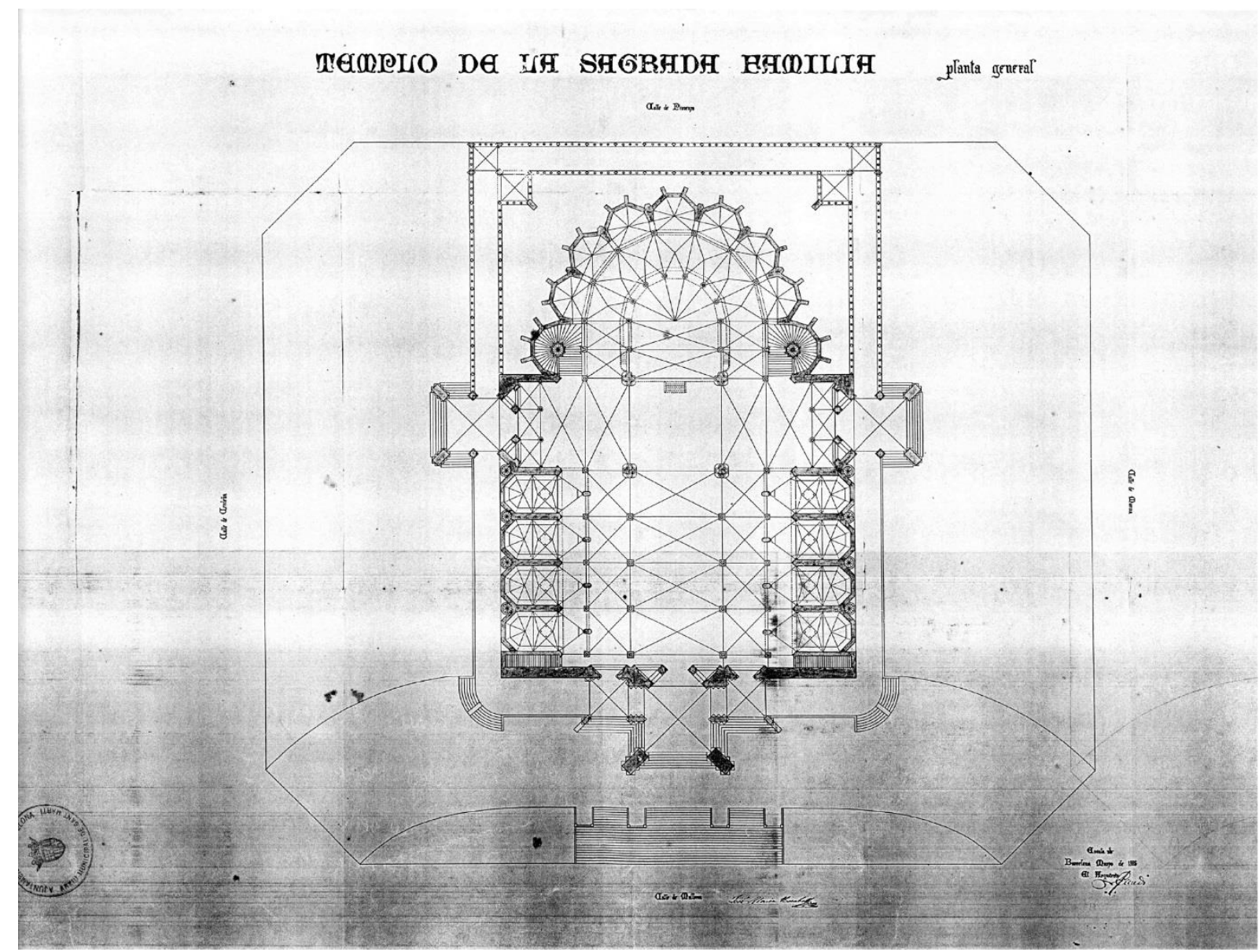

Planta del proyecto de Gaudí presentado en 1885 al Ayuntamiento de Sant Martí de Provençals para la obtención del Permiso de Obras. Fuente: Archivo de la Sagrada Familia. 


\section{d.3 Los proyectos gaudinianos de la Sagrada Familia.}

El Anejo del Pliego de Condiciones de 1884, da instrucciones precisas al contratista Macario Planella para seguir en todo las órdenes del nuevo arquitecto y es el mejor testimonio para ilustrar el acuerdo establecido entre todas las partes ${ }^{309}$, puesto que el discurso a los josefinos demuestra una idea conceptual madura pero cuya envergadura debe desarrollarse en múltiples líneas de trabajo que a buen seguro alertarían respecto a la previsible cantidad de nuevos planos, estudios, y trabajos para llevar a cabo, además de los puntos de conexión con el proyecto que ahora se interrumpe y modifica.

La información del nuevo proyecto nos ha llegado (tras los sucesos de la quema de su estudio y archivo en la obra, en el año 19369 a través de algunos dibujos, planos y maquetas que se salvaron, encontraron o restauraron posteriormente y cuya datación cronológica respecto de su creación y publicación se han reproducido con anterioridad en diversas ocasiones, destacando la catalogación y análisis realizados por Jordi Faulíi ${ }^{310}$, por lo que la reseña se hace en la presente investigación no será exhaustiva sino indicativa de los procesos de interés para el desarrollo de la presente Tesis.

El principal objeto de la atención de Gaudí en los primeros años de su dirección de las obras fue el de disponer cuanto antes de la Cripta para su utilización por los josefinos y presentar unos planos que permitiesen adaptar la Licencia municipal de obras al nuevo proyecto. Teniendo en cuenta esto, en el periodo de ejecución de las obras que va desde 1884 hasta 1900 podemos entender que las primeras modificaciones van encaminadas según una triple directriz en constante dialogo entre sí pero con un orden de precedencia, que partiendo de la actividad cultual que impulsan los josefinos y del espacio arquitectónico que ha de adecuar el arquitecto, desarrolla una amplio programa de actuaciones:

- $\quad$ Directriz Litúrgica. El diseño de la primera capilla dedicada a San José (firmado por Gaudí en diciembre de 1884 e inaugurada en marzo del año siguiente) marca el inicio de estos trabajos en la Cripta, la cual no se terminaría completamente hasta 1893. En este periodo de tiempo de construcción tan dilatado para lo que venía siendo una cripta en las iglesias de la época, acomete un completo proyecto que incluye esculturas, mobiliario litúrgico y grandes cambios en la construcción del recinto y sus aledaños.

\footnotetext{
${ }^{309}$ Bassegoda, J. (1989) El gran Gaudí. Sabadell. AVSA. P.211, señala la existencia de un documento en el archivo de la familia Rogent, que pudo consultar Cesar Martinell, por el cual Macario Planella solicita el 303-1884 el arbitraje de Elias Rogent, entonces director de la Escuela de Arquitectura, para resolver a unas discrepancias que tenia con Antonio Gaudí, que pretendía romper completamente con la fase anterior del proyecto, cuando únicamente se han realizado la excavación y desmonte de la Cripta.

${ }^{310}$ Cf. Faulí, J. (2009) Composició i continuitat en les columnas i voltes de les naus del Temple de la Sagrada Familia. Tesis Doctoral en la UPC. Barcelona.
} 
Gaudí ya contaba con una amplia experiencia en obras litúrgicas pues a principios de los 80 había intervenido en los altares y capilla del Colegio Jesús-Maria de Tarragona y de San Andrés del Palomar, además de los dibujos para el proyecto de la iglesia de Villaricos (1882) y la fachada de la catedral de Barcelona (1883), en colaboración con Martorell, con el que también colabora en la iglesia de los Jesuitas de la Calle Caspe (1883-1889) y en la de las Salesas (1882-1885), por lo que no debe extrañarnos lo completo del programa litúrgico de la Cripta y precisas las instrucciones que da para la ejecución de la escultura del santo y de las correspondientes a un Corazón de Jesús y una Inmaculada Concepción que debían ocupar las capillas adyacentes. El programa de esculturas debía ocuparse también de las capillas de la rotonda (la central de la Sagrada Familia y las laterales dedicadas a santos de la Sagrada Familia) y de la significativa clave escultórica de la bóveda central que desarrolla el tema de la Anunciación en presencia del Espíritu Santo. En este contexto se ha considerar igualmente el cambio en la comunicación entre Cripta e Iglesia superior, que permite disponer sendas escaleras curvas ocupando el lugar de las primeras capillas laterales del ábside y aprovechar sus huecos libres para las sacristías. Conseguida, pues, la plena autonomía funcional de la Cripta como recinto de culto, con protagonismo muy superior al que le otorgaba la idea originaria de Bocabella y el proyecto de Villar como simple contenedor de una reproducción de la casa lauretana, Gaudí comienza a desarrollar el ambicioso programa litúrgico que describe en 1891.

- Directriz Arquitectónica. Ya se ha dicho que Gaudí no es un arquitecto de formas preconcebidas o maximalistas que encuentra en su catalogo mental y decide aplicar -al menos en su producción eclesiástica queda bastante claro que no se comporta de esta manera e incluso cuando puede hacerlo, como es el caso de Sta. Coloma, la planta no reproduce ningún tipo al uso como ya hemos visto - sino que la mayor parte de las veces partiendo de espacios o plantas ya construidos interviene hábilmente hasta conseguir su transformación más sútil. En este aspecto podríamos decir que domina la técnica de las suturas y rehabilitaciones en sus intervenciones en los lugares y edificios de culto. Es más, podría parecer que lo que pretende es estirar, doblar y retorcer las formas a partir de unos requisitos básicos de implantación al topos si con ello consigue su objetivo de plena habitabilidad y funcionalidad al uso comunitario que persigue. Esta concepción unitaria del proyecto que lo aborda en su totalidad desde su implantación, sistema constructivo, dimensión artística y funcionalidad, concede una fuerte dosis de modernidad a la arquitectura gaudiniana, especialmente si se considera su rechazo de todo tipo de apriorismo histórico sino es previamente cribado y aceptado como válido por el pensamiento de Gaudí.

La acción de derribo del "establishment" de los sistemas sustentantes, formas y ornamentación conocidos para un edificio-iglesia, sin postular teorías ni tratados, con tan sólo la lógica analítica, la experimentación y la coherencia en el proyecto y la construcción han de verse en su arquitectura eclesiástica y especialmente en la Sagrada Familia. 

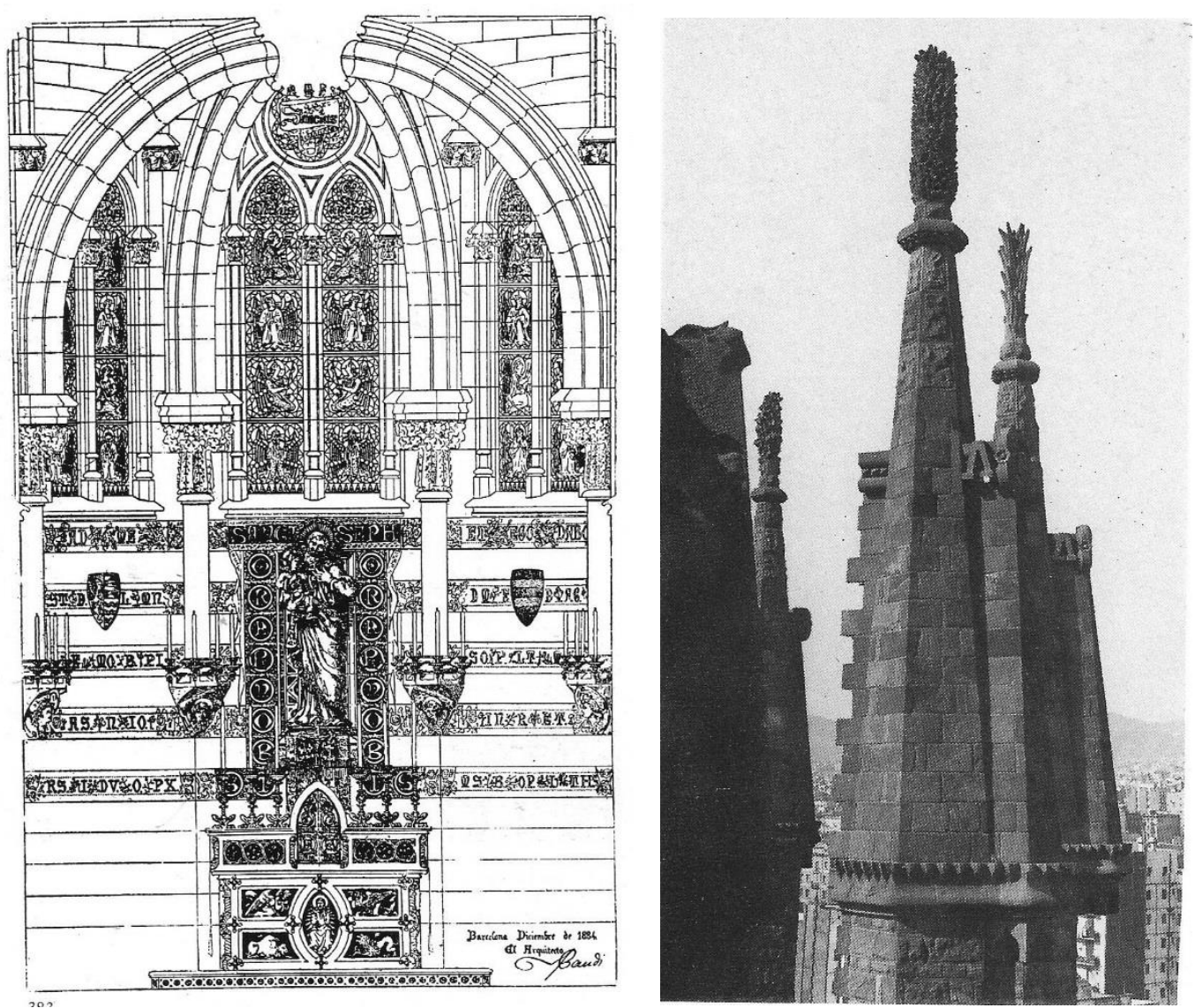

Dibujo de alzado del altar de la capilla de San José en la Cripta publicado en el Pro. (15-121887). Pináculos del Abside con los motivos naturales de espigas de trigo, centeno, cebada, etc.

Fuente: Torii, T. (1983) El mundo enigmático de Gaudí. Madrid. Instituto de España.
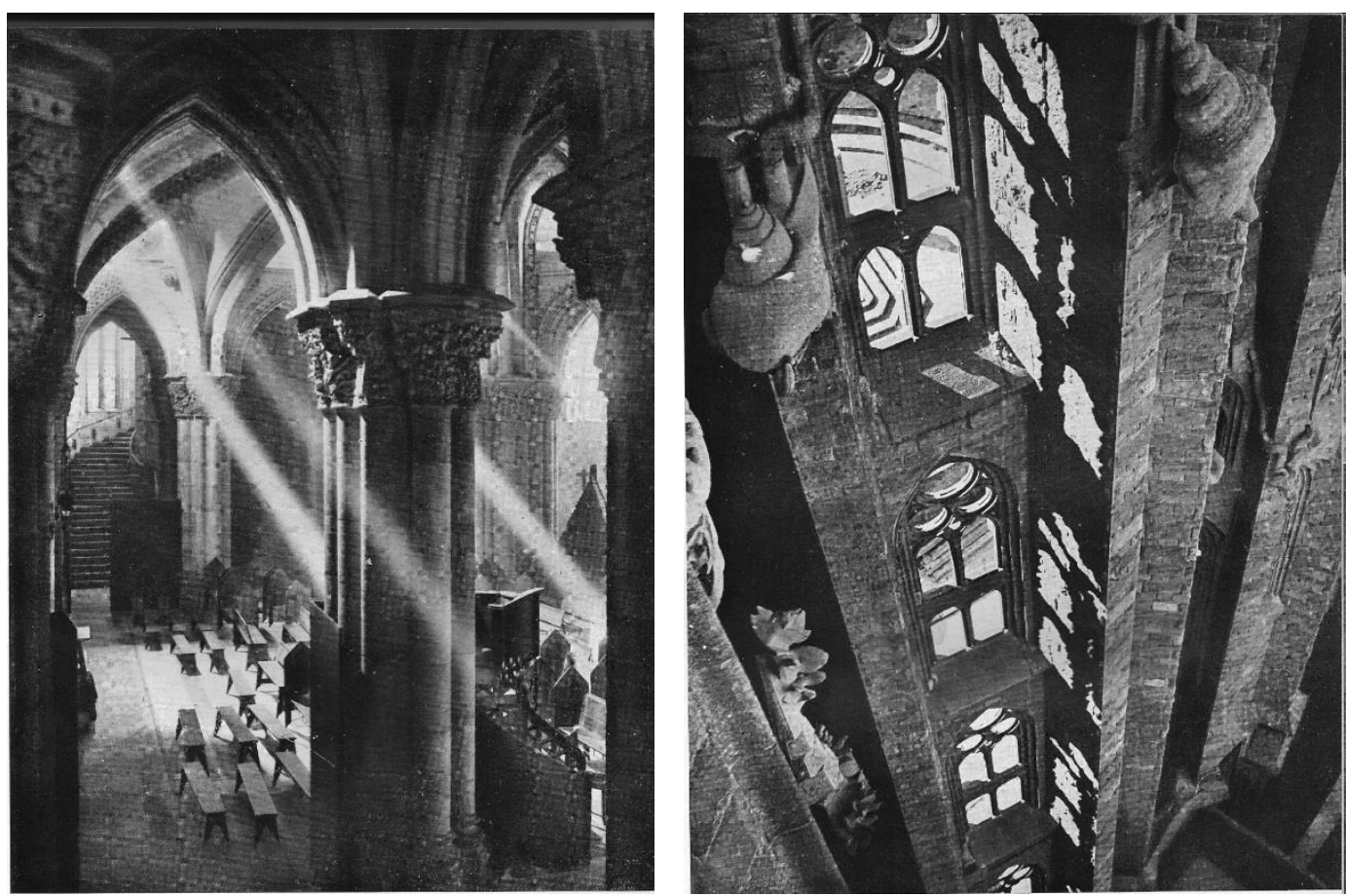

Interior de la Cripta antes de 1936. Contrafuertes y ventanales del Abside.

Fuente: Martinell, C. (1952). La Sagrada Familia. Barcelona. Aymà. 
No en balde el trabajo de investigación y desarrollo de proyecto que han realizado los sucesivos directores de la obra y su equipo técnico así lo demuestra con el hallazgo de sus medidas, módulos y dimensiones que unidos a las ilustrativas maquetas y moldes restaurados permiten una visión completa del proyecto que supera con mucho la dimensión estructuralista para abarcar también aspectos relacionados con la composición de los espacios, los materiales y su utilización, las formas y texturas, la luz, el color, etc. y cuantos aspectos conforman lo que hoy día se conoce como una obra completa.

Todo está supeditado a su sentido unitario de la obra arquitectónica y al "carácter" que quiere imprimir al edificio-iglesia, cuestión que ya se apunta decididamente desde el inicio de su intervención al sustituir la escalera central de acceso a la Cripta por escaleras lateralizadas con respecto al ábside liberando el espacio correspondiente al crucero y presbiterio de la nave y recuperándolo para una mayor libertad compositiva. Análogamente el patio inglés y la elevación de $10 \mathrm{~m}$ en la altura interior de la Cripta suponen también un anticipo de la importancia que cobrará la iluminación y ventilación naturales en el resto del proyecto, y constituyen una primera afirmación de la voluntad auto-sustentante de una iglesia sin apoyaturas externas concebida como una declaración de permanencia. Otra muestra de remodelación del proyecto eclesial está en la utilización de los huecos de las escaleras lateralizadas para núcleos de comunicación vertical del edificio, incorporando ascensores en una ubicación que no impide la diafaneidad al espacio interior. Por último cabe mencionar como desde el primer plano (1855) hay constancia de la disposición perimetral del claustro uniendo las entradas y del desarrollo de éstas como fachadas, (cuestiones a las que nos referiremos oportunamente) abriendo nuevas e interesantes posibilidades compositivas que una planta rígida de cruz habría impedido.

- Directriz Artístico-Simbólica. Siendo consustancial con la producción arquitectónica gaudiniana la utilización de un lenguaje iconológico, es en la Sagrada Familia cuando éste adquiere su pleno desarrollo y protagonismo según el cometido que le otorga el arquitecto. Esta eclosión de simbolismo, cuyas primeras manifestaciones podemos encontrarlas en el periodo de su producción modernista y que ha supuesto un largo proceso de brillantes experiencias tanto en el campo de la arquitectura profana como religiosa parece estar completamente madura en su mente al terminarse la Cripta (1893). Prueba de ello es el discurso a los josefinos (1891) que tiene en la iconología uno de sus pilares básicos.

Al principio tímidamente -en la cúspide de piñones, gárgolas y contrafuertes del ábside-, después en las portadas y finalmente en un numerosos elementos del exterior y del interior de la basílica, las formas naturales de animales y vegetales, los motivos decorativos (palmas alusivas al Domingo de Ramos, laurel como símbolo de realeza, olivos como fuente de bendición y abundancia, rosal perfumado del edén, ciprés y cedro del Líbano como elementos de construcción en la antigua Alianza, frutos en alusión a la Tierra 


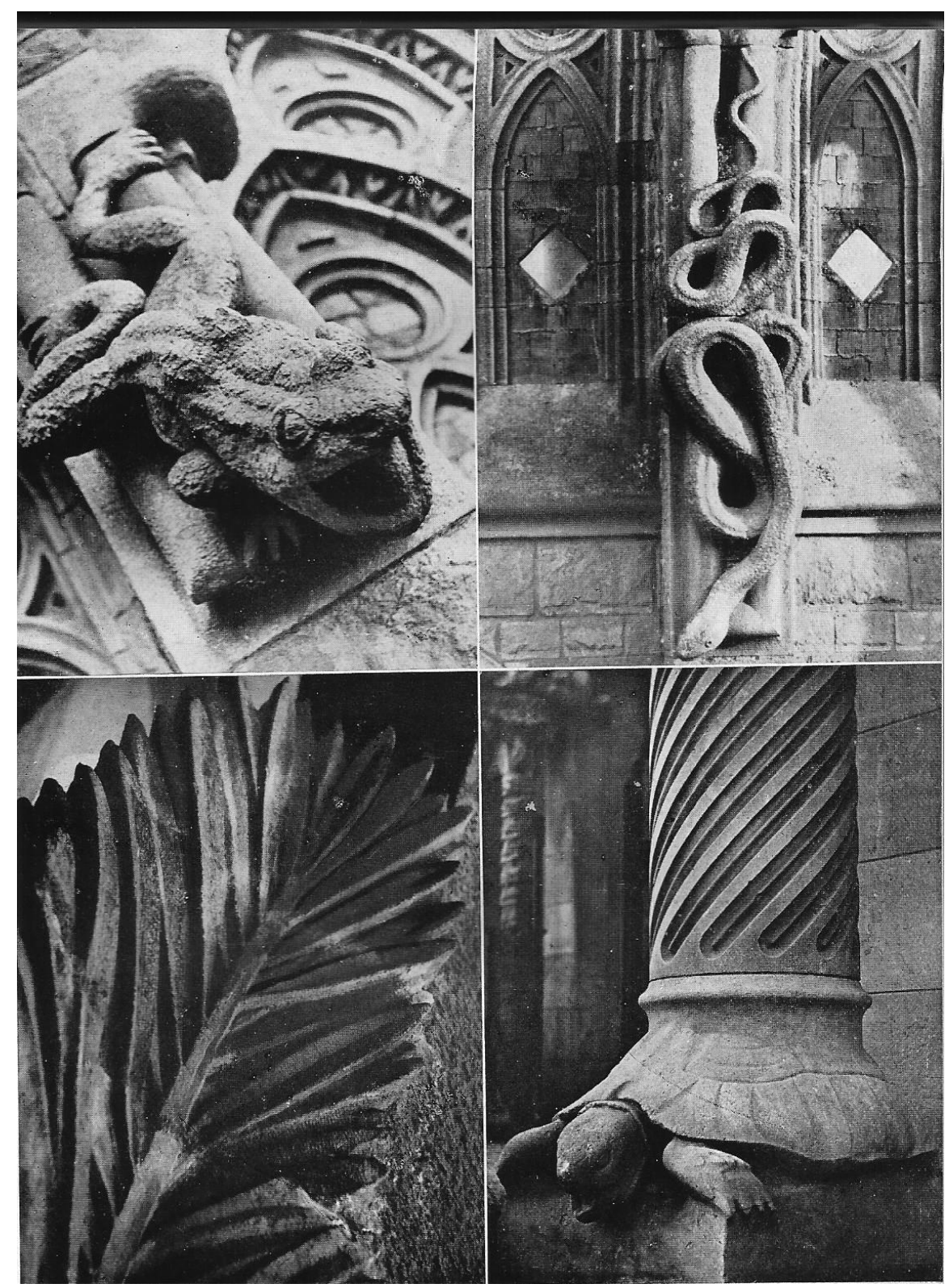

Decoración naturalista del Abside y Fachada del Nacimiento.

Fuente: Martinell, C. (1952) La Sagrada Familia. Barcelona. Aymà. 
Prometida, especies eucarísticas del Pan y del Vino, etc.) visualizan pasajes, hacen recordar textos bíblicos, o constituyen la representación simbólica en piedra de la materialidad más importante del Cristianismo. De esta manera son reproducidos en diversos elementos arquitectónicos a través de volúmenes pétreos, texturas y colores que buscan entrar en diálogo con aquellos que son convocados a las celebraciones litúrgicas ayudándoles en su activa participación. No se podría entender la Sagrada Familia, como tampoco hubiese sido posible en el caso de Santa Coloma o en la misma Mallorca si se hubieran llevado a término dichos proyectos, sin la inserción de estos textos, imágenes y formas escultóricas tan íntimamente insertados en los diversos elementos de su arquitectura. Porque esta arquitectura quiere utilizar un potente discurso simbólico tanto en el exterior como en el interior para alcanzar el "carácter" de espacio litúrgico y el confort que pretende.

Según la cronología de la obra - véase Puig Boada (1952), Bergós (1974), Bassegoda (1989), Torii (1983), Carlos Flores (2002), etc.- en 1891, además de la cubrición de la Cripta y la exposición del proyecto a los josefinos, se comienza a ejecutar el ábside y la fachada del Nacimiento juntamente con el arranque del claustro. ${ }^{311}$ Nuestra pretensión se centrará ahora en reproducir de modo sintético y no exhaustivo los principales dibujos de Planta, Alzados y Secciones que permitan contemplar la evolución que ha ido teniendo el proyecto de Antonio Gaudí.

\section{DIBUJOS DE ALZADO.}

En los años siguientes a la gestión del Permiso de Obras ante el Ayuntamiento de San Martí de Provençals (1885) no parece que haya nuevas versiones de la planta pero sí dibujos de Alzado. Éstos, por su visualización ligeramente en escorzo, y los dibujos de conjunto perspectivo nos dan una primera idea de la skyline del proyecto y los cambios que se producen en sus fachadas, por lo que nos referiremos a ellos en primer lugar. Prácticamente todos se refieren a la fachada lateral de Levante o del Nacimiento, cuestión fácilmente de entendible por la cronología de la ejecución de las obras, y provienen de un primer dibujo realizado por Joan Rubió de ese alzado longitudinal0 que se publica en La llustració Catalana el 18-03-1906, en Arquitectura y Construcción el 1-011908 y que posteriormente se reprodujo en otras publicaciones, entre ellas el Propagador (en 1915, 1917 y 1922).

\footnotetext{
${ }^{311}$ Nota del autor: No se pretende realizar un catálogo exhaustivo ni ficha cronológica de los planos que va produciendo el Taller de Arquitectura u Obrador de Gaudí, cuestión que ha sido desarrollada por Jordi Faulí en su Tesis Doctoral Composició i continuitat en les columnes i voltes de les naus del Temple Expiatori de la Sagrada Família (2009), sino que se quieren analizar los hitos que marcan la evolución del proyecto gaudiniano a luz del programa, de las ideas del arquitecto respecto de la arquitectura litúrgica y de las claves arquitectónicas que, en este sentido, pueden rastrearse.
} 


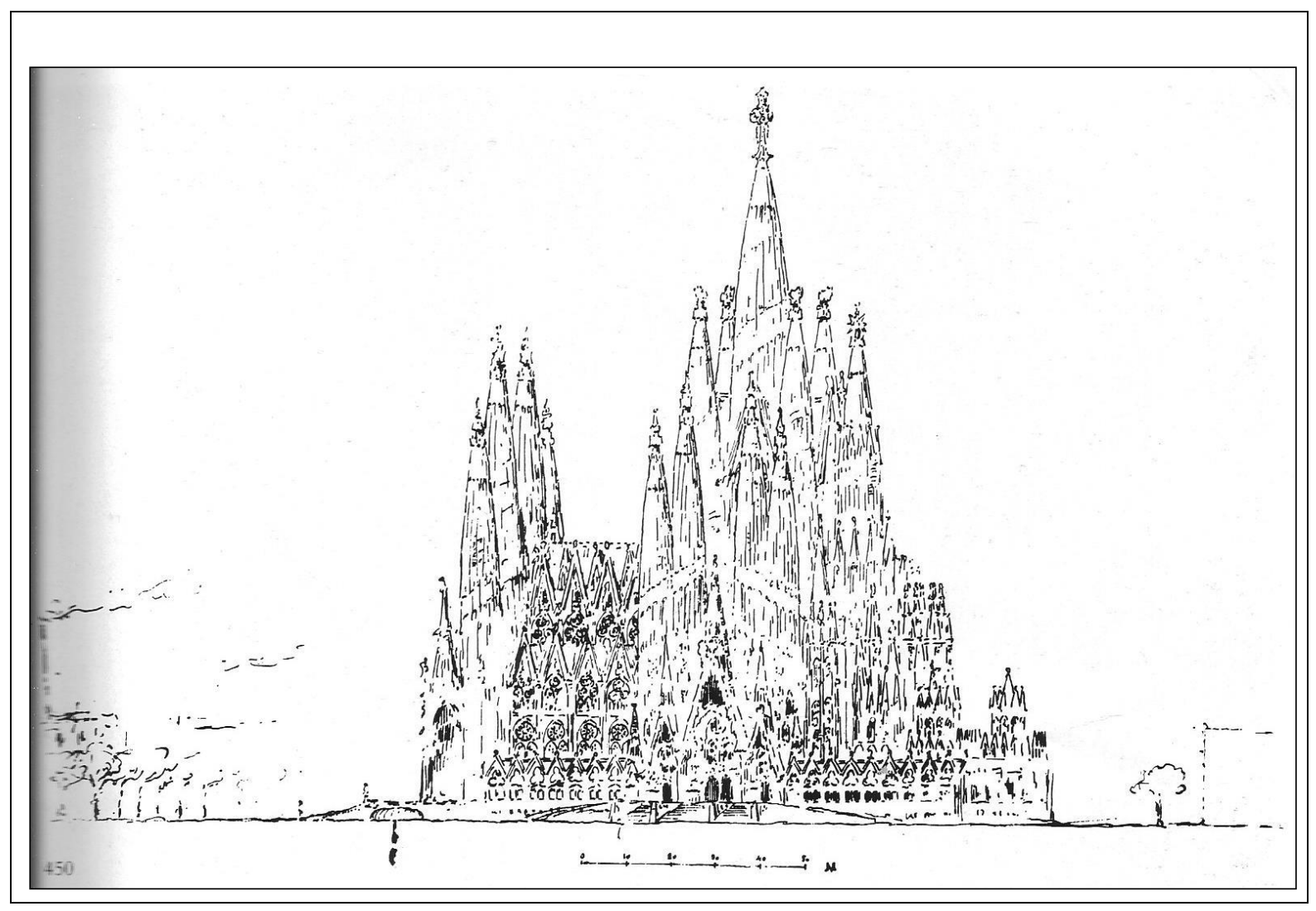

Dibujo de Joan Rubió realizado según Torii bajo la dirección de Gaudi y publicado en La Ilustració Catalana el 18-03-1906 y en Arquitectura y Construccion el 1-01-1908, que sirvió de base a otros que se publicaron entre 1913 y 1922. Fuente: Torii, T. (1983) El mundo enigmático de Gaudí. Madrid. Instituto de España.

Este dibujo da una idea bastante aproximada de la volumetría que se pretendía desarrollar pues permite observar los dos cimborios y las torres de los evangelistas proyectadas alrededor del mayor de ellos, dedicado a Jesucristo. La composición de cada portada queda perfectamente enfatizada por las cuatro torres y sus dimensiones con respecto al alzado recayente a cada calle permite identificarlas como auténticas fachadas, aspecto reforzado por el hecho de que el resto del alzado esté constituido por un elemento de baja altura como el claustro, que relega a un segundo o tercer plano el cerramiento lateral de las naves. También se pueden distinguir los diferentes niveles en que se configuran los alzados: en primer lugar el claustro y posteriormente dos planos, en que se desarrollan las naves laterales y la central.

En él son perfectamente identificables unas cúpulas, similares a una torre o cimborio, próximas a las esquinas del claustro en la orientación de la calle Provenza que se corresponden con las futuras Sacristías aunque se sitúan más bien en la ubicación que señala la planta de 1885 . No se vislumbran con claridad los volúmenes de las capillas del Bautismo y de la Penitencia (por lo demás no dibujadas en la planta mencionada) y desde luego, no aparece el volumen de la futura capilla de la Asunción. 


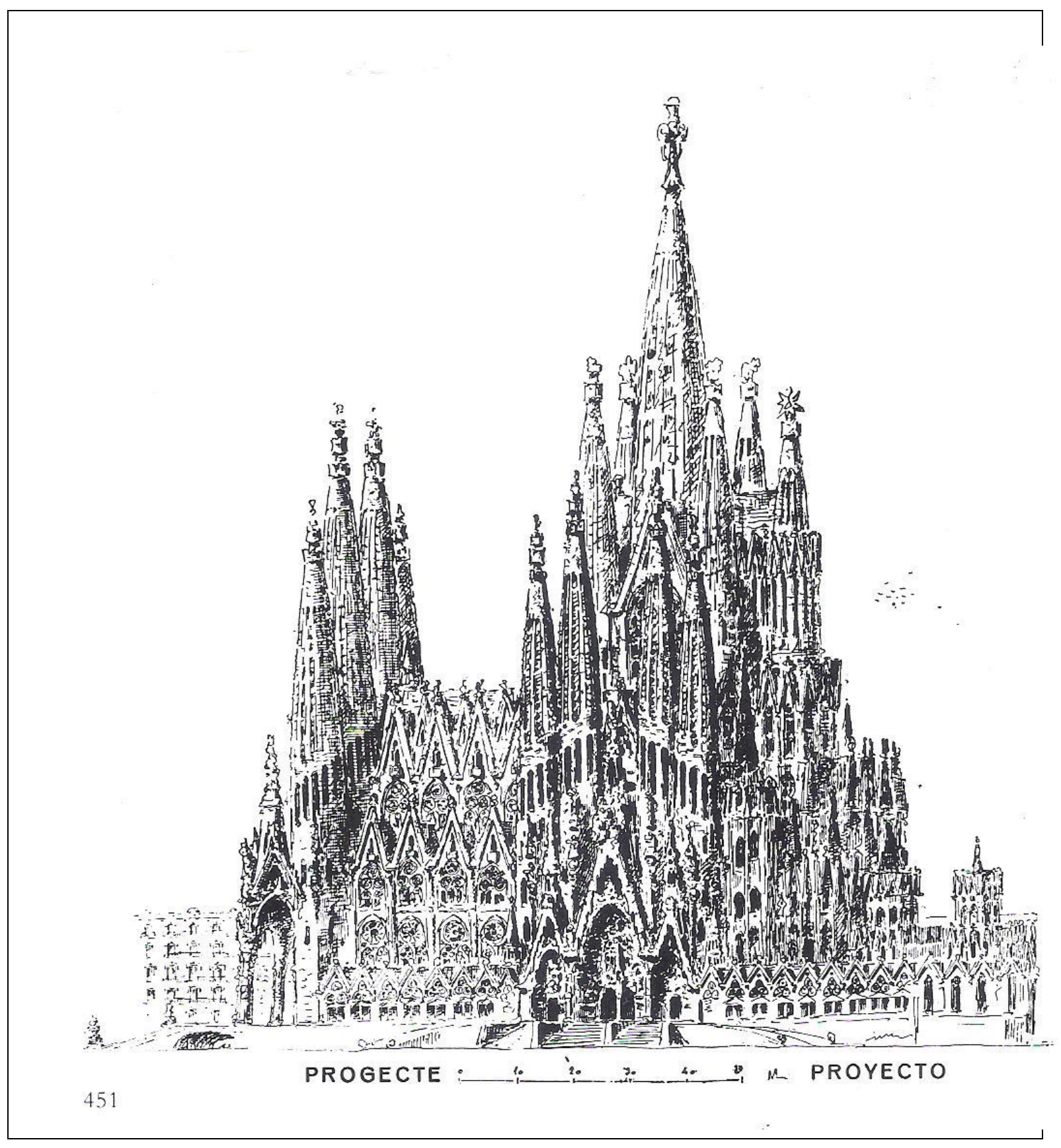

Grabado publicado en el Propagador el 15-12-1912 y en CC el 26-1-1913, reproducido en el Album del Templo en 1915, 1917 y 1922. Fuente: Torii, T. (1983) El mundo enigmático de Gaudí. Madrid. Instituto de España.

Prácticamente idéntico al dibujo de Rubió de 1906, se aprecia un mayor grado de detalle en el lateral de la portada de la Gloria, en los accesos y en el claustro, aunque la estructura del cimborio del ábside no parece tan rotunda como en aquel sino más bien estratificada. 


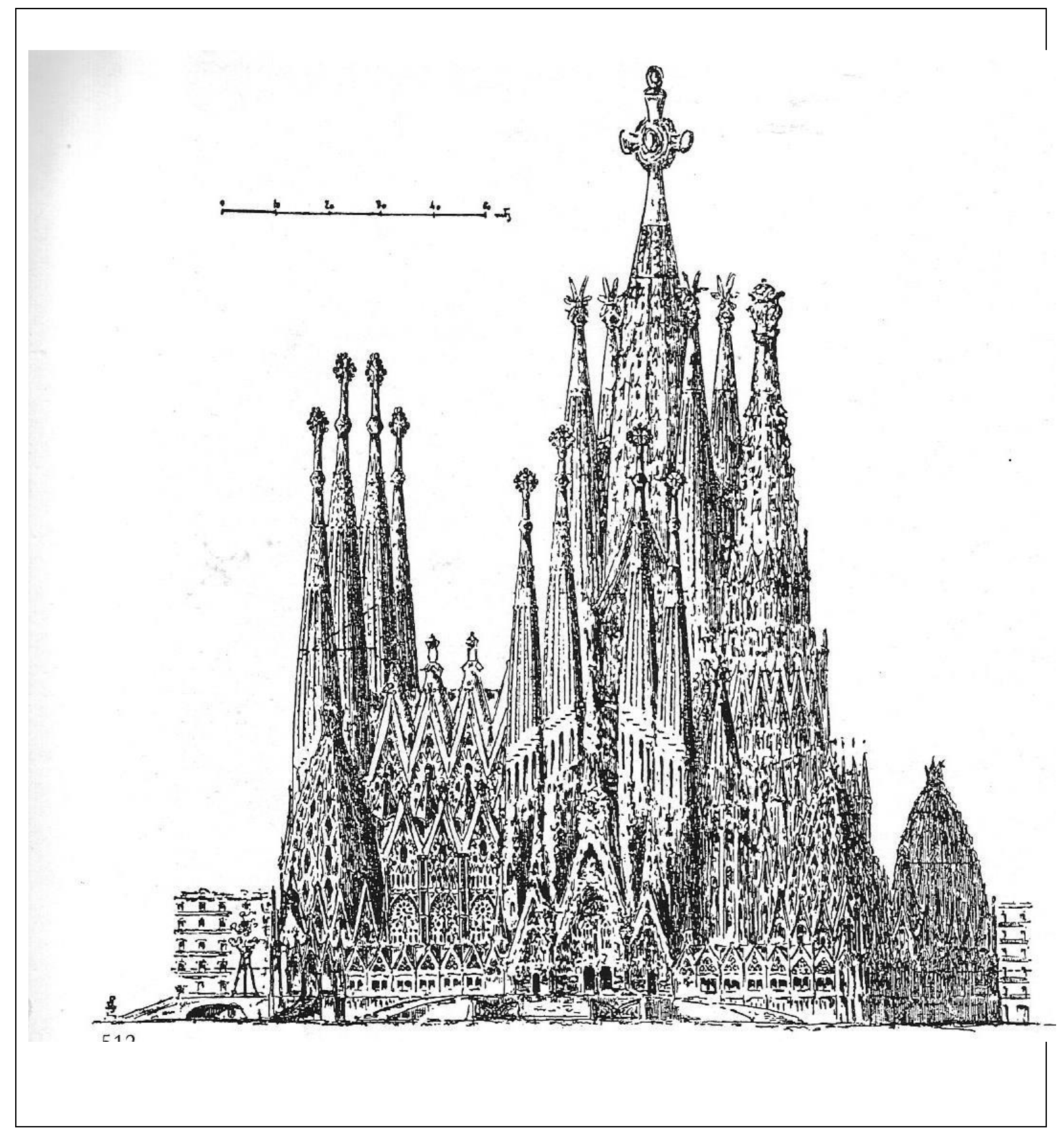

Boceto publicado en el Album de 1929. Fuente: Torii, T. (1983) El mundo enigmático de Gaudí. Madrid. Instituto de España.

En este dibujo, publicado después de la muerte de Gaudí, aparecen ya los volúmenes de las capillas del Bautismo y de la Penitencia a imitación de las cúpulas de las Sacristias, cuya forma responde a las últimas soluciones. La altura del cimborio de la Virgen alcanza prácticamente la misma altura que las torres de los evangelistas y los alzados de claustro y naves se ven muy bien definidos.

Aparecen con rotundidad y semejanza formal los volúmenes de las capillas laterales y las sacristías, a la vez que se vislumbra la cubrición de la capilla de la Asunción. 


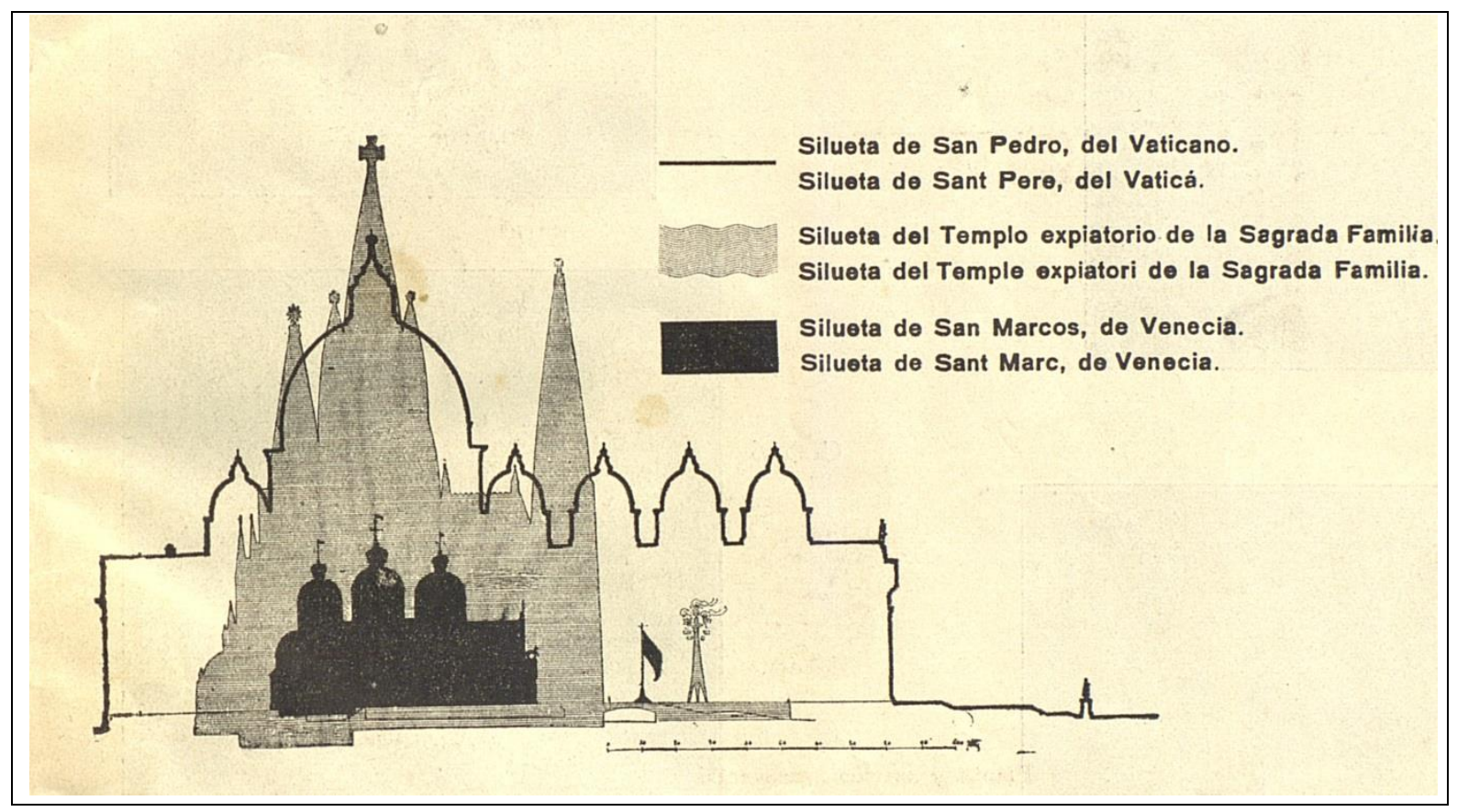

Silueta de la Sagrada Familia comparada con San Pedro del Vaticano y San Marcos de Venecia, publicada en el Album de 1917. Fuente: Arxiu de la Sagrada Familia.

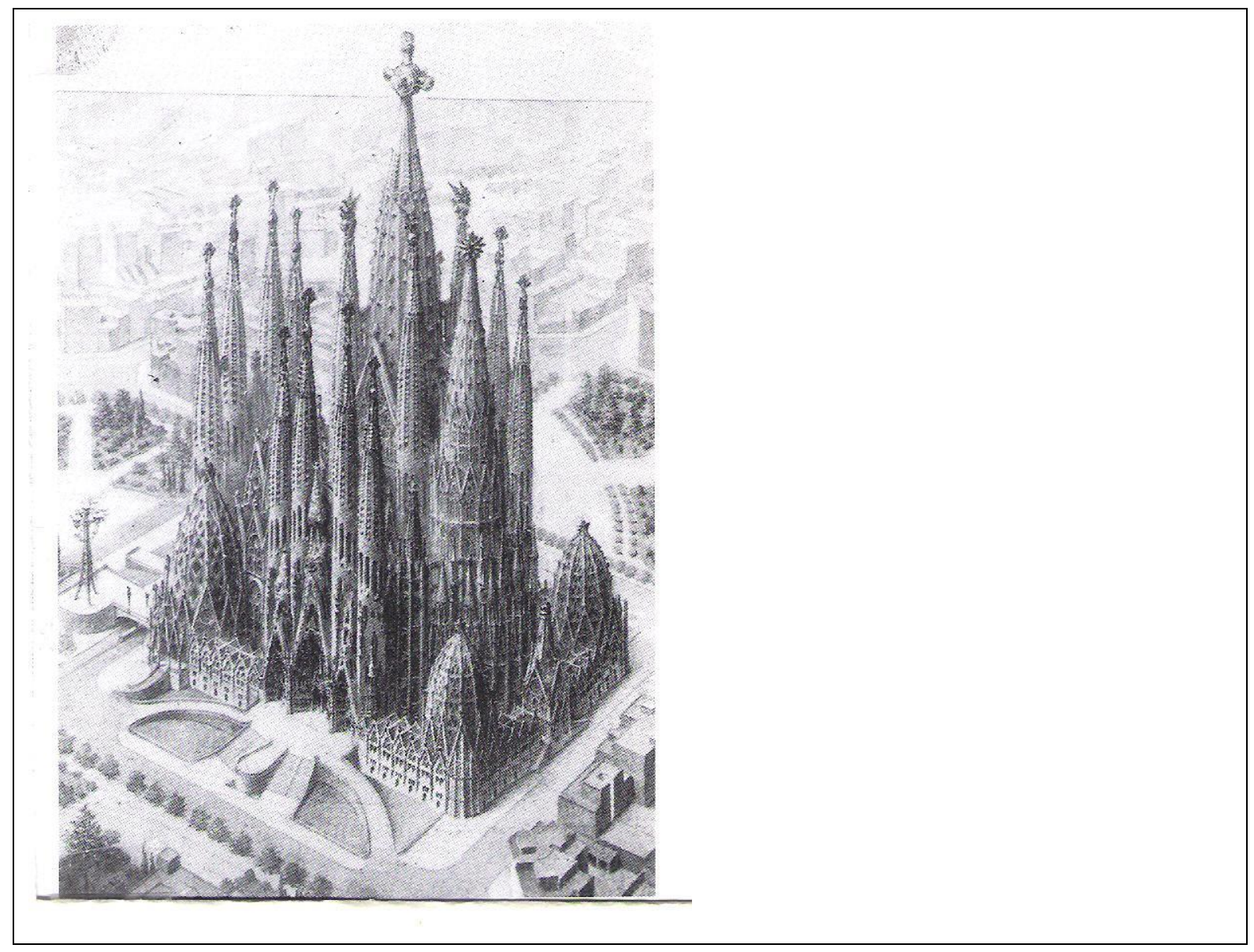

Dibujo de Francisco Vall sobre un boceto publicado en el Album de 1929. Fuente: Torii, T. (1983). El mundo enigmático de Gaudí. Madrid. Instituto de España. 


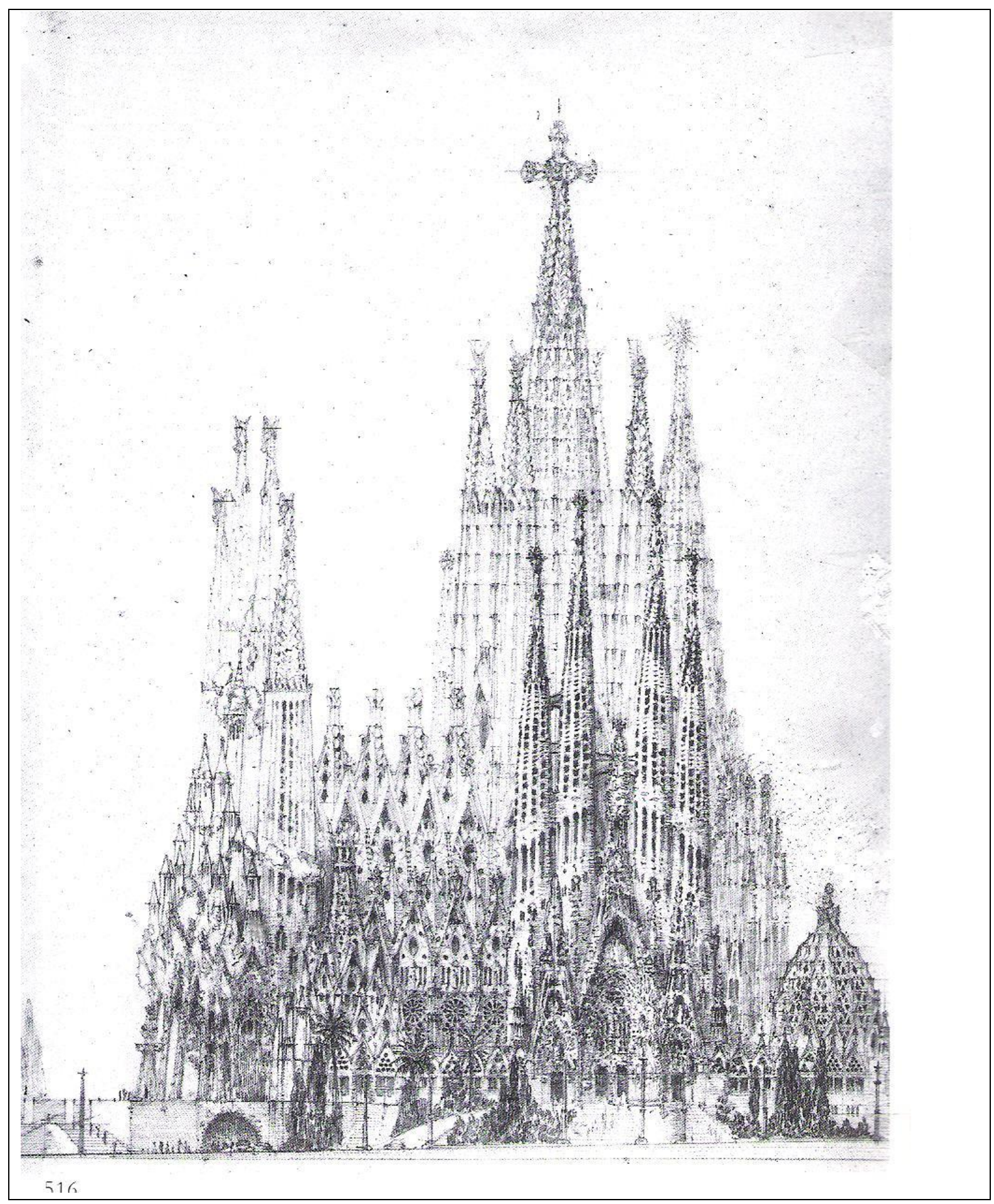

Dibujo realizado durante los años de Dirección de Obra de Lluis Bonet Garí, datado por Torii en 1945-1950. Fuente: Torii, T. (1983) El mundo enigmático de Gaudí. Madrid. Instituto de España.

En este dibujo la fachada de la Gloria presenta un grado de detalle importante y la cúpula de la capilla de la Penitencia presenta una solución similar al estudio que realizó Gaudí para cubrir la capilla de la Asunción. Hay que destacar también que la altura del cimborio del ábside, dedicada a la Virgen sobrepasa la correspondiente a las torres de los evangelistas. 


\section{DIBUJOS DE SECCION}

Se distingue entre secciones transversales, útiles para conocer la solución estructural y su evolución en el tiempo, y secciones longitudinales, que permiten visualizar el volumen interior y con él las visuales más importantes que Gaudí quiere para el proyecto siendo de importante ayuda para comprender su simbolismo.

En estas secciones se aprecia la situación del altar y sus gradas que lo sobreelevan respecto del nivel de la nave litúrgica y presbiterio. En todas se ellas es visible la secuencia de los tres lampadarios: en la bóveda del cimborio de la Virgen, encima del altar y en la bóveda del cimborio principal, que hacen referencia a la Encarnación por obra y gracia del Espíritu Santo, al misterio pascual de la muerte y resurrección de Jesucristo y a la Jerusalén celestial que describe el libro del Apocalipsis, respectivamente. Gaudí conocía perfectamente y tenía muy presente toda la doctrina cristiana, las Escrituras y la Tradición católica, y gozaba en reflejar la visión de la comunión de la asamblea litúrgica terrestre con la celeste como mencionan sus colaboradores. A mi parecer, estas secciones y su posterior desarrollo buscando la fidelidad a la idea gaudiniana explican a través de sus elementos constructivos y visuales el sentido litúrgico que Gaudí quiso dar al proyecto, como veremos posteriormente. El arquitecto también mostraba en determinadas ocasiones sus bocetos y dibujos a sus colaboradores más próximos explicándoles con gran precisión que en ellos estaba contenidos los principales misterios del Cristianismo. Bergós habla de que al proyectar la iconografía y color que debía acompañar a bóvedas de cimborios, ornamentación de columnas y geometrías de los antepechos del graderío del coro, etc. , es decir, al diseñar y componer todos los elementos que configuran el espacio interior, Gaudí había imaginado el conjunto del aula litúrgica de manera que se viera claramente que por su situación los santos subían de la tierra al cielo y los ángeles descendían a la tierra desde el cielo, localizado en la cúpula del ábside, en la que está representado el Padre Eterno como lo describe Isaías con su vestidura llenando todo el espacio y cabezas de serafín entre los pliegues. ${ }^{312}$ En estas secciones no sólo la cúpula del ábside remite a la acción creadora divina sino que el lampadario de la nueva Jerusalén -a $60 \mathrm{~m}$ de altura- y la luz cenital que se vierte sobre ella en el cimborio central parecen simbolizar el trono de Dios que se menciona en el libro del Apocalipsis.

Las secciones longitudinales publicadas por los josefinos en los álbumes de 1917, 1922 y 1925 han sido posteriormente desarrollados según las investigaciones basadas en las proporciones encontradas para la estructura y a partir de las maquetas y elementos de yeso restaurados, dando lugar a los dibujos de Ramón Berenguer publicados por Puig Boada en 1971 y Jordi Bonet en 1992, así como los más recientes realizados por el Equipo que dirige Jordi Faulí como Director de las Obras, en 2006 y 2007.

312 Cf. Bergós, J. (1974) Gaudí, el hombre y la obra. 2a Edición. Barcelona. Publicaciones de la Universidad Politécnica de Barcelona. P.137. 


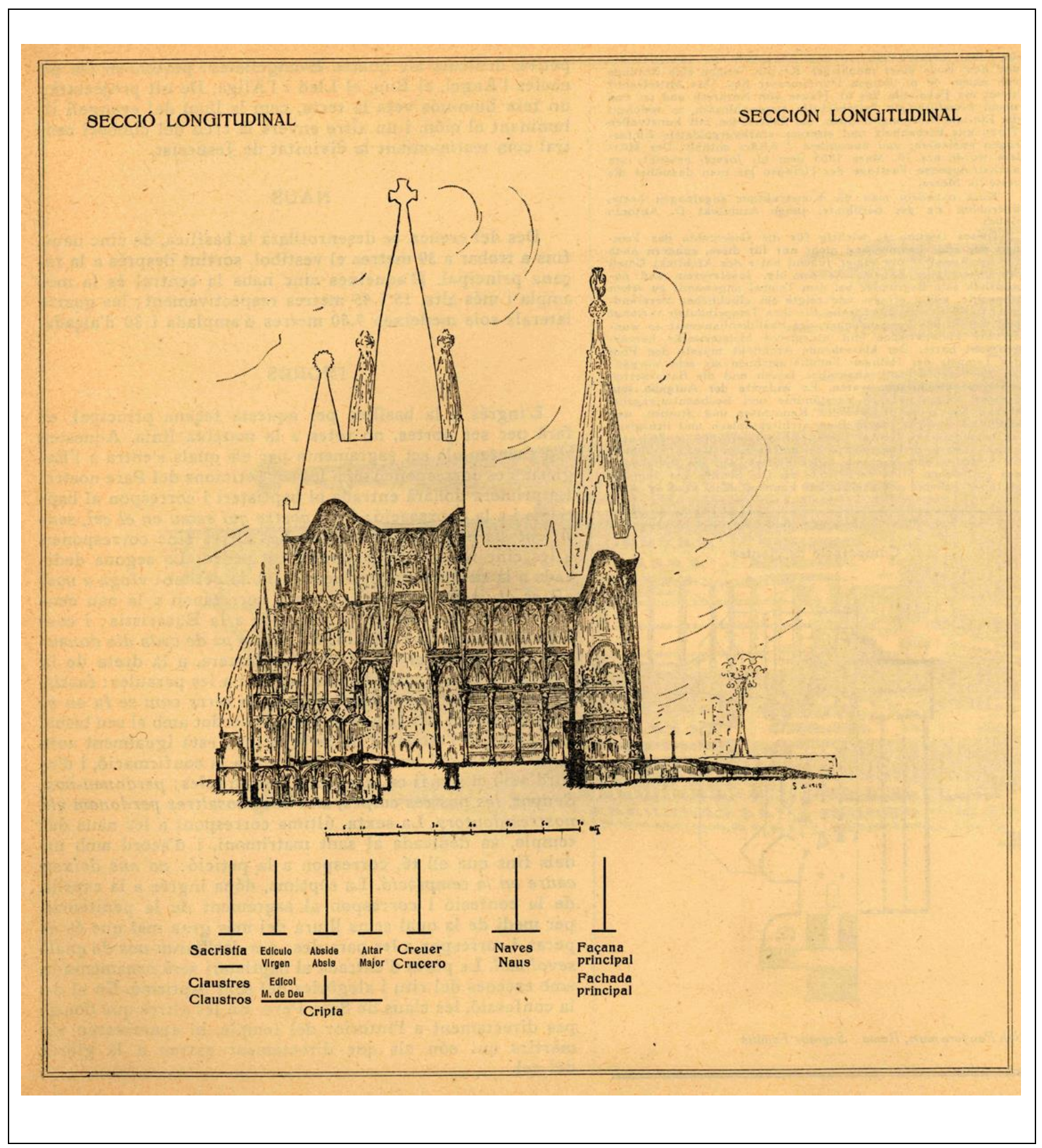

Sección longitudinal, publicada en El Propagador en 1917. Fuente: Archivo de la Sagrada Familia.

Además de los graderíos para el Coro, se aprecian los lampadarios y la relación existente entre las bóvedas de los dos cimborios principales, tema que seguirá desarrollándose con posterioridad, en el que la del ábside presenta una ligera inclinación respecto de la vertical.

La solución estructural corresponde a la segunda versión, parabólica con elementos horizontales de rigidización. Se observa que en los tres dibujos de sección que se reproducen la altura del cimborio de la Virgen ha bajado respecto de las torres de los evangelistas. 


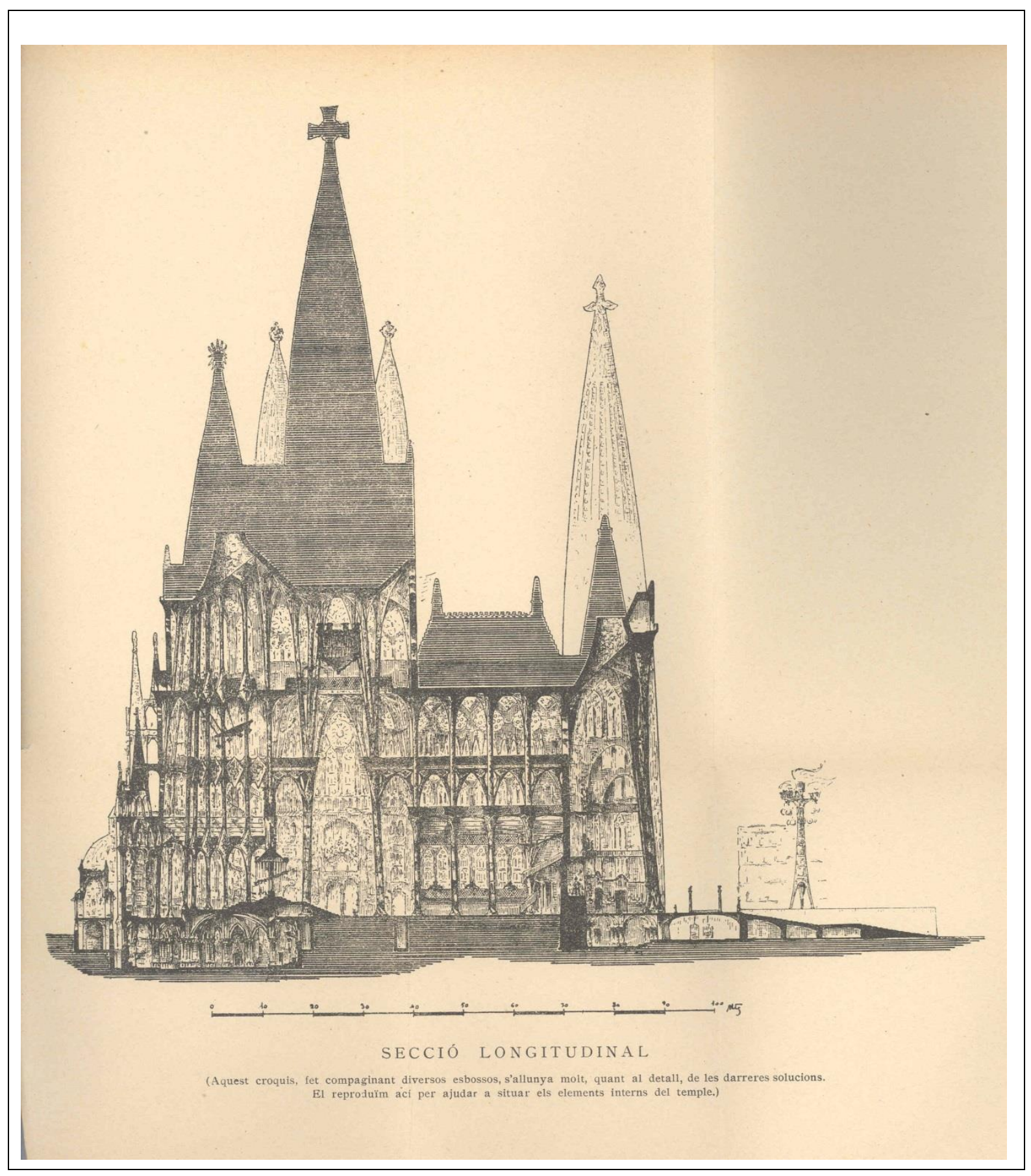

Sección longitudinal publicada en los álbumes de la Sagrada Familia de 1917 y 1922 . La leyenda alerta de su falta de detalle por ser un ensamblaje de diversos bocetos y su alejamiento de las soluciones que se realizaban en esos años. No obstante, aporta una visión del interior que permite percibir la complejidad de niveles del espacio interior. Fuente: Archivo de la Sagrada Familia

En este dibujo ya es perfectamente visible la relación entre las bóvedas de los cimborios y la inclinación respecto de la vertical del correspondiente al ábside, apreciándose su prolongación en altura y desarrollo. La nitidez respecto de los lucernarios del cimborio principal y de la fachada de la Gloria es mucho mayor. 


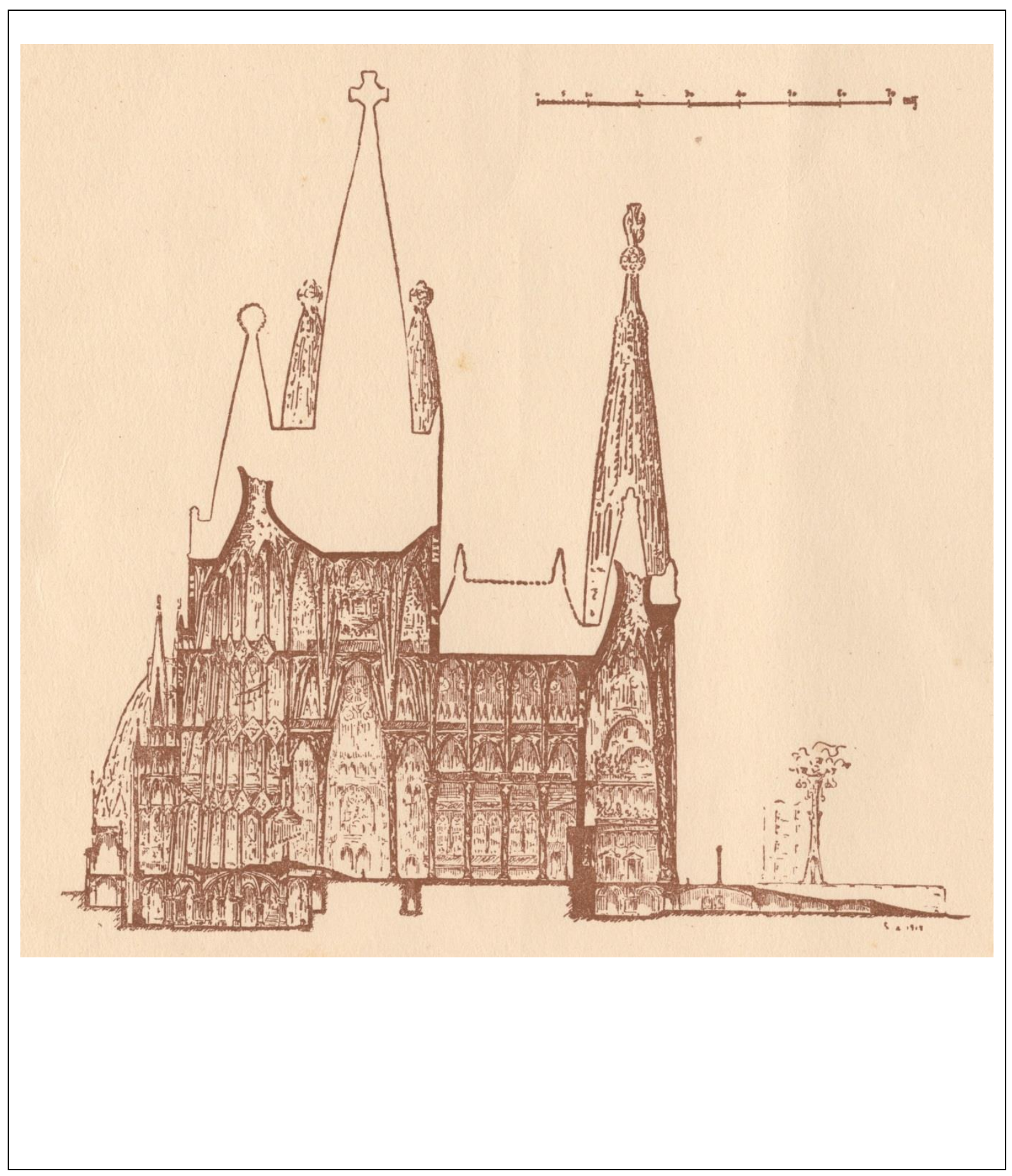

Sección longitudinal publicada en la revista Temple, 1925: Fuente: Archivo de la Sagrada Familia.

Son perfectamente visibles los hiperboloides que conforman la bóveda del cimborio del ábside y los lucernarios de la fachada de la Gloria. La cúpula de las Sacristias presenta una solución completamente diferente al dibujo anterior, realizada mediante paraboloides. 


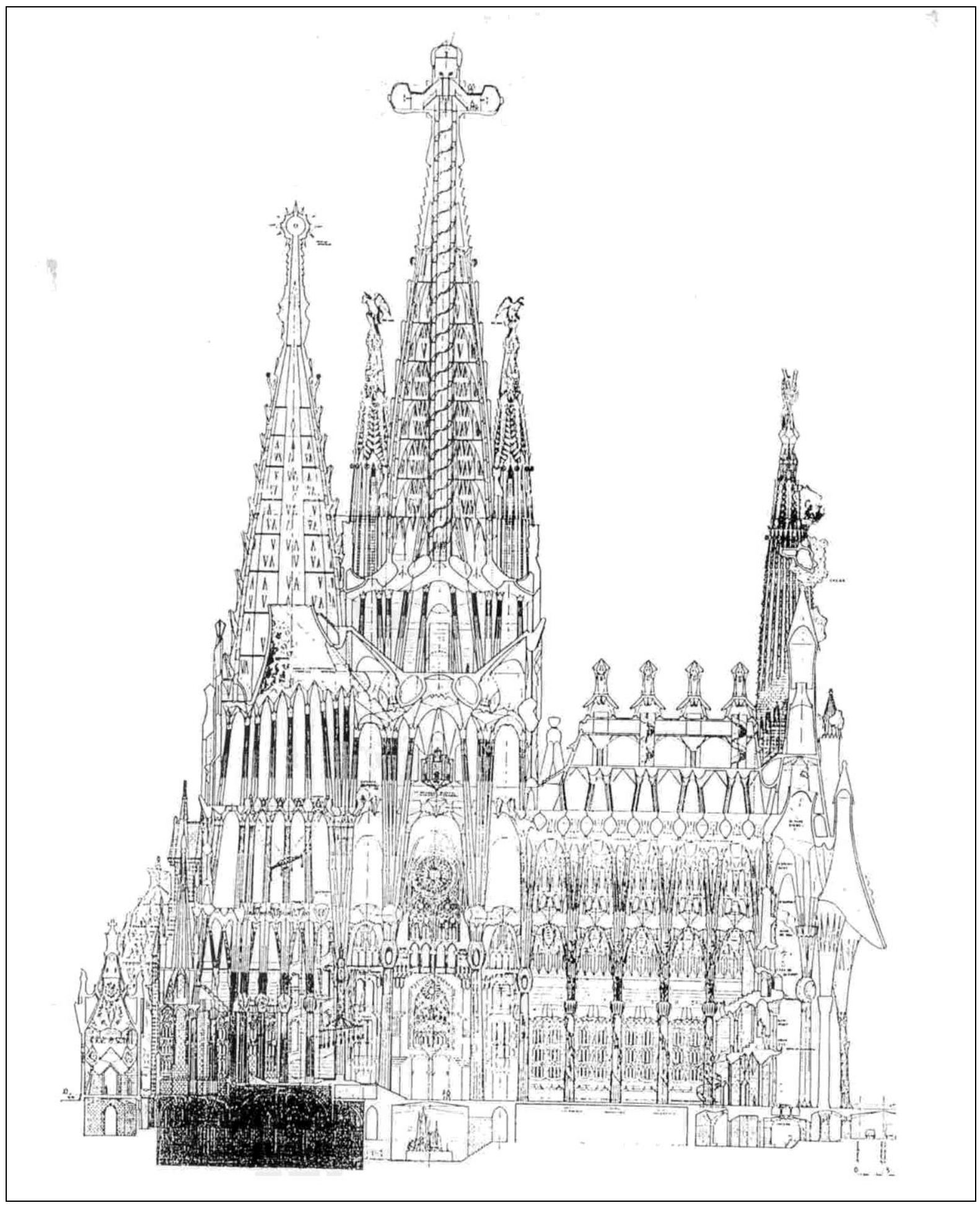

Sección longitudinal dibujada por Ramón Berenguer en 1971, publicada por Puig Boada en 1992. Fuente: Archivo de la Sagrada Familia.

Dibujado en los últimos años de Dirección de Obra de Puig Boada (1966-1974), es un estudio posterior a la sección siguiente. Continua el desarrollo de las torres cimborios principales y los hiperboloides de sus bóvedas, de la sala del cimborio principal y de la fachada de la Gloria. Se mantiene la altura de la Torre del ábside por encima de las torres de los evangelistas. Obsérvese la inclinación de la bóveda del cimborio del ábside. 


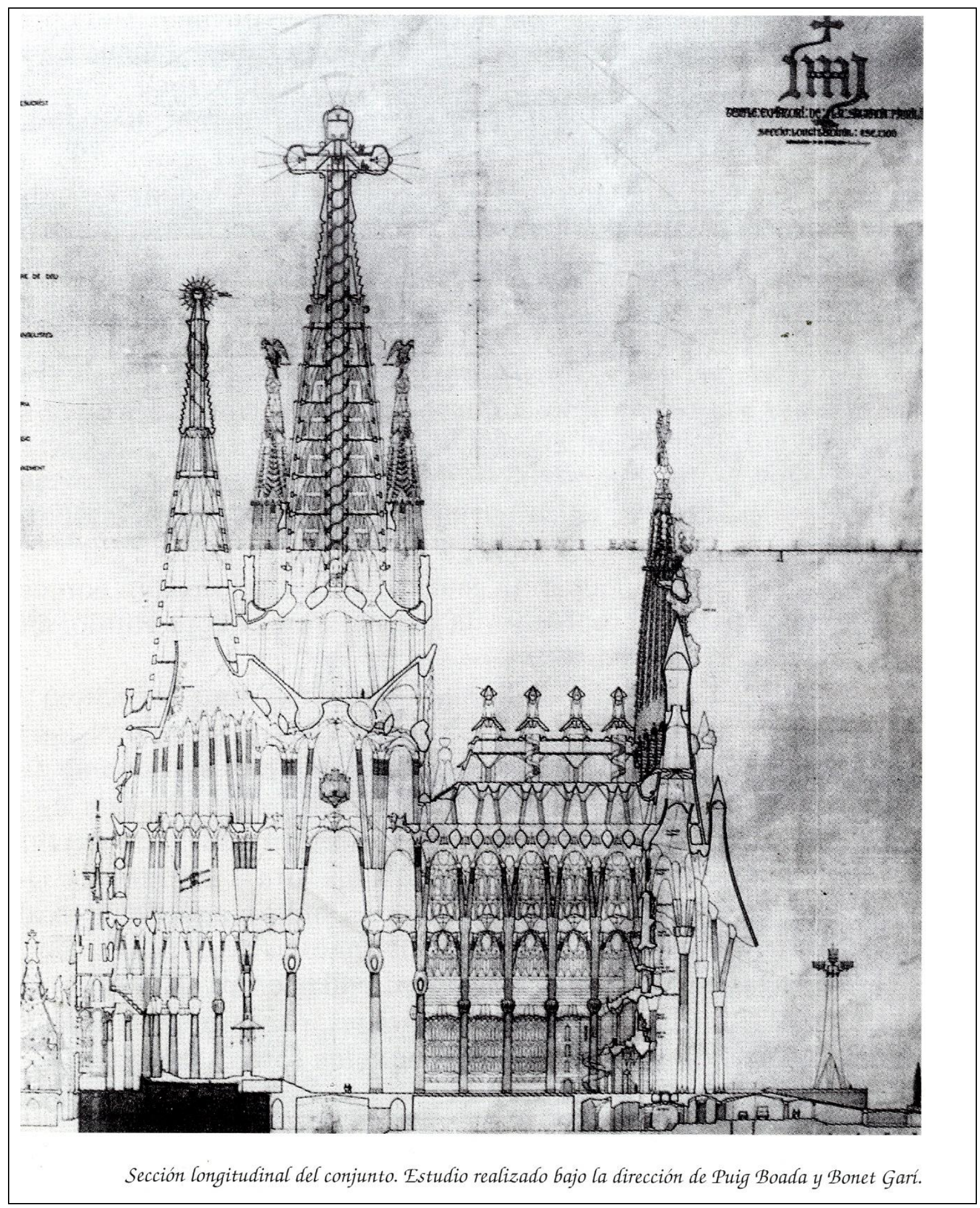

Sección longitudinal. Fuente: Bonet i Armengol, J. (2000) Temple de la Sagrada Familia. Barcelona. Escudo de Oro.

Estudio del periodo de Dirección de Obras de Isidre Puig Boada y Lluis Bonet Garí (1954-1966). Busca ser lo más fiel posible a la sección publicada en 1925 y los estudios de Gaudí, apareciendo por primera vez la Capilla de la Asunción. manteniéndose el paso sobre la C/ Mallorca. Cobra protagonismo el estudio de la fachada de la Gloria y de los cimborios del ábside y del crucero. La torre del ábside crece superando a las de los evangelistas. 


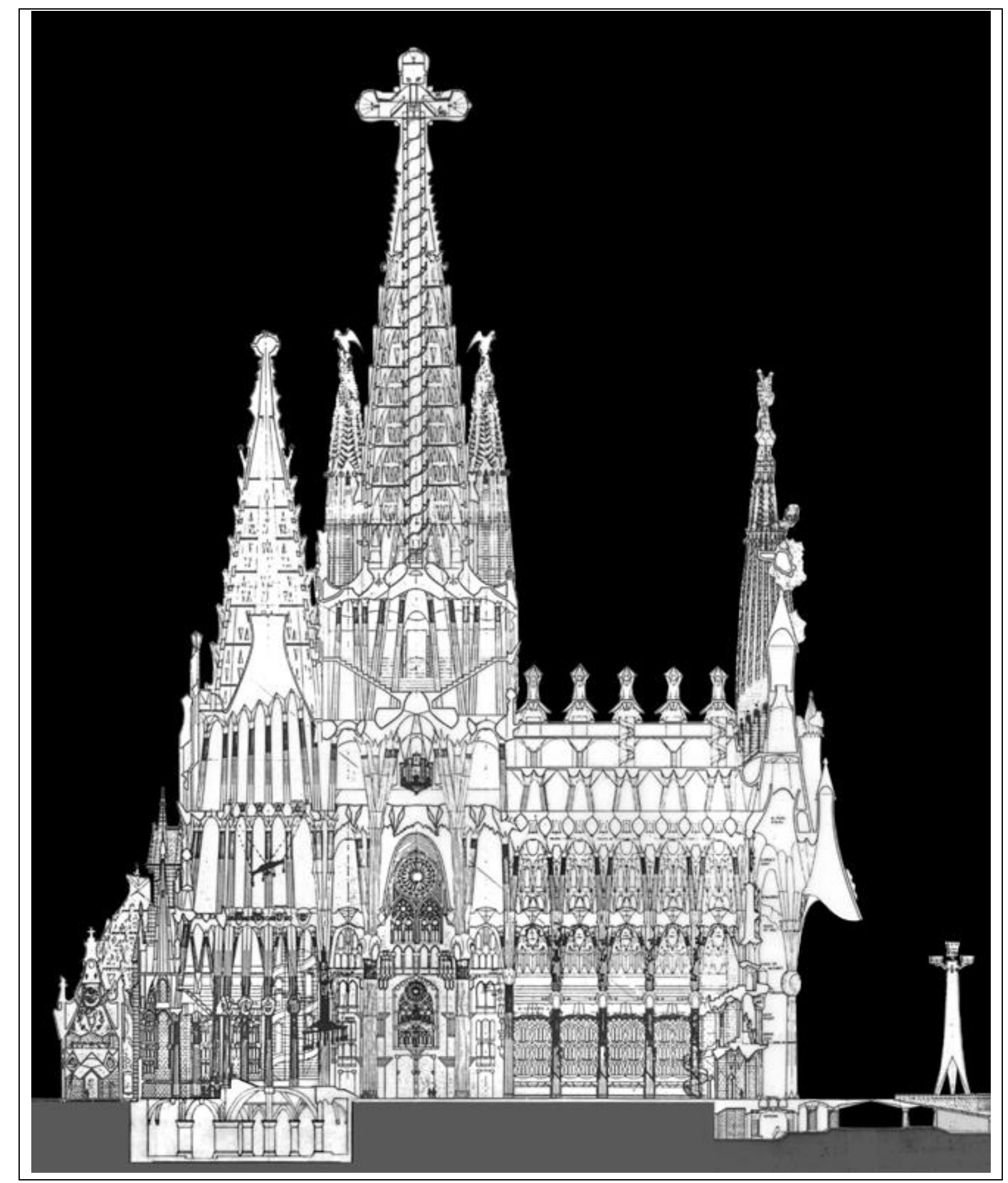

Sección longitudinal dibujada por Ramón Berenguer y Xavier Moreno, publicada por Jordi Bonet, Director de las Obras (2000). Fuente: Oficina Técnica de la Sagrada Familia.

La altura de la torre de la Virgen se equilibra con la de las torres de los evangelistas, y su bóveda interior adquiere ahora la posición vertical. Presenta una gran nitidez el interior de la nave y prosigue la definición de la sala del cimborio del crucero y sus estructuras de sustentación. Se mantiene la disposición del ascensor y escalera en el interior del cimborio del crucero hasta la cruz de remate, aunque sin definición. 


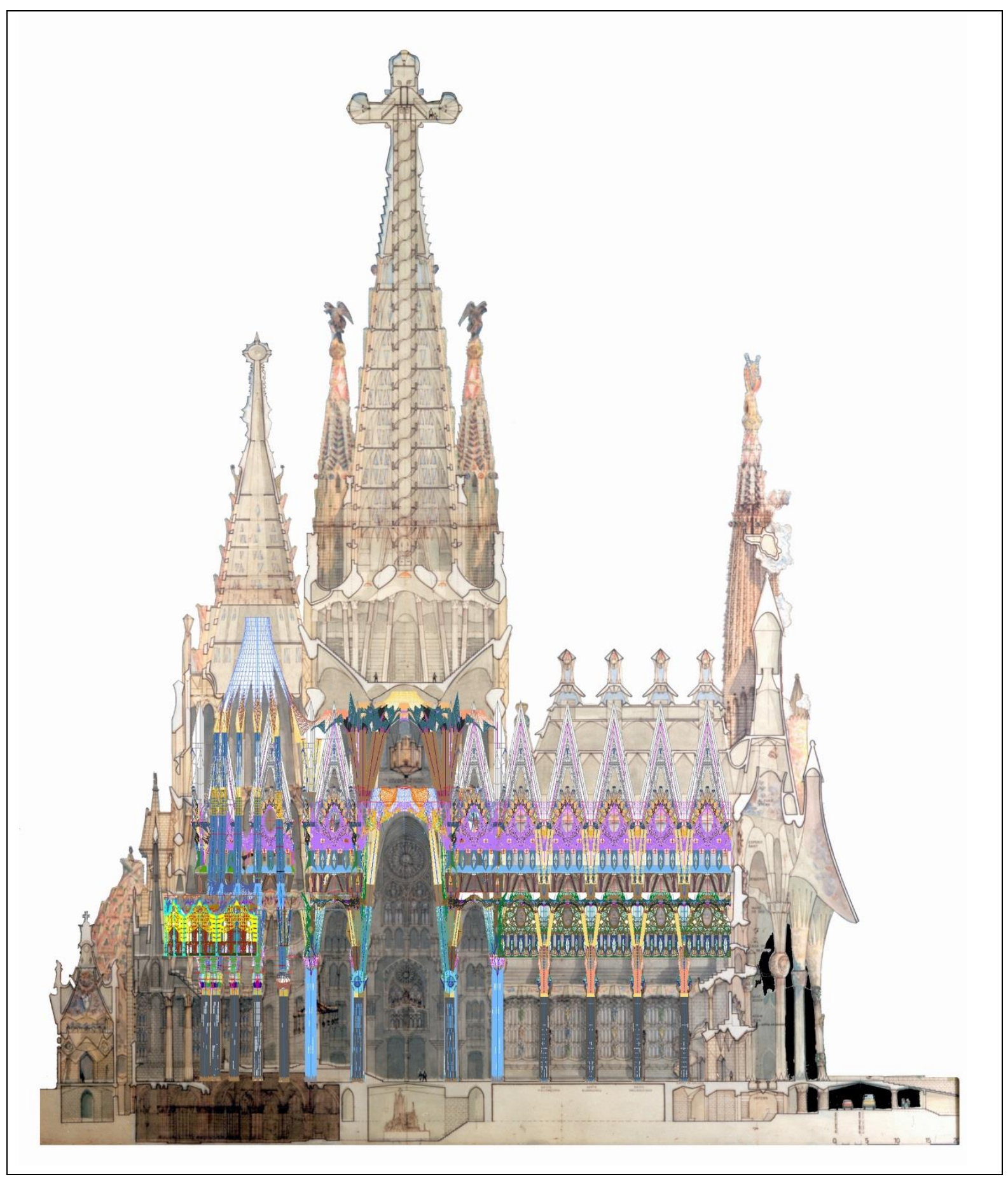

Sección longitudinal publicada por Jordi Faulí, Director de las Obras, en 2006, El Temple de la Sagrada Familia. Madrid. Aldeasa. Fuente: Oficina Técnica de la Sagrada Familia.

Las bóvedas y lampadarios del interior se visualizan mucho más detallados, así como el desarrollo de la secuencia de la iconografía de la fachada de la Gloria: el tema -Padre Eterno-Espíritu Santo-Jesucristo-, la incorporación de las imágenes de Maria y San José con el Niño, y la Casa de Nazaret en una posición intermedia entre ambos. La solución de la bóveda del ábside no es la definitiva pero aparece mucho más desarrollada en forma y materiales, y el protagonismo constructivo y simbólico de la bóveda del crucero no cesa en su desarrollo.

Comienzan a desarrollarse las formas estructurales de la cubierta de la capilla de la Asunción. La altura del cimborio del ábside vuelve a descender. 


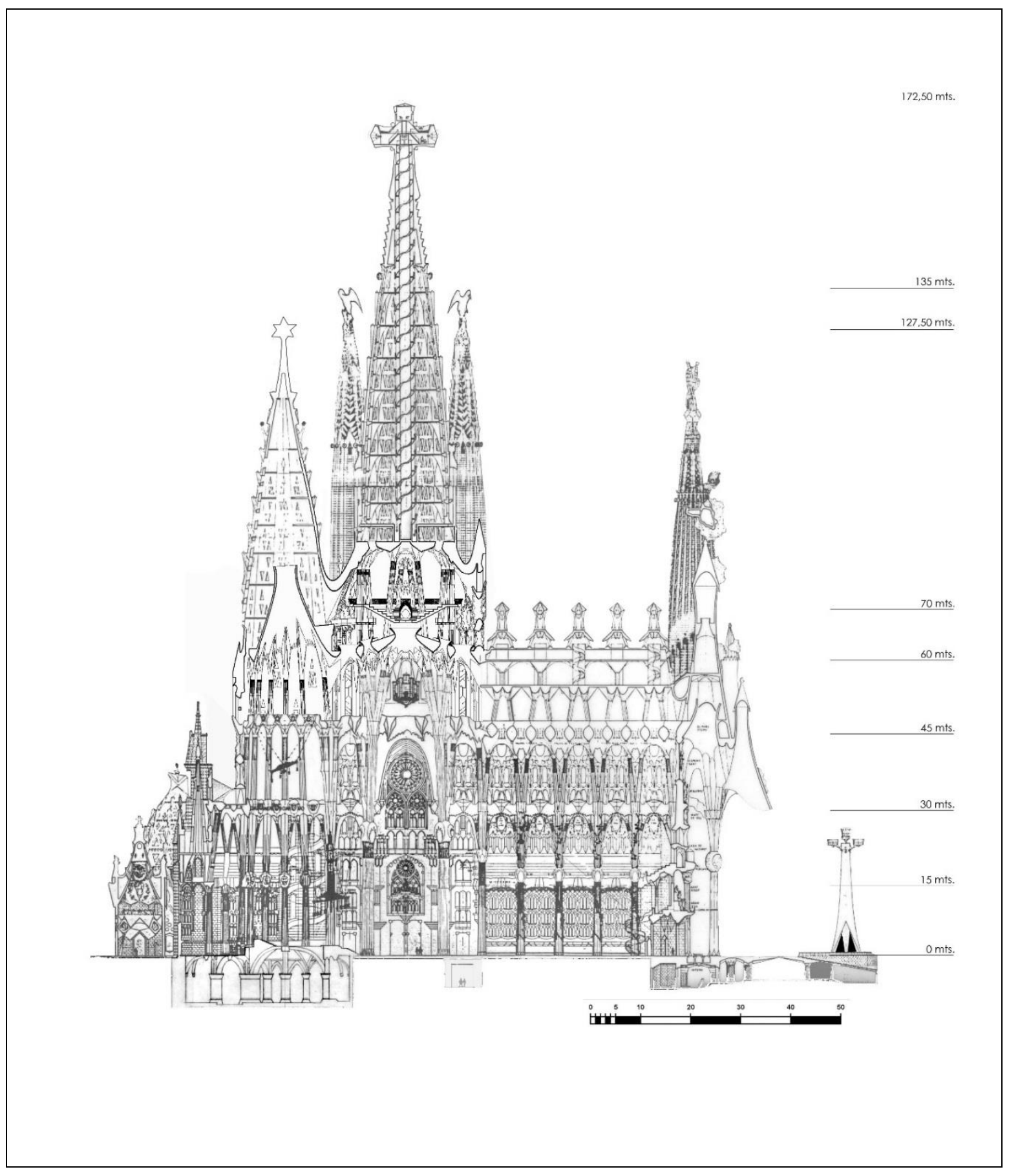

Dibujo de Sección longitudinal realizado para la Exposición de Frankfurt de 2007. Fuente: Oficina Técnica de la Sagrada Familia.

Vuelven a aparecer las referencias a cotas de altura. Se observa con notable claridad que el hiperboloide de la bóveda de ábside retoma una ligera inclinación, así como el desarrollo de la Sala a $70 \mathrm{~m}$ del cimborio central y su hiperboloide lucernario sobre el lampadario de la nueva Jerusalen, quedando por estudiar la situación y sujeción del lampadario del Espiritu Santo, situado a una altura intermedia. 


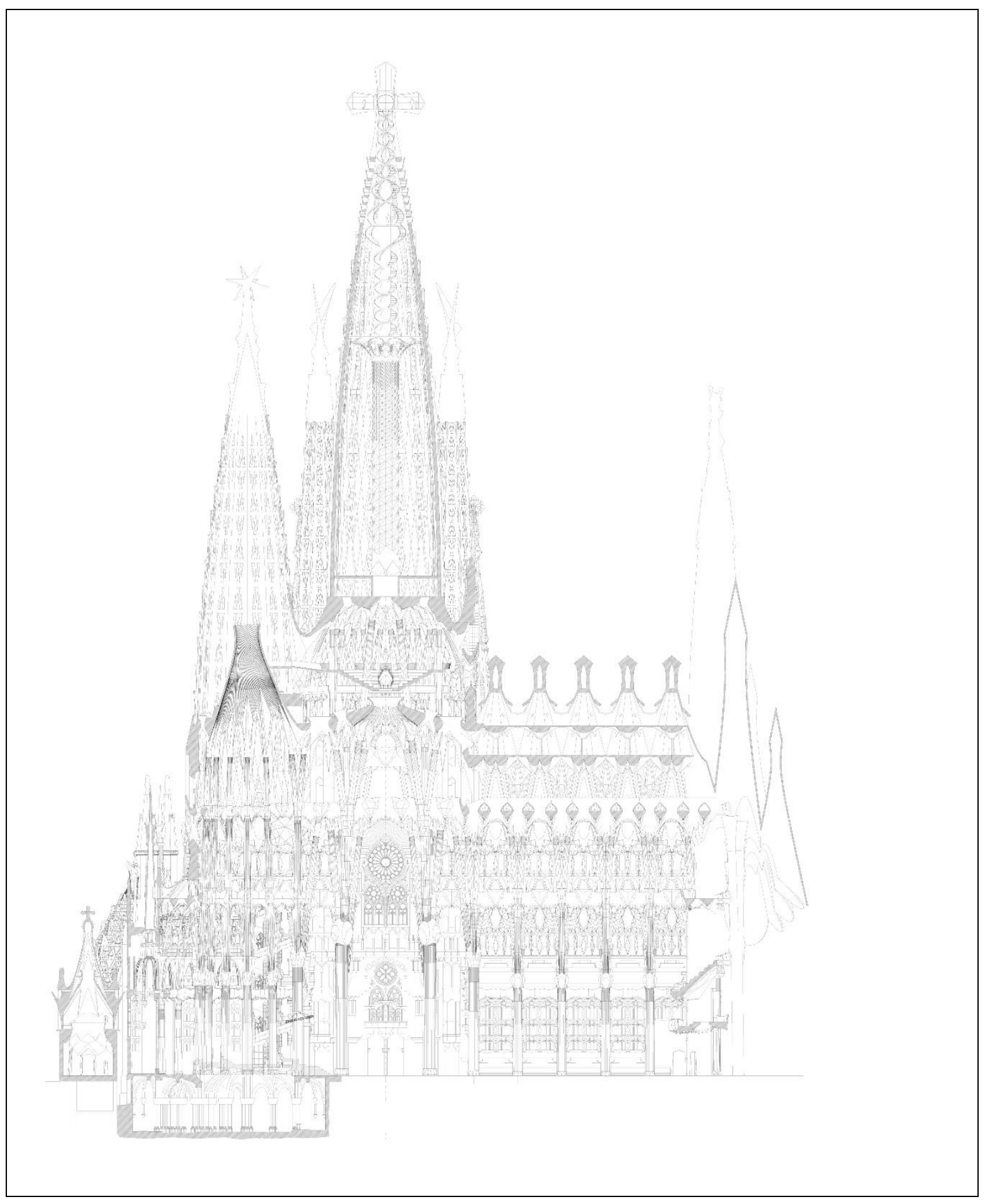

Dibujo de Sección longitudinal realizado en 2014. Fuente: Oficina Técnica de la Sagrada Familia.

Se ha detallado con total precisión la sala en el cimborio del crucero, definiéndose la estructura ambos cimborios, tanto en lo que hace referencia a su estructura de piel como al elevador que discurre por su eje hasta los $125 \mathrm{~m}$. Se mantiene como definitiva la inclinación de la bóveda del cimborio del ábside que recupera su altura sobrepasando ligeramente las torres de los evangelistas que rodean el cimborio central. Así mismo comienzan a dibujare las formas de la estructura de cubrición de la capilla de la Asunción. 


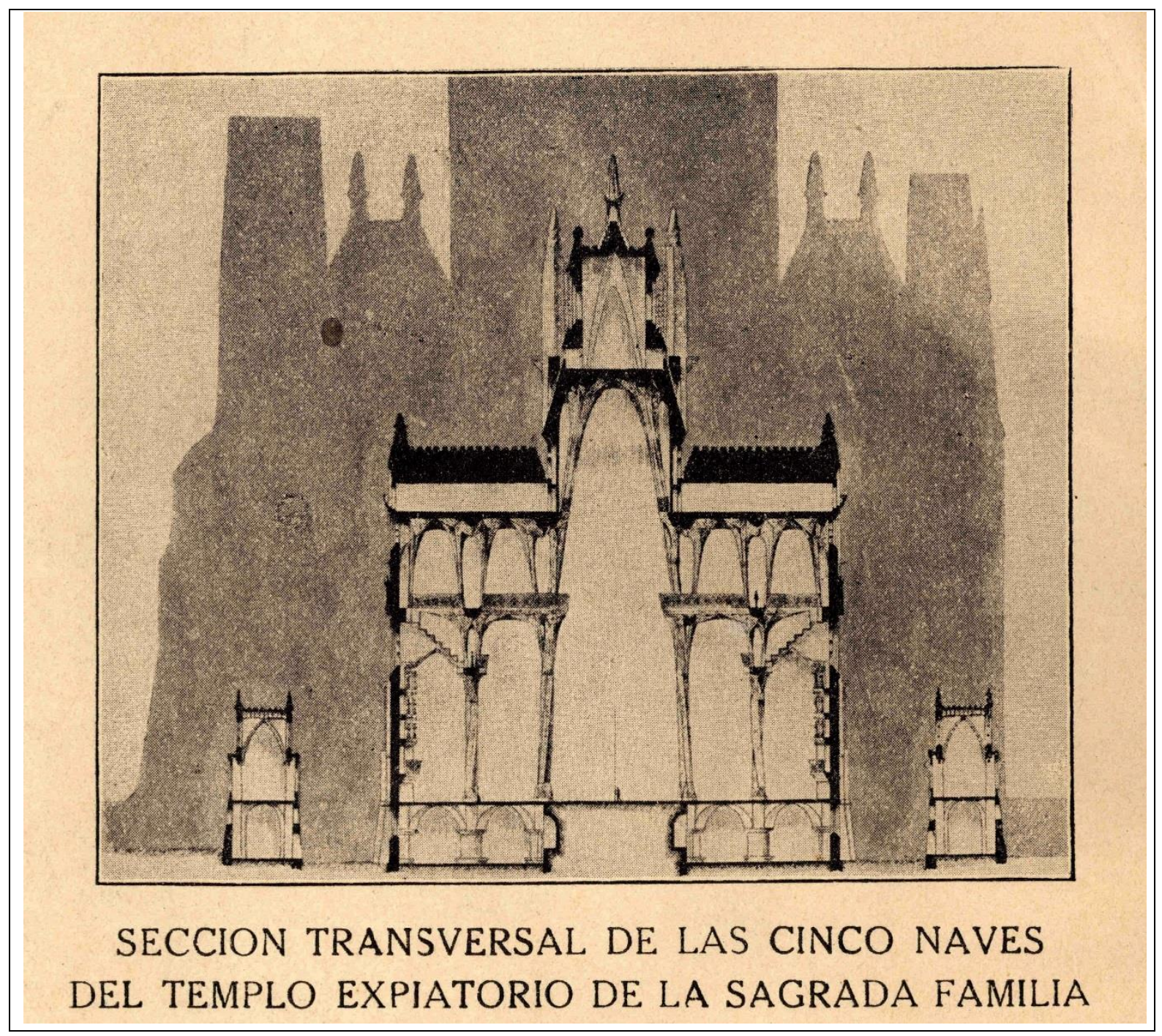

Sección Transversal publicada en el Album de la Sagrada Familia de 1915. Fuente: Archivo de la Sagrada Familia

Se corresponde con la segunda versión para la estructura, basada en paraboloides. Se aprecia que la sección del claustro sigue siendo ojival y también las pasarelas que arriostran la estructura de las naves. 


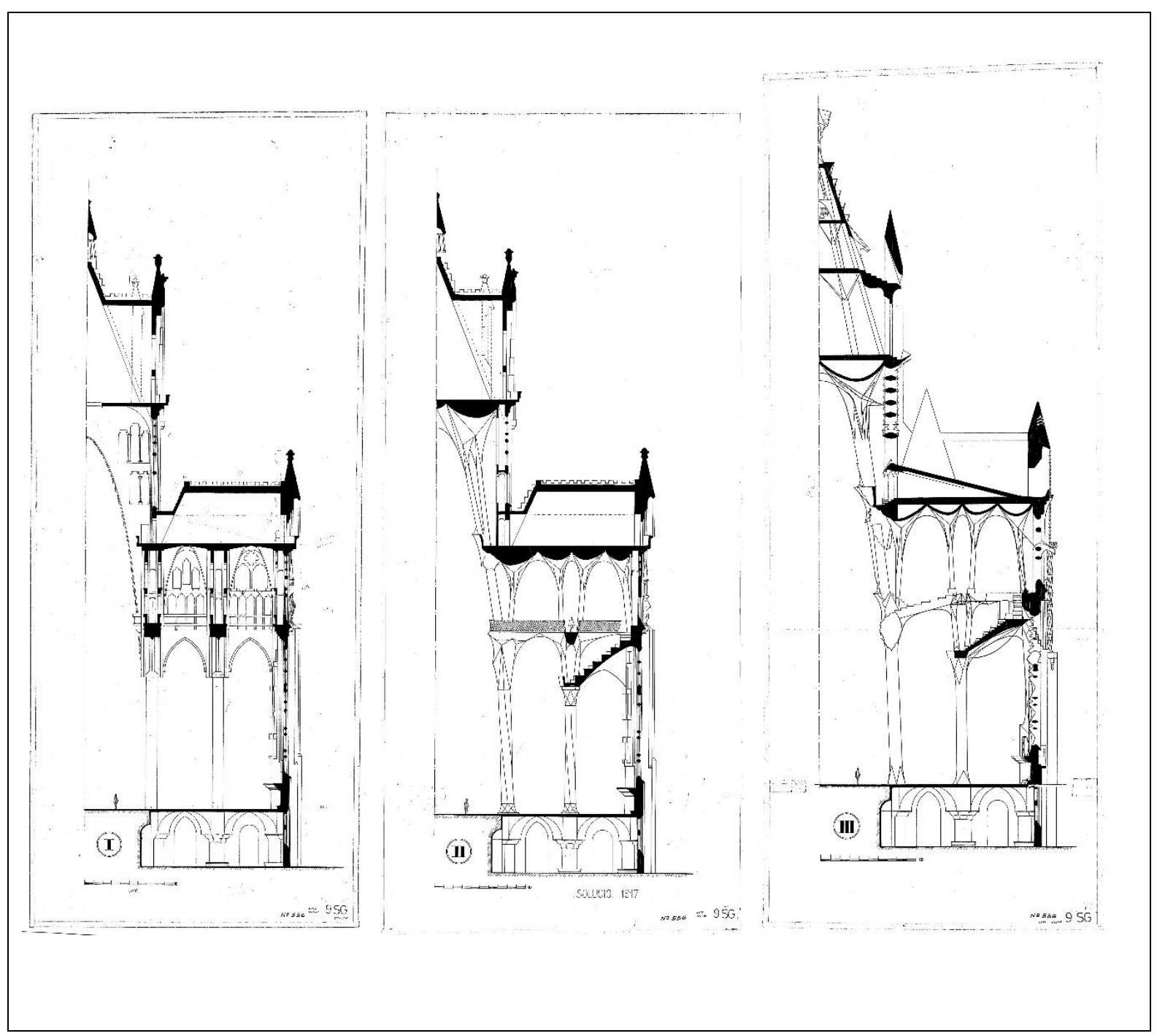

Comparación de las tres soluciones estructurales: neogótica, arboriforme de arcos parabólicos, arboriforme definitiva con hiperboloides y sin elementos horizontales de arriostramiento. Fuente: Archivo de la Sagrada Familia.

La distribución de vanos e imágenes en fachada sigue un orden historicista.

Obsérvese la inclinación de las columnas de la nave central en la segunda solución y el "olvido" o pérdida de interés por el arco ojival en dicha solución. Así mismo la aparición de la estructura arboriforme en los niveles superiores y el estudio de la aplicación de paraboloides e hiperboloides para los ventanales de fachada abren el camino a una gran variedad de iluminación y vitrales.

En la tercera solución cobran mayor protagonismo los nudos de las columnas a la vez que se aligera notablemente la cubierta de las naves laterales. La solución de formas y vanos de la fachada se complica liberándose de la rigidez historicista de soluciones anteriores y adoptando formas geométricas alabeadas. Las imágenes y formas de vanos y macizos de fachadas adquieren un protagonismo mucho mayor con relación a la luz e iluminación de la nave litúrgica, y el programa iconográfico y simbólico. 


\section{DIBUJOS DE PLANTA}

Los dibujos de Planta por sí solos no permiten hacerse una idea del proyecto. Sabido es que Gaudí no otorgaba un excesivo valor a la información que pudiera aportar la planta del edificio y a la misma formulación del documento proyectual al considerar que la obra se iba definiendo con mayor precisión mediante la realización de maquetas y elementos de yeso que le permitían visualizar con mayor precisión el volumen y experimentar con diferentes soluciones constructivas.

El primer plano de planta que se conserva con posterioridad a 1885 (permiso de obras en el Ayuntamiento) es la planta de enterramientos de 1916, realizada para acompañar la solicitud de inhumación en la Cripta. Aunque se trata de una planta subterránea, en el se perciben inmediatamente los cambios producidos:

- Las portadas se han desarrollado en extensión adoptando una disposición esquemática en planta correspondiente a una autentica fachada que básicamente será la que se mantendrá a posteriori. Se aprecia que la portada del Nacimiento está mucho más perfilada que las otras dos.

- El claustro sigue uniendo las portadas pero no tiene una anchura fija pero se ha desarrollado sobremanera incorporando los espacios correspondientes a las sacristías y capillas provocando además soluciones especiales en los ángulos del solar. En el caso de las capillas del Bautismo y de la Penitencia se visualizan diversos espacios adyacentes que las envuelven, y la portada de la Gloria dispone de exonártex o pórtico previo.

- El volumen de las naves aparece claramente separado del claustro por espacios libres completándose el claustro que aparecía esbozado en el plano de 1885.

Las plantas publicadas en 1917 y 1923, siguen la disposición general establecida en la planta subterránea anterior, siendo su diferencia más notable la aparición de la capilla de la Asunción en el claustro en la versión de 1923.

En ambas el esquema de planta de la portada de la Pasión aparece ya completamente configurado con detalle, a diferencia de la portada de la Gloria que permanece a un nivel esquemático. Sin embargo, ambos dibujos recogen con bastante precisión sendas propuestas para el diseño de la zona de aproximación y acceso en la vía pública, con soluciones diferenciadas para cada fachada que incluyen el diseño del resto de la manzana y más allá de ella en el caso de la orientación de la calle Mallorca. La fachada de la Gloria incorpora una escalinata sobre un túnel para salvar la calzada de vehículos y el esbozo de dos grandes elementos exteriores próximos a las esquinas para el desarrollo de la fuente y del tedero como símbolos de las capillas.

En ambos casos la solución prevista para las capillas es independiente de la nave litúrgica, con acceso directo desde la calle aunque articulada con el resto del edificio mediante el claustro y con una comunicación propia con aquella. La planta de 1926 recoge la última solución general en vida de Gaudí -por ello la tomaremos como planta base para diversos planteamientos y comentariosapreciándose en ella una composición en planta madura de los espacios litúrgicos aunque todavía con algunos encuentros puntuales pendientes de resolución como por ejemplo los encuentros de Capillas y Sacristías con el Aula Litúrgica, o las escaleras que comunican los distintos niveles de estas últimas. En cambio, la portada de la Gloria ha adquirido un fuerte protagonismo, claramente diferenciado de las otras dos, configurando una interesante secuencia de pórtico y nártex a nivel de planta, estructura e iluminación. 


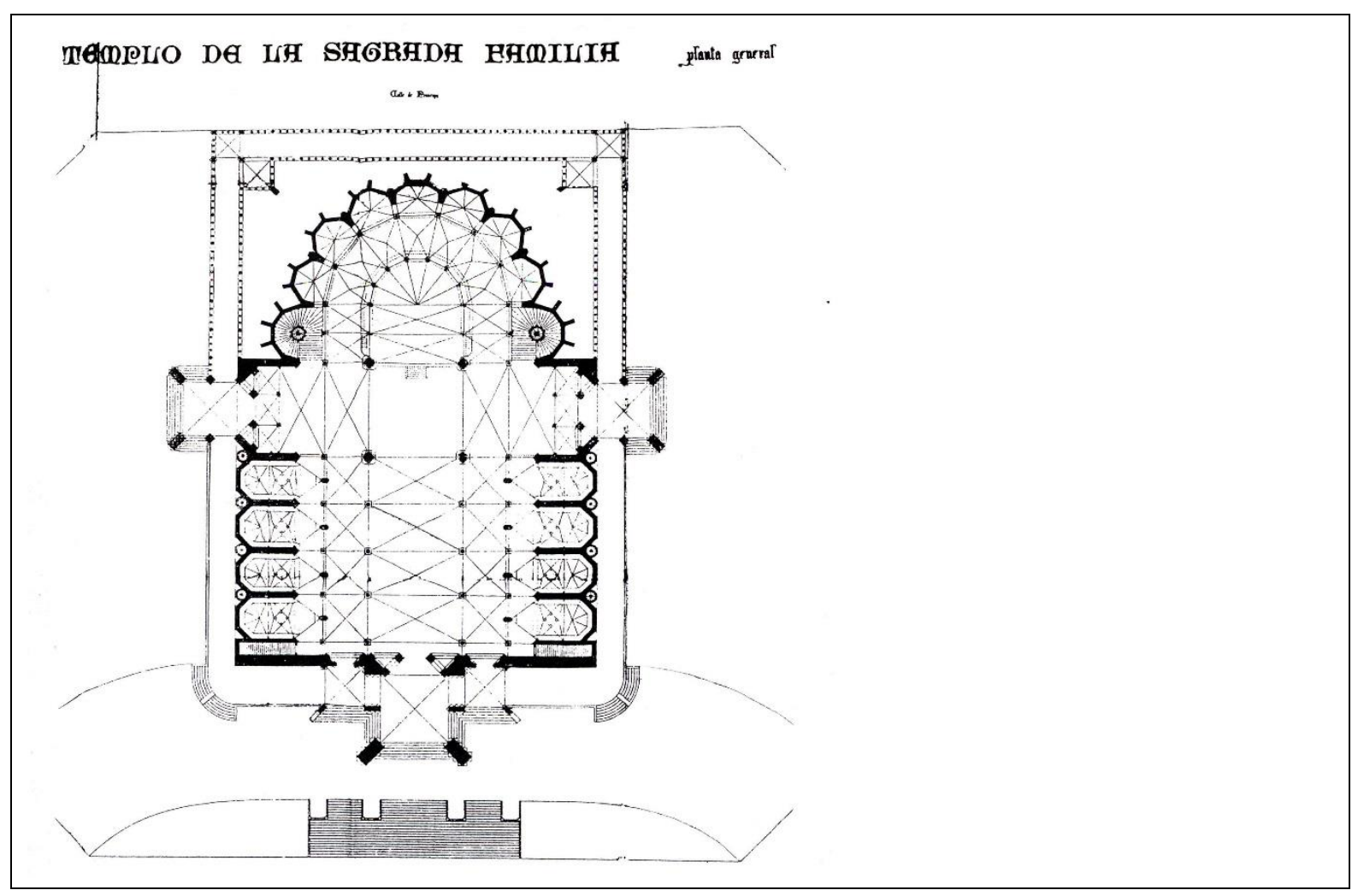

Planta del proyecto de Gaudí presentado en 1885 al Ayuntamiento de Sant Martí de Provençals para la obtención del Permiso de Obras. Fuente: Archivo de la Sagrada Familia.

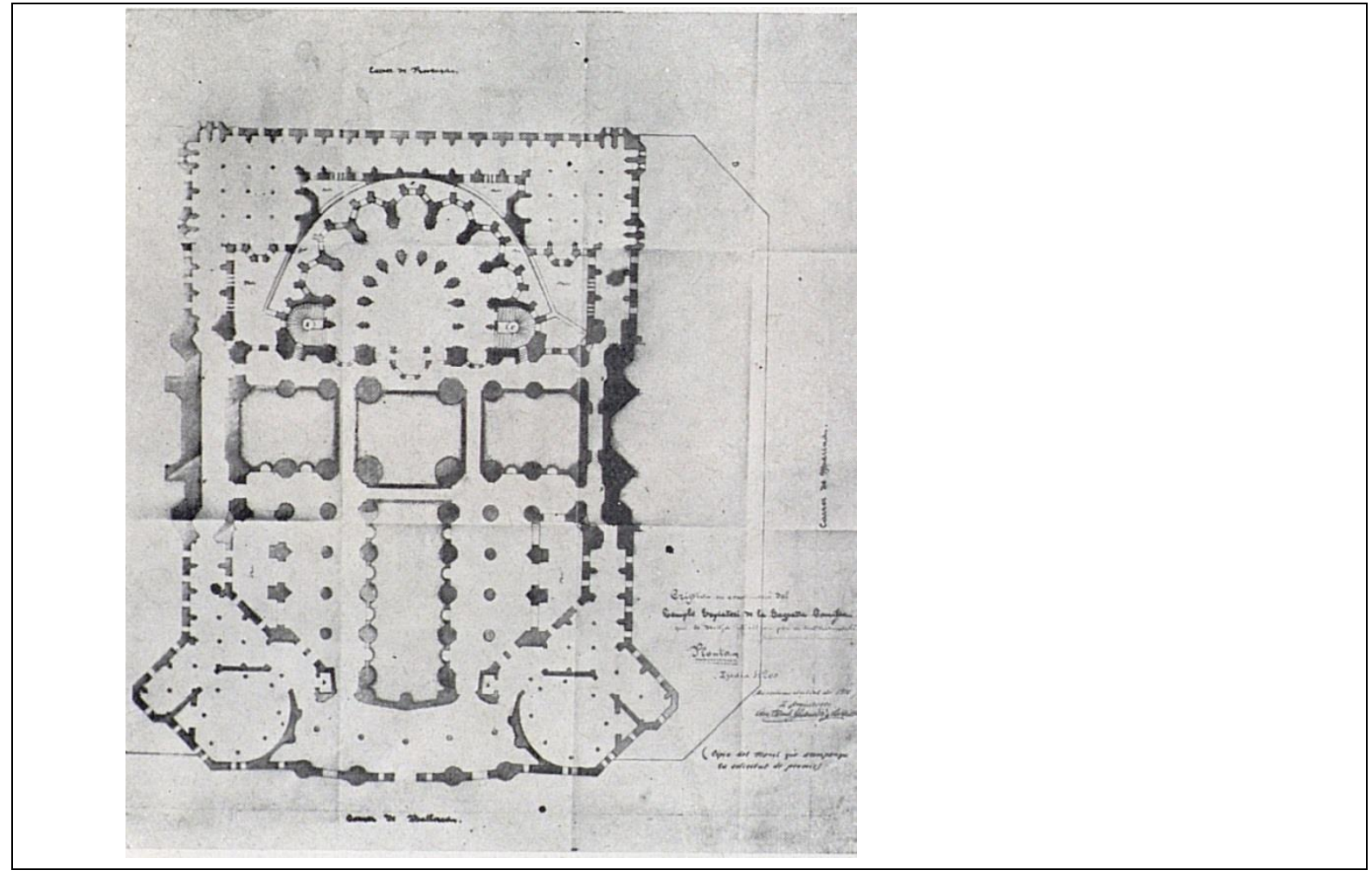

Planta de Enterramientos, subterránea, firmada por Gaudí en 1916. Fuente: Puig Boada, I. 
La solución de la portada de la Gloria aparece definida en su complejidad de acuerdo con la sección longitudinal y las maquetas realizadas por Gaudí en el taller, constituyendo una nueva propuesta completamente diferente a las del transepto, en la que cobra protagonismo esencial la luz. La construcción de sendos lucernarios en voladizo y la madura adaptación de las bases de los campanarios como nártex de acogida son consecuencia de la mayor definición de la nave celebrativa. Llama la atención la creación de nuevos accesos desde el exterior al claustro. La distribución de las capillas del Bautismo y la Penitencia está más elaborada y estudiada en su comunicación con el resto del edificio y el exterior. Se percibe una cierta pérdida del esquema básico de planta cruz latina en beneficio de una solución más centralizada. También hay que mencionar la rotundidad de la diferenciación de espacios en las Sacristias con una solución exenta para la escalera que ha de comunicar sus cuatro niveles y la comunicación con la girola, así como las entradas al claustro en los laterales de la Capilla de la Asunción con lo que el total de accesos a la Sagrada Familia que aparecen en este dibujos seria de 7 en el nivel de las naves:

- Portada del Nacimiento

- Portada de la Pasión

- Portada de la Gloria

- Acceso al Claustro desde calle de la Marina

- Acceso al Claustro desde calle Córcega

- Acceso lateral derecho de la Capilla de la Asunción desde calle Cerdeña

- Acceso lateral izquierdo de la Capilla de la Asunción desde calle Cerdeña

Se reproducen a continuación las plantas generales realizadas con posterioridad a la muerte de Gaudí:

- Planta acuarelada por Ramón Berenguer, publicada en 1992 por la revista Temple, recogiendo desarrollos correspondientes a los periodos de dirección de las obras de Isidro Puig Boada (etapa final), y Lluis Bonet Garí y Francesc Cardoner, así como el comienzo de la etapa de dirección de Jordi Bonet i Armengol. Recoge la denominación de los distintos espacios y recintos así como la simbología. Como cambios más importantes se aprecia el cambio de dirección en las capillas del Bautismo y la Penitencia que pasan a estar orientadas según el eje longitudinal del Templo. Así mismo se visualiza su permeabilidad con el claustro a través de diferentes accesos y la disposición de este rodeando circularmente las capillas. También se replantea la ubicación de los ascensores y escaleras de las cantorías en su proximidad.

- Planta del año 2000, correspondiente al periodo de dirección de las obras de Jordi Bonet i Armengol. Continua el desarrollo de Capillas y Sacristias -y el Claustro que las rodea- según las directrices tomadas en la planta de 1992, reelaborando con mayor precisión la solución de la fachada de la Gloria y de los ascensores y escaleras de las cantorías. Se percibe en esta planta con nitidez el ambicioso programa de la fachada de la Gloria que anteriormente aparecía sólo esbozado.

- Planta del año 2004, correspondiente a los últimos años de dirección de obra de Bonet i Armengol. Se reestudia la orientación de las capillas y sus accesos volviendo a una concepción semejante a la avanzada en 1926. La solución de detalle de la fachada de la Gloria se estabiliza con la ubicación de los ascensores y escaleras encajados entre los muros de las torres campanarios. El claustro que envuelve las capillas pasa de ser radial a longitudinal. 


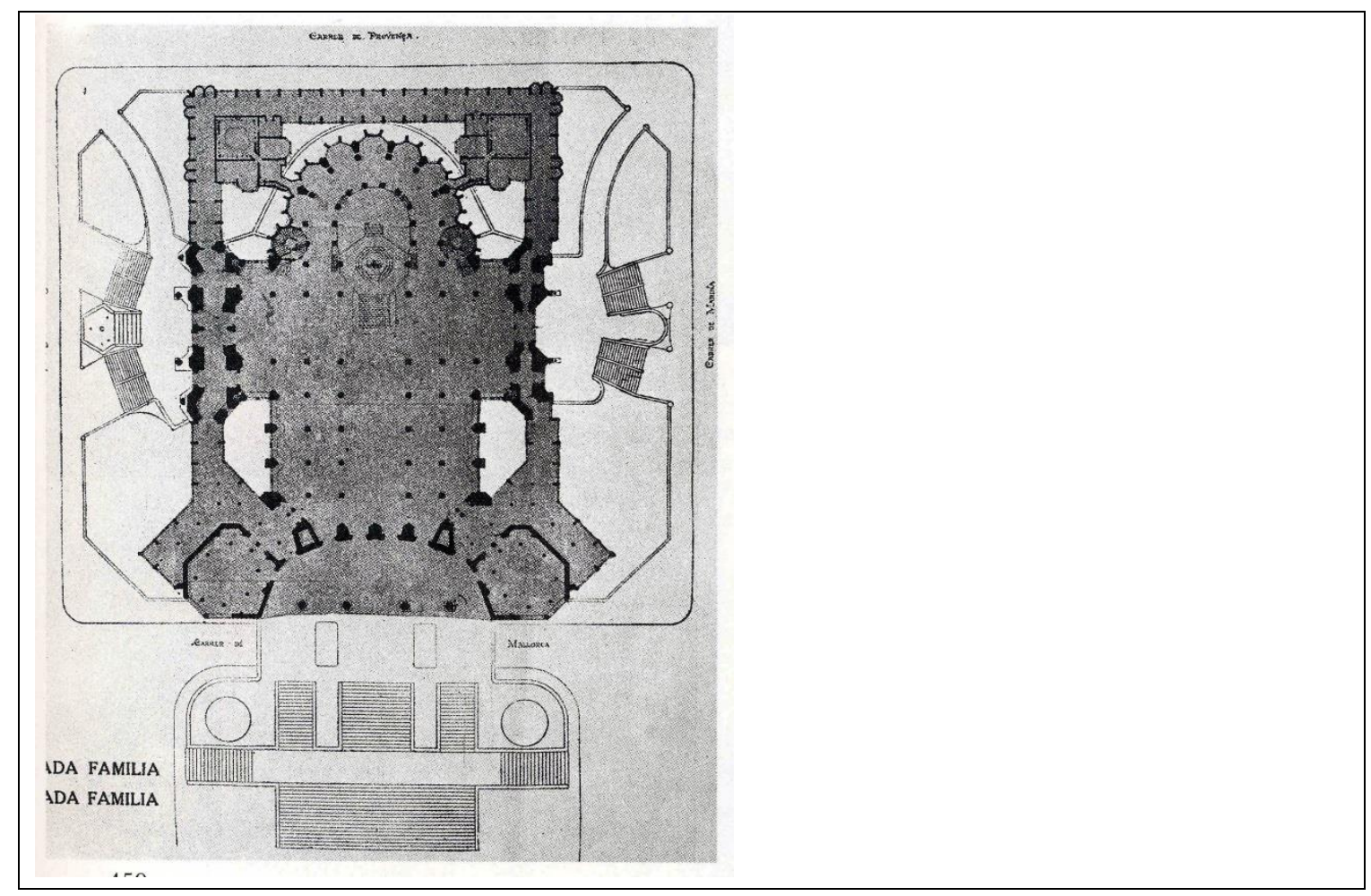

Planta dibujada en 1917 y publicada en el Propagador el 1-04-1917. Fuente: Archivo de la Sagrada Familia.

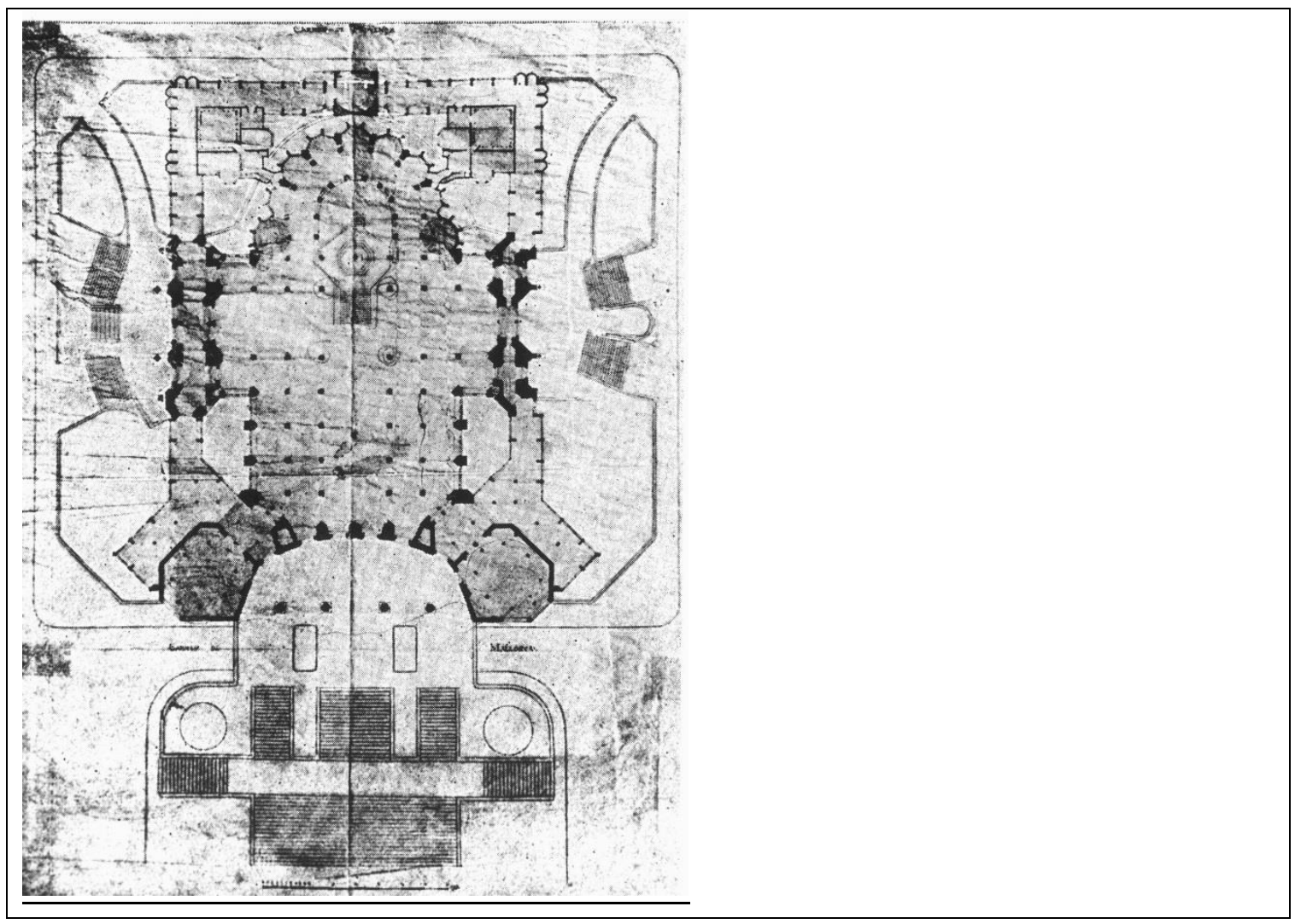

Planta de la Sagrada Familia, 1917, modificada en 1923 y publicada en la Hormiga de Oro el 17-03-1923 y en el Album de la Sagrada Familia 1925 del Propagador. Fuente: Archivo de la Sagrada Familia. 


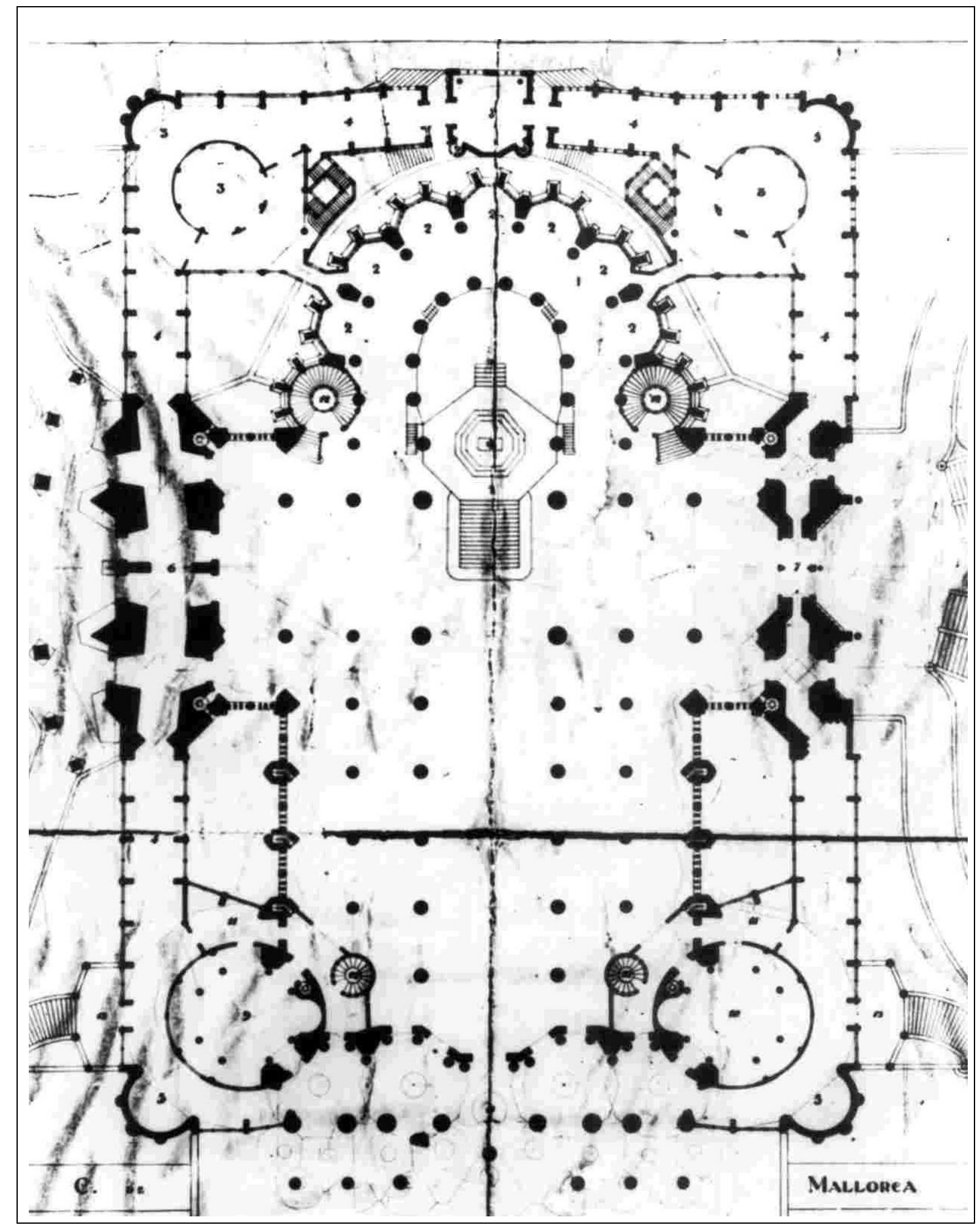

Planta de la Sagrada Familia según los últimos dibujos de Gaudí en 1926, publicada en el 4 Album de la SF en 1929, reproducida también por Puig Boada en 1981. Fuente: Archivo de la Sagrada Familia. 


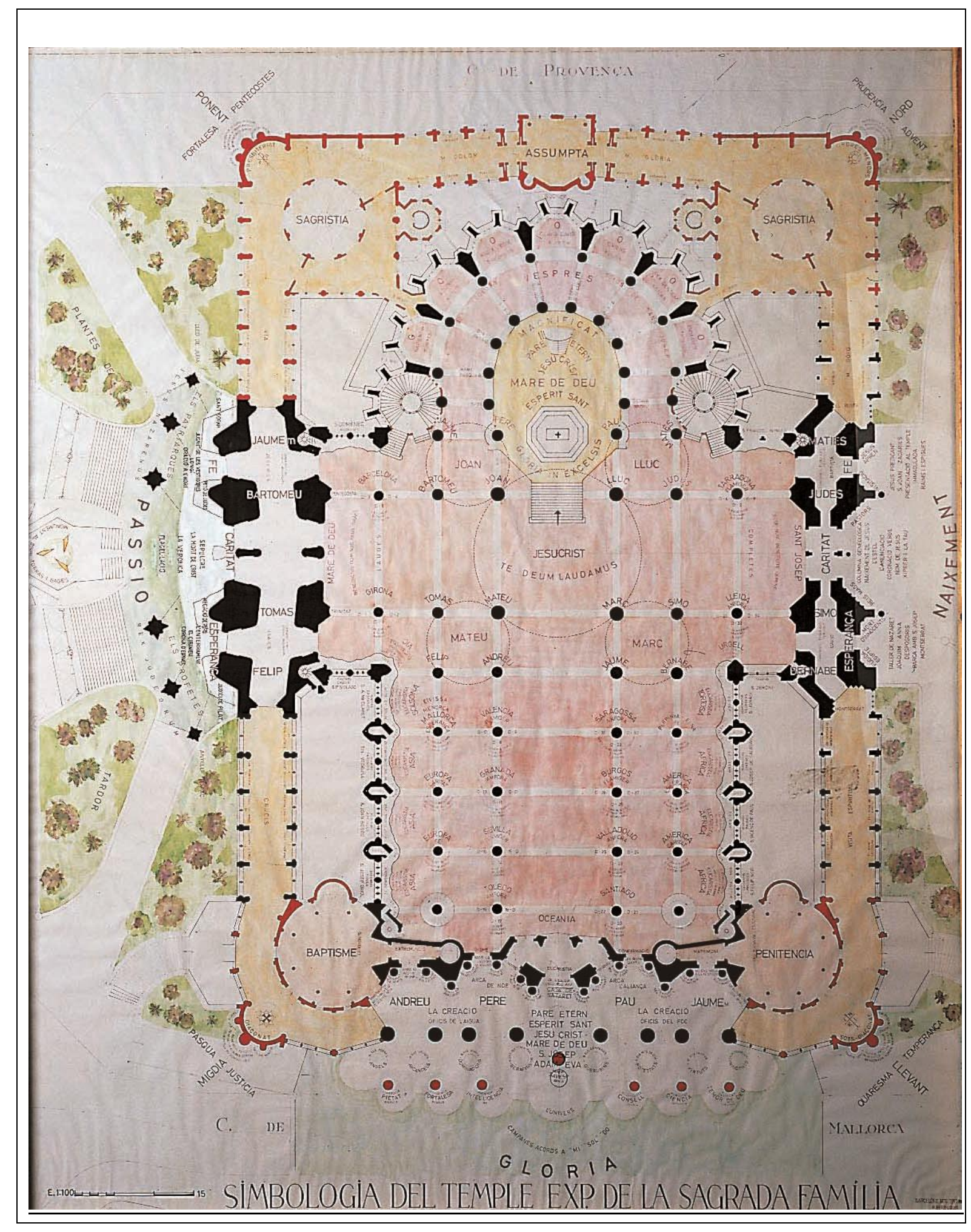

Planta de la Sagrada Familia que realizada durante las sucesivas etapas de Dirección de las Obras de Puig Boada, Bonet Garí y Codoner, acuarelada en 1992 por José Ramón Berenguer.Fuente: Archivo de la Sagrada Familia y Tesis Doctoral de Jordi Faulí. 


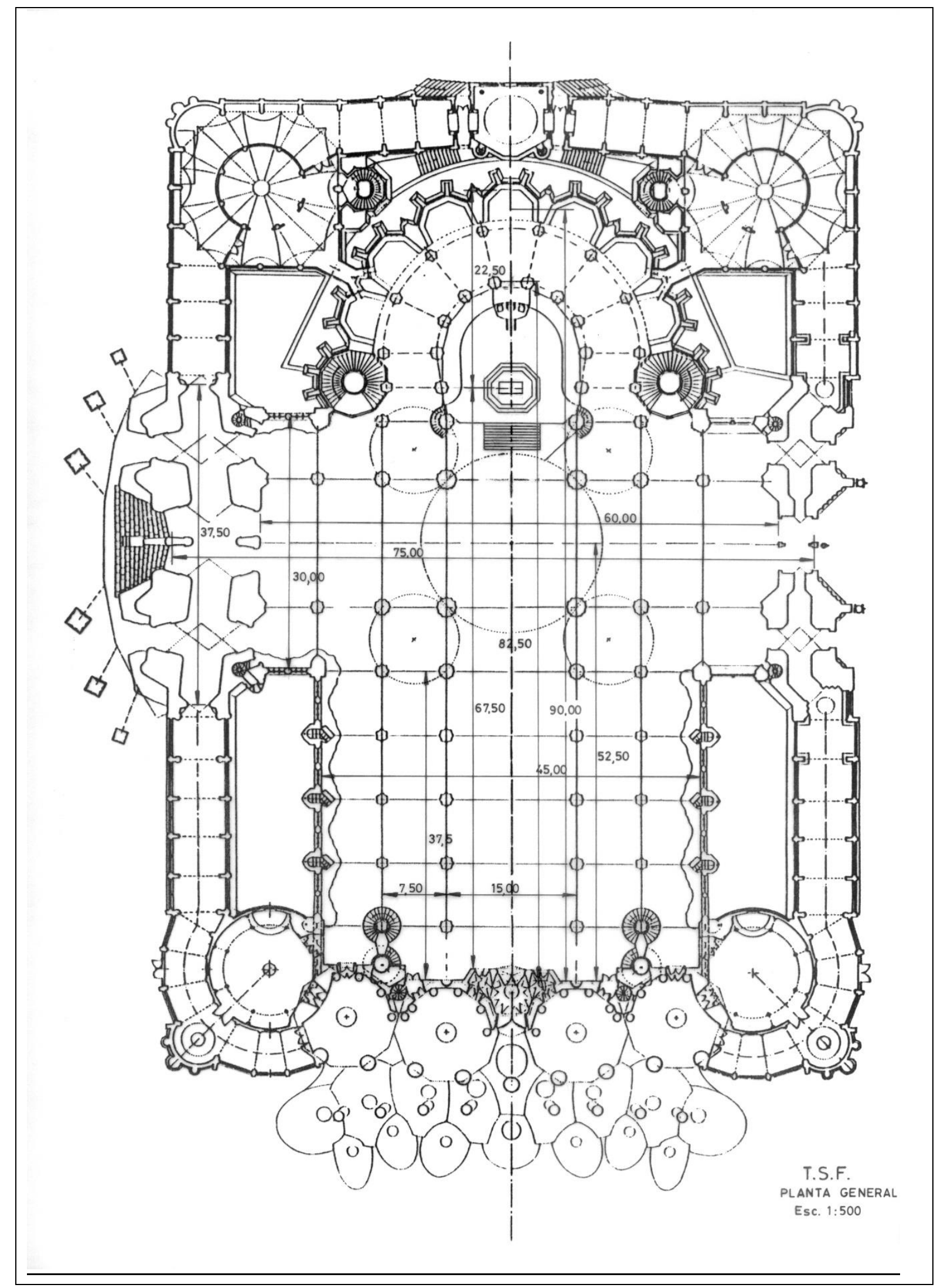

Planta de la Sagrada Familia de 2000, durante el periodo de Dirección de las Obras de Jordi Bonet i Armengol.

Fuente: Archivo de la Sagrada Familia y Tesis Doctoral de Jordi Faulí. 


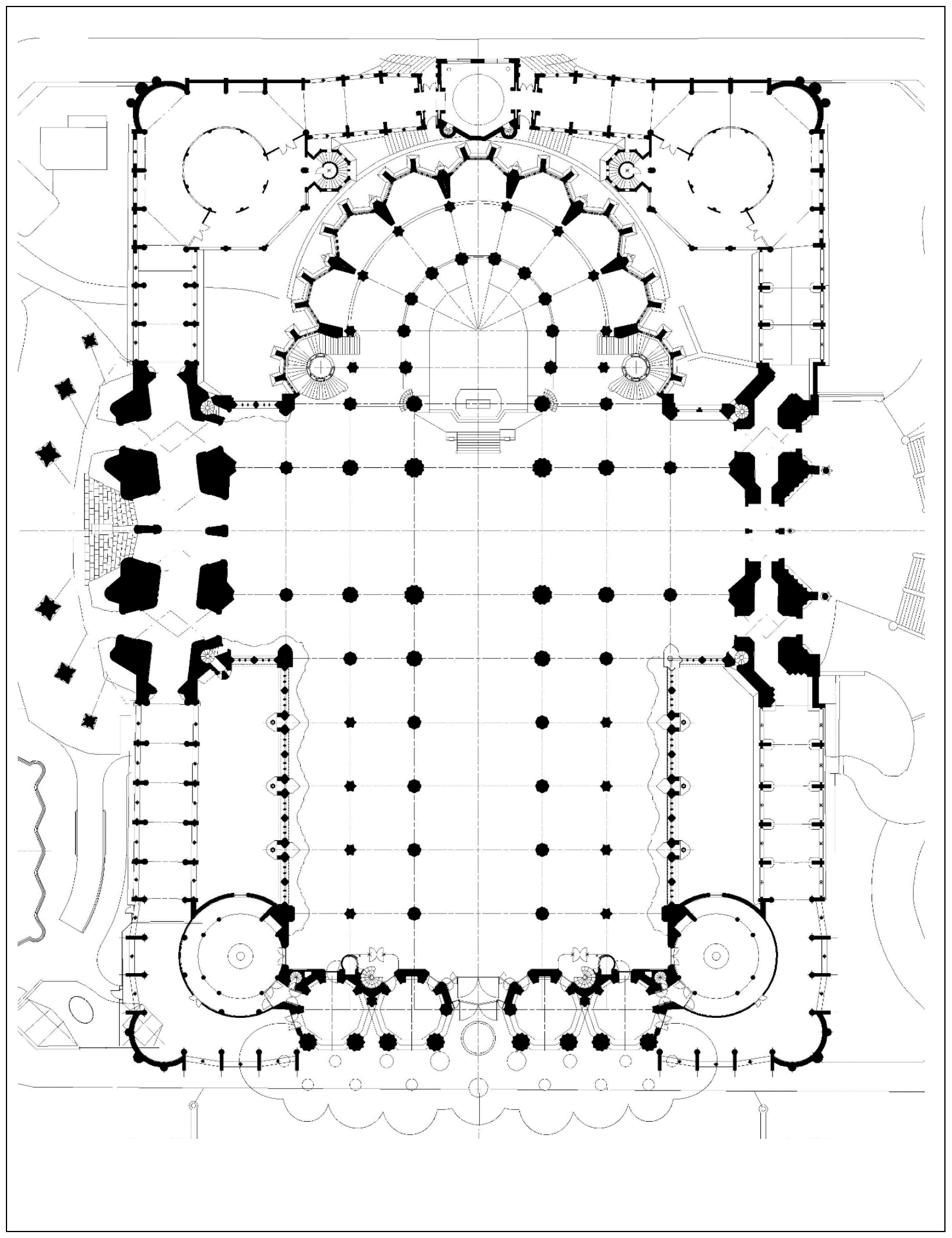

Planta de la Sagrada Familia del año 2004 durante el periodo de Dirección de las Obras de Jordi Bonet. Fuente: Archivo de la Sagrada Familia y Tesis D. de Jordi Faulí, actual Director de la Oficina Técnica. 


\subsection{El enfoque cultual del proyecto de Gaudí a través de la tdentificación de los espacios litúrgicos en la Sagrada Familia.}

\section{a) Identificación del proyecto arquitectónico con la dimensión celebrativa.}

Históricamente la arquitectura eclesiástica nos ha dejado iglesias de gran valor artístico pero que no siempre han respondido a la dimensión celebrativa de la asamblea cristiana allí reunida, unas veces porque se edificaban en tiempos de decadencia litúrgica y en consecuencia su funcionalidad era muy limitada, otras porque su carácter paradigmático se podía percibir más nítidamente como profano que religioso, como un monumento o templo al uso de cualquier creencia o religión de la antigüedad. La concepción del edificio-iglesia como lugar arquitectónico donde una comunidad se reúne para celebrar la Pascua cristiana -el misterio de la muerte y resurrección de Jesucristo-, el resto de sacramentos y otras acciones sagradas de los bautizados, no siempre se ha percibido claramente. En este sentido, con relación a la adecuación teológico-litúrgica del lugar donde se reúne la asamblea cristiana, la Sagrada Familia supone un hito histórico. El proyecto de Gaudí se enmarca, desde finales del siglo XIX hasta 1926, en unos años en que la Iglesia Católica bendice la Renovación litúrgica iniciada en los monasterios benedictinos centroeuropeos como el impulso oportuno para despertar del letargo individualista y devocionista en que se había anquilosado la vida eclesial. Si nos atenemos a las palabras de Gaudí -en la Sagrada Familia todo es providencial- la conjunción de una amplia iniciativa popular con un arquitecto de la formación, inquietud, sensibilidad y brillantez de la talla del joven reusense da lugar a una obra singular en la que ni el coste económico, ni la oportunidad política ni los mass media han sido determinantes.

Juan Eduardo Cirlot es pionero en centrar el estudio de las intervenciones de Gaudí en edificios de culto dentro de su concepción teológico arquitectónica (coincidente con lo que señala McNamara de la arquitectura eclesiástica al servicio de la percepción de realidades celestiales que de otra manera serian invisibles) y concretamente, respecto de la Sagrada Familia, dice que en ella Gaudí "intenta realizar la idea absoluta de basílica, en la que cada elemento soporta una intención teológica"313, de tal manera que nos encontraríamos ante un ejemplo "vivo" de la relación teología-liturgia-arquitectura.

Cesar Martinell (La Sagrada Familia, 1952) vincula el proyecto de la Sagrada Familia con su aptitud respecto del alto fin a que se destinaba y la dignidad que éste requería, y ésta visión se corresponde plenamente con la idea de la arquitectura de los espacios de culto que Gaudí avanzaba en el Manuscrito de Reus ${ }^{314}$.

313 Cf. Cirlot, J.E. (2002) "El Arte de Gaudí", en Gaudí. AAVV. (Reproducción del libro original del mismo título de Cirlot .1950. Barcelona. Omega) Barcelona. Ajuntament de Barcelona/ Triangle Postals.

${ }^{314}$ Cf. En esta misma investigación el apartado 4a. La idea de arquitectura religiosa en Antonio Gaudí a través de sus escritos. 
Afirma que su constante y meditado trabajo de creación, investigación y ensayos se encauza a resolver las cuestiones del culto y la excelencia del porte que quiere dar al conjunto del edificio. Sin concesiones acomodaticias a estilos históricos o soluciones genéricas su imaginación y capacidad creadora afrontan cuantos problemas se presentaban ante su ambicioso propósito. Desde esta perspectiva de autor, de la que Martinell se hace eco, éste propone estudiar el proyecto desde cuatro puntos de vista: Utilitario, Iconográfico, Artístico y Constructivo, siendo que a mi parecer los tres últimos están al servicio del primero, pues ya Gaudí escribía que la primera cualidad que ha de tener un objeto para ser bello es satisfacer el objeto a que está destinado pero sin que eso suponga caer en el utilitarismo, sino afrontando el reto proyectual desde todos los ángulos posibles al objeto de lograr su unidad y armonía. Para ello explica que la composición, dimensión, forma, color y medida de los elementos han de estar íntimamente relacionadas y Gaudí encuentra en la Liturgia Católica la argamasa intelectual y espiritual que tiene todo previsto. ${ }^{315}$

La presente investigación quiere destacar la coherencia entre la idea de arquitectura religiosa que Gaudí plantea en sus escritos y comentarios, y su posterior plasmación práctica en los proyectos de arquitectura eclesiástica que ejecuta. Es más, quiere incidir en el diálogo entre el conocimiento litúrgico que poseía el arquitecto y la dimensión comunitaria del culto cristiano, como idea fundamental a la que subordinar aspectos técnicos y artísticos del edificio-iglesia en la relación causa fin. Funcionalidad litúrgica, técnica y concepción artística se unen en un trípode proyectual sobre el que se asienta el concepto del edificio cultual. Ciertamente que la funcionalidad ha de seguir las líneas que marca para su uso la liturgia cristiana y el enfoque de ésta y sus ritos no han sido iguales en la Edad Media, Trento, a comienzos del siglo XX o con posterioridad al Concilio Vaticano II, por lo que cada arquitectura es hija de su tiempo, pero también de la estabilidad del trípode. Por ello se pretende un acercamiento al proyecto desde la óptica de un diálogo interactivo de la Arquitectura con la Liturgia cristiana para el atemperamiento del topos, pero sin perder de vista el momento histórico en que se establece ni descontextualizarlo de él. En la Sagrada Familia hay suficientes indicios de este diálogo como para que, si se encuentran sus claves, se puedan extraer conclusiones válidas para el ejercicio de la arquitectura eclesiástica. Aquí se encuentra una construcción asentada en sólidos cimientos teológicos, estructurales y artísticos con independencia de su lenguaje formal.

\footnotetext{
${ }^{315}$ Cf. Puig Boada, I. (1981) El Pensament de Gaudí: compilació de textos i comentaris Barcelona. La Gaya Ciencia. Pp. 34, 103, 218, etc.
} 

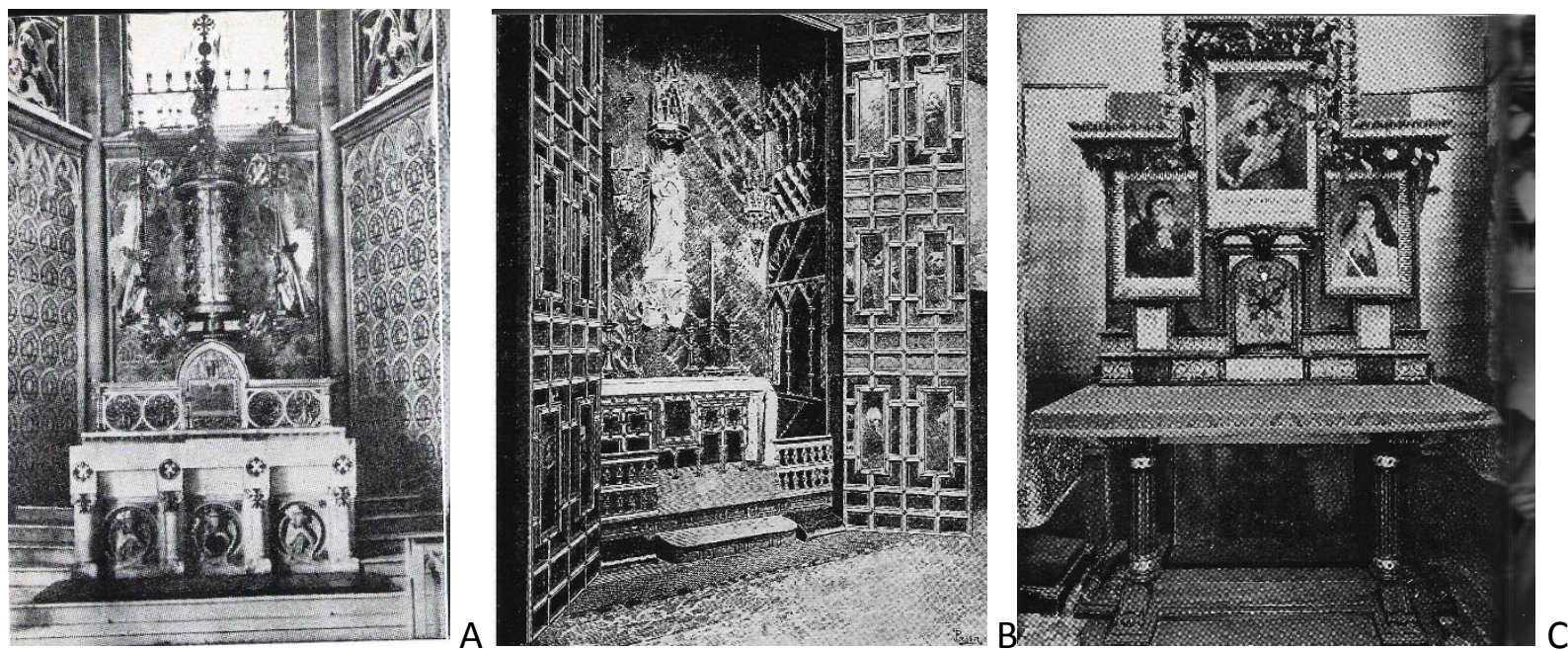

A: Altar del Colegio Jesús-Maria de Tarragona. B: Altar de la Capilla Oratorio del Palacio Güell. C: Altar del Oratorio en Casa de la familia Bocabella. Fuente: Martinell, C. (1967). Gaudí: su vida, su teoría, su obra. Barcelona. COAC.

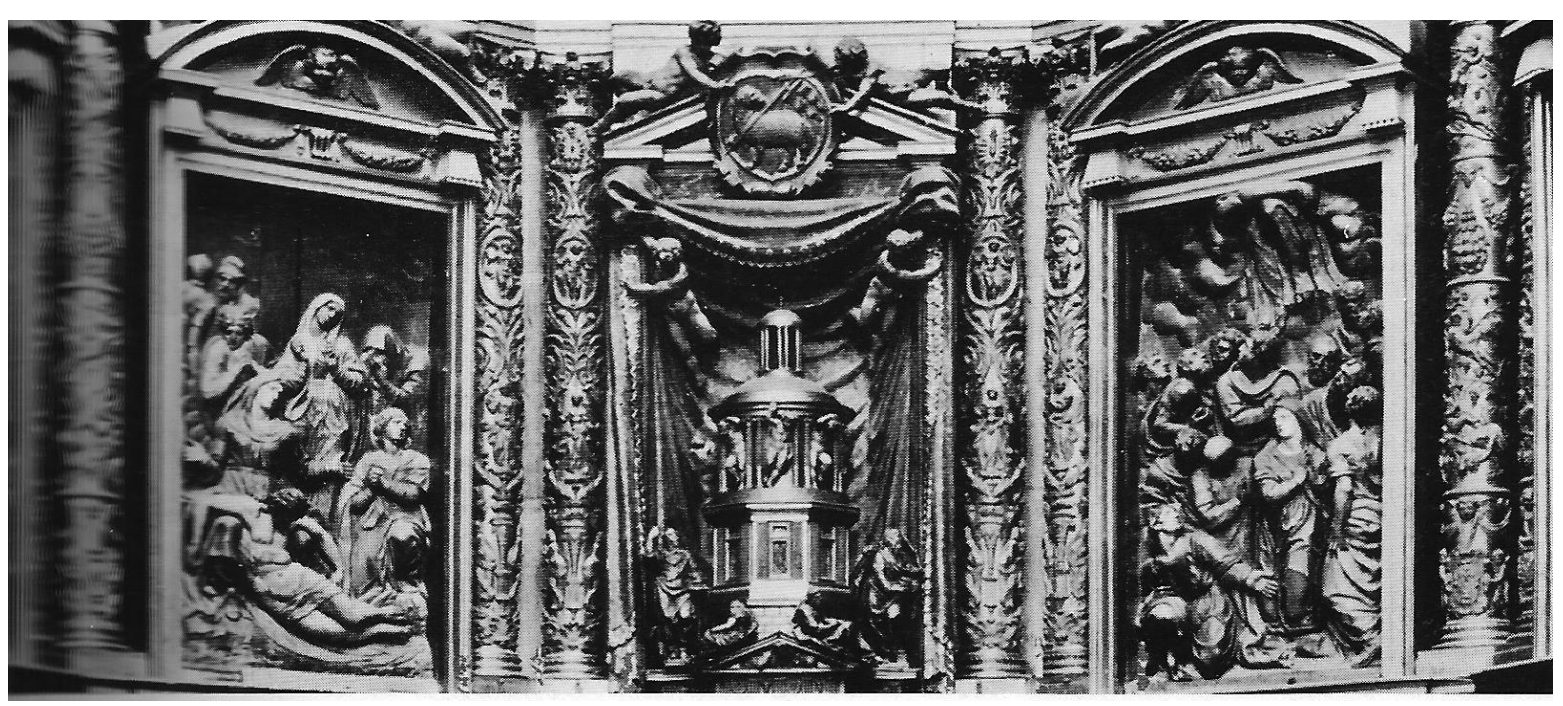

Sagrario de la Catedral de Astorga que Gaudí admiraba. Fuente: Martinell, C. (1967). Gaudí: su vida, su teoría, su obra. Barcelona. COAC. 
Con anterioridad se han establecido como bases de la Tesis tanto los manuscritos y comentarios de Gaudí como su entorno humano y profesional más inmediato. Se ha reseñado la influencia de la práctica litúrgica en su pensamiento y ejercicio profesionales, así como la conjunción de su inconformismo arquitectónico con una fundamentada e imaginativa propuesta constructiva que le impulsa a la auto-exigencia más radical.

Bien se puede decir que sin haberse sentido fuertemente atraído por la liturgia y haber captado su esencia más teológica, sus proyectos de iglesias habrían sido otra cosa, quizá aquello que el mismo criticaba radicalmente en el Sacrée Coeur, Sant Sernin y $N \underline{a} S \underline{a}$ del Taur en Touluse, la catedral de Carcasonne...u otras iglesias coetáneas, nuevas o reformadas, que le defraudaron profundamente. Sin estos presupuestos sus proyectos, aunque bien armados técnica y artísticamente, probablemente no habrían sido un hito para la arquitectura eclesiástica. La "utilitas" del proyecto que menciona Martinell se visualiza en la identificación de los espacios celebrativos que son jerárquicamente ordenados por la Liturgia, como diría Cassingena-Trévedy ${ }^{316}$, análogamente a como lo hacen los espacios sirvientes y servidos en la praxis khaniana.

Como ha estudiado Francesc de P. Cardoner (La evolución de la obra de Gaudí, 1967) si consideramos sus dieciocho proyectos más importantes observamos que sólo dos son iglesias -Santa Coloma y la Sagrada Familia- (aunque Cardoner no cuenta en el cupo la intervención parcial en la catedral de Mallorca), otros dos conventos ${ }^{317}$, pudiendo parecer que aquellas florecen más o menos espontáneamente después de una dilatada trayectoria profesional en la que denomina segunda etapa de su obra hacia 1900. Sin embargo, este escaso porcentaje de temática religiosa en sus principales proyectos no nos ha de hacer olvidar que en los años 1879-1881, recién obtenido el título y coetáneamente con el inicio de sus trabajos para la Casa Vicens, Gaudí trabaja en dos encargos sumamente humildes pero muy significativos que describe Bassegoda: el altar de la capilla en el colegio de la Congregación de Jesus-Maria en Tarragona, y la decoración de la capilla y altar de otro colegio de la misma orden en San Andrés del Palomar ${ }^{318}$ de la mano de Juan Bautista Grau, vicario general de la diócesis de Tarragona por aquellos años. En estos dos proyectos ya aparecen gran cantidad de elementos litúrgicos y un cuidado tratamiento de las imágenes y símbolos que Bassegoda menciona, como por ejemplo el tetramorfos y los ángeles genuflexos en el ostensorio, la síntesis de imágenes angélicas, símbolos cruciformes y capiteles naturalistas del antipendio del altar, el diseño del pavimento de mosaico romano o el de la sillería de madera del coro, algunos de cuyos diseños decorativos afirma que están en relación con dibujos de su etapa de estudiante.

${ }^{316}$ Cf. Cassingena-Trévedy F. (2008). La belleza de la Liturgia. Salamanca. Ed. Sígueme

317 Cf. Cardoner Blanch, F. de P. (1970). "Evolución de la obra de Gaudí”. Comunicación en Jornadas Internacionales de Estudios Gaudinistas, 1967. Barcelona. Editorial Blume.

318 Cf. Bassegoda Nonell, J. (1969). Los proyectos de Gaudí para las religiosas de Jesús-Maria (18771882). Barcelona. Ediciones literarias y científicas. 

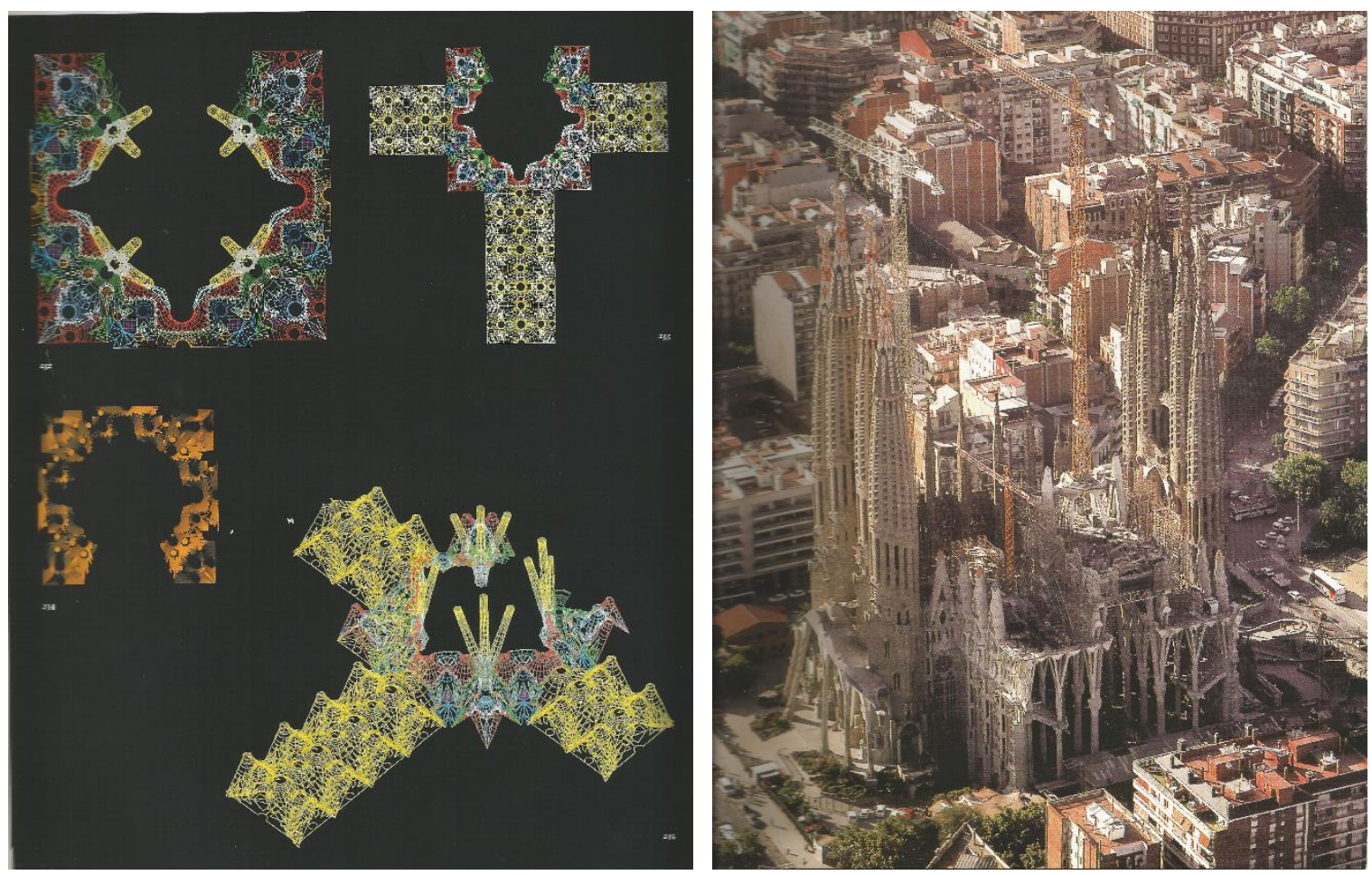

Las bóvedas a $45 \mathrm{~m}$, nave, crucero y transepto. Vista panorámica con las sección transversal que muestra la estructura de la nave celebrativa.

Fuente: Gomez Serrano, J. y AA.VV. (2008) Sagrada Familia XXI/ Gaudi ara. Barcelona. Edicions UPC
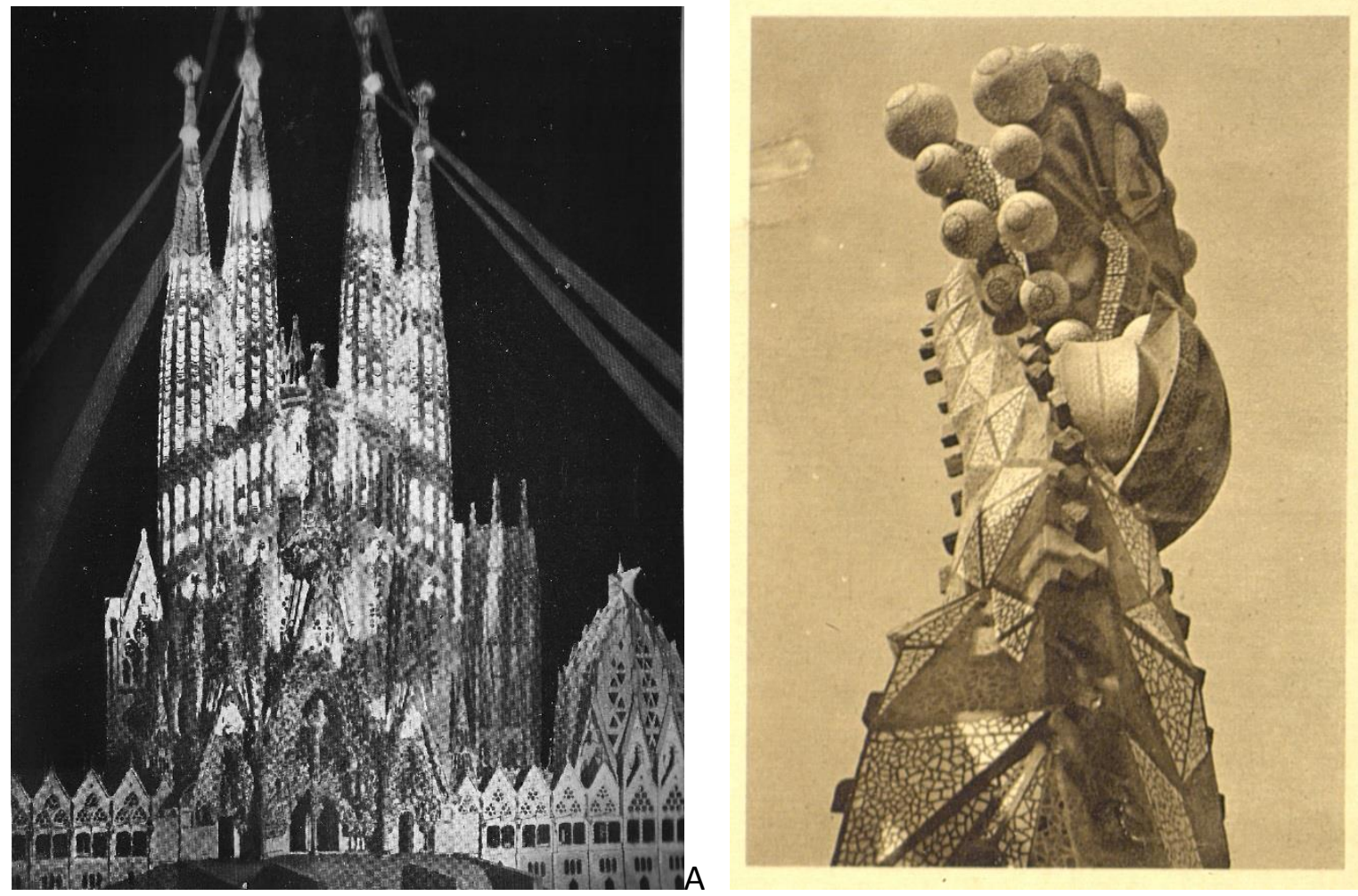

B

A: Iluminacion artificial ensayada en la maqueta. Fuente: Martinell, C. (1950) Gaudí y la Sagrada Familia comentada per ell mateix. Barcelona. Aymá S.L. Edicions B: Detalle del remate de un campanario con lasimbología de los signos episcopales. Fuente: Arxiu de la Sagrada Familia. Album de 1929. 
Son importantes estas obras y su cuidada realización porque podemos considerarlos, en unión con los que realiza para Fontseré en la Fuente Monumental y las farolas del Ayuntamiento de Barcelona, como los primeros de su carrera profesional. Tampoco hay que dejar pasar por alto el hecho de que dichos encargos vinieran por recomendación del doctor Grau.

Quiere esto decir que a su indudable interés por resolver problemas concretos de hidráulica, calderería o iluminación en fuentes y farolas del Ayuntamiento de Barcelona hay que unir una gran sensibilidad por la liturgia y un gran conocimiento de la simbología cristiana, que muestra en gran cantidad de detalles decorativos y constructivos. En consecuencia, si no hay duda en que el carácter utilitario de la arquitectura gaudiniana está presente desde sus tiempos de colaboraciones de estudiante como una característica propia de su ejercicio profesional, tampoco hay duda en el hecho de que esta cualidad puede aplicarse con toda propiedad a su producción eclesiástica desde un principio: "El templo ha de reunir la grandeza con la necesidad". ${ }^{319}$

Esta misma noción de orden que establece la Liturgia católica ${ }^{320}$, fundamentada teológicamente y vivida en la práctica cotidiana por el arquitecto no como un mero catalogo de rúbricas, movimientos, actitudes y acciones que descontextualizados de su estructura interna sólo darían como resultado ritualismo, funcionalismo y mimetismo formal, es la proporciona funcionalidad al edificio mediante la simbiosis del planteamiento compositivo del espacio y sus elementos con las necesidades del culto cristiano en sus diferentes funciones, celebraciones y ritos. De esta manera el ordenamiento jerarquizado del edificio, que implica la diferenciación detallada de sus partes y el criterio pormenorizado de los ejes que rigen su composición, se funda sobre las premisas de la eucaristía y del resto de sacramentos y acciones sagradas de los fieles.

De ahí que para que el espacio arquitectónico pueda configurarse como espacio cultual es necesaria una interacción con la Teología litúrgica y por consiguiente con su simbología. La simbología cristiana se ha desarrollado abundantemente en los lugares de culto desde sus inicios a través de una rica y amplia iconología de las imágenes, los atributos, textos y signos que ha contribuido a atemperar adecuadamente el espacio arquitectónico y su propia dignidad contribuyendo no poco al confort religioso de los fieles y por tanto a su participación en el culto.

\footnotetext{
319 Cf. Puig Boada, I. (1981). El Pensament de Gaudí: compilació de textos i comentaris. Barcelona. La Gaya Ciencia. P. 69

${ }^{320}$ Cf. Cassingena-Trévedy, F. (2008). La belleza de la Liturgia. Salamanca. Ed. Sígueme. P. 67: “La liturgia administra el espacio, determinados espacios. En su realidad material, el edificio cultual es al mismo tiempo instrumento para la liturgia y una manifestación de la teología que la sostiene."
} 


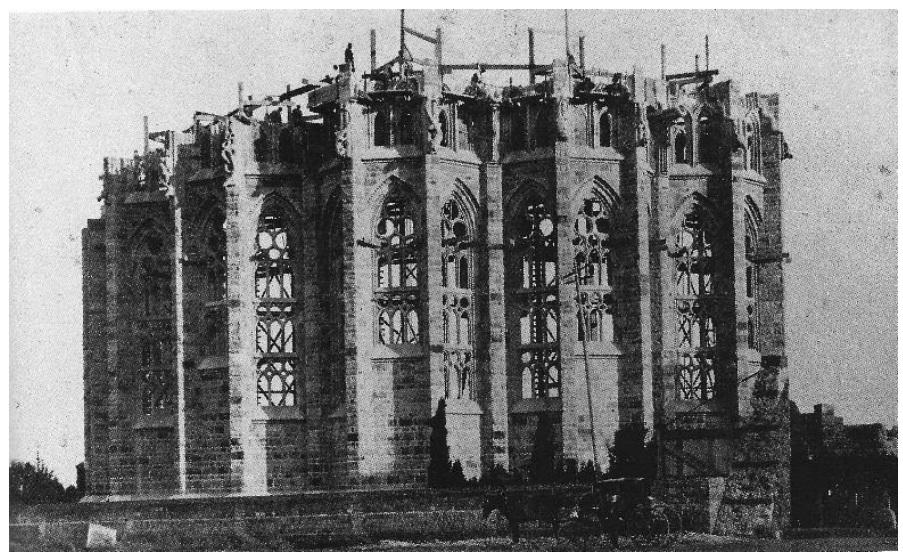

Fotografia del abside en construcción publicada el 1-011892 en El Propagador. Fuente: Torii, T. (1983) El mundo enigmático de Gaudí. Madrid. Instituto de España.
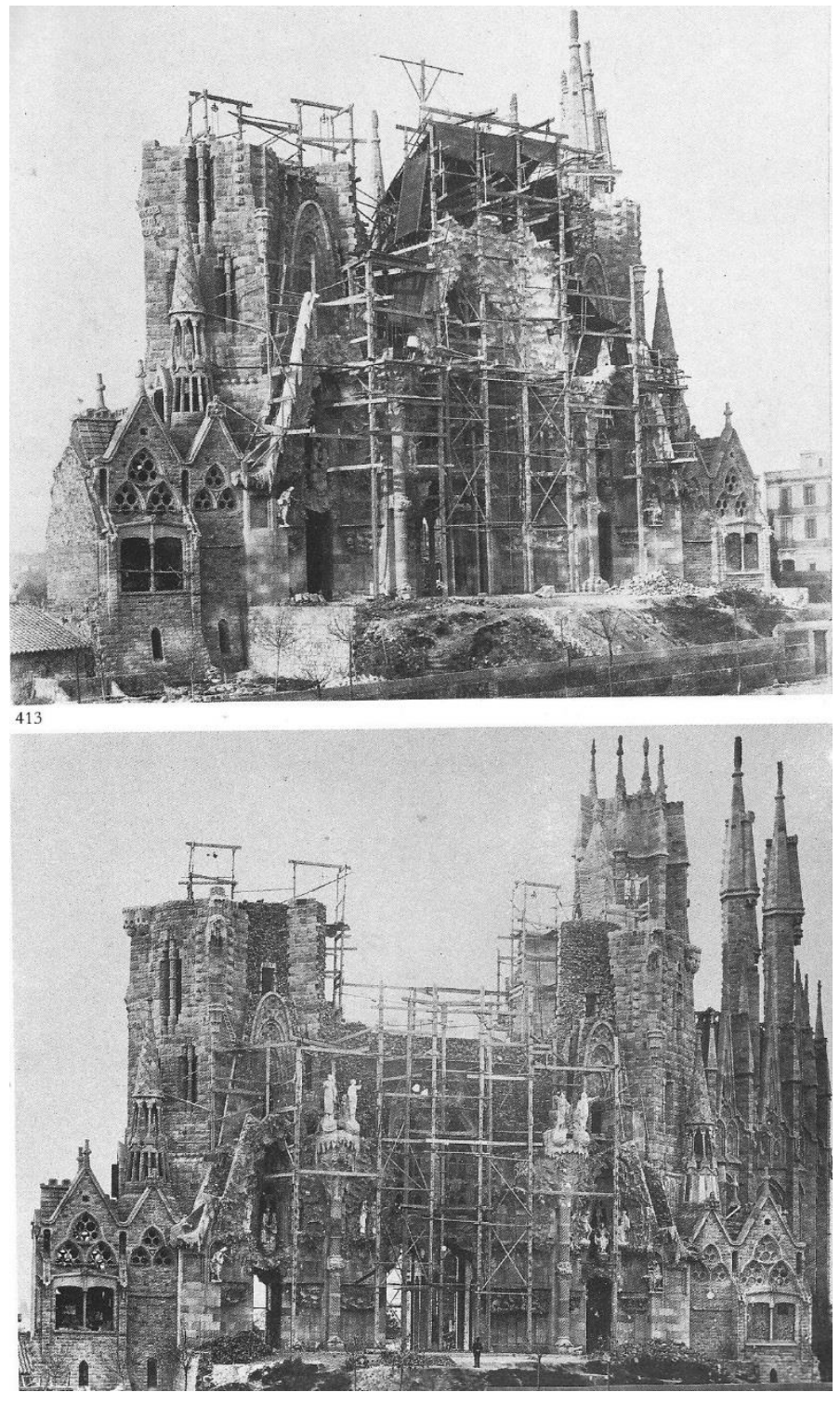

Fotografías de la fachada del Nacimiento en construcción, 1898-1899, publicadas en El Propagador el 15-03-1898 y el 15-03-1899. Fuente: Torii, T. (1983) El mundo enigmático de Gaudí.Madrid. Instituto de España. 
Gaudí es un profundo conocedor de la simbología cristiana y ya en sus trabajos de estudiante incluyó textos e imágenes que consideraba ligados al proyecto que dibuja. Como ejemplo citado comúnmente de ese periodo está su dibujo de la puerta de un cementerio con profusión de textos tomados del Apocalipsis. La tarea de Gaudí, en diálogo permanente con las Escrituras y la tradición católica, con la liturgia más actual de su tiempo y su calendario anual de fiestas y manifestaciones religiosas persigue un fin a la vez celebrativo y didáctico. Celebrativo en cuanto al confort religioso de la asamblea a la que nos hemos referido, didáctico en su dimensión edilicia como hito urbano de primera magnitud.

Mediante el concurso e integración de las artes plásticas en su proyecto arquitectónico Gaudí desarrolla un ambicioso programa de tal manera que escultura y pintura, geometría y materiales, luz y color, son utilizados como expresión de una arquitectura en continuo movimiento que quiere significarse en su uso. Por este motivo su pensamiento artístico radica en que la belleza no es exclusiva de determinados estilos y no ha de perseguirse en el proyecto arquitectónico como una estética determinada sino que se encuentra cuando se busca la funcionalidad y la bondad constructiva. De ahí que su concepción del edificio sea unitaria buscando dar respuesta a todas las cuestiones que en él concurren.

Siguiendo esta línea de argumentación Carlos Flores ha sugerido cuatro grandes áreas de actividad en las que trabajaría simultáneamente Gaudí para poder dar forma y construir su proyecto: criterios de proyecto y composición tanto del conjunto como de detalle; temas constructivos, estructurales y de funcionamiento (donde se incluirían soluciones a problemas específicos como campanas, vidrieras, iluminación, etc.); la forma y el lenguaje; y finalmente, los significados de índole religioso representativo y simbólico ${ }^{321}$. Comparando este análisis metodológico de Flores con lo que el mismo Gaudí menciona como primer paso para la buena realización de un proyecto -el estudio de las necesidades morales y materiales, y después la fijación de los materiales y sistema constructivo- ${ }^{322}$

\footnotetext{
${ }^{321}$ Carlos Flores ha sintetizado la progresiva implicación de Gaudí en el proyecto sugiriendo cuatro grandes aréas de actividad en las que debió trabajar, unas veces autónomamente y otras confluyendo en el total de la obra, para poder acometer y dar forma a un proyecto de esta envergadura y complejidad: los aspectos relacionados con criterios de proyecto y composición tanto del conjunto como de detalle; los temas constructivos, estructurales y de funcionamiento (donde incluye soluciones a problemas específicos como campanas, vidrieras, iluminación, etc.); los aspectos relacionados con la forma y el lenguaje; y finalmente, los significados de índole religioso representativo y simbólico. Señala además la implicación del arquitecto con este proyecto: "entre 1884 y 1914 la Sagrada Familia represente para el arquitecto la misión de su vida, y entre 1914 y 1926, su propia vida." Cf. Flores, C. (2002). La lección de Gaudí. Madrid. Espasa Calpe. P.109.

322 Cf. Mercader, L. (2002). "Antoni Gaudí: escritos y documentos". Barcelona: El Acantilado. P.89: "Método para la buena realización de un proyecto. Estudio en general de la cuestión como principio de forma; fijación de ideas más concretas sobre el asunto con los croquis sin escala, y en la solución adoptada sujetarlo a una escala diminuta para solventar las dificultades; detalles en mayor escala, y últimamente ejecución de detalles al natural y sujeción del modelo. Constituyen cinco partes, y el modelo o realización."
} 


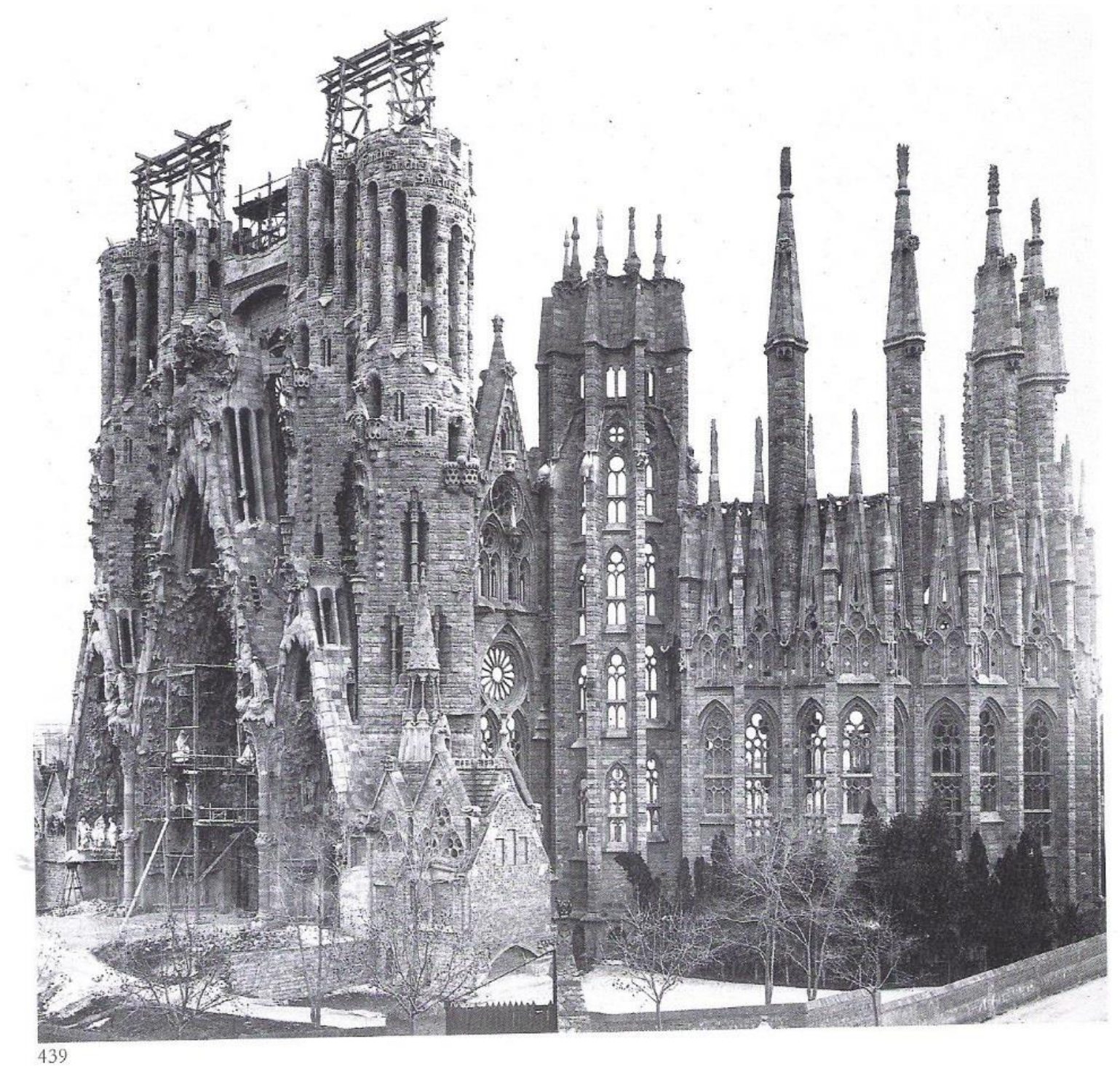

Fotografia del estado de la construcción en 1908, publicada en El Propagador.

Fuente: Torii, T. (1983) El mundo enigmático de Gaudí. Madrid. Instituto de España. 
Comparando este análisis metodológico de Flores con lo que el mismo Gaudí menciona como primer paso para la buena realización de un proyecto -el estudio de las necesidades morales y materiales, y después la fijación de los materiales y sistema constructivo- ${ }^{323}$ vemos que su idea de lo que es una iglesia y la composición general del proyecto se aprecian claramente en el discurso a los josefinos. El sistema constructivo y los materiales le llevarían largos años pudiendo llegar a establecerse los hitos principales de acuerdo con las distintas soluciones estructurales, en cuya evolución también es posible destacar la decisión para el empleo del hormigón armado.

El proceso es interactivo como lo muestra con qué prontitud concibe la iconología de los grandes temas teológicos que quiere mostrar a los josefinos y su composición en el esquema general del proyecto, y conlleva el estudio en profundidad de todos los detalles constructivos y ornamentales con un orden preciso: una vez definidos la fachada del Nacimiento y el módulo tipo del Claustro afronta la resolución del conjunto del presbiterio, crucero y transepto (incluyendo su otra fachada), antes de pasar al diseño completo de las naves, y después al resto de espacios, Sacristias, Capillas, etc.

En este proceso -mental, proyectual y constructivo- cuyos últimos pasos para Gaudí son los detalles del natural y la propia realización del proyecto no hay que perder de vista que prevalece siempre la idea originaria del enaltecimiento del edificio como casa de la oración comunitaria y lugar sagrado de la celebración litúrgica, que se brinda y se abre a todas las gentes. De ahí el interés con que trata en el proyecto las fachadas -portadas y claustro- y el número de accesos que se propone realizar, no sólo en aquellas sino en distintos puntos del perímetro claustral. Como también hay que remarcar la importancia que cobra la luz, no como gestor del movimiento o de la definición edilicia sino al servicio de la celebración litúrgica: "la luz de los templos ha de ser solamente la necesaria y no más... "324 La originalidad del tratamiento de la luz en la Sagrada Familia lo abarca todo: estructura, fachadas, portadas, bóvedas, consiguiendo no sólo el deseado efecto de la adecuada iluminación del aula celebrativa sino involucrándola completamente en la simbología teológica. En los siguientes apartados se entrará a analizar los diferentes espacios celebrativos y de servicio del proyecto, cuyos criterios de composición arquitectónica están basados más en la teología litúrgica y en los ritos y ceremonial vigentes que en consideraciones espaciales, estructurales, o urbanísticas. Abundaremos, pues, en esta línea tanto en el contexto temporal como programático del proyecto.

\footnotetext{
${ }^{323}$ Cf. Puig Boada, I. (1981). El Pensament de Gaudí: compilació de textos i comentaris. Barcelona. La Gaya Ciencia. P.62: "Primers estudis: necessitats morals i materials, extra construccions, indicació lleugera dels materials. Segon: fitxació dels materials i del sistema constructiu. Tercer: detalls separats, motius ornamentals i estudi de la construcción própiament dita. Quart: estudi de conjunt i unificació, que és la que serveix per a la presentación als profans, correcció de l'anterior. I talls i mitjans de realització. Cinqué: detalls al natural, per tal de fixar decididament, i sense vacil-lacions, l'execució. Sisè: realització."

${ }^{324}$ Ibid. P.119
} 


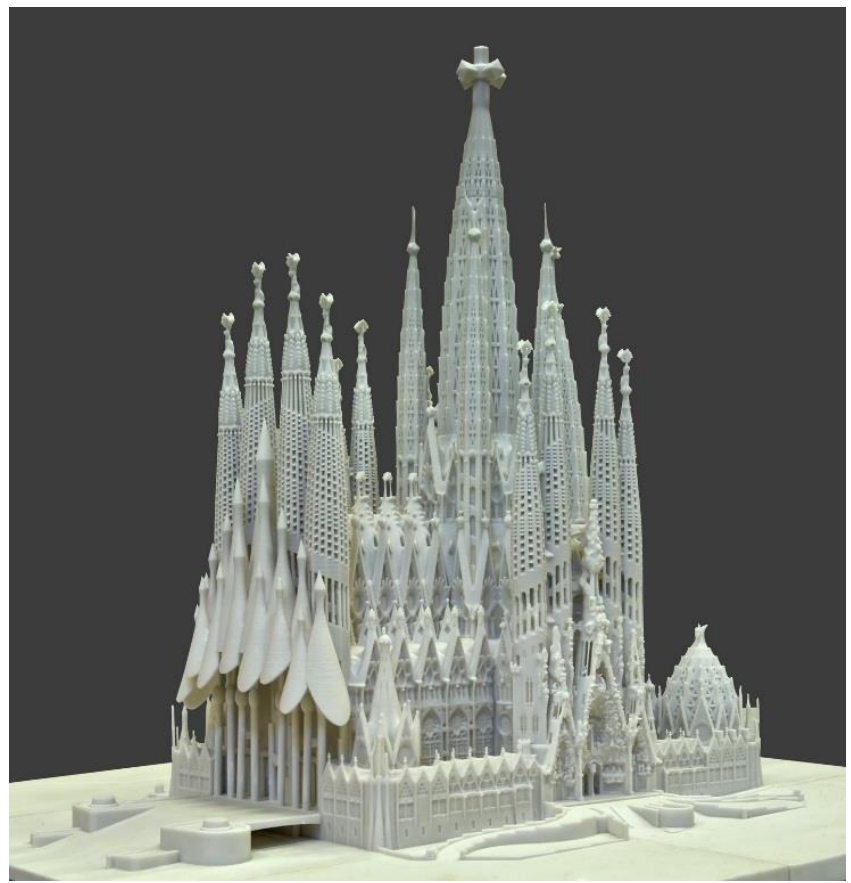

Maqueta de la Sagrada Familia, orientación de las portadas del Nacimiento y de la Gloria. Fuente: Oficina Técnica de la Sagrada Familia.

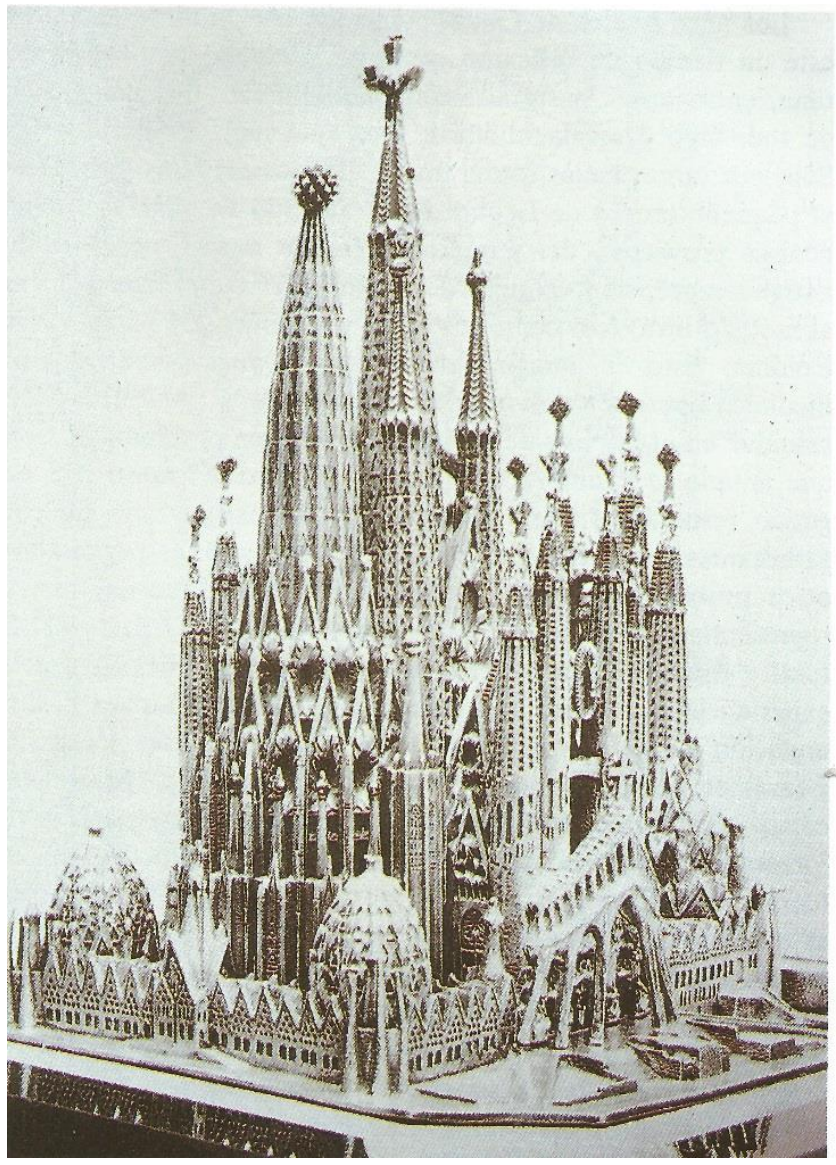

Maqueta, orientación de la portada de la Pasión, ábside, capilla de la Asunción y sacristías. Fuente: Navascués, P. (1993) “Arquitectura Española 18081914", en Summa Artis Historia General del Arte Tomo XXXV. Madrid. Espasa Calpe. 
Con relación a estos criterios compositivos Flores menciona algunos elementos que dan idea del cambio de proyecto respecto a la etapa de Villar pero no se plantea qué objetivo se persigue, en términos khanianos qué quiere ser el edificio a construir, siendo a mi parecer clave el fundamento teórico gaudiniano expresado en el Manuscrito de Reus, el discurso a los Josefinos y los propios comentarios a discípulos y colaboradores. Todos ellos nos obligan a insistir en una concepción previa de lo que ha de ser un edificio-iglesia muy asentada en la mente del arquitecto de cuya magnitud da idea el hecho de implicar también a otros proyectos como Santa Coloma o Mallorca. En unos casos el proyecto iglesia se acomoda arquitecturas existentes como en el caso de la Cripta de la Sagrada Familia o en Mallorca, pero en otros propone estructuras -Santa Coloma y Sagrada Familia- que se apartan completamente de las tipologías coetáneas

En todos los casos, sin embargo, es la dimensión celebrativa del espacio que se construye o atempera la que marca los criterios constructivos y el programa simbólico porque "el carácter religioso es el que tiende siempre a lo más grandioso, desde el momento en que su objetivo es un misterio" 325 .

En este sentido se constata en los sucesivos planos y maquetas cómo persiste la unidad del proyecto y cómo las diversas soluciones para resolver la transmisión de cargas, la forma de una torre o la plasticidad de una portada no la niegan ni perturban en lo más mínimo. Juega a su favor la concepción del aula celebrativa y su programa simbólico, que actúan desde el primer momento a favor de la ejecución de las obras, hasta tal punto de convencer al mismo Flores cuando explica su postura respecto de su posible terminación, evolutiva al igual que el proyecto: el interés por la percepción del espacio interior gaudiniano. ${ }^{326}$

\footnotetext{
325 Cf. Mercader, L. (2002). Antoni Gaudí: escritos y documentos. Barcelona: El Acantilado. P. 50

${ }^{326}$ Cf. . Flores, C. (2002). La lección de Gaudí. Madrid. Espasa Calpe. Pp. 283-284: "esta obra que se continúa siguiendo lo más fielmente posible un proyecto o anteproyecto 'congelado', si se quiere, nos va a permitir experimentar de una forma real el espacio interior que Gaudí concibiera en un momento dado, no importa que años después él mismo hubiera llegado a soluciones finales que lo modificaran."
} 


\section{b)__Criterios de composición arquitectónica en clave litúrgica.}

Afirma Martinell la intencionalidad litúrgica del proyecto es clara y primordial ${ }^{327}$, basando su afirmación en el plan general de sus trazas y en la composición de sus elementos. No obstante esta afirmación hay que analizarla. Cuando Gaudí recibe el encargo en 1883, la orientación y el tipo de planta están establecidos, con escaso margen para un cambio radical, aunque tampoco se puede asegurar que lo hubiese pretendido, más allá de una orientación de la cabecera de la iglesia hacia el este como sugiere la modificación del Pliego de Condiciones del Contratista y las desavenencias iniciales con el promotor que relata el propio Martinell. De hecho Gaudí está colaborando entonces con Martorell, cuyas iglesias son siempre de planta d cruz latina, y la interpretación de Torii respecto del proyecto de Tánger es eso, interpretación. Mayor información parece dar la planta de 1885 en la que se puede vislumbrar una actitud muy culta, que partiendo de las preexistencias de todo tipo de la obra recibida sugiere nuevos planteamientos compositivos sin adscribirse claramente a una u otra disposición histórica.

En realidad, superada la primera impresión neo-medieval, reforzada por una "catalogación supragótica" a la que el mismo Gaudí no escapa al considerar la mejor manera de explicar su proyecto (1910) -un intento de superación de las catedrales góticas- la sensación que se tiene cuando se recorre su interior es que las trazas de la planta parecen difuminarse por obra del ingenioso espacio conseguido, de tal manera que el visitante que la recorre parece encontrarse dentro de un imaginativo salón columnario en el que difícilmente se mantiene la noción de planta de cruz latina, pues su altura interior, diafaneidad y luminosidad recrean un singular espacio más próximo a las Hallenkirche alemanas, al espacio interior de Sta. Maria del Mar o de la catedral de Mallorca, que a una catedral de la Isla de Francia. Todo ello sin desmerecer de los puntos de contacto con la volumetria exterior que desarrollan iglesias del ámbito ortodoxo como la catedral de San Basilio de Moscú, o iglesias occidentales claramente influenciadas por gusto bizantino como San Marcos de Venecia. Así pues la simplicidad de una traza cruciforme cede paso bien pronto a la complejidad de una yuxtaposición de volúmenes y elementos que sólo parecen tener en común el orden de la estructura portante y la alta dosis de inmaterialidad conseguida.

\footnotetext{
327 Cf. Cf. Martinell, C. (1952) La Sagrada Familia. Edición en castellano de Gaudi i la Sagrada Familia comentada per ell mateix. (1951). Barcelona. Aymá. P. 24: "La idea primordial de Gaudí fue que este templo se adaptase con la mayor perfección posible a las práctica de los cultos divinos. Para ello partió del tipo de templo basilical gótico en planta de cruz latina, con cinco naves longitudinales y tres transversales, ábside lobulado con siete capillas, dos cuerpos de escalera en los extremos y girola."
} 


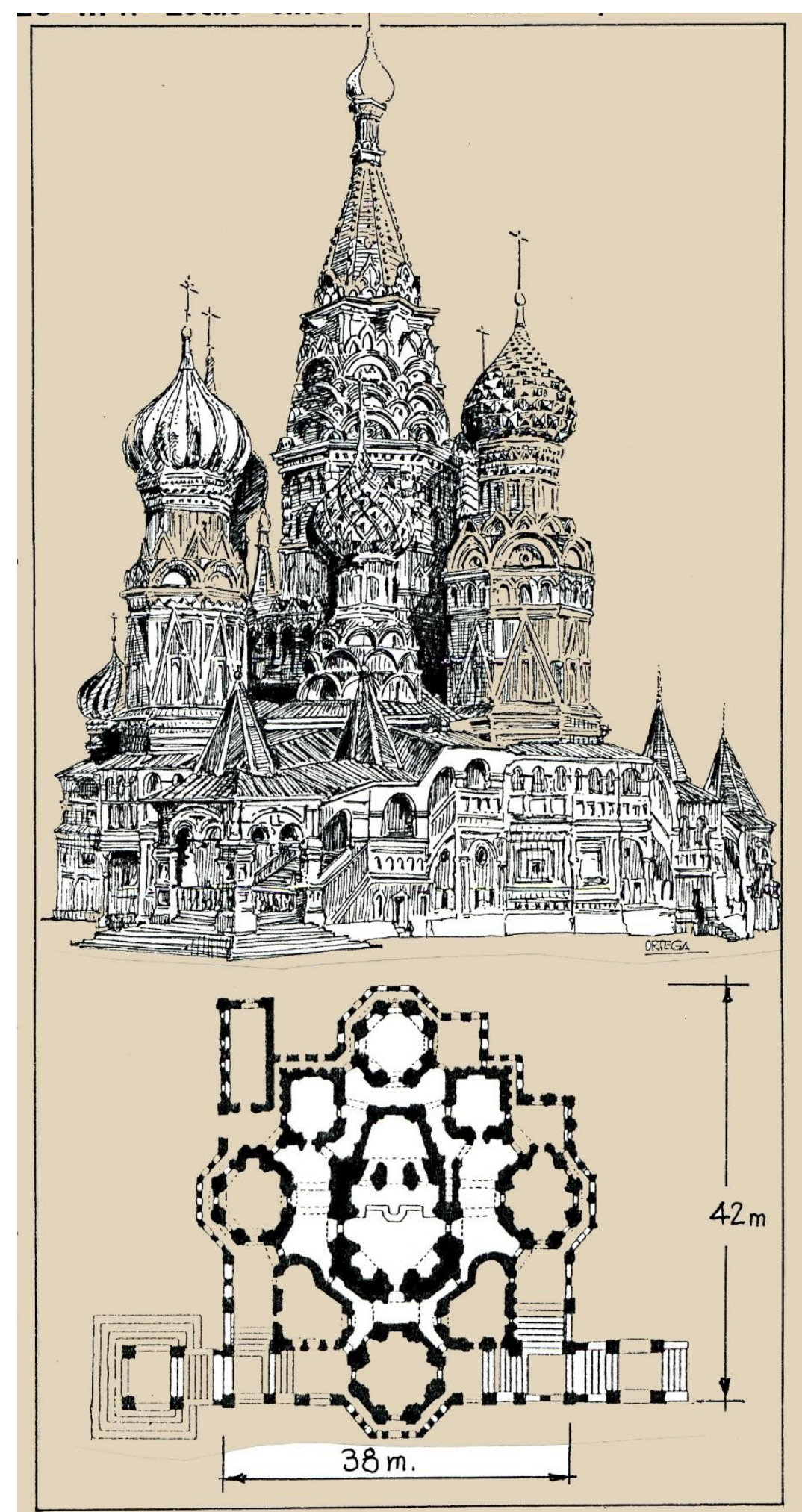

Catedral de San Basilio de Moscú (1555-1561), axonometría y planta. Fuente: Universidad de Las Palmas de Gran Canaria, departamento de Construcciones Arquitectónicas. 
En realidad, si se comparan los dibujos de planta realizados en vida de Gaudí (con excepción de la primigenia de 1885), - 1917, 1923 y 1926- se aprecia que todas ellas presentan una solución de conjunto con una concepción bastante orgánica del espacio y una organización del mismo que manteniendo como núcleo generador el presbiterio y el crucero (donde se sitúan los dos cimborios) ordena las naves y los espacios sirvientes según unos ejes y direcciones marcadamente litúrgicos. El que se mantenga en su cuerpo central el tradicional esquema latino heredado carece de importancia si tenemos en cuenta que la arquitectura cultual cristiana ha permanecido bastante fiel a él durante siglos, excepción hecha de incursiones en la centralidad renacentista, la elipse barroca o el neoclasicismo de salón, algunas de ellas de gran éxito artístico como San Pedro de Bramante, San Andrés de Bernini, La Madeleine de Vignon, etc. En la Sagrada Familia se plantea un cuerpo central cruciforme pero este esquema no se refuerza sino que más bien se diluye sutilmente mediante la inclusión de otras direcciones en capillas y sacristías, y el claustro que circunscribe el conjunto. A esta disposición en el plano horizontal se une la singular espacialidad consecuencia de la altura que alcanzan las naves y especialmente los cimborios, por lo que las visuales que se establecen en el interior del aula litúrgica adquieren un protagonismo fuertemente conceptual obteniéndose un resultado ajeno completamente a la tradicional bóveda longitudinal, ya sea de cañón o de crucería.

Para encontrar antecedentes que puedan sugerir la disposición de dos cimborios -en crucero y ábside- hay que pensar en plantas medievales con doble crucero como Cluny III o mejor buscar referencias en la modulación cupular que establecen San Juan de Efeso, Santa Irene o Santa Sofía. Interpretando estas últimas encontramos la actuación de Paul Abadie en Saint Front de Perigueux (1852-1895) rediseñando con el mismo tamaño y posición lo que eran cúpulas diferentes que seguían el patrón de San Marcos de Venecia.

El caso de las iglesias de doble crucero es diferente, por lo que la singularidad del cimborio en crucero y ábside parece apuntar a una sobrevaloración de este que podría arrancar de su exitoso tratamiento iconográfico en la arquitectura eclesiástica bizantina y la utilización de la cúpula como módulo estructural repetitivo que configura toda la planta. En mi opinión, el inicial planteamiento estructural e iconográfico de iglesias bizantinas en la época de Justiniano como Santa Sofia (532) o Santa Irene (548) pudo dar lugar a la seriación del módulo en San Juan de Efeso (565) e interpretaciones posteriores de planta más libre como San Marcos de Venecia en el area occidental (iniciada alrededor de 1063) o San Basilio de Moscú (1561). En todos estos casos encontramos diferentes configuraciones de planta pero un desarrollo estructural semejante a partir del modulo de la cúpula dotado de un vasto programa iconográfico. Es curioso en el caso de la arquitectura rusa de origen bizantino el desarrollo de agrupaciones de cúpulas en número de tres, símbolo de la Santísima Trinidad, o de cinco simbolizando a Jesucristo y los cuatro evangelistas, tal y como ocurre con el proyecto de Gaudí. 

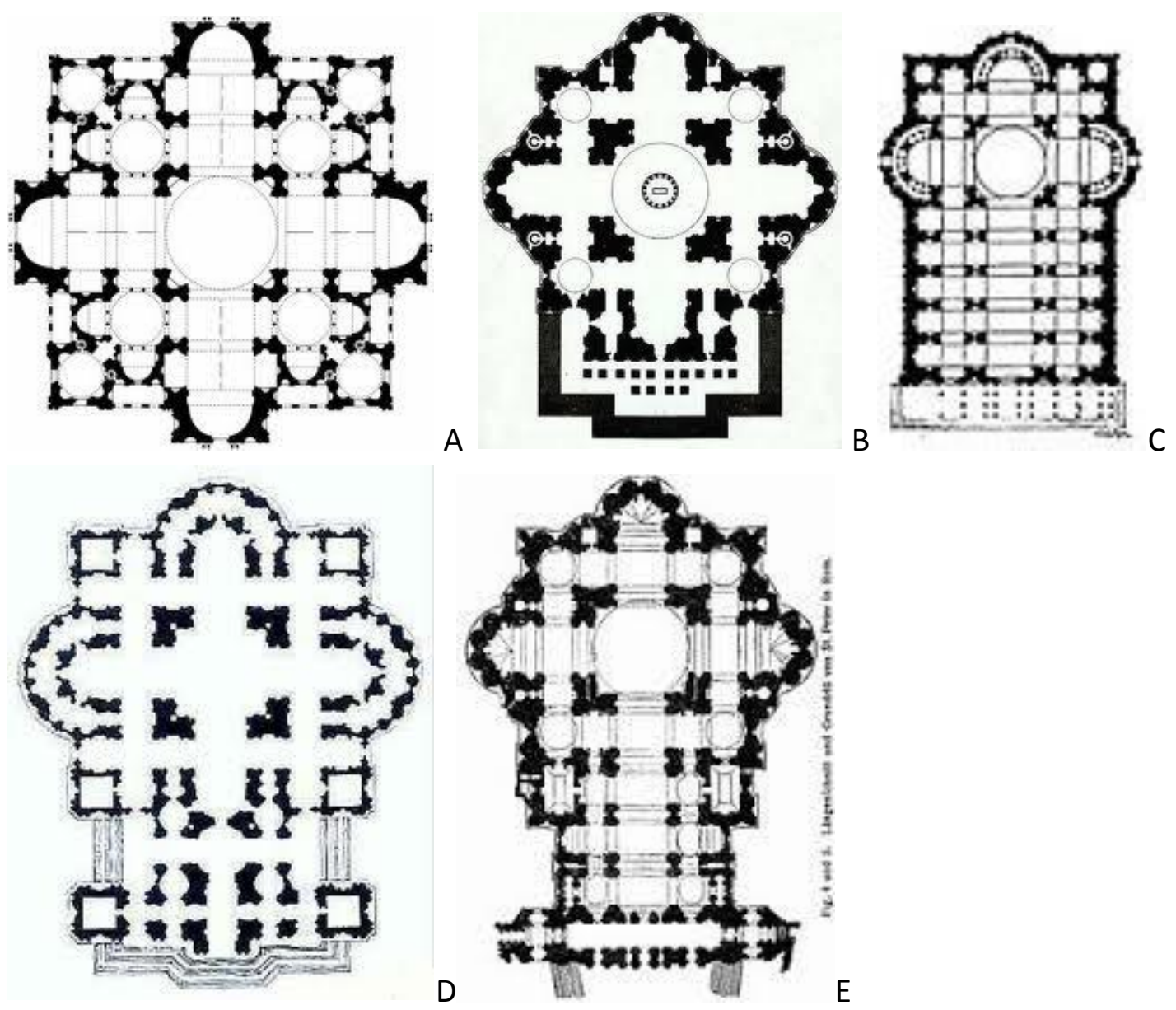

Variaciones sobre centralidad y cruz latina en la Basilica de San Pedro. A: Bramante.

B: Miguel Angel. C: Rafael. D: Antonio Sangallo el joven. E: Carlo Maderno.
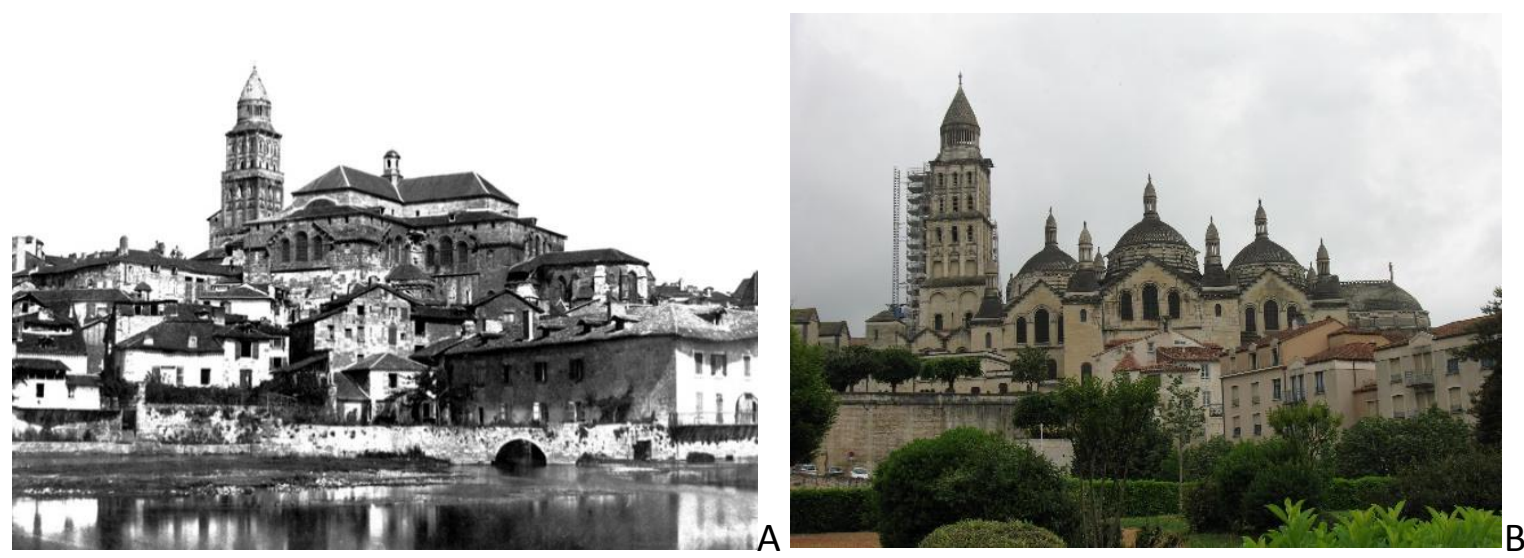

Fotografia de la catedral de Saint Front de Perigueux antes de la intervención de Paul Abadie (1852-1895), y actual después de ella. Fuente: fotografía histórica de Méderic Mieusement. 
También en otros ejemplos de arquitectura bizantina rusa, como Santa Sofia de Kiev (1057), especialmente en su disposición inicial, encontramos un deambulatorio en el perímetro de la iglesia que recuerda a la Sagrada Familia.

En consecuencia, relación existente entre la novedad del sistema estructural de base cupular desarrollado por las iglesias bizantinas y la abundante iconografía que desarrolla la magnificencia del rito cristiano oriental -tanto en lado católico como en el bizantinoparecen estar presentes en la inspiración de Gaudí para la magnificación arquitectónica del ábside mediante la incorporación de un segundo cimborio. Una similitud entre los criterios rectores de lo que debe ser un proyecto de iglesia para Gaudí, que recoge Puig Boada (El Pensament de Gaudí: textos i comentaris, 1981), y algunas ejemplos de la arquitectura bizantina, cuya característica esencial dentro de la tipología del edificioiglesia es precisamente su creatividad estructural y espacial respecto de la liturgia cristiana, sugieren la apoyatura teológico litúrgica que Gaudí otorga a la bóveda de este cimborio y el estudio de la luz, a los que nos referiremos más tarde. Gaudí proyecta el edificio-iglesia asentándolo no sólo en su proyecto de estabilidad estructural sino fundamentándolo en las fuentes de la Teología y la Liturgia. De ahí que su arquitectura eclesiástica -como hemos visto en el caso de Sta. Coloma en primera instancia- aúne forma y función resaltando las cuestiones que estima esenciales de la acción celebrativa mediante la composición arquitectónica de los elementos constitutivos de la materialidad del edificio.

En todos sus dibujos es posible apreciar su voluntad de enfatizar los elementos de la acción litúrgica disponiendo un elemento que circunscriba el conjunto como delimitación entre el mundo profano y el espacio sagrado, aunque no como un bastión cerrado que preserve del exterior un recinto restringido sino como un espacio de transición permeable, simbólico y funcional. Se trata de una nueva versión del genuino del nártex de las basílicas cristianas, abierto al exterior y comunicado con el interior, que acoge e introduce en el espacio celebrativo más que separa de él, que se sobredimensiona y expande vertical y horizontalmente en sus torres y claustro, o se contrae y se ensancha en sus portadas. De esta manera este nuevo nártex orgánico se constituye en protagonista principal de la acogida y llamada al culto, en espacio deudor del culto mismo en cuanto que recinto procesional que une y armoniza el resto de espacios litúrgicos de la basílica.

Ya en los primeros planos de la planta (1885) se maclan varias formas geométricas correspondientes a otros tantos cuerpos de edificación inscribiéndose el edificio principal de la iglesia en el rectángulo que define el claustro, de tal manera que la longitud del transepto y la de la misma nave principal quedan disfrazadas al igual que la planta cruciforme en una composición de conjunto cuyas trazas no se pretende en modo alguno simplificar en una forma geométrica determinada sino resolver en el volumen, en la estructura del espacio interior. 

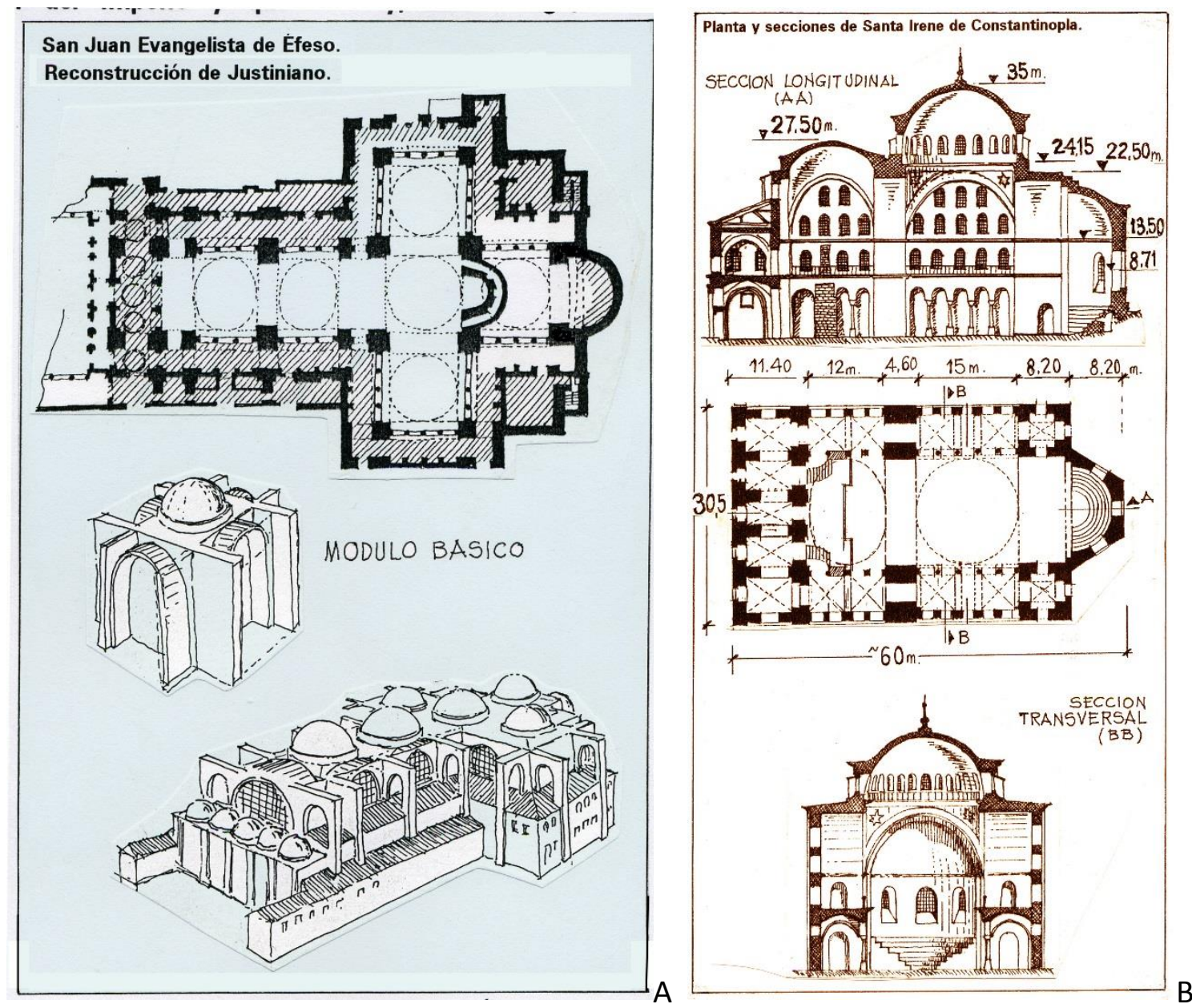

A: Planta, axonometría y modulo estructural de San Juan de Efeso según la reconstrucción de Justianiano (566). B: Santa Irene de Constantinopla según el proyecto de Justianiano (548) Fuente: Universidad de las Palmas de Gran Canaria. Depto. Construcciones Arquitectónicas.

C y D: Bovedas interiores curvas y planta de la iglesia de los catorce santos en Vierzehnheiligen, de Balthasar Neumann (1772).
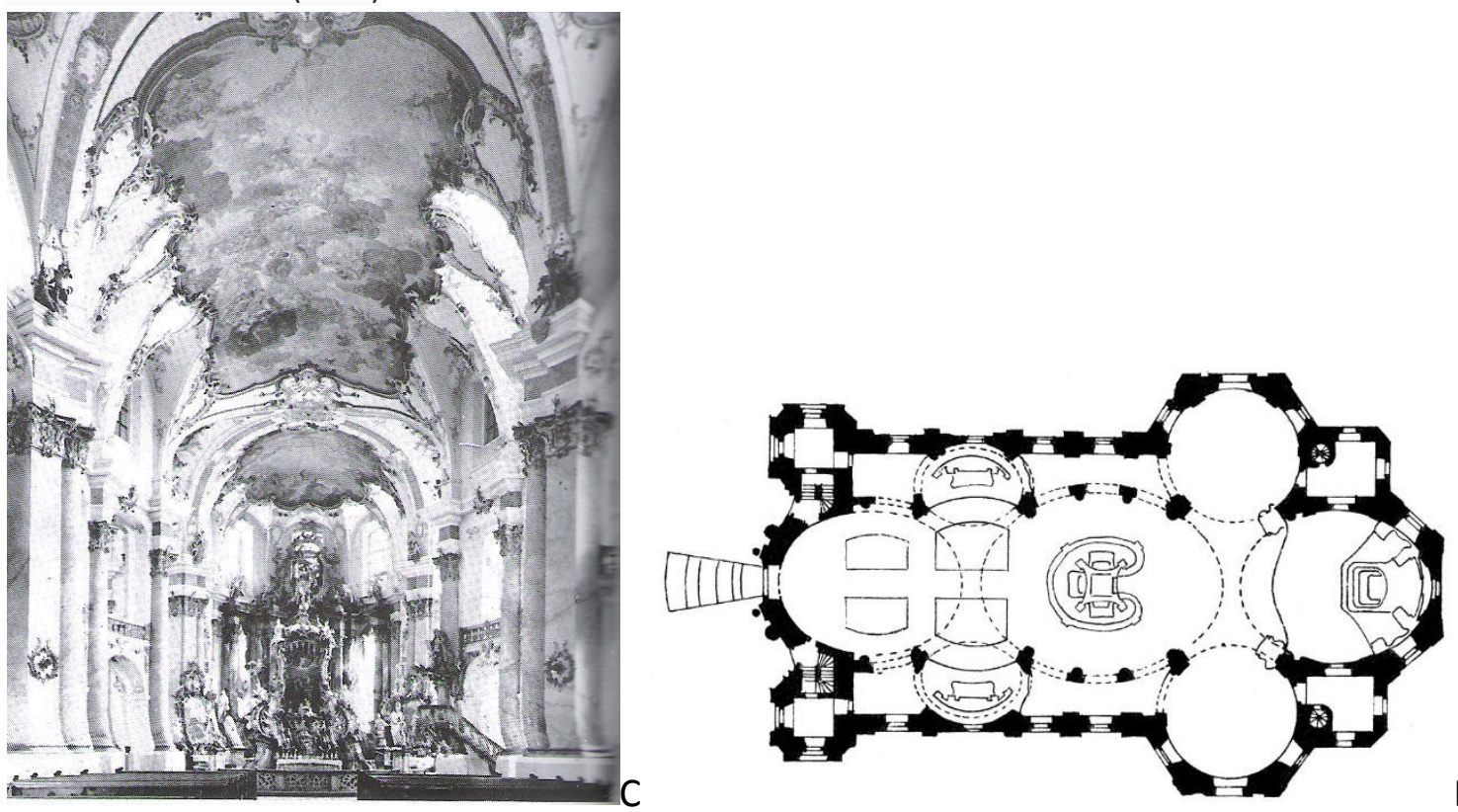
Lo que parece interesar a Gaudí es utilizar y resaltar los elementos de la arquitectura eclesial que considera más valiosos para su idea de iglesia, de ahí que proyecte desde el núcleo primigenio interior hacia el exterior, es decir desde donde entiende que radica la esencia del edificio hacia fuera y desde la materialidad y la espiritualidad aunadas del aula celebrativa hasta las formas y volúmenes que lo significan como hito urbano. El análisis no debe quedarse meramente en el plano formal, no se trata plantas cruciformes ya sea en Reims o en la Sagrada Familia, sino que todos y cada uno de los elementos arquitectónicos que integran el Templo Expiatorio están dispuestos según una concepción celebrativa de la vida. ¿Tienen la misma significación la torre campanario situada como elemento de entrada en su eje longitudinal en una iglesia de Puguin, Scott o Upjohn que en la composición de las cuatro torres que constituyen cada uno de los tres accesos principales del proyecto gaudiniano? ¿Responde a la misma concepción, tienen la misma lectura, el cimborio de Sant Sernin de Touluse, el de la catedral de la Almudena o de la fachada de la catedral de Barcelona?

Esta característica de análisis, síntesis e interpretación de las características simbólicas de los elementos arquitectónicos que tradicionalmente han configurado una iglesia para su expresión dentro de una directriz litúrgica guía la constante evolución del proyecto, impregnando la geometría del espacio interior. Gaudí pretende lograr la unicidad de un proyecto resolviendo la composición en términos de funcionalidad y de exaltación litúrgicas, implicando además en ello al amplio y rico simbolismo cristiano en el sistema constructivo del edificio, no como una decoración u ornamentación añadida sino como un elemento constituyente con protagonismo propio en la configuración del aula celebrativa ideal. Nadie sería capaz de explicar la Sagrada Familia como yuxtaposición de soluciones formales que la sensibilidad arquitectónica de Gaudí maneja, hace y deshace con singular maestría ${ }^{328}$, sino que su visión e interpretación es mucho más compleja aunando una imaginativa dimensión estructural y constructiva a la expresividad que considera adecuada a la acción litúrgica.

Sus referencias formales y de lenguaje no son inmediatas aunque analice los discursos y ejemplos más notorios de la arquitectura religiosa y si se declara deudor lo hace de un itinerario profesional y humano como el de Martorell, pero no de un lenguaje o proyecto concretos. Gaudí no es un teórico de la arquitectura ni tiene la pretensión de serlo sino un investigador, y su actitud es la del que estudia un problema, experimenta hasta encontrar soluciones fundamentadas y las plantea con vehemencia inusitada.

\footnotetext{
${ }^{328}$ Cf. Puig Boada, I. (1981) El Pensament de Gaudí: compilació de textos i comentaris. Barcelona. La Gaya Ciencia. P.190: "Fa poc que ha estar publicada una historia de la catedral de Reims, la catedral gótica més bella..."
} 

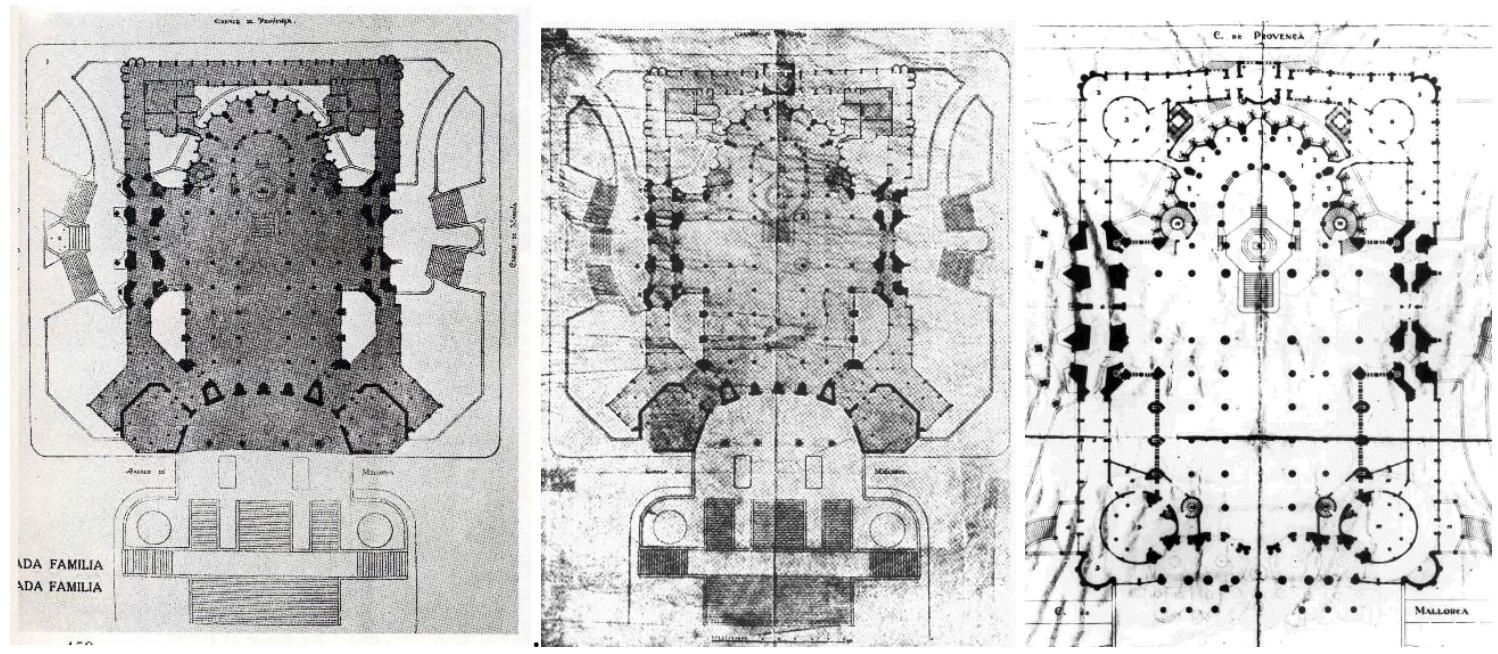

Plantas de la Sagrada Familia publicadas en los Albumes de 1915-17 y 1924-25, y en 1929 en el libro de Puig Boada El Temple de la Sagrada Familia, esta última según el último dibujo en vida de Antonio Gaudí. Fuente: Arxiu de la Sagrada Familia.
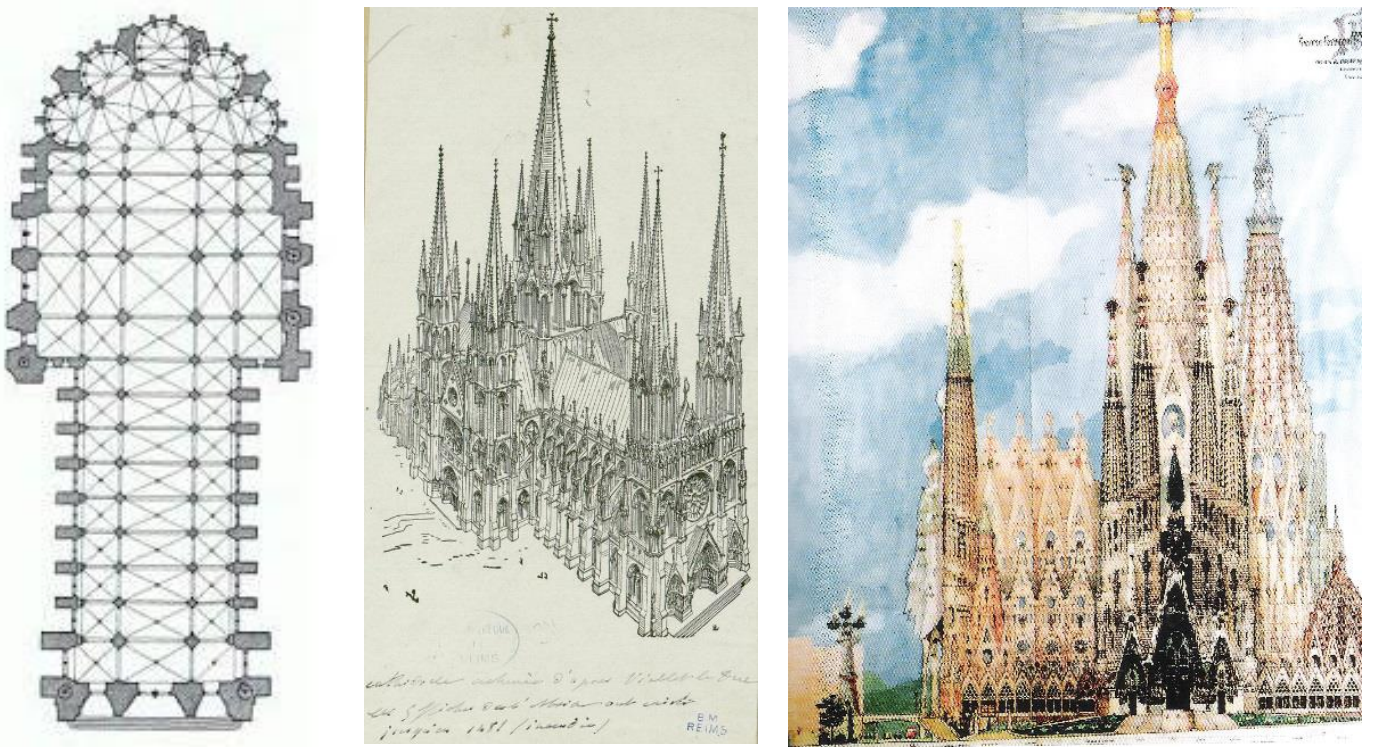

Planta de la catedral de Reims. Dibujos de la catedral de Reims en el Diccionario de Viollet-le-Duc y de la Sagrada Familia, realizado por la Oficina Técnica. 
A finales del siglo XIX las obras de la Sagrada Familia toman un gran impulso espoleadas por el éxito de la cubrición de la Cripta, la presentación del proyecto a los josefinos (1891) y un breve pero significativo superávit económico. Debido a una donación importante se puede encarar la construcción de la portada del Nacimiento con toda la magnificencia que ha preparado Gaudí. La gran ambición simbólica y dimensional de esta entrada comienza a apreciarse hacia 1908 cuando el estado de las obras ya hace presagiar su importancia y la del conjunto del proyecto, pero es en 1911 cuando sus colosales dimensiones redimensionan la escala del ábside y comienza a desarrollarse el amplio programa iconológico de la Natividad como una de las características esenciales del proyecto.

En los planos que se publican entre 1915 y 1917 es cuando se puede apreciar la importancia del claustro y de las portadas en el conjunto del proyecto respondiendo a un tratamiento de auténticas fachadas del edificio, que no sólo accesos, por muy magnificados que estén. En este mismo apartado se ha planteado una ascendencia bizantina en el número y disposición de cimborios y torres, y en otros anteriores hemos considerado, a juzgar por los estudios de Puig Boada, Tomlow y Torii, su ensayo en los proyectos de Santa Coloma y Tánger. En el dilatado periodo de ejecución de este proyecto Gaudí goza de explicar teología a sus colaboradores, haciendo alusión constante a la dimensión simbólica y trascendente de la celebración de la Misa y a todo lo que tiene que ver con el Apocalipsis de San Juan. No deja las cosas a la casualidad o la improvisación sino que su método es lógico en lo conceptual y experimental en lo constructivo, obedeciendo a un lento y sólido proceso interactivo, de ahí su atractivo. Podrá variar la geometría de la planta y la configuración estructural de los elementos y sus formas, los materiales, el color, etc. pero sus objetivos siguen siendo los mismos. Por ejemplo, la verticalidad, símbolo de lo sagrado en gran número de arquitecturas religiosas históricas, adquiere aquí un sentido plenamente orientado a la acción litúrgica que se celebra y que se anuncia, tanto por la materialidad como por simbología de la secuencia visual e iconográfica del espacio celebrativo como por la utilización de la luz, el color, y el sonido como componentes de ella. ${ }^{329}$

Así pues, en la evolución de las distintas soluciones de la sección transversal y de la cubrición de las bóvedas, dentro del proceso de depuración y simplificación conceptual y geométrica del sistema sustentante, hay que hacer notar el hecho de que el inicio de su versión arborescente se produzca en torno al año 1915.

\footnotetext{
${ }^{329}$ Litúrgicamente los campanarios representan a los predicadores del Evangelio, la voz de la Iglesia, por eso los doce campanarios de las portadas representan y toman el nombre de 12 apóstoles de Jesucristo. Cf. EI Propagador 1922.11 (pag. 328) sobre los campanarios.
} 


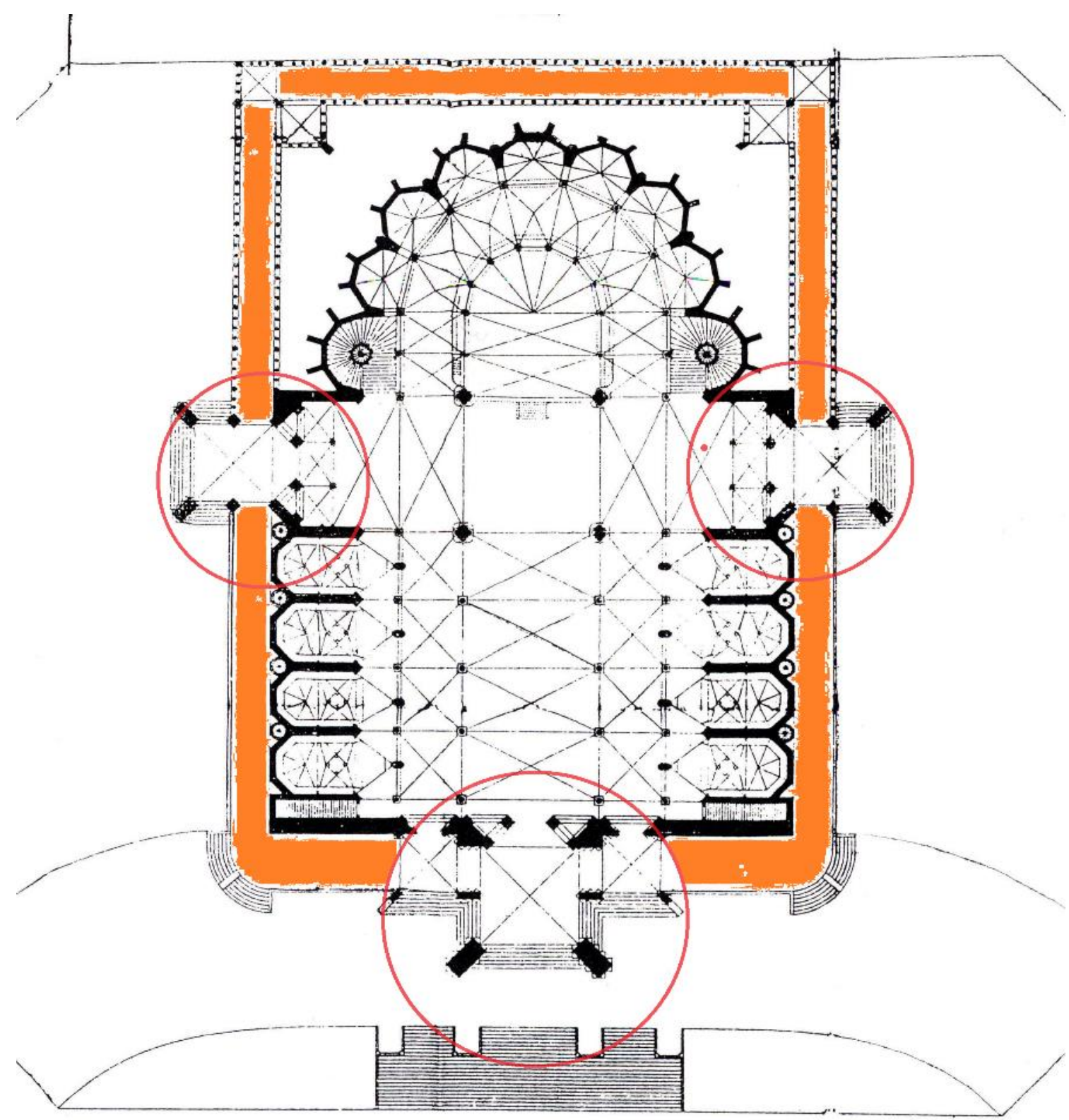

Planta de la Sagrada Familia en 1885. Enfatización de los tres accesos mediante la disposición de tres torres campanario y el claustro perimetral. Fuente: Archivo de la Sagrada Familia. 
Esta solución, radicalmente diferente en sus formas geométricas y forma de transmitir las cargas, también lo es en cuanto a su funcionalidad litúrgica -aparecen las cantorías-. No se tiene constancia de su aparición en el proyecto con anterioridad a 1915, año en que se celebra el Congreso Litúrgico de Montserrat, y sí de la gran actividad que desarrolla Gaudí el año anterior en los proyectos del Parque Güell, Santa Coloma y Mallorca.

Si el sobre-dimensionado de la cabecera de la iglesia pudo tener patrones neogóticos bien valorados (Reims, Chartres, Koln, etc.) que indujesen a Villar a aumentar el ámbito de la Cripta subyacente -testigo que recoge Gaudí transformando la idea inicial común a otras iglesias votivas historicistas-, el singular ordenamiento de los focos litúrgicos del aula celebrativa a partir de la experiencia restauradora de la catedral de Mallorca cobra nuevo impulso con la implicación de las cantorías en el sistema sustentante del edificio y el desarrollo espacial interior que nos muestran las secciones publicadas en 1917.

Si a esto añadimos la participación de Gaudí en los cursos de canto gregoriano como consecuencia de su participación en el congreso de Montserrat y los testimonios de Manuel Trens y Josep Tarré alabando el proyecto como una aplicación práctica de los principios allí hablados, hemos de concluir que existen suficientes indicios como para considerar el año 1915 y la asistencia de Gaudí al citado congreso como claves en la composición arquitectónica de la Sagrada Familia, pues resitúan el proyecto en su configuración definitiva que le permite expresar su funcionalidad litúrgica de una manera hasta el momento no conseguida.

La intención de la presente investigación es explicar esta evolución geométrica y estructural, el diseño de los distintos recintos y la utilización de los recursos que maneja la arquitectura para la construcción de un edificio, especialmente la luz y la acústica, como fruto de la voluntad de Gaudí por realzar la dimensión trascendente de las celebraciones del culto cristiano. Para ello nos detendremos en analizar los recintos que configuran su espacio interior: Aula litúrgica, Claustro, Capillas, Sacristías, etc. También resultará conveniente incidir en cómo se resuelve la estructuración del edificio y acondiciona el espacio obtenido mediante la acústica, la luz, el color, las imágenes, etc. para conseguir la finalidad pretendida. Por último será conveniente reseñar su dimensión urbana. 


\section{c) La Cripta como declaración de intenciones del arquitecto.}

La Cripta es el primer espacio arquitectónico en ser construido y el único cuyas trazas originales no se deben al diseño de Gaudí. En él comienza a manifestarse la idea que preside su actuación en el proyecto, primero tímidamente, con respeto a la obra ya comenzada, después ingeniosamente, sabiendo utilizar los recursos constructivos disponibles para cambiar sustancialmente la concepción funcional del espacio que proyecta.

La actuación de Gaudí en la Cripta revela una gran claridad de ideas, tanto en lo que respecta a la significación litúrgica de este espacio dentro del conjunto de la iglesia como a la habilidad arquitectónica que desarrolla para llevar a cabo un recinto brillantemente resuelto como espacio habitable. Partiendo de una primera tentativa "arqueologista" de variar la orientación del edificio en la dirección del Oriente litúrgico ${ }^{330}$ a la que ha de renunciar por innegables razones económicas, utiliza su ingenio arquitectónico para trasformar lo que sería un espacio simbólico destinado a la contemplación y la oración personales -inicialmente previsto para albergar un facsímil de la casa de la Anunciación de Nazaret que los josefinos quieren copiar de Loreto-, en un recinto apto para celebraciones litúrgicas de carácter público que como tal es autónomo del resto del proyecto, permitiendo su plena utilización en cualquier circunstancia. Desde el punto de vista práctico constituye además un excelente punto de partida para no demorar la utilización del proyecto por los promotores más de lo estrictamente necesario, en tanto no esté disponible el aula celebrativa de la iglesia superior, con la que sin embargo no rivaliza en ningún momento circunstancia.

Desde el punto de vista práctico constituye además un excelente punto de partida para no demorar la utilización del proyecto por los promotores más de lo estrictamente necesario, en tanto no esté disponible el aula celebrativa de la iglesia superior, con la que sin embargo no rivaliza en ningún momento.

circunstancia. Desde el punto de vista práctico constituye además un excelente punto de partida para no demorar la utilización del proyecto por los promotores más de lo estrictamente necesario, en tanto no esté disponible el aula celebrativa de la iglesia superior, con la que sin embargo no rivaliza en ningún momento.

Cronológicamente Gaudí trabaja en la Cripta desde que entra a llevar la dirección de la obra en 1884 hasta 1891, en que se inaugura tras completar la cubrición de su bóveda.

\footnotetext{
${ }^{330}$ En los primeros siglos del Cristianismo fue muy frecuente, especialmente en el area geográfica de Siria, Palestina y Mesopotamia, la orientación de la plegaria eucarística que se realiza sobre el altar en la dirección de Oriente, lugar por donde sale el sol y por donde mencionan las Escrituras volverá Jesucristo resucitado en su segunda venida.
} 


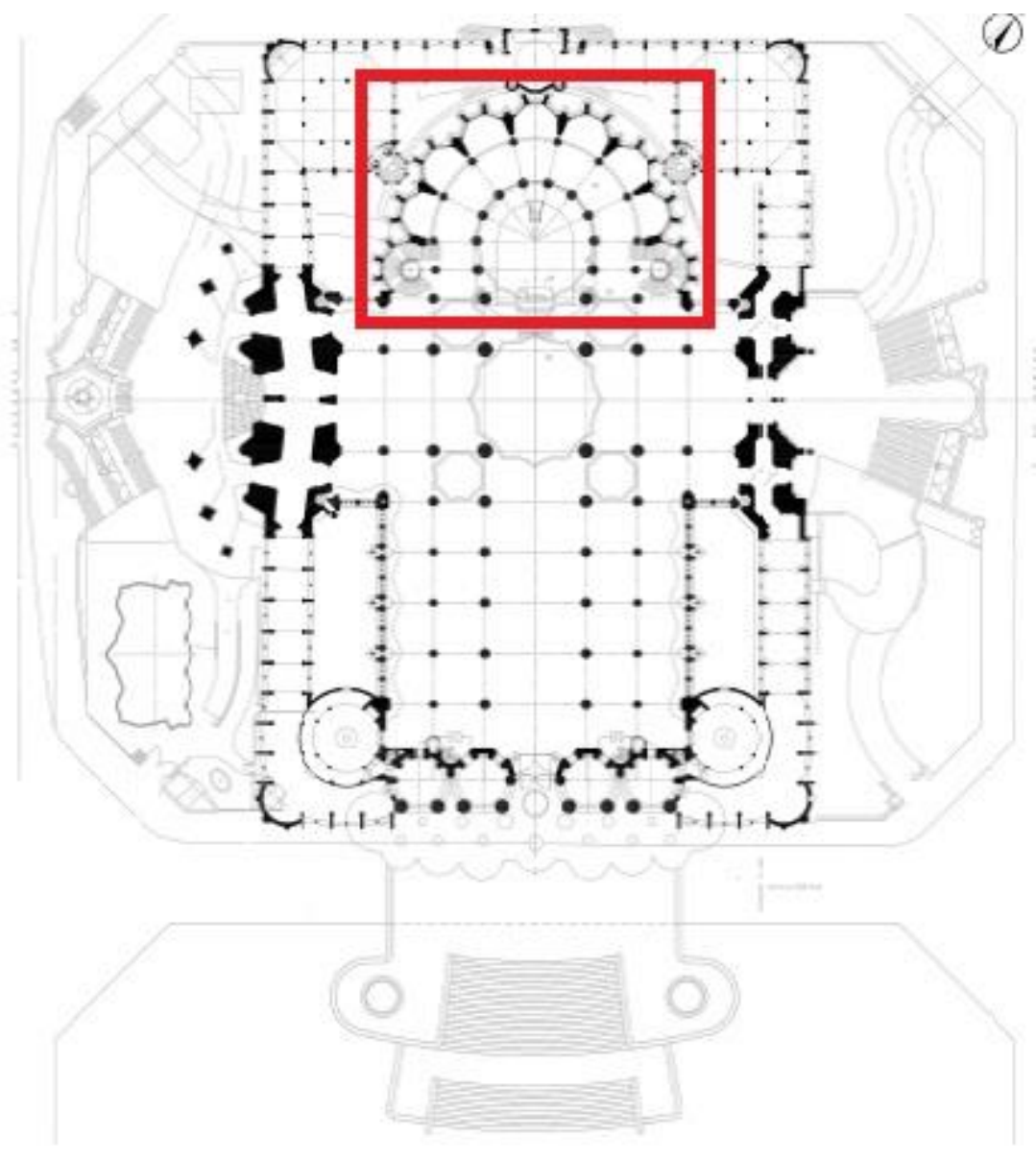

CRIPTA.

SITUACION RESPECTO DE LA PLANTA. Planta (2004) Oficina Técnica de la Sagrada Familia. Fuente: Oficina Técnica de la Sagrada Familia.

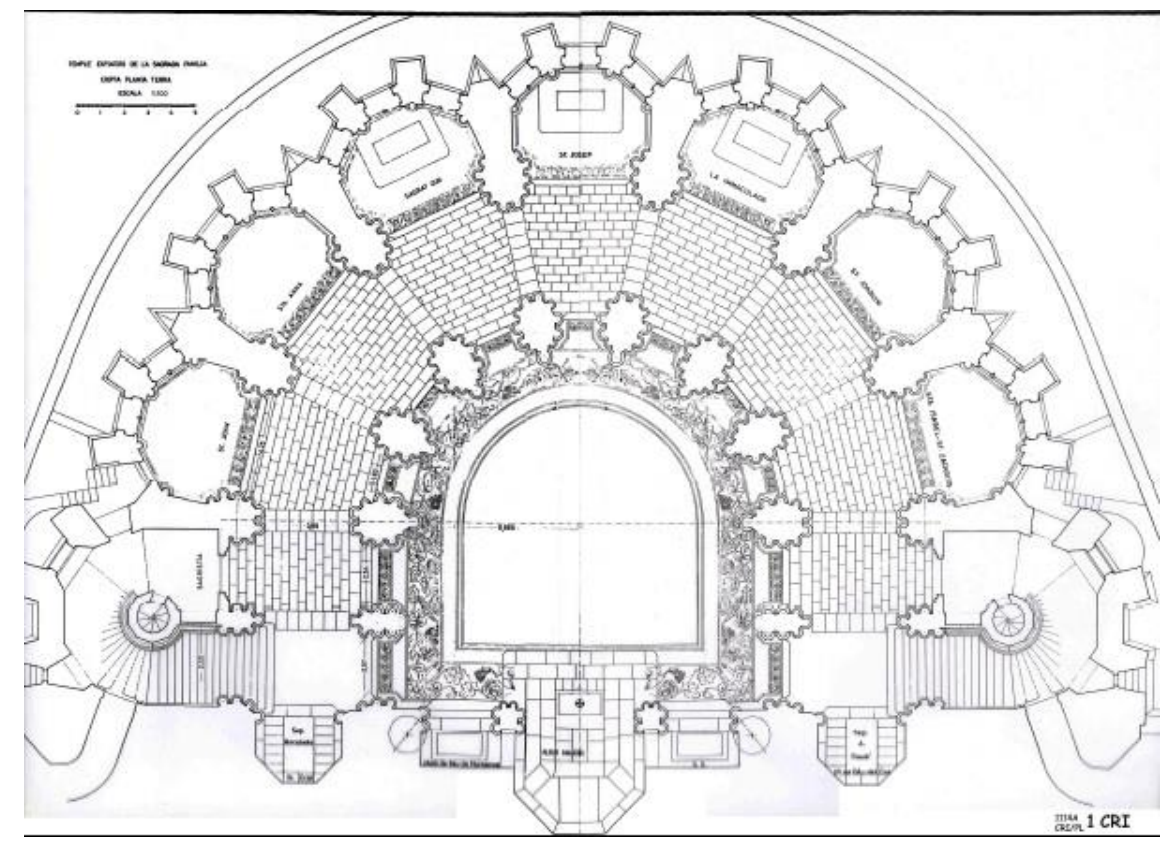

CRIPTA

PLANO DE PLANTA

Fuente: Oficina Técnica de la Sagrada Familia. 
En esos siete años la concepción litúrgica de este recinto habrá variado totalmente. Arquitectónicamente parece seguir en todo el proyecto de Villar y así encontramos que la disposición semicircular del espacio y sus dimensiones en planta, la situación de las capillas y disposición del espacio para el culto son los mismos, respetando lo construido hasta ese momento y la intención primigenia de Bocabella y su Asociación de albergar en su parte central una reproducción de la Santa Casa de Nazaret que se venera en Loreto. Pero el espacio arquitectónico y su significación van a cambiar completamente, como veremos.

Al no poder forzar la pretendida orientación de la planta (la cimentación está realizada y los pilares comenzados a un metro de altura) introduce hábilmente dos variaciones que resultan de hondo calado. En primer lugar, el acceso deja de ser central bajo el altar mayor, como ocurría en el proyecto de $V_{i l l a r}^{331}$, para pasar a ocupar una posición simétrica ocupando las primeras capillas laterales, de tal manera que no interrumpe ni distrae de la celebración que pudiera realizarse en la nave de la iglesia superior y posibilita la creación de un verdadero espacio celebrativo orientado en sentido contrario al del presbiterio superior. El planteamiento simétrico o doble, característico del proyecto gaudiniano, se pone aquí al servicio de un espacio al que se le quiere dotar de un fuerte protagonismo litúrgico, independizándolo funcionalmente de la Iglesia superior.

De otra parte la realización del foso perimetral y la elevación de la altura libre de la Cripta dan lugar a una mejora de las condiciones de iluminación y ventilación, fundamentales para un espacio que ha de acoger funciones litúrgicas colectivas en detrimento de las meramente ligadas a la piedad individual. La ejecución de las capillas absidales, empezando por la central dedicada a San José, dibujada en 1884 e inaugurada al año siguiente, parece seguir criterios de composición tradicionales en cuanto a un altar adosado a un muro de fondo, la imagen del santo al que se dedica sobre una peana y el enfoque a la devoción particular. Esta disposición está en sintonía con el plan original de Bocabella de reproducir en la Cripta la Casa de la Sagrada Familia de Loreto. Pero nos encontramos después con un hecho sorprendente: la realización de tras altares en la dirección opuesta, de los cuales el central se dedica a la Sagrada Familia, con una disposición claramente orientada a la celebración eucarística que altera completamente el planteamiento devocionista y arqueológico inicial. ${ }^{332}$

\footnotetext{
${ }^{331}$ Villar, arquitecto diocesano, se ve probablemente influenciado por la actuación que en esos años se promueve para la catedral de Barcelona, que estaba también de actualidad por el concurso para su nueva fachada principal. La catedral tiene un acceso central a la cripta desde la nave central delante del altar mayor y la notoriedad y polémica del concurso pudo ser un acicate para la propia evolución del proyecto de Villar que va ganando en dimensión y altura como se ha visto anteriormente.

${ }^{332}$ Cf. Torii, T. (1983) El mundo enigmático de Gaudí. Madrid. Instituto de España. Fotografia de la Cripta antes de 1936. Se puede apreciar las diferencias entre este altar y el recinto del presbiterio respecto del altar dedicado a S. José en el deambulatorio, así como los altares laterales con el Sagrario y las tumbas de los fundadores y del arquitecto.
} 

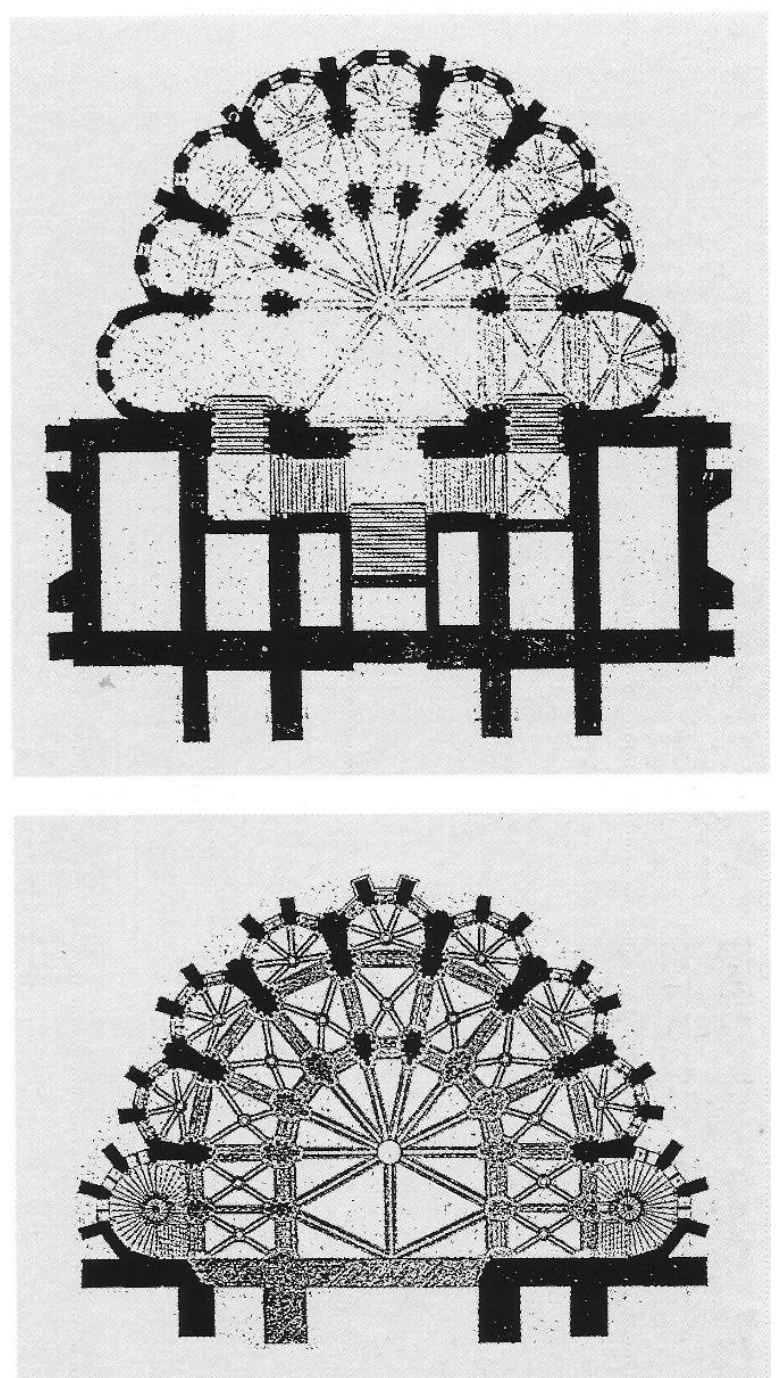

Planimetria comparada de la Cripta de la Sagrada Familia Planta superior, planta de la Cripta del proyecto de Villar. Planta Inferior, el proyecto de Gaudí. Fuente: Lahuerta, J.J. (1993). Antonio Gaudí: arquitectura, ideología y política. Madrid. Alianza Editorial.

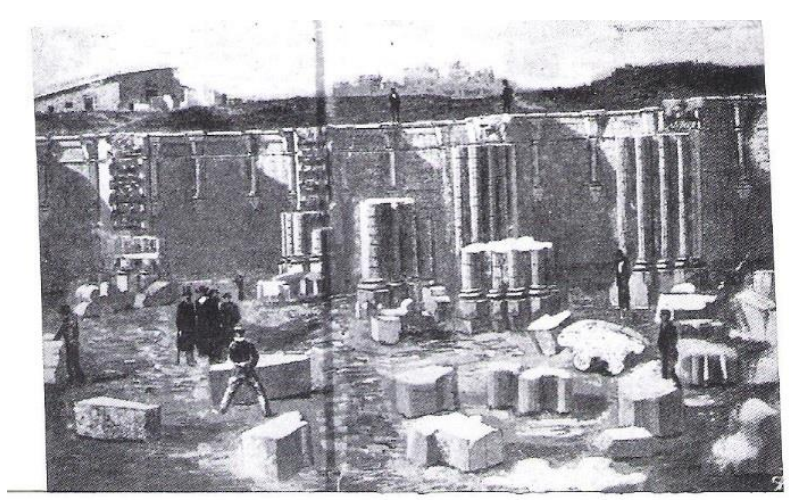

Obras de la Cripta a finales de 1883. 
Algo parece que ha ocurrido y este altar dedicado a la Sagrada Familia, cuyo carácter provisional (en tanto no esté ejecutada la reproducción de la Santa Casa de Loreto) cita Bergós $^{333}$, se va a convertir en definitivo. En marzo de 1891, al inaugurarse la Cripta y celebrarse en ella la solemne eucaristía del día de San José, nadie parece acordarse de la Casa que allí debía erigirse.

Tal vez la mentalidad práctica de los josefinos, viendo el dilatado plazo de ejecución del Templo a tenor de las dificultades financieras que ya se habían constatado para terminar la Cripta, convencieran a los promotores de que no podían prescindir de este espacio litúrgico recién ganado y de que la bondad de su funcionalidad superaba con creces a una construcción mimética que nunca podría compararse con el original. Pero también la brillantez y ambición teológico-litúrgica del proyecto que Gaudí describe en esa mañana, del cual la Cripta es un logrado anticipo, animase a los josefinos, con Bocabella a la cabeza, a dejarse conducir por el arquitecto. Lo cierto es que no se vuelve a encontrar ninguna alusión documental a la Santa Casa de Loreto con posterioridad a esa fecha.

Por otro lado, la liberación del muro sur de la Cripta en sus extremos al desaparecer el muro previsto por Villar, en lo que sería el frente del presbiterio en el nivel inferior, posibilita la comunicación con nuevos espacios a desarrollar en este nivel conformando un carácter abierto y evolutivo del programa del proyecto desde esta primera intervención dentro del plan general -que como veremos va a constituir una de las características más significativas de todo el proyecto-. Para habilitar la Cripta a su nueva condición de espacio celebrativo comunitario -no solo de oración- se ha aumentado la altura de la bóveda y se ha rodeado el recinto de una fosa o patio inglés, consiguiendo una sustancial mejora en las condiciones de habitabilidad de un recinto subterráneo en contacto con el terreno. No se trata pues, de una cripta tradicional al uso ${ }^{334}$-espacio en penumbra de carácter conmemorativo y sepulcral- a la que se le ha dejado huérfana de una pieza fuertemente simbólica sino de un recinto que está absolutamente acondicionado para las celebraciones litúrgicas por su luminosidad y volumetría, la cuidadosa disposición de la asamblea, altar, sacristía y mobiliario, unidos a una franca independencia del resto del edificio y cómoda accesibilidad desde el exterior.

\footnotetext{
${ }^{333}$ Cf. Bergós, J. (1974) Gaudí, el hombre y la obra. Barcelona. Universidad Politécnica de Barcelona. Pg. 109

${ }^{334}$ Cf. Flores, C. (2002) La lección de Gaudí. Madrid. Espasa Calpe. P.73.Como dice Carlos Flores respecto de la iluminación directa natural a la cripta Gaudí se aparta del concepto tradicional de espacio subterráneo "siguiendo una norma que mantendrá, prácticamente sin excepción, a lo largo de toda su labor, consistente en iluminar, de modo directo, cada uno de los recintos incluidos en sus edificios."
} 


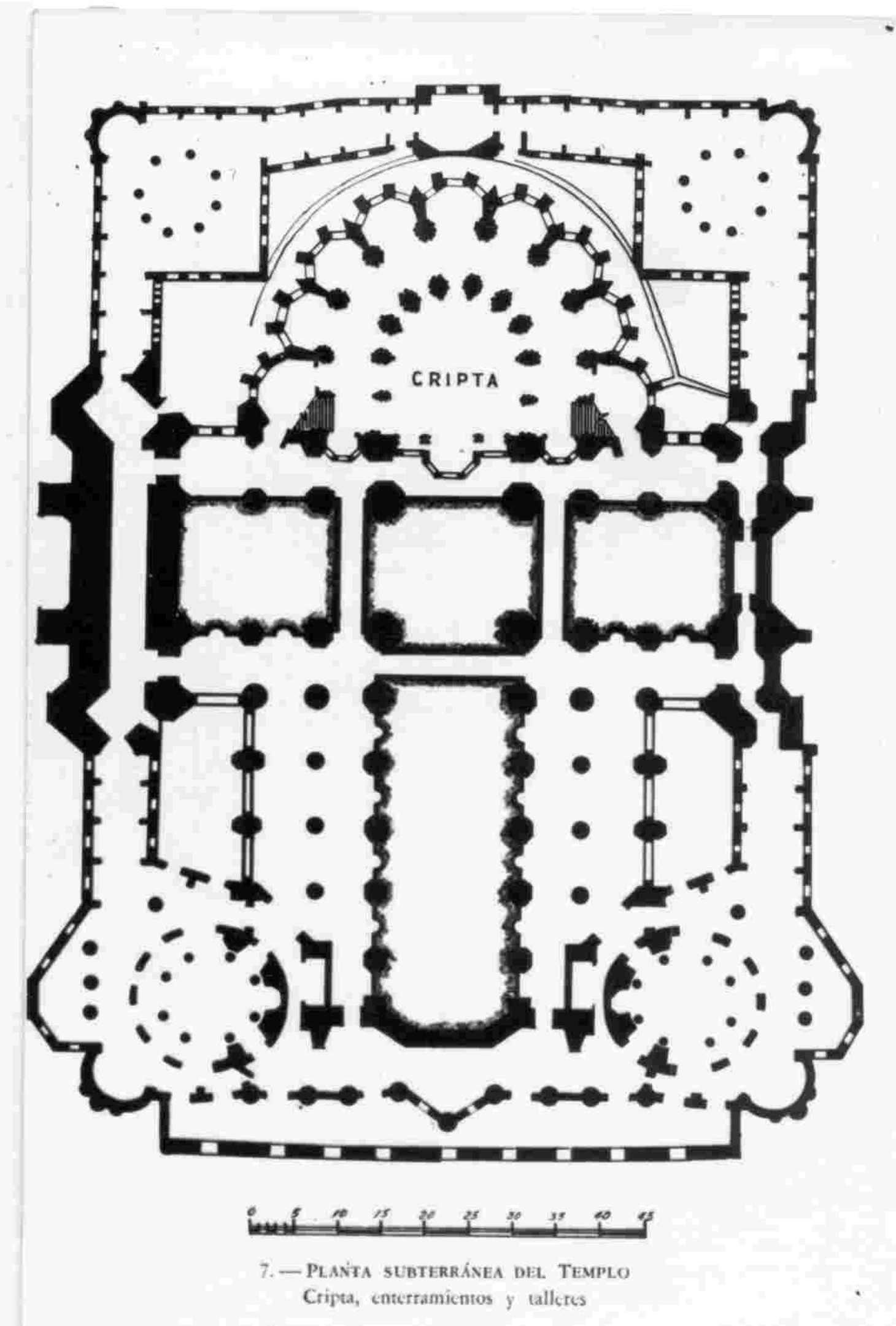

Planta de Enterraments, firmada por A. Gaudí en 1916, según Puig Boada. Fuente: Arxiu de la Sagrada Familia 
La desmaterializacion del espacio y el carácter concéntrico de un espacio vacío protegido por otro igualmente vacio de que habla Lahuerta ${ }^{335}$, tendría una explicación en el carácter sagrado de la función que allí se propone celebrar. En el centro, el espacio litúrgico, en su perímetro, primero el deambulatorio que lo sirve y después el patio inglés, la frontera que lo distingue y significa del espacio mundano a través de la luz.

La Cripta es el primer ensayo de la idea que preside la planta dibujada en 1885. En ella se encuentra ya esbozada la dimensión sagrada de la funcionalidad del edificio, su carácter concéntrico y algunos elementos de su futura configuración volumétrica. Curiosamente, esta dimensión celebrativa de la Cripta no le lleva a perder su condición de enterramiento, pues allí se dispone el sepulcro de la familia del fundador y se prevé la extensión del complejo funerario a lo largo del espacio que se quiere ganar debajo de las naves.

Contando con las circunstancias de una financiación incierta y ciertamente insuficiente para el ritmo de ejecución de las obras que hubiesen deseado los promotores y que supone un constante vaivén en su continuidad, como ha estudiado Torii (El mundo enigmático de Gaudí, 1983), es muy posible que Gaudí, profundo conocedor de las arquitecturas históricas, y Bocabella, entusiasta activista de iniciativas pías, confluyeran pronto en un planteamiento renovado y ampliado de la idea original del Templo, y que después vieran las posibilidades que éste les abría, como por ejemplo, la extensión de los enterramientos en el subsuelo del Templo como nueva línea de financiación de las obras. Se pensaba, pues, en la contribución económica que pudiera obtenerse del donativo de cuantos quisieran ser enterrados en la nueva iglesia, habida cuenta de que existía el precedente de otros enterramientos en iglesias de la época, como la catedral de la Almudena de Madrid o la del Buen Pastor de San Sebastián.

El plano que Gaudí firma en 1916, junto con una Memoria técnica, para acompañar a la solicitud de autorización que hace la Junta Constructora ${ }^{336}$, muestra claramente que se proponía utilizar toda la extensión en planta del edificio. Las galerías previstas para los enterramientos ocupan todo la planta subterránea con excepción de la proyección del espacio ocupado por la nave central y transepto del espacio celebrativo superior. Precisamente el espacio dedicado a los fieles, la Iglesia militante que participa de la celebración eucarística.

335 Cf. Lahuerta, J.J. (1993). Gaudí: Arquitectura, Ideologia y Política. Madrid. Electa España. Pp. 303-305. Lahuerta analiza la solución de los arcos superiores del deambulatorio y la desmaterialización que parece desprenderse, gracias a la diferente luminosidad, entre éste y el espacio central de la Cripta.

336 Gaudí justifica técnicamente la viabilidad de la inhumación de cadáveres en la cripta. Laura Mercader reproduce las Notas aclaratorias del Proyecto de la Cripta que se presentó en el Ministerio de la Gobernación, y menciona que iba acompañada de planos del proyecto no localizados. Anteriormente se había autorizado, mediante Real Orden de 6 de mayo de 1908, el traslado a la cripta de los restos mortales del fundador del Templo, Josep Maria Bocabella Verdaguer (1815-1892) y los de su esposa, hija y yerno. 


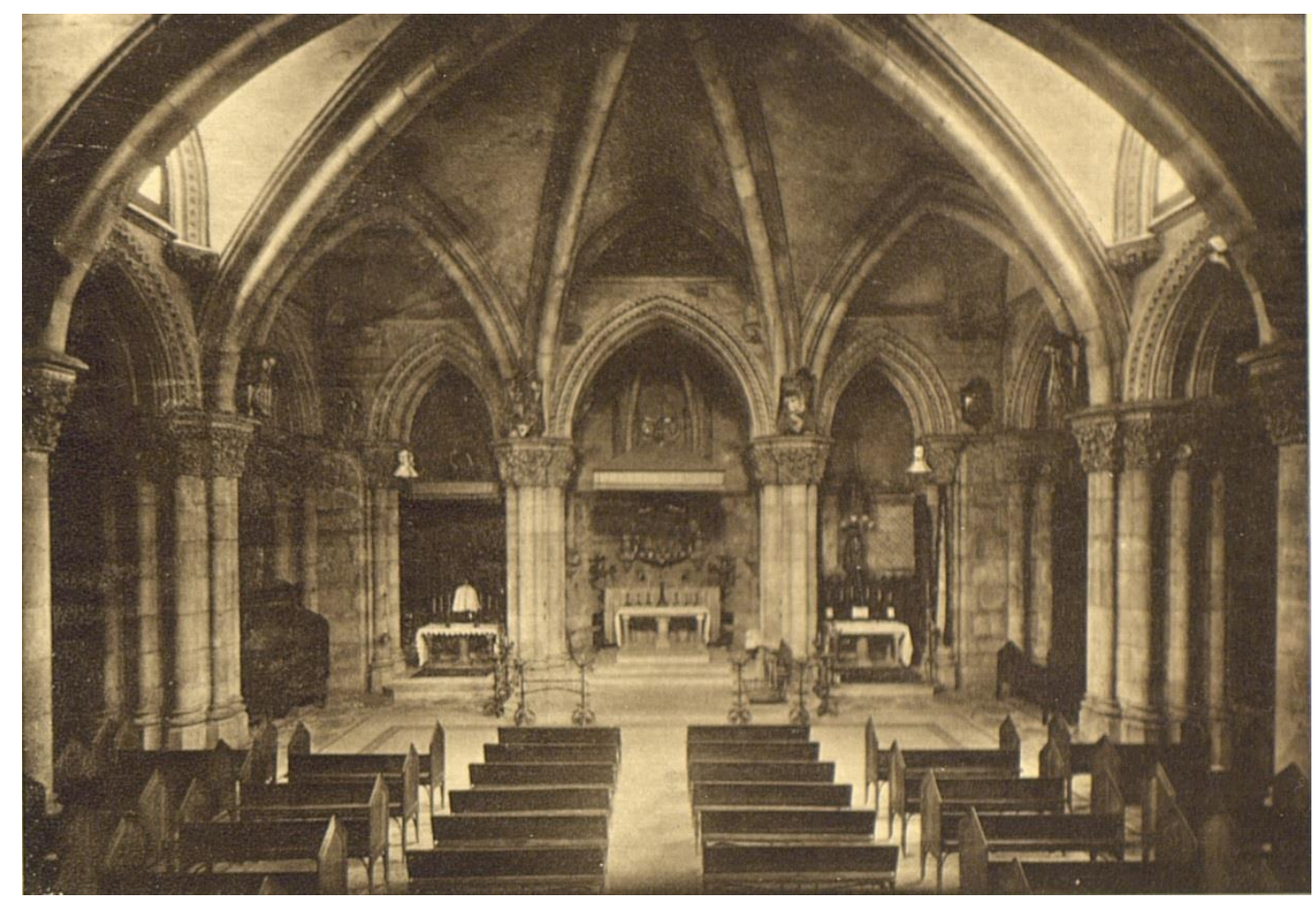

Fotografia de la Cripta antes de 1936, publicada el 40 Album de la Sagrada Familia, 1929. Nótese cómo el altar central, exento y con bancos que lo circundan, está preparado para la Misa, admitiendo incluso determinadas plegarias o celebración cara al pueblo. En cambio los dos altares laterales se han dispuesto para alojar el Sagrario y la devoción a la Virgen. Fuente: Archivo de la Sagrada Familia La Cripta antes de 1936. Fuente: Archivo de la Sagrada Familia

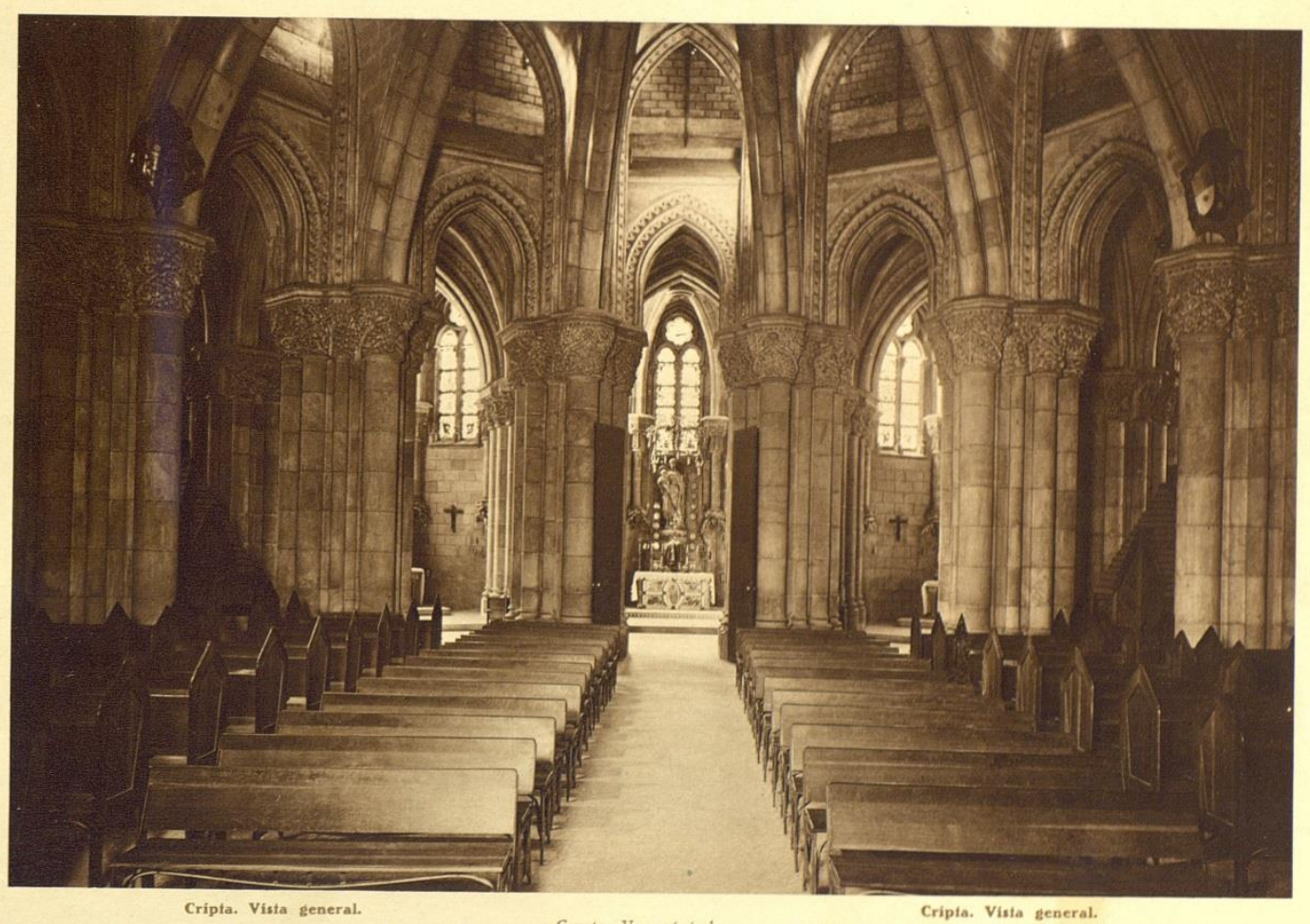

Fotografia de la Cripta en el 3er Album (1922-25). Se observa cómo Gaudí distingue en cada altar según su dedicación. En el altar dedicado a San José, junto con otros previstos en el deambulatorio, tiene un carácter de Oratorio, presencia del Sacramento y devocionario individual Fuente: Archivo de la Sagrada Familia 
En realidad el planteamiento de conjunto recuerda las catacumbas de los primeros tiempos del Cristianismo, cuando se excavaban largos túneles como un auténtico camposanto y en ocasiones se podía celebrar la liturgia en determinados ensanchamientos y capillas. La Cripta diseñada por Gaudí satisface inmejorablemente las necesidades que pudieran darse en este sentido. Esta planta subterránea va a servir de fundamento a la planta dibujada en 1917 para la iglesia superior, que salvo pequeñas variaciones persistirá hasta la última solución dibujada en vida de Gaudí (1926), lo que da idea de la bondad y firmeza con que el arquitecto valoraba su propuesta técnica para los enterramientos. ${ }^{337}$ Gaudí debió de tomarse muy en serio el proyecto de inhumación de cadáveres en el subsuelo de la Sagrada Familia, puesto que se involucra claramente en la exposición de motivos sobrepasando con mucho las meras cuestiones técnicas del caso diciendo: "esta práctica de ceder el derecho de enterramiento en templos de aquellas personas que, por la cuantía de sus donativos, pueden considerarse como protectoras del mismo no pertenece solamente a pretéritas edades, sino que actualmente aquí en España tenemos buenos ejemplos de ello." ${ }^{\prime 38}$ Manifiesta, pues, lo acertado para él de esta práctica por ayudar a reducir los costes de construcción de estas iglesias, siempre elevados, citando los casos ya autorizados de San Sebastián y la Almudena en Madrid.

En la Memoria se citan los planos que acompañaban la solicitud -plantas, secciones trasversales y longitudinales de la cripta, planta de la iglesia, etc.- que permitían hacerse una clara idea de las medidas precautorias incorporadas para garantizar la higiene y salubridad de los enterramientos, de la propia cripta, y de las vías pública colindantes. Gaudí describe en el texto con precisión las características de los enterramientos y de las condiciones de ventilación e iluminación. Básicamente, las medidas que dispone para garantizar la ventilación e iluminación consisten en la excavación de un patio inglés alrededor del perímetro de la cripta en cuya fachada se disponen las aberturas precisas para provocar la constante renovación de aire, que garantiza una adecuada ventilación e iluminación natural -ya realizados en aquel momento-; la instalación de cuatro ascensores que han de comunicar la cripta con las partes altas del templo, provocando además corrientes de aire ascendentes por las diferencias térmicas y de presión, a modo de respiraderos naturales; la instalación de cuatro ventiladores centrífugos accionados eléctricamente que succionen el aire de la cripta y mediante conducciones metálicas lo

\footnotetext{
${ }^{337}$ En octubre 1916 el Obispo de Barcelona dirige una carta al Ministerio de la Gobernación y se dirige en una alocución al Senado para demandar la aprobación de la solicitud. Gaudí dibuja una planta de conjunto de la iglesia superior en 1917 que reproduce la subterránea, publicada en el Pro el 1-04-1917. Vuelve a ser reproducida el 17-03-1923 en la Hormiga de Oro, y en el Album de la Sagrada Familia de 1925. No será hasta 1926, año en que muere el arquitecto, cuando hay una nueva planta que es publicada en 1929.

338 Cf. Mercader, L. (2002) “Notas aclaratorias del proyecto de cripta para enterramientos en el templo expiatorio de la Sagrada Familia, en Barcelona (1916)", en Antoni Gaudí: escritos y documentos. Barcelona. El Acantilado. Pp. 157-162.
} 
impulsen dentro de los campanarios a una altura considerable donde es reintegrado a la atmosfera.

Soluciones todas ellas de un gran ingenio y precisión para la época que dan idea de la seriedad con la que afrontaba los problemas que pudiesen generar obstáculos a la realización del proyecto. Exactamente escribe:

"Las tumbas que se podrán construir en esta cripta tendrán, naturalmente según su capacidad y situación, distinta importancia, al objeto de que ésta esté en relación con la cuantía de la limosna de dé la persona o personas que deseen utilizar este derecho de enterramiento.

La cripta que se proyecta utilizar para que en ella se practiquen enterramientos estará en inmejorables condiciones de iluminación y ventilación, puesto que todos los locales de la misma las tienen directas e inmediatas, como puede verse en la planta y secciones longitudinal y transversal que de la misma se acompañan.

Además en $A$ y $A^{\prime}$ y $B$ y $B^{\prime}$ (véase la planta) se proyectan unos ascensores que han de comunicar esta parte baja con las partes más elevadas del templo, como se comprende fácilmente, esta especie de pozos en los que se

moverán los ascensores serán cuatro grandes chimeneas de ventilación, puesto que, además de la circulación de aire que por ellas se establecerá a causa de las diferencias térmicas y de presión que por la acción solar se producirán en las mismas, la actuación de éstos como un émbolo, hará que cada uno se convierta en una gran bomba aspirante impelente, provocando, por consiguiente, una renovación del aire de la cripta, suficiente para que pueda garantizarse la absoluta pureza del mismo. ${ }^{339}$

En la parte de la cripta construida actualmente y destinada al culto desde hace más de treinta años se 'puede observar cómo las disposiciones adoptadas para la ventilación natural de la misma son eficaces, lo que prueba que ellas son acertadas y efectivas; siendo, por lo tanto, garantía para el resto de la cripta que falta construir, debiendo observar que actualmente no existe el poderoso medio auxiliar de ventilación natural que, como queda dicho, son los ascensores.

Las disposiciones a que hemos hecho referencia consisten sencillamente en haber rodeado la cripta, correspondiente al ábside de la iglesia superior, por un foso $F$ (véase la planta y la sección longitudinal), y haber puesto el interior de la cripta en constante comunicación con el aire del exterior mediante aberturas convenientemente dispuestas, asegurándose de esta manera, una constante renovación de aire.

\footnotetext{
${ }^{339}$ Sobre la disposición de los ascensores véase el art. de Jordi Bonet i Armengol
} 


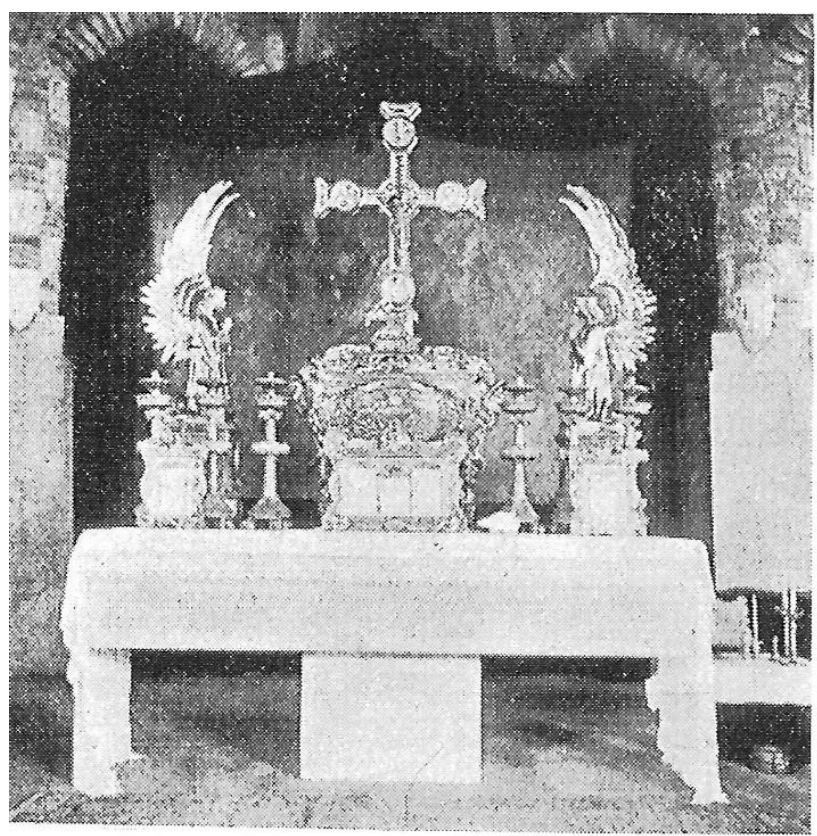

Altar de la Cripta preparado para celebración eucaristica, Iglesia de la Colonia Güell, en 1917. La disposición exenta del mismo, alejada del muro o retablo del fondo del presbiterio, muestra la relevancia que se le quiere dar. La disposición de sacras, crucifijo y candelabros, que la celebración es de espaldas a los fieles. Ambas disposiciones indican que se seguía la línea de renovación impulsada por el Movimiento Litúrgico, que en estos años todavía se halla en camino de lo que sería la constitución Sacrosanctum Concilium del Vaticano II. Fuente: Lahuerta, J.J. (1993) Antonio Gaudí: arquitectura, ideología y política. Madrid. Alianza Editorial

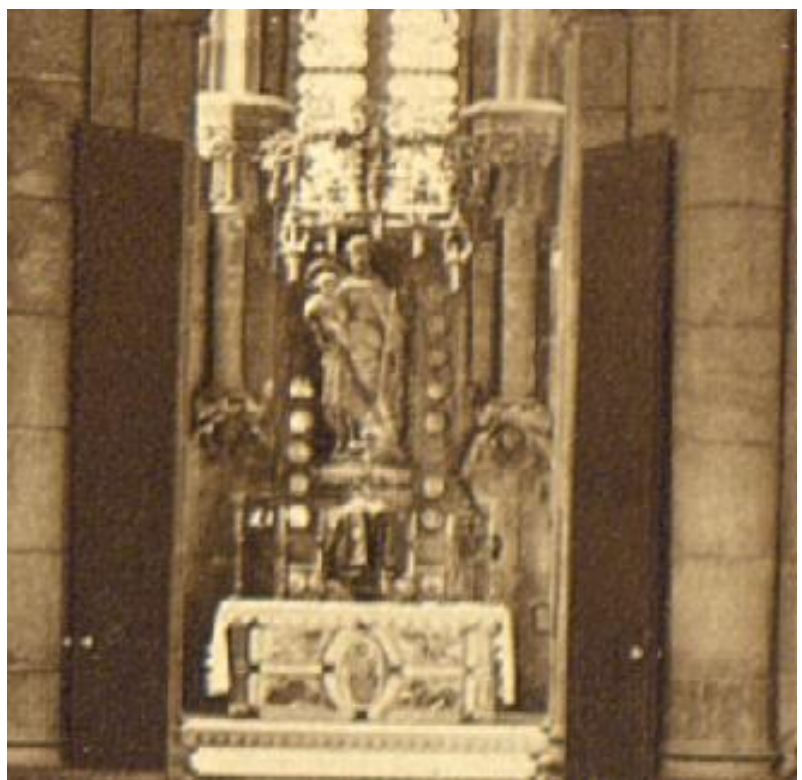

Altar de San José en la Cripta de la Sagrada Familia dedicado a la oración ante el sagrario, Album de 192225 Fuente: Archivo de la Sagrada Familia 
No obstante lo que queda dicho, y al objeto de prever hasta la exageración lo que a la salubridad se refiere, se proyecta la instalación de cuatro ventiladores centrífugos movidos mediante un motor eléctrico acoplado al mismo ventilador en $C$ y $C^{\prime}$ y $D$ y $D^{\prime}$ (véase la planta). Estos ventiladores serán de los llamados de succión o aspirantes, capaces, cada uno, para aspirar 3,31 metros cúbicos de aire por segundo, o sea 11.941 metros cúbicos por hora; entre los cuatro dan un volumen total aspirado por hora de 47.764 metros cúbicos, que es el cubo total de aire contenido en toda la cripta.

El aire aspirado por los ventiladores será impulsado por los mismos y conducido mediante tuberías de hierro estirado por el interior de los campanarios y reintegrado a la atmosfera en la parte superior de los mismos, o sea, a una altura de unos 100 metros." ${ }^{\prime 340}$

De las tres medidas propuestas, dos son de tipo netamente arquitectónico y redundan principalmente en la iluminación, comunicación y ventilación que considera adecuadas para el uso continuo de la capilla de la cripta. La tercera, más en el campo de las instalaciones, supone una medida adicional pero igualmente válida casi por si sola capaz de garantizar la extracción del posible aire enrarecido de la cripta, ya que es dimensionada para evacuar en una hora el total del volumen de aire de la misma.

De igual manera, Gaudí hace una detallada descripción del proyecto de las tumbas a los efectos de recabar la autorización gubernativa:

"Los enterramientos se verificarán en tumbas abiertas en el suelo: estas tumbas serán para uno o más cadáveres, pero siempre estarán convenientemente revestidas lateralmente mediante muro de ladrillo por lo menos de 0,30 metros de espesor, teniendo el fondo formado por una capa de hormigón hidráulico por lo menos de 0,20 metros de grueso, y superiormente estarán cubiertas por una bóveda, en cuyo centro tendrá la abertura que ha de servir para la introducción de los féretros.. esta abertura estará cerrada mediante una losa de piedra o metal perfectamente ajustada. Además, las tumbas o cámaras sepulcrales estarán enteramente revocadas y enlucidas con cemento Portland, al objeto de que resulten completamente impermeables y, por lo tanto, aisladas de la tierra que las circunda.

\footnotetext{
340 Cf. Mercader, L. (2002) "Notas aclaratorias del proyecto de cripta para enterramientos en el templo expiatorio de la Sagrada Familia, en Barcelona (1916)", en Antoni Gaudí: escritos y documentos. Barcelona. El Acantilado. El documento está fechado en 1916 y la aprobación del Ministerio de Gobernación el 18-121916 después de una carta e intervención del Obispo de Barcelona en el Senado el 23-10-1916.
} 


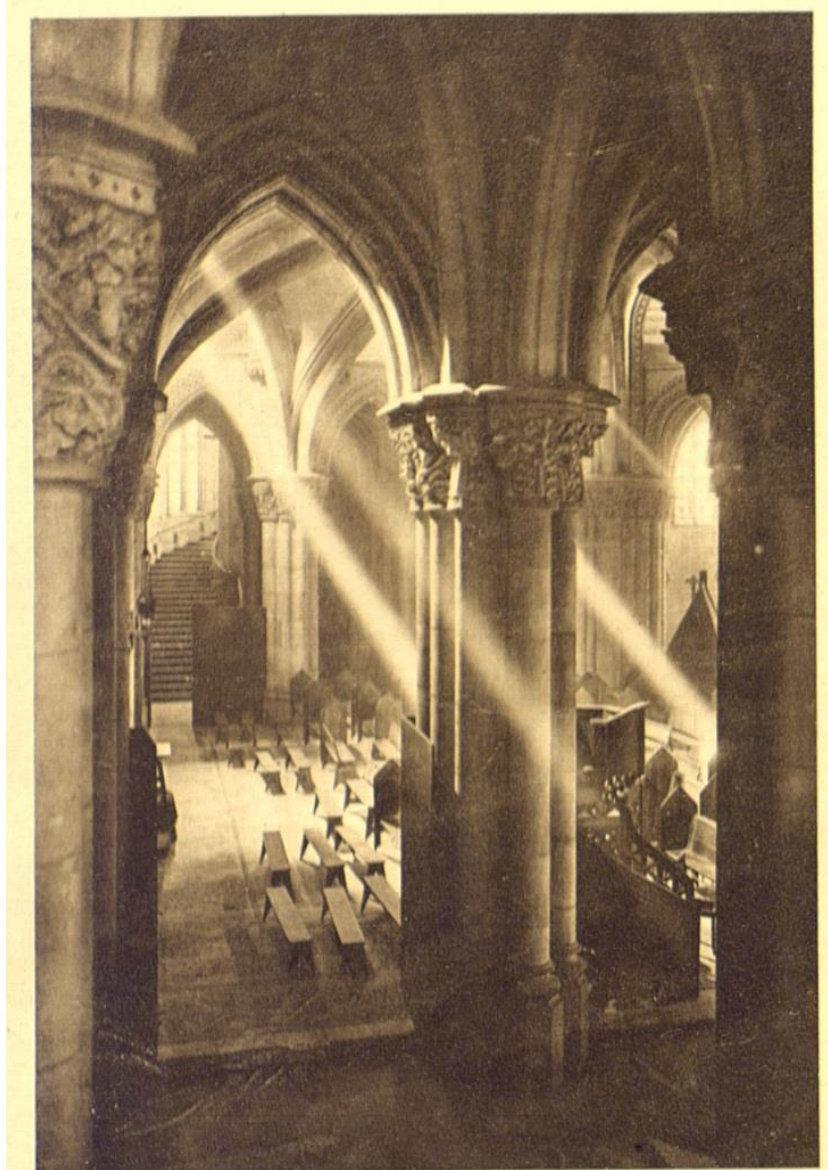

Cripta: Conjunt i escala d'entrada

Cripta: Conjunto y escalera de entrada

La Cripta iluminada de forma natural. Obsérvese el púlpito de madera diseñado para colocarse junto a la columna y el confesionario en el fondo, en el deambulatorio. Fuente: Album de la S.F. (1929). Archivo de la S.F.

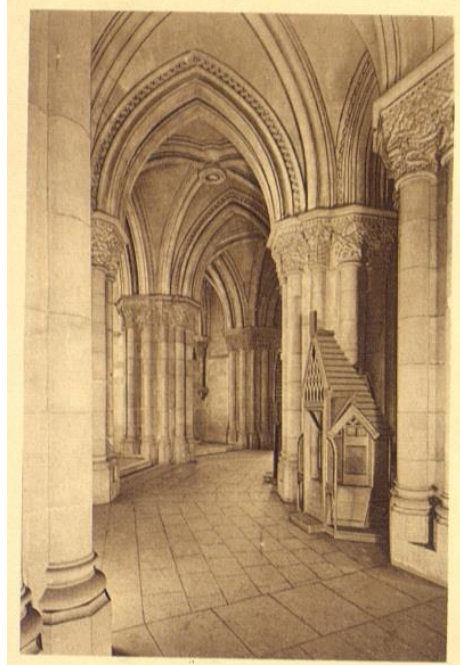

Cripta: girola.

Cripta: tirola.

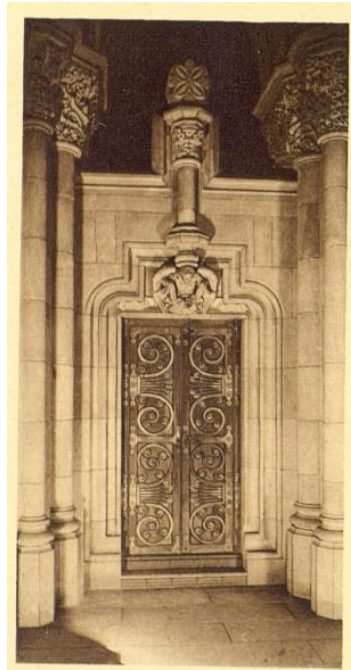

Cripta: Porta d'una sacristio

Deambulatorio de la Cripta y Puerta de entrada a la Sacrsitia que muestran la adecuación que Gaudí realiza para convertir la Cripta en aula celebrativa de la Misa. 3er Album (1922-25). Fuente: Archivo de la SF. 
En las tumbas dispuestas para varios enterramientos, éstos se practican de manera que cada uno de ellos quede enteramente aislado de los restantes dentro de la misma tumba, y ésta, aislada del terreno conforme queda indicado.

El espacio destinado a verificar los enterramientos comprende toda el área de la cripta, a excepción hecha de los pasos o corredores que tienen por objeto facilitar la comunicación entre las distintas partes de la misma, y al mismo tiempo, la libre circulación del aire."

Es interesante señalar que no sólo describe la ubicación y características de las tumbas a autorizar en el subsuelo de la Cripta sino que en la Memoria amplia la posibilidad de enterramientos a los espacios macizos de la nave principal y crucero del Templo:

"Los espacios macizos que, correspondiendo a la nave principal y al crucero, se ven en la planta que se acompaña, se reservan para abrir en los mismos las llamadas tumbas de derecho, si es que algún día, como probablemente sucederá, se concede a alguien tal distinción, y al mismo tiempo, se utilizarán estos macizos, y su parte colindante con los muros de la cripta, para abrir en ellos unas cámaras sepulcrales de mayor distinción, sujetándose los enterramientos en ellas a las mismas condiciones de aislamiento que hemos indicado para los que se verificarán en el suelo de la cripta.

Estas son las principales aclaraciones que para la debida inteligencia de los planos que se acompañan hemos creído debíamos formular, y estamos plenamente convencidos que las disposiciones adoptadas en la parte construida y las que, como queda indicado, se proyectan en la parte que falta construir son suficientes y más que suficientes para

asegurar una suficiente aireación de todos los ámbitos de la cripta, de manera que no sea posible la formación de lo que podríamos llamar lagunas de aire estancado, quedando por lo tanto salvado el grave inconveniente que para la salubridad podría representar la existencia de tales masas de aire viciado y, por ende, garantizada la posibilidad de la visita y permanencia en los locales de la referida cripta, así como la completa inocuidad de la misma para con respecto de la vías públicas que circundan el templo." 341

\footnotetext{
${ }^{341}$ Cf. Mercader, L. (2002) "Notas aclaratorias del proyecto de cripta para enterramientos en el templo expiatorio de la Sagrada Familia, en Barcelona (1916)", en Antoni Gaudí: escritos y documentos. Barcelona. El Acantilado.
} 


\section{d) Los espacios litúrgicos en la Sagrada Familia.}

El edificio dedicado al culto cristiano recibe históricamente el nombre de iglesia por ser el lugar donde se reune la asamblea, convocación o reunión-ecclesia- de los bautizados para celebrar comunitariamente la nueva Alianza fundamentada en la Pascua cristiana. Bien pronto la afluencia masiva de nuevos conversos y la estabilidad social derivada del Edicto de Milán en el siglo IV hacen necesario abandonar la reunión en las casas para disponer de un edificio en el que el puedan tener lugar todas las acciones que desarrollo litúrgico propicia. Ello conlleva la necesidad de disponer de una multiplicidad de recintos que tienen que ver con el catecumenado o proceso de incorporación plena de los fieles a la asamblea litúrgica para ser la comunidad cristiana misma el templo de la inhabitación de Dios y poder celebrar dignamente las distintas acciones de culto. ${ }^{342}$

De esta manera se asiste históricamente a la incorporación de diferentes recintos al edificio de la iglesia, nártex o espacio de acogida, aula celebrativa o de la asamblea eucarística, aulas de impartición de la doctrina y catequesis, baptisterio, atrios y deambulatorio, lugar de la penitencia, campanarios, sacristías y espacios destinados a servir a las celebraciones, camposantos, etc., configurándose un complejo edificatorio ordenado y dinámico aún cuando en épocas de decaimiento litúrgico haya sido más difícil de percibir. Precisamente Gaudí, por su conocimiento teológico-litúrgico y enraizamiento con la renovación propugnada en su tiempo por el Movimiento Litúrgico, es capaz de concebir y ordenar los distintos espacios del edificio -celebrativos o nodesde todas las perspectivas que intervienen en su acondicionamiento. ${ }^{343}$

\footnotetext{
${ }^{342}$ Cf. Farnés Scherer, P. (1989) Construir y adaptar las iglesias". Barcelona. Regina.

${ }^{343}$ Cf. Bouyer, L. (2000) Arquitectura y Liturgia. Bilbao. Grafite Ediciones. P. 27: "Cuando nos fijamos en las iglesias que fueron adaptadas o construidas para albergar la liturgia cristiana en lo mejor de su lozania y de su potencia creadora, vemos que lo importante no es una serie de detalles determinados, tomados aisladamente, sino más bien la relación dinámica recíproca de los diferentes focos de la celebración, encarnada en sus diferentes elementos y en un orden coherente. Esto puede dar origen, como así ha sido, a una variedad casi ilimitada de formas. Pero todas estas formas carecen de vida cuando se las copia materialmente sin comprender de dónde venia su sentido."
} 


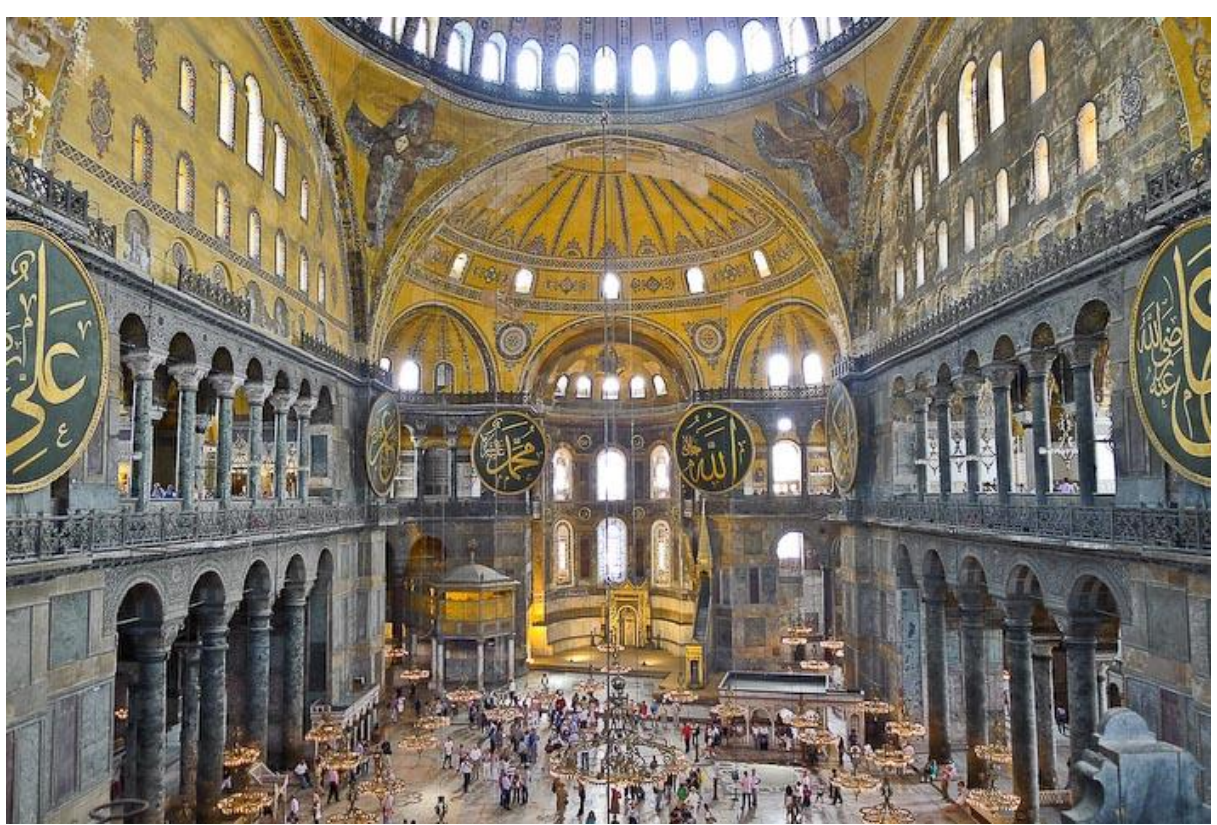

Santa Sofia de Constantinopla, hoy Museo. El aula litúrgica tal y como fue diseñada presenta tres naves pero la disposición de columnas entre ellas y la magnitud del volumen central con la gran cúpula la hacen percibir como una planta perfectamente centralizada. Los fieles, hombres y mujeres separados, se situaban en las naves laterales de planta baja y piso. En la nave central se disponía el emperador y su corte alrededor del bema y delante del presbiterio que ocupaba la clerecía. Al comienzo y en determinados momentos de la celebración litúrgica se realizaban procesiones del clero y sequito imperial por la nave central y el encuentro de ambos para intercambiar el beso santo de la paz. Fuente: Beckwith, J. (1997) Arte paleocristiano y bizantino. Madrid. Cátedra

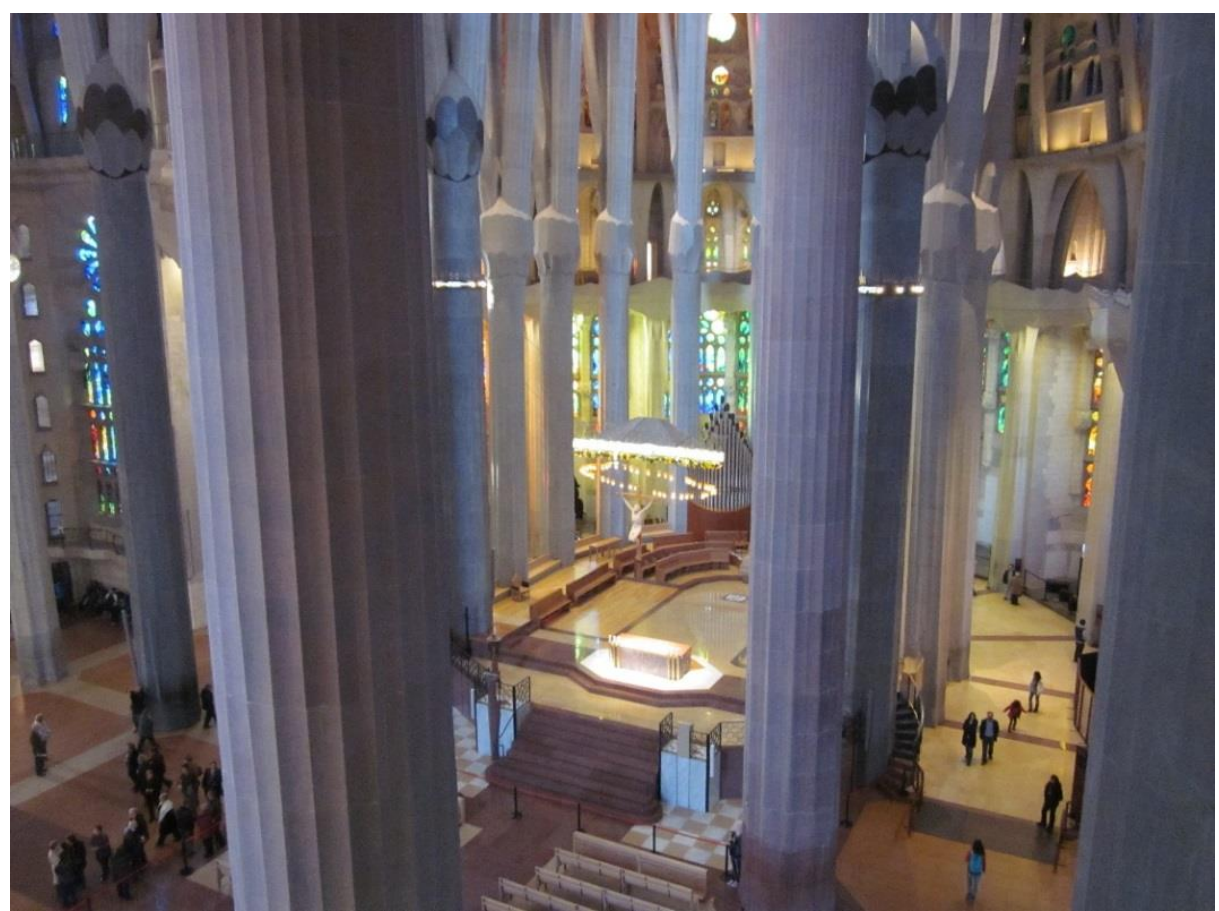

Aula litúrgica de la Sagrada Familia. Presbiterio sobreelevado y altar exento en la ubicación prevista por Gaudí, Deambulatorio, y Coro infantil elevado en el ábside. La asamblea dispuesta con el foco visual en el altar s/ Movimiento Litúrgico. Fotografía del Autor. 


\section{d.1- Planteamiento del aula celebrativa.}

Vemos, pues, que históricamente la organización en planta de una iglesia ha debido responder en alguna medida a las necesidades funcionales marcadas por las acciones sagradas y los ritos establecidos para ellas según cada geografía y época. En consecuencia las trazas y el conjunto del espacio interior de una iglesia aportan datos, además de constructivos y artísticos, que nos permiten acercarnos a una lectura simbólica del edificio en consonancia con la esencia de la liturgia cristiana visualizándose de alguna manera cómo serian las celebraciones que en ellas se realizaban. El lugar de la Asamblea Eucarística, fuente y culmen de la liturgia cristiana, viene definido principalmente por la identificación espacial de sus principales focos litúrgicos, el altar o mensa Christi en primer lugar, el ambón o altar de la Palabra, la sede, el coro, la organización de la asamblea de los fieles, etc. Las condiciones de iluminación, acústica y visibilidad contribuyen grandemente disponer de unas condiciones mínimas de confort que ayuden a la participación de los fieles en la celebración. La propia consideración que la comunidad celebrante hace de la dignidad del lugar destinado a la celebración mueve a promover su ornamentación en el término preciso que huye tanto de la presunción decorativa fuera de lugar como de la miseria deplorable.

Las características de este espacio celebrativo en la Sagrada Familia hay buscarlas en los álbumes publicados por la Asociación de devotos de San José en los años 1915, 1917, $1922-25$ y $1929^{344}$, aunque muchas veces son más fidedignos los documentos gráficos que los textos, supuestamente revisados por el mismo Gaudí3 ${ }^{345}$.En los álbumes no podemos encontrar una descripción cronológicamente ordenada de la construcción del edificio sino una exaltación de los temas y efemérides que la asociación josefina considera relevante mencionar, sean arquitectónicos, escultóricos o simbólicos. Ya en el primer álbum se hace referencia a la situación de altar y coro encima de la cripta pero se precisa que el altar se asienta (sobre un corredor que simboliza el Purgatorio con vistas a la cripta) sobre tres graderías, una de las cuales bajará hasta el crucero ${ }^{346}$

\footnotetext{
344 Lahuerta menciona que probablemente a partir de 1893 Gaudí había comenzado a dar forma a un esquema de conjunto de la planta de la Sagrada Familia (cf. Antoni Gaudi, 1852-1926: Arquitectura, ideología y política. P. 306), pero lo cierto es que no hay pruebas de dibujos anteriores a los publicados en los álbumes del Propagador de estos años. Sin embargo, ya se ha hecho mención al discurso a los josefinos en 1891, cuyo texto permite constatar que Gaudí ya tenia en ese momento una idea bastante completa del conjunto de la planta y principales elementos de la iglesia.

345 Llama la atención la contradicción entre la descripción que hace el texto de la ubicación de los altares de la Cripta y la información que aportan los dibujos y fotografías publicados en el mismo Album.

346 Cf. Album de la S.F. (1917): "Encima mismo de la cripta, asentándose sobre un corredor en que se simbolizará el Purgatorio, por el que se celebra el sacrificio, con vistas a la cripta, estará el altar mayor, sobre tres graderías, una de las cuales bajará hasta el crucero."
} 


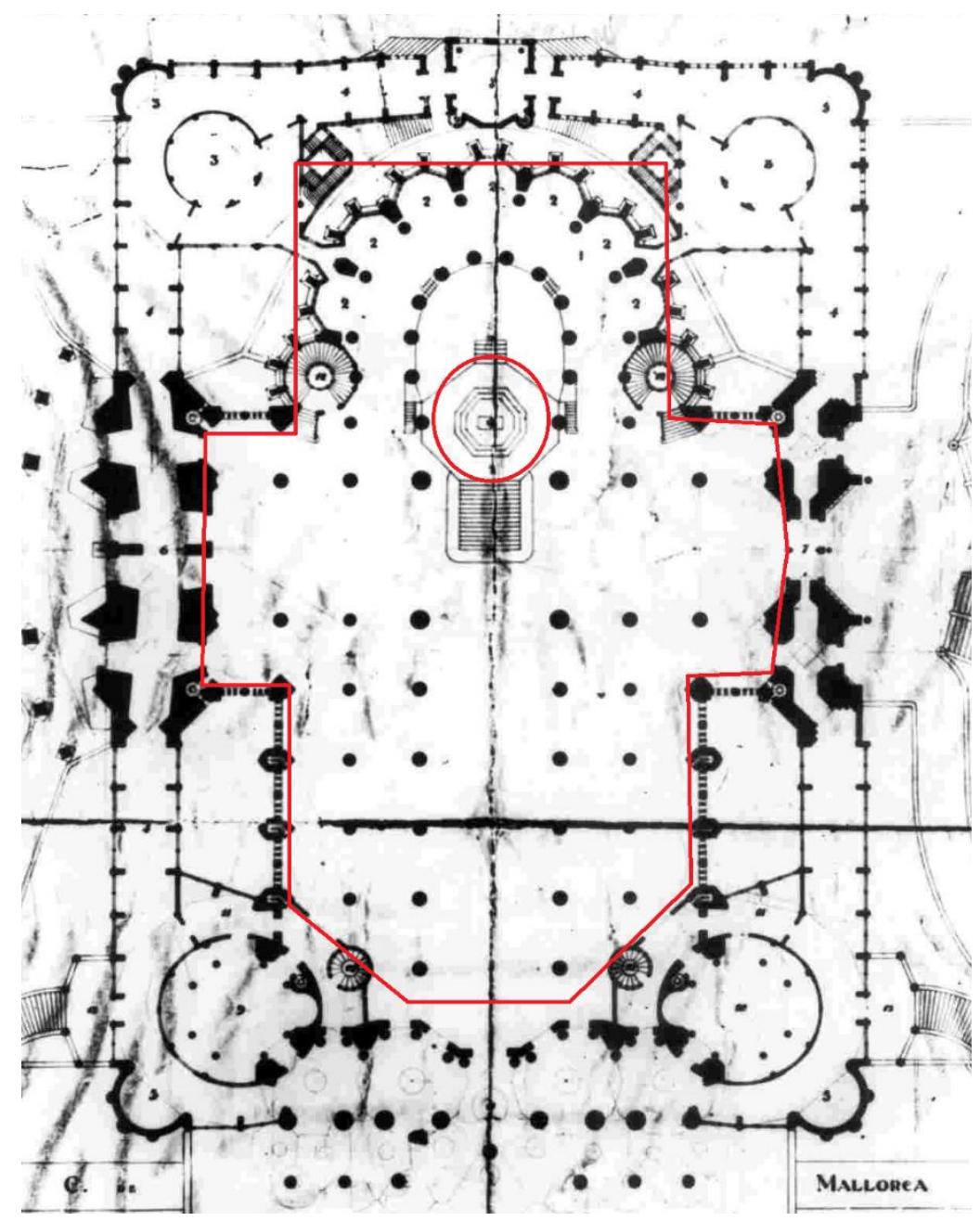

Aula celebrativa y altar según la planta de 1926, publicada por Puig Boada en la revista Temple, 1981. Obsérvese la base de planta octogonal sobre la que se eleva el altar por medio de tres escalones y la disposición focal centralizada sobre el mismo teniendo en cuenta también las cantorías. Fuente: Archivo de la Sagrada Familia.

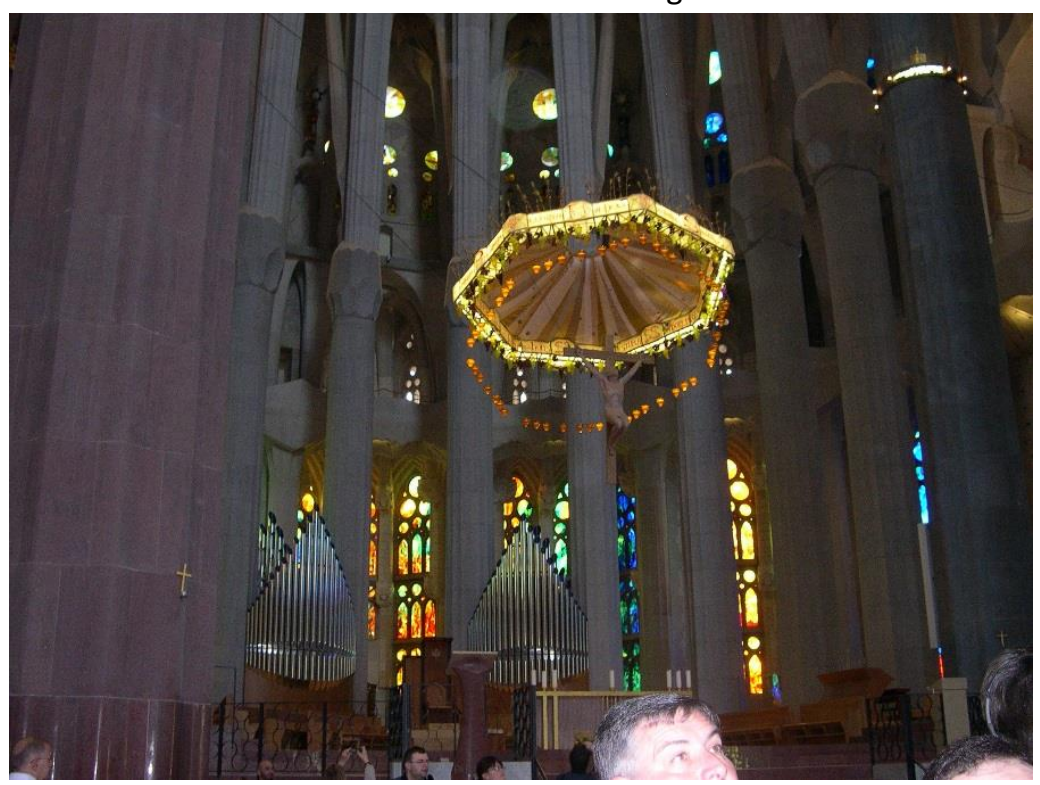

Lampadario y crucifijo colgante sobre el altar. Fotografía del autor. 
constatándose la importancia que se da al hecho de su sobreelevación y de su extrema proximidad con el crucero así como el fuerte contenido simbólico que tienen todos los elementos constructivos.

Respecto de los focos de la asamblea, Bassegoda (El Gran Gaudí, 1989, p. 188) cita que ya en 1883. en el proyecto de la iglesia de Villaricos (Almeria), Gaudí y Martorell fijan el altar en una posición exenta y centralizada, bastante novedosa para la época por lo que Rafols (Gaudí, 1929, p.30) indica que "el estudio gráfico de la iglesia de Villaricos responde al carácter religioso de todos los principios que rigen la composición de las Salesas, y en él el altar se ve indicado como en el gran Templo Expiatorio que debía emprender en poco tiempo: en el lugar más propio, en el centro del crucero."

No obstante, no hay datos ni información gráfica para pensar en una centralidad geométrica exacta, además de que todavía no se había promulgado el Motu Proprio Tra le sollicitudini. En el álbum de la Sagrada Familia no se menciona la situación exacta del altar en la iglesia, sino que se dice que estará encima de la bóveda de la Cripta y. eso sí, se describe con gran precisión la secuencia visual de una pintura del Padre Eterno cuyas vestiduras cubrirán toda la bóveda del ábside, el lampadario colgante del Espiritu Santo entre dicha bóveda y el Hijo en el altar, remarcándose el hecho de que se verá desde la entrada principal.

También se detiene en señalar que encima del altar habrá un crucifijo, con una parra simbólica a modo de dosel, un lampadario de 50 lámparas como en el primitivo altar constantiniano de la basílica de Letrán y un baldaquino según establecia el ritual. En consecuencia la validez del testimonio de Rafols, en mi opinión, atiende más a los principios generales de composición autoimpuestos en el entorno de Martorell-Gaudí basados en un interés y contactos eclesiásticos comunes que eran coincidentes con lo que dichos medios liturgistas propugnaban -arqueologismo litúrgico, propuestas benedictinas en torno a la dignificación del altar en la asamblea y potenciación del canto gregoriano- y se pretendía destacar, que a una situación geométricamente precisa. ${ }^{347}$

La intención es clara y es recogida desde el principio por el Propagador y por los primeros biógrafos de Gaudí: situar el altar mayor en el centro focal de la asamblea litúrgica valiéndose de todos los elementos arquitectónicos, escultóricos y lumínicos disponibles a su alcance. En este aspecto Gaudí es un innovador de la arquitectura cultual y la centralidad focal del altar la considera como una cuestión de primer orden.

\footnotetext{
${ }^{347}$ Resulta de interés señalar cómo las obras del tandem Martorell y Gaudí responden a un innovador y culto criterio de la arquitectura eclesiástica que anticipa de alguna manera actuaciones del movimiento del Quickborn alemán.
} 

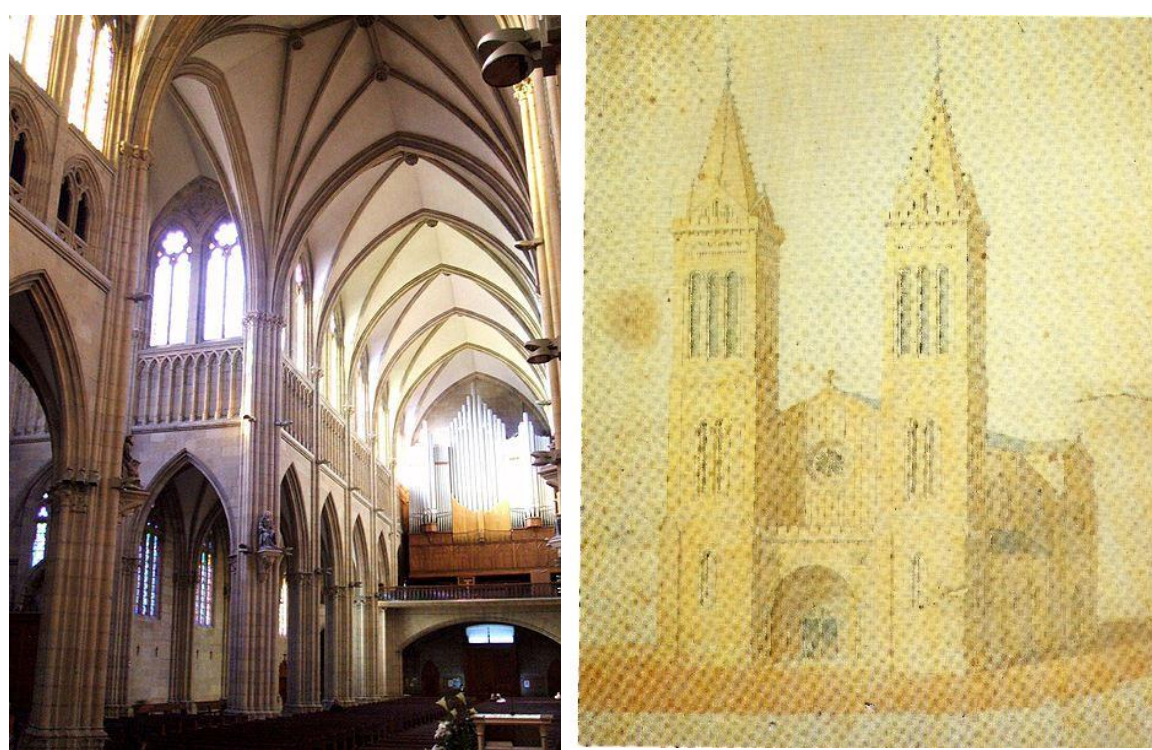

Interior de la catedral del Buen Pastor, San Sebastián. Grabado de la primera solución para la basilica de Covadonga. Fuente: Navascués, P. (1996) "Arquitectura Española 1808-1914", en Summa Artis, Historia General del Arte. Tomo XXXV. Madrid. Espasa Calpe

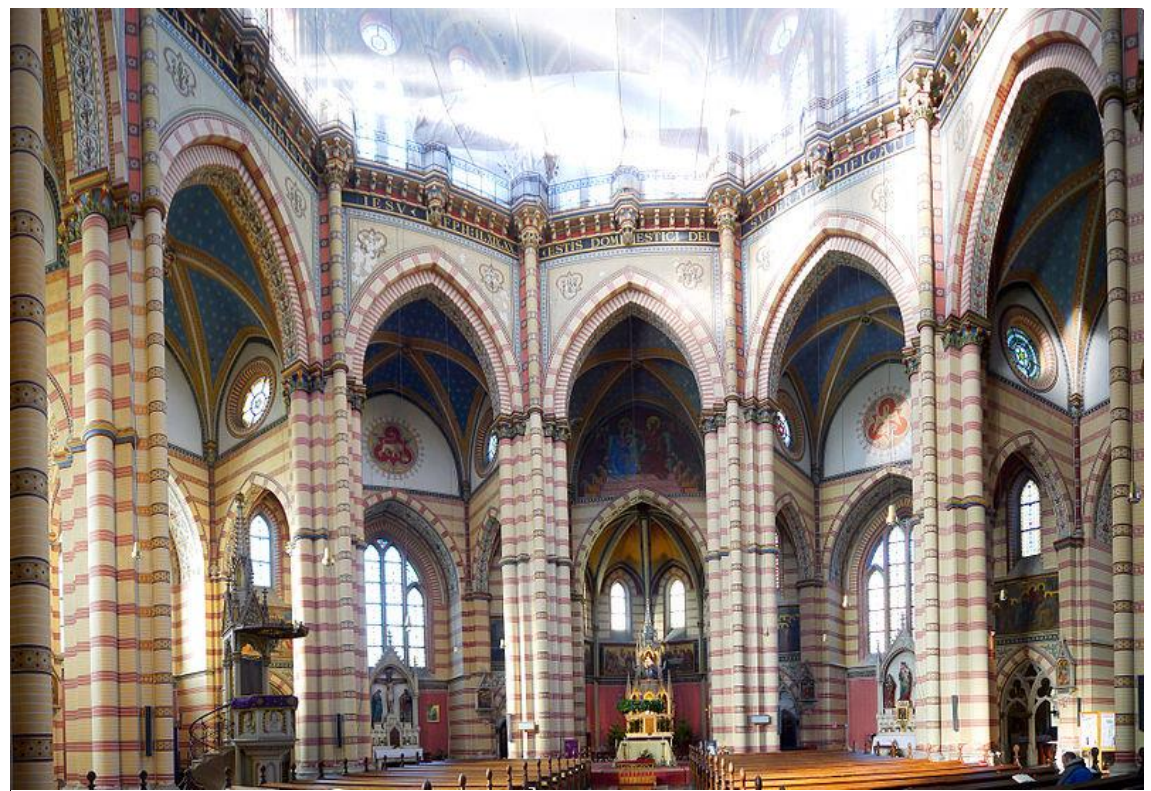

Interior de la iglesia de Maria vom Siege Kirche.

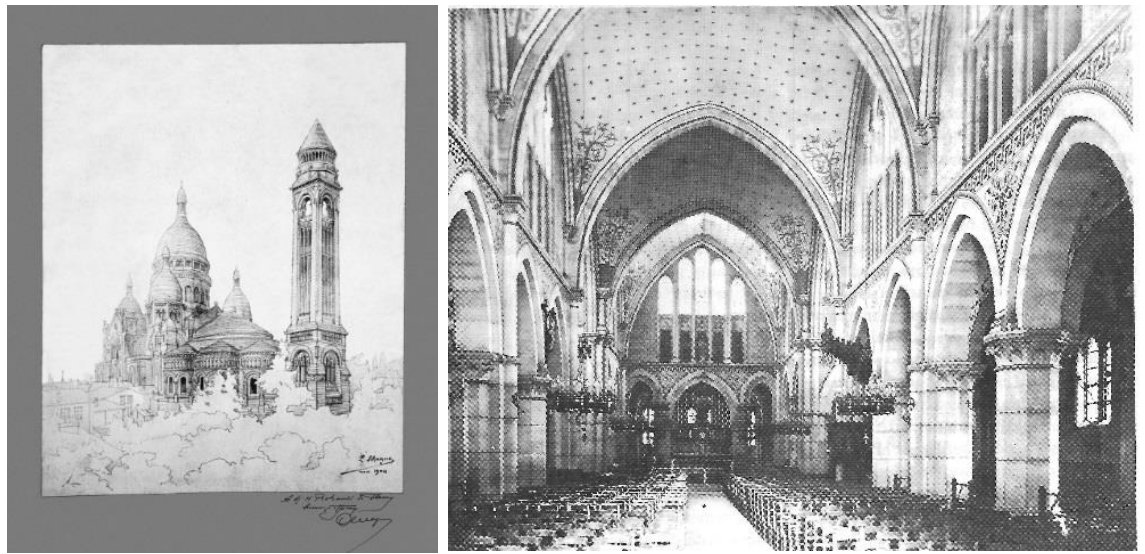

Grabado original del Sacreé Coeur. Interior de Saint Denis-de-I’Entrée 
No sólo lo aísla de cualquier fondo mural o retablo (situándolo lo más cerca de la asamblea que puede y elevándolo respecto del suelo de la nave mediante una serie de peldaños) sino que busca su máxima visibilidad a través de la diafaneidad del espacio interior, la ubicación circundante del coro (que realza la centralidad de la asambleaen torno a él) y el tratamiento que con la luz da a los signos y símbolos cristianos.

Por ello, para evaluar la aportación de la Sagrada Familia hay que tener en cuenta las iglesias que se construyen en Europa en la segunda mitad del siglo XIX y comienzos del $X X, y$ el ceremonial litúrgico que se arrastraba con anterioridad al arqueologismo litúrgico que propugna la orden benedictina. Hemos visto ejemplos de arquitectura historicista y de iglesias votivas al tratar el panorama de la arquitectura religiosa en tiempos de Gaudí3 ${ }^{48}$, percibiéndose como nota común una multiplicidad de estilos y soluciones formales o decorativas sobrepuestas a una ritualidad sin apenas variación respecto de los criterios explicitados por el Concilio de Trento y su posterior desarrollo. Gaudí también parte de una utilización de lenguajes historicistas, de aire goticista y bizantino fundamentalmente, pero su inquietud va mucho más allá de un lenguaje formal como continuador de una investigación estructural y una forma de concebir el espacio que descubre en el arte bizantino. Percibe en las cualidades del espacio interior de Santa Sofia una esmerada síntesis de disposiciones constructivas y espaciales, juntamente un amplio programa iconográfico, que aspira a perfeccionar. En el espacio interior proyectado por Gaaudí se modifica una disposición tradicional de cinco naves en planta de cruz para percibir un espacio litúrgico muy unitario. Altura, disposición estructural y tratamiento de la luz aportan a la organización de la asamblea una carga mucho más elocuente que lo que las trazas de la planta dejan entrever a primera vista $^{349}$.

Históricamente llama la atención la inmutabilidad de la planta de cruz latina con coro sobreelevado a los pies de la iglesia, o incluso con la solución medieval en medio de la nave (aun contando con las excepciones de algunos ejemplos de elipses, círculos y plantas rectangulares ya mencionadas); la disposición unitaria o doble de la torre campanario en la portada principal; la concepción de las naves con una solución de altar adosado a un retablo en la cabecera de la iglesia y su tratamiento casi como peana o base para multitud de elementos conmemorativos; la ausencia de una verdadera sede y la persistencia de los púlpitos en sustitución del originario ambón; la inmediatez de la sacristía respecto del altar y presbiterio; la disposición de bancos en batallón en la nave de la iglesia, delante y/o detrás del coro, para el asiento separado de hombres y mujeres en su asistencia a las funciones litúrgicas; la proliferación de altares secundarios y capillas destinados a la devoción y culto eucarístico privado o restringido, etc.

\footnotetext{
${ }^{348}$ Cf. Apartado 5.a de la presente investigación.

${ }^{349}$ Cf. Fotografias comentadas de Santa Sofia de Constantinopla y Sagrada Familia de Barcelona en la p. 112.
} 


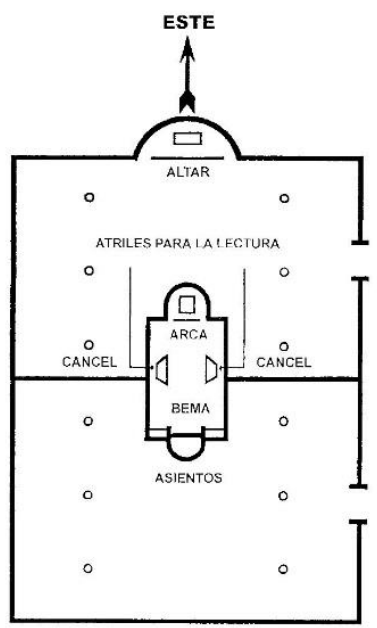

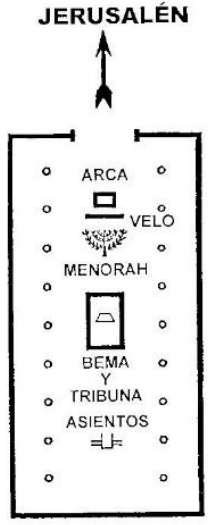

A
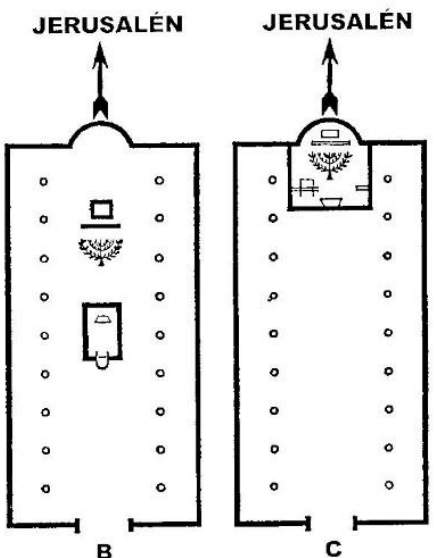

Izda.: Esquema de Iglesia siria oriental. Toma su disposición del modelo de las sinagogas pero a diferencia del juadaismo en el que las mujeres no formaban parte del sacerdocio común y cuya asistencia era sólo orante sin poder recitar la acción de gracias (dcha), las mujeres si participan del sacerdocio real a través del bautismo y de la eucaristía y los ministros se sitúan en el centro en medio de los fieles. Fuente: Bouyer, L.y Del Palacio, J.L: (2000) Arquitectura y Liturgia. Bilbao. Grafite Ediciones.
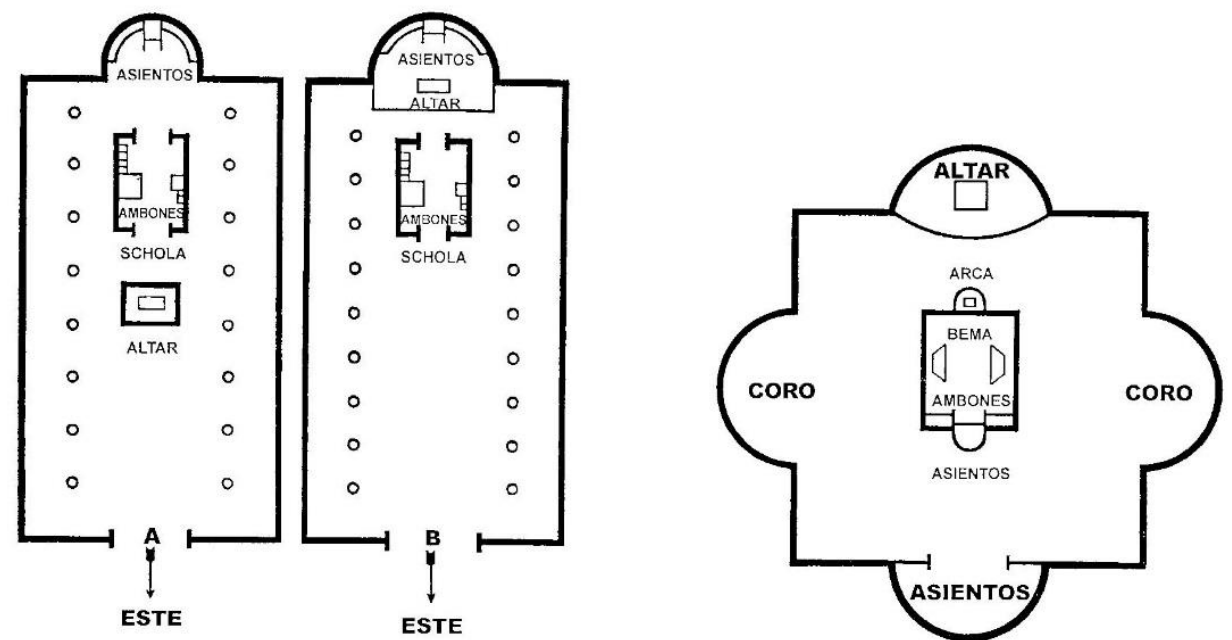

Izqda.: Esquema de Basílica romana. Ubicación de los ministros ordenados en el ábside al fondo de la basilica y consecuente consideración de los mismos como grandes señores a imitación de los magistrados de los tribunales romanos. Traslado del altar en la basilica vaticana por san Gregorio al ábside, encima de la tumba de S. Pedro, "cara al pueblo". Masa de fieles que no comulgan, élite espiritual en el ábside, comunidades monásticas. Desaparición de la homilía papal. Cancel de separación del presbiterio de la nave. Permanencia del altar en la nave en S. Juan de Letrán e iglesias del norte de Africa. Permanencia del sitial de Pascual I en la nave en Sta. Maria la Mayor y posterior traslado al fondo del ábside.

Dcha.:Esquema de Iglesia bizantina primitiva. Adaptación a la liturgia: bema, facistoles, sede y asientos de los ministros en el centro bajo la cúpula circular; altar aislado en un ábside. Nártex para catecúmenos y penitentes. Coro en laterales. Modelo: Santa Sofía. Posteriormente: traslado de la sede al ábside, lectura del evangelio a la entrada del santuario y resto de lecturas en el bema. Desarrollo de la iconografía: selección de episodios bíblicos con interpretación cristiana. Cúpula central decorada en su interior con un fresco o mosaico de Cristo Pantocrator. Cristo resucitado en su gloria con el libro de los Evangelios en su mano derecha. En la cúpula del ábisde, la Virgen ascendiendo hacia su Hijo y la Iglesia orante. 
No conviene olvidar tampoco que hasta finales del siglo XVII no había asientos para los fieles comunes en la nave, pero que una vez se introdujeron éstos su disposición no ha variado en cuatro siglos. Que la separación entre presbiterio -santuario- y el pueblo era físicamente notoria desde la Edad Media puesto que no se acostumbraba a dar la comunión a los fieles durante el trascurso de la Misa y que la predicación, realizada desde el púlpito, normalmente tenía lugar fuera de ella con ocasión de los grandes sermones cuaresmales.

Se trata de un largo periodo histórico en el que la utilización de numerosos elementos tipológicos sobrepuestos -multiplicidad de capillas, presbiterio separado de la nave por un cancel (iconostasio en el ámbito ortodoxo) coro en posición central, baptisterio reducido a la mera pila bautismal en una capilla lateral, etc.- hacen concebir el edificio iglesia como un gran contenedor artístico que se va adaptando al languidecer litúrgico progresivo, visualizado más como una representación que como una actualización del misterio. El lugar de la asamblea ha perdido su carácter comunitario en beneficio de otras acepciones mucho más restringidas: la celebración privativa de los clérigos y el devocionismo individual del laicado. Al mismo tiempo, siendo el espacio interior del edificio de notables e intrincadas dimensiones se vuelve apto para las representaciones religiosas y autos de fe -especialmente con ocasión de las grandes festividades- y las procesiones, que pretendían concitar la atención del pueblo cuando éste apenas podía participar en la misa. La penumbra interior y el fraccionamiento del espacio en múltiples capillas laterales se constituyen en soporte material de una espiritualidad fundamentada básicamente en la oración individual, las devociones particulares, las misas privadas y la dispensación de sacramentos fuera de la misa. Ya se ha mencionado el ejemplo de la catedral de Mallorca antes de la intervención de Gaudí.

En este contexto histórico arquitectónico irrumpe el planteamiento de Gaudí de una planta ordenada y diáfana sin capillas laterales, con una gran claridad en los focos de la asamblea litúrgica que son fácilmente visualizados desde toda ella, un considerable componente simbólico del espacio celebrativo y un amplio programa iconográfico que se desarrolla en imágenes, textos, pinturas, etc. como lugar celebrativo plenamente acorde con la praxis renovada de la Misa que inspiran los monjes benedictinos $y$ sanciona el pontificado de Pio X. ${ }^{350}$ En la Sagrada Familia Gaudí busca, como afirma Puig Boada, la subordinación del espacio -el templo- a la liturgia ${ }^{351}$ a través de una composición en planta que responda fidedignamente a las necesidades del ceremonial que Roma quiere difundir.

\footnotetext{
${ }^{350}$ Cf. Apartado 3.b de esta Investigación: El renacer litúrgico de la Iglesia desde la segunda mitad del siglo XIX hasta el pontificado de Pio $X$.

351 Cf. Puig Boada (1950) L'ideal del temple cristià. Barcelona. Templo. № Octubre. Pg. 175. Para Puig Boada la ordenación interior de la Sagrada Familia gira en torno al altar y la celebración de la Misa.
} 

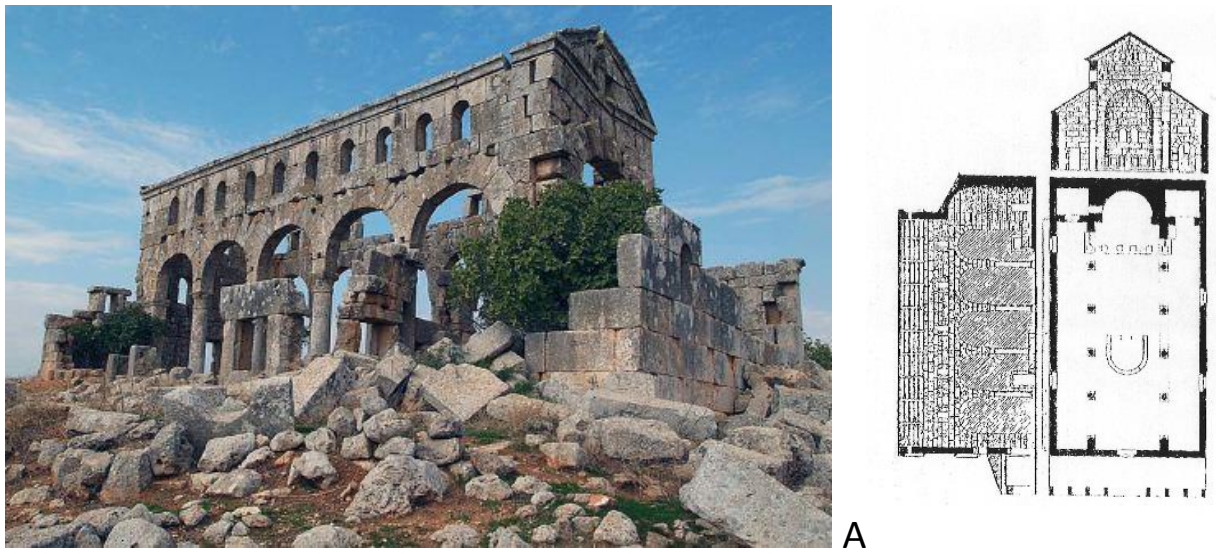

B

Ruinas Basilica paleocristiana de Kharab Shams en Siria (siglos IV-V). Fotografia de Jim Gordon. Planos: Bergamo, M. y Del Prette, M. (2001) Spazi Celebrativi. Edizione Dehoniane Bologna. Bolonia.

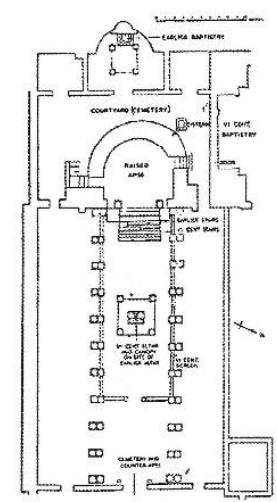

113

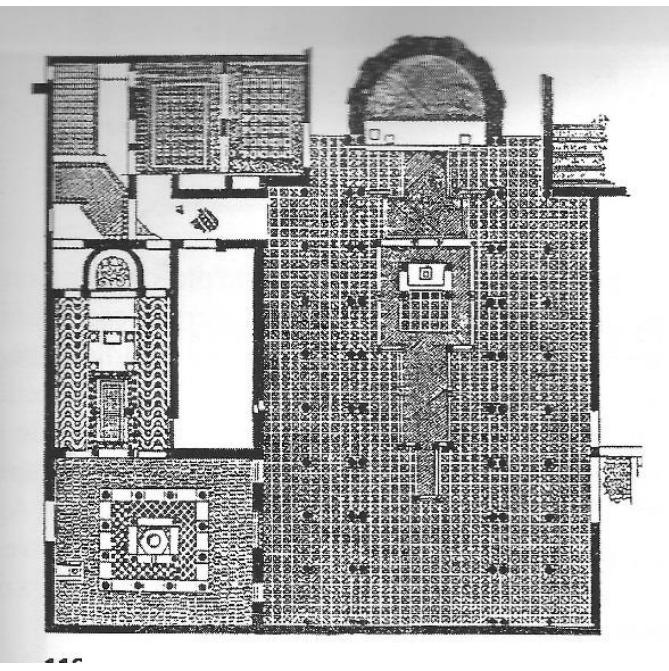

D

C: Basilica de Sabratha, Tripolitania (s. IV). D: Basilica de Dermech, Cartago (s. VI). Fuente: Bergamo, M. y Del Prette, M. (2001) Spazi Celebrativi. Edizione Dehoniane Bologna. Bolonia.
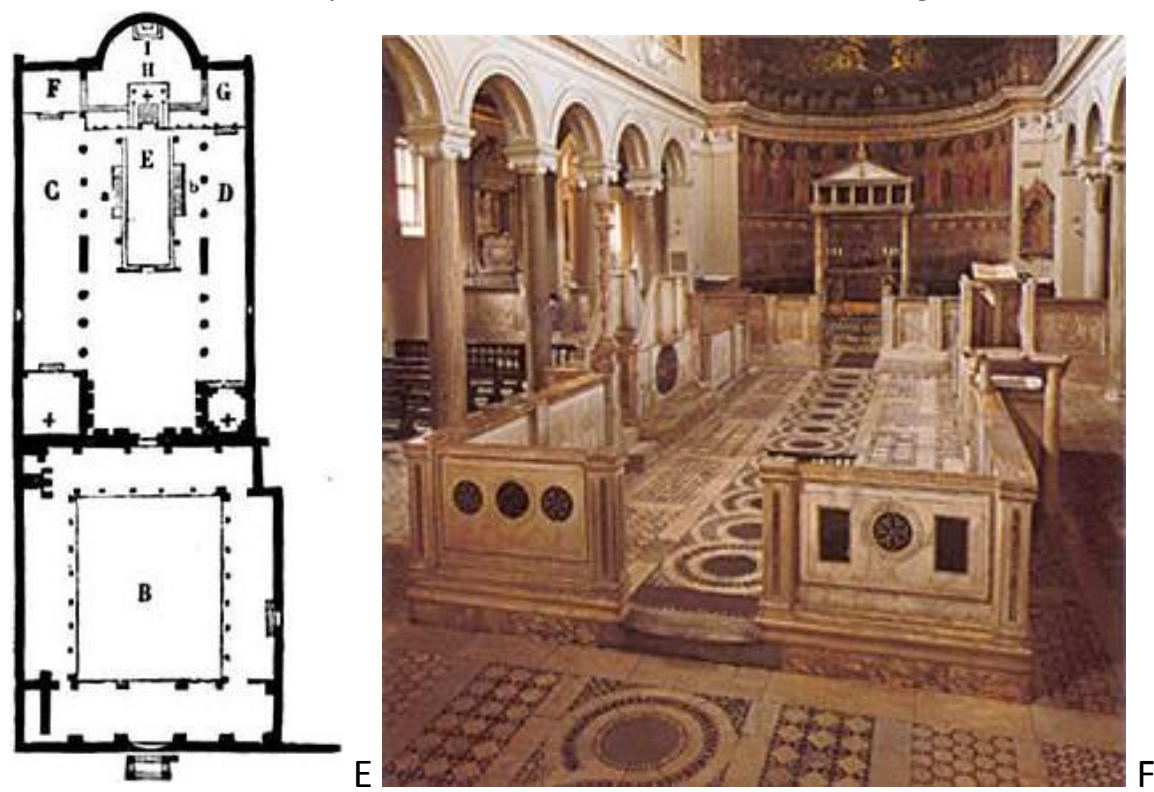

E y F: Planta y vista interior de la Basílica de San Clemente de Roma, finales del siglo IV. Fuente: Plazaola, J. (2006) Arte sacro actual. Madrid. BAC. 
Su proyecto se apoya en la concepción del lugar de la asamblea cristiana: un recinto amplio, convenientemente iluminado, ordenado según la secuencia de los ritos litúrgicos, que recupera el sentido y visualización de sus principales focos, altar, ambón y sede. Ahora la estructura y la luz responden a un cometido funcional y simbólico -por encima del artístico o del emblemático- en una gran aula en la que se pretende involucrar en lo que se celebra a todos los que allí están sin que nada distraiga la atención.

En el proyecto gaudiniano la ubicación del altar bajo el arco triunfal y su centralidad focal se ven reforzados por la utilización de la luz a través de los elementos definitorios de la construcción como generadora del espacio. Un espacio, ciertamente desmaterializado, que es objeto del estudio e interpretación de Armand Puig según unos ejes teológico-simbólicos ${ }^{352}$. La utilización histórica del baldaquino colgante -pleno de inscripciones alusivas a la Divinidad y las virtudes morales-, del que penden cincuenta lámparas -símbolo de Is cincuenta días de fiesta de la Pascua-, es aprovechada en grado sumo y sirve también para disponer de la misma forma un crucifijo sobre el altar, significando según estos ejes teológico-simbólicos la epíclesis eucaristica. ${ }^{353}$ No se deja nada a la improvisación, de tal manera que Gaudí quiso que el crucifijo mostrara precisamente la imagen de un hombre exhausto en su agonía y próximo a la entrega de su vida.

Toda la nave celebrativa de la Sagrada Familia gira, pues, alrededor del altar y por el altar. No hay espacio para la peregrinación en la nave, ni físico ni simbólico, sino que ésta se dispone como la gran sala del banquete de bodas con el cordero como dice el libro del Apocalipsis. Los invitados a ella han pasado por el Baptisterio, la capilla de la Penitencia, han peregrinado por el Claustro o han accedido directamente por cada una de las entradas a la iglesia, porque están preparados (la vestidura blanca de que habla la parábola del evangelio) para participar plenamente en la liturgia eucarística.

352 Cf. Cf. Puig, Armand. (2011). La Sagrada Familia según Gaudí. Barcelona. El Aleph.

353 Cf. Bouyer, L. (2000). Arquitectura y Liturgia. Bilbao. Grafite Ediciones. Según Louis Bouyer la Instrucción de la Constitucion SC del Vaticano II al referirse años después a este mismo tema no aportó nada nuevo a las reglas litúrgicas de Occidente y de Oriente respecto de la consideración del altar como mesa y por tanto no adosada a la pared, puesto que ya aparecia claramente en el Ceremoniale Episcoporum y el Pontificale romanorum al describir la consagración del altar mayor de una iglesia. P. 99: "cuando se respeta esta antigua prescripción, tal como debería haberse hecho, es posible, siempre que así se desee, la celebración versus populum en todos los casos. Pero la Instrucción no afirma en ninguna parte ni da entender de ningún modo que ésta sea siempre y en todos los casos las mejor forma posible de celebración." 

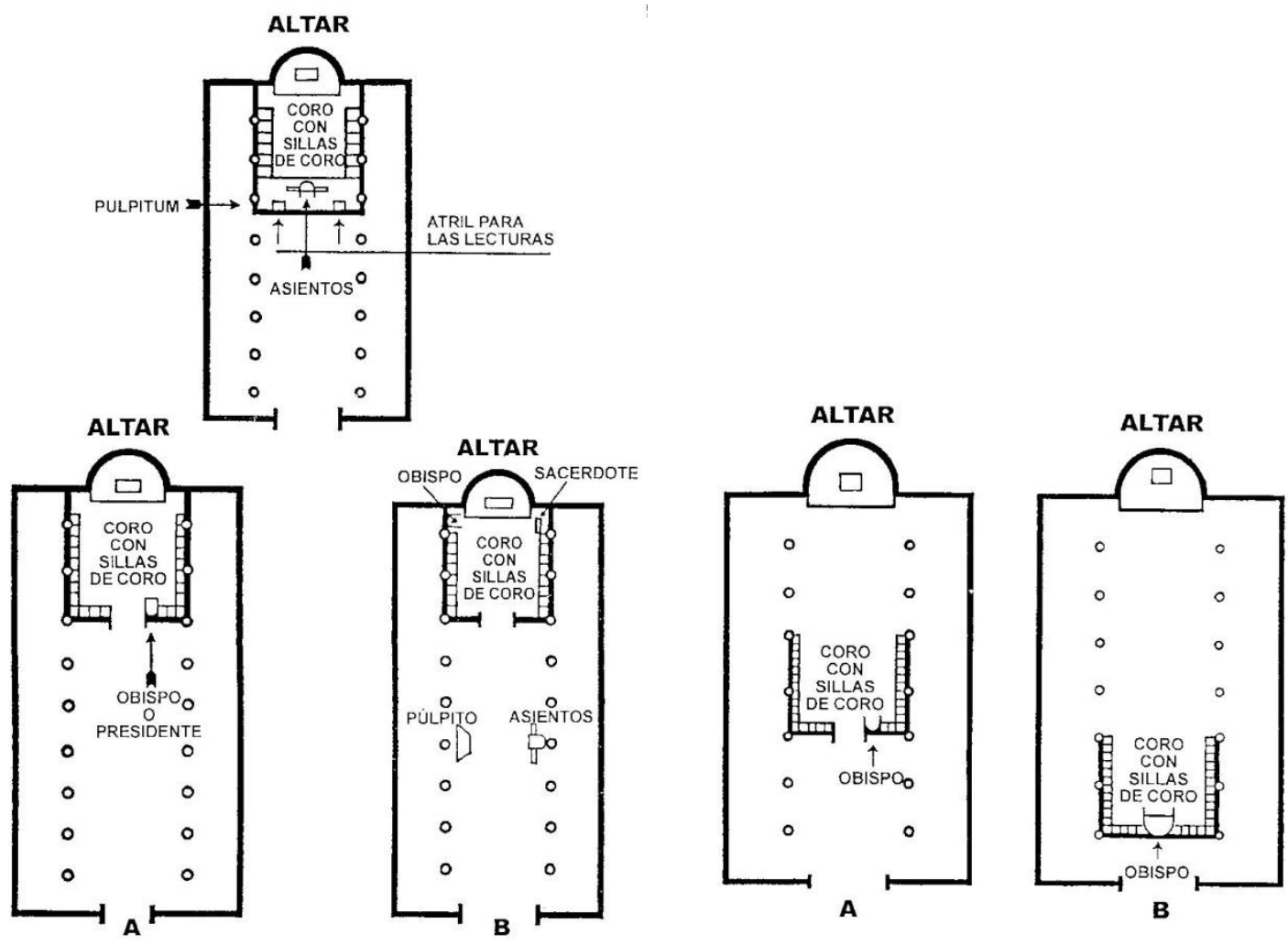

$\cdots$

B

Esquemas de Asamblea eucarística en la Edad Media. Izqda.: Coro orientado situado a oriente. Dcha.: Coro central o situado a occidente. Fuente: Cf. Bouyer, L. (2000). Arquitectura y Liturgia. Bilbao. Grafite Ediciones

Según Louis Bouyer aparece un cancel separador del presbiterio y la nave donde se sitúan el altar, la sede, el coro y el bema para las lecturas, convirtiéndose en un santuario. Desaparece la procesión del ofertorio. Excepcionalidad de la comunión de los fieles, coral, ininteligibilidad del oficio de la Palabra por utilización de una lengua muerta. Como consecuencia aparece el Devocionismo de los laicos y posteriormente las Ceremonias o representaciones en las fiestas. Aparición de los lectores en la tribuna o pulpitum situado encima del muro perimetral del coro para poder ser vistos por el pueblo. Predicación de la homilía desde el pulpito e. Introducción del sermón para explicar las lecturas en lengua vulgar y repetirlas en lengua vulgar.

Hacia el final Edad Media y en el Renacimiento aparece el retablo por encima del altar, equivalente de la tradición oriental del muro del ábside y cúpula, y también las capillas laterales y con ellas las misas semiprivadas. La reserva del Sacramento se situa en armarios de los muros norte o sur del santuario, y en el Renacimiento se traslado al altar, habilitándose en las catedrales una capilla especial, normalmente dedicada a la Virgen.

En la Contrarreforma se suprime la cancela y se traslada el coro a los pies de la nave (oeste).

En el Siglo XIX se introducen los bancos en la nave. Y se utiliza el púlpito solo para la predicación. EI Ceremonial de los obispos y el Pontifical romano admitían como altar una mesa, no adosada a la pared (consagración del altar mayor de una iglesia), que permitía la celebración hacia el pueblo aunque no se afirmase ni se diera a entender que fuese la mejor forma posible. El Movimiento Litúrgico promociona esta práctica. Bouyer apunta como posibles causas: el hecho de que las rubricas obligaban a leer textos bíblicos en un libro sobre el altar que de esta forma podía ser visto por los fieles; quizá la recuperación del sentido de comida, cena, comunitario; el Intento de centrar el foco central en el altar; la promoción de las lecturas bíblicas. El caso es que se procura una ligera elevación del altar mediante unos escalones, de modo que siempre está más alto que la sede. También se procura una iluminación cenital por lámparas colgantes y la disposición de una gran crucifijo colgado sobre el altar. 
Compositivamente la disposición de esta gran asamblea que circunda el altar toma caracteres ciertamente singulares: de un lado un amplio presbiterio completamente abierto en todo su perímetro y organizado como un coro ministerial que acompaña al Obispo en su cátedra; del otro, el espacio destinado a los fieles laicos con sus asientos correspondientes; envolviendo a ambos un coro de laicos, hombres, mujeres y niños, que completa la asamblea y contribuye a darle unidad. Esta disposición envolvente sin más interferencias visuales que las estrictamente necesarias para garantizar la cubrición de las bóvedas, confiere un carácter unitario a la asamblea eucarística novedoso para la época. Mediante la cubrición del espacio (a la que luego nos referiremos) y la organización coral en diferentes niveles $-a+0,+16$ y $+20 m$ y diferentes disposiciones según se trate ministros ordenados, niños, mujeres y hombres- se consigue un efecto de notable proximidad visual y acústica en la celebración.

Espacialmente la asamblea alcanza unas características todavía más sorprendentes. Armand Puig ha señalado cómo la simbología del espacio interior es mística ${ }^{354}$ y llama la atención sobre tres itinerarios teológicos de la basílica: la via de la humanidad, la via de Jesucristo y la via de la Iglesia.

A mi parecer, dentro de la nave litúrgica es posible visualizar material y simbólicamente un itinerario inmaterial de carácter escatológico que tiene su centro en el altar. Partiendo de que el interior es primordialmente el espacio de la celebración litúrgica encontramos desarrollada en la que es su fuente y culmen, la asamblea eucarística, la visión teológica de la Historia de la Salvación que describe el libro del Apocalipsis a través de la secuencia de la sección longitudinal de la nave.

Tal y como se describe en el Propagador desde la entrada de la fachada de la Gloria son perfectamente visibles para una persona de pie: el interior de la bóveda del ábside, o cimborio de la Virgen, cuya pintura representa las vestiduras del Padre Eterno, Dios Creador; un lampadario colgante de las paredes de dicha bóveda simbolizando el Espíritu Santo, Señor y dador de Vida, por quien es concebido Jesucristo en el seno de Maria según reza el Credo de los Apóstoles; y el altar, que siempre es Jesucristo, cuyo simbolismo se refuerza mediante un expresivo crucifijo colgante y el baldaquino de 50 lámparas, a los que hemos hecho referencia como dones del Espiritu Santo. Sobre el altar, que constituye el punto más bajo de esta trayectoria teológico-litúrgica, en lo alto de la bóveda interior del cimborio central o de Jesucristo, habrá de situarse otro lampadario simbolizando la Jerusalén celestial. Y finalmente, iluminando ésta, el trono de Dios y del Cordero (tal y como menciona también el libro del Apocalipsis) apoyado en las cuatro columnas centrales del crucero.

${ }^{354}$ Cf. Puig, Armand. (2011). La Sagrada Familia según Gaudí. Barcelona. El Aleph. 

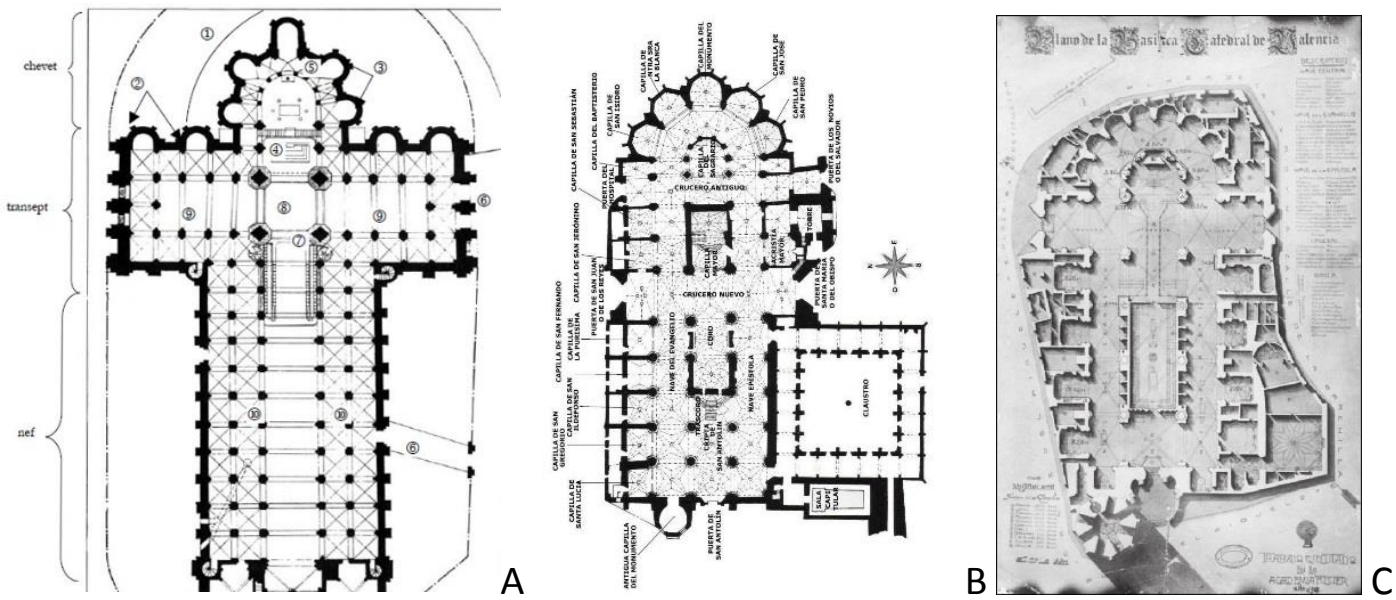

Plantas originales de catedrales con coro central.

A: San Sernin, Touluse B: Catedral de Palencia C: Valencia.

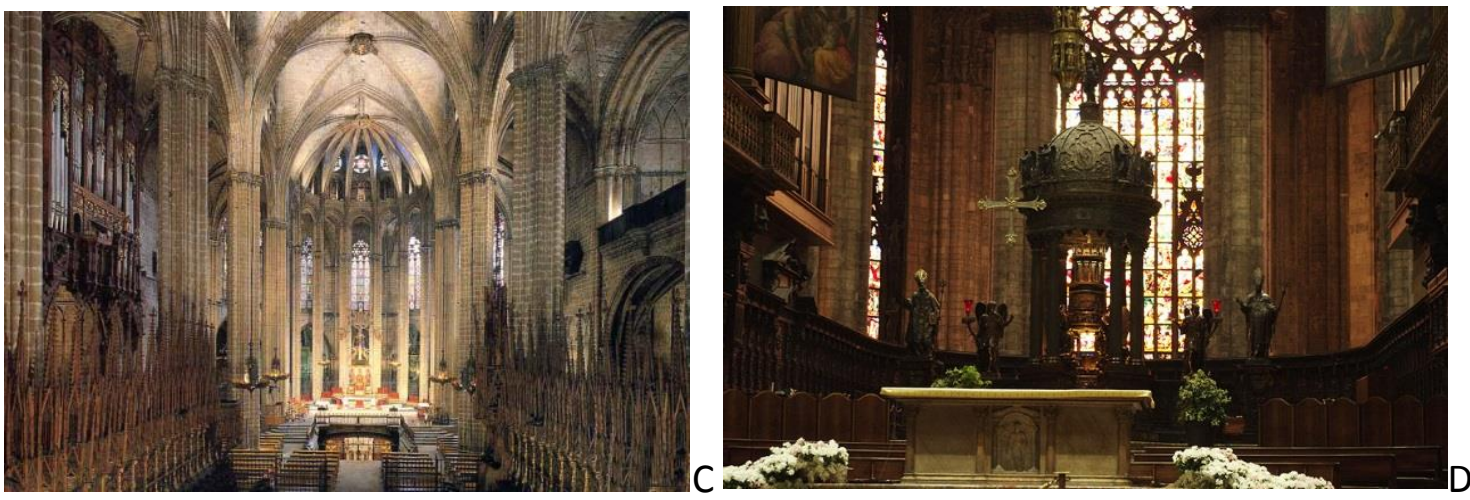

C: Coro central de la catedral de Barcelona. D. Coro en el presbiterio de la catedral de Milán.
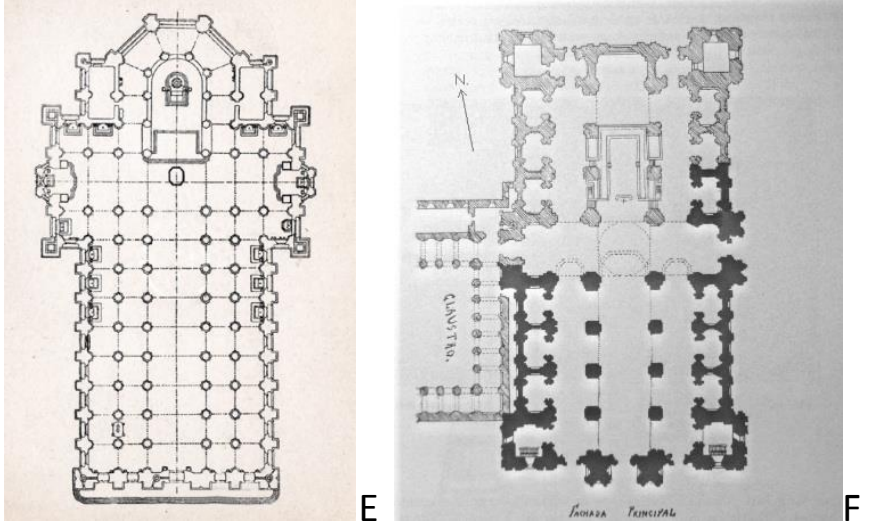

Plantas originales de catedrales con coro en el presbiterio. E: Milan. F: Valladolid

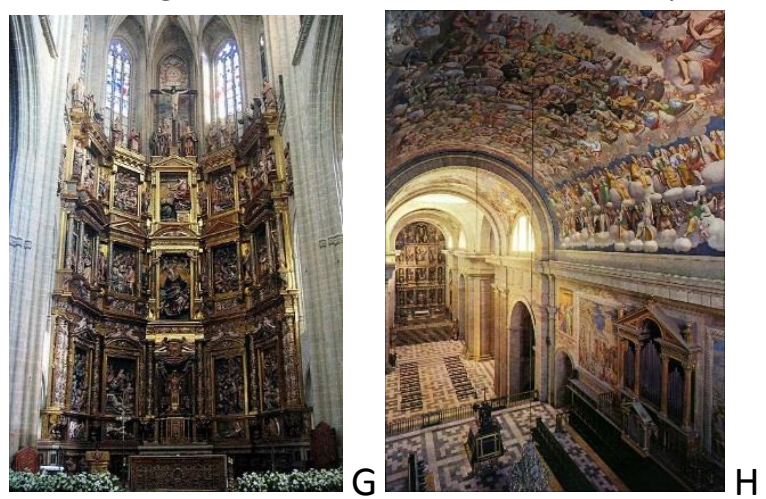

G: Retablo de la catedral de Astorga. H: Coro de la Iglesia del Monasterio de El Escorial. 
Consecuentemente con su pensamiento, hecho convicción, Gaudí organiza constructiva, visual y espiritualmente el espacio de la asamblea, ordenándolo litúrgicamente desde la Eucaristía según el designio salvador de Dios que narra el Apocalipsis: la Creación, la Encarnación en el seno de la Virgen por obra del Espiritu Santo y la recreación pascual, que llega a su momento culminante en la Resurrección, anticipación de la Jerusalén celestial. Por encima, de momento oculto a los ojos de los hombres, el trono de Dios y del Cordero, de donde descienda ésta según el Apocalipsis, al modo de la Etimasía o representación de dicho trono vacío y preparado para el mundo venidero. Etimasia en griego significa "preparación del trono" y la iconografía de este tema prevé la representación del trono divino para el juicio final. Se pueden encontrar muestras iconográficas en el mosaico bizantino del baptisterio de Rávena e incluso en la bóveda de la macsura de la Mezquita-Catedral de Córdoba. ${ }^{355}$ Este podría ser muy probablemente el significado simbólico del hiperboloide que remata superiormente la bóveda del crucero a 60 m, como también menciona Puig (La Sagrada Familia según Gaudí, 2011).

Según afirma Jordi Bonet, Gaudí no dejó detallado el diseño del espacio superior, esto es la sala que posteriormente se ha diseñado conformando el graderío de un anfiteatro y que según explica se piensa dedicar a organizar el flujo de personas que cojan que van a lo alto del cimborio ${ }^{356}$, pero el mencionado recinto por encima de la bóveda que apoya sobre las cuatro columnas centrales y el hiperboloide cenital por donde entra la luz sobre el lampadario de la nueva Jerusalén si que responden a su autoría personal. Armand Puig se pregunta, partiendo de la identificación del proyecto con la Jerusalén celestial si hay un trono, lugar propio de Dios y del Cordero, en la Sagrada Familia, llegando a la conclusión de que éste es el sentido del hiperboloide mencionado. En mi opinión, ambas cuestiones pueden coexistir independientemente, es decir, no sería necesario identificar toda la Sagrada Familia con la ciudad celestial del Apocalipsis para pensar en este simbolismo concreto de la bóveda del crucero, ya que la misma concepción arquitectónica y simbólica del espacio interior ordenado como aula celebrativa de la eucaristía la explica desde el plano teológico-litúrgico.

\footnotetext{
${ }^{355}$ Cf. Parada Lopez de Cordelas, M. (2013) “El trono preparado, reflexiones sobre Estética”, en Anales de Historia del Arte Vol 23. P. 105-122. En los siglos X y XI se desarrolla en el mundo bizantino, con interpretaciones en el ámbito visigótico toledano y en el Islam heterodoxo del califato cordobés, la representación iconográfica del trono vacio de Dios con los símbolos de Cristo cuando venga para el juicio final. El autor relaciona este elemento con la liturgia del culto eucarístico y la necesidad de reivindicar el dogma. Otras influencias del arte bizantino en las iglesias de Occidente se tendrían en la representación de temas de la Ascension, Juicio Final y Apocalipsis en las portadas principales de las iglesias.

356 Cf. Bonet, J. y Puig, A. (2013) Arquitectura i símbol de la Sagrada Familia. Barcelona. Raval Edicions, Portic. Pp.208-210.
} 


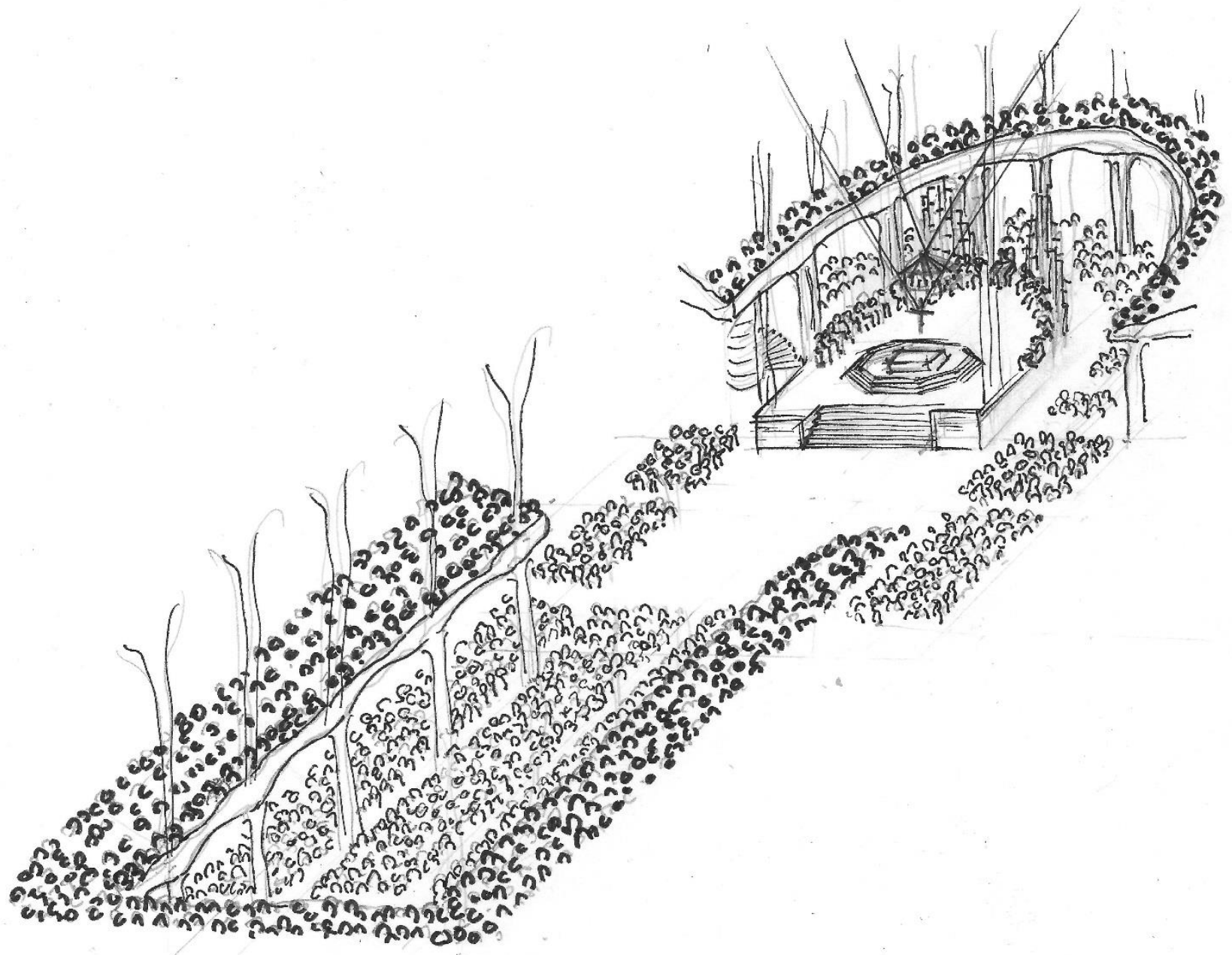

Asamblea en el Aula Liturgica de la Sagrada Familia. Fuente: dibujo del autor. 
Respecto de una posible lectura simbólica del conjunto del edificio como la nueva Jerusalen hablaremos más adelante.

Ya hemos visto que Gaudí concibe el proyecto desde el sentido más profundo de la liturgia, desde su espíritu como diría Guardini, y para la liturgia. De ahí que la composición y adecuación del lugar litúrgico lleve consigo la utilización del rico simbolismo cristiano, de todos sus signos y significados, como atestiguan siglos de arquitectura eclesiástica y sus mismos proyectos anteriores. Gaudí impregna la materia de simbolismo, no sólo a través del figurativismo escultórico y pictórico sino mediante la materialidad de la forma arquitectónica. Una muestra de ello la encontramos en la realización de la bóveda del cimborio del ábside como representación geométrica y lumínica del Padre Eterno. En lugar de recurrir a la histórica representación pictórica se prefiere recurrir a la santidad creadora representada por la potente luz cenital que ilumina no la tradicional figura humana del anciano con vestiduras blancas de la Capilla Sixtina sino la representación cerámica de las vestiduras del Padre Eterno que nos recuerdan el episodio bíblico de Moisés pretendiendo ver el rostro de Dios.

Esta imaginativa y moderna iconografía geométrica que Gaudí diseña para simbolizar al padre Eterno en la bóveda del ábside supone una aportación arquitectónica de primera magnitud de la que probablemente son deudores más proyectos de los que nos imaginamos. ¿Quién no recuerda la luz en el fondo del presbiterio de la iglesia de Ronchamp o el juego lumínico de la bóveda de Firminy? O más cercanamente, ¿la concepción estructural, lumínica y visual de la iglesia del puerto de Xàbia? En la Sagrada Familia de Barcelona la arquitectura se sitúa en un plano más elevado todavía, como una exaltación total del banquete de bodas eucarístico, presente y anticipo de las realidades que describen los capítulos 21 y 22 del Apocalipsis. El edificio quiere ser la sustentación material e inmaterial de la sala del banquete, algo que ya buscaba Gaudí en Sta. Coloma y Mallorca. Ahora su proyecto es tan completo y unitario que la materia está inmersa en el simbolismo, el espacio también y las visuales son ejes litúrgicos en su sentido teológico más profundo.

Sabiendo, pues, de la exhaustividad con que Gaudí se documentaba para la realización de sus proyectos de arquitectura eclesiástica, el grado de detalle con que afrontaba elementos y mobiliario litúrgico y la amplitud de sus conocimientos en materia de Sagradas Escrituras y tradición arquitectónica, no es de extrañar que utilizara la simbología de la Etimasia hecha piedra para rematar el itinerario visual y simbólico que une la secuencia de los dos cimborios y el altar. En mi opinión, esta sería la principal via pensada por Gaudí, que denominaré Via de la Liturgia o de la Escatología (con permiso de la terminología que emplea Armand Puig), y a la que Gaudí invita a adherirse a la comunidad celebrante. 


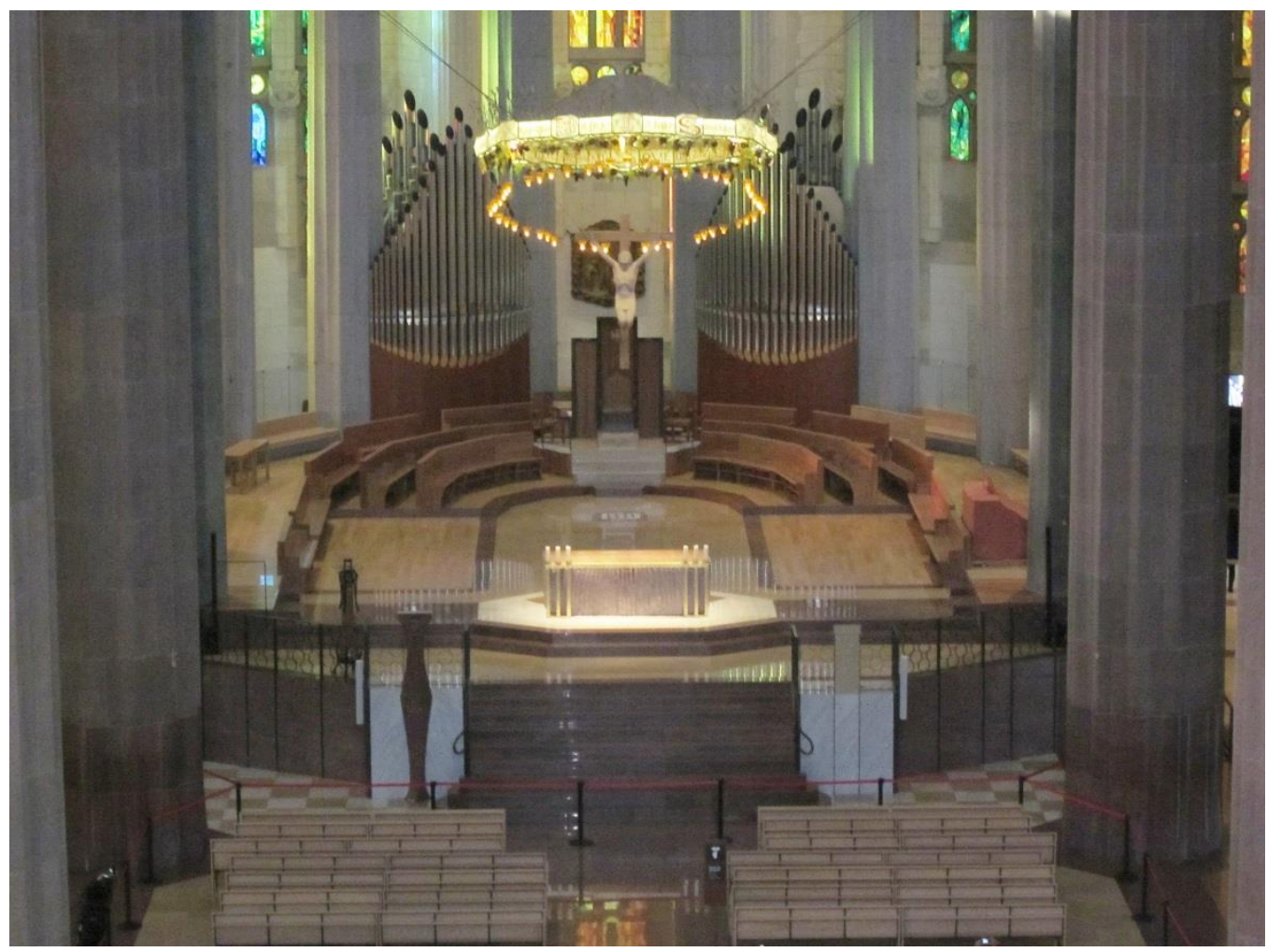

Vista del Presbiterio, Altar, Sede, Ambones y Coro ministerial. Fuente: Fotografia del autor. 
Gaudí proyecta el aula celebrativa queriendo abarcar todas sus dimensiones materiales e inmateriales, su arquitectura y construcción, su iconografía y simbolismo, pero también buscando explicitar artísticamente la experiencia espiritual de una comunidad que celebra el misterio. Desde el plano material el espacio arquitectónico es creado por la disposición secuenciada de las columnas y su jerarquización, la modulación de las bóvedas, la disposición estructural de las cantorías, cimborios, etc. conformando una asamblea envolvente en un espacio multicupular. En el sentido inmaterial del espacio la utilización que hace de la luz, derramándose sobre los elementos constructivos, ya sea cenital e inclinada, blanca o coloreada, contribuye -conjuntamente el simbolismo de los elementos constructivos- a crear un espacio singular difícilmente describible, más bien pensado para ser aprehendido desde su interior.

Hay que situarse en el ambito de la Iglesia primitiva, y más concretamente en el área de la arquitectura bizantina, primeramente, y después en algunas realizaciones en el occidente europeo, para encontrar un esquema tan ambicioso en todos sus niveles estructural, espacial e iconológico. En el empeño gaudiniano encontramos un intento por volver a los orígenes y aunar ambas tradiciones, empeño que en términos eclesiales modernos bien podríamos denominar como arquitectónicamente ecuménico. Pues si bien espacialmente encontramos su inspiración en el espacio interior que cubre la bóveda central de Santa Sofia y en la misma utilización repetitiva de la cúpula que encontramos en San Marcos, no puede dejar de observarse su planta de cruz latina, y la disposición de que hace para las capillas de la Penitencia y del Bautismo, de tradición occidental. Cruz latina, probablemente condición de partida de los josefinos que no hubiesen entendido una planta más libre como en Santa Coloma, que es distorsionada al incorporar las capillas del Bautismo y la Penitencia, las Sacristías y el Claustro. También las tradicionales portadas son alteradas respecto de su disposición tradicional en aras de una mayor extensión y complejidad, para funcionar no sólo como pórticos catedralicios, sino como verdaderos espacios de acogida insertos en el peregrinaje terrestre que simboliza el claustro. En consecuencia, Gaudí se mueve igualmente libre en la composición del edificio que en el lenguaje empleado por su método de proyectar una iglesia es original.

Si el espacio así concebido dispone una secuencia visual que acompañe y refrende la aprehensión espiritual de la acción litúrgica fundamental, la Misa, ésta es perceptible para la comunidad celebrante desde cualquier punto del aula. La luz que desciende del ábside, pasa por el lampadario del Espíritu Santo y llega al altar, parece abrazar espiritualmente a los fieles y encaminarlos simbólicamente hacia la Jerusalén celestial en lo alto del crucero, el cual no dispone de más luz que la que desciende de la Etimasía, de la sala situada encima del nivel de $+60 \mathrm{~m}$. Este itinerario visual y lumínico principal, que quiere ser también espiritual, es el que narra el libro del Apocalipsis 21,23: 


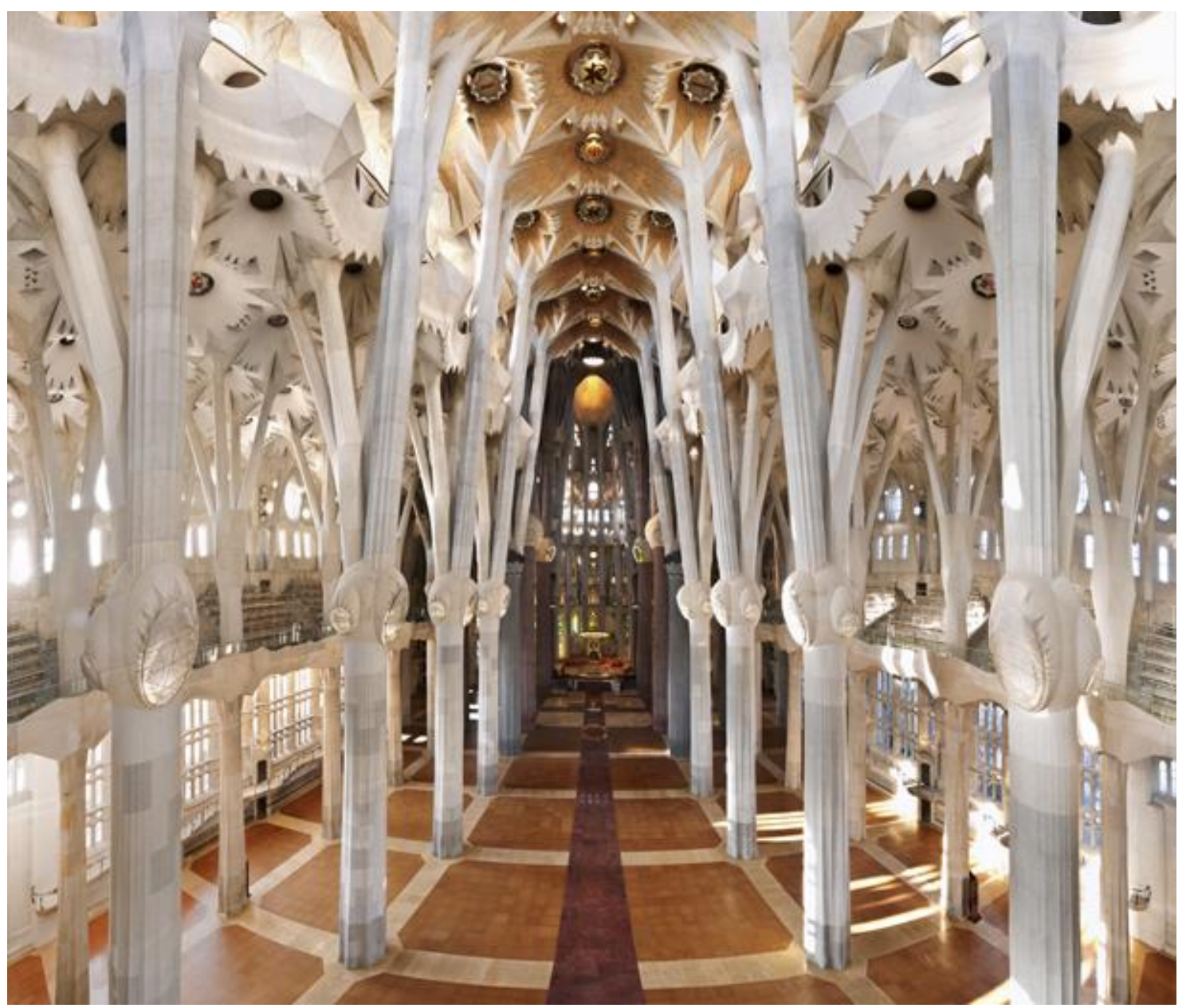

Fotografia del interior de la nave celebrativa desde el coro correspondiente a la fachada de la Gloria. Fuente: Junta Constructora de la Sagrada Familia. 
"La ciudad no necesita ni de sol ni de luan que la alumbren, porque la ilumina la gloria de Dios y su lámpara es el Cordero", y responde también al espíritu de la liturgia que expondría por esos mismos años Guardini en Alemania. Por ello, según mi parecer, la Sagrada Familia es un edificio primordialmente litúrgico en el sentido más estricto de la palabra, aunque sea un proyecto plagado de simbolismo, aunque signifique una renovación estructural, aunque constituya un hito urbano.

En la Sagrada Familia la solución espacial de la asamblea es mucho más imaginativa y radical de lo que había supuesto la remodelación del presbiterio de la catedral de Mallorca y de lo que pudo ser la iglesia de Santa Coloma y a ello contribuye la ingeniosa construcción de las cantorías. Si en Mallorca los ministros ordenados acompañan al Obispo medieval en su cátedra recuperada y la schola cantorum se resitua a ambos lados del altar (en una posición intermedia entre ellos y el pueblo), y en Santa Coloma se vislumbra una iconografía muy desarrollada en columnas y volúmenes con una posibleubicación del coro en galerías superiores, ahora las cantorías cobran un protagonismo litúrgico de primer orden de la mano de su concepción estructural y su visualización en el espacio interior. La participación en el canto de toda la comunidad celebrante, ministros, niños, mujeres, varones y toda la asamblea (objetivo perseguido por la Iglesia Católica en los albores del siglo XX) presenta una disposición en niveles sumamente curiosa. Por un lado recorre todo el perímetro del aula celebrativa, lo cual es inédito hasta el momento en las iglesias católicas y no volverá a repetirse pero que significa un paso coincidente con la dirección que seguiría desarrollando el Movimiento Litúrgico en Alemania. Por otra parte asume la verticalidad como eje de desarrollo, lo cual nos hace volver la mirada sobre la intencionalidad musical y coral del proyecto, cuestión a la que volveremos al tratar los campanarios. En términos del discurso de Gaudí se puede decir que la propuesta arquitectónica es coherente con su deseo de ser alabanza del misterio trascendente que se celebra.

\section{El Presbiterio.}

El presbiterio ahora no es un espacio en penumbra, distante en la lejanía de la nave y aislado físicamente de ésta, según la tradicional concepción de un santuario, sino que se inserta física, visual y lumínicamente en la nave celebrativa, de la manera más original posible, entendiendo el concepto original según el razonamiento gaudiniano de una vuelta a los orígenes. Si llama la atención la ausencia de un muro al fondo del ábside o de un retablo como fondo perspectivo del altar, soluciones que siguen otras iglesias de la misma época ya sean votivas (Montmartre, Viena, Tibidabo,...) o no (Steinhoff,...), el carácter totalmente y exento y relevante del altar, la sustitución del tradicional Pantocrator, o incluso de la imagen de la Virgen, en el ábside por la secuencia de las bóvedas de los cimborios, lampadarios y el altar ya mencionada, le confieren al Templo Expiatorio características ciertamente singulares, inexistentes en otras iglesias votivas. 


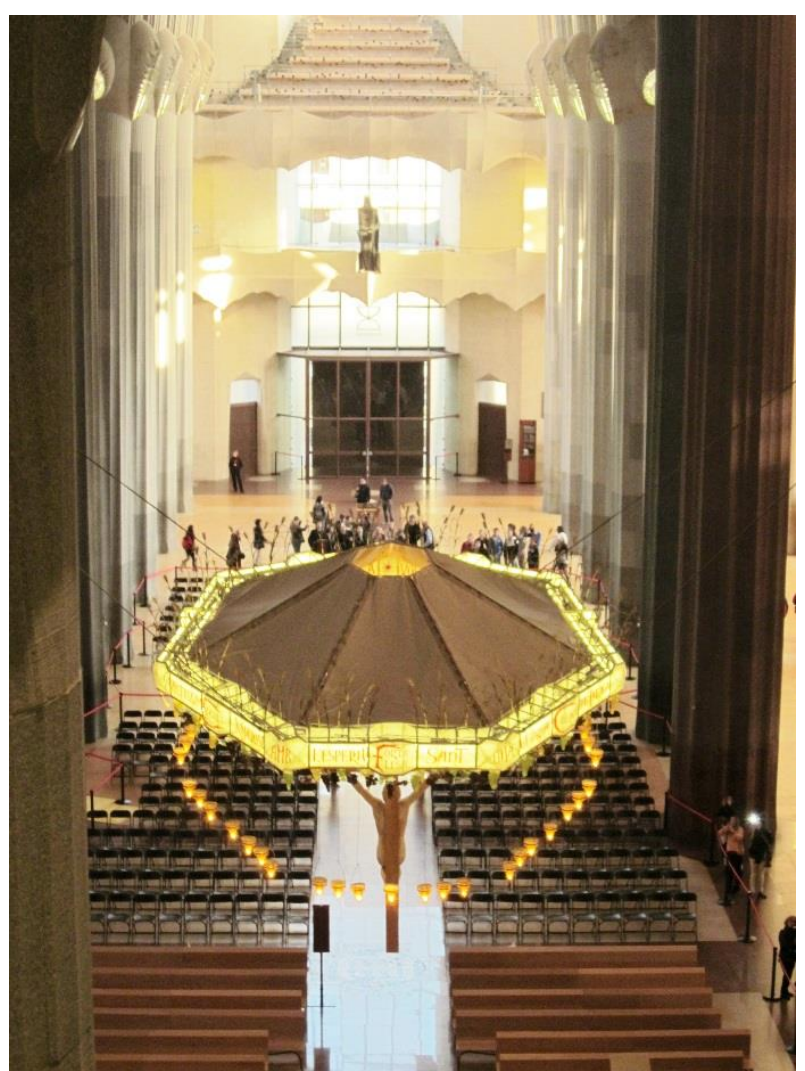

Lampadario y Crucifijo. Al fondo Coro.

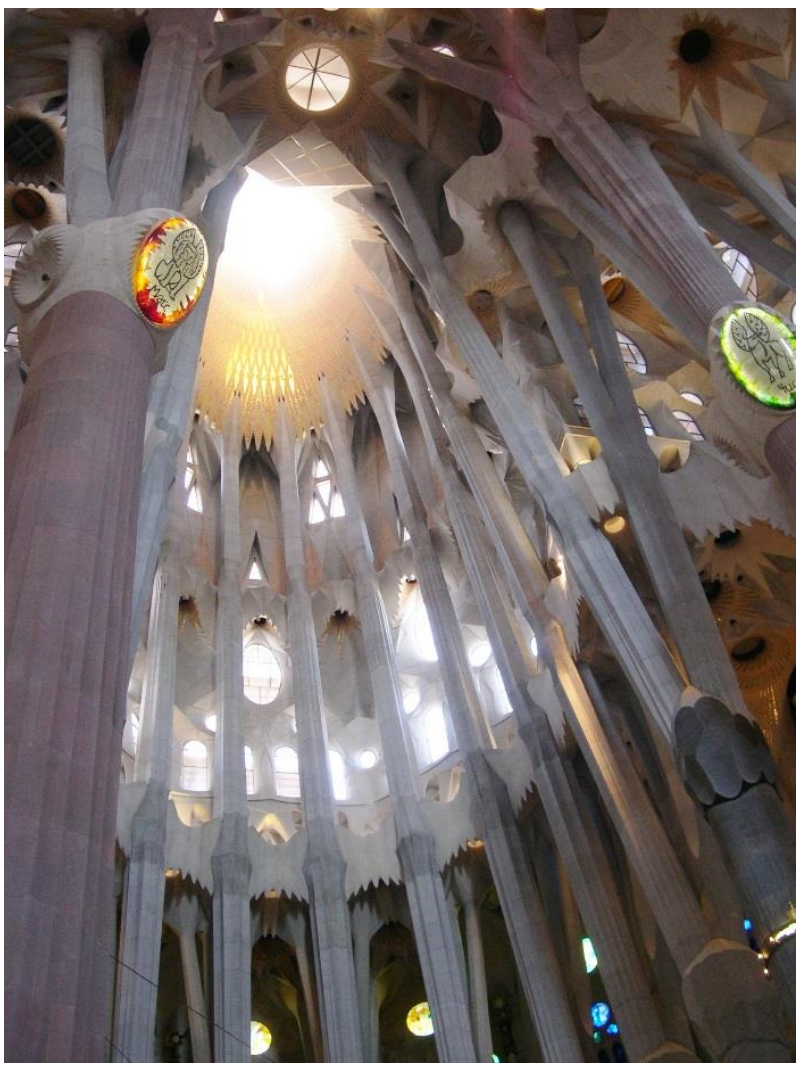

La luz entra por la bóveda del cimborio del ábside.

Fuente: fotografías del autor. 
Esta propuesta gaudiniana no resulta arbitraria, sujeta a un estilo o moda sdeterminados, sino que está fundamentada teológicamente. También la disposición centralizada y permeable de la cátedra episcopal y el coro de los ministros ordenados se conforma recordando su originaria ubicación en el recinto o bema de las domus ecclesiae y basílicas primitivas, rompiendo así la tradicional visión de un santuario clericalizado y completamente separado del resto de la asamblea -cuyo frente estaba delimitado por un iconostasio, cancel, o balaustrada-. Este presbiterio gaudiniano bastante centralizado con respecto a la nave y muy diáfano en virtud de la alineación de las columnas que sostienen la estructura- resulta sutilmente diferenciado del resto del aula celebrativa por la misma alineación de las columnas. En una iglesia medieval o historicista las columnas del presbiterio seguirían la misma alineación de la nave mayor configurando un deambulatorio de la capilla mayor o presbiterio.

Nada de esto sucede aquí. Las columnas que lo delimitan no siguen la disposición ortogonal al plan semicircular de la Cripta, tal y como había proyectado Villar, y según el plan medievalista, sino que sorprendentemente se cierran ligeramente para crear un ámbito tan hábilmente diferenciado que apenas se distingue a simple vista observando la alineación de las columnas de las naves. Entre el semicírculo de la Cripta y el transepto se sitúa, pues, un intercolumnio intermedio correspondiente con el ámbito de las escaleras laterales y los altares de Cripta e Iglesia superior que cose una alineación de columnas con la otra -Cripta y naves de la Iglesia superior-. En consecuencia la disposición de las columnas del aula litúrgica de la Sagrada Familia, en la que se ha buscado un intereje de $7 \mathrm{~m}$ (en clara alusión a su significado bíblico), no supone la continuidad inmediata del módulo, intereje y alineación de las columnas de la Cripta, reforzando aún más la autonomía de ambos espacios. Además de esto, en el Presbiterio el intercolumnio es de 3,5 m y entorno a él y a $+20 \mathrm{~m}$ se sitúa el Coro de niños por lo que el objetivo visual, y por consiguiente participativo, se puede considerar conseguido en una alto porcentaje.

Bonet, Faulí, Gomez-Serrano y otros arquitectos que han trabajado en el desarrollo y construcción del sistema columnas y superficies alabeadas de las bóvedas de las naves nos muestran en toda su complejidad la estructura y procedimiento constructivo del proyecto. Pero, ¿qué buscaba Gaudí con todo ello cuando menciona que no es funiculario ni que la geometría ha de marcar el proyecto? En mi opinión, Gaudí resuelve con la estructura las condiciones de iluminación ambiental que quiere aplicar al aula celebrativa, tal y que como avanzaba en el Cuaderno de Notas, que no debían ser ni excesivas ni quedarse cortas siendo reguladas por el ritual litúrgico. No obstante, construcción y simbolismo, materialidad y teología litúrgica se mezclan a cada paso. Así, la elevación de del nivel del Presbiterio, que le sirve para realizar un vaciado en su perímetro otorgando una mayor riqueza espacial y visualización de la Cripta, también identifica simbólicamente a ésta con el Purgatorio. 


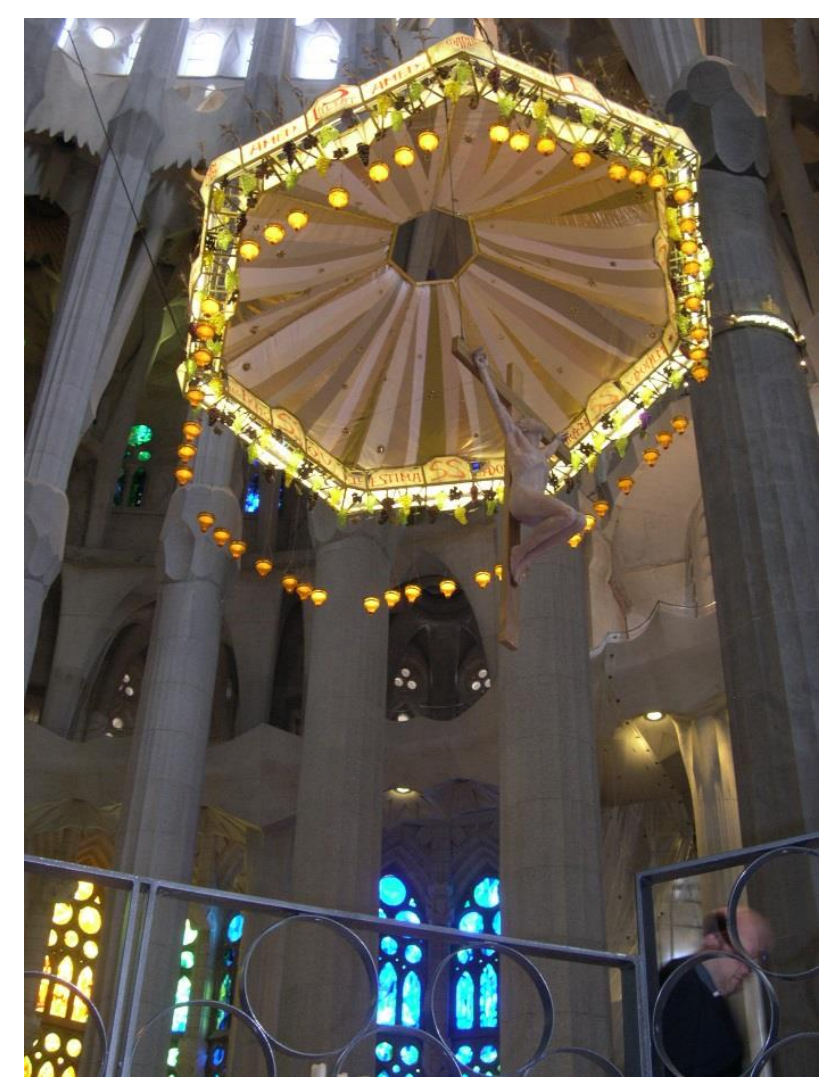

Baldaquino, lampadario y crucifijo colgante sobre el altar mayor. Observese los siete lados del baldaquino y del lampadario, símbolo de los siete dones del Espíritu Santo. Fotografia del autor. 
La proclamación de la Palabra y el Ambón.

Si en la cabecera se han introducido estas transformaciones, en el lado opuesto la visualización del altar es magnífica desde la nave central a +0 $\mathrm{m}$ y desde el coro circundante a $+20 \mathrm{~m}$. Desde aquí también se contempla perfectamente la sede y el colegio presbiteral rodeando al centro visual de la asamblea -altar- al que se le otorga la máxima atención.

No se dispone de información suficiente respecto del tratamiento del ambón como foco de proclamación de la Palabra en el proyecto estudiado por Gaudí -tal y como atestiguan las primeras iglesias cristianas en el bema- pero a juzgar por la ubicación de los púlpitos o tronas en Mallorca y en la Cripta del templo Expiatorio, así como la incorporación en aquella de los tornavoces para mejorar la audición por parte de la asamblea de los fieles dispuestos en la nave mayor de la catedral, es posible pensar en un púlpito junto a la columna dedicada al apóstol Pedro en el lado derecho o del evangelio junto al altar, tal y como el primer Album del Templo (1915) avanza, solución que pensaría realizar doble y simétrica -en el lado de la epístola- como otros muchos elementos.

Aunque no se conocen dibujos al respecto, el conocimiento teológico-litúrgico del arquitecto y el desarrollo de su proyecto simbólico vendrían a corroborar esta hipótesis. Téngase en cuenta además que en todos los planos de planta dibujados en vida de Gaudí aparecen las gradas sobre las que se sitúa el altar con forma de octógono y las escaleras de acceso al presbiterio junto a las columnas mencionadas. El número ocho hace referencia siempre a la resurrección de Jesucristo el primer dia de las semana después del séptimo dia que era el sábado o dia del descanso judío, asociándosele comúnmente con la disposición en planta de la piscina bautismal en las primitivas iglesias y basílicas. Aquí es aplicado al fundamento o base sobre el que se erige el altar eucarístico, símbolo de Jesucristo y de su Resurrección, razón de ser de la fe cristiana. Por ello nada tendría de extraño que Gaudí asociara a las columnas próximas a la mesa eucarística unos lugares elevados para la proclamación de la Palabra, como hace en la reubicación de los pulpitos de Mallorca y en el púlpito de madera de la Cripta, siendo que los pioneros del Movimiento Litúrgico promovían la importancia de ésta en la Misa.

Conocedor de la tradición existente de los dos ambones, uno mayor para la proclamación del Evangelio y otro de menores dimensiones para el resto de lecturas bíblicas, como así lo había encontrado en la seo mallorquina, nada obliga a pensar en una variación del esquema, siendo que la valoración de ambos por su uso era lo que promovía el Movimiento Litúrgico. 


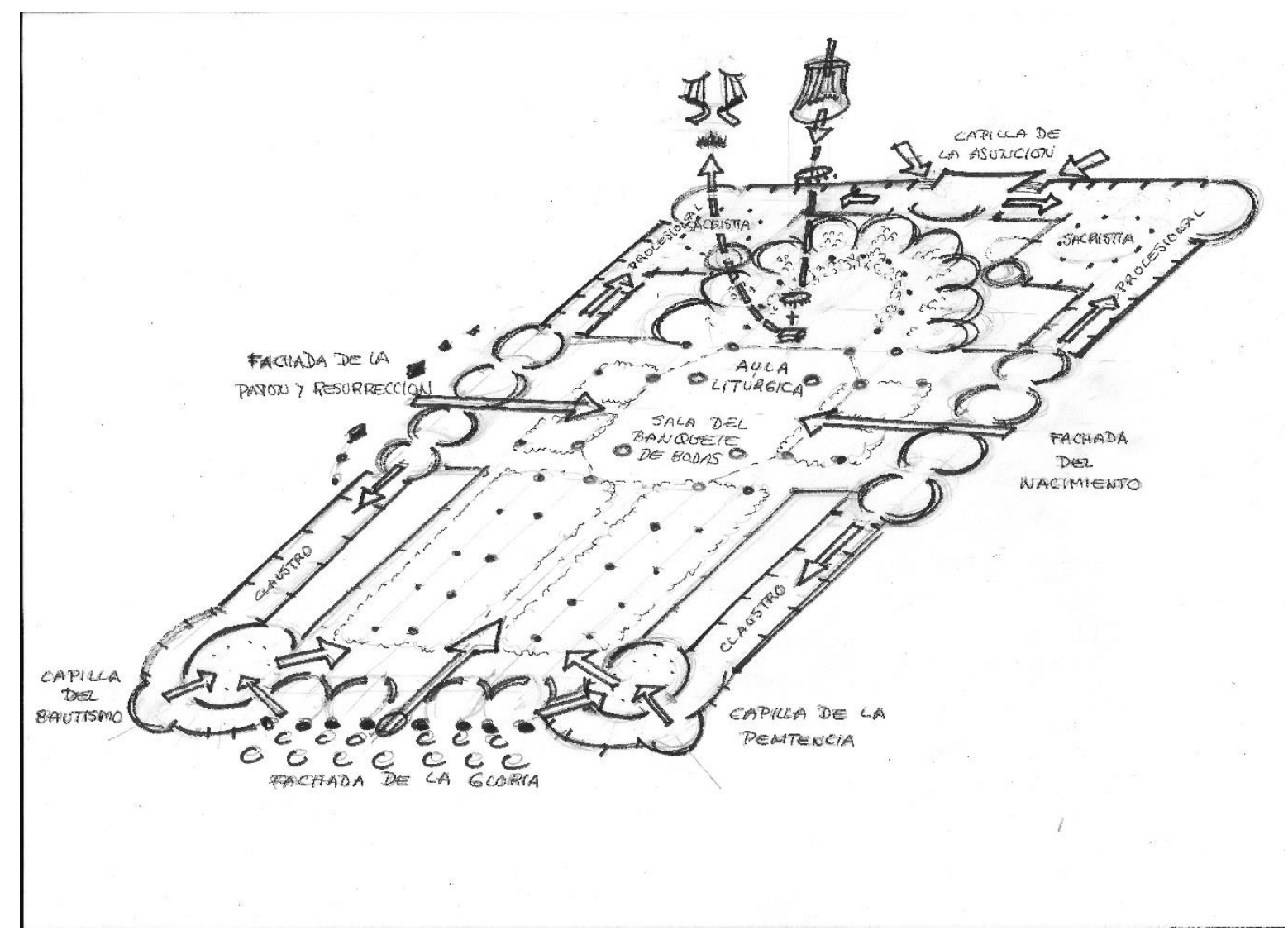

Itinerarios litúrgicos de la Sagrada Familia. Fuente: dibujo del autor. 


\section{El Sagrario y la exposición del Sacramento.}

Otra cuestión de notable interés es el tratamiento de la reserva del Sacramento en el proyecto que nos ocupa. Con posterioridad a Trento se había impuesto mayoritariamente en Occidente la costumbre, que no regla, nacida en Italia y apoyada por San Carlos Borromeo de situar el Sagrario para la reserva del Sacramento en el altar mayor como lugar más digno y propicio para su adoración.

En algunos casos, sin embargo, y coincidentes en el tiempo, otros prelados como el arzobispo Aliaga y San Juan de Ribera en Valencia, igualmente seguidores de los postulados eucarísticos que nacen posteriormente a este Concilio, promueven de espacios específicos para la reserva del Sacramento llegando incluso a la creación de capillas mayores dedicadas expresamente a la disposición permanente del tabernáculo para el Sacramento, abriendo el camino a las más posteriores disposiciones sobre la Capilla de la Comunión del Concilio Vaticano li. ${ }^{357}$

El benedictino Dom Lambert Beauduin no debía ser ajeno a la conveniencia de separar el altar mayor y el monumento de la reserva eucarística. Es por ello que unas veces, con la temporalidad que establece la Liturgia del jueves y viernes santo, organiza esta capilla en la mencionada como de la Penitencia, y en otras, con una vocación de permanencia, sitúa el sagrario en un altar diferente al altar mayor. Este sería el caso que le lleva a situar el sagrario en el altar de la capilla de San José de la Cripta (como así lo refiere Manuel Trens en el Propagador, no11 de noviembre de 1926 ${ }^{358}$ ) diferenciándolo del altar mayor de la Cripta, que era el de la Sagrada Familia, cuando se establece en ella una parroquia en tiempos del Obispo Casañas. Salvador Casañas i Pagés, obispo de Barcelona desde 1901, había participado en 1903 en la elección de Pio X (del cual ya se ha dicho anteriormente fue el impulsor del Movimiento Litúrgico a nivel de todo el orbe católico) y muere en 1908, año en que precisamente se inician las obras en la iglesia de Sta. Coloma y en la catedral de Mallorca.

\footnotetext{
${ }^{357}$ Cf. AA. VV. (1983) Catàleg de Monuments i Conjunts de la Comunitat Valenciana. Valencia. Conselleria de Cultura, Educació i Ciència. La recomendación tridentina de promover el culto eucarístico mediante la construcción de espacios reservados al efecto es asumida por el sínodo valentino convocado por el Arzobispo Aliaga en 1631. Con posterioridad el Arzobispo Ribera promueve la construcción de la Iglesia y Colegio del Corpus Christi y de la Iglesia de San Andrés (hoy de San Juan de la Cruz) con capillas habilitadas ex profeso para el sagrario. En esta última se amplió la capilla de la Virgen de los Dolores con mayores dimensiones, planta de cruz, cúpula y acceso directo desde la calle, que volvió a rehacerse como Capilla de la Comunión en 1741. Otras construcciones de capillas dedicadas al culto eucarístico en Valencia se realizan en la Iglesia de la Sta. Cruz (1613) y en la iglesia de San Martin (1674).

358 Cf. El Propagador (1926). № 11. Pag. 351: “Al convertir la Cripta en Parroquia en tiempos del cardenal Casañas, se convierte el altar de San José en altar del Santísimo", adaptándose para altar mayor el central de la rotonda de la Cripta dedicado a la Sagrada Familia. Pag. 352: "Muchas iglesias han seguido esta iniciativa."
} 


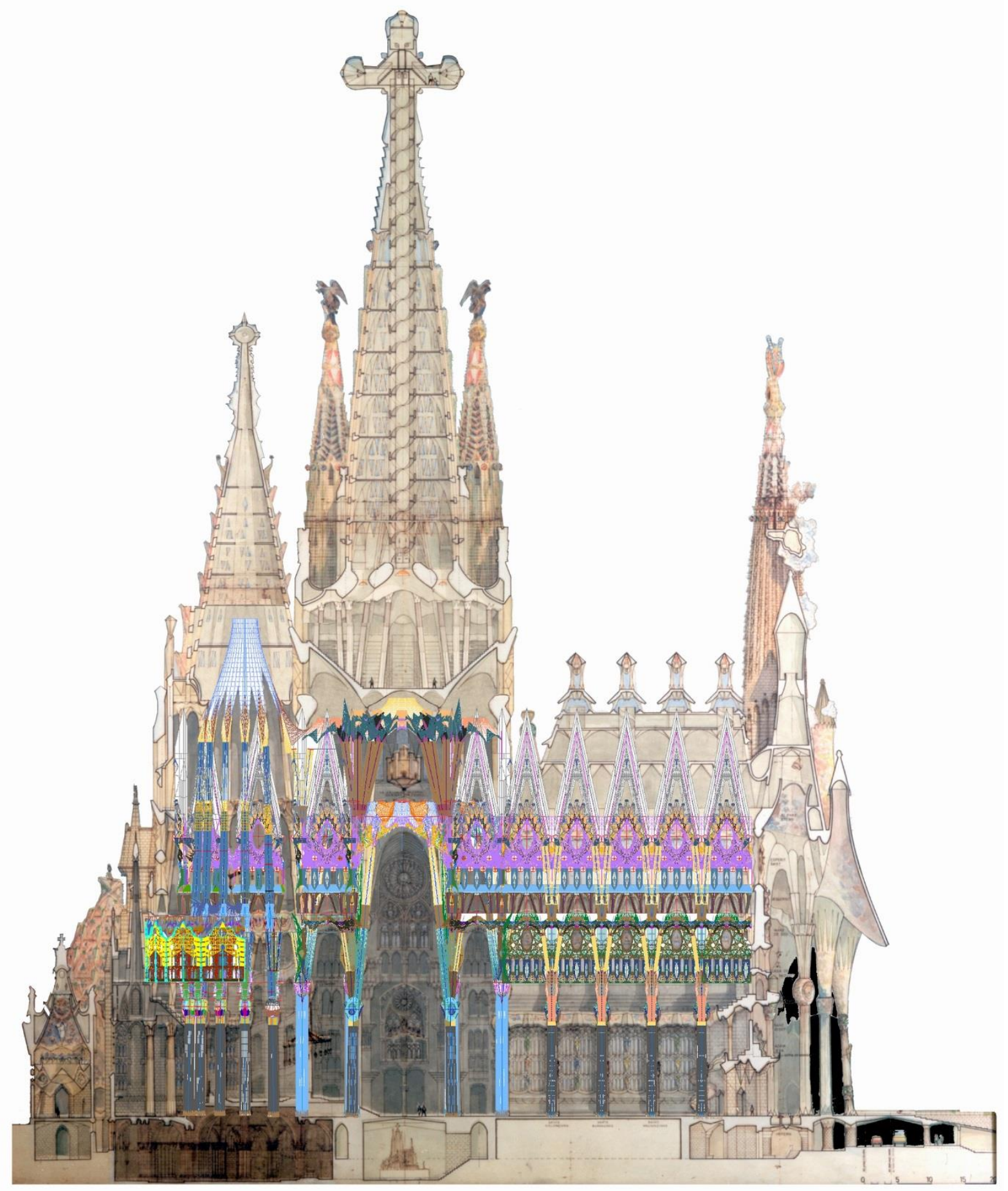

Sección longitudinal donde se aprecia la solución de graderío para las tribunas de los coros. Fuente: Faulí. J (2006) El Temple de la Sagrada Familia. Madrid. Aldeasa. 
Gaudí nunca ubica el tabernáculo del Sacramento en el altar mayor. Tan sólo en las primeras actuaciones realizadas en las capillas de los colegios de Tarragona (1879) y de San Andrés del Palomar (1881) seguirá esta pauta. Impregnado del espíritu renovador de la participación comunitaria en el culto que presidió las actividades de los iniciadores del Movimiento Litúrgico en Centroeuropa y en contacto con eclesiásticos como Luis Carreras, José Ma Llovera, Manuel Trens, Suñol, etc. que se relacionaban directamente con el cardenal belga Mercier, seguirá sus propuestas más innovadoras dentro del margen de aceptación del $\mathrm{CIC}$ y disposiciones litúrgicas de su tiempo ${ }^{359}$. En síntesis podemos decir que la actitud de todos estos eclesiásticos, asumida por Gaudí, era la de concentrar los esfuerzos en el aula eucarística y su accesibilidad universal, que era donde pensaban se dirimía la vida litúrgica la Iglesia.

Nada tiene pues de extraño que en el periodo que va entre 1901 y 1908, terminada la Cripta diez años antes se quisiera apoyar el esfuerzo de los josefinos con la erección de una parroquia en el recinto ya terminado, y que en ella Gaudí volcase su habilidad para adaptarla a las normas litúrgicas que proponía Roma. Como se puede apreciar en la descripción del Propagador y en fotografías de la época "Se adapta para altar mayor el central de la rotonda de la Cripta, recubierto de frontales litúrgicos, con sólo los cirios encima de la mesa y presidiéndolo la propia cruz procesional. Bancos para los presbiteros detrás -retro tabulae- adosado al muro de fondo de la Sagrada Familia. Un amplio baldaquino, no usado en ninguna de nuestras iglesias cubre el altar." 360

Tenemos ya aquí tres componentes del culto se afirman como importantes para el arquitecto: la separación del sagrario respecto del altar mayor, la situación del altar mayor exento y consiguiente ordenación del presbiterio en torno a él, y la significación del altar como mesa con sólo los cirios sobre ella y un baldaquino suspendido encima. Sin embargo Gaudí no se conforma con ésto, como señala el Propagador (1 y 15-111926) "a Gaudí esto no le satisface aún; le faltaba la vida del culto, en lo cual sus deseos coincidían con los del clero adscrito al Templo. El momento era feliz por cuanto una renovación litúrgica llenaba el ambiente proyectado desde el foco benedictino de Montserrat. Los primeros Congresos litúrgicos se celebraban en Barcelona con éxito imponderable....". Testimonios todos ellos que corroboran la fuerte impronta litúrgica del proyecto arquitectónico gaudiniano.

\footnotetext{
${ }^{359}$ Cf. Las fotografías del altar mayor de la Cripta en la P. 106 de esta investigación.

${ }^{360}$ Cf. El Propagador (1926). № 11. Pag. 352.
} 

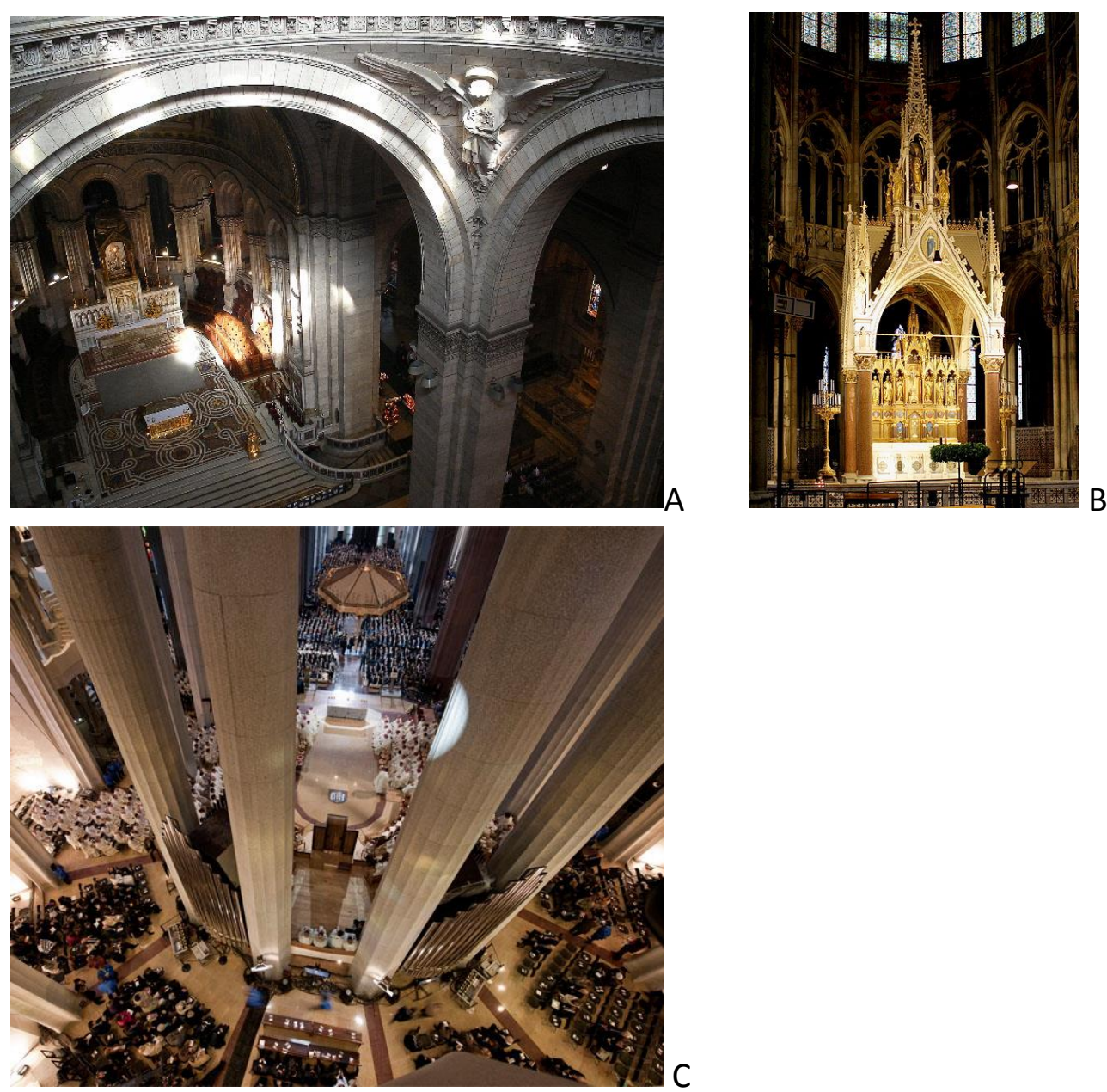

Tres presbiterios, tres altares. A. Sacrée Coeur, Paris. B. Votivkirche, Wien. C. Sagrada Familia, Barcelona. Fuente: Junta Constructiva de la Sagrada Familia.
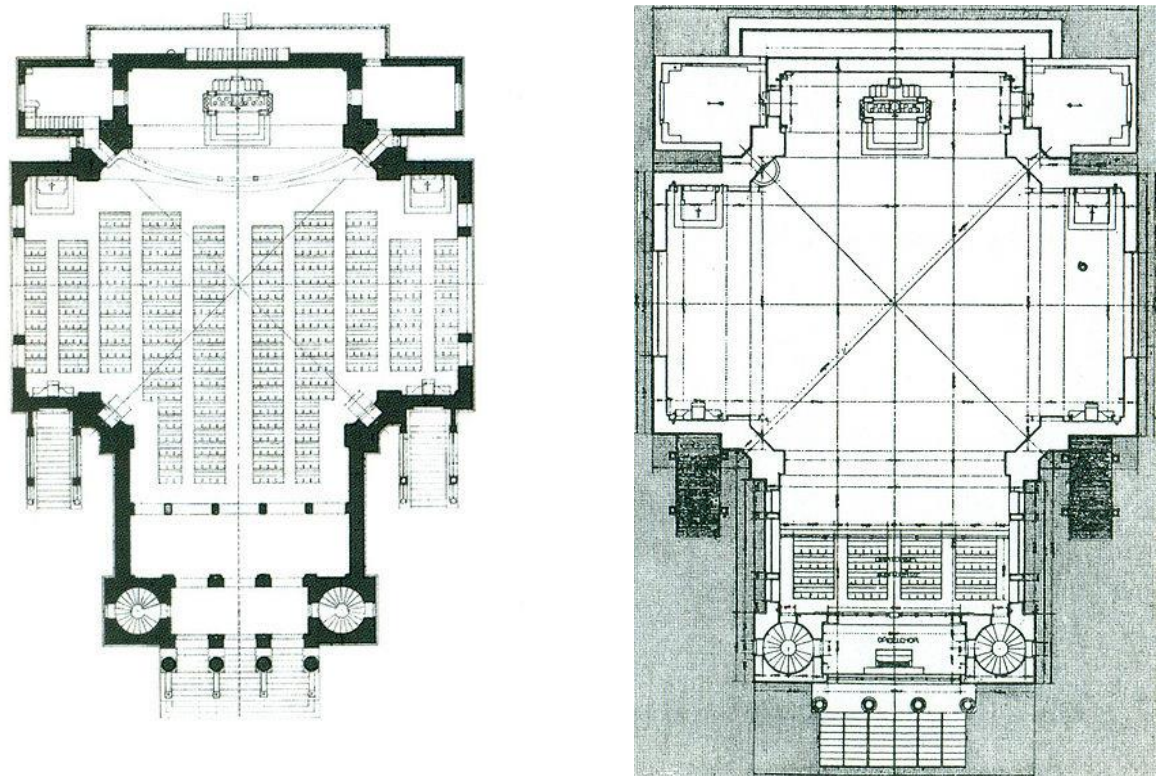

Iglesia de St. Leopold am Steinhoff, planta baja y coro. 
Altar mayor $y$ altares.

La posición exenta y avanzada del altar (reforzada por las gradas y el baldaquino) respecto del profundo y amplio presbiterio -capaz para albergar 200 asientos de presbíteros que constituirán el coro ministerial en el ábside de acuerdo con las instrucciones que preconizaba el Motu Proprio de Pio X- llegando a invadir el crucero responde a la intención de focalizarlo como centro neurálgico de la asamblea facilitando la proximidad de los fieles al corazón de la celebración.

$\mathrm{Ni}$ en las iglesias historicistas del siglo XIX ni en otras iglesias votivas (Montmartre, Koekelberg, Votivkirche de Viena, Tibidabo de Barcelona,...) encontramos eco de estas cuestiones. St. Leopold de Steinhoff, de Otto Wagner, con un brillante lenguaje modernista y una cuidadosa ejecución de los detalles, se halla muy lejos de la pretensión teológico-litúrgica y de la investigación estructural de la Sagrada Familia. Si encontramos similitudes entre los altares laterales de Steinhoff o Montmartre con otros como el de San José en la Cripta de la Sagrada Familia -con un fondo murario a la manera de retablo, una imagen que los preside, etc.- estas coincidencias no se repiten en el altar mayor, en el altar de la asamblea eucarística, que es radicalmente diferente.

Gaudí diseña cada elemento con arreglo a su uso, que en cada caso se corresponde con la finalidad a la que se dedica, pues en un caso se trata de respetar la devoción y oración particulares de los fieles, y en otro de presidir el espacio de la asamblea eucarística en su dimensión más genuinamente comunitaria.

No tenemos constancia exacta y detallada de que la idea de una celebración de la Misa versus populum presidiera el diseño del altar y su ubicación pero es interesante mencionar la descripción que hace el Propagador para situar los asientos de los presbíteros -retro tabulae- detrás del altar, al adaptarse el altar central de la Cripta para altar mayor, ya mencionado anteriormente, con ocasión de su transformación en parroquia, y también la descripción que refiere de la celebración por el prelado al fondo del altar y de cara al pueblo durante las rúbricas de oficios diversos, así como la homilía sentado delante de ese mismo altar ${ }^{361}$.

Estas descripciones nos hacen ver con claridad que existía inquietud por este tema y que al menos se procuraba la significación del altar y la máxima visualización por el pueblo y cercanía a él. En la Sagrada Familia queda por contestar si se pensó desde el principio en una celebración cara al pueblo, en cuyo caso al estar el altar sobreelevado difícilmente se visualizaba la cátedra del obispo, o aún disponiendo el altar exento el sacerdote celebraría delante del altar. En ambos casos también existe la posibilidad de que las homilías se realizarán delante del altar como en la Cripta pero es una cuestión que queda por determinar.

${ }^{361}$ Cf. El Propagador (1926). № 11. Pag. 355. 

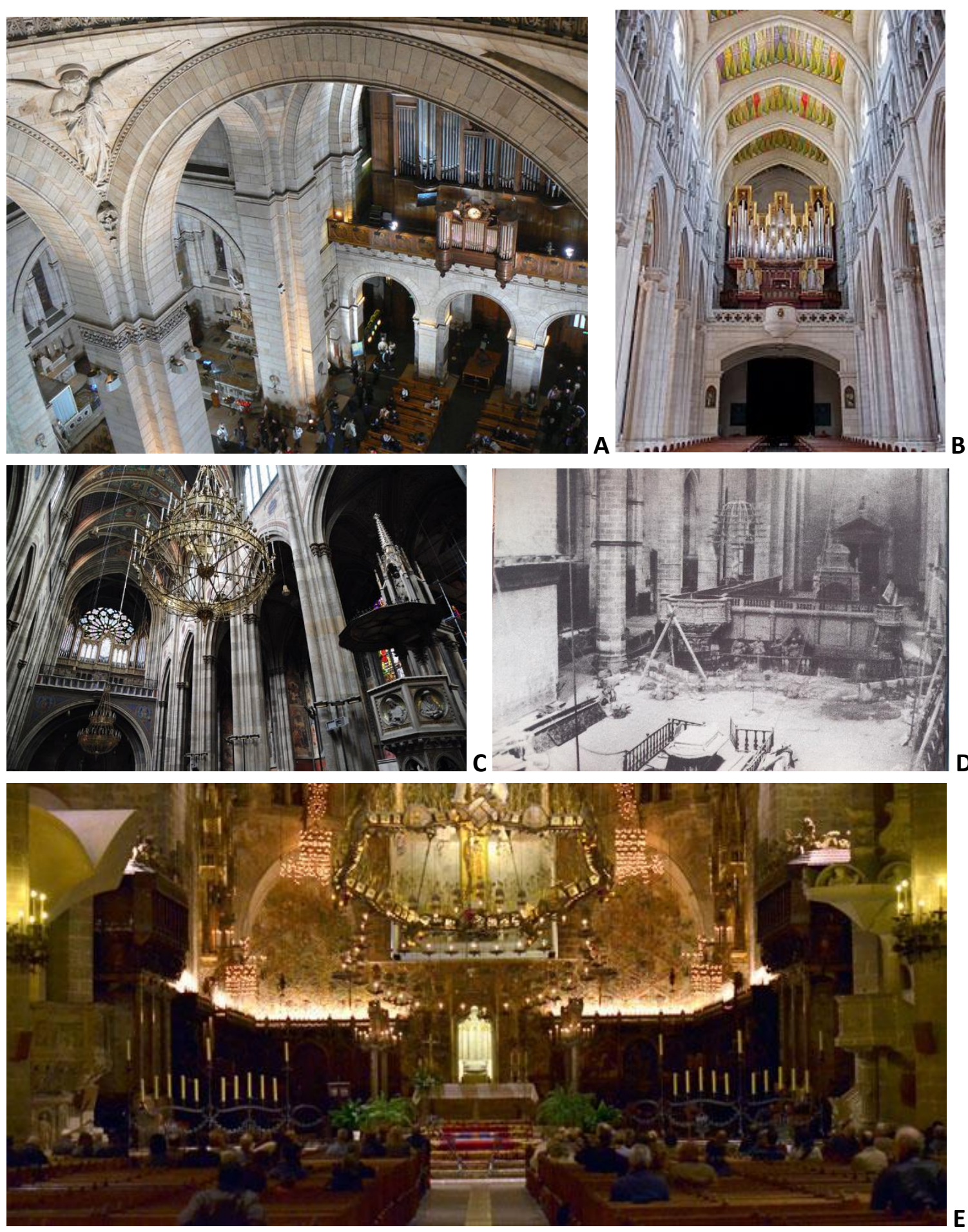

El Coro en la iglesia en el siglo XIX:

A: Sacrée Coeur de Montmartre, Paris, Coro sobreelevado a los pies de la nave.

B: Catedral de la Almudena, coro sobreelevado a los pies de la nave-

C: Iglesia votiva del Divino Salvador. Viena. Coro sobreelevado a los pies

D: Demolicion del coro central de la catedral de Mallorca.

E:Coro de canónigos y Schola Cantorum de la catedral de Palma después de la intervención de Gaudí. 
Recorridos y circulaciones.

Lo que si parece claro es que en la Sagrada Familia el espacio del aula celebrativa no es un recorrido longitudinal en peregrinación hacia el altar como pudiera ocurrir en una catedral gótica o románica, no hay ningún altar lateral, y la disposición de la asamblea es como hemos visto envolvente. El recorrido físico y espiritual es previo a la entrada en el espacio celebrativo, bien desde las capillas del Bautismo y de la Penitencia o a través del Claustro, y tiene la significación de una acción religiosa preparatoria a la celebración eucarística. Aquí, al franquear el nártex de cada portada nos encontramos con un aula celebrativa configurada ya como anticipo del banquete escatológico de que habla el Apocalipsis -"Pero no vi Santaurio alguno en ella porque el Señor, el Dios Todopoderoso y el Cordero, es su Santuario"_-362, lugar de celebración de los rescatados que antes estaban alejados y que ahora son admitidos en la asamblea, bien por que han adquirido esta condición después de pasar por la capilla del Bautismo o la de la Penitencia bien porque ya la tuviesen.

En la fotografía C de la página anterior se aprecia la disposición de la asamblea litúrgica envolvente en torno al altar mayor. No es extraño que Gaudí pensara en ella conociendo otras disposiciones semejantes, como por ejemplo San Pedro del Vaticano, y teniendo en cuenta que los álbumes de la Sagrada Familia mencionan que se podría congregar cómodamente sentados a más de 14.000 fieles $^{363}$. Por esto mismo, el ábside, continuación de las trazas heredadas de la Cripta, es sutilmente transformado por la disposición del altar, el coro y la estructura de las nuevas escaleras simétricas que ocupan el lugar de las primeras capillas absidales en una continuación del aula litúrgica a la que sirve. De esta manera el espacio interior de las naves es reelaborado sin apenas modificar sus trazas de cruz latina, distorsionando la planta y simplificando su lectura como la de una sala, mediante la significación de los principales focos de la asamblea, el tratamiento visual y lumínico del espacio, y la sorprendentemente disposición del Claustro. Este se constituye, como vernos, en el autentico deambulatorio del aula litúrgica. Gaudí tiene el mérito arquitectónico de saber conjugar las preexistencias con las herramientas que utiliza para la reconversión del espacio arquitectónico. No es una semejanza formal lo que encontramos, es un juego de estructura y luz, de volumen e inmaterialidad y funcional la que origina soluciones espaciales y constructivas de gran familiaridad con la arquitectura bizantina.

${ }^{362}$ Cf. Apocalipsis 21, 22.

${ }^{363}$ Cf. Los diferentes Albumes de la Sagrada Familia. En concreto ya en el primer álbum de 1915, P. 12 hasta llegar al Album de 1929, P. 28 se repite: “En el Templo podrán congregarse comodamente sentados más de 14.000 fieles. 


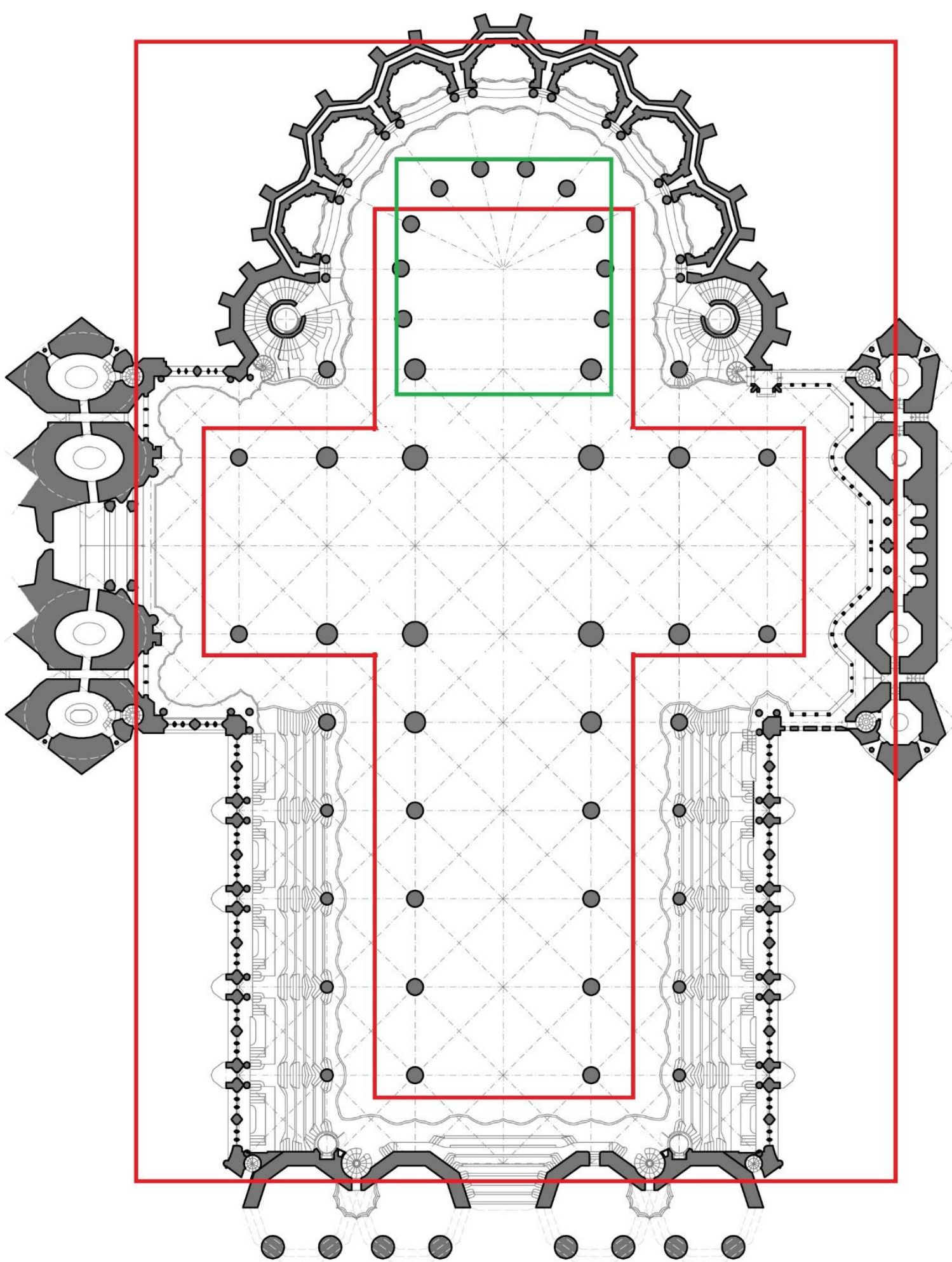

Situación de los coros de laicos y de ministros en la S.F. Fuente: Plano de la Oficina Tecnica de la Sagrada Familia. 


\section{El Coro según la Sagrada Familia.}

Ya en los primeros siglos del Cristianismo se tiene noticia de la incorporación de salmos cantados a la liturgia de la Iglesia, en el Oficio de las horas y también en la misma plegaria eucarística. Desde el siglo IV, en la disposición de las basílicas en diversas zonas de la geografía del Imperio Romano se aprecia una ubicación para la schola cantorum próxima al altar y los ministros celebrantes. Con el auge del monaquismo medieval y el surgimiento de las iglesias de peregrinación y catedrales el coro quedó restringido, sin embargo, a una élite de monjes o cabildo catedralicio cuyas voces cada vez más eran percibidas únicamente como música de acompañamiento por los fieles, ignorantes de la lengua latina. De tal manera que el canto gregoriano subsistió en el discurrir de los siglos siguientes como un repertorio ligado al culto, en contraposición de otros cantos y músicas más populares, pero únicamente conocido por los eclesiásticos. De ahí que pareciese lógico, ante la imposibilidad de realizar la liturgia en lengua vulgar, pensar en la recuperación y potenciación del canto litúrgico como modus operandi de la participación del pueblo en la Misa. Fue un primer paso -junto con la investigación arqueológica de ritos, arte y arquitecturas que propugnaron los monasterios benedictinos centroeuropeos- pero que fue acogido con entusiasmo tanto por la Jerarquía de la Iglesia -tan preocupada unos años antes por la pérdida de los Estados Pontificios- como por los fieles laicos que sinceramente buscaban se acercarse a la práctica religiosa en unos tiempos convulsos en lo económico y social.

El Coro se había situado en los precedentes siglos XVI y XVII a los pies de la nave, en una posición elevada, con vocación de acompañamiento a los participantes en la celebración eucarística al recorrer su canto el espacio que media entre la entrada y el presbiterio. Al mismo tiempo que comienza a desarrollarse la polifonía, las piezas musicales de inspiración religiosa y los coros de voces blancas, también se desarrollan las manifestaciones religiosas populares que acompañadas de música y cantos no formaban parte, sin embargo, de las celebraciones litúrgicas. Ante una situación un tanto confusa respecto de la multiplicidad de piezas musicales y representaciones que se desarrollan en el interior de las iglesias, algunas de ellas en similitud con la utilización del canto y la música por la Reforma Protestante pero dentro de la cultura y tradición popular católicas, el Movimiento Litúrgico viene a deslindar el ámbito de la música y canto en las celebraciones litúrgicas de otras polifonías religiosas, recuperando la salmodia, preces e himnos de la liturgia como el modo más oportuno para favorecer la participación de los laicos en las celebraciones de la Iglesia, preconizando al mismo tiempo que saliera del ámbito de los especialistas para entregarlo a la asamblea comunitaria.

Por este motivo Pio X, a través de su Motu Proprio Tra le sollicitudini y las academias de música sacra, promueve la actualización del canto gregoriano y su difusión como la auténtica manifestación musical propia de la celebración litúrgica, cuestión que Gaudí 


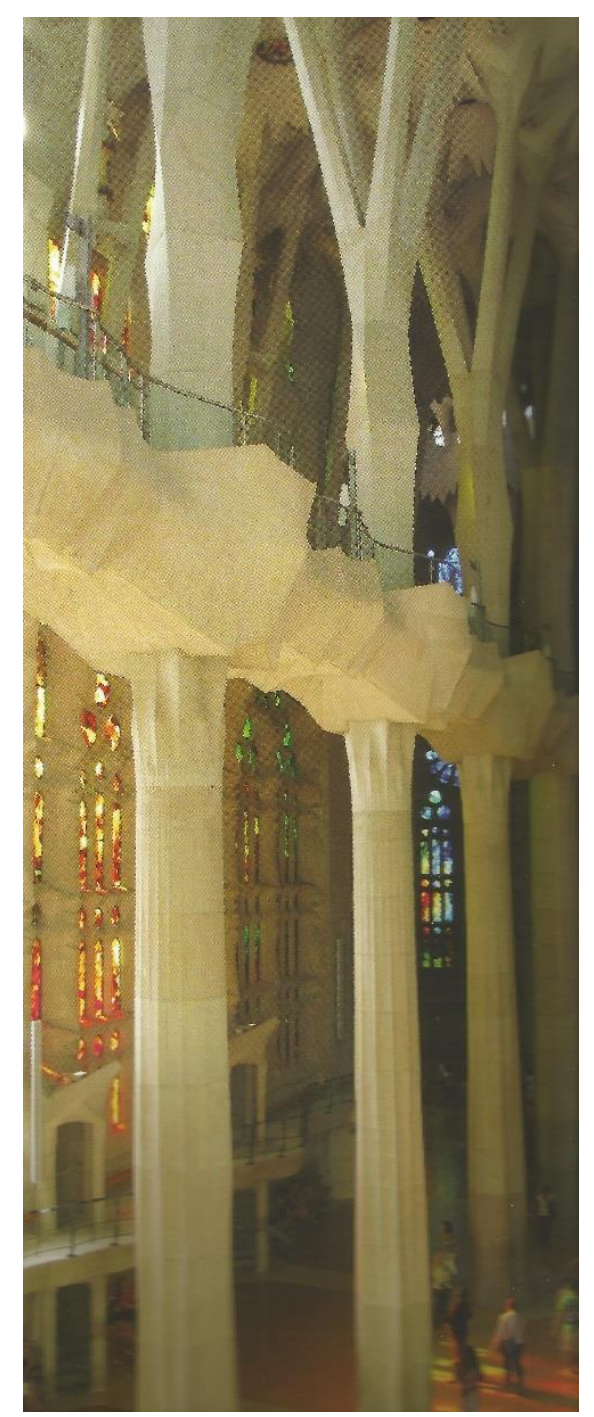

Sustentacion cantorías y vitrales sobre las naves laterales. Fuente: Burry, M. y AA.VV: (2014). Les naus de la Sagrada Familia. Barcelona. Ed. Mediterrània.

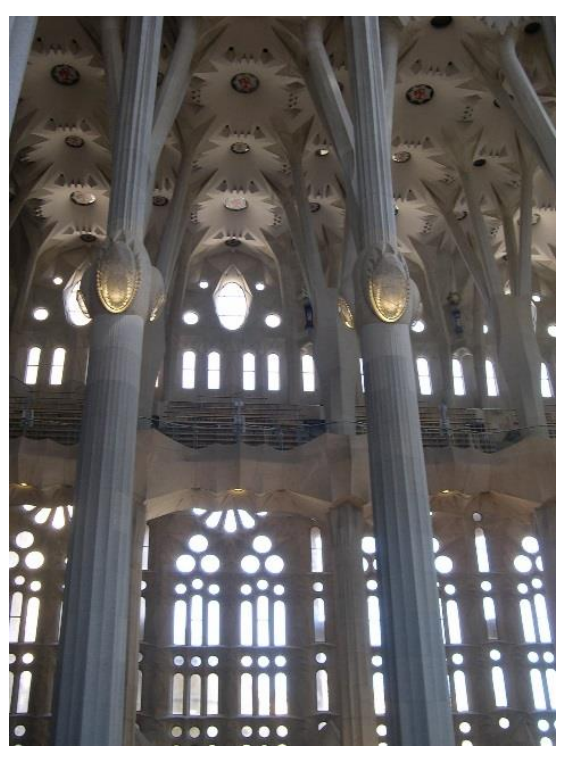

Las mismas cantorías, columnas, nudos y bóvedas, antes de la colocación de los vitrales de colores. Fuente: fotografía del autor, octubre 2014. 
-inmerso en un ambiente de eclesiásticos ilustrados que se adhieren a estas iniciativas desde el primer momento- recoge, asume e incorpora en sus diseños de iglesias.

Así pues la disposición perimetral de un coro, que ahora es universal de todos los fieles que participan en la celebración, se entronca con la necesidad de incorporar elementos estructurales al edificio que permitan su sustentación y estabilidad interna sin elementos externos añadidos al modo de muletas, como gustaba Gaudí de denominar en sus escritos a arbotantes y contrafuertes. Este planteamiento aparece discretamente esbozado en la planta de 1885 en las escaleras situadas al pie de la nave y los trazos que parecen circundarla a ambos lados de las naves, y desde luego, claramente dibujado en todos los alzados y secciones interiores posteriores a 1917. Los alzados interiores y secciones que se conservan permiten datar en 1915 los primeros dibujos en los que aparece el coro en su implantación actual.

Alrededor de 1884, en la iglesia de los Jesuitas de la C/ Caspe y en la de las Salesas, encontramos además de una especie de tribuna o jubé a los pies de la nave mayor, una solución de presbiterio exento pero comunicado en todo su perímetro con un deambulatorio -a modo de reducida girola- mediante una arquería- que ocasionalmente pudiera haberse utilizado como coro de voces blancas cercanas al altar- que podría haber anticipado la solución de la Cripta de Santa Coloma, dada la conexión profesional existente entre Martorell y Gaudí, y la asunción por éste de la importancia del coro y canto gregoriano a los que ya nos hemos referido.

No se han podido encontrar planos desarrollados del proyecto de las Misiones franciscanas de Tanger (1892-93), del dibujo del conjunto exterior publicado por Ráfols T. Torii propone unas plantas y secciones interiores de la nave de la iglesia en las que podría interpretarse una solución de galerías altas -al modo de los dibujos de Santa Coloma- como posiblemente destinadas al Coro. ${ }^{364}$ Precisamente es en este proyecto, en el que trabaja desde 1898 a decir de Ràfols $^{365}$, en el que apreciamos unas tribunas para un coro en altura, lo cual es bastante coincidente en el tiempo con la reubicación del Coro y Schola Cantorum la catedral de Mallorca. En consecuencia, entre los años 1892 y 1916 Gaudí trabaja en plano o en obra, en diversos proyectos, sobre ubicaciones del Coro que no responden ya a emplazamientos tradicionales a los pies de la nave.

Pero lo que es una intervención de pretendida rehabilitación litúrgica en Mallorca y que apenas aparece esbozada en los dibujos de Sta. Coloma -y acaso en la galería de la Cripta- se manifiesta con absoluta rotundidad en los graderíos de la Sagrada Familia.

\footnotetext{
${ }^{364}$ Cf. Torii, T. (1983) El mundo enigmático de Gaudí, y Bassegoda Nonell, J,.(1989) El gran Gaudí.

365 Según refiere Ràfols (1929) Gaudi: 182-1926, citado por Bassegoda, este proyecto se le encargó a Gaudí en 1898.
} 


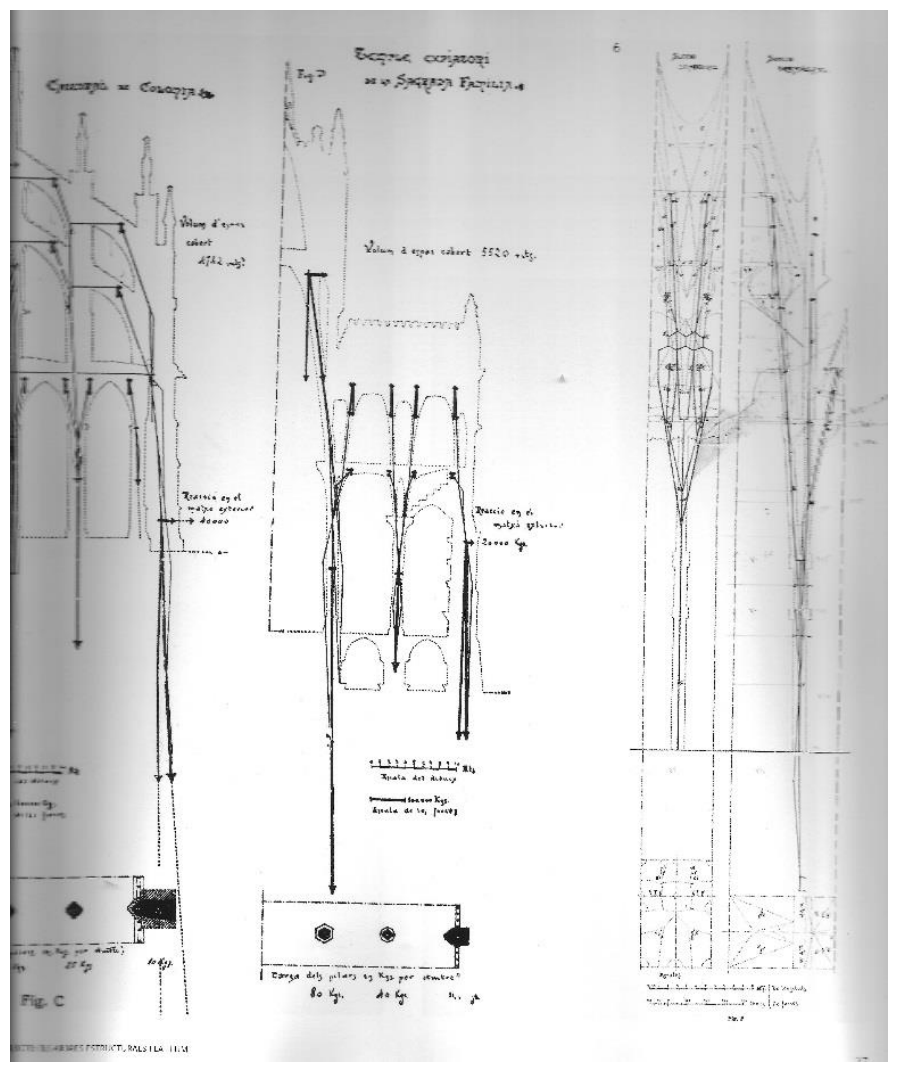

Izda.: Comparación entre resultantes de las cargas que se trasmiten a los cimientos de la catedral de Colonia y de la Sagrada Familia. Dcha.: Cálculo gráfico de la nave realizado por Gaudí y expuesto por Doménec Sugrañes en su conferencia en el Colegio de Arquitectos del año 1923. Fuente: Burry, M. y AA.VV: (2014). Les naus de la Sagrada Familia. Barcelona. Ed. Mediterrània.

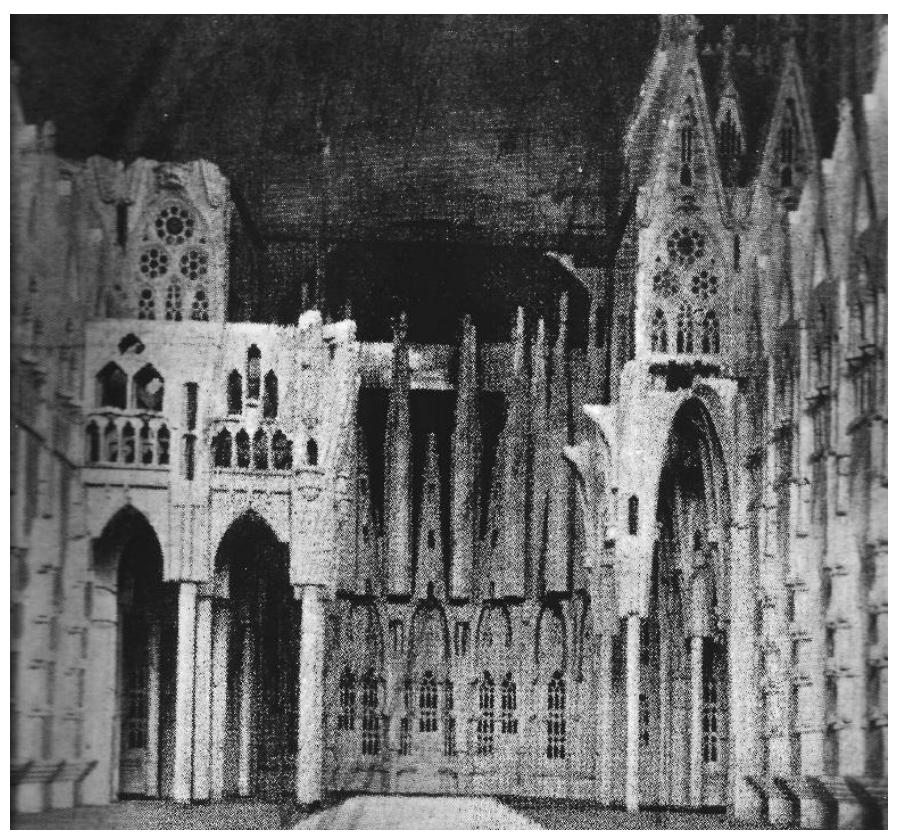

Maqueta de la primera solución del proyecto estructural. Se aprecia el protagonismo de las tribunas y galerías, según una disposición medievalista. Fuente: Burry, M. y AA.VV: (2014). Les naus de la Sagrada Familia. Barcelona. Ed. Mediterrània. 
Parece que es a partir de 1915 cuando comienza a definirse el coro de la Sagrada Familia descrito con detalle en el Album de ese año y en la sección longitudinal que se publica en 1917. Según Doménec Sugrañes la estructura neogótica la tiene resuelta Gaudí en 1898 y en las maquetas publicadas en 1915 en la Ilustració Catalana (Archivo Mas, 17-11915) todavía aparece esta solución sin ningún elemento que pueda apreciarse como destinado al coro.

En imágenes publicadas en el Pro en 1918 (1-04-1918) todavía aparecen dichas maquetas pero, en cambo, en el Album del Templo de 1915 y en la sección de 1917 la sección transversal ya es arboriforme con sendos graderíos laterales para el coro de mujeres tal y como se describe en el texto escrito. No debiendo extrañar la simultaneidad de fechas en la publicación de soluciones diferentes, la que se venía arrastrando desde 1898 y la que aparece por primera vez a la luz pública en 1915, ni el solape entre maqueta, textos y dibujos, completamente natural en una obra de estas dimensiones cuyo proceso de resolución de problemas constructivos exigiría el aprovechamiento de todos los recursos disponibles para el estudio, análisis y comparación de alternativas. En consecuencia debemos tomar el entorno de este último año como el cambio de criterio del proyecto, en el que van unidos estructura y coro.

El año -1915- cuando se publica por primera vez el nuevo proyecto estructural y solución de los graderíos del coro, es el mismo de la celebración del Congreso Litúrgico de Montserrat. El hecho de cambiar la estructura motivaría, sin duda, la recomposición de la planta completa del edificio respecto a la solución de 1855, con las diversas alternativas para la sutura entre los diversos recintos, dándose publicidad a los diferentes planos de 1915, 1916 y 1917 (ya mencionados anteriormente) que conduciría a la planta de 1926, consideraba como la última realizada en vida de Gaudí. Encontramos, además, que a partir aquella fecha el proyecto estructural del coro y por extensión de toda la nave celebrativa -unidos de por sí en la misma solución constructiva arborescente- casa tan íntimamente con la simbología y el discurso teológico del interior de las naves que se hace verdaderamente difícil separarlos. Así, a los elementos constructivos que van a constituir las bóvedas del interior de los cimborios que van tomando cuerpo en los dibujos de secciones, hay que añadir ahora la iconografía que se proyecta para los pilares inclinados y antepecho de los graderíos del nuevo proyecto estructural.

Menos de una de una década separa el coro de Steinhoff (1903-1907), litúrgica y espacialmente tridentino -aunque con un lenguaje modernista que lleva a considerar la iglesia de Otto Wagner como una de las más memorables del panorama internacionaldel sistema coral de la Sagrada Familia, totalmente involucrado en la renovación litúrgica de su tiempo. En Steinhoff, independientemente de la solución constructiva y formal, apenas hay diferencia funcional con el coro herreriano de la iglesia del 
Monasterio de El Escorial, y tampoco con los de la Almudena de Madrid (1883-1999), Montmartre de Paris o Iglesia votiva de Viena, ya que el discurso conceptual es el mismo aunque se exprese bajo diferentes lenguajes.

Ni siquiera el admirado Joan Martorell llega a recorrer este camino que si que se plantea Gaudí en Sta. Coloma, Palma de Mallorca y Sagrada Familia con gran despliegue de detalles. En esta última es fácil distinguir la singular solución de las tribunas altas laterales -destinadas al coro de las mujeres con la previsión de un reclinatorio individual para las 1500 cantoras y forma de graderío para poder visualizar el altar- del coro de 700 niños situado en la parte alta del ábside, el coro elevado de los pies de la nave para la proclamación de las bendiciones al acceder desde el pórtico de la Gloria o Jubé (de inspiración francesa) y las capillas de música en torno al crucero.

Ahora bien, ¿Gaudí aprovecha para cantorías un elemento estructural necesario para el equilibrio de su estructura arborescente una vez que ha descartado la primera solución goticista en la que tribunas y triforios arriostraban los arcos? 0 , descubre que la incorporación de las cantorías entre los muros de cerramiento y las columnas laterales reelaborando el tema medieval de las tribunas y dotándolo de un contenido novedoso como es el coro- contribuye a la estabilidad del nuevo sistema sustentante? Según se aprecia en la maqueta de la primera solución estructural (pag. 148 de esta Tesis) la disposición de tribunas y galerías ejerce una función de arriostramiento estructural que resulta insuficiente para llevar la resultante de las cargas dentro del ámbito del edificio.

Para conseguir este objetivo se tiene que llegar a la segunda solución estructural en la que la inclinación de las columnas y las cantorías consiguen el efecto deseado por el arquitecto. Por otro lado, dada la relación entre anchura y altura de las naves, la disposición de las tribunas de la primera solución -a unos $30 \mathrm{~m}$ - hace inviable su utilización como coro universal de la asamblea litúrgica. Si se sigue el razonamiento descrito por Doménec Sugrañes en su artículo Disposició estática del Temple de la Sagrada Familia ${ }^{366}$ se entiende que cada columna sostiene la parte de cubierta que le corresponde y que su inclinación se debe a la resultante de la composición de cargas que gravitan encima de ella, es decir, que los funículos catenarios ensayados en Santa Coloma dan lugar en la Sagrada Familia a superficies regladas -hiperboloides y paraboloides hiperbólicos utilizados para las bóvedas- que distribuyen los pesos obteniendo, mediante su composición, unos centros de gravedad por los que ha de pasar el pilar o columna.

${ }^{366}$ Cf. Domènec Sugrañes (1923) "Disposició estática del Temple de la Sagrada Familia", en Anuario de la Asociación de Arquitectos de Cataluña. Barcelona. COAC. También citado en Ràfols, J.F. (1929) Gaudí: 1852-1926. Canosa. Y en la reproducción faccisimil de este último libro, preparada por la Catedra Gaudí y editado por Claret en 2006. 


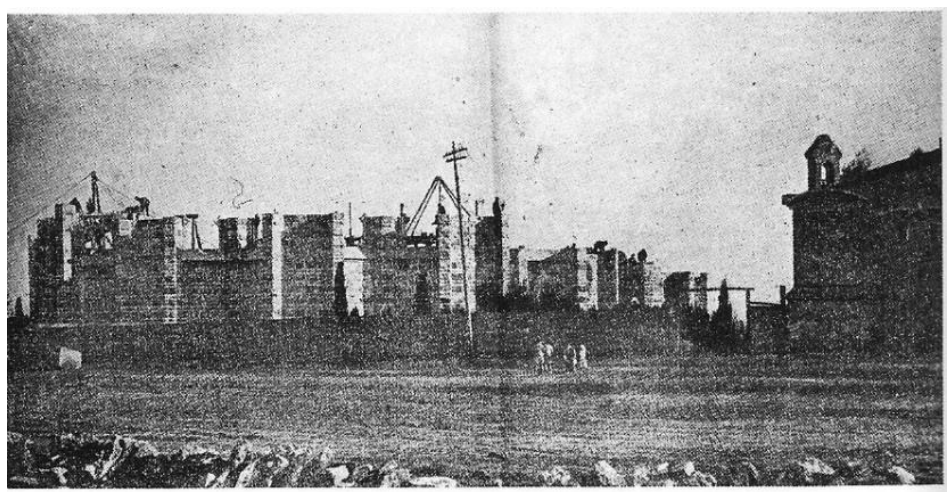

Fotografias del Abside en construccion publicadas en el Pro (1-11891 y 1-1-1892) Fuente: Torii, T. (1983) El mundo enigmático de Gaudí. Madrid. Instituto de España.
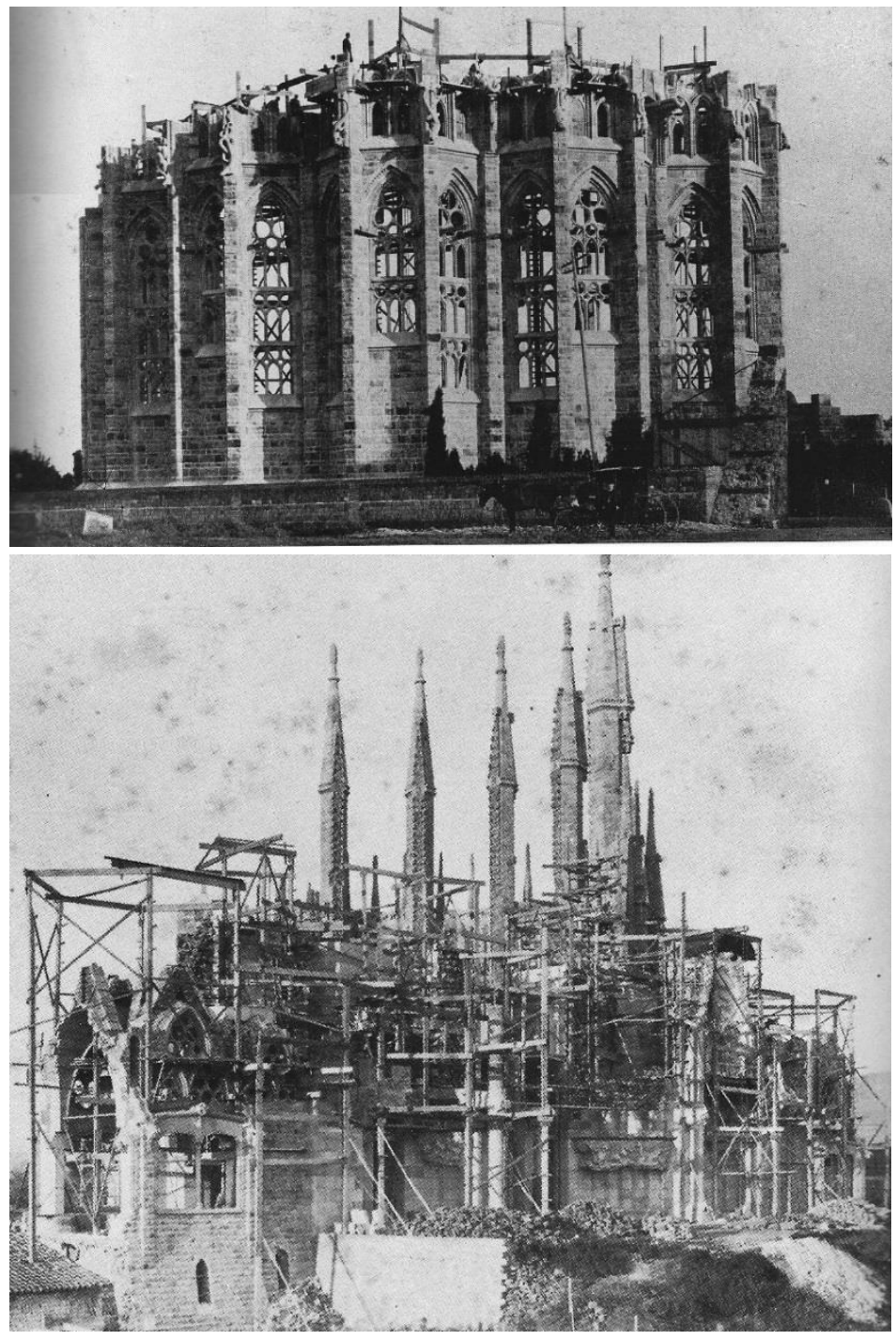

Fotografia de la Fachada lateral del Nacimiento en construccion publicada en el Pro (1-4-1896) Fuente: Torii, T. (1983) El mundo enigmático de Gaudí. Madrid. Instituto de España 
De esta forma las cantorías contribuirían no sólo a centrar las cargas y al arriostramiento entre columnas, al nivel de $15 \mathrm{~m}$ (anteriormente encomendado a tribunas y galerías a partir de $+25 \mathrm{~m})$, sino que ayudarían a la disminución de la reacción horizontal en el muro exterior. En este sentido es interesante observar la sección transversal publicada en el Album de 1915 en la que aparecen todavía, junto con las cantorías (con un apoyo intermedio) unas pasarelas de rigidización sin funcionalidad de uso, lo que da idea del tanteo y progresiva adopción de la nueva solución. Es más, el doble objetivo conseguido es el que le hace abandonar el apoyo intermedio de las cantorías y las pasarelas, al darse cuenta que la estructura así "concretizada" (de concreto, hormigón) y el optimo uso litúrgico de las cantorías hacen innecesario mantener formas neogóticas.

Sea como fuese, proyecto estructural y funcionalidad litúrgica van de la mano como corresponde al sentido arquitectónico unitario del proyecto gaudiniano ${ }^{367}$, y su aparición pública alrededor de 1915 no debe interpretarse como una casualidad siendo que Gaudí por entonces está plenamente dedicado a la incorporación del canto y la música gregoriana en la celebración litúrgica. Desde este último punto de vista la incorporación de una Schola Cantorum estructural de estas dimensiones al aula celebrativa diseñada según los criterios de la renovación litúrgica supera completamente cuanto Gaudí había pensado anteriormente para Sta. Coloma y evidentemente no podía plantear en Mallorca, consiguiendo una mayor visualización del altar para los fieles de lo que había propugnado la herencia tridentina (cuestión que sin embargo ya había sido objeto de amplio debate en tierras hispanas por la especial situación histórica del coro en mitad de la nave).

Esta hipertrofia del Coro generosa y libremente expandido en una planta superior apunta a posteriores soluciones en plantas geométricamente diversas -circular, poligonal, o cuadrada- que serán desarrolladas unos años más tarde en Alemania por Bohm, Schwarz, etc. pues ni siquiera Baudot en St. Jean de Montmartre o Wagner en Steinhoff llegaron a plantearse esta cuestión. También en los años cincuenta y sesenta encontramos ejemplos de soluciones que pudieron haberse hecho eco de este aspecto de la Sagrada Familia en iglesias como la nueva basílica del santuario de Aránzazu, de Saiz de Oiza y Luis Laorga.

${ }^{367}$ Cf. Puig Boada, I. (1926). “L'ideal del Temple Cristià i la Sagrada Familia. Realització técnica i artística de la obra capital d'en Gaudí", conferencia recogida en El Propagador de la Devoción a San José. Barcelona. 1-06-1927. 


\section{d.2 La Envolvente: Fachadas, Portadas y espacio de acogida.}

Históricamente la fachada de una iglesia ha aportado las tradicionales funciones que se le han encomendado como uno de sus elementos delimitadores o de cerramiento, funciones de seguridad, aislamiento térmico y acústico, iluminación y ventilación cuando no también de estabilidad, que había que alcanzar en un grado suficiente como para garantizar la adecuada habitabilidad del espacio interior. La lectura simbólica de la fachada de las iglesias, en la práctica reducida a un número muy limitado de elementos la mayor parte de los cuales se ha

insertado en los mismos accesos o portadas, experimenta en la Sagrada Familia un desarrollo y una variedad de símbolos ciertamente inusual. ${ }^{368}$

Según la información fotográfica que se va publicando en el Propagador la ejecución de las fachadas da comienzo por el ábside, en los años en que se cierra la cubrición de la Cripta (1890-91). En 1893 ya están construyéndose los elementos del claustro que van a discurrir junto a la fachada del Nacimiento. Por otra parte, Bassegoda (El gran Gaudí, 1989) señala un periodo muy largo, entre 1892 y 1917, para los estudios para la fachada de la Pasión que Torii sitúa a partir de 1911, publicándose el proyecto definitivo en el número de 15-03-1917 del Pro según dibujo del mismo Gaudí y recogiéndose también en el Album de 1929.

Si tomamos como primera descripción de la fachada del Templo el discurso de 1891 a los josefinos y como referencias escritas fundamentales lo publicado en los álbumes sucesivos desde 1915 se observa que salvo el mayor detalle expositivo de la idea, ésta sigue siendo la misma: plantear una composición totalmente independiente y singular para cada una de las tres portadas, y que el número y disposición de entradas, campanarios y torres o cimborios es el mismo.

También se aprecia desde el principio que la importancia que se da al programa iconográfico de cada portada y a su lectura simbólica, a la que Gaudí alude constantemente en el discurso mencionado y en sus conversaciones con colaboradores y ayudantes.

\footnotetext{
${ }^{368}$ Cf. Puig Boada, I. (1926). "L’ideal del Temple Cristià i la Sagrada Familia. Realització técnica i artística de la obra capital d'en Gaudí", en La mort de Gaudí i el seu ressò a la revista <el Propagador de la devoción a San José>, edición a cargo de Lluis Bonet i Armengol, Barcelona. 2010. Claret y Catedra Gaudí. P. 164: "El Templo de la Sagrada Familia es el primer templo cristiano en el que se desarrolla, en un organismo integral y dentro de la más completa unidad, el pensamiento simbólico y plásticamente representativo del contenido espiritual de nuestra religión; se desarrolla integral y orgánicamente, porque la arquitectura se convierte en simbólica...."
} 


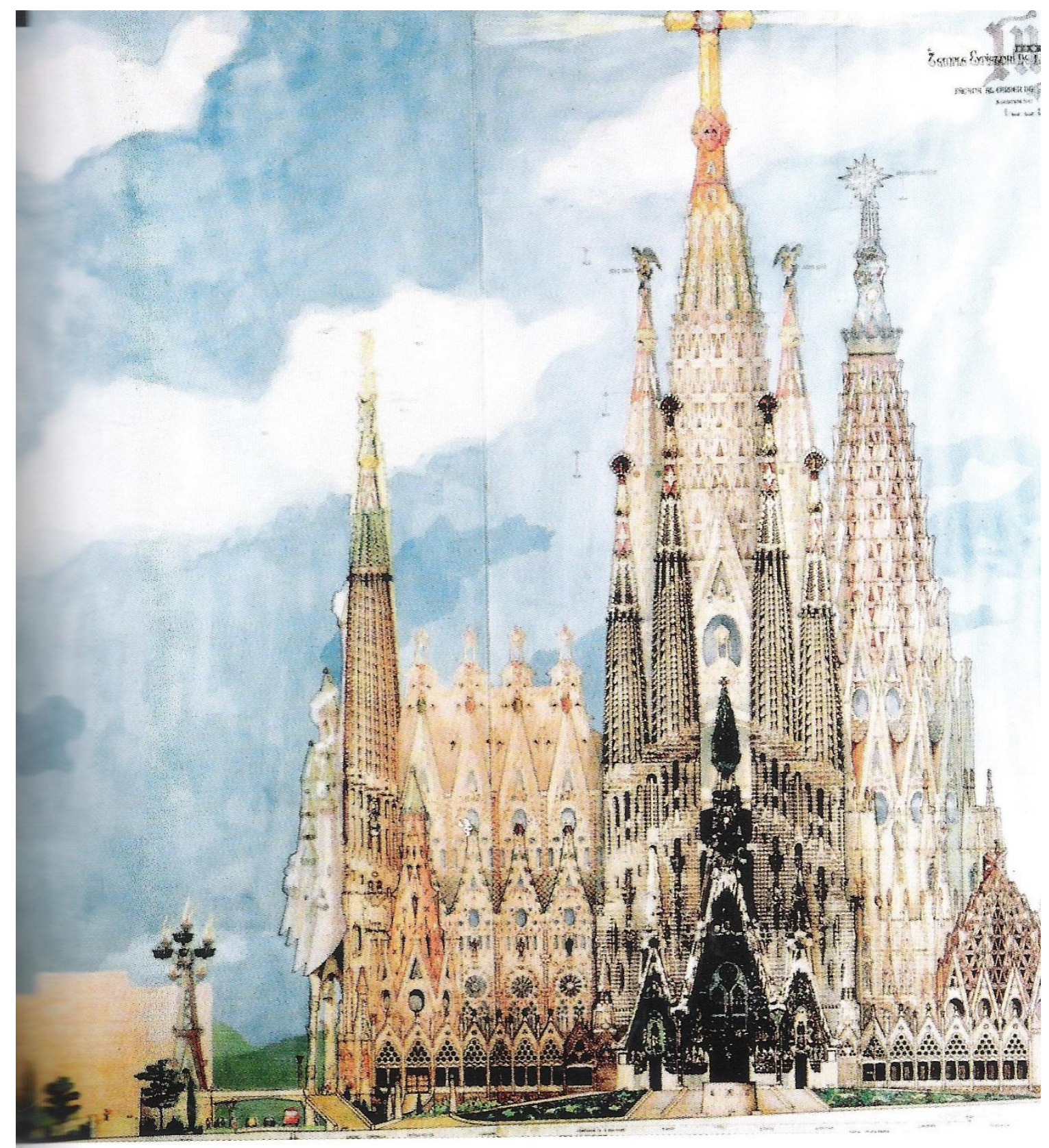

Dibujo coloreado de la fachada lateral en la orientación de la Portada del Nacimiento realizado durante el periodo de la dirección de obra de Puig Boada y Bonet Garí. Se aprecian los distintos planos del Claustro y las Naves, así como el paso elevado sobre la calle Mallorca y el monumental Pebetero delante de la Portada de la Gloria en la orientación de la Capilla de la Penitencia. Fuente: Puig, A. (2011) La Sagrada Familia según Gaudí. Barcelona. El Aleph. 
En 1906 se publica en la Ilustració Catalana (18-03-1906) el primer croquis de conjunto de la fachada lateral dibujado por Joan Rubió, bajo las ordenes directas de Gaudí, que sirve de base a los publicados en el Correo Catalán (26-1-1913), en los álbumes de 1915, 1917 y 1922-25 y en el Propagador (1-07-1921). Todos ellos reflejan únicamente la fachada en la orientación de la Portada del Nacimiento, como es lógico por ser la única construida en esas fechas y por tanto susceptible de ir incorporando los detalles y cambios que se iban realizando, correspondiendo las diferencias más significativas a este último dibujo en el que aparece el volumen de la capilla de la Penitencia y versiones finales del remate de los campanarios.

Las secciones longitudinales publicadas a partir de 1917 también nos dan información respecto de las diferentes versiones de la cúpula de las sacristías, de la iluminación cenital prevista en el pórtico de la fachada de la Gloria y de la aparición del pebetero y fuente en el exterior de la fachada principal. Como ha señalado Torii (El mundo enigmático de Gaudí, 1983), en el dibujo publicado en el álbum de 1929 después de la muerte de Gaudí, se aplica la misma forma volumétrica de las sacristías a la capilla de la Penitencia y se incrementa la altura del núcleo del cimborio central, pero la composición de todas las fachadas sigue siendo la misma.

En la composición y desarrollo de las fachadas una de las primeras cosas que llama a atención es la extensión del programa iconográfico, muy por encima de lo usual en la arquitectura gótica e incluso barroca, alcanzando a un número extraordinario de elementos de la fachada, entre pináculos del ábside y de las naves, portadas hiperdesarrolladas, fachadas laterales de las naves, remates de torres, cimborios y cúpulas de las capillas, etc. por no citar el amplio despliegue escultórico de las fachadas y de imágenes en las vidrierías, con una superficie mucho más importante de lo que habitualmente se ha dado en el curso de la historia.

Este programa incluye la tradicional imaginería escultórica de temática religiosa en las Portadas del Nacimiento, de la Pasión y de la Gloria que se dispone en cada una de ellas partiendo de un encuadre de marcado cariz medievalista en la primera, pasando por una amplia escenografía de tinte más barroco y composición más libre en la segunda e introduciéndola de una forma más novedosa y moderna en la fachada lumínico musical de la Gloria.

En segundo lugar, la profusa utilización de elementos provenientes de la simbología eucarística y bíblica en los pináculos de la nave celebrativa es ciertamente novedosa y sugerente de las pretensiones del arquitecto, convirtiendo la envolvente del edificio en exaltación y acogida permanentes. Exaltación porque en ella se describen, como decía él mismo, las principales verdades de la religión. Acogida, porque como veremos, su arquitectura se desarrolla para crear un espacio de transición que invita a la entrada. 

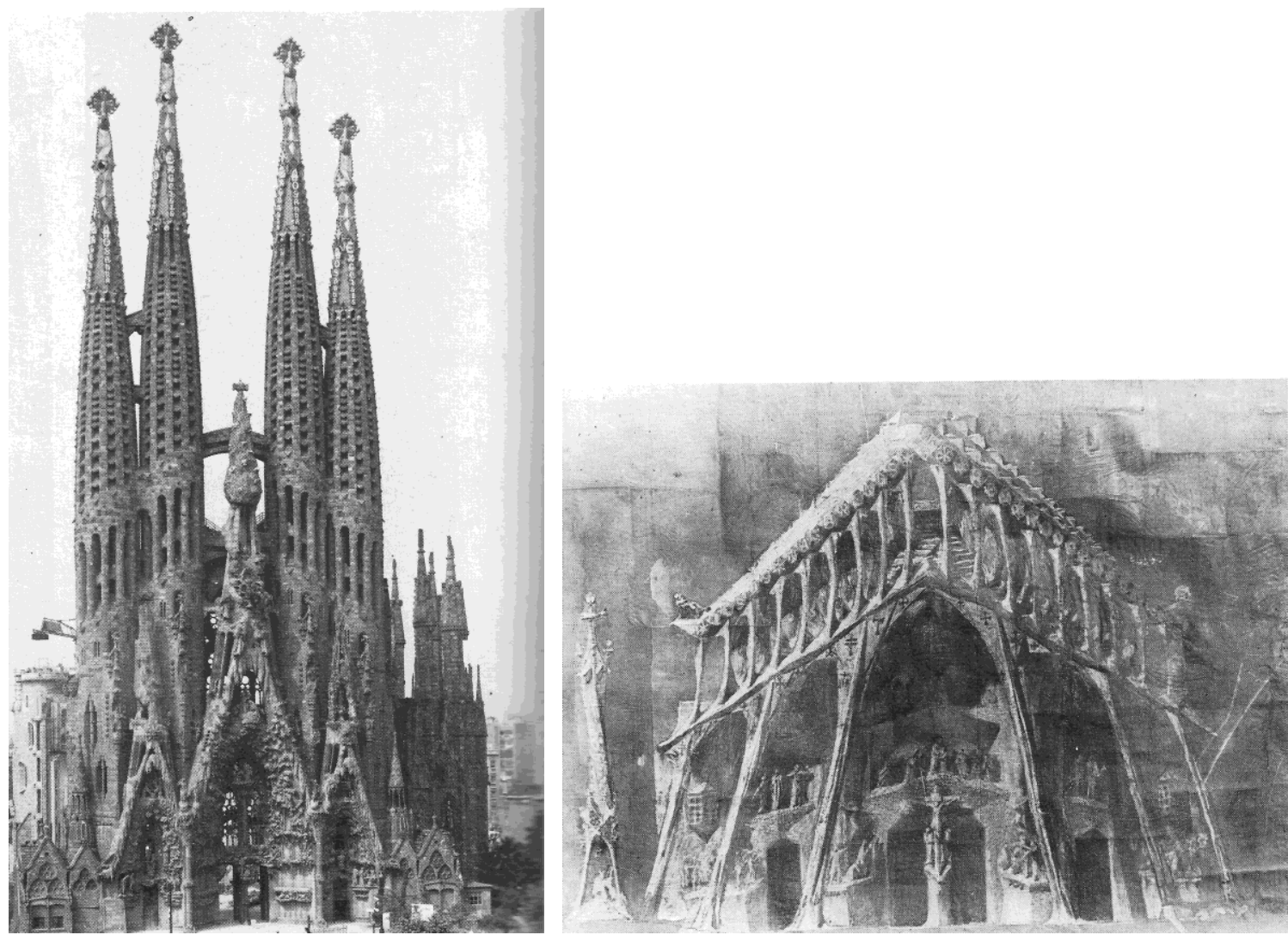

Fachadas del Nacimiento y de la Pasión. Fuente. Bergós, J. (1974) Gaudí, I'home i l'obra. Barcelona.Aymà.
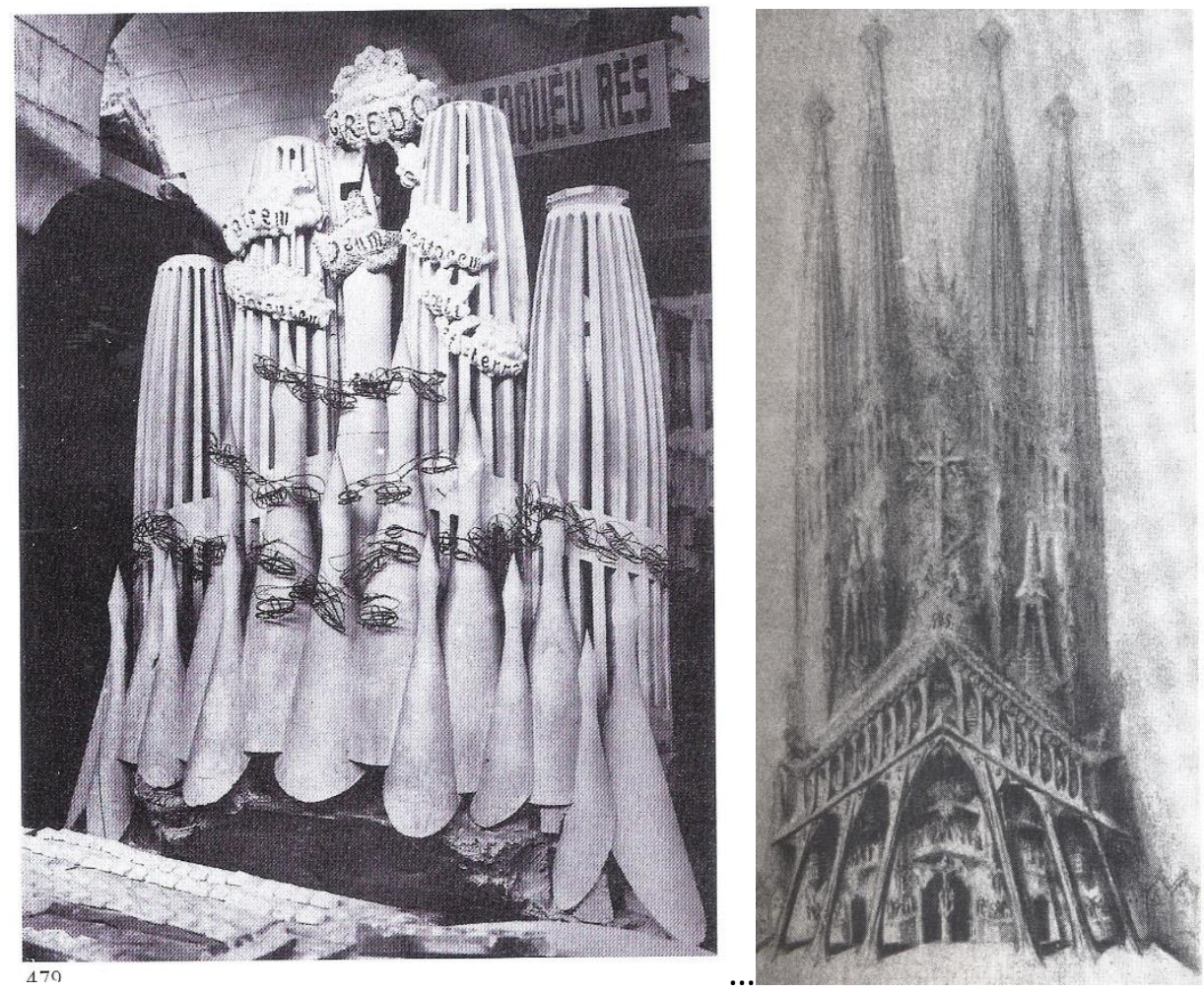

Izqda.: Maqueta original de la Fachada de la Gloria publicada en el Album de 1915. Fuente: Archivo de la Sagrada Familia. Dcha. Dibujo de la Fachada de la Pasión. Fuente: Bassegoda Nonell, J. y AA.VV. (2002) Gaudí. Espais Sagrats. Barcelona. Lunwerg. 
Gaudí, que había comenzado introduciendo formas vegetales y animales en el ábside a las que añade posteriormente en la Portada del Nacimiento otras -humanas y angélicas, introduce en ésta, gracias al mayor desarrollo que le brinda la construcción de cuatro torres en lugar de dos y su giro en planta respecto de la perpendicular al acceso, una disposición iconografíca con notable profusión de imágenes escultóricas, escenas, signos y símbolos que amplia con mucho el ámbito del hastial. A los personajes de la natividad e infancia de Jesús se unen textos bíblicos, símbolos religiosos como el ciprés y la paloma, atributos de la dignidad episcopal eclesiástica, etc. de tal manera que la plasticidad arquitectónica del conjunto es máxima sobrepasando con mucho los niveles de altura de las portadas. En cambio las imágenes de la Portada de la Pasión, aún siendo de rasgos más descarnados como corresponde a su temática religiosa, presentan una mayor adecuación a su composición arquitectónica, muy definida y ordenada. La disposición de formas escultóricas y signos presenta aquí una estratificación que es más difícil de percibir en la fachada del Nacimiento en la que el ámbito redefinido de gabletes y arquivoltas parece abarcarlo todo. En la Pasión, no solamente no se pierde la noción de cueva de que habla Torii (El mundo enigmático de Gaudí, 1983) sino que se supera mediante una original composición del frontón.

En mi opinión asistimos a un singular ejercicio de composición arquitectónica y estructural en el diseño de las tres portadas, que evoluciona análogamente a como lo hace el proyecto. Sin entrar en una descripción y análisis pormenorizados de cada una de ellas deseo llamar la atención sobre lo que, a mi entender, representa cada una de ellas en esta transformación de lo que tradicionalmente ha sido una portada, manifestando su protagonismo respecto del desarrollo total de los alzados del edificio que no disminuye por la incorporación de dos elementos -claramente unificadores por su modulación- como son el deambulatorio, que denomina claustro, y la seriación de la fachada alta de las naves.

En la evolución compositiva, constructiva y simbólica de las tres fachadas, Gaudí da muestras -como haría un arquitecto medieval- de poner su arquitectura al servicio de la revelación cristiana, utilizando los accesos al aula celebrativa como una suerte de introducción artística a la celebración litúrgica a la que se invita a participar y proponiendo una visión de la misma desde la escatología del libro del Apocalipsis. Pero lo que llama la atención es cómo partiendo de un esquema neogótico con tres entradas enmarcadas por las torres campanarios en la portada del Nacimiento, éstas no están limitadas o encajonadas entre ellas, ya que al construirse éstas en número de cuatro y con un giro de 45 e en la base a la vez que estilizarse extraordinariamente la superficie de los teóricos gabletes se genera una superficie escultórica mucho mayor. Al mismo tiempo, el giro ofrece la oportunidad de abrirse conceptualmente a la curvatura, tanto en la planta como en el alzado iconográfico de cada torre, con lo que el efecto "cueva" que menciona Torii es mucho más real. La transformación en altura de la sección de la planta aporta un tercer elemento distorsionador de la rígida planimetría medieval. 

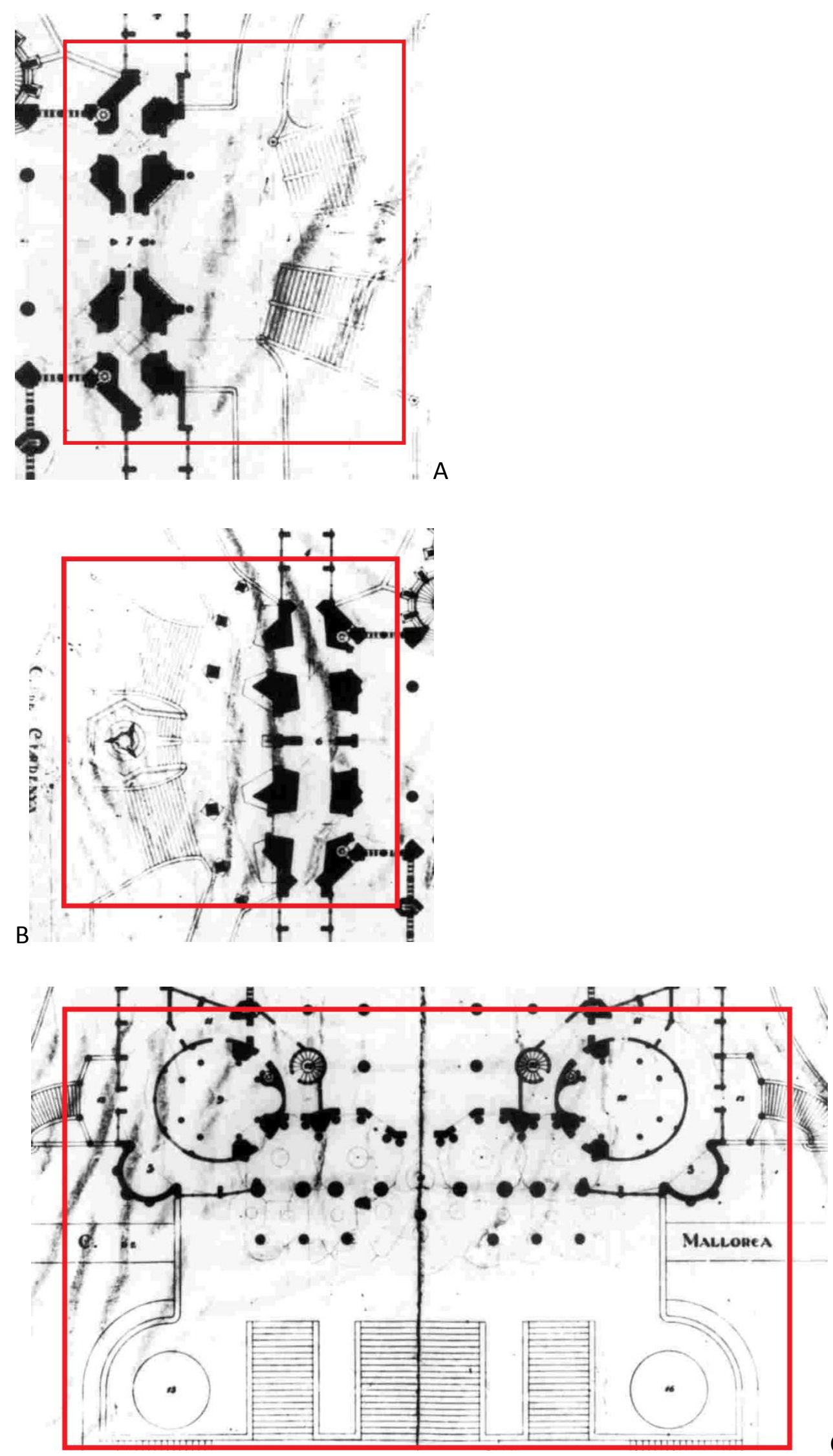

Ambito de las tres Entradas a la Sagrada Familia según plano de Planta de 1926.

A: Portada del Nacimiento.

B: Portada de la Pasión.

C: Portada de la Gloria. 
Este esquema cambia completamente en la Portada de la Pasión, lo cual de por sí ya seria inaudito en una iglesia medieval o historicista, presentado una composición clasicista muy del gusto barroco. Gaudí interpreta el clásico frontón sobre columnas partiendo de una composición general estilizada y semejante al efecto "cueva" de la fachada del Nacimiento pero aportando una serie de caracteristicas importantes: el movimiento conseguido por la inclinación de columnas y el distorsionamiento del frontón, la ordenación por niveles de la imaginería escultórica, y el crecimiento 'de ésta en altura en seguimiento de las torres campanario. ${ }^{369}$

En la Portada de la Gloria, se abandonan en gran medida estas cuestiones para pasar a una estructuración de la fachada moderna y revolucionaria para su época. La fachada se muestra como un gigantesco voladizo de múltiples elementos de troncocónicos, dispuestos sobre la estructura de las torres de planta sensiblemente circular, que actúan a la vez de lucernarios cenitales sobre el ámbito de la entrada. Estos lucernarios tubulares en voladizo acompañados de textos y otros elementos icónicos (en mayor medida que imágenes escultóricas), quieren simbolizar además un órgano musical en alabanza como alabanza a la gloria de la Trinidad a quien está dedicada la fachada. Por ser la última dibujada y maquetada en tiempos de Gaudí sin duda se vio afectada en su imaginativa solución formal por la importancia que se daba a la música en el ambiente eclesiástico de renovación litúrgica que rodeaba a Gaudí en esos años y que también se traduciría en su asistencia a clases de canto gregoriano.

De otra parte es llamativa la formulación de cada una de las tres portadas -tan radicalmente diferentes en términos arquitectónicos- como nártex o espacio de acogida del edificio-iglesia. En la Sagrada Familia el concepto de nártex se resuelve en unas dimensiones y términos sorprendentes, sobrepasando de alguna manera el ámbito estricto de las Portadas para llegar a involucrar litúrgicamente a toda el perímetro del edificio entre claustro y portadas. En éstas su propio diseño en planta las configura como espacios de transición entre el aula celebrativa y el exterior, pero en el caso de la Sagrada Familia esta dimensión como espacio de acogida viene reforzada por la singular forma arquitectónica y su dimensión que parecen abrazar a quien accede al interior, por el movimiento y realismo de la iconografía desplegada, y por el espacio exterior diseñado que se configura en cada uno de los tres casos como un auténtico atrio exterior o exonártex.

\footnotetext{
${ }^{369}$ Cf. El dibujo de Matamala interpretando los croquis de Gaudí para la fachada de la Pasión publicado, entre otros, en Bassegoda Nonell, J. y AA-VV. (2002) Gaudí. Espais Sagrats. Barcelona. Lunwerg.
} 

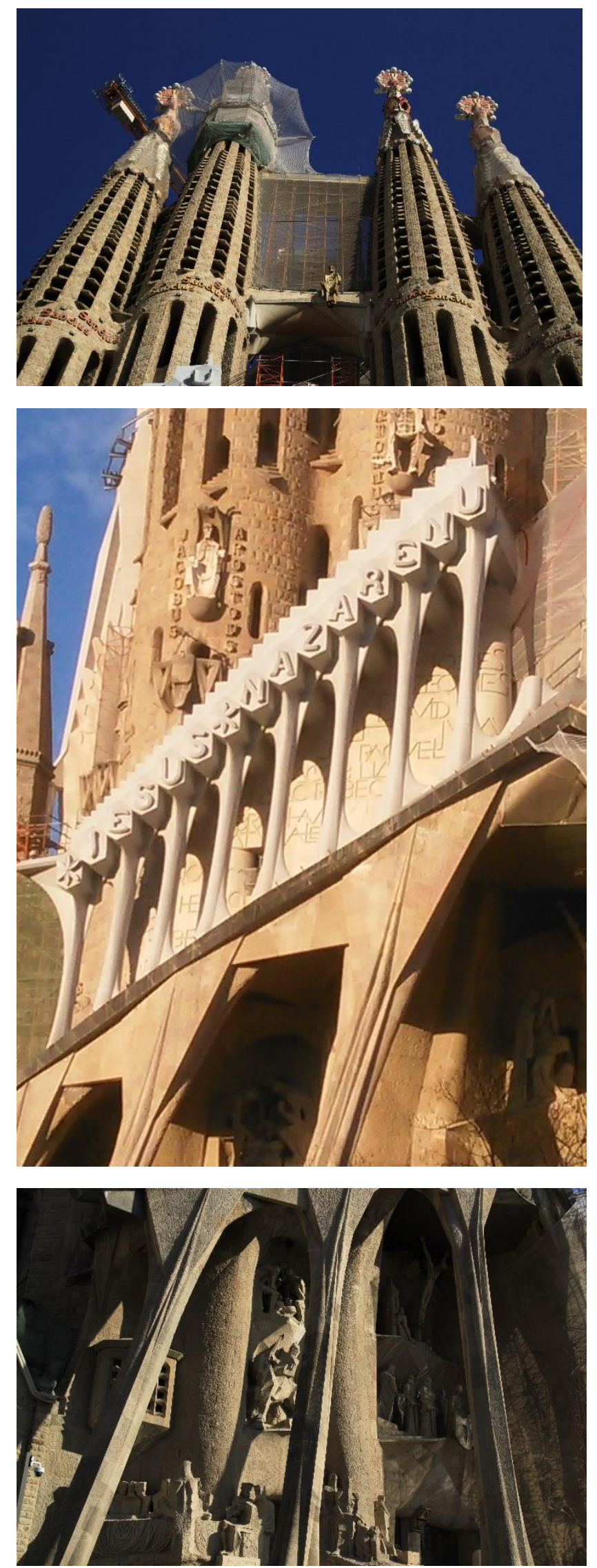

Detalles de la Portada de la Pasión. Fuente: Fotografias de Miguel Reig Jimenez 


\section{Campanarios}

Si en el caso de los cimborios podemos encontrar alusiones a la disposición cupular de la estructura de San Marcos de Venecia y a la idoneidad que encontraba en este sistema estructural para la cubrición del espacio de culto (Manuscrito de Reus) como reflejo de su admiración por la arquitectura bizantina -común a muchos otros arquitectos de la época-, en el caso de los campanarios y en la mayoría de los estudios analizados tan sólo nos encontramos con alusiones a la inspiración de su forma (Torii) o referencias al simbolismo de la Nueva Jerusalén (Puig). En mi opinión, su adscripción a cada uno de los doce apóstoles -que se menciona en el Album de 1915- hace pensar en una referencia al lenguaje de signos eucarísticos del arte paleocristiano llevado a los elementos arquitectónicos constituyentes de esta tipología edilicia. Así como los lugares celebrativos paleocristianos presentan una profusión de pinturas, mosaicos, esculturas,... alusivas a motivos evangélicos y eucarísticos, Gaudí muy bien pudo querer llevar este lenguaje al número y disposición de los elementos de su arquitectura.

Al referirse a la forma de los campanarios, de gran semejanza formal con el proyecto de las misiones franciscanas de Tanger, Torii (El mundo enigmático de Gaudí, 1983) hace mención también a la coincidencia en el número, 12, si bien en la interpretación que hace de aquel proyecto cuenta indistintamente como campanarios los que sitúa en el cuerpo central que asigna a la iglesia y los que interpreta como entradas en las uniones de los lóbulos exteriores. Torii interpreta también los planos asignando una cripta en el nivel inferior del cuerpo central análogamente al proyecto de Santa Coloma y una capilla para el Sagrario inmediatamente detrás de donde considera está el altar mayor. Sin embargo, esta ubicación que propone para el Sagrario parece más voluntarista en función de las Iglesia superior de la Sagrada Familia. En el dibujo de Tanger aparecen muchas más torres que las situadas en el cuerpo central -donde presumiblemente se encuentra la iglesia o capilla- de diversa altura y funcionalidad-accesos, patios, etc.cuya similitud formal con los campanarios de la Sagrada Familia, a mi parecer, no concluye nada respecto de su número.

En mi opinión, resulta mucho más fiable la referencia que ofrece el propio Gaudí en su discurso a los josefinos (1891) indicando que, a diferencia del proyecto de Villar, el suyo dispondrá 12 campanarios, cuatro por fachada, dedicados a los apóstoles de Jesucristo. Dicha adscripción no debe extrañar si consideramos el resto del discurso en el que se adscriben otras cuatro torres a los evangelistas (o mejor evangelios según interpreta Puig) y los dos cimborios a Jesucristo y a la Virgen, pues todo ya hemos visto que esta agrupación central de campanarios entorno al cimborio no es ajena a la arquitectura eclesiástica, sea bizantina o latina, y el proyecto está plagado de referencias, signos y símbolos correspondientes al Nuevo Testamento -que es el tiempo de la fundación de la Iglesia-. 


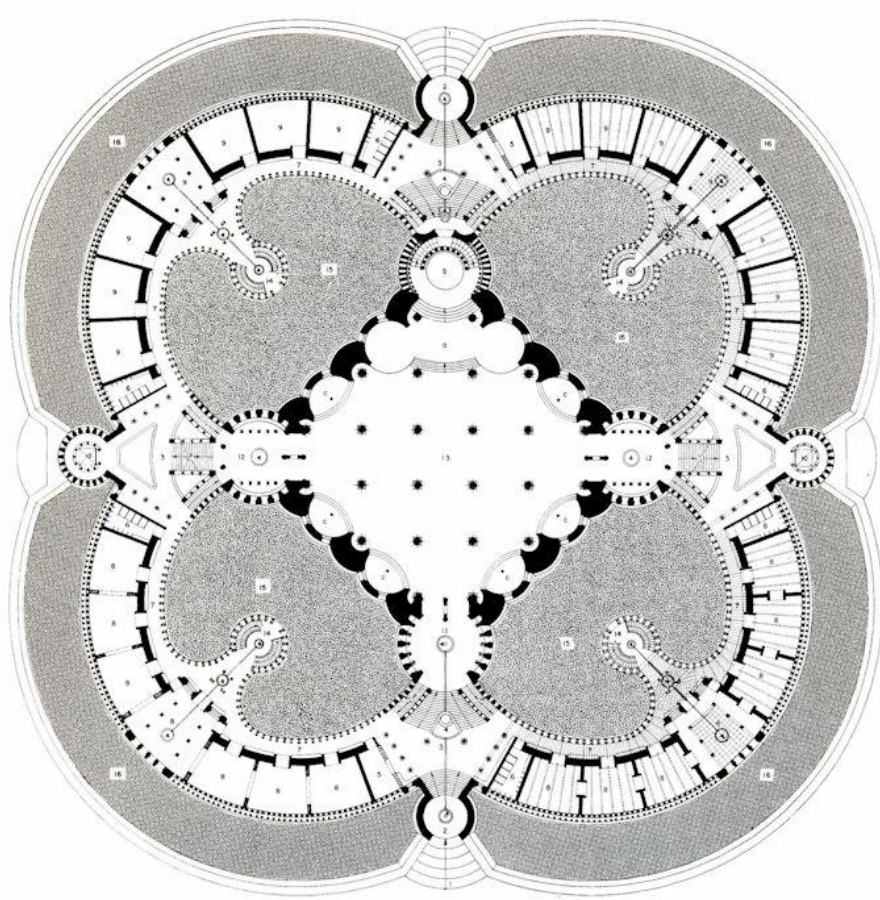

Planta baja del proyecto de las Misiones Franciscanas de Tanger (1892-93), de Antonio Gaudí, interpretado por T. Torii. Fuente: Torii, T. (1983) El mundo enigmático de Gaudí. Madrid. Instituto de España.

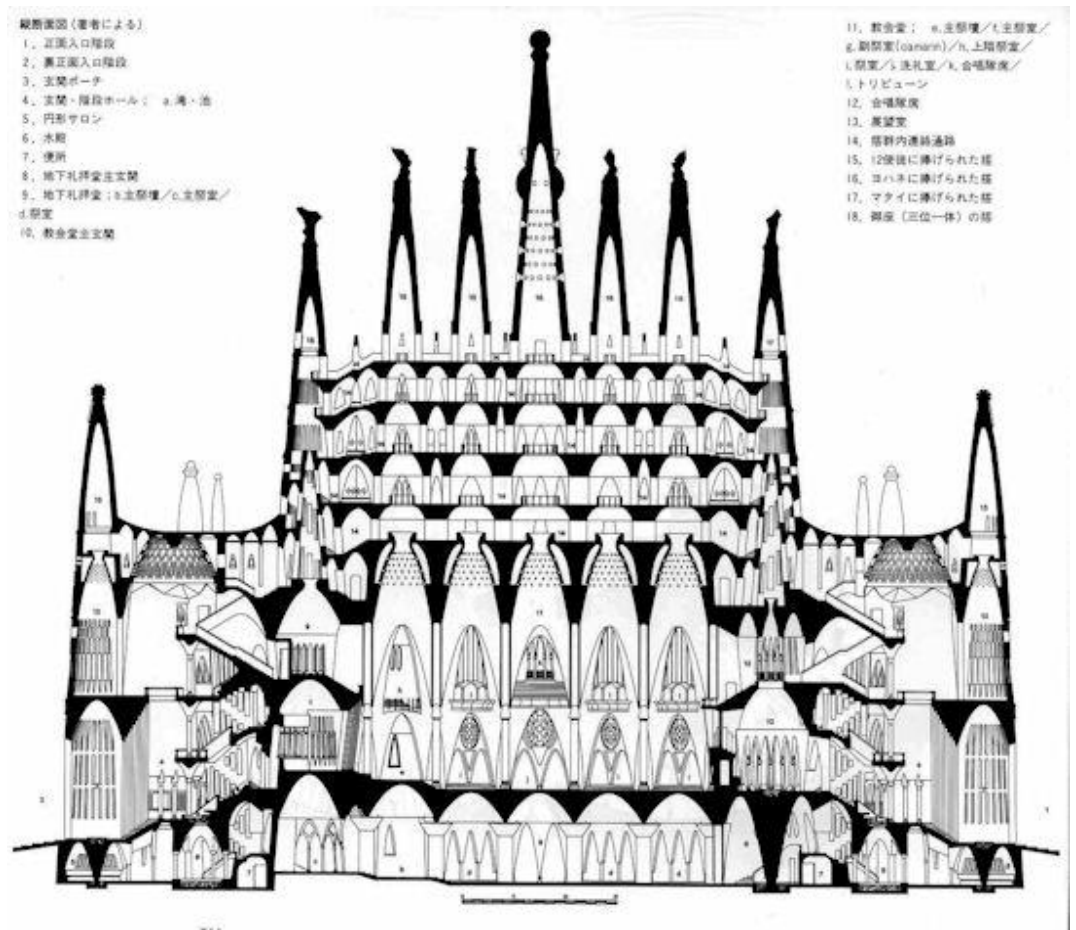

Sección del proyecto de las Misiones Franciscanas de Tanger (1892-93), de Antonio Gaudí, interpretado por T. Torii. Fuente: Torii, T. (1983) El mundo enigmático de Gaudí. Madrid. Instituto de España. 
simetrías de la planta que otra cosa y desde luego, bastante improbable a tenor de la época y de las realizaciones en este sentido que vemos en Santa Coloma, y en la Cripta e En cuanto a la forma concreta de los campanarios, F. Cardoner Blanc, al referirse a la forma de los torreones de Tanger afirma (Evolucion de la obra de Gaudí, p. 5) que los fuertes vientos reinantes en Africa le obligan a dibujar los campanarios del proyecto de Tanger siguiendo las directrices de las cargas y que luego utiliza esta forma en la fachada del Nacimiento. Otros autores hablan de la comunicación de ideas en el grupo de jóvenes arquitectos seguidores de Martorell, condiscípulos y amigos de Gaudí, dado que en muchos proyectos $\mathrm{y}$ direcciones de obras trabajan unos para otros, o en colaboración. Se puede mencionar el trabajo de Camilo Oliveras y Gaudí para Martorell en la iglesia de los Jesuitas de la C/ Caspe y en las Salesas, en Barcelona, el de Cristobal Cascante y Gaudí para Martorell en Comillas, el de Oliveras para Gaudí en la decoración interior del Palacio Güell, el de Cascante también para Gaudí en el Capricho de Comillas, etc. Es altamente probable, pues, la aplicación por cada uno de ellos de ideas y soluciones que se dan entre sus diferentes proyectos coetáneos en el tiempo.

Por ello nada tiene de extraño ni puede descartarse, que la gran verticalidad de las torres de la Sagrada Familia pudiese estar influenciada por el panteón para los marqueses de Comillas, el anteproyecto de Martorell para la fachada de la catedral de Barcelona y la misma aspiración que presenta la iglesia de las Salesas, así como también se aprecian influencias de las galerías de vanos de la Iglesia del Inmaculado Corazón y del Palacio de Sobrellano, de Martorell y, del Hospital de Comillas de Cascante, en la galería del frontón de la fachada de la Pasión o en los mismos vanos verticalizados para las campanas de las torres, bien que convenientemente reelaborados por Gaudí en función de su gran imaginación puesta al servicio de una idea. En este sentido también sería interesante comparar el dibujo de Gaudí para el monumento a Torras i Bages, o para Prat de la Riba, con el monumento al Marqués de Comillas de Cascante y Doménech i Montaner.

Por eso, aún pudiendo haberse tomado la forma de un cono de los campanarios del proyecto Tanger según las investigaciones que realiza Torii (1983) -análogamente a lo que sucede con la maqueta funicular para el estudio de las cargas y estructura de la iglesia de Santa Coloma que es precursora de la estructura definitiva de la Sagrada Familia- es totalmente verosímil que Gaudí tuviese la idea de realizar la Sagrada Familia con planta de cruz latina y cuatro campanarios en cada una de las tres fachadas, tal y como explica en 1891, anteriormente a la realización de estos estudios y dibujos, y por tanto con independencia de cuál habría de ser su forma concreta. El discurso a los josefinos expresa claramente la idea conceptual de lo que ha de ser la Sagrada Familia, el momento de la exposición pública del arquitecto a su cliente, de la aplicación práctica de lo que supone para él una iglesia, aquello que lleva pensando desde que escribiera el Manuscrito de Reus y que a partir de 1884 puede comenzar a llevar a la práctica. 


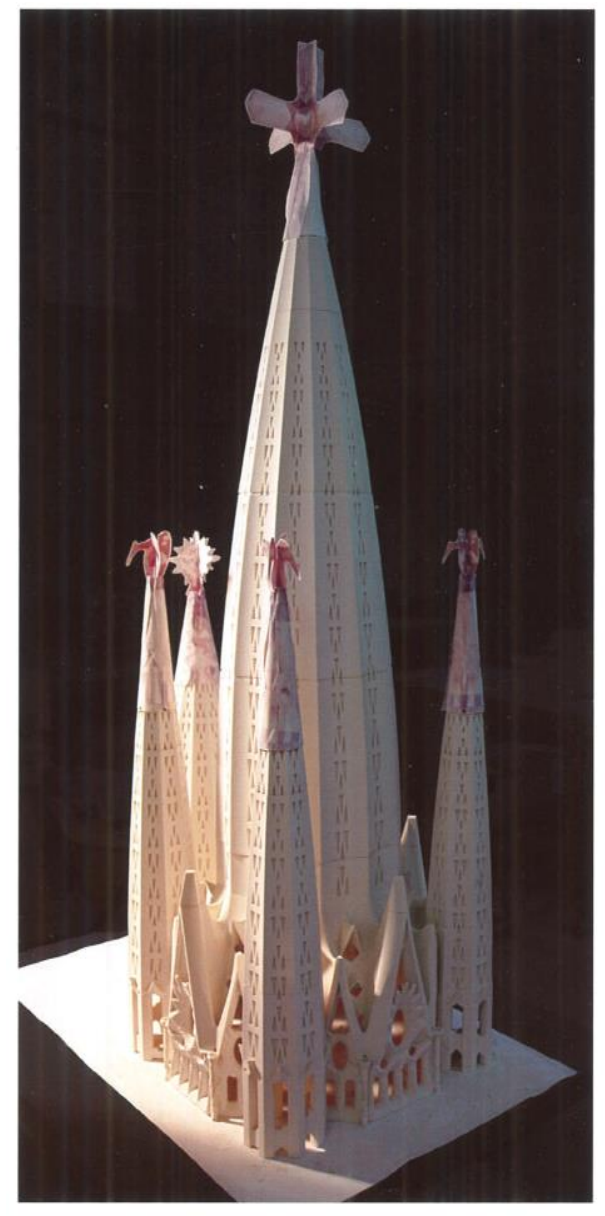

A

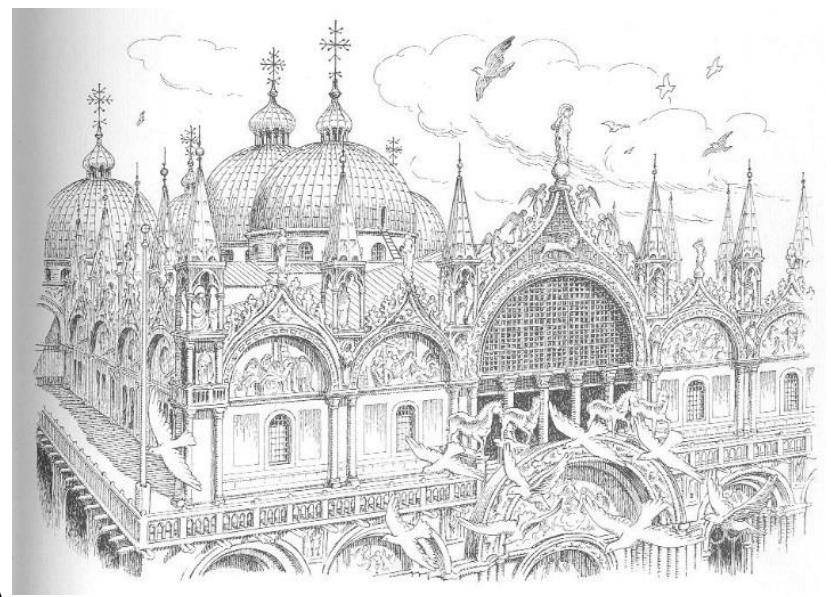

A: Maqueta del cimborio principal dedicado a Jesucristo, de $170 \mathrm{~m}$ de altura, y los correspondientes a los cuatro evangelistas. Fuente: Bonet i Armengol; J. y AAVV. (2010) Sagrada Familia: de temple expiatori a basilica. Barcelona. Lunwerg.

B: Grabado San Marcos de Venecia. Fuente: Bassegoda, J. (1976) $H^{\underline{a}}$ de la Arquitectura. Barcelona. Tecnicos Asociados.
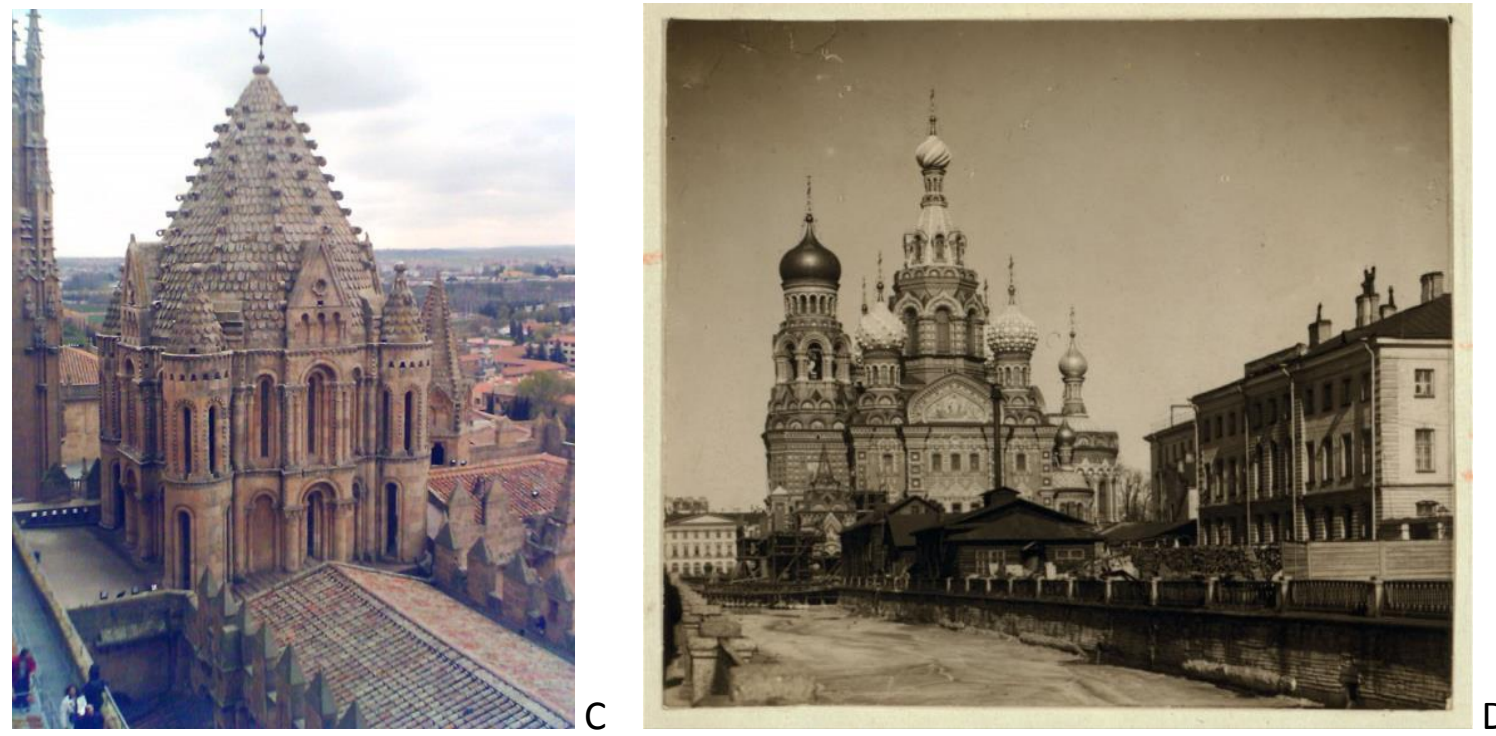

C: Cimborio y torres del crucero de la catedral vieja de Salamanca.

D: Iglesia de la Resurrección de Cristo. Fuente: Fotografia de Sergei M. Prokudin-Gorskii realizada entre 1905-1915 
Así pues, Tanger y Santa Coloma, como también Mallorca, son ensayos, dibujos, obras, en las que experimentar lo que ya ha concebido en su mente para la Sagrada Familia y no se atreve a aplicar sin probar antes en otros proyectos de más rápida y pronta ejecución que una iglesia expuesta a las incertidumbres presupuestarias de las aportaciones voluntarias de los fieles.

Esta visión volumétrica y verticalizada del edificio-iglesia concuerda con la imagen espiritualizada que pretenden dar las iglesias votivas cual nuevos santuarios del siglo $\mathrm{XIX} \mathrm{X}^{370}$. Así mismo llama la atención el número de cuatro para los campanarios de cada una de las portadas, cuando la tradición histórica es de uno o dos. Es evidente que nos encontramos con un nuevo ejemplo de implicación de la razón estructural y la lectura simbólica en el hecho arquitectónico, pues como afirma Josep Gómez, las estilizadas torres de las tres fachadas necesitan para su estabilidad el concurso de dos parejas hasta disponer de un mínimo de cuatro unidades entrelazadas. Con independencia de lo dicho respecto de y la realización de dos cimborios - en el ábside y el crucero- siendo que tan sólo aparece este número cuando se trata de iglesias de doble transepto (iglesias románicas germanas como San Miguel de Hildesheim, monasterios franceses como Cluny, o algunas catedrales inglesas, Durnham, Salisbury, et.).

En cualquier caso, esta descripción de cimborios y campanarios ligada a una concepción simbólica -doce apóstoles, así como sus signos y atributos episcopales en la coronación de las torres- es anterior en el tiempo al dibujo del proyecto de Tanger o a su trabajo en Sta. Coloma y abunda en la interpretación personal que Gaudí hace de otros proyectos como ensayos para el desarrollo de la exposición vertida a los josefinos (1891) al cerrarse la Cripta de la Sagrada Familia, cuestión que también aprecia Bergós ${ }^{371}$.

\footnotetext{
370 Llama la atención cierta similitud de formas con el proyecto de Langerock para la basilica nacional de Koekelberg en Bruselas, por la verticalidad y la composición de las tres fachadas con dos torres cada una sobre una base neogoticista. También presenta puntos de similitud ciertas iglesias del aérea bizantina y con otros proyectos votivos como Maria vom Siege (Wien), Koekelberg (Brussel), o el mismo Corazón de Jesús del Tibidabo (Barcelona).

${ }^{371}$ Joan Bergós (Gaudí, el hombre y su obra. Barcelona. 1974. UPC, cátedra Gaudí, Ed. Aymá) Con referencia a las formas de los campanarios es de gran interés ver lo que afirma Bergós (p. 66, p. 80, p.82) cuando señala el antecedente del Palacio Güell del que dice que"Si bien el cupulín es cónico, la envolvente de las viseras de sus lucarnas es ya parabólica, lo que las hace precedente de los campanarios de la Sagrada Familia"; en referencia al proyecto de Tanger: "Al poco tiempo de iniciada esta fachada, Gaudí estudió el proyecto de las misiones Franciscanas, en Tánger (1892-1893), muy apropiado para la función y el país a los cuales iba destinado; en él ensayó la plástica de las torres circulares de perfil parabólico, caladas por una serie de aberturas, dispuestas helicoidalmente, tipo que adoptó después en los campanarios de la Sagrada Familia que había empezado a construir de planta cuadrada"; y para recapitular: "El día que me mostró ese proyecto no pude ocultar la sorpresa que me produjo conocer este precedente de las formas de la obra maestra que había de seguir después, y Gaudí me explicó, aludiendo también al cupulín del hall del palacio Güell: $<Y a$ ve, no hemos cambiado; cuanto más tiempo hemos pasado y más hemos reflexionado sobre estas nuevas formas de arquitectura, más certeza hemos tenido de la necesidad de emplearlas.>"
} 


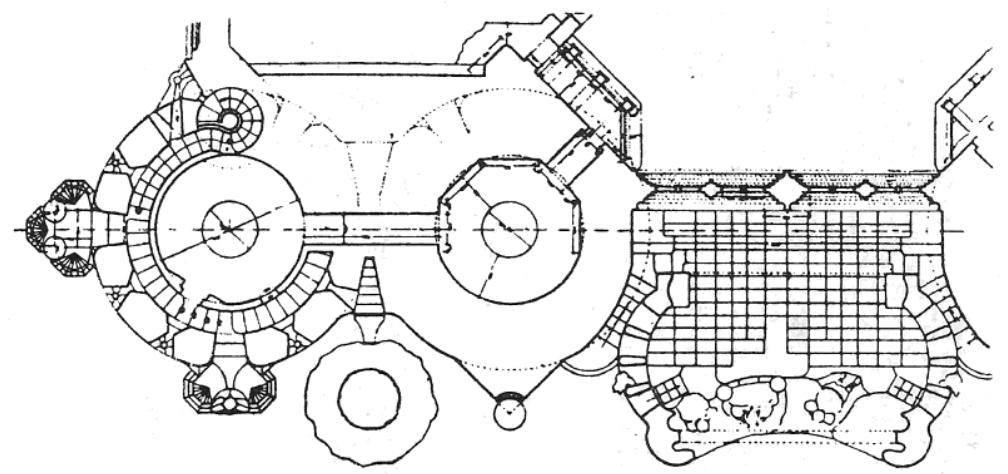

Nivel 3.

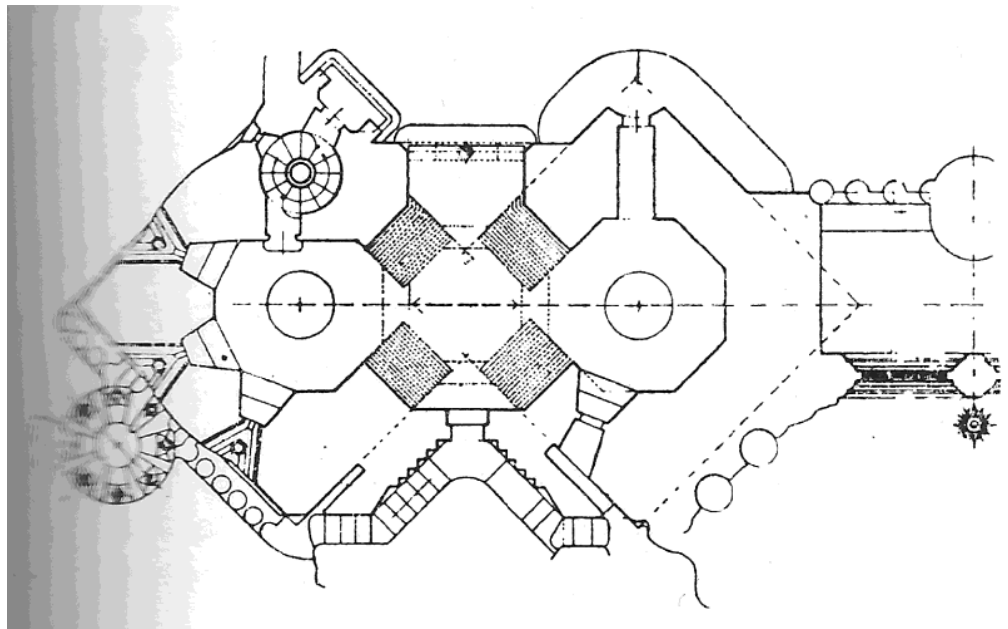

Nivel 2.

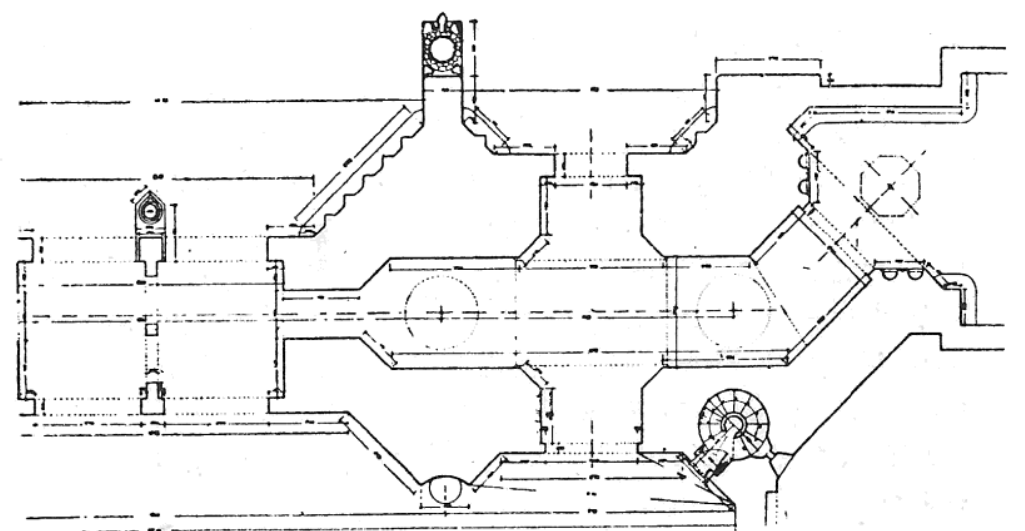

Nivel 1.

Planta seccionada de los campanarios de la Fachada del Nacimiento según niveles de altura. Esta imaginativa solución de Gaudí, magistralmente resuelta en las transiciones como resalta Bergós, es aprovechada para servir de soporte al programa iconográfico de la fachada, para ampliar la superficie de las portadas como espacios de acogida y para resolver el recorrido claustral al llegar a las Portadas. Fuente: Bergós, J. (1974). Gaudí. El hombre y la obra. Barcelona. Aymà Editores. 
Es normal que proyectos como el Palacio Güell o las Misiones de Tanger, de financiación privada y exclusiva de los Güell y los Lopez respectivamente, pudiera resultar a primera vista un excelente campo de experimentación para Gaudí que permitiría al arquitecto concentrarse con mayor rapidez y disponer antes de los dibujos que habían de sustentar formas tan sugerentes. En el caso de Tánger, si se hubiese llevado a cabo su construcción, ésta habría sido mucho más rápida -debido a su viabilidad financiera- que la de una gigantesca obra cuyo carácter expiatorio necesitaba de un dilatado periodo de tiempo para reunir las limosnas suficientes para su construcción. De ahí que a Gaudí le afectara tanto el desestimiento de esta obra por parte del Marqués de Comillas. ${ }^{372} \mathrm{Se}$ puede decir que Gaudí parecía haber encontrado en el proyecto para la orden franciscana la ocasión ideal para dibujar y ensayar las formas geométricas que imaginaba más adecuadas para una edificación dedicada al culto cristiano que gozaba de su total complacencia y que ahora tenía la oportunidad de realizar en condiciones precarias en lo económico pero lo suficientemente dilatadas en el tiempo como para investigar cuanto primeramente imaginaba.

Incluso la conjunción de torre y balcón de la Casa Batlló (1904-1906) también puede considerarse como un antecedente de la solución de cambio de la planta cuadrada a circular en los campanarios de la fachada del Nacimiento (1891-93), y las galerías acristaladas de la Casa Batlló (1904-1906) y de la Casa Milà (1906-1910) un ensayo de la galería alta del frontón de la fachada de la Pasión (1911 en adelante). Bergós pondera la habilidad de Gaudí al realizar la transición de una planta cuadrada a otra circular en función del nivel o altura, a lo que podemos añadir que es aprovechada para como elemento soporte al programa iconográfico de la fachada, para ampliar la superficie de las portadas como espacios de acogida y para resolver el recorrido claustral en planta baja al llegar a las Portadas. Desde un punto de vista funcionalista Bergós ${ }^{373}$, Puig Boada y Martinell también nos invitan a fijar la atención en los campanarios como elemento litúrgico ya que Gaudí había estudiado con detalle las campanas, sus características y ubicación, como mencionan los Albumes.

\footnotetext{
${ }^{372}$ Cf I. Puig Boada (El Temple de la Sagrada Familia. 1929. Barcelona. Barcino. Pp 195-196 y su reedición en 1979 por Nuevo Arte Thor, P. 100; El Temple de la Sagrada Familia. Barcelona. Nuevo Arte Thor. P. 100) que conoció personalmente a Gaudí, se hace eco de esto cuando afirma: "La idea de los cuatro campanarios colocados por arista encima de cada portal (del Templo Expiatorio) es la inicial; la forma, el enlace y el estilo iba cada vez más desnudándose del primitivo gótico siendo siempre más personal. La forma definitiva de los campanarios magnificos se concreta después del proyecto de edificio que Gaudí estudió para las Misiones de Tanger..."

${ }^{373}$ Cf. Bergós, J. (1974). Gaudí, el hombre y la obra. Barcelona. Aymà. P.124:" También en el exterior han sido cuidadosamente estudiadas las condiciones acústicas de los campanarios; están dotados de viseras inclinadas de piedra para dirigir el sonido de las campanas hacia abajo y poderlo así utilizar para acompañar las procesiones, que recorran tanto el claustro como las calles de la ciudad; permitirán dar conciertos de música sacra, para solemnizar las grandes festividades de la Iglesia.
} 

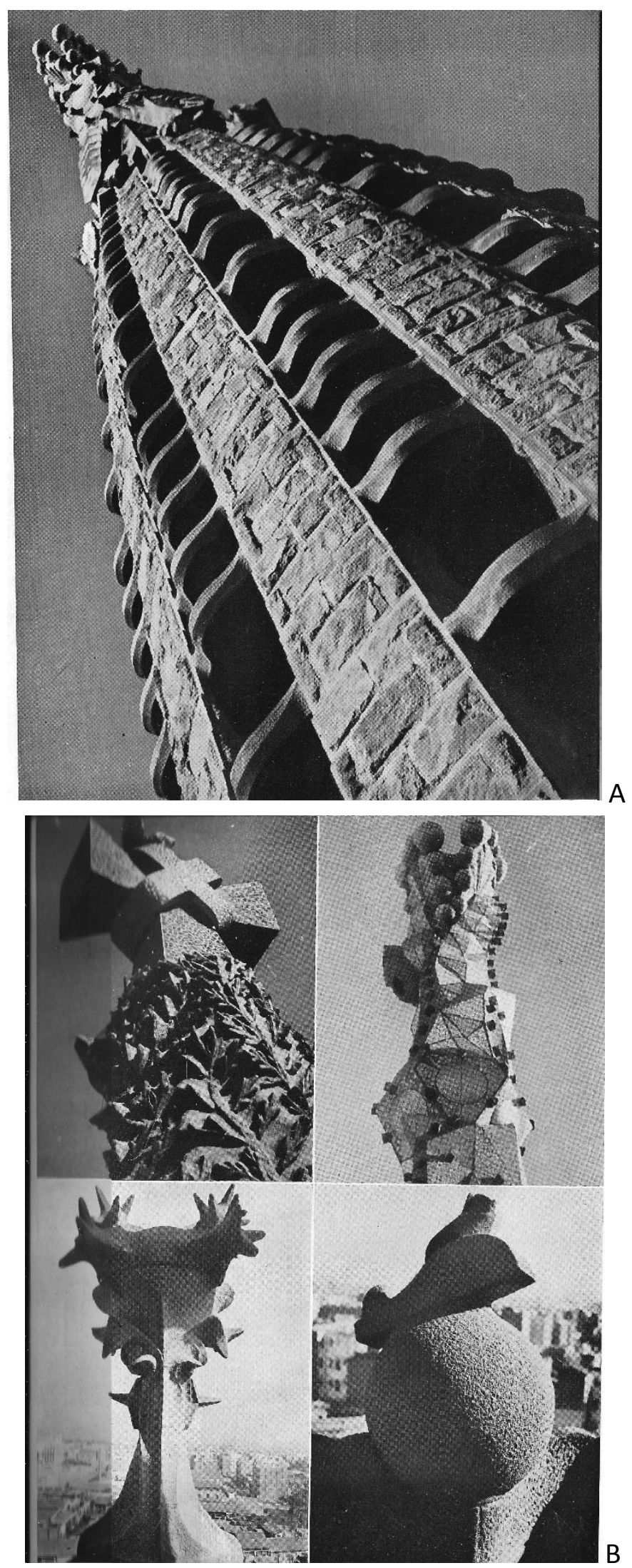

A: Parte alta de un campanario con los tornavoces.

B: Elementos finales de la Fachada del Nacimiento.

Fuente: Martinell, C. (1950) Gaudí i la Sagrada Familia comentada per ell mateix. Barcelona. Aymá Ediciones. 
En la actualidad han caído en desuso los campanarios pero en el contexto del cambio de siglo continuaba siendo un elemento importante de la arquitectura de una iglesia. Aún en realizaciones muy posteriores -como la iglesia de la Virgen del Camino del P. Coello de Portugal- el campanario sigue marcando un hito simbólico importante sin perder del todo su funcionalidad litúrgica. Los albumes resaltan su función litúrgica y describen con bastante precisión los diferentes tipos de campanas y su accionamiento. ${ }^{374} \mathrm{Si}$ tenemos en cuenta que tradicionalmente los campanarios solían tener funciones civiles de vigía y religiosas de aviso para el culto, sorprende el número de 12 en referencia a los primeros obispos -apóstoles- de la Iglesia (correspondientes a su vez con las doce tribus de Israel). La función de vigilancia y la función litúrgica de llamada para el culto no tienen sentido en una urbe industrializada del siglo XIX. Sin embargo, como signo de la entrada en el espacio litúrgico del edificio-iglesia puede tener una doble explicación litúrgica y simbólica.

Los campanarios comienzan a transformar su sección en planta a $26 \mathrm{~m}$ según recoge el Propagador del 15-03-1898. A partir de los 35m su sección vertical es plenamente curva (circular o elíptica según el caso) y a los $60 \mathrm{~m}$ disponen aberturas para los tornavoces hasta una altura próxima a los $100 \mathrm{~m}$ de una altura total de $125-127 \mathrm{~m}$. Quiere esto decir que aproximadamente la tercera parte de su altura está conformada por tornavoces y en consecuencia destinada a la emisión del sonido de las campanas, una proporción considerablemente superior a la que correspondería en un campanario tradicional. Martinell se refiere a ellos al decir que la disposición de los huecos en los campanarios se realizó de tal manera que las aberturas dirigiesen el sonido hacia abajo donde se sitúan en las vías de acceso los transeúntes, y no se perdiese en el aire. ${ }^{375}$ ¿Cuál es el sonido que ha de dirigirse hacia abajo? Sin duda, el de las campanas. Pero dos de sus tres tipos se accionan eléctricamente desde los órganos musicales, lo cual introduce las introduce en el ritmo y desarrollo de la celebraciñon litúrgica. Para confirmarlo, en la fachada de la Gloria los lucernarios tubulares de su pórtico, semejando los tubos de un órgano, nos lo recuerdan claramente. En ambos casos Gaudí pretende difundir real y simbólicamente el canto y la música de la celebración litúrgica que tiene lugar en el interior en las calles ${ }^{376}$, haciendo también posible en el exterior la celebración.

\footnotetext{
${ }^{374}$ Cf. Album de 1915, Pp. 6-7: "Los doce campanarios poseerán un número extraordinario de campanas acordadas en octavas por tonos y medios tonos. Estas se distribuirán en tres grupos de cuatro campanarios, con campanas homogéneas. Uno de los grupos será de campanas tubulares que sonarán por percusión. Otro grupo de campanas, también tubulares, sonará por presión de aire, esto es, verdaderas trompetas o flautado de órgano. El tercer grupo se pulsarán por teclados eléctricos y permitirán acompañar los cánticos de las funciones que se celebren, en el exterior de la basilica."

375 Cf. Martinell, C. (1952) La Sagrada Familia. Edición en castellano de Gaudi i la Sagrada Familia comentada per ell mateix. (1951). Barcelona. Aymá. P. 29-30.

${ }^{376}$ Cf. Album de la Sagrada Familia de 1929.
} 


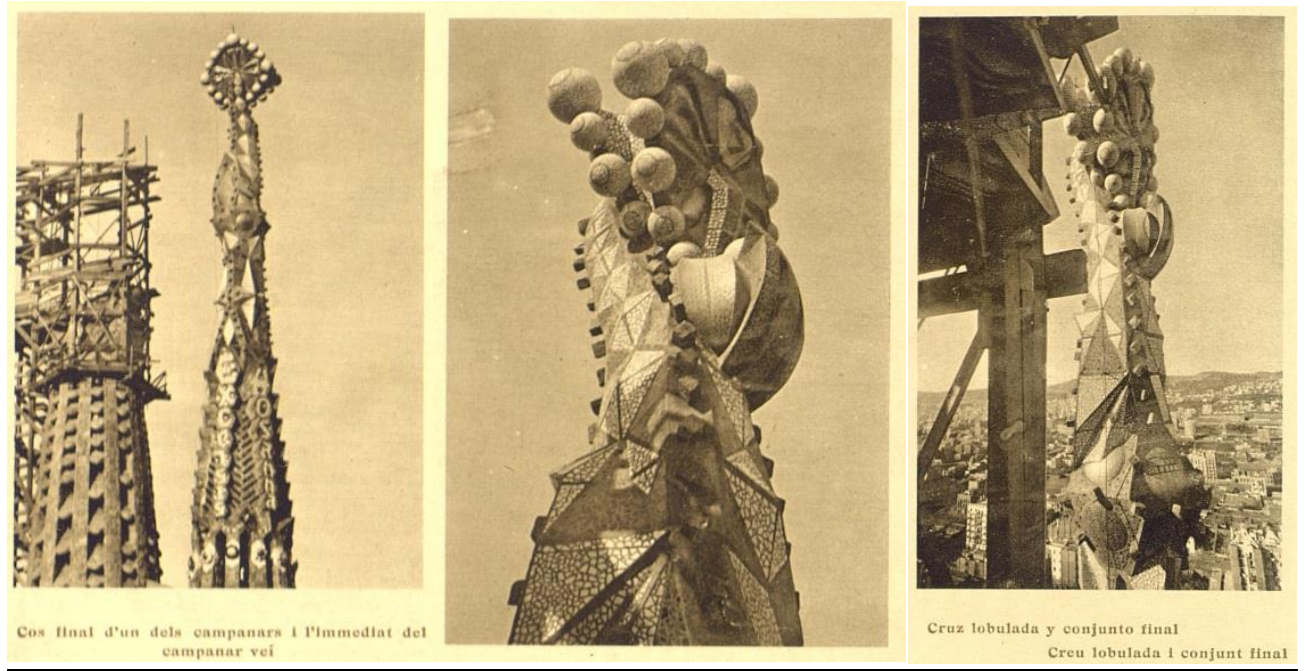

Fotografias del remate de las torres campanarios con la representación de baculos y anillos episcopales en cerámica veneciana, publicado en el Album de 1929. Fuente: Archivo de la Sagrada Familia.

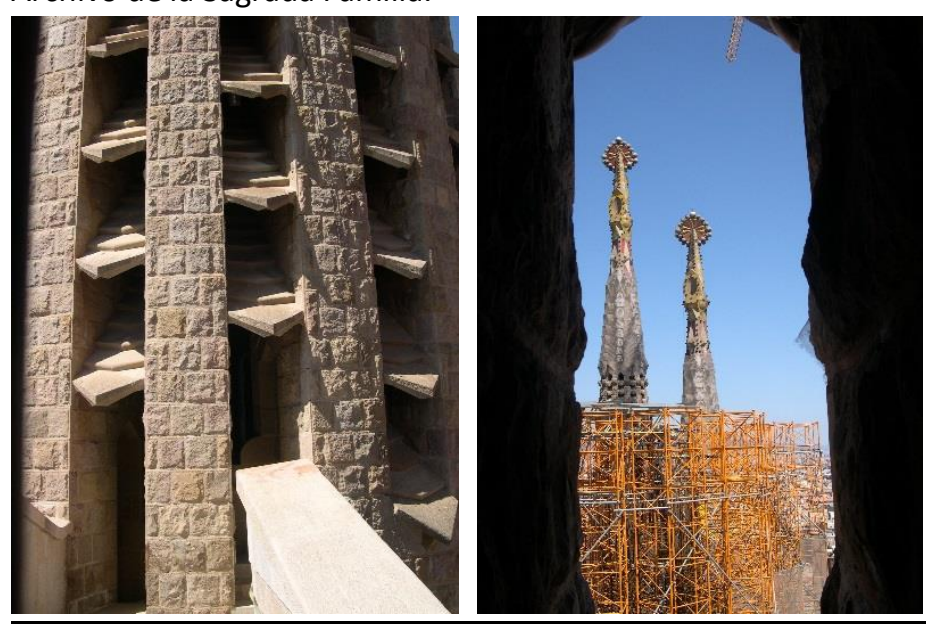

Detalle de los tornavoces de un campanario. Formas, signos, inscripciones en el remate de los campanarios. Fuente: fotografías del autor.

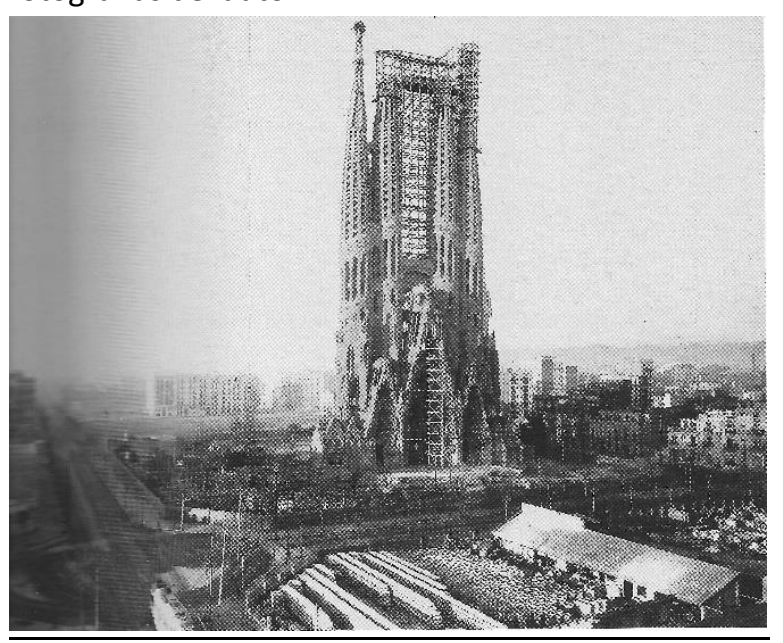

Los campanarios de la F. del Nacimiento a la muerte de Gaudí.Fuente: Lahuerta, J.J. (1993). Antonio Gaudí. Arquitectura, ideología y política. Madrid. Alianza Editorial. 


\section{d.3- Capillas del Bautismo y Penitencia}

Afirma Lluis Bonet Garí que "para estudiar de una manera adecuada el Templo de la Sagrada Familia hay que conocer primero las características del Templo cristiano, el cual está subordinado al culto, cuyos actos vienen regulados por la liturgia....", señalando que "han de haber separadas la capilla del Santísimo y el Baptisterio, con entrada directa de la calle y el nártex o porche exterior, siempre necesario a un templo." 377 Así pues, al hablar del aula celebrativa de una iglesia como el espacio donde se congrega la asamblea cristiana que participa plenamente de las acción litúrgica por excelencia -la Eucaristia-, no podemos olvidar que la incorporación a la misma se produce a través de las aguas del bautismo y que históricamente se producían también casos de exclusión temporal de la asamblea debido a pecados de gravedad cometidos que impedían al pecador participar en los misterios sagrados hasta que no hubiese recibido el perdón a través del sacramento de la Penitencia.

Y si bien la administración de este sacramento ha pasado por diferentes situaciones a lo largo de la historia, en las que unas veces se había dado mayor énfasis a los aspectos relacionados con la visualización de una penitencia pública por las faltas cometidas (como en la Edad Media) o en otros casos a las condiciones individuales con las que cada pecador confesaba sus culpas al sacerdote (según la tradición ignaciana), nunca perdió el carácter de reconciliación del individuo pecador con Dios y con la comunidad que lo acogía y readmitía al banquete eucarístico tras la confesión de sus pecados al ministro ordenado. De igual manera, ya se tratara del catecumenado de iniciación cristiana y el bautismo de adultos anterior al Concilio de Letrán, ya del bautismo de niños individual cuando la población se declaraba mayoritariamente cristiana, la dignidad de la condición de bautizado que se otorga al neófito a la vida de la gracia parece que siempre ha exigido un recinto especial para su celebración.

Por esta condición de paso previo a la participación en la Misa, ya sea de catecúmenos que son recibidos en el seno de la comunidad cristiana o de penitentes por cuya conversión a la fe y perdón de los pecados se alaba a Dios y se acoge al pecador que viene del paganismo o de la mundanidad, históricamente se han dispuesto los recintos específicos para la administración de este primer sacramento de la iniciación y del que conlleva la restauración de la vida cristiana, según el caso, a los pies de la nave, o en un recinto claustral previo a la misma. Incluso -como ocurre con los confesionarios individuales- en las naves laterales de la iglesia, en aquellos espacios de paso y comunicación previos al espacio de la asamblea eucarística.

377 Cf. Bonet i Garí, LI. (2010)."Les diferents etapes d’En Gaudí i evolució del sentit plàstic de la seva arquitectura", conferencia del 3 de abril de 1927, en La mort de Gaudí i el seu ressó a la revista $<E I$ Propagador de la devoción a San José> Ed. Facsimil a cargo de Lluis Bonet i Armengol publicada en Barcelona. Real Cátedra Gaudí y Ed. Claret. P.146 

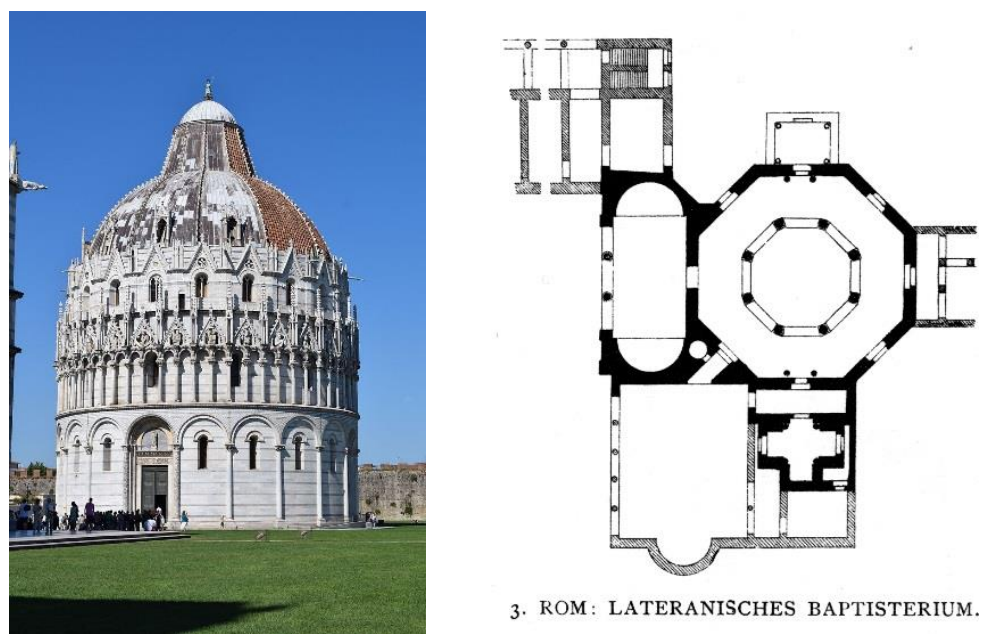

3. ROM: LATERANISCHES BAPTISTERIUM.

A. Baptisterio exento de Pisa

B. Planta del Baptisterio en capilla adosada al aula liturgica en la Basílica de San Juan de Letrán, según Georg Dehio/Gustav von Bezold. Kirchliche Baukunst des Abendlandes. Stuttgart: Verlag der Cotta'schen Buchhandlung 1887-1901.

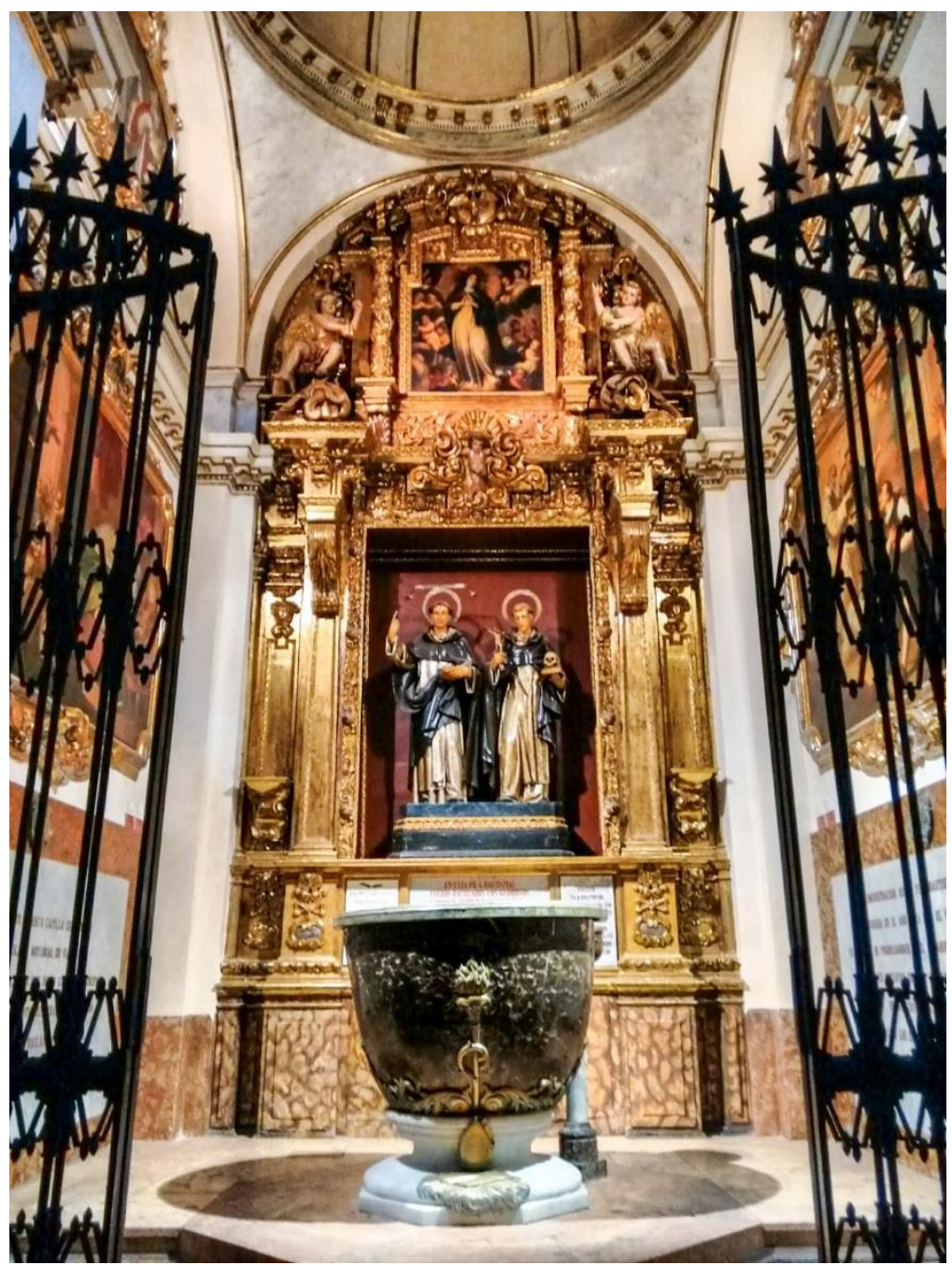

C. Capilla de la pila bautismal de San Vicente Ferrer en la iglesia de San Esteban, Valencia. Fotografia de Juancar. 
Gaudí, conocedor de la tradición histórica de la arquitectura pero también de la historia de la Iglesia, sabe de la disposición del Baptisterio en un edificio especial, adecuado al ritual $^{378}$ que en un principio prescribía por el bautismo por inmersión en una piscina o fuente y que a partir del siglo VI con la generalización de la infusión dio lugar a las amplias pilas sobreelevadas, situado en las inmediaciones -a veces exento- del aula litúrgica pero completamente diferenciado respecto de ella. Su planta podía ser poligonal (normalmente octogonal) o circular, pero siempre con una estructura y cubrición especial recogiendo en la disposición de la planta y en la rica iconografía de las pinturas murales toda la amplia simbología del sacramento: Rávena, San Juan de Letrán, etc. Puesto que históricamente se han dado tres tipologías diferenciadas respecto del baptisterio: edificio exento, capilla adosada a la nave litúrgica y capilla integrada en ésta, podemos juzgar las diferentes propuestas que aparecen en los planos de planta de 1917, 1923 y 1926 como estudios de Gaudí por encontrar la solución más adecuada teniendo en cuanta la funcionalidad del espacio según su uso litúrgico, la composición general de la Sagrada Familia y la estructura sustentante que estaba desarrollando.

En el dibujo A (planta publicada en los álbumes de 1915 y 1917, así como en el número del Propagador de 1-04-1917) aparece una disposición del Baptisterio bastante exenta con acceso independiente desde el exterior (aunque dentro del conjunto de la Portada de la Gloria) y comunicación con la nave a través del deambulatorio o claustro que lo envuelve por dos de sus lados. La planta es heptagonal, como el número de los sacramentos, conformando sus lados al atrio de la fachada de la Gloria, alineación de la calle Mallorca y deambulatorio, y orientado su estructura interior diagonalmente hacia la nave central de la basilica.

En el dibujo B (Modificación de la anterior planta que se publico en la Hormiga de Oro en 1923 y el álbum de 1925) apenas aparecen diferencias en el ámbito del Baptisterio y la capilla de la Penitencia, salvo que en la conexión con la nave de la iglesia y la disposición de columnas en el interior de las capillas parecen vislumbrarse indicios para un estudio más particularizado a desarrollar.

En el dibujo C (correspondiente a la última planta dibujada en vida de Gaudí y publicada en 1926) vemos que la composición de estos recintos se ha desarrollado notoriamente en el sentido de que el claustro rodea completamente las capillas como elemento unificador que conforma las alineaciones de fachada del conjunto; la composición en planta y orientación de las capillas ha variado sustancialmente pasando a ser ortogonales al eje longitudinal de la basílica y presentado una ordenación del espacio en el que se distingue un pequeño deambulatorio interno marcado por la alineación circular de las columnas, una cabecera del espacio a modo de hornacina y dos comunicaciones a sus lados, con la nave de la iglesia y con el pórtico de la Gloria.

\footnotetext{
${ }^{378}$ El Ritual del Bautismo ya aparece en uno de los textos más antiguos de la tradición cristiana como es la Didaché o Doctrina de los 12 Apóstoles, del siglo I.
} 

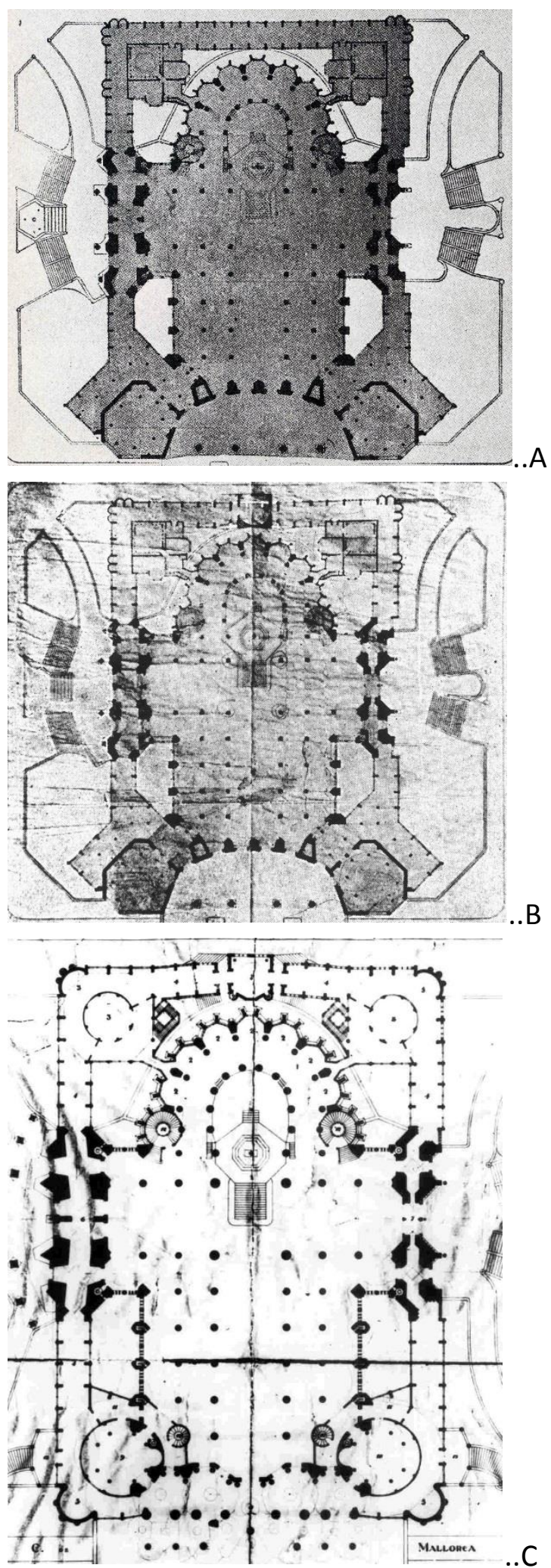

Tres dibujos de Planta desde 1915 a 1926: distinta composición y orientación de las capillas del Bautismo y la Penitencia, así como evolución de su comunicación con el Claustro y la Nave litúrgica. Fuente dibujos: Arxiu S.F. 
La comunicación con la nave de la iglesia se ha complicado y particularizado mediante un espacio intermedio desde el que se accede también por una escalera al coro superior, y en el claustro cercano a las capillas ha aparecido un acceso nuevo desde la calle a la vez que una solución especial de esquina enfatizada con espacio cóncavo.

Respecto de los dibujos de fachadas y de secciones, no aparece ningún volumen correspondiente a estas capillas en el dibujo de Joan Rubió publicado en 1906 cuando se aprecia un cimborio octogonal con aguja para las sacristías, pero sí, con una estructura similar sin aguja en la versión que se publica el 1-07-1921 en el Pro. En el álbum de 1925 no parece apreciarse ningún volumen para la capilla de la Penitencia, si bien, como ya hemos dicho anteriormente, este hecho no debe extrañarnos al utilizarse en los álbumes dibujos y fotografías con un afán divulgador general del proyecto sin carácter cronológico para lo cual resulta más fidedigno lo publicado en el Pro y en otros diarios y revistas. En cambio si que puede deducirse que en 1917 ya estaba perfilada una primera idea de ambas capillas, pues además de los dibujos de planta mencionados, se aprecia en las secciones longitudinales la aparición de una fuente y su simétrico tedero, que van unidos a la configuración de ambos recintos, en el exterior de la iglesia.

En el croquis original de Gaudí (que reproduce Torii en su libro El mundo enigmático de Gaudí y que parece corresponder a un largo proceso de continua reelaboración) aparece una versión de cúpula para las capillas del Bautismo y la Penitencia similar a los croquis para la cubrición de la capilla de la Anunciación del periodo 1922-25. Como conclusión del análisis de los croquis y dibujos se puede pensar que Gaudí tiene los primeros estudios de estos espacios hacia los años 1915-1917 y su versión última en el periodo 1923-1926.

Podemos constatar, pues, que la mente de Gaudí no paraba de darle vueltas al diseño de ambas capillas, tanto en lo que se refiere a su organización interior como a su involucración con el resto de la iglesia, su sistema de comunicaciones y accesos. Además, es posible intuir la singularidad de la estructura de la cubrición por la disposición de las columnas en ambos recintos (en el plano de 1926) que adopta una un modelo octogonal con dos anillos concéntricos orientados según las dos direcciones principales del Templo y dispuestos en el interior de un cerramiento circular: en el sentido del eje longitudinal y el transversal. Por tanto esta última versión de la planta confirma una solución de cúpula verticalizada en la línea de la solución adoptada para las sacristías anteriormente perfilando un orden de actuación: primero el aula de la liturgia eucarística y sus espacios de servicios, después el resto de espacios litúrgicos dedicados a otros sacramentos, procesiones, etc. De la intencionalidad litúrgica que presidia sus estudios compositivos, estructurales y constructivos nos aporta un valioso testimonio Joan Bergós, (el arquitecto que más horas pasó con Gaudí incluso paseando por la ciudad y conversando los domingos por la tarde, cuyo grado de confianza llegó a la participación de aquel en su boda) cuando asevera que: 

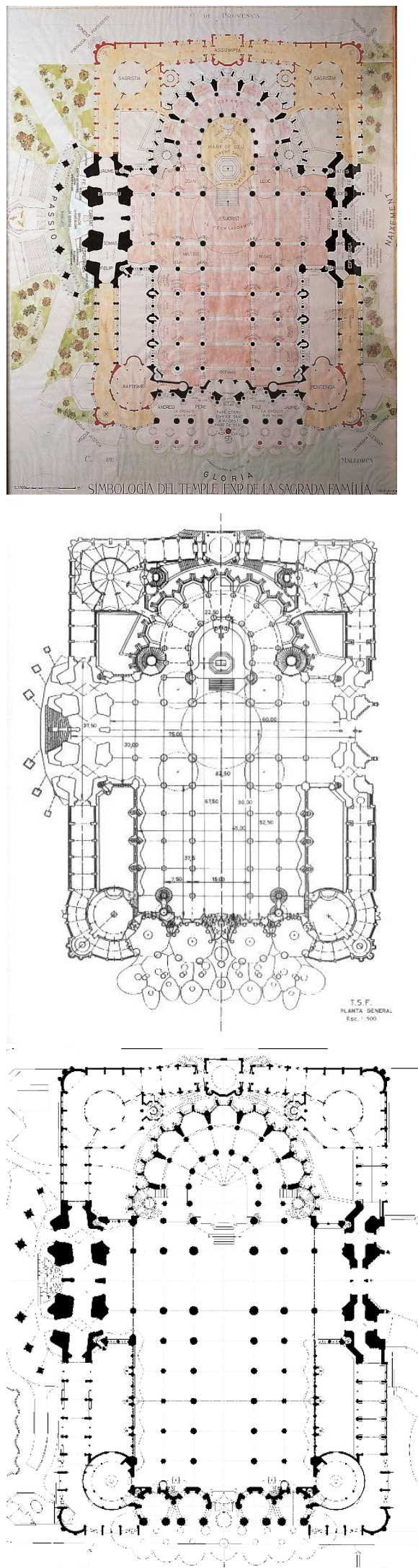

Planos de Planta (1992, 2000 y 2004) elaborados por la Oficina Técnica de la Sagrada Familia en los que se observa el desarrollo de la planta de las capillas. Fuente: Arxiu SF. 
"La disposición de todos los elementos es rigurosamente litúrgica, concordando con el despliegue de ceremonial que es propio del culto y con los conceptos básicos del catolicismo: desde el monumental atrio de la fachada principal se entra en la capilla bautismal, desde donde los neófitos pasan al templo, y a la capilla de la Penitencia, donde deben purificarse los pecadores antes de entrar en él."379

El resultado final es un espacio ordenado cuya singularidad estructural se quiere resaltar en función de su significación litúrgica, en el cual todavía no está detalla la solución de comunicación con las naves del Templo, razón por la cual se han seguido planteado propuestas en los sucesivos años. Así, en planos posteriores de 1992, 2000 y 2004 manteniendo las formas circulares del plano de 1926 se redireccionan ambas capillas según el eje longitudinal del conjunto o en diagonal y se ensayan diversas propuestas para la conexión directa con las naves de la iglesia.

De la importancia que otorga Gaudí a estas capillas da idea el hecho de que piensa en la Capilla de la Penitencia para realizar el Monumento y reserva del Sacramento de la De la importancia que otorga Gaudí a estas capillas da idea el hecho de que piensa en la Capilla de la Penitencia para realizar el Monumento y reserva del Sacramento de la Eucaristía en la Misa del Jueves Santo, y que las completa con el diseño exterior de una fuente monumental que simboliza la Eucaristía en la Misa del Jueves Santo, y que las completa con el diseño exterior de una fuente monumental que simboliza la purificación por el Bautismo y evoca los ríos del Paraiso delante del Baptisterio, y un gran tedero delante de la capilla de la Penitencia. ${ }^{380}$

${ }^{379}$ Cf- Bergós, J. (1974). "Gaudí, el hombre y la obra”. Barcelona. Publicaciones de la Universidad Politécnica de Barcelona. 2o Edición

${ }^{380}$ Cf. Rafols, J.F. (2006) Gaudí. Ed. Facsímil del original de 1929. Barcelona. Ed. Claret y Catedra Gaudí. P. 143. 


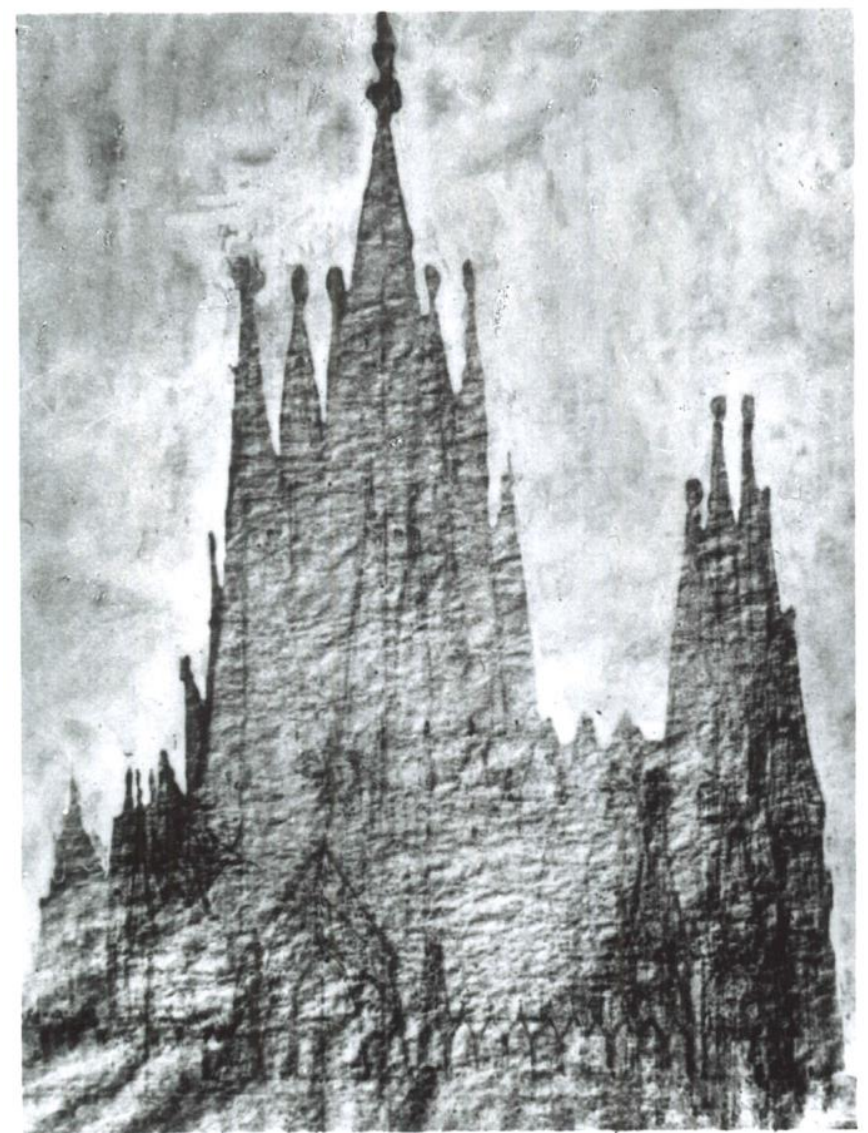

Dibujo original de Gaudí, reelaborado a lo largo de los años, donde se aprecian las fachadas de la Pasión y de la Gloria, las siluetas de la cubrición de las Sacristias y de la Capilla del Bautismo, así como el conjunto de las torres centrales de la Basilica. Fuente: Bonet i Armengol, J. y AAVV. (2010) Sagrada Familia: de temple expiatori a basilica. Barcelona. Lunwerg. 


\section{d.4- El Claustro y la capilla de la Asunción.}

Uno de los espacios más singulares de la Sagrada Familia lo constituye el Claustro. Hay que considerar la significación especial que tiene el diseño de un claustro a finales del siglo XIX en una iglesia de estas dimensiones. El proyecto de Villar no lo tenía como tampoco las principales iglesias votivas y catedrales que se construyeron en el transito del XIX al XX. Sin embargo, desde el primer momento Gaudí piensa en un deambulatorio perimetral al edificio de la iglesia (1885) uniendo todas las entradas a la nave, perfectamente dibujado entorno al ábside e insinuado en la orientación de la fachada de la Gloria. En los años siguientes este deambulatorio, abarcando todo el perímetro en sus cuatro orientaciones, sustancialmente con el mismo desarrollo, no cesará de experimentar estudios de detalle y cambios puntuales en la línea de un protagonismo creciente, pues a él confluirán no sólo las portadas en todo su desarrollo sino las Sacristías, capillas del Bautismo y de la Penitencia, y finalmente, la capilla de la Anunciación.

La importancia de este elemento en el proyecto de Gaudí radica en su espacio construido ya que el espacio libre existente entre el deambulatorio y el cuerpo de la iglesia ha tenido y tiene diversas funciones según la orientación y el proceso de desarrollo del proyecto -sacristías y sus núcleos de comunicación con el ábside, patio inglés de la cripta y su muro perimetral, elementos de conexión con las capillas del bautismo y de la penitencia, etc.- estando sujeto a los estudios y soluciones de los mismos, lo que ha impedido hasta la fecha su tratamiento como un espacio unitario. Gaudí siempre tuvo en mente la construcción de este deambulatorio al que denominaba Claustro. Las razones para ello hay que buscarlas en la propia realidad geométrica de la pieza de edificación como en su función.

Desde siempre se ha buscado que el aula celebrativa de una iglesia reuniese unas mínimas condiciones de aislamiento sonoro respecto del exterior al objeto de no interferir en una buena audición de las acciones litúrgicas. J. F. Ràfols (Gaudí, 1929) se refiere al carácter aislador del recinto sagrado que tiene el claustro, razón por la cual quizá Lahuerta (Antoni Gaudi 1852-1926. Arquitectura, ideología y política, 1993) lo ve como frontera del recinto sagrado y por tanto como foso que separa la nueva muralla de la fachada de la basílica, del centro en torno al cual gravita todo. ${ }^{381}$

381 Cf. Lahuerta, J.J (1993) Antoni Gaudi 1852-1926. Arquitectura, ideología y política. 1a edición 1992, Milán. Madrid. Electa. P. 311: "El claustro al atravesar las fachadas, se convierte en foso que, de nuevo, separa del centro, ese centro que, aquí más que en ninguna otra obra de Gaudí, se deja ver al mismo tiempo que se muestra inalcanzable: rodearlo es literalmente una condena." 


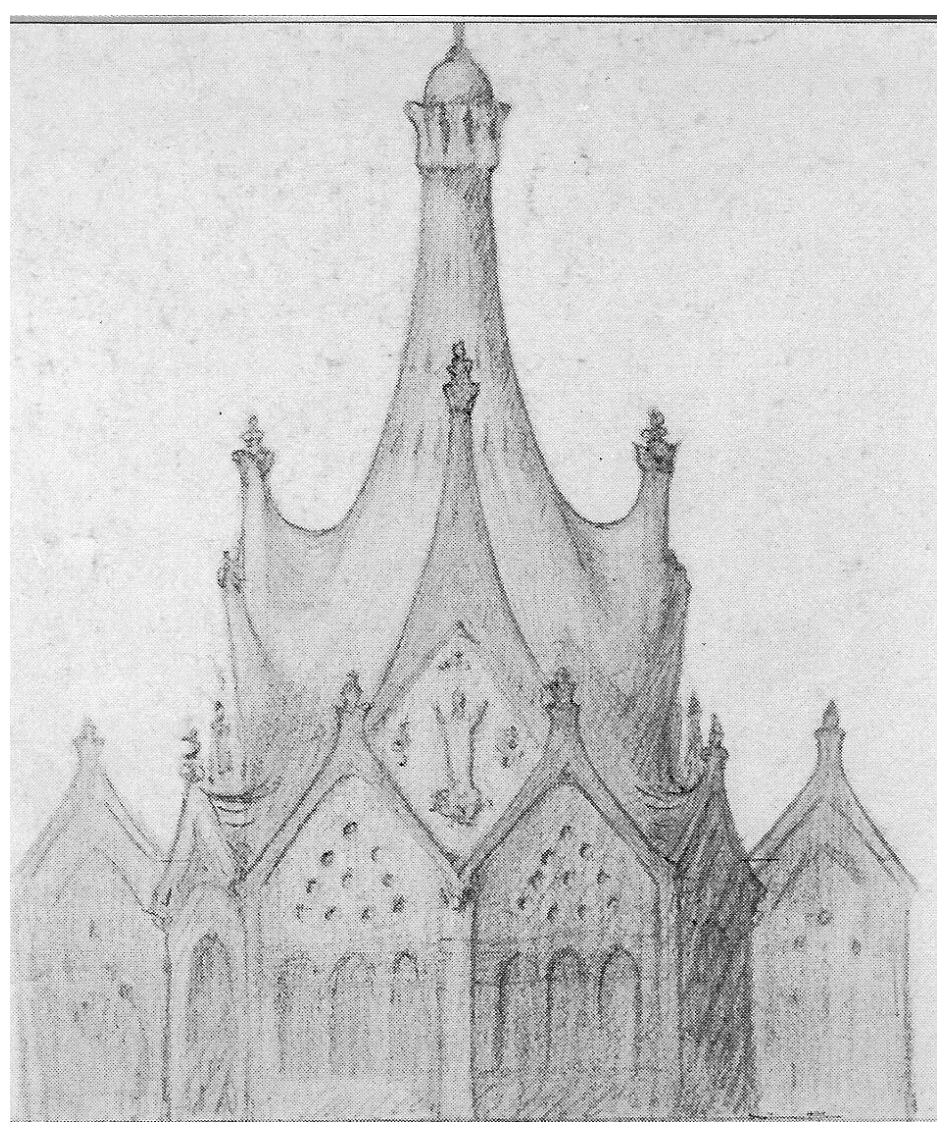

Interpretación de un dibujo de Gaudí para la capilla de la Asunción. Fuente: Martinell, C. (1967). Gaudí: su vida, su teoría, su obra. Barcelona. COACB. 
Sin embargo Bonet Garí (1927), en su condición de colaborador y posterior director de las obras, destaca el papel del claustro perimetral en el conjunto del edificio uniendo las sacristías, fachadas y capillas, y Martinell (1967) de nuevo -amigo, colaborador y fundador del Centro de Estudios gaudinistas- señala la oportunidad de Gaudí al disponer el claustro alrededor del edificio con pequeños espacios dedicados a jardín para alejar los ruidos de la calle sin olvidar su fundamento litúrgico ya que por él podrán discurrir actos litúrgicos o procesiones que no requieran la salida a la calle ${ }^{382}$

La realidad geométrica del claustro heredera de la tradición medieval supone un modulo que se repite longitudinalmente a lo largo de todas las fachadas actuando como pieza de sutura entre diferentes espacios, litúrgicos y de servicio, adaptándose en sus tramos rectos, de esquina, etc. al espacio construido.

Los acontecimientos de vandalismo antirreligioso ocurridos en Barcelona durante la Semana Trágica de 1909 produjeron una fuerte impresión a Gaudí, quien no dudaba en alertar a tomar determinadas medidas al párroco de San Juan de Gracia, según refiere Martinell. Es posible que estos hechos le reforzaran en la idea de prolongar el claustro dibujado en el plano de 1885 a todo el perímetro de la iglesia, pero la decisión es anterior puesto que su ejecución comienza, ya que en el dibujo de 1906 aparece flanqueando los inicios de la fachada del Nacimiento, permaneciendo invariable desde entonces su imagen en todos los croquis de alzados. No así en planta, pues ya hemos visto que en los planos de 1917 y 1923 se bifurcaba al llegar a la fachada de la Gloria y las capillas del bautismo y la penitencia, mientras que en el plano de 1926 la disposición en recto de los tramos sólo se ve alterada por la solución especial de esquina que resuelve con la concavidad propia de un ábside. ¿Qué factores han inducido a Gaudí a decantarse por esta última solución menos orgánica pero más lineal, rotunda y elaborada? La razón hay que buscarla en la funcionalidad litúrgica de este elemento.

\footnotetext{
${ }^{382}$ Cf. Martinell, C. (1967) Gaudí: su vida, su teoría, su obra. Barcelona. COACB. P. 310-311: "Por regla general el claustro de los templos está a un lado y en ocasiones al frente, a manera de atrio; aquí, Gaudílo dispuso alrededor, con pequeños espacios destinados a jardín, para alejar los ruidos de la calle......Por él, una vez en función el templo, podrán discurrir actos litúrgicos o procesiones que no requieran la salida a la calle."
} 

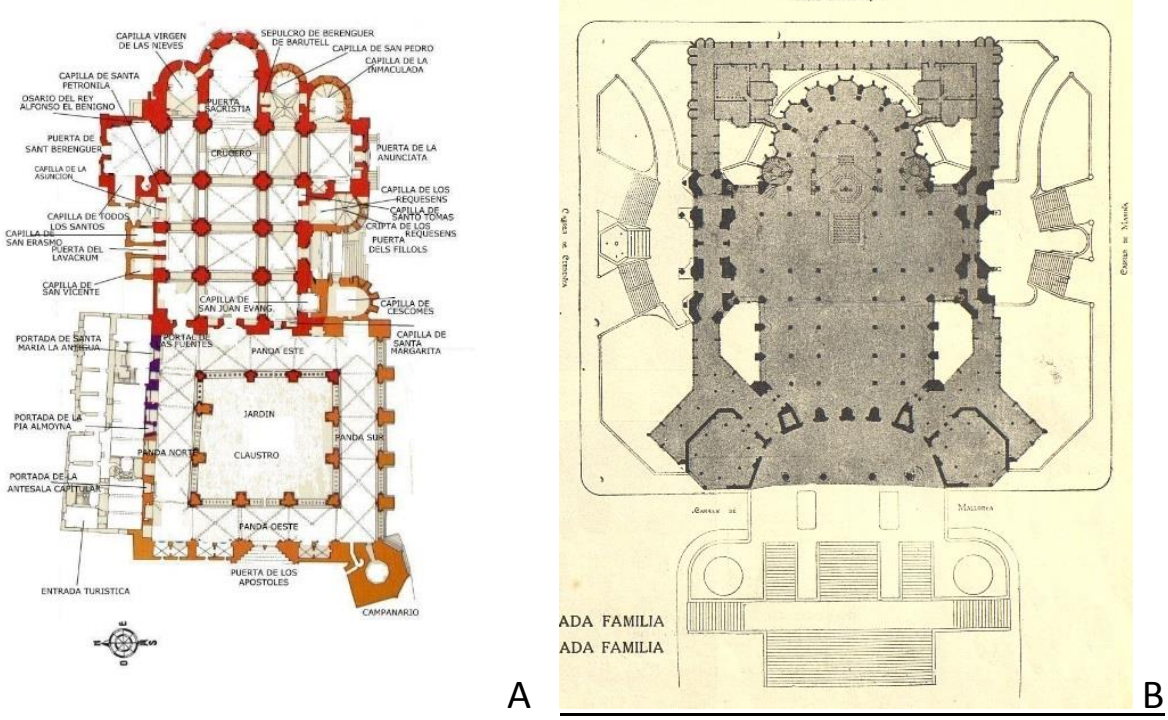

A, C y D: Catedrales de Lérida, Tarragona y Barcelona según Diaz Bernal. B: Planta de la SF publicada en el Album de 1917, donde se aprecia la importancia del Claustro como elemento vertebrador de todo el conjunto. Fuente: Archivo de la SF
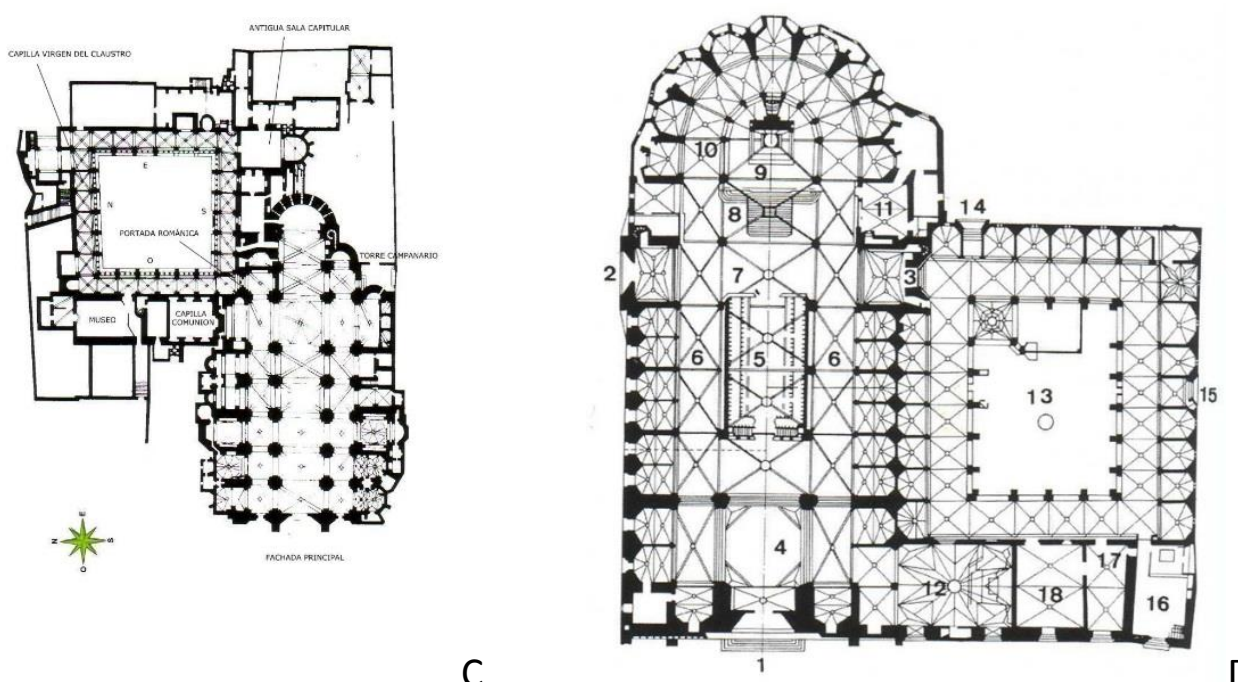

C

D
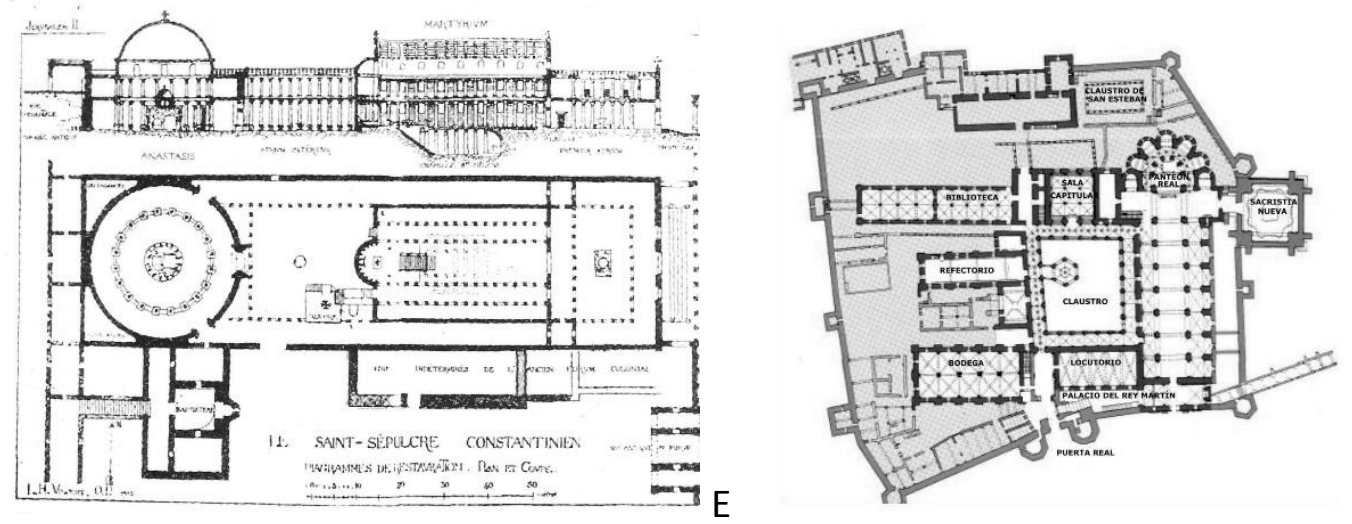

E: Basilica constantiniana del Santo Sepulcro por L.H. Vincent, O.P., publicada en 1912 Jerusalem: recherches de topographie, d'archeologie et d'histoire. Paris. Gabalda Que pudo ver Antonio Gaudí. F: Monasterio de Poblet. 
Las disposiciones más antiguas del claustro en el edificio de la iglesia datan de los primeros siglos del Cristianismo y tienen que ver con la preparación de los catecúmenos y su recorrido bautismal antes y después de su introducción en la piscina situada en el baptisterio para pasar a la plena participación en la liturgia eucarística. Con posterioridad al año $313 \mathrm{dC}$. (Edicto de Milán) el claustro adopta una planta netamente cuadrada o rectangular situada a los pies de la basílica e incorpora más notoriamente una función de atrio porticado a cielo descubierto que solemnizaba mayormente los ritos litúrgicos y procesiones de los catecúmenos y neófitos, así como diversas procesiones y actos previos de las liturgias de las solemnidades. Así podemos verlo en la reproducción de la planta de Santa Sofia y en gran número de catedrales del Occidente cristiano, tanto a los pies del edificio como en un lateral. Con el auge de la vida cenobítica en Occidente el claustro de los monasterios deviene un espacio interior al edificio en torno al cual se desarrolla la vida espiritual de la comunidad, comunicando diferentes recintos como la iglesia, el aula capitular, refectorio, sala de visitas, capillas diversas, salas de instrucción del noviciado, etc. y siendo escenario de procesiones y acciones litúrgicas.

Por descontado que en el siglo XIX, periodo de honda decadencia litúrgica, no se construían iglesias con claustro y éste había pasado a ser un elemento histórico artístico de las edificaciones históricas. Por tanto, para comprender los motivos que llevan a Gaudí a pensar y repensar la realización de un deambulatorio como claustro de este tipo hay que remontarse a los orígenes de su función, tal y como brevemente se han expuesto. Gaudí es un analizador de arquitecturas históricas que conoce a través de los libros, grabados y fotografías que llegan a sus manos y que disecciona buscando su fundamento y motivación funcional al mismo tiempo que la razón constructiva de sus formas. Gaudí es también un admirador de determinadas arquitecturas y edificios como también un detractor de aquellos que le parecen fallidos en sus expectativas.

Para él la basílica del Santo Sepulcro de Jerusalén es una fuente de inspiración que nace de su condición histórica como lugar de nacimiento de su fe católica y que además ve como paradigma del simbolismo eucarístico. En ella se inspira para realizar la iglesia de la Colonia Güell y ella será también su inspiradora para la singular disposición del claustro de la Sagrada Familia.

Un claustro que cumple las funciones litúrgicas asignadas a este recinto en los tiempos del catecumenado de adultos y que es a la vez todo él nártex del aula celebrativa -por la gran cantidad de accesos que tiene en todo su recorrido dentro y fuera de las Portadaspuede evocar al elemento de comunicación entre Martyrium, Gólgota, Anástasis y Baptisterio plasmado en los dibujos que se publican del Santo Sepulcro (como por ejemplo la hipótesis de su reconstrucción de I.H. Vincent O.P., Paris 1913) resultando una pieza unificadora del conjunto de primera magnitud. 

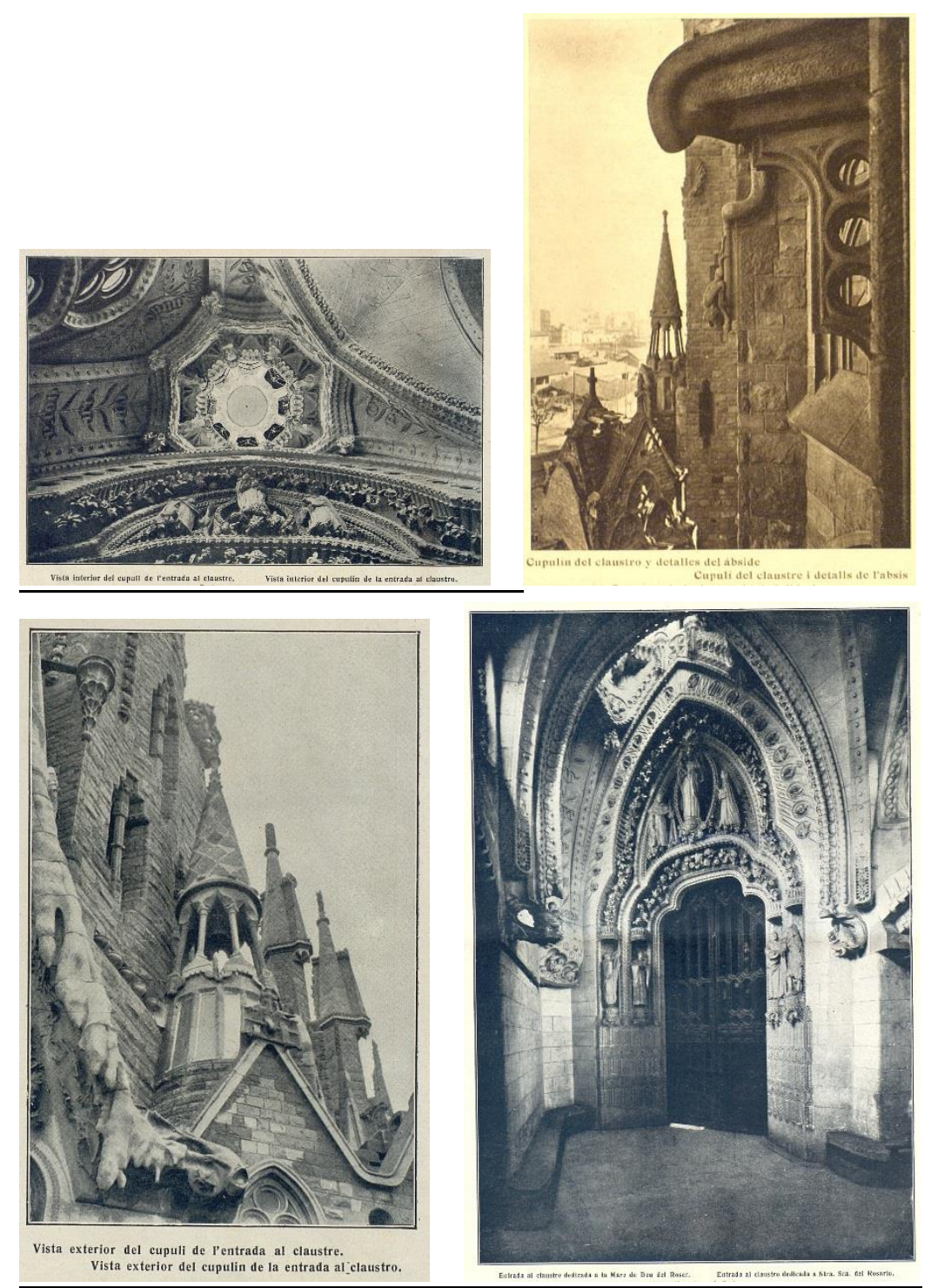

Fotografias de la entrada al Claustro en el álbum de la SF de 1915. Fuente: Archivo de la Sagrada Familia.
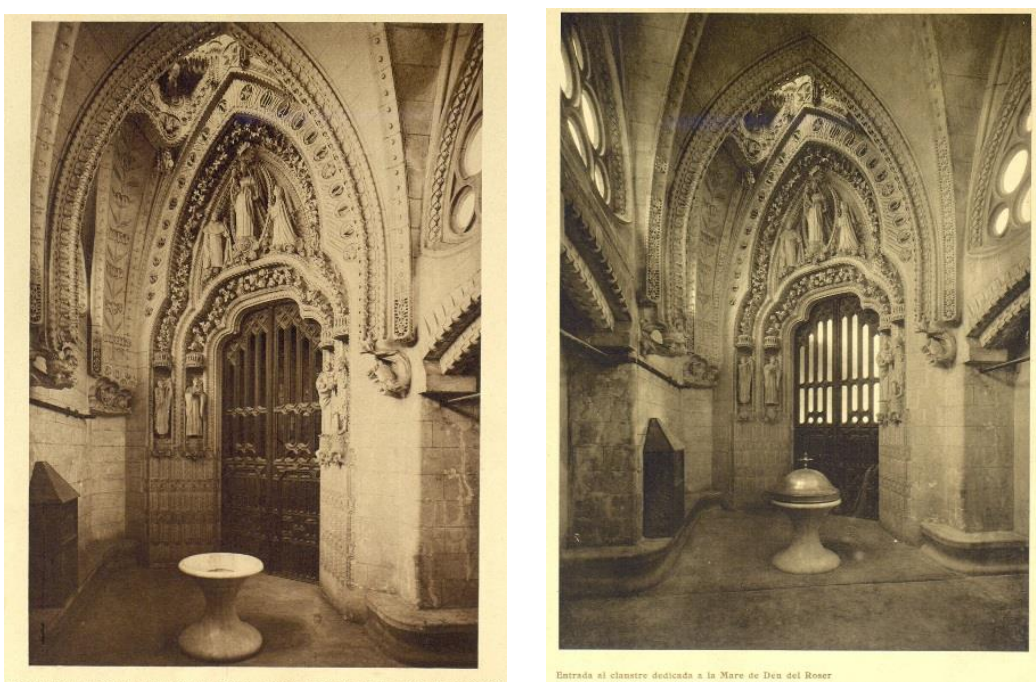

Fotografias de la entrada al Claustro en el 3er y 40 álbum (1922-25 y 1929). Fuente: Archivo de la Sagrada Familia. 
En el Album de 1915 y en los siguientes se describe el claustro y se dice que tendrá una bóveda -de crucería- sin pintar, aspectos ambos en los que merece la pena detenerse. La bóveda nos indica que la idea de su realización es ciertamente muy antigua en el tiempo, lo cual es confirmado por el plano de 1885, y que Gaudí no tiene excesivo interés en modificarla cuando cambia la solución estructural, al contrario que su trazado en planta, los cuatro accesos que diseña y las adaptaciones especiales en las cuatro esquinas.

La intención primigenia de no pintar la bóveda indica una sutil distinción respecto del interior de la iglesia cuyas bóvedas y ventanales son objeto de la atención colorista de Gaudí, de acuerdo con lo que había escrito con anterioridad y con la tradicional iconografía colorista de los lugares liturgicos. ¿A qué se debe esta ausencia de color que no de imágenes y esculturas? A que Gaudí concibe el claustro como un lugar exterior al espacio celebrativo que es el aula de la Eucaristía, espacio de acceso en cuyo recorrido se disponen hasta 7 entradas, símbolo del recorrido de la comunidad de fieles que está en movimiento como preparación al banquete litúrgico. Portada del Nacimiento, Portada de la Pasión, Portada de la Gloria, dos entradas en el Claustro junto a la Capilla de la Asunción y dos entradas en el Claustro junto a las capillas del Bautismo y de la Penitencia, a través de las cuales se accede al interior de la basílica, total 7 accesos. ¿A qué obedece si no el hecho del inicio de su construcción -antes incluso que la fachada del Nacimiento a la que enmarca- y la dedicación a la Virgen, -bajo diferentes advocaciones- en todos sus accesos desde cada una de las fachadas de la iglesia?

Es igualmente significativa la modificación de su trazado en el plano de 1926 circunscribiendo completamente todo el edificio, incluso las capillas del Bautismo y la Penitencia, respecto al plano de 1917. Presenta una distribución muy estudiada de estas capillas y de sus accesos, al igual que soluciones especiales de esquina en el Claustro a modo de capillas ${ }^{383}$ que recuerdan lugares especiales de oración ligados al rezo del Rosario o del Via Crucis. Del mismo modo la apertura de accesos directos en el Claustro desde la calle -en las inmediaciones de las capillas del Bautismo, de la Penitencia y de la Anunciación- parece querer contradecir su visión de muro o foso a la que alude Lahuerta. Estos accesos se ven también en el dibujo perspectivo de Francisco Vall publicado en el Album de 1929. Si nos atenemos a lo descrito en este Album respecto del Claustro una cosa llama la atención, su carácter de deambulatorio o corredor que distribuye, que no de lienzo, foso o frontera, entre la calle y el interior de la basílica o aula litúrgica. 384

\footnotetext{
${ }^{383}$ Cf. Album de la Sagrada Familia de 1929. P.19: “...el claustro, que en el vértice del angulo recto que se produce al cambiar de dirección forma una capillita, cubierta a su vez por un hiperboloide en forma de cupulín."

384 Ibid.. P.18: "Así como la planta superior se abre a las puertas de la fachada resultando como un corredor entre el exterior y la iglesia, igualmente la planta inferior se encuentra con los enormes macizos de los cimientos y pasa a través de ellos...."
} 
El mismo Gaudí responde cuando afirma su carácter litúrgico al decir que se hará para el rezo del rosario en procesión y aislar la iglesia del ruido callejero, comentario que recoge y trascribe Puig Boada y también sustenta Laura Mercader en su libro sobre los escritos de juventud del arquitecto ${ }^{385}$. Martinell también se hace eco de esta condición que describe el mismo Gaudí (Gaudí i la Sagrada Familia, comentada per ell mateix, 1950) cuyas entradas desde los pórticos de las fachadas, tratamiento ornamental y capilla que lo ha de presidir están dedicados a la Virgen como correspondía según la dedicación de espacios entre los miembros de la Sagrada Familia que hace Gaudí: la Cripta, donde inicialmente iba la Casa de Nazaret, presidida por la imagen y altar de San José y los del resto de la familia; Jesucristo presidiendo en el altar el aula litúrgica donde se celebra el culto eucarístico; la Virgen, asunta al cielo, presidiendo el peregrinar de la Iglesia en la tierra, el claustro. ${ }^{386}$ El propio discurso de Gaudí a los josefinos, en vida todavía de Bocabella, lleva a considerar también otros argumentos del tipo litúrgico para esta novedosa disposición: "Detrás de las alas del transepto, junto al ábside, habrá dos grandes sacristías que comunican con el presbiterio y con los claustros. Éstos correrán alrededor del templo sin interrupción a lo largo de las fachadas, siguiendo por detrás del ábside, donde se levantará la capilla dedicada a la Asunción de la Virgen. Su extenso circuito permitirá realizar procesiones solemnes en tiempo lluvioso o frio. Tendrán también función aislante del ruido, separando las naves de la calle." 387

Es interesante señalar la profusión de accesos que proyecta Gaudí en el perímetro del edificio y su diferenciación. Cada Portada, temáticamente distinta, es también fundamentalmente diferente en su composición y construcción, pero además proyecta hasta cuatro accesos en el Claustro, junto a la capilla de la Asunción, al Baptisterio y a la capilla de la Penitencia.

\footnotetext{
${ }^{385}$ Cf. Puig Boada, I. (1981) El Pensament de Gaudí: compilació de textos i comentaris. Barcelona. La Gaya Ciencia. P. 193. "el claustre del que forma parte la porta del Roser, estarà fet per resar-hi el rosari en processó i per isolar el temple dels sorolls del carrer"; Mercader, L. (2002). Antoni Gaudí: escritos y documentos. Barcelona. El Acantilado.

386 Ibid. P. 198: "Li faltava, a la Verge, un lloc preferent en el Temple....L'edicula estará dedicada a la Verge, per fora com a simbol. L'Esglesia es la Verge, després de l'Anunciació. La seva diada principal és la Mare de Deu d'Agost, l'assumpció, la dels Angels."

387 Cf. Bassegoda Nonell, J. (2001). Gaudí: la arquitectura del espíritu. Barcelona. Salvat Editores. Pags. 192-205.
} 


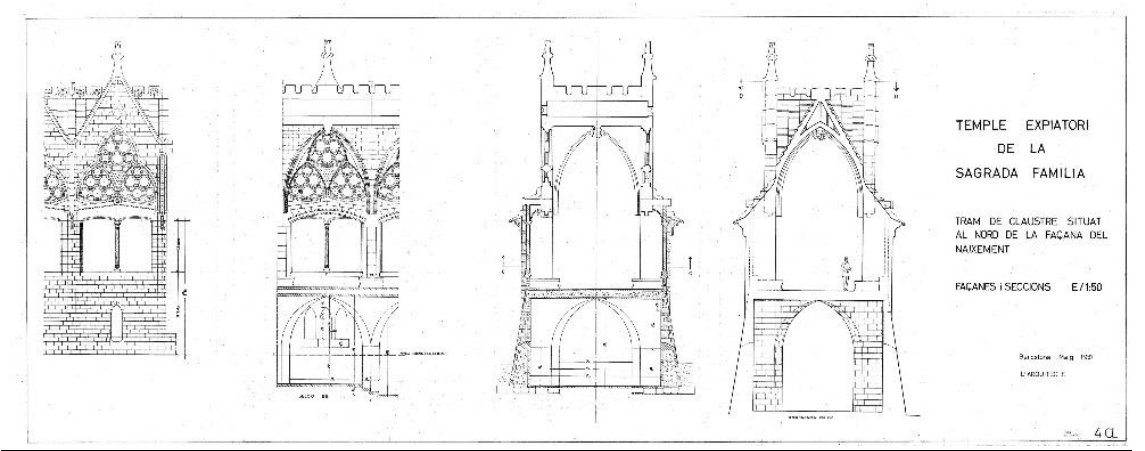

Modulo alzados y sección del Claustro de la Sagrada Familia. Fuente: Oficina Técnica de la Sagrada Familia.

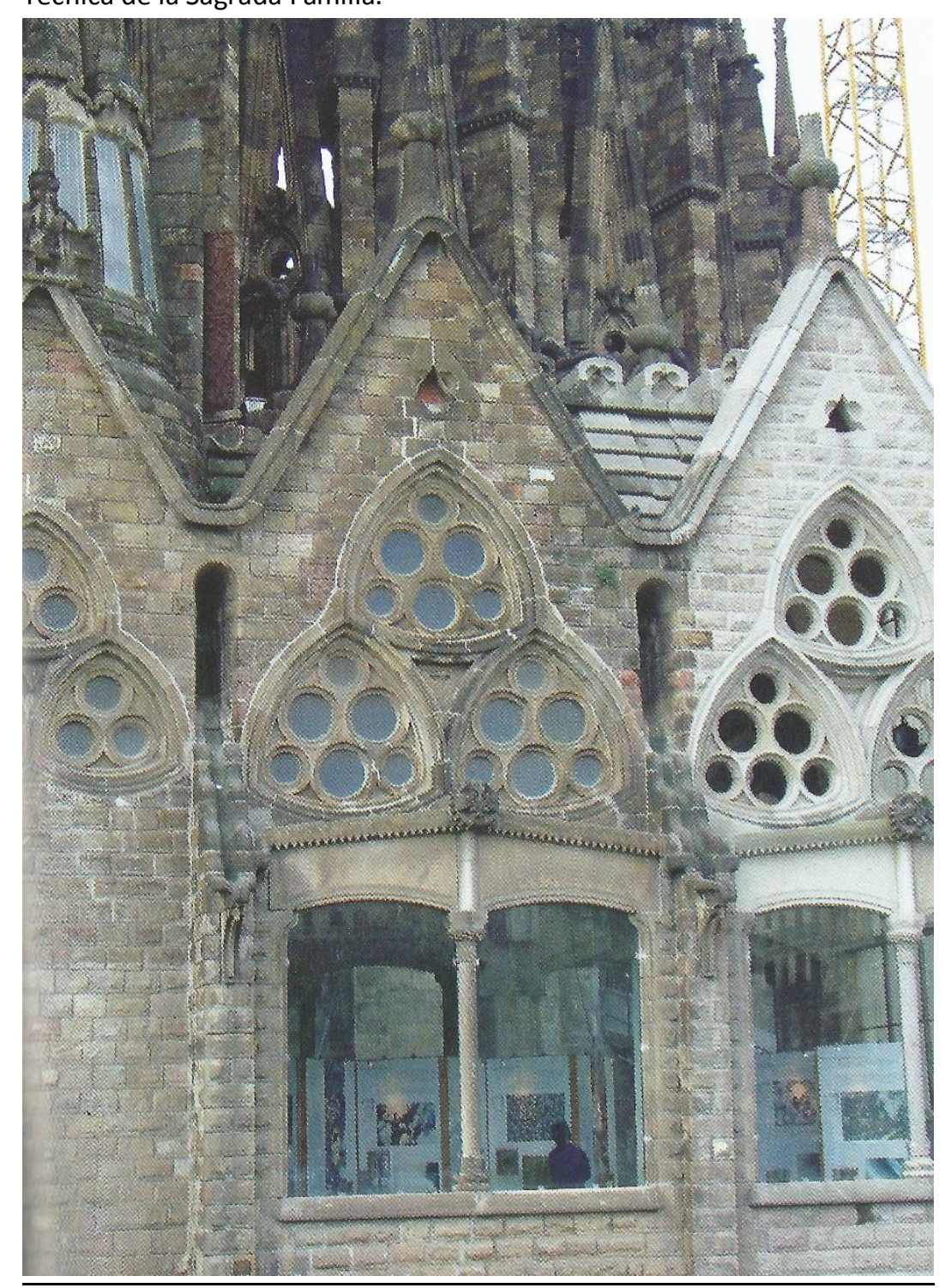

Modulo de fachada del Claustro de la Sagrada Familia: Fuente: Puig, A. (2011) La Sagrada Familia según Gaudí. Barcelona. El Aleph. 


\section{d.5- Espacios sirvientes: sacristías, accesos, talleres, etc.}

\section{Sacristías}

Según la formulación khaniana de los espacios sirvientes y espacios servidos es posible dotar de un fuerte protagonismo geométrico y constructivo, y en consecuencia de similar dignidad arquitectónica, a unos y otros, confiriendo una gran unicidad al conjunto del edificio. Esta aseveración del arquitecto americano presenta puntos de conexión con la ponderación que hace Gaudí de la geometría como factor primordial en la composición de edificios públicos y religiosos, cuya funcionalidad es condición imprescindible para su belleza, y a la cual no ha de hurtarse todas las piezas y elementos secundarios del edificio. En la Sagrada Familia encontramos algunos espacios de servicio sumamente interesantes en cuanto a su concepción y tratamiento, como las Sacristías, las Escuelas, los Talleres, los Accesos o atrios, que por su relevancia en el conjunto del proyecto bien podrían considerarse de alguna manera en la misma línea que los espacios de servicio de la Galería de Arte de la Universidad de Yale u otros proyectos del arquitecto americano a finales del siglo XX.

En el plano del culto se significan como espacios sirvientes las Sacristías y los accesos o atrios de la iglesia. Aunque en el plano de planta de 1885 apenas se encuentra alguna indicación que pudiera sugerir un recinto destinado a sacristía de la iglesia y que pueda ser desarrollado con posterioridad, ya que tan sólo es posible apreciar dos elementos esquemáticos situados en el ángulo interior del deambulatorio o claustro en la alineación de la calle Provenza -que duplican la solución dibujada para la esquina de las calles- lo cierto es que en los planos publicados en 1917 y posteriores se aprecia en la misma ubicación unos espacios destinados a este fin de notable complejidad distributiva.

En los dibujos que se publican en 1916 y 1917, tanto en la planta subterránea como en la superior ${ }^{388}$, sus dimensiones, estudio de la compartimentación interior, y comunicación con la nave celebrativa -y el claustro- anuncian la importancia que se le quiere otorgar a estos recintos en el proyecto. Incluso llega a apreciarse un esbozo de cúpula en la estancia principal de cada recinto. Esta compartimentación se mantiene idéntica en la planta que se publica en 1923 en la Hormiga de Oro, que encontramos repetida en los álbumes de 1925.

\footnotetext{
${ }^{388}$ Cf. La planta subterránea de enterramientos firmada por Gaudí en 1916: la superficie del elemento rudimentario que aparecía en el plano de 1885 se ha incrementado de tal manera que ya es tangente con el muro que delimita el patio inglés de la Cripta. En la planta publicada el 1-04-1917 en el Pro, así como en los álbumes de 1915 y 1917, aparece claramente dibujada una compleja distribución de estos recintos y su comunicación con el ábside de la iglesia.
} 

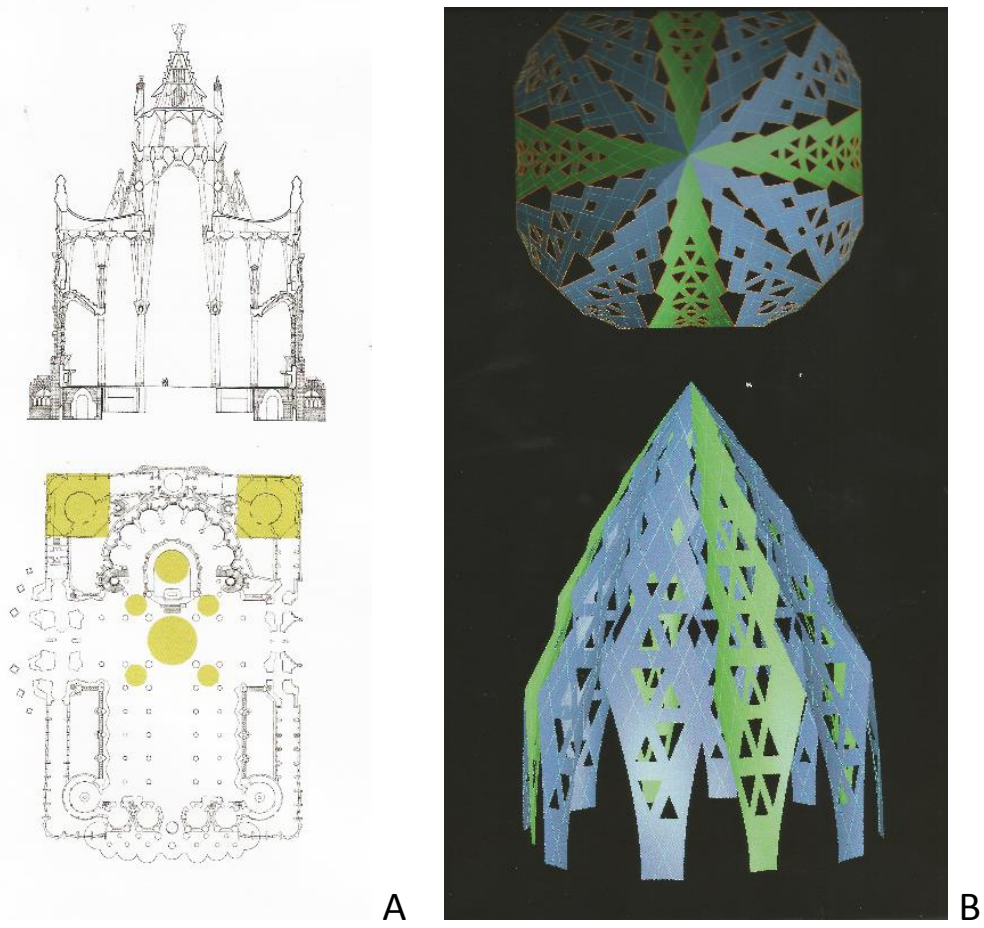

A

\section{$B$}

A: Las sacristías y las torres de crucero y ábside en la planta general. Fuente: Gomez Serrano, J. y AAVV. (2008) Sagrada Familia XXI: Gaudí ara. Baercelona. Edicions UPC.

B: Modelización cúpula de la sacristía. Fuente: Giralt Miracle, D. (2002) Gaudí, la búsqueda de la forma. Barcelona. Lunwerg
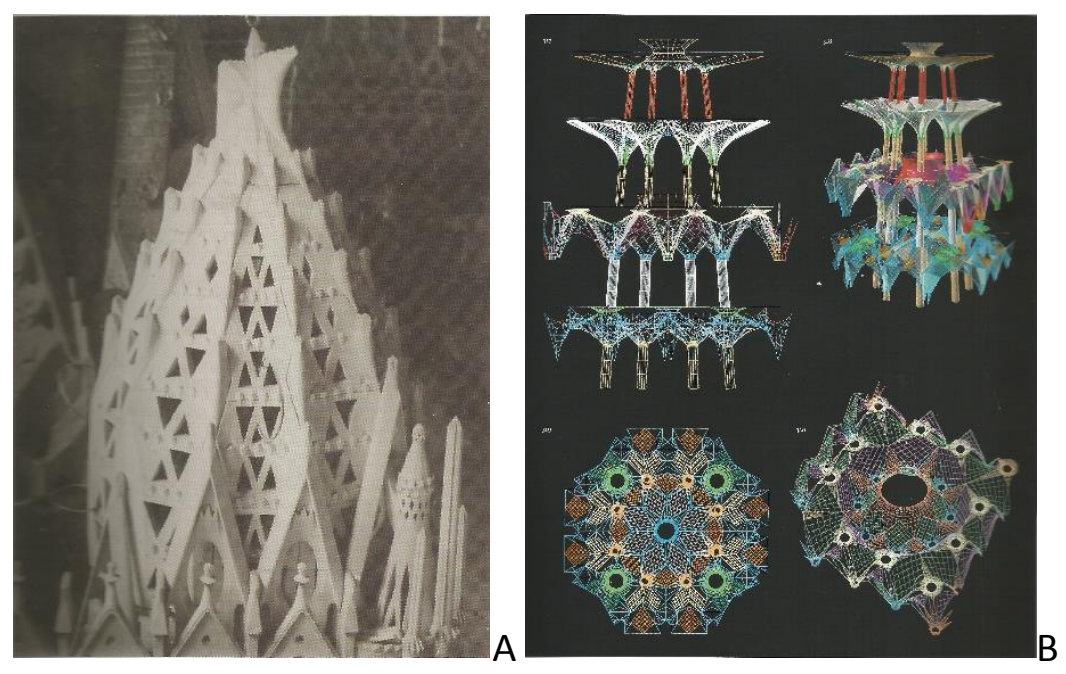

A: Maqueta original de la estructura de cubrición de la Sacristia restaurada. B: Estructura de las Sacristias. Fuente: Gomez, J. y AA. VV. (2008) Sagrada Familia XXI/Gaudí ara. Barcelona. Edicions UPC. 
T. Torii (El mundo enigmático de Gaudí. Vol II., 1983) hace una interesante recopilación de dibujos del conjunto, secciones y fotografías de maquetas con algunas fechas de su publicación, a partir de las cuales y de los mismos documentos originales que se conservan en el Archivo de la Sagrada Familia es posible seguir la evolución que toman los diseños concernientes a las sacristías. Así por ejemplo, en las secciones interiores publicadas en el Propagador el 1-05-1917 y en 1922, así como en la Hormiga de Oro en marzo de 1923 se percibe perfectamente una cúpula de media naranja con linterna para las sacristías que se mantiene por lo menos hasta la solución de formas parabólicas, que según Torii se resuelve en 1922 y que se publica en el álbum del Templo de 1925. Quiere esto decir que sólo en los últimos años de su vida pudo ocuparse Gaudí de desarrollar con detalle la estructura de las sacristías, cuya idea primigenia y ubicación no habían cambiado en todos esos años, pero que cuando lo hace le dedica un gran interés pensando en varias soluciones para su cubrición.

Durante el periodo de tiempo que media entre el dibujo del Templo de Joan Rubió, publicado el 18-03-1906 en Ilustació Catalana y el grabado que se publica por primera vez el 26-01-1913 en el Correo Catalán ${ }^{389}$, se mantiene una solución de cimborio en dos niveles de altura diferenciados, con cierta apariencia neogótica y cuyo ámbito probablemente sólo abarcaría la estancia central de las sacristías según la compartimentación que se corresponde con la planta que se publica en 1917.

En otros dibujos realizados con posterioridad a 1915 -sección longitudinal publicada en 1917- se observa que la Sacristia presenta un volumen mucho mayor, apareciendo como una gran estructura en el Propagador y como una cúpula redonda con linterna de trazas más clásicas en los álbumes de 1917 y 1922. Aunque la planta no parece variar mucho entre 1917 y 1923, posteriormente aparece publicada en el Album de 1929 una solución muy verticalizada de la cúpula casi idéntica a la versión final que según Jordi Bonet (citando a Puig Boada) dice que Gaudí preparó entre 1919 y 1920. Es decir que con la desestimación de la primera solución estructural neogótica del proyecto se cae también la primera solución de cubrición para las Sacristias cuya nueva versión irá en la misma línea del nuevo proyecto estructural intersectando paraboloides para cubrir una planta poligonal con varios niveles o pisos, y cuyo destino -según Bonet- era cubrir las necesidades pastorales, sociales y de alojamiento de los custodios del Templo. ${ }^{390}$ También se ha dicho que una de las dos Sacristías estaría destinada a atender a los novios que se preparaban para el Matrimonio, pero no se ha podido comprobar esta cuestión.

\footnotetext{
389 Posteriormente también se publica en los álbumes de 1915, 1917 y 1922, aunque esto no debe extrañar pues se trata de una reutilización de dibujos que también se da en otros ámbitos del proyecto y que no se opone a que cronológicamente se superponga con estudios o soluciones nuevos cuya materialización o publicación se retrasa o coexiste con soluciones ya desechadas por Gaudí.
}

${ }^{390}$ Cf. Bonet, J i Puig, Armand (2013). Arquitectura i simbol a la Sagrada Familia. Barcelona. Pórtic. P. 171. 

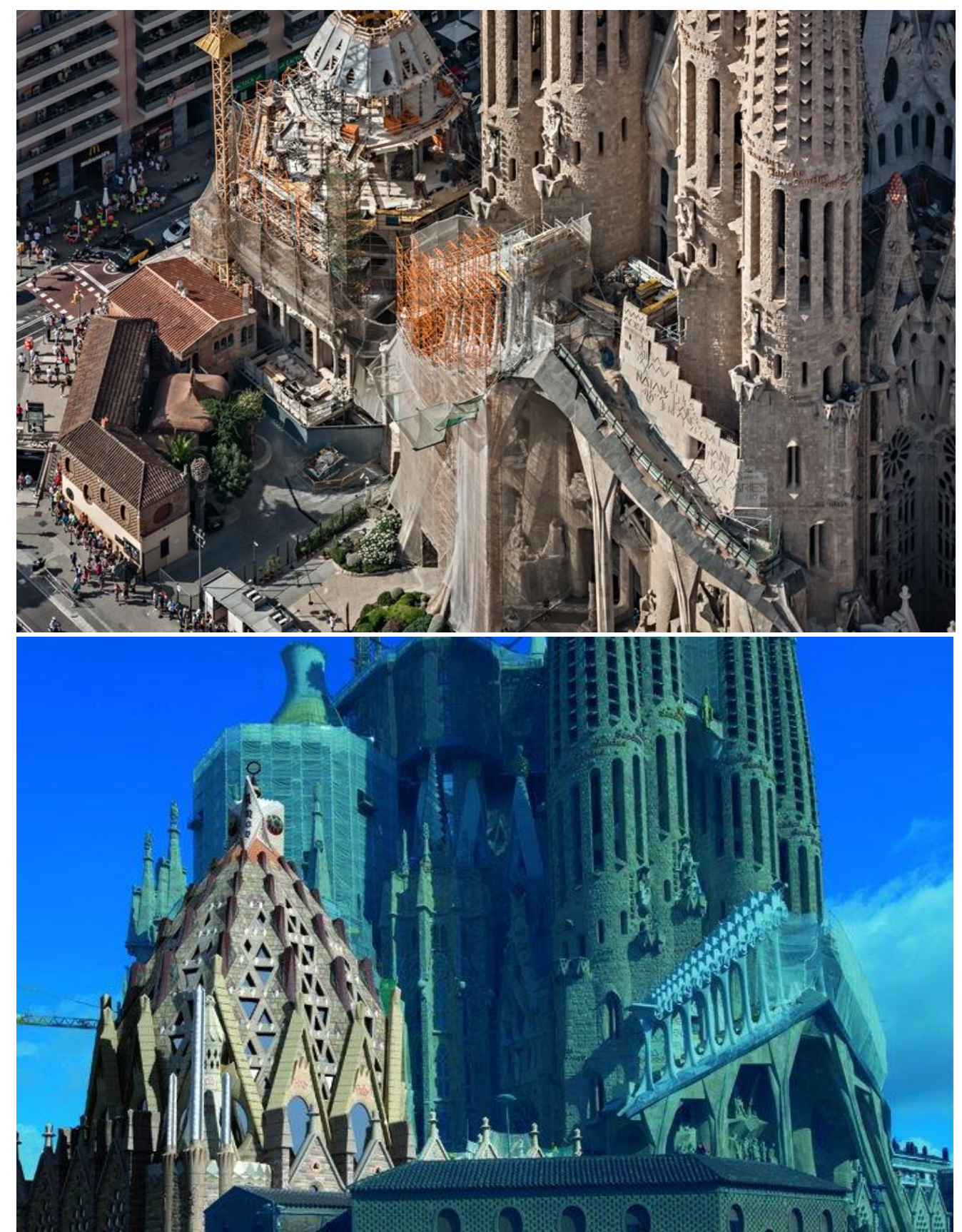

Fotografias de la Sacristia en la orientación de la C/ Provenza. Fuente: Fundación de la Sagrada Familia. 
En la última versión de la planta dibujada en vida de Gaudí en 1926 y publicada en 1929 se observa un paulatino proceso de simplificación entre estructura y planta, y entre ésta y su cubrición, así como un núcleo exterior de escaleras para la comunicación entre los distintos niveles, que denota una notable clarificación y maduración en el esquema de comunicaciones con el aula celebrativa y el claustro.

En el dibujo de fachada datado por Torii en los años 1945-50, periodo de la dirección de obra de Lluis Bonet Gari, la volumetría de la Sacristía se correspondería con la maqueta original restaurada.

En consecuencia, parece que nuevamente el periodo comprendido entre 1913 y 1917 es clave en la evolución del proyecto para llegar a soluciones más maduras. En el álbum de 1929, tres años después de la muerte de Gaudí, encontramos una precisa descripción de las Sacristias, de los doce paraboloides que se interseccionan y de los detalles simbólicos de ornamentación que rematan exteriormente la cúpula (Jesucristo, y su imagen en la figura del vendimiador, decoración de palmas, textos de invocaciones bíblicas, etc.) percibiéndose el detalle arquitectónico y simbólico que se otorga a estos espacios sirvientes. Se las califica como magníficas por sus dimensiones (planta cuadrada achaflanada de $17 \mathrm{~m}$ de lado y altura total de $43.50 \mathrm{~m}$ ), con una cúpula constituida por 12 paraboloides hiperbólicos que se intersectan dando lugar a una serie de ventanales que se dice iluminarán las distintas cámaras que ocuparán el interior de la cúpula, por lo cual no estamos hablando de un recinto único ni simple, sino amplio y complejo en su planta y hábilmente tratado en su cubrición. ${ }^{391}$ Evidentemente la complejidad de la estructura, la amplitud de la planta y los diferentes niveles que se proponen, indican que Gaudí pensaba en unos usos muy concretos para este cuerpo de edificio en los que pretendía volcar en un particular proyecto decorativo y simbólico todo su conocimiento teológico tal y como anuncia la descripción del último álbum, que no contradeciría en absoluto lo manifestado por Jordi Bonet, fruto de su análisis y conocimiento directo del proyecto y de las narraciones oídas de labios de su padre, Lluis Bonet Garí.

Compositivamente la disposición simétrica del conjunto fuerza también una solución doble en el caso de las Sacristías. Partiendo de una implantación relativamente alejada del Presbiterio y el Altar, pero insertada en el recorrido del deambulatorio denominado Claustro, -a cuyo uso procesional y de oración, mencionado en los Albumes y confirmado por la disposición de edículos en las esquinas dedicados a las virtudes cardinales y vinculados al rezo de témporas, ya hemos hecho alusión-, su consideración como espacio de de servicio es notoria sin perder un ápice de su dignidad arquitectónica.

\footnotetext{
${ }^{391}$ Cf. Album de la Sagrada Familia de 1929. P.22. Vease también el dibujo por ordenador de la estructura del edificio de las Sacristias que realiza el equipo liderado por el profesor de la UPC Josep Gómez Serrano y que se reproduce junto a la imagen de la maqueta restaurada.
} 

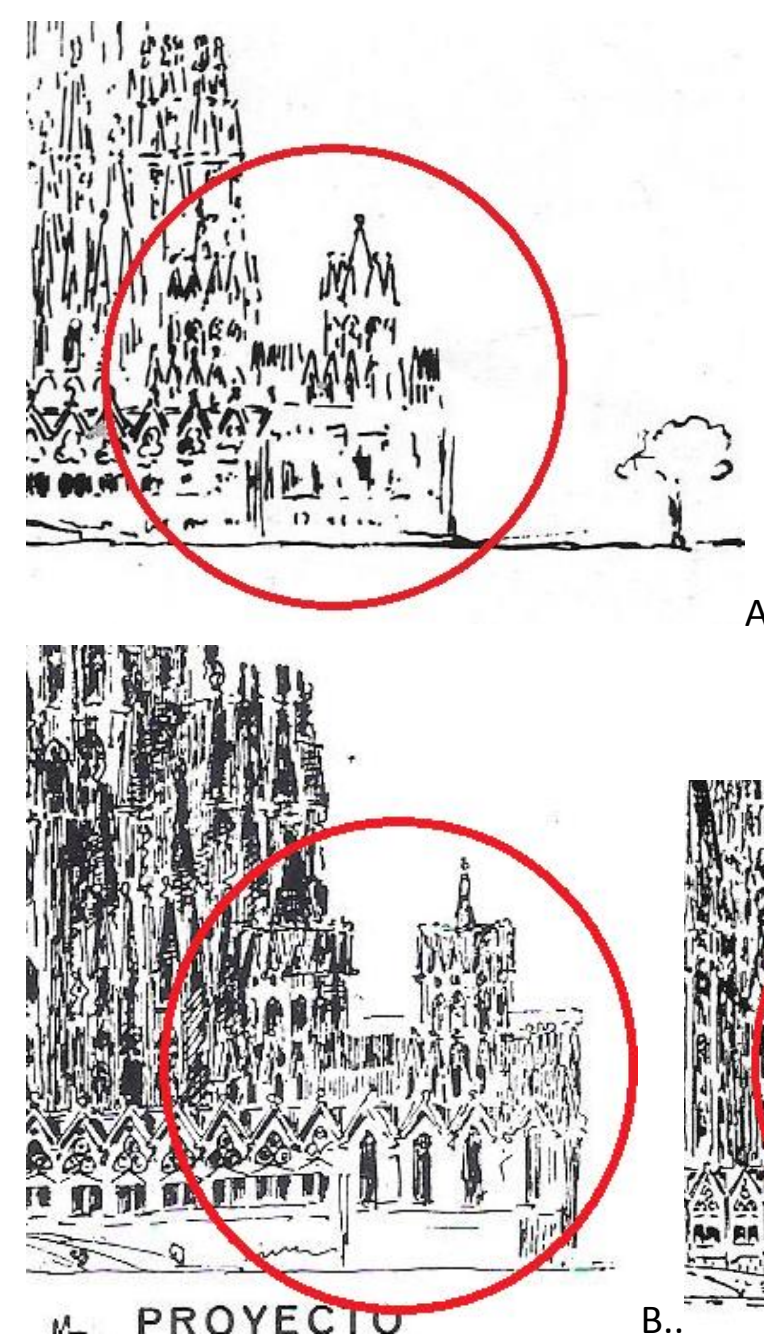

A

Cubrición de las Sacristias. A en el dibujo de Joan Rubió publicado en 1906. B en: Fuente: Torii, T. (1983) El mundo enigmático de Gaudí. Madrid. Instituto de España.

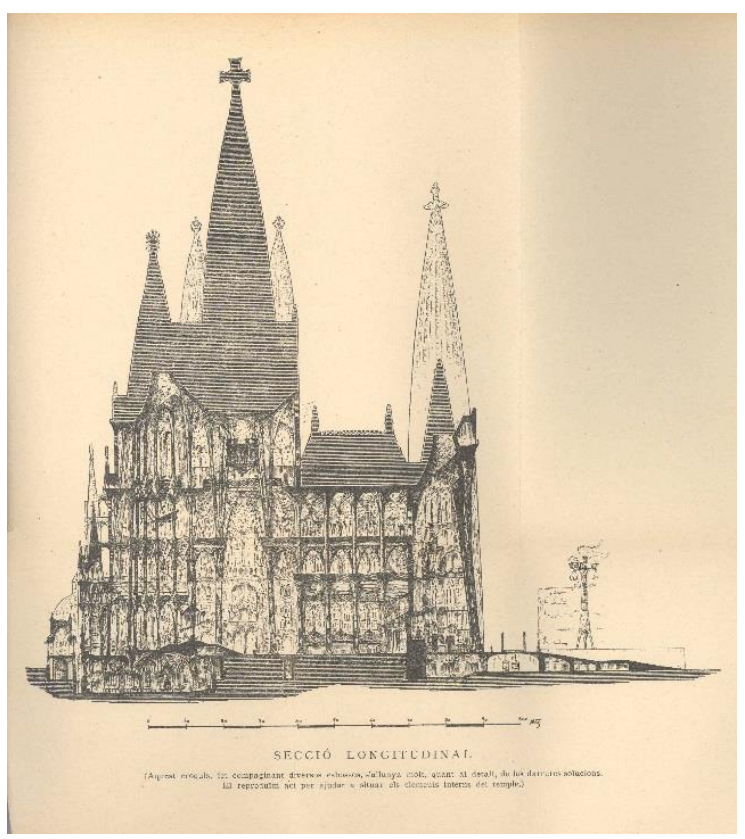

Sección publicada en el Pro el 1-05-1917. Cúpula y linterna de Sacristias. Fuente: Archivo de la Sagrada Familia. 
Una sacristía exclusivamente pensada para resolver la funcionalidad eucarística no tiene sentido ubicarla en un lugar ciertamente alejado de la nave litúrgica según la tradición tridentina. Por esa razón se preconizaba, especialmente a partir de las iglesias jesuíticas barrocas, una ubicación inmediata al presbiterio y transepto de las iglesias. Además, sus dependencias eran idóneas para la custodia de los enseres litúrgicos, las ofrendas, etc. Sólo parece tener sentido este relativo alejamiento cuando se quiere realzar la dignidad propia de este espacio -dedicado a la oración, el recogimiento y el revestimiento de los ministros ordenados que han de presidir la celebración litúrgica- y cuando su funcionalidad está ligada también a otros espacios, usos y funciones, como es el caso del Claustro y quizá de la Cripta, en cuyos diferentes niveles cabrían también otros usos dentro del ámbito eclesiástico: alojamiento, custodia de enseres litúrgicos, etc. Sin menoscabo, pues, de la proximidad y funcionalidad, se persigue resaltar las cualidades de cada recinto mediante su autonomía constructiva y la obligada procesión que marcaba en aquel tiempo el Ceremonial de los Obispos para las misas solemnes. La sacristía mantendrá pues una cierta distancia en beneficio de su propia configuración y uso para las diferentes acciones, oficios, instrucciones, etc. que pueden darse en la iglesia. El deambulatorio de las naves, el claustro, la comunicación de las capillas con el exterior y con las naves, la ubicación de las sacristías entre estas y el claustro, etc. dan idea de una gran variedad de itinerarios y flujos diversos según las celebraciones litúrgicas y la admisión plena de los fieles a la celebración eucarística.

Otros espacios complementarios: Escuelas Infantiles, Talleres de Artes y Oficios, etc.

Gaudí concibe el edificio-iglesia con un sentido de modernidad que resulta hasta cierto punto intemporal, pues lo plantea volviendo a los orígenes. Su composición es la de una edificación plurifuncional ordenada jerárquicamente y estructurada según el espíritu de la Liturgia Católica entendida en su acepción más verídica y amplia, con la visión de la renovación emprendida en los albores del siglo XX por el Movimiento Litúrgico aplicada a la interpretación de las disposiciones puntuales del Ceremonial de los obispos y Manuales de su tiempo. De ahí que uniendo la acción social y la función de enseñar que emanan del primer Código de Derecho Canónico (código pio-benedictino de 1917), Gaudí se plantee dar instrucción en un edificio cuya temporalidad y sencillez de medios no son obstáculo a su imaginativa solución estructural que se ha convertido en un emblema más del proyecto.

Aunque no es objeto de esta Tesis el análisis del edificio de las Escuelas provisionales de la Sagrada Familia, si que merece, no obstante, reseñarse como otro Espacio complementario del proyecto en función de su singularidad dentro de la pluralidad de recintos y funciones que constituye el conjunto gaudiniano. El edificio del pabellón de 

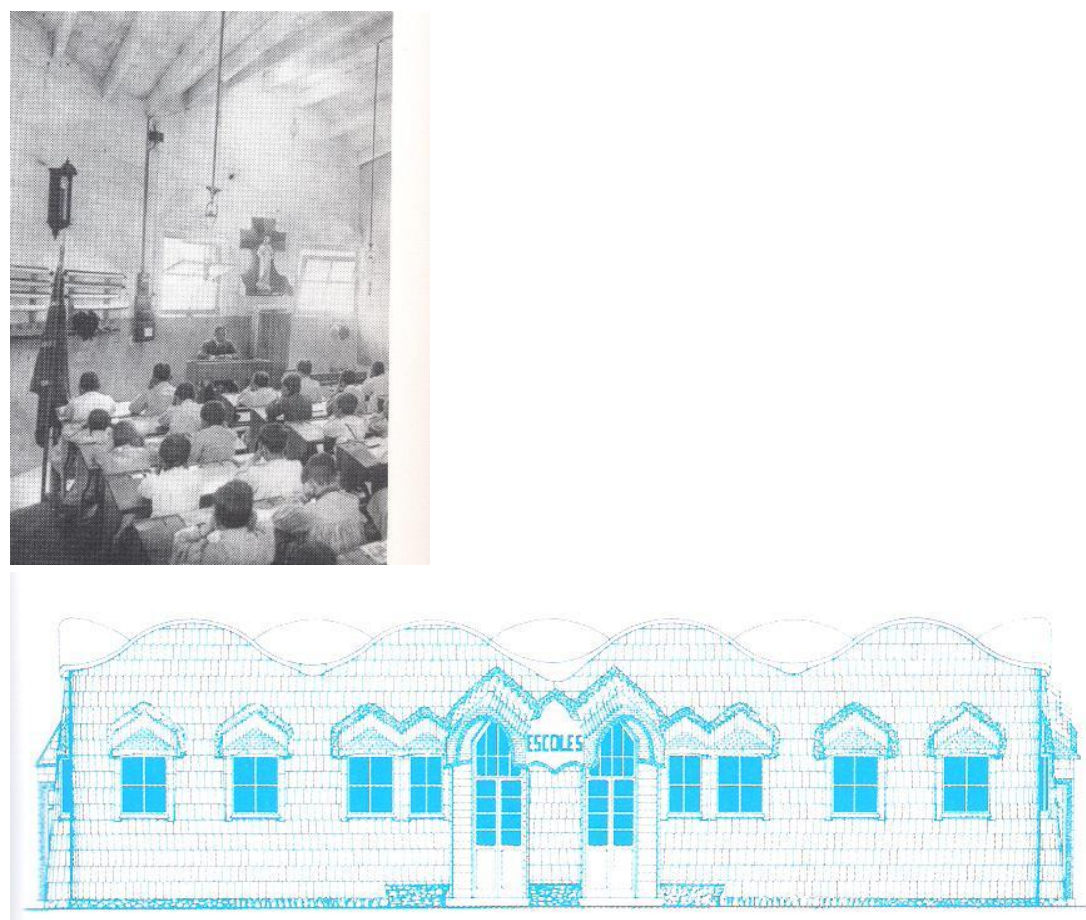

Izqda.: Interior de las Escuelas de la Sagrada Familia. Dcha.: Alzado principal Escuelas de la Sagrada Familia. Alzado Fuente: Bonet i Armengol, J. y AAVV. (2002) Espais Sagrats. Bareelona. Lunwerg.

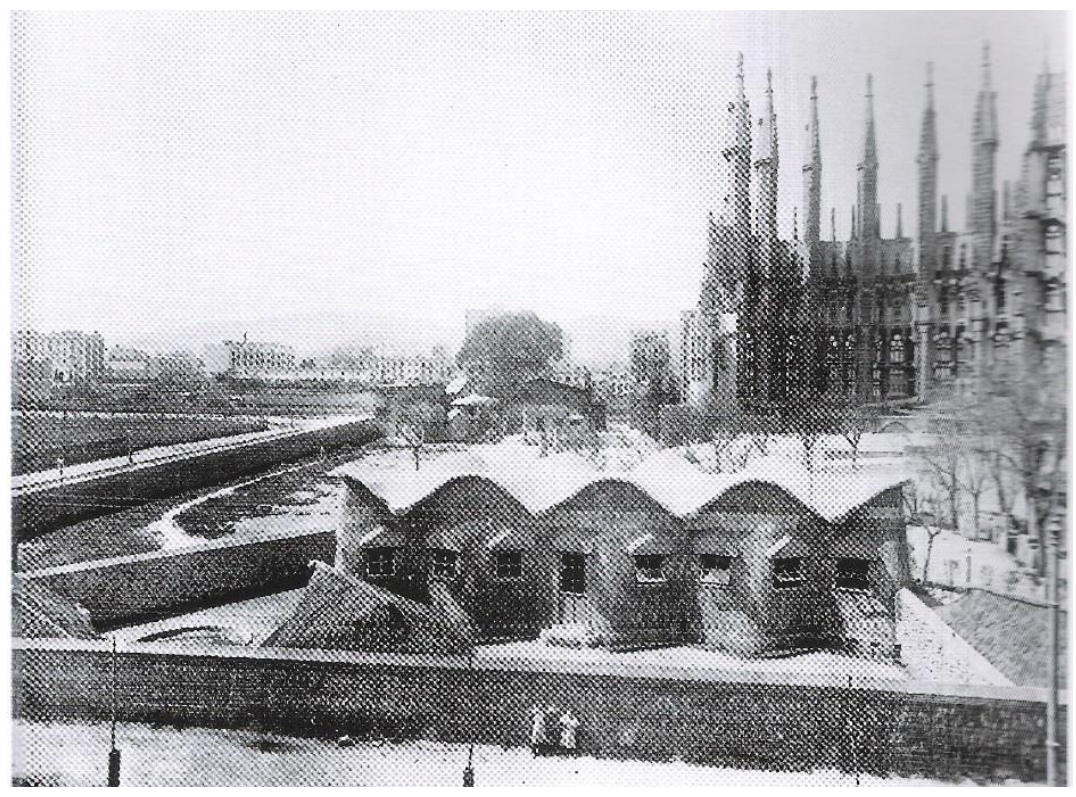

Fotografia alzado posterior Escuelas. Fuente: Martinell, C. (1967) Gaudí: su vida, su teoría, su obra. Barcelona. COACB. 
las Escuelas de la Sagrada Familia arranca en muy tempranas fechas (1909) dedicado a la formación de los hijos de los operarios que trabajaban en las obras del templo.

Su provisionalidad no lo hace desmerecer y su lenguaje tampoco, hasta el punto de seguir interesando a maestros del Movimiento Moderno como Le Corbusier o servir de inspiración para Enric Miralles y Benedetta Tagliabue en la cubierta del mercado de Santa Catalina en Barcelona.

Tampoco hay que dejar de mencionar la previsión de otro espacio de servicio en las galerías dedicadas a Escuelas de Artes y Oficios, que ocupando el nivel inferior del claustro $^{392}$ se abren a usos complementarios como sería una Escuela y Taller de restauración artística, previéndose la conservación del edificio y de sus elementos móviles.

392 Cf. Album de la Sagrada Familia de 1914. P.11: "Correspondiéndose con este claustro, y a manera de semisótano, habrá unas galerías -en parte ya construidas- que servirán para Escuelas de Artes y Oficios. 

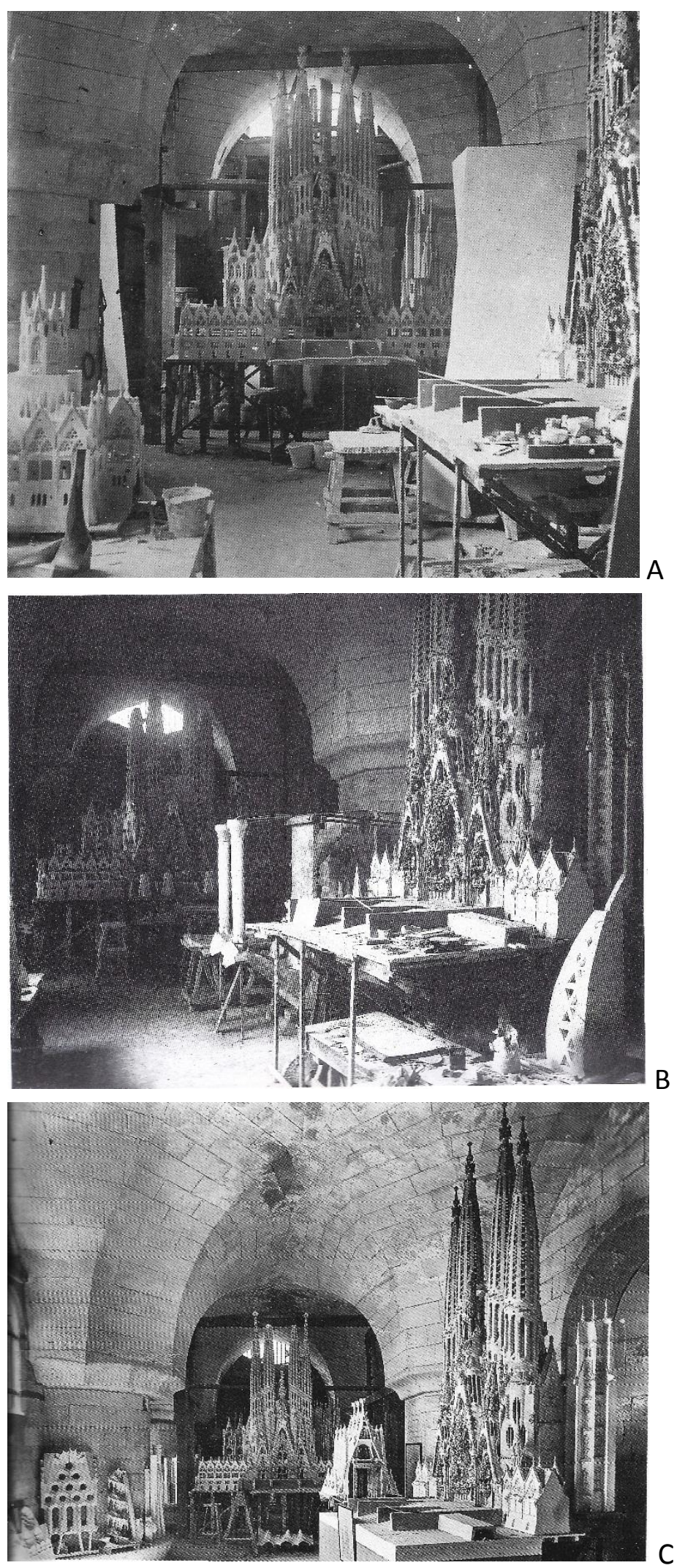

Fotografias del Taller de Maquetas. A: 1917, según el Archivo Mas. B: 1923, publicada el 7-03-1923 en la Hormiga de Oro. C: 1930, publicada en el Propagador el 1-09-1930. Fuente: Torii, T. (1983) El mundo enigmático de Gaudí. Madrid. Instituto de España. 


\subsection{Elementos que estructuran el espacio litúrgico de la Sagrada Familia:}

Se ha planteado la dimensión litúrgica de la Sagrada Familia basándonos en el pensamiento gaudiniano ${ }^{393}$, en los estudios realizados con anterioridad y en el análisis de su proyecto desde el dialogo de la Arquitectura-Liturgia, de tal manera que encontramos fundamentos para plantear la configuración del proyecto arquitectónico a partir de la idea conceptual que se tiene del espacio celebrativo. Identificados los diferentes recintos que intervienen en ella y cómo interactúan entre sí, corresponde plantearse qué elementos del proyecto utiliza Gaudí para llevar a la práctica su idea del espacio celebrativo cristiano. Desde este dialogo entre Arquitectura y Liturgia tres son los elementos primordiales que estructuran el lugar arquitectónico de culto cristiano:

- El sistema sustentante, que lo sitúa en el topos, lo erige y configura como atemperación del medio físico dotándole de una estabilidad y una forma que es única para cada iglesia y que dialoga con las personas, en cada celebración, y con el medio físico en el que se sitúa, como locuaz testigo de la intervención humana en él. Esta tectónica de la iglesia es primordial que discurra por cauces técnicos coincidentes con todo lo que representa la asamblea litúrgica en la Iglesia.

- El acondicionamiento del Aula litúrgica propiamente dicha, como el lugar donde se reúne la asamblea cristiana para celebrar comunitariamente la filiación divina -que se expresa en la liturgia de los sacramentos, oración comunitaria y otras acciones eclesiales- y cuyo confort espiritual depende también en gran medida de la materialidad del recinto. De esta manera, y aún cuando el Cristianismo parte de la consideración del lugar de culto como sagrado, no por sí mismo sino por lo que celebran las personas y su misma convocación, el simbolismo del espacio arquitectónico y su dimensión figurativa, el confort lumínico y térmico, la acústica de la palabra y del canto, y aún su mismo mobiliario litúrgico, contribuyen notablemente a la bondad de la percepción espiritual del hecho religioso.

- La dimensión comunitaria de la esperanza que anhela todo hombre en su vida, sea en el ámbito civil o de la fe cristiana, -razón por la cual el lugar el edificio iglesia tiene vocación de espacio público abierto a la sociedad humana- precisa del dialogo urbano del lugar de convocación elegido, que se hace ver, acoge y le acompaña como hito de primera magnitud social, en contraposición a una noción ancestral del espacio religioso sagrado como puro y cerrado en sí mismo, aislado del espacio circundante profano.

${ }^{393}$ Cf. Puig Boada, I. (1981) El Pensament de Gaudí: compilació de textos i comentaris. Barcelona. La Gaya Ciencia. P. 118: "En els temples tot ha d'ésser ponderat i regulat per les sàvies lleis de la litùrgia, sense adulteracions." 


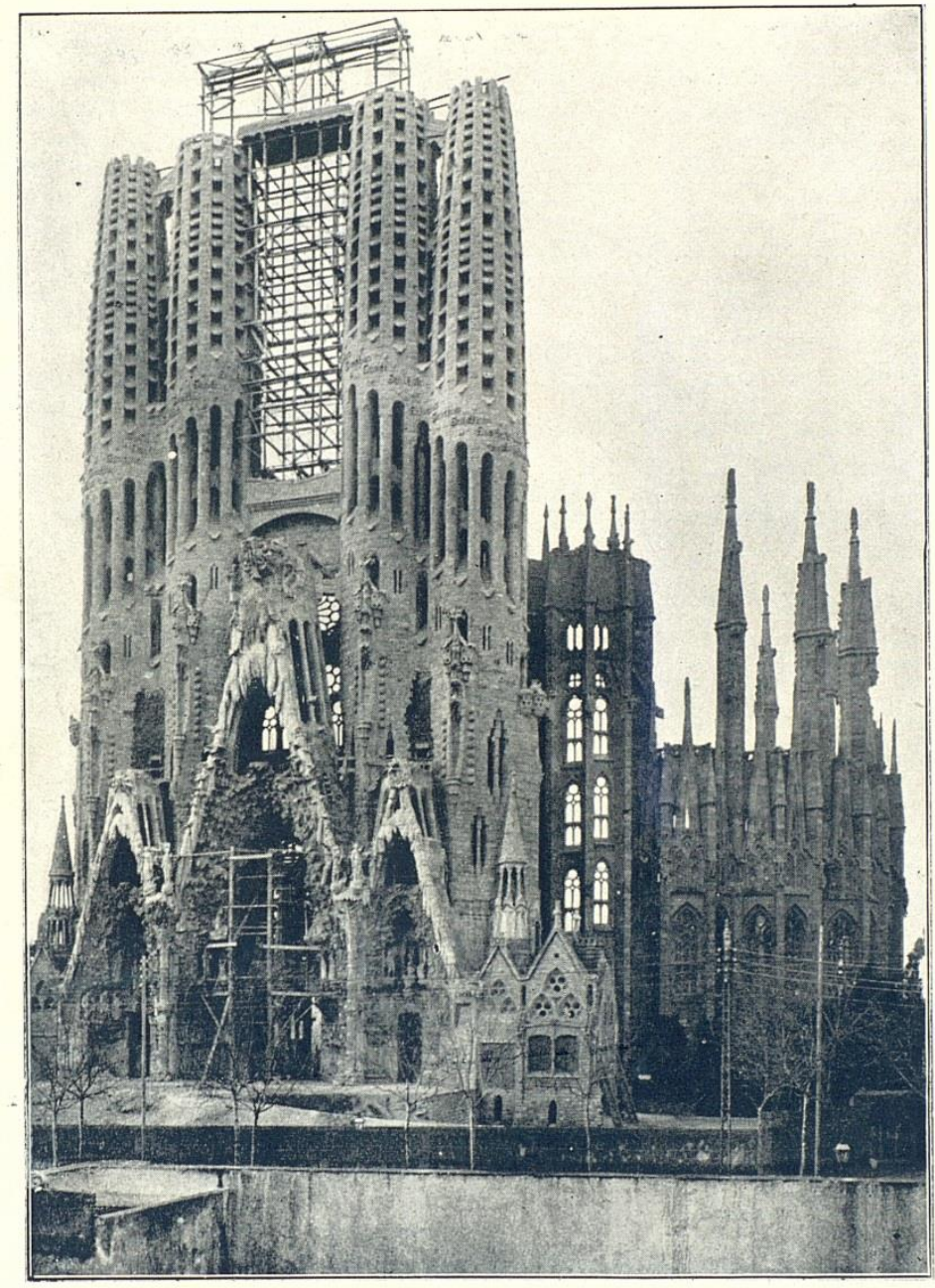

Fatxada Naixement, escala $\mathbf{i}$ absis, vista exterior.

Fachada del Nacimiento, escalera y ábside, vista exterior.

Album de 1915. Estado de las obras. Fuente: Arxiu de la Sagrada Familia.

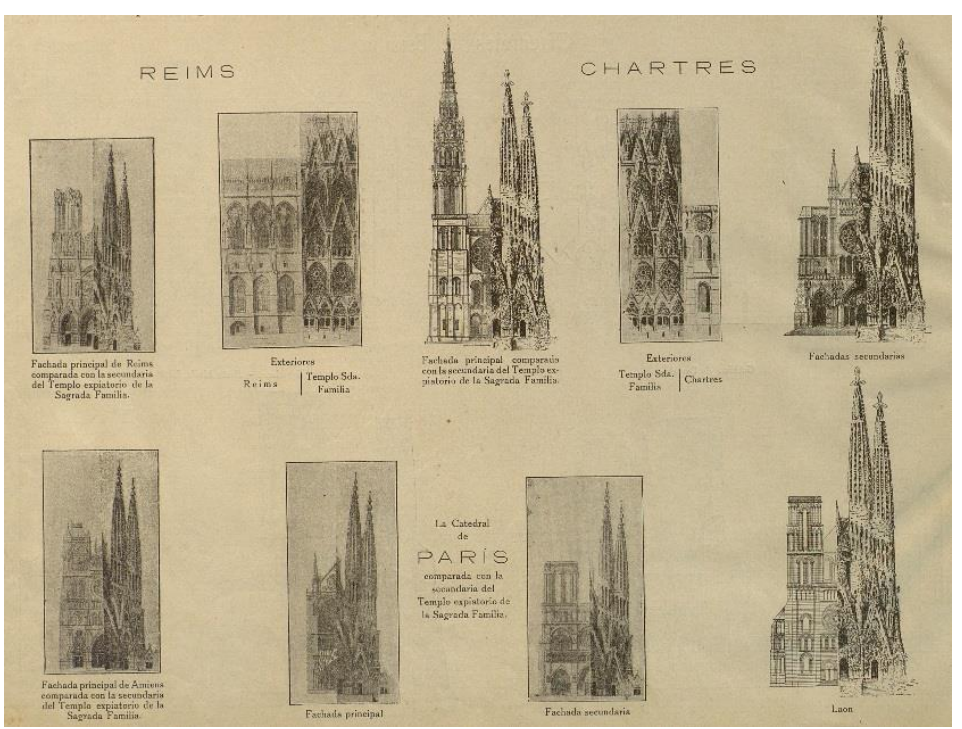

Album de 1917. Comparación de fachadas con catedrales góticas. Fuente: Arxiu de la Sagrada Familia. 


\section{a) El Sistema sustentante.}

\section{Estabilidad y sistema estructural en la Sagrada Familia.}

El posicionamiento que Gaudí se hace respecto de la estabilidad y el sistema estructural de una iglesia hunde sus raíces en su pensamiento arquitectónico y vital, pues no en balde se puede rastrear su inquietud en los escritos y reflexiones que jalonan las diferentes etapas de su vida. Nos referimos a todo el discurso teórico-práctico que se despliega a lo largo de sus obras emergiendo en el proyecto de la Sagrada Familia, en su configuración más completa, con una potencia e imaginación tal que le confiere un atractivo sorprendente. Para estar en condiciones de apreciar esta aportación gaudiniana a la arquitectura eclesial resulta imprescindible realizar primeramente una breve aproximación cronológica y conceptual, que consideramos asentada en tres planteamientos: los Manuscritos de Reus, como corpus conceptual del pensamiento arquitectónico de Gaudí probablemente escrito entre los años 1873 y 1883; las reflexiones y maduras opiniones, muchas veces sobre los mismo temas, del Gaudí de madurez, recogidas y anotadas por sus asistentes y colaboradores más inmediatos como Rafols, Bergós, Puig Boada y Martinell ${ }^{394}$; La visión mística del espacio celebrativo, que parece emerger hacia los años 1914-1915 en el proyecto de la Sagrada Familia, una vez que se interrumpen las obras de Santa Coloma y Mallorca y concentra toda su atención en él.

Primer planteamiento: Los Manuscritos de Reus.

El primer testimonio que refleja la inquietud de Gaudí por la sustentación y estabilidad de una iglesia lo encontramos en estos escritos sobre Ornamentación, el Templo y otras cuestiones, dentro de la alta consideración que otorga a los edificios públicos y religiosos cuya funcionalidad (celebraciones litúrgicas y oficios religiosos diversos, predicaciones. sermones, conferencias o catequesis, etc.) se plantea en completa armonía con el sistema constructivo. Es importante señalar como estas primeras ideas, escritas de su propia mano intenta llevarlas a la práctica en diversas obras, puesto que su planteamiento siempre es de carácter eminentemente práctico.

\footnotetext{
394 Según Bassegoda (Introducción a la edición facsímil de 2006 del libro de Ràfols, Gaudí, 1929), Ràfols entra en contacto con Gaudí en el periodo 1913-1916, trabajando en la Sagrada Familia hasta la muerte de Gaudí en 1926. En otro apartado de esta Tesis ya se ha hecho alusión a la declaración de Martinell de su toma de contacto con Gaudí en 1914.
} 


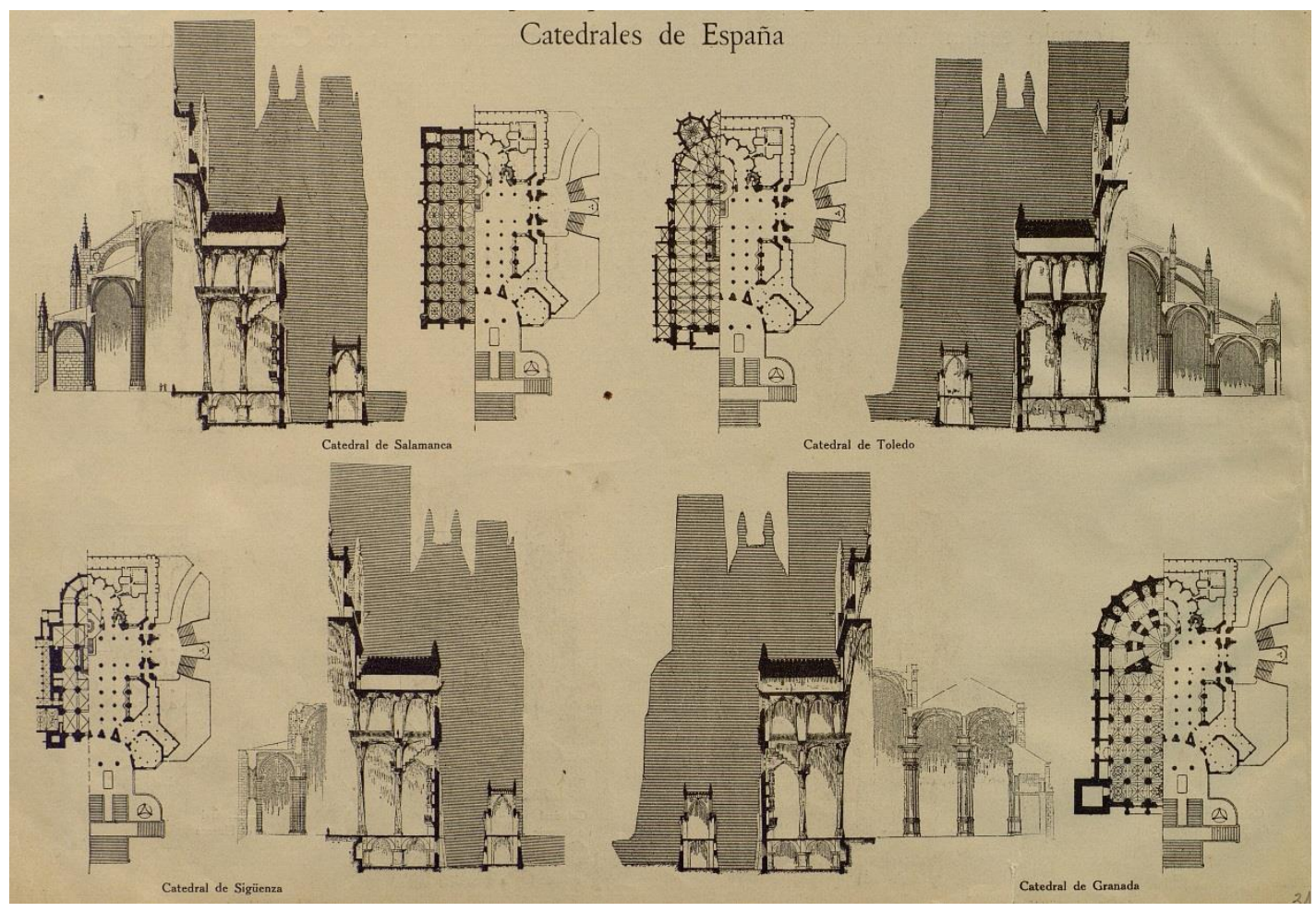

El Templo expiatorio de la Sagrada Familia y la Catedral de Colonia

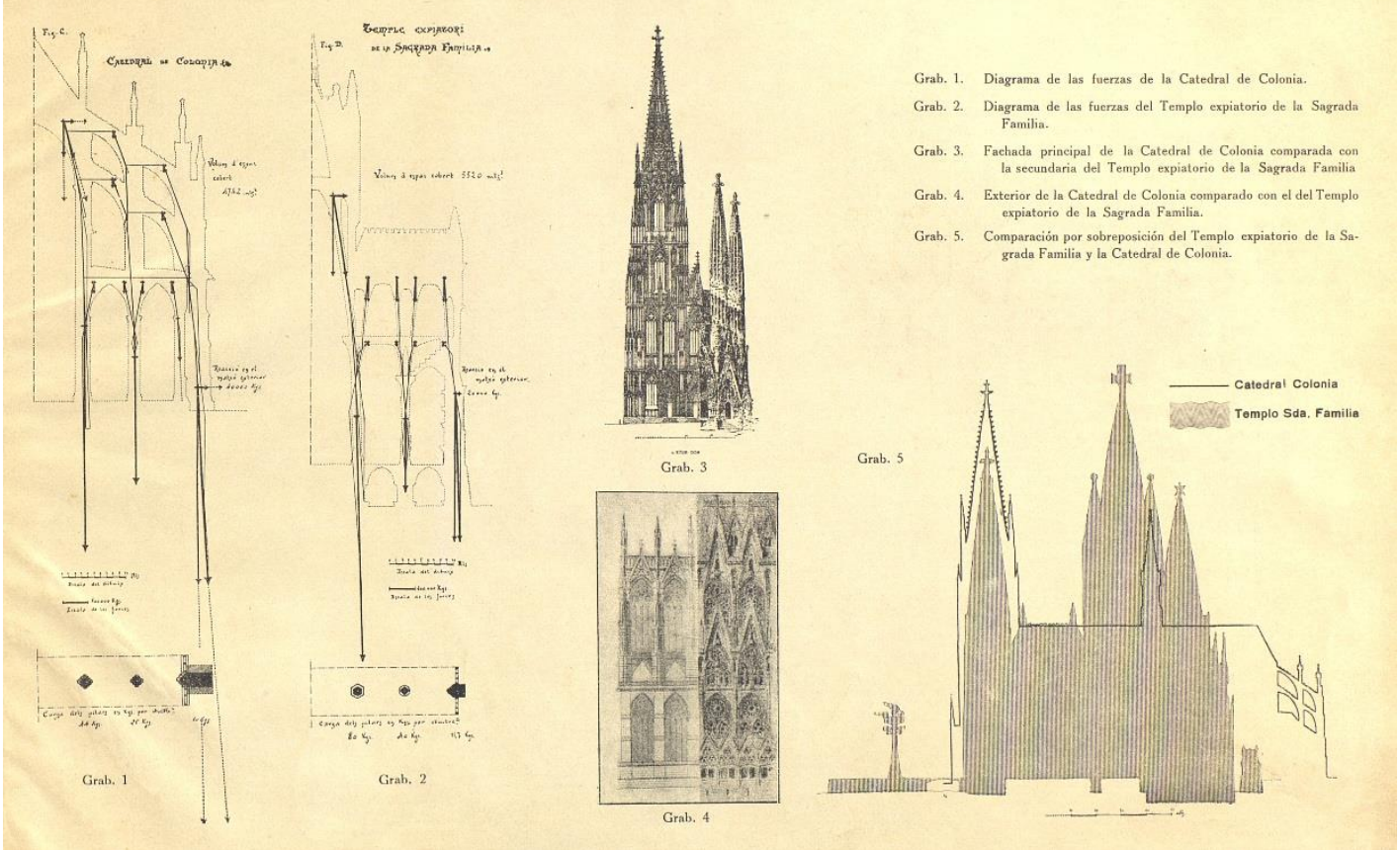

Album de 1917. Arriba: Comparación de planta y sección con algunas catedrales de España. Abajo: Comparación del sistema de transmisión de esfuerzos en la estructura de arbotantes de la catedral de Colonia y en la estructura diseñada por Gaudí para la Sagrada Familia. Fuente: Arxiu de la Sagrada Familia. 
En estos escritos se percibe cómo Gaudí se replantea el edificio eclesial y lo concibe partiendo del interior al exterior en todos los sentidos. Si su razonamiento tectónico se remonta a los orígenes de la construcción y de esta manera su razón primera es la estabilidad de la cubrición de una planta y los medios a utilizar para ello, diciendo: "... la forma esférica inscrita en un cuadrado, dando por resultado cuatro pechinas, y éstas sostenidas por cuatro pilares, es una forma sumamente aérea. ${ }^{1395}$, este planteamiento no se queda en el plano teórico sino que está plenamente ligado al carácter del edificio y su funcionalidad.

Desde esta situación valora la cúpula como un sistema eficaz para la cubrición de un espacio cuadrado teórico de aplicación a una iglesia, sea cual sea su tamaño, como fruto de una triple herencia: su conocimiento de la histórico de la Arquitectura a través de la analítica contemplación de fotografías y grabados, la consciencia de lo que representa la cúpula en la simbología cristiana, y la constatación de su idoneidad para conferir estabilidad al espacio subyacente. Por tanto, asumiendo el papel simbólico que la tradición ha otorgado a la cúpula con referencia a la expresión de la divinidad extrae de ella su utilidad para resolver la cubrición de cualquier espacio que pueda ser estructuralmente modulable, así como su idoneidad para hacer desaparecer una pesadez y materialidad excesivas. Ya tenemos, pues, dos factores importantes en el pensamiento estructural de Gaudí que este aplica a lo que debe ser la construcción de una iglesia: la modulación estructural según la bóveda y el papel que en ella puede desempeñar la cúpula esférica para crear espacios cuya luminosidad les dota de una fuerte componente de inmaterialidad al disminuir la pesadez de las formas macizas.

\section{2a planteamiento: Gaudí nos habla.}

En la madurez del ejercicio profesional Gaudí puede replantearse la trasmisión de las cargas en una estructura mediante el estudio de las curvas de presión y contenciones de fuerzas, sustituyendo la intuición y práctica de épocas pasadas por un procedimiento analítico y experimental que narra a Martinell y que sintéticamente consistiría en: primero, el cálculo de cargas suponiendo unos pesos para buscar el funículo, después el revestimiento del funículo encontrado con las formas y materiales a emplear, cuyos pesos se vuelven a revisar llegando a variar ligeramente dichos funículos, como método aproximativo continuo con el que llegar a encontrar la forma lógica nacida de las necesidades. ${ }^{396}$

395 Cf. Mercader, L. (2000) Antoni Gaudí: escritos y documentos. Barcelona. El Acantilado; Puig Boada I. (1981) El Pensament de Gaudí: compilació de textos i comentaris. Barcelona. La Gaya Ciencia.

396 Cf.; Puig Boada I. (1981) El Pensament de Gaudí: compilació de textos i comentaris. Barcelona. La Gaya Ciencia. P. 207 y Martinell Brunet, C. (1950) Gaudí i la Sagrada Familia explicada per ell mateix. Barcelona. Aymá. P. 61 
Santa Coloma es ejemplo primordial de esta experimentación estructural y la Sagrada Familia muestra preeminente de su reelaboración y desarrollo en un edificio de grandes dimensiones cuya planta dada ha de adecuar. Pero también los capiteles fungiformes del Palacio Güell, los arcos y bóvedas del Palacio episcopal de Astorga, las columnas inclinadas y la modulación del Parque Güell, etc. son edificios construidos que analizados por su pensamiento sintético- disponen de un amplio bagaje práctico susceptible de ser reflexionado con sus asistentes y colaboradores, tal y como nos muestra Puig Boada mayormente ("Gaudí ens parla", dentro de El Pensament de Gaudí, 1981).

Se puede decir que a partir de los estudios e interpretaciones de Puig Boada respecto del proyecto y maqueta funicular para la iglesia de Sta. Coloma, continuados y más tarde desarrollados por Tomlow, lo enunciado un dia lejano en sus escritos adquiere carta de naturaleza real. Aunque este proyecto presenta otros muchos aspectos además de su sorprendente planteamiento estructural, muchos de ellos relacionados con la concepción del lugar para la asamblea y la simbología cristiana, se comprenden las palabras de Gaudí al reconocer en él un eslabón importante en la evolución del proyecto de una iglesia, que él veía como continuación de la arquitectura bizantina.

No obstante, como señala el propio Gaudí, el sistema funicular es sólo una herramienta, -en la arquitectura no todo es estabilidad-, y el proyecto está sujeto a condiciones estéticas, formales y funcionales previas debido a lo cual hay que satisfacer también sus necesidades de capacidad, iluminación, relación ordenada de los servicios y funciones, etc. en definitiva la composición del proyecto. ${ }^{397}$ De análoga manera que el sistema funicular para la trasmisión de cargas le resultaba un poderoso aliado, preconizaba la sencillez, distinción y claridad de las formas geométricas regladas para su utilización en elementos constructivos por su relativa sencillez de ejecución posibilita la continuidad estructural, claridad de formas y estabilidad constructiva, preconizando su utilización para los espacios de culto. Al mismo tiempo juzga estas superficies -paraboloides, hiperboloides y helicoides- como idóneas para la ornamentación por su sencilla expresividad y con condiciones muy favorables para la acústica y la iluminación. Tenemos, pues, un segundo elemento a experimentar en la estructura de una iglesia (después de juzgar la idoneidad teórica de los polígonos funiculares para la concepción analítica de la transmisión de las cargas de una estructura): la construcción de superficies regladas a partir de materiales tan tradicionales como el ladrillo.

\footnotetext{
${ }^{397}$ Cf.; Puig Boada I. (1981) El Pensament de Gaudí: compilació de textos i comentaris. Barcelona. La Gaya Ciencia. P. 155-156: "Pretendre que els funicles donin les formes d'arquitectura és una puerilitat, perque només constitueixen un mitjà de verificació o de comprobació de l'estabilitat, que s'utilitzarà en el momento convenient.....Seria bo de veure com el funicularis buscarien les corbes de pressions en els monuments, com a Santa Sofia de Constantinoble, per exemple.
} 
Su preocupación se centra pues en garantizar las mejores condiciones técnicas posibles en la transmisión de los esfuerzos debidos a la carga estructural, huyendo del estereotipo de una clasificación en soportes verticales y dinteles horizontales que no le preocupa en un edificio singular como es una iglesia -considera el sistema sustentante como un todo continuo a imitación de la Naturaleza en la que, advierte, no hay esa distinción- ${ }^{398}$, evitando los puntos débiles de las uniones. Y ésto sólo puede llevarlo a cabo libremente y sin ataduras en una iglesia o en un edificio público, pues ambos reúnen las condiciones de singularidad del espacio interior que permiten su puesta práctica. El camino de la edificación pública quedó truncado en los entresijos del Ayuntamiento barcelonés y las exposiciones, por lo que la única vía que queda expedita es la arquitectura eclesiástica, en la cual sólo podrá terminar la plasmación de sus investigaciones sobre la estabilidad estructural y las formas geométricas en la Sagrada Familia.

En esta misma Tesis se ha mencionado los puntos de contacto del espacio interior de la Sagrada Familia con otras soluciones históricas del gótico mediterráneo en sus versiones eclesiástica -Sta. Maria del Mar, catedrales de Mallorca, Barcelona, etc- como civil Lonjas de Valencia y Mallorca-, e incluso con las hallenkirche del gótico germano. Sin embargo el interés de Gaudí se vuelca en diseccionar esos ejemplos históricos concretos que llaman su atención, sintetizando sus problemas y defectos, buscando soluciones radicales basadas en la perdurabilidad de la vida útil del edificio. Citando un antiguo proverbio -divide y vencerás- se muestra partidario cubrir el espacio interior de la Sagrada Familia mediante numerosos soportes que dividan las bóvedas hasta disponer porciones o módulos cuyos esfuerzos sean fácilmente absorbidos y trasmitidos, según explica a Bergós ${ }^{399}$. Su método parte de un conciso discurso conceptual que amplia mediante la experimentación de nuevas soluciones constructivas para las que utiliza materiales tradicionales imaginativamente dispuestos u otros nuevos como el hormigón armado o el hierro.

Si en el Cuaderno de Notas intuía el papel a desempeñar por los soportes aislados de hierro posteriormente considera la construcción con hormigón armado como la más racional porque todos los edificios están sometidos a vibraciones y movimientos difíciles de analizar -sobre todo con los medios disponibles en su época- (dilataciones,

\footnotetext{
398 Cf.; Puig Boada I. (1981) El Pensament de Gaudí: compilació de textos i comentaris. Barcelona. La Gaya Ciencia. P. 147-152: "Les formes continues són les perfectes. Usualment es la distinció entre elements sustentants $i$ sostinguts amb evident inexactitud, ja que dels uns $i$ dels altres n'hi ha que són alhora sostinguts i sustentants."....."Al món no hi ha una sola columna que sigui vertical..."

399 Cf. Bergós, J. (1974) "Conversaciones de Gaudí con Joan Bergó", en revista Hogar y Arquitectura, que recoge Puig Boada (1981) en su libro El Pensament de Gaudí: compilació de textos i comentaris. Barcelona. La Gaya Ciencia. P. 152.
} 


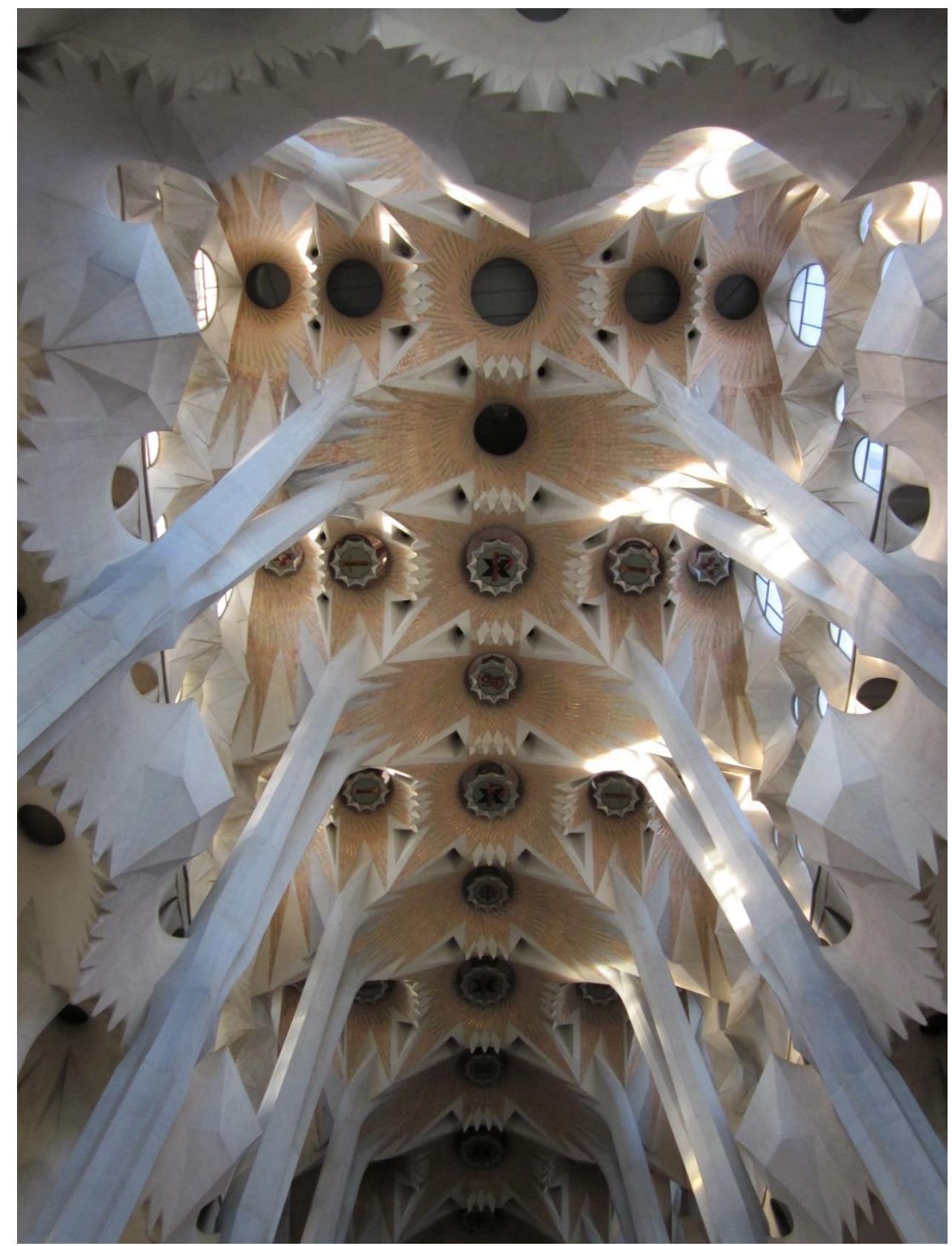

Bóvedas de la nave mayor. Fuente: fotografía del autor 
compresiones, flexiones...) y por tanto es la armadura de hierro la que ha de tener un papel primordial. 400

Por tanto, cuando Gaudí tiene claro que en la Sagrada Familia no habrá contrafuertes y así se lo manifiesta a Martinell, explicitando la técnica de trabajo de los modelados y maquetas, no lo hace con carácter teórico sino planteándose las columnas sustentantes del cimborio principal de hierro sin revestir, a causa de las grandes cargas a soportar y del excesivo espacio que se ocuparía del templo con otro material. ${ }^{401}$ ¿Por qué abandona Gaudí esta idea para las columnas del cimborio principal? Martinell (Gaudí: su vida, su teoría, su obra, 1967) nos refiere que en 1914 con ocasión de un déficit extraordinario en la administración de las obras y ante una alarmante falta de limosnas que amenazaba con paralizar la construcción, Gaudí se opone a ello y, paralizada la obra de Sta. Coloma, decide estudiar a fondo el problema estructural y poner en práctica la recaudación personal de donativos para las obras (en ese momento concibe también el plan de enterramientos como panteón de familias próceres que a cambio de que legasen importantes sumas a la construcción del edificio, así como un programa de visitas técnicas a las obras que el mismo conduciría y explicaría).

Aunque Carlos Fernández Casado analizando modernamente el comportamiento de la estructura gaudiniana opina que el esfuerzo realizado por Gaudí es ucrónico y utópico: por cuanto en ese momento ya se impone la construcción en hormigón armado en sustitución de la piedra y, por otra parte, resulta incapaz para dar una adecuada respuesta a la Inevitable aparición de esfuerzos de transversales de tracción como el viento y las diferentes situaciones o estados intermedios por los que pasa una estructura ${ }^{402}$, eso no impide valorar en su justo término el proyecto gaudiniano.

${ }^{400}$ Cf. Idem. P. 154: "La construcción armada és la més racional, perque tots els edficis están sotmesos a vibracions i a moviments difícils d'analitzar (dilatacions, compressibilitats). Tot aixó vol dir flexió, i, per tant, armadura."

${ }^{401}$ Cf. Martinell, C. (1950) Gaudí i la Sagrada Familia explicada per ell mateix. Barcelona. Aymà. P.59-60. Que recoge Puig Boada (1981) en su libro El Pensament de Gaudí: compilació de textos i comentaris. Barcelona. La Gaya Ciencia. P.209: "La construcción del modelat del Temple no és un caprici, sinó que serveix d'estudi, puix en ell han d'esser resolts gairebé es mateixos problemas que al natural. Els peus drets tindrán la secció i dirección que resultin dels funicles. Les quatre columnas sustentants del cimbori serán de ferro, a cuasa del gran pes que hauran de sostener. Si fossin de pedra ocuparien massa espai, precisament al centre del temple. Aquests quatre peus drets de ferro aniran sense revestir d'altre material $i$ probablement pintats d'or."

402 Cf. Fernández Casado, C. (2002).“Gaudí visto desde la arquitectura del ingeniero”, conferencia inaugural del curso 1971-80 en la ETSAB, recogida en la Miscelánea Bassegótica VV.AA. Memoria del curso 1990-2000 Real Cátedra Gaudí. Barcelona. 


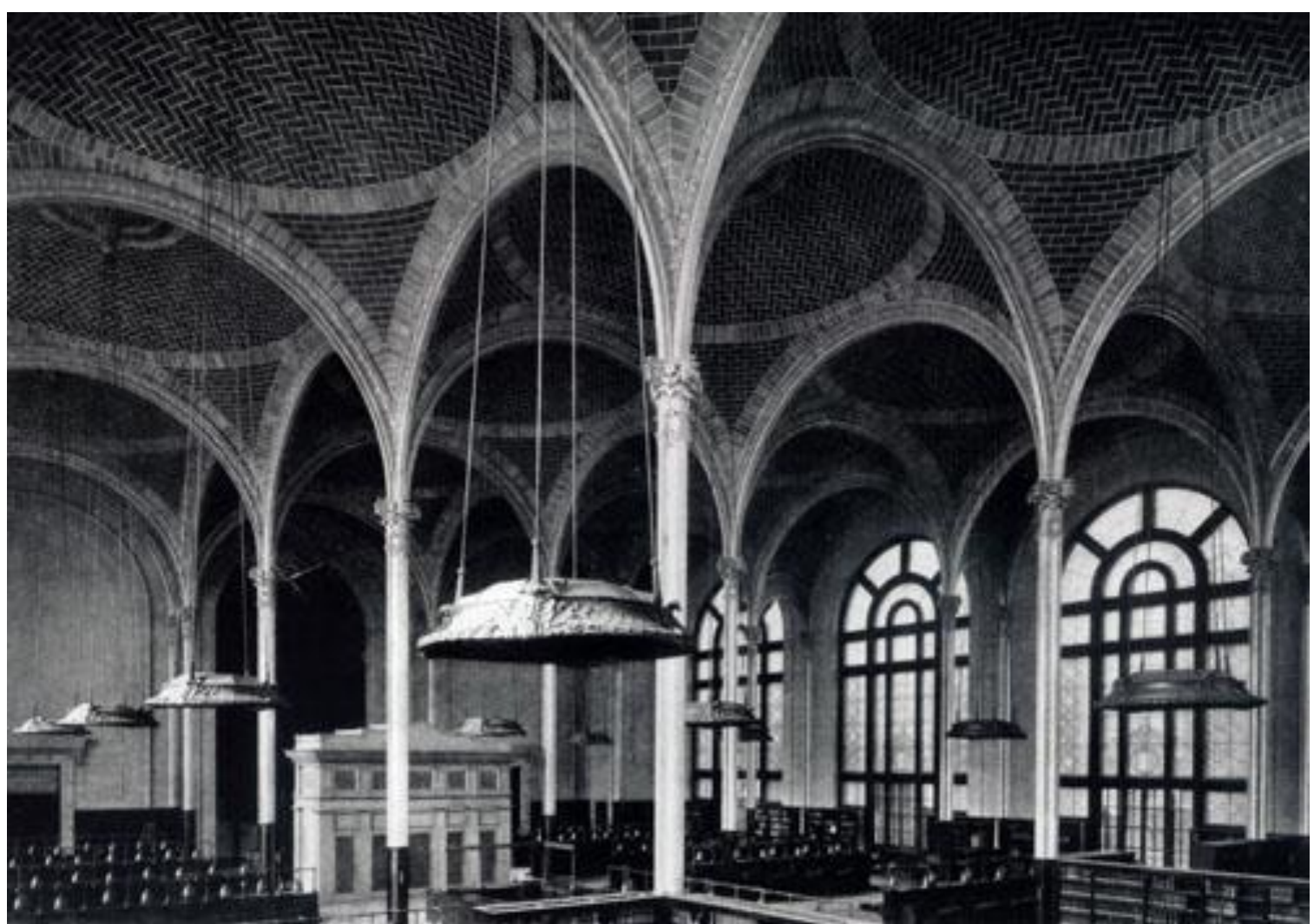

Biblioteca Pública de Albany, New York, USA (1908-1911). Realizada con el sistema de bóvedas de ladrillo plano patentado por Rafael Guastavino. Fuente: Garcia-Gutierres Mosteiro, J. (2002). “Implantación y aventura de las bóvedas de Guastavino en América", en Revista Menhir-Arquitectura, Construcción y Diseño. 2002, №5. Bilbao. Ed. Company. 
Josep Gomez Serrano y el equipo de la UPC que ha estado colaborando con la Dirección Técnica de las obras de la Sagrada Familia han puesto de manifiesto el conocimiento y utilización del hormigón armado por parte de Gaudí a la vez que han realizado su idónea representación y análisis por ordenador ${ }^{403}$. Gaudí no podía prever la normativa de cálculo actual, como es lógico, pero sí diseñar una estructura que, con los medios que tenía a su alcance, fuese posible perfeccionar por sus sucesores hasta el punto de viabilizarla completamente.

Lo cierto es que después de plantearse y desechar la utilización del hierro para las columnas principales opta por el hormigón armado e inicia un itinerario porque se da cuenta de sus posibilidades, y confía en el posterior desarrollo del proyecto comenzado, cuestión corroborada por la labor llevada a cabo por el Equipo de la Junta Constructora. ${ }^{404}$ Dibujada por ordenador, y desarrolladas las bóvedas con hormigón armado, la estructura se torna completamente rígida y en condiciones de asumir los esfuerzos horizontales. Seria de interés investigar el conocimiento y posible relación que pudo tener Gaudí con Rafael Guastavino en la Escuela de Arquitectura o en los primeros años de actividad profesional. Guastavino, difusor del empleo de la geometría aplicada a las bóvedas de ladrillo plano en grandes edificios públicos - sistemas que éste patentó años después en USA- aconsejó al Conde Güell en la construcción de su fábrica de Castellar de Nuch donde inició la fabricación de cemento portland. ${ }^{405}$

Aunque Cardoner afirma que el segundo proyecto estructural lo introduce Gaudí a principios de 1920, apoyándonos en la información que nos da Martinell creemos que su aparición en escena es algunos años anterior. Señala Martinell que el 23 de enero de 1915 dieron comienzo las visitas a las obras, y él mismo se incorporó a ellas al objeto también de retomar la relación con Gaudí al que sólo había visto dos veces con anterioridad en la calle.

\footnotetext{
${ }^{403}$ Cf. Gomez Serrano, J. y AAVV. (2011) “Los primeros ejemplos de Gaudí con el hormigón armado", en Actas del Congreso de Historia de la Construcción. Santiago de Compostela. Gomez Serrano, J. y AAVV. (2008). Sagrada Familia XXI/Gaudí Ara. Barcelona. Edicions UPC.

${ }^{404}$ Cf. Cf. Burry, M., Espel, R., Faulí, J. y Gomez, J. (2014) Les naus de la Sagrada Familia. Els secrets arquitectònics d'una obra irrepetible. Barcelona. Mediterrània.

${ }^{405}$ Gaudí comienza comienza a estudiar en la Escuela de Arquitectura en 1873 y se gradúa en 1878 , siendo a partir de ese cuando a raíz de la exposición de Paris entra en contacto con Güell. Guastavino llega a Barcelona en 1861, comienza estudios como Maestro de obras y en 1866 comienza a trabajar como constructor y arquitecto antes de terminar sus estudios. En 1881, cuando se inaugura su teatro de La Massa en Vilasar de Dalt, llega a Estados Unidos.
} 


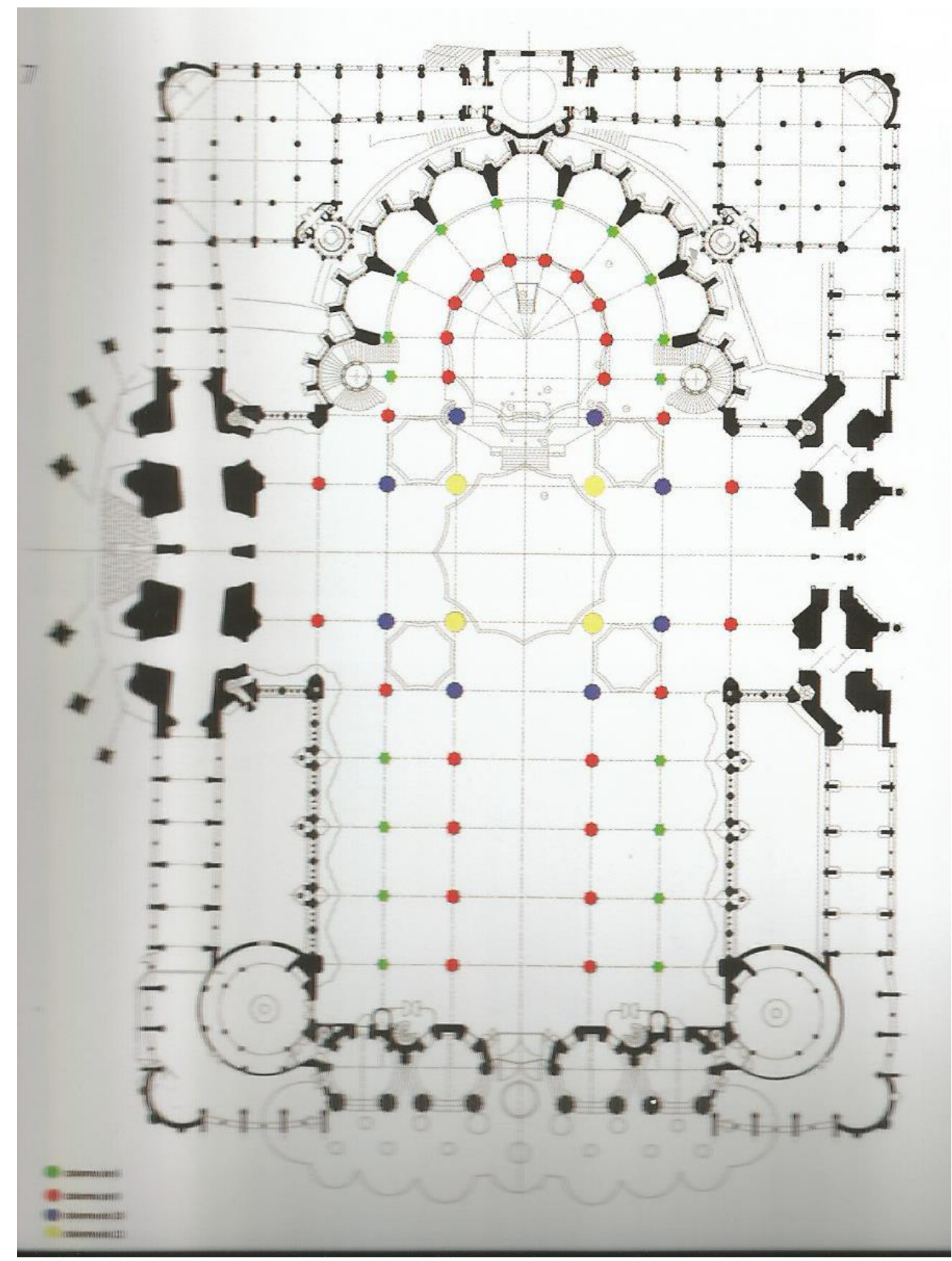

Columnas según no de aristas, diámetro y altura en la Sagrada Familia. Fuente: Burry, M., Espel, R., Faulí, J. y Gomez, J. (2014) Les naus de la Sagrada Familia. Els secrets arquitectònics d'una obra irrepetible. Barcelona. Mediterrània. P. 100

Es importante destacar esta fecha, pues a partir de la misma las 
Es importante destacar esta fecha, pues a partir de la misma las visitas de Martinell a Gaudí se generalizan en un año importante para el proyecto como es 1915 -año del congreso litúrgico de Montserrat al que asiste Gaudí, del primer álbum del Templo y en que muy probablemente se modifica la sección transversal y con ella aparece el sistema estructural arborescente por primera vez-, teniendo ocasión Martinell de presenciar la evolución de los pies derechos de base cuadrada en el crucero que pasan a ser columnas enroscadas en hélice. ${ }^{406}$ Menciona además que en 1916, año en que comienza a ejercer la profesión, decide sustituir en una obra suya los cuchillos de madera por arcos equilibrados que Gaudí había puesto en práctica, cuestión que vuelve a realizar en otro edificio en 1919. Así pues, teniendo en cuenta lo que dice Martinell y cómo desde 1914 Gaudí se había quedado únicamente con el proyecto de la Sagrada Familia en unos momentos de extraordinaria precariedad económica de las obras, tuvo tiempo de aplicar la experiencia adquirida en Santa Coloma y debió ser inmediatamente después de la finalización del congreso litúrgico de Montserrat pues ya desde el principio aparece ligada la nueva estructura a las cantorías.

Además, cuando Gaudí abandona la idea de los pies derechos metálicos lo hace para sustituirlos por un elemento de hormigón armado al que ha incorporado una forma inclinada y helicoidal. Si que se muestra partidario Cardoner (Evolucion de la obra de Gaudí, 1967) de la conjunción de cuestiones estáticas, acústicas y lumínicas como claves para la nueva geometrización del proyecto estructural. Es decir que se han fundido la técnica funicular, la geometría del paraboloide y el helicoide, las propiedades del hormigón, y como veremos más adelante el figurativismo de la iconografía cristiana.

3er planteamiento: Visión mística del espacio estructurante del aula litúrgica.

Gaudí tiene estudiada por primera vez la estructura completa de la Sagrada Familia hacia 1898, si hemos de creer a Ràfols, y esta solución goticista perdurará hasta 191314. ${ }^{407}$ Aunque las pruebas de los asientos que se habían proyectado en las bases de los pies derechos no resultan satisfactorias (Martinell, Gaudi: su vida, su teoría, su obra) hace su aparición la crisis en la fabricación y disposición de perfiles de hierro provocada por el elevado consumo de este material con destino a los países combatientes en la Gran Guerra, y si se quiere, el reducido número de realizaciones con este material en el campo de los espacios de culto tampoco anima demasiado a su utilización-, lo cierto es que hacia 1915 parece cambiar doblemente la tendencia constructiva del proyecto pues

\footnotetext{
${ }^{406}$ Martinell, C. (1967) Gaudí: su vida, su teoría, su obra. Barcelona. COACB. Pp.: 101-105.

${ }^{407}$ Cf. Ràfols, J.F. (2006) Gaudí. Ed. Facsímil de la edición de 1952. Primera edición 1929. Barcelona. Claret y Catedra Gaudí. P. 153. También Burry, M., Espel, R., Faulí, J. y Gomez, J. (2014) Les naus de la Sagrada Familia. Els secrets arquitectònics d'una obra irrepetible. Barcelona. Mediterrània.
} 


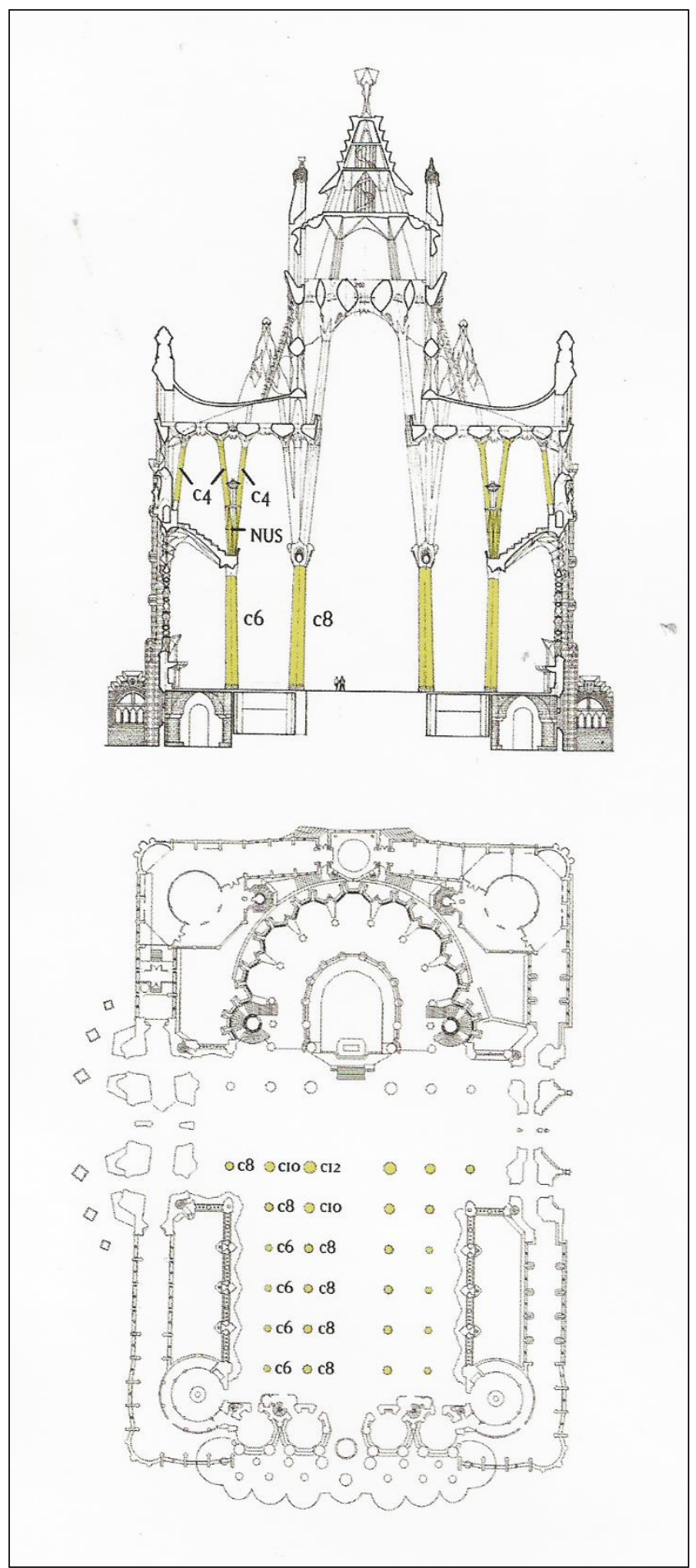

Orden jerarquico de las columnas de $x$ vértices que llevan asociadas alturas y diámetros diferentes. Fuente: Gomez Serrano, J. y AA.VV. (2008). Sagrada Familia XXI/ Gaudí ara. Barcelona. Edicions UPC. 
se abandona definitivamente la estructura goticista con la que arrancó y queda descartado también el empleo de perfiles de hierro para solventar el problema del incremento de cargas y sus empujes, que se perciben como verdaderamente importantes conforme la extensión de las obras obliga a concretar su resolución.

En 1901 fallece el obispo Morgades y con él la exigencia de una pronta terminación de las obras, y en 1914 se paran las obras de Santa Coloma y de Mallorca, concentrándose Gaudí únicamente en los trabajos de la Sagrada Familia. En ese mismo año y debido a la escasez de recursos económicos casi se paralizan las obras. En esos momentos y según refiere Martinell, Gaudí dedica todos sus esfuerzos al estudio estructural sin aceptar ningún otro encargo, cuestión ratificada por Quintana. En 1915, habiendo asistido al Congreso Litúrgico de Montserrat, Gaudí sale de él con el ánimo de enfrascarse en cursos de canto gregoriano con el P. Suñol, imbuido de la renovación litúrgica que preconizaba la jerarquía de la Iglesia Católica, y con la idea de llevar adelante el desarrollo de un completo programa simbólico que no ha podido realizar en Santa Coloma y se ha frustrado en Mallorca. A mi parecer, al disponer de mayor tiempo para resolver la estructura, una vez que la portada del Nacimiento ha sido resuelta y lleva su propio ritmo de ejecución, a la vez que imbuirse completamente del espíritu del Movimiento Litúrgico es cuando comienzan a fundirse en la mente del arquitecto Simbolismo y Estructura al servicio de la funcionalidad litúrgica del edificio.

Como explica Puig Boada, ahora quiere hacer las bóvedas con paraboloides hiperbólicos por muchas razones: dichas superficies regladas constituyen un símbolo que considera muy acertado de la Trinidad; expresan la unidad, al considerar que los paramentos verticales son un caso particular del paraboloide, y por tanto hay un mejor enlace entre los elementos; su empleo elimina las aristas y contrafuertes, que constituyen a su juicio una imperfección del gótico, y diversifica la masa según una disposición orgánica a la manera de un organismo viviente. ${ }^{408}$

En esta argumentación que se reproduce en el mismo orden citado por Martinell llama la atención que primero se arguye una explicación teológico-simbólica y después una estructural, y ese orden es sintomático. Bien porque se pretende anteponer dicha justificación a la razón constructiva en función del auditorio promotor de las obras, bien porque las fuertes convicciones de Gaudí en la materia le lleven a buscar inmediatamente su simbolismo religioso, el hecho es que el orden explicativo da idea de la importancia que el arquitecto otorga a la simbiosis teológica-constructiva del proyecto.

\footnotetext{
${ }^{408}$ Cf. Puig Boada (1981) en su libro El Pensament de Gaudí: compilació de textos i comentaris. Barcelona. La Gaya Ciencia. P.209-210.
} 


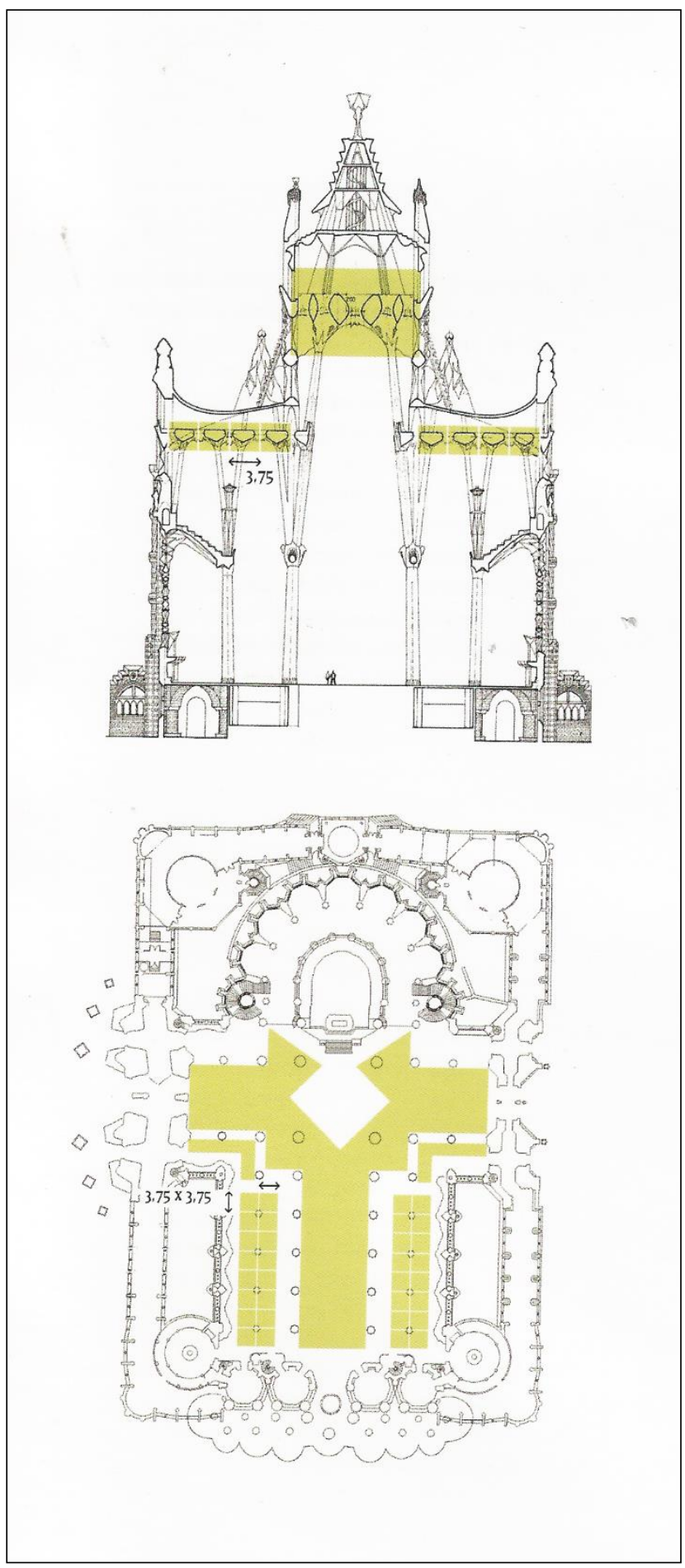

Bóvedas de la Sagrada Familia, ordenación por tipos. Fuente: Gomez Serrano, J. y AA.VV. (2008). Sagrada Familia XXI/ Gaudí ara. Barcelona. Edicions UPC. 
En términos similares nos narra Martinell la pretensión de Gaudí de que todas las formas y elementos resistentes del Templo se apoyen en las funículas de las fuerzas actuantes, por lo cual se puede prescindir de los contrafuertes. ${ }^{409}$ En este momento es cuando la columna vertical que soporta las bóvedas de la nave litúrgica, entrelazada por encima de sus capiteles con pasadizos y galerías rigidizadoras al nivel de triforios y tribunas, y cuya estabilidad se conseguía gracias al peso de las cubiertas laterales, abandona el arco apuntado y la disposición de crujías neogóticas para pasar a seguir la inclinación que marca el diagrama funicular. Recordemos aquí la explicación naturalista de la nueva solución estructural encontrada. Los arcos parabólicos junto con la inclinación y un giro de las columnas posibilitan la reducción de muros en el interior y la disminución de la peso de las cubiertas laterales, aumentando la estabilidad del conjunto con las cantorías a la manera de contrafuertes inversos interiores. Los pasadizos en esta segunda versión son elementos planos, no pasadizos, cuya función es únicamente de rigidización, a partir de los cuales comienzan a aparecer estructuras de varios brazos para la soportación de las cargas.

Sin dejar de referirnos a esta evolución del sistema sustentante, dos grandes cambios han aparecido en el espacio interior: de un lado la eliminación de muros ha propiciado una gran diafenidad del espacio -ahora únicamente ocupado por el número de columnas estrictamente necesario para absorber los esfuerzos del funicular de fuerzas- y ya no aparece servidumbre de unas trazas neogóticas. De otro, la aparición de paraboloides e hiperboloides en bóvedas y huecos de ventana abre el camino a la modulación y aligeramiento de las bóvedas de cubrición y a la proliferación de distintos huecos para la difusión y tratamiento de la luz natural.

Es difícil precisar otros motivos para llegar a la tercera solución estructural -alrededor de $1918^{410}$ - fuera de la lógica de perfeccionar y profundizar en la ramificación de los elementos sustentantes y optimización de su capacidad resistente, hasta el punto de hacer innecesarios los elementos planos de rigidización y aligerarse notablemente las cubiertas laterales. Quintana se hace eco de las posibilidades lumínicas de los hiperboloides que cubren las naves central y laterales (Les formes guerxes del temple de la Sagrada Familia, 1927). Siendo este hallazgo lumínico de Gaudí para el aula litúrgica mediante el uso de los hiperboloides en bóvedas y fachadas el que, a mi parecer, debió ser clave para esta concepción desmaterializada del espacio interior que permitía la solución definitiva. A este respecto Quintana señala la mejora que supone le empleo de los hiperboloides -que sustituyen a los paraboloides- en bóvedas y techos, consiguiendo unos artesonados sorprendentes pero también formando unos fanales o farolas a modo de lucernarios.

\footnotetext{
${ }^{409}$ Cf. Martinell, C. (1950) Gaudí i la Sagrada Familia explicada per ell mateix. Barcelona. Aymà. P.58.

${ }^{410}$ Cf. Burry, M., Espel, R., Faulí, J. y Gomez, J. (2014) Les naus de la Sagrada Familia. Els secrets arquitectònics d'una obra irrepetible. Barcelona. Mediterrània.
} 

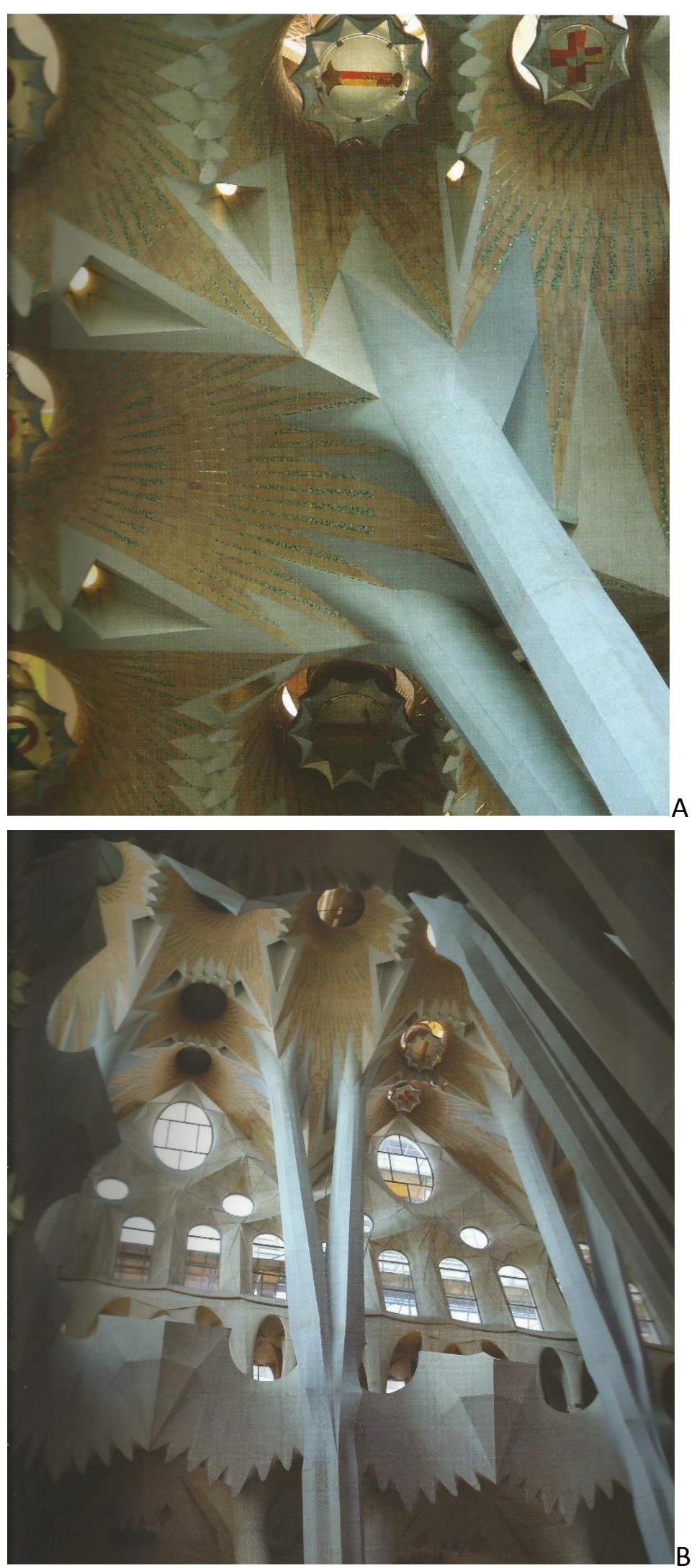

A: Luz natural, luz artificial, intersección de formas geométricas. B: Vista ventanal inferior de la nave central e intersección con bóvedas. Fuente: Burry, M., Espel, R., Faulí, J. y Gomez, J. (2014) Les naus de la Sagrada Familia. Els secrets arquitectònics d'una obra irrepetible. Barcelona. Mediterrània 
La ejecución de estas bóvedas perforadas sistemáticamente a modo de lucernarios gracias al empleo de los hiperboloides y el resultado que preveía alcanzar mediante su empleo de la generalización de la luz cenital constituyen un hallazgo, en mi opinión, de primera magnitud. Si a ello unimos el tratamiento de esa misma iluminación natural con carácter simbólico en los cimborios y su colorido en el lateral de las fachadas de la nave -con su espectacular derrame de luz sobre las superficies regladas de los elementos estructurales (cuestión narrada por Lluis Bonet Garí a su hijo Jordi Bonet Armengol y que éste reseña en uno de sus libros)- nos encontramos con una auténtica sinfonía lumínica natural que justifica por sí misma la depuración del sistema de sustentación estructural.

Por fin, pues, hacia 1918, su mente y espíritu inquietos -una vez alcanzada en grado sumo su experiencia litúrgica y disponiendo de un laboratorio a escala natural jamás soñado- pueden llevar a cabo su idea primigenia de la regulación de la luz de la celebración litúrgica. Captación, conducción y efusión de la luz natural se convierten en poderosas herramientas arquitectónicas al servicio de la Liturgia que ahora avanzan una página más en el itinerario histórico de una iglesia. Lo que el arquitecto medieval inició con los cimborios y vitrales, Gaudí lo reestudia en una disparidad de soluciones que sistematiza tanto en el plano vertical como horizontal.

A esta simbiosis de iluminación natural y artificial del aula celebrativa -que aprovecha también las intersecciones geométricas de la bóveda- hay que añadir la ornamentación estructural conformada por la geometría en bóvedas, columnas de doble giro en altura, y todo tipo de formas alabeadas, organizándose un espacio místico imbuido de modernidad en su método, en su disposición y en su resultado que escapan a cualquier reduccionismo y calificación goticista o modernista de su lenguaje arquitectónico. ${ }^{411}$

\section{El módulo estructural y la cubrición del aula celebrativa.}

Dice $M$ antonia Crippa que a partir de los estudios más actuales sobre la arquitectura gótica europea se puede considerar la aportación de la catedral gótica a la arquitectura eclesiástica como la conjunción de tres elementos fundamentales, su esqueleto estructural, la monumentalidad de su escultura y la grandeza de su arte vitral ${ }^{412}$. En mi opinión, en estos tres elementos es donde encontramos fundamentado el juicio de Gaudí sobre su proyecto, como una superación del estilo gótico.

\footnotetext{
411 Cf. Burry, M., Espel, R., Faulí, J. y Gomez, J. (2014) Les naus de la Sagrada Familia. Els secrets arquitectònics d'una obra irrepetible. Barcelona. Mediterrània. P. 100.

${ }^{412}$ Cf. Crippa, M‥ (2010). "El carácter religiós de la catedral de Gaudí”, en AA. VV. Sagrada Familia: de Temple Expiatori a basilica. Barcelona. Lunwerg.
} 


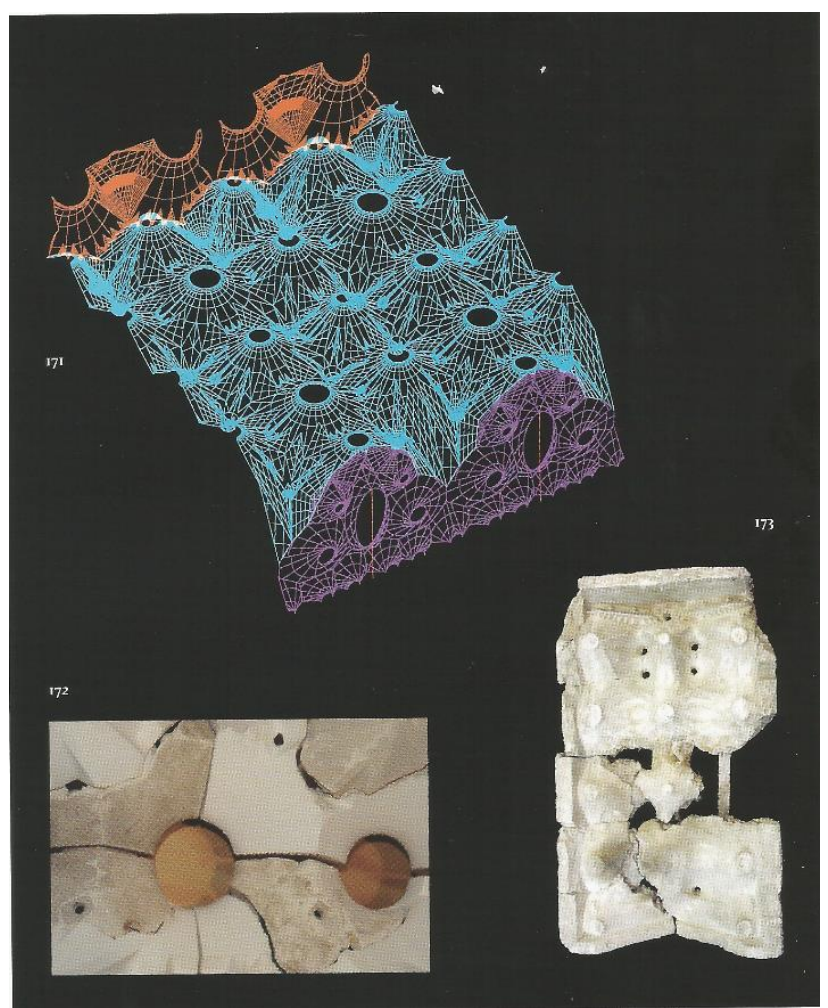

Fragmento de bóveda en nave lateral desde ventanal a baranda. Fuente: Gomez Serrano, J. y AA.VV. (2008). Sagrada Familia XXI/ Gaudí ara. Barcelona. Edicions UPC.

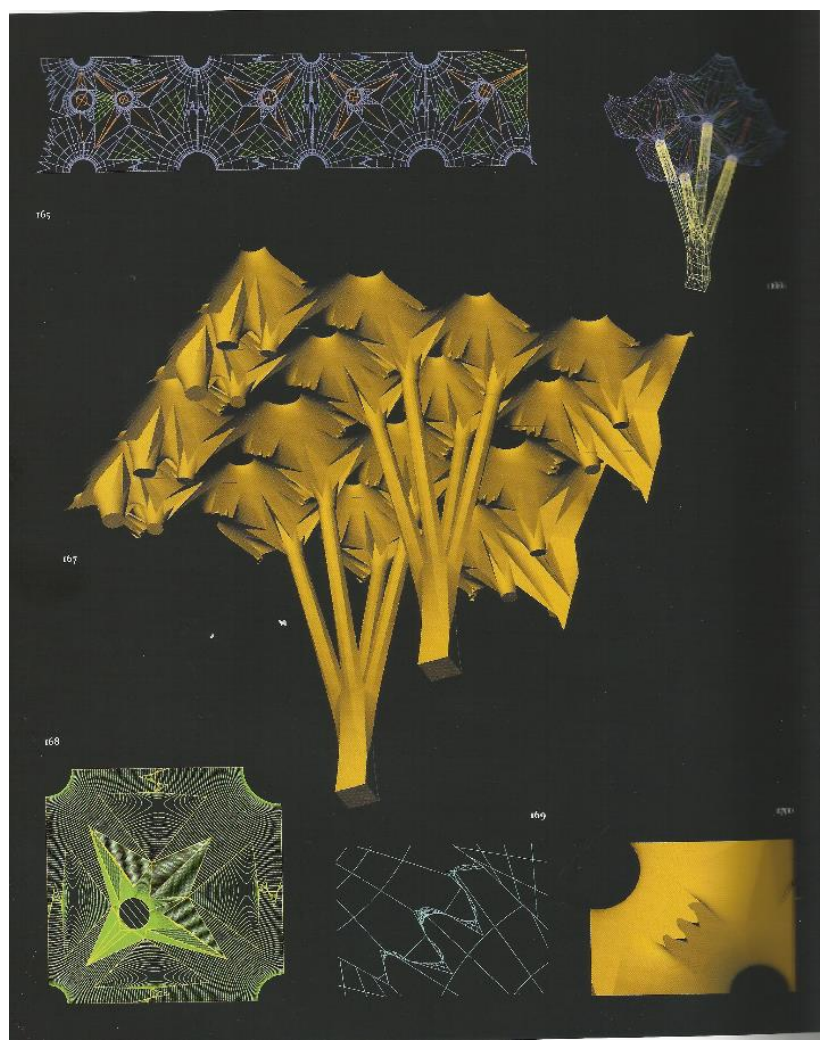

Franja básica de la bóveda en navel lateral. Fuente: Gomez Serrano, J. y AA.VV. (2008). Sagrada Familia XXI/ Gaudíara. Barcelona. Edicions UPC. 
Para Crippa, el sentimiento cristiano de la vida y del tiempo que tiene Gaudí le hace concebir la Sagrada Familia con un sentido de sacralidad que se había casi perdido en el siglo XIX. De ahí que el carácter catedralicio de su proyecto y la explicación "como superación del gótico", que se puedan inscribir perfectamente en esa búsqueda de los orígenes que caracteriza su planteamiento constructivo del aula celebrativa cristiana.

Según explica Ràfols en el sistema estructural empleado por Gaudí como solución final de la Sagrada Familia se comienza con la modulación o cubicación de los distintos elementos que componen la cubierta de la nave central, determinando su centro de gravedad y por tanto el punto de aplicación del peso para cada uno de dichos módulos, realizándose esta operación también en las bóvedas de dicha nave, y repitiéndose en las cubiertas y bóvedas laterales. De esta manera se cambia el tradicional sistema de crujías transversales a la dirección de las naves -que como bien señala Gaudí- necesita de arbotantes y contrafuertes en ambos extremos además de imponer una limitación importante en dimensiones, a una modulación de las bóvedas que anticipa la moderna absorción de esfuerzos de una losa o forjado reticular por los ábacos y pilares convenientemente dispuestos. En este sentido la estructura de bóvedas y columnas que Gaudí plantea puede y debe ser evaluada como un protorracionalismo que se anticipa al Movimiento Moderno. Su finalidad persigue, a semejanza de éste, en liberar en la medida de lo posible a los muros de fachada de elementos auxiliares de sustentación para optimizar su función de cerramiento a la vez que aligerar al máximo la cubierta permitiéndole abundar en su función de cobertura o envolvente superior.

Es innegable que este planteamiento permite concentrar la atención en el estudio del tratamiento de la iluminación natural a través de las perforaciones que se puedan practicar en ambos elementos constituyentes de la envolvente del edificio, separando esta función de la que se ocupa de la estabilidad del edificio. Nos encontramos, pues, ante una estructuración del edificio moderna y totalmente novedosa para su tiempo, que es desarrollada por Gaudí en una iglesia, contribuyendo y no poco a la alta consideración que en todas las edades ha tenido y tiene la arquitectura eclesiástica. En este sentido hay que reconocer que Gaudí se mantiene fiel a sí mismo y a la alta consideración que le merecía el carácter de esta tipología de edificios, como manifestaba en el Manuscrito de Reus al comenzar su trayectoria profesional.

Las dimensiones básicas de las que tuvo que partir Gaudí vienen condicionadas por el diámetro y espacio libre central de la Cripta, cuyos cimientos e inicio de las columnas se habían construido según el proyecto de Villar. Con la variación provocada por la ubicación lateral de las escaleras de acceso a la Cripta se introduce una sutil variación estructural consistente en la aparición de una nueva crujía de columnas, en el eje que une los ojos de dichas escaleras, cuya alineación respecto a las columnas de la rotonda central de la Cripta permite pasar al intercolumnio de $15 \mathrm{~m}$ de la nave central. 


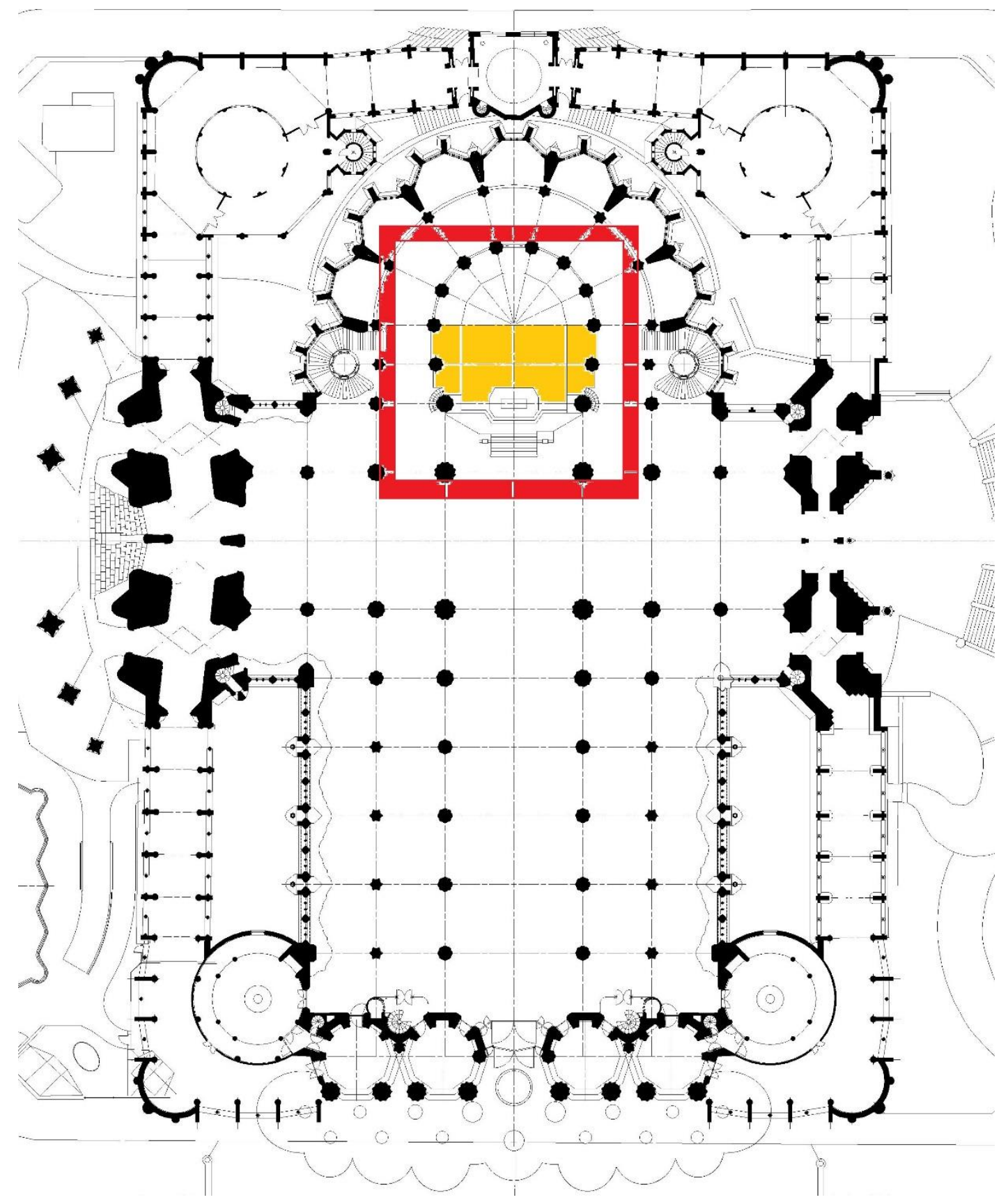

Transición de la medida del intercolumnio correspondiente al diametro de la Cripta a las Medidas Fundamentales de malla geométrica de las Naves, con módulo básico 7,5 m ( 15 m entre columnas de la nave mayor), reflejado en el plano base elaborado por la Oficina Técnica de la Sagrada Familia en 2004. Obsérvese la crujía intermedia, introducida por Gaudí, en el eje de las escaleras laterales diseñadas para el acceso a la Cripta. 
A partir de aquí, esto es de las columnas y muro de fondo del altar mayor de la Cripta, se dispone toda la modulación general de la planta de la Sagrada Familia. ${ }^{413}$ Cabe preguntarse el por qué no sigue la alineación de las columnas de la Cripta cuando el intercolumnio en la crujía que constituye el diámetro del circulo de la Cripta es muy similar a la distancia de $15 \mathrm{~m}(2 \times 7,5)$ que hay entre las columnas de la nave central. En mi opinión las razones hay que buscarlas, como dice Armand Puig (La Sagrada Familia según Gaudí, 2011), en las medidas fundamentales del proyecto. A partir de éstas se establece una geometría modular de la planta cuya transición se encomienda a un espacio altamente representativo y simbólico, el que ocupa el ámbito del Presbiterio entre el coro eclesiástico y el Altar mayor. Y la transición se realiza con notable habilidad visual, muy al gusto barroco de Gaudí: conformando una disposición in crescendo de las columnas que definen el Presbiterio.

Si Gaudí explica todo el proyecto a los josefinos en 1891 -una vez concluida la cubrición de la Cripta- es que ya con anterioridad tenía en mente las líneas básicas y seriación de las crujías y naves de la Sagrada Familia, como queda reflejado en el plano de 1885, con ocasión de la petición del permiso de obras para su proyecto. Es interesante constatar cómo en este dibujo aparece la dimensión del intercolumnio de la nave central y de las dos primeras naves laterales sensiblemente alineadas con las columnas de la Cripta, siendo difícil distinguir alguna variación. La directriz de este plano es sensiblemente longitudinal, pues la disposición de naves laterales no se encuentra en el transepto y el intercolumnio en las crujías de éste tiene el mismo ancho que el de la nave central. Quiero esto decir que la disposición general de la planta es básicamente la de una planta de cinco naves longitudinales (las dos extremas apenas vislumbradas como antesala de las capillas laterales) en la que se dispone un transepto y sobre todo tres portadas de considerables dimensiones, y se anuncia un deambulatorio exterior que circunscribe toda la iglesia.

En el Album de 1915 se describe el edificio y se aportan sus dimensiones más importantes, que no han variado desde entonces (como se comprueba en el Album de 1929). Sin embargo, en las plantas de 1916 -Subterráneo- y sobre todo en la de 1917, se aprecia ya con toda claridad la transición dimensional referida entre Cripta y Naves.

\footnotetext{
413 Para la descripción pormenorizada de la seriación y proporciones de planta, alzados, columnas, desarrollo gráfico y explicación de la construcción, etc. Cf. Burry, M., Espel, R., Faulí, J. y Gomez, J. (2014) Les naus de la Sagrada Familia. Els secrets arquitectònics d'una obra irrepetible. Barcelona. Mediterrània; Bonet, J. y Puig, A. (2013) Arquitectura i símbol de la Sagrada Familia. Barcelona. Raval Edicions SLU, Portic.; Gomez, J. y AA. VV. (2008) Sagrada Familia XXI/Gaudí ara. Barcelona. Edicions UPC.
} 

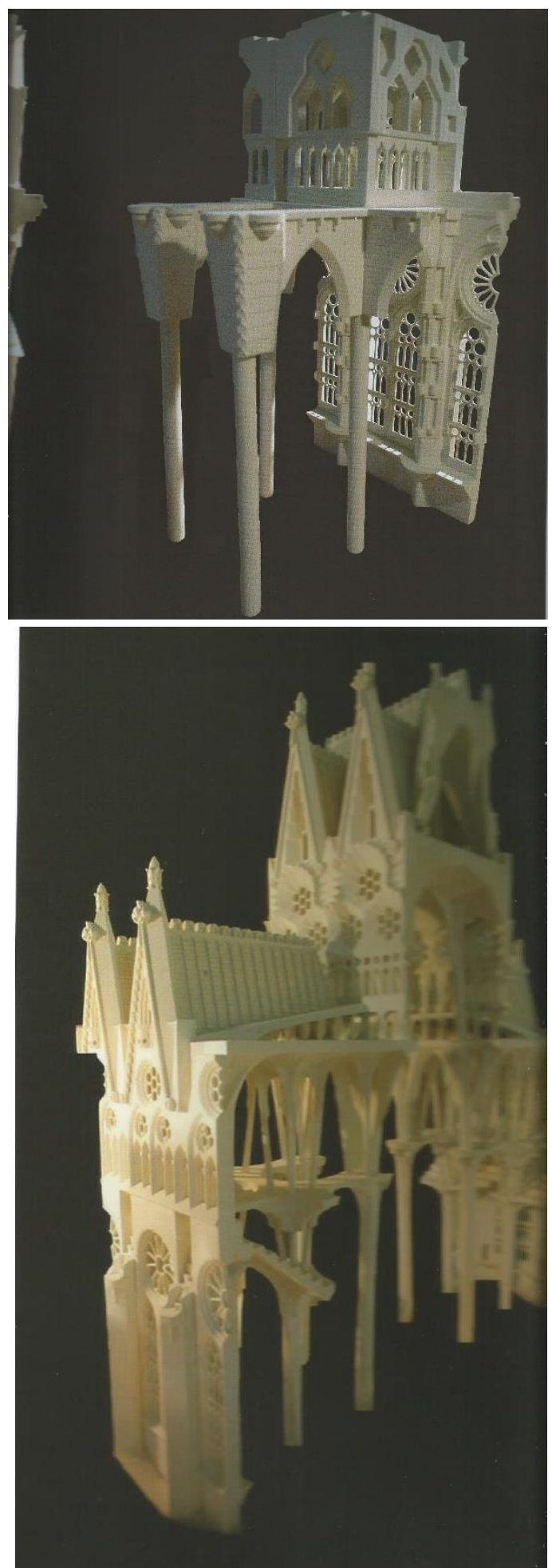

Izqda. Maqueta primera solución estructural.Decha.: Maqueta de la segunda versión estructural. Fuente: Burry, M., Espel, R., Faulí, J. y Gomez, J. (2014) Les naus de la Sagrada Familia. Els secrets arquitectònics d'una obra irrepetible. Barcelona. Mediterrània 
Dichos dibujos, publicados en los álbumes de 1915 y 1917, y también en el número del Propagador de 1-04-1917, muestran una planta con la misma modulación geométrica que hoy en día conocemos, aunque con una crujía menos en su dirección longitudinal correspondiente al posterior desarrollo de la fachada de la Gloria y las capillas del Bautismo y la Penitencia. Así pues, Gaudí pudo tomar exactamente la alineación de las columnas definida en la Cripta, según el proyecto de su antecesor, continuando toda la nave central con dicho intercolumnio fijo como ocurre con todas las catedrales góticas e incluso con las iglesias votivas de su misma época, pero prefiere introducir dos crujías intermedias para enlazar con la modulación de 7,5 m que sirve a toda la planta.

Otro hecho estructural hay que señalar. Cómo diseña la secuencia de diferentes diámetros, lados, y altura de las columnas con arreglo dos criterios de marcado corte litúrgico: la distinción clara de los distintos ámbitos del aula celebrativa -cúpula central, presbiterio o santuario, nave central y transepto, naves laterales y capillas absidalessegún el diámetro, sección horizontal, fuste y altura de las columnas con una variación en las mismas sorprendentemente mayor que la de cualquier iglesia construida hasta la fecha (las catedrales góticas tan sólo distinguían las columnas de la nave central y las iglesias votivas en ocasiones se plantean más gruesas las columnas del crucero). La jerarquización de las columnas según la disposición de la asamblea eucarística en planta y en volumen, según su número de lados, diámetro y altura, desde las de 12 vértices que sustentan el cimborio principal, 10 vértices para las cuatro torres de los evangelios que lo circundan en el crucero, 8 vértices para presbiterio, nave central y transepto, y 6 vértices para las de las naves laterales y capillas del ábside, es sorprendente, pues responde a una estudiada jerarquización del volumen espacial que va mucho más allá de la tradicional distinción entre nave central y laterales en la dirección longitudinal y el transepto de la iglesia. Esta composición que comienza a apreciarse en la planta de 1917 sufre ya sólo ligeras modificaciones que aparecen en la planta publicada en la Hormiga de Oro el 17-03-1923 y en la última planta dibujada por Gaudí en 1926.

Retomando el tema de las Medidas Fundamentales del proyecto también hay que seguir preguntándose por qué Gaudí no sigue los intercolumnios predefinidos por Villar ni tampoco agota la luz de $20 \mathrm{~m}$ que venía siendo el límite de las bóvedas de arista, para disponer una modulación de 7,5 m entre ejes de columnas, que da $15 \mathrm{~m}$ para la nave central. Jordi Bonet avanza una explicación basada en las dimensiones generales del proyecto, $90 \mathrm{~m}$ de largo desde la entrada, cuya división por 12 -sistema tradicional empleado en Cataluña desde hace siglos- da $7,5 .{ }^{414}$

\footnotetext{
${ }^{414}$ Cf. Bonet, J. y Puig, A. (2013) Arquitectura i símbol de la Sagrada Familia. Barcelona. Raval Edicions SLU, Portic. P. 176
} 


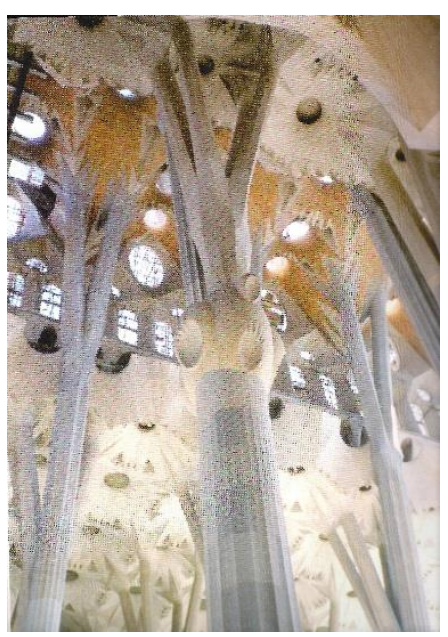

Bovedas,

columnas

arboriformes y vitrales en el aula liturgica. Fuente: Puig, A.

(2011) La Sagrada Familia según Gaudí. Barcelona. El Aleph.
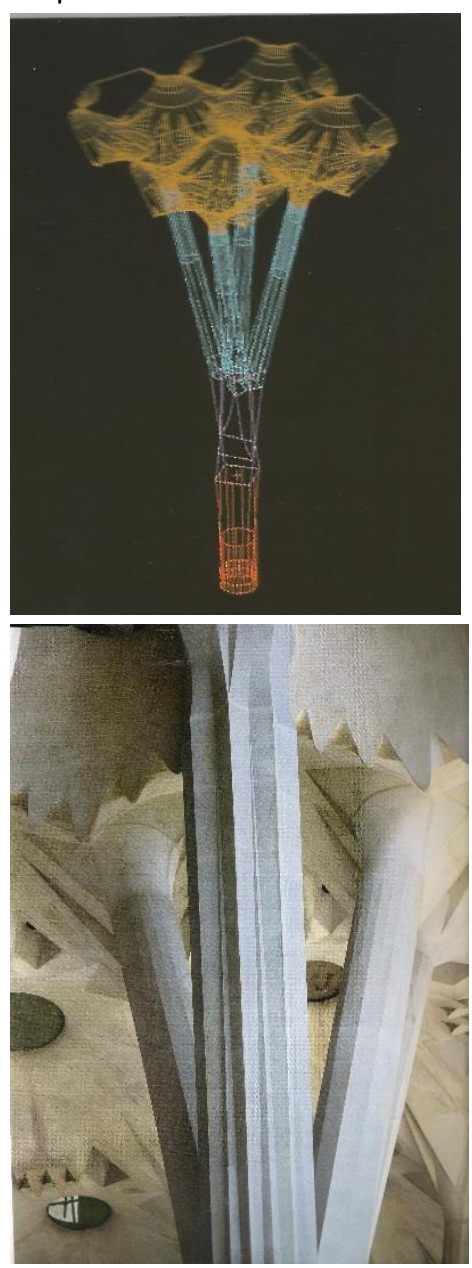

Estructura arboriforme de una columna. Fuente: Josep Gomez Serrano y AAVV (2008) Gaudí ara: la Sagrada Familia siglo XXI. Barcelona. Edicions UPC. 
Armand Puig ofrece tres posibles interpretaciones partiendo del hermanamiento de las decisiones constructivas con los criterios simbólicos y de las afirmaciones de Gaudí que recoge Puig Boada respecto de la proporción ${ }^{415}$ : la proporción de la cabeza con el cuerpo en la escultura griega ( $1 / 7$ a $1 / 8$, entre 7 y 8 ), la geometría de la sección de las pirámides egipcias, triangulo de medidas $3-4-5(3+4=7,3+5=8)$, y finalmente, y a mi parecer la más próxima al pensamiento gaudiniano (sin descartar las otras), la concepción judeocristiana que otorga un valor simbólico a los números: el 7 representa la perfección humana, lo que Gaudí quiere conseguir, y el 8 la plenitud divina, lo que no puede alcanzar. El mismo Puig hace mención a la función principal de la Sagrada Familia como espacio para la celebración de la santa misa o eucaristía, señalando además que su arquitectura no se encuentra en el registro de una espiritualidad difusa. ${ }^{416} \mathrm{~A}$ ésto se podría añadir la enfatización de la singularidad de cada uno de los espacios y visuales según el gusto barroco de manera que Gaudí querría singularizar o distinguir el ámbito particular del Presbiterio donde se sitúan la Sede y el Coro ministerial del ámbito focal del Altar -bajo el denominado arco triunfal- que se adelanta hacia las naves.

En la primera solución neogótica la visibilidad del espacio interior queda comprometida por los paramentos verticales de los muros de los triforios y de los arcos ojivales, cuestión que queda ampliamente mejorada en la segunda solución mediante la transformación de aquellos en simples elementos planos horizontales que aumentan la rigidez de las bóvedas cuando las columnas ya son inclinadas, aún cuando no dejan de ser elementos extraños a la nueva estructura. Prueba de que esta cuestión no es menor para Gaudí es el hecho de que los dos aspectos que aparecen más veces reflejados en los estudios comparativos del exterior e interior de la Sagrada Familia con respecto a otras catedrales y basílicas del mundo católico occidental, que se publican en el Propagador durante el año 1918 -precisamente el año en que se sitúa el cambio a la solución definitiva de la estructura- son: el amplio desarrollo de las fachadas o entradas a la iglesia (liberadas del encajonamiento que las situaba entre las torres o campanarios) y la visibilidad del espacio interior (la dimensión en planta no parece preocupar a la publicación de los josefinos).

Lo que el Movimiento Litúrgico propugnaba como principios inspiradores de la renovación pasa por una vuelta a las fuentes, que significa una investigación seria de la Teología, de la Biblia y de la Historia, y una recuperación del sentido comunitario y participativo de la celebración eucarística resituándolo en la Pascua cristiana y, por tanto, en el centro de la vida de la Iglesia.

\footnotetext{
${ }^{415}$ Cf. Puig, A. (2011) La Sagrada Familia según Gaudí. Barcelona. El Aleph Editores. Pp. 58-59

${ }^{416}$ Cf. Bonet, J. y Puig, A. (2013) Arquitectura i símbol de la Sagrada Familia. Barcelona. Raval Edicions SLU, Portic. P.22.
} 

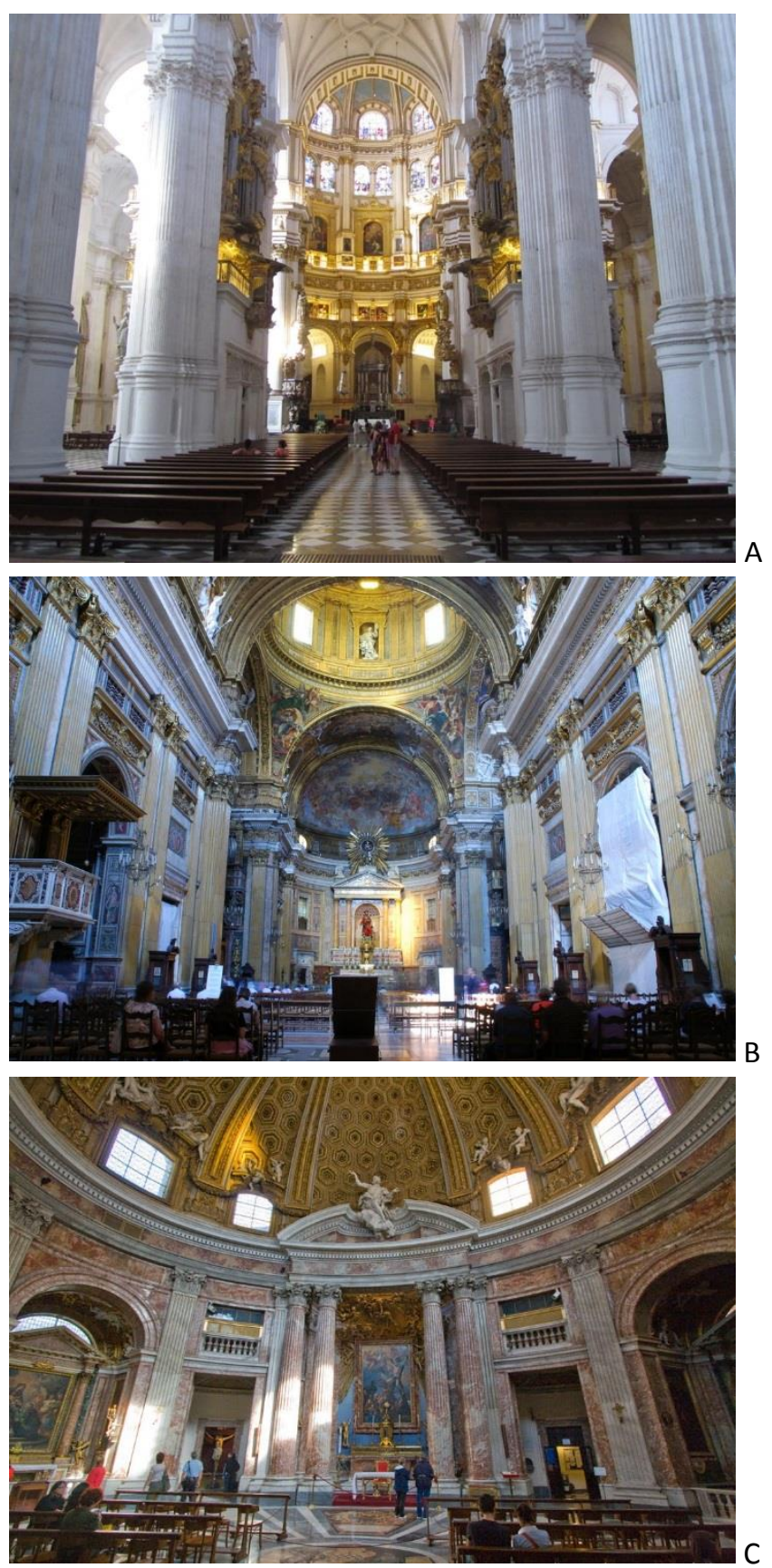

Tres maneras de interpretar de la visibilidad del altar mayor en el interior de la Iglesia.

A Catedral de Granada, Diego de Siloé (1528-1563)

B II Gesú, Jacopo Vignola (1568-1573)

C San Andres del Quirinal, Bernini (1658-1661) 
Por el conocimiento de la liturgia que tiene Gaudí y el entorno renovador en que se mueve -basta recordar su asistencia al congreso de Montserrat y consiguiente aprendizaje del canto gregoriano, así como su participación en exposiciones de arte cristiano, y los mismos proyectos de Santa Coloma y Mallorca- su identificación con estos principios es total.

A mi parecer el esfuerzo conceptual manifestado en la disposición de los focos de la asamblea celebrante, y en la misma composición real y simbólica del lugar litúrgico necesitaba encontrar una estructura sustentante y sostenida que permitiese dicho espacialidad, tanto en términos de libertad compositiva en planta como de diáfana visualización del espacio "espiritual", porque Gaudí sólo se sujeta a dos cosas: pacientemente a los condicionantes constructivos del proyecto anterior (aún cuando los va variando en cuanto puede), y vehementemente a la teología litúrgica, según la cual quiere adecuar el espacio del aula celebrativa. Por ello la solución definitiva de la Sagrada Familia es la solución de la sustentación y adecuación estructural, lumínica y simbólica de esta aula, caracterizándose por la utilización del hiperboloide como forma básica compositiva para una bóveda que es mucho más que un elemento estructural, es la extensión simbólica de la luz que ilumina el espacio litúrgico. ${ }^{417}$

De esta manera se consigue una modulación geométrica del techo del aula celebrativa y de su estructura sustentante que se puede adaptar a cualquier planta (según la inquietud que reflejaba el Manuscrito de Reus), pero de una manera especial a una planta jerárquicamente organizada. La Oficina Técnica de la Sagrada Familia demuestra con su labor de investigación de años y los modernos medios informáticos que el desarrollo del proyecto estructural confirma lo previsto por Gaudí en sus dibujos, maquetas y pruebas, llegando incluso a comprobar la adecuada adaptación de las soluciones previstas para el encuentro con la modulación de Villar o la entrega de la nueva estructura con la fachada neogótica del Nacimiento. ${ }^{418}$

417 Cf. Burry, M., Espel, R., Faulí, J. y Gomez, J. (2014) Les naus de la Sagrada Familia. Els secrets arquitectònics d'una obra irrepetible. Barcelona. Mediterrània. Como mencionan los autores, todas las bóvedas están formadas por combinación de hiperboloides lucernarios con capiteles hiperbólicos que los sustentan de una manera equilibrada (P. 132). También describen las dimensiones de la modulación de las bóvedas y los elementos especiales que Gaudí concibe para ganar plasticidad en los encuentros de los hiperboloides.

418 Cf. Burry, M., Espel, R., Faulí, J. y Gomez, J. (2014) Les naus de la Sagrada Familia. Els secrets arquitectònics d'una obra irrepetible. Barcelona. Mediterrània. P. 137: "El que a les naus és una retícula ortogonal amb una franja repetida linealment, a l'absis és una solució que es repeteix radialment set cops en el sector de 180으, tants como intercolumnis de l'absis o com capelles absidals existents. Desprès continúen les voltes fins el transsepte amb un modul no estándar que suporta el canvi de modulació de l'esglesia inicial de F. de P. Villar (modulació de la cripta) al nou projecte de Gaudí (modulació de les naus)". 


\section{Visualización del espacio litúrgico.}

Como se ha reseñado en el apartado anterior, una de las virtudes del nuevo proyecto estructural de Gaudí radica en la visualización del espacio de la asamblea litúrgica, en consonancia con las pretensiones de renovación litúrgica de aquel tiempo.

Históricamente, con el decaimiento de la vida litúrgica, las iglesias se habían proyectado con criterios basados más en la sustentación y estabilidad de muros y bóvedas, en la geometría de sus formas o en su dimensión artística, que con relación a la visualización del espacio interior y consecuente participación de los fieles en la celebración litúrgica. Tan sólo después de Trento con la adopción de la planta jesuítica de nave única a la que se subordina toda la espacialidad del aula litúrgica se preconiza la importancia de la visualización por el pueblo de todo cuanto acontece en el presbiterio, fundamentalmente en el altar. Es cierto que Miguel Angel diseña San Pedro con la ubicación del altar debajo de la cúpula, en el crucero, pero esta situación venía bastante condicionada por la cripta donde reposan los restos del primer Papa, cuestión que fue el eje de las actuaciones en dicha basílica desde los tiempos de Gregorio Magno. Es preciso, pues, atenerse a la planta jesuítica barroca inspirada en la iglesia del Gesú de Roma (1568-1573), de Vignola, o a plantas elípticas del mismo periodo, como San Andrés del Quirinal (1658-1661), de Bernini o la misma Basílica de la Virgen de los Desamparados en Valencia (1647), de Diego Martínez, para observar unas trazas que permitan una buena visualización por los fieles del altar y otros focos de la asamblea.

A mediados del siglo XIX, en pleno auge de la arquitectura historicista, se mantienen los parámetros tipológicos de plantas medievales históricas y la preocupación artística como los aspectos más relevantes del diseño de la arquitectura eclesiástica. Algunas incursiones en el territorio de los nuevos materiales, hierro, vidrio, hormigón, y los ejemplos aislados como la planta circular de Sta. Maria vom Siege o la centralizada de cruz griega de St. Leopold en Steinhof, ambas en Viena, intentan una composición de la asamblea y una visualización diferentes. En este contexto, el proyecto de la iglesia de la Colonia Güell en Santa Coloma, avanza un planteamiento rompedor: una planta irregular cuyo espacio interior está más basado en la estructura multicupular (Iglesia superior) y en la disposición envolvente de la asamblea de fieles favorecida por la ubicación de los pilares (cripta) que en un trazado geométrico o la adscripción a un estilo artístico. De esta manera, la Sagrada Familia se configura como un caso único en el que la voluntad del arquitecto se superpone a los condicionantes de un proyecto anterior y a la sensibilidad artística del promotor para plantear un lugar arquitectónico plenamente litúrgico. La inserción de Gaudí en el itinerario renovador del Movimiento Litúrgico es total y, en mi opinión, debe considerarse su aportación como el eslabón previo a la arquitectura del Quickborn alemán que inician Schwarz y Guardini. 


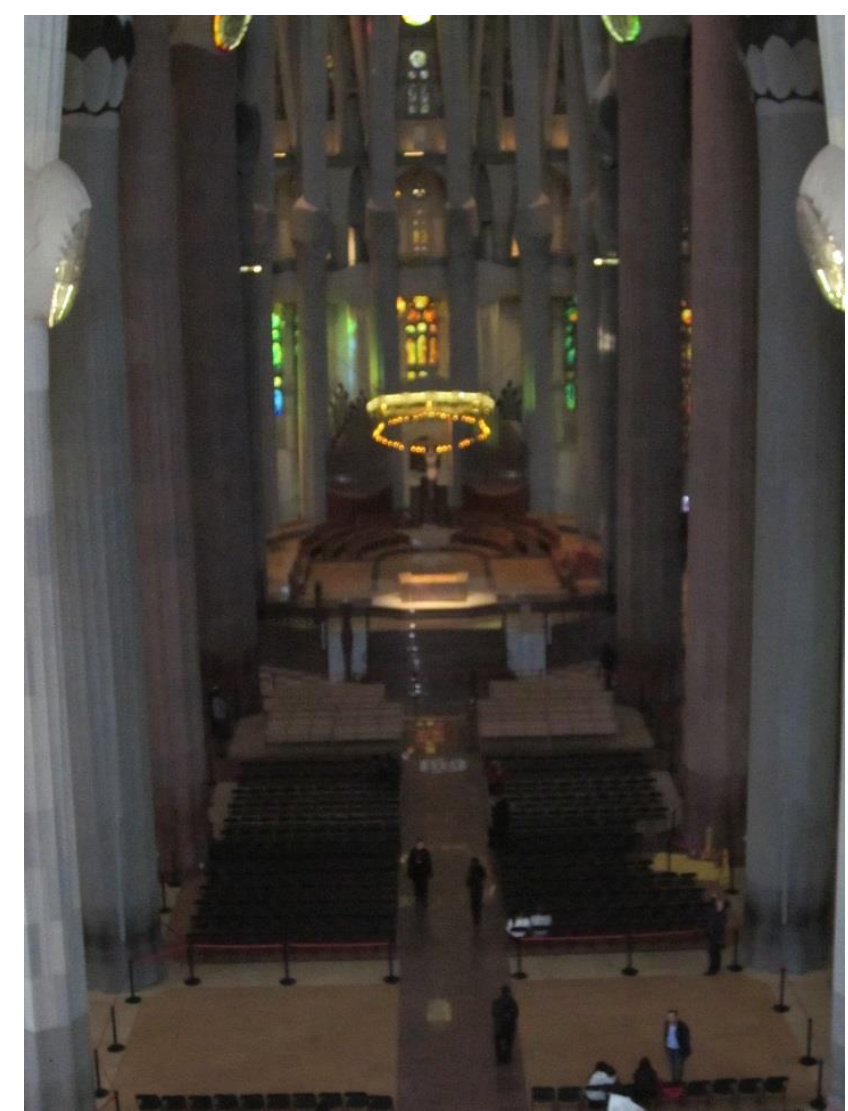

Visualizacion de los focos de la Asamblea Eucaristica desde el Coro situado encima de la entrada principal. Fuente: Fotografia del autor.

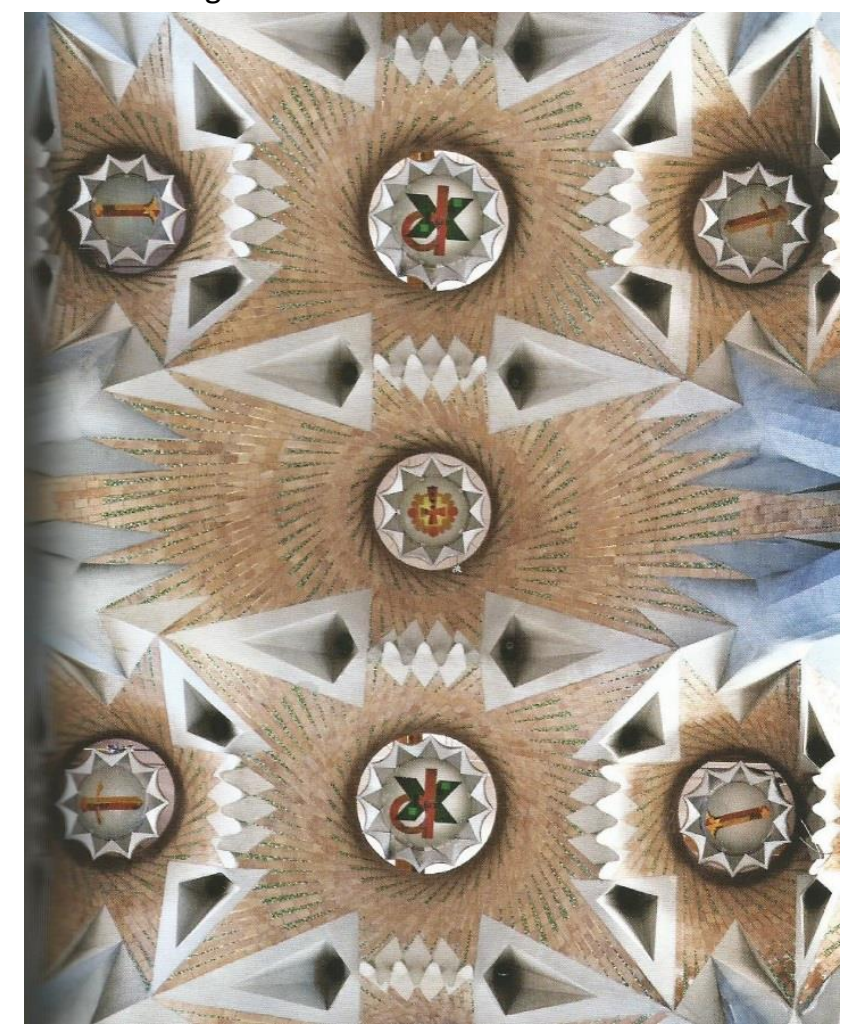

Simbologia en los fanales de la bóveda. Fuente: Bonet, J. y Puig, A. (2014) Arquitectura y símbols de la Sagrada Familia. Barcelona. Pórtic. 
De ahí que la convencionalidad del esquema de la planta de cruz latina que habla Lahuerta $^{419}$ se distorsiona enseguida porque lo que se diseña es el lugar de la celebración, no la planta, para una liturgia terrestre pero con vocación de celeste. La interacción en términos de trascendencia entre la materialidad de los elementos constructivos y esta visión espiritualizada del espacio es biunívoca y también se puede rastrear en el sentido de permanencia buscado por Gaudí en la elección del tipo de cubierta, doble y de piedra, en contraposición a la vulnerabilidad de las cubiertas de madera de las catedrales góticas.

Su planteamiento de la arquitectura eclesial y de su estructura va más allá de lo descrito, y la denominamos como plenamente litúrgica, no porque pudiera ser un catálogo de simbología cristiana sino porque está al servicio de la liturgia cuyo sujeto no es la persona sino sencillamente, en palabras de Guardini, la unión de la comunidad creyente como tal considerada. ${ }^{420}$ Las iglesias de Gaudí rompen moldes. Santa Coloma dispone una estructura cupular sustentada en un muestrario de superficies regladas y con un amplio programa simbólico que quiere resaltar el acontecimiento pascual de Jesucristo, origen y causa de la fe cristiana en la predicación de Pablo de Tarso, partiendo su programa del martyrium del Santo Sepulcro de Jerusalen o Cripta cuyo fondo reproduce un Calvario. La deconstrucción de Mallorca no es entendida como una intervención en contradirección de su evolución histórica sino como una repristinación cuyo objeto es el confort litúrgico de la comunidad cristiana. En este sentido la reordenación de su interior, como la exaltación de Santa Coloma, pueden ser vistos, caminados y aprehendidos como ejercicios de arquitectura plenamente humana, para las personas, cuya escala no es sólo física ni tiene únicamente que ver con la piedra, sino espiritual cuya escala se mide por lo social. La Sagrada Familia es una exaltación de los principales misterios de la Revelación cristiana pero es ante todo la visión mística de los espacios litúrgicos cristianos.

\footnotetext{
${ }^{419}$ Cf. Lahuerta, J.J. (1993). Gaudí: Arquitectura, Ideologia y Politica. Madrid. Electa España. P. 307.

${ }^{420} \mathrm{Cf}$. Guardini, R. (1945) El espíritu de la Liturgia. Traduccion al castellano de Vom Geist der Liturgie, 1a edición en 1918. Barcelona. Araluce. P, 129-130: "El símbolo existe cuando lo interno y espiritual encuentra su expresión externa y sensible....Para que el símbolo exista es preciso la transposición, que la proyección de lo interno al exterior se verifique con carácter de necesidad esencial, y además obedezca a una exigencia de la naturaleza."
} 


\section{b) Acondicionamiento del aula litúrgica.}

El espacio arquitectónico de la Sagrada Familia, como espacio litúrgico que es, es un lugar para el encuentro de la comunidad cristiana con Dios, y como tal hemos visto el cuidado tratamiento que Gaudí le concede. Hemos visto que su sacralidad nace la convergencia que se produce en su seno entre el Dios Creador y re-creador con el hombre creado y re-creado, y cómo esta convergencia es celebrada, exaltada y proclamada con todos los medios que el ingenio gaudiniano considera a su alcance.

Cada uno de los espacios litúrgicos es diseñado y construido desde su dimensión teológico-litúrgica específica haciendo de la estructura y la simbología instrumentos al servicio del acondicionamiento del lugar litúrgico. De ahí que cada uno de ellos en particular y su composición de conjunto, conlleve un minucioso orden establecido por la acción cultual pero también un programa iconográfico propio a desarrollar, un cuidado estudio de sus condiciones acústicas y lumínicas, y el soporte de un mobiliario y objetos litúrgicos propios.

Cuando Gaudí menciona que el edificio de la iglesia ha de ser trasunto de su interior no se refiere únicamente al concepto físico o material sino que este pensamiento abarca la interioridad conceptual más plena, aquella que puede dar sentido a su uso y disfrute. Esta vuelta a los orígenes es total y requiere la inmersión del arquitecto en las circunstancias y necesidades morales y materiales que se dan en el proyecto, que él mismo define como el primer paso en su realización.

A lo largo de esta investigación hemos tratado de centrar la mirada en estas necesidades que Gaudí considera resolver en su proyecto, tanto desde el punto de vista de la acción litúrgica concreta a la que libremente se adhiere y participa como desde el campo del conocimiento histórico de la arquitectura con el que cuenta para su libre interpretación. Si por aula litúrgica hemos entendido y entendemos el lugar que es ocupado por la asamblea celebrante, especialmente la eucarística, hemos de convenir que la preocupación de Gaudí no se vincula al virtuosismo estilístico, a la teorización de un discurso ni a la materialización de un alarde tecnológico. ${ }^{421}$ Precisamente su crítica a la dimensión artística desvinculada de la funcionalidad de una iglesia le hace indemne a rigorismos y veleidades, y su discurso no está enfocado hacia la audiencia sino que naciendo de su propia inquietud sólo busca su materialización, entendiendo la tecnología no como un fín en sí mismo sino como un medio, razón por la cual ensaya una y mil veces antes de su utilización.

\footnotetext{
${ }^{421}$ Algunos autores han hecho referencia a un posible y progresivo distanciamiento entre Gaudí y su colaborador Jujol, cuando éste se preocupa por la sistematización de los logros estructurales de su maestro el cual, sin embargo, estaría más preocupado por la concepción unitaria del proyecto eclesiástico del cual la estructura basada en la estática gráfica seria una herramienta más para lograr el espacio celebrativo óptimo.
} 


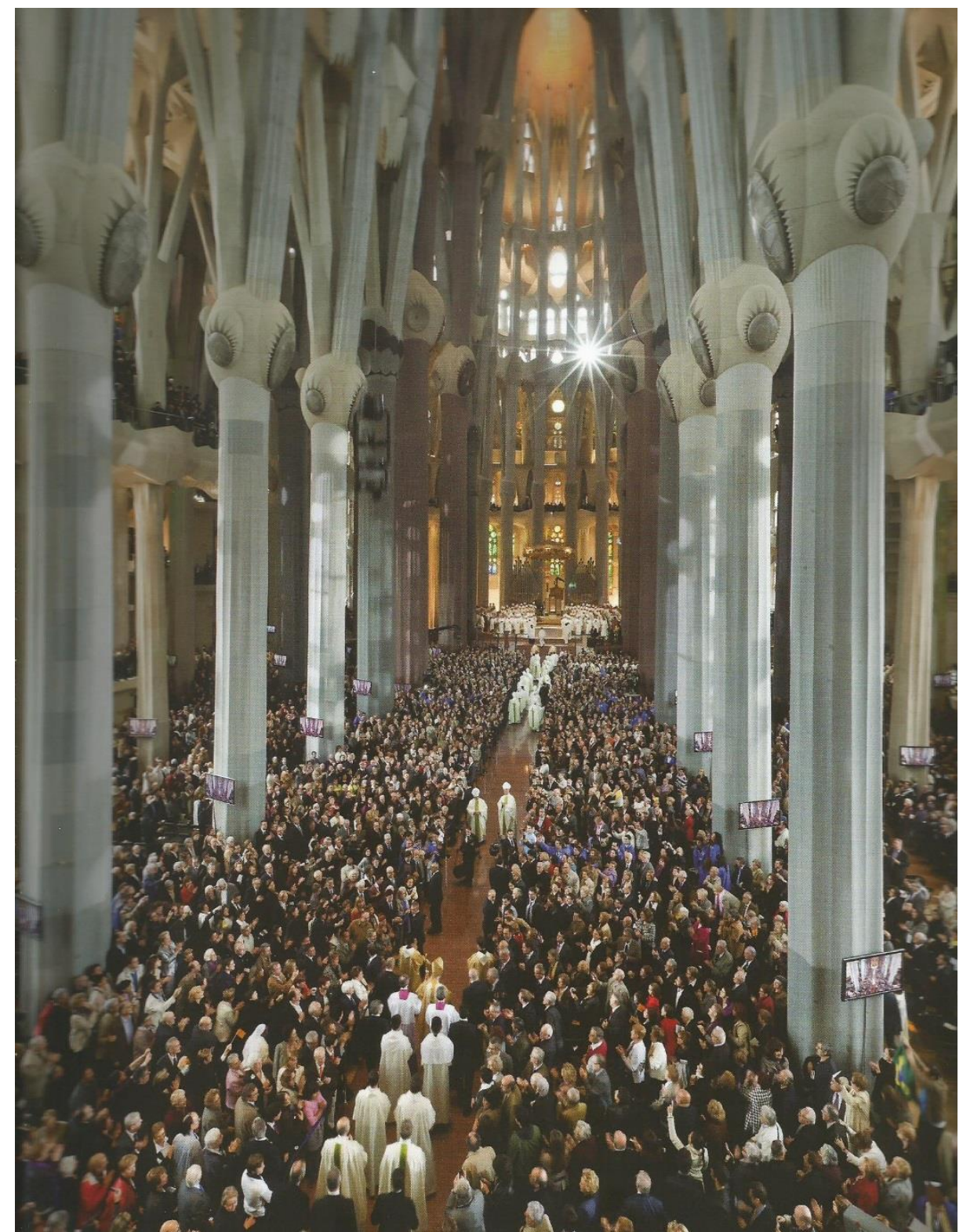

Procesión de entrada en la celebración eucarística de la dedicación de la basilica por S.S. Benedicto XVI. Fuente: . Burry, M., Espel, R., Faulí, J. y Gomez, J. (2014) Les naus de la Sagrada Familia. Els secrets arquitectònics d'una obra irrepetible. Barcelona. Mediterrània 
Su interés es el del artista que se suma al carro de la liturgia en el acondicionamiento del espacio celebrativo.

En apartados anteriores nos hemos acercado a los espacios litúrgicos de la Sagrada Familia, veamos ahora qué elementos arquitectónicos utiliza para estructurarlos y cómo tienen que ver con la visión mística del aula celebrativa y su confort litúrgico.

\section{-Aproximación a la dimensión teológica y simbólica del aula litúrgica.}

Si tomamos en sentido literal la definición de Braun mencionada por Puig Boada ${ }^{422}$ respecto del simbolismo litúrgico podemos afirmar que El Medievalismo intentó desarrollar un fuerte lenguaje simbólico que sin embargo ya estaba presente en la domus-iglesia desde los primeros tiempos del Cristianismo.

Con el Renacimiento esta tradición decae en beneficio de aspectos geométricos, perspectivos o estilísticos que se consideran de la mayor importancia. En el trascurso del Clasicismo y el Neoclasicismo, tomando como referencia la libertad compositiva y el ideario humanista, religioso o político del momento se llegan a producir edificios cuya materialidad les aporta una imagen polivalente, sea cual sea el estilo arquitectónico que utilice, alejada en muchos casos de este simbolismo y funcionalidad originales como edificio de culto cristiano aunque dotada de un gran componente escenográfico. En el historicismo se vuelve a poner como paradigma de la arquitectura eclesial el lenguaje medievalista pero despojado de toda referencia simbólica de ahí que se caiga en el decorativismo que tanto critica Antonio Gaudí.

Nos hemos intentado acercar a la Sagrada Familia como proyecto unitario, siguiendo al propio Gaudí en su pensamiento, en las obras que anticipan la Sagrada Familia y en una visión de ésta desde las inquietudes litúrgicas de su principal autor. Si tuviésemos que volver a contestar a la clásica pregunta de Louis Khan reformulada en términos de qué quiere ser el edificio-iglesia hemos visto que Gaudí respondería preguntándose desde los comienzos de su actividad profesional qué es una iglesia en sus origen teológico, litúrgico, simbólico y constructivo. Su contestación le lleva toda una vida pero incluye en ella una composición arquitectónica del espacio basada en la ordenada conjunción de espacios celebrativos y sirvientes partiendo de la centralidad que otorga la exaltación del misterio pascual actualizado y celebrado en el aula litúrgica.

\footnotetext{
422 Puig Boada hace mención de la definición del Diccionario Liturgico del P. J Braun, SJ: "Simbolismo, en el sentido litúrgico, es una señal externa por mediación de la cual se manifiesta externamente una idea religiosa o un hecho religioso. Cf. Puig Boada (1950) L'ideal del temple cristià. Conferencia publicada por la Revista Templo en octubre de 1950.
} 


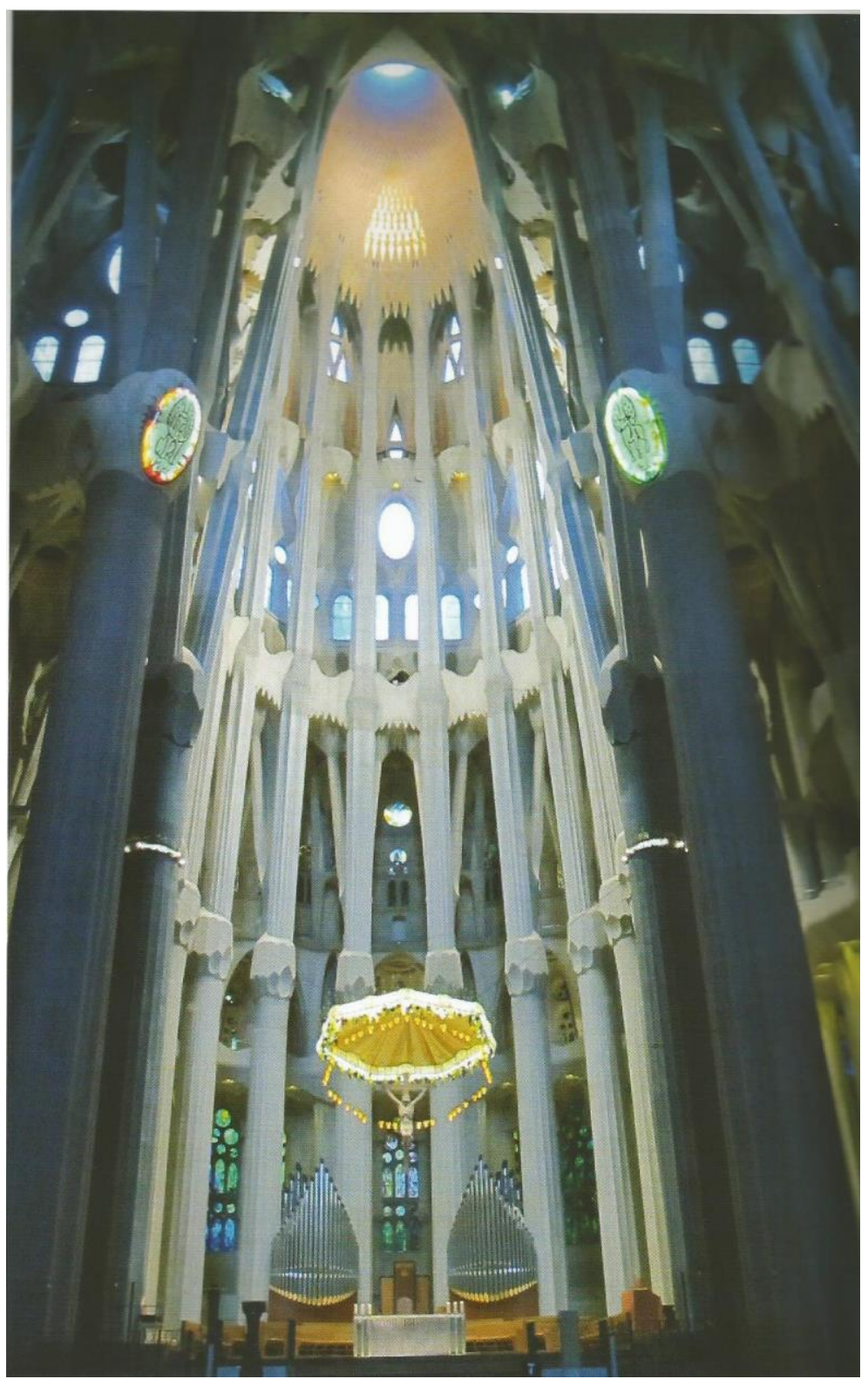

Visión desde la entrada principal. Fuente: Burry, M., Espel, R., Faulí, J. y Gomez, J. (2014) Les naus de la Sagrada Familia. Els secrets arquitectònics d'una obra irrepetible. Barcelona. Mediterrània 
Ha quedado claro que Gaudí es un convencido de la renovación que promueve el Movimiento Litúrgico y, como tal, al describir los espacios celebrativos de la Sagrada Familia, los diseña para el cuerpo de Cristo -la asamblea cristiana- y no para la devoción particular. Veíamos que esta radical actitud le lleva a abandonar proyectos como el de la Capilla del colegio teresiano, pero también a concebir sus tres proyectos de lugares de culto como hitos de la era preconciliar de los que todavía es posible sacar lecciones válidas para la era posconciliar.

En la Sagrada Familia el orden o jerarquía de las acciones litúrgicas toma como fundamento la Eucaristía pero contando con una cuidada conexión del aula litúrgica con la pila bautismal, que es condición primigenia a la participación en ella, y con la capilla de la Penitencia, itinerario imprescindible para la reinserción. En esta misma dinámica teológico-litúrgica se ha analizado el deambulatorio o claustro como un espacio celebrativo más ligado a la oración oficial de la Iglesia, así como el sentido de acogida y servicio de las fachadas o nártex y de las sacristías. La misma asamblea que se congrega para celebrar la eucaristía en el aula litúrgica está jerárquica y escatológicamente ordenada en los términos que mencionan Maurizio Bérgamo y Mattia del Prette (Espacios celebrativos, 1997) disponiendo de los signos y ambiente adecuados para sostener y significar los ritos. La estructura está al servicio de la funcionalidad y ritualidad litúrgica y la simbología, toma sus fuentes de las Sagradas Escrituras para ayudar sensiblemente a la exaltación y participación en el acontecimiento eucarístico.

En el apartado anterior se ha sintetizado el proceso evolutivo del sistema estructural que da estabilidad al edificio, y cómo hace posible mediante el tratamiento de la luz la estructuración del espacio celebrativo. Este viene definido materialmente por la adecuada disposición de los focos litúrgicos, la iluminación y visibilidad conseguidas en la asamblea, la iconografía y simbología del lugar celebrativo, su confort sonoro y adecuada movilidad.

La idea que tiene Gaudí de la asamblea litúrgica mira a la movilidad. Partiendo del Ceremonial de los Obispos y de la planta general de la Sagrada Familia se observa el detallado estudio de las circulaciones que realiza: una disposición espacial envolvente de la asamblea cuyo centro focal es el Altar y jerárquicamente organizada sobre la base de disponer un lugar para la Sede, los diferentes ministerios y sus funciones, cantores y resto del pueblo, en el cual cada uno de los actores dispone de su ámbito de movilidad más adecuado. Sede y coros gozan de la adecuada visibilidad; el celebrante dispone del recorrido y espacio apropiados para la procesión introductoria, la plegaria eucarística y los ritos alrededor del altar; el que proclama la Palabra y el que predica lo hacen desde el lugar y foco adecuado a la vista de toda la asamblea; los que presentan la ofrenda pueden acceder fácilmente al altar; los que realizan otro tipo de procesiones o acceden a la asamblea también pueden hacerlo fácilmente en virtud de los diversos itinerarios que la circunscriben. 


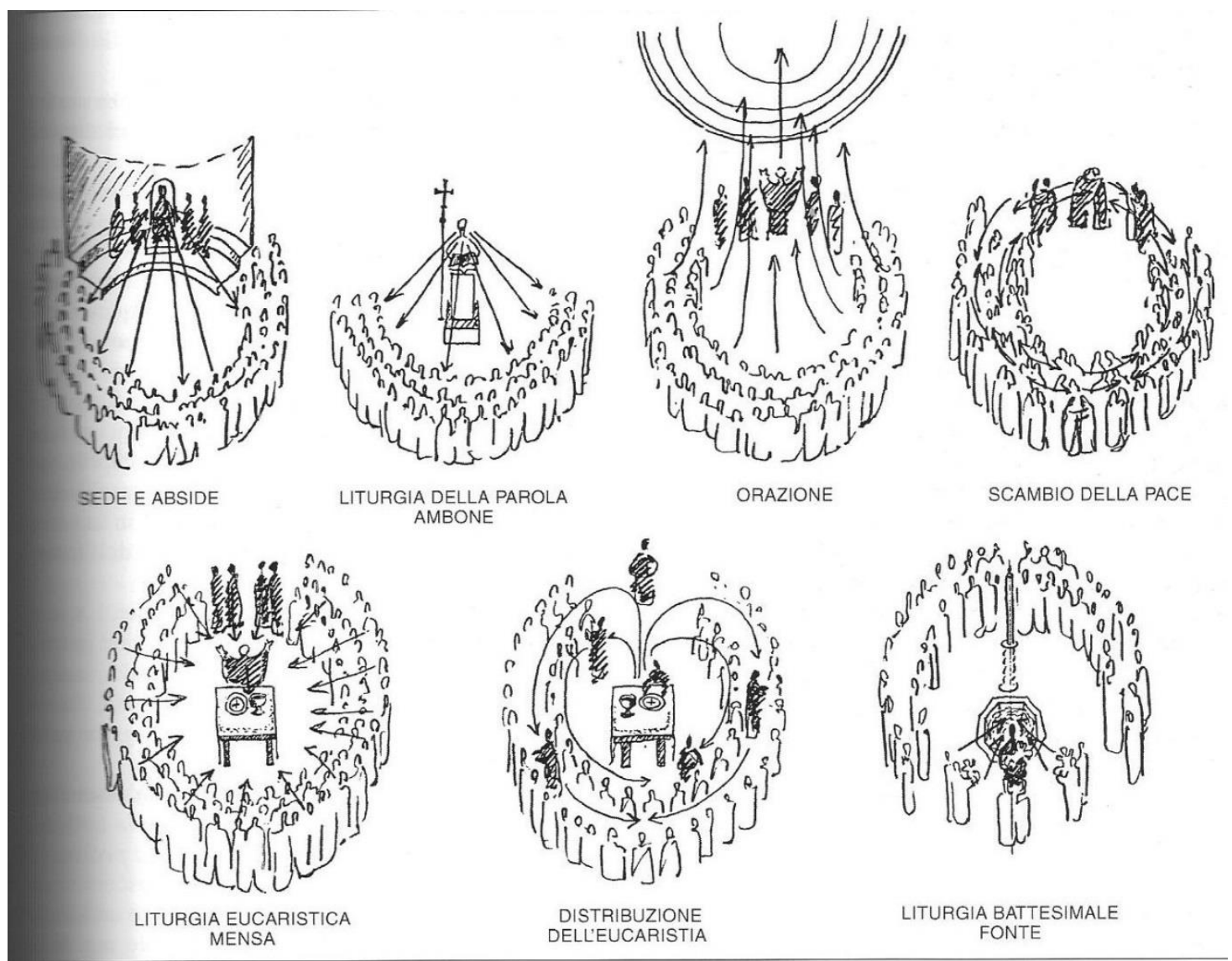

Geometria sacramental en el rito eucaristico. Fuente: Bergamo, M. y Del Prette, M. (2001) Spazi celebrativi. Bologna. EDB Edizione Dehoniane Bologna. 
En el proyecto de Gaudí para la asamblea litúrgica la forma escapa del debate geométrico y cede paso a una visión mística del espacio en la que la inmaterialidad juega un papel esencial, pues son el espacio mismo y la función que cada miembro de la asamblea ha de realizar los que se se constituyen en protagonistas del mismo. El resultado es de una centralidad funcional sorprendente para su tiempo aún manteniendo las trazas de una planta de cruz latina.

En el apartado 5.b de esta Tesis se ha hecho mención a cómo el proyecto de Sta. Coloma avanza una asamblea liturgica con una configuración muy semejante a los gráficos y proyectos que Rudolf Schwarz realiza en 1928: una disposición de los fieles que permite su mutuo reconocimiento y visualización, configurando una envolvente del altar -aun cuando éste no ocupara el centro geométrico- y ordenada según una presidencia. Con una escala dimensional ciertamente recoleta rompe -en la Cripta de Santa Coloma- con la tradicional disposición de bancos en filas de batallón, tal y como se concibe en tiempos posconciliares una asamblea sagrada. ${ }^{423}$ Esta misma disposición (aunque ciertamente no tan libre y rotunda en cuanto a la ordenación de los bancos de los fieles) se repite, como ya hemos visto, en la Cripta de la Sagrada Familia cuando es transformada en Parroquia. En ella el altar se sitúa exento y la presidencia con el presbiterio quedan claramente distinguidos dentro de una asamblea cuyos bancos para los fieles se han dispuesto en tres lados conformando una cruz.

En el aula litúrgica de la Sagrada Familia la centralidad de la asamblea (con los condicionantes que en otros apartados se han reseñado) es, como decimos, menos geométrica y más sacramental, pues manteniendo su conjunto la disposición jerárquica y orientación focal hacia el altar, y significando la cátedra episcopal, la ordenación es realizada por la misma dinámica de la celebración litúrgica, esto es, por el concurso de los distintos ritos de la asamblea que se ven realzados en el espacio celebrativo diseñado. Son, pues, los ritos de la liturgia de la Palabra y la liturgia Eucarística los que acompañados por la oración y la salmodia en nave y cantorías, los que conforman la dimensión trascendente del aula litúrgica convenientemente dispuesta. Aquí el papel de la luz y la iconografía prevista resultan fundamentales para una visión espiritualizada del espacio. $^{424}$

${ }^{423}$ Cf. Bérgamo, M. y Del Prette, M. (1997) Espacios celebrativos. Bilbao. Ed. Ega. Pp. 55-59: Una asamblea sagrada.

424 Cf. Bérgamo, M. y Del Prette, M. (1997) Espacios celebrativos. Bilbao. Ed. Ega. P. 61: “El espacio sagrado cristiano, por consiguiente, será no un lugar de características sagradas en sí mismo, sino el espacio que permitirá que se realice esta intervención de Dios. No existe, pues un 'espacio sagrado', un 'lugar del espíritu' con especiales características arquitectónicas de misticismo, de silencio, de interioridad , de ascensionalidad u otras cosas semejantes, en que tenga que realizarse este encuentro entre el hombre y Dios.....El 'espacio sagrado cristiano' es el espacio de la Asamblea cristiana, en donde ésta vive como tal $y$, por consiguiente, es espacio de una acción litúrgica y de una experiencia colectiva de encuentro con Jesucristo, que la conduce a su Pascua." 


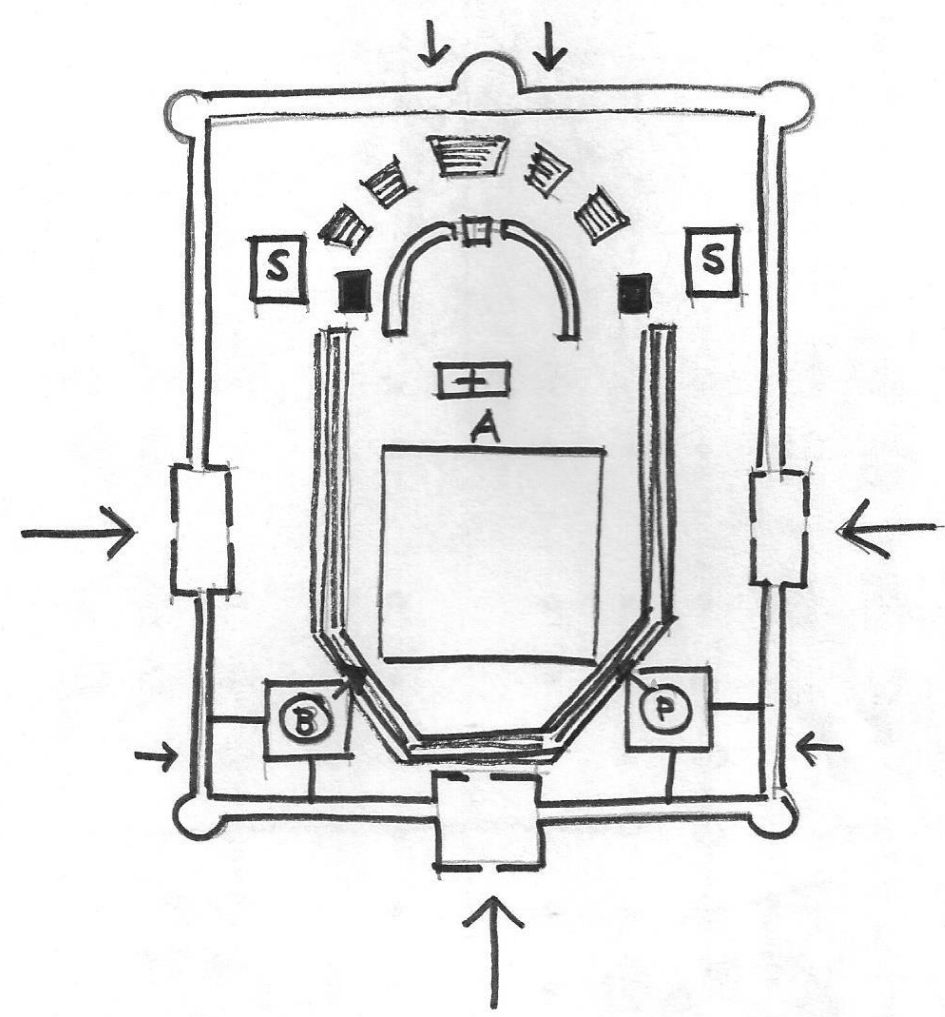

Movilidad de la Asamblea Liturgica en la Sagrada Familia: Accesos y Plan General. Dibujo del autor.

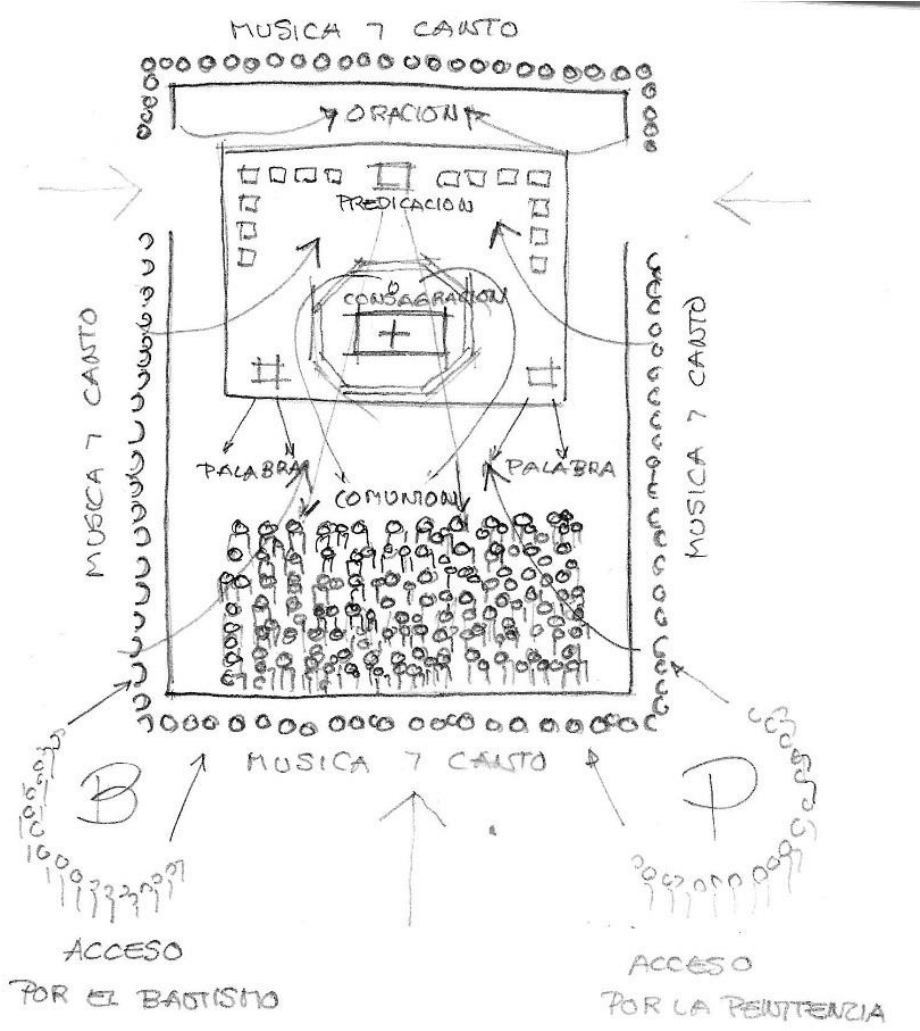

Geometria sacramental del Aula Liturgica de la Sagrada Familia. Dibujo del autor. 
La relación entre los focos y la asamblea es completa porque es precedida de la dimensión de acogida y procesional en sus muy diversas acciones y momentos previos a la plegaria eucarística: acceso y recepción, peregrinación claustral, liturgia bautismal, liturgia penitencial, procesión de las ofrendas, inciensación de altar, presidente y asamblea, etc. La centralidad visual del proyecto gaudiniano gana con la disposición y preeminencia del altar que permite su visualización por la asamblea, la dignificación de la liturgia de la Palabra ${ }^{425}$, la situación y visualización de la sede y coros, así como el cuidadoso estudio de la acústica y la música. Se ha destacado en el apartado de los espacios litúrgicos de la Sagrada Familia (6.2.d) la explicita forma arquitectónica con la que Gaudí relaciona los focos litúrgicos de la celebración y su carácter escatológico, trascendente, ordenado a la liturgia celeste.

En la Sagrada Familia, la axialidad de Bérgamo y del Prette desborda el ámbito puramente material para adquirir también un completo significado simbólico y litúrgico. La tensión escatológica que históricamente se expresaba a lo largo de un eje longitudinal occidente en la puerta de entrada desde el mundo-oriente en el ábside por donde ha de venir Jesucristo en su gloria al fin de los tiempos, se muestra aquí en un recorrido visual y celebrativo peatonal y horizontal pero también místico y vertical.

La visualización de la representación del Padre Eterno -sus vestiduras- en la bóveda del ábside, del lampadario del Espíritu Santo simbolizando la Encarnación del Hijo de Dios en el seno de Maria -El ábside-, la Epíclesis sobre el Altar-Jesucristo-, y la referencia hacia lo alto de la Jerusalén celestial, como lampadario bajo la bóveda de la cúpula central que simboliza el Trono de Dios y del Cordero según el Apocalipsis, constituye una muestra de la tensión escatológica que nos propone Gaudí para el aula litúrgica. Una axialidad teológica y simbólica que tiene su centro en el altar y desde aquí aspira a lo alto, según la tradición litúrgica y artística de la Etimasía en las iglesia cristianas de Oriente, especialmente, que orienta no físicamente en la dirección de este punto cardinal sino litúrgicamente según expresa el Papa Benedicto $\mathrm{XVI}^{426}$, que explica esta tradicional orientación de la Eucaristía como un volverse la asamblea hacia el acto común de adoración trinitaria; así, mediante la orientación ontológica se hace patente la dimensión cósmica de la Eucaristía en los ritos litúrgicos y la esperanza en la parusía.

\footnotetext{
${ }^{425}$ Apoyado en los textos de los Albumes, en el traslado y tratamiento de los púlpitos o tronas en la catedral de Mallorca, y en la ejecución de un ambón de madera para dicha catedral y otro para la Cripta de la Sagrada Familia, que muestran la puesta en práctica por Gaudí de los postulados del Movimiento Litúrgico que resaltaba la proclamación de la Palabra como uno de los elementos a recuperar para la participación de los fieles en la Eucaristia.

${ }^{426}$ Cf. Ratzinger, J. Benedicto XVI (2010). La fiesta de la fe. Sevilla. Desclée de Brouwer. P. 186: "La orientación interior de la Eucaristía sólo puede ser una determinada: desde Cristo en el Espíritu Santo hacia el Padre."
} 


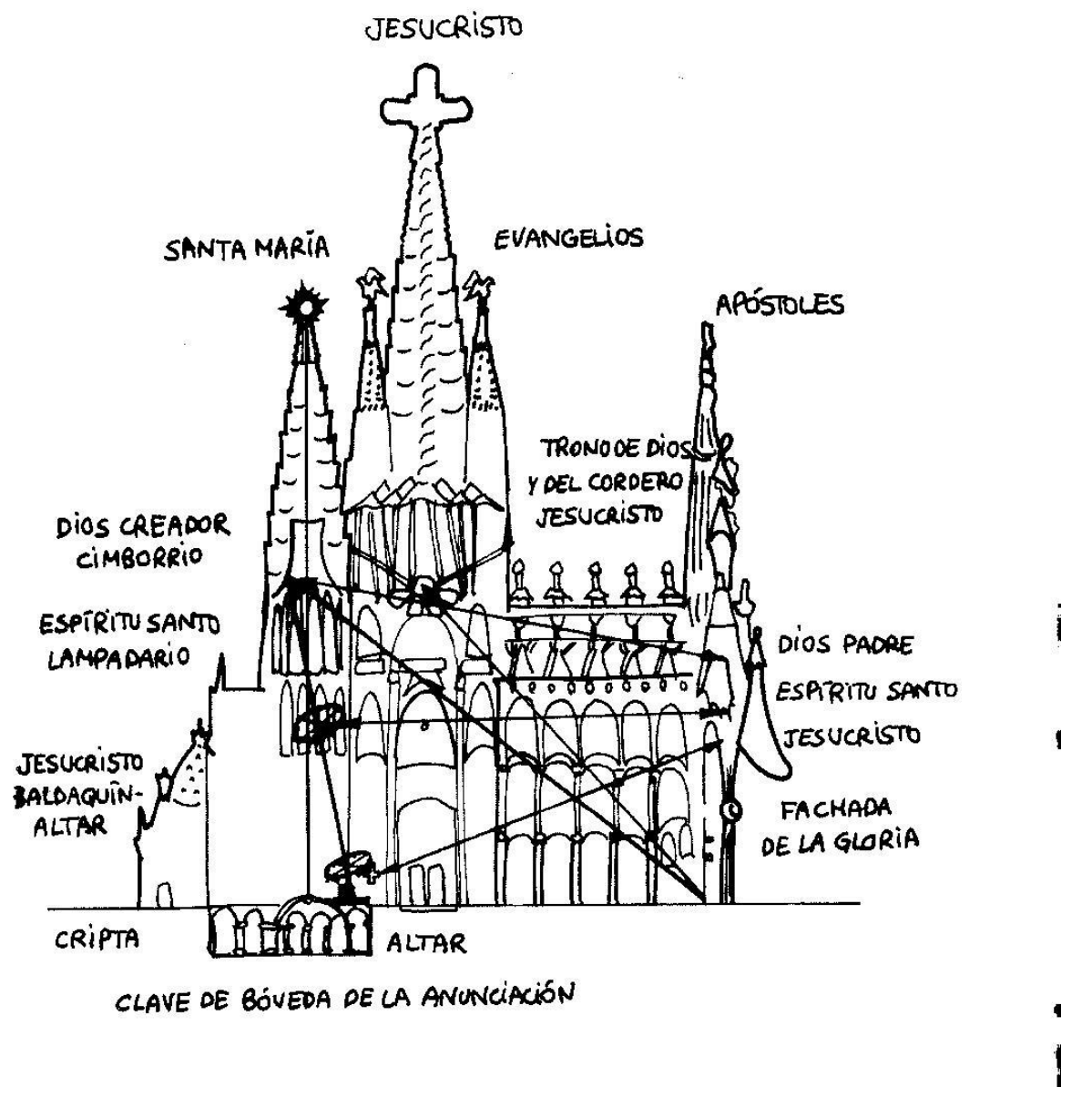

Visuales teológicas interiores. Fuente: Puig, A. (2011). La Sagrada Familia según Gaudí. Barcelona. El Aleph.

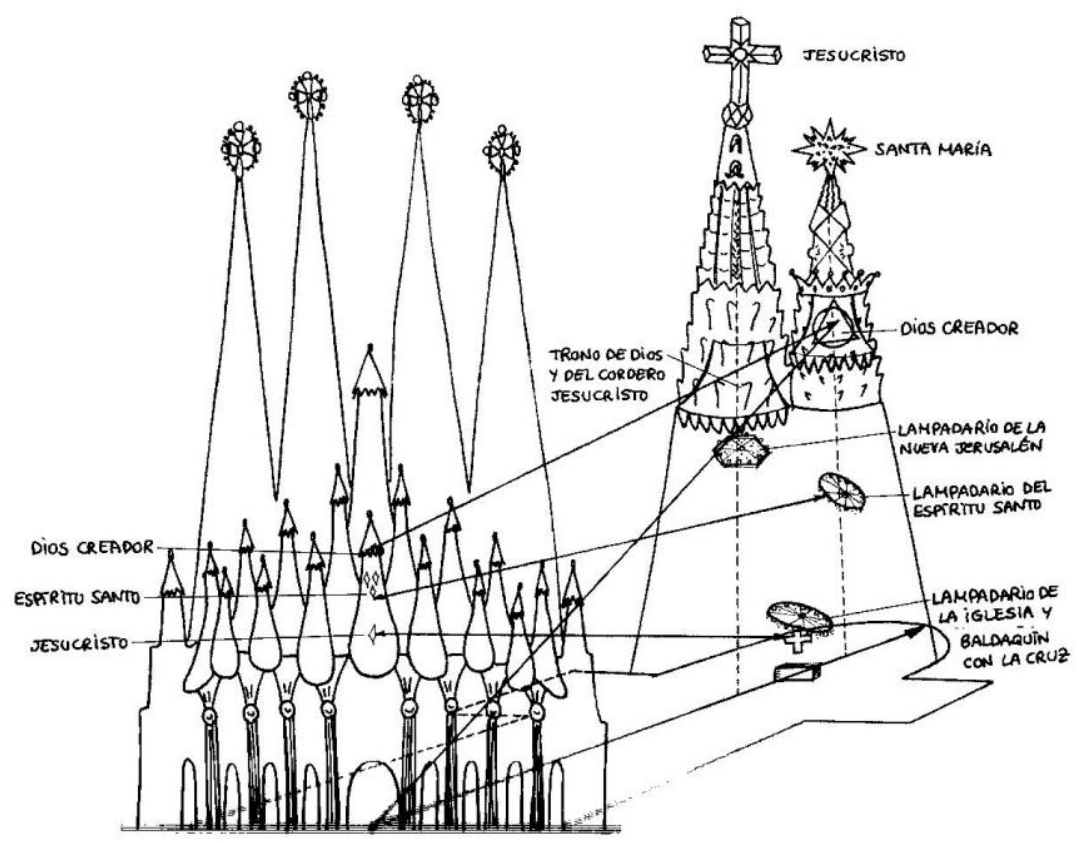

Via de la Humanidad, según Armand Puig. Fuente: Puig, A. (2011). La Sagrada Familia según Gaudí. Barcelona. El Aleph. 
Esta es la convergencia que emerge en la dimensión teológica y simbólica del proyecto gaudiniano de adecuación del aula litúrgica, la teología del "Oriens" preconizada por los monasterios benedictinos del Movimiento Litúrgico llevada a todas sus consecuencias arquitectónicas y artísticas: sintetizada en los signos de un crucifijo colgante sobre el altar exento y centralizado, y la visión cósmico-parusial de la asamblea de los santos en la Jerusalén celestial, representada en su lampadario bajo el trono-etimasía ya no iconográfico sino arquitectónico en la bóveda de la cúpula. En la Sagrada Familia la axialidad longitudinal se hace también presente en el itinerario procesional del celebrante y del resto de la asamblea, tanto en el deambulatorio o claustro como en la propia aula litúrgica, en la que la situación de la sacristía y la extensión del aula significan en el plano horizontal lo que la iconografía de las columnas, con ángeles que descienden y santos que ascienden, quiere mostrar en el plano vertical.

\section{-La lluminación del espacio litúrgico.}

Desde los primeros tiempos del Cristianismo la iluminación del espacio litúrgico ha comportado un importante sentido simbólico, pues Jesucristo desde el primer momento de su predicación se define como luz del mundo y encarga a quien la acoja que también lo sea, siendo esta luz muchas veces símbolo de Cristo y de su Iglesia en contraposición a las tinieblas exteriores. Junto a ella e íntimamente unidos, el fuego, que igualmente proporciona una luz natural, aparece en los Hechos de las Apóstoles como simbolizando el Espíritu Santo que derrama sus dones sobre la Iglesia reunida. La luz también tiene connotaciones de visión y como tal es necesaria desde el punto de vista funcional para la participación en la celebración liturgica, ya que si puede cegar al venir directamente del cielo en grado excesivo para la escala humana (ceguera de Saulo) siempre actúa al servicio de los elegidos, que desde el principio se reúnen en el Cenáculo (Act. 20,8). Por ello Gaudí al ponderar la luz de las iglesias entiende que no ha de ser excesiva sino la conviene y es regulada por la liturgia. ${ }^{427}$

Con la aparición de los grandes edificios-iglesia las necesidades de iluminación se incrementan y aún sin perder el sentido primordial cultual que tiene la luz en el aula litúrgica ${ }^{428}$, dentro de los cánones de cirios y candelas de cera o vidrieras, ha de atender en su disposición a la funcionalidad del culto.

\footnotetext{
${ }^{427}$ Cf. Puig Boada, I. (1981) El Pensament de Gaudí. Barcelona. La Gaya Ciencia. P. 118: “En la il'luminació de les esglèsies hi ha el malentès dels qui creuen que l'abundor de llum afavoreix. No es així. La llum ha d'esser la justa: ni massa ni poca, puix que totes dues coses enceguen i els cecs no hi veuen....En els temples tot ha d'esser ponderat i regulat per les sàvies lleis de la liturgia, sense adulteracions."

${ }^{428} \mathrm{Cf}$, Plazaola, J. (2008) Arte sacro actual. Madrid. BAC.
} 


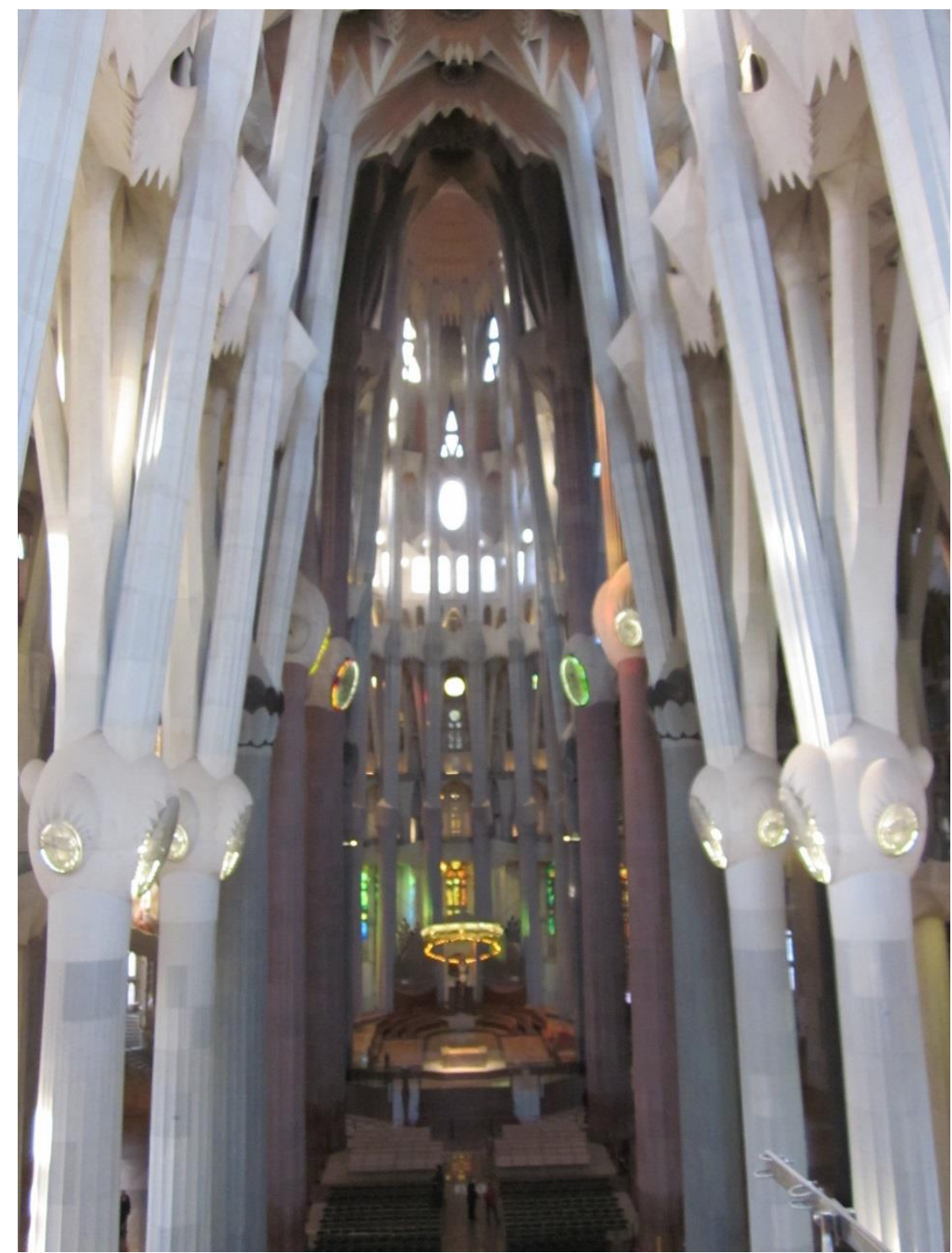

Fotografia del autor 
Durante años la dualidad lumínica entre luz natural-luz artificial, luz de culto-luz funcional, se ha presentado como un problema para los arquitectos que proyectan este tipo de edificios. Si a estos dos tipos de iluminación añadimos la denominada iluminación arquitectónica del edificio el asunto se complica algo más. Gaudí lo afronta en primera línea, desde la liturgia, que en su opinión lo tiene todo previsto. Para ello supedita ambos focos lumínicos, natural o artificial, a la acción litúrgica y a las necesidades que se plantean en el aula. De esta manera el diseño de los ventanales y vidrieras evoluciona desde un planteamiento purista respecto de la obtención del color de los vitrales (Mallorca) hasta una evolución formal de los ventanales y, posteriormente, la integración de la luz con la estructura. En la Sagrada Familia se puede apreciar la evolución formal de los vanos del edificio en la disposición medievalista o modernista de los ventanales inferiores de las naves laterales, el desarrollo de un nuevo diseño de los ventanales superiores mediante el empleo de la geometría reglada, y finalmente en la integración aludida de lucernarios cenitales en techos y bóvedas de cada espacio celebrativo. El criterio de Gaudí es que la arquitectura es la ordenación de la luz por lo cual ésta ha de ser conducida o derramada para evitar que su exceso impida la visión. Además señala que la luz contribuye certeramente a la armonía del espacio arquitectónico siendo la dirección de ésta más conveniente la que se obtiene con un ángulo de 45․ ${ }^{429}$ Bajo estas premisa trabajará con la luz natural y la luz artificial en sus tres acepciones: cultual o simbólica, funcional para hacer posible la visualización de la celebración y arquitectónica, que muestra el edificio.

En cuanto a la luz natural, encontramos una triple dirección en la investigación y diseño de la iluminación. Tal y como se puede apreciar en los dibujos de secciones, Gaudí, concibe muy pronto la idea de iluminar cenitalmente el crucero y presbiterio, lugares donde se han de situar los principales focos de la celebración litúrgica, así como la entrada o nártex desde la fachada de la Gloria. Por supuesto, que en ese momento también está planteada la iluminación funcional, según la disposición históricamente tradicional de los grandes ventanales vidriados neogóticos. De hecho, a ambos lados de la fachada del Nacimiento, en el transepto, hay dos ventanales que junto con los del ábside corresponden al primer proyecto neogótico y son el punto de partida para los ventanales inferiores de las naves laterales, en los cuales se pasa de una interpretación personal medievalista a la elaboración del mismo elemento bajo los parámetros de los hiperboloides de revolución, los cuales se intersectan para definir y conducir el haz lumínico. ${ }^{430}$.

\footnotetext{
${ }^{429}$ Cf. Puig Boada, I. (1981) El Pensament de Gaudí. Barcelona. La Gaya Ciencia. P. 96: "La llum que assoleix la máxima harmonia és la inclinada a 45o".

430 Cf. Burry, M., Espel, R., Faulí, J. y Gomez, J. (2014) Les naus de la Sagrada Familia. Els secrets arquitectònics d'una obra irrepetible. Barcelona. Mediterrània. Los autores sitúan la construcción del ventanal del transepto entre 1898-89.
} 

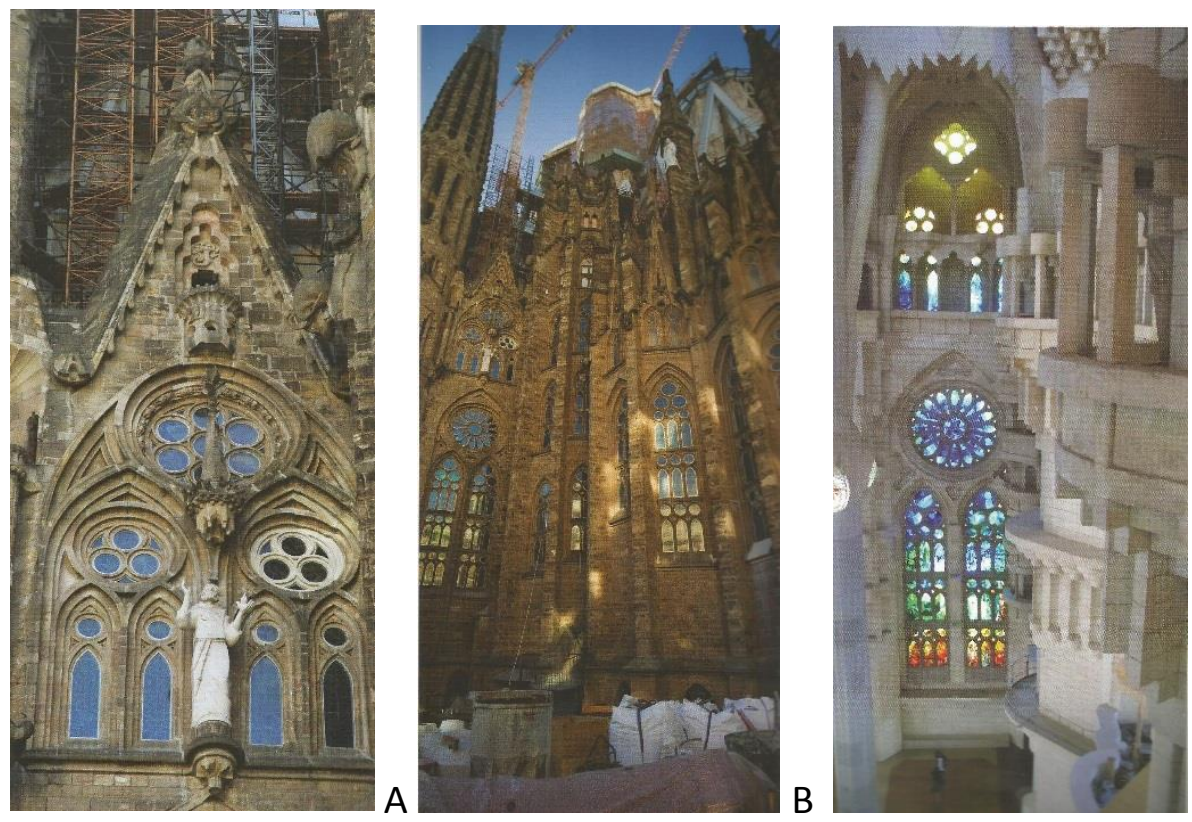

A Vista exterior del primer diseño de Gaudí para los ventales superiores laterales.

$B$ Ventanales neogóticos del ábside.

C Interior de ventanales neogóticos en el transepto.

Fuente: Burry, M., Coll, J., Espel, R., Faulí, J. y Gómez, J. (2014) Les Naus de la Sagrada Familia. Barcelona. Mediterrània.

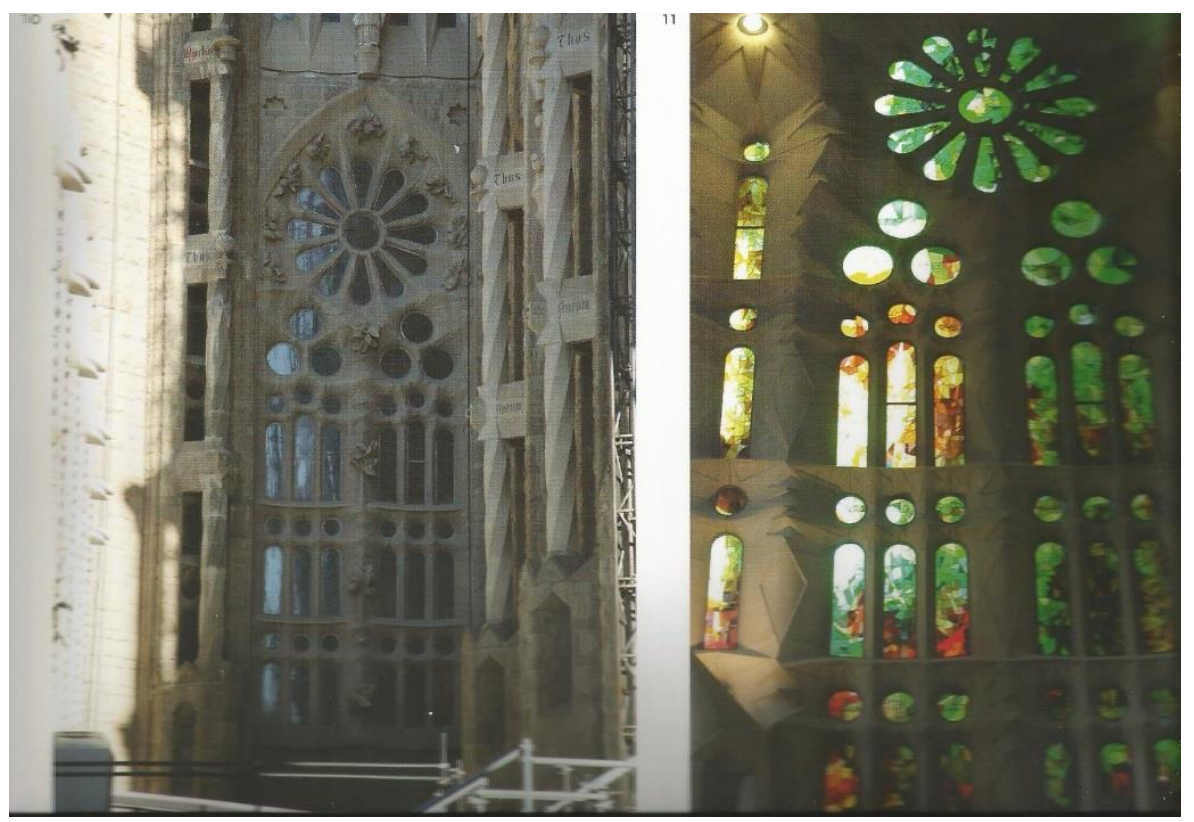

Ventanal inferior de naves laterales incorporando el diseño final con superficies regladas. Fuente: Burry, M., Coll, J., Espel, R., Faulí, J. y Gómez, J. (2014) Les Naus de la Sagrada Familia. Barcelona. Mediterrània. 
Dentro del largo proceso de elaboración del proyecto, del cual ya se ha mencionado su sintética exposición formal y simbólica de 1891 como punto de arranque y el importante cambio estructural que se produce en torno a 1915, hay que situar también la evolución formal de los ventanales de las naves. Terminada la Cripta en 1891, se trabaja en el ábside y el entorno de la fachada del Nacimiento, en los cuales encontramos los tipos neogóticos anteriormente mencionados. La reelaboración de los ventanales de las naves, laterales y central, van en la línea del nuevo proyecto estructural y por tanto tienen que ver con la concepción del espacio místico en la nave litúrgica, de tal modo que al mismo tiempo que se abandonan las molduras neogóticas por las superficies regladas que se intersectan y definen los pasos de luz, aún sin variar excesivamente las formas generales neogóticas, se cambia el diseño y tratamiento del color de los vitrales, pasando a ser incoloros en la nave central.

El por qué de este cambio en el color, cuando el mismo Gaudí manifiesta que el color es vida, hay que buscarlo en la liturgia cristiana y su sentido como manifestación o vida de la Iglesia. ${ }^{431}$ La iluminación situada a la altura que es capaz de percibir el ojo humano cuando los fieles participan en la acción litúrgica es suave, se derrama en las superficies de hormigón, ilumina moderadamente con el color de imágenes y simbolismos para no distraer de la concentración respecto de la visualización del altar y el resto de focos litúrgicos. ${ }^{432}$

En cambio la iluminación que proviene de las partes altas de la nave central o de los techos es una iluminación sin color porque no es necesaria para la acción litúrgica, tan sólo ha ayudar a la inmaterialidad del espacio, disponiendo del color propio de los ornamentos litúrgicos de las grandes festividades como la Pascua y la Navidad, el blanco, orientando la mirada levantada hacia las bóvedas de los cimborios de donde baja la luz que viene de lo alto.

Gaudí realiza el diseño de los ventanales superiores de las naves laterales y de los ventanales de la nave central utilizando hiperboloides elípticos de revolución en lugar de los circulares de las partes bajas de las naves laterales. Además, en la nave central, dos de los tres hiperboloides están girados respecto del eje horizontal. Es como si quisiera preparar el camino a la solución estructural y lumínica de los techos perforados por la ordenación geométrica de lucernarios constituidos por hiperboloides en la que éstos también producen con sus encuentros los detalles de la bóveda estrellada de las naves.

431 Cf. Puig Boada, I. (1981) El Pensament de Gaudí. Barcelona. La Gaya Ciencia. P. 119: "La Ilum dels temples ha d'esser solament la necessària i no més, puix que en un temple ha d'haver recolliment, $i$ els focus massa potents distreuen i donen neguit".

${ }^{432}$ Cf. Idem. P. 42: "A la Sagrada Familia sols policromarem les parts baixes i aquelles no toqui el sol". 


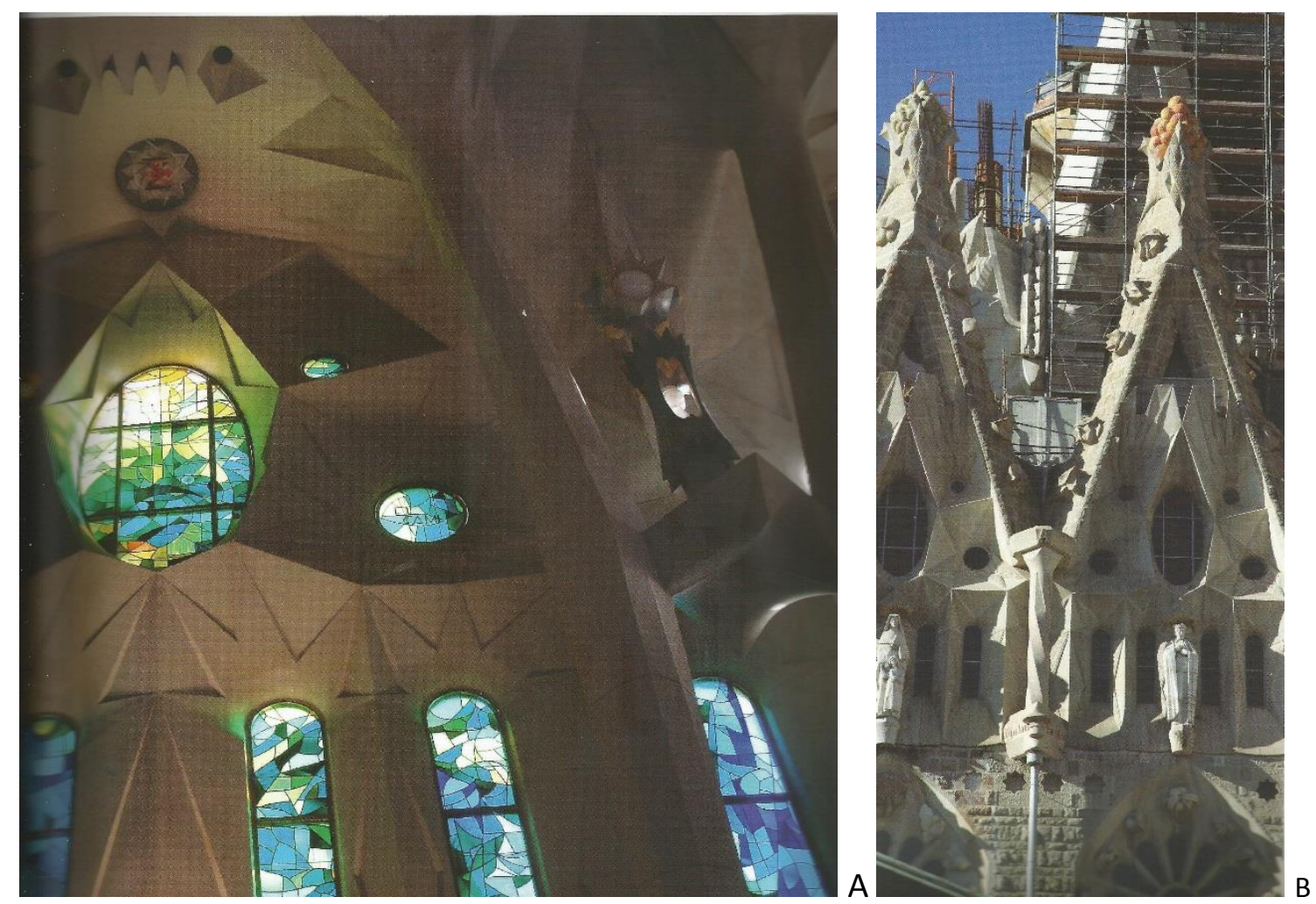

A: Intersecciones entre los ventanales superiores de la nave lateral y las bóvedas, y Vitrales.

B: Vista exterior de los ventanales superiores de las naves laterales.

Fuente: Burry, M., Coll, J., Espel, R., Faulí, J. y Gómez, J. (2014) Les Naus de la Sagrada Familia. Barcelona.

Mediterrània.
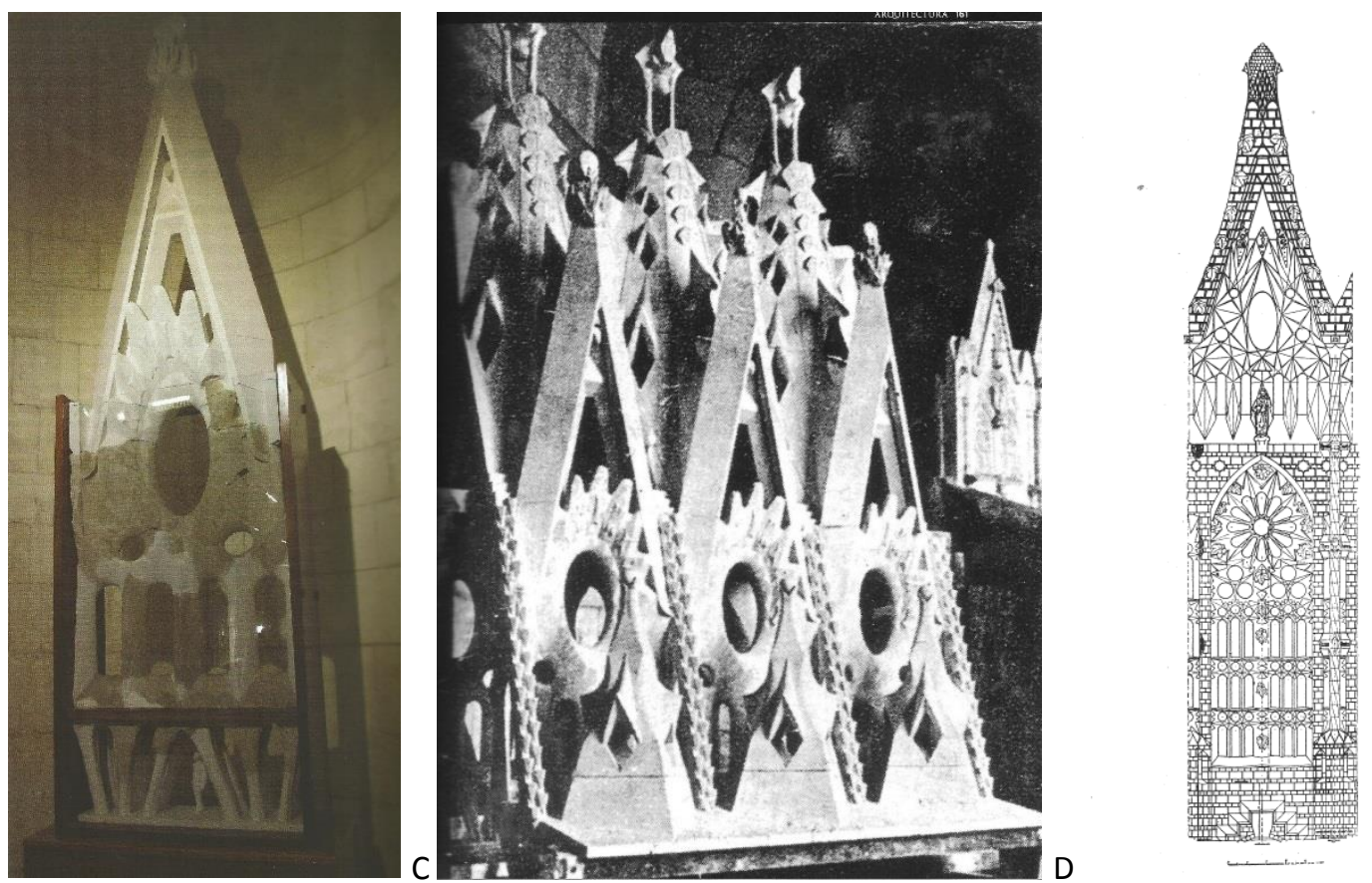

C: Modelo original de Gaudí restaurado de la ventanas de la nave central. Fuente: Burry, M., Coll, J., Espel, R., Faulí, J. y Gómez, J. (2014) Les Naus de la Sagrada Familia. Barcelona. Mediterrània.

D: Fotografia Maqueta original cubiertas de las naves. Fuente: Bonet, J. y Puig, A. (2013) Arquitectura y símbolo de la Sagrada Familia. Barcelona. Pórtic.

E: Dibujo del módulo de ventanas de la nave lateral. Fuente: Bergós, J. (1974) Gaudí, el hombre y su obra. Barcelona. UPC, Cátedra Gaudí, Aymá. 
Es curioso cómo en bóvedas y techos la coloración está encomendada exclusivamente a la iluminación que produce la luz natural cenital blanca de los signos y símbolos litúrgicos: cerámica, vidrio veneciano azul y dorado, gres cerámico dorado, de la bóveda del ábside; los "fanals" o faroles con motivos decorativos de Jesucristo, Maria y José, atributos de Jesús, etc. colocados en la base de los hiperboloides que perforan el techo del aula litúrgica.

En el espacio cultual -el rito en el altar- la luz está producida únicamente por la cera de abeja ardiendo en el cirio del altar. La luz del lampadario y del baldaquino que cuelgan sobre el altar únicamente refuerza la dignidad y santidad del mismo sin producir ningún efecto dramático ni teatral, en la línea que establece la Sagrada Congregación de Ritos. Aunque Gaudí es consciente de la necesidad de la luz artificial ${ }^{433}$, en la Sagrada Familia siempre está subordinada a la luz natural.

Si observamos la cara inferior de las cantorías o de su baranda apreciaremos focos dispuestos en una situación que nunca entra en competencia con los vitrales y que intenta aprovechar también las concavidades y convexidades de las superficies regladas para intentar derramarse por ellas.

En cuanto a las luminarias dispuestas en el techo de las naves se sigue la misma norma, su disposición siempre reafirma la iluminación natural que entra por lucernarios y bóvedas situándose a su alrededor y aprovechando los huecos producidos por las "lenguas". 434

\footnotetext{
${ }^{433}$ Cf. Puig Boada, I. (1981) El Pensament de Gaudí. Barcelona. La Gaya Ciencia. P. 219: "Hom ha de servirse de la llum eléctrica. La llum escassa no afavoreix la devoció. La llum ha d'esser justa, ni massa ni poca, ja que tant l'una como l'altra enceguen; hi ha d'haver la llum suficient per a poder llegir el missal i prendre part activa en el sacrifici."

${ }^{434}$ Cf. Burry, M., Espel, R., Faulí, J. y Gomez, J. (2014) Les naus de la Sagrada Familia. Els secrets arquitectònics d'una obra irrepetible. Barcelona. Mediterrània. P. 132-137. Los autores definen como "lenguas" los pequeños paraboloides entrelazados por las generatrices comunes de dos hiperboloides adyacentes con mucho relieve que están recubiertos de azulejo de color fragmentado. Precisamente, en este encuentro estrellado de los hiperboloides en el techo de las naves se producen unos pequeños hiperboloides que alojan las luminarias.
} 


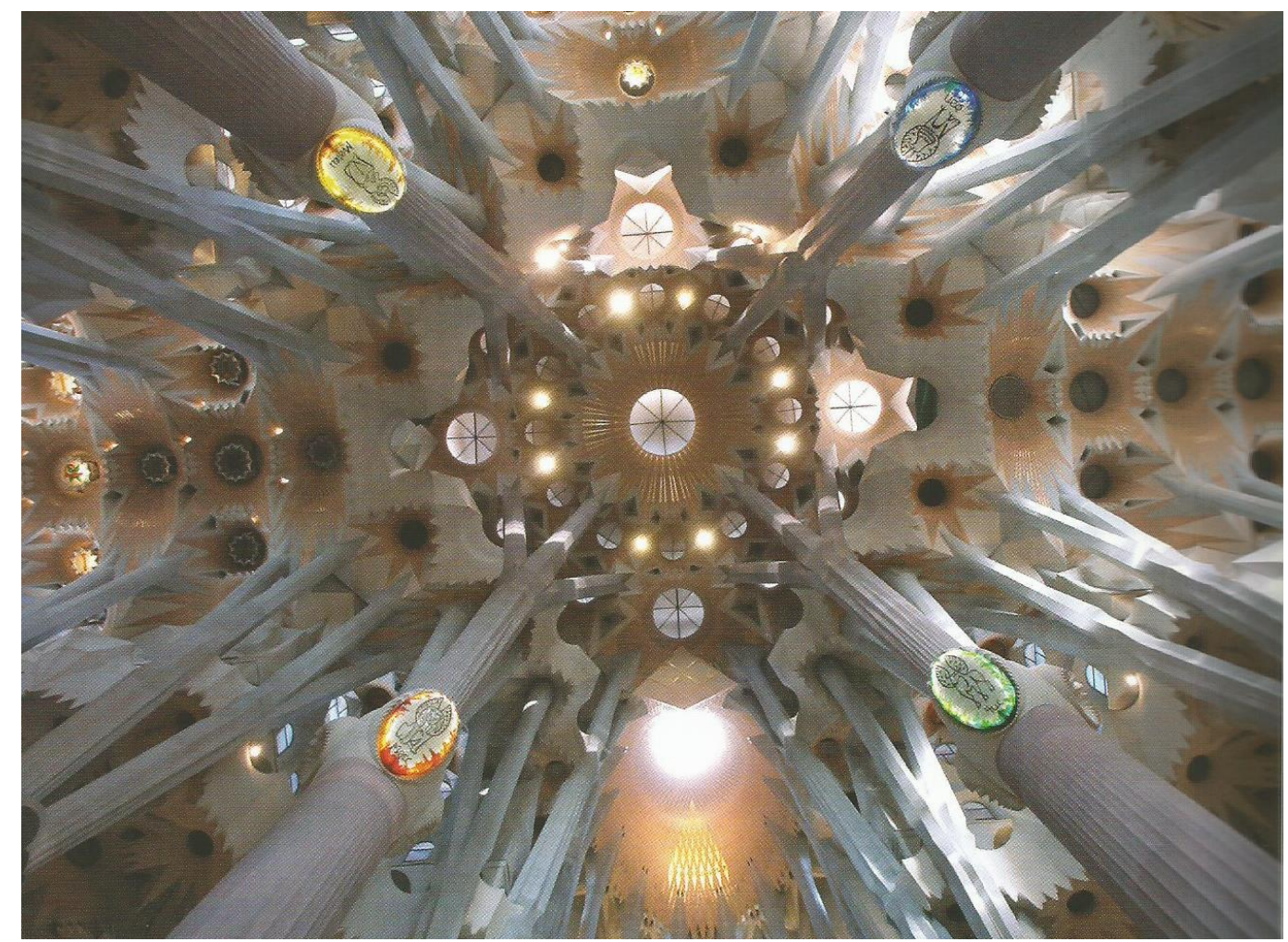

Visión del crucero. Fuente: Burry, M., Espel, R., Faulí, J. y Gomez, J. (2014) Les naus de la Sagrada Familia. Els secrets arquitectònics d'una obra irrepetible. Barcelona. Mediterrània
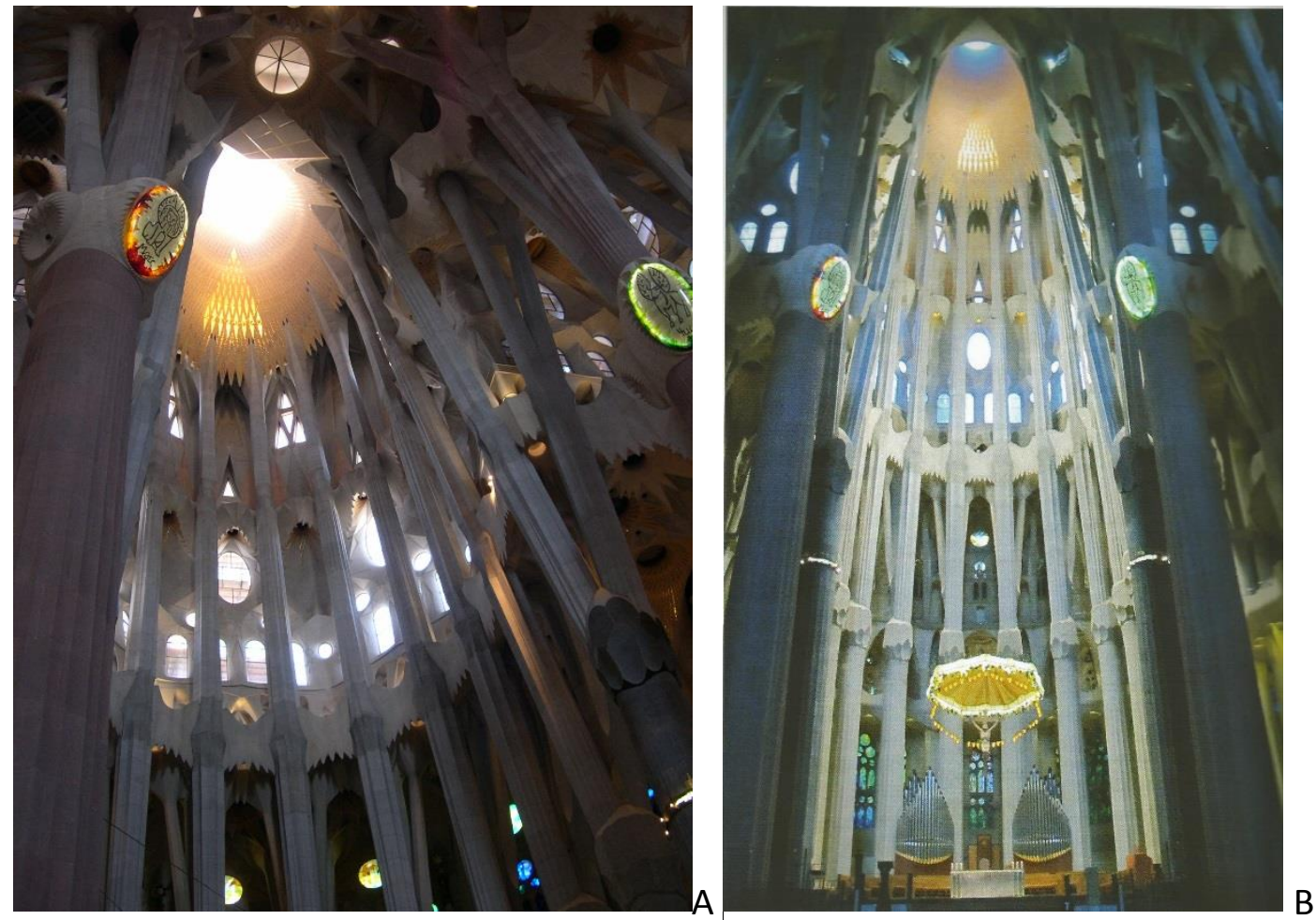

A. Vista desde el crucero de las bóvedas de los dos cimborios. Fuente: Fotografia del autor.

B. Vista desde la entrada principial. Fuente: Burry, M., Espel, R., Faulí, J. y Gomez, J. (2014) Les naus de la Sagrada Familia. Els secrets arquitectònics d'una obra irrepetible. Barcelona. Mediterrània 


\section{-Acústica.}

Ciertamente que en una iglesia moderna ha de tenerse muy en cuenta las condiciones de calidad acústica al objeto de garantizar su funcionalidad, especialmente en lo que hace referencia a la escucha de la voz y también por la participación de la asamblea en el canto coral, pero el punto histórico de donde arrancan las condiciones de confort sonoro de una iglesia no es éste.

Las catedrales históricas han tenido fama de disponer unas buenas condiciones acústicas por el enorme volumen y altura de la nave central, su buenas condiciones de aislamiento respecto del ruido exterior y la claridad con que el sonido llegaba a los fieles. En los últimos años se están realizando numerosas mediciones en catedrales medievales y otras iglesias al objeto de estudiar detalladamente su comportamiento acústico. ${ }^{435}$

Como ya se ha mencionado, al quedar restringida durante siglos la participación litúrgica en las grandes iglesias al clero, único que podía entender el latín y responder con el canto coral a las plegarias del celebrante, la asistencia de los fieles decayó en asistencia pasiva sujeta casi exclusivamente a la visibilidad, y ésta en ocasiones precaria. Al plantearse el Movimiento Liturgico la participación activa de los fieles en la liturgia lo hace promoviendo la mejora de la visualización de la asamblea y sus focos así como el canto coral colectivo, dando lugar a una mayor concienciación de jerarquía y arquitectos respecto de los parámetros acústicos del edificio.

Gaudí, al proyectar la Sagrada Familia como una asamblea envolvente entorno al altar, en la que el canto gregoriano tenia una función relevante dentro de la celebración litúrgica, tuvo siempre presente el estudio y ejecución de las condiciones acústicas más idóneas posibles para el interior del edificio, tal y como atestiguan sus colaboradores y asistentes. Estudios recientes han mostrado unas condiciones generales acústicas muy razonables tanto en el plano de su propuesta para la ubicación de los órganos como en el comportamiento acústico del espacio celebrativo. ${ }^{436}$ Josep $\mathrm{M}^{\mathfrak{a}}$ Tarragona habla de que Gaudí estudió y diseño cuidadosamente el proyecto acústico de la Sagrada Familia aunque no pudo prever la megafonía, y los estudios acústicos realizados por BOSE para el refuerzo electroacustico de la voz denotan unos materiales muy reflectantes y un tiempo de reverberación ciertamente elevado.

\footnotetext{
${ }^{435} \mathrm{Cf}$, El Proyecto de Acústica de las catedrales del Instituto Universitario de Arquitectura y Ciencias de la Cnstruccion de la Universidad de Sevilla o el Estudio Acústico de la Catedral de Valencia, de la Universidad Politecnica de Valencia y Universidad de Valencia, actualmente en curso.

${ }^{436}$ Cf. Campos, J. y Daumal, F. (2015). "Las tonalidades de Gaudi" en Espacios sonoros y audiovisuales 2013, Creacion, representación y diseño. Madrid. Autor Editor.
} 

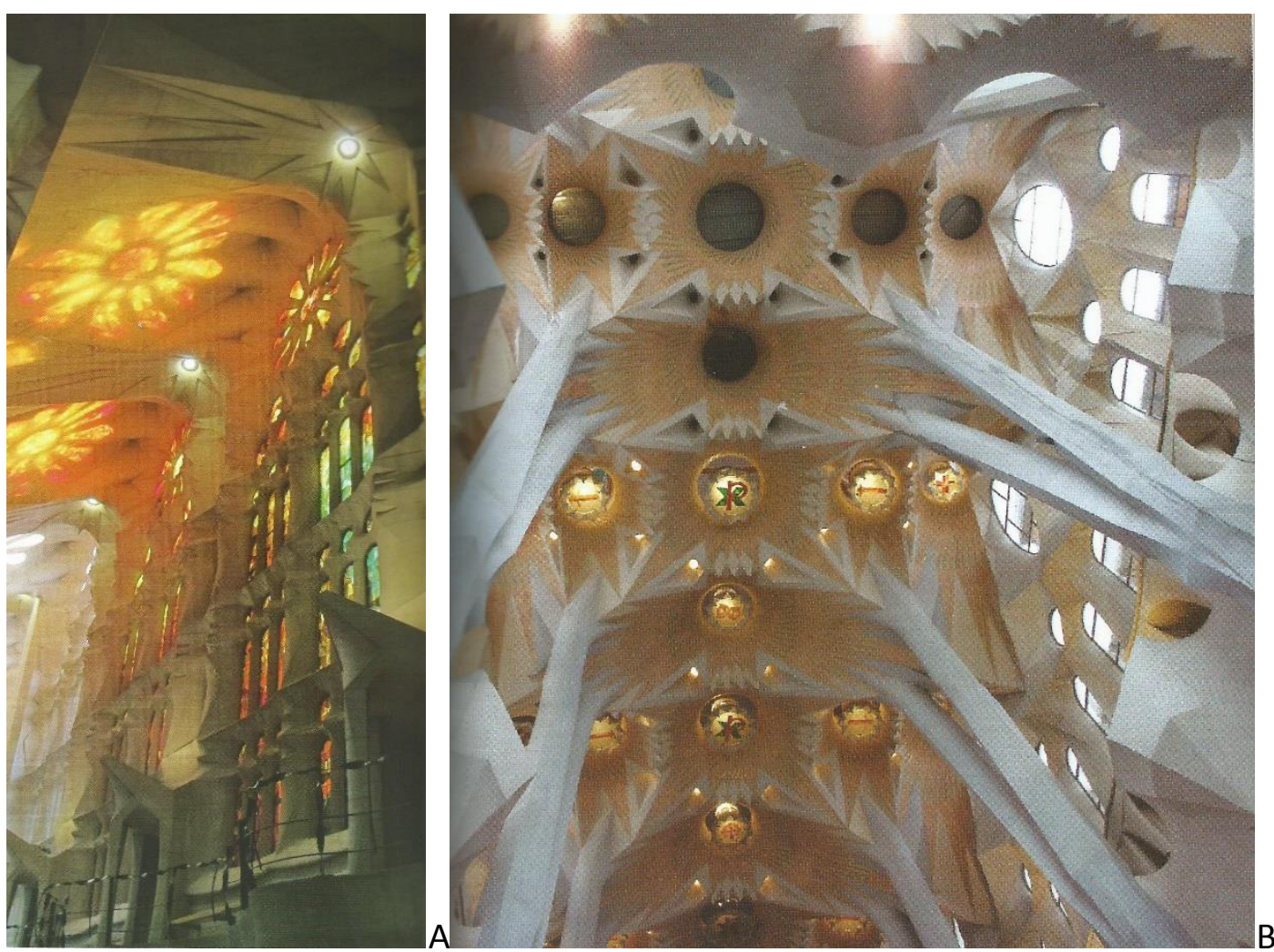

A. Luz natural de los vitrales de la parte baja de las naves laterales derramada por bajo de las cantorías. Se aprecia también Is situación de las luminarias artificiales. Fuente: Burry, M., Espel, R., Faulí, J. y Gomez, J. (2014) Les naus de la Sagrada Familia. Els secrets arquitectònics d'una obra irrepetible. Barcelona. Mediterrània B. Techo nave central: ventanales, fanales, luminarias. Fuente: Cf. Bonet, J. y Puig, (2013). Arquitectura i simbol de la Sagrada Familia. Barcelona. Raval Edicions SLU. Pórtic.

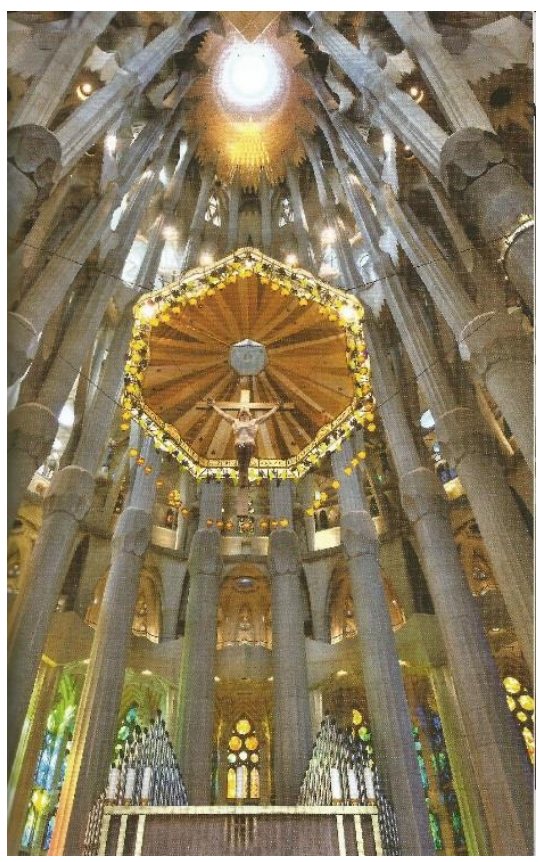

Altar, crucifijo, lampadario, baldaquino y bóveda del ábside. Fuente: Cf. Bonet, J. y Puig, (2013). Arquitectura i simbol de la Sagrada Familia. Barcelona. Raval Edicions SLU. Pórtic. 
En el Album de 1915 se atestigua la confianza de los promotores y arquitecto en las condiciones acústicas del edificio en razón de su volumetría y bóvedas, cuya refracción del sonido será tal que no se producirán reverberaciones que distorsionen la audición. ${ }^{437}$. En los sucesivos álbumes se insiste en la bondad del sonido dentro del aula liturgica y en el Album de 1929 se añade que en gran medida es debido al uso del paraboloide hiperbólico que resuelve todos los problemas de forma, luz y sonido. Llama la atención que este comentario se sitúa en el apartado que hace referencia a Gaudí como arquitecto del Templo y a éste como casa de Dios, es decir, que se vincula directamente con la concepción unitaria del proyecto y éste como espacio celebrativo.

\section{-Mobiliario Litúrgico.}

La producción de mobiliario y objetos litúrgicos atribuidos a Gaudí es extensa y se remonta a los inicios de su actividad profesional, pues ya en el colegio de Tarragona rediseña la capilla de la iglesia con todos sus elementos y también se conocen aportaciones muy variadas para estandartes de cofradías y asociaciones religiosas, dibujos de ostensorios, etc. que muestran cómo esta faceta de su quehacer profesional está muy presente en el campo de su arquitectura eclesiástica. Seria de interés realizar un estudio de catalogación de estos diseños y obras, fundamentado en su significado litúrgico, al objeto de intentar extraer cuantos aspectos y elementos pudiesen seguir siendo válidos como fuente de inspiración para el diseño del Arte Sacro actual según las directrices litúrgicas del Concilio Vaticano II.

En la presente Tesis doctoral nos limitaremos a llamar la atención sobre los objetos diseñados y construidos por Gaudí que están encaminados a conformar los espacios celebrativos de la Sagrada Familia, como una muestra más de la unicidad y globalidad de su proyecto arquitectónico. Destaquemos que su aportación en este campo comienza en un periodo de fuerte decaimiento litúrgico -siglo XIX- implicándose viva y progresivamente con la renovación que entonces quiere llevar a cabo la Iglesia Católica bajo el impulso de la Santa Sede. Con este soporte jerárquico y la inestimable ayuda de la orden benedictina esta marea de inquietudes litúrgicas y artísticas llega también a España a comienzos del siglo XX, siendo Antonio Gaudí uno de sus principales puntales profesionales.

\footnotetext{
${ }^{437}$ Cf. Asociacion de devotos de San José (1915) Album de la Sagrada Familia. Barcelona. Herederos de la Viuda Plá. P. 12: "Estas bóvedas, además de refractar la luz y el sonido, sin concentrarlos...."
} 

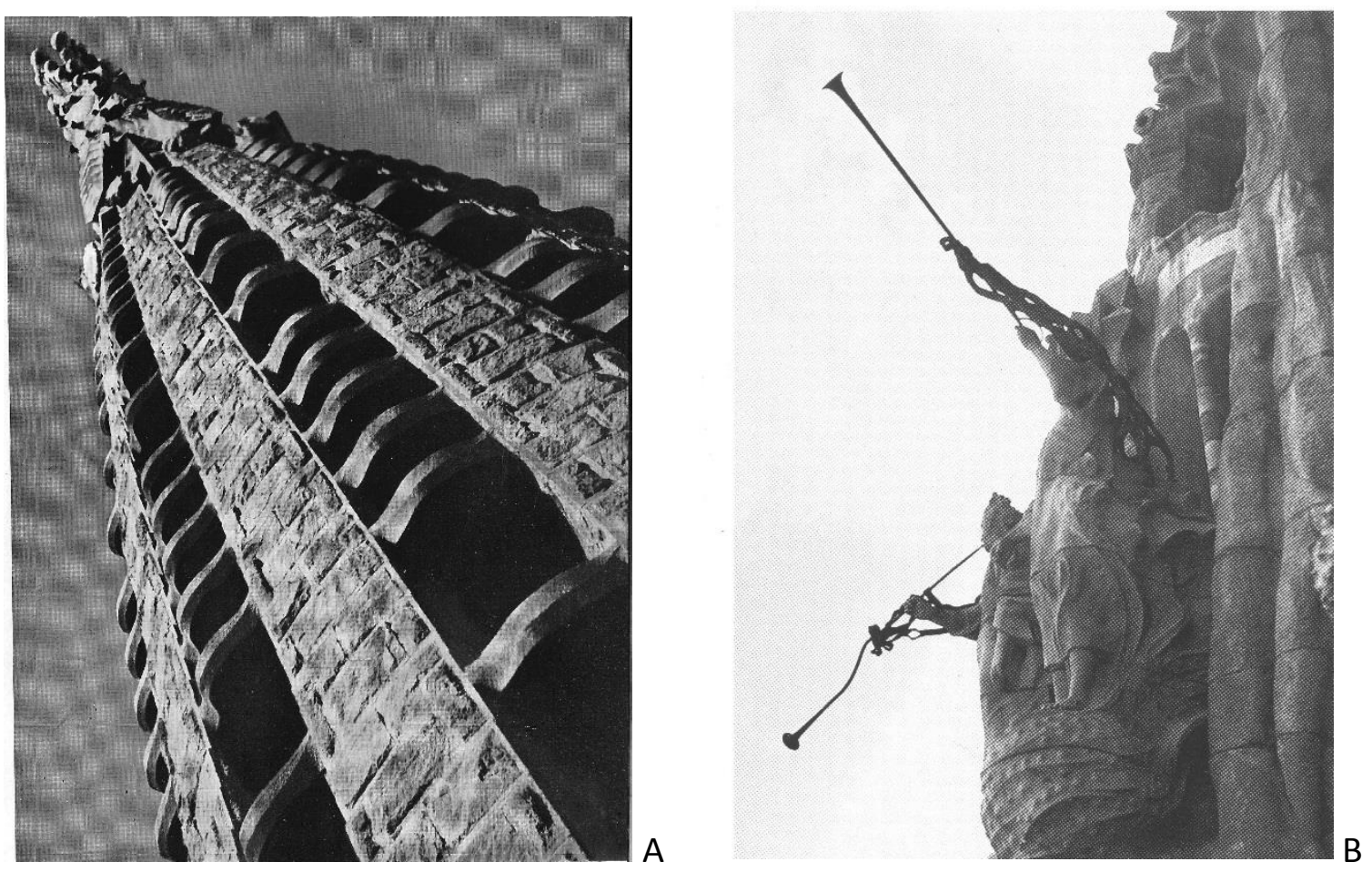

A: Parte de alta de las torres campanario con los tornavoces para la difusión del sonido de las campanas. Fuente: Martinell, C. (1967) La Sagrada Familia. Barcelona. Aymà Ediciones.

B. Esculturas de ángeles músicos en la Fachada del Nacimiento. Fuente: Exposición Gaudí
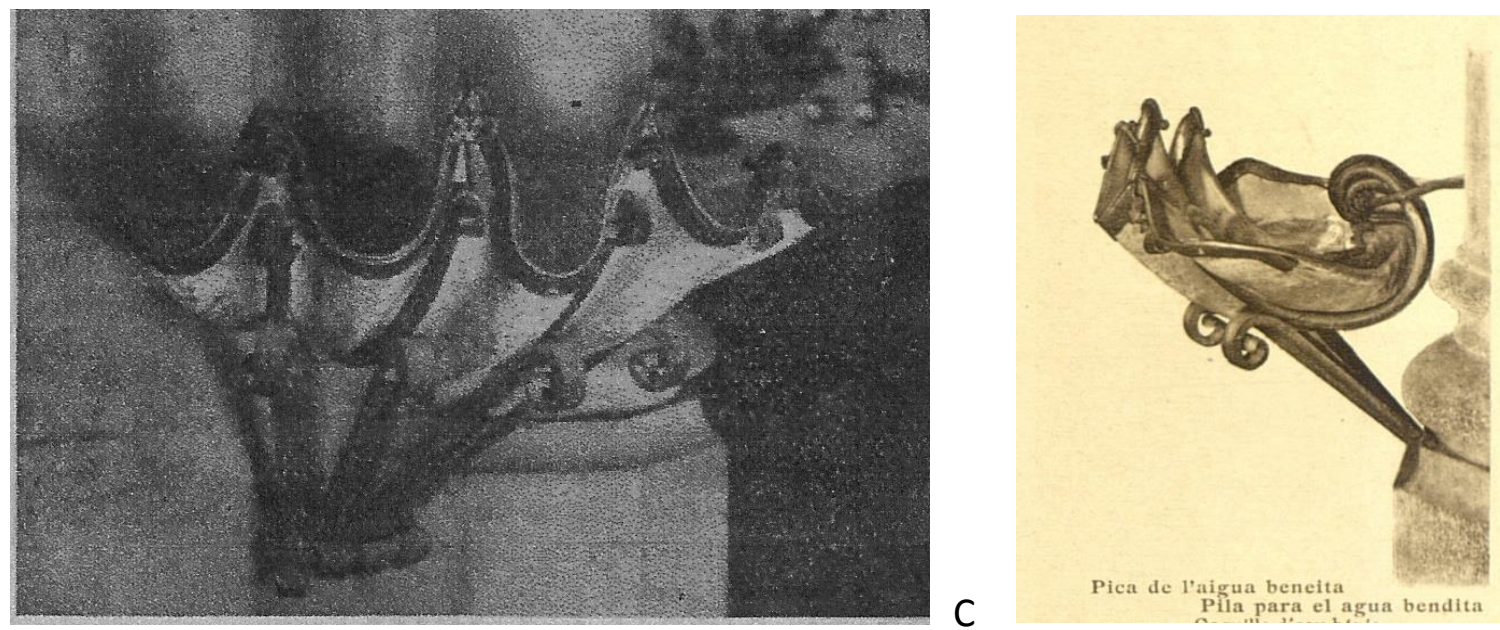

$\mathrm{D}$

C y D: Pila de agua bendita. Cripta de la Sagrada Familia. Fuente: Ratera, F. (1949) "El Arte de la Forja”, en Templo, № Noviembre 1949. 
El cardenal Isidro Gomá (EI valor educativo de la Liturgia católica 1918), describe el Mobiliario Litúrgico desde una ordenación "ascético-litúrgica: invitación, purificación, instrucción y sacrificio" 438 , que muestra el dinamismo pastoral del Congreso Litúrgico de Montserrat celebrado tres años antes. Seguiremos este índice para estudiar el mobiliario litúrgico diseñado por Gaudí en la Sagrada Familia al objeto de valorar más adecuadamente sus aportaciones en el contexto de la arquitectura eclesiástica de la época aún a sabiendas de que, dentro del impulso del Movimiento Litúrgico, su concepción resulta más innovadora que el texto de Gomá. En este sentido, ya se ha hecho mención en los apartados 4 -Antonio Gaudí y su concepto de la Arquitectura del Sagrado- y 6.2.d -Los espacios litúrgicos de la Sagrada Familia- de esta Tesis, de la estrecha relación de Gaudí con eclesiásticos catalanes como Carreras, Tarré, etc. muy bien relacionados con el cardenal Mercier promotor del Congreso Liturgico de Malinas.

En este aspecto, pues, se puede afirmar que el Mobiliario Litúrgico presente en la arquitectura gaudiniana, desarrollado más ampliamente en la catedral de Mallorca y en El interés de clasificación de los objetos que hace Gomá radica para este estudio en la Sagrada Familia, fue muy celebrado en los círculos artísticos de arte cristiano de la época, como la Exposición de Arte Litúrgico Contemporáneo de Cataluña que se organiza en el año 1925, y resulta inseparable de su concepción unitaria del edificioiglesia. servir de guía para situarse dentro de la concepción litúrgico-arquitectónica del aula celebrativa de Gaudí. Gomá sitúa las campanas como elementos para la invitación del pueblo cristiano, destaca su antiquísimo uso desde el momento en que pudo haber libertad de culto con el edicto de Constantino y su simbolismo litúrgico como signum, señal, no sólo por la indicación de la vida de la comunidad cristiana sino como símbolo de la voz de Dios que "troncha los cedros del Líbano" y "conmueve el desierto de Cadés". Afirma además que la campana también es símbolo de la vigilancia y de la Providencia de Dios sobre la Iglesia y los cristianos, símbolo de la contemplación, suspendida entre la tierra y el cielo, símbolo de los apóstoles y de los hombres evangélicos, de quienes está escrito que el sonido de su voz se ha dejado oir en toda la tierra. Señala su dignidad como vaso sagrado, que con los demás vasos del altar es ungida con el Santo Crisma, y cómo acompaña a la liturgia de la Misa en diferentes momentos, así como también su función difusora -desde los campanarios de las altas torres- de la alegría de la Iglesia en las solemnidades litúrgicas. ${ }^{439}$

Evidentemente Gaudí no es ajeno a este carácter invitatorio de las campanas, pero según mi parecer acentúa un poco más su carácter celebrativo al realizar un amplio estudio sobre ellas que le lleva a disponer de tres tipos distintos de campanas en cada una de las torres de las tres fachadas.

\footnotetext{
${ }^{438}$ Cf- Gomá, I. (1918). El valor educativo de la Liturgia católica. Barcelona. Rafael Casulleras Editor. P.397.

${ }^{439}$ Ibid.. Pp.398-402.
} 


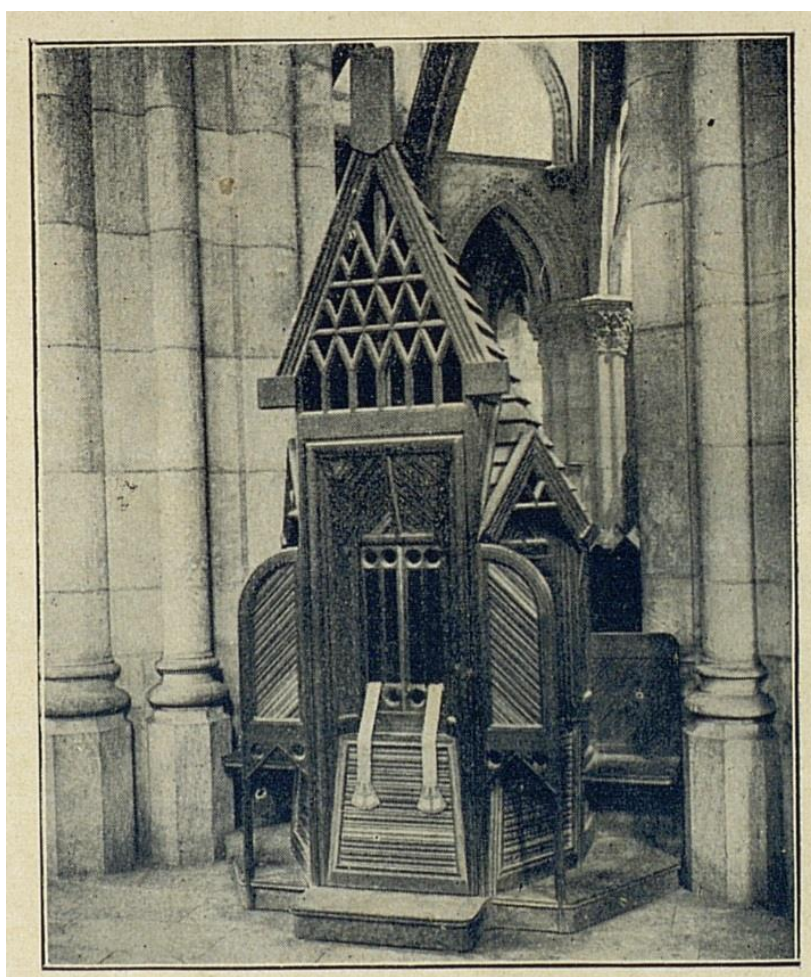

Confesionari en la cripta.

Uno de los confesionarios de la cripta. A

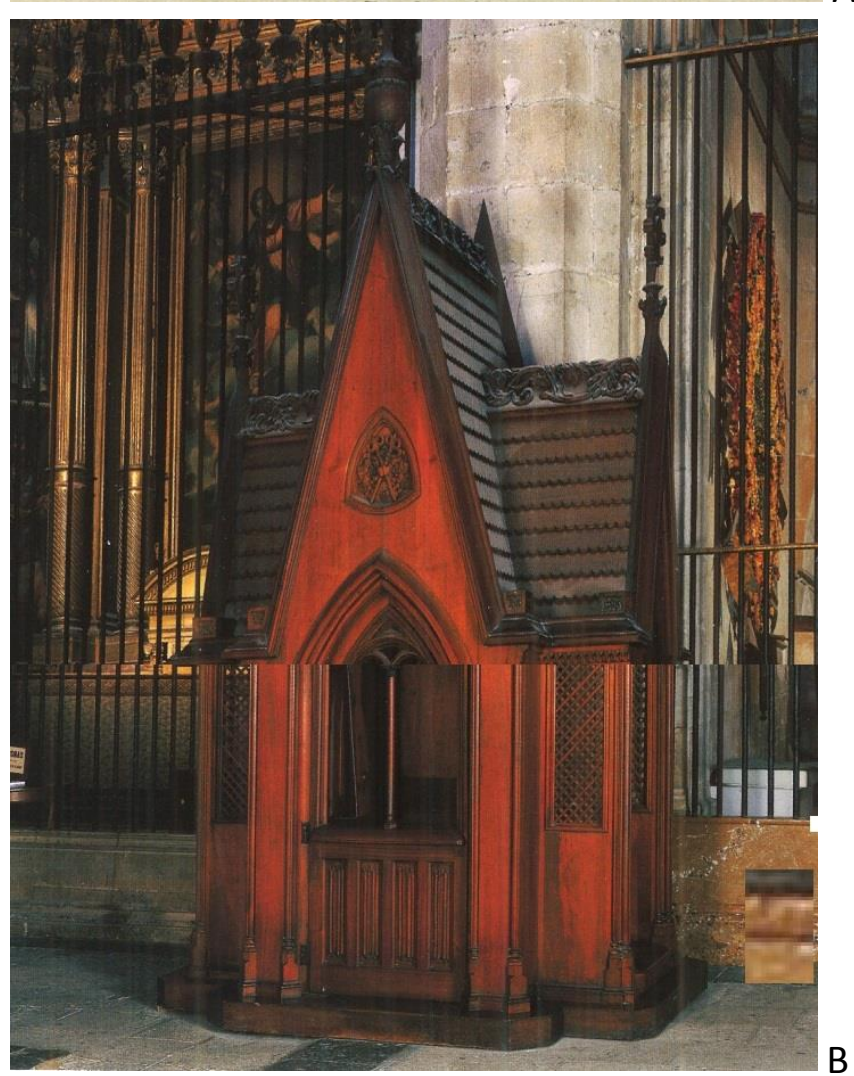

A: Confesionario de la Cripta de la Sagrada Familia. Fuente: Album de 1915. Archivo de la Sagrada Familia. B. Confesionario Catedral de Palma. Fuente: Llabrés, P.J. (2005) Gaudí a la catedral de Palma. Barcelona. Triangle Postals. 
En el Album de 1917 ya se anuncia -con la denominación campanarios- que las torres estarán dedicadas a cada uno de los doce Apóstoles y que poseerán un "número extraordinario de campanas acordadas en octavas por tonos y medios tonos", distinguiéndose tres grupos: las tubulares que sonarán por percusión, las también tubulares por presión del aire como trompetas o "flautado de órgano", y las de metal y forma corrientes, también por percusión. Las dos primeras pertenecen al funcionamiento del órgano que pretendía instalar, pero se menciona que todas ellas "permitirán acompañar los cánticos de las funciones que se celebren en el exterior de la basílica." En posteriores álbumes se sigue insistiendo en esta funcionalidad y en la simbología de los campanarios; así en el de 1929 se recuerda el simbolismo de los campanarios como símbolo de los apóstoles, que hablaba Gomá, explicando que "Gaudí quiere que los campanarios tomen la expresión del báculo del apóstol" y de ahí su trazado final que asemeja el báculo, anillo y mitra episcopales. Anteriormente ya se ha mención también de los elementos situados en los vanos de los campanarios que actúan a la manera de tornavoces para dirigir el sonido hacia los fieles situados en el exterior del edificio, cual altavoces de los cantos y música que acompañarían a las plegarias litúrgicas.

Respecto de los objetos litúrgicos que Gomá menciona en la línea de la purificación del hombre -Pila bautismal, Pila de agua bendita y Confesionario-, podemos establecer su correspondencia arquitectónica con los espacios celebrativos de la Sagrada Familia que tienen que ver con plena admisión y participación en el Aula litúrgica -Capillas del Bautismo y de la Penitencia-. Gaudí sitúa el Baptisterio en la misma disposición respecto del edificio que Gomát40, comunicado y ordenado a la Eucaristía, con la histórica planta octogonal y cubierto con una bóveda especial "símbolo de la operación sobrenatural e íntima, la fecundación por el agua y el Espíritu Santo, que allí tiene lugar" ${ }^{441}$.

Si siguiéramos el texto de Gomá encontraríamos que la configuración arquitectónica del Baptisterio de la Sagrada Familia tal y como aparece en la planta de 1926 y en el grabado publicado en el Album publicado en 1929 emularía los baptisterios de Letrán, Pisa y Florencia que Gomá expone como modelos ${ }^{442}$. Queda por saber si Gaudí, tan conocedor de la Liturgia y con esa visión histórica, unitaria y completa del espacio celebrativo, tuvo tiempo de dibujar la Pila Bautismal, y si ésta se inspiraría, como narra Gomá, en una depresión en el suelo e inscripciones como las de San Juan de Letrán.

\footnotetext{
${ }^{440}$ Cf- Gomá, I. (1918). El valor educativo de la Liturgia católica. Barcelona. Rafael Casulleras Editor.P. 405: "A la entrada del templo, y al lado izquierdo de ordinario, se halla, en las iglesias parroquiales, la piscina de la regeneración cristiana, la pila bautismal."

441 Ibid..P. 406

${ }^{442}$ En los grabados publicados en el Propagador el 15-12-1912 y en CC el 26-1-1913, y reproducidos en los Albumes del Templo de 1915, 1917 y 1922 todavia no se aprecia con precisión dicha cúpula.
} 


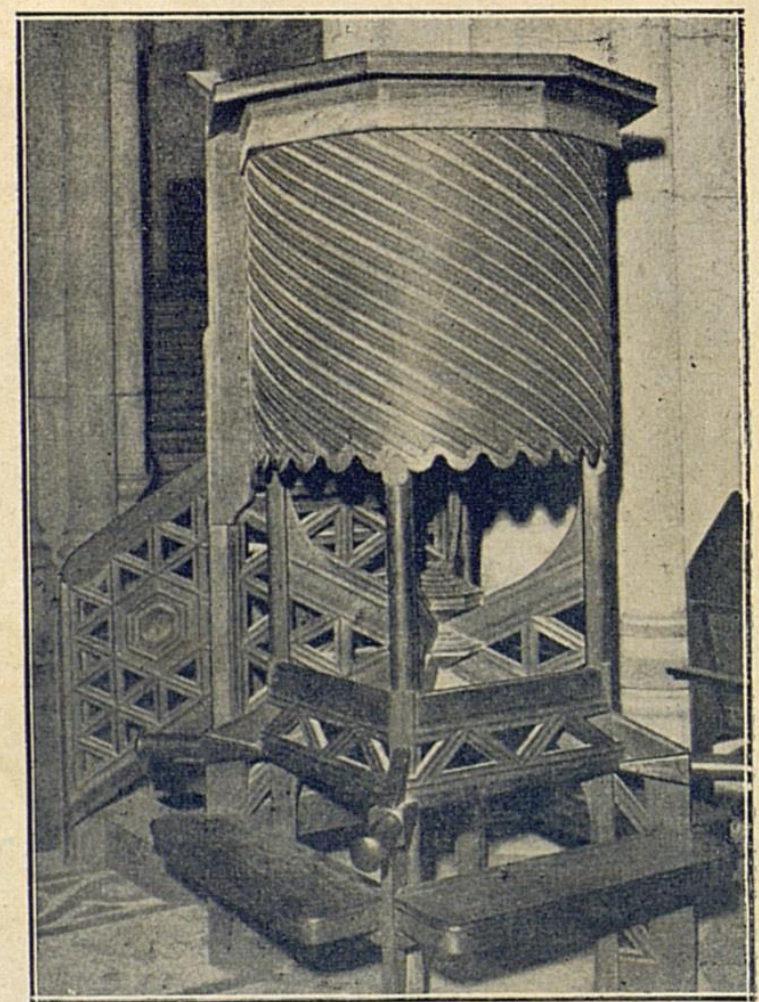

Trona de la cripta.

Púlpito de la cripta.

Púlpito para la Cripta de la Sagrada Familia. Album 1915.

Fuente: Archivo de la Sagrada Familia.
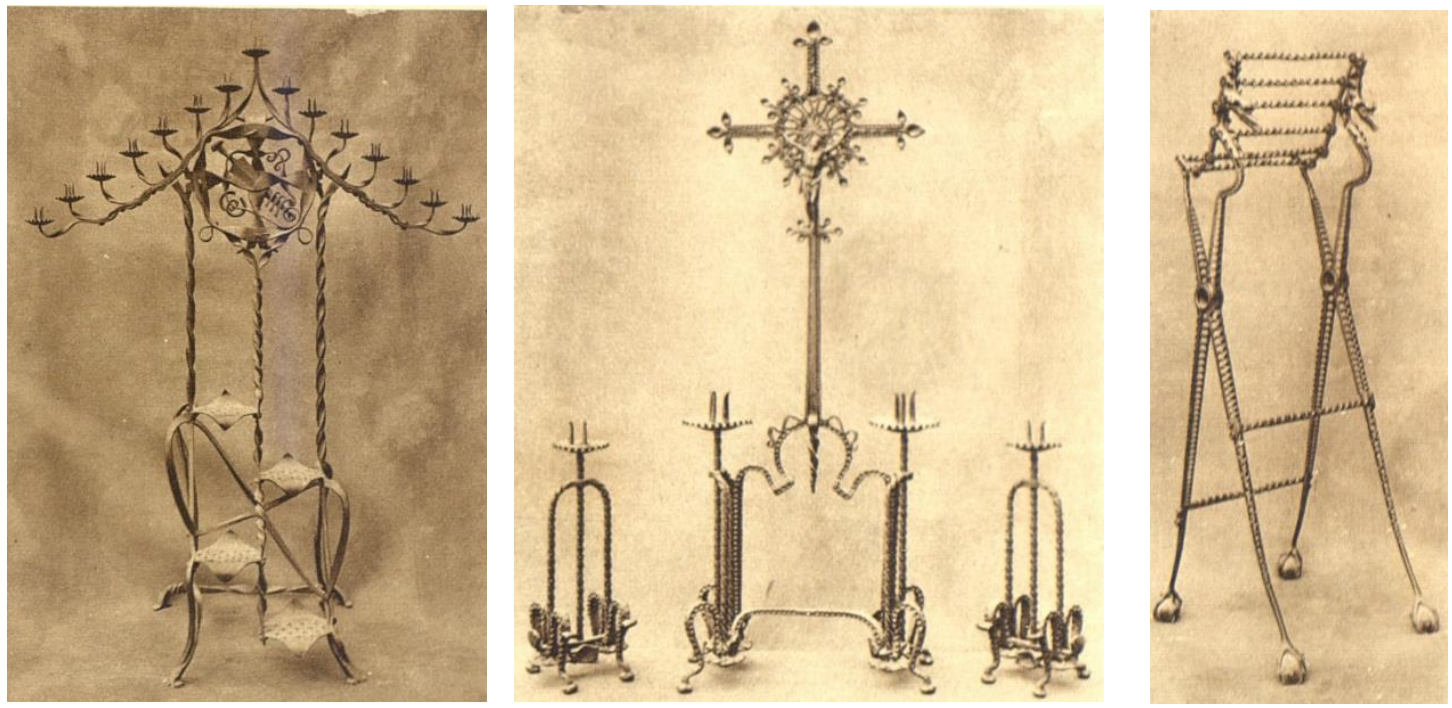

Candeleros y Cruz, Facistol y Tenebrario, diseñados para la Sagrada Familia. Album de 1922-25. Fuente: Archivo de la Sagrada Familia. 
Gomá recuerda como en el siglo IV, según testimonio de Teodoreto, aparecen las pilas o fuentes en los vestíbulos de las iglesias, y que según Eusebio de Cesarea se disponían en el atrio para lavar las impurezas del cuerpo como una purificación radical que recordaba el baño bautismal. Este rito, reducido al uso de agua que lleva disuelta sal -signo de incorruptibilidad- en la pila, y formando la señal de la cruz, preparaba la entrada en el aula eucarística al hacer presente la muerte y resurrección de Jesús. Gaudí no pudo descender al detalle de las Pilas de agua bendita en el Aula Litúrgica, pero si en la Cripta adaptada como Parroquia (en tiempos del obispo Casañas, entre 1901 y 1908), para la cual diseñó, según nos narra Federico Ratera, un elemento en hierro forjado que sostenía la concha marina de la pila, bordada en metal dorado, según la simbología que recuerda la pila bautismal y la Iglesia peregrina en la tierra.

Afirma Gomá que el confesionario es trono de misericordia y tribunal de justicia, debe situarse en un lugar retirado de la iglesia, y puesto que el bautismo no hace impecables a los hombres, este mobiliario evoca el lugar litúrgico de la Reconciliación, antesala de la vuelta a la celebración de la Eucaristía. Con anterioridad a 1908 encontramos un diseño de confesionario de Gaudí para la Cripta que reproduce el Album de 1915. Sin embargo en todos los dibujos de planta conocidos con posterioridad a 1915 aparece una capilla de la Penitencia, simétrica del Baptisterio, como espacio litúrgico adecuado para la celebración de este sacramento, sin detrimento de la existencia de confesionarios o lugares para la confesión individual de la culpa, donde se hace celebre públicamente la penitencia y la reconciliación. ${ }^{443}$ Menciona Plazaola que los liturgistas defienden la existencia de una capilla penitencial con una presidencia bien visible y orientada en frente de la asamblea penitencial y Farnés advierte de la importancia de esta disposición para salvaguardar el contenido de este sacramento. En sintonía y comunicación con el movimiento de renovación litúrgica de principios del siglo XX Gaudí no dudaría en plantear una capilla en estos términos, en simetría y consonancia con la capilla bautismal, ambas orientadas hacia una presidencia y con acceso directo desde la calle y comunicación con el espacio de la asamblea eucarística.

Al igual que en aquella, en esta capilla tan sólo podemos percibir su configuración octogonal con una especial cúpula para su cubrición, deambulatorio circular que admite la ubicación de confesionarios y la circunscribe, y una presidencia que marca su eje longitudinal. Obsérvese no obstante la diferencia entre el confesionario de Mallorca y el de la Sagrada Familia, mucho más estilizado y ligero, con tres posible accesos del penitente.

\footnotetext{
${ }^{443}$ Cf. Plazaola, J. (2006) Arte Sacro Actual. Madrid. BAC. Plazaola menciona que históricamente siempre ha existido el sacramento de la Penitencia para los pecados graves cometidos después del Bautismo y que contaba con tres elementos esenciales: una confesión de la culpa (pública o privada), una penitencia pública y una reconciliación o absolución por parte de la autoridad eclesiástica.
} 

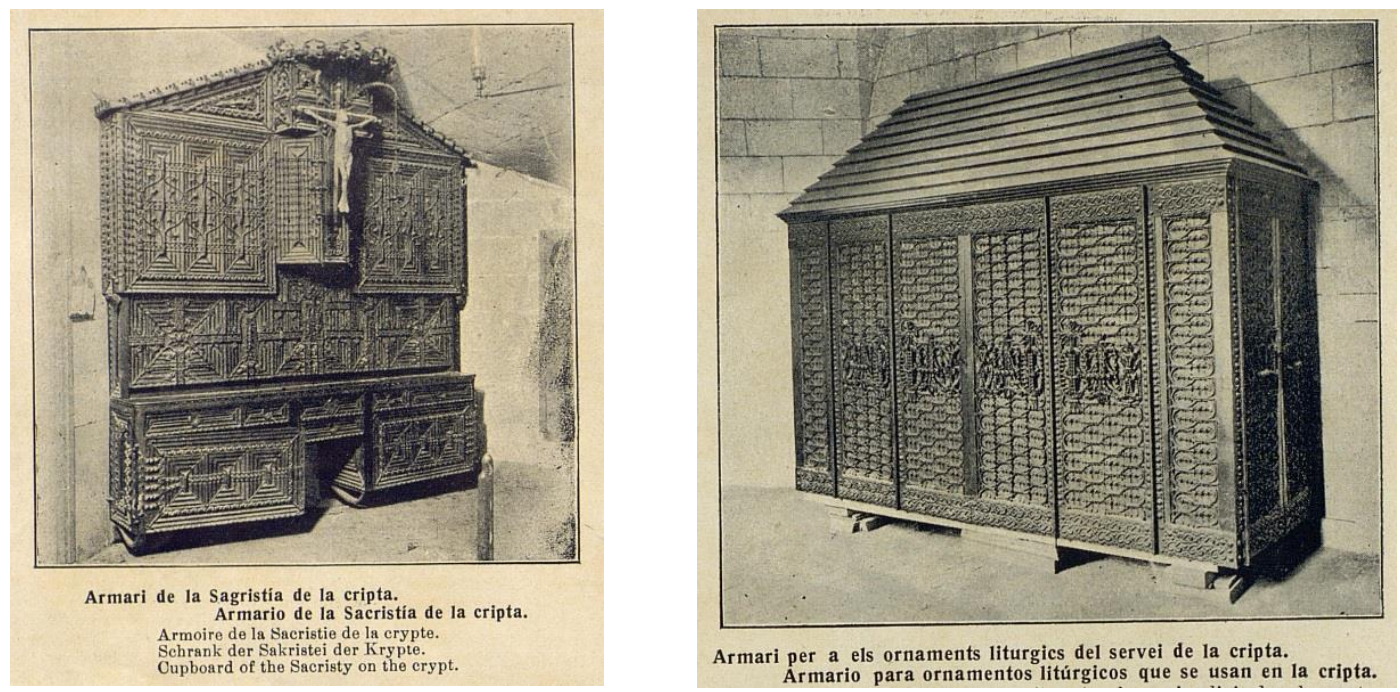

Armarios de la Sacristia de la Cripta. Album de la Sagrada Familia 1915. Fuente: Archivo de la Sagrada Familia.
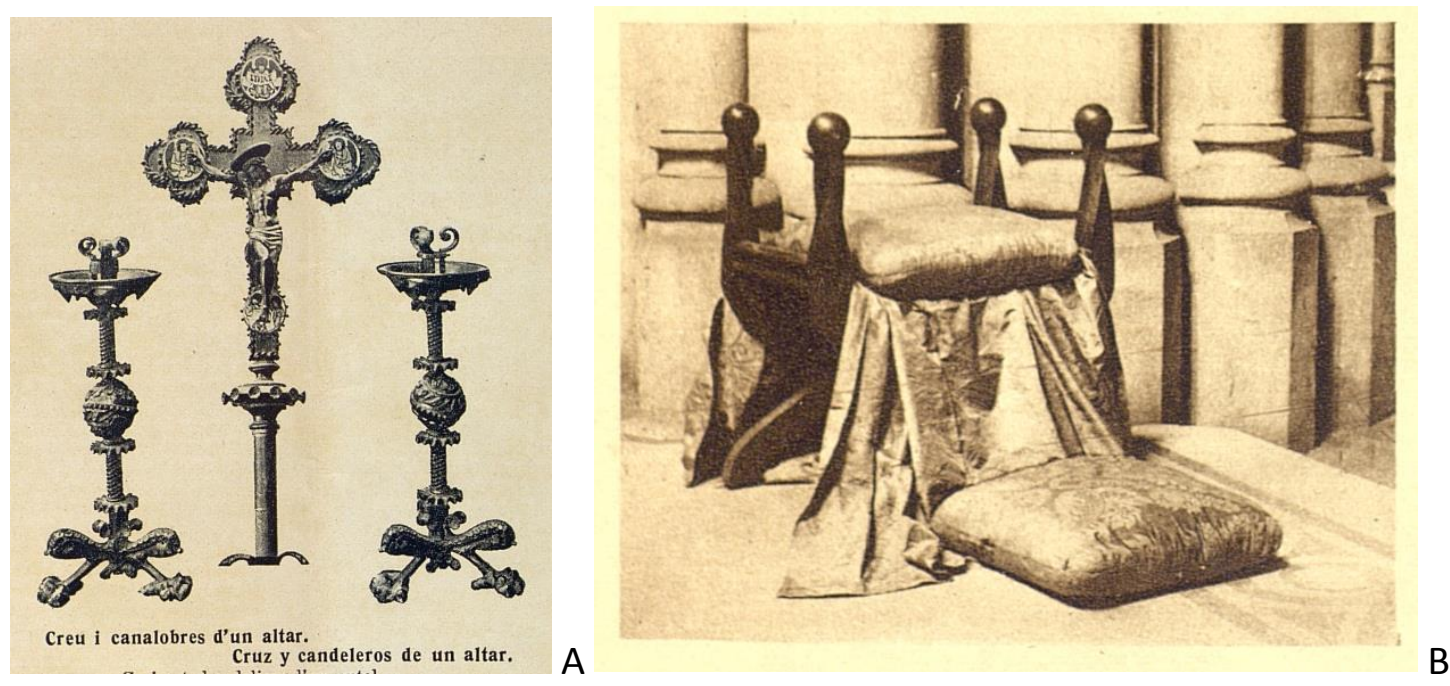

A: Cruz y candeleros de un altar. B: Faldistorio. Album de 1915. Fuente: Archivo de la Sagrada Familia.
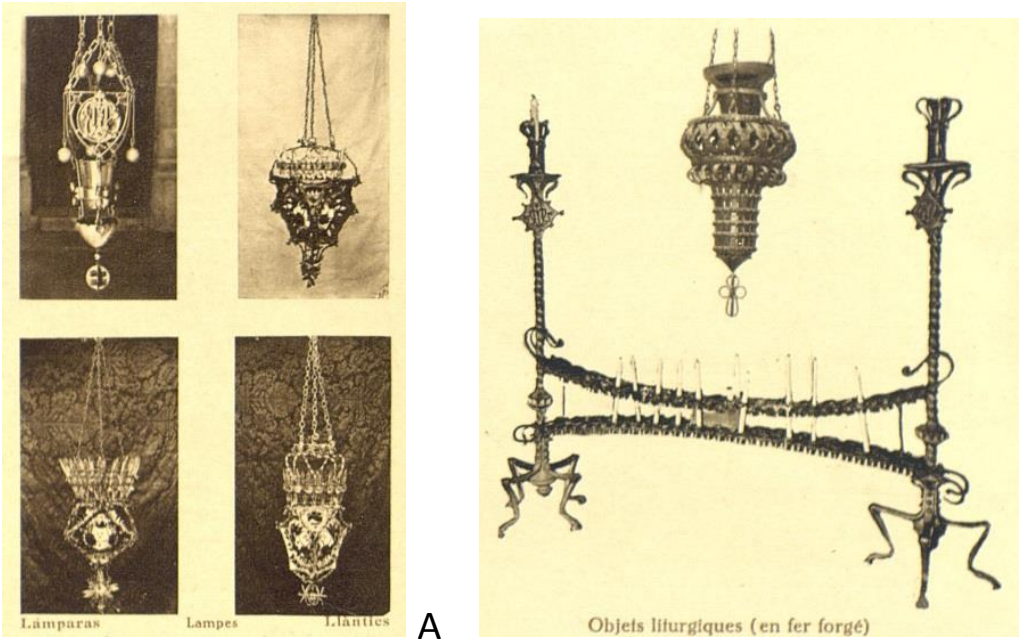

A: Lámparas para la Cripta. B: Objetos litúrgicos. Album de 1929. Fuente: Archivo de la Sagrada Familia. 
Respecto del Mobiliario para la Instrucción advierte Gomá que ésta responde a uno de los oficios de la jerarquía eclesiástica que es el magisterio doctrinal, con independencia de la proclamación de la Palabra de Dios, y que para su desempeño existen el Púlpito, Atriles y la

Ornamentación del Templo. El ambón, cuyo origen histórico proviene del estrado rabínico, tuvo un gran desarrollo en los primeros tiempos del Cristianismo para la proclamación de las lecturas bíblicas y la homilía durante la celebración de la Eucaristía pero fue decayendo cuando en la Edad Media el pueblo no entendía el latín e hizo su aparición el púlpito. Desde éste lugar elevado las ordenes mendicantes, principalmente, predicaban al pueblo los sermones dentro o fuera de la Misa. San Carlos Borromeo aún recomendó colocar dos ambones en las iglesias insignes y catedrales, diferenciando lo que era la proclamación del Evangelio del resto de lecturas, pero la gran difusión que tuvo el púlpito como estrado destinado a la predicación en las iglesias de la Reforma y la Contrarreforma en detrimento de la importancia de la proclamación de las Sagradas Escrituras terminó por eliminar el ambón hasta los inicios del siglo XX en que el Movimiento Litúrgico lo rescató al reivindicar la liturgia de la Palabra y el Concilio Vaticano II lo restableció en su dignidad profética y kerigmática.

En España la introducción de la renovación litúrgica fue gradual a partir del Pontificado de Pio $X$ y la difusión del canto gregoriano. Siendo que el Congreso de Montserrat siguió unos derroteros más pastorales que teológicos, y que el principal acento se puso en el canto litúrgico, la realización de eucologios en lengua vernácula y el arte cristiano, las opiniones con respecto a la utilización de púlpitos, atriles y pupitres quedaron bajo la inercia de la tradición aunque conviviendo por el interés por la recuperación de cuanto elementos arquitectónicos tenían que ver con la esencia de la Liturgia cristiana en sus inicios. ${ }^{444}$ Gaudí no se planteó cuestiones de carácter teológico y arqueológico sino que siguió en el diseño del mobiliario litúrgico lo que veía y vivía en su práctica religiosa con una gran dosis de sentido común alimentado por el sincero ideario renovador de sus amistades eclesiásticas, su conocimiento de la historia de la arquitectura y portentosa imaginación.

Así pues, Gaudí no se planteó realizar ambones sino púlpitos y atriles o facistoles. En cuanto a los primeros aprovechó el interés emergente por la vida litúrgica y la necesidad de instrucción del pueblo en su propia lengua -ya que la liturgia de la Palabra de la Misa todavía se realizaba en latín- para ubicar los púlpitos en la ubicación más provechosa para la escucha y dotarlos de las condiciones especificas de implantación, movilidad o acústica, según el caso -Mallorca, Cripta de la Sagrada Familia,...- más adecuadas.

\footnotetext{
${ }^{444}$ Cf. Tarré, J. (1925) “L'estructura liturgica de la construcció dels temples" en Anuari dels Amics de l'Art Litùrgic. Barcelona. Cercle Artistic de Sant Lluc.
} 


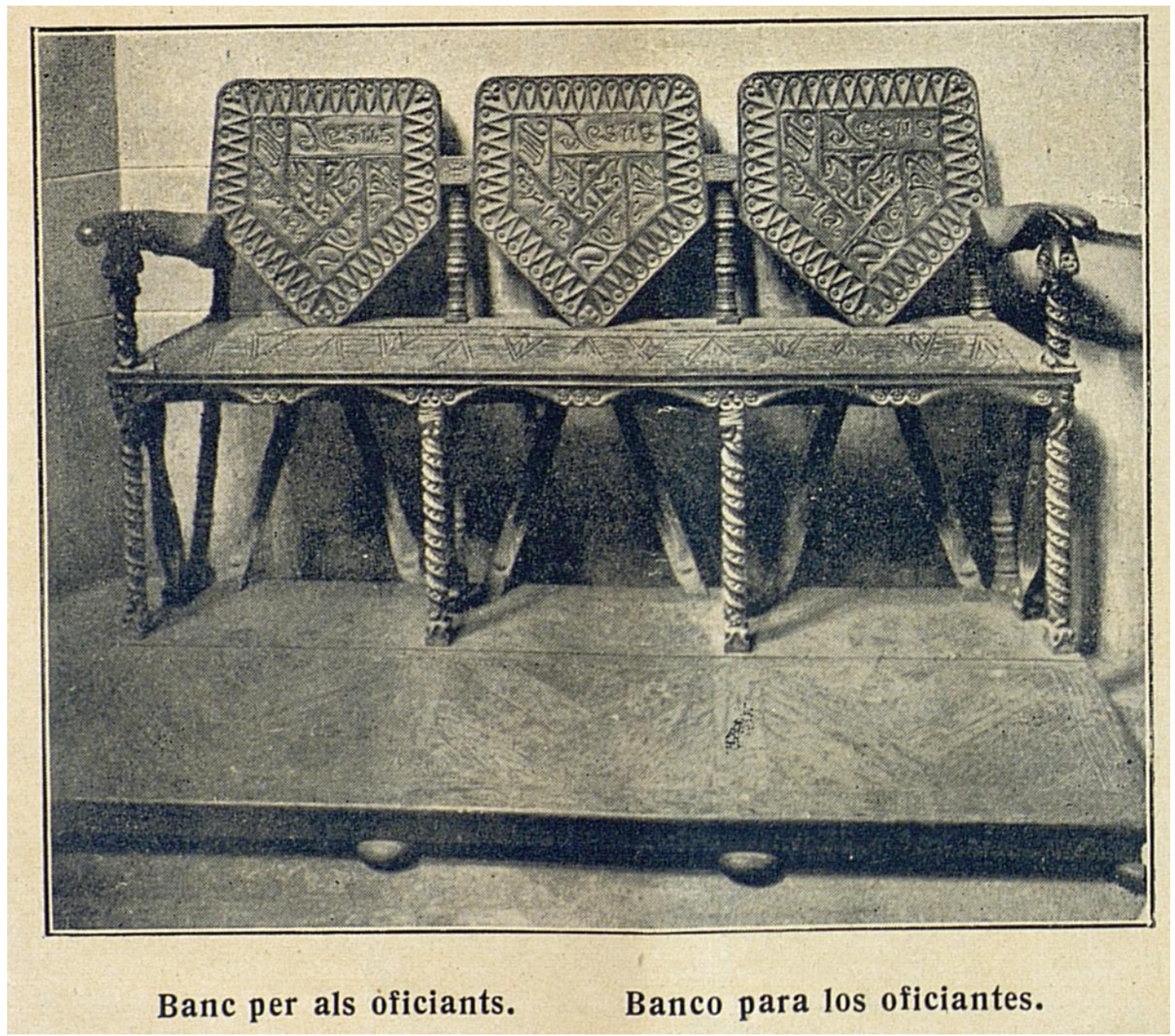

Banco de los oficiantes. Cripta de la Sagrada Familia. Album de 1915. Fuente: Archivo de la Sagrada Familia.
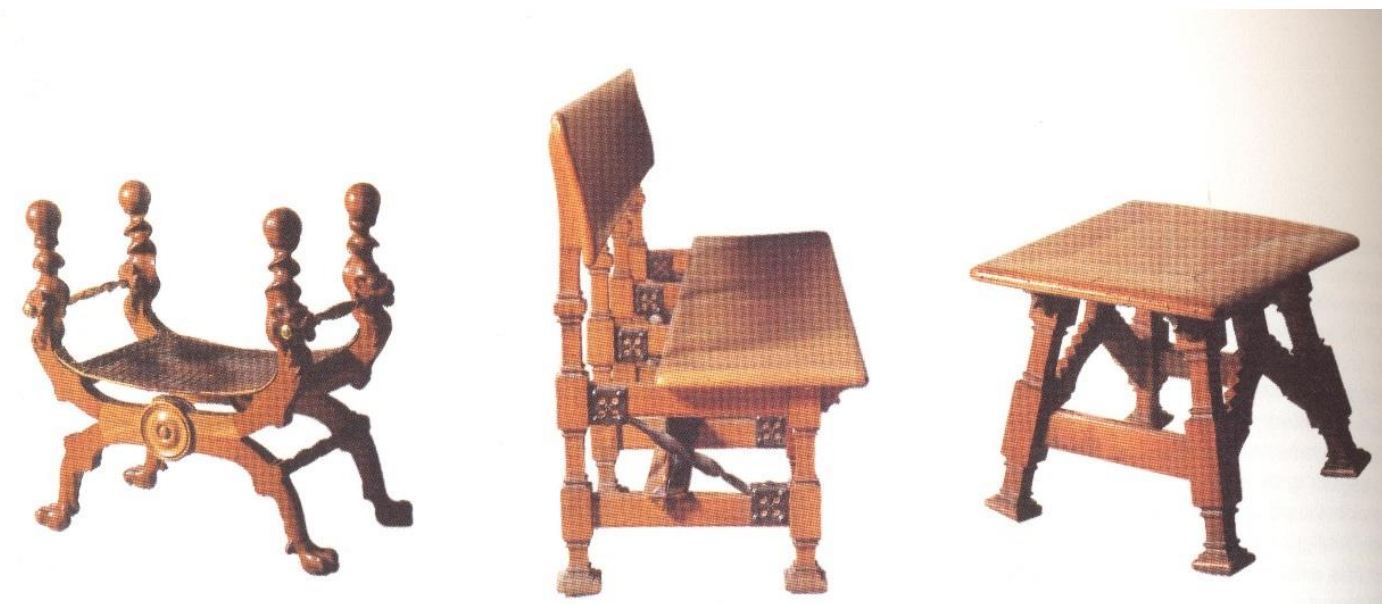

taldistori

banc dels oficiants

banco de los oficiantes

tamboret

banqueta

Faldistorio, Banco de los Oficiantes y Banqueta. Catedral de Mallorca. Fuente: Llabrés, P. J. (2002) Gaudí a la Seu de Mallorca. Palma de Mallorca. Govern de les Illes Balears. 
Gaudí reubica las tronas o púlpitos de la catedral de Mallorca según el esquema de dos ambones existente, pero al servicio de la asamblea litúrgica que preconiza el obispo Campins -cara al pueblo y para el pueblo-, completando además su funcionalidad con sendos tornavoces que además siguen la simbología tradicional de la Iglesia. En la Cripta de la Sagrada Familia predomina la temporalidad y movilidad de un espacio celebrativo que va cambiando de uso según avanzan las obras, y a ellas se adapta en el diseño del púlpito de madera.

Aunque se ha destacado mucho la cadencia y habilidad gaudinianas para la utilización del hierro fundido, no es la primera vez que Gaudí utiliza la madera para los objetos litúrgicos, siendo prueba de ello los armarios para sacristías y confesionarios de la Cripta de la Sagrada Familia o las escaleras para la exposición del Sacramento en la catedral de Mallorca.

En los atriles o pupitres destaca la ejecución de los facistoles construidos con madera y hierro alrededor de un eje central en Mallorca, herederos de la tradición de la Schola Cantorum que convive con la masa coral de la asamblea que ahora se pretende, destinados a sostener los libros de canto. Sin embargo, desde el punto de vista del diseño y de la adaptabilidad litúrgica del lugar a la participación de la asamblea merece reseñarse los facistoles de forja de la Cripta de la Sagrada Familia y también de Mallorca.

Gomá cree firmemente en el papel catequético de la arquitectura de la iglesia y de su ornamentación, que como libro abierto al espíritu contribuyen a la acción sagrada por antonomasia, la celebración de la Eucaristia o Misa., a modo de iluminación. Se entiende que en este aspecto su línea es coincidente con la búsqueda que protagoniza Gaudí en el edificio iglesia al integrar la ornamentación en la arquitectura y potenciar el lenguaje simbólico. Además, el interés de Gaudí por el implantación y diseño del altar (cuya larga trayectoria hemos visto que arranca de sus primeros trabajos para el colegio de Tarragona), el ciborio y lampadario que lo enfatizan y hasta los mismo objetos litúrgicos que tienen que ver directamente con él, hay que situarlo en el contexto del ambiente especializado en el que se mueve, es decir, lo que dicen especialistas como Gomá, Tarré, Trens, Carreras, etc.

Gomá considera el ábside como el lugar de lo que denomina el "sacrificio cristiano", aunque también muestra una síntesis histórica de todo lo que atañe a su ubicación, construcción y materiales, y por ello es interesante su precisión de que puede disponerse al fondo del ábside o bien en medio de éste "oficiando el celebrante de cara al pueblo". ${ }^{445}$

\footnotetext{
${ }^{445}$ Cf. Gomá, I. (1918). El valor educativo de la Liturgia católica. Barcelona. Rafael Casulleras Editor. P. 421: "Ora se nos presenta aislado en el centro del presbyterium, teniendo a su rededor la jerarquía sagrada, oficiando el celebrante de cara al pueblo; ora se presenta al fondo del ábside, adelantándose el Coro hacia las gradas del presbiterio hasta que la jerarquía que no debe servir el altar queda desplazada de su lugar para ocupar, desde el siglo XV, los suntuosos Coros actuales."
} 

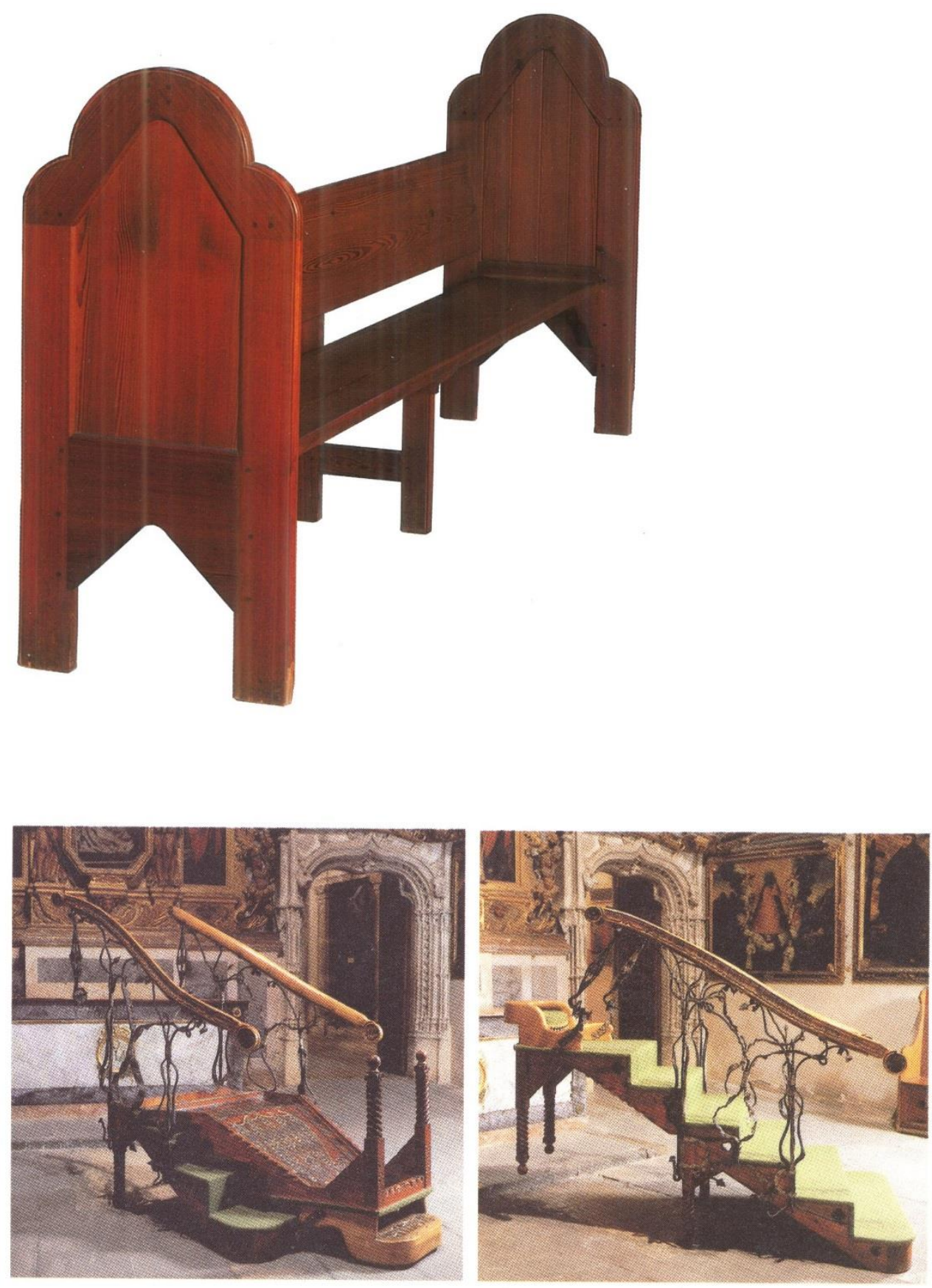

escala per a l'exposició del Santíssim

escalera para la exposición del Santísimo

A: Bancos de fieles. Fuente: Llabrés, P. J. (2005) Gaudí a la Catedral de Mallorca. Palma de Mallorca. Triangle Postals. B: Escaleras para la exposición del Sacramento. Catedral de Mallorca. Fuente: Llabrés, P. J. (2002) Gaudí a la Seu de Mallorca. Palma de Mallorca. Govern de les Illes Balears 
Hace mención al ciborio y al retablo como elementos al servicio del altar, destacando de éste último es el que menos tiene que ver con la tradición de la Iglesia, aunque más corriente desde hace tiempo, y que en muchas ocasiones "ha relegado el altar a un plano secundario". ${ }^{446}$

Tarré realiza un repaso histórico de la construcción de las iglesias ${ }^{447}$ y al dar sus consejos prácticos sobre la estructura litúrgica de las iglesias menciona cómo el Ceremonial de los obispos distingue con claridad entre ambones y púlpito, y pone como ejemplo de la reorganización litúrgica del presbiterio de una iglesia la intervención de Gaudí en la catedral de Mallorca. Destaca cómo más idóneo para la Liturgia la potenciación del crucero bajo una cúpula cuando existe éste, -situando allí o en sus proximidades el altar realzado por el ciborio como es históricamente tradicional-, que el ábside y el presbiterio, mostrando sus preferencias por la iglesia de San Sulpicio de Paris, de Gamard y el proyecto de Van Huffel para Koekelberg, en Bruselas, sobre Montmartre y el Sacro Cuore de Roma. Muestra la conjunción del empleo de nuevos materiales en la construcción de iglesias con respecto a lo que establece la Congregación de Ritos (1902) y se declara partidario del proyecto de Gaudí para la Sagrada Familia y de la arquitectura eclesiástica de Carl Moritz (1863-1944) en Alemania, llegando a la conclusión de que la mejor solución para el altar es situarlo aislado.

Trens concluye sus orientaciones prácticas, como ya se ha mencionado anteriormente en otro apartado de esta investigación, señalando que en algunas restauraciones litúrgicas de presbiterios se han construido los altares exentos para celebrar de cara al pueblo siguiendo la antigua tradición histórica -especialmente de Roma- y que no hay ninguna rúbrica ni texto litúrgico que lo impida sino que, al contrario, los que se refieren a ello contemplan que alguna vez se celebre la Misa cara al pueblo (Ritus servandus in celebratione Missae, V. 3) ${ }^{448} \mathrm{Es}$, pues, totalmente comprensible entender la mutua afinidad y aprecio que se establece entre todos estos liturgistas y Gaudí, pudiéndose considerarse el tratamiento que éste hace del altar, su baldaquino y lampadarios en la Sagrada Familia como una idónea realización práctica de todo lo que la Iglesia Católica se planteaba en materia de renovación litúrgica, y por tanto artística y arquitectónica, al comienzo del siglo XX.

\footnotetext{
${ }^{446}$ Cf. Gomá, I. (1918). El valor educativo de la Liturgia católica. Barcelona. Rafael Casulleras Editor. P. 422.

447 Josep Tarré (1884-1957), liturgista, historiador del Arte, doctor en Teologia, director de la revista Vida Cristiana en 1913, participó activamente en el Congreso de Montserrat de 1915, tiene una extensa producción bibliografía sobre Nociones de Liturgia, Arte y Liturgia y el Eucologio, manteniendo una estrecha relación con el cardenal Mercier y el Movimiento Liturgico belga. Cf.

${ }^{448}$ Cf. Trens, M. (1925) "L'Altar" en Anuari dels Amics de l'Art Litùrgic. Barcelona. Cercle Artistic de Sant Lluc. Manuel Trens (1892-1976), profesor de Iconografia y arte sagrado en el Seminario de Barcelona, director del Museo diocesano y Consiliario del Circulo Artistico de San Lucas, participó activamente en el Congreso Liturgico de Montserrat constituyendo la Asociación de Amigos del Arte Litúrgico.
} 


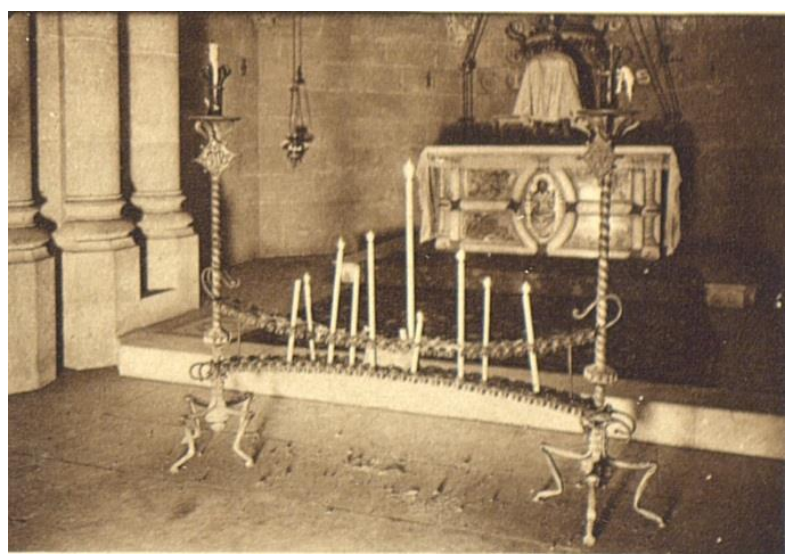

Delimitación del ámbito del altar de San José con el Tabernáculo o Sagrario realizados durante el pontificado del obispo Casañas (1901-1908) en que se adecua la Cripta de la Sagrada Familia como Parroquia. Album de la Sagrada Familia de 1922-25. Fuente: Archivo de la Sagrada Familia.

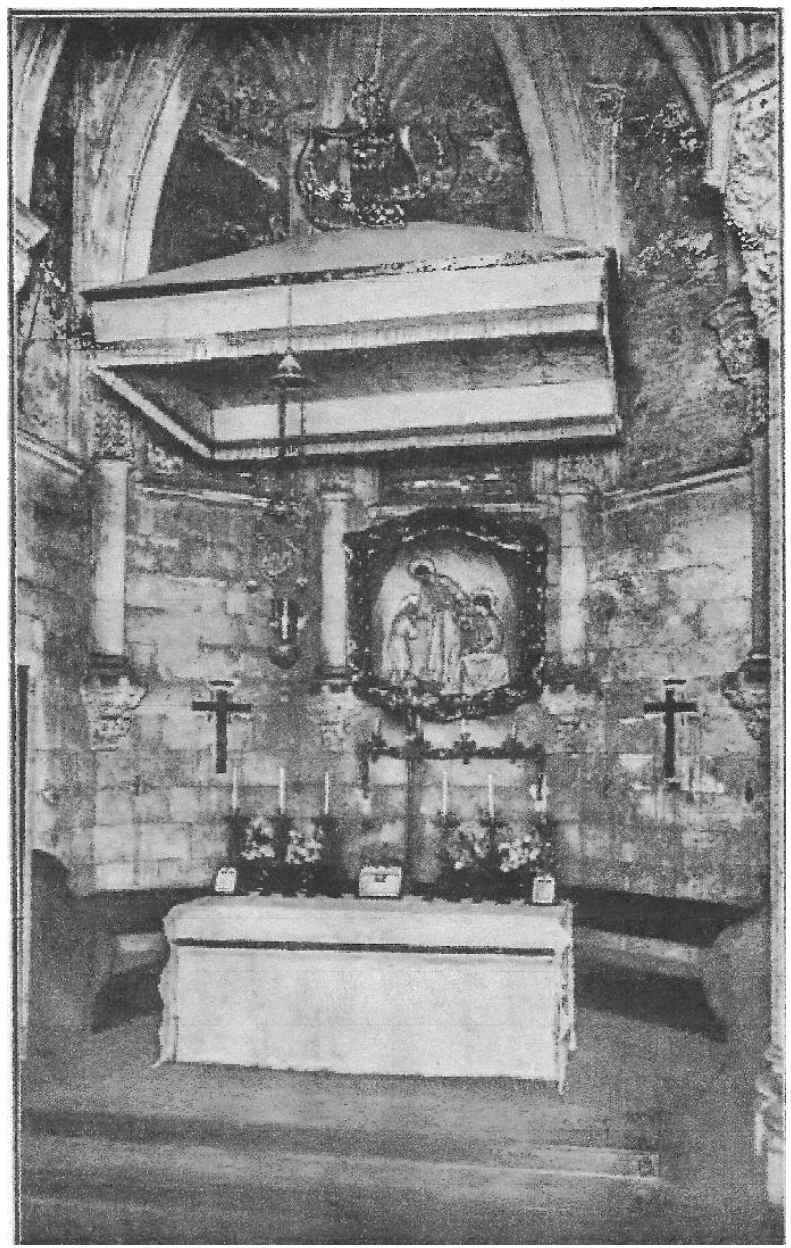

Altar exento y sobre gradas, cruz, cirios y portapaces sobre él, lámpara y ciborio colgantes,... en la Cripta de la Sagrada Familia, recogidos en el art. de Manuel Trens "L'Altar". Fuente: Anuario de los Amigos del Arte Liturgico, Barcelona 1925. Circulo Artistico de San Lucas. 
En este ambiente se puede entender el gran lujo de detalles y la significación simbólica que se observa en los tres lampadarios proyectados para la Sagrada Familia -a los que ya hemos referencia anteriormente al hablar de la Etimasia y el Aula Liturgica-, en su artístico y original ciborio, y en la singular disposición de Cristo en el Crucifijo colgante sobre el altar. Este cuidado diseño de los objetos litúrgicos abarca también las lámparas y bancos de la Cripta, el faldistorio realizado para el obispo, etc. Una vez más otro proyecto -Mallorca en este caso- se encuentra en plena simbiosis proyectual con la Sagrada Familia, situándose unas veces como ensayo arquitectónico de la organización del presbiterio y de toda la asamblea litúrgica, otras como muestra de una interacción mutua respecto del mobiliario litúrgico.

Respecto del Sagrario, ya se ha mencionado anteriormente, al hablar de los Espacios Celebrativos de la Sagrada Familia y de la dedicación de la Cripta como Parroquia en tiempos del obispo Casañas (1901-1908), de la adecuación del altar de San José como altar del Sagrario, lo cual estaba en consonancia con las recomendaciones prácticas que preconizaban Trens y Tarré, con la tradición histórica de que habla Gomá en su tratado y con disposiciones especificas de algunas diócesis, como la de Valencia, que desde los tiempos del santo arzobispo Sto. Tomás de Villanueva establecían la conveniencia de ubicar separadamente el Sagrario del altar mayor disponiendo, si era posible, una capilla específica para su adoración.

También Gaudí recoge la distinción que hace Gomá entre Cruz de altar y Cruz procesional realizando diversos diseños para la Sagrada Familia -sobre el altar mayor en la Cripta, Procesional, colgante sobre el altar mayor en el Aula Liturgica de la Sagrada Familia, etc.-, que constituyen un ejemplo de su fidelidad a la Teologia y a la Liturgia, y se pueden apreciar en las fotografías de los distintos álbumes de la Sagrada Familia y en las reseñas del Anuario de Arte Liturgico de 1925 promovido por el Circulo Artistico de San Lucas.

En esta misma merece la pena reseñar la realización de Custodias u Ostensorios y de las escaleras para facilitar su funcionalidad, ejemplos de los cuales ya se habían dado en Mallorca y en el dibujo del proyecto de Relicario para la Cofradia de la Virgen que se conserva en el Museo de Reus.

Otros elementos que señala Gomá relacionados con la Misa entran en el campo de la ubicación de las reliquias de los mártires y de las imágenes sagradas. En cuanto a las reliquias podemos afirmar que Gaudí se muestra partidario de la unicidad del altar en el Aula litúrgica (ya se ha señalado anteriormente el diferente tratamiento, ajeno a la Misa, que tienen otros altares diseñados para el ábside y la cripta), y de la tercera solución de que habla Trens para alojar las reliquias de los mártires -altar con las reliquias en la mesa- en contraposición con las soluciones del tipo confessio que aún seguían realizándose en esa época. 

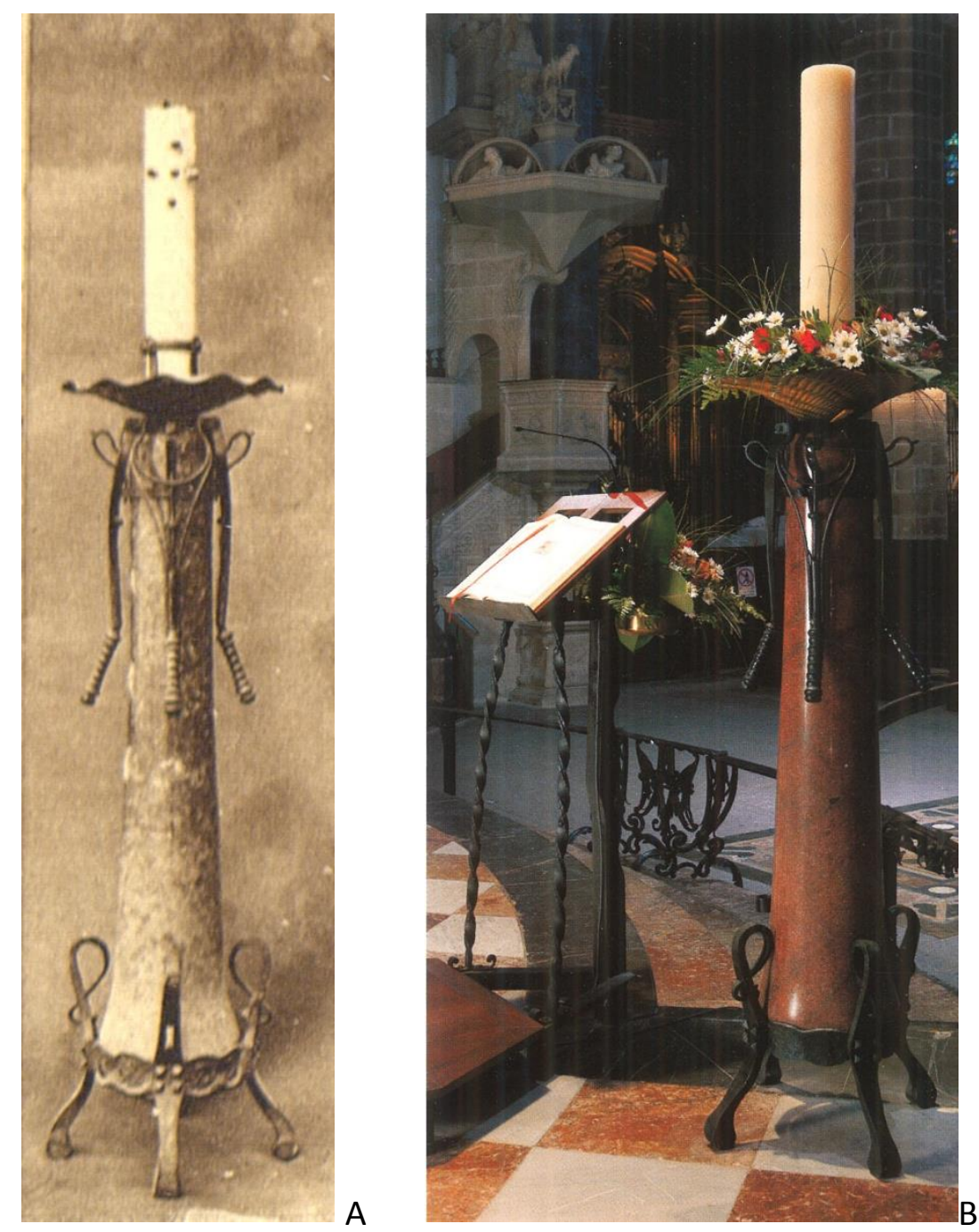

A: Candelero Portacirio Pascual diseñado por Gaudí, Cripta de la Sagrada Familia. Album 1922-25. Fuente: Archivo de la Sagrada Familia. B: Reproducción del mismo Portacirio Pascual, que se realizó en 2001 para la Catedral de Mallorca bajo la dirección de Jordi Bonet i Armengol, Director de Obra de la Sagrada Familia. Fuente: Llabrés, P. J. (2005). Gaudí a la Catedral de Mallorca. Palma de Mallorca. Triangle Postals. 
Una vez más el diseño gaudiniano irá en la línea que preconizaban los nuevos liturgistas y que acabará imponiéndose como la actual.

Las imágenes sagradas conforman otro campo de actuación al que Gaudí dedicó gran parte de su tiempo y energías. Con anterioridad ya se ha hecho alusión en esta Tesis al tratamiento gaudiniano de la esculturas en las portadas de la Sagrada Familia, desarrollando autenticas fachadas donde los elementos estructurales, la imagineria religiosa, el contenido teológico y el simbolismo cristiano se juntan en admirable integración. Se ha hecho mención igualmente de la progresión de su diseño arquitectónico con arreglo a un plan preestablecido que tiene que ver con la propia celebración eucarística que se quiere resaltar en el aula.

Con independencia de este despliegue de imágenes bíblicas orientadas según la escatología del libro del Apocalipsis conviene reseñar ahora el tratamiento de las imágenes sagradas en el interior del recinto de la iglesia. Lo haremos desde el punto de vista cronológico y litúrgico, puesto que además de las esculturas de las imágenes sagradas también utiliza las imágenes en objetos litúrgicos y elementos arquitectónicos como componentes importantes de la celebración liturgica.

Gaudí comienza esta actuación en la Sagrada Familia con las imágenes que concibe para la Cripta pero también, como hemos visto, con los objetos y mobiliario litúrgico que la acompaña. Como imágenes propiamente dichas se puede mencionar a San José (en el altar del deambulatorio del mismo nombre), la Sagrada Familia (de Josep Llimona, al fondo y detrás del altar mayo) y la Anunciación (en la clave de la bóveda). En este primer periodo se aprecia el respeto por los atributos que históricamente han adornado la veneración de estas imágenes, confiriéndoles además un matiz especialmente querido por el arquitecto. Así, a la figura de San José se le asocia siempre la imagen del Jesús Niño y los caracteres que definen la misión protectora de la figura paterna que representa el santo.

En la Anunciación, labrada en piedra y colocada en la clave de la bóveda, Gaudí quiere resaltar la radical importancia que para el Cristianismo supone la Encarnación y la protección de María como Madre de la Iglesia simbolizada en la asamblea que ha de ocupar el espacio de la Cripta. En la Sagrada Familia se da protagonismo al carácter familiar de la escena.

En la que podríamos denominar segunda etapa -imágenes situadas en el interior del Aula litúrgica- el tratamiento está más plenamente integrado en su dimensión arquitectónica, al igual que sucede en su exterior. En esta fase podríamos incluir las imágenes de la Virgen y de San José en los extremos del transepto y las proyectadas, de ángeles y santos, para las columnas arborescentes -no realizadas en vida de Gaudí- al objeto de simbolizar la dimensión trascendente de la asamblea celebrando la Eucaristía. 
Finalmente, en una tercera fase, en lo que sería imágenes que tienen que ver directamente con la liturgia de la celebración de la Misa, se podría encuadrar la escultura de Cristo agonizante en el crucifijo que cuelga sobre el altar mayor.

También desde una visión teológica, y simbólica se puede hacer referencia aquí a las formas artísticas y arquitectónicas que quieren simbolizar las vestiduras del Padre Eterno en la bóveda del ábside, el lampadario del Espíritu Santo con sus dones, la imagen de la Nueva Jerusalén y el Trono de Dios y del Cordero, aunque no respondan exactamente a la categoría de imágenes sagradas. En esta misma dimensión existencial y sagrada Denis McNamara ve la nave de la iglesia no como el lugar donde las personas se sientan sino como un sacramento del mundo renovado por la gracia, se trataría como él dice de la alta teología de la arquitectura. ${ }^{449}$

Por ello, y como también señalan Bérgamo y Del Prette, el arte figurativo no está reñido con la vida litúrgica y sino que al contrario ayuda a la plena involucración y participación en la vida de la Iglesia. De ahí que tenga plena actualidad la búsqueda gaudiniana de formas nuevas para expresar en términos arquitectónicos realidades pertenecientes a la escatología, la cosmología y la doxología cristianas. ${ }^{450}$

\footnotetext{
449 Cf. McNamara, D. (2013) "La Edad de Oro de la Arquitectura Religiosa. ¿Existe realmente un estilo americano?" en II Congreso Internacional de Arquitectura al servicio de la Liturgia. Madrid. Uv. CEU San Pablo: "Nuestro tiempo actual en la Tierra es el de la 'imagen', entre-tiempo en que se está produciendo la victoria de Cristo, pero no está completa. Así que una iglesia o una estatua religiosa no es simplemente un ejemplo de las últimas tendencias en las escuelas de arte, sino un sacramento, es el medio de realización y cumplimiento de las promesas del Antiguo Testamento y anticipa la perfección celestial que esperamos en el futuro."

${ }^{450}$ Escatología: estudio de los últimos tiempos. Cosmología: estudio de la Creación. Doxología; conocimiento de la gloria y estudio de lo que da gloria a Dios.
} 


\section{d) Dimensión urbana.}

Desde la Edad Media el edificio-iglesia ha constituido un hito urbano de primera magnitud con referencia al cual se ha desarrollado la población en innumerables ocasiones, quebrándose únicamente esta dimensión con la revolución industrial al crecer la ciudad fuera de los recintos amurallados buscando la proximidad de los asentamientos fabriles.

Bocabella y la Asociación espiritual de devotos de San José promovieron la construcción de la Sagrada Familia como un Templo expiatorio por el ambiente de descristianización social que percibían en las ciudades, situación de la que Gaudí también se había hecho eco unos años antes en el Manuscrito de Reus: "...ha pasado el tiempo en que la fe y el entusiasmo religioso levantaron el infinito número de catedrales." ${ }^{451}$ Esta dimensión de referente espiritual que se quería conferir al edificio tenía que tener su correspondencia en el hecho constructivo, de ahí que se buscara para el proyecto primeramente un arquitecto diocesano -Villar- y que después el mismo Gaudí aprovechara la oportunidad para plasmar en él su particular concepción del carácter religioso de un edificio y de lo que debía ser una iglesia.

Es cierto que fiel a su pensamiento de que las formas exteriores de una iglesia habían de ser trasunto de las interiores su inquietud por la dimensión celebrativa le lleva a desarrollar una arquitectura plenamente cultual en la que todo está enfocado a la magnificencia espiritual de la asamblea eucarística, pero este eje directriz de su actuación no le hace olvidar en ningún momento su preocupación porque el proyecto se convirtiese en un hito urbano de primera magnitud. Tanto los promotores como el mismo arquitecto buscan hacer presente la Sagrada Familia en el ambiente urbano de Barcelona en la línea que señalan Bergamo y Del Prette: como un axis, un punto de referencia para los habitantes, no sólo del barrio, sino de la ciudad. ${ }^{452}$

En este sentido han de verse las iniciativas urbanísticas de Gaudí para la mejor visualización del Templo expiatorio ${ }^{453}$, que no persiguen la magnificencia de una solución urbanística de carácter jerárquico sino la mejor visual de los elementos definidores del hito urbano. La solución propuesta al Ayuntamiento barcelonés en 1916 era una propuesta comedida en su ámbito y viabilidad con un cuidado estudio de las distancias mínimas necesarias para la visión esencial del edificio.

\footnotetext{
${ }^{451}$ Cf. Mercader, L. (2002) Antoni Gaudí: escritos y documentos. Barcelona. El Acantilado. P.50.

${ }^{452}$ Cf. Cf. Bérgamo, M. y Del Prette, M. (1997) Espacios celebrativos. Bilbao. Ed. Ega. P. 208

453 Cf. Bonet, J, y Puig, A. (2013) Arquitectura i Símbol a la Sagrada Familia. Barcelona. Raval Edicions SLU. Pórtic. Pp. 114-118.
} 


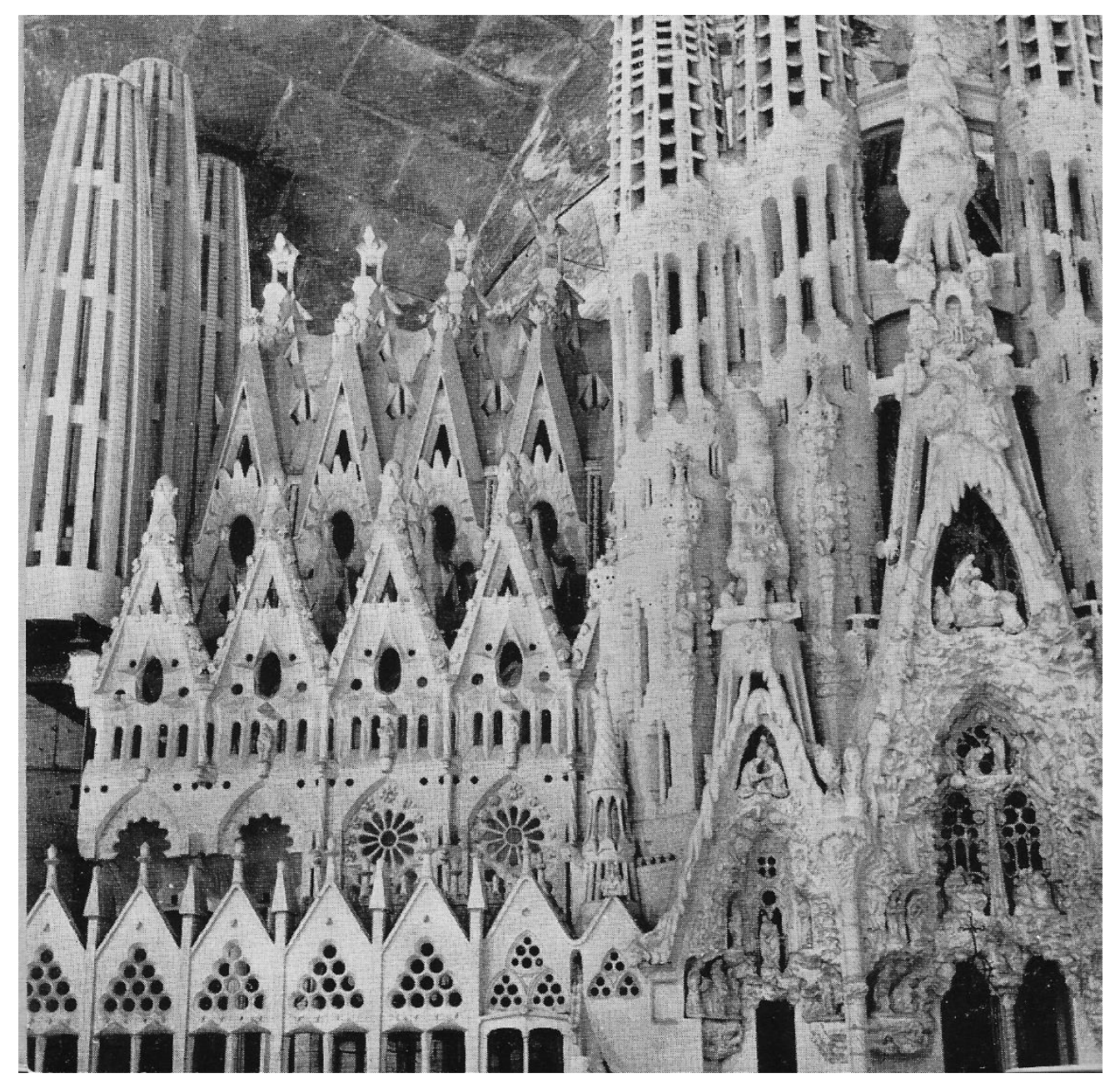

Maqueta Exteriores de la Sagrada Familia. Fuente: Martinell, C. (1967) Gaudi: su vida, su teoría, su obra. Barcelona. COACB 
En ella se dan, además, varios aspectos de interés litúrgico: en primer lugar, y según el CIC de 1917, se aprecia la adecuada separación del resto de edificios para que, de acuerdo con lo que señalaba el Pontifical Romano para la consagración de las iglesias, se pueda pasar todo a su alrededor ${ }^{454}$; respecto a su disposición y emplazamiento, la conformación de un amplio espacio delante de cada uno de los tres accesos principales claramente delimitado por elementos arquitectónicos exteriores de la iglesia y previo al nártex de cada uno de ellos, viene a interpretar según la óptica gaudiniana el histórico tema del atrio que según Plazaola nunca debería faltar en una iglesia grande y desde los primeros tiempos del Cristianismo ha preparado a los fieles para la acción litúrgica con los ritos de acogida e inicio ${ }^{455}$; un tercer aspecto de interés para el edificio iglesia es el tratamiento que se da a la noción de recogimiento del espacio sacro y su apertura al mundo, o si se quiere la relación espacio sagrado-espacio profano, habiéndose señalado anteriormente el carácter de nártex continuo que tiene el deambulatorio o claustro proyectado por Gaudí. En este aspecto su propuesta urbanística resulta totalmente actual por lo sintética, conceptual y flexible, en contraposicióncon la anodina situación actual a que ha conducido el urbanismo municipal.

El volumen de este edificio irrepetible no disminuye su funcionalidad y viabilidad celebrativas, que hemos descrito en anteriores apartados de esta Tesis, pues no nos encontramos con las limitaciones que para el mutuo conocimiento de la asamblea litúrgica impondría su excesiva amplitud y capacidad en una Parroquia al uso, sino que su condición y espacio responden más al concepto de un Santuario eclesial "para aquellos que nunca entran, para aquellos que quieren estar cerca y para aquellos que sí entran" ${ }^{456}$, que todavía tiene por hacer su programa pastoral. Durante los últimos años del siglo XX ha surgido el fenómeno de las arquitecturas al servicio de lugares de culto temporales, confirmando que en el Cristianismo cualquier lugar puede ser sagrado y abierto al mundo, así como el de las liturgias multitudinarias.

Hay que mencionar igualmente el diseño de los espacios exteriores adscritos a las Portadas y accesos de la Sagrada Familia como un notable ejercicio de inserción del edificio en la ciudad, resuelto de términos de acertada modernidad tanto en lo que significan por su valor arquitectónico como por la configuración de su accesibilidad.

\footnotetext{
${ }^{454}$ Cf. Tarré, J. (1925) “L'estructura litúrgica en la construcció dels temples”, en Anuari dels Amics de l'Art Liturgic. Barcelona. Cercle Artistic de Sant Lluc. P. 30

455 Cf. Plazaola, J. (2006). Arte Sacro Actual. Madrid. BAC. Pp. 207-213.

456 Zielinski, M. J. (2013) “Dimensiones sacramentales de la arquitectura, una propuesta actual”, en III Congreso Internacional de Arquitectura Religiosa Contemporánea. Sevilla. Universidad de Sevilla, Fundación San Juan, Arzobispado de Sevilla. Fundación CajaSol.
} 


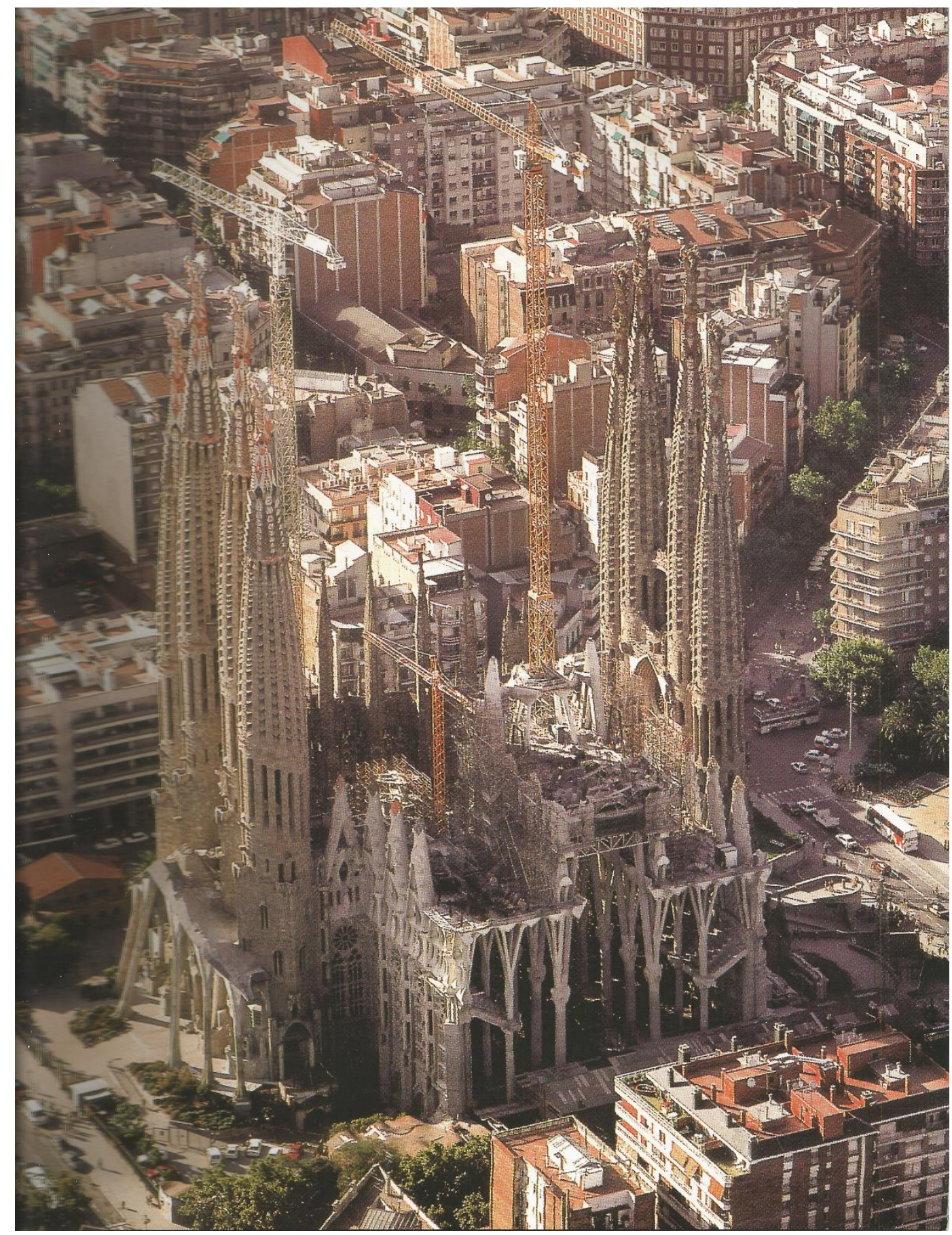

Vista general de la Sagrada Familia donde puede apreciarse la sección transversal de la Estructura de las naves. Fuente: Gómez Serramo, J. y AA.VV. (2008) Sagrada Familia XXI/ Gaudí ara. Barcelona. Edicions UPC. 
Admitiendo esta significación que tiene cada uno de dichos espacios -con sus escalinatas, rampas, explanadas, esculturas, fuente, pebetero, iconografía del paso elevado sobre la C/ Mallorca, etc.- como atrio de acceso o exonártex de la iglesia, comprendemos también su función como ámbito de transición y acogida del aula litúrgica. Las características de estos diseños externos al edificio remarcan su condición de apertura a la ciudad en contraposición a la imagen tradicional del espacio sagrado como un espacio separado, encerrado y aislado en si mismo respecto del mundo profano.

Si bien cada una de estos espacios externos responden a estas características comunes, su significado iconológico, su composición arquitectónica y su solución constructiva son radicalmente diferentes. A la vez que sus correspondientes fachadas o portadas y siguiendo su misma evolución podemos situarnos frente a una solución goticista del umbral en el que casi imperceptiblemente se pasa a través del espacio resultante de la intersección de los cuerpos girados de los campanarios, abriéndose a las dos direcciones ortogonales del acceso al Aula litúrgica y del recorrido claustral.

También se puede gozar de la amplitud y diafaneidad del espacio generado por la doble alineación de machones y columnas inclinadas de la fachada de la Pasión y la escenografía de su muro de acceso. De esta manera la secuencia es todavía más rica en este itinerario de acceso, atravesando después de este espacio exterior -a modo cávea iconográfica- lo que es el nártex de esta entrada (que sigue el mismo trazado curvo de la entrada). La experiencia sensorial y narrativa conseguida se vislumbra todavía más completa el diseño previsto para el acceso a la Portada de la Gloria, verdaderamente sorprendente en su tratamiento de la desmaterialización del espacio arquitectónico. De un lado la triple secuencia de atrio, porche y umbral con la flexibilidad de la alineación en planta, de otro la disposición secuencial de estructuras huecas de sección troncocónica en voladizo, utilizadas como iluminación natural cenital sobre el umbral de acceso, configuran un escenario arquitectónico barroquizante de una modernidad no esperable en su tiempo.

La utilización de la luz natural en el umbral del acceso al Aula Litúrgica y su ocultación en el tratamiento iconográfico del intradós del paso elevado sobre la $\mathrm{C} /$ Mallorca revelan sensibilidad y madurez al servicio del simbolismo religioso que se quiere resaltar. La visual pretendida desde la $\mathrm{C}$ / Valencia y la disposición de dos hitos escultóricos -fuente y pebetero- en las inmediaciones al edificio contribuyen a la recuperación de la dimensión urbana del edificio-iglesia como hito urbano de primera magnitud en la urbe moderna, de una manera poco utilizada hasta ese momento. 

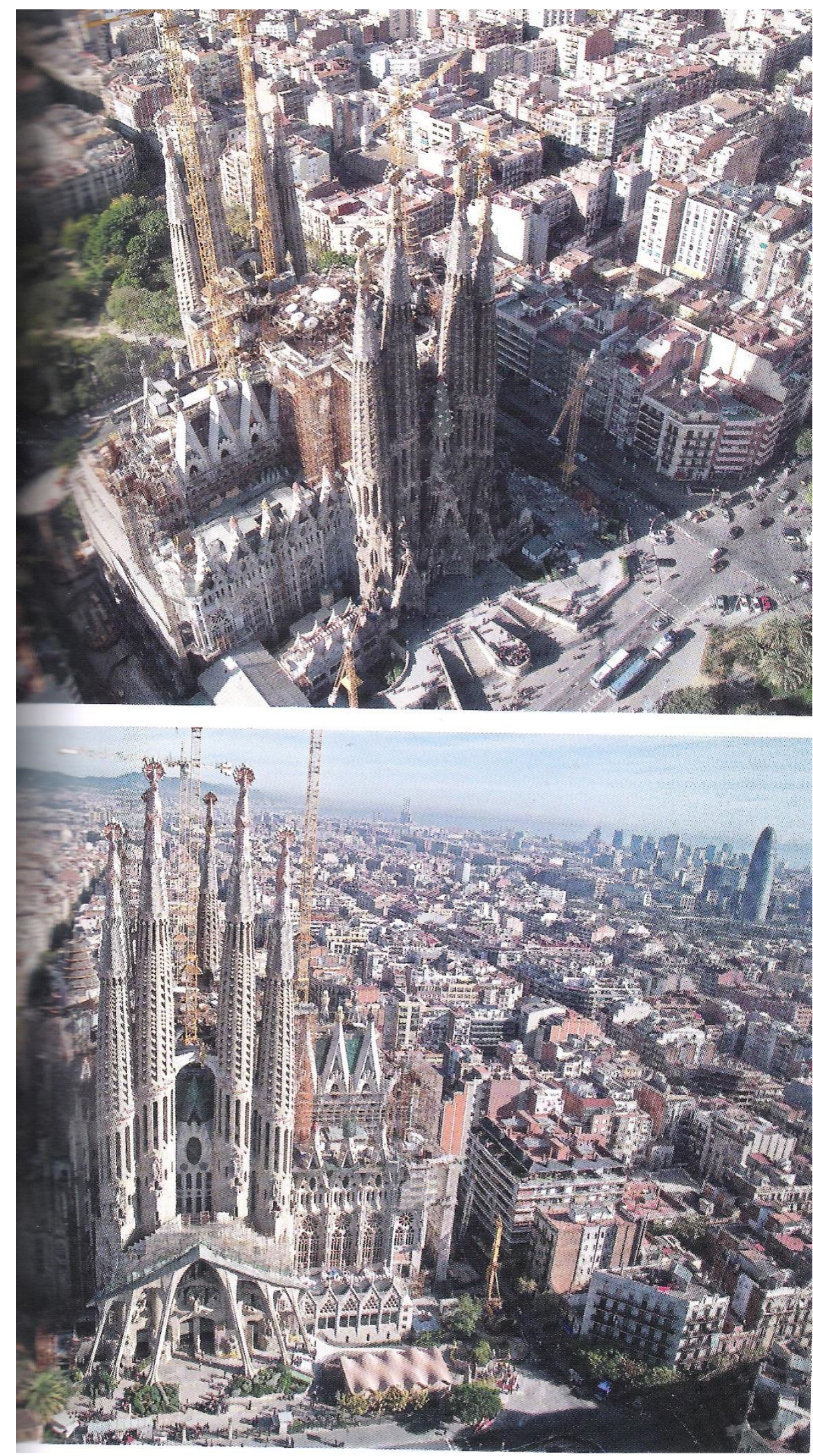

Fotografias aéreas de las Portadas del Nacimiento y de la Pasión donde se aprecia su ámbito externo como atrio abierto y la misma concavidad de la entrada remarcando su acogida arquitectónica. Fuente: Puig, A. (2011) La Sagrada Familia según Gaudí. Barcelona. El Aleph. 


\section{CONCLUSIONES.}

La Sagrada Familia constituye a mi modo de ver uno de los ejemplos más fácilmente reconocibles de coherencia entre pensamiento y realización arquitectónica. Desde los inicios de su actividad como arquitecto, Gaudí manifiesta en el Manuscrito de Reus su interés por la arquitectura eclesiástica y cómo persigue su funcionalidad litúrgica mediante la adecuada composición e integración de estructura, ornamentación y simbología. A lo largo de su ejercicio profesional seguirá una línea analítica de experimentación en orden a dar respuesta a sus propias inquietudes quedando claro que, a partir del encargo de este proyecto en 1883, los resultados obtenidos en otros proyectos serian estudiados para su aplicación a la obra del Templo Expiatorio.

Gaudí trabajó en múltiples encargos de arquitectura para el culto cristiano que desarrolló en proyectos de ámbito reducido, reformas y propuestas de nueva planta. Aunque no siempre pudo llevarlos a término, sí le permitieron adquirir una gran experiencia en la forma de tratar los requerimientos concretos del programa y disponer las soluciones constructivas más adecuadas para su resolución. De ahí que su libertad estilística esté al servicio de un programa teológico-litúrgico, y no de una estética previa determinada.

La concepción del proyecto, siempre unitaria y global hasta en sus más mínimos detalles, responde a un planteamiento básico de cómo diseñar la asamblea litúrgica según las ideas, plenamente asumidas por su más inmediato entrono, que caracterizan la renovación litúrgica que impulsa la Santa Sede al sancionar las iniciativas surgidas en Centroeuropa en el seno de la orden benedictina. En consecuencia, el desarrollo del proyecto parte de la concepción de una asamblea eucarística en la que se busca la identificación y máxima relevancia de sus principales focos litúrgicos y la mejor participación posible de los fieles, teniendo como centro neurálgico la simbología de la cúpula del crucero en la tradición arquitectónica cristiana de los espacios de culto y la enfatización del altar. En seguimiento de estos principios rectores del diseño se buscará la disposición y modulación de espacios y elementos estructurales que den estabilidad y cubrición al espacio celebrativo, y se dispondrá el resto de espacios y elementos que configuran la envolvente del edificio iglesia.

Gaudí reinterpretará los elementos constructivos en clave simbólica y teológica, para hacer del espacio y su visualización mística un elemento clave de la arquitectura del espacio de culto, de tal forma que transformará en muchos casos los recorridos físicos asimilables a la idea de peregrinación- en itinerarios simbólicos y visuales aptos para la experiencia celebrativa. 
Al ser unitaria la concepción del edificio y subordinada a su dimensión litúrgica es lícito considerar que la armonía de dimensiones del edificio y de sus elementos constituyentes,

así como el simbolismo de los elementos constructivos, tenga su fundamentación en la tradición escriturística cristiana. Como síntoma de esta buscada implicación Gaudí también propiciará una explicación teológica para sus principales hallazgos constructivos.

Gaudí se plantea una triple línea de intervención arquitectónica para conseguir este objetivo: la investigación y desarrollo de un sistema sustentante capaz de reducir los riesgos derivados de la permanencia en el tiempo de la estructura, y por consiguiente su estabilidad, hasta unos límites aceptables según los conocimientos técnicos disponibles en cada época; la puesta en valor de un acondicionamiento de los espacios celebrativos en general y del aula litúrgica en particular como espacio vivo mediante el concurso de la ordenación y composición de los diferentes recintos, el tratamiento diferenciado de su iluminación, la teologia de las imágenes, el canto coral y el mobiliario litúrgico; y finalmente, la valoración de la arquitectura eclesiástica en el tejido de las ciudades. Y todo ello impregnado y sostenido por un simbolismo que lo abarca todo y hunde sus raíces en el significado teológico-litúrgico de lo que congrega, de lo que se celebra en la asamblea eucarística.

En consecuencia, despliega todo un repertorio proyectual que goza de enorme vitalidad si nos atenemos a sus fundamentos, procesos y expresividad, dejando de lado, como así querría el arquitecto, cualquier tentación de traslación mimética. Muy probablemente, si hubiese partido de cero en la Sagrada Familia nos hubiésemos encontrado con otra solución de planta diferente y más libre, como sucede en el proyecto de Santa Coloma. En nuestro caso se puede hablar de un estadio intermedio con respecto al grado de libertad de aquel proyecto y la intervención realizada en la catedral de Mallorca.

Aún así y todo es posible remarcar como claves de la asamblea litúrgica gaudiniana: -su disposición envolvente respecto de un foco principal -altar- exento y significado mediante su elevación respecto del nivel del resto del espacio celebrativo, y la utilización de ciborios, lampadarios y crucifijo colgantes que acentúan su dimensión mistérica.

-la dimensión visual y acústica del espacio arquitectónico, al objeto de contribuir a una lectura teológica y simbólica inseparable de la realidad constructiva, cuya suma garantice un elevado grado de confort litúrgico.

-la composición arquitectónica de los espacios y recintos del edificio-iglesia fundamentada en la integración de la tradición histórica con el itinerario de instrucción de los fieles para su plena incorporación a la celebración eucarística. 
La metodología de trabajo que Gaudí lleva a cabo para la construcción del espacio litúrgico adquiere un protagonismo inusual en su tiempo. Basándose en una síntesis programática previa (que alcanza mediante la observación y análisis integral de los problemas), realiza un notable ejercicio de composición e integración de espacios, estructura, y simbolismo en el que el estudio y experimentación detallada de las posibles soluciones (incluyendo la preparación de una amplia maquetación de formas arquitectónicas e imagineria) actúa como catalizador.moldes de la imaginería), actúan como catalizadores del proceso proyectual. Su discurso compositivo, basado en la escala humana y la visualización tridimensional del espacio y las formas, resulta de una extraordinaria originalidad otorgándole aún hoy una buena dosis de reflexión. ${ }^{457}$

El pensamiento de Gaudí acerca del carácter de un edificio precede al discurso arquitectónico que años después proclama Louis Khan en seminarios y conferencias, puesto que el tratamiento unitario, la organización y jerarquización de espacios, y la vocación de cada uno de ellos responden a implicaciones en el orden espiritual. Cuando el arquitecto americano habla de diferenciar el espacio de un edificio y relacionarlo con la estructura, no podemos dejar de pensar que medio siglo antes Gaudí ha clarificado de tal modo los espacios de la Sagrada Familia que ello ha supuesto la completa transformación de su proyecto estructural. Si Khan rememora el Panteón y aspira a reproducir formas geométricas puras cual mundo dentro de otro mundo, Gaudí contempla la naturaleza y quiere encontrar la geometría más natural, aquella que sirva mejor a la estabilidad del edificio, no sólo por el debate entre arquitectos y celebrantes sino por la esencia misma de la arquitectura cultual cristiana, que reclama en términos khanianos su voluntad de existir y expresarse sin necesidad de especiales aditamentos postizos.

La propuesta que representa la Sagrada Familia es la de un proyecto concebido desde y para los espacios celebrativos, imbuido de la fundamentación teológico-litúrgica de éstos y ordenado con arreglo a la renovación que impulsaba la Santa Sede a comienzos del siglo XX a partir de la labor investigadora y difusora realizada por la Orden benedictina.

Es posible encontrar en la metodología de trabajo que guía las actuaciones de Gaudí en la Sagrada Familia elementos todavía válidos para el quehacer profesional en el campo de la arquitectura eclesiástica, que tiene una primordial componente de servicio, razón por la cual exige una auténtica misión evangelizadora por parte del arquitecto que

\footnotetext{
${ }^{457}$ Cf. Belfiore, P. (2004) "Tres suposiciones sobre la modernidad de Gaudi", en Giulio Pane y AAVV. (2008) Attualità di Antoni Gaudí. Nápoles: CLEAN Edizioni. P.68: "“Una personlità artistica, moderna allora e moderna ancor oggi per almeno tre fondamentali proposizioni: perché ha inteso la modernità come pratica globale e locale dei liguaggi della architettura; perché ha inteso la modernità come capcità de cogliere la relazione tra le cose; perché ha inteso la modernitá come percorso simbolico."
} 
asume un encargo de estas características. A su vez, la realización de un proyecto de índole cultual supone la estrecha colaboración del promotor con el arquitecto hasta extremos quizá todavía no entendidos por el mundo eclesiástico. En la Sagrada Familia se dio esa conjunción de voluntades entre la asociación josefina y sus dirigentes, y el arquitecto Antonio Gaudí.

A mi parecer es posible abundar en el proyecto arquitectónico del espacio litúrgico teniendo como fuente de inspiración la Sagrada Familia en varias líneas o propuestas:

a) La realización de una ficha arquitectónica de los espacios cultuales de la Sagrada Familia -ejemplo de integración compositiva, estructural y figurativa- a la luz de las aportaciones litúrgicas posconciliares como programa.

b) La valoración de la iconografía y el simbolismo de la Sagrada Familia como aportación a la dimensión celebrativa del espacio litúrgico, ad-intra y ad-extra.

c) La consideración de la libertad formal respecto del dilema forma-función en la arquitectura eclesiástica. 


\section{FUENTES Y BIBLIOGRAFIA CLASIFICADA}

\section{FUENTES}

\section{Edificio}

Se considera que el edificio mismo, exterior e interiormente, sigue siendo una valiosa fuente de documentación, puesta a disposición de quien lo contemple y recorra con detenimiento, aprehendiendo su espacialidad, orden y sentido, que con independencia del dilatado tiempo de ejecución de las obras y las sucesivas aportaciones de los arquitectos directores de obra, conforman en unión de la estructura y materiales, la luz, el color, etc. siguen permitiendo percibir su carácter original.

Fuentes gráficas. Proyectos, croquis y dibujos de Antonio Gaudí.

Las fuentes o vías de acceso a la información gráfica original de los proyectos gaudinianos de la Sagrada Familia son principalmente: la Fundación Eclesiástica de la Sagrada Familia, fundada en 1895, a través del Archivo de la Junta Constructora y de la Oficina Técnica de las Obras, y la Cátedra Gaudí de la Escuela de Arquitectura de Barcelona.

Se dispone de la publicación de croquis y dibujos originales del edificio a través de las recopilaciones realizadas y publicadas por sus primeros biógrafos y colaboradores y también por diversos articulistas ligados a la Asociación de devotos de San José, en cuya revista oficial El Propagador de la devoción a San José son recogidos y comentados durante años (revista denominada más tarde Templo y finalmente Temple). Los originales de esta revista se conservan catalogados en el Archivo de la Junta Constructora de la Sagrada Familia.

También en los años finales de la construcción en vida de Gaudí, cuando las obras de la Sagrada Familia se ralentizan por la escasez de fondos, es cuando, ayudado por sus colaboradores Berenguer, Jujol, Sugrañes y Quintana, entre otros, en el taller de este edificio, alcanza las soluciones finales del proyecto plasmadas en croquis, maquetas de todo tipo y escala, dibujos, etc. que, aunque destruidos en 1936 antes ya se habían plasmado en también en biografías y ensayos sobre su obra. Entre estos hay que destacar los que escriben J.F. Ràfols, Isidre Puig Boada, Joan Bergós y César Martinell, considerados como los cuatro biógrafos-colaboradores que más fidedignamente trasmiten noticia del arquitecto y su obra.

En el caso de las maquetas hay que señalar que fueron posteriormente restauradas por el Equipo Técnico de la Junta Constructiva del Templo.

Con respecto a las recopilaciones realizadas hasta la fecha de los croquis y dibujos originales de Antonio Gaudí se dispone en la Real Cátedra Gaudí de toda la información 
recopilada y encontrada que se salvó de su destrucción por no estar en el taller de Gaudí de la Sagrada Familia, que conveniente catalogada, archivada y publicada desde el año de su creación, 1968, hasta la actualidad, ha sido una labor pacientemente desarrollada especialmente en el periodo de dirección de Joan Bassegoda.

La Oficina Técnica de las Obras, directamente y con el concurso de profesionales adscritos a distintas universidades (especialmente la Universidad Politécnica de Barcelona y la Universidad de Sidney), ha realizado el trabajo de restauración de maquetas, desarrollo de planos y cálculos del proyecto, bajo la dirección de los diferentes arquitectos que se han sucedido desde Doménec Sugrañes (designado por Gaudí para sucederle) hasta los más recientes Jordí Bonet y Jordí Faulí, actual director de las obras.

\section{Fuentes gráficas. Fotografias Edificio.}

- Las fotografías originales de la construcción del edificio fueron publicadas ya en los álbumes y boletines del Propagador de la Asociación de devotos de San José, y en las primeras biografías y ensayos realizados por sus inmediatos colaboradores, en vida de Antonio Gaudí, así como en diarios y revistas de Barcelona en los años de la ejecución de las obras por el arquitecto y posteriormente a su muerte.

- Las fotografías del edificio que se han realizado con posterioridad a la muerte de Gaudí se han publicado principalmente en los boletines de la revista Templo, sucesora del Propagador, y en numerosos libros, artículos y ensayos. En los últimos años fotógrafos de reconocido prestigio y el servicio de prensa de la Fundación de la Sagrada Familia han tomado gran número de fotografías con destino a exposiciones nacionales e internacionales. Se ha procurado referenciar la publicación de donde se han tomado y la fecha.

- El servicio de Documentación y Archivo de la Junta Constructora de la Sagrada Familia dispone de un amplio material gráfico general y de detalle de la obra, tanto de las primeras etapas como de los años sucesivos, que constituye un ingente patrimonio de todo el proceso de construcción del edificio.

- La Oficina Técnica de las Obras ha realizado un seguimiento muy detallado del desarrollo del proyecto, también a través de un amplio y documentado reportaje fotográfico.

- El autor de esta Tesis también ha realizado algunas fotografías que se incorporan a su desarrollo.

En esta Tesis se recogen fotografías de diversa procedencia, referenciándolas cuando ha sido posible a sus autores. Esta documentación gráfica ha sido adaptada en cuanto a formato, encuadres y ajustes al formato de la Tesis mediante programas informáticos. 
Fuentes gráficas. Fotografias obra arquitectónica de Antonio Gaudí.

Las fotografías que se recogen en esta Tesis sobre la variada obra arquitectónica de Gaudí proceden en su mayor parte de libros, artículos, ensayos y revistas publicados, citándose siempre que se conocen la autoría y referencia. En la incorporación a la Tesis se ha procurado mantener formatos, encuadres y ajustes que se adecuen fidedignamente al original. Así mismo se han incorporado así mismo algunas fotografías realizadas por el autor de la Tesis.

Fuentes gráficas. Planos, croquis y dibujos de obra arquitectónica de otros autores. La documentación gráfica relativa a proyectos de otros autores se ha incorporado a la Tesis citando la autoría y referencia en cuanto ha sido posible disponer de dicha información.

Así mismo se han incorporado así mismo algunas fotografías realizadas por el autor de la Tesis.

Fuentes gráficas. Fotografias e Imágenes de otros edificios.

La documentación gráfica relativa a fotografías de obras realizadas por otros autores se ha incorporado a la Tesis citando la autoría y referencia en cuanto ha sido posible disponer de dicha información.

Así mismo se han incorporado así mismo algunas fotografías realizadas por el autor de la Tesis.

\section{Fuentes escritas:}

- Textos originales manuscritos de Antonio Gaudí.

- Libros publicados sobre el edificio de la Sagrada Familia.

- Artículos y ensayos publicados en libros y revistas sobre la Sagrada Familia.

- Libros publicados sobre la obra arquitectónica de Antonio Gaudí.

- Artículos y ensayos publicados en libros y revistas sobre la obra arquitectónica de Antonio Gaudí.

- Artículos, ensayos y libros publicados sobre la biografía de Antonio Gaudí.

- Artículos, ensayos y libros publicados sobre la relación Arquitectura y Liturgia.

- Artículos, ensayos y libros publicados de la Liturgia en tiempos de Gaudí.

- Tesis doctorales leídas con referencia a la obra arquitectónica de Antonio Gaudí. 


\section{BIBLIOGRAFIA TEMATICA}

\section{LITURGIA}

1. AAVV Asociación Española de Profesores de Liturgia. (2009) El Movimiento Liturgico y la reforma litúrgica". Barcelona: Centre de Pastoral Litúrgica, Culmen et Fons.

2. Antoñana, Gregorio Martinez de. (1923) Manual de Liturgia Sagrada, segunda edición del original de 1921. Madrid. Editorial del Corazón de Maria.

3. Arozena, Felix Ma (2006) "El altar cristiano", en Biblioteca Litúrgica. Barcelona. Centro de Pastoral Litúrgica.

4. Basurko, Xabier. (2006) Historia de la Liturgia. Barcelona: Centre de Pastoral Litúrgica.

5. Borobio, D. (2008) La dimensión estética de la liturgia. Barcelona. Cuadernos Phase 180. CPL.

6. Botte, B. (2013) El Movimiento Liturgico, Testimonios y recuerdos. Barcelona. Cuadernos Phase 211

7. Carreras i Mas, Lluis y Tarré, Josep (1915) "Eucologi", en Publicació oficial del Congrés Liturgic de Montserrat", edición de 1933. Barcelona. Sucesores de Joan Gili.

8. Cassingena Trevedy, François. (2008). La belleza de la liturgia. Madrid. Sígueme.

9. Comisión episcopal de Patrimonio y Liturgia CEE. (2009) Enchiridion del Patrimonio Cultural de la Iglesia. Madrid. Ed. José A. Martinez Garcia.

10. Corbon, Jean. Litúrgia Fonamental. Madrid (2001). Palabra.

11. Della Torre, Luigi y AA.VV. (1968). Per una nuova pietà popolare, (Monografia) en Studi Cattolici no 89/90. Milano. Associazione ARES.

12. Farnés, P; Aldazabal, J. El lugar de la celebración. Barcelona. DOSSIERS CPL nำ14.

13. Ferreres, Juan B. (1929) "Historia del Misal Romano: su origen." Barcelona. Eugenio Subirana. 
14. Ferrer Grenesche, Juan Miguel y AAVV. (2013) La liturgia, inspiradora de las artes. Barcelona. CPL

15. Franquesa, Adalbert. (1966) II Congrés Liturgic de Montserrat, Vol. 1. (2a Ed.) Montserrat: Publicaciones de la Abadía.

16. Franquesa, Adalbert. (1965) El Congreso litúrgico de Montserrat de 1915. Qüestions de vida cristiana, no25, separata. (2- Ed.) Montserrat: Publicaciones de la Abadía. 25-32

17. Franquesa, Adalbert. (1974) "La constitución Sacrosanctum Concilium en su contexto histórico", en Concilio Vaticano II, tomo I, Comentarios a la Cosntitucion Sacrosanctum Concilium. Madrid. Morcillo Gonzalez Ed.

18. Gallego Barnés, André. (2008). "La vulgarización de la liturgia en el ambiente del Concilio de Trento. Una fuente privilegiada por Juan Lorenzo Palmireno: el Rationale divinorum officiorum de Guillaume Durand". CRITICON no102. 21-35.

19. Garrido Bonaño, Manuel. Grandes maestros y promotores del Movimiento Liturgico. Madrid. (2008) BAC.

20. Gomá y Tomás, Isidro. (1918) El valor educativo de la Liturgia Católica. Barcelona. Rafael Casulleres ed.

21. Gonzalez Lopez-Corps, M. (2007) "Orientem versus" en Consideraciones en torno al altar en la Eucaristia al inicio del tercer milenio, Ponencias II. Bilbao. Culmen et Fons 7. Asociacion Española de Profesores de Liturgia.

22. Guardini, Romano. (1952). El espíritu de la liturgia. Barcelona.

23. Guardini, R. y AAVV (1995) Líneas básicas del Movimiento Liturgico. Barcelona: CPL.

24. Gueránguer, Dom Prósper. (1954). El Año litúrgico. Primera edición española del original L'Année Liturgique de 1875, traducida por los monjes de Silos. Tomo I. Burgos: Ed. Aldecoa.

25. Kunzler, M. (1999).La liturgia de la Iglesia. Valencia: Edicep.

26. Lercaro, G. (1965). "Liturgia viva per gli uomini vivi”. Roma. Herder. 
27. Lercaro, G. y Rousseau, O. (2001) Pio X y la Reforma Litúrgica. Barcelona: Cuadernos Phase 112.

28. Lopez Martin, J. (2000) La liturgia de la Iglesia. Teología, historia, espiritualidad y pastoral. (3a Ed., rev.) Madrid: BAC.

29. Maldonado, L. (2002) Liturgia, arte, belleza. Madrid: San Pablo.

30. Oñatibia, I. (1964). "La reforma liturgica desde San Pio X hasta el concilio Vaticano II" en Concilio Vaticano II, vol 1, Comentario a la constitución sobre sagrada liturgia. Madrid. Ed.

31. Pardo, A. (2000).Enchiridion. Documentación litúrgica postconciliar. Barcelona: Ed. Regina.

32. Ratzinger, Joseph. (2010). La fiesta de la Fe. (4ạ Ed.) Bilbao: Desclée De Brouwer.

33. Ratzinger, Joseph. (2005) La belleza, la chiesa. Roma: Ed. Vaticana e Itaca.

34. Ratzinger, Joseph. (2001) El Espiritu de la Liturgia. Una Introducción. Madrid: Ed. Cristiandad

35. Righeti, Mario. (1956). Historia de la Liturgia. Madrid. BAC.

36. Rigualt, Tomás d'A. "Eucologi catalá: 1858-1904" mes de diciembre.

37. Schuster, Cardenal A.I. (1956) Liber Sacramentorum. Estudio histórico-litúrgico sobre el Misal Romano. Edición original, Turín, 1919. (Tomo 1) Barcelona: Herder.

38. Solans, Joaquin. (1901) Manual Litúrgico. Octava edición del original de 1880. Barcelona: Imprenta de Subirana Hermanos.

39. Tena, P. y AAVV. La Iglesia celebrante y su teología. Barcelona: Cuadernos Phase $\mathrm{n}$-54. Barcelona: CPL.

40. Tena, P. y AAVV. "Las iglesias y su dedicación". Barcelona. Cuadernos Phase 20.

41. Tena, P. (1988) La Iglesia Asamblea. Una nueva aportación teológica. Barcelona. Cuadernos Phase no28. Pags. 415-436. 
42. Tena, P."El canon de la Misa. Siglos IX-XVI". Barcelona.

43. Zelli lacobuzzi; F. Leopoldo. "Gita a Maredsous. (1888)". Roma. (1999) Benedictina. (BEPB Depósito 244 Zel Disponible)

ARQUITECTURA Y ARTE SACRO

44. AAVV (1999) "Arte Sacro, un proyecto actual", en Actas del I Curso de Arte Sacro. Madrid. Fundación Felix Granda.

45. AAVV (2000) "Artes Plásticas: experiencia y gestión de lo sagrado", en Actas II Curso de Arte Sacro. Madrid. Fundación Felix Granda.

46. AAVV (2003) "Templo cristiano y espacio litúrgico", en Actas III Curso de Arte Sacro. Madrid. Fundación Felix Granda

47. Aldazábal, J. y Farnés, P.(1982) El lugar de la celebración. Barcelona Dossier CPL

48. Anderlo, Michele. (2005) "Casa di Dio, progetazione e adeguamento di chiese nel terzo milenio". Firenze. CEI.

49. Arozena, Felix Ma. (2006) El altar cristiano. Biblioteca Litúrgica. Barcelona Centro de Pastoral Litúrgica.

50. Bérgamo, Maurizio y Matia del Prette. (1998) Espacios celebrativos. Estudio para una arquitectura de las iglesias a partir del Concilio Vaticano II. Bilbao Teshuvá.

51. Bergamo, Maurizio y Mattia del Prette.(2001) Spazi celebrativi. L'architettura dell'ecclesia. Bologna. Edizione Dehoniane Bologna.

52. Bouyer, Louis. (2000).Arquitectura y Liturgia. Bilbao. Grafite Ediciones.

53. Browlee, D. B., De Long, D. G., Scully, V. (1998). Kahn. Barcelona. Gustavo Gili

54. Campo, S. (2006) "10 años de Ars Sacra", en Ars Sacra no37.

55. Ciampini, Pina y AAVV. (1965) Archittetura e Liturgia. Assisi: Edizioni Pro Civitate Cristiane.

56. Comité National d'Art Sacré.(1971) L'Église maison du peuple de Dieu. Paris. Editions del CERF 
57. Crippa, Maria Antonietta. (2002) "Espacio Sagrado y Arquitectura", en Diccionario de Iconografia y Arte Cristiano. Madrid. Paulinas.

58. Dubuy, George; Gomez de Liaño, Ignacio; Mari, Antoni; Garaudy, Roger; Tapies, Antoni; Valverde, José Mạ. "El Sagrat en l'Art". Barcelona. Cristianisme i Cultura. Fundació Joan Maragall.

59. Evdokimov, P. (1991).El arte del icono, teología de la belleza. Madrid: Ed. Claretianas.

60. Farnés, P. (1989) Construir y adaptar las iglesias. Orientaciones doctrinales y sugerencias prácticas sobre el espacio celebrativo, según el espíritu del Concilio Vaticano II. Barcelona. Ed. Regina.

61. Fernandez del Amo Moreno, J.L. (2006) "Arquitectura de la Liturgia", en Ars Sacra no37.

62. Godoy Fernandez, Cristina. (1989). Arquitectura cristiana y liturgia. Reflexiones en torno a la interpretacion funcional de los espacios. Barcelona. UNED.

63. Humphrey, Caroline y otro. (1997) Arquitectura sagrada. Madrid-Barcelona. Circulo de lectores.

64. Lavergne, Sabine de. (1992) Art sacrée et modernité: les grandes années de la revue L'Art Sacrée". Namur. Art Sacrée.

65. Lercaro, G. (1971) "Art Sacrée et achitecture moderne”. Paris. Ed. Du Cerf

66. Licardo, Giovani. (2005) "Archittetura e liturgia nella Chiesa antica”. Milano. Skira.

67. Lopez Quintás, A. “Aproximación al concepto de Estética” en Ars Sacra no37.

68. McNamara. (2012). Cómo leer las iglesias. Una guía de arquitectura eclesial. Barcelona. Blume.

69. Moldován, T. (2000) "La función del Arte Sacro en la Liturgia Oriental", en AA VV, Actas I Congreso de Arte Sacro de Madrid, 1999. Madrid. Fundación Felix Granda. 
70. Parada Lopez de Cordelas, M. (2013) "El Trono preparado, reflexiones sobre Estética", en Anales de Historia del Arte Vol 23, № especial 105-122. Madrid. Universidad Complutense de Madrid.

71. Plazaola, J., (2001) la Iglesia y el arte. Madrid: BAC, Iglesia y sociedad 2.

72. Plazaola, J. (1999). Historia del arte cristiano. Madrid. BAC.

73. Plazaola, J. (1996). Historia y sentido del arte cristiano. Madrid. BAC

74. Plazaola, J. (1998) “Razón y sentido del arte cristiano". Bilbao. Uv. Deusto.

75. Plazaola, J. (1965).Arte sacro actual. Madrid. BAC

76. Tarré, Josep. (1925) "Estructura litúrgica en la construcció dels temples" en Anuari dels Amics de l'Art Cristià. Barcelona. Cercle Artistic de Sant Lluc.

77. Tena, P. y AA.VV. (1995) El arte en la Liturgia. Barcelona Cuadernos Phase no47

78. Trens, Manuel. (1925) "L'Altar. La Creu de l'Altar. La Mensa”, en Anuari dels Amics de l'Art Litúrgic. Barcelona. Cercle Artístic de Sant Lluc.

79. Zielinski, M. (2013) “Dimensiones sacramentales de la Arquitectura, una propuesta actual", Ponencia en III Congreso Internacional de Arquitectura Religiosa Congemporànea. Sevilla. Universidad de Sevilla, Fundación San Juan, Arzobispado de Sevilla, Fundación Cajasol.

\section{ARQUITECTURA, HISTORIOGRAFIA BÁSICA}

80. Barjau, Santiago. (1993). D'Enric Sagnier a Salvador Andreu, notes sobre I'urbanització de l'avinguda del Tibidabo, en Boletin Museo Nacional de Catalunya, Vol. 1. Barcelona. Museo Nacional de Catalunya.

81. Benévolo, Leonardo. (1999) " $H \underline{a}$ de la Arquitectura Moderna". 8o Edición. Barcelona. Gustavo Gili.

82. Giedion, Sigfried. (2005) "La arquitectura contemporánea en España", en Revista de Critica Arquitectónica. 
83. Giedion, Sigfried. (2009). Espacio, tiempo y arquitectura. Barcelona. Ed. Reverté.

84. Gillo Dorfles, (1957) "Joan Martorell" en La arquitectura moderna. Barcelona. Seix Barral.

85. Mc Carter, Robert. Louis Khan. London, 2005. Ed. Phaidon

86. Norberg-Schultz, Christian. (2001) Arquitectura Occidental. Barcelona: Gustavo Gili.

87. Pevsner, Nikolaus. (1992).Los orígenes de la Arquitectura y el diseño modernos. Barcelona. Ed. Destino.

\section{ARQUITECTURA ECLESIASTICA}

88. Aymar i Ragolta, Jaume. (1993). L'arquitecte Joan Martorell i Montells mestre d'Antoni Gaudí. Barcelona. UB, Tesi doctoral Geografia i Historia, Dept. Ha de l'Art, dirigida per Mireia Freixa i Serra.

89. Berchez, J, Catalá Gorges, M.A. y AA.VV. (1983) Catàleg de Monuments i Conjunts de la Comunitat Valenciana. Valencia. Conselleria de Cultura de la Generalitat Valenciana.

90. Fernández Cobián, Esteban. (2005) El espacio sagrado en la arquitectura española contemporánea. La Coruña. COAG.

91. Flores, Carlos (1989). Arquitectura española contemporánea, 1880-1950. Vol. 1. Madrid. Ed. Aguilar.

92. Gomez Segade, Juan Manuel. (1985) Función y símbolo en la arquitectura eclesial del siglo XX. Granada. Hospital Real: secretariado de publicaciones.

93. Hichtcock, Henry-Russell. (2008).Arquitectura de los siglos XIX y XX. Madrid: Ed. Cátedra.

94. Gil Gimenez, Paloma. (1999) La idea del Templo en la Arquitectura del siglo XX. Barcelona. Ed. del Serbal. Tesis Doctoral 1996, profesora ETSA Valladolid. 
95. Gomez y Gonzalez de la Buelga, Juan. (2003) Epopeya de la piedra, la evolución arquitectónica de la basílica cristiana desde Roma hasta la catedral gótica. Madrid: COAM, Univ. Alcalá, F. Juan de Herrera.

96. Navascués, Pedro (1996). Arquitectura Española 1808-1914, en "Summa Artis, Historia General del Arte", Tomo XXXV. Madrid. Espasa Calpe.

97. Paredes Benitez, Cristina. (2009) Arquitectura de los templos sagrados. Barcelona.

98. Richardson, P. (2004).Arquitectura para el espíritu. Barcelona: Blume.

99. Rodriguez de Ceballos, A. (1990) "La planta eliptica: del Escorial al clasicismo español”, en Anuario de Historia y Teoría del Arte. Madrid. Universidad Autónoma de Madrid. Vol. II.

100. Vicens Hualde, I. (2007) "Veinticinco años de arquitectura religiosa", en Actas II Congreso de Arquitectura Religiosa. La Coruña.

101. Vicens Hualde, I. (2014) "Contra la Voluptuosidad", articulo inédito.

102. Yerasimos, Stéphane. (2005) Constantinopla: la herencia histórica de Estambul.

ANTONIO GAUDI Y SU ARQUITECTURA

103. AAVV (2002) Univers Gaudí. Barcelona: Consorcio Centro de Cultura Contemporánea de Barcelona (Diputacion B., M N Centro Arte Reina Sofia) Muestra organizada en el Centro de CC de Barcelona en 2002 con motivo del Año Internacional de Gaudí 2002.

104. Bassegoda Nonell, Joan. "Conversaciones de Gaudí con Joan Bergós". En REVISTA HOGAR Y ARQUITECTURA №112. (1974).

105. Bassegoda Nonell, J. (2008) "Gaudí y los estructuralistas críticos". Conferencia en la Academia de BBAA Sta. Isabel de Hungria. Sevilla: Real Maestranza de Caballeria.

106. Bassegoda Nonell, Joan. (2007) "Gaudí, todas las obras". Barcelona. Triangle Postals. 
107. Bassegoda Nonell, Joan. (1976) Exposición: dibujos del arqto. Antonio Gaudí i Cornet. Barcelona. Cátedra Gaudí.

108. Bassegoda Nonell, Joan, y Garcia Gabarró, Gustavo.(1999) La cátedra de Gaudí. Estudio analítico de su obra." Barcelona 1999- Ediciones de la UPC.

109. Bassegoda Nonell, Joan (1992) Aproximación a Gaudí. Barcelona. Cátedra Gaudí.

110. Bassegoda Nonell, Joan. (1977) Antonio Gaudí: vida y arquitectura. Barcelona.

111. Bassegoda Nonell, Joan. (2001) El senyor Gaudí. Recull d'assaigs i articles. Barcelona. Claret.

112. Bohigas, O. (1968) Arquitectura Modernista. Barcelona. Lumen

113. Bohigas, O. (1972) Reseña y catálogo de Arquitectura Modernista. Barcelona. Lumen

114. Bonet i Armengol, J. (2004) "Gaudí admirat pels grans arquitectes germanics..." Conferencia en la Academia de BBAA de Sant Jaume. Barcelona. Boletin no18.

115. Bonet, Bohigas, Cirici y AAVV (1960). "Gaudí", en Conferencias del Centro de Estudios Gaudinistas (1958-1959). Barcelona. COACB

116. Casanelles, E. (1965). "Schweitzer ante Gaudí", en diario La Vanguardia, 1-101965. Barcelona.

117. Casanelles, E. (1965). Nueva visión de Gaudí. Barcelona: Polígrafa.

118. Casanelles, E. , Collins, G. y AAVV (1991). Antoni Gaudí. Barcelona: Eds. del Serbal.

119. Centro de Estudios Gaudinistas (1970). Jornadas Internacionales de Estudios Gaudinistas. Exposicion 1967. Barcelona. Blume.

120. Cirlot, Juan-Eduardo. (1950) El arte de Gaudí. Barcelona. Eds. Omega.

121. Cirlot, Juan-Eduardo. (1966) "Gaudi”. Barcelona. R.M.

122. Cirlot, Juan-Eduardo. (2002) "Gaudi". Fotografias de Pere Vivas y Ricard Pla. Barcelona. Ajuntament de Barcelona/ Triangle Postals. 
123. Collins, George R. (1977). The Drawings of Antonio Gaudí. New York: The Drawing Center. (Ed. castellana. Dibujos de Gaudí, catalogación. Estudios Pro Arte no10. Barcelona. Abril-junio 1977, 88-104.

124. Collins, George R. (1970). "Gaudí: Estructura y Forma", en Jornadas Internacionales de Estudios Gaudinistas. Barcelona. Ed. Blume

125. Collins, G.R. "Antonio Gaudí: estructura y forma", en revista HOGAR y ARQUITECTURA. Sept-oct. 1966. GG.

126. Collins, G.R. “Antoni Gaudi”, en revista AAVV. Barcelona. 1991.

127. Cordinachs, Marcià. (1982) Antoni Gaudí: manuscritos, artículos, conversaciones y dibujos. Murcia. Colegio de Arquitectos Técnicos y Aparejadores.

128. Crippa, Maria Antonietta y AA.VV (2001) Gaudí: hábitat, naturaleza y cosmos. Barcelona/ Madrid: Lundwerg.

129. Crippa, Maria Antonietta.(2000) "Gaudí entre la historiografía contemporània i la recerca efectiva de la bellesa", en Bergós, J. y AAVV. Gaudí, l'home i l'obra. Barcelona. Lundwerg.

130. Crippa, Ma Antonietta. (2007). Antoni Gaudí 1852-1926: de la naturaleza a la arquitectura. Madrid: Alianza Ed.

131. Cruz Guáqueta, Monica. (2008) Catalogació dels fons d'Arxiu documental. Barcelona ETSAB-UPC

132. Fernandez Casado, C. (2002)."Gaudí visto desde la arquitectura del ingeniero", en Gaudí, Estructura y Naturaleza. Madrid. Revista OP Ingenieria y Territorio, no59.

133. Fernandez Ordoñez, J.A. (2002)."Gaudí, un precursor", en Gaudí, Estructura y Naturaleza. Madrid. Revista OP Ingenieria y Territorio, no59.

134. Flores, Carlos. (1983) Gaudí, Jujol y el modernismo catalán. Madrid Ed. Aguilar.

135. Giralt Miracle, Daniel. (2002) Gaudí, la búsqueda de la forma. Barcelona. Lundwerg.

136. Garcia Gabarró, G. (2002)."Gaudí y la superación del gótico", en Gaudí, Estructura y Naturaleza. Madrid. Revista OP Ingenieria y Territorio, no59. 
137. Gomez-Serrano, Josep y AAVV. "Los primeros ejemplos de Gaudí con el hormigón armado", en "Actas del 7o Congreso Nacional de Construcción. 26-29 de octubre de 2011". Santiago de Compostela. COAG

138. Gonzalez Moreno-Navarro, José Luis y Casals Balagué, Albert. (2002). Gaudí y la razón constructiva. Madrid: Akal.

139. Gonzalez Moreno-Navarro, José Luis y Casals Balagué, Albert. (2002) “Estructura y espacio en la Arquitectura de Gaudí", en Gaudí, Estructura y Naturaleza. Madrid. Revista OP Ingenieria y Territorio, no59.

140. Hensbergen, Gijs van. Antonio Gaudí. Barcelona (2001). Ed. Plaza y Janés.

141. Hitchcock; Henry Russell. (2012) Gaudí. New York. Ed. Museum of Modern Art.

142. Lahuerta, Juan José y AA.VV. (1990). Gaudí i el seu temps. Barcelona. Barcanova.

143. Lahuerta, Juan José. (1993) Antonio Gaudí: arquitectura, ideología y política. Madrid: Alianza Editorial.

144. Lloveras i Montserrat, J. (1989). "La proporción medieval en Gaudi", en Simposio sobre Gaudí y su obra. Barcelona-Astorga.

145. Lahuerta, Juan José (2002). Antoni Gaudí 1852-1926: antología contemporánea. Madrid: Alianza Editorial.

146. Martinell, C. (1979) L'arquitecte Gaudí. Reus. Asociación de Estudios Reusenses.

147. Martinell Brunet, Cesar. (1970). "Procedimientos constructivos y texturas en la obra de Gaudí", en Jornadas Internacionales de Estudios Gaudinistas. Barcelona: Ed. Blume

148. Pane, Giulio y AAVV. (2008) "Attualità di Gaudí/ a cura di Giulio Pane", ponencias de los distintos congresos celebrados en Nápoles hasta 2008. Napoli CLEAN.

149. Pane, Giulio y AAVV. (1993) "Libertá profética di Antonio Gaudí, en Antoni Gaudí: una proposta di libertá. Simposio sobre Antonio Gaudí, Politécnico de Milano. Milán. Facultad de Ingeniería.

150. Serrablo, V. (2002) "Hierro y acero en la arquitectura del gaudinismo", en Gaudí, Estructura y Naturaleza. Madrid. Revista OP Ingenieria y Territorio, no59.

151. Solá-Morales, Ignasi. (1983) Gaudí. Barcelona: Ediciones Polígrafa. 
152. Tarragó i Cid, S. (2002)."La relación estructura y forma en Gaudí", en Gaudí, Estructura y Naturaleza. Madrid. Revista OP Ingenieria y Territorio, no59.

153. Tello, A. B. (1990).Antonio Gaudí. Barcelona. 1990.

154. Vilardell Santacana, J. E. (2002) "Gaudí i la historiografía clássica de l'arquitectura moderna", en IX Jornades Internacionals d'Estudis Gaudinistes. Gaudí a Mallorca. Barcelona. Centro de Estudios Gaudinistas.

155. Zebst, Rainer. (2005) Gaudí, 1852-1926. Antoni Gaudí i Cornet, una vida dedicada a la arquitectura. New York. Taschen cop.

\section{GAUDI Y LA ARQUITECTURA ECLESIASTICA}

156. Asociación Pro-Beatificación de Gaudí. Gaudí, arquitecto de Dios (1852-1926) Folleto divulgativo para la Causa Pro Beatificación, con oración.

157. AAVV "Gaudí y Verdaguer". Barcelona 2002. Triangle Ed.

158. AA.VV. Gaudí y Jujol en la catedral de Palma. Arquitectura. №344. Madrid. septiembre-octubre 1983.

159. Arxiu Martí Matlleu. (1914-1922) Legajos: 1 (envoltorio nำ, “Carta de Dalmases a Martí Matlleu), 2 (envoltorio no4, Apologias de Rafols y Folguera, Cronologia obras del Templo, diarios 1914-1922, El Propagador 1914-1915), 3 (envoltorio nำ10, art. de Gaudí en el Propagador), 4 (envoltorio n15) y 5 (envoltorio nำ, reseña de las obras en diarios de Barcelona). Barcelona. Archivo Diocesano.

160. Campins, Pere. (1904) "Restauración de la Santa Iglesia Catedral de Mallorca", en Carta Pastoral . Palma de Mallorca: Ed. Bisbat de Mallorca.

161. Casanovas, S.J., P. Ignasi. (1928) "Plantejament estètic del problema de les relacions entre l'Art i la Moral", en L'Art i la Moral. Barcelona: Balmes.

162. Bassegoda Nonell, J., Crippa, Mạ A. y AAVV. (2002) Gaudí. Espais Sagrats. Barcelona: Lundwerg. 
163. Bassegoda Nonell, J. (1969). Los proyectos de Gaudí para las religiosas de Jesús Maria (1877-1882) Barcelona: Ediciones Literarias y Científicas.

164. Blasco Bardas, Anna Mạ y AAVV. (2004) Gaudí i la dimensió trascendent. Barcelona: Fundació Joan Maragall y Ed. Cruïlla.

165. Bonet i Armengol, J. (2002) "El mobiliari litúrgic religiós de la catedral de Palma de Mallorca", en IX Jornades Internacionals d'Estudis Gaudinistes. Gaudí a Mallorca. Barcelona. Centro de Estudios Gaudinistas.

166. Cantarellas Camps, C. (2002) "Gaudí i la catedral de Palma de Mallorca. La decoració cerámica."en IX Jornades Internacionals d'Estudis Gaudinistes. Gaudí a Mallorca. Barcelona. Centro de Estudios Gaudinistas.

167. Cendón Fernandez, Marta. (2006). "Nuevos espacios para la liturgia. El arte medieval en la arquitectura religiosa de Gaudí", en Revista de Arte no5. León. Universidad de León.

168. Crippa, Mạ Antonietta. (1986). Gaudí e il sacro Milán. ICARO.

169. Crippa, Maria Antonietta y AAVV.(1993) "Una tradizione vivente: solidamente ragionata", en Gaudí. Una proposta di libertà. Actas del Congreso sobre Antonio Gaudí celebrado en el Politécnico de Milano. Milán. Politécnico de Milán, Facultad de Ingenieria.

170. Descharnes, Prévost y Pujols. (1969). La visió artistica y religiosa de Gaudí. Barcelona: Aymá.

171. Flores, C. (2002) "Noves dades per una anàlisi de l'arquitectura gaudiniana", en IX Jornades Internacionals d'Estudis Gaudinistes. Gaudí a Mallorca. Barcelona. Centro de Estudios Gaudinistas.

172. Genís i Terre, Jaume. (2006). Els fonaments ideològics de l'arquitectura religiosa del Gaudí de maduresa. Barcelona. Universitat Pompeu Fabra. Tesis Doctoral dirigida por Antoni Mari Muñoz, catedrático de Teoría del Arte.

173. Genís i Terre, Jaume. (2009). Gaudí, ente l'arquitectura cristiana i l'art contemporani. Barcelona. Publicacions de l'Abadia de Montserrat. 
174. Gueilburt, L., Vallespir, J. y Moll, M. (2002) "Comentaris sobre l'estudi històric i constructiu de la catedral de Palma de Mallorca i la Sagrada Familia", en IX

175. Jornades Internacionals d'Estudis Gaudinistes. Gaudí a Mallorca. Barcelona. Centro de Estudios Gaudinistas.

176. Kent, Conrad. (1989) "El obispo Grau y la arqueología sagrada", en Simposio sobre Gaudí y su obra. Centenario 1889-1989 Astorga.

177. Kerrigan, Anthony. (1960) Gaudí en la catedral de Mallorca. Palma de Mallorca: Impremta Mossen Alcover.

178. Llabrés i Martorell, Pere Joan. (2002). Gaudí a la Seu de Mallorca. Palma de Mallorca: Govern de les Illes Balears.

179. Llabrés i Martorell, P. J. (2002) "La litúrgia a la restauració de la catedral de Palma, el bisbe Campins i Gaudí"en IX Jornades Internacionals d'Estudis Gaudinistes. Gaudí a Mallorca. Barcelona. Centro de Estudios Gaudinistas.

180. Llabrés i Martorell, Pere Joan. (2005). Gaudí a la catedral de Mallorca. Barcelona. Triangle Postals.

181. Liaño Gisbert, Ma Soledad. (2010) "Joan Rubió I Bellver en Mallorca", en Revista Depto. $H^{\underline{a}}$ del Arte Uv. Barcelona. Barcelona. Publicaciones de la Universidad de Barcelona.

182. Liaño Gisbert, Ma Soledad. Arquitectura religiosa. Mallorca. Siglo XIX. Barcelona Depto. $\mathrm{H}^{\mathrm{a}}$ del Arte Uv. Barcelona, Tesis Doctoral.

183. Lloveras i Montserrat, Joaquim. (1990). La proporción medieval en Gaudí. Barcelona: Astorga.

Forma parte de la Tesis Doctoral "La Persona proyectual".

184. Mercader, Laura. (2002). "Antoni Gaudí: escritos y documentos". Barcelona: El Acantilado.

185. Molema, J. (2002) "La balada de Mallorca", en IX Jornades Internacionals d'Estudis Gaudinistes. Gaudí a Mallorca. Barcelona. Centro de Estudios Gaudinistas.

186. Navarro Arisa, J.J. (2002) “Gaudí: I'arquitecte de Deu”. Barcelona. Planeta. 
187. Pascual, Aina; Durliat, Marcel; Murray, Donald G. (1995) La catedral de Mallorca. Palma de Mallorca. Jose J. de Olañete Ed.

188. Prévost, C. y Descharnes, R. "La visió artística y religiosa de Gaudí". Barcelona 1969. Ed. Ayma.

189. Puig Boada, I. (1976). L'Esglesia de la Colonia Güell. Barcelona. Lumen.

190. Quetglàs, Josep. “Gaudí, Jujol i la catedral de Palma”. En Quaderns d'arquitectura i urbanisme no179-180 y en Arquitectura n244, sep-oct 1983.

191. Ramirez, Juan Antonio. (1992). Gaudí: la arquitectura como obra de arte total. Madrid: Anaya.

192. Rotger Capllonch, M. (1907) Restauración de la catedral de Mallorca. Palma de Mallorca: Armengol i Montaner

193. Rubió, Joan. (1923). Algunes observacions sobre la Seu de Mallorca. Palma de Mallorca: Imprenta Católica Vda. De S. Pizza.

194. Sagristà, Emilio. (1962) Gaudí en la catedral de Mallorca. Castellón: Sociedad Castellonense de Cultura.

195. Tokustoshi, T. (2002) "Mallorca a les obres de Gaudi", en IX Jornades Internacionals d'Estudis Gaudinistes. Gaudí a Mallorca. Barcelona. Centro de Estudios Gaudinistas.

196. Tomlow, J. (2002) "Aspects of the work by Juan Rubio Bellver in Mallorca", en IX Jornades Internacionals d'Estudis Gaudinistes. Gaudí a Mallorca. Barcelona. Centro de Estudios Gaudinistas.

197. Tomlow, J. (2002)."La evolución de la innovación estructural de Gaudí: los proyectos de la sede de la Misión Franciscana, la iglesia de la Colonia Güell y el templo de la Sagrada Familia", en Gaudí, Estructura y Naturaleza. Madrid. Revista OP Ingenieria y Territorio, n59 
198. AA.VV. (2003) Actas 6o Congreso Internacional de la Sagrada Familia. Barcelona: Claret.

199. Asociación Espiritual de Devotos de San José (1915) Primer Album del Templo Expiatorio de la Sagrada Familia. Barcelona: Herederos de la Vda. Pla.

200. Asociación Espiritual de Devotos de San José (1917) Segundo Album del Templo Expiatorio de la Sagrada Familia. Barcelona: Herederos de la Vda. Pla.

201. Asociación Espiritual de Devotos de San José (1922) Tercer Album del Templo Expiatorio de la Sagrada Familia. Barcelona: Herederos de la Vda. Pla.

202. Asociación Espiritual de Devotos de San José (1929) Cuarto Album del Templo Exp. de la S.F. Barcelona: Herederos de la Vda. Pla. (Una nueva planta igual a la actual)

203. Asociación de Devotos de San José. El Propagador de la Devoción a San José. Barcelona. 1-01-1895.

204. Asociación de devotos de San José. El Propagador de la Devoción a San José. Barcelona. 1-10-1901.

205. Asociación de devotos de San José. El Propagador de la Devoción a San José. Barcelona. 15-10-1912.

206. Asociación de devotos de San José. El Propagador de la Devoción a San José. Barcelona. 15-11-1913

207. Asociación de devotos de San José. El Propagador de la Devoción a San José. Barcelona. 15-05-1915.

208. Asociación de devotos de San José. El Propagador de la Devoción a San José. Barcelona. 1-03-1917

209. Asociación de devotos de San José. El Propagador de la Devoción a San José. Barcelona. 1-05-1917

210. Asociación de devotos de San José. El Propagador de la Devoción a San José. Barcelona. 15-06-1917 
211. Asociación de devotos de San José. El Propagador de la Devoción a San José. Barcelona. 1-04-1918

212. Asociación de devotos de San José. El Propagador de la Devoción a San José. Barcelona. 15-09-1922

213. Asociación de devotos de San José. El Propagador de la Devoción a San José. Barcelona. 15-03-1923.

214. Asociación de devotos de San José. El Propagador de la Devoción a San José. Barcelona. Marzo-1925.

215. Asociación de devotos de San José. El Propagador de la Devoción a San José. Barcelona. 1-09-1925.

216. Asociación de devotos de San José. El Propagador de la Devoción a San José. Barcelona. 1-02-1926

217. Asociación de Devotos de San José. El Propagador de la devoción a San José. Barcelona. 15-06-1926.

218. Asociación de devotos de San José. Revista el Propagador. Año LX no16, 15-081926. 2o № extraordinario a la memoria de Antonio Gaudí.

219. Asociación de devotos de San José. Revista el Propagador. Año LX nำ19, 1-10-1926.

220. Asociación de devotos de San José. Revista el Propagador. Año LX no21 y 22, 1 y 15-11-1926.

221. Asociación de devotos de San José. El Propagador de la Devoción a San José. Barcelona. 5-12-1927.

222. Asociación de devotos de San José. El Propagador de la Devoción a San José. Barcelona. Marzo de 1932.

223. Asociación de devotos de San José. El Propagador de la Devoción a San José. Barcelona. 1-06-1932.

224. Asociación de devotos de San José. El Propagador de la Devoción a San José. Barcelona. Febrero de 1948. 
225. Asociación de devotos de San José. El Propagador de la Devoción a San José. Barcelona. Abril de 1948.

226. Asociación de devotos de San José. Templo (El Propagador de la Devoción a San José). Barcelona. Marzo de 1949.

227. Asociación de devotos de San José. Templo. Barcelona. Mayo de 1949.

228. Asociación de Devotos de San José. El Propagador de la Devoción a San José. Desde 87 (abril-Mayo 1952) a 138 (Ene-Feb 2004)

229. Bassegoda Nonell, J. y AAVV. (1996) L'Estudi de Gaudí: selección d'articles publicats a la revista Temple entre 1971 i 1994. Barcelona: Publicaciones de la UPC.

230. Bassegoda Nonell, Joan. (2001) Gaudí, la arquitectura del espíritu. Barcelona: Salvat Editores

231. Bassegoda Nonell, Joan. (1989) El gran Gaudí. Sabadell AVSA

232. Bassegoda Nonell, J. (2002) Gaudí: o espacio, luz y equilibrio. Madrid: Criterio Libros

233. Bergós Massó, Joan. (2000) Gaudi, el hombre y su obra. (2a Ed.) Barcelona: Universidad Politécnica de Cataluña, Cátedra Gaudí, Ed. Aymá.

234. Blasco i Bardas, Anna Maria. (2003) Els articles de Maragall i de Pijoan sobre la Sagrada Familia. Barcelona. Claret. Fundació Joan Maragall.

235. Bofill, Rafael M. (1990) La Premonició gaudiniana respecte dels criteris liturgics del Concili Vaticà II. Barcelona. Sociedad catalana de estudios liturgicos.

236. Bonet i Armengol, Lluis. (2010) La mort de Gaudí i el seu ressò a la revista El Propagador de la devoción a San José. Barcelona. Claret y Real Cátedra Gaudí.

237. Bonet i Armengol, Lluis. (2011). La mort de Gaudí i el seu ressò en els diaris i revistes de l'època. Barcelona. Claret y Real Cátedra Gaudí.

238. Bonet i Armengol, J. (1996) Gaudí, dibuixos originals. Barcelona: Publicaciones de la UPC. 
239. Bonet i Armengol, Jordi. (2001). El modulat geometric del Temple de la Sagrada Familia. (2a Ed.) Barcelona: Pórtic.

240. Bonet i Armengol, Jordi. (2010).Sagrada Familia, de temple expiatori a basilica. Barcelona: Lundwerg.

241. Bonet i Armengol, Jordi y AAVV (2012) La Sagrada Familia de Gaudí: el Templo Expiatorio desde sus comienzos hasta hoy. Versión en castellano de "Sagrada Familia: de temple expiatori a basílica" 2010.. Barcelona: Lundwerg.

242. Bonet i Armengol, Jordi y Puig, Armand. (2013) Arquitectura y símbolo de la Sagrada Familia. Barcelona. Pórtic.

243. Bonet Garí, L.(1949) "El templo de la Sagrada Familia y la Catedral de Mallorca" en REVISTA TEMPLO no octubre 1949. Barcelona.

244. Burry, M., Coll, J., Espel, R., Faulí, J. y Gómez, J. (2014) Les naus de la Sagrada Familia. Els secrets arquitectònics d'una obra irrepetible. Barcelona. Ed. Mediterrània.

245. Cirici, Alexandre. (1952). La Sagrada Familia de Antonio Gaudí. Barcelona: Omega.

246. Faulí i Oller, Jordi. (2006) El Temple de la Sagrada Familia. Madrid: Aldeasa

247. Faulí i Oller, Jordi. (2009) Continuitat i composició en les columnas $i$ voltes del Temple de la Sagrada Familia. Barcelona. UPC, Tesi Doctoral d'Arquitectura.

248. Ferrín, Ana Mạ. (2001) Gaudí, la huella del genio. Barcelona: Jaraquemada.

249. Flores, Carlos (2002). La Lección de Gaudí. Madrid. Aguilar.

250. Garcia Gabarró, Gustavo (1994) Leyes de la naturaleza y composición arquitectónica: el ejemplo de Antonio Gaudí. Barcelona. ETSAB. Tesis Doctoral dirigida por Joan Bassegoda.

251. Gil Parés (1921) "Culte diví al Temple Expiatori de la Sagrada Familia", en el diario EL CORREO CATALAN 4-12-1921. Barcelona.

252. Gómez Serrano, Josep y AAVV. (2008). Sagrada Familia XXI/ Gaudí ara. Barcelona. Edicions UPC. 
253. Gómez Serrano, J. y Coll i Grifolí, J. (2002) "El proyecto de la Sagrada Familia en el siglo XXI", en Gaudí, Estructura y Naturaleza. Madrid. Revista OP Ingenieria y Territorio, no59.

254. Gómez Serrano, Josep y AAVV. (1996). L'Obrador de Gaudí. Barcelona: Edicions UPC.

255. Gonzalez Moreno-Navarro, José Luis y AAVV. Gaudí: estructura y espacio, en Revista del CICCP n59. Madrid.

256. Matamala, Joan.(1999) Antonio Gaudí, mi itinerario con el arquitecto. Barcelona. Claret.

257. Martí i Bonet, Josep. (2012). La inspiració ve de la catedral: Gaudí, Mossen Cinto i Bassegoda. Barcelona.

258. Martinell Brunet, César. (1950). Gaudí i la Sagrada Familia, comentada per ell mateix. Barcelona: Aymá SL Edicions.

259. Martinell Brunet, César. (1969). Conversaciones con Gaudí. Barcelona: Punto Fijo.

260. Martinell Brunet, César. (1967). "Gaudí: su vida, su teoría, su obra". (1a ed.) Barcelona. COACB.

261. Oliva Sala, Antoni. (2012) "Biografia de Bocabella", en revista Temple, no julioagosto 2012. Barcelona.

262. Obispado de Barcelona (1917). "Solicitud de inhumar cadáveres en las criptas del Templo expiatorio de la Sagrada Familia", intervención en la sesión del Senado de 18 de diciembre de 1916. Barcelona. El Propagador de la Devoción a San José, no de febrero 1917.

263. Parés, Gil, Pvre. (1921) "Culte diví al Temple Expiatori de la Sagrada Familia", en El Correo Catalán. Barcelona. 4-12-1921

264. Perucho, J. (1967). Gaudí, una arquitectura de anticipación. Barcelona. Polígrafa.

265. Puig Boada, Isidre. (1927) "L'ideal del Temple Cristià i la Sagrada Familia" en EI Propagador de la Devoción a San José. Barcelona. 1-06-1927. 
266. Puig Boada, Isidre. (1949) "La plástica gaudiniana", en revista TEMPLO. Barcelona. Agosto-septiembre 1949.

267. Puig Boada, Isidre. "Los problemas de la luz", en revista TEMPLO. Barcelona. Octubre 1951.

268. Puig Boada, Isidre (1981) El Pensament de Gaudí: compilació de textos $i$ comentaris. Barcelona: La Gaya Ciencia.

269. Puig Boada, Isidre (1982). El Templo de la Sagrada Familia. Barcelona. Thor

270. Pujol, Nuria. (2010). "Ceremonia Inaugural de la primera piedra de la Sagrada Familia". Revista Diplomacia i Protocol, № 7 de diciembre de 2010.

271. Pujols, Francesc. (1996) "La visió artística i religiosa de Gaudi". Barcelona. Quaderns Crema.

272. Puig, Armand. (2011). La Sagrada Familia según Gaudí. Barcelona: El Aleph.

273. Quintana, Francesc de P. "Les formes guerxes del Temple de la Sagrada Familia", en La Ciutat i la Casa. Barcelona, no6 1927.

274. Quintana, Antonio/ Bassegoda, Joan.(1985) Manyanet, Bocabella, Gaudí: tres grandes para un gran Templo. Barcelona.)

275. Ràfols, Josep Francesc. (2006). Gaudí. Barcelona. Claret y Cátedra Gaudí.

276. Reig Martinez, Juan (2011). Antoni Gaudí y la Belleza. La Sagrada Familia un proyecto vivo. Valencia. Edicep.

277. Rohrer, J. (1990) "Una visió apropiada: el Temple de la Sagrada Familia de Gaudí i la política arquitectónica de la Lliga Regionalista", en AA.VV. Gaudí i el seu temps. Barcelona. Barcanova.

278. Revista "Veu". Any XVI, n⒉437, 20 gener 1906: dibujo completo del Templo.

279. Revista "Veu", 11 octubre 1907: conseguir el terreno frente a la fachada principal.

280. Serra, Modesto. (1921) Conferencia en la Escuela Municipal de Comercio de Pforzheim (Alemania). El Propagador de la Devoción a San José. Barcelona. 1-051921. 
281. Sugrañes, Doménec. (1923) Disposició estática del Temple de la S.F. Barcelona: Anuario de la Asociación de Arquitectos de Cataluña.

282. Tarragona i Clarassó, J.M. (2002) "Quan Gaudí va voler abandonar la Sagrada Familia", IX Jornades Internacionals d'Estudis Gaudinistes. Gaudí a Mallorca. Barcelona. Centro de Estudios Gaudinistas.

283. Tarré, Josep, Pvre. (1915) "La nova Basílica", en Vida Cristiana. Abadia de Montserrat. Quaresma i Tots Sants.

284. Torrents, Ricard. (2006). "Art, poder i religió: la Sagrada Familia”, en Verdaguer i en Gaudí. Barcelona: Proa.

285. Torrents, Ricard. (2012). Entorn Maragall i Gaudi. Barcelona. Fundació Maragall i Claret.

286. Tokutthosi, Torii (1983). El mundo enigmático de Gaudí. Madrid. Instituto de España.

287. Vogel, Dr. (1921). "Referències a les seves lliçons sobre el Temple de la Sagrada Familia, donades I'any 1912 a Alemanya", en El Propagador de la devoción a San José. Barcelona, 1-05-1921.

288. VEU, Revista 20 de enero 1906 y 11 de octubre de 1907

289. Rucabado, Ramón. "El arquitecto Sartoris y la urbanización”, en revista Templo. Enero 1950. Barcelona.

TEOLOGIA Y PASTORAL

290. Arzobispado de Barcelona. (2010). Con el Papa en la Sagrada Familia. Siete catequesis. Barcelona: Arzpdo. de Barcelona.

291. Balthasar, Hans Urs von. "Gloria” Vol 1. Ediciones Encuentro Madrid 1985.

292. Fibla, P. (1996). "Una aproximación a la teología de la belleza". Madrid. Phase $\mathrm{n}$ 웅. 
293. Ratzinger, J. (Benedicto XVI) Exortacion Apostólica ·Sacramentum caritatis", ars celebrandi.

294. Pio X (1903) Motu Proprio Tra le Solicitudini. Ciudad del Vaticano.

295. Pio X (1905) Decreto Sacra Tridentina Synodus. Ciudad del Vaticano.

296. Pio X (1906) Decreto Post Editum. Ciudad del Vaticano

297. Pio X (1911) Decreto Divinu Afflatu. Ciudad del Vaticano.

\section{RECURSOS ELECTRÓNICOS}

298. Benedicto XVI. (2010). Homilía en la dedicación del templo de la Sagrada Familia. www.vatican.va/holy father/...xvi/index sp.html/ (Diversas fechas).

299. Benedicto XVI. (2009) Homilía del Papa en Nazaret. Nazaret (Israel). 8-05-2009 www.vatican.va/holy father/...xvi/index sp.html//(Diversas fechas).

300. Benedicto XVI. (2009) La catedral gótica y la belleza. Audiencia general 18-112009. www.vatican.va/holy father/...xvi/index sp.html/ (Diversas fechas).

301. Benedicto XVI. (2010) Discurso en la institución el Nen Deu. Barcelona, www.vatican.va/holy father/...xvi/index sp.html/ (Diversas fechas).

302. Solá Grané, Jaime (2009). El Tibidabo entre dos columnas. www.noticiascristianas.es/ (30-03-2014).

303. Benedicto XVI. (2010) Entrevista al Papa en sus viajes a Santiago y Barcelona, www.vatican.va/holy father/...xvi/index sp.html/ (Diversas fechas).

304. Stroik, Duncan G. (2012) Benedicto XVI y la Via Pulchritudinis, en www.sacredarchitecture.org (30-03-2014). 
ANEXOS

\section{TEXTO DEL DISCURSO DE ANTONIO GAUDI A LOS JOSEFINOS}

"El templo - dijo- es la casa de Dios, casa de oración. Cuantos qué nos reunimos tenemos el mismo espíritu cristiano que se tenía en los primitivos templos en las catacumbas de Roma, cuando rezaban, como nosotros, en una cripta. Bajo el suelo de Barcelona, se ha construido ya el primer espacio del gran templo que anhelamos. En esta cripta se venerará el facsímil de la Santa Casa de Nazaret, trasportada a Loreto. Dado que el terreno lo permite, se desarrollará totalmente el plan previsto en toda la extensión del solar. Sobre la cripta estará el altar mayor. La planta será de disposición basilical, con cruz latina y cinco naves, que en el transepto serán tres. Tendrá tres fachadas, la principal sobre la calle Mallorca, accesible por cinco puertas correlativas a las naves, y las laterales con tres puertas para las tres naves. Cerrará el perímetro, por el lado norte, el ábside, cuyos muros serán continuación de los de la cripta.

El templo será accesible en cada fachada por amplias escalinatas, pues estas, a modo de basamento, imprimen carácter a los edificios, así como grandeza y monumentalidad. Armonizaremos la traza gótica que condicionaba el plan de mi antecesor, arquitecto Del Villar, con soluciones originadas en el estilo bizantino que se ajustan a la liturgia católica actual.

Quisiéramos que el conjunto del templo fuera un verdadero símbolo, una obra de arte, a tono con la época que vivimos.

El desarrollo del estudio sobre el primitivo plan nos permitirá una riqueza de elementos asimilable a lo que lograron los constructores medievales con las catedrales.

Ostentará en el exterior las imágenes apologéticas y catequizantes para introducir a los fieles en la contemplación del mundo sobrenatural que se proyectará en el interior.

Si en el proyecto de nuestro antecesor era un solo campanario el que se destacaba de la masa del templo, además del cimborrio, en nuestro proyecto emergerán de cada fachada cuatro campanarios, que con el conjunto de las tres fachadas representarán a los doce Apóstoles.

Encima de los cruceros emergerán cuatro torres, representativas de los evangelistas, alrededor del cimborrio principal. En el ábside se levantará otra, dedicada a la Virgen, de altura intermedia. El cimborrio principal, dedicado a Jesucristo, culminará con la cruz de cuatro brazos.

La fachada que mira a levante estará dedicada al Nacimiento de Jesús, su infancia y adolescencia. En cada una de las tres puertas se representarán escenas de estas tres edades. Presidirá en la principal el acontecimiento de la venida de Dios al mundo. Coros de ángeles músicos y cantores rodearán a las tres personas de la Sagrada Familia. En frisos cercanos a la puerta se representará la adoración de los Reyes y los pastores. 
En las puertas laterales seguirán representaciones de la infancia, entre las que destacará la figura de la Virgen María y del padre nutricio, San José. Sobre las tres arquivoltas y en las

lonjas correspondientes se situarán figuraciones de la vida y glorificación de la Sagrada Familia.

Cada una de estas puertas culminará superiormente con los símbolos de la Fe, la Esperanza y la Caridad.

En la fachada de poniente estarán descritas las escenas del drama de la Pasión de Cristo, desde la entrada triunfal de Jesús en Jerusalén hasta el grupo de la Crucifixión, que presidirá en parteluz de la puerta central. Una inscripción sobre la cabeza del Redentor dirá "Veritas", Jesús es la verdad en la vida, es el sacrificio y el dolor.

Algunas de las escenas tendrán su correspondiente inscripción, como la del Lavatorio, que ostentará la palabra "Vita", que concentra el sentido de la humildad y el amor, pues la vida es amor, sin amor ella no es posible; es su esencia.

Encima aparecerá la Última Cena, cuando fue instituida la Eucaristía, y encima, la Oración en el huerto de Getsemaní, para entrar en las escenas de la Pasión, que estarán en las puertas laterales. Las tres arquivoltas son de austera desnudez y en ellas destacarán las escenas trágicas. Estarán cubiertas por un pórtico frontal y encima habrá una galería en cuyo frontón estarán representados, a cada lado, el León de Judá y el Cordero Místico. En el interior de la galería estarán las almas puras que aguardan la bajada del Redentor para entrar en la Gloria, así como a ambos lados de la galería estarán los patriarcas y profetas en su salida del Limbo. En el fondo de tal galería, el impresionante sepulcro vacio de Cristo resucitado. En el punto culminante de las dos alas de la galería, que formará ángulo, estará el Santo Nombre de Jesús, del cual arrancará la exaltación de la Santa Cruz rodeada de ángeles con alegorías del Antiguo y Nuevo Testamentos.

En lo alto de la fachada, entre las cuatro torres, resplandecerá la Ascensión de Cristo con un séquito de ángeles. Esta representación que confirma la divinidad de Cristo, induce ya a la contemplación de la tercera fachada o fachada de la Gloria, donde la representación de Jesús-Hombre ya no figurará.

Esta fachada principal, de cara a mediodía, estará lineada con la calle Mallorca. Como principal tendrá un fuerte contenido simbólico. Siendo el ideal supremo del hombre la Glorificación de Dios, se honrará en la fachada a la Santísima Trinidad, a la Sagrada Familia, sus virtudes y ejemplaridad en el trabajo. Se expondrán todos los dogmas de Fe, Esperanza y Caridad. Y el estado del alma después de la muerte, con su castigo o su premio. Se glosarán escenas descritas en el Apocalipsis de San Juan. En el túnel, debajo de la explanada, frontera a la fachada principal, donde discurrirá la calle de Mallorca, se verán alusiones a los condenados, monstruos en actitudes grotescas, ídolos del paganismo y heresiarcas que podrán contemplar a través de algunos orificios el triunfo de la Verdad de la Iglesia.

La fachada presentará un pórtico cuyas columnas ostentarán en los capiteles los dones del Espíritu Santo y los símbolos de las virtudes, y en las bases, los vicios opuestos.

Sobre las cinco puertas, un friso y en voladizo en la parte central, los padres del 
linaje humano, Adán y Eva, encima, San José, con Jesús adolescente en su trabajo de carpinteros, remembranza y glorificación del trabajo humano de la Sagrada Familia.

En el friso tienen que ir las almas del purgatorio que van purificándose a medida que se acercan al Redentor. Alrededor de San José habrá representaciones de todos los oficios manuales que usan el agua o el fuego. Encima, la imagen de la Virgen rodeada de santos, mártires, confesores y vírgenes.

En las galerías altas, presidiendo la puerta central, el grupo de Cristo Nuestro Señor, con los atributos de la Pasión, rodeado de ángeles, la Majestad Divina en el momento del juicio de las almas. En las bóvedas del pórtico estarán representadas las Bienaventuranzas, y en el centro de la bóveda, una plasmación de la creación del mundo, según el Génesis. Junto a ella, la Santa Casa de Nazaret que cobijó a Jesús, como símbolo de la Caridad. A un lado, el Arca de Noé, y en el otro, la del Alianza, símbolos de la Fe y la Esperanza, según se infiere de los textos sagrados.

La bóveda del pórtico será iluminada por catorce lámparas y delante de la central estará Jesús en el trono de la Divinidad, entre la Virgen y San José, patrón de la Iglesia Universal. Encima de Jesús estará el Espíritu Santo, y más arriba, el Padre Eterno, presidiendo el Universo. Aureolando la Santísimo Trinidad en escala descendente estarán las jerarquías angélicas formando un círculo de alas.

Nubes luminosas llevarán escrita la palabra "Credo" y serán visibles día y noche. También estará iluminada la parte alta de los campanarios con la leyenda "Gloria" de la alabanza de los cielos y la tierra al Creador. Esta fachada, además de las cinco puertas correspondientes a las naves, tendrá otras dos flanqueantes para entrar en las capillas del Bautismo y de la Confesión, desde las que se podrá pasar a alas naves laterales o a los claustros indistintamente.

Detrás de las alas del transepto, junto al ábside, habrá dos grandes sacristías que comunican con el presbiterio y con los claustros. Éstos correrán alrededor del templo sin interrupción a lo largo de las fachadas, siguiendo por detrás del ábside, donde se levantará la capilla dedicada a la Asunción de la Virgen. Su extenso circuito permitirá realizar procesiones solemnes en tiempo lluvioso o frio. Tendrán también función aislante del ruido, separando las naves de la calle.

El subsuelo de las naves laterales y parte del de los claustros estará destinado a escuelas de artes y oficios; así junto a la iglesia, el pueblo hallará formación y cultura.

En cuanto al interior, pensamos dotarlo de ambiente propicio para la devoción y fiel a las normas litúrgicas.

Como hemos dicho, el altar mayor estará situado encima de la bóveda de la cripta, bajo el arco triunfal, entre los dos cimborrios principales, y se subirá al mismo por una amplia escalinata. En el altar se adorará al Divino Crucificado, de cuyo madero saldrá una parra simbolizando las palabras de Cristo: "Yo soy la vid, vosotros los sarmientos. Si estáis unidos a mi produciréis frutos; si os separáis os secaréis y seréis lanzados al fuego." La parra formará un dosel que será lampadario al mismo tiempo. Cincuenta lámparas penderán de él, recordando la frase del Salvador: "Yo soy la luz del mundo", al igual que en el primitivo altar de San Juan de Letrán.

Encima del lampadario, según es de ritual, habrá un gran baldaquino. En la bóveda interna del cimborrio de la Virgen se representará el Padre Eterno, según la 
visión profética que dice: "La veste del Padre llena la bóveda del cielo". De su manto, extendido por toda la cúpula, saldrán figuras de querubines y debajo estará el lampadario representando al Espíritu Santo, que, situado entre el Padre, en la bóveda, y el Hijo, en el altar, completarán el símbolo trinitario evocado en el Credo.

En cambio, otro lampadario, situado en el cimborrio principal, dedicado a Jesucristo, representará la Jerusalén celeste.

En la capilla alta de la fachada del Nacimiento se venerará la imagen de San José rodeado de ángeles portadores de los atributos de las virtudes y labores del Esposo de María.

En la capilla frontera, en el crucero de la fachada de la Pasión, se venerará la imagen de María Inmaculada, así mismo con ángeles portadores de los atributos de la virginidad y el amor al hogar.

En las capillas absidales se representarán los sietes dolores y gozos de San José. Las cuatro columnas del cimborrio principal serán los cuatro evangelistas; las que rodearán a éstas en los cruceros serán los doce Apóstoles. Las más próximas a las puertas del Nacimiento y de la Pasión se dedicarán a las diócesis catalanas, y las de la nave central, a las diócesis de España, América Hispana y Filipinas. En lo alto ostentarán los escudos de los arzobispos que contribuyan a la obra.

En mística visión, en las naves laterales las columnas se verán rodeadas de ángeles que descienden de la Gloria portadores de palmas y coronas, y otras con las almas santificadas ascendiendo hasta las bóvedas. Los santos fundadores de órdenes religiosas tendrán sus imágenes en hornacinas a diversas alturas. Los ventanales con vidrieras de colores formarán un todo armónico con la arquitectura. También habrá profusión de leyendas con textos del Evangelio o de las Epístolas que conforman las enseñanzas de la Iglesia. 


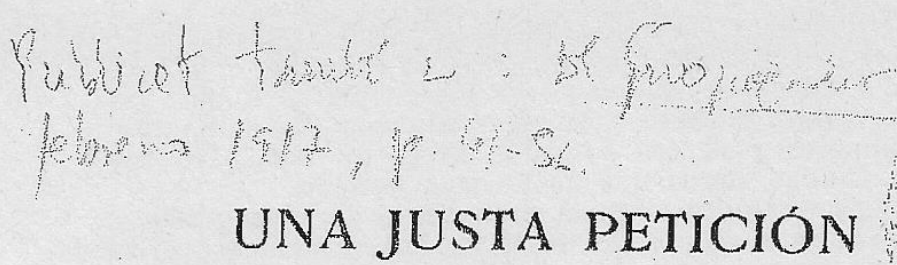

Solicitud de inhumar cadáveres en las criptas del Templo expiatorio de la Sagrada Familia

Intervención de S. E. Ilma. el Obispo de Barcelona, Presidente de nuestras obras, en la sesión del Senado de 18 de Diciembre de 1916

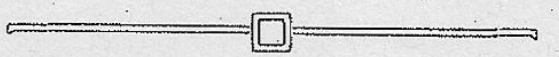

\section{Previamente}

Nurestros lectores y cuantos se interesan por las graindes obras que en España ha hecho nuestra Asociación espiritual de devotos de San José, diulas a la publicidad por este nuestro tan querido cono humilde Propagador de la devoción a Sant fosé, sin duda bendrán ya conocimiento de la cuestión planteada a propósito de la solicitud de la Junta de construcción del Templo expiatorio de la Sagrada Familia, con la firma de S. Ilmo. Presidente el Obspo de Barcelona, pidiendo autorización para inhumar cadáveres en la cripta del monumental Templo expiatorio.

No siendo cosa oonseguida no quiso la Junta dar noticia alguna a este respecto ni por su portavoz oficial, nuestro Propagador de la devoción a San José, ni por otro medio cualquiera de publicidad. Las cosas que en sí yya son grandes no buscan su grandeza en el ruido tormidable que a su alrededor pueda producirse; ocultandio. asi su insignificancia; es decir, mucho ruido y pocas nuteces.

Pero ha querido La Providencia que sucediese de nodo muy diferente.

\section{Antecedentes}

1. Seria una ofensa a los conocimientos de nuestros lectores si quisiéramos insistir en que no ya desde el catolicismo sino descle que et mundo es mundo están los templos en f́ntima unión con las sepulturas. Esto es, que rara vez uin templo deja de ser sepultura. Citemos un caso que hable por todos. Agripa, emperador romạto, 
construyó en Roma el Panteon, en memoria de Augusto, el priner emperador. El panteón de Augusto está aún en pie en Roma ; tué purificadio; se dedicó: ail culta católico, y aún hoy! día es panteón de grandes hombres $y$ de los llamados Reyes die Italia. No hay visitante de la Ciudad eterna que no lo haya visitado.

Pero la religión católica elevó el sentimiento de vana grandeza del paganismo hasta el alto solio de la te. Los crislianos querjan que sus cenizas esperasen su resurrección en el día del juicio cobijadas por la Iglesia que les había abierto las puertas a uná etertriclad feliz. En el atrio tle los templos, en grandes mausoleds o en sencillos enterramientos en el interior, eran inlumados los cristianos. Junto a ellos en las catacumbas se celebraron los divinos oticios, y junto a ellos se han ido celebrando a través de los siglos.

La le ponía tanto aprecio en ello que los cristianos no sólo dotaban largamente el permiso, sino, que muchas veces contralan deudas para satislacer los derechos de enterramiento. Otras veces era unz iglesia o convento quien agradecido a los grandes beneficios recibidos solicitaban la honra de ser: depositarios de los restos del bienhechor: Reyes, magnates, obispos, abades $y^{\prime}$ ann simples particulares hicieron surgir esa abra portentosa de inmmerables basílicas y cenobios en que rema la religión sobre tronos de grandeza y de arte.

\section{Ia Higiene}

Al rodar de los tiempos vino ol siglo XIX, saltando atolondradamente por las aciagas postrimerias del XVIII. Y quiso Dios ciue tuera el siglo pasado siglo verdaderamente prodigioso en todors los ramos del saber $y$ de la industria. La ciencia médica hizo maravilosos descubrimientos. Se ensalzó a la higiene como se merece; pero en la campaña contra el clericalismo, que es como encubren a la Iglesia en. Su odio, se apoderaron de la higiene, y la vana ciencia consiguió leyes de escepción para cementerios, entierros, etc., etc, siempre con perjuicio de la Iglesia y sus ministros, a lí que antes en nombre de la libertad arrebataron los cementerios $y$ aun sus derechos sobre ellos.

A la vana ciencia no le decía nada que cuando las ciudades eran pequeñar y mal acondicionadas, viviéndose en casas apiñaclas en derredor del templo en cuyo interiolr se enterraba constantemente, Ia pujanza numérica de la humanidad fué siempre creciendo. I á higiene! i los microbios! los gémnenes! Todo salía en la discusión contra la ignorancia clerical. Pero la ciencia verdadera lia sálido at fin al palenque $y$ ha hecho luz con el microscopio y los análisis sobre estas vulgaridades de la vana ciencia.

\section{La tradición}

Henos dicho que templlos y cenobios debein su vida, principalmente, a las dotaciones por permisos de entemanientos. Esta ha. sido y es la tradición constante.

Nuestro grandioso templo expiatorio de la Sagrada Familia necesita medios extraordinarios para su constrtición. Lats limosuas que recibe de los devotos de Sau José son muy. cuantiosas, pero. 
no bastan ni para cubrir la marcha languidísima de la constricción. Ademas cuanto más despacio se construye, más caro cuesta lo édificado. Y siempre se está bajo la amenaza de una suspensión de las obras.

Esti tué causa de que la funta estudiase medios de robustecer los ingresos. Y nada encontró más contorme con el espíritu y la tradicion constante de la lglesia que los enterramientos, en las debidas condiciones de higiene.

\section{Los precedentes}

Ciertamente que no tenía que remontarse a los tiempos del mayor esplendor religioso para hallar precedientes, pues los hay muy numerosos en nuestros días. Nuestro mismo templo contiene ya lơs cadáveres de sus tundadores. En Barcelona había el precedente de nuestra iglesia Catedral; algo más lejos la basilica de Montserrat. En Madrid, entre otros, la Catedral de la Almuderia, y. la parroquia de la Concepción, la capilla del Instituto de la Moncloa y el Museo Antropológico del Dr. D. Pedro Gonnzález. En San Sebastián, la iglesia del Buen. Pastor; en Zaragoza un convento de religuosas de la calle de la Democracia; en Casteliclefels; fa iglesia parroquial; y atros que sería prolijo entumerar.

Visto loo cual se redactó, y firmó nuestro llmo. Paresidente, la solicitun que sigue :

El Obispo ide Barcelona, Presidente de la Junta de Construcción del Templo expiatorio de la Sagrada Familia, que está levantandose en esta ciuldad a V. E. expone: Que sin duda habrá llegado a noticia de V. E. la magnitud de la obra que constituye dicho templo, vendaderamente monumental por su grandiosidad, por la altezá de miras de su construcción, por la idea que presidió a la erección Idel mismo, y por lo admirable y simbólico de sti fábrica, que le ha dado tanna universal, y merecido entusiastas y calurosos aplausos de S. M. el Rey y de otras personas de la Fannilia Real en sus viajes a Barcelona, de muchas personalidades importantes de España y extrangero, que la han visitado y visitan alguna de ellas periódicamente, $y_{1}$ en esle mismo año, del Rdnio. Nuncio de Su Santidad en nuestro país, quien no cesa de hacer pública la impresión que la detenida inspección de la parte construłada le causó.

La construcción de tamania obra se costea y ha costeado hasta ahora, exclusivamente con limosnas de fielesi católicos $y_{1}$ de entusiastas de la misma, merced a las cuales se terminó la grandiosa Cripta, abierta hace tiempo al culto y: a la cura de almas, y se ha fevantado una buena parte del ábside, de los claustros que han de rodearle y de los portales que han de darle acceso; pero la crisis económicá que agobia a Europa y que hace sentir sus efectos e!n España, ha determinado una considerable baja en los donativos. que, como consecuencia indeclinable, ha obligado a amenguar el desarrollo de las obras que hoy vair desizándose con lanentabie lentituld, haciendo entrever la casi seguridad de que la generación actual no verá la terminación de las mismas, y que han de trascirrir años y más años hasta que pueda realizarse el piadoso fin à que el Templo está destinado. 
Para obviar tannaño inconveniente la Junta a fin de proporcionarse recursos de cuantía para imprimir el conveniente desarrollo is la fábrica, utilizar provechosamente los años que restan de vida a su genia Director $y$ tomentar a la vez la piedad en los fieles, ha conoebido el propósito de solicitar: que se autorice para verificar enterramientos en las capillas y deambulatoriois de la cripta, en. la esperanza tunidada de que la autorización ha de producir resultados eticaces, puesto que ya sie han hecho indicaciones por parte de pirsonas pudientes, de estar dispuestas a contribuir con donativos te importancia, a cambio del denecho de ser enterrados sus cadáveres $\mathrm{y}$ los de sus allegados $s_{\text {p }}$ en aquel sagrado lugar.

No es lla prinera vez que se dirige al Ministerio del digno actual cargo tle $V$. E. una petición en tal sentido; y existe más de un precedente de haber sido atendida, por las mismas razones y con na mismo objeto con que lo realiza en la actualidad el infrascrito
Prelado.

Por Rea Oriden de 28 de Febrero de 1894 y previo el informe tavorable del Rea Consejo de Sanidad, se autorizo a la Marquesa de Bueno para inhumar los restos de su esposo don José Herrera en la capilla de la Santa Faz, de la iglesia de Nuestra Señora de 1a Amuldena; por otra Real Orden de 11 de Octubre de 1900 se otorgó concesión análoga con carácter general, a- la junta de tábrica de la iglesia parroquial del Buen Pastor, de la ciudad de San Sebastián; y por otra de 4 de Abril de 1908 , se accedió a lo solicitado por iel Ilmo. Sr. Obispo de Madrid-Alcalá para construir, también con carácter general, enterramientos en la cripta del mencionado Templo Catedral, donde reposen los restos mortales de lars personas piadosas que soliciten esta gracia, mediante el permiso de ila Autoridad Eclesiástica.

Más aun; existe otro preadente en este nismo Templo, y consiste en que por otra Real Orden emanada de ese mismo Ministerio, con techa 6 de Mayo de 1908, se autorizó el trasiado a la cripta del mismo, para recibir en ella cristiana sepultura como en electo la recibieron, de los restos mortales de D. José Ma Bocabella, mas que iniciador verdadero fundador de las obras, de su Esposa, de su lija Da Francisca y del marido de esta D. Manuel de Dalmases, haciendo extensiva esta concesión, para en su caso, a los del hijo de estos tultimos D. José M. a de Dalmases y Bocabella, viviente en Ia actualidad y vocal de esta Junta, sin empero carácter exclusivo, puesto que la misma soberana disposición indica el medio a que ha de atenerse para obtener autorización de enterramiento de tos cadáveres de lias personas de su tamilia.

El. Obispo que suscribe considera inutil recordar a $V$. E: que la Real Orden de 18 de Julio de 1897 Ie faculta para otorgar la gracia que de $V$. E: solicita, y que asi se reconoció, adenás de las citadas, en las de 28 de Febrero de 1894 y 15 de Octubre de 1898 ; asi como estima ocioso amipliar la manifestación, que se complace. en hacer, de que en el esperado caso de que se acceda a lo que solicita está dispuesio a acatar y cumplir todas las prevenciones con que sea. condicionada la autorización, por lo que, pueda afectar a ta higiene y salubridad del vecindario.

Por to tanto, A. V. E. SUPLICO : que de conformidad con las Reales disposiciones que dejo invocadas, tenga a bien autorizar 
at que suscribe en su calidad de Presidente de la Junta constructora det Templo de la Sagrada Familia para verificar enterranientos en tas capillas $y_{\text {: }}$ deambulatorio del mismo en los que reposen en su día los restos mortales de las personas piadosas que contribuyan con donativos de importancia al coste de las obras de dicho. Templo, $\mathrm{y}_{\text {, de }}$ los individuos de sus tamilias.

- Barcelona, a 23 de Octubre de 1915.

† EnrJque, Obispo de Barceloma.

Excesentísimo Señor Ministro de la Gobernación

Acompañaban a la solicitud los planos correspondientes $y$ uma mernoria explicativa que dice así :

\section{Notas aclaratorias del proyecto de cripta para enterramientos en el Templo expiatorio de la Sagrada Familia, en Barcelona}

Ha sido práctica constante el efectuar en ciertas 1glesias enterramientos de personas que ya por su gerarquía como ilos Sies. Obispos, tienen derecho propio a ello, ya de otras personalidades que en premio a sus meritos o valor se les concede tal distinción, 0 bien de aquellas otras personas piadosas que deseandd reposar en la Casa del Señor, han aportado limosnas más o nienos cuantiosas con que subvenir a la construcción o conservación de los Templos.

Y esta práctica de ceder el derecho de enterramento en los Templos a aquellas personas que por la cuantía de sus donativos puedan considerarse como protectores del mismo, tho perteneces solamente a pretéritas edades, sino que actualmente aquí en España tenemos buenos ejemplos de ello, ejemplos por otra parte que idemuestran de manera bien elocuente lo acertado de tal práctica, puesto que en unos casos permite la extinción del déficit resultante de la construcción del Templo, como en el caso de lá iglesia del Buen Pastor, en San Sebastián, y en otros casos permite la continuación de las obras de construcción del Templo, como en el caso del de Nuestra Señora de la Almudena, en Madrid:

Fundados en esta práctica se ha proyectado utilizar la Cripta cuyos planos se acompañan, para que en ella puedan en su dia tener sepultura todas aquellas persinas que contribuyan con sus limosnas, de una manera eficaz, à la continuación de las obras del Tempro Expiatorio de la Sagrada Familia, hasta poder llegai a su tota. teminación. Al objeto de poder utilizar la citadal Cripta para el fir que se solicita, se han adoptado, como luego veremos, todas aquellas precauciones que la higiene $y$ salubridad aconisejan, y se han tenido presentes las disposiciones legales que sobre este particular se han dictado.

Las tumbas que se podrán construir en esta Cripta tendrán nat turalmente, según su capacidad y situación, distinta inuportancia, al objeto de que esta esté en relación con la cuantía de la limosna que dé ta persona o personas que deseen utilizar estè derecho de enterramiento.

La Cripta que se proyecta utilizar para que en ella se practiquen enterramientos, estará en inmejorables condiciones de iluminación 
y de ventilación, puesto que todos los locales de la misma las tienen directas e inmediatas como puede verse en la planta y secciones. longitudinal y transversal que de la misma se acompanan: Además en $\mathrm{A}$ y A' y $\mathrm{B}$ y" $\mathrm{B}$ ' (véase ta planta) se proyectan unos ascensores que han de comunicar esta parte baja con las partes más elevadas del Templo; como se oomprende fácilmente, esta especie de pozos en los que se moverán los ascensores, serán cuatro grandes chumeneas de ventilación, puesto que además de la circulación del aire que por ellas se establecerá a causa de las diferencias térmicas $y$ de presión, que por la acción solar se producirán en las mismas, actuando estos de émbolo, hará que cada uno se convierta en una grau bomba aspirante-impelente, provocando de consiguiente una renovación del aire de la Cripta, suficiente para que pueda garantizarse la absoluta pureza del mismo.

En la parte de la Cripta construida actualmente y destinada al culto desde hace más de treinta años se puede observar como las disposiciones adoptadas para la ventilación natural de lá misma son! eticaces, lo que prueba 'que ellas son acertadas y' efectivas siendo por lo tanto garantía para el resto de la Cripta que talta cons- truir, debiendo observar que actualmente no existe el poderoso medio auxiliar de ventilación natural que, como queda dicho, serán los ascensores. Las disposiciones a que hemos hecho referencia consisten sencillamente en haber rodeado la parte de Cripta correspondiente al ábside de la iglesia superior, por lun foso; F. (véase la planta y Ia sección longitudinal) y haber puesto el interior de la Cripta en constante comunicación con el aire del exterior mediante aberturas convenientenente dispuestas, asegurándose de esta manera una constante renovación de aire.

No obstante lo que queda dicho, y al objeto de preveer hasta ict exageración lo que a la salubridad se refiere, se proy'ecta la installación de cuatro ventiladores centrítugos movidos mediante urr. motor eléctrico acoplado al mismo ventilador en C. y $C^{\prime} y^{\prime} D$. y $D$. (véase lla planta). Estos ventiladoreś serán de los llamados de succión o aspirantes, capaces cada uno para aspirar 3.31 metros cúbicos de aire por segundo o sean 11941 metros cúbicos por hora; entre los cuatro dan un volumen total aspirado por hora de 47764 metros cúbicos que es el cubo total de aire conlenido en toda la Cripta; el aire aspirado por los ventiladores será inpulsado por los mismos y conducido mediante tuberías de hierro estirado por el interior de los campanarios y reintegrado a la atmóstera en la parte superior de los nismos o sea a una altura de unos 100 metros.

Los enterranientos se verificarán ell tumbas abiertas en el suelo: estas tumbas serán para uno a más cadáveres, pero siempre estarán convenientemente revestidas lateralmente mediante un muro de ladrillo por lo menos de 0.30 mms. de espesor, teniendo el tonds tormado por una capa de hormigón hidráulico por lo menos de 0.20 tunns, de grueso y superiormente estarán cubiertas por una bóveda, en cuyo centro tendrá la abertura que ha de servir para la introducción de los féretros. Esta-abertura estará cerrada mediante una losa de piedra a metal perfectamente ajustada. Adennís las tumbas o cámaras sepulcrales estarán, enteramente revocadas y enHucidas con cemento Portland al objeto de que resulten completamente impermeables y por lo tanto aisladas de la tierra que las 
Examinados con el mayor detenimiento los planos que acompaño y estudrada la Memoria, resulta que se trata de aprovechar la cripta actual y la que resulte de la conclusión de la construcción para inhumar los cadáveres de los tavorecedores $y$, de las personalidadies a quien se les conceda este derecho. Resulta que se trata de un amplio local de 47,764 metros de capacidad, con amplia ventilación natural por medio de ventanas, escaleras, etc., con ventilación artificlai indirecta por la acción kle los cuatro ascensores proyectados $y^{\prime}$ cont ventilación artificial directa por la acción de cuatro ventiladores que pueden lanzar todas las lioras a la atmóstera en lo alto del templo todo ei cubo de aire contenido en la cripta. Hacen impermeables el tondo yi tas paredes de las sepulturas y se someten desdie linego a todas las prescripciones de higiene de carácter general o especial dictadas por la superioridad. La comisión que suscribe examinado el articulo 134 de la Instrucción General de Sanidad, haciéndose cargo de que en el párrata 9.8 exige el embalsamatniento completo o sea de la primera categoría para los cadáveres que lian de ser inhumados en capillas o criptas que alguna vez estén abiertas al público, no purede menos de aplaudir la previsión del legislador con fa cual se evitan totalmente los peligros que pudieran llevan consigo los enterramientos en lugares como el de que nos venimos ocupando. La capacidad dei local, su aislamiento (ocupa una manzana de 11,300 metros cuadrados) Ia ventilación natural espléndida y la artificial que llena completamente las mayores exigencias higiéncas, la impermeabilidad de la sepultura y. sobre todo ef embalsamamiento completo de los cadáveres para que puedan couservarse en su totalidad $y_{1}$ por tiempo indefinido, inclinan a la Comisión que suscribe en el sentido tavorable a lo solicitado. De realizarse siempre en buenas condiciones el embalsamamiento completo, sería como ya decimos anteriontmente, ta mejor solución porque quedaria bien protegida la salud pública, pero como la Real Academia de Medicina de Madrid no ha dado cumplimiento a lo dispuesto en el párrato 9.9 del artículo 134 de la Instrucción General de Sanidau y por la tanto no se conocen procedimientos oticiales para practical los embalsamamientos de esita clase, teme la Comisión que suscribe que los embalsamamientos no sear tan completos como tuera de desear, por to que, para en el caso que la Superioridaa no pueda recomendar uno o varios métodos que garanticen' completamente 'la conservación indefinida de los cadáveres, estiman que sólo debian autorizarse la inhumación de restos con las garantias exıgidas por nuestras leyes; tratándose de liechos excepcionales entienden también los que suscriben, que deben limitarse los permisos para la inhumación de cadáveres o restos, no autorizando en ningún caso más de 10 inhumaciones cada año, debiendo tratarse de permisos individuales que recaigan precisamente en las personas de los tavorecedores y: extinguiéndose con ellas' el dierecho adquirido.

Cumplidos todos estos requisitos, los previstos en los planos y, Memoria que acompañan, los dispuestos en la lnstrucción Cieineral de Sanidad y: aquellas precauciones que considere pertinentes la Superioridad pata la mayior garantía de la salud pública, estiman tos que suscriben que puede informarse tavorablemente la petición de Ia Junfa de obras de la Sagrada Fannilia: 
I. J Junta cual siempre en su superior ilustracion intormara to mejor en deterisa de la salud públicá.

Dada cuenta a la Junta Provincial Municipal de Saniciad en la sesión extraordinaria 1. a de Octubre últino, después de delenirja discusión. propuso el Doctor Cardenal la adición siguiente:

Aunque la Junta de Sandad cienlílica y doctrinalmente es contraria en absoluto a toda inlumación tuera de Cementerios, si la ley permite en casos excepcionales la inhumación de los cadáveres en das criptas, reune la de la Sagrada Familia buenas condiciones para ello Fué aceptada por la Comisión.

\section{Desorientándose}

Dentro de la dignisina Junla provincial municipal de Sandad, no paso fei asunto sin un detenido examen y ardua controversia. Hay en dicha Junta elementos politicos además de los de ciencia. Aún dentro de esta había la manía de la super-higiene Quedo la ponenca unas sesiones sobre la mesa; se discutó primerol sin recaer acuerdo: votóse al fin ; discutióse nuevamente il votar el actar y quodó, por littimo, aprobado por considcrable mayoria el dictamen propuesto.

\section{Politica y sectarismo}

Los elementos políticos que integran en parte la funla de Sanidau tienen numerosa representación en el Ayuntamiento de Barcetona. La complexidad de la ciudad hace que actualusente 110 exista mayorta absoluta de ningún particlo. Hay en él dos grancles minorias, regionalista la una, y ridical (lerrouxista) la ofral quedando para inclinar el fiel las minorias tradicionalista, liberal e zquierdista: catalana, compuestas de muy. reducido número de personas.

Crrcunstancias que aqui es ocioso consignar tenían dividida lat minoria terrouxista, alguno de cuyos concejales, los disidenles, no acudian a las sesiones. La prensa lerrouxista y la sinilar empezaron una campaña inflando el perro acerca de la solicitud de la junta del Templo y dictamen de la Junta de Sanidad. Un lemomista dió estado a asunto en las sesiones del municipio barcelonés. Las condiciones de sagacidad que hay. que reconocer en Lerrons hicieronle aprovechar la coyuntura: invoós el chim chin clel cericalismo y los disidentes asistieron a la sesión para, mitidos con Jo demás lerouxistas, obstruccionar.

Con gallardia que homa a las minorias regionalista y tadicionalista, tue contenida la actuación sectaria. Se habto en his sesiones no de lo solicitado, sino de enormidades, conne, por cipmplo, que se trataba de un cementerio con más de 3000 cadtácres.

Fi Ayuntaniento acordó, como primer acuerch, quit in comisión de cementerios se ocupase del asunto.

\section{Legiuleyos y pseudo-higienistas}

Prensa y concejales lerronxistas y sus similares comenzaron at vomitar leyes y dictánenes ein contra, falsendo, como no puede extrañarse, la verdial.

Notemos algo a este respecto. 
Lo prmero es que todas las argucias y distingos de los que ponen reparo a ta concesión de enterramientos 110 pueden negar, y por eso lo callat, que si la R. O. de 15 de Julia de 1887 prohibe toda inhunación fuera de los cementerios, en cambio su artículo 1. párrato 2.8 dice textualmente que se exceptúa de dicha prohibicion a los individuos de la tamilia Real Arzobispos, Obispos, monjas y a aquellos a quienes el Gobierno de $S$. M. por circunstancias especiales conceda de $R$. O. excepción para ser inhumados en iglesias, panteones y otros lugares.

En la concesión de enterramientos a la Catedral de Madrid, o sea la citada varias veces iglesia de Ntra. Sra. de la Almudena, se han dictado varias reales órdenes. $\mathrm{La} 1.3$ de 16 de Diciembre de 1908 SE concedió al Obispo de Madrid-Alcalá, autorización para construir enterramientos en las capillas de dicho templo en la torma preceptuada por. R. O. de 17 Marzo 1900 reterente a construcción de criptas, y previo embalsamamiento de los cadáveres. o transcurridos diez años desde tas inhumaciones, plazo que señala la R. O. de 15 Octubre de 1898 . La segunda R. O. es de 28 Abril de 1912 . declarando visto el informe de la junta Provincial de Sanidad que las nencionadas criptas reunían las concliciones de salubridad e higiene necesarias, cumpliéndose en todo momento lo preceptuado en el art. 134 de la instrucción de sanidad vigente. Pol último una R. O. de Marzo de 1914 dispone que habra de cumplirse "la precisa e inexcusable tormalidad de solicitar en todos y cada uno de los casos, autorización de dicho Ministerio, acompañando el permiso de la autoridadi eclesiástica y demás do-
cumentación necesaria. »

\section{Un precedente de sumo interés}

El ayuntaniento de Madrid pasó este asunto a intorme del abogado consistorial y éste informó, que la R. O de 1914 no era susceptible de recursos contenciosos, por no poder alegar el Ayuntamiento que dicha $R$. $O$. vulnera un derecho preexistente establecido a su favor y está dictada en el ejercicio de la tacultad discrecional que al ministerio de la Gobernación contesponde para autorizar enterramientos en las iglesias y otros lugares tuera de los cementerios comunes por R. O. de 15 de Julio 1887. El Ayuntamiento de Madrid quiso un plena de letrados; $y$ este intormó que a su juicio procedía recurrir contra dicha $R$. O. por no hallarse en pertecta armonía la $\mathrm{R}$. O. de 1887 con las atribuciones ieconocidas como de la exclusiva competencia de los Ayuntamientos en el art. 72 de la Ley Municipal en lo que se refiere a la higiend y sadubridad del pueblo. En vista de este informe la Comisión de Cementerios proptiso a Ayuntamiento que fuese, empero, aceptado el del letrado. de que no procedía recurrir contra la R. $O$. de 1914 toda vez que el pleno informaba que el recurso tendría dificultades, El Ayuntaniento la acordó aś por 18 votos contra 11

No dudamos que de esto está bien intormado el Ayuntantenta de Barcelona, y no obstante viene armando el gran lio. 
$\mathrm{XVI} \cdot \not{x}+;$

deyendo que el criterio de unos pocos, el criterio y la actitud fiera del Cobierno lasta en las cose una manera decisiva la conducta más sagradas. Repito que cosas más elementales y más justas y. aqui ese criterio; que no creo esto.

\section{Welicitaciones} Muy efusivas las recibió el Ilmo. Sr. Obispo de Barcelona. Pri-
mero los telefonemas se las llevaroin a Madrid. Al Itegar a Barcelona
el gran recibimiento que le hicimo después, durante las fiestas de Navidad, diocesanos, y pocos dias ción de pascuas a nuestro Pre Navidad, no hubo visita de telicitasión a cuanto dijera en el Senado, que no hiciera constar su adhe-

\section{Gracias}

Debemos darlas muy efusivas, todos los josefinos al Obispo mero de 15 de eneros nuestras obras. Lo hicimos ya en el núconstar.

Queremos también darlas especialmente a los amigos que en la Junta de Sanidad y. Ayuntamiento de Barcelona nos han hontado

Ademias debenal apoyo.

concurrido a la información! y: nos entidades y partioulares, han bajos.

\section{Resumiendo}

Hie aqui, fielmente transcrito cuanto hasta hoy se ha actuado. dejará nlevar de como nosotros, confía en que el Gobierno no se sana, que va salvaguardada poría sino que ateríderá a la opinión

Rebajarnos a repetir las por la ley del Reino:

tres lerrouxistas contra lo solicitado vertidas en la prensa y mitihrelga porque no hay, en ellas empeño queremos. Contestarlas, baba dei odio y del sectarismo. meño del bien público, siro lá

Pretendemos que siguiendo la tradición de la Iglesia se pernitan
unhumaciones de cadáveres en la cripta de nute torio de la Sagrada Familia a fa cripta de nuestra Templo expiatan grandiosa obra, y en ello ofrecen poder activar y aun terninar Ley $y$ la Higiene verdadera obliguecenos limitarnos a cuanto la guna merna a los intereses de la ciudad, yo queremos causar nin-

Ei asumto es importantísimo. Hemos, que quedará tavorecida. trabajo y entusiasmo. Quieran. Hemos puesto en él todo nuestro oraciones para obtener el éxito anhelado.
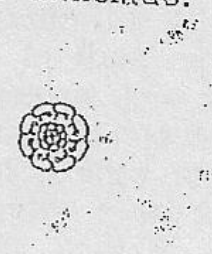
celona os dirán si no es para Barcelona, ¿qué digo para Barcelona? para España, ¿qué digo para España? para el mundo, ma verdadera gloria el templo de la Sagrada Familia, ese nommmento que se está leyantando y que apenas iniciado ligura en las guias extranjeras: en ta de los Estados Unidos y el Boedeker no tienent inconveniente en señalarlo con todos los asteriscos con que señala los montumentos notables. Nadie va a Barcelona sin que lo primero que haga sea visitar el temiplo en construcción de la Sagrada Familia.

Pues bien, con ese templo de la Sagrada Fanilia ha pasado lo siguiente: La Junta dirigió una instancia al Gobiemo, finmándola yo, pidiéndole la antorización para determinados sepelios, de aquellos que se muestren generosos, en gran manera, para cont la Sagradr. Familia. Estaba perfectamente dentro de la Jegislaciun y dentro de lia práctica: son varios, son casi múltiples los casos en que eso se ha concedido, porque está dentro de la ley, es perfectamente legal $\mathrm{Ha}$ pasado la instancia a informe de la junta provincial de Sanidad y. en esta Junta se intentó a todo france cegar esa tuente.

Téngase entendiclo que este Templo, gloria de Espalia, no le ha costado an Estado una peseta y se llevan gastados cerda de cuatro millones de ellas. Acudió esa Junta al Estado pidiendo la antorización para los enterramientos con todas las regias de trámite y cumpliendo todos los requisitos que la hïgiene prescribe.

Pasó a informe de la Junta de Sanidad como he dicho, y en esta Junta el digno gobernador de aquella provincia; que con grant prestigio y muy dignamente se sentó dos veces en ese bancọa (serialando al ministerial), el señor Rector de la Universidad, que no reconoce rivat en el cumplimiento de todos sus deberes, todo to que vale y representa algo, todos votaron mánimemente por la autorización y hubo quince votos contra sietr. De tal manera estos. siete votos han ilevado a mal la derrota en la Junta provincial de Sanidad, de tal manera han levantado el grito contra esos enterramientos legales, justificadísimos, perfectamente justos, de tal manera se han levantado, que al venir yo aquí hace pocos días (y cetebro que en este momento esté phesente el señor presidente del Consejo de ministros), casi todos los individuos de la junta me? dijeron: "Por Dios no lleve el expediente ahora a Madrid; por Dios no diga nada al señor ministro de la Gobernacion, no recomiende nada, que si esto llega allá, con este rum rum; con este griterio continuo, con esta protesta ( hasta interpelaciones se han anunciado en la otra Cámara sobre esto !), tenga isled ha seguridad de que tros condenan, de que no lograremos in que tan legal, In que tan justa y tan legítinamente pedimos". Ese es el concepta que se teno. ; No y mil veres no ! Mientras que tenga pruebas tehacientes en conlrario, yo creeré firmementex que el Gobierno de S. M. no se deja intimidar por nadie, que cumple la ley en todos los casos. Y yo pedí el expediente porque les dije: "de ninguna manera, esa es una apreciación injusta ; denme el expediente que yo mismo lo llevaré al ministro de la Gobermación». Sin embargo, bueno es que sepáis, birno es que sepa el Gobiermo ese ambiente delestable qure cumde por loda España. 
duda, do que merced a manejos de los sectarios, resiltaria contraria a in petición de la Junta. La influencia lerrouxista al redactarse la convocatoria trizo darle un deterninado sentido contrario lo solicitado por nuestra lunta Al ir a finir en pontrario a acerdóse prorrogar la información Al ir a finir el primer plazo, derdose prorrogat la información modificandol algo la redacción del antuncio; persistiendo empero el error inicial de contintar, llamando cementerio lo que no es más que unos pocos entermamientos A Hos tres días de terminado el plazo el Ayuntamiento acordis abrir nuevamente la información que terminará, si no hay nueva prórroga, el 30 del corriente Enero.

No podernos, por consiguiente, dar nota exacta del resultado. Pero por las noticias que tenemos es un éxito verdadero el que obtiene el Templo expiatorio de Ia Sagrada. Familia. Una vez conocido el informe consignaremos en nuestras columins que hayan concurrido $y$. en qué senticlo. Oportunamente publicare mos el informe de la Asociación espiritual de devolos de San lo de España y el de la Junta constrictora de devotos de San Jose

\section{En el Congreso}

El asunto apasionaba, y apasiona aun al público, de un modo que no puede ponderarse. En una de las sesiones del Ayuntaniento se manitestó que Lerroux se oruparía del asunto en el Congreso. Ciertamente tué asî pero en torma tan mansa que ni en $B$ arcelona cas1 nadie llegó a enterarse Anteriormente el diputado Castroviclo cuyas doctrinas todos lamentamos, se habia te del mismo asunto con un poco tmás de valentia, auncue sin atach de frente. Sin duda prome sin atacar

Jn el Senado. Tabla el Tlmo Obispo de Barcelona

Durante aquellos dias ocipaba gran parte de las sesiones de las cámaras españolas la cuestión de una asignación pesetas para los párrocos. El episcopado españoi honró d obispo de Barcelona para que en su nombre tratara la cuestión al Obispo una manera clara, concienzuda, seria, definitiva: tal como debet hacerlo un Prelado.

En su discurso, ilevado del amor a nuestras obras, siempre tan en su corazón, quiso ocuparse de ellas. He aquí como:

\section{Del discurso en el Senado, el 18 Diciembre 1916 , pronunciado por el Inno. Obispo de Barcelona entresacamos, por lo que iuteresa a nuestras obras, los párafos siguientes:}

Más aun, y con esto termino, y esto es de actualidad; ann que daba una rendijita y esta rendijita se está preparando la cal par taparla. Pasa lo siguiente: aquí veo cariñosísimos representante por Barcelona, con los cuales me liga estrecha amistad porentan caballeros dignisinos sirven perfectomente a la por sue propulsores de toda idea noble $y$ levantada a lo para sino para España entera; y. estos señores representantes de Bar. 
terencia de delisidad, pone el aire en moviniento, estableciridose fa cortiente que proporciona la ventilacion completa de la cripta.

Por si festo 110 bastare, se establecen tubos de ventilación desde la cripta a lo alto de los campanarios, que dada la altura que deben tener (150 metros el cimborio) cumple esta ventilación muchísjmo. mejor que en edificios industriales, cuyas chimeneas como máximym llegan hasta 60 metros y. ell otras ni siquiera se preocupan de êto, como la fábrica del gas de Oracia (Barciona) de Ia que por carecer de ella, salen los gases carbónicos y sufurosos nocivos para la salud directamente introduciéndose en las viviendas.

En cuanto a los líquidos producidos por la descomposición comn ia ley obliga a que en los enterrarnientos efectuados ef templos sean ellos pembalsamados y además que vayan en féretro metálico soldado, ya queda evitado todo peligro de infección, y es rel todio inútil si se trata de restos procedentes de exhumacioves.

Añade que una señora hizo mu legado de 140,000 duros y somete a la consideración de la Comisión de Cementerios, si un! individuo que haga un legado de tal importancia, es digno de ser enterrado en ta relenda construcción, y que es muy posible que casos semejantes pueden repetirse.

\section{Digresión interesante}

También cita varios ejenplos de subvenciones a tumplos en diversos países aun no católicos, citando en detalle, lo costoso que ha sido la construcción del templo del Sagrado Corazón de Montmartre, en París, por estar cimentado en canteras antiguas, situada.z en un montículo, para lo cual tuvienon que lacerse ciantiosas obras de contención y cimentación a lo cual contribuyó con tuertes subvenciones el Ayuntamiento de París, de carácter declaradanente socialista.

Otro ejemplo es el de la Caledral de Colonia que empezada en el siglo Xll no tué terminada hasta el siglo XIX, teniendo durante este trempo una cubierta provisional. Formałndo Colonia un principado independiente regido por un Arzobispo al formatse el reino de Prusia, pasó a formar parte del mismo, y el rey envió min arquilecto para apreciar el coste y. estado para la teminación, subvencionando el estado por 40 años los trabajos en la [1roporción de las rlos terceras partes del coste, y, habiendo costado la construcción 17,000,000 marcos, el estado protestante contribuyé a la construcción de un templo católico en la cantidad de $11,(100,000$ de 111arcos $(1,25$ Ptas. $)$

En España, en la iglesia de Ia Almudena de Madrid, chyo presiipuesto anuat es de 40,000 duros el estado contribuye con 20,000 duros, siendo conveniente pues que el Estado contribuya con una cantidad a la construcción del Templo expiatorio de la Sagrada Familia como caso senejante, y asi piensan perirlo al Rey en su próximo viaje a Barcelona, conor ya se pidió a la Infanta Isabel en su reciente visila.

\section{Información pública}

Elo we obstante, buscando el Aytutaniento algo en que apoyarose, acordo abrir una intomación püblica, con la esperanza, sin 
duda, de que merced a manejos de los sectarios, resiltaría contrarla a in petición de la Junta. La influencia lerrouxista al redactarse la convocatoria hizo darle un determinado sentido contrario a lo solıcitado por nuestra Junta. Al ir a finir el primer plazo, acerdóse prorrogar la intormación modificandol algo la reclacción del antuncio; persistiendo empero el error inicial de continuar. llamando cententerio lo que no es más que unos pocos enterramientos. A los tres dias de terminado el plazo el Ayuntamiento acordió abrir nuevamente lla información que terminará, si no hay nueva prórroga, el 30 del corriente Enero.

No podemos, por consiguiente, dar nota exacta del resultado. Pero por las noticias que tenemos es un éxito verdaclero el que obtiene el Templo expiatorio de la Sagrada. Familia. Una vez conocido el informe consignaremos en nuestras columias las enticlades que hayan concurrido y. en qué sentido. Oportunamente publicaremos el intorne de la Asociación espiritual de devotos de San José de España y el de Ia Junta constructora del Templo.

\section{En el Congreso}

El asunto apasionaba, y apasiona aun al público, de un modo que no puede ponderarse. En una de las sesiones del Ayuntaniento Se manitestó que Lerroux se ocuparía del asunto en el Congreso. Ciertamente tué asi pero en forma tan mansa que ni en Barcelona cası nadie llegó a enterarse. Anteriormente el diputado Castrovido, cuyas doctrinas todos lamentamos, se había ocupado incidentalmente del mismo asunto con un poco más de valentía, aunque sin atacar de trente. Sin duda porque no era posible hacerlo.

\section{Mn el Senado. Habla el Ilmo. Obispo de Barcelona}

Durantre aquellos dias ocupaba gran parte de las sesiones de las cámaras españolas la cuestión de una asignación mínima de 1000 pesetas para los párrocos. El episcopado españoi honró al Obispo de Barcelona para que en su nombre tratara la cuestión. Hízolo de una manera clara, concienzuda, seria, definitiva: tal como deber hacerio un Prelado.

Eı su discurso, illevado del amor a nuestras obras, siempre tan en su corazón, quiso ocuparse de ellas. He aquí como:

\section{Del discurso en el Senado, el 18 Diciembre 1916 , pronunciado por \\ el Ilmo. Obispo de Barcelona entresacamos, por lo que interesa a nuestras obras, los parrafos siguientes:}

Más aun, y con esto termino, y esto es de actualidad; ann quedaba una rendijita y esta rendijita se está preparando la cal para taparla. Pasa lo siguiente: aquí veo cariñosísimos representantes por Barcelona, con los cuales me liga estrecha amistad, porque son propulsores de toda idea noble y levantada, no para Barcelona; sino para España entera; y. estos señores representantes de Bar- 
celona os dirán si no es para Barcelona, ¿que digo para Barcelona?. para España, ¿qué digo para España?, para el mundo, nna veldadera gloria el templo de la Sagrada Familia, ese nonnmento que se está levantando, y que apenas iniciado figura en las guías extranjeras : en la de los Estados Unidos y el Boedeler 110 tienen. inconveniente en señalarlo con torlos los asteriscos cont que señala los montumentos notables. Nadie va a Barcelona sin que lo primero que hontumentos visitar el templo en constricción de la Sagrada Fa-

Pues bien, con ese templor de la Sagrada Familia tha pasado to sıguiente: La Junta dirigió una instancia al Gobiemó firmándola yo, piciéndole la autorización para determinados sepelios, de aquellos que se muestren generosos, en gran manera, para cort la Sagrada. Familia. Estaba perfectamente dentro de la legislacion y dentro de lia práctica: son varios, son casi múltiples los casos en que eso se ha concediclo, porque está dentro de la ley, es perfectamente legal $\mathrm{Ha}$ pasada la instancia a informe de la Junta provincial de Sanidad y. en esta Junta se intentó a todo rance cegar esa tuente.

Jéngase entendicio que este Templo, gloria de Espajia, no le ha costado aı Estado una peseta y se llevan gastados cerca de cuatro millones de ellas. Acudió esa Junta al Estado pidienclo la autorización para dos enterramientos con todas las regas de trámite y cumpliendo todos los requisitos que la higiene prescribe.

Pasó a informe de la Junta de Sanidad como he dicho, y en esta Junta el digno gobernador de aquella provincia; que con grant prestigio y muy dignamente se sentó dos veces en ese binco (serialando al ministerial), el señor Rector de la Universidad, que no reconoce rivas en el cumplimiento de todos sus deberes, todo to que vale y representa algo, todos votaron mánimemente por la autorización, y hubo quince votos contra sietc. De tal manera estos. siete votos han llevado a mal la derrota en la Junta provincial cle Sanidad, de tal manera han levantado el grito contra tosos enterramienlos legales, justificadísimos, perfectamente justos, de tal manera se han levantado, que al venir yo aquí hace pocos días ly cetebro que en este momento esté prnesente el señor presidente del: Consejo de ministros), casi todos los individuos de la junta me: dijeron : «Por Dios no lleve el expediente ahora a Madrid; por Dios no diga nada al señor ministro de la Gobernación, no recomiende nada, que si esto llega allá, con este rum rumr; con ester griterío continuo, con esta protesta (i hasta interpelaciones se han anunciado en la otra Cámara sobre esto !), tenga usled la seguridad de que rios condenant, de que no lograremos in que thu legal, In que tan justa y tan legítinamente pedimos:.

Ese es el concepto que se tiene por ahí, concepto equivocado, que yo rechazo, que yo condeno. i No y mil veres no ! Micntras ro tenga pruebas tehacientes en contrario, yo creeré firmenimenter que el Cobierno de S. M. no se deja intimidar por nadie, que tcumple la ley en todos los casos. $Y$ yo pedí el expediente porque les dije: "sle ninguna manera, esa es una apreciación injusta : denme el expediente que yo mismo lo llevaré al ministwo de la (jobermación \%. Sin embargo, bueno es que sepáis, biteno es que sepa en Gobierno ese ambiente delestable qux cumde por lonla España. 
$\mathrm{XVI} \cdot \mathrm{j}+\mathrm{j}$ creyendo que el criterio de unos pocos, el criterio y la actilud fiera
de ciertos elementos deternina de una manera decisiva la conducta más sagradas. aqui ese criterio que que yo condeno, que yo estigmatizo descle

\section{Telicitaciones}

Muy etusivas las recibió el Ilmo. Sr. Obispo de Barcelona. Primero los telefonemas se las llevaroin a Madrid. Al Itegar a Barcelona después, durante las fue le hicimols sus diocesanos, y pocos días ción de pascuas a nuestro pre Navidad, no hubo visita de telicitasión a cuanto dijera en el Senado, que no hiciera constar su adhe-

\section{Gracias}

Debemos darlas muy efusivas, tados los josefinos al Obisipo de Barcelona que preside nuestras obras. Lo hicimos ya en el níconstat.

Querenos también darlas especialmente a los amigos que en la Junta de Sanidad y. Ayuntamiento de Barcelona nos than quon en la
con su incondicional apoyo.

Adienias debemos darlas a cuantos, entidades y particulares, han concurrido a la información! y: nos han ayudado en nuestros tra-
bajos.

\section{Resumiendo}

He aqui, fielmente transcrito cuanto hasta hoy se ha actuado. dejará llevar de la vocingleos, confía en que el Gobiermo no se sana, que va salvaguardadalería sino que atendierá a la opinión

Rebajarnos a repetir las por la ley del Reino.

nes lerrouxistas contra atrocidades vertidas en la prensa y mitihuelga porque no hay, en ellas emo, no queremos. Contestarlas, baba de odio y del sectarismo.

Pretendemos que sectarismo.

mhumaciones de cadáveres en tradición de la Iglesia se permitan torio de la Sagrada Fantilia a fin de poder nuestra Templo expiatail grandiosa obra y en ello ofrecemos activar y aun terninar. Ley $y$ la Higiene verdadera obligueces limitarios a cuanto la guna merna a los intereses de la ciudad, queremos causar nin-

El asunto es importantísimo ciudad, que quedará tavorecida. trabajo y entusiasmo. Quierano. Hemos puesto en él todo nuestro oraciones para obtener el exito anhelado. 